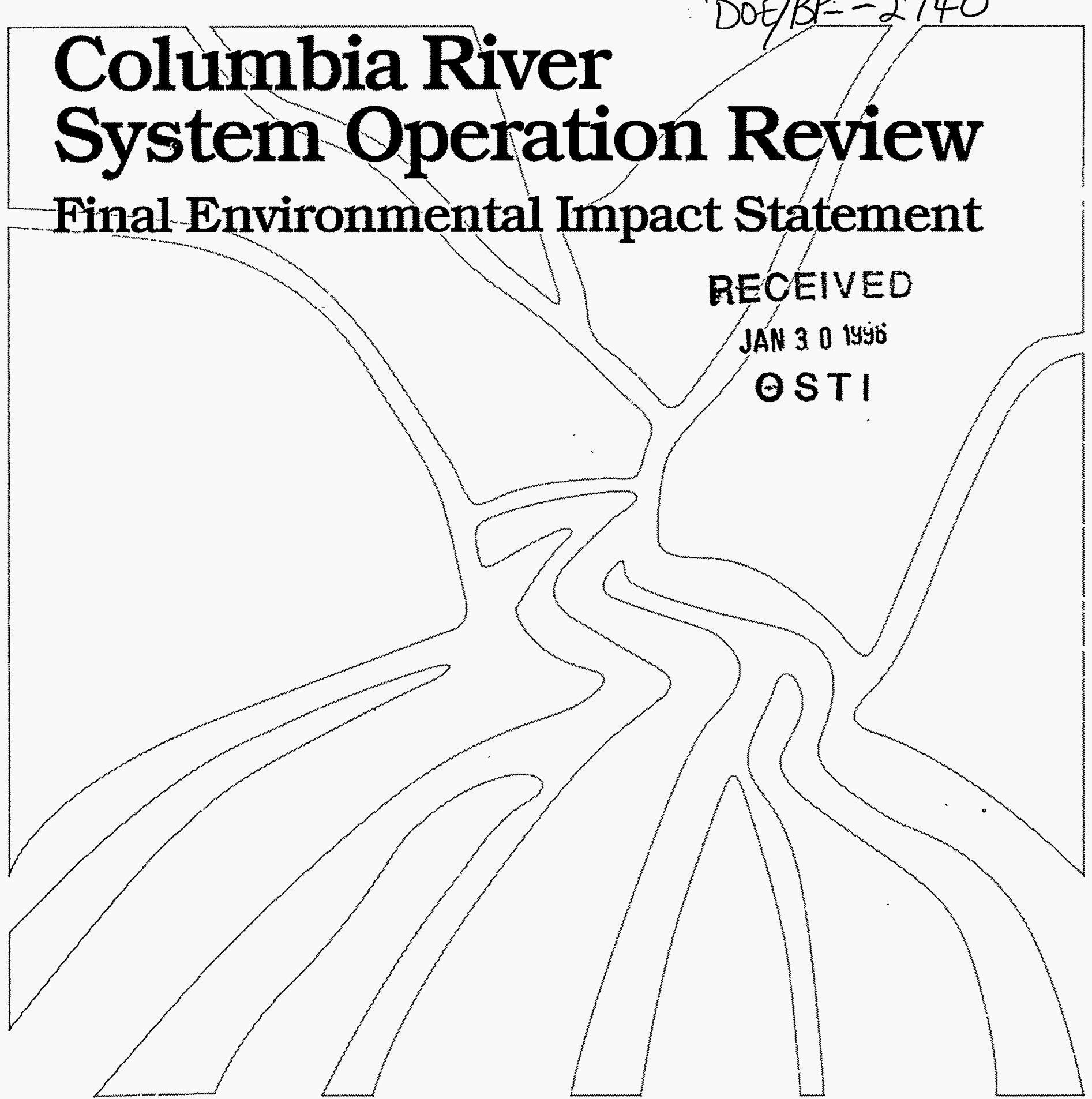

\title{
Appendix 0
}

Economic and Social Impact

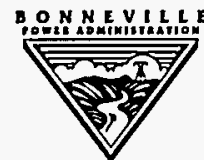

DOE/EIS-0170-App $O$
US Army Corps of Engineers

North Pacific Division
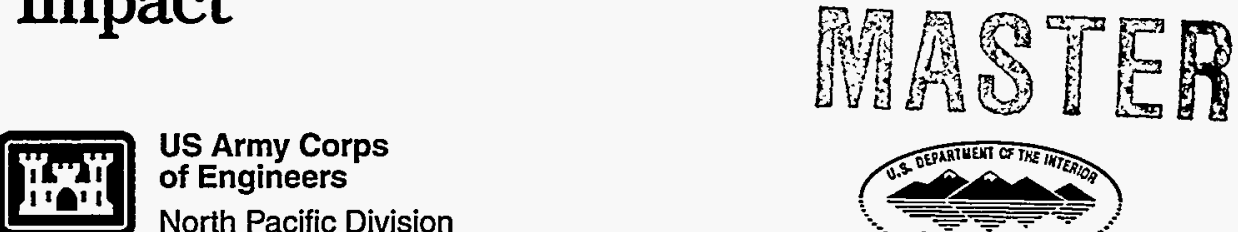

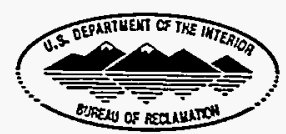

November 1995 


\section{PUBLIC INVOLVEMENT IN THE SOR PROCESS}

The Bureau of Reclamation, Corps of Engineers, and Bonneville Power Administration wish to thank those who reviewed the Columbia River System Operation Review (SOR) Draft EIS and appendices for their comments. Your comments have provided valuable public, agency, and tribal input to the SOR NEPA process. Throughout the SOR, we have made a continuing effort to keep the public informed, and involved.

Fourteen public scoping meetings were held in 1990. A series of public roundtables was conducted in November 1991 to provide an update on the status of SOR studies. The lead agencies went back to most of the 14 communities in 1992 with 10 initial system operating strategies developed from the screening process. From those meetings and other consultations, seven SOS alternatives (with options) were developed and subjected to full-scale analysis. The analysis results were presented in the Draft EIS released in July 1994. The lead agencies also developed alternatives for the other proposed SOR actions, including a Columbia River Regional Forum for assisting in the determination of future SOSs, Pacific Northwest Coordination Agreement alternatives for power coordination, and Canadian Entitlement Allocation Agreements alternatives. A series of nine public meetings was held in September and October 1994 to present the Draft EIS and appendices and solicit public input on the SOR. The lead agencies-received 282 formal written comments. Your comments have been used to revise and shape the alternatives presented in the Final EIS.

Regular newsletters on the progress of the SOR have been issued. Since 1990, 20 issues of Streamline have been sent to individuals, agencies, organizations, and tribes in the region on a mailing list of over 5,000. Several special publications explaining various aspects of the study have also been prepared and mailed to those on the mailing list. Those include:

The Columbia River: A System Under Stress

The Columbia River System: The Inside Story

Screening Analysis: A Summary

Screening Analysis: Volumes 1 and 2

Power System Coordination: A Guide to the Pacific Northwest Coordination Agreement

Modeling the System: How Computers are Used in Columbia River Planning

Daily/Hourly Hydrosystem Operation: How the Columbia River System Responds to Short-Term Needs

Copies of these documents, the Final EIS, and other appendices can be obtained from any of the lead agencies, or from libraries in your area.

Your questions and comments on these documents should be addressed to:

SOR Interagency Team

P.O. Box 2988

Portland, OR 97208-2988 


\section{PREFACE: SETTING THE STAGE FOR THE SYSTEM OPERATION REVIEW}

\section{WHAT IS THE SOR AND WHY IS IT BEING CONDUCTED?}

The Columbia River System is a vast and complex combination of Federal and non-Federal facilities used for many purposes including power production, irrigation, navigation, flood control, recreation, fish and wildlife habitat and municipal and industrial water supply. Each river use competes for the limited water resources in the Columbia River Basin.

To date, responsibility for managing these river uses has been shared by a number of Federal, state, and local agencies. Operation of the Federal Columbia River system is the responsibility of the Bureau of Reclamation (Reclamation), Corps of Engineers (Corps) and Bonneville Power Administration (BPA).

The System Operation Review (SOR) is a study and environmental compliance process being used by the three Federal agencies to analyze future operations of the system and river use issues. The goal of the SOR is to achieve a coordinated system operation strategy for the river that better meets the needs of all river users. The SOR began in early 1990, prior to the filing of petitions for endangered status for several salmon species under the Endangered Species Act.

The comprehensive review of Columbia River operations encompassed by the SOR was prompted by the need for Federal decisions to (1) develop a coordinated system operating strategy (SOS) for managing the multiple uses of the system into the 21st century; (2) provide interested parties with a continuing and increased long-term role in system planning (Columbia River Regional Forum); (3) renegotiate and renew the Pacific Northwest Coordination Agreement (PNCA), a contractual arrangement among the region's major hydroelectric-generating utilities and affected Federal agencies to provide for coordinated power generation on the Columbia River system; and (4) renew or develop new Canadian Entitlement Allocation Agreements (contracts that divide Canada's share of Columbia River Treaty downstream power benefits and obligations among three participating public utility districts and BPA). The review provides the environmental analysis required by the National Environmental Policy Act (NEPA).

This technical appendix addresses only the effects of alternative system operating strategies for managing the Columbia River system. The environmental impact statement (EIS) itself and some of the other appendices present analyses of the alternative approaches to the other three decisions considered as part of the SOR.

\section{WHO IS CONDUCTING THE SOR?}

The SOR is a joint project of Reclamation, the Corps, and BPA-the three agencies that share responsibility and legal authority for managing the Federal Columbia River System. The National Marine Fisheries Service (NMFS), U.S. Fish and Wildlife Service (USFWS), and National Park Service (NPS), as agencies with both jurisdiction and expertise with regard to some aspects of the SOR, are cooperating agencies. They contribute information, analysis, and recommendations where appropriate. The U.S. Forest Service (USFS) was also a cooperating agency, but asked to be removed from that role in 1994 after assessing its role and the press of other activities.

\section{HOW IS THE SOR BEING CONDUCTED?}

The system operating strategies analyzed in the SOR could have significant environmental impacts. The study team developed a three-stage process-scoping, screening, and full-scale analysis of the strategies-to address the many issues relevant to the SOR.

At the core of the analysis are 10 work groups. The work groups include members of the lead and cooperating agencies, state and local government agencies, representatives of Indian tribes, and members 
of the public. Each of these work groups has a single river use (resource) to consider.

Early in the process during the screening phase, the 10 work groups were asked to develop an alternative for project and system operations that would provide the greatest benefit to their river use, and one or more alternatives that, while not ideal, would provide an acceptable environment for their river use. Some groups responded with alternatives that were evaluated in this early phase and, to some extent, influenced the alternatives evaluated in the Draft and Final EIS. Additional alternatives came from scoping for the SOR and from other institutional sources within the region. The screening analysis studied 90 system operation alternatives.

Other work groups were subsequently formed to provide projectwide analysis, such as economics, river operation simulation, and public involvement.

The three-phase analysis process is described briefly below.

- Scoping/Pilot Study-After holding public meetings in 14 cities around the region, and coordinating with local, state, and Federal agencies and Indian tribes, the lead agencies established the geographic and jurisdictional scope of the study and defined the issues that would drive the EIS. The geographic area for the study is the Columbia River Basin (Figure P-1). The jurisdictional scope of the SOR encompasses the 14 Federal projects on the Columbia and lower Snake Rivers that are operated by the Corps and Reclamation and coordinated for hydropower under the PNCA. BPA markets the power produced at these facilities. A pilot study examining three alternatives in four river resource areas was completed to test the decision analysis method proposed for use in the SOR.

- Screening-Work groups, involving regional experts and Federal agency staff, were created for 10 resource areas and several support functions. The work groups developed computer screening models and applied them to the 90 alternatives identified during screening. They compared the impacts to a baseline operating year-1992_and ranked each alternative according to its impact on their resource or river use. The lead agencies reviewed the results with the public in a series of regional meetings in September 1992.

- Full-Scale Analysis-Based on public comment received on the screening results, the study team sorted, categorized, and blended the alternatives into seven basic types of operating strategies. These alternative strategies, which have multiple options, were then subjected to detailed impact analysis. Twenty-one possible options were evaluated. Results and tradeoffs for each resource or river use were discussed in separate technical appendices and summarized in the Draft EIS. Public review and comment on the Draft EIS was conducted during the summer and fall of 1994. The lead agencies adjusted the alternatives based on the comments, eliminating a few options and substituting new options, and reevaluated them during the past 8 months. Results are summarized in the Final EIS.

Alternatives for the Pacific Northwest Coordination Agreement (PNCA), the Columbia River Regional Forum (Forum), and the Canadian Entitlement Allocation Agreements (CEAA) did not use the three-stage process described above. The environmental impacts from the PNCA and CEAA were not significant and there were no anticipated impacts from the Regional Forum. The procedures used to analyze alternatives for these actions are described in their respective technical appendices.

For detailed information on alternatives presented in the Draft EIS, refer to that document and its appendices. 


\section{WHAT SOS ALTERNATIVES ARE CONSIDERED IN THE FINAL EIS?}

Seven alternative System Operating Strategies (SOS) were considered in the Draft EIS. Each of the seven SOSs contained several options bringing the total number of alternatives considered to 21 . Based on review of the Draft EIS and corresponding adjustments, the agencies have identified 7 operating strategies that are evaluated in this Final EIS. Accounting for options, a total of 13 alternatives is now under consideration. Six of the alternatives remain unchanged from the specific options considered in the Draft EIS. One is a revision to a previously considered alternative, and the rest represent replacement or new alternatives. The basic categories of SOSs and the numbering convention remains the same as was used in the Draft EIS. However, because some of the alternatives have been dropped, the numbering of the final SOSs are not consecutive. There is one new SOS category, Settlement Discussion Alternatives, which is labeled SOS 9 and replaces the SOS 7 category. This category of alternatives arose as a consequence of litigation on the 1993 Biological Opinion and ESA Consultation for 1995.

The 13 system operating strategies for the Federal Columbia River system that are analyzed for the Final EIS are:

SOS 1a Pre Salmon Summit Operation represents operations as they existed from around 1983 through the 1990-91 operating year, prior to the ESA listing of three species of salmon as endangered or threatened.

SOS 1b Optimum Load-Following Operation represents operations as they existed prior to changes resulting from the Regional Act. It attempts to optimize the load-following capability of the system within certain constraints of reservoir operation.

SOS 2c Current Operation/No-Action Alternative represents an operation consistent with that specified in the Corps of Engineers' 1993 Supplemental EIS. It is similar to system operation that occurred in 1992 after three species of salmon were listed under ESA.

SOS 2d [New] 1994-98 Biological Opinion represents the 1994-98 Biological Opinion operation that includes up to $4 \mathrm{MAF}$ flow augmentation on the Columbia, flow targets at McNary and Lower Granite, specific volume releases from Dworshak, Brownlee, and the Upper Snake, meeting sturgeon flows 3 out of 10 years, and operating lower Snake projects at MOP and John Day at MIP.

SOS 4c [Rev.] Stable Storage Operation with Modified Grand Coulee Flood Control attempts to achieve specific monthly elevation targets year round that improve the environmental conditions at storage projects for recreation, resident fish, and wildlife. Integrated Rules Curves (IRCs) at Libby and Hungry Horse are applied.

SOS 5b Natural River Operation draws down the four lower Snake River projects to near river bed levels for four and one-half months during the spring and summer salmon migration period, by assuming new low level outlets are constructed at each project.

SOS 5c [New] Permanent Natural River Operation operates the four lower Snake River projects to near river bed levels year round.

SOS 6b Fixed Drawdown Operation draws down the four lower Snake River projects to near spillway crest levels for four and one-half months during the spring and summer salmon migration period.

SOS 6d Lower Granite Drawdown Operation draws down Lower Granite project only to near spillway crest level for four and one-half months.

SOS 9a [New] Detailed Fishery Operating Plan includes flow targets at The Dalles based on the previous year's end-of-year storage content, specific volumes of releases for the Snake River, the drawdown of Lower Snake River projects to near spillway crest level for four and one-half months, specified spill percentages, and no fish transportation. 
SOS 9b [New] Adaptive Management establishes flow targets at McNary and Lower Granite based on runoff forecasts, with specific volumes of releases to meet Lower Granite flow targets and specific spill percentages at run-of-river projects.

SOS 9c [New] Balanced Impacts Operation draws down the four lower Snake River projects near spillway crest levels for two and one-half months during the spring salmon migration period. Refill begins after July 15 . This alternative also provides 1994-98 Biological Opinion flow augmentation, integrated rule curve operation at Libby and Hungry Horse, a reduced flow target at Lower Granite due to drawdown, winter drawup at Albeni Falls, and spill to achieve no higher than 120 percent daily average for total dissolved gas.

SOS PA Preferred Alternative represents the operation proposed by NMFS and USFWS in their Biological Opinions for 1995 and future years; this SOS operates the storage projects to meet flood control rule curves in the fall and winter in order to meet spring and summer flow targets for Lower Granite and McNary, and includes summer draft limits for the storage projects.

\section{WHAT DO THE TECHNICAL APPENDICES COVER?}

This technical appendix is 1 of 20 prepared for the SOR. They are:
A. River Operation Simulation
B. Air Quality
C. Anadromous Fish \& Juvenile Fish Transportation
D. Cultural Resources
E. Flood Control
F. Irrigation/Municipal and Industrial Water Supply
G. Land Use and Development
H. Navigation
I. Power
J. Recreation
K. Resident Fish

L. Soils, Geology, and Groundwater

M. Water Quality

N. Wildlife

O. Economic and Social Impacts

P. Canadian Entitlement Allocation Agreements

Q. Columbia River Regional Forum

R. Pacific Northwest Coordination Agreement

S. U. S. Fish and Wildlife Service Coordination Act Report

T. Comments and Responses

Each appendix presents a detailed description of the work group's analysis of alternatives, from the scoping process through full-scale analysis. Several appendices address specific SOR functions (e.g., River Operation Simulation), rather than individual resources, or the institutional alternatives (e.g., PNCA) being considered within the SOR. The technical appendices provide the basis for developing and analyzing alternative system operating strategies in the EIS. The EIS presents an integrated review of the vast wealth of information contained in the appendices, with a focus on key issues and impacts. In addition, the three agencies have prepared a brief summary of the EIS to highlight issues critical to decision makers and the public.

In addition to presenting the study results, the appendix includes an overview of the study scope and process, the historic and current social and economic condition in the Columbia River Basin, and the analytical methods used to measure the economic and social impacts. Considerable background and supporting material is presented in the separate resource appendices. The level of detailed background and supporting data presented in this appendix for any river use was gauged by the information provided in the resource appendix for that river use. An effort was made to avoid unnecessary duplication, but sufficient detail is presented to provide the reader with information required to comprehend the data and analyses presented in this appendix without continually having to refer back to 
the supporting resource appendices. Table $\mathrm{P}-1$ provides the information needed to identify the resource or physical impacts appendix related to each river use. This appendix relies on supporting data contained in the Anadromous Fish, Resident Fish, Wildlife, Flood Control, Irrigation/Municipal and Industrial Water Supply, Navigation, Power, Recreation, and Water Quality appendices. For complete coverage of all aspects of the economic and social analysis, readers may wish to review all ten appendices in concert.

\section{DISCLAIMER}

This report was prepared as an account of work sponsored by an agency of the United States States Government nor any agency thereof, nor any of their Government. Neither the United States Government nor any agency legal liability or responsiemployees, makes any warranty, express or implied, or assu fration, apparatus, product, or bility for the accuracy, completeness, or usefulness of any information, apparated rights. Referprocess disclosed, or represents that its use would not infringe private by trade name, trademark, ence herein to any specific commercial product, process, or service by trade name, trademeremmanufacturer, or otherwise does not necessarily constitute or imply its endorsement, recows mendation, or favoring by the United States Government or any agency therect those of the and opinions of authors expressed herein do not

United States Government or any agency thereof. 


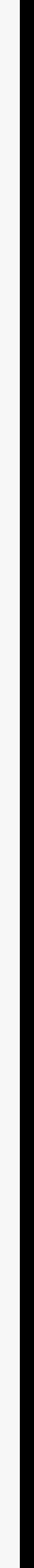




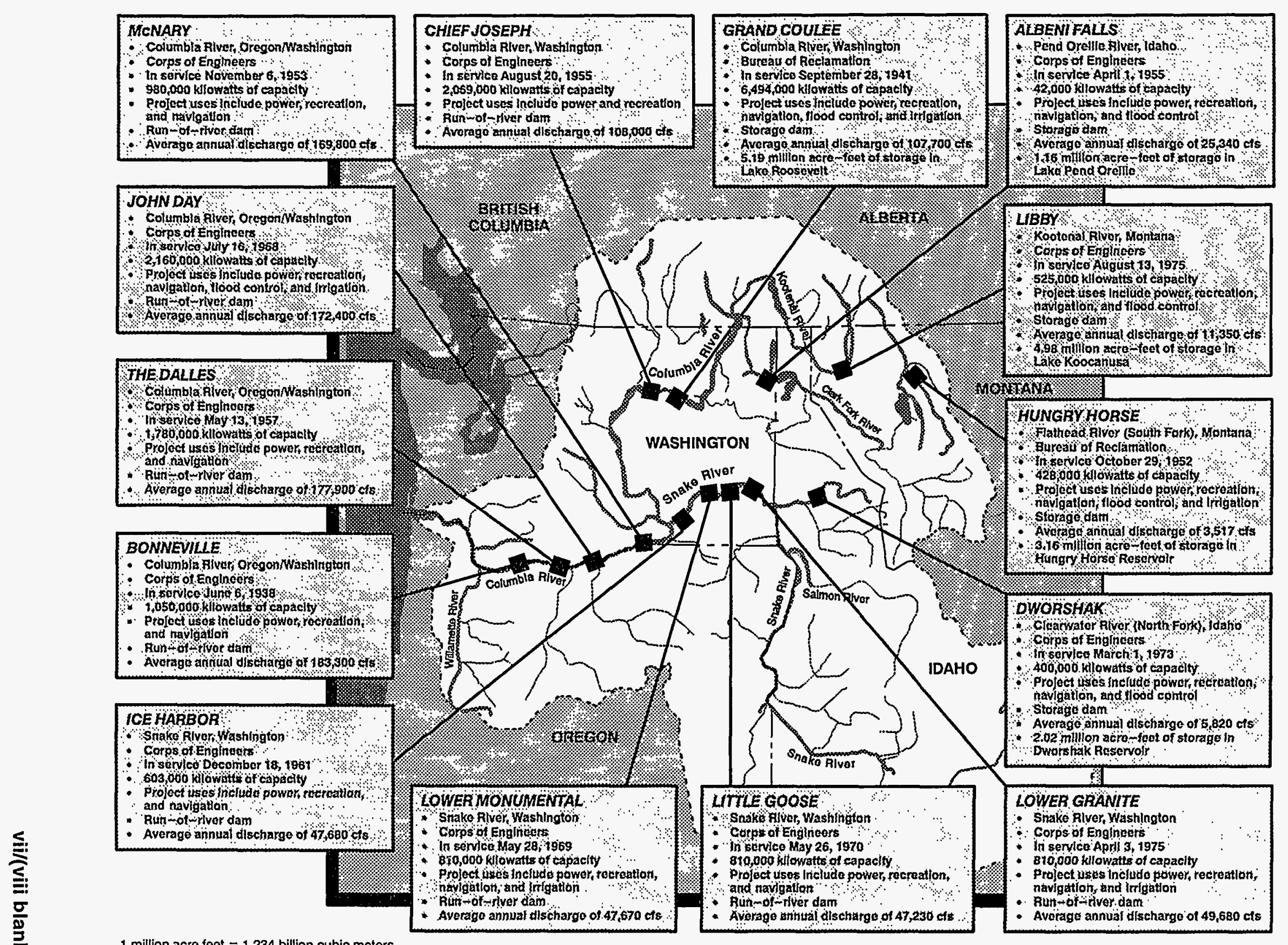

1 million acre feet $=1.234$ billion cubic meters

1 cubic foot per second $=0.028$ cubic meters per second

Figure P-1. Projects in the System Operation Review. 


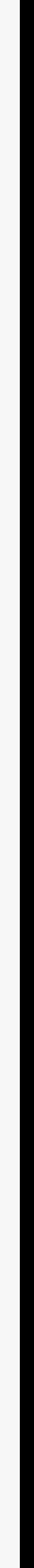


Table P-1. Summary of River Uses and Associated information Contained in the SOR Technical Appendices

\begin{tabular}{|c|c|c|}
\hline River Use & Economic and Social Impacts & Supporting Resource Technical Appendix \\
\hline $\begin{array}{l}\text { Anadromous } \\
\text { Fish }\end{array}$ & $\begin{array}{l}\text { Economic and social impacts related } \\
\text { to commercial, recreational, and tribal } \\
\text { harvests }\end{array}$ & $\begin{array}{l}\text { Anadromous Fish } \\
\text { - Biological impacts to representative } \\
\text { stocks }\end{array}$ \\
\hline Resident Fish & $\begin{array}{l}\text { - Brief discussion related to } \\
\text { recreational fishing }\end{array}$ & $\begin{array}{l}\text { Resident Fish } \\
\text { - Biological impacts }\end{array}$ \\
\hline Wildlife & $\begin{array}{l}\text { - Brief discussion related to } \\
\text { recreational use }\end{array}$ & $\begin{array}{l}\text { Wildlife } \\
\text { - Biological impacts }\end{array}$ \\
\hline Flood Control & $\begin{array}{l}\text { Economic and social impacts related } \\
\text { to changes in annual damages from } \\
\text { flooding }\end{array}$ & $\begin{array}{l}\text { Flood Control } \\
\text { - Stage or discharge vs frequency } \\
\text { impacts }\end{array}$ \\
\hline $\begin{array}{l}\text { Irrigation and } \\
\text { Water Supply }\end{array}$ & $\begin{array}{l}\text { Economic and social impacts related } \\
\text { to changes in net farm income }\end{array}$ & $\begin{array}{l}\text { Irrigation and Water Supply } \\
- \text { Changes in water withdrawal costs } \\
\text { and net farm income }\end{array}$ \\
\hline Navigation & $\begin{array}{l}\text { Economic and social impacis related } \\
\text { to changes in the cost of transporting } \\
\text { commodities }\end{array}$ & $\begin{array}{l}\text { Navigation } \\
\text { - Impacts to the congressionally } \\
\text { authorized navigation system within } \\
\text { the Columbia and Snake River } \\
\text { system }\end{array}$ \\
\hline Power & $\begin{array}{l}\text { Economic impacts related to changes } \\
\text { in rates; impacts of rates on power } \\
\text { demand; net system costs; and } \\
\text { changes in consumer surplus }\end{array}$ & $\begin{array}{l}\text { Power } \\
\text { - Annual gross system generation and } \\
\text { capacity costs }\end{array}$ \\
\hline Recreation & $\begin{array}{l}\text { Economic and social impacts related } \\
\text { to the economic value of recreation } \\
\text { activity }\end{array}$ & $\begin{array}{l}\text { Recreation } \\
\text { - Recreation days by type of activity } \\
\text { and by site }\end{array}$ \\
\hline Water Quality & $\begin{array}{l}\text { - Economic and social impacts related } \\
\text { to impacts on water }\end{array}$ & $\begin{array}{l}\text { Water Quality } \\
\text { - Impacts on water quality }\end{array}$ \\
\hline
\end{tabular}




\section{TABLE OF CONTENTS}

Chapter/Para

1 INTRODUCTION: PURPOSE, SCOPE, AND PROCESS

$1-1$

1.1

PURPOSE OF ECONOMIC AND SOCIAL IMPACTS APPENDIX

$1-1$

Geographic Scope

$1-1$

1.2.2

Economic and Social Scope

1-2

1.2.2.1

National Economic Analysis

1-2

1.2.2.2

1.2.2.3

1.3

Regional Economic Analysis

1-2

Social Analysis

$1-3$

PUBLIC INVOLVEMENT AND AGENCY COORDINATION $\ldots \ldots \ldots \ldots \ldots \ldots \ldots .1-3$

1.3.1

1.3.2

1.3.3

1.4

1.4.1

1.4 .2

Economic Analysis Group

1-3

Public Involvement

$1-4$

Coordination within SOR Work Groups

$1-5$

ECONOMIC AND SOCIAL ISSUES RAISED DURING STUDY

$1-5$

General Economic and Social Issues

$1-5$

Technical Issues

$1-5$

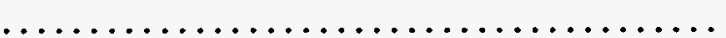

Resource Base

Native American Culture and the Columbia River

$2-1$

The Fur Trade

$2-1$

$2-2$

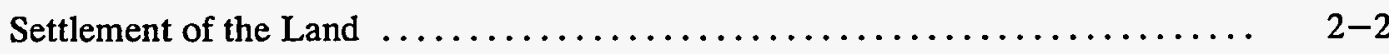

Gold .

Timber

$2-4$

Salmon

$2-4$

The Columbia River.

Population and Current Economic Development

Current and Projected Population

Economic Development 


\section{TABLE OF CONTENTS - CONT}

\section{Chapter/Para}

2.2.3

2.2.4

2.2.4.1

2.2.4.2

2.2 .5

2.2.5.1

2.2.5.2

2.2.5.3

2.2.6

2.2.7

2.2.7.1

2.2.7.2

2.2.7.3

2.2.8

3

3.1

3.1.1

3.1.2

3.1.3

3.1.4

3.1.4.1

3.1.4.2

3.1.4.3

3.1.4.4

3.1.4.5

3.1.4.6

3.1.4.7

3.1.4.8

3.1.4.9

3.1.5

3.1.5.1

3.1.5.2
Flood Control

Irrigation and Municipal and Industrial Water Supply

Irrigation

Municipal and Industrial (M\&I) Water Supply

Navigation

Deep-Draft Navigation

Shallow-Draft Navigation

Dworshak Reservoir

Power

Recreation

Introduction

Recreation Visitor Days

Occurrence of Recreation Activity

Water Quality ...

ANALYSIS PROCEDURES AND METHODOLOGIES

NATIONAL ECONOMIC EVALUATION, THE CONCEPTS

Scarcity

Optimal Use of Scarce Resources

Willingness - to - Pay

Prices and the NED Principle

Demand Curve

Price Elasticity of Demand

Profit Maximization

Opportunity Cost

Supply Curve .

Producer Surplus

Markets and Prices

Supply, Demand, and Social Welfare

When Demand and Supply Curves Don't Exist

Market Failure

Externalities

Public Goods
Page

$2-10$

$2-11$

2-11

$2-13$

2-13

2-15

2-17

2-21

2-21

2-22

2-22

2-22

2-22

2-24

3-1

3-1

3-1

3-2

3-3

3-3

$3-3$

3-5

3-7

3-8

3-8

$3-9$

3-9

3-11

3-14

3-14

3-14

$3-16$ 


\section{TABLE OF CONTENTS - CONT}

Chapter/Para

$\underline{\text { Page }}$

3.2

NATIONAL ECONOMIC ANALYSIS ASSUMPTIONS FOR SOR

$3-16$

3.2.1

Discounting and Discount Rates

$3-16$

3.2 .2

3.2 .3

Expected and Equivalent Annual Values

$3-17$

3.2 .4

Price Level and Inflation

$3-17$

3.2 .5

Period of Analysis

$3-17$

Implementation Timing

$3-18$

3.2 .6

Full Employment

$3-18$

3.3

3.3.1

NATIONAL ECONOMIC ANALYSIS FOR SPECIFIC RIVER USES

$3-18$

Anadromous Fish

3-19

3.3.1.1

Resource Assessment

3-19

3.3.1.2

Fish Harvest Analysis

3-21

3.3.1.3

Fish Allocation

$3-24$

3.3.1.4

3.3.1.5

3.3.1.6

3.3.2

3.3.3

3.3.4

3.3.4.1

3.3.4.2

3.3.4.3

3.3.5

3.3.5.1

3.3.5.2

3.3.6

3.3.6.1

Commercial and Sport Fish Values

$3-24$

Computation of Direct Impacts

$3-26$

Existence Value

$3-27$

Resident Fish and Wildlife

$3-28$

Flood Control

$3-30$

Irrigation and Municipal and Industrial Water Supply

$3-32$

Overview

$3-32$

Irrigation

3-32

Municipal and Industrial Water Supply

$3-33$

Navigation

3-34

Introduction

$3-34$

Analysis of Impacts

$3-34$

Power

$3-37$

Overview of Analysis

$3-38$

Implementation Costs

$3-38$

Gross System Generation and Capacity Costs

$3-38$

Rate Impact Analysis Methodology .

3-39

Recreation

$3-41$

Individual Willingness-To-Pay for Recreation .

$3-41$

3.3.7.1

Recreation Use and Value Estimation Procedures

$3-42$ 


\section{TABLE OF CONTENTS - CONT}

Chapter/Para

Page

WATER OUALITY

$3-47$

3.5

REGIONAL ECONOMIC EVALUATION, THE CONCEPTS

$3-47$

Validating the Basic Data $. . \ldots \ldots \ldots \ldots \ldots \ldots \ldots \ldots \ldots \ldots \ldots \ldots \ldots \ldots . \quad 3-47$

Adjusting the Trade Relationships and Production Functions

$3-47$

3.5 .3

3.5.3.1

Construction of the Models

$3-48$

Transaction Tables

$3-48$

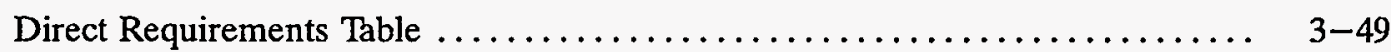

3.5.3.2

Total Requirements Table

3-49

Multipliers

$3-51$

REGIONAL ECONOMIC ANALYSIS IN SOR ................... $3-52$

Study Areas

$3-52$

Linking the Direct and Indirect Economic Impacts $\ldots \ldots \ldots \ldots \ldots \ldots \ldots \ldots . \quad 3-52$

Focus Communities

$3-53$

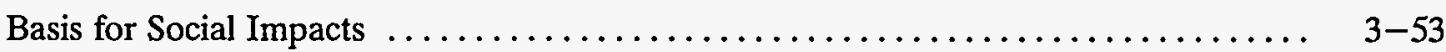

Social Impacts Assessment Process

$3-54$

ALTERNATIVES AND THEIR IMPACTS

4-1

GENERAL DESCRIPTION OF ALTERNATIVES ...................... 4 4-1

SOS 1-Pre-ESA Operation

4-14

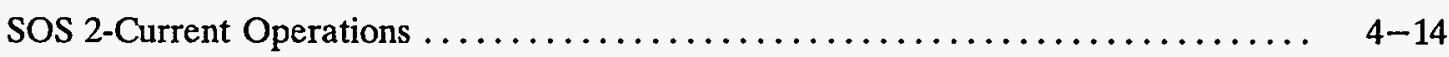

SOS 4-Stable Storage Project Operation

4-15

SOS 5-Natural River Operation

4-15

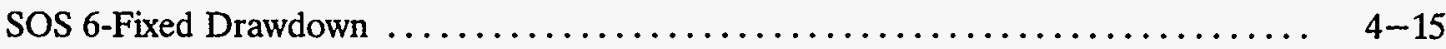

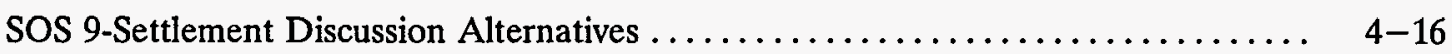

SOS PA-Preferred Alternative $\ldots \ldots \ldots \ldots \ldots \ldots \ldots \ldots \ldots \ldots \ldots \ldots \ldots \ldots, 4,16$

Rationale for Selection of the Final SOSs $\ldots \ldots \ldots \ldots \ldots \ldots \ldots \ldots \ldots \ldots \ldots \ldots, 4-17$

IMPLEMENTATION COSTS $\ldots \ldots \ldots \ldots \ldots \ldots \ldots \ldots \ldots \ldots \ldots \ldots \ldots \ldots \ldots \ldots \ldots \ldots \ldots, 4-20$

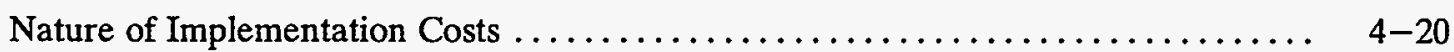

Potential Cost Savings to the Existing System Operation ................ $4-20$

Construction Requirements and Implementation Timing $\ldots \ldots \ldots \ldots \ldots \ldots \ldots \ldots$ 4-21

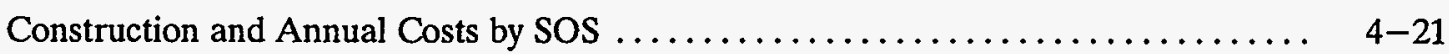

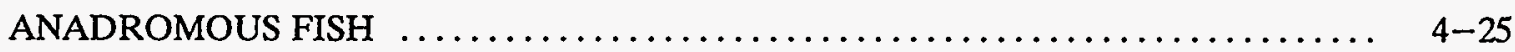

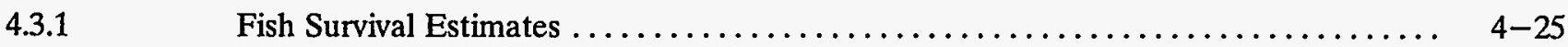




\section{TABLE OF CONTENTS - CONT}

Chapter/Para

$\underline{\text { Page }}$

4.3.1.1

General

$4-25$

4.3.1.2

Transportation Survival Uncertainty

4-25

4.3.1.3

Drawdown Survival Uncertainty

$4-25$

4.3.1.4

Variability of Estimates of Survival

4-25

4.3.1.5

Discounting Estimates of Survival

4-26

4.3.2

4.3.2.1

Analysis of Number of Fish Harvested

4-26

Catch Estimates Over Time

$4-26$

4.3.2.2

Average Annual Equivalent Catch

$4-27$

4.3.3

Undiscounted Value of Recreational and Commerical Fisheries

$4-28$

4.3.4

Average Annual Value of Recreation and Commercial Fishery

$4-34$

4.4

RESIDENT FISH AND WILDLIFE

4-37

4.5

FLOOD CONTROL

4-37

4.5.1

Upper Columbia River

4-37

4.5.2

4.5.3

4.5.4

4.5 .5

4.6

Clearwater River

4-38

Tri-Cities

4-40

Lower Columbia River

4-40

Summary of Flood Damages

4-41

IRRIGATION AND MUNICIPAL AND INDUSTRIAL WATER SUPPLY

$4-41$

Overview

$4-41$

4.6 .2

4.6.2.1

Impacts of Reservoir Drawdown on Commercial Irrigation

$4-44$

Grand Coulee

$4-44$

4.6.2.2

4.6.3

4.7

4.7.1

Ice Harbor and John Day

$4-44$

Impacts on M\&I Water Users - Pumpers

$4-48$

ANALYSIS OF NAVIGATION IMPACTS

4-51

Introduction

4-51

4.7.2

4.7.3

4.7.3.1

4.7.3.2

4.7.4

4.7.4.1

Shallow Draft Navigation

$4-52$

Deep Draft Navigation

$4-55$

Analysis for the FEIS

$4-55$

Analysis for the DEIS

$4-55$

Reservoir Navigation .

$4-61$

Summary of Analysis

$4-61$

4.7.4.2

Conclusions

4-61 


\section{TABLE OF CONTENTS - CONT}

Chapter/Para

$\underline{\text { Page }}$

4.8

POWER

$4-64$

4.8.1

Gross System Replacement Costs

4-64

4.8.2

Equivalent Annual Changes in Gross System Replacement Costs

4-65

4.8.3

4.8.4

Equivalent Annual Implementation Costs

4-66

Initial Rate Impacts .

4-66

4.8.5

Price Elasticities

4-67

4.8.6

4.8.7

Effects on Demand

4-67

Net System Replacement Costs .

4-68

Equivalent Annual Changes in Net System Replacement Costs

4-68

Final Rate Impacts

4-69

Aluminum Industry Impacts

$4-70$

4.8.10

RECREATION

4-71

Summary of Impacts $\ldots \ldots \ldots \ldots \ldots \ldots \ldots \ldots \ldots \ldots \ldots \ldots \ldots \ldots \ldots \ldots \ldots \ldots \ldots \ldots \ldots \ldots, 4-71$

4.9.1

4.9 .2

4.9.3

4.10

Average Annual Recreation Values

$4-71$

Average Annual and Equivalent Annual Recreation Values

$4-73$

SUMMARY OF SYSTEM ANNUAL COSTS--CHANGES FROM SOS 2C

$4-75$

REGIONAL ECONOMIC ANALYSIS

4-90

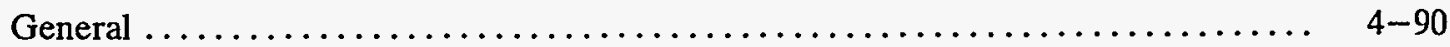

4.11 .1

4.11 .2

Anadromous Fisheries

4-91

Expenditure Patterns for Commercial Fisheries .................... 4-91

4.11.2.1

4.11.2.2

4.11.2.3

4.11.2.4

4.11.2.5

4.11.2.6

4.11.2.7

4.11.3

4.11.3.1

4.11.3.2

Allocation of Harvest to Subregions

4-92

Expenditure Patterns for Fish Processors $\ldots \ldots \ldots \ldots \ldots \ldots \ldots \ldots \ldots \ldots \ldots$ 4 4 -92

Allocation of Processing to Subregions $\ldots \ldots \ldots \ldots \ldots \ldots \ldots \ldots \ldots \ldots, 4-93$

Expenditure Patterns for Recreational Fisheries ................... 4-93

Allocation of Harvest to Subregions $\ldots \ldots \ldots \ldots \ldots \ldots \ldots \ldots \ldots \ldots \ldots .4 . \ldots \ldots$

Combined Anadromous Fisheries Impacts .................... 4-93

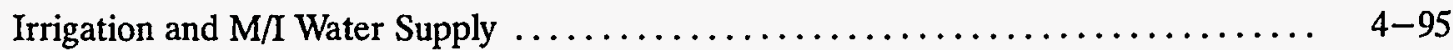

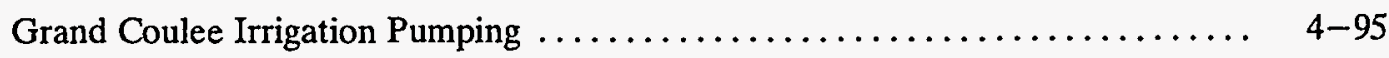

Allocation of Grand Coulee Costs to Subregions ................. 4-95

4.11.3.3

4.11.3.4

4.11.3.5

4.11.3.6

Ice Harbor/John Day Agricultural Irrigation

4-95

Allocation of Ice Harbor/John Day Costs to Subregions . . . . . . . . . . . . . . 4-96

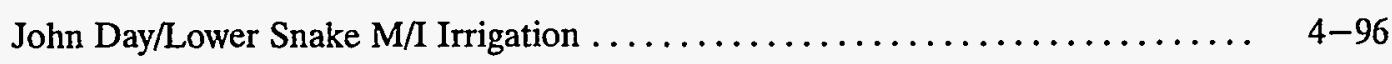

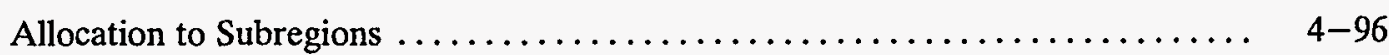




\section{TABLE OF CONTENTS - CONT}

Chapter/Para

4.11.4

Navigation

4-97

4.11.4.1

Deep Draft Navigation

4-97

4.11.4.2

Dworshak Reservoir Log Transportation

4-97

4.11.4.3

4.11.4.4

Allocation of Dworshak Log Transportation Costs to Subregions

4-97

Shallow Draft Navigation

4-97

4.11.4.5

4.11.5

4.11.5.1

4.11.5.2

4.11 .6

Allocation of Shallow Dra

Navige

Power

$4-98$

4-99

Ratepayer Response to Power Costs ........................ 4-99

Allocating the Power Costs to Subregions $\ldots \ldots \ldots \ldots \ldots \ldots \ldots \ldots \ldots \ldots .4$ 4 $49 . \ldots$

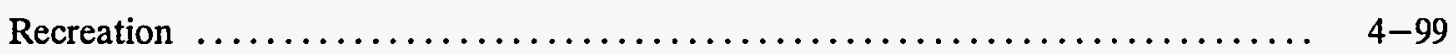

4.11.6.1

4.11.7

4.11.7.1

4.12

Allocation of Recreation Impacts to Subregions

$4-100$

Regional Economic Impacts Related to Project Implementation

$4-100$

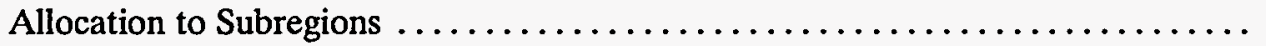

$4-102$

SOCIAL IMPACTS ASSESSMENT

$4-102$

SIGNIFICANCE AND APPLICABILITY OF ESTIMATES OF

ECONOMIC IMPACTS IN DECISION MAKING

Comparison of Direct Economic Impacts at 7.75 Percent Interest Rate.

Economic Impacts in the Pacific Northwest Region

Pacific Northwest Regional Employment Impacts

Pacific Northwest Regional Income Impacts

Economic Impacts in the States

State Level Employment Impacts

State Level Income Impacts 


\section{TABLE OF CONTENTS - CONT}

Chapter/Para

Page

5.5 .5

5.5.5.1

Economic Impacts of Project Implementation and Pump Modification

$5-19$

5.5 .5 .2

Employment Impacts of Project Implementation

$5-20$

5.6

Employment Impacts of Pump Modification

$5-20$

5.6 .1 SOCIAL IMPACTS

$5-22$

Anadromous Fish

$5-22$

5.6 .2

Irrigation and Municipal and Industrial Water

$5-22$

5.6.2.1

5.6.2.2

5.6 .3

5.6.3.1

5.6.3.2

5.6 .4

Irrigation

$5-22$

M\&I

$5-22$

Navigation

$5-23$

Reservoir Navigation

$5-23$

Shallow Draft Navigation

$5-23$

Power

$5-24$

Recreation

$5-24$

Construction

$5-24$

Impacts to Subregions and Focus Communities

$5-24$

\section{6 .7}

6

LIST OF PREPARERS

6-1

GLOSSARY

7-1

TECHNICAL REFERENCES

8-1

ANADROMOUS FISH

A-1

$\mathbf{A}$

GENERAL

A-1

A.2

A.3

SALMON AND STEELHEAD HARVEST OVER TIME

$A-1$

AVERAGE ANNUAL EQUIVALENTS WITH DIFFERENT

TRANSPORT CONDITIONS

$A-1$

B

FLOOD CONTROL

B-1

SECTION B1.0 - UPPER COLUMBIA RIVER SUBAREA $\ldots \ldots \ldots \ldots \ldots \ldots \ldots \ldots \ldots \ldots \ldots \ldots$ B-1

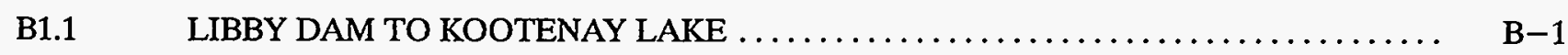

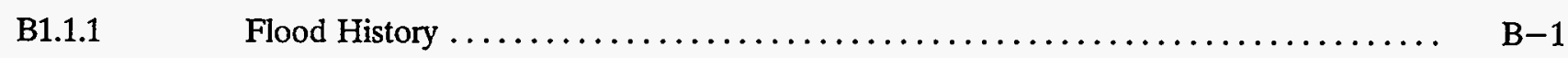

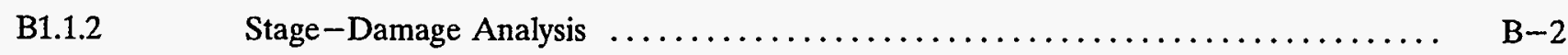

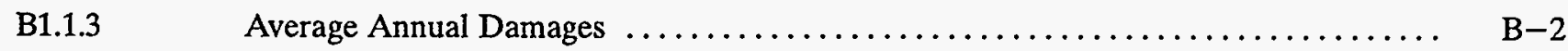

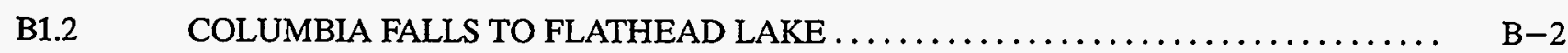

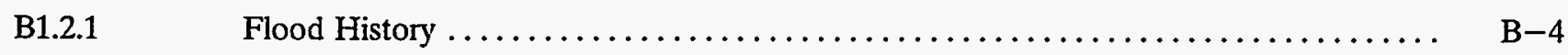

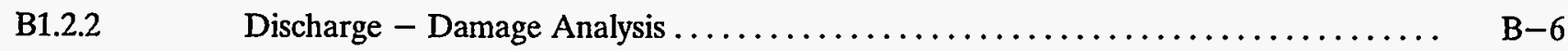

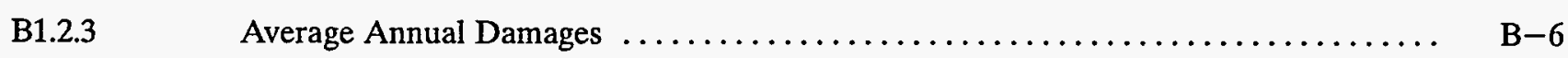




\section{TABLE OF CONTENTS - CONT}

Chapter/Para

$\underline{\text { Page }}$

B1.3

FLATHEAD LAKE

B-7

B1.3.1

Flood History

B-7

B1.3.2

Stage-Damage Analysis

B-7

B1.3.3

Average Annual Damages

B-8

B1.4

KERR DAM TO THOMPSON FALLS

B-8

B1.4.1

Flood History

B-9

B1.4.2

Discharge - Damage Analysis

B-9

B1.4.3

Average Annual Damages

B-9

B1.5

B1.5.1

PEND OREILLE LAKE

B-11

B1.5.2

Flood History

B-11

Stage-Damage Analysis

B-11

B1.5.3

Average Annual Damages

B-11

B1.6

ALBENI FALLS DAM TO CUSICK

B-14

B1.6.1

B1.6.2

Flood History

B-14

B1.6.3

Discharge-Damage Analysis .

B-14

Average Annual Damages

B-14

B1.7

SUMMARY OF FLOOD DAMAGES

B-15

SECTION B2.0 - CLEARWATER RIVER SUBAREA .

B-17

B2.1

INTRODUCTION

B-17

B2.2

DAMAGE CENTERS

B-17

B2.2.1

B2.2.2

B2.3

B2.3.1

B2.3.1.1

B2.3.1.2

B2.3.2

B2.3.2.1

Characteristics of the Floodplain

$\mathrm{B}-17$

Flood History .

$\mathrm{B}-18$

PROPERTY INVENTORY

B-18

$\mathrm{B}-18$

Analytical Procedures

B-20

Reach 1 - Dworshak Dam to Lewiston Levees

$\mathrm{B}-20$

Reach 2 - Lewiston Levees to the Snake River.

B-20

Description of the Floodplain

$\mathrm{B}-20$

Reach 1

B-20

B2.3.2.2

Reach 2

B-21

B2.3.3

B2.3.3.1

Quantitative Reach Information

B-21

Reach 1

$\mathrm{B}-21$

B2.3.3.2

Reach 2 


\section{TABLE OF CONTENTS - CONT}

Chapter/Para

$\underline{\text { Page }}$

$\mathrm{B}-21$

B2.4.1

Reach 1

B-22

B2.4.2

Reach 2

$\mathrm{B}-24$

B2.5

DISCHARGE - DAMAGE ANALYSIS

B-29

B2.5.1

Reach 1

B-29

B2.5.2

Reach 2

$\mathrm{B}-30$

B2.6

DISCHARGE - FREQUENCY ANALYSIS

B-30

B2.7

EXPECTED ANNUAL DAMAGE .

$\mathrm{B}-31$

$\mathrm{B} 2.8$

FUTURE DEVELOPMENT

$\mathrm{B}-31$

B2.9

EFFECTIVE LEVEE HEIGHT

$\mathrm{B}-33$

B2.10

RISK AND UNCERTAINTY .

$\mathrm{B}-33$

B2.11

IMPACT OF INCREASED FREQUENCY OF HIGH FLOWS ON LEVEES

$\mathrm{B}-33$

SECTION B3.0 - LOWER COLUMBIA RIVER SUBAREA

$\mathrm{B}-34$

B3.1

DESCRIPTION OF THE SUBAREA

B-34

B3.1.1

General .

B-34

B3.1.2

Bonneville Dam to Washougal .

B-34

B3.1.3

Washougal to the Willamette River ...

B-35

B3.1.4

Willamette River to River Mile 40

B-35

B3.1.5

River Mile 40 to the Mouth

$\mathrm{B}-36$

B3.2

FLOOD PROBLEMS AND CHARACTERISTICS

$\mathrm{B}-36$

B3.3

EXISTING FLOOD PROTECTION AND DAMAGES

$\mathrm{B}-38$

B3.3.1

Description of Flood Protection Systems

B-38

B3.3.2

Existing Flood Damages

$\mathrm{B}-38$

B3.4

B3.4.1

ANALYSIS OF FLOOD DAMAGES

B -40

Introduction

B-40

B3.4.2

Stage/Frequency Analysis

$\mathrm{B}-40$

B3.4.3

Potential Damages .

$\mathrm{B}-43$

B3.4.4

Consideration of Safe Levee Height

B-43

B3.4.5

Summary and Conclusions

B-44

SECTION B4.0 - SUMMARY OF FLOOD DAMAGE ANALYSES

B-46

B4.1

SUMMARY OF RESULTS

B-46

B4.2

REVIEW OF SYSTEM FLOOD CONTROL

B-46 


\section{TABLE OF CONTENTS - CONT}

Chapter/Para

$\underline{\text { Page }}$

C SHALLOW-DRAFT NAVIGATION

$\mathrm{C}-1$

C.1

GENERAL

C-1

C.2

DESCRIPTION OF THE SOR TRANSPORTATION MODEL

$\mathrm{C}-1$

C.3

ANALYSIS OF ALTERNATIVE SYSTEM OPERATION STRATEGIES

$\mathrm{C}-2$

C.3.1

Base Case .

$\mathrm{C}-2$

C.3.2

Drawdown Simulation

$\mathrm{C}-8$

C.3.3

Modeling Criteria and Assumptions

C-9

C.3.3.1

C.3.3.2

C.3.3.3

C.3.3.4

C.3.3.5

C. 4

General

C-9

Capacity Assumptions

C-9

Monthly Volume of Shipments .

$\mathrm{C}-9$

Storage, Handling and Transportation Rates

C -10

Modal Shifts with Drawdown

C-10

C.5

C.5.1

C.5.2

C. 6

C.7

C.8

C.9

C.9.1

C.9.2

C.9.2.1

CHANGES IN TRANSPORTATION COSTS

$\mathrm{C}-10$ MODAL SHIFTS

C-12

Base Case

$\mathrm{C}-12$

Drawdown

$\mathrm{C}-12$

IMPACT OF WATERWAY CLOSURE ON TRANSPORTATION REVENUES

$\mathrm{C}-12$

TRANSPORTATION RATE IMPACTS

C-15

IMPACT OF INCREASED TRUCK TRAFFIC ON HIGHWAY MAINTENANCE

$\mathrm{C}-15$

RAILROAD IMPACTS

$\mathrm{C}-15$

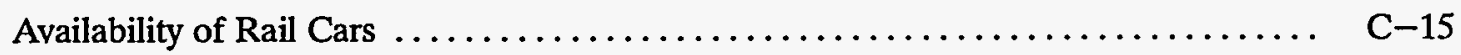

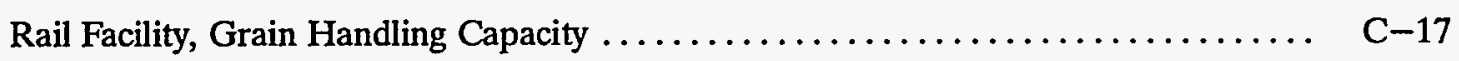

C.9.2.2

Country and River Elevators

$\mathrm{C}-17$

Export Elevators .

$\mathrm{C}-17$

C.9.3

LIMITATIONS TO THE ASSESSMENT OF RAIL CAPACITY

$\mathrm{C}-17$

\section{D}

RECREATION

D-1

D.1

OVERVIEW

$\mathrm{D}-1$

D.2

RECREATION USE WITH DIFFERENT WATER CONDITIONS

$\mathrm{D}-1$

D.3

E

RECREATION USE BY RECREATION ACTIVITY AND PROJECT .

D-1

THE FRAMEWORK FOR ANALYSIS

E-1

E.1

INTRODUCTION .

$\mathrm{E}-1$

E.2

STUDY REGIONS

E-1 


\section{TABLE OF CONTENTS - CONT}

Chapter/Para

Page

E.3

DEVELOPING THE INPUT-OUTPUT MODELS

E-2

E.3.1

Validating The Basic Data

$\mathrm{E}-3$

E.3.2

Adjusting the Trade Relationships ...

E-4

E.3.3

Construction of the I-O Models

E-4

E.3.4

Documentation for the Models

$\mathrm{E}-5$

E.4

E.4.1

LINKING THE DIRECT ECONOMIC IMPACTS TO THE REGIONAL ANALYSIS ..

$\mathrm{E}-5$

Measures of Direct Economic Impacts

E-5

E.4.1.1

Linking the Direct and Indirect Economic Impacts

E-6

E.4.2

E.4.2.1

Anadromous Fish

E-6

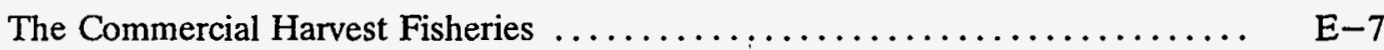

E.4.2.2

E.4.3

E.4.3.1

The Sport Harvest Fisheries

$\mathrm{E}-13$

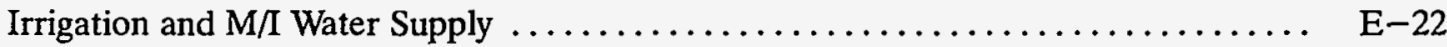

E.4.3.2

E.4.3.3

E.4.3.4

E.4.4

E.4.4.1

E.4.4.2

E.4.4.3

E.4.5

E.4.5.1

E.4.5.2

E.4.6

E.4.6.1

Grand Coulee Irrigation Pumping

E-22

Ice Harbor/John Day Agricultural Irrigation $\ldots \ldots \ldots \ldots \ldots \ldots \ldots \ldots \ldots . . . \ldots \ldots$

John Day and Lower Snake Municipal and Industrial Water Use $\ldots \ldots \ldots \ldots \ldots$ E-25

Combined Irrigation Impacts

$\mathrm{E}-27$

Navigation

$\mathrm{E}-27$

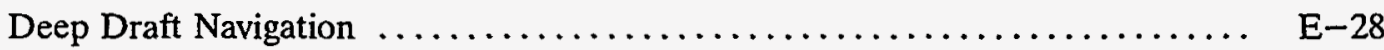

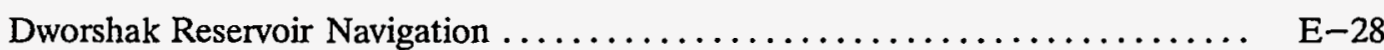

Non-Grain Commodity Movements $\ldots \ldots \ldots \ldots \ldots \ldots \ldots \ldots \ldots \ldots \ldots \ldots \ldots \ldots \ldots$

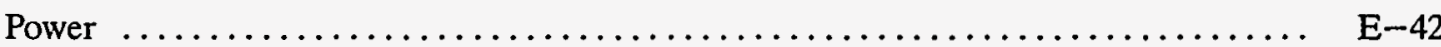

Allocating the Power Cost Impacts to Subregions $\ldots \ldots \ldots \ldots \ldots \ldots \ldots \ldots \ldots$ E-42

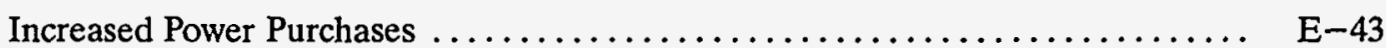

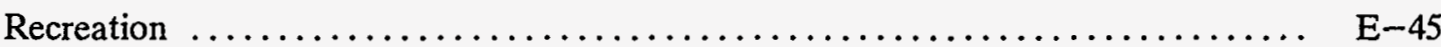

Characteristics of the Federal Project Recreation Visitors $\ldots \ldots \ldots \ldots \ldots \ldots \ldots$ E -45

E.4.6.2

E.4.7

E.4.8

E.4.8.1

E.5

E.5.1

E.5.1.1

E.5.2

Recreation Visitor Expenditures

$E-46$

Allocation of Recreation Impacts to Subregions $\ldots \ldots \ldots \ldots \ldots \ldots \ldots \ldots \ldots \ldots \ldots \ldots \ldots$

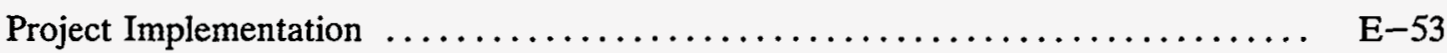

Allocations to Subregions $\ldots \ldots \ldots \ldots \ldots \ldots \ldots \ldots \ldots \ldots \ldots \ldots \ldots \ldots \ldots \ldots \ldots \ldots \ldots \ldots$

RESULTS OF THE REGIONAL ECONOMIC IMPACT ANALYSIS $\ldots \ldots \ldots \ldots \ldots \ldots$ E-56

SOR Alternatives Evaluated in the Regional Analysis $\ldots \ldots \ldots \ldots \ldots \ldots \ldots \ldots$ E-56

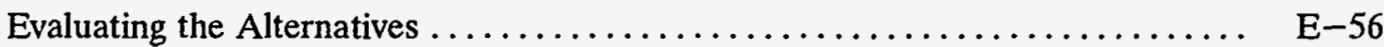

Summary of Output from the Regional Economic Analysis .............. E-57 


\section{TABLE OF CONTENTS - CONT}

Chapter/Para

E.5.2.1

E.5.2.1.1

E.5.2.2

E.5.2.3

E.5.2.3.1

E.5.2.4

E.5.2.4.1

E.5.2.5

E.6

F

SOCLAL IMPACTS ANALYSIS

F.1

F.1.1

F.1.2

F.1.2.1

F.1.2.2

F.1.2.3

F.1.2.4

F.1.3

F.1.3.1

F.1.3.2

F.1.3.3

F.1.3.4

F.1.3.5

F.1.4

F.1.4.1

F.1.4.2

F.1.4.3

F.1.4.4

F.1.4.5

F.1.4.6

F.1.4.7

F.1.4.7.1

F.1.4.7.2

Regional Income

Background
Economic Impacts in the Pacific Northwest Region

Regional Employment

Economic Impacts in Washington, Oregon, Idaho, and Montana

State Employment Impacts

Economic Impacts in the SOR Subregions

Employment Impacts

Regional Economic Impacts Related to Project Implementation

COMPARISON OF ALTERNATIVES

FOCUS COMMUNITY PROFILES

Focus Communities Located in Montana

The Community of Libby

The Community of Flathead Lake

The Community of Columbia Falls

The Flathead Indian Reservation

Focus Communities Located in Idaho

The Community of Bonners Ferry

The Kootenai Indian Reservation

The Community of Orofino

The Nez Perce Indian Reservation

The Community of Lewiston

Focus Communities Located in Washington

The Community of Clarkston

The Communities of Grand Coulee and Coulee Dam

The Community of Grand Coulee

The Community of Coulee Dam

The Colville Indian Reservation

The Spokane Indian Reservation

The Communities of the Tri-Cities

The Community of Richland

The Community of Kennewick $\underline{\text { Page }}$

E-58

$\mathrm{E}-58$

E-58

$\mathrm{E}-60$

$\mathrm{E}-60$

$\mathrm{E}-63$

$\mathrm{E}-63$

E-67

E-68

F-1

F-1

F-1

F-1

F-1

F-3

F-4

F-5

F-6

F-6

F-6

F-7

F-8

F-9

F-11

F-11

F-11

F-12

F-12

F-12

F-13

F-13

F-14

F-14 


\section{TABLE OF CONTENTS - CONT}

Chapter/Para

$\underline{\text { Page }}$

F.1.4.7.3

The Community of Pasco

$\mathrm{F}-15$

F.1.5

Focus Communities Located in Oregon

F-16

F.1.5.1

The Communities of Umatilla/Morrow

F-16

F.1.5.1.1

F.1.5.1.2

The Community of Umatilla

F-16

The Community of Irrigon ...

F-17

F.1.5.1.3

F.1.5.2

The Community of Boardman

F-17

The City of Portland

F -17

F.1.5.3

The City of Astoria

F-18

F.2

F.2.1

F.2.2

F.2.2.1

ESTIMATING THE SOCIOECONOMIC IMPACTS OF THE SOR

ALTERNATIVES ON THE FOCUS COMMUNITIES $\ldots \ldots \ldots \ldots \ldots \ldots \ldots \ldots \ldots \ldots \ldots \ldots \ldots$

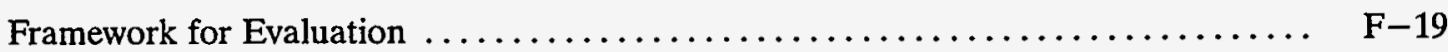

F.2.2.2

F.2.2.2.1

F.2.2.2.2

F.2.3

F.2.3.1

F.2.3.2

F.2.3.3

F.2.3.4

F.2.3.5

F.2.3.6

Regional and Subregional Economic Impacts

$\mathrm{F}-20$

Pacific Northwest Regional Impacts ........................ F-20

Economic Impacts in the SOR Subregions $\ldots \ldots \ldots \ldots \ldots \ldots \ldots \ldots \ldots \ldots, F-21$

Subregion-Level Employment Impacts $\ldots \ldots \ldots \ldots \ldots \ldots \ldots \ldots \ldots \ldots \ldots, F-22$

Impacts Related to Project Implementation and Pump Modifications ....... F-23

Allocation of Expected Economic Impacts to the Focus Communities $\ldots \ldots \ldots \ldots$ F-23

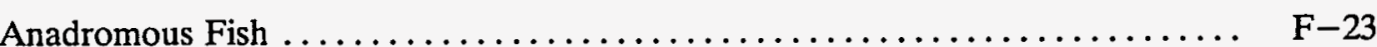

Irrigation and Municipal \& Industrial Water $\ldots \ldots \ldots \ldots \ldots \ldots \ldots \ldots \ldots, F-24$

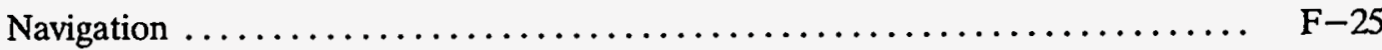

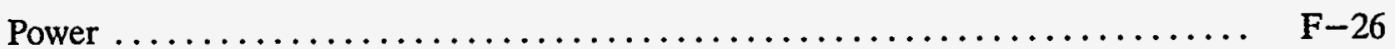

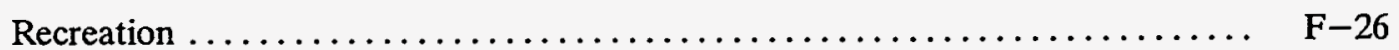

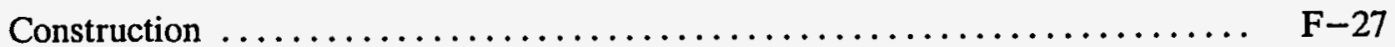

F.3

SIGNIFICANCE OF SOCIOECONOMIC IMPACTS IN THE

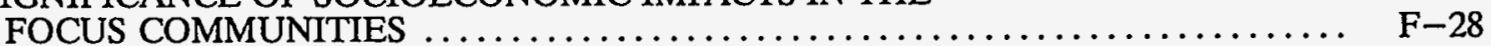

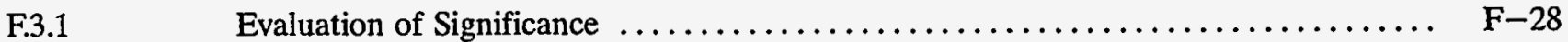

F.3.2 Socioeconomic Evaluations for the Seventeen Focus Communities ............ F-28

F.3.2.1

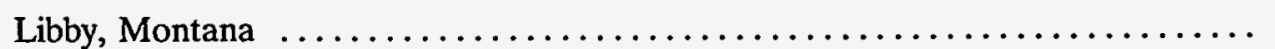

$\mathrm{F}-31$

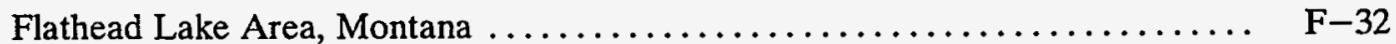

F.3.2.2

F.3.2.3

F.3.2.4

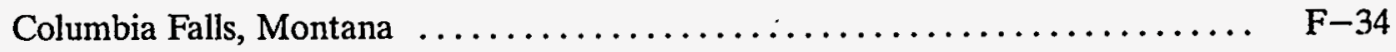

F.3.2.5

Flathead Indian Reservation.$\ldots \ldots \ldots \ldots \ldots \ldots \ldots \ldots \ldots \ldots \ldots \ldots$

F-35

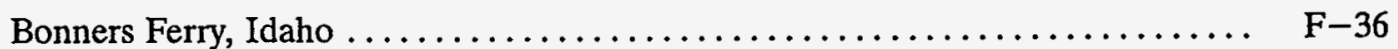

F.3.2.6

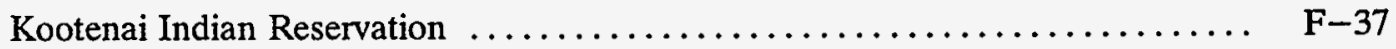

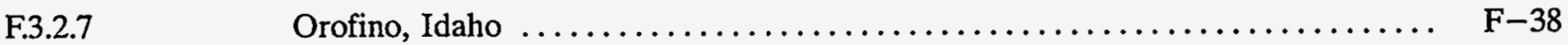




\section{TABLE OF CONTENTS - CONT}

Chapter/Para

F.3.2.8

F.3.2.9

F.3.2.10

F.3.2.11

F.3.2.12

F.3.2.13

F.3.2.14

F.3.2.15

F.3.2.16

F.3.2.17

F.3.3

F.4

F.5
Nez Perce Indian Reservation

Lewiston, Idaho

Clarkston, Washington

Grand Coulee and Coulee Dam, Washington

Colville Indian Reservation

Spokane Indian Reservation

Tri-Cities, Washington

Umatilla/Morrow, Oregon

Portland, Oregon

Astoria, Oregon

Summary of Expected Socioeconomic Impacts

REFERENCES

FOCUS COMMUNITY PROFILES
Page

$\mathrm{F}-40$

F-41

F-44

F-46

F-47

$\mathrm{F}-48$

F-49

$\mathrm{F}-52$

$\mathrm{F}-54$

$\mathrm{F}-56$

F-57

$\mathrm{F}-58$

$\mathrm{F}-61$

\section{LIST OF TABLES}

Table

Title

$\underline{\text { Page }}$

1-1 Subregions Identified for the SOR Regional Economic Analysis $\ldots \ldots \ldots \ldots \ldots \ldots \ldots \ldots \ldots$

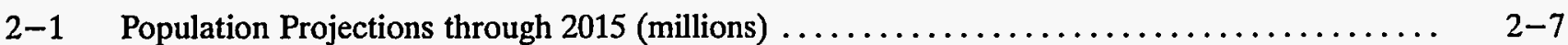

2-2 Flood Control Study Areas ...................................... 2-10

2-3 Irrigated Acreage in Columbia River Basin by State $-1989-90$ (acres) . ............ 2-12

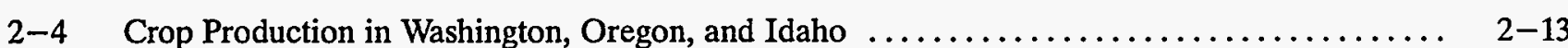

2-5 Irrigation Diversions and Net Depletions by Basin $\ldots \ldots \ldots \ldots \ldots \ldots \ldots \ldots \ldots \ldots \ldots .2-14$

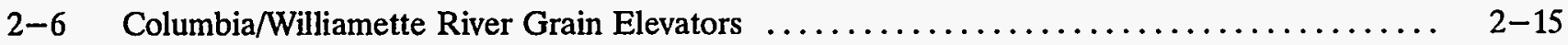

2-7 Top Five Export Countries - 1990, Columbia River Deep-Draft Channel ........... 2-16

2-8 Top Five Import Countries - 1989, Columbia River Deep-Draft Channel ............ 2-16

2-9 Major Export Items from the Columbia River (short-tons) $\ldots \ldots \ldots \ldots \ldots \ldots \ldots \ldots \ldots \ldots .2-17$

2-10 Location of Elevators with Grain Handling Capability, Columbia/Snake Shallow-Draft Navigation Channel .................................. 2-18

2-11 Annual U.S. Rail-to-Port Grain Traffic Pacific Northwest Ports,

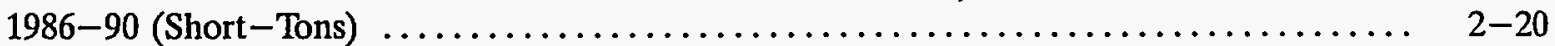

2-12 Receipts of Wheat and Barley at Columbia River Export Houses by Mode of Transportation for Crop year 1987-88 to 1990-91 (in thousands of bushels) $\ldots \ldots \ldots \ldots \ldots .2-20$ 


\section{LIST OF TABLES - CONT}

Table

2-13 Recreation Areas and Recreation Activities .

Title $\underline{\text { Page }}$

$2-23$

$3-23$

Period (1,000 Fish)

Columbia River Salmon Ex-Vessel Average Values per Fish for the

1987 to 1991 Period

$3-25$

$3-26$

3-3 Columbia River Salmon Angler Trips from 1987 to 1991

3-4 Recreation Values for SOR Analysis--Based on National Studies from 1983 to 1992 and/or Regional Studies for OR, WA, ID, and MT (Consumer Surplus Values, Mid-1993 Dollars per Recreation Day)

"Low" Value Estimates of Columbia River Salmon and Steelhead

Catch - - Annual Averages for the 1987 to 1991 Period

$3-29$

3-6 Columbia River Salmon Catch and "High" Value Estimates - - Annual Averages

for the 1987 to 1991 Period

$3-30$

$3-34$

$3-44$

$3-45$

$3-49$

$3-50$

$3-51$

$3-53$

$3-54$

$4-2$

$4-18$

Summary of Alternatives in the Draft and Final EIS

$4-21$

(POL--project-on-line) Dates of System Operation Strategies

4-4 Summary of Implementation Costs for Lower Snake River Projects--

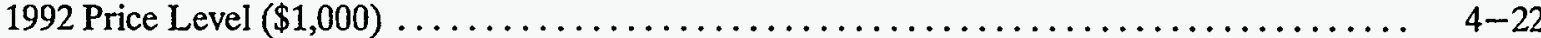

4-5 Summary of Implementation Costs for John Day Project-1992 Price Level $(\$ 1,000)$

$4-24$

4-6 Equivalent Annual Harvest Based on 100 Year Analysis for Interest Rates of 3.0 and 7.75 Percent (Number Of Fish Harvested)

$4-29$

4-7 Allocation of Annual Catch to Commercial and Sport Fisheries in 2010 for SOS 2c, SOS $9 \mathrm{~b}$, and the Preferred Alternative (1,000 Fish Per Year)

$4-30$

$4-31$ SOS $2 \mathrm{c}$ and SOS $9 \mathrm{~b}$

Columbia River Salmon and Steelhead "High" Value Estimates for Catch in 2010

for Preferred Alternative 


\section{LIST OF TABLES - CONT}

Table

Title

$\underline{\text { Page }}$

4-10 Annual Commercial and Sport Values $(\$ 1,000)$ of Salmon and Steelhead Catch

for Each SOS for Selected Years .

$4-33$

4-11 Summary of Equivalent Annual Catch (@ 3.0 percent) Number of Fish Harvested (1,000 Fish Per Year)

4-12 Summary of the Equivalent Annual Value of the Commercial and Sport Catch of Salmon

and Steelhead for Each SOS--Annual Values Discounted at 3.0 Percent $(\$ 1,000) \ldots \ldots$

$4-34$

$4-35$

4-13 Summary of the Equivalent Annual Value of the Commercial and Sport Catch of Salmon and Steelhead for Each SOS--Annual Values Discounted at 7.75 Percent $(\$ 1,000) \ldots \ldots$.

4-14 Summary of Flood Damages, Upper Columbia River Subarea $(\$ 1,000) \ldots \ldots \ldots \ldots \ldots$

4-36

4-15 Analysis of Equivalent Annual Flood Damages Dworshak to Lewiston

Levees (7.75 Percent Interest)

$4-38$

$4-39$

4-16 Analysis of Equivalent Annual Flood Damages, Dworshak to Lewiston Levees (3.0 Percent Interest)

$4-40$

4-17 Comparison of Levee Crest Elevations to River Stages* - 500-Year Discharge Event at The Dalles, OR (in Feet NGVD)

4-42

4-18 Total Equivalent Annual Flood Damages, Columbia Basin (Discount Rate of 7.75 Percent $--\$ 1,000$ )

$4-43$

4-19 Total Equivalent Annual Flood Damages, Columbia Basin (Discount Rate of 3.0 Percent $--\$ 1,000$ )

4-20 Annual Irrigation Pumping Requirement and Cost from Grand Coulee to Banks Lake (Federal Columbia Basin Project)

$4-45$

4-21 Summary of Modification and Annual Costs for Irrigation Pump Stations on the John Day and Ice Harbor Pools

$4-46$

4-22 Summary of Total Increased Costs for Commercial Irrigation @ 73/4\%, Compared to SOS 2c

$4-46$

4-23 Summary of Total Increased Costs for Commercial Irrigation @ 3\%, Compared to SOS $2 \mathrm{c}$

$4-47$

4-24 Summary of Pump Station Modification Costs for M\&I Pumpers

$4-48$

4-25 Increased Annual Operation Maintenance and Power Cost, M\&I Pumpers, Compared to SOS $2 \mathrm{c}$

4-26 Summary of Total Increased Pumping Costs for M\&I @ 73/4\%, Compared to SOS $2 \mathrm{c}$

4-27 Summary of Total Increased Pumping Costs for M\&I @ 3\%,

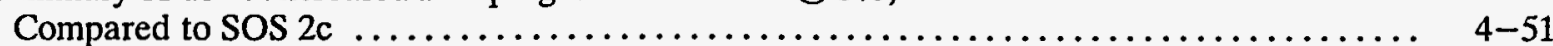

4-28 Gross Annual Costs of Commodity Shipments on the Columbia-Snake River System (1992 dollars) 


\section{LIST OF TABLES - CONT}

Table

$\underline{\text { Title }}$

$\underline{\text { Page }}$

4-29 Average Annual and Equivalent Annual Transportation Costs Associated with

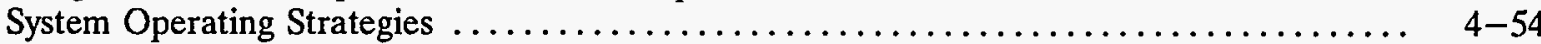

4-30 Kalama Percent of Time Stage is within the Stage Interval for Specific

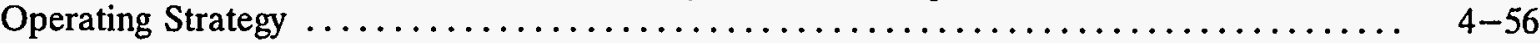

4-31 Wauna Percent of Time Stage is within the Stage Interval for Specific

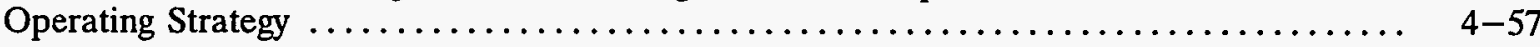

4-32 Vancouver Percent of Time Comparison of Specific Operating Strategy with SOS 2c ....... 4-58

4-33 Kalama Percent of Time Comparison of Specific Operating Strategy with SOS 2c ......... 4-59

4-34 Wauna Percent of Time Comparison of Specific Operating Strategy with SOS $2 c \ldots \ldots \ldots .4-60$

4-35 Average Annual Cost of Transportation of Logs by Truck,

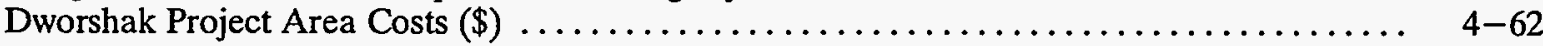

4-36 Average Annual Cost of Transportation of Logs by Truck, Dworshak Project

Area (\$): Ascending Order by Mean Value $\ldots \ldots \ldots \ldots \ldots \ldots \ldots \ldots \ldots \ldots \ldots \ldots \ldots \ldots, 4,63$

4-37 Average Annual and Equivalent Annual Cost of Transportation of Logs by Truck,

Dworshak Project Area (\$), as Compared to SOS 2c: Ascending Order by Average

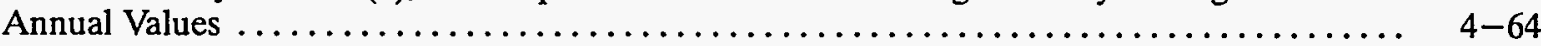

4-38 Total Gross System Replacement Costs (Millions 1993 Dollars) ................... 4-65

4-39 Equivalent Annual Gross Replacement Cost Deltas from SOS 2c

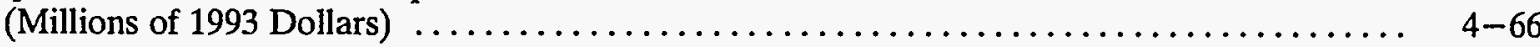

4-40 Equivalent Annual Implementation Cost Deltas from SOS 2c (Millions 1993 Dollars) ....... 4-66

4-41 Total Equivalent Annual Gross Costs Delta from SOS 2c (Millions 1993 Dollars) ......... 4-67

4-42. Gross Average Regional Retail Rate Impact, Percent Change from SOS $2 c$

(Discount Rate of 3 Percent) ...................................... 4-67

4-43 Change in Regional Electricity Demand, from SOS 2c (Average MWs,

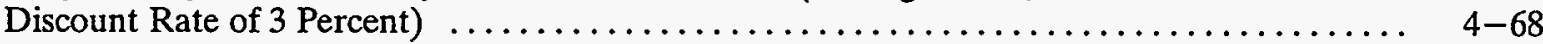

4-44 Total Net System Replacement Costs (Millions 1993 Dollars) $\ldots \ldots \ldots \ldots \ldots \ldots \ldots \ldots \ldots \ldots$. $4-68$

4-45 Equivalent Annual Net Replacement Cost Deltas from SOS 2c

(Millions 1993 Dollars) ..................................... 4-69

4-46 Total Equivalent Annual Net Cost Deltas from SOS 2c (Millions 1993 Dollars) .......... 4-70

4-47 Net Average Regional Retail Rate Impact, Percent Change from SOS $2 c \ldots \ldots \ldots \ldots \ldots . .4 \quad 4-70$

4-48 Recreation Use Summary in Annual Recreation Days Based on 50-Year

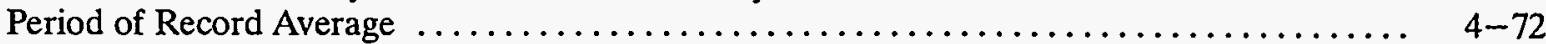

4-49 Average Annual Summer Consumer Surplus for Modeled Reservoirs and

River Reaches (Undiscounted) - - 50-year Period of Record ............... 4-73

4-50 Equivalent Annual Consumer Surplus (\$), Summer Season $\ldots \ldots \ldots \ldots \ldots \ldots \ldots \ldots \ldots .4 . \ldots \ldots$ 


\section{LIST OF TABLES - CONT}

Table

$\underline{\text { Title }}$

$\underline{\text { Page }}$

4-51 Summary of Costs and Benefits of Alternative SOSs as Compared with

SOS 2c- - Average Annual Values by Year of Impact ( 7.75 percent discount rate) $\ldots \ldots \ldots$ 4-77

4-52 Summary of Costs and Benefits of Alternative SOSs as Compared with

SOS 2c-- Average Annual Values by Year of Impact (3.0 percent discount rate) ....... 4-84

4-53 Economic Measures Used to Value Direct Impacts for the Analysis of Indirect Impacts ...... 4-91

4-54 Allocation of Commercial Harvest to Subregions, in Percent ................. 4-92

4-55 Allocation of Sport Harvest to Subregions, in Percent .................... 4-94

4-56 Allocation of Shallow Draft Navigation Economic Impacts to the States and

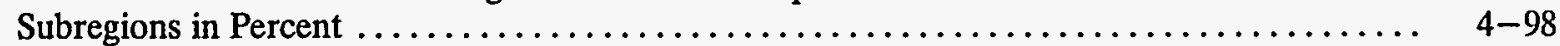

4-57 Location of Federal Projects within SOR Subregions $\ldots \ldots \ldots \ldots \ldots \ldots \ldots \ldots \ldots \ldots \ldots \ldots$ 4-101

5-1. Economic Cost/Benefit Differences from the Base Case - SOS 2c

(Equivalent Annual Values, 7.75 Percent Interest Rate) $\ldots \ldots \ldots \ldots \ldots \ldots \ldots \ldots \ldots \ldots .5-3$

5-2. Alternatives Ranked From Best to Worst Bases on Differences in Total System

Costs: Economic System Cost Differences From the Base Case - SOS 2c

(Equivalent Annual Values, 7.75 Percent Interest Rate) $\ldots \ldots \ldots \ldots \ldots \ldots \ldots \ldots \ldots \ldots \ldots$

5-3. Ranking of Alternatives - Best to Worst - By Cost/Benefit Category Using

Differences From the Base Case - SOS 2c (Equivalent Annual Values,

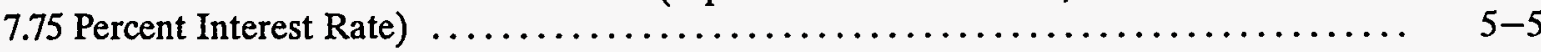

5-4 Economic Cost/Benefit Differences from the Base Case - SOS 2c

(Equivalent Annual Values, 3.0 Percent Interest Rate) $\ldots \ldots \ldots \ldots \ldots \ldots \ldots \ldots \ldots \ldots \ldots$

5-5 Alternatives Ranked From Best to Worst Based on Differences in Total System Costs:

Economic System Cost Differences from the Base Case - SOS 2c

(Equivalent Annual Values, 3.0 Percent Interest Rate) $\ldots \ldots \ldots \ldots \ldots \ldots \ldots \ldots \ldots \ldots \ldots$

5-6 Ranking of Alternatives - Best to Worst - By Cost/Benefit Category using

Differences from the Base Case - SOS 2c (Equivalent Annual Values,

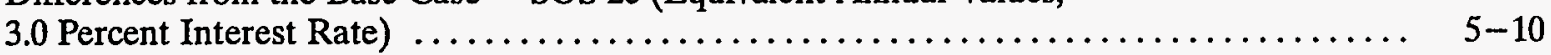

5-7 SOR Alternatives Evaluated in the Regional Analysis $\ldots \ldots \ldots \ldots \ldots \ldots \ldots \ldots \ldots \ldots \ldots$. $5-15$

5-8 Summary of Pacific Northwest Regional Employment Impacts

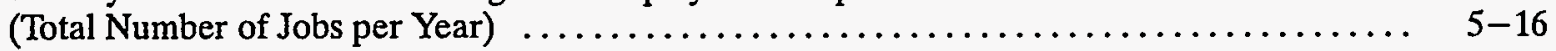

5-9 Summary of Pacific Northwest Regional Income Impacts (Million Dollars per Year) ....... 5-17

5-10 Summary of State Employment Impacts--Washington, Oregon, Idaho and

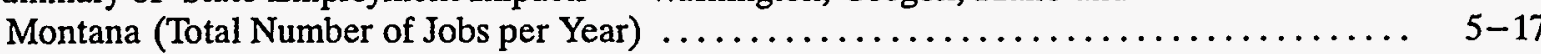

5-11 Summary of State Income Impacts--Washington, Oregon, Idaho and

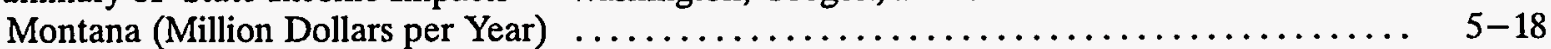

5-12 Summary of Subregional Employment Impacts (Total Number of

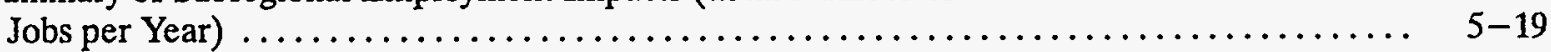

5-13 Summary of Subregional Income Impacts (Million Dollars per Year) $\ldots \ldots \ldots \ldots \ldots \ldots \ldots .5-20$ 


\section{LIST OF TABLES - CONT}

Table Title

5-14 Employment Impacts Related to Project Construction (Total Number of

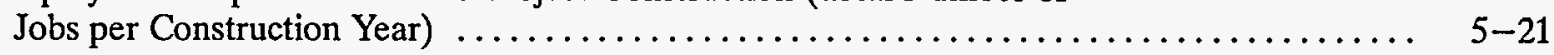

5-15 Employment Impacts Related to Pump Modification (Total Number of

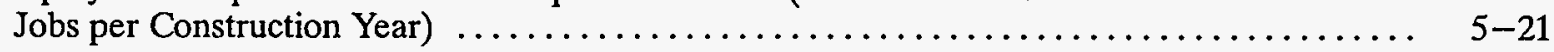

6-1 List of Preparers, U.S. Army Corps of Engineers $\ldots \ldots \ldots \ldots \ldots \ldots \ldots \ldots \ldots \ldots \ldots \ldots \ldots \ldots \ldots \ldots$

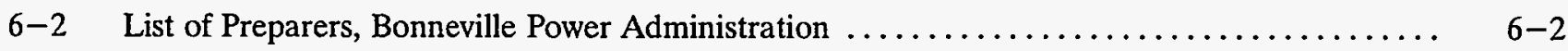

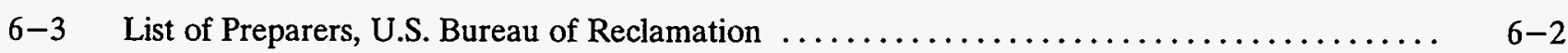

6-4 List of Preparers, Northwest Economic Associates ........................ 6-2

6-5 List of Preparers, Transportation Research Analysis Center ................... 6-3

6-6 List of Members of the Economic Analysis Group ....................... $6-3$

A-1 Estimated Harvest Over Time of Fall Chinook (Numbers of Fish Harvested per Year) ....... A-2

A-2 Estimated Harvest Over Time of Spring-Summer Chinook (Numbers of Fish

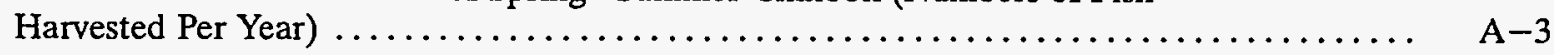

A-3 Estimated Harvest Over Time of Steelhead (Numbers of Fish Harvested Per Year) ......... A-4

A-4 Average Annual Harvest - Transport Sensitivity (Scenario A86 for Spring-Summer

Chinook and Sockeye - 36\% Survival and Scenario F86 for Fall Chinook

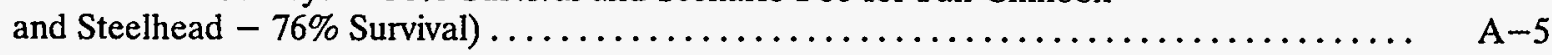

A-5 Average Annual Harvest - Transport Sensitivity (Scenario FB - 98\%

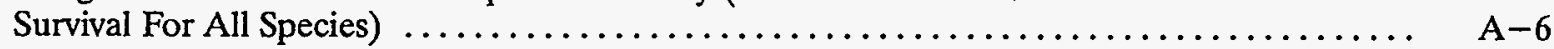

A-6 Summary of Average Annual Values With Transportation (Scenario A86 - 36\%

Survival), Annual Values Discounted At $3.0 \%(\$ 1,000) \ldots \ldots \ldots \ldots \ldots \ldots \ldots \ldots \ldots \ldots \ldots$

A-7 $\begin{gathered}\text { Summary of Average Annual Values With Transportation (Scenario FB }-98 \% \\ \text { Survival), Annual Values Discounted At } 3.0 \%(\$ 1,000) \ldots \ldots \ldots \ldots \ldots \ldots \ldots \ldots \ldots \ldots\end{gathered}$

A-8 Summary of Average Annual Values With Transportation (Scenario A86 - 76\%

Survival), Annual Values Discounted At $7.75 \%(\$ 1,000) \ldots \ldots \ldots \ldots \ldots \ldots \ldots \ldots \ldots \ldots$

A-9 Summary of Average Annual Values With Transportation (Scenario FB - 98\%

Survival), Annual Values Discounted At $7.75 \%(\$ 1,000) \ldots \ldots \ldots \ldots \ldots \ldots \ldots \ldots \ldots \ldots$

B-1 Stage vs Flood Damage Libby Dam to Kootney Lake

(July 1992 Prices \& 1995 Conditions) $(\$ 1,000) \ldots \ldots \ldots \ldots \ldots \ldots \ldots \ldots \ldots \ldots \ldots \ldots \ldots$

B-2 Average Annual Damages Libby Dam to Kootnay Lake

(July 1992 Prices \& 1995 Conditions) $(\$ 1,000) \ldots \ldots \ldots \ldots \ldots \ldots \ldots \ldots \ldots \ldots \ldots \ldots \ldots \ldots \ldots \ldots$

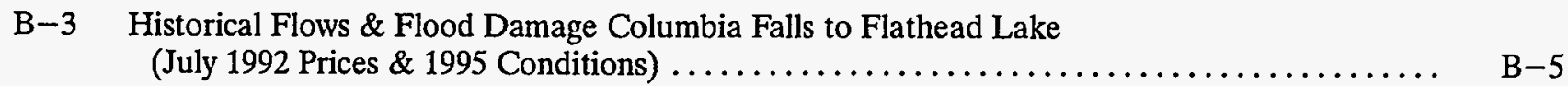

B-4 Discharge vs Flood Damage Columbia Falls to Flathead Lake

(July 1992 Prices \& 1995 Conditions) $(\$ 1,000) \ldots \ldots \ldots \ldots \ldots \ldots \ldots \ldots \ldots \ldots \ldots \ldots$ 


\section{LIST OF TABLES - CONT}

Table

$\underline{\text { Title }}$

$\underline{\text { Page }}$

B-5 Average Annual Damages Columbia Falls to Flathead Lake

(July 1992 Prices \& 1995 Conditions) $(\$ 1,000)$

B-7

B-6 Stage vs Flood Damage - Flathead Lake (July 1992 Prices \& 1995

Conditions) $(\$ 1,000)$

$\mathrm{B}-8$

B-7 Average Annual Damages Flathead Lake (July 1992 Prices \& 1995 Conditions) $(\$ 1,000)$

B-8 Discharge vs Flood Damage Kerr Dam to Thompson Falls (July 1992 Prices \& 1995 Conditions $-\$$ )

B-10

B-9 Average Annual Damages Kerr Dam to Thompson Falls (July 1992 Prices \& 1995 Conditions) $(\$ 1,000)$.

B-10

B-10 Maximum and Minimum Elevation for Pend Oreille Lake, as Measured at Hope Idaho .

$\mathrm{B}-12$

B-11 Maximum Stages of Lake Pend Oreille for Historic Floods (at Hope, Idaho) .

$\mathrm{B}-12$

B-12 Stage vs Flood Damage Pend Oreille Lake (July 1992 Prices \& 1995

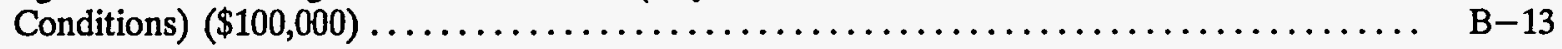

B-13 Average Annual Damages Pend Oreille Lake (July 1992 Prices \& 1995 Conditions) $(\$ 1,000)$.

B-13

B-14

Peak Discharges for Historic Floods (at Albeni Falls Damsite)

B-14

B-15

Discharge vs Flood Damage Albeni Falls to Cusick (July 1992 Prices \& 1995 Conditions) $(\$ 1,000)$

B-15

B-16 Average Annual Damages Albeni Falls to Cusick (July 1992 Prices \& 1995 Conditions) $(\$ 1,000)$

B-15

B-17 Summary of Flood Damages, Upper Columbia River Subarea $(\$ 1,000)$.

B-16

B-18 Clearwater River Winter Rainstorms and Winter and Spring Snowmelt Floods Summary of Unregulated Discharge and Runoff at Spalding

B-19 Inventory of Damageable Property, Reach $1 \ldots \ldots \ldots \ldots \ldots \ldots \ldots \ldots \ldots \ldots \ldots \ldots$

B-20 Inventory of Damageable Property, Reach 2 B-22

B-21 SOR Flood Control - Discharge/Damage Summary Clearwater River - Reach 1 Mouth of North Fork, Clearwater River to the Upstream End of Lewiston Levees, October 1992 Price Level

B-22 SOR Flood Control - Damage Summary Clearwater River - Reach 2 Confluence of Snake River to Downstream of Lewiston Levee with Occurrence of a Levee Overtopping Flood $(151,000 \mathrm{cfs})$ - October 1992 Price Level $\ldots \ldots \ldots \ldots \ldots \ldots \ldots \ldots$ B 25

B-23 SOR Flood Control, Lewiston, Idaho--Percent Damage to Structures and Contents

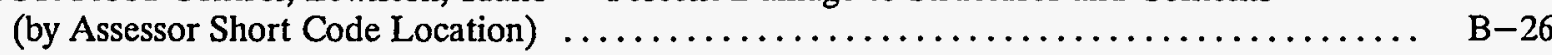

B-24 Transportation Cost by Commodity Group--October 1992 Price Level .............. B-28

B-25 Generation (Kilowatt Hours) - -October 1992 Price Level ..................... B-29 


\section{LIST OF TABLES - CONT}

Table

$\underline{\text { Title }}$

$\underline{\text { Page }}$

B-26 SOR Flood Control - Damage Summary Clearwater River - Total of Reaches

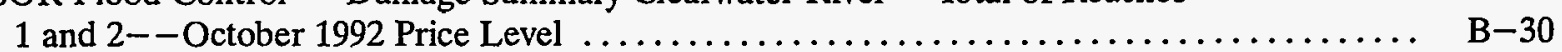

B-27 Analysis of Equivalent Annual Flood Damages Dworshak to Lewiston Levees

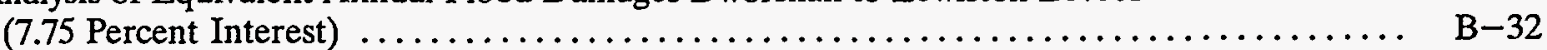

B-28 Analysis of Equivalent Annual Flood Damages, Dworshak to Lewiston

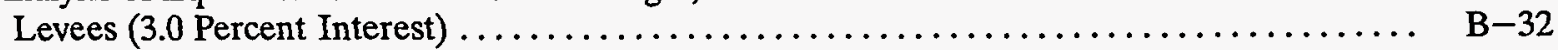

B-29 Major Tributaries to the Columbia River Downstream from Bonneville Dam .......... B-34

B-30 Frequency of Occurrence and Elevation of Regulated Flood Events as Measured

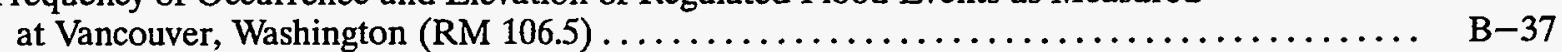

B-31 Flood Protection Levee Districts on the Lower Columbia River Between Bonneville

Dam and River Mile $40 \ldots \ldots \ldots \ldots \ldots \ldots \ldots \ldots \ldots \ldots \ldots \ldots \ldots \ldots \ldots$

B-32 Flood Protection Levee Districts on the Lower Columbia River ............... B-40

B-33 Columbia River Discharge Frequency Data at The Dalles Alternative Plans

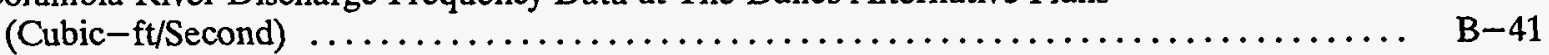

B-34 Columbia River Stage-Discharge Relationships by Location (ft-NGVD) $\ldots \ldots \ldots \ldots \ldots$ B-42

B-35 Comparative River Stages, Base Condition vs. Alternative Plans* 500-Year

Discharge Event at The Dalles, OR - River Stage in feet, msl ................ B-43

B-36 Comparison of Levee Crest Elevations to River Stages * - 500-Year Discharge

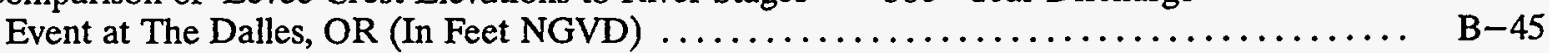

B-37 Total Average Annual Equivalent Damages Columbia Basin at a Discount

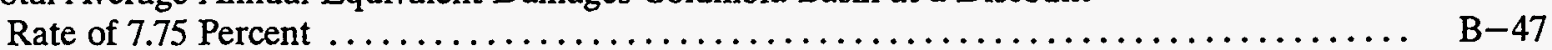

B-38 Total Average Annual Equivalent Damages Columbia Basin $3.0 \% \ldots \ldots \ldots \ldots \ldots \ldots \ldots \ldots$ B-48

C-1. Volume of Grain Shipped by Barge on the Shallow-Draft Waterway,

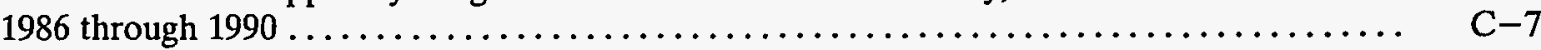

$\mathrm{C}-2$. Number of Country Elevators by State $\ldots \ldots \ldots \ldots \ldots \ldots \ldots \ldots \ldots \ldots \ldots \ldots \ldots \ldots \ldots \ldots \ldots$

C-3. River Ports and Elevators Located on the Shallow-Draft Waterway, by

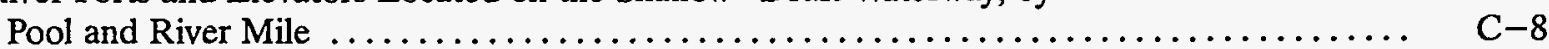

C-4 Percent Shift of Grain Movements from Barge to Rail by River Port with

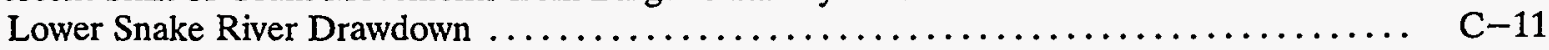

C-5. Grain Transportation Costs for Storage, Handling, and Transportation Mode,

C-6. Grain Transportation Costs for Storage, Handling, and Transportation Mode,

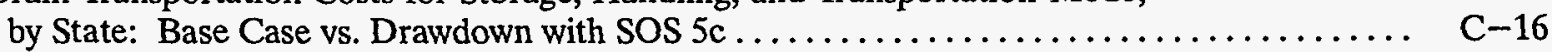

C-7. Difference in Bushels Shipped by Rail for a Drawdown During the Month of August ....... C-17

D-1 Summary of Recreation Use by Project/Reach (Annual Recreation Days -

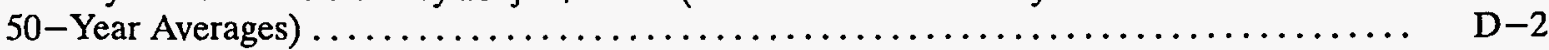




\section{LIST OF TABLES - CONT}

Table

Title

$\underline{\text { Page }}$

D-2 Summary of Recreation Use by Project/Reach (Annual Recreation Days -

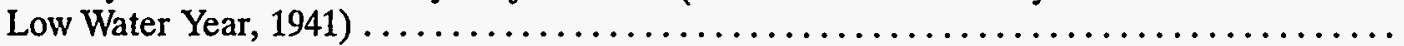

D-3

D-3 Summary of Recreation Use by Project/Reach (Annual Recreation Days -

High Water Year, 1976)

D-3

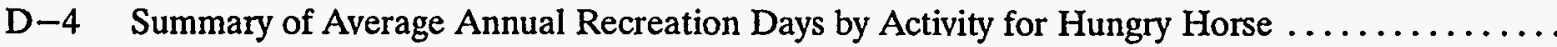

$\mathrm{D}-4$

D-5 Summary of Average Annual Recreation Days by Activity for Lake Pend Oreille ..........

D-4

D-6 Summary of Average Annual Recreation Days by Activity for Lake Koocanusa ............

$\mathrm{D}-5$

D-7 Summary of Average Annual Recreation Days by Activity for Kootenai River ............

$\mathrm{D}-5$

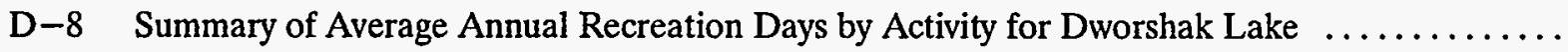

D-6

D-9 Summary of Average Annual Recreation Days by Activity for Clearwater River ...........

D-6

D-10 Summary of Average Annual Recreation Days by Activity for Lower Granite

$\mathrm{D}-7$

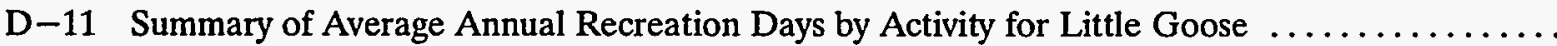

$\mathrm{D}-7$

D-12 Summary of Average Annual Recreation Days by Activity for Lower Monumental .........

$\mathrm{D}-8$

D-13 Summary of Average Annual Recreation Days by Activity for Ice Harbor $\ldots \ldots \ldots \ldots \ldots$

$\mathrm{D}-8$

D-14 Summary of Average Annual Recreation Days by Activity for Lake Roosevelt .............

D-9

D-15 Summary of Average Annual Recreation Days by Activity for John Day . . . . . . . . . . .

D-9

E-1 Multi-County Subregions Identified for the Regional Economic Impact Analysis .........

E-3

E-2 Economic Measures Used to Value the Direct Impacts of the SOR Alternatives ...........

E-6

E-3 Distribution of Anadromous Stocks by Harvest Fisheries $\ldots \ldots \ldots \ldots \ldots \ldots \ldots \ldots \ldots$

E-7

E-4 Allocation of Commercial Harvest to Subregions $\ldots \ldots \ldots \ldots \ldots \ldots \ldots \ldots \ldots \ldots \ldots \ldots \ldots \ldots \ldots \ldots \ldots$

$\mathrm{E}-8$

E-5 Estimated Number of Fish Harvested in the Ocean Commercial Fishery, 2020 and Beyond

E-6 Estimated Number of Fish Harvested in the In-River Commercial Fishery, 2020 and Beyond

E-7 Operating Expenditures for the In-River Commercial Fisheries $\ldots \ldots \ldots \ldots \ldots \ldots \ldots \ldots$

$\mathrm{E}-12$

E-8 Operating Expenditures for the Ocean Commercial Fisheries $\ldots \ldots \ldots \ldots \ldots \ldots \ldots \ldots$

E-13

E-9 Operating Expenditures for Fish Processing $\ldots \ldots \ldots \ldots \ldots \ldots \ldots \ldots \ldots \ldots \ldots \ldots \ldots \ldots$

$\mathrm{E}-14$

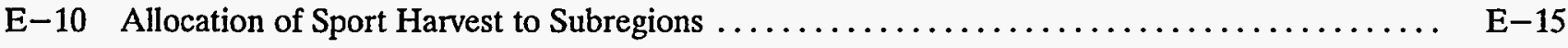

E-11 Estimated Number of Fish Harvested in the Ocean Sport Fishery, 2020 and Beyond

E-12 Estimated Number of Fish Harvested in the In-River Sport Fishery,

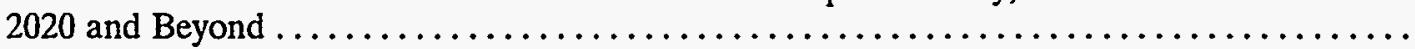




\section{LIST OF TABLES - CONT}

Table

$\underline{\text { Title }}$

$\underline{\text { Page }}$

E-14 Average Annual Pumping Costs for Grand Coulee Irrigation Pumping $\ldots \ldots \ldots \ldots \ldots \ldots \ldots$ E-24

E-15 Average Annual Modification Pumping Costs for Ice Harbor/

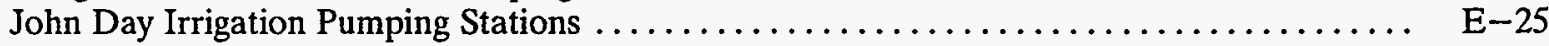

E-16 Average Annual Modification Costs for John Day and Lower Snake

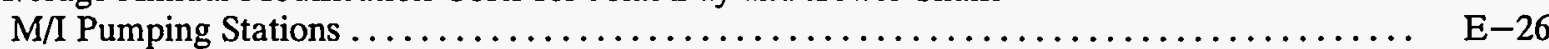

E-17 Allocation of Increased Pumping Costs to Subregions $\ldots \ldots \ldots \ldots \ldots \ldots \ldots \ldots \ldots \ldots \ldots \ldots \ldots$

E-18 Average Annual Truck Transportation Costs for Dworshak Reservoir

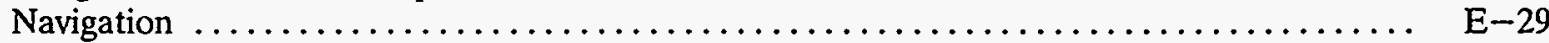

E-19 Transportation Costs Paid by Farmers Shipping Grain on the Columbia-Snake

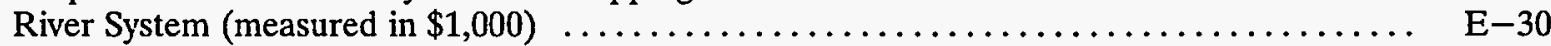

E-20 Transportation Revenues from Grain Shipments, Allocated by Mode and

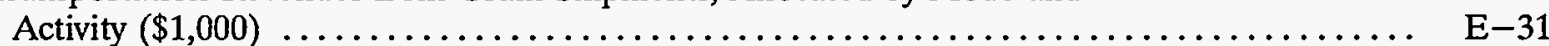

E-21 Allocation of Non-Grain Commodity Origins to Subregions $\ldots \ldots \ldots \ldots \ldots \ldots \ldots \ldots \ldots \ldots$

E-22 Transportation Revenues from Non-Grain Commodity Shipments $(\$ 1,000) \ldots \ldots \ldots \ldots \ldots$ E-37

E-23 Net System Power Replacement Costs Allocated to States,

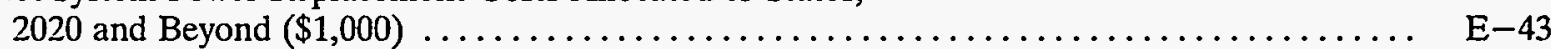

E-24 Net System Power Replacement Costs Allocated to Subregions,

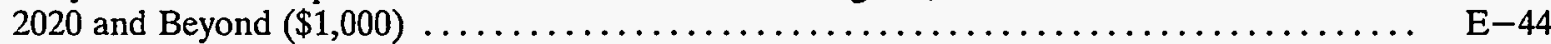

E-25 Location of the Federal Projects Within SOR Subregions $\ldots \ldots \ldots \ldots \ldots \ldots \ldots \ldots \ldots \ldots \ldots$

E-26 Residence Origin and Length of Stay for Recreation Visitors at the

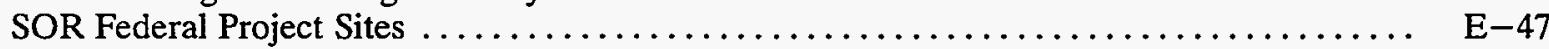

E-27 Choice of Lodging by Overnight Visitors to the SOR Federal Project Sites . . . . . . . . . E E-47

E-28 Recreation Expenditures of Non-Resident Visitors to the Federal Projects ............ E-48

E-29 Annual Recreation Days and Length of Stay at the SOR Federal Project Sites,

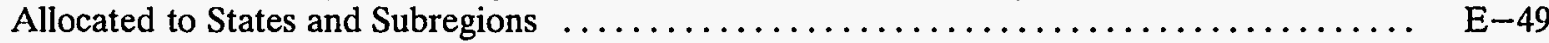

E-30 Construction Costs for Project Implementation, $(\$ 1,000)$

(Does Not Include Irrigation Pump Modifications) $\ldots \ldots \ldots \ldots \ldots \ldots \ldots \ldots \ldots \ldots \ldots \ldots \ldots \ldots$

E-31 Construction Costs for Irrigation Pump Modifications $\ldots \ldots \ldots \ldots \ldots \ldots \ldots \ldots \ldots \ldots \ldots$

E-32 SOR Alternatives Evaluated in the Regional Analysis $\ldots \ldots \ldots \ldots \ldots \ldots \ldots \ldots \ldots \ldots \ldots$ E-56

E-33 Summary of Pacific Northwest Regional Employment Impacts $\ldots \ldots \ldots \ldots \ldots \ldots \ldots \ldots \ldots \ldots$ E-59

E-34 Summary of Pacific Northwest Regional Income Impacts $\ldots \ldots \ldots \ldots \ldots \ldots \ldots \ldots \ldots \ldots$

E-35 Distribution of Expected Resource Changes by State $\ldots \ldots \ldots \ldots \ldots \ldots \ldots \ldots \ldots \ldots \ldots$ E -60

E-36 Summary of State Employment Impacts $\ldots \ldots \ldots \ldots \ldots \ldots \ldots \ldots \ldots \ldots \ldots \ldots \ldots \ldots \ldots$

E-37 Distribution of Expected Resource Changes by SOR Subregion $\ldots \ldots \ldots \ldots \ldots \ldots \ldots \ldots \ldots$ E -63

E-38 Summary of Employment Impacts in the SOR Subregions $\ldots \ldots \ldots \ldots \ldots \ldots \ldots \ldots \ldots \ldots \ldots$ 


\section{LIST OF TABLES - CONT}

Table

Title

$\underline{\text { Page }}$

E-39 Employment Impacts Related to Project Implementation Construction $\ldots \ldots \ldots \ldots \ldots \ldots$ E-67

E-40 Employment Impacts Related to Construction for Pump Modifications $\ldots \ldots \ldots \ldots \ldots \ldots$ E-68

E-41 Ranking of SOR Alternatives by Regional Employment Impacts for All Resources in the Pacific Northwest Region $\ldots \ldots \ldots \ldots \ldots \ldots \ldots \ldots \ldots \ldots \ldots \ldots \ldots \ldots \ldots \ldots \ldots$

E-42 Ranking of SOR Alternatives by Net Regional Employment Impacts for Each Resource Category ..................................... E-69

E1-1 Pacific Northwest Region, Summary of Regional Economic Impacts $\ldots \ldots \ldots \ldots \ldots \ldots \ldots$ E-72

E2-1 State of Washington, Summary of Regional Economic Impacts ................. E-78

E2-2 State of Oregon, Summary of Regional Economic Impacts $\ldots \ldots \ldots \ldots \ldots \ldots \ldots \ldots \ldots \ldots$

E2-3 State of Idaho, Summary of Regional Economic Impacts $\ldots \ldots \ldots \ldots \ldots \ldots \ldots \ldots \ldots \ldots$

E2-4 State of Montana, Summary of Regional Economic Impacts $\ldots \ldots \ldots \ldots \ldots \ldots \ldots \ldots \ldots \ldots$ E-90

E3-1 Puget Sound Subregion, Summary of Regional Economic Impacts ............... E-94

E3-2 West Coast Subregion, Summary of Regional Economic Impacts . . . . . . . . . . . E

E3-3 Portland Subregion, Summary of Regional Economic Impacts . . . . . . . . . . . . E

E3-4 Mid-Columbia Subregion, Summary of Regional Economic Impacts . . . . . . . . . . . E E-99

E3-5 Upper Columbia Subregion, Summary of Regional Economic Impacts . . . . . . . . . . . E-103

E3-6 Lower Snake Subregion, Summary of Regional Economic Impacts $\ldots \ldots \ldots \ldots \ldots \ldots \ldots$ E-106

E3-7 Northeast Subregion, Summary of Regional Economic Impacts $\ldots \ldots \ldots \ldots \ldots \ldots \ldots \ldots \ldots$ E 110

E3-8 Southern Idaho Subregion, Summary of Regional Economic Impacts $\ldots \ldots \ldots \ldots \ldots \ldots \ldots$ E-112

$\mathrm{F}-1$ Focus Community Location and Selection Reason $\ldots \ldots \ldots \ldots \ldots \ldots \ldots \ldots \ldots \ldots \ldots \ldots \ldots \ldots \ldots$

$\mathrm{F}-2$ SOR Alternatives Evaluated in the Regional Analysis $\ldots \ldots \ldots \ldots \ldots \ldots \ldots \ldots \ldots \ldots \ldots$ F 19

F-3 Summary of Pacific Northwest Regional Employment Impacts

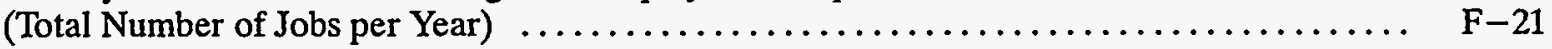

F-4 Summary of Subregional Employment Impacts (Total number of jobs per year) . ....... F-22

F-5 Evaluation Measures to Identify Socioeconomic Impacts in the SOR Focus Communities .... F F-29

F-6 Evaluation of Social Impacts for Libby, Montana $\ldots \ldots \ldots \ldots \ldots \ldots \ldots \ldots \ldots \ldots \ldots \ldots$

F-7 Evaluation of Social Impacts for the Flathead Lake Area, Montana $\ldots \ldots \ldots \ldots \ldots \ldots \ldots \ldots$ F -33

F-8 Evaluation of Social Impacts for Columbia Falls, Montana $\ldots \ldots \ldots \ldots \ldots \ldots \ldots \ldots \ldots \ldots$ F -34

F-9 Evaluation of Social Impacts for the Flathead Indian Reservation $\ldots \ldots \ldots \ldots \ldots \ldots \ldots \ldots$ F -36

F-10 Evaluation of Social Impacts for Bonners Ferry, Idaho $\ldots \ldots \ldots \ldots \ldots \ldots \ldots \ldots \ldots \ldots \ldots \ldots \ldots \ldots$

F-11 Evaluation of Social Impacts for Kootenai Indian Reservation $\ldots \ldots \ldots \ldots \ldots \ldots \ldots \ldots \ldots$ F-38

F-12 Evaluation of Social Impacts for Orofino, Idaho $\ldots \ldots \ldots \ldots \ldots \ldots \ldots \ldots \ldots \ldots \ldots \ldots$

F-13 Evaluation of Social Impacts for the Nez Perce Indian Reservation ............... F-41 


\section{LIST OF TABLES - CONT}

Table

Title

Page

F-14 Evaluation of Social Impacts for Lewiston, Idaho $\ldots \ldots \ldots \ldots \ldots \ldots \ldots \ldots \ldots \ldots \ldots \ldots \ldots \ldots \ldots \ldots$

F-15 Evaluation of Social Impacts for Clarkston, Washington $\ldots \ldots \ldots \ldots \ldots \ldots \ldots \ldots \ldots \ldots \ldots$ F-45

F-16 Evaluation of Social Impacts for Grand Coulee and Coulee Dam, Washington .......... F-47

F-17 Evaluation of Social Impacts for the Colville Indian Reservation $\ldots \ldots \ldots \ldots \ldots \ldots \ldots \ldots \ldots$ F-48

F-18 Evaluation of Social Impacts for the Spokane Indian Reservation . . . . . . . . . . . . F

F-19 Evaluation of Social Impacts for Tri-Cities, Washington $\ldots \ldots \ldots \ldots \ldots \ldots \ldots \ldots \ldots \ldots \ldots$ F-51

F-20 Evaluation of Social Impacts for Umatilla/Morrow, Oregon $\ldots \ldots \ldots \ldots \ldots \ldots \ldots \ldots \ldots$ F-53

F-21 Evaluation of Social Impacts for Portland, Oregon $\ldots \ldots \ldots \ldots \ldots \ldots \ldots \ldots \ldots \ldots \ldots \ldots \ldots$

F-22 Evaluation of Social Impacts for Astoria, Oregon $\ldots \ldots \ldots \ldots \ldots \ldots \ldots \ldots \ldots \ldots \ldots \ldots \ldots$

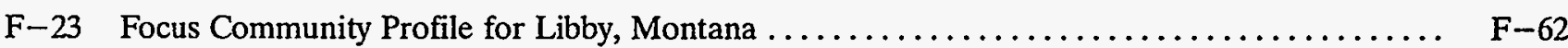

F-24 Focus Community Profile for Flathead Lake Area, Montana . . . . . . . . . . . . . . . . . F 64

F-25 Focus Community Profile for Columbia Falls, Montana $\ldots \ldots \ldots \ldots \ldots \ldots \ldots \ldots \ldots \ldots \ldots$

F-26 Focus Community Profile for Flathead Indian Reservation, Montana ............. F-68

F-27 Focus Community Profile for Bonners Ferry, Idaho $\ldots \ldots \ldots \ldots \ldots \ldots \ldots \ldots \ldots \ldots \ldots$ F -70

F-28 Focus Community Profile for Kootenai Reservation, Idaho $\ldots \ldots \ldots \ldots \ldots \ldots \ldots \ldots \ldots \ldots$ F -72

F-29 Focus Community Profile for Orofino, Idaho $\ldots \ldots \ldots \ldots \ldots \ldots \ldots \ldots \ldots \ldots \ldots \ldots \ldots \ldots \ldots \ldots \ldots$

F-30 Focus Community Profile for Nez Perce Reservation, Idaho $\ldots \ldots \ldots \ldots \ldots \ldots \ldots \ldots \ldots \ldots$ F-76

F-31 Focus Community Profile for Lewiston, Idaho $\ldots \ldots \ldots \ldots \ldots \ldots \ldots \ldots \ldots \ldots \ldots \ldots \ldots \ldots \ldots$

F-32 Focus Community Profile for Clarkston, Washington $\ldots \ldots \ldots \ldots \ldots \ldots \ldots \ldots \ldots \ldots \ldots \ldots \ldots$

F-33 Focus Community Profile for Grand Coulee and Coulee Dam, Washington $\ldots \ldots \ldots \ldots \ldots \ldots$ F-82

F-34 Focus Community Profile for Colville Reservation, Washington $\ldots \ldots \ldots \ldots \ldots \ldots \ldots \ldots \ldots$ F-86

F-35 Focus Community Profile for Spokane Indian Reservation, Washington . . . . . . . . . . F -88

F-36 Focus Community Profile for Tri-Cities, Washington $\ldots \ldots \ldots \ldots \ldots \ldots \ldots \ldots \ldots \ldots \ldots \ldots$

F-37 Focus Community Profile for Umatilla, Oregon $\ldots \ldots \ldots \ldots \ldots \ldots \ldots \ldots \ldots \ldots \ldots \ldots \ldots \ldots \ldots \ldots \ldots \ldots$

F-38 Focus Community Profile for Portland, Oregon $\ldots \ldots \ldots \ldots \ldots \ldots \ldots \ldots \ldots \ldots \ldots \ldots \ldots$ F -98

F-39 Focus Community Profile for Astoria, Oregon $\ldots \ldots \ldots \ldots \ldots \ldots \ldots \ldots \ldots \ldots \ldots \ldots \ldots \ldots$

\section{LIST OF FIGURES}

Figure

Title

$\underline{\text { Page }}$

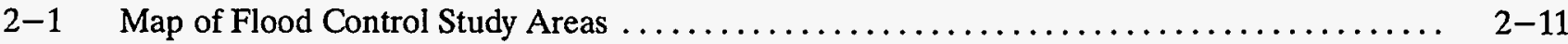

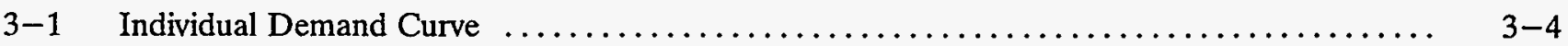




\section{LIST OF FIGURES - CONT}

Figure

Title

$\underline{\text { Page }}$

3-2 Consumer Surplus

$3-6$

3-3 Market Demand and Consumer Surplus

$3-7$

3-4 Supply Curve

3-9

3-5 Producer Surplus and Opportunity Cost

$3-10$

3-6 Market Supply and Demand

$3-11$

$3-7$

Maximum Net Benefits

$3-12$

$3-8$

Overproduction

$3-12$

3-9

Underproduction

...

3-10 Underproduction of Flood Control

$3-13$

3-11 Overproduction of Flood Control

$3-15$

4-1 Annual Fish Harvest with SOS 2c

$3-15$

4-2

Fall Chinook with SOS $2 \mathrm{c}$ and $5 \mathrm{~b}$

4-27

4-3

Grand Coulee Irrigation

$4-28$

4-4 Differences in Annual Recreation Days from SOS 2c.

4-45

$4-5$

Summer Consumer Surplus for SOS $2 c$.

$4-72$

5-1 Total System Cost Differences from the Base Case - SOS 2c (7.75 Percent Interest Rate) ....

5-2 Total System Cost Differences from the Base Case - SOS 2c (3.0 Percent Interest Rate) .....

5-3 Cost-Effectiveness SOSs Compared with SOS 2c (7.75 Percent Interest) $\ldots \ldots \ldots \ldots \ldots \ldots$

Cost-Effectiveness of SOSs, Compared with SOS $2 c$ (3.0 Percent Interest Rate)

$4-74$

$\mathrm{B}-1$

Analysis of Flood Damages

$5-6$

B-2 Discharge Damage Curve Dworshak to Clearwater

$5-11$

$5-13$

$5-14$

C-1 SOR Transportation Model User Defined Options Schematic for Grain ...

B-3

C-2 SOR Transportation Model User Defined Options Schematic for

Non-Grain Commodities

B-31

$\mathrm{C}-3$

C-4

C-3 SOR Transportation Model Grain Computation Schematic

C -5

C-4 SOR Transportation Model Non-Grain Computation Schematic . .

C -6

C-5 Grain (in bushels) Currently Shipped for Each State by Mode under SOS $5 b$

$\mathrm{C}-13$

C-6

Grain (in bushels) Currently Shipped for Each State by Mode under SOS $5 \mathrm{~b}$

C-14 


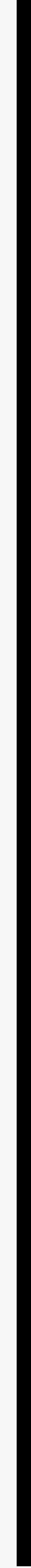




\section{CHAPTER 1}

\section{INTRODUCTION: PURPOSE, SCOPE, AND PROCESS}

Chapter 1 discusses study scope and processes undertaken to identify and measure economic and social impacts of alternative system operating strategies.

\subsection{PURPOSE OF ECONOMIC AND SOCIAL IMPACTS APPENDIX}

The purpose of this appendix is to measure the economic and social effects of the alternative system operation strategies. Section 102 of the National Environmental Policy Act (NEPA) and guidelines from the Council on Environmental Quality (CEQ), which interprets NEPA, requires that economic and social impacts be identified. This information is useful to decision makers and others interested in the SOR outcome. Economic measures are used to evaluate efficiency changes in the nation's production of the goods and services and how regional economies are impacted. From the economic assessment, the social analysis identifies the impacts to individuals and groups. Such evaluation identifies the gains and losses to society as a whole and to specific elements of society of implementing a particular alternative.

Typically, the economic effects are stated in monetary terms. Where monetary measures were not readily available, such as with the tribal ceremonial use of anadromous fish, qualitative assessments were used. No attempt was made to monetarily measure non-use values. These principally include existence, option, and bequest values for anadromous fish, resident fish, wildlife and recreation/scenic areas. The concepts of non-use measures are discussed, however, and non-use values from existing studies are presented (see Section 3.3.1.6).

\subsection{SCOPE OF ECONOMIC AND SOCIAL IMPACTS ASSESSMENT}

The scope of the economic and social analysis has a geographic component and a methodology component.

\subsubsection{Geographic Scope}

The geographic scope of the economic impacts analysis conducted for the SOR is consistent with the analysis of the physical effects of the SOSs. The SOSs directly influence the operation of the 14 Federal dams on the Columbia and lower Snake Rivers. The operations of other, non-Federal dams in the Columbia River Basin are indirectly affected. In general, the economic impacts were evaluated wherever significant physical impacts were identified. The assessment of social impacts, however, was limited to focus communities considered to be representative of impacted communities in each of eight subregions of the Pacific Northwest. Restriction of the analysis of economic impacts to areas specifically evaluated for physical impacts omits from analysis some important potential impacts. Some of the more important of these are discussed below.

The geographic area for the SOR was the Columbia River Basin, including that portion which lies in Canada, which is influenced by the 14 Federal projects (see Figure $P-1$ ). Impacts to Canadian interests, however, were not evaluated, except for potential recreation impacts at Lake Koocanusa (Libby Dam). Some of the SOSs involve changes to power marketing arrangements with other regions, such as the Pacific Southwest, that would impact those regions. Except for consideration the economic value of exporting and importing power to/from outside the region, economic impacts on other regions are not evaluated in this appendix.

The SOR also examined potential flow augmentation benefits to anadromous fish of additional water 
from the middle and upper Snake River Basins (above Brownlee Reservoir). This water was assumed to be available in varying amounts at different times of the year. Although several potential sources of water have been identified for portions of the water needed, permanent re-direction of this water from Federal storage projects would require Congressional authorization. Rights to use all of the basin's natural flow have been granted to existing water users, under state law. Acquisition of rights to natural flow from individuals or from the State Water Bank would require establishment of a legal process which would allow water rights to be transferred and its use to be changed from existing uses to use for anadromous fish. National and regional economic and social tradeoffs associated with obtaining this water were not addressed in the SOR. Although this issue was not addressed in the SOR, two different estimates of impacts on irrigated land and the cost of obtaining the additional water are available. One estimate was prepared by Economic Research Service, US Department of Agriculture, and the other estimate was submitted as a comment on the Draft Environmental Impact Statement by the state of Idaho. These two estimates are presented in this appendix for the reader's information.

\subsubsection{Economic and Social Scope}

For each alternative operating strategy, social and economic values were assigned to the primary uses of the Columbia River system. However, not all uses were measured in a direct way. For example, the economic impacts resulting from changes in resident fish populations were measured through the recreation analysis because sport fishing was identified as the primary use of resident fish.

The main uses of the river system evaluated in the SOR analysis were navigation, flood control, irrigation, municipal and industrial water supply, electric power generation, anadromous fish, resident fish, wildlife, recreation, and water quality. For each operating strategy some river uses would be made better off and some would be made worse off. The scope of the analyses presented in this appendix was to measure these tradeoffs from an economic and social viewpoint.
The SOR economic and social analyses measured impacts from three perspectives. The Federal or national view considers the net affects to the nation. The regional economic analyses identified economic gains and losses to specific sub-regions and the social analyses evaluates how selected communities within the sub-regions are affected by the strategies.

\subsubsection{National Economic Analysis}

The first perspective considered the National Economic Development (NED) consequences of alternative system operating strategies. NED analyses are concerned with economic efficiency at the national level. Thus, economic gains (income and/or employment) achieved by one region of the nation at the expense of another region do not represent an increase in the national economy. Generally, NED effects represent the initial or primary response of specific elements of the economy to a change in the operation of the Columbia/Snake River system. For example, an alternative could result in less water being available to generate power. If other resources, such as a combustion turbine plants, are needed to replace the lost hydropower production, the cost of producing power goes up. This increased cost would be a negative NED effect. See Section 3.1 for additional information on NED concepts.

National Economic Development (NED) evaluation procedures (Water Resources Council, 1983) were used as a guide in the derivation of direct impacts. Deviation from NED procedures are identified in the appendix text primarily in chapters 3 and 4 .

\subsubsection{Regional Economic Analysis}

The second perspective presents the economic consequences of system operating changes on regional and sub-regional economies. Regional Economic Development (RED) impacts may be the change in the economy of a community or sub-region as a result of improved fishing at a reservoir near the community or within the sub-region. For example, if an SOS improved fishing at a recreation site, the number of visits to that site would likely increase. As the visitors purchase greater amounts of fishing supplies, meals, gas, lodging, etc. in the community or sub-region, the economy is stimu- 
lated creating a positive regional impact--an increase in employment and/or income. However, if the improved fishing at the site results in a decrease in fishing and associated expenditures at another site, the gain in one community or sub-region could be offset by a loss in another. For the SOR analysis, regional economic impacts generally are made on the basis of an assumption that economic activity is not transferred among sub-regions in response to the direct impacts of the SOSs, with one exception. The exception is in the case of recreation where the assumption is that residents of a sub-regions will continue to recreate at the same level even if visitation to a specific site is projected to decrease. Thus, the assumption is that these recreators would substitute an alternative site within the same sub-region.

Regional impacts were determined using the IMPLAN input-output model with 1989 datasets, the most recent data available. County data were aggregated into eight subregion models. In addition, models were developed for Oregon, Idaho, Washington, and Montana and the entire four-state region. Table 1-1 shows the sub-regions which were used in the regional impact analysis.

\subsubsection{Social Analysis}

The third perspective presents some of the likely social impacts on selected local communities and individuals because changes in the operation of the system will affect communities differently. One community may lose recreation-related business and suffer an increase in unemployment and decreases in income and tax revenue as a result of a change in reservoir operations. Another community may benefit from increased business, jobs, income, and tax revenue if recreators choose to visit their reservoir instead. Some changes will affect all individuals, but groups of individuals will be affected differently. A change in power rates, for example, will affect everyone, but low income individuals will feel a greater impact, if as a proportion of their budgets, power expenditures are greater than for higher income individuals and if they have fewer substitutes available. Potential social impacts for the selected focus communities were determined through analysis of the indirect economic impacts by the technical staff of the Corps of Engineers, and the Bureau of Reclamation with the assistance of a social impacts assessment consultant.

\subsection{PUBLIC INVOLVEMENT AND AGENCY COORDINATION}

This section describes the team directly involved in the study effort and the role of the general public and others in shaping the economic and social analysis.

\subsubsection{Economic Analysis Group}

The team directly responsible for the socio-economic analyses for the SOR is the Economic Analysis Group (EAG). The EAG is one of 16 work groups formed to manage the SOR study and to analyze the environmental, economic, and social impacts of alternative system operating strategies. The EAG had the lead role in managing the evaluation of the social and economic effects. Technical analyses were conducted by the EAG as well as other functional work groups. For example, the Power Work Group estimated the effect of alternatives on regional power system costs.

The EAG consists of 18 core members from the three SOR sponsoring agencies, Bonneville Power Administration (BPA), U.S. Army Corps of Engineers (Corps), and U.S. Bureau of Reclamation (Reclamation) and 38 other interested parties and agency representatives. A list of members of the EAG is included in Chapter 6.

The EAG encouraged anyone interested to participate in work group meetings. Besides official meeting announcements, the work group and the economic analyses conducted for the SOR were discussed in an issue of Streamline, the SOR newsletter.

Typically, three to four individuals outside the core group attended meetings. Representatives from the Northwest Power Planning Council, U.S. Bureau of Mines, Port of Portland, Public Power Council, Pacific Northwest Utilities Conference Committee, and state agencies frequently participated in EAG meetings. About 20 other interested parties received EAG mailings and reviewed work group output, including this appendix. 
Table 1-1. Subregions Identified for the SOR Regional Economic Analysis

\begin{tabular}{|l|l|}
\hline \multicolumn{1}{|c|}{ SubRegion } & \multicolumn{1}{c|}{ Counties Included in the SubRegion } \\
\hline 1. Puget Sound & Washington: Whatcom, Skagit, Snohomish, King, Pierce, Thurston \\
\hline 2. West Coast & $\begin{array}{l}\text { Washington: Clallam, Jefferson, Grays Harbor, Pacific, Wahkiakum, } \\
\text { Cowlitz } \\
\text { Oregon: Clatsop, Tillamook, Lincoln, Columbia }\end{array}$ \\
\hline 3. Portland & $\begin{array}{l}\text { Oregon: Multnomah, Washington, Clackamas, Yamhill } \\
\text { Washington: Clark }\end{array}$ \\
\hline 4. Mid Columbia & $\begin{array}{l}\text { Oregon: Hood River, Wasco, Sherman, Gilliam, Morrow, Umatilla } \\
\text { Washington: Skamania, Klickitat, Benton, Franklin, Walla Walla }\end{array}$ \\
\hline 5. Upper Columbia & $\begin{array}{l}\text { Washington: Yakima, Kittitas, Chelan, Okanogan, Douglas, Grant, } \\
\text { Lincoln, Adams }\end{array}$ \\
\hline 6. Lower Snake & $\begin{array}{l}\text { Washington: Columbia, Garfield, Asotin, Whitman } \\
\text { Oregon: Wallowa } \\
\text { Idaho: Latah, Nez Perce, Lewis, Clearwater, Idaho, Custer, Lemhi }\end{array}$ \\
\hline 7. Northeast & $\begin{array}{l}\text { Washington: Pend Orielle, Spokane, Ferry, Stevens } \\
\text { Idaho: Boundary, Bonner, Kootenai, Benewah, Shoshone } \\
\text { Montana: Lincoln, Flathead, Sanders, Lake, Missoula, Mineral }\end{array}$ \\
\hline 8. Southern Idaho & $\begin{array}{l}\text { Oregon: Malheur } \\
\text { Idaho: Adams, Washington, Payette, Gem, Canyon, Ada, Imore, } \\
\text { Owyhee, Boise, Valley, Camas Blaine, Gooding, Lincoln, Jerome, } \\
\text { Minidoka, Twin Falls, Cassia, Jefferson, Madison, Teton, Clark, } \\
\text { Fremont, Butte, Bingham, Bonneville, Power, Bannock, Caribou, } \\
\text { Oneida, Franklin, Bear Lake }\end{array}$ \\
\hline
\end{tabular}

\subsubsection{Public Involvement}

Other than the EAG meetings and comments on mailings, the primary opportunities for public involvement came during the scoping meetings, midpoint meetings, meetings on the draft environmental impact statement, and public review of the draft report. The scoping meetings were held in late 1990 and the mid-point meetings were held in 1992. The 14 scoping meetings and the $14 \mathrm{mid}$-point meetings were held region wide and about 1300 people attended. Economic and social concerns expressed during these meetings are discussed in Section 1.4, Economic and Social Issues Raised During Study. The public input was critical in shaping the scope of the SOR economic and social analyses. For exam- ple, the regional and sub-regional impacts analyses were undertaken because of concerns raised during the scoping process.

A draft of the SOR Environmental Impact Statement, including this appendix was completed in July 1994 and was provided to Federal and state agencies, the Tribes, interest groups, and the public for review and comment. In addition, a series of public meetings were held. The public meetings and review resulted in more than 100 comments on the analyses of economic and social impacts. Responses to 100 comments which were logged into the SOR comment tracking database were prepared and are included in Appendix T (Comments and Responses) of the SOR Final Environmental Impact Statement. It was not 
possible to respond to all of the comments because of time and resource constraints. The most notable of the comments which we were unable to address are contained in a report submitted by the Coeur D'Alene Tribe entitled, "Economic Consequences of Management Strategies for the Columbia and Snake Rivers," July 1995. The report was prepared for the Confederated Tribes of the Umatilla Reservation by ECONorthwest of Eugene, Oregon.

\subsubsection{Coordination within SOR Work Groups}

The EAG coordinated closely with other SOR work groups. Economic and social effects are dependent on the physical impacts identified by the functional work groups, thus driving the need for close relationships. Coordination was facilitated because several EAG members were representatives on the functional work groups. The dependency of the EAG on the other work groups and their products is shown in Table $\mathrm{P}-1$, located in the Preface.

\subsection{ECONOMIC AND SOCIAL ISSUES RAISED DURING STUDY}

Numerous economic and social issues were raised during the study. Some were general in nature, while others centered around specific technical measurement concerns. Different analytical requirements of the three lead agencies added to the varied perspectives on the issues. Although measurement of economic activity is relatively well understood theoretically, applying the theory to complex and dynamic conditions, as is the case with this study, can be extremely difficult. The EAG worked toward a goal of reasonably accurate estimates given time and budget constraints. While much long and challenging dialogue took place, consensus was reached on most issues. The results of these discussions were set forth in a requirements and procedures document (Economic Analysis Requirements and Procedures, 1993). The document prescribes the information and tools to be used to measure the impacts analyzed in this study. The issues related to the economic and social analysis are presented in the following paragraphs. In addition, the EAG participated in resolving broader SOR issues such as geographic scope, definition of the no-action alternative, etc. which are discussed in the main EIS document.

\subsubsection{General Economic and Social Issues}

General economic and social issues mainly came from public comments on the SOR process during the scoping and mid-point meetings. In general, the following types of concerns were expressed.

- Possible negative effects to local economies

- The importance of economic considerations in the decision making process, especially balancing economic and environmental goals

- The need to know the economic assumptions used

- The need for a fair distribution of costs

- The desire to see explicit presentation of economic benefits and costs

- The importance of honoring Tribal and treaty rights

- Concern over possible negative impacts to existing ways of life.

\subsubsection{Technical Issues}

In addition to general issues, many technical issues were raised in the EAG relating to specific study methods. These are briefly discussed below.

- Economic value of environmental resources, such as anadromous fish - - An issue arose over whether non-use values (existence, option, and bequest) of environmental resources should be measured in the SOR analysis. The economic analysis is limited to use values like recreation and commercial fishing. The decision not to estimate and include non-use values in the SOR was a difficult one. The following discussion provides some background on the difficulty and practicality of estimating non-use values in this study. If non-use values are to be used in the evaluation of alternatives, then for a rational assessment they need to be esti- 
mated for all river services that have nonuse value. For the SOR, this would likely include wild and hatchery anadromous salmon and steelhead, resident fish, wildlife, recreation, cultural resources, water quality, and possibly others. Some of the more important problems arising from existing contingent valuation (CV) studies which are used to measure non-use values include: 1 ) results that appear inconsistent with the economic assumptions of rational choice; 2) $\mathrm{CV}$ responses that sometimes appear implausibly large given the many alternative programs for which individuals might be asked to contribute and the availability of substitutes for the resources being evaluated; 3) inadequate reminders of the respondent's budget constraint; 4) difficulty in communicating clear policy or program information about what the respondents are being asked to value; 5) difficulty in determining the market extent; and 6) separating the "warm glow" of giving from the actual willingnessto-pay for the program in question. A study which fully considers non-use value and addresses measurement issues would be extremely difficult and would clearly exceed the resource constraints for SOR. Despite analytical problems associated with non-use values, these types of studies are routinely estimated. One such study was conducted for the Corps in 1990. This study estimated the existence value of doubling Pacific Northwest salmon and steelhead runs. The draft and final SOR environmental impact statements present the results of the study. A reference to the study is included in Chapter 8 .

- Period of analysis, price level, discount rate, and forecasting - - Considerable discussion took place within EAG meetings regarding these important elements of an economic analysis. They can significantly affect results, especially the ability to compare alternatives across the different river uses and implementation time frames. The EAG adopted the following assumptions. A discussion on how these assumptions are considered in economic evaluations is included Section 3.2 of this appendix, National Economic Analysis Assumptions for SOR.

- Period of Analysis: 100 years from a base year of 1995.

- Price Level: October 1992, with a few exceptions which are noted in the text. Updating all costs to a more current price level for the FEIS was not possible due to time and resource constraints.

- Discount Rate: Two discount rates are used, 7-3/4 percent, the discount rate which Federal water resource agencies are required to use during fiscal year 1995 and 3 percent, the inflation-free interest rate which is used by BPA.

- Measure of impacts to irrigators - - Three technical economic measurement issues were related to the irrigation analysis. The first and most direct issue involved water availability. That is, can water currently used by irrigators be shifted to other uses? The right to use water from natural flow is granted by the states. For this study these rights were considered an inviolable institutional constraint. The use of water stored in Federal projects is controlled by contracts between water users and the Federal Government. As with state-granted rights to use water from natural flow, existing contractual agreements on the use of stored water were considered to be an inviolable constraint in this study. As a result, the analytical assumption was that current water availability will remain the same under all operating strategies. The second issue addressed whether the alternative operating strategies would cause a change in the crop mix. While measuring crop mix changes is technically correct, it requires dynamic modeling to predict. Because of limited resources and time, the analytical assumption was that no change in crop mix would occur. Given these two assumptions the estimated impact to irriga- 
tors was limited to the change in costs associated with pumping water from Federal reservoirs under drawdown conditions. The third issue centered around how to value the energy used to pump water over increased lifts. For this study, electrical energy used by irrigators and other water users is valued at the power rates the users currently pay. This measure of the value of electricity is appropriate because estimated economic impacts are not being used to optimize system operation and because an economic efficiency analysis of irrigated agriculture is a subsidy issue beyond the scope of SOR. Analytical procedures and methods are discussed in Section 3.3.4 of this appendix. Detailed information on the analysis of water use costs can be found in Appendix F (Irrigation/Municipal and Industrial Water Supply).

- Consistency in measuring impacts among river uses - - To describe the economic impacts of each SOS, the impacts estimated for each river use were summed to yield the total impacts for the SOS. This summation approach was surfaced as an issue because not all impacts were defined on the same basis or level of detail, and some impacts were not translated into economic terms. The limitations of summing across river uses are documented in this appendix. Alternative approaches of evaluation such as ranking or grouping alternatives by the respective river uses are presented in Chapter 5 . It should be noted that the SOR analysis evaluates economic impacts from two perspectives, the Federal or national perspective and the regional perspective. The Federal or national perspective considers the net effects to the national economy. This is the National Economic Development (NED) or direct impact analysis. From this perspective, the general measurement standard for goods and services is the net willingness of users to pay for each increment of output from an alternative. Since it is usually not possible to obtain willingness to pay values, alternative or proxy measures are used. These include actual or simulated market prices, changes in net income, cost of the most likely alternative (e.g., replacement cost of hydropower), and administratively established values. The same type of measure does not have to be used for all goods and services effected by an alternative or across alternatives. The employment of such values is less than ideal, but they are widely used in applied economic analysis. This convention is specified in the US Water Resources Council's Economic and Environmental Principles and Guidelines for Water and Related Land Resources Implementation Studies, which is the principal guidance for economic analysis conducted by Federal water resource agencies. The SOR analysis uses proxy measures which can be summed and compared from one alternative to another. The analysis is based on existing economic conditions. It would be conjecture to assume current subsidies will no longer exist in the future and an impossible task to identify the economic structure that would exist in the absence of subsidies. The second perspective considers the indirect impacts to the affected regions and subregions. These impacts stem from the initial shocks to the regional economy brought about by the direct impacts and are commonly measured using input-output models which estimate the multiplier effect on a region's economy of specific direct impacts of a project, e.g. an increase in transportation costs due to closure of the Snake River shallow-draft waterway during drawdown. For the SOR 13 regional, state and subregional models were developed using IMPLAN, an input-output modeling system developed by the US Forest Service. The results of the two perspectives can not be compared and were not compared or used interchangeably in the SOR analysis.

- Positive regional impacts of increased flood damages - - Increased flooding can result in positive economic benefits to the flooded region in terms of regional income and 
employment as money flows into the economy for emergency services, cleanup, and rebuilding. Should these regional benefits be measured for SOSs which increase flood damages? The EAG determined that since flooding is never viewed as a positive impact, it would be inappropriate to assess potentially beneficial regional economic impacts of increased flooding associated with some of the SOSs.

- Gross system generation and capacity cost, net system generation and capacity cost, and consumer surplus in evaluating power impacts - - The gross system cost method is the most commonly used means of evaluating power projects, where the economic feasibility of increasing system generation capability is typically being considered. This method, however, does not account for demand responses to changes in price when low-cost existing generation resources are replaced by new resources which have much higher costs. For this reason, the EAG determined that the net system cost method should be used in the SOR. This method reflects the concept of price elasticity whereby increases in system fixed and variable costs and associated increases in rates to consumers result in decreases in the quantity of electricity consumed (the concept of price elasticity is discussed in Section 3.1.4.2). The analytical approach used for the SOR to estimate system costs is based on balancing resources with loads under each SOS such that system reliability remains the same as it is in the base case. Thus, system reliability requirements define the need for additional resources to meet demand. Costing out these changes gives the change in the gross system costs of meeting Northwest regional loads. These costs are then translated into rate impacts on the major Pacific Northwest customer classes. If the quantity of electricity demanded would change because of the rate impacts, the original estimate of need for additional resources is revised. This process results in net system resource requirements and costs, which takes into account the reduction in the quantity of power demanded in response to a rate increase. Ideally, estimating net system costs is an iterative process which is continued until the supply of electricity is equal to the demand. The difference between system costs for the no action alternative (SOS 2c) and net system costs for a given alternative SOS is the net replacement cost of power. Gross system costs are presented in Appendix I (Power) and Section 4.8.1 of this appendix. Replacement of existing resources with higher cost resources forces rates higher and causes consumers to reduce the quantity of electricity consumed. The increased cost of electricity and the decrease in quantity consumed results in a loss of consumer surplus (decrease in social well-being). The magnitude of the loss in consumer surplus was estimated for the DEIS, but was not estimated for the FEIS.

- Value of water quality impacts -- Several ways of evaluating water quality economic impacts were considered for the SOR study. The most technically correct way measures the economic value in terms of people's willingness - to-pay either to restore or maintain the quality of water to a specified standard. This method is difficult and expensive to undertake. Given time and budget constraints, the EAG agreed to value water quality changes indirectly through the analysis of water uses. For example, the anadromous fish analysis includes the impact of dissolved gases on fish production. In addition, the EAG agreed that where water quality is degraded to the level that it does not meet legal water quality standards for a specific use, the economic value of the degradation would be measured in terms of the costs which would be incurred to fully restore water quality to meet or exceed the standard. Analyses conducted by the Water Quality Work Group did not show that any of the 
SOSs would cause a violation of legally defined water quality standards. Therefore, application of this analytical approach was not required. Details of the effects of the SOSs on water quality are contained in Appendix M (Water Quality).

- Deep-draft navigation impacts on the lower Columbia River - - After study scoping, an issue surfaced over the concern that deepdraft navigation in the Columbia River downstream of Vancouver, Washington could be affected by alternative operating strategies. The potential impacts would be associated with alternatives which included drawdown of the lower Snake River projects for extended periods of time. The issue was that late summer refill of the lower Snake River dams could cause a decrease in river stages on the lower Columbia River. Current deep-draft navigation practices maximize the draft of outbound ships based on the actual stage and tidal cycle. Even small changes in available water depth could have economic consequences. To resolve the issue, the SOR study scope was broadened to include navigation on the lower Columbia River. An analysis of the effect of the SOSs on the stage of the Columbia River from Portland to the ocean was conducted by the Navigation Work Group. The results of the study are summarized in Appendix $\mathrm{H}$ (Navigation). Analytical procedures and methods used are discussed in Section 3.3.5.2 of this appendix.

- Temporal shifts in the shipment of grain on the river - - A key assumption of the SOR navigation analysis is that the flow of grain will continue to move at historical monthly rates for all alternative operating strategies. The issue is whether this is a reasonable assumption. Some transportation analysts believe farmers who now ship from ports on the lower Snake River will likely ship their grain before or after reservoir drawdown and closure of the navigation system rather than use alternative modes of shipment. These analysts believe that farmers who are not affected by closure of the Snake River to navigation would adjust their shipments to facilitate expected changes in shipping patterns of impacted farmers. If this is true the navigation analysis would tend to overstate economic impacts for the drawdown alternatives. Pre-conditions of temporal shifts, however, are that upper and lower river grain types are the same; that farmers have sufficient economic flexibility to make a significant change in their present grain marketing practices; and, that exporters have sufficient flexibility of supply to meet the demands of the export market with a limited geographic supply of grain. Due to resource and time constraints these pre-conditions for temporal shifts were assumed not to occur. This assumption was informally confirmed through discussions with grain exporters who agreed that continued availability of grain from throughout the region would be needed to meet export market demands. Analytical procedures and methods used in the analysis of shallow-draft navigation, including grain transportation, are discussed in Section 3.3.5.2 of this appendix.

- Input/Output Models and Dynamic Changes - - Input/output (I/O) models cannot be used to determine the effects of dynamic changes that would result from implementation of the long-term strategies being evaluated in the SOR. The secondary effects of dynamic changes cannot be estimated because coefficients which drive the $\mathrm{I} / \mathrm{O}$ model are fixed by current economic relationships. Thus, the best that the $1 / O$ modeler can do is provide a "snap-shot" estimate of the secondary impacts of a change to a region's economy. Since many of the changes which will result from SOR strategies will change (typically increase) over time, the EAG determined that I/O model studies should be run using average annual estimates of expected changes. Concepts and use of input/ output models to evaluate regional economic 
impacts of the SOSs are discussed in Section 3.5 of this appendix. Results of the analysis are discussed in Chapter 4.

- Subsidies - - In general, a subsidy (financial transfer from one individual, economic sector, societal group, etc., to another) occurs whenever goods and services are not priced at marginal cost. In the case where marginal costs are higher than average costs, existing users subsidize new users. On the other hand, where marginal costs are lower than average costs, new users subsidize old users. In the case of the river uses of the Columbia/ Snake River system, marginal cost-based prices and average cost-based prices are present. In addition, irrigators served by the Columbia Basin Project pay a contract rate for power used to pump water from Lake Roosevelt (Grand Coulee dam) which is administratively set. At issue is whether existing subsidies should be addressed. That is, should impacts be valued at rates actually paid by users or at the marginal cost to the Nation. The EAG determined that analysis of subsidies was beyond the scope of the SOR. As a result, the analysis reflects a mix of average - and marginal-cost based prices and administratively set prices. The type of prices used for each river use is listed below:

\begin{tabular}{|l|l|}
\hline River Use: & Basis for Prices: \\
\hline Anadromous Fish & Marginal costs \\
Flood Control & Marginal costs \\
Irrigation & \\
Pump Modification & Marginal costs \\
Power & \\
Columbia Basin & Administratively set \\
Other Areas & Average cost \\
Navigation & Marginal cost \\
Power & \\
New Resources & Marginal cost \\
Rates & Average cost \\
Recreation & Marginal cost \\
& (willingness-to- \\
& pay) \\
\hline
\end{tabular}

- Allocation of Anadromous Fish to Harvest - - The fish models used in the analysis fixed the ratio of the number of salmon and steelhead harvested in the numerous fisheries and the fish that escape to spawn. The ratio of harvest to escapement was established based on data through the 1980s. This approach does not reflect fact that fishery management agencies, at least in the short run, will likely reduce the harvest of the fish listed under the ESA and hence increase the escapement amounts. The issue is, should the estimation of salmon harvest and steelhead be adjusted to change the historic harvest to escapement ratios? The harvest allocation issue is very complicated because reducing harvest in one area may only increase harvest in another. The mixed-stock nature of the fisheries would require reduction in harvest of non-targeted species. Some research is ongoing on this issue and fishery management decisions are being made continually. It was decided that it is simply too soon to determine the long range changes in harvest to escapement ratios for all the Columbia River salmon and steelhead. So, the economic analysis of salmon and steelhead harvest is based on historic allocations to the various fisheries. This probably overstates the economic value associated with the fisheries, especially in the short run. But, as ESA stocks recover, historic allocations may be restored. The allocation of fish to harvest is discussed in detail in Section 3.3.1.2 of this appendix.

- Recreation Demand - - Several issues were raised in the economic analysis of recreation impacts in the DEIS. It was recognized that the recreation use and value models had numerous limitations, foremost of which were: (1) heavy reliance on professional judgment of expected reaction of recreators to pool level fluctuations and varied flows; (2) application of economic values derived in other studies to the conditions being examined in the SOR; and, (3) inadequate 
accounting for substitution of lost recreation opportunity at one site to another recreation site. To address these concerns significant modifications were made in the recreation analysis for the FEIS. The analysis presented in this appendix of the FEIS and described in detail in Appendix J (Recreation) used results from an extensive survey of potential recreators throughout the Pacific Northwest and parts of Canada. Approximately 3,000 useable survey responses were utilized to develop information on changes in visitation at Federal projects in the Columbia River Basin with the different system operating strategies. Using this information, regional models were developed to estimate both expected visitation and to monetize the changes in aggregate welfare (direct economic impacts) associated with the impacts to recreation. The models account for substitution among regional waters. Survey responses provided descriptions of actual 1993 recreation behavior, such as trips to Federal water projects and trip expenditures. To help identify the number of recreation trips that would result from changes in operation of Federal projects with the various SOSs, the respondents expressed their intended behavior (contingent behavior) with reservoirs and rivers at various elevations and flows. Respondents indicated whether they would increase or decrease the number of trips to the impacted Federal reservoir, other Federal reservoirs, or other waters in the region. Computer enhanced photos of different reservoir elevations, pool elevations charts, and impacts on recreation facilities were included in the mail-out questionnaires to provide the respondents with the information needed to express their contingent behavior. Since the FEIS includes empirically based and technically valid recreation use and value models, linked directly to the SOR alternatives, the major technical concerns raised in the DEIS have been addressed. 


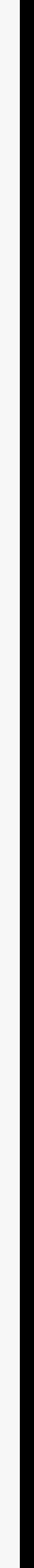




\section{CHAPTER 2}

\section{AN ECONOMIC HISTORY OF THE COLUMBIA RIVER BASIN AND ITS USE TODAY}

This chapter describes the socio-economic history of the Columbia River Basin. It relates how the Columbia River system influenced development in the Pacific Northwest. Demographic characteristics of the people who live in the region and how the river system is used are also described. In addition, the importance of the Columbia River to Native Americans is briefly discussed.

\subsection{THE COLUMBIA RIVER AND SOCIO- ECONOMIC DEVELOPMENT IN THE NORTHWEST}

The Pacific Northwest has been characterized as a hinterland to the metropolitan-dominated economic system of Europe and North America. Historical trading patterns suggest that Asia also be included with Europe and North America. In this context, hinterland refers to the economic supporting role of the region in supplying raw materials and semi-finished products--aluminum, for example- - to national and international markets. The region's economic supporting role began with the emergence of the fur trade in the 1780's and continues today through exports of forest products, agricultural commodities, and semi-finished manufactured products. The purpose of this section is to briefly describe the significance of the Columbia River to Native Americans and the socio-economic development of the region following arrival of the Europeans. The linkage between historical socio-economic development of the region and the development and operation of the Columbia River system of water control projects is also described.

\subsubsection{Resource Base}

In general, Native American cultures and the economic development of the Pacific Northwest and the Columbia River Basin are closely tied to the region's natural resources. Economic development has progressed in accordance with exploitation of the region's natural resources, largely in response to national and international demand. Among the most significant of the region's natural resources, listed in their general chronological order of exploitation, are: sea and land fur-bearing animals; the land with the region's favorable climate, ranging from cool and wet west of the Cascades to temperate and dry to the east; gold and other minerals; timber; salmon; and, finally, the Columbia River. The region's natural location on the Pacific Rim and its relative nearness to Asian markets provides a locational comparative advantage which has also influenced economic development.

\subsubsection{Native American Culture and the Columbia River}

Within the Pacific Northwest, scholars identify three great Native American cultural areas: Northwest Coast, Plateau, and Great Basin. Each of these areas included a variety of subgroups commonly referred to as tribes that shared traits and life styles, but not necessarily a common language. In all, there were about 125 different tribes speaking more than fifty languages. Although the boundaries of the cultural areas were indistinct, the Plateau cultural area largely consisted of the Columbia River Basin, with the Columbia River as its dominant feature.

The Plateau Native American economy was based on hunting and gathering. Depending on the season, the Plateau people engaged in various types of food-gathering and - preserving activities, but their diet was rich in salmon, which made annual runs up all of the major rivers of the interior. They dried fish for later use and trade. The significance of fish to the Plateau people is illustrated by the fact that until they acquired horses in the early 1700 s, fish constituted approximately 80 percent of the Nez Perce diet. Following the acquisition of horses, buffalo, 
elk, deer, and antelope became increasingly more important in their diet.

The culture and economy of the Plateau people were centered on the region's rivers. When Euro-American fur traders and explorers arrived, in the early years of the nineteenth century, the people lived in small semi-permanent fishing settlements along major streams and tributaries. The Dalles of the Columbia River, home territory to the Wishrams and Wascos was a gathering place for many of the tribes of the Plateau and other cultural areas. Great tribal meetings took place at the Dalles and many tribes traveled to the Dalles to fish for salmon in the spring before the salmon reached their villages. Here was the cosmopolitan center of Northwest Indian life. It was the site of great month-long trade fairs, with dancing, ceremonial displays, games, gambling, and marriages taking place along with the trading. Sometimes the Wishrams and Wascos hosted several thousand visitors who came to trade dried salmon meal, buffalo robes, and slaves from the interior for canoes, marine shell beads, and fish oil from the coast. As testament to the extensive geographical importance of these trading fairs, the goods traded have been found as far away as Alaska, southern California, and Missouri (Schwantes, 1989).

\subsubsection{The Fur Trade}

The fur trade, which exploited coastal and interior fur-bearing animals, rose in the early 1740 's, flourished through the early 1800 's and ceased to be a significant economic activity by 1850 . Initially, the fur trade was centered on sea otters.

By 1829 the sea otter had been all but exterminated. To replace them, the Americans began to bid for inland furs, primarily beaver. British trappers and traders were already well established in the beaver fur trade. With the entry of the Americans, traders and trappers from the two countries engaged in intense competition to dominate the industry. As with the sea otter, competitive exploitation quickly led to the commercial extermination of the resource. The intensity of the competition for the resource is illustrated by the fact that it took just two years to thoroughly despoil the beaver population in the
Snake River country. As with sea otter trade, the rewards of the inland trade were spectacular.

During the century-long reign of the fur trade, the Columbia River was used by the British in moving furs up-river to eastern sea ports by way of a route through Canada. The Americans, on the other hand, transported their furs down-river for export to markets in Canton where they were traded for tea. Asian markets were not accessible to British traders because they could trade there only under license from the East India Company, an excessively expensive proposition. The river was also used by both the Americans and British to bring in supplies by way of the ocean and the river, in spite of the fact that entrance to the river was extremely hazardous.

\subsubsection{Settlement of the Land}

From the early days of the fur trade until a boundary was established between Canada and the United States, the Oregon Country was jointly occupied by the British and the Americans. It is of interest to note that the Oregon Country was generally the same geographic region as that which we now consider to be the Pacific Northwest. Louisiana lay to the east, bounded on the west by the Rocky Mountains, and Spanish Territory lay to the south of the Columbia River basin. Oregon Country was formally declared to be a territory of the United States in 1849. Even though it took the United States almost 60 years to take control of the Pacific Northwest, the desire to occupy and control Oregon appears to date from the unveiling of the Columbia River by the American Robert Gray in 1792. An early interest in control is demonstrated by the extension of the Lewis and Clark expedition to the Pacific Ocean, following the purchase of Louisiana in 1803.

The British also wanted at least a portion of the Oregon Country. Their interest was expressed by a recommendation by representatives of the Hudson's Bay Company that the Columbia River be defined as the international boundary. Although the British attempted to support their claim to the territory north of the Columbia River by attracting settlers to occupy it, their efforts were unsuccessful, largely due to the fact that prospective settlers were not to be allowed to own any land. Instead, provisions for 
settlement offered them long-term leases of land from the Hudson's Bay Company and required them to sell a large portion of their produce to the company. During the first year of the settlement program, not a single prospective settler applied to immigrate. The Americans on the other hand, motivated by what has become known as Manifest Destiny, were successful in attracting settlers to Oregon, both to the south and to the north sides of the Columbia. Settlement efforts by the Americans proceeded, until after Oregon became a Territory, without assistance by the Federal Government. These private efforts to get Americans to migrate to Oregon began as early as 1819 , but the first settler, Nathaniel Wyeth did not depart for Oregon until 1831. The first wagon train was organized in 1843 , thus establishing the Oregon Trail and initiating the flood of immigrants that would follow.

Although some immigrants traveled on the Columbia River, navigation of the river was expensive, dangerous and required a number of portages. As a result, in 1845 a company of immigrants led by Sam Barlow located an alternate land route which left the river at The Dalles and went around the south side of Mount Hood. This route became known as the Barlow Trail and in 1846 was developed as a toll road.

The issue of control and ownership of the Oregon Country and the international boundary was essentially settled when the British concluded that they should accept a proposal by the United States that the boundary be set at the 49th parallel. Their decision to drop their claim to land north of the Columbia was based on a military intelligence report prepared in 1845. The report noted that, except for Puget Sound, the whole section north of the river was a "pine swamp." The author of the report expressed the view that the Americans were justified in wanting control of the sound because there was no other first-class Pacific harbor. In the author's opinion, the Columbia's bar rendered that river all but unusable. Furthermore, the report indicated that population figures favored the Americans, with an estimated 2110 residents south of the Columbia River and another 3000 immigrants en route on the Oregon Trail. Other than employees of the Hud- son's Bay Company, there were no British settlers north of the river. The treaty establishing the international boundary was signed in 1846 .

Following formal recognition of the Oregon Country as a territory of the United States in 1849, the Congress, in 1850, passed the Donation Land Law. Under terms of the law any resident who was a citizen of the United States could claim 320 acres (129.5 hectares) in his own name and, if married, another 320 acres (129.5 hectares) in the name of his wife. The Donation Act, although intended to be temporary, was extended to 1855 and was a step toward establishing the nation's unoccupied territory as a free commodity- - a policy that culminated with the Homestead Act of 1862 . The promise of free land was a significant factor in attracting new settlers to the territory. However, it is interesting to note that getting to the land was expensive so only people who were already relatively well-to-do could make the trip. Historians generally agree that few, if any, immigrants improved their economic state by trekking the Oregon Trail to the land at "Eden's Gate."

\subsubsection{Gold}

The flood gates of immigration to the Oregon Territory were thrown wide open with the discovery of gold on a tributary to Idaho's Clearwater River in 1859. Ironically, the discovery was made by an Indian who passed the information on to an Indian Trader named Elias Pierce. Access to the area was over land of the Nez Perce reservation. The Tribe protested against prospectors crossing reservation lands, but their protests were ignored and the rush was on. In the spring of 1861, the first steamboat made its way up the Snake River to what is now Lewiston and unloaded its cargo in the midst of farms that the Indians had established. By the time fall came the Indians had been displaced and a shack town of 1200 inhabitants sprawled across the site.

With the discovery of gold, changes to the territory came quickly. New territories were formed: Idaho in 1863- - Washington Territory had been established in 1852--and Montana in 1864. Also, transportation systems were developed, initially commercial navigation of the river and then roads and railroads. For a time the Columbia River played a vital role. 
In 1856 a wagon road was built around Celilo Falls, and portages were built around rapids (The Cascades) near the lower end of the Columbia Gorge. In 1860 various navigation interests combined to form the Oregon Steam Navigation Company (OSN), which began operation in January of 1861 . When the company started operations there was little prospect of a profitable business, but then the Idaho gold rush started. By 1865 the OSN fleet consisted of eighteen steamers.

With the OSN charging freight rates based on the concept of "all that the traffic will bear," the door for competition from the railroads was opened. Development of a rail system was further encouraged by the Federal Government's offer of generous land grants, consisting of as much as twenty alternate sections (square miles) of land for each mile of track constructed, the railroads soon captured most of the freight and forced waterborne freight rates to be lowered.

\subsubsection{Timber}

The Pacific Northwest contains the largest softwood forest in the United States. When fur traders of John Astor's Pacific Fur Company arrived at the mouth of the Columbia River in 1810 to construct a fort and trading post, potential sites were all overgrown with gigantic old-growth trees. At that time the trees were more of a nuisance than a resource because they had to be cleared to make room for the fort and they were too big to use either for lumber or for building logs. Some of the trees reached fifty feet in circumference and took four ax-men working simultaneously days to bring one down. After the trees were felled the stumps had to be blown apart with gunpowder so that the pieces could be hauled away.

Commercial exploitation of the region's timber resources remained insignificant until the demand for lumber in California, spurred by the gold rush, caused entrepreneurs to begin commercial harvest of the forest beside Puget Sound. In 1849, the first steam mill was setup to produce lumber for the California trade. With the demand for lumber associated with the Gold Rush and fires which razed
San Francisco no less than six times between December 1849 and July 1851, the lumber industry boomed. Attempts to establish the industry south of the Columbia were curtailed by continuing difficulties in navigating the bar at the mouth of the river.

\subsubsection{Salmon}

According to estimates of recent investigators, before 1855 between 10 and 16 million salmon returned to the Columbia River each year. Prehistoric Indians harvested an estimated eighteen million pounds (8 million kilograms) of fish annually. According to the Lewis and Clark Journal of 1805 , dried fish took up as much as one-half the space inside the homes of Indians. The Columbia was the hub of a trading place where as many as 5,000 tribal people gathered during the fishing season. Goods to trade came from all over the Northwest, the Great Plains, the Great Basin, and as from as far away as the Great Lakes.

The first recorded attempt to commercialize the harvest of salmon apparently occurred in 1832 when Nathaniel Wyeth arrived on the Columbia River from Boston to "ascertain if possible to make a business of curing Salmon in this River..." The enterprise was apparently not immediately successful because commercial salmon fishing on the Columbia did not reach its peak until the 1880 s and 1890 s. During those decades canneries packed as many as 630,000 cases of forty-eight one-pound $(.4536$ kilogram) tins during the annual runs. In 1906, fish wheels were taking more than a million fish each year and, in Oregon alone, there were 55 canneries. The intense harvest effort soon led to declines in the annual catch. In order to halt the declining harvest, toward the end of the nineteenth century, Oregon and Washington began to impose restrictions on harvest and to establish closed seasons. However, the laws were haphazard; until 1909, for instance, there was no uniformity of closed seasons.

Today only about two and one-half million fish return to the Columbia River. A number of stocks are extinct; Snake River sockeye are endangered; and, Snake River spring/summer and fall Chinook are listed as threatened under the Endangered Species Act. The depressed size of salmon runs has consid- 
erably reduced the economic significance of the fishing industry from its heyday in the late 1800's.

\subsubsection{The Columbia River}

The bar at the mouth of the Columbia River made entrance to the river hazardous. And between the time of its discovery until jetties were constructed at its mouth in the late 1880 s, numerous ships were lost attempting to cross the bar. In spite of the hazards, the discovery of gold in California induced more than fifty ships to push their way across the bar and into the river in 1849. Construction of the jetties, however, tamed the river's fearsome bar. With safe passage over the bar assured, the river was established as a major waterway and Portland was assured a role as sea port. Later, construction of locks at Willamette Falls extended navigation up the Willamette River.

Navigation on the Columbia River upstream from Portland required portages until canals and locks were built past Cascades Rapids in 1896 and Celilo Falls in 1915. In 1893 when the Corps of Engineers recommended construction of the canal and locks around Celilo Falls, there was no commerce on the river above the falls. In spite of this, the Board of Engineers stated they had no doubt that "... when the obstructions to navigation near The Dalles shall be removed there will be commerce, although the extent of its development cannot be foreseen." When the project was completed in May of 1915, six steamboats passed through the newly opened canal. As speculated, waterborne commerce developed and the canal helped keep rail rates below monopoly levels, but until the multi-purpose dams were constructed on the Columbia and Snake Rivers beginning in 1938, commerce on the river remained light.

Impetus to continue development of the water resources of the Columbia River basin came from the need for water to irrigate land which was given to settlers under various laws, including the Desert Land Act of 1877. Under this Act, a settler was allowed 640 acres ( 259 hectares) if he undertook to irrigate eighty acres (32.4 hectares). Although a number of attempts were made to comply with the law, projects large enough to irrigate eighty acres (32.4 hectares) were generally beyond the capability of individual farmers. To remedy the problem, Congress passed the Carey Act in 1894 under which, upon application, one million acres $(404,700$ hectares) of Federal land would be transferred to a state if the state would undertake reclamation (irrigation) of those acres. Except for Idaho, where 868,000 acres (351,280 hectares) were eventually put under irrigation, relatively little land was brought into production under the Act.

The general failure of provisions of the Carey Act to result in irrigation projects and continued difficulties of private interests to bring water to the free land, eventually led Congress to pass the Newlands Act of 1902. Under this Act, the Reclamation Service (since 1923 the Bureau of Reclamation) was created. By 1918 , Reclamation was busy studying a proposal for a dam at Grand Coulee. The proposal was originally made in 1892 by a Big Bend real estate agent who envisioned use of Grand Coulee not only for irrigation, but also as "a first-class ship canal." At the same time, the Corps of Engineers and the Federal Power Commission had been authorized to conduct a nationwide survey of the irrigation, navigation, flood control, and power potential of all major rivers of the United States. The study was completed in 1931 and, regarding a dam at Grand Coulee, concluded that the project could be largely paid for by selling surplus power. In all, construction of ten dams on the Columbia and Snake Rivers was recommended.

At the time the Corps' study was completed, the country was gripped by the depression of the 1930s. Private interests and public officials agreed that construction of multiple purpose dams on the Columbia would put people to work; would generate power; would provide for improved navigation; and, would irrigate farms. Accordingly, construction of dams at Cascades Rapids and Grand Coulee was authorized in 1933, with the former--to be known as Bonneville--to be constructed by the Corps of Engineers and the latter to be constructed by Reclamation. Thus, the construction of the Columbia River system was initiated. The decision to proceed was not justified based on economic analyses which 
are now required under Principles and Guidelines (Water Resource Council, 1983), but on the basis of the judgment of the nation's leaders that development of the nation's rivers was in the nation's best interest. This judgment was expressed by President Franklin D. Roosevelt in 1934, as follows:

\begin{abstract}
"There is another reason for the expenditures of the taxpayers money in very large amounts on the Columbia ... we are creating power, more power--and I always believe in the old saying, 'more power to you.' I don't believe you can have enough power for a long time to come, and the power we are developing here is going to be power which for all time is going to be controlled by the government."
\end{abstract}

Although the decision to construct the dams was not based on an analysis of potential economic benefits, as with the locks and canal at Celilo Falls, economic benefits sufficient to more than justify their construction occurred. Almost immediately following completion of the first projects, World War II broke out and created a demand for large amounts of electricity. The "pump-priming" effects that construction of the dams and World War II had on the region's economy did not end with the war. Today more than 700,000 acres $(283,300$ hectares) of irrigated land along the Columbia and Snake Rivers benefit directly from projects on the Columbia and lower Snake Rivers. Federal and non-federal hydropower projects in the region supply approximately 75 percent of the electricity used in the Northwest and provide the region with the lowest power rates in the nation. The Columbia-Snake waterway extends navigation to Lewiston, Idaho, 465 miles ( 750 kilometers) from the ocean, and provides for low-cost transportation of farm commodities to ports on the lower Columbia River's deep-draft navigation channel for export to international markets. In addition, storage projects in the basin prevent flooding of rural communities, agricultural lands, and major metropolitan centers like Portland. The contribution of the existing system of water control facilities to each of the various beneficiaries of a regulated Columbia River are described in greater detail later in this appendix and in appendices on each river use.

\subsubsection{Population and Current Economic Development}

This section presents a brief overview of the region's current and projected population and economic development. The information presented in this section was taken from the Bonneville Power Administration 1993 Resource Programs EIS.

\subsubsection{Current and Projected Population}

In the Pacific Northwest, population centers around Seattle/Tacoma (WA), Portland/Vancouver (OR/ WA), Eugene/Springfield (OR), Spokane (WA), and Boise/Nampa/Caldwell (ID). Based on the 1990 Census of Population, the population in Washington grew from about 4.13 million in 1980 to about 4.87 million in 1990, an 18 percent net increase and an annual rate of growth of 1.8 percent. The population of Oregon increased from about 2.63 million in 1980 to about 2.84 million in 1990 , an 8.1 percent net increase and an annual growth rate of 0.8 percent. The population in Idaho grew from 947,000 to about 1 million, a 6.6 percent net increase and an annual growth of 0.6 percent. The population of western Montana increased from 294,500 in 1980 to 303,300 in 1990, a 3.0 percent net increase and an annual growth rate of 0.3 percent. Table 2-1 shows population projections for the four state area through 2015.

Approximately eight million people lived in the region (Idaho, Oregon, and Washington) in 1980, and by 2015 this figure is expected to grow to about 12 million. Population growth is expected to be higher than the average growth rate for the Nation. While the recession during the 1980's contributed to outward migration, the enhanced prospects for the region have reversed this trend. The regional economy is expected to foster increased inward migration during the forecast period. Comparatively stronger economic growth and increases in retirement and recreation help foster population growth above U.S. averages. 


\subsubsection{Economic Development}

Over the past 10 years, the economy of the Pacific Northwest has evolved from resource-based to more diversity, with growing trade and service sectors. In 1980, resource-based industries accounted for 30.9 percent of manufacturing employment; by 1990 , their share had fallen to 27.2 percent. High technology industries (aerospace, electronic, and scientific instruments), have grown in share over the last decade from 30.3 to 42.0 percent of total manufacturing. Overall, the manufacturing share of the regional economy was 19.4 percent in 1980 and fell to 17.7 percent by 1990 .

The lumber and wood products industry still plays an important role in the region's economy, with 3.4 percent of the total regional employment, but this sector has declined from a decade ago, when it accounted for 4.4 percent of total employment. Food processing has fallen from 2.5 percent of total employment in 1980 to 2.1 percent in 1990 . This loss of employment share has been due to an increase in the relative size of the employment base and productivity gains brought on by plant upgrades and other efficiencies. Transportation equipment, primarily Boeing, has remained at nearly 4 percent of total employment over the last decade, and the electronics and scientific instruments industries have grown from 13.4 percent of manufacturing employment to $\mathbf{1 7 . 7}$ percent. Energy-intensive aluminum production is economically important to the region, but the level of employment in this sector is relatively small ( 0.7 percent of total employment in 1990).
While the manufacturing share fell over the decade, the non-manufacturing share of total employment rose from 80.6 to 82.3 percent. A rise in wholesale and retail trade and services accounts for most of the gain. Employment in trade grew from 24.1 percent of total employment in 1980 to 25.0 percent in 1990. The services sector grew from 18.8 percent of total employment in 1980 to 22.9 percent in 1990. The region's growing trade with California and the Far East also broadens the economic base.

Twenty-five percent of U.S. exports to Asia and 30 percent of all U.S. exported goods are handled through Pacific Northwest ports.

The advantage of low-cost energy relative to other areas has strengthened the region's economic base. Due to the availability of natural gas from Canada and the region's hydro base for electricity, the Pacific Northwest has a long-term energy advantage. Recently, the region's electricity prices ran 40 percent lower on average than the nation and natural gas prices were 16 percent less.

The region still can be hard-hit by high interest rates and their dampening effect on housing, which is the biggest source of demand for the region's lumber and wood products. However, more diversity and efficiency in industries in the region means more resistance to severe fluctuations now than in the past. Continued high levels of international trade should help offset the negative impact of periodic national business cycles, and the nonmanufacturing service sector of the region's economy is expected to continue to grow faster than total employment.

Table 2-1. Population Projections through 2015 (millions)

\begin{tabular}{|l|c|c|c|c|c|c|c|}
\hline & $\mathbf{1 9 8 0}$ & $\mathbf{1 9 9 0}$ & $\mathbf{1 9 9 5}$ & $\mathbf{2 0 0 0}$ & $\mathbf{2 0 0 5}$ & $\mathbf{2 0 1 0}$ & $\mathbf{2 0 1 5}$ \\
\hline \hline Washington & 4.13 & 4.87 & 5.31 & 5.62 & 5.91 & 6.21 & 6.52 \\
\hline Oregon & 2.63 & 2.84 & $\mathbf{3 . 1 7}$ & 3.38 & 3.57 & 3.76 & 3.96 \\
\hline Idaho & .95 & 1.0 & 1.11 & 1.18 & 1.24 & 1.29 & 1.35 \\
\hline $\begin{array}{l}\text { Western } \\
\text { Montana }\end{array}$ & .29 & .30 & .32 & .34 & .36 & .38 & .40 \\
\hline $\begin{array}{l}\text { Regional } \\
\text { Totals }\end{array}$ & 8.00 & 9.01 & 9.91 & 10.52 & 11.08 & 11.64 & 12.10 \\
\hline
\end{tabular}


California, with over 29 million people (more than 10 percent of the nation's total population) represents an important market for the Pacific Northwest. The tourism industry, fueled by the scenic coast, Columbia River Gorge, and Hells Canyon, provides economic stimulus in less populated regions and helps stimulate activity in the service and trade sectors. Agriculture also is a substantial industry in the region, employing about 275,000 in 1990 , down from about 285,000 in 1980 . the decline in agriculture employment is part of the shift toward a less resource-dependent economy and also is due to growing productivity in the farm sector.

For the forecast period 1990 to 2010, overall growth for major sectors of the regional economy in each state is expected to be moderate. Manufacturing employment is forecasted to be generally stagnant while non-manufacturing employment is expected to be relatively robust. Growth in the electronics industries is expected to be strong but the natural resource industries are expected to suffer declining employment levels. Embedded into the declining lumber and wood products forecast is the assumption of supply constraints due to the implementation of the spotted owl recovery plan. This forecast also assumes there are no military base closures although it does anticipate gradual reduction of military in the Region of about .7 percent per year. There are no assumptions of impacts from listing species of Columbia and Snake Rivers salmon and steelhead as endangered.

Manufacturing is forecast to drop from about 17 to around 13 percent of total employment. The actual level of employment in manufacturing will grow slightly over the forecast, but due to the rapid growth in non-manufacturing, the share will be declining.

Employment in the finance, trade, and service sectors is expected to remain strong as the economic base shifts toward a service economy and reflects continuing shifts in national demographics. Increased foreign trade and current management trends also suggest growth in business services.
Non-manufacturing employment is projected to grow faster than the national average for the same sector.

\subsection{MAJOR USES OF THE RIVER SYSTEM}

The Columbia River and its tributaries touch the lives of nearly every resident of the Northwest-from providing the world-famous Pacific salmon to supplying the clean natural fuel for over 75 percent of the region's electrical generation. This section introduces the major uses of the river system. The Final Environmental Impact Statement (FEIS) has an appendix for each one of the primary uses. The focus here is on an economic perspective. References to the other appendices where additional detail can be found are made throughout this section.

\subsubsection{Anadromous Fish}

The harvest of Columbia River anadromous fish has been a major activity of man throughout history in the Pacific Northwest. Anadromous fish have been an important food source for indigenous people for centuries and remain an important part of the cultural heritage of Native Americans. In more modern times, harvest rates by the 50,000 to 60,000 Native Americans who lived in the Columbia Basin in the early 1880's was estimated to have been about five to six million adult salmonids per year (NPPC, 1986). Non-native commercial harvest has occurred in the Lower Columbia River since the 1860's and peaked for the different runs in the late 1880's and 1890 's with the harvest of Chinook at 43 million pounds (19 million kilograms), sockeye at 45 million pounds ( 20 million kilograms), coho at seven million pounds (3.2 million kilograms), and chum at over eight million pounds ( 3.6 million kilograms). Through the 1920 's essentially all Columbia River salmon were commercially harvested in the river with gillnets and fish wheels. Historically, local processors canned most of the salmon for national and international markets. Over time, the market for Columbia River canned salmon has been replaced to a large extent by the frozen and fresh salmon market. 
In the 1930's, the ocean troll fishery began, and over the years moved from the mouth of the Columbia River to further out in the ocean to the salmon feeding grounds, roughly a band from ocean beaches to about 25 miles to sea. The ocean troll industry resulted in harvest of anadromous fish from other river basins and spread the harvest of Columbia River fish up and down the West Coast of the US and Canada.

Like the non-native commercial fisheries, sport fishing for anadromous fish began in the late 1800's, but catch statistics are sparse until the 1950's. Sport fishing occurs in the ocean, the lower river, the mainstem, and the spawning tributaries.

The Native American fishery has continued to exist and is protected through treaty rights that assure that the four Columbia River treaty tribes can continue to fish from Bonneville Dam to McNary Dam. A major dip net native fishery was located at Celilo Falls until 1957 when the rising pool behind The Dalles Dam inundated the falls. The Columbia River Native American fishery consists primarily of set gillnets, but dip net fishing still occurs at several locations.

All three Columbia River anadromous fisheries-non-native commercial, sport, and Native American--have experienced immense declines in harvest from before the turn of the century. In recent years, the Columbia River salmon runs have displayed substantial variations. For example, the Columbia River sockeye runs had a low in 1978 of 18,400 fish and a high in 1985 of about 200,000 fish. The upriver fall Chinook run size has fluctuated greatly over the last decade. In 1983, the run size was about 175,000 fish as compared to about 540,000 fish in 1987 (ODFW, 1991). With the variations in run sizes and changing market conditions, the income generated by salmon harvest has also varied greatly, but this income continues to be a strong element in the local economies of Oregon, Washington, and the four treaty tribes. The total gross annual value of the commercial harvest of the fishery in the Columbia River (excluding ocean and sport harvest) averages about $\$ 15,200,000$ (1990 dollars based on a weighted average value for 1986 to 1990) (Olsen, 1992). The economies of coastal and lower river communities include significant amounts of employment in fish harvesting, fish processing, boat services, recreational charters, and tourist related industries. The commercial fishery and charter fishing industries tend to be labor intensive, so much of the revenue generated goes directly to households. Therefore, consumer supported businesses like retail, housing, restaurants, etc. are indirectly effected if income from fishing declines substantially.

The treaty tribes rely on the fishing industry to help maintain economic viability and economic diversity of the Indian communities. The cultural, historical and spiritual values of salmon runs continue to be of extremely high value to the tribes.

\subsubsection{Resident Fish and Wildlife}

The economic importance of resident fish and wildlife is tied directly to the recreation use at the reservoirs and river reaches of the Columbia River Basin. The abundance of fish and wildlife resources influences recreation activity and the economic value recreators place on fishing, hunting, and other recreation experiences. Accordingly, to the extent that changes in the operation of the hydropower system impact fish and wildlife resources at the reservoirs and river reaches are affected by the system, these changes could influence the amount of recreation activity and quality of the recreation experience. For example, when the number and size of resident fish in a reservoir increases or decreases, the number of recreational fishing days could change along with the angler's willingness - to-pay for the recreation experience. Similarly, site-seeing, boating, and hunting activities can all be influenced by the condition and quantity of fish or wildlife. However, the economic impacts of changes in resident fish and wildlife are not directly reflected in the SOR recreation economic analysis, because data required to establish a statistically valid relationship between fish and wildlife abundance and economic values (willingness-to-pay) were not available. While it was not possible to specifically asses economic effects of changes in fish populations, etc., respondents to the recreation survey which was 
conducted for the SOR by the Recreation Work Group based their perceived value of their expected fishing experience under river and reservoir conditions associated with the alternative SOSs on their perception of their expectations regarding the abundance and quality of the fishery. Therefore, potential changes in resident fish populations, etc., are embedded in the values obtained through the survey. The appendices for resident fish (Appendix $\mathrm{K}$ ) and wildlife (Appendix $N$ ) present details on specific fish stocks and wildlife populations and details on the recreation survey are presented in the recreation appendix (Appendix J).

\subsubsection{Flood Control}

Because the Columbia River's flow varies so widely, the river was subject to severe floods prior to construction of major reservoirs in the US and
Canada and levees at a number of damage centers throughout the region. Controlling damaging flood waters was one of the original purposes of many of the dams on the river. And flood control remains a high priority for system operations today. Due the high priority placed on controlling floods through operation of the system's major storage projects, the potential impact of the alternative SOSs on the system's ability to control floods was evaluated. The economic effects of existing and changed flood control operations are measured in terms of expected annual flood damages at damage centers throughout the basin. These damage centers are grouped into three study areas as shown in Table 2-2 and displayed in Figure 2-1. The Flood Control Exhibit (Exhibit B) to this appendix provides additional details on the Columbia River flood control system and the derivation of average annual damages.

Table 2-2. Flood Control Study Areas

\begin{tabular}{|c|c|}
\hline Study Area & Damage Center \\
\hline Upper Columbia River & $\begin{array}{l}\text { Libby Dam to Kootenay Lake } \\
\text { Albeni Falls to Cusick } \\
\text { Pend Oreille Lake } \\
\text { Columbia Falls to Flathead Lake } \\
\text { Flathead Lake } \\
\text { Kerr Dam to Thompson Falls }\end{array}$ \\
\hline Clearwater River & $\begin{array}{l}\text { Dworshak Dam to Lewiston Levees } \\
\text { Lewiston Levees to Snake River }\end{array}$ \\
\hline Lower Columbia River ${ }^{1 /}$ & $\begin{array}{l}\text { Washougal Drainage District - near Vancouver, WA } \\
\text { Sandy Drainage District - at Portland, OR } \\
\text { Multnomah Drainage District } \\
\text { Peninsula Drainage District No. } 1 \text { - at Portland, OR } \\
\text { Peninsula Drainage District No. } 2 \text { - at Portland, OR } \\
\text { Cowlitz I at Longview Drainage District - at Longview, WA }\end{array}$ \\
\hline
\end{tabular}

1/ There are a total of 53 flood protection levee systems (drainage districts) along the lower Columbia River. Of these, 29 are above RM40 and are included in the study area for the SOR. 


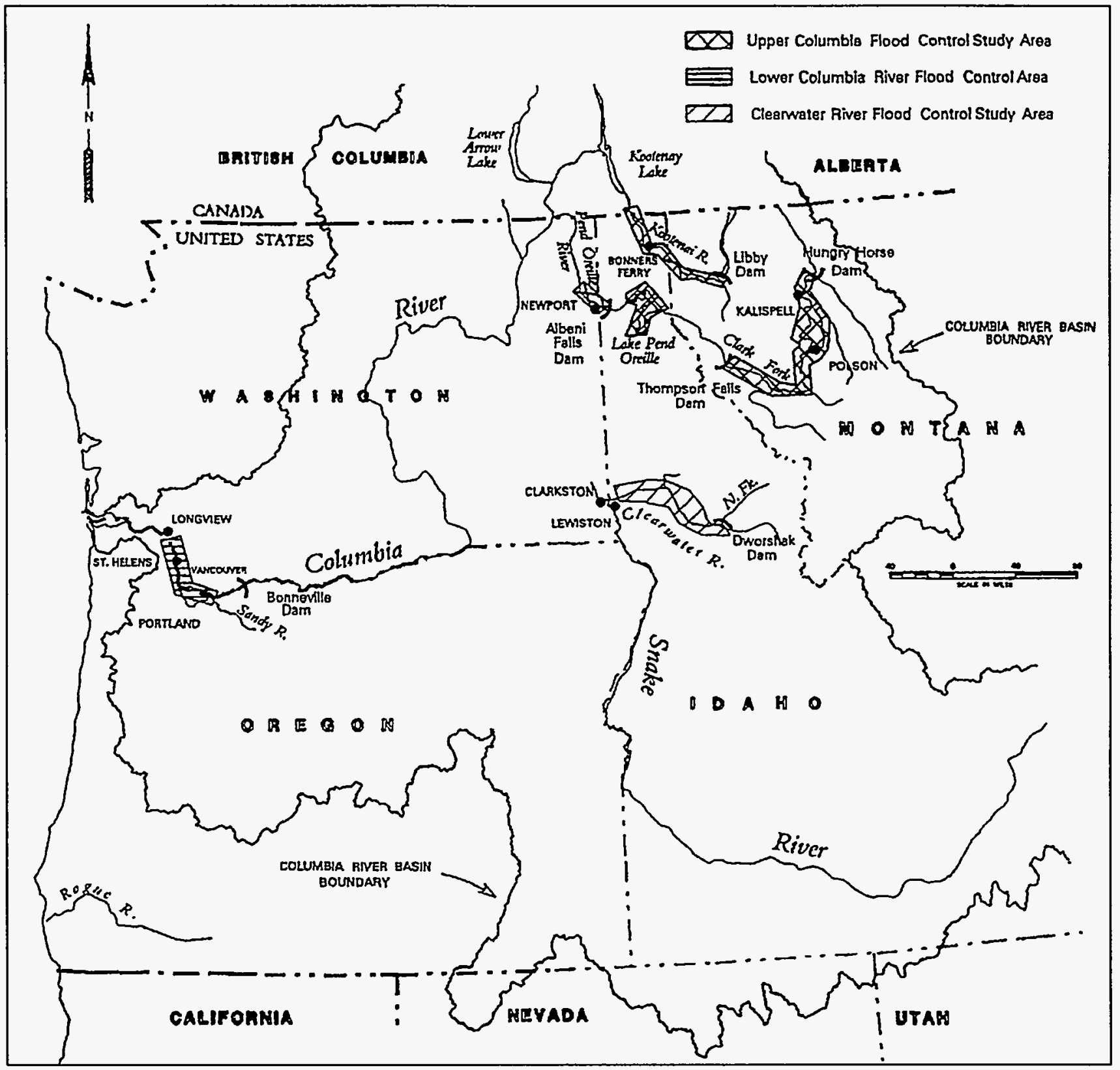

Figure 2-1. Map of Flood Control Study Areas

\subsubsection{Irrigation and Municipal and Industrial Water Supply}

\subsubsection{Irrigation}

Agriculture, including the production from irrigated lands, is an important industry to the economy of the Columbia River Basin. In 1991, crop and live- stock sales amounted to $\$ 9.7$ billion in the region, excluding British Columbia. In addition to the direct effect of these sales on the region's employment and income, the region's economic base is enhanced by the induced and stemming impacts generated by the processing, shipping and handling, and transportation of agricultural products, as well 
as the provision of production inputs to agricultural producers. A vast network of supporting infrastructure has been built up around the production of food and fiber in the region.

Water is one of the region's most important natural resources. In 1989-1990 the irrigated acreage for the Columbia River Basin (including British Columbia) was $7,324,300$ acres $(2,964,049$ hectares), or approximately 4 percent of the region's total area. This acreage includes full and supplemental irrigation service to lands that range from low intensive meadow hay production at high elevations in Idaho, eastern Oregon, and western Montana to intensive irrigation of fruits and vegetables in southern Idaho, Yakima Valley, Willamette Valley, central Washington, Columbia River corridor, and other areas. Idaho has the largest irrigated acreage with 3.3 million acres ( 1.33 million hectares), while Washington and Oregon have 1.878 million and 1.317 million acres respectively ( 0.76 million hectares and 0.53 million hectares).

The major blocks of concentrated irrigation development are located in the Yakima Valley, Boise and Payette Valleys, along the Snake River Plain in southern and eastern Idaho, central Washington, north central Washington, the Deschutes basin, and lands adjacent to the Columbia River near the Tri-cities area. There have been extensive private irrigation developments pumping from the McNary, John Day, and Ice Harbor reservoir pools.

Table 2-3 displays the distribution of irrigated acreage in the region, including British Columbia, Canada.

Production from irrigated land accounts for a substantial portion of the total crop production in the region. Some crops like potatoes, sugar beets, hops, mint, and fruit are almost exclusively from irrigated lands. Table 2-4 demonstrates the importance of irrigation and shows total crop production in Washington, Oregon, and Idaho in 1987 as well as the portion estimated to come from irrigation.

Irrigation diversions from the region's streams, rivers, and reservoirs is a function of the crops' consumptive use requirements, delivery system losses, on-farm losses, and the method of irrigation application. Net irrigation depletions, essentially diversions minus return flows, is the more meaningful indicator to system operations because the residual water is the actual amount available for instream flow purposes, including running the hydropower system. Return flows must be accounted for in flood control operations.

Table 2-3. Irrigated Acreage in Columbia River Basin by State - 1989-90 (acres)

\begin{tabular}{|l|r|r|r|r|r|r|}
\hline \multicolumn{1}{|c|}{$\begin{array}{c}\text { State or } \\
\text { Province }\end{array}$} & $\begin{array}{c}\text { Above } \\
\text { Grand } \\
\text { Coulee }\end{array}$ & $\begin{array}{c}\text { Grand Coulee } \\
\text { to Mouth of the } \\
\text { Snake }\end{array}$ & $\begin{array}{c}\text { Above Ice } \\
\text { Harbor Dam }\end{array}$ & $\begin{array}{c}\text { Ice Harbor Dam } \\
\text { to } \\
\text { Bonneville Dam }\end{array}$ & $\begin{array}{c}\text { Below } \\
\text { Bonneville } \\
\text { Dam }\end{array}$ & Total \\
\hline \hline Idaho & 25,800 & 0 & $3,306,400$ & 0 & 0 & $3,332,200$ \\
\hline Montana & 433,700 & 0 & 0 & 0 & 0 & 433,700 \\
\hline Washington & 60,600 & $1,509,800$ & 77,300 & 207,900 & 23,300 & $1,878,900$ \\
\hline Oregon & 0 & 0 & 502,000 & 531,500 & 283,100 & $1,316,600$ \\
\hline $\begin{array}{l}\text { British } \\
\text { Columbia }\end{array}$ & 89,700 & 103,100 & 0 & 0 & 0 & 192,800 \\
\hline Wyoming & 0 & 0 & 94,100 & 0 & 0 & 94,100 \\
\hline Utah & 0 & 0 & 5,600 & 0 & 0 & 5,600 \\
\hline Nevada & 0 & 0 & 70,400 & 0 & 0 & 70,400 \\
\hline Total Acres & 609,800 & $1,612,900$ & $4,055,900$ & 739,400 & 306,400 & $7,324,300$ \\
\hline
\end{tabular}

Source: 1990 level modified streamflow,Columbia River and Coastal Basin, A.G. Crook Company, April 1993. 
Table 2-4. Crop Production in Washington, Oregon, and Idaho

\begin{tabular}{|c|c|c|c|}
\hline \multirow[t]{2}{*}{ Crop } & \multicolumn{3}{|c|}{ Selected Major Commodities } \\
\hline & Units & Production & Percent of Total \\
\hline Corn for grain & $\mathrm{Bu}$. & $14,134,000$ & 86.9 \\
\hline Wheat & $\mathrm{Bu}$. & $249,907,000$ & 31.0 \\
\hline Potatoes & Cwt & $178,452,000$ & 99.0 \\
\hline Hops & Lbs & $14,457,000$ & 100.0 \\
\hline Mint, Oil & Lbs & $5,748,000$ & 100.0 \\
\hline Hay, alfalfa \& mix & Tons & $8,480,000$ & 63.7 \\
\hline Vegetables & Acres & 331,000 & 73.2 \\
\hline Orchards & Acres & 46,000 & 85.0 \\
\hline Sugar Beets & Tons & $4,710,000$ & 100.0 \\
\hline \multicolumn{4}{|c|}{$\begin{array}{l}\text { 1/ Source: } 1987 \text { Census of Agriculture data for Idaho, Oregon and Washington. Data excludes western } \\
\text { 2/ Sontana and portions of the basin in Wyoming, Utah and Nevada. } \\
\text { supplement with } 1988 \text { data. }\end{array}$} \\
\hline
\end{tabular}

Total irrigation diversions in the region were 32.56 million acre-feet $(40,179$ million cubic meters) for the 1990-1991 base level of development, with a net depletion of 13.73 million acre-feet (16.94 million cubic meters). Table 2-5 summarizes irrigation diversions and depletions for the hydrologic basins in the region for the 1990-1991 period (base level of development).

\subsubsection{Municipal and Industrial (M\&I) Water Supply}

The current level of M\&I depletions were not considered to be significant in the measurement of impacts under SOR alternative operating strategies.

Approximately 90 percent of the total water withdrawn in the Pacific Northwest is for irrigation (BPA, 1993). Public water supply and domestic use account for about 4 percent, commercial use about
2 percent, and industrial use about 2 percent. The remaining amount is shared by livestock, mining, and thermoelectric. Water withdrawn for non-agricultural use has a higher return rate than for agricultural uses. Accordingly, total depletion for the M\&I uses is estimated at less than 2 percent.

\subsubsection{Navigation}

Columbia River Basin economic growth has been closely associated with water transportation. The history of the basin records a program of continuing improvements to increase the serviceability of the deep-draft and inland waterway systems and to keep them adapted to the changing needs of navigation. Four river segments have had improvements: (1) the deep-draft channel which serves ocean-going commerce and extends from the Pacific Ocean to Vancouver, Washington and to Portland on the Willamette River; (2) the Columbia-Snake River 
Table 2-5. Irrigation Diversions and Net Depletions by Basin

\begin{tabular}{|l|r|r|}
\hline \multicolumn{1}{|c|}{ Hydrologic Basin } & $\begin{array}{c}\text { Irrigation Diversion } \\
\text { (Acre-Feet) }\end{array}$ & $\begin{array}{c}\text { Net Irrigation Depletion } \\
\text { (Acre-Feet) }\end{array}$ \\
\hline Upper Columbia \& Kootenai & 179,256 & 113,576 \\
\hline Clark Fork-Pend Oreille \& Spokane & $1,287,004$ & 768,602 \\
\hline Columbia Plateau, East Cascade, \& Yakima & $5,632,369$ & $3,425,053$ \\
\hline Upper Snake River & $14,365,500$ & $4,661,060$ \\
\hline Central Snake River & $7,545,580$ & $2,623,520$ \\
\hline Lower Snake River & 849,012 & 533,494 \\
\hline Mid Columbia & $2,352,607$ & $1,334,923$ \\
\hline Lower Columbia & 59,020 & 22,300 \\
\hline Willamette & 290,668 & 231,874 \\
\hline Total & $32,561,057$ & $13,734,403$ \\
\hline
\end{tabular}

Source: Draft USBR/BPA, Columbia River Basin System Operating Review Irrigation Delpetion estimate, September 10,1993, prepared for Bonneville Power Administration by A.G. Crook Company

shallow-draft navigation channel which extends from Portland, Oregon/Vancouver, Washington into the interior of the Columbia Basin all the way to Lewiston, Idaho, on the Snake River; (3) the Willamette River shallow-draft channel which extends from Portland, Oregon up the Willamette River to Eugene, Oregon; and, (4) the Yamhill River shallow-draft channel which extends from the confluence of the Willamette and Yamhill Rivers to McMinnville, Oregon. In addition, ferry service is provided on Lake Roosevelt (Grand Coulee Dam) in Washington and logs are transported on Dworshak reservoir in Idaho. The only improved systems which would be potentially affected by the alternatives SOSs are the deep-draft channel, the ColumbiaSnake River shallow-draft channel, and ferry service on Lake Roosevelt.

The Columbia River navigation channel services an enormous area that covers much of the western United States. The region produces a variety of commodities, foodstuffs, and other products. Agri- culture dominates the regional industries associated with waterborne commerce. Trade revolves around grains (such as wheat, alfalfa, corn, grass seed), fruits, and vegetables, with wheat being the largest export item. Other regional industries that use water transport include aluminum, pulp and paper, petroleum, logs, lumber, and beef. Products shipped on the shallow-draft channel are comprised mainly of wheat, grain, wood products, logs, petroleum, chemicals, and other agricultural products. Containerized commodities are also transported via the waterway. Containers are typically loaded at Lewiston Idaho, Pasco Washington and Boardman and Umatilla Oregon, with approximately 97 percent of these shipments destined for Portland, Oregon and the remainder going to Vancouver, Washington. Petroleum products have historically made up the bulk of upriver barge shipments on the waterway. The following paragraphs in this section contain relatively brief descriptions of the waterways and associated commerce. Additional information is contained in Appendix $\mathrm{H}$ (Navigation). 


\subsubsection{Deep-Draft Navigation}

The Federal deep-draft navigation channel begins at the Columbia River entrance channel and extends inland to Portland-Vancouver (Oregon and Washington, respectively). The entrance channel extends two miles $(3.2 \mathrm{~km})$ seaward and three miles $(4.8 \mathrm{~km})$ landward from the outer ends of the Columbia River jetties at the Pacific Ocean. In 1957, the entrance was deepened to 48 feet $(14.6 \mathrm{~m})$ and maintained at that depth until 1984 when it was deepened to 55 feet $(16.8 \mathrm{~m})$ to provide improved navigability of the bar. The 40-foot $(12.2 \mathrm{~m})$ deep-draft channel extends inland from the Pacific Ocean 106 river miles (170.6 $\mathrm{km}$ ) to Vancouver, Washington, and also up Willamette River from its confluence with the Columbia River to the Broadway Bridge at Portland, Oregon. In addition to channels and turning basins, there are numerous small harbors along the river. Deep-draft anchorage sites have been designated by the US Coast Guard at Astoria, Longview, Kalama, Woodland, Henrici Bar, Willow Bar, Kelley Point and Hayden Island. The deep-draft channel is used extensively by oceangoing vessels transporting products and commodities to and from national and international markets.

\section{Port Facilities}

Import-export terminals are located adjacent to the 40 -foot $(12.2 \mathrm{~m}$ ) channel between its upstream terminus at Vancouver and the river's entrance. The Port of Vancouver exports wheat, barley, lumber, paper/newsprint, and linerboard, and imports such products as alumina, cement, iron and steel products and fertilizers. The Port of Portland exports wheat, barley, logs, lumber, soda ash, and metal scraps, and imports autos and auto parts, iron and steel products, limestone, salt (crude), and alumina. Port Longview exports logs, soda ash, coke, wood chips and paper products, and imports alumina, salt (crude), coal tar pitch, fertilizers, sand, and zircon. The Port of Kalama specializes in the export of grains such as corn, sorghum, wheat, and barley, and imports toluene and chemicals.

With the exception of Longview, all the major ports with deep water access off-load and reload grain for shipment to export markets. A tabulation of major lower Columbia/Willamette River grain elevators and their respective capacities is shown in Table 2-6.

\section{Fleet Composition}

Approximately 90 percent of oceangoing cargo ships calling at lower Columbia River ports operate under

Table 2-6. Columbia/Williamette River Grain Elevators

\begin{tabular}{|l|l|l|l|c|}
\hline & \multicolumn{1}{|c|}{ Location } & $\begin{array}{c}\text { Storage } \\
\text { Receiving } \\
\text { Facilities }\end{array}$ & $\begin{array}{c}\text { Loading } \\
\text { Capacity } \\
\text { (bushels) }\end{array}$ & $\begin{array}{c}\text { Capacity } \\
\text { (Tons/Hr) }\end{array}$ \\
\hline United Grain Corp & Vancouver, WA & barge, rail & $5,000,000$ & 2,400 \\
\hline Louis Dreyfus & Portland, OR & barge, raill, truck & $1,500,000$ & 1,200 \\
\hline Bunge Corp & Portland, OR & barge, rail, truck & $1,500,000$ & 1,200 \\
\hline Columbia Grain & Portland, OR & barge, rail & $4,000,000$ & 1,800 \\
\hline $\begin{array}{l}\text { Cargill Inc. } \\
\text { Terminal 4 }\end{array}$ & Portland, OR & barge, rail, truck & $8,000,000$ & 2,400 \\
\hline Harvest States Co-op & Kalama, WA & barge, rail, truck & $6,400,000$ & 1,500 \\
\hline Peavey Grain & Kalama, WA & barge, rail & $2,000,000$ & 3,000 \\
\hline Port Longview & Longview, WA & barge, rail, truck & $5,000,000$ & 800 \\
\hline
\end{tabular}


foreign flag. These include liquid and dry bulk carriers, container ships, auto carriers, tankers, and general-cargo ships. General cargo, tanker, and container ships that use the lower Columbia River range in size from 15,000 to 50,000 deadweight tons $(15,240$ to 50,800 metric tons) and draft 25 to 40 feet (7.6 to 12.2 $\mathrm{m})$ loaded. Dry bulk carriers are designed to carry non-containerized, non-liquid products such as corn, wheat, logs, lumber, and wood chips. Many of the ships used to transport corn and wheat to export markets are panamax-class vessels ranging up to $60-80,000$ deadweight tons, $(60,960-81,280$ metric tons) with design drafts of 37 to 44 feet (11.4 to $14.4 \mathrm{~m})$ and lengths exceeding 700 feet $(213 \mathrm{~m})$. Since the initiation of midwest corn exports from Kalama in 1983 and the deepening of the river entrance in 1984, the number of deep-draft vessel transits of the lower Columbia River has increased significantly. Approximately 12.5 percent of the grain vessel fleet calling at lower Columbia River ports are panamax-sized vessels, with the remainder ranging in length from 450 to 650 feet (137 to $198 \mathrm{~m}$ ).

\section{Waterborne Commerce}

Major commodities transported on the deep-draft portion of the Columbia River navigation channel are wheat, grain, and corn. Other products include autos, containerized products, logs, petroleum, chemicals, and other miscellaneous products. Most of the commerce on the river is associated with the export/import trade with other countries. Major countries involved in the region's export trade are Japan, Korea, and Taiwan, as well as other Pacific Rim countries. Total tonnage of Columbia River export products to the top five countries for 1990 are shown in Table 2-7.

Import trade is conducted worldwide with countries such as Australia, Japan, Canada and Mexico. The lower Columbia River is one of the largest auto import areas on the west coast. In 1992, Portland was the largest automobile port on the west coast and the fourth largest auto port overall in the United States. The top five import partners for products and commodities are listed in Table 2-8.

Table 2-7. Top Five Export Countries - 1990, Columbia River Deep-Draft Channel

\begin{tabular}{|l|l|l|}
\hline \multicolumn{1}{|c|}{ Country } & \multicolumn{1}{|c|}{ Commodity } & Total Short Tons \\
\hline Japan & Wheat, Corn, Logs, Other & $12,264,209$ \\
Korea & Corn, Wheat, Logs, Other & $5,116,483$ \\
Taiwan & Corn, Wheat, Soda Ash, Other & $3,202,711$ \\
Philippines & Wheat, Soda Ash, Peas, Other & $1,413,535$ \\
Pakistan & Wheat, Machinery, Household, Other & $1,075,883$ \\
\hline Source: & Waterborne Commerce Statistics, U.S. Army Corps of Engineers. \\
\hline
\end{tabular}

Table 2-8. Top Five Import Countries - 1989, Columbia River Deep-Draft Channel

\begin{tabular}{|c|l|l|}
\hline Rank & \multicolumn{1}{|c|}{ Import Country } & \multicolumn{1}{|c|}{ Commodity } \\
\hline 1 & Australia & Alumina \\
2 & Japan & Autos \& Vans \\
3 & Mexico & Salt, Crude Oil \\
4 & Canada & Limestone \\
5 & Korea & Cement \\
\hline
\end{tabular}


Major Columbia River export items are ranked in Table 2- 9 by tonnage. Nearly all of these commodities rely on barge transport through the inland system of locks for delivery to export terminals and ultimately, to markets worldwide.

\subsubsection{Shallow-Draft Navigation}

The Columbia-Snake River shallow-draft waterway is a Federally-maintained channel and system of locks between Portland-Vancouver and Lewiston, Idaho. The waterway is used by commercial tug and barge companies to move products and commodities to and from upstream origin and destination points. Access to the inland areas by barge traffic is made possible by a system of locks, which allow passage through the Federal dams on the river. Within the Columbia/Snake Federal navigation system there are four dams and locks on the Columbia River: Bonne- ville, The Dalles, John Day and McNary; and four on the Snake River: Ice Harbor, Little Goose, Lower Monumental, and Lower Granite.

The authorized navigation channel (27-foot deep $(8.2 \mathrm{~m})$ by $300-$ foot $(91.4 \mathrm{~m})$ wide) extends from Vancouver, Washington, to The Dalles, Oregon (RM 191.5) (km 308.1). From The Dalles to Lewiston, Idaho, the channel is 14 feet $(4.3 \mathrm{~m})$ deep and 250 feet $(76.2 \mathrm{~m})$ in width. The authorized minimum depth of the channel is 14 feet $(4.3 \mathrm{~m})$ at minimum operating pool (MOP) elevations at each of the dams. Lock sills are at -15 feet $(-4.6 \mathrm{~m})$ MOP but the rest of the channel is maintained to -14 feet $(-4.3 \mathrm{~m})$ MOP. Under normal operation of the system, pool elevations generally fluctuate between full pool and two feet $(.6 \mathrm{~m})$ below full pool, providing channel operating depths of about 18 feet. $(5.5 \mathrm{~m})$

Table 2-9. Major Export Items from the Columbia River (short-tons)

\begin{tabular}{|c|c|c|c|}
\hline Export & 1990 & 1989 & 1988 \\
\hline Wheat & $11,569,427$ & $11,350,330$ & $15,073,585$ \\
\hline Corn & $6,968,267$ & $7,048,202$ & $5,797,559$ \\
\hline Logs & $3,155,651$ & $3,805,574$ & $3,719,711$ \\
\hline Soda Ash & $1,464,768$ & $1,136,370$ & $1,044,776$ \\
\hline Wood chips & 898,804 & $1,160,367$ & $1,030,573$ \\
\hline Barley & 715,265 & 492,613 & 856,919 \\
\hline Lumber & 513,361 & 898,999 & 620,372 \\
\hline Sorghum & 498,374 & 409,010 & 199,709 \\
\hline Beet Pulp Pellets & 405,532 & 202,712 & 182,083 \\
\hline Coke & 332,416 & 445,917 & 500,684 \\
\hline Total & $26,521,865$ & $26,950,094$ & $29,025,971$ \\
\hline$\%$ of Columbia River exports & $92 \%$ & $92 \%$ & $92 \%$ \\
\hline Total - Columbia River & $28,763,587$ & $29,437,819$ & $31,397,753$ \\
\hline
\end{tabular}




\section{Port Facilities}

Riverside facilities managed by port districts or other public or private entities are located on each of the pools created by the locks and dams in the system. There are 54 port and other shipping operations that provide transportation for agricultural, timber, and other products. On the shallow-draft segment there are 20 ports that have grain handling capability out of a total of 22 ports. These are listed in Table $2-10$, below:

\section{Table 2-10. Location of Elevators with Grain Handling Capability, Columbia/Snake Shallow-Draft Navigation Channel}

\begin{tabular}{|c|c|c|c|}
\hline Pool & Port & River Mile & Major Commodities \\
\hline \multirow[t]{3}{*}{ Lower Granite } & Lewiston & 2 (Clearwater $\mathrm{R}$ ) & Grain, pulses, logs, containers \\
\hline & Clarkston & 138 (Snake R) & Grain, containers, logs \\
\hline & Wilma & 135 (Snake R) & Grain, wood concrete, petroleum \\
\hline \multirow[t]{3}{*}{ Little Goose } & Almota & 104 (Snake R) & Grain \\
\hline & Central Ferry & 83 (Snake R) & Grain fertilizer \\
\hline & Garfield & 83 (Snake R) & Grain \\
\hline Lower Monumental & Lyons Ferry & 61 (Snake R) & Grain \\
\hline \multirow[t]{2}{*}{ Ice Harbor } & Windust & 38 (Snake R) & Grain \\
\hline & Sheffler & 29 (Snake R) & Grain \\
\hline \multirow[t]{6}{*}{ McNary } & Burbank & 2 (Snake R) & Grain \\
\hline & Pasco & 328 (Col. R) & $\begin{array}{l}\text { Petroleum, chemicals, fertilizer, plate } \\
\text { glass }\end{array}$ \\
\hline & Kennewick & 328 (Col. R) & Grain, fertilizer \\
\hline & Wallula & 314 (Col. R) & Grain \\
\hline & Port Kelley & 312 (Col. R) & Grain \\
\hline & Umatilla & 293 (Col. R) & $\begin{array}{l}\text { Containers, logs, woodchips, general } \\
\text { cargo }\end{array}$ \\
\hline \multirow[t]{4}{*}{ John Day } & $\begin{array}{l}\text { Hogue Warner, Port of } \\
\text { Morrow }\end{array}$ & 278 (Col. R & Grain \\
\hline & Morrow & 275 (Col. R) & Grain, containers, logs, wood chips \\
\hline & Roosevelt & 240 (Col. R) & Grain \\
\hline & Arlington & 240 (Col. R) & Grain \\
\hline The Dalles & Biggs & 208 (Col. R) & Grain \\
\hline \multirow[t]{2}{*}{ Bonneville } & The Dalles & 190 (Col. R) & Wood chips, grain \\
\hline & Klickitat & 170 (Col. R) & Lumber, grain, aggregate \\
\hline
\end{tabular}




\section{Fleet Composition}

The existing towboat and barge fleet consists of approximately 40 tow boats and 175 barges operated by six barge companies. These are used principally on the shallow-raft segment of the river. Commodities are transported through the inland waterway system on non-powered barges propelled by tow boats. The barges are rectangular, with flat bottomed hulls, and vary in size and design depending on the type of cargo they are intended to carry (open deck, tank, bin, etc.). Barges draft between $11(3.4 \mathrm{~m})$ and 14 feet $(4.3 \mathrm{~m})$ loaded. The size and weight of the tow determines the size or horsepower of the towboat required to move it. To facilitate efficient movement through the system of locks on the Columbia and Snake Rivers, barges are assembled together in tows of one to six barges. The optimum tow is made up of barges that can pass through the upstream locks as a unit. A typical tow configuration consists of five barges and a towboat in the configuration of two sets of barges side by side, with one barge and the tow boat side by side in the rear. The data below describe the types of barges used to transport various commodities.

Standard and Jumbo Combination Barge: Grain and petroleum products, alfalfa, potatoes, paper.

Standard \& Jumbo Covered Bin: Dry bulk cargo such as grain under protective cover (30 percent of the total barge traffic).

Open Bin: Dry bulk commodities such as wood chips and sawmill scrap.

Flat Deck: Logs, construction equipment and materials, containers.

Tank Barges: Bulk liquid commodities, petroleum products, anhydrous ammonia (fertilizer).

Log Rafts: The standard log raft is 455 feet (138.7 $\mathrm{m})$ long by 65 feet $(19.8 \mathrm{~m})$ wide and contains 250,000 board-feet net Scribner Scale, $(590 \mathrm{~m} 3)$ or 937 tons. (952 metric tons)

Tow boats operating on the waterway vary in size and horsepower. About 60 percent of the barge movements passing through Bonneville Lock use tow boats having from 250 to 1,840 horsepower. These tow boats range in length from 42 to 108 feet $(12.8$ to $32.9 \mathrm{~m}$ ), in width from 13 to 34 feet (4 to $10.4 \mathrm{~m}$ ), and draft from 6 to 11 feet $(1.8$ to $3.4 \mathrm{~m})$. The remaining movements require tow boats with 2,000 to 3,600 rated horsepower. The largest vessels in this group are 127 feet $(38.7 \mathrm{~m}$ ) long, 35 feet (10.7 $\mathrm{m})$ wide, and draft up to 12 feet $(3.7 \mathrm{~m})$.

\section{Alternate Transportation Modes}

Alternative or complementary modes of commodity transport are rail and truck. Union Pacific and Burlington Northern Railroads are the predominant rail companies which operate in the region. There is relatively little grain traffic from Oregon, Washington, or Idaho that is moved by rail to Pacific Northwest ports. Most of the region's grain production is transported by water. Of the total volume of annual rail-grain carloads unloaded at Pacific Northwest export elevators, including Seattle and Tacoma, wheat makes up about 25 percent. More than half of the rail traffic is corn, most of which originates from Nebraska, Minnesota and South Dakota. Shown in Table 2-11, below, is the volume of grain moved by rail to Pacific Northwest Ports over a five year period, 1986 to 1990.

Trucks are used for commodity transport, particularly for upriver movement of petroleum and chemical products. Trucks are also used almost exclusively in moving grain from the farm to country or river elevators, and also to transport products arriving at river terminals to their final destinations. Shown in Table 2-12, below, are comparative data on shipments of wheat and barley to export houses by various mode for the years 1987 to 1991 .

\section{Waterborne Commerce}

The Columbia/Snake River waterway services an enormous area that covers much of the western United States. Agriculture dominates the regional industries associated with waterborne commerce. Trade revolves around grains, such as wheat, alfalfa, corn, grass seed, fruits, and vegetables, with wheat being the largest export item. Other regional industries that use water transport include aluminum, pulp and paper, petroleum, logs, lumber, and beef. 
Table 2-11. Annual U.S. Rail-to-Port Grain Traffic Pacific Northwest Ports, 1986-90 (Short-Tons)

\begin{tabular}{|l|c|c|c|c|c|c|}
\hline \multicolumn{1}{|c|}{ Port } & $\mathbf{1 9 8 6}$ & $\mathbf{1 9 8 7}$ & $\mathbf{1 9 8 8}$ & $\mathbf{1 9 8 9}$ & $\mathbf{1 9 9 0}$ & Average \\
\hline Portland & 31,940 & 39,037 & 43,536 & 36,543 & 39,411 & 38,093 \\
\hline Vancouver & 13,482 & 14,520 & 21,281 & 13,957 & 17,732 & 16,194 \\
\hline Kalama & 32,015 & 50,254 & 61,274 & 85,398 & 77,299 & 61,248 \\
\hline Longview & 0 & 487 & 594 & 301 & 0 & 276 \\
\hline Tacoma & 21,618 & 23,109 & 44,918 & 46,206 & 48,203 & 36,811 \\
\hline Seattle & 4,486 & 13,439 & 15,171 & 24,252 & 15,900 & 14,650 \\
\hline
\end{tabular}

Table 2-12. Receipts of Wheat and Barley at Columbia River Export Houses by Mode of Transportation for Crop year 1987-88 to 1990-91 (in thousands of bushels)

\begin{tabular}{|c|c|c|c|c|}
\hline Transport Mode & $1987-88$ & $1988-89$ & $1989-90$ & $1990-91$ \\
\hline Barge & 199,855 & 198,185 & 165,197 & 179,528 \\
\hline$\%$ of total & 40.6 & 43.0 & 40.9 & 40.4 \\
\hline Rail & 274,825 & 247,441 & 226,714 & 254,514 \\
\hline$\%$ of total & 55.9 & 53.8 & 56.2 & 57.2 \\
\hline Truck & 17,032 & 14,707 & 11,798 & 10,505 \\
\hline$\%$ of total & 3.5 & 3.2 & .9 & 2.4 \\
\hline
\end{tabular}

Products shipped on the shallow draft channel are comprised mainly of wheat, grain, wood products, logs, petroleum, chemicals, and other agricultural products. Containerized commodities are also transported via the waterway. Containers are typically loaded at Lewiston, Pasco, Boardman, and Umatilla, with approximately 97 percent of these shipments destined for Portland and the remainder going to Vancouver. Petroleum products have historically made up the bulk of upriver barge shipments on the waterway.

\section{Projected Commerce}

A review was made of projected growth in tonnage for the Columbia-Snake Rivers' segment of the Nation's inland waterways (IWR 1992 ). Over a 10-year period, (1990-2000) the projected change in total volume of goods shipped on the ColumbiaSnake inland waterway is low to moderate. This growth could have a long-term impact on system transportation, handling and storage requirements. However, due to constraints on time and resources 
to conduct analyses for the SOR, the navigation analysis was based on existing commodity volumes.

\subsubsection{Dworshak Reservoir}

Commercial navigation on project waters includes transporting logs on Dworshak reservoir. Logs from harvest operations in the North Fork Clearwater River drainage above the reservoir are hauled to staging areas at various points along the reservoir and are rafted to log dumps near the dam. They are then collected at the dumps and transferred to trucks for transport to mills. Use of the reservoir for this purpose saves time and cost when compared to trucking logs the entire distance. Dworshak Reservoir is thus used on a seasonal basis to transport approximately 20 million board - feet $(47,195 \mathrm{~m} 3)$ of logs annually. About 90 percent of this commercial operation occurs during the months of June, July, and August. The recent history of log handling on Dworshak Reservoir is shown below. Although log handling facilities continue to be maintained, currently logs are not being transported on the reservoir because tb:pool elevation is unreliable.

\begin{tabular}{|c|c|}
\hline Year & $\begin{array}{c}\text { Volume (million } \\
\text { board-feet) }\end{array}$ \\
\hline 1988 & 25 \\
1989 & 14 \\
1990 & 22 \\
1991 & 20 \\
\hline \multicolumn{2}{|c|}{ Source: U.S. Army Corps of Engineers, } \\
Walla Walla District. \\
\hline
\end{tabular}

\subsubsection{Power}

The electric generating resources of the Pacific Northwest are capable of producing nearly 44,000 megawatts of electricity from all sources: hydro, coal, nuclear, combustion turbines, etc. This generating capacity produces nearly 20,000 average megawatts (aMW) of energy under the worst water conditions, and an additional 5,000 aMW when water conditions are average.
The hydroelectric dams on the Columbia and Snake Rivers are the foundation of the Northwest's power supply. Falling water provides the energy to turn power-generating turbines at the dams. Hydropower supplies approximately 76 percent of the generating capacity in the Pacific Northwest, and approximately 62 percent of the firm energy supply. When in surplus, it is also an export product for the region. A more detailed description of the hydropower system can be found in Appendix I (Power).

The Bonneville Power Administration was created in 1937 to market and transmit the power produced at Bonneville Dam. Today, BPA markets the power from 30 Federal dams in the Pacific Northwest operateded by the Corps and Reclamation and has built one of the largest transmission systems in the United States.

The Federal generating and transmission system serves an area that includes Oregon, Washington, Idaho, western Montana and small parts of Wyoming, Nevada, Utah, California and eastern Montana. Public and private utilities, as well as some large industries, buy power from these federal facilities. Utilities in California and Canada also buy and exchange power with the Pacific Northwest.

About 86 percent of the firm energy BPA sells is hydroelectric. The projects under review in this FEIS account for 88 percent of the Federal system's hydroelectric capability and 57 percent of the region's hydroelectric capability.

Because hydropower is a relatively inexpensive source of electricity, electricity rates in the Northwest are among the lowest in the nation. This benefits Northwest rate payers, and explains why many energy-intensive industries, such as aluminum manufacturers, have located in the Northwest. For fiscal year 1992, approximately one-third of the power BPA sold went to industries it directly served. These direct service industries include 15 industrial firms operating 19 plants in the Pacific Northwest, producing products such as aluminum and other primary metals, pulp and paper, ferroalloys and chlor-alkalies.

Hydropower's relative cost advantage also explains the intensity of residential electric use in the Pacific 
Northwest. The average Pacific Northwest residential consumer uses over 50 percent more electricity than an average homeowner in the rest of the nation.

Many of the alternative SOSs evaluated in the FEIS will reduce the ability of the Federal dams to generate electricity. This electricity will need to be replaced by higher cost resources, which will lead to rate increases for Northwest consumers. This may affect the viability of Northwest industry, and will increase the electric bills of residential and commercial consumers of electricity. The methodology used to evaluate these effects is described in Chapter 3 (Section 3.3.6) and the effects are explained in Chapter 4 (Section 4.8) of this appendix.

\subsubsection{Recreation}

\subsubsection{Introduction}

The economic impacts of changes in recreation activity can be separated into direct and indirect impacts, which are described in more detail in Chapter 3 (Section 3.3.7). The direct impacts are the change in visitation and the change in willingness-to-pay values. The associated indirect or secondary impacts, are the change in recreation expenditures and are of interest to the general public and many communities in the region. The economies of communities located near recreation use areas depend directly on the number of visitors and the amount of money they spend in the area. For example, if operation of a reservoir like Lake Koocanusa is changed in a way that limits the use of boat ramps during the major recreation season, then fewer visitors will come to the area and purchase supplies like gasoline, food, and lodging in Libby, Montana. Businesses will suffer and possibly close resulting in reduced employment, regional income, and tax revenues. However, some recreators that did not visit Lake Koocanusa may visit Pend Oreille Lake instead, boosting the economy in the Sandpoint, Idaho area. The indirect impact analysis will identify these tradeoffs on local economies using regional input-output models. The extent of impacts can be substantial as indicated by a few Pacific Northwest studies that have estimated expenditures by recreators. For example, a study of lake and river fishermen in Montana showed that, on average, a Montana resident fishermen expended about $\$ 48$ per lake fishing trip, and those traveling from outside Montana spent about $\$ 360$ in Montana on each lake fishing trip (Duffield, 1987). The results from a survey of northwest recreators by the SOR Recreation Work Group were used to define the direct and indirect values associated with recreation at the impacted rivers and reservoirs. Detailed information on historic recreation activity and recreation facilities which could be impacted by the alternatives is contained in Appendix J (Recreation).

\subsubsection{Recreation Visitor Days}

Recreation visitor days at the reservoirs and river reaches within the geographic scope of the SOR were over 20 million in 1991 and have averaged over 18 million for the past five years. Recreation visitors participate in numerous activities. Generally, these recreation activities can be separated into water-dependent (swimming, fishing and boating) and water-related (picnicking, hiking and camping) activities. The water-related activities rely on water as an aesthetic complement that enhances the activity.

\subsubsection{Occurrence of Recreation Activity}

Recreation activity occurs throughout the study area. However, the analysis of recreation impacts associated with alternative SOSs included in the SOR was limited to just those areas where recreation use of affected lakes and streams could be significantly impacted by a change in the operation of the system. The projects and associated stream-reach areas for which use estimates and economic values were developed are shown in Table 2-13. Also shown in the same table are the types of recreation activity of concern and the occurrence of those activities at projects or stream-reach areas. 
Table 2-13. Recreation Areas and Recreation Activities

\begin{tabular}{|l|c|c|c|c|c|c|}
\hline \multicolumn{2}{|c|}{} & \multicolumn{5}{|c|}{ Recreation Activities } \\
\hline Project or Area & $\begin{array}{c}\text { Type of } \\
\text { Project or } \\
\text { Area }\end{array}$ & Boating & Fishing & Camping & $\begin{array}{c}\text { Picnicking \& } \\
\text { Other Day } \\
\text { Use }\end{array}$ & Swimming \\
\hline Hungry Horse & Lake & Yes & Yes & Yes & Yes & Yes \\
\hline Grand Coulee & Lake & Yes & Yes & Yes & Yes & Yes \\
\hline Libby & Lake & Yes & Yes & Yes & Yes & Yes \\
\hline Below Libby & Stream & No & Yes & No & No & No \\
\hline Albeni Falls & Lake & Yes & Yes & Yes & Yes & Yes \\
\hline Chief Joseph & Lake & Yes & Yes & Yes & Yes & Yes \\
\hline Dworshak & Lake & Yes & Yes & Yes & Yes & Yes \\
\hline $\begin{array}{l}\text { Below } \\
\text { Dworshak }\end{array}$ & Stream & No & Yes & No & No & No \\
\hline Lower Granite & Lake & Yes & Yes & Yes & Yes & Yes \\
\hline Little Goose & Lake & Yes & Yes & Yes & Yes & Yes \\
\hline $\begin{array}{l}\text { Lower } \\
\text { Monumental }\end{array}$ & Lake & Yes & Yes & Yes & Yes & Yes \\
\hline Ice Harbor & Lake & Yes & Yes & Yes & Yes & Yes \\
\hline McNary & Lake & Yes & Yes & Yes & Yes & Yes \\
\hline John Day & Lake & Yes & Yes & Yes & Yes & Yes \\
\hline The Dalles & Lake & Yes $1 /$ & Yes & Yes & Yes & Yes \\
\hline Bonneville & Lake & Yes $1 /$ & Yes & Yes & Yes & Yes \\
\hline 1/ Includes windsurfing & & & & & \\
\hline
\end{tabular}

Other impact areas were examined by the Recreation Work Group (RWG) and the results are presented in Appendix J. Recreation impacts in some areas were not assessed in quantitative terms or used a different assessment model, and therefore, were not included in the economic impact analysis. For example, the RWG made recreation use estimates for the Columbia River reach above Lake Roosevelt and below Arrow, in Canada. However, this Canadian reach was not included in this appendix for the following reasons: (1) the reach was assessed with a different recreation model that did not separate impacts into the different activities; and, (2) the EAG was not comfortable in using recreation value estimates from United States studies for the Canadian impacts.

In addition to the recreation activities shown in Table 2-13, sport fishing for anadromous fish is also a significant recreation activity that could be impacted by the alternative operating strategies. A description of this activity is include in section 2.2.1, above. 


\subsubsection{Water Quality}

The Pacific Northwest region has an abundant water supply, and water quality has generally been maintained at a high level. Water quality in the Columbia River Basin is important to fish and wildlife, recreation, aquatic environment, and the economy. Many activities influence water quality including, dam operations, agriculture, navigation, mining, timber and wood products, and urban development. From the SOR perspective, the study focus is on water quality affects from the operation of Columbia River system Federal dams.

Dams impound water and can sharply reduce river velocity. As a result, sediment will either settle on the bottom of the reservoir or become suspended in the reservoir's water column, potentially increasing turbidity and concentrations of contaminants in the reservoir or downstream. Spilling or increased discharge below dams can also increase gas levels which can cause gas bubble disease in fish. Gas bubble disease can kill fish or cause behavioral disorders. Water temperature is also affected by dams. Creation of large deep reservoirs normally causes stratification or layers of water with different physical and chemical properties. Dams can also change the temperature of the water released from the reservoirs, causing impacts to the aquatic ecosystem. The SOR water quality analysis is limited to the primary affects of sedimentation, dissolved gas saturation, and water temperature.

The economic value of water quality changes are measured indirectly through the analysis of water uses, such as fish production and recreation. Appendix $M$ (Water Quality) provides detailed information on water quality in the Columbia River basin. 


\section{CHAPTER 3}

\section{ANALYSIS PROCEDURES AND METHODOLOGIES}

Chapter 3 describes how the economic and social effects were measured. It begins with an introduction to basic NED concepts. Then general study assumptions and definitions are discussed, followed by specific discussions on how the NED impacts were measured. The remainder of the chapter concentrates on conceptual and SOR specific discussions regarding input-output analysis and social impact assessments.

\subsection{NATIONAL ECONOMIC EVALUATION, THE CONCEPTS}

This section provides the reader with a brief overview of some of the concepts used in NED economic evaluation. Many of the topics introduced are the subject of entire courses and texts in the field of economics. The goal here is to strive for an intuitive understanding of the basic economic principles involved, not a rigorous treatment of the issues. Much of this section is excerpted directly from the Overview Manual for Conducting National Economic Development Analysis (Institute for Water Resources, 1991).

\subsubsection{Scarcity}

A general definition of economics, is that it is "a study of mankind in the ordinary business of life." This general definition, however, is a bit too broad for the purpose of this study. For the SOR we will confine our interest in the science of economics to theroy of economic analysis. In this more narrow context, economics can be defined as the study of the processes by which scarce resources are or might be allocated toward the achievement of competing objectives. The scarce resource being considered within the SOR is the Columbia River system and the competing objectives are the interests of the various users of the the system.
Consider a single stretch of river. It can be preserved in its natural state with restricted access. Or, it can be moderately developed for recreational uses, such as hiking, fishing, hunting, and canoeing. Or, the banks could be cleared and developed for industrial, commercial, and residential usage. Yet another alternative would be to dam the lower end of the reach and flood the entire stretch of river to provide flood protection, hydropower, water supply, and general recreation to thousands of people. The reach can't be used for all these purposes, so the fundamental problem becomes how, and on what basis, to decide among these competing choices. This is the exact problem facing users of the Columbia River system as they increasingly compete for the limited water resources in the basin. One purpose of SOR is to decide how the Columbia's water should be allocated among the river uses.

All resources are scarce. Choosing to use a resource one way means choosing not to use it another way. Potential benefits foregone by the choice to use a resource in one way rather than another, are referred to as opportunity costs. Thus, every choice made by mankind costs something, even if the best choice is made. In the case of the operation of the Columbia River system, choices must be made from among the system operation alternatives, at a minimum the cost of the choice that is made will be the foregone benefits of uses of the system that are not complementary to the objective which is maximized by the selected operation.

The opportunity cost of resources changes over time as supply and demand for goods and services change. If storage area of a reservoir has been allocated to flood control, leaving it dedicated to flood control precludes the opportunity to use that same storage for water supply or recreation. If the value of water supply or recreation is now valued more highly than flood control, society would be better off by reallo- 
cating the reservoir storage area to the higher valued use.

The process of developing a plan for the use of a water resource, such as the Columbia River, is an exercise in the fundamental economic problem of scarcity. The fundamental problem of scarcity is not confined to such broad issues as what to do with a unique reach of river. The concrete and steel used in a fish bypass structure could be used in many other ways as well. Using these resources for fish bypass means they will not be available for alternative use elsewhere in, for example, an office building. Thus, the fish bypass structure costs the nation an opportunity to do something else with the resources. In essence, the NED principle is intended to ensure that the benefits to the nation of the use of these resources in a project exceed the costs of the project to the nation. In other words, the NED principle ensures that concrete and steel will be used in a bypass structure only if the benefit to the nation exceeds the cost. Non-economists might be inclined to argue that concrete and steel are not "scarce" in the common usage of the word, that is precisely the point. All resources are scarce, their prices are an indication of their relative scarcity. Thus, concrete and steel, though easy to obtain are indeed scarce.

\subsubsection{Optimal Use of Scarce Resources}

To understand the NED objective requires some understanding of a field of economics known as welfare economics. Welfare economics focuses on using resources optimally so as to achieve the maximum well-being for the individuals in society.

Evaluating projects is complicated by the fact that "welfare" is not an observable variable like bushels of wheat, kilowatts of energy, or pounds of fish. The economic welfare of an individual is formally given by his or her utility level. Utility is a term that is generally synonymous with happiness or satisfaction. Thus, project outputs have value because they make people happy or provide them with satisfaction.

It is commonly accepted among economists that the only objective basis under which one can say that society is better off with a water resource project than without it, is when some people are made better off and no one is made worse off by the project. This adaptation of what has come to be known as the Pareto principle is not experienced in the realm of practice. Project benefits are generally localized, while the Federal share of costs come from taxpayers across the country. Thus, though the residents of a protected flood plain are made better off, some taxpayers are made worse off because they receive no benefits from the project and must pay some of the costs. If even one person is made worse off, there are no objective grounds to support the project on the basis of increased utility because it is impossible to objectively compare the increased happiness of the protected beneficiaries with the decreased happiness of the taxpayers.

If economic theory stopped here, there would be no such thing as economically justified public works projects. In an effort to extend the class of issues that can be addressed by welfare economics, the compensation principle was developed in 1939. Again adapting the principle to water resource development, it says a project should be undertaken if potential "with-project" gains are sufficiently large that everyone could be made better off by some redistribution of goods or income following implementation of the project.

The significant difference is that the compensation principle recognizes the existence of "winners" and "losers". It goes on to allow that if the winners gain enough from the project that they could, hypothetically, reimburse the losers, then the project is worth undertaking whether there is reimbursement or not. Society as a whole is better off, even if some of its members are worse off.

For example, if a project costs one million people $\$ 1$ each and 100,000 people realize $\$ 20$ in benefits each, there are clearly winners (the 100,000 ) and losers (the $1,000,000$ ). However, the $\$ 2,000,000$ in benefits could be redistributed in such a way that each of the $1,000,000$ gets his $\$ 1$ back so no one is made worse off and each of the 100,000 could still have $\$ 10$ each. This compensation principle provides the theoretical basis for undertaking water resource projects--society can, hypothetically, be better off. 
To decide whether to build a project, benefit-cost analysis is often used to determine if the total and incremental benefits produced by the project exceed the total and incremental costs of the project. The optimum level of development or scope of a project is achieved when incremental benefits are just equal to incremental costs. When this condition exists, net benefits--the difference between total benefits and total costs--are maximized. Benefits are measured as the willingness-to-pay for project outputs, and costs are the necessary opportunity costs of the project. Usually, willingness-to-pay is measured indirectly through the use of proxies such as the least-cost alternative for power and navigation and the value of damages prevented for flood control. In addition to economic measures, however, non-economic factors such as public acceptability; technical feasibility; and, environmental impacts, including impacts on threatened or endangered species are considered. Generally, if economic benefits exceed costs, net benefits have been maximized, and noneconomic criteria are met, the project is recommended for implementation.

In the case of SOR, the question is not whether to build a project, but rather, would society be better off if the Columbia River system were operated differently. Using economics in making this decision is complicated by the fact that the river system produces outputs which are difficult to accurately measure in economic terms. Examples include the biological outputs such as anadromous fish, resident fish, and wildlife. While economic principles are important to the SOR decision process, they are not the only criteria being used.

\subsubsection{Willingness-to-Pay}

Willingness-to-pay can be measured in one of two ways. One method involves estimating the amount of money an individual would be willing to pay for the output of a project (level of output associated with an operating strategy in SOR). The other method involves estimating the money an individual would require to willingly forego the output of a project and be as satisfied as in each case.
These willingness to pay concepts are applicable for firms as well. On the producer side of economy, however, more measurable quantities, such as profits, substitute for utility.

Economists generally measure these willingnessto-pay values as the areas under curves. Consumer surplus is defined as the area below the demand curve and above the price line. Producer surplus is defined as the area above the marginal cost curve (supply curve for a competitive firm) and below the price line. Both of these concepts are discussed in greater detail in the next section.

\subsubsection{Prices and the NED Principle}

All the techniques used to estimate NED benefits and costs rely on the availability of prices or the ability to reasonably estimate prices if they are unavailable. Since prices are so important to NED, it is important to understand a little bit about them.

In the following sections, supply and demand curves are introduced separately. The combination of the forces of supply and demand to produce prices is then examined. Finally, the equilibrium price as determined by supply and demand is considered as a societal optimum. However, it should be noted that when a resource has a clear owner then the price of the resource will measure the value of its next best use because that is at least what must be "bid" to obtain its use from competitors. When no clear owner can exercise property rights to a resource then economic markets will not determine a price or opportunity cost because there is no single owner to insist on payment for the value of lost opportunities. Such "unowned" resources will tend to be underpriced and overused.

\subsubsection{Demand Curve}

Demand represents the maximum quantity of a good or service people are willing and able to purchase at various prices. The "Law of Demand" states that, all other things equal, if the price of a good goes up, the quantity purchased will go down, and vice versa.

The demand curve is sometimes referred to as a willingness-to-pay curve because it measures how much people are willing to pay for each additional 
unit of the good or service. People buy additional amounts of a good until the last unit is worth exactly what it costs.

Figure 3-1 shows a hypothetical consumer's demand curve for recreation days at a specific project. If a $\$ 5$ user fee is in effect, the consumer will purchase 10 recreation days. The 10 th recreation day is worth exactly five dollars to the consumer.

Each of the first nine recreation days is worth more than $\$ 5$ to the consumer. S/he would have purchased them if the price were higher than $\$ 5$. In fact, the figure shows that the consumer would still have purchased 8 of the 10 recreation days at a price of $\$ 6$. Even though the price of each day is $\$ 5 \mathrm{~s} / \mathrm{he}$ was willing to pay more than that for them. Willingness-to-pay should not be confused with price.

The area under the demand curve is an approximation of the total benefit a person derives from being able to consume a certain amount of a good. It is the person's total willingness-to-pay for the good. In Figure $3-1$, total willingness - to-pay is $\$ 100$ (areas $a+b+c$ ), i.e., 20 days of recreation at this site is worth a maximum of $\$ 100$ to our consumer. How many days our consumer will actually buy depends on the price.

For example, our consumer won't use the site at all if the fee is $\$ 10$. S/he is willing to pay a maximum of $\$ 9.50$ for the first recreation day because the utility $\mathrm{s} / \mathrm{he}$ gets from this one day is worth $\$ 9.50$ to her. Because the price is only $\$ 5$, and the day is worth $\$ 9.50$, s/he'll surely purchase it. The utility of the second day is worth $\$ 9$ to her, and it costs only $\$ 5$, so $\mathrm{s} /$ he'll clearly purchase it, and so it goes until the 10th recreation day, which is worth $\$ 5$ and costs $\$ 5$. Though s/he will purchase the 10th day, the 11th day is worth only $\$ 4.50$ to her and it costs $\$ 5$. S/he will not buy it. Her purchase rule is, like your own, if you are willing to pay an amount equal to or greater than the price, you buy. If you aren't, you pass.

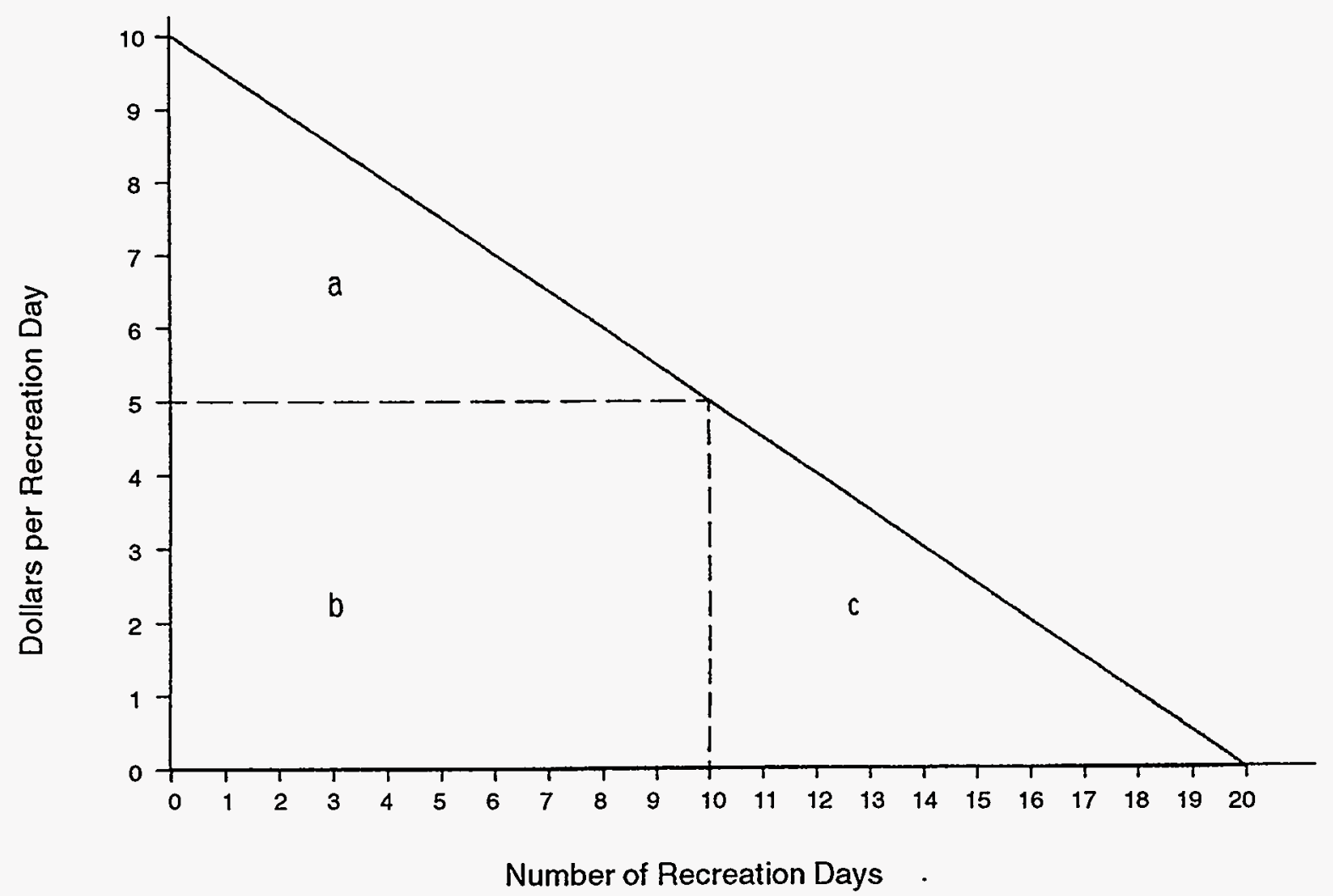

Figure 3-1. Individual Demand Curve 


\subsubsection{Price Elasticity of Demand}

As explained above, the demand (quantity consumed) of a good is related to the price of the good. The amount by which demand changes in response to a change in price is referred to as the price elasticity of demand. Formally, this relationship (elasticity) is defined as the ratio of the percentage change in quantity demanded to the percentage change in price. This relationship can be either zero, inelastic, or elastic. Elasticity is zero if there is no change in quantity demanded when price changes. The relationship is inelastic when the percentage change in the quantity demanded is less than the percentage change in price. When the percentage change in the quantity demanded is greater than the percentage change in price, the demand is said to elastic. For most goods, the demand curve (the quantity demanded at varying prices) slopes downward to the right as is shown in Figure 3-1. This type of demand curve includes elasticies ranging from elastic to inelastic, with the left portion of the curve being elastic and the right portion being inelastic.

It is important that readers understand that a rise in price results in a decrease in the quantity demanded (not demand), all else being equal, regardless of the elasticity. Elasticity is the measure of the degree of consumer response to the change in price. In the case of the effects of the SOSs on the supply of electricity from the Columbia River system, the higher the price elasticity of demand for electricity, the less concerned the region needs to be about potential losses of generation, because the percentage decrease in quantity demanded will be greater for any rise in price. Thus, rising prices decrease the quantity demanded and reduce the need to replace lost hydro system generation with higher cost thermal or other resouces. The effect of price elasticity on the quantity of electricity demanded is explained in Section 3.3.6 (methodology) and Sections 4.8.5 and 4.8.6 (results).

\subsection{Consumer Surplus}

The willingness-to-pay interpretation of the demand curve allows us to measure how much better (worse) off a person is when the price decreases (increases). At a price of $\$ 9.50$, our consumer buys one day of recreation use. To induce the purchase of a second day, the price must be reduced to $\$ 9$. At a price of $\$ 9$, s/he pays $\$ 9$ for each of the two recreation days $\mathrm{s} / \mathrm{he}$ buys even though $\mathrm{s} / \mathrm{he}$ would have paid $\$ 9.50$ for the first day. The area under the demand curve and above the price (area a in Figure $3-1)$ represents the surplus the consumer realizes from having the lower price. This consumer surplus is only an approximation of the value of the increased utility to the consumer, but it is sufficient for this demonstration. The area under the demand curve to the left of a quantity of 10 is $\$ 75$ (areas $a+b$ in Figure 3-1). This represents the total benefit of 10 recreation days to our consumer; hence, it also represents her total willingness-topay for 10 days of recreation at this site. At a price of $\$ 5$, s/he pays only $\$ 50$ (area $b$ in Figure $3-1$ ) for 10 recreation days though $\mathrm{s} / \mathrm{he}$ was willing to pay $\$ 75$. S/he realizes a consumer surplus of $\$ 25$, i.e., the difference between her total willingness-to-pay and what $\mathrm{s} / \mathrm{he}$ actually pays or the area below the demand curve and above the price line.

If we add all the individual demand curves to get the market demand curve, we can obtain a measure of consumer surplus for all consumers by taking the area under the demand curve and above the price line. Figure 3-2 shows the consumer surplus for a consumer. Consumer surplus for the entire market would be measured in the same way, but the quantities of recreation days would reflect the quantity demanded by all users of this site, as shown in Figure 3-3.

Relating this to consumer benefits is a simple matter. The area under the individual's demand curve ( $\$ 75$ in the Figure 3-2 example) is a measure of total benefits for the quantity of output (10 in the example). The cost of these benefits is the area below the demand curve and the price line $(\$ 50)$. The consumer surplus of $\overline{\$ 25}$ is, analogously, the consumer's net benefits.

Because certain resources have unique characteristics, some economists question whether standard demand analysis incorporates all of the resource's value. Consumer surplus is an area under a demand 
curve. Demand curves reflect the willingness and ability of people to buy a resource. Not everyone who values a resource is both willing and able to pay for it at a given point in time.

Individuals, who are not consuming the good or service, may be willing to pay some amount of money to preserve their option to consume the service at some later date. This value, called "option value" is a value over and above the consumer surplus because these people are not included in the market demand curve. This option is important if there is some possibility that the resource, such as an endangered species, will not be available at some time in the future.

Considerable controversy has developed among economists over the sign of this option value. In other words, option value may increase or decrease benefits depending on what are, for purposes of this chapter, rather esoteric arguments. The empirical evidence has not been conclusive.

The economics literature broadens this option value concept to include "existence value" and "bequest value". Some individuals who are not consuming the resource might be willing to pay some amount of money just to know the resource exists, though they have no intention of ever using it. Voluntary organizations, such as the one organized to preserve the Statue of Liberty, provide evidence of existence value. People who will never visit the site contributed to its preservation. A more esoteric extension of this idea is that some people may be willing to pay some amount of money to be able to pass a unique resource on to future generations. These people affix some value to a resource because of what it might mean to future generations, bequest value.

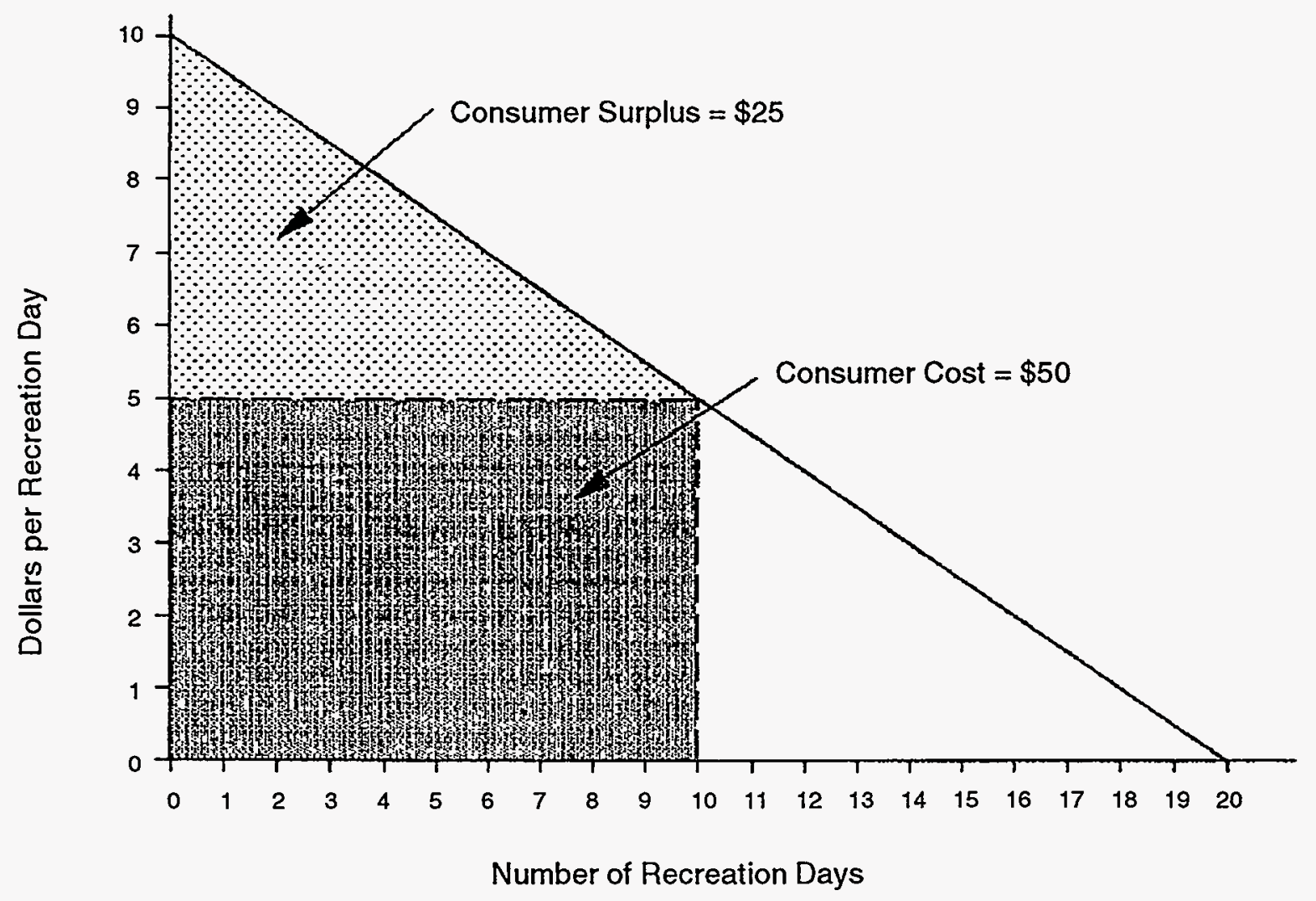

Figure 3-2. Consumer Surplus 


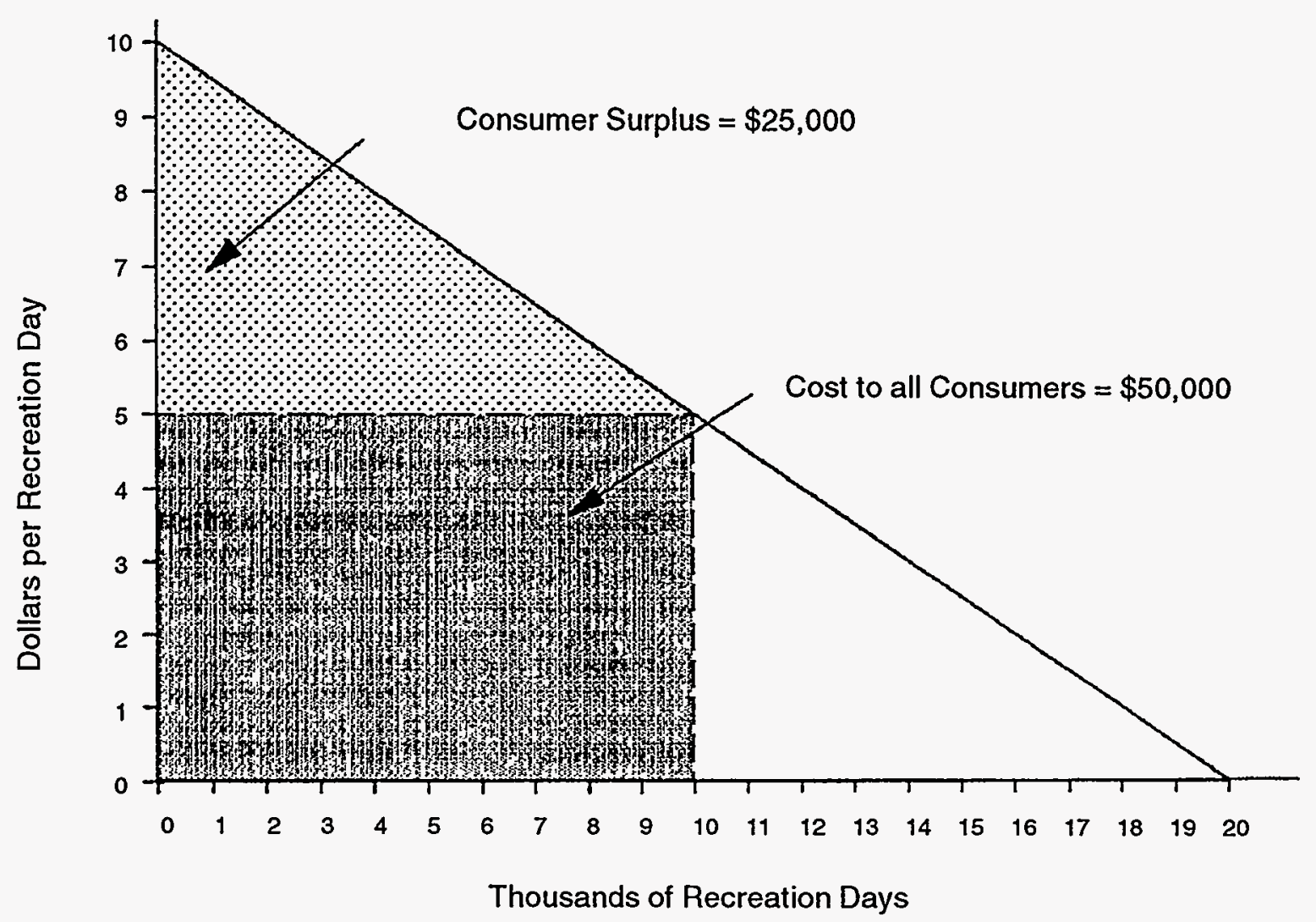

Figure 3-3. Market Demand and Consumer Surplus

The SOR economic analysis recognizes that these values may exist for resident fish and wildlife, and for wild anadromous fish. Due to measurement difficulties and the controversy surrounding these values, no measurement of them was used in estimating the economic effects.

\subsubsection{Profit Maximization}

Economic analysis requires the assumption that people act rationally to maximize their utility subject to their available budgets. This same assumption of rational behavior to maximize utility is applied when people organize as firms. Firms are assumed to be profit maximizers. If profit is defined as total revenues (TR) minus total costs (TC), it is impossible to maximize profits unless costs are minimized. If total revenues are fixed at any level, profit will not be as large as possible unless costs are as small as possible. Thus, profit maximization implies cost minimization.

It is a simple matter to make the jump from profit maximization to net benefit maximization. Total revenues become total benefits (TB), total costs remain total costs. The water resources agency becomes the rational firm and the difference between $\mathrm{TB}$ and $\mathrm{TC}$ represents net benefits.

In some instances actual benefits are not known and are not estimated. For example, environmental mitigation and restoration is often based on the assumption that the benefits of providing some fixed level of output (TB) exceed the costs (TC) of doing so. Rational economic behavior requires the analyst to minimize the costs of providing these benefits.

Thus, cost minimizing behavior is an important subcategory of profit maximizing behavior used 
when the level of benefits is unknown but assumed to exceed costs.

\subsubsection{Opportunity Cost}

As discussed above, because of scarcity, choices have to be made. Whenever a choice is made there is a corresponding cost. A choice to do one thing is a choice not to do another. Choosing to use a resource, say reservoir storage, for any one purpose costs at least the opportunity to use that storage for another purpose. Thus, if storage is allocated to flood control it cannot be allocated to hydopower. If hydropower is the next best alternative use of the storage, the cost of the flood control storage is the value of that storage as hydropower.

Price is routinely used as the measure of the cost of a good or service. While $\$ 50$ per acre-foot may be the price of water, that may not be its cost. The economic definition of cost is that which must be foregone to use the resource in a given way. The opportunity cost of any decision is the foregone value of the next best alternative not chosen. Fortunately, for most goods purchased in a competitive market, price includes opportunity cost. Unfortunately for water resource planners, there are many goods and services used and produced by water resource projects that are not produced in competitive markets, for which price does not exist nor does price equal opportunity cost.

The SOR study provides an excellent example of opportunity costs at work. The storage and operation of Columbia River projects built long ago were allocated for a specific mix of purposes. Presumably that mix of purposes was optimal at the time the projects were constructed. The projects are being studied now to determine if the existing storage and operations should be reallocated for a different mix of purposes. Why? Changing opportunity cost is the answer. Since costs of the Federal system are borne by the various river uses as prescribed by Federal law, if, as a result of the analysis of the SOR alternatives, decision makers determine that the operation of the system should be changed from the present operation, it may be necessary to reallocate project and system costs among river uses.

\subsubsection{Supply Curve}

Supply represents the quantities of a good or service a firm is willing and able to produce at different prices. A supply curve, as shown in Figure 3-4, shows the amount of output the firm will offer for sale at any given price. The supply curve for a competitive industry represents the cost to that industry of providing the last unit of output.

Figure 3-4 shows how the output choice of the firm, in this case a fisherman, will respond to market price. Let's assume that if the price of fish is $\$ 3$ per pound, he will harvest 800 pounds per week. At any harvest beyond this amount, the cost to him to catch the fish is greater than $\$ 3$ per pound. This may be because 800 pounds is the maximum he can catch with the amount of equipment and labor available. To increase the catch, he may have to add a laborer or buy new equipment. If the price rises to $\$ 4$, the fisherman finds that the higher price covers the higher cost (i.e., the extra wages or the cost of new equipment) of catching more fish, and at the new price he would be willing to provide 1,200 pounds of catch.

The cost of the 1,200 th pound of fish is $\$ 4$. The fisherman won't harvest more because he would incur costs greater than the $\$ 4$ per pound he receives. A rational fisherman would not incur costs to catch fish that would exceed the value of the fish.

Just as the area under the demand curve shows total willingness - to-pay, areas under the supply curve show total costs of harvesting a given level of output. The total cost of harvesting 800 pounds of fish is $\$ 1600$ (area $b$ in Figure 3-4).

Deriving the market supply curve can be more complicated than simply adding the output that each fisherman would produce at each possible price. Nonetheless, the intuition developed from thinking of market supply in this way best suits this section's purposes. 


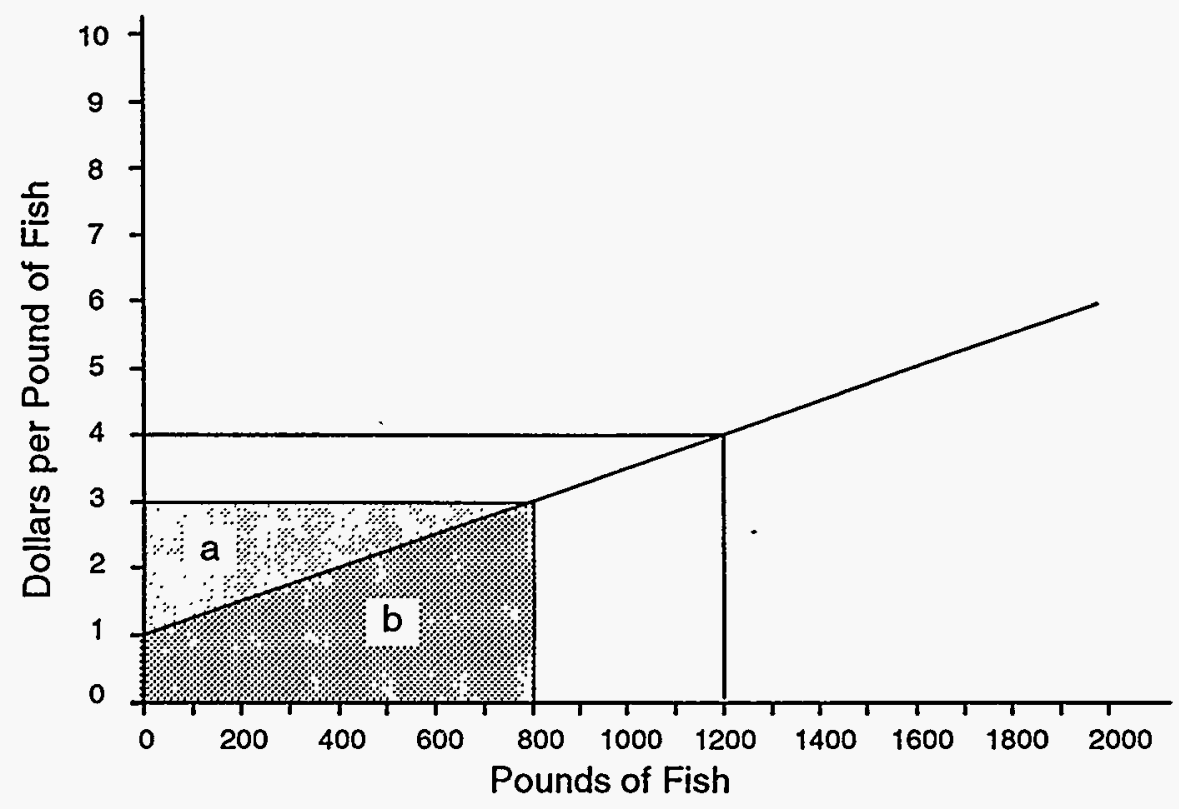

Figure 3-4. Supply Curve

\subsubsection{Producer Surplus}

The points on the supply curve can be interpreted as the producers "willingness to pay the cost of production" at each level of production. Producer surplus, represented by the area below the price and above the supply curve, identifies what the producers are willing to pay (but don't have to) and allows us to measure how much better (worse) off a producer is when the price increases (decreases). Interpretation of the supply curve in a willingness-to-pay concept is just a little bit trickier than is the case for the demand curve.

At a price of $\$ 4$ per pound, our fisherman is willing to harvest 1,200 pounds of fish. His total revenue is $\$ 4,800$. Therefore, maximum amount the producer would be willing to pay (or, if you find it more intuitive, the maximum cost he would be willing to incur) to catch the 1,200 pounds of fish is $\$ 4,800$. Revenues at the margin would exactly cover his marginal costs, which include a fair return on his capital.

The shaded rectangle in Figure 3-5 represents the fisherman's total revenues, $\$ 4,800$. The triangle beneath the supply curve (darker shade), represents the producers total costs of $\$ 3,000$ for catching these fish. The area above the supply curve and below the price line (lighter shade) represents producer surplus of $\$ 1,800$.

\subsubsection{Markets and Prices}

A competitive market equilibrium allocates resources efficiently. The intent of the NED principle is, likewise, to allocate resources efficiently. Thus, it is useful to consider market equilibrium.

The self-interests of the consumers and producers are fundamentally in conflict. One seeks the lowest price possible, the other the highest price possible. Consider the market for wheat. "If wheat costs $\$ 2$ per bushel, I'll buy so much; if it's $\$ 1.75$ I'll buy more," the consumer plans. This is the basis of the demand relationship described above. "If wheat sells for $\$ 2$, I'll produce so much; if it sells for $\$ 2.50$, I'll produce even more," the producer plans. This is the basis of the supply relationship. These independent plans are coordinated and the players' actions are influenced by the market.

Figure 3-6 shows hypothetical supply and demand for the wheat market. Each good is assumed to provide benefits only to the person who consumes it. Each seller is assumed to pay all the costs of producing the output. The intersection of supply and 
demand represents the market's equilibrium position. Equilibrium is essentially a state of balance between consumers and producers who have conflicting interests.

When the price of wheat is above equilibrium, say at $\$ 3.00$, consumers want only 4,000 bushels, while producers are willing to provide 12,000 bushels. There is a surplus of wheat at this price. Everyone who is willing to buy wheat at this price has done so, so the only way to sell the surplus wheat is to drop the price. Thus, if price is above the equilibrium there will be forces at work, the "force" of self-interest, that will drive prices lower.

If the price of wheat is below equilibrium, say at
$\$ 1.00$, consumers want 12,000 bushels but producers are willing to provide only 4,000 bushels. Now, there is a shortage of wheat. Consumers who want wheat and fear they won't get it will offer a higher price to assure they get some wheat, producers in search of profits will raise the price. Once again, self-interest assures that a price that is too low will rise.

Only at the equilibrium price of $\$ 2.00$ per bushel will there be no tendency for prices to change in the short term. The quantity of wheat produced at this price, 8,000 bushels, will be exactly what people want to buy. Everyone who produces wheat at that price can sell it. Everyone who wants wheat at that price can buy it. No one has an incentive to lower or raise prices.

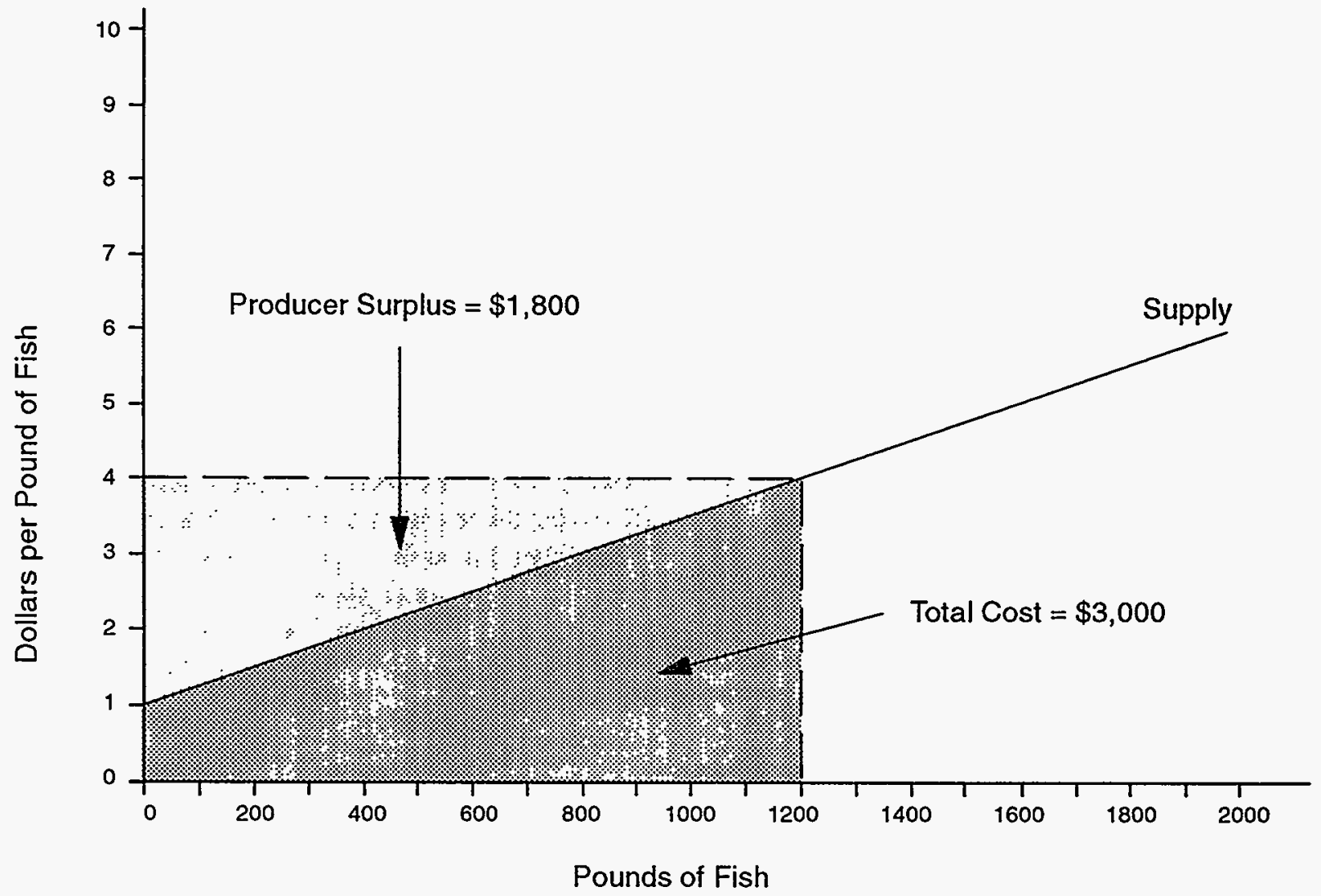

Figure 3-5. Producer Surplus and Opportunity Cost 


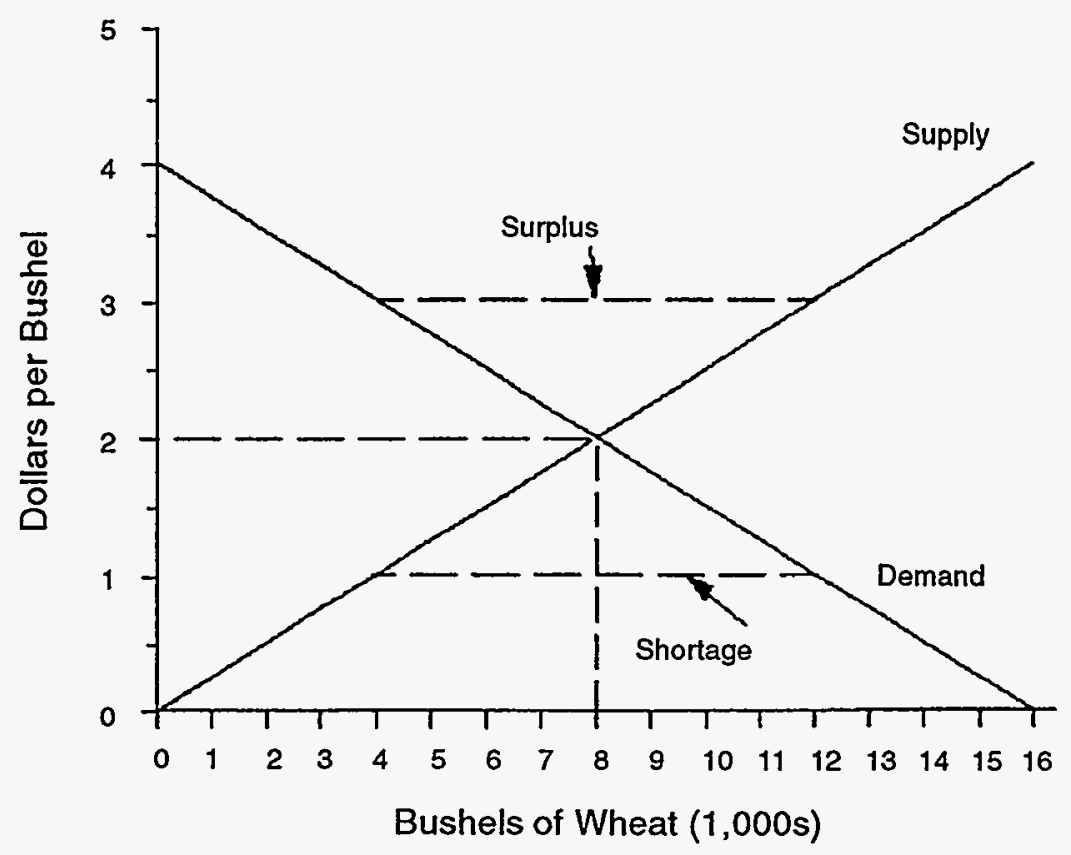

Figure 3-6. Market Supply and Demand

Prices are the result of a dynamic balance of the self-interests of buyers and sellers as they meet in the marketplace.

\subsubsection{Supply, Demand, and Social Welfare}

Social welfare is maximized at the equilibrium price. The demand curve represents the consumers' willingness to pay for additional output, and the supply curve represents the producers' cost of producing additional output. At equilibrium, society's opportunity cost and its willingness to pay for additional output (the last unit produced) are exactly equal. Also at equilibrium, all of the wheat produced will just clear the market, i.e., there is neither a market surplus or shortage.

Consider the market for wheat again. Total benefits, consumers' total willingness-to-pay, are shown as the area under the demand curve. Producers total costs are shown as the area under the supply curve. Maximization of net benefits (total benefits minus total costs) occurs at an output of 8,000 bushels of wheat and is represented by the shaded areas of
Figure 3-7. Net benefits are defined as consumer surplus plus producer surplus at any level of output.

Any increase in quantity beyond 8,000 bushels would reduce net benefits because the cost of producing the wheat, read from the supply curve at that quantity, exceeds consumers willingness to pay for it, read from the demand curve at that quantity.

It would be possible to increase net benefits reduced by overproduction (past equilibrium) by dropping the last additional unit of wheat. For example, the opportunity cost of the 10,000 th bushel of wheat is $\$ 2.50$, while consumers are only willing to pay $\$ 1.50$ for it. Net benefits are therefore diminished by $\$ 1.00$ for the 10,000 th bushel produced. Figure 3-8 shows that at an output of 10,000 bushels net benefits would be $\$ 15,000$, reduced by the shaded triangle which represents an excess of costs over benefits.

In Figure 3-9, net benefits are shy of their maximum value by the shaded triangle. At any quantity below the equilibrium, the benefits of an additional bushel would exceed the costs of producing it so it would be impossible for a quantity in this range of output to be optimal. 


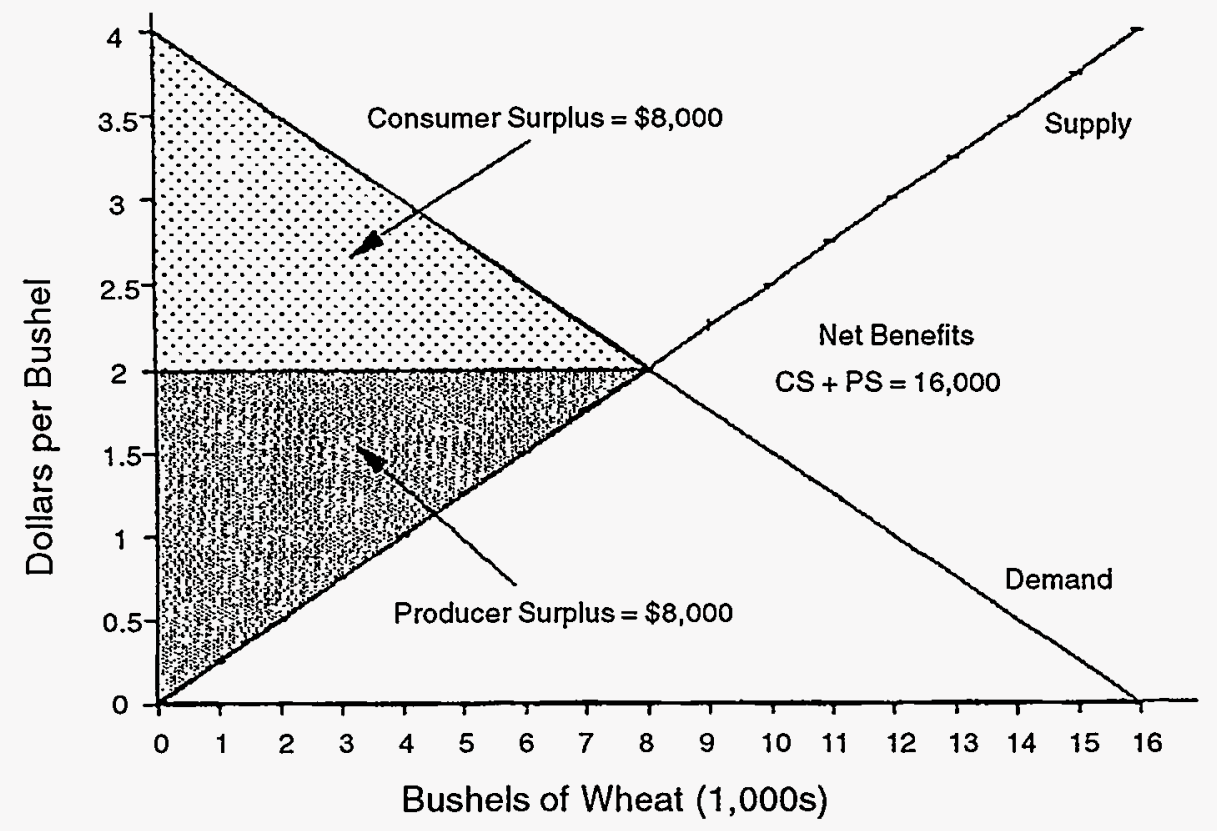

Figure 3-7. Maximum Net Benefits

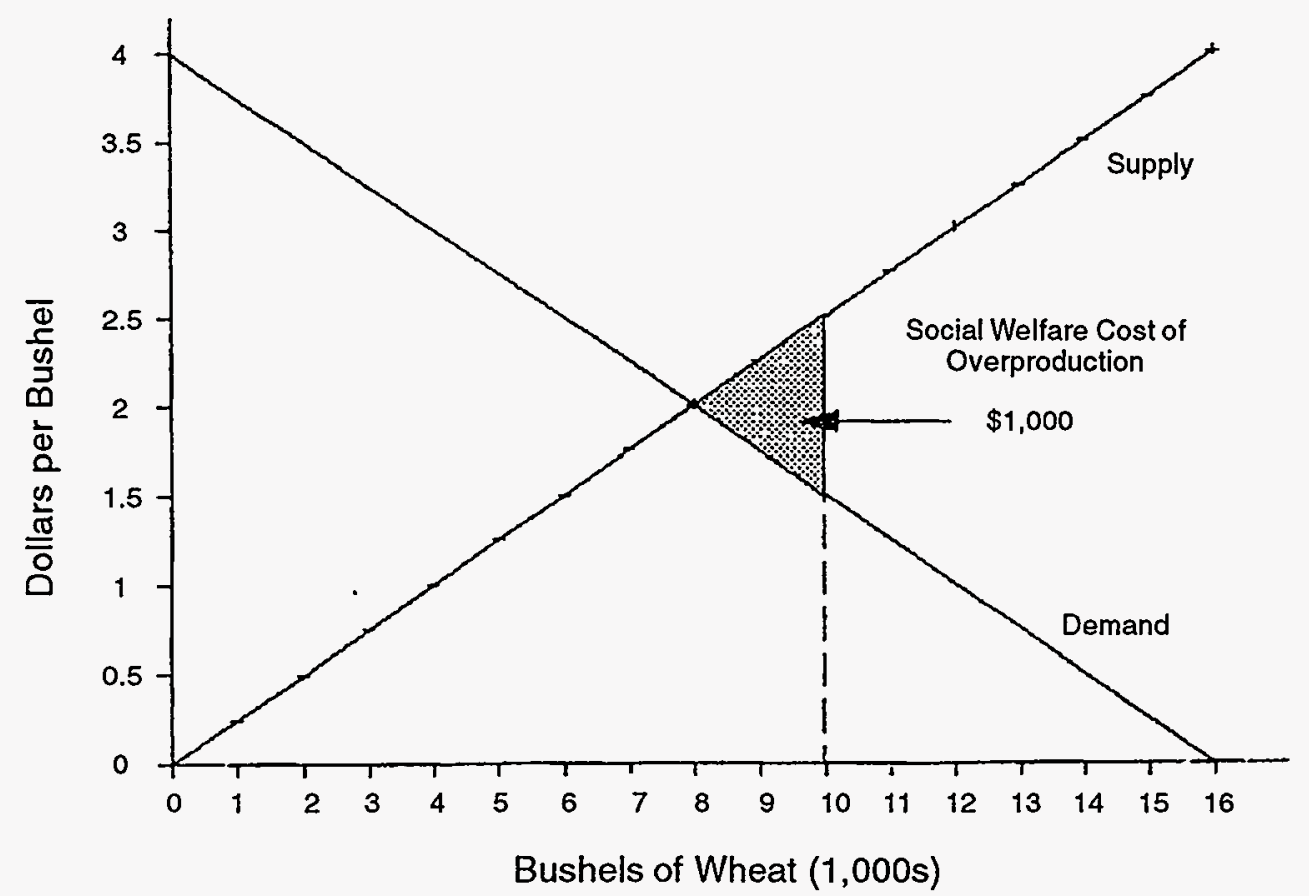

Figure 3-8. Overproduction 


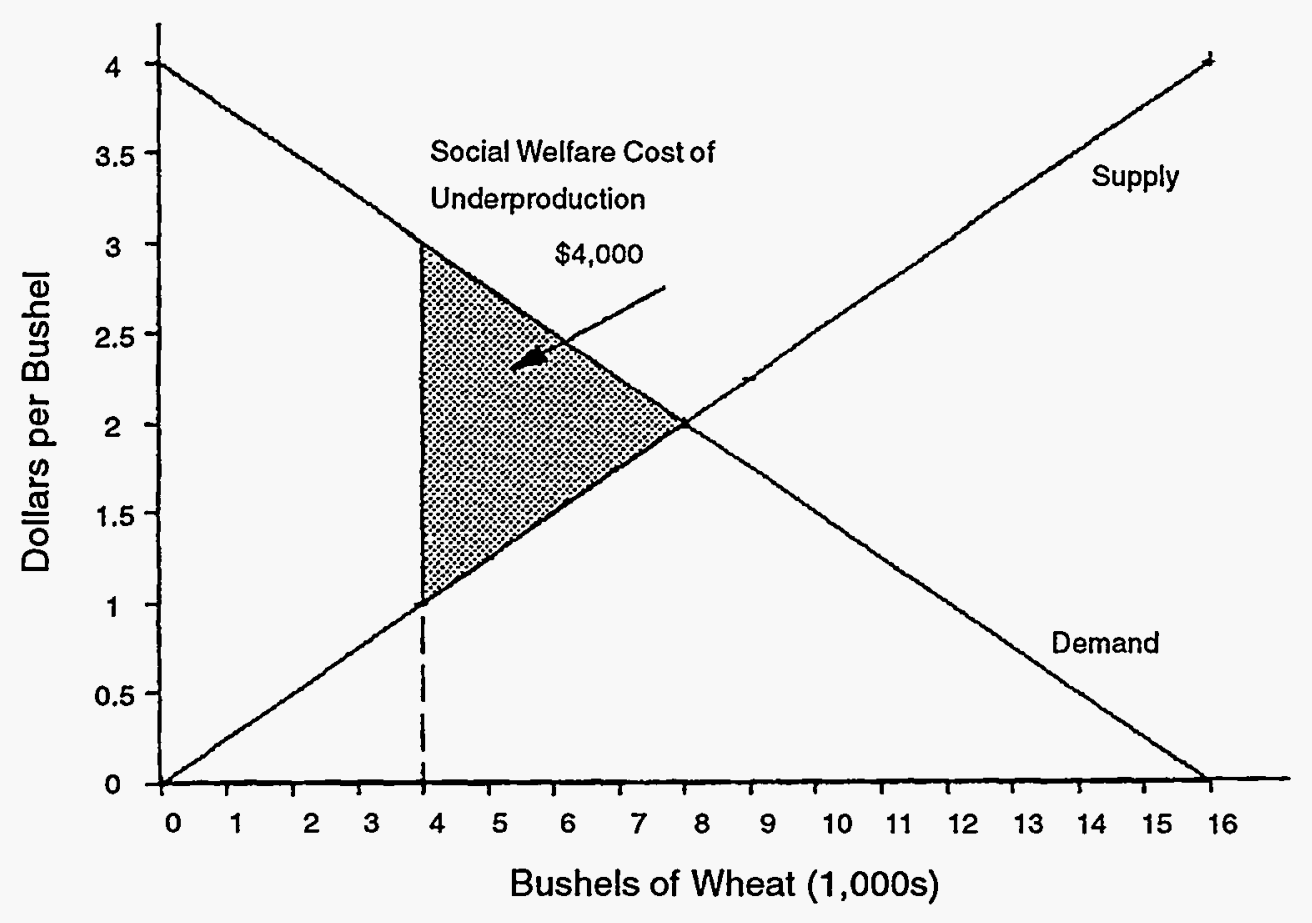

Figure 3-9. Underproduction

Underproduction makes consumers worse off than they could be because at equilibrium they could get more wheat at a cheaper unit price, increasing their consumer surplus, from $\$ 2,000$ to $\$ 8,000$ in Figure $3-9$

Producers are selling wheat for $\$ 3 / \mathrm{bu}$ which is $\$ 2$ per bushel more than it costs them to produce it. Their total revenue $(\$ 12,000)$ at 4,000 bushels could be greater $(\$ 16,000)$ if they sold more wheat (satisfied demand) at equilibrium price but producer surplus would decline from $\$ 10,000$ to $\$ 8,000$.

The net loss to society (social welfare cost of underproduction) is the potential net benefit not realized at underproduction. At an output of 4,000 bushels, the net loss is $\$ 4,000$ ( $\$ 6,000$ consumer surplus loss plus $\$ 2,000$ producer surplus gain).

Over production would never be voluntarily arrived at. Buyers do not value the additional wheat enough to even pay the equilibrium price. Producers must pay more than the equilibrium price to produce the additional wheat. If this quantity of wheat is produced there would be a lost opportunity to make better use of the resources used in the extra production. This lost opportunity is an efficiency loss to society.

When all conditions for a competitive market are met, competitive market prices are a measure of the true opportunity costs of the marginal resource.

Given these conditions, it is impossible for society to improve over the market equilibrium output. Thus, in estimating NED benefits and costs it is important that opportunity costs be used or very closely approximated when valuing resources, because otherwise resources will be misallocated and society is not as well off as it could be.

The value of the increased wheat output from a water resource project would be obtained by comparing net benefits with the project to net benefits without the project. 


\subsubsection{When Demand and Supply Curves Don't Exist}

Estimating the area under a demand or supply curve can be a simple matter when the curves exist and prices and quantities are known. Unfortunately, in the case of water resource development, such is rarely the case.

Deriving demand and supply curves can be difficult, costly, time consuming, or impossible. When demand and supply curves do not exist or cannot be estimated, consumer and producer surpluses can't be directly measured. In these cases, other techniques are used to approximate these areas. The NED evaluation procedures (Water Resources Council, 1983) state:

"Since it is not possible in most instances for the planner to measure the actual demand situation, four alternative techniques can be used to obtain an estimate of the total value of the output of a plan: Willingness to pay based on actual or simulated market price; change in net income; cost of the most likely alternative; and administratively established values."

Similar techniques are used when supply curves are unavailable. The most important thing to remember at this point is that all benefit measurement techniques estimate the willingness to pay for the output of a project. In the case of the SOR, a number of different techniques are used to estimate the willingness to pay for changes in the way the PNW hydropower system is currently operated.

\subsubsection{Market Failure}

Situations that prevent efficient market-determined allocations of resources are called market failures. There are many reasons for market failure. Externalities and public goods, two of the best known examples, are briefly described below.

\subsubsection{Externalities}

Many economic activities provide incidental benefits to people for whom they were not intended. Other activities indiscriminately impose incidental costs on others. These effects are called externalities. When externalities are present, a market based economy will underproduce goods with positive externalities and overproduce goods with negative externalities resulting in an inefficient allocation of resources.

Externalities are defined as benefits or costs associated with production of a good or service which are not accounted for in the price of the good or service. Positive externalities make someone better off without that person being required to reimburse the party responsible for the positive effect. Negative externalities make members of society worse off, but individual consumers are not required to pay for the cost of mitigating the externality at the time the good or service is produced. Flood control projects frequently generate both positive and negative externalities.

Consider a large cannery in the flood plain that is the primary customer for a can factory several miles removed from the flood plain. Flood control protects the cannery and in so doing incidentally benefits the can factory as well. The can factory realizes a positive externality for which it does not have to pay.

Negative externalities make someone worse off without that person being compensated for the negative effect. Floodwalls and levees can produce higher flood stages or more frequent flooding at downstream locations. The residents of communities affected by this induced flooding suffer and are not compensated for a negative externality.

The NED principle requires that externalities be accounted for in order to assure efficient allocation of resources. Figure 3-10 shows how failure to account for the positive externalities of a flood control project can result in underproduction of flood protection.

Demand $D_{1}$ in the figure, consists of benefits to flood plain occupants only. Maximizing net benefits to flood plain occupants only leads to an output of $Q_{1}$ which falls short of the efficient output $Q_{2} . D_{2}$ includes the benefits of $D_{1}$ plus positive externalities to beneficiaries like the can factory. 


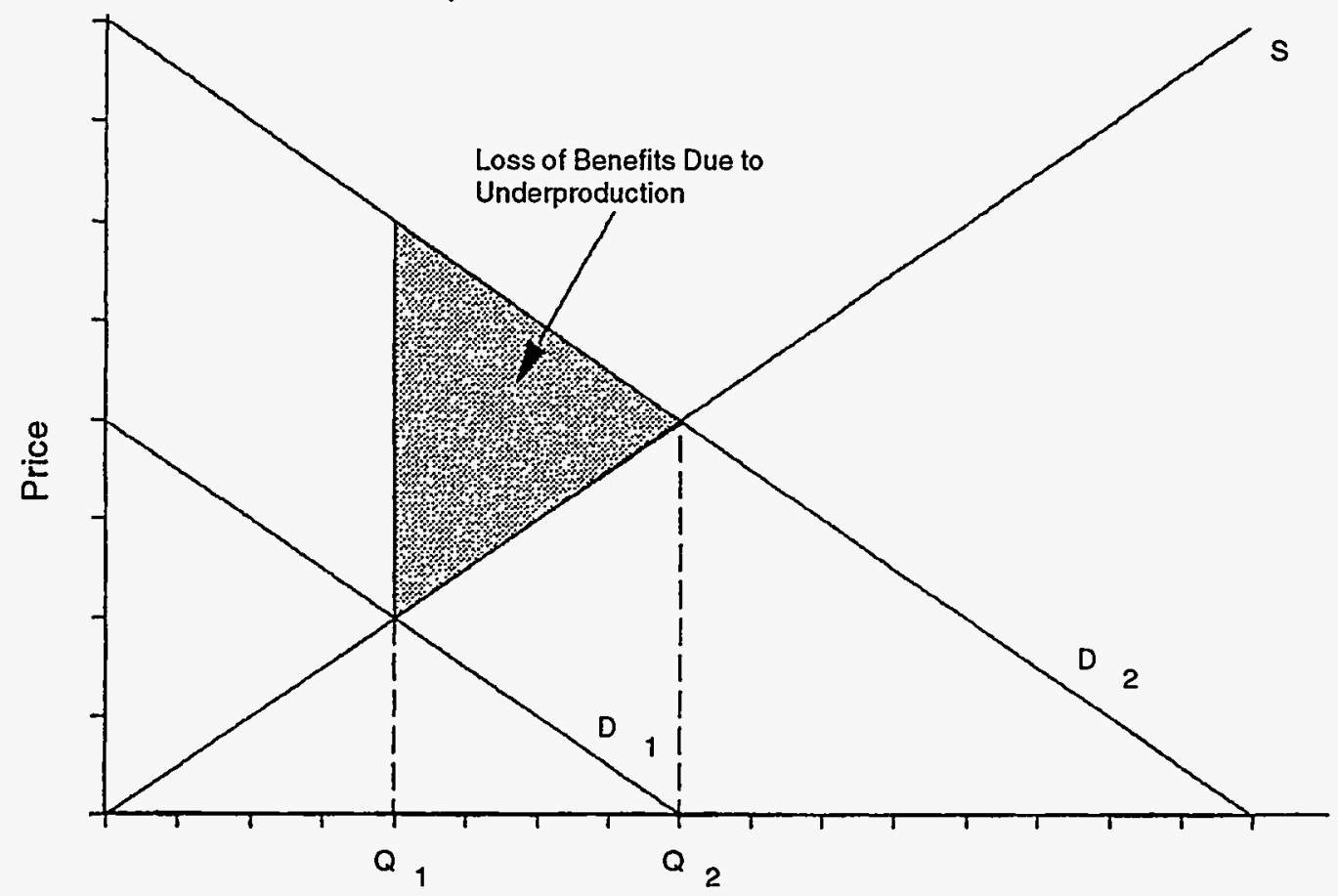

Flood Protection

Figure 3-10. Underproduction of Flood Control

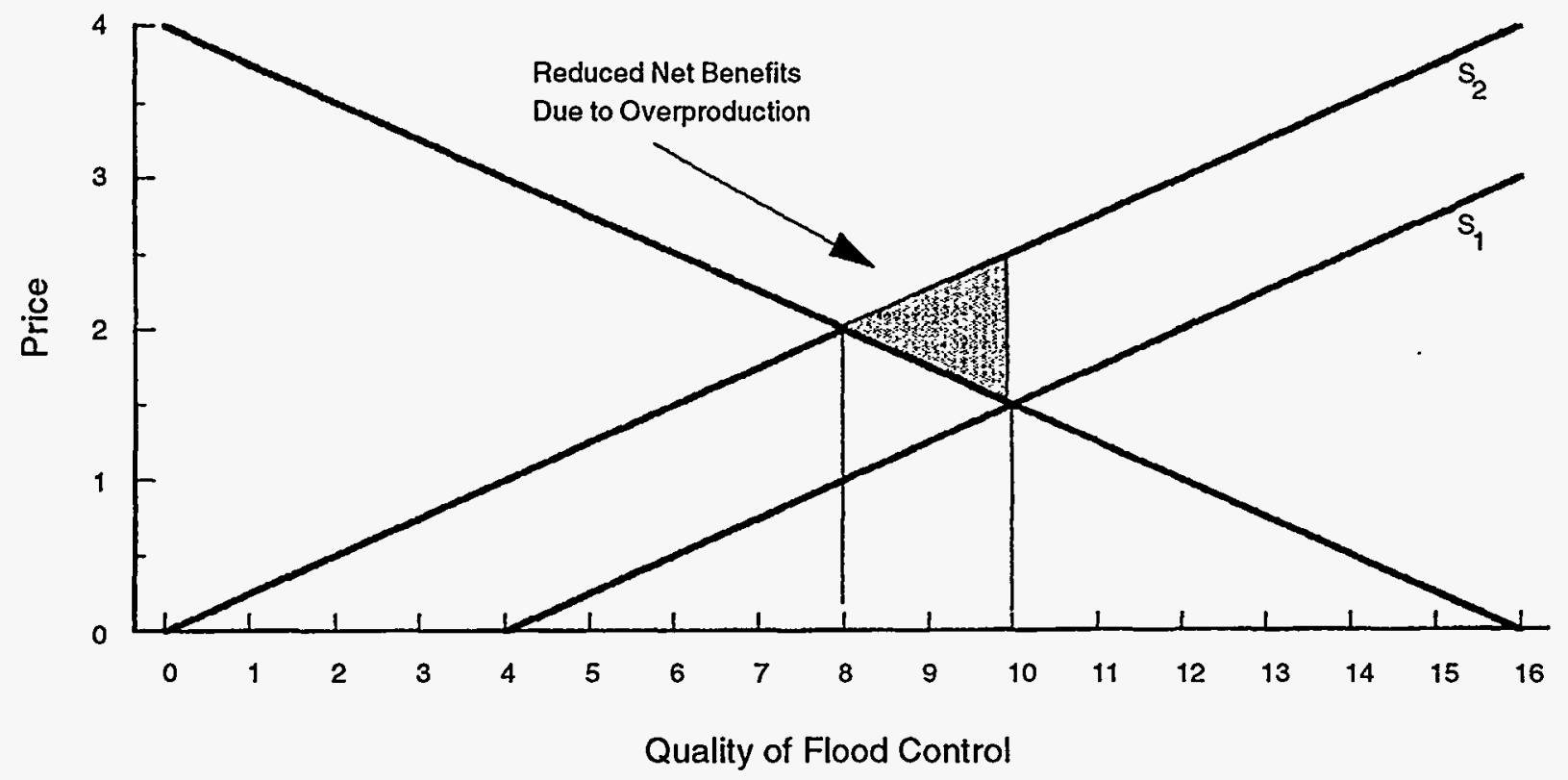

Figure 3-11. Overproduction of Flood Control 
Figure 3-11 shows how failure to account for negative externalities can result in over production of flood protection. When only the direct costs of the project are considered $\left(S_{1}\right)$, the level of flood protection is 10 . When the negative externality of induced flooding is included $\left(\mathrm{S}_{2}\right)$ becomes the true supply curve and the efficient output is 8 .

\subsubsection{Public Goods}

Another area in which the market fails to allocate resources efficiently is in the production of public goods. Public goods are best defined by first considering private goods. Private goods have two important attributes. First, they are depletable, i.e., they are used up when they are consumed. Second, they are excludable, i.e., anyone who does not pay for the good can be excluded from enjoying it.

Public goods do not have these attributes. For example flood control is neither depletable nor excludable. Once a local flood protection project is built, anyone in the protected floodplain enjoys flood protection, no one can be excluded. Nor does one person's consumption of flood control use it up (deplete it) and make it unavailable to another. Everyone living in the protected area can essentially consume the same level of protection.

Under market conditions, a private party would provide the flood protection and then try to "sell" it to residents of the area, but since nonpaying users could not be excluded from enjoying the public good, the private suppliers of such goods would find it difficult or impossible to collect for providing the benefits of such services. This is the "free rider" problem. How many people would voluntarily pay $\$ 5,000$ for flood protection if they know that if their neighbors buy it they will get it for free? Such goods cannot be provided by free enterprise because people will not pay for what they can get for free.

A more subtle point about public goods is that if one person's consumption of the good does not use it up or deplete it, then the additional, or marginal, cost of one more person using the good is zero. With zero marginal cost, efficient resource allocation requires that anyone who wants the good or service be provided it at no cost. So, not only is it often impossible to collect for consumption of a public good, it is also undesirable.

There is a legitimate role for government to provide public goods and to create conditions (e.g., taxes or local cooperation agreements) for cost recovery. The economists' challenge is identifying the optimal quantity of such goods in the absence of market prices.

Benefit-cost analysis is a general technique for doing this. NED analysis is a more specific application of this technique.

\subsection{NATIONAL ECONOMIC ANALYSIS ASSUMPTIONS FOR SOR}

This study, as with all economic analyses, begins with a set of working assumptions and definitions on which the analysis depends. These definitions and assumptions are important to a clear understanding of what the results of the study represent.

\subsubsection{Discounting and Discount Rates}

The process of equating money values across time is to equate future sums of money with their present equivalent value. This process is known as discounting. The discount rate is society's opportunity cost of current consumption. That is, it's the rate society uses to equate amounts of money at different points in time. Generally, discounting applies to the economic value of something. Such that the present value or average annual economic value of fisherman days would be calculated, rather than average annual fisherman days, for example. However, the results are same, regardless of whether fisherman days, in our example is discounted or the value of the days is discounted.

Economic theory suggests that the social rate of discount should reflect the return that can be earned on resources employed in alternative private use. To avoid losses of well-being, resources should not be transferred from the private sector to the public sector if those resources can earn a higher return in the private sector. Setting the discount rate equal to the social opportunity cost of funds ensures an efficient allocation of resources across time. There 
are, of course, certain complications that prevent economists from identifying and even agreeing on what the social opportunity cost of funds should be.

The issue has been resolved for the Corps and Reclamation through Section 80 of PL93-251, which bases the interest rate used in the analysis of water resources investment analysis on the cost of government borrowing. For fiscal year (FY) 1995, the federal discount rate is 7.75 percent.

BPA uses a discount rate of 3.0 percent. This rate specifically excludes an allowance for future inflation and is considered to be an estimate of the real rate of return; i.e., the rate of return on all types of investments after the return has been adjusted to remove the effects of inflation. By virtue of the fact that the Federal discount rate is based on the cost of long-term borrowing by the Federal Government, it contains an inflation premium component. For example, comparing the real rate of 3.0 percent used by BPA with the Federal discount rate of 7.75 percent would suggest that the latter has an inflation premium of about 4.75 percent. This premium is a function of the expectations of investors regarding the future rate of inflation. Thus, if rate of inflation is expected to increase in the future, investors will ask a high inflation premium and interest rates will rise.

To accommodate the analytical requirements of all three agencies, both the 3.0 percent and 7.75 percent rates of interest have been used in measuring the NED economic impacts. It is noted, however, that no attempt was made to include inflation in the estimates of implementation costs or benefits. Because future inflation has not been incorporated in the analysis, the 3.0 percent inflation - free discount rate is the appropriate rate to use for making comparisons of the alternative SOSs considered in the SOR.

\subsubsection{Expected and Equivalent Annual Values}

Economic impacts are expressed as average annual dollars. For a hypothetical example, alternative " $\mathrm{X}$ " will result in expected average annual flood damages of $\$ 100,000$. The annual estimates gener- ally represent either an expected value or equivalent value or a combination of the two.

Expected annual values are stochastically determined from observations over many years. Expected values are typically seen in flood control studies where the expected annual damage is the average damage which can be expected to result from many years of flow experiences with conditions remaining unchanged. It is computed by weighing each damage value according to its probability of exceedance. Graphically, it represents the area under the damage-frequency curve.

Equivalent annual values take into account conditions that change over time. Economic impacts are estimated for future years over the period of analysis. The estimates are then discounted to a base year and amortized over the life of the project. Amortization is equivalent to calculating a loan payment that repays principal and interest. This process takes into account the social discount rate and allows impacts that occur at different points in time to be directly compared.

\subsubsection{Price Level and Inflation}

With a few exceptions which are noted in the text, constant prices expressed at a mid-1992 price level were used in the SOR economic analysis. No adjustment for future inflation was made, even though several of the alternatives would require several years (up to 15 years) to implement. Under this frequently used and simplifying assumption of a constant price level over the life of a project, prices do not change relative to one another and inflation has no bearing on the results.

\subsubsection{Period of Analysis}

The NED impacts were evaluated over a 100 year planning horizon. The base year or beginning of the analysis period is 1995 . This represents the first year in which an alternative could be implemented. A 100-year planning horizon was selected to minimize the effect of the discounting process on the present and average annual values of system costs and benefits associated with the various SOSs. This is a significant factor because some of the alternatives cannot be implemented before 2010,15 years 
from the beginning of the period of analysis. In addition, anadromous fish models use a 40 -year period to estimate an equilibrium level of production. That is to say, impacts of an alternative on anadromous fish production are not fully realized until 40 years after an alternative is implemented. Thus, with an alternative which takes 15 years to implement, full production of anadromous fish would not be reached until 55 years after the beginning of the period of analysis (1995).

Due to time and resource constraints, forecasts of changes in socio-economic factors which could affect the value of an alternative over time, such as population growth, new construction in flood plains, and demand for electricity, were not made. As a result, the analysis tends to understate impacts associated with river uses where the use would be expected to increase in the future. Annual values are shown both in terms of "undiscounted" and "discounted" amounts to allow for comparison among alternatives. Average annual values represent the amortization of costs over a 100-year period of analysis which begins when the alternative is implemented. Equivalent annual values are the average annual values discounted back to the beginning of the SOR period of analysis --1995 .

\subsubsection{Implementation Timing}

The timing of implementation of alternative investments has an effect on the annual cost of the alternative because of the time value of money, as indicated by the discount (interest) rate. Thus, alternatives which cannot be implemented for several years into the future have lower annual costs than those which can be implemented sooner, when the alternatives are compared at a common point in time. The effects of implementation timing on the annual costs of alternative operations of the Columbia-Snake system are accounted for in the cost analysis by present valuing implementation costs to the base year of the period of analysis for the SOR- -1995, as explained in Section 3.2.4 of this chapter. The analysis of imple- mentation costs of the alternatives is presented in Chapter 4 (Section 4.2) of this appendix to the FEIS.

\subsubsection{Full Employment}

National economic development analyses assume a full employment economy. If all resources are fully employed, this means that all resources have alternative uses, i.e., all resources have opportunity costs. The significance of this assumption is that it provides the planner with a rationale for using market prices.

"Full employment" of labor resources does not mean the absence of unemployment. It is generally recognized that there is some normal level of unemployment in our economy. Even when the economy is strong, with plentiful jobs, there are people who are unemployed because they are changing careers, moving to another part of the country, graduating from school, entering the work force for the first time, or reentering the work force after some absence.

In recent years, mobility in the United States has resulted in a general consensus that a natural rate of unemployment is about three to six percent. Thus, the assumption of full employment is that over the planning horizon the economy will generally have an unemployment rate within this range.

\subsection{NATIONAL ECONOMIC ANALYSIS FOR SPECIFIC RIVER USES}

Presenting the information and methods used to measure the national economic development affects is the purpose of this section. The procedures used in this study are imperfect. As usual the effort was constrained by time and money. Moreover the data required for such a complex undertaking were lacking and in some cases unknowable. Nonetheless, the procedures used were formulated to reasonably approximate the willingness to pay or opportunity costs given the study constraints and realizing that rational decisions regarding the operation of the 14 Federal projects may depend on the resulting estimates. 


\subsubsection{Anadromous Fish}

The anadromous fish of the Columbia River represent a very valuable resource of both regional and national interest. The economic value of the fish runs can be broken into the value to users and the non-users of the resource. Users consist of the commercial fishermen, sport fishermen, and the Native American fishermen who harvest the fish for commercial, sport, subsistence, and ceremonial purposes. Examples of non-users are the public that perceive a value knowing that anadromous fish runs exist or will exist for future generations. These values are referred to as existence and bequest values. Defining these values in monetary terms is not easy because neither the users nor non-users "purchase" or sell their existence and bequest values. Therefore, a market price, i.e. economic value, cannot be accurately defined.

Many approaches have been developed by economists to assign monetary values for environmental resources like fish, but these approaches are not widely accepted. Due to the controversy surrounding monetizing the existence and bequest value of an anadromous fish, no assignment of a dollar value per fish is made. The analysis, however, provides estimates of the economic values of the fish which are harvested and sold in the commercial market. In addition, the recreation or sport value in terms of consumer surplus for fishing for the Columbia River salmon and steelhead runs is estimated. Since different system operation alternatives will impact the size of fish runs, the economic activity surrounding the fish runs will change. This appendix provides descriptions of this economic activity both from an NED standpoint and a regional economy standpoint. However, it should be made clear that economic estimates provided here do not represent the full value of the fish runs and should not be manipulated to define a "value per fish."

\subsubsection{Resource Assessment}

For each SOS, estimates of expected fish runs are presented in Chapter 4. These estimates were developed by the Anadromous Fish Work Group (AFW) and are presented in Appendix C (Anadromous Fish). Anadromous fish of the Columbia River consist of several species of salmon, steelhead trout, shad, smelt, etc. The species of primary interest from an economic standpoint are salmon and steelhead and these are the only species examined here.

\section{Fish Models}

Appendix $\mathrm{C}$ provides an assessment of historic and current runs of Columbia River salmon and steelhead. For evaluation of alternative SOSs the AFW utilized three computer models to simulate the life cycles of salmon and steelhead. Appendix C describes these computer models in considerable detail. Two in-river survival models were utilized to estimate survival of juvenile fish on their downstream migration. The two juvenile passage models were the Columbia River Salmon Passage model (CRiSP) used primarily by BPA and the Passage Analysis Model (PAM) developed and used by the Power Council. In addition a life-cycle model, entitled Stochastic Life Cycle Model (SLCM), was used to estimate survival through the entire eggto-adult spawning life cycle. SLCM was designed to mimic the basic mechanisms regulating populations of Pacific salmon and steelhead. In addition, SLCM attempts to capture some of the intra-annual and inter-annual variation inherent in these populations by incorporating stochastic variation into each step in the life cycle. This enables SLCM to reflect some of the variability inherent in nature. The economic analysis used the life cycle model SLCM to describe the economic activity associated with the catch of adult salmon and steelhead.

The results of the life-cycle model provides long term trends in fish survival for each of the alternatives. Because fish survival through one life cycle influences the number of fish in the following life cycle, the long-term trends are the most descriptive output. The AFW used the life cycle results for year 40 of each of the SOSs to describe fish survival. The variability in possible fish runs were also modeled by AFW, and results are presented in Appendix $\mathrm{C}$ for the median estimate of fish surviv- 
al and expected confidence intervals from 10 percentile to 90 percentile for all the SOSs. This appendix presents fish survival information for the median values estimated for each SOS.

\section{Indicator Stocks}

The fish life-cycle models did not estimate changes to the entire Columbia River salmon and steelhead runs, even though it was recognized that the SOSs have the potential to impact every fish run in the system. To model all species was simply too large of a task and all the necessary data were not available. The AFW identified a group of indicator stocks to model that, in their judgment, sufficiently describe the impacts of each SOS on salmon and steelhead in the different geographic regions in the Columbia basin. The spring chinook indicator stocks were Methow and Snake River stocks. Summer chinook indicators included the Methow and Snake River stocks and fall runs of chinook were modeled with the Hanford Reach and Snake River stocks. Steelhead were modeled with Dworshak hatchery steelhead.

The limitation of the analysis to indicator stocks is a practical reality that somewhat complicated the presentation of economic information. This appendix is intended to present the commercial and sport economic impacts to the impacted Columbia River runs and hence some assumptions had to be made to extrapolate the partial estimates of fish runs to the entire Columbia River fishery. To test how well the indicator stocks represented the total runs of the various species a simple bivariate Pearson correlation study was done. The correlation between indicator stocks and the dam counts at six mainstem Columbia and Snake River dams were examined. The data used for the correlations were the spawning escapement of the indicator stocks and dam counts from the mid -70 s through the late 1980's. The correlation studies are shown in Appendix $\mathrm{C}$, and the general conclusions are summarized by stock below.

For spring chinook, at least one indicator stock was highly correlated with each of the dam counts. For summer chinook, the results were less encouraging. McNary, Priest Rapids and Wells summer chinook counts were highly correlated with the Methow summer chinook counts. However, Ice Harbor and Lower Granite counts were not correlated with either of the indicator stocks. Dam counts for fall chinook at Bonneville, Ice Harbor, McNary, and Priest Rapids were strongly correlated with the Hanford Reach indicator stock, while Lower Granite fall chinook counts were strongly correlated with the Snake River indicator stock. Steelhead dam counts did not correlate well with the Dworshak indicator stock..

Given the results of the correlation studies the following general caveats are made concerning the description of the economic activity associated with each SOS. The anadromous fish indicator stocks modeled in the SOR process are good indicators of spring and fall chinook runs of the Columbia River. The indicator stocks are only fair indicators of the summer chinook run and poor indicators of the steelhead run. For these reasons a high degree of error of estimate is assumed for the summer chinook and steelhead estimates.

The Columbia River coho runs comprise a significant component of the ocean and lower Columbia River commercial and sport fisheries. However, as explained in the Appendix $\mathrm{C}$, the Columbia River coho run consists almost exclusively of fish produced at lower river hatcheries. Wild coho salmon are now considered to be extinct in the Snake and upper Columbia River sub-basins. The SOSs investigated in SOR will not have any appreciable impact on the Columbia River coho runs. For this reason, this major economic component of the Columbia River fisheries was excluded from the SOR analysis.

The AFW determined that sockeye would not be modeled because measures of migrational characteristics (e.g., dam passage parameters, travel time, and survival) are not available. Therefore, the impacts on sockeye for the various SOSs are not reported. Some economic information is provided below for sockeye, but the size of the sockeye run and its economic value is relatively low. As a result, including or excluding 
sockeye from the analysis of economic impacts does not present a significant problem.

\subsubsection{Fish Harvest Analysis}

A description of the harvest of Columbia River salmon and steelhead runs impacted by the alternative SOSs is a critical element of this economic analysis. The economic information provided here is only that associated with harvesting of salmon and steelhead for the commercial market and the economic values associated with harvesting salmon and steelhead in the sport fishery. In addition a description of the fish catch by Native Americans for ceremonial and subsistence purposes is presented. The number of fish that escape harvest and become the spawners necessary to perpetuate the run are not shown here, but they comprise a large portion of the entire fish run. For example, the escapement amounts for the Columbia upriver bright chinook from 1987 to 1991 represented 35 to 50 percent of the in-river run.

The SLCM model provided estimates of the number of fish harvested for the indicator stocks, but the indicator stocks comprised only a small component of the total Columbia River runs influenced by SOR alternatives. The impacts on the indicator stocks were used to define impacts of each SOS in relative terms to a base case. That is, if the model results for the indicator stocks for fall chinook had an estimated 10 percent reduction in harvest from the base case condition, then a 10 percent reduction was assumed for the entire Columbia River fall chinook run.

Considerable data exist on the harvest of salmon and steelhead in both the ocean and in-river fisheries. The historic catch information provided the basis for most of the analysis. Since the SLCM model was calibrated on information from the mid-1980s to early 1990 s, historic information is compiled for this same time frame. As described in Section 2.2.1, Columbia River salmon are harvested in four major fisheries: (1) ocean troll commercial fishery in waters off the coast of Alaska, Canada, Washington, Oregon, and California, (2) sport fishery in the ocean, at Buoy 10, and the main stem and tributaries of the Columbia River, (3) non-Native American gill-net commercial fishery in the Columbia River below Bonneville Dam, referred to as Zone 1 to Zone 5 fishery, and (4) Native American fishery from Bonneville Dam to McNary Dam which includes harvest for the commercial market and ceremonial and subsistence purposes. The management zone for the Native American fishery is entitled Zone 6.

\section{Ocean Harvest}

Ocean harvest of Columbia River stocks of salmon and steelhead by fishery can only be defined with a relatively high degree of uncertainty. Most ocean harvest data is compiled for the states in which the fish are landed. This ocean harvest data are not easily disaggregated into particular stocks of fish because the migratory nature of salmon in the eastern Pacific Ocean creates a mixed stock of fish from a multitude of home streams ranging from California to Alaska. Identification of the home stream of any salmon caught in the ocean can only be done for those fish that are marked with tags such as the coded wire tags (CWT). Data bases are maintained for recoveries of CWT from the various fisheries. These data have limitations because only a small sample of fish are marked with CWT, not all recoveries are reported, and typically only hatchery fish are marked.

The CWT data have been used extensively by several researchers and agencies. The Pacific Salmon Commission (PSC) used CWTs to produce their PSC Chinook Model to evaluate alternative fishery management regimes in conjunction with international treaties between Canada and the US The PSC Chinook Model incorporates nearly all stocks originating from the Columbia River northward for which adequate CWT recovery data are available for estimation of fishery impacts. The 1993 calibration of the PSC Chinook Model was employed to describe the historic harvest by fishery (Morishima, 1993). The general findings of CWT studies by Columbia River species are: (1) steelhead are not a target species for harvest in the US or Canadian ocean commercial or sport fisheries, however, some small percentage of steelhead 
have been caught in nets targeting non-salmon and non-steelhead species, (2) ocean harvest of Columbia River sockeye has been minimal, and (3) ocean harvest of Columbia River fall chinook runs has been significant and occurs from Alaska to Northern California. Given these general findings, the harvest description for the ocean fisheries provided here is limited to the harvest of chinook. Steelhead and sockeye ocean harvests were not quantified because CWT data showed ocean harvest to be minimal.

Table 3-1 provides the estimated breakdown of fish catch for the Columbia River stocks of salmon and steelhead investigated in the SOR for the period of 1987 to 1991 . The stocks presented represent those in which significant CWT data existed. Therefore, smaller runs from tributaries of the Columbia River are not included. For this reason the estimates somewhat understate the catch of Columbia River salmon and steelhead. Ocean catch is shown for commercial and sport fisheries for Alaska,, Canada, and the US.

The fall chinook run is presented in two columns. The first column, entitled total Columbia River Fall Chinook, includes information on catch of falls from the major tributaries in the lower Columbia River such as the Cowlitz and Lewis rivers. The SOSs are unlikely to impact these lower river runs, so the second column, entitled SOR Fall Chinook includes an estimate of the runs likely to be impacted by the SOSs. The SOR fall chinook catch estimates presented consist of Columbia River upriver brights, Spring Creek tules, Lower Bonneville tules, and Snake River falls. A similar approach was taken for the spring and summer chinook runs. The Total Columbia River column includes the large Willamette and Cowlitz Rivers spring chinook runs which will not be impacted by the SOSs. As explained above, no significant ocean catch has been identified for steelhead and sockeye. Some of these species are caught in the ocean. While the extent of the catch is not known, it is believed to be relatively small.

\section{In-River Harvest}

The in-river harvest is shown in Table 3-1 in two rows: In-River Commercial and In-River Sport. The in-river commercial consists of gillnet commercial fishing in Zones 1 to 5, and the Native American harvest in Zone 6. The largest component of the in-river sport fishery for fall chinook occurs in the Buoy 10 fishery at the mouth of the Columbia River. The steelhead sport fishery occurs throughout the Columbia River basin, but the largest concentrated steelhead sport fishery occurs in the Clearwater River. The sockeye catch is harvested in the Native American fishery, but since the listing of sockeye as endangered under the Endangered Species Act, there has not been a tribal commercial harvest of this species.

\section{Native American (Tribal) Fishery}

The Native American fishery is a special subset of the in-river fishery and is described briefly in this section. Treaty fishing rights are established for the Treaty Tribes of the Nez Perce Tribe, the Confederated Tribes of the Umatilla, the Confederate Tribes of the Warm Springs Reservation of Oregon, and the Confederated Tribes and Bands of the Yakima Indian Nation. The Treaty Tribes have rights to fish in their usual and accustomed fishing places from Bonneville Dam upstream to McNary Dam. The treaty Indian fishing can be divided into three functional categories; tribal commercial fishing, tribal subsistence fishing, and tribal ceremonial fishing. All these fishing activities are managed according to the Columbia River Fish Management Plan (CRFMP, 1988).

For the most part, the tribal commercial fishery provides their commercial catch to the wholesale buyers as whole fish, delivered "in the round." The wholesale fish dealer is licensed by the state of operation.

Tribal subsistence fishery refers to those fish caught by enrolled members of treaty tribes for personal consumption of the tribal member or immediate family, or for trade, sale or barter, or to give to other Native Americans for their consumption. Salmon and steelhead that are taken for 
subsistence purposes during the commercial fishing season are treated as commercial fish by fishery agencies. However, since these fish are generally not sold, they are not tracked by the fish ticket method; so, landings of tribal subsistence and ceremonial fish are estimated by the tribes. Tribal ceremonial fish are those fish caught and used pursuant to tribal authorization for religious or other traditional Native American cultural purposes. Ceremonial fish may not be sold, bartered or offered for sale. At least two days notice must be given to the Directors of Fish and Wildlife before ceremonial fishing may occur on the Columbia River.

Table 3-1. Columbia River Salmon Catch Estimates, Averages for the 1987 to 1991 Period (1,000 Fish).

\begin{tabular}{|c|c|c|c|c|c|c|}
\hline \multicolumn{7}{|c|}{ AVERAGES FOR THE 1987 TO 1991 PERIOD (1,000 FISH) } \\
\hline & $\begin{array}{c}\text { Total Col } \\
\text { Riv Fall } \\
\text { Chinook } \\
1 /\end{array}$ & $\begin{array}{c}\text { SOR } \\
\text { Fall } \\
\text { Chinook } \\
2 /\end{array}$ & $\begin{array}{c}\text { Total Col Riv } \\
\text { Sp/Sum } \\
\text { Chinook } \\
3 /\end{array}$ & $\begin{array}{c}\text { SOR } \\
\text { Sp/Sum } \\
\text { Chinook } \\
4 /\end{array}$ & Steelhead & Sockeye \\
\hline \multicolumn{7}{|c|}{ COMMERCIAL CATCH: 5/ } \\
\hline ALASKA & 52.0 & 48.7 & 11.2 & 0.1 & 0.0 & 0.0 \\
\hline CANADA & 176.1 & 162.8 & 40.9 & 10.9 & 0.0 & 0.0 \\
\hline U.S. OCEAN & 46.0 & 39.0 & 13.0 & 0.3 & 0.0 & 0.0 \\
\hline IN-RIVER & 213.2 & 213.0 & 18.0 & 0.7 & 64.9 & 23.7 \\
\hline $\begin{array}{l}\text { TOTAL } \\
\text { COMMERCIAL }\end{array}$ & 487.3 & 463.5 & 83.1 & 12.0 & 64.9 & 23.7 \\
\hline \multicolumn{7}{|l|}{ SPORT CATCH: } \\
\hline ALASKA & 3.0 & 2.8 & 0.7 & 0.0 & 0.0 & 0.0 \\
\hline CANADA & 12.5 & 12.0 & 1.9 & 0.0 & 0.0 & 0.0 \\
\hline U.S. OCEAN & 31.9 & 28.8 & 9.8 & 0.1 & 0.0 & 0.0 \\
\hline IN-RIVER & 27.3 & 14.4 & 101.9 & 0.1 & 50.9 & 0.0 \\
\hline TOTAL SPORT & 74.7 & 58.0 & 114.3 & 0.2 & 50.9 & 0.0 \\
\hline TOTAL CATCH & 562.0 & 521.5 & 197.4 & 12.2 & 115.8 & 23.7 \\
\hline \multicolumn{7}{|c|}{$\begin{array}{l}\text { 1/ Includes Cowlitz \& Other lower river tributaries. } \\
\text { 2/ Fall chinook impacted by SOSs. Upriver brights, lower Bonneville, Spring Creek, and Snake River. } \\
\text { 3/ Includes Willamette \& other lower river tributaries. } \\
\text { 4/ Columbia upriver spring and summer chinook. } \\
\text { 5/ Includes Native American harvest for commercial, ceremonial, and subsistence. } \\
\text { SOURCES: Morishima, Gary S. "Distribution of Columbia River, Washington Coastal, \& Puget Sound } \\
\text { Salmon Stocks." Presented to PUD\#1 Clark Co., Wa. Feb. 1993. } \\
\text { ODF\&W and WDF. "Status Report: Columbia River Fish Runs \& Fisheries, 1960-1990." }\end{array}$} \\
\hline
\end{tabular}




\subsubsection{Fish Allocation}

In order to define the economic activity associated with salmon and steelhead, the adjusted survival estimates from the fish models must be allocated to the different fisheries and to escapement for spawning. A key assumption for the analysis is that the historic allocation rate of fish to the harvest and escapement will continue into the future, regardless of change in production. This assumption is embedded in the fish survival models and in the analysis of economic impacts. With the ESA stocks in particular, this may be a weak assumption, but any other distribution assumption would be purely arbitrary because of the total absence of supporting data.

\subsubsection{Commercial and Sport Fish Values}

As described above, values are not assigned to the salmon and steelhead on a per fish basis because of the inadequacies of economic valuation techniques for all benefits to society, and not accounting for all fish (e.g., spawners and non-CWT stocks). What is presented is limited to the values associated with the harvest of salmon and steelhead by the commercial and sport fishery. These estimates are presented for informational purposes and are not meant to be compared to other economic values in a "trade-off" analysis.

\section{Commercial Values}

One measure of the direct economic value of the fish harvested for commercial purpose is the ex-vessel value which is the price received by the harvesters from fish buyers. The ex-vessel value may not always be the net economic (NED) value because it represents the gross income which has not been reduced to net income by subtracting the cost of harvesting. However, the ex-vessel value is the most appropriate economic value for decision making when only small marginal changes in fish catch are involved and where the small change in the supply of fish would not measurably change the incremental cost of harvesting. In this case, the ex-vessel value reasonably estimates the net economic value. This condition does not hold for large changes in fish catch and in situations where the total net economic value of the commercial fishery are being estimated. Since the SOR is examining large and small changes in fish supply, both the full ex-vessel value and an estimated net economic value are presented to cover the range of economic output.

Numerous researchers have attempted to define net income by identifying a variable harvesting cost to define a net-to-gross ratio that could be applied to the ex-vessel values received by the commercial fish harvester. No consensus has been reached on the net-to-gross ratio. Hanemann (1986) and Meyer (1988) adopted a ten percent of ex-vessel revenues for short-run incremental costs (a 90\% net-togross ratio). In an economic study of the Sacramento River chinook salmon, Hydrosphere Resource Consultants (1991) suggested a variable cost of 11 to 21 percent of ex-vessel value assuming no change in fishing effort. If a change in fishing effort occurs, a variable cost range of 26 to 50 percent was recommended. To demonstrate a range of possible values for the commercially caught salmon and steelhead, net-to-gross ratios of 50 and 100 percent, representing "low" and "high" values, are presented for the current catch (see Tables 3-5 and 3-6, respectively) and for catch with alternative operations of the Columbia River system (see Chapter 4, Section 4.3). The net income derived by these net-togross ratios is meant to estimate the return for the operator's labor, management, and capital.

The average ex-vessel prices for salmon and steelhead for the years of 1987 to 1991 are shown in Table 3-2, on a per species basis. These average ex-vessel values were based on price leveling the prices received over this time frame to 1992 price levels using the gross domestic product price deflator. The price per pound varies by location of catch to reflect the difference in quality and size of the fish and market conditions. The size of fish caught also varies geographically. For example, ocean troll harvest provides a relatively high quality of salmon compared to the same species of salmon that is caught in-river. The in-river fish is nearing the spawning stage and the physiological changes associated with spawning deteriorates the marketability of the fish. Alternatively, the in-river fish are at their peak growth age and hence may be larger than ocean 
Table 3-2. Columbia River Salmon Ex-Vessel Average Values per Fish for the 1987 to 1991 Period

\begin{tabular}{|c|c|c|c|c|}
\hline & $\begin{array}{c}\text { SOR } \\
\text { Fall } \\
\text { Chinook 1/ }\end{array}$ & $\begin{array}{c}\text { SOR } \\
\text { Sprg/Summ } \\
\text { Chinook 2/ }\end{array}$ & $\begin{array}{c}\text { SOR } \\
\text { Steelhead }\end{array}$ & $\begin{array}{c}\text { SOR } \\
\text { Sockeye }\end{array}$ \\
\hline & $\begin{array}{c}\text { Ex-Vessel } \\
\text { \$/Fish }\end{array}$ & $\begin{array}{c}\text { Ex-Vessel } \\
\text { \$/Fish }\end{array}$ & $\begin{array}{c}\text { Ex-Vessel } \\
\text { \$/Fish }\end{array}$ & $\begin{array}{c}\text { Ex-Vessel } \\
\text { \$/Fish }\end{array}$ \\
\hline \multicolumn{5}{|c|}{ COMMERCIAL: 3 / } \\
\hline Alaska 4/ & 26.3 & 26.3 & 0.0 & 0 . \\
\hline Canada 4/ & 26.3 & 26.3 & 0.0 & 0 . \\
\hline U.S. Ocean 4/ & 26.3 & 26.3 & 0.0 & 0 . \\
\hline In-River $\underline{5}$ & 17.6 & 63.0 & 11.0 & 8. \\
\hline \multicolumn{5}{|c|}{$\begin{array}{l}\text { 1/ Fall chinook impacted by SOSs. includes: upriver brights, Bonneville and Spring Creek, and Snake River. } \\
\text { 2/ Columbia upriver spring and summer chinook. } \\
\text { 3/ Includes Native American harvest for commercial, ceremonial, and subsistence. } \\
\text { 4/ Used Oregon and Washington average ex-vessel value. } \\
\text { 5/ Used weighted average for Zones } 1-6 \text { for falls. Only spring values used for spring/summer chinook. }\end{array}$} \\
\hline
\end{tabular}

caught fish. The values shown here simplify this variability by averaging over several catch locations, size of fish, and the five year period.

\section{Sport Values}

Table 3-3 shows the estimated annual number of angler trips experienced over the 1987 to 1991 period for the specific stocks of salmon and steelhead. These estimates were derived from the ODFW \& WDF (1991) data, and IDF\&W steelhead creel census.

The two most widely used methods to derive demand curves for recreation activity are the travel cost method (TCM) and the contingent valuation method (CVM). Section 3.3.7 describes these two procedures. Studies utilizing these accepted evaluation procedures were examined to determine their suitability for use in valuing salmon and steelhead sport fishing in this FEIS. All available TCM and CVM studies of salmon and/or steelhead fishing were screened by the EAG to identify those thought to be must suitable for this study. Hence, the values used here represent a transfer of findings from other studies. There are numerous conceptual and empirical issues surrounding the transfer of recreation value estimates from one site or study to another. This issue of "benefit transfer" is discussed extensively in Section 3.3.7.2, and the interested reader is directed to that section.

Several researchers have compiled and/or compared recreation studies in which either the TCM or CVM approaches were used to estimate the consumer surplus. The most thorough comparative studies are (Walsh, Johnson and McKean, 1992), (Walsh, 1986) and (Sorg and Loomis, 1984). Since Richard Walsh's work is more recent than Sorg and Loomis (1984), it includes several additional studies and is used as the major reference for compilation of values for this FEIS. Additional literature searches were done for the SOR and additional benefit studies were added to the list if the study team judged them to meet the screening criteria. 
Table 3-3. Columbia River Salmon Angler Trips from 1987 to 1991

\begin{tabular}{|c|c|c|c|c|}
\hline \multirow{3}{*}{ Area } & \multicolumn{4}{|c|}{ Recreational Trips } \\
\hline & $\begin{array}{c}\text { Fall } \\
\text { Chinook } 1 /\end{array}$ & $\begin{array}{l}\text { Sprg/Sum } \\
\text { Chinook 2/ }\end{array}$ & Steelhead & Sockeye \\
\hline & (1000 Trips) & (1000 Trips) & (1000 Trips) & (1000 Trips) \\
\hline \multicolumn{5}{|l|}{ SPORT: } \\
\hline Alaska 3 I & 2.2 & 0.0 & 0.0 & 0. \\
\hline Canada 3/ & 9.6 & 0.0 & 0.0 & 0. \\
\hline U.S. OCEAN 3 / & 23.0 & 0.1 & 0.0 & 0. \\
\hline In-River 4/ & 23.2 & 0.2 & 127.3 & 0. \\
\hline TOTAL TRIPS & 58.1 & 0.2 & 127.3 & 0. \\
\hline \multicolumn{5}{|c|}{$\begin{array}{l}\text { 1/ Fall chinook impacted by SOSs. includes: upriver brights, Bonneville and Spring Creek, and Snake River. } \\
\text { 2/ Columbia upriver spring and summer chinook. } \\
\text { 3/ Based on trips per fish for WA and OR at } 0.8 \mathrm{trips/fish.} \\
\text { 4/ For chinook used bouy } 10 \text { data of } 1.61 \mathrm{trips} / \text { fish. for steelhead. Used } 2.5 \mathrm{trips} / \text { fish for salmon. }\end{array}$} \\
\hline
\end{tabular}

The studies compiled in Walsh, et al. (1992) were stratified into the most recent studies and those that were conducted in the states of Washington, Idaho, Oregon, and Montana. In addition, any British Columbia, Canada studies were included. This stratification was done to meet the screening criteria of: (1) age of studies, (2) the need to meet similar population characteristics, and (3) similar market conditions. The Walsh, et al. (1992) literature search included nine anadromous fishing value studies which utilized acceptable TCM or CVM study procedures. The study team was aware of additional studies that met the screening criteria and added these to the list (see table footnote). Table 3-4 summarizes the 12 acceptable studies that were considered for the SOR analysis. The values presented in Table 3-4 are the average of the studies shown in each category with the values price indexed to the mid-1992 dollars with the consumer price index.

Because of the uncertainty associated with the valuation approach described above, the analysis utilized a range of values. The recommended "low" consumer surplus value for an angler day of anadromous fishing was $\$ 50.50$, and the "high" value was $\$ 63.50$.

\subsubsection{Computation of Direct Impacts}

Tables $3-5$ and $3-6$ present the ranges of the average annual direct economic value of the Columbia River anadromous fish stocks over the period of 1987 to 1991. "Low" and "high" ranges were developed by varying two key parameters. The "low" values shown in Table $3-5$ are based on a 50 percent net-to-gross ratio to compute net income for fish caught in the commercial fishery, and a recreation day value for salmon and steelhead fishing of $\$ 50.50$. The "high" values shown in Table 3-6 are based on full ex-vessel value for fish caught in the commercial fishery, and a recreation day value of $\$ 63.50$. The information shown in these two tables was computed by combining catch information in Table 3-1 with value information in Tables $3-3$ to 3-4 and adjusting commercial values by the net-togross ratios.

The information provided in Tables $3-1$ to $3-5$ above are based on historic averages of the actual catch, commercial price, and recreational consumer surplus. The catch and price information were compiled from the five-year period of 1987 to 1991. The size of the Columbia River salmon and steel 
Table 3-4. Recreation Values for SOR Analysis-Based on National Studies from 1983 to 1992 and/or Regional Studies for OR, WA, ID, and MT (Consumer Surplus Values, Mid-1993 Dollars per Recreation Day).

\begin{tabular}{|c|c|c|c|c|}
\hline Area & $\begin{array}{c}\text { Average } \\
\text { Low Value } \\
\underline{1} \text { / }\end{array}$ & $\begin{array}{c}\text { Average } \\
\text { High Value } \\
2 \text { 2] }\end{array}$ & $\begin{array}{c}\text { \# Of } \\
\text { Studies }\end{array}$ & $\begin{array}{l}\text { Average of All } \\
\text { Studies } 3 \text { l }\end{array}$ \\
\hline Anadromous Fishing & 50.50 & 63.50 & 12 & 62.90 \\
\hline \multicolumn{5}{|c|}{$\begin{array}{l}\text { 1/ Values are the lowest of average values computed for the regional studies, or the studies done from } 1983 \\
\text { to } 1992 \text {. }\end{array}$} \\
\hline \multicolumn{5}{|c|}{$\begin{array}{l}\text { Values are the highest of average values computed for the regional studies, or the studies done from } \\
1983 \text { to } 1992 \text {. }\end{array}$} \\
\hline
\end{tabular}

SOURCES: Richard G. Walsh, Donn M. Johnson, John R. McKean, "Benefit Transfer of Outdoor Recreation Demand Studies, 1968-1988," Water Resources Research, Vol. 28, No. 3, March 1992. Supplemented by Wandschneider, et al. (1993), Olsen, et al. (1990), Cameron and James (1986), and Crutchfield and Schelle (1979).

head runs in this period was influenced by the operation of the Columbia System through that period and several years before because of the twoto five-year life cycles of salmon and steelhead. This information serves as the basis for computing the impacts associated with the different SOSs in Chapter 4 of this appendix. The SLCM results estimated the harvest numbers for year 1995 which is used as the initial year of project evaluation.

\subsubsection{Existence Value}

The computation of economic values for the salmon and steelhead fisheries do not include estimates of existence values. The existence value, as discussed here, is the value to the region's non-users of anadromous fish of knowing that Columbia Basin salmon and steelhead runs exist. Several reasons precluded using an estimate of existence value in the SOR economic analysis. Within the economic profession there is considerable debate concerning the theory which supports existence values. Of those economists who accept the theory, there is no agreement on the proper way to measure existence values. For these reasons, existence values were left out of the economic valuation of Columbia river anadromous fish.

Though these existence values were not used in the SOR analysis, a study done in the Pacific Northwest that defined existence values for Columbia River salmon and steelhead is discussed here to give the reader a general feeling for the possible magnitude of benefits that are not included in this appendix.

The study entitled "A Study of Existence and Sport Values for Doubling the Size of the Columbia River Basin Salmon and Steelhead Runs," (Olsen, Richards, and Scott, 1990) presented results of a household survey of Pacific Northwest ratepayers. The study estimated what the ratepayers would be willing to pay to double the Columbia basin salmon and steelhead runs. The doubling of runs is a general goal of the Council. 
Approximately 2,900 Northwest households participated in the study by answering contingent value questions. The individuals that do not participate in either the commercial or sport fishery were considered as expressing an almost "pure" form of existence value because they were considered as resource non-users. Approximately 54 percent of the resource non-users indicated a willingness-to-pay to double the size of the fish runs. The non-users responded that they would pay an additional $\$ 26.42$ per year (mean value 1990\$) on their power utility bills to double the fish runs. When this number is extrapolated to the appropriate number of households in the Pacific Northwest, the annual willingness - to-pay value is over $\$ 42$ million.

This study was done before the listing of several stocks under the Endangered Species Act, and hence the values are probably not valid for current conditions. The SOR alternatives will not double the fish runs so the values are not directly applicable to this analysis. Furthermore, there is no supportable way to apply the results of this study to the individual SOSs.

\subsubsection{Resident Fish and Wildlife}

From an economic standpoint, the impacts of the different SOS on resident fish and wildlife will be reflected in the impact on recreation. The abundance of fish and wildilife resources at the impacted reservoirs and river reaches can influence the amount of recreation activity and quality of the recreation experience. For example, when the number and size of resident fish in a reservoir increases or decreases, the number of recreational fishing days will likely change along with the angler's willingness to pay for the recreation experience. The national economic development values are represented by the recreator's willingness to pay for the recreation activity, while the regional economic impacts are associated with the expenditures that recreators make and who will receive income and jobs from these expenditures.
Relative changes in resident fish and wildlife which are estimated for each of the SOSs are discussed in Appendix K (Resident Fish) and Appendix N (Wildlife), respectively. Section 3.3.7 of this appendix describes how estimated recreation use and values were derived for this draft EIS. It is important to note, however, that the recreation use estimates were based primarily on the ability to use the recreation facilities at different pool elevations or flow levels. This access-based recreation use estimate did not account for impacts on recreation use associated with changes in the abundance of fish and wildlife resources. The study team was unable to find any acceptable methodology to modify the recreation use estimates to reflect the different levels of resident fish and wildlife associated with the different SOS. Ideally, this would require an econometric model that relates recreation use and values to changes in fish and wildlife abundance. Some recreation value studies have identified possible "fish or wildlife abundance" explanatory variables, such as number of fish caught, to define the economic value of recreation. But, it was the study team's opinion that these studies were not directly applicable to the SOR projects. No quantitative adjustments are made for this draft EIS.

The impacts on recreation from changes in resident fish and wildlife are, therefore, discussed in a qualitative manner in Appendix J (Recreation). A similar approach was used to reflect possible changes in economic impacts with the different SOSs. For those SOSs with the largest impacts, either positive or negative, on the resident fish and wildife resources, the possible economic impacts are discussed in a qualitative fashion. The ongoing Pacific Northwest recreation survey will attempt to identify the effects of fish and wildlife abundance on recreation use and values. For the final EIS the results of the recreation survey will be utilized to make adjustments in the recreation use, the willingness to pay values, and expenditures for recreation. 
Table 3-5. "Low" Value Estimates of Columbia River Salmon and Steelhead Catch Annual Averages for the 1987 to 1991 Period. 1/

\begin{tabular}{|c|c|c|c|c|c|}
\hline \multicolumn{6}{|c|}{ VALUE OF CATCH $\underline{1}$ / } \\
\hline & $\begin{array}{l}\text { Fall } \\
\text { Chinook 2/ } \\
\text { Annual } \\
\text { Value } \\
(\$ 1000)\end{array}$ & $\begin{array}{l}\text { Sprg/Sum } \\
\text { Chinook 3/ } \\
\text { Annual } \\
\text { Value } \\
(\$ 1000)\end{array}$ & $\begin{array}{c}\text { Steelhead } \\
\text { Annual } \\
\text { Value } \\
(\$ 1000)\end{array}$ & $\begin{array}{c}\text { Sockeye } \\
\text { Annual } \\
\text { Value } \\
\mathbf{( \$ 1 0 0 0 )}\end{array}$ & $\begin{array}{l}\text { Totals of } \\
4 \text { Species } \\
\text { Annual } \\
\text { Value } \\
\text { (\$1000) }\end{array}$ \\
\hline \multicolumn{6}{|l|}{ COMMERCIAL: 4] } \\
\hline Alaska 5/ & 640 & 0 & 0 & 0 & 640 \\
\hline Canada 5/ & 2,140 & 140 & 0 & 0 & 2,280 \\
\hline U.S. Ocean 5/ & 510 & 0 & 0 & 0 & 510 \\
\hline In-River & 1,870 & 20 & 360 & 100 & 2,350 \\
\hline \multicolumn{6}{|l|}{ SPORT: } \\
\hline Alaska & 110 & 0 & 0 & 0 & 110 \\
\hline Canada & 480 & 0 & 0 & 0 & 480 \\
\hline U.S. Ocean & 1,160 & 0 & 0 & 0 & 1,160 \\
\hline In-River & 1,170 & 10 & 6,430 & 0 & 7,610 \\
\hline $\begin{array}{l}\text { TOTAL } \\
\text { COMMERCLAL }\end{array}$ & 5,160 & 160 & 360 & 100 & 5,780 \\
\hline TOTAL SPORT & 2,920 & 10 & 6,430 & 0 & 9,360 \\
\hline $\begin{array}{l}\text { TOTAL COMM + } \\
\text { SPORT }\end{array}$ & 8,080 & 170 & 6,430 & 100 & 15,140 \\
\hline \multicolumn{6}{|c|}{$\begin{array}{ll}\frac{1}{2} / & \text { Recreation day value }=\$ 50.50 \quad \text { Commercial net }- \text { to-gross }=50 \text { percent } \\
\text { River. } \\
\text { 3/ } \text { Columbia upriver spring and summer chinook. } \\
\overline{4} \text { / Includes Native American harvest for commercial, ceremonial, \& subsistence. } \\
\text { Used Oregon \& Washington average ex-vessel value. }\end{array}$} \\
\hline
\end{tabular}


Table 3-6. Columbia River Salmon Catch and "High" Value Estimates - Annual Averages for the 1987 to 1991 Period. 1/

\begin{tabular}{|c|c|c|c|c|c|}
\hline & $\begin{array}{l}\text { Fall } \\
\text { Chinook 2/ } \\
\text { Annual } \\
\text { Value } \\
(\$ 1000)\end{array}$ & $\begin{array}{l}\text { Sprg/Sum } \\
\text { Chinook } 3 / \\
\text { Annual } \\
\text { Value } \\
(\$ 1000)\end{array}$ & $\begin{array}{c}\text { Steelhead } \\
\text { Annual } \\
\text { Value } \\
(\$ 1000)\end{array}$ & $\begin{array}{c}\text { Sockeye } \\
\text { Annual } \\
\text { Value } \\
(\$ 1000)\end{array}$ & $\begin{array}{l}\text { Totals of } \\
4 \text { Species } \\
\text { Annual } \\
\text { Value } \\
(\$ 1000)\end{array}$ \\
\hline \multicolumn{6}{|l|}{ COMMERCIAL: 4 I } \\
\hline ALASKA $5 /$ & 1,280 & 0 & 0 & 0 & 1,280 \\
\hline CANADA 5/ & 4,280 & 290 & 0 & 0 & 4,570 \\
\hline U.S. OCEAN 5/ & 1,030 & 10 & 0 & 0 & 1,040 \\
\hline IN-RIVER & 3,750 & 40 & 710 & 200 & 4,700 \\
\hline \multicolumn{6}{|l|}{ SPORT: } \\
\hline ALASKA & 140 & 0 & 0 & 0 & 140 \\
\hline CANADA & 610 & 0 & 0 & 0 & 610 \\
\hline U.S. OCEAN & 1,460 & 10 & 0 & 0 & 1,470 \\
\hline IN-RIVER & 1,470 & 10 & 8,080 & 0 & 7,940 \\
\hline $\begin{array}{l}\text { TOTAL } \\
\text { COMMERCIAL }\end{array}$ & 10,340 & 340 & 710 & 200 & 11,590 \\
\hline TOTAL SPORT & 3,680 & 20 & 8,080 & 0 & 10,160 \\
\hline $\begin{array}{l}\text { TOTAL COMM + } \\
\text { SPORT }\end{array}$ & 14,020 & 360 & 8,790 & 200 & 21,750 \\
\hline \multicolumn{6}{|c|}{$\begin{array}{l}\text { 1/ Recreation day value }=\$ 63.50 \text {. Commercial net }- \text { to }- \text { gross }=100 \text { percent } \\
\frac{2}{2 /} \text { Fall chinook impacted by SOSs. Includes: upriver brights, Bonneville and Spring Creek, and Snake River. } \\
\overline{3} / \text { Columbia upriver spring and summer chinook. } \\
\overline{4} / \text { Includes Native American harvest for commercial, ceremonial, \& subsistence. } \\
\text { s/ Used Oregon \& Washington average ex-vessel value. }\end{array}$} \\
\hline
\end{tabular}

\subsubsection{Flood Control}

Flood control is an important use of the regulated Columbia River system. Several locations within the Columbia River basin in Idaho, Montana, Washington, and Oregon are particularly vulnerable to flooding. These damage centers are the focus of the SOR flood control analysis. Some proposed operating strategies could increase the flood risk to these communities. Physical aspects of the flood control system and analysis of the stage/frequency relationship can be found in the Appendix E (Flood Control). Detailed economic analysis of flood control for each Damage Center can be found in Technical Exhibit B of this appendix. The basic concepts used to evaluate the flood control effects of the SOSs are discussed below.

\section{Stage-Damage Estimates}

As flood waters exceed the river banks and flow onto nearby developed properties, damages occur. Gener- 
ally, the deeper and longer water stands on structures, the greater the damage. Likewise, greater damage is caused by larger floods which inundate more structures This stage-damage relationship is used to predict the amount of damage that could occur at various depths of flooding at each damage center.

\section{Discharge-Stage Relationship}

Discharge is the measure of water moving across a given point. Generally discharge is expressed in cubic feet per second. For any given geographic area to be flooded to a certain depth requires a sufficient quantity of water. This relationship between discharge and stage is called the rating curve. The rating curve is integrated with the stage-damage curve to yield the discharge-damage curve.

\section{Discharge-Frequency Relationship}

The discharge-frequency relationship describes the probability of exceeding a given discharge in any year. The discharge frequency curve is integrated with the discharge-damage curve to yield the frequency-damage curve.

\section{Expected Annual Damages}

Expected annual damages are equal to the area under the frequency-damage curve. This area is normally estimated by mathematical approximation. Computer programs, such as the Corps's Hydrologic Engineering Center program, Expected Annual Damage (EAD), are frequently used to estimate expected annual flood damages. Flood control/economic impacts are presented in detail for each Damage Center in Exhibit $B$, and in summary detail in Chapter 4.

Flood damages were collected and analyzed for the following categories of damages. All damage reaches will not contain all categories.

Residential - Residential damages include inundation losses to residential structures and contents, appurtenant buildings, and grounds. Damage to structures and contents was estimated by combining water depths and depth damage functions for various structure types. Average content value was estimated to be 40 percent of the structure value.
Flood losses include damage to floors, walls, heating equipment, furniture, appliances, personal property, and damages to grounds such as yards and fences.

Commercial - Commercial damages include inundation losses to all properties used in commerce, business, wholesale and retail trade, services, and entertainment. Physical flood damages to commercial property and facilities included damages to land, buildings, equipment, supplies, inventory, and other items used to conduct business.

Industrial - Industrial damages represent inundation losses to properties and facilities used in manufacturing and food processing and include physical damage to buildings, raw materials, equipment, finished products, and overhead expenses.

Agricultural - Agricultural damages include loss and destruction of growing crops, land, barns, and other appurtenant buildings and their contents. Losses to equipment, stored crops and feed, livestock, fences, and other farm facilities are also included in this category. Siltation, loss of soil fertility, and cost of removal of debris and weed seed are also analyzed.

Public - Public damages include inundation losses to schools, parks, and other facilities, including equipment and furnishings owned or operated by Federal, State, county, or local government units. Utility damages include losses to electric, water, telephone plants, transmission lines, and similar facilities. This category also includes inundation and destruction losses to roads, streets, pavement, sidewalks, bridges, and other highway structures, supplies, and equipment.

Emergency Aid - Emergency aid includes expenditures essential to the preservation of life and property, such as clearance of debris and wreckage, emergency repair or temporary replacement of private and public facilities, evacuation assistance, Federal aid for flood fighting, flood emergency preparation, rescue operations, police protection, and repair and restoration of damaged flood control works. Also included is Federal assistance to State and local governments to accomplish channel clearing, debris removal, and other emergency channel work on unimproved streams. 
Other - Other damages include losses to railroad property, vehicles and mobile equipment. Railroad losses include damage to tracks, roadbed rights - ofway, supplies and equipment directly attributable to flooding. Vehicle damage include buses, trucks, automobiles, and mobile equipment.

\subsubsection{Irrigation and Municipal and Industrial Water Supply}

\subsubsection{Overview}

The analysis of economic impacts of SOR alternative operating strategies on entities who pump from reservoir pools on the Columbia and Lower Snake rivers is divided into two components: (1) the irrigation pumping associated with commercial agriculture termed "commercial irrigation," and (2) M\&I users, which includes pumpers who utilize reservoir water for municipal and industrial purposes (M\&I), Corps of Engineers pumping for recreation areas and wildlife habitat, irrigation of state parks, irrigation of golf courses, and other consumptive uses. Additional information on the analysis of economic impacts to irrigation and M\&I water pumpers is contained in Appendix F (Irrigation and M\&I Water Supply).

Because the alternative SOSs have different implementation dates, it was necessary to discount the pumping costs associated with each alternative plan to year zero of the analysis (1995). This procedure, consistent with standard time value of money evaluation concepts, is necessary to insure that the comparison among SOR alternatives is on an equal basis. Interest rates of 7.75 percent and 3.0 percent were used to compute the present value of future capital expenditures as well as average annual equivalent values over a 100-year period of analysis. To reflect the present value of capital expenditures, costs were discounted from future implementation dates to 1995, the base year used for the SOR. To estimate the annual costs of pump modifications, capital costs were amortized over the estimated life of the modification (20 years).

\subsubsection{Irrigation}

Analysis of the alternative SOSs indicates that up to six reservoirs would experience lowered reservoir pools under at least one of the SOSs which include drawdown of lower Snake River projects and John Day. These reservoirs by name of dam are: (1) Grand Coulee (Columbia River), (2) Lower Granite (Snake River), (3) Little Goose (Snake River), (4) Lower Monumental (Snake River), (5) Ice Harbor (Snake River), and (6) John Day (Columbia River). Grand Coulee would experience drawdown to supply additional water to the lower Columbia River during the juvenile fish migration. The four Snake River projects and John Day would be drawn down in SOSs 5,6 , and $9 \mathrm{c}$ to increase water velocity through the pools, also during the juvenile migration. However, of the Snake River projects only Lower Granite would be drawn down for SOS 6d. In addition, the John Day pool alone is draw down to MOP in the Preferred Alternative.

Irrigation water is pumped from Grand Coulee, Ice Harbor, and John Day reservoirs. Irrigation pumpers at these reservoirs will be impacted by those SOR operating strategies which propose a drawdown of the pool during the pumping season. It is currently estimated that pumpers on the John Day and Ice Harbor pools irrigate about 175,000 acres. In addition, for those alternative system operating strategies that lower the level of Franklin D. Roosevelt Lake (FDR) at Grand Coulee Dam, the increased pumping costs to irrigators who receive water from the Federal Columbia Basin Project were identified. Over 655,000 acres are irrigated from this project.

The pumping plants on John Day and Ice Harbor reservoirs are operated and maintained by individual owners. Under reservoir drawdown these pumping plants would have to be modified in order to continue operation. The Grand Coulee pumping plant is owned, operated, and maintained by Reclamation. The assumption of the Irrigation/M\&I Work Group was that irrigated land would not go out of production because of alternative operating strategies. 
Pump modification costs were estimated by the Corps of Engineers and private engineering consultants. Modification of John Day and Ice Harbor facilities are necessary, in general, to lower the intake structure, extend the intake lines further into the reservoir pool, to dredge a channel to the intake line, or some combination of all three remedies.

In addition to pump modification, additional operating and power costs are incurred due to the increased lift with drawdown. The pump modification costs along with the increased operating and pumping costs were included in the analysis. The increased costs are essentially mitigation costs associated with those particular SOSs.

Because pump modification costs are not necessary at FDR Lake, only the cost of the increased electrical consumption under drawdown conditions was used to measure impacts at Grand Coulee.

The major input components to the pumping cost analysis include the following items, with the identified data source.

- Reservoir pumpers on John Day and Ice Harbor pools --the only irrigation pumpers identified as being affected by the drawdown alternatives (Corps).

- Quantity of water pumped for each reservoir pool (Corps).

- The cost of existing pumping stations, including $\mathrm{O}, \mathrm{M}, \mathrm{R} \& \mathrm{P}$. Normalized to current prices --October 1992 price level- - (Corps and Reclamation data).

- Current electrical rates for irrigation \& M\&I pumping.

- The cost of modifying the pumping stations to insure their continued operation under alternative proposals with drawdown, including the increased annual pumping cost and ownership cost (Corps and Reclamation).
- Estimation of increased pumping costs to irrigators receiving water from FDR Reservoir - Federal Columbia Basin Project (Reclamation).

The pumping cost analysis is a static-equilibrium analysis of the current farm practices of reservoir pumpers. That is, current representative yields, crop distribution, prices received and paid, and the general agronomic conditions in the area were held constant. Electrical power rates used in the analysis of each SOS are the rates currently in affect (1993). The power rates used in the analysis are shown in Table 3-7. Although cost estimates for pump modifications were estimated for each pump station, the analysis is not intended to be a micro-feasibility analysis of modifying the pumping plants for each reservoir pumper.

\subsubsection{Municipal and Industrial Water Supply}

In addition to commercial irrigation, other reservoir water users have been identified who would be impacted by drawdown of the six reservoirs. These users include M\&I water users, fish hatcheries, water for parks, and irrigation of wildlife habitat. Impacts to all of these water users were evaluated under the category of M\&I water supply. Although M\&I water users would be impacted at all six projects, impacts were evaluated for only John Day, Ice Harbor, Lower Monumental, Little Goose and Lower Granite. Impacts at Grand Coulee were not evaluated because they were judged to be relatively insignificant.

As with irrigation water users, potential impacts on M\&I pumpers was measured by determining the pumping plant modification costs and the increased pumping cost for those installations to obtain a total annual cost. This analysis is based on the same general assumptions as were used for the analysis of impacts to irrigation pumpers. 
Table 3-7. Electrical Power Rates used in the Analysis of Pumping Costs Power Rate (mills/kwh)

\begin{tabular}{|c|c|c|}
\hline Project/State & Irrigation & M\&I Water \\
\hline $\begin{array}{l}\text { Grand Coulee } \\
\text { Washington }\end{array}$ & 0.95 & 29.0 \\
\hline $\begin{array}{l}\text { Lower Granite } \\
\text { Washington }\end{array}$ & 29.0 & 29.0 \\
\hline $\begin{array}{l}\text { Little Goose } \\
\text { Washington }\end{array}$ & 29.0 & 29.0 \\
\hline $\begin{array}{l}\text { Lower Monumental } \\
\text { Washington }\end{array}$ & 29.0 & 29.0 \\
\hline $\begin{array}{l}\text { Ice Harbor } \\
\text { Washington }\end{array}$ & 29.0 & 35.0 \\
\hline $\begin{array}{l}\text { John Day } \\
\text { Oregon } \\
\text { Washington }\end{array}$ & 33.5 & 25.0 \\
\hline na $=$ not applicable & 25.0 & \\
\hline
\end{tabular}

\subsubsection{Navigation}

\subsubsection{Introduction}

The measure of direct economic impacts to navigation was defined as the change in total system-related transportation costs resulting from each alternative compared to existing system transportation costs. The analysis of indirect economic impacts, meanwhile, measures secondary impacts, or ripple effects, that will occur within the regional economy as a result of changes or disruption within the existing transportation network.

Realization of this overall objective requires determining the physical impacts of each system operating plan on commercial navigation use of the waterway, assessing alternative shipping modes and costs; and determining the least-cost combination or combinations of storage, handling, and transport modes given different operating scenarios. Identifying the least-costly alternative mode involves an analysis of existing commodity storage facilities, regional rail and truck capacity, handling rates, and numerous other related factors.

\subsubsection{Analysis of Impacts}

\section{Deep Draft Navigation}

An analysis was performed to determine the extent to which deep draft commercial navigation would be impacted during the refill of Snake River reservoirs and pools that would be drawn down annually under certain scenarios. This was done to determine whether ocean going vessels which presently utilize the 40-foot navigation channel between Vancouver, Washington and the Columbia River entrance would incur significant delays or other problems due to reduced flows in the river during refilling operations.

A comparison of the stage available at key points in the lower Columbia River with varying discharges from Bonneville Dam was combined with the probability of occurrence of those discharges for plans requiring drawdown of the lower Snake River dams during March and/or April and refill during the months of August, September, and October. The 
greatest potential for navigation impacts from refill operations would be present during this period. The analysis identified the actual stage at several locations on the lower Columbia River for a range of discharges from Bonneville during those months. These locations include Wauna at river mile 41.6 $(66.9 \mathrm{~km})$, Kalama at river mile $75.0(120.7 \mathrm{~km})$, and Vancouver at river mile $106.5(171.4 \mathrm{~km})$. The port locations of Kalama and Portland/Vancouver are reported to be the most depth sensitive locations on the river, while Wauna is recognized as a critical passage location for loaded outbound vessels.

A family of tidal curves was developed for the Lower Columbia River coincidental with a range of discharges from Bonneville Dam. Using hydraulic modeling software, (DWOPR) data for the months of August, September, and October were sorted for each year of a 50-year period of record to determine the distribution of daily flows on an annual basis. Inflows from the Willamette River and other significant Columbia River tributaries were included based upon mean flows during August, September, and October, as was 1985 hourly tidal data recorded at Tongue Point for those same months. Outflows from Bonneville were varied in increments of 2500 cfs $(70.8 \mathrm{~m} 3 / \mathrm{s})$ between $70,000 \mathrm{cfs}$ and $80,000 \mathrm{cfs}$, $(2,264.8 \mathrm{~m} 3 / \mathrm{s})$ and by $5,000 \mathrm{cfs}(141.6 \mathrm{~m} 3 / \mathrm{s})$ between $80,000 \mathrm{cfs}$ and $100,000 \mathrm{cfs}(2,831 \mathrm{~m} 3 / \mathrm{s})$. The probability of occurrence was then determined for significant flows; 70,000 cfs $(1,981.7 \mathrm{~m} 3 / \mathrm{s})$ occurrences, the maximum flow, and a value that represents the mid-range between those two flows). The relationship between flow occurrence and the availability of stage on the lower Columbia River during the three month period was thus established at the three key locations.

Stage availability is defined as feet relative to $\mathrm{Co}$ lumbia River Datum (CRD), in one-foot $(.3 \mathrm{~m})$ increments through the range of data. From this, stage loss that would result from the drawdown strategies was determined for each SOS, as was the total time in hours for each foot of stage loss at each location. The results of this analysis are presented in Chapter 4.

\section{Dworshak Log Transport}

Analysis of potential impacts related to the use of Dworshak Reservoir for transporting raw logs identifies the additional costs of log shipment to Lewiston, Idaho when pool elevations are reduced to levels that restrict access to log dumps. System operating strategies that cause significant changes in pool elevations during the conservation season will affect access to dump sites located on the reservoir, such that log rafting operations would be restricted or curtailed whenever the pool elevation drops below the level of a dump site. Where dump sites become inaccessible, logs must then be transported by truck to other available sites on the reservoir or to their final destination at Lewiston.

The analysis of potential impacts in this appendix used 50 years of simulated data. A model which measures the added cost of transporting logs to Lewiston by truck was utilized to assess the monetary impacts of restricted log rafting activity. Basic elements of the model include the monthly volume of shipments, road miles and trucking costs, log quantities per site, and consideration of the minimum pool elevation required to use each site. Impacts are expressed as the alternative cost of truck transport of logs that would normally be rafted via the reservoir.

Based upon historical data, annual log quantities were divided between three main dump sites on Dworshak pool as follows:

\begin{tabular}{|c|c|c|}
\hline Dump Site & $\begin{array}{l}\text { Percent } \\
\text { of Total }\end{array}$ & $\begin{array}{l}\text { Minimum Operating } \\
\text { Elevation (Feet) }\end{array}$ \\
\hline Little North Fork & $\overline{56 \%}$ & 1,575 \\
\hline Benton Creek & $34 \%$ & 1,570 \\
\hline Milk Creek & $10 \%$ & 1,585 \\
\hline
\end{tabular}

Until the pool elevation drops below 1570 feet $(478.5 \mathrm{~m})$, logs would be transported by truck to the nearest usable site on the pool. When the pool elevation drops below 1570 feet, all logs would be moved by truck to Lewiston. Detailed information on the model is contained in Appendix $\mathrm{H}$ (Navigation). The results of the analysis are presented in Chapter 4 of this appendix. 


\section{Shallow Draft Navigation}

A transportation model (SOR Transportation Model) was prepared by contract to analyze the direct economic impacts of various operating strategies. It was designed to measure the costs of commodity shipments under existing and alternative operating conditions and allow NED impacts to be quantified. The model simulates transportation responses to different river conditions associated with salmon mitigation measures (water flow) on the Columbia/ Snake waterway. It computes transportation, handling, and storage costs and capacity utilization of nodes and links for the status quo, (base case) and for changes in project operations that affect the utilization of barge transportation. It thus captures the changes in costs (transportation, storage and handling) that users of the Columbia/Snake River system would incur as a result of navigation impairment. The model consists of separate modules for analysis of grain and non-grain commodities. A description of methodology and data employed is set forth in the report "System Operation Review Transportation Model, Final Report", prepared by Transportation Research and Analysis Center, Inc., 1993. The report is available from the US Army Corps of Engineers, Portland District, upon request.

The model traces commodity movements on a monthly basis from origin to destination, including the seasonal movement of grain from farm to elevator to river port. Changes can be made with respect to input data and assumptions about the monthly flow of grain from origin to destination, handling and storage costs, and alternative transport modes. This capability allows users to model effects of seasonal shifts of shipments between upper river and lower river origins and destinations.

The level of commerce on the waterway is represented by the volume of waterborne shipments via the river system for 1992-93. Data have been compiled for the system of locks, using Waterborne Commerce Statistics and the Lock Performance Monitoring System (LPMS) of the Corps of Engineers. These data were then compared to the volume of products arriving by water at deep-water terminals and were correlated with seasonal volumes shipped from upstream river elevators.

For purposes of modeling, major commodities presently shipped on the Columbia-Snake River were grouped as follows: grain, petroleum products, wood chips and logs, wood products, and all other (primarily export products shipped via containers such as peas, beans and lentils, lumber, and wood pulp, and also fertilizer). Although a variety of commodities benefit from the inland navigation system, wheat and other grain are the products predominantly shipped using this mode of transportation. Wheat and other grains grown throughout the Columbia River Basin, Montana and North Dakota that are destined for export markets typically move from farms to country elevators, to river elevators, and then to export elevators downstream where oceangoing vessels can use deep water. Grain shipped to export elevators via rail is normally delivered by truck to the country elevators where it is loaded on rail cars.

Waterborne movements from upstream to deepdraft destination ports are thus traced from their points of origin. In the case of grain, volume moving from farm through country elevators to river elevators, passing through Columbia/Snake River shallow-draft waterway, and arriving at export ports were identified. Costs of transport for these shipments are aggregated and include handling and storage costs incurred at interim destinations. This procedure has also been used for other commodities shipped by water, upstream as well as downstream.

Regionally, grain makes up the overwhelming majority of tonnage moved by water. This is reflected in the model, which contains 900 flow links (movement from one point to the next) for grain and 120 flow links for other commodities. For grain, transportation costs are an aggregation of costs associated with movement from farm to country elevator, to river elevator, to deep-draft export elevator. Origins include growing areas within Oregon, Washington, Idaho, Montana and portions of North Dakota. A survey was made of those country elevators which serve as interim destinations for down bound grain. River elevators along the Columbia and Snake 
Rivers were likewise identified. The number of elevators surveyed for this purpose is shown below by state.

\begin{tabular}{|c|c|c|}
\hline State & $\begin{array}{c}\text { No. of } \\
\text { County Elevators } \\
\end{array}$ & $\begin{array}{c}\text { No. of } \\
\text { River Ports } \\
\end{array}$ \\
\hline Washington & 313 & 14 \\
\hline Oregon & 46 & 6 \\
\hline Idaho & 111 & 1 \\
\hline Montana & N.A. & N.A. \\
\hline $\begin{array}{l}\text { North Dakota } \\
\text { (N.A. = Not } A\end{array}$ & $\begin{array}{l}\text { N.A. } \\
\text { ailable) }\end{array}$ & N.A. \\
\hline
\end{tabular}

For other commodities moved downstream by water, origins are considered river ports (loading points) and destinations are locations of off-loading. For upstream movements, costs reflect transport by water from point of entry to the waterway to the location where commodities are off-loaded.

Major criteria which govern the modeling process are as follows: The model is demand driven, such that the existing level of monthly exports from the region will be maintained. Where a particular SOS places constraints upon the navigation system, the monthly volume of shipments and the total amount exported from lower Columbia River and Puget Sound elevators would continue to be maintained from within the region.

For grain flows, the model contains seasonal parameters to reflect seasonal variations in flows. These seasonal indices were derived from historical data (1986-1991) using Waterborne Commerce Statistics data. For all non-grain commodities, the monthly (seasonal) indices are assumed to be 1 (equal monthly shipments throughout any given month of the year). Therefore, for each non-grain commodity, the monthly transportation costs were determined and calculated for the applicable duration of each respective SOS that involved drawdown. For the remaining portion of the year when the locks would be accessible, the monthly costs associated with normal shipping conditions would remain unchanged. Drawdown of the Snake River pools prevents use of the locks for varying periods of time and precludes light-loading of barges as a mitigation measure. Also, since historical export volume is assumed to be maintained, temporary storage would be viable only on a limited basis.

The analysis defines the transportation system in terms of long-run equilibrium. Potential changes in the operation of the system are assumed to be long-term. On this basis, replacing the tug and barge fleet with shallower draft equipment would be possible, but of no practical value since the locks would be closed during drawdown because the water level in the pools would be below the elevation of the lock sills. Also, the supply of railroad cars could be increased should commodities switch from the waterway to rail transport. Although a number of types of wheat are blended for export, the specific makeup of export grain commodity is not a consideration in the analysis. However, because of the necessity to mix or blend the various types of wheat for the export market, the analysis assumes that grain supplies are not subject to temporal shifts among regions.

All model outputs are adjusted to reflect the date of implementation of each particular SOS. All values are expressed in 1992 dollars and reflect 1995 conditions. System transportation costs associated with each SOS are expressed as average annual amounts at both 3 percent and 7.75 percent over a 100 -year period of analysis.

\subsubsection{Power}

This section discusses the approach and methodology used to measure and compare the economic impacts to power resulting from the alternative system operating strategies (SOS). The analysis of hydropower system generation and total regional system power costs for each SOS are described in Appendix I (Power). The rest of the analysis of power system impacts, including a summary of gross system generation and capacity costs, net system costs, and rates is described in this appendix. Consumer surplus effects of changes in system power costs with representative SOSs was discussed and estimated for the DEIS. However, it was not possible to assess these effects for the FEIS, because of time and resource constraints. 


\subsubsection{Overview of Analysis}

The gross system cost method described in Appendix I (Power) is the traditional method used to evaluate the economic feasibility of the addition of alternative generation and conservation resources to the system to meet increasing demand for electricity. This method, however, does not account for demand responses to changes in price when low-cost existing generating resources are replaced by new resources with much higher costs. The net system cost method used in this appendix reflects the concept of price elasticity, whereby rate changes can result in changes in the demand for electricity. These changes in demand lead to a revised (lower) estimate of the amount of additional resources to meet projected loads, resulting in net system costs. The net system costs reflect the costs for additional resources after accounting for the reduction in the demand for electricity due to rate increases.

For each SOS, the cost of meeting regional demand assuming no changes in demand due to elasticities was estimated in Appendix I and will be referred to in this appendix as "gross system generation and capacity costs" or simply "gross system costs." The rate impacts from the SOSs, the subsequent elasticity effects, and the resulting net system costs are estimated and described in this appendix.

\subsubsection{Implementation Costs}

Changes in the operation of the Columbia-Snake hydropower system as specified by the alternative SOSs result in changes in system power generation and, for some SOSs, costs incurred to implement the strategy. Specifically, implementation costs would be required for those SOSs which include physical modification of projects to permit drawdown of reservoirs below current minimum operating pool elevations. SOSs which will require modifications to the existing projects are: SOSs $5 \mathrm{~b}$ and $5 \mathrm{c}$; SOSs $6 \mathrm{~b}$ and $6 \mathrm{~d}$; SOSs 9a and 9c; and the Preferred Alternative (PA).

Implementation costs were developed by the Corps of Engineers for its Columbia River Salmon Mitigation Analysis System Configuration Study, Phase I.
Except for costs for SOS 5c, cost data presented in this appendix are from Appendices A and B of the report, Columbia River Salmon Mitigation Analysis, System Configuration Study, Phase I, US Army Corps of Engineers, April 1994. Costs for SOS 5c were prepared by the Walla Walla District of the Corps during continuing studies of projects modifications and operations addressed in Phase I of the System Configuration Study. Costs are reconnaissance-level and would be expected to change as more detailed site-specific data are obtained during feasibility studies. Implementation costs are allocated to project purposes (e.g., power, navigation, flood control, etc.) in accordance with their share of total benefits. Since the dominate project beneficiary of each of the affected projects (Lower Granite, Little Goose, Lower Monumental, Ice Harbor, and John Day) is power, most of the implementation costs are allocated to power. These costs are included with system generation costs to obtain estimates of total system costs and power rates. The allocation of implementation costs is discussed in Chapter 4 (Section 4.8.3) of this appendix.

\subsubsection{Gross System Generation and Capacity Costs}

Much of the analysis of potential impacts on the Pacific Northwest region's electrical power system was done by the Power Work Group. The methodology employed and the results of their analyses are presented in Appendix I of this FEIS. The analysis presented in Appendix I had three major purposes: first, to determine the effects of each of the SOSs on power generation from the Northwest regional power system; second, given these effects, to determine what, if any, actions would be required to meet forecast regional energy demand; and finally, to estimate the cost for serving the forecast regional energy demand. The analysis was based on costs associated with an assumption that losses in hydropower system generation for each SOS would be replaced, in total, without regard to the effect that higher cost replacement power would have on the demand for power.

The analysis was based on the regional electrical energy demand forecast for the 1995-96 and 
2003-04 operating years. The analysis estimated both the capacity and energy (system generation) costs of operating the Pacific Northwest power system to meet this regional demand under hydropower system conditions described by each SOS. Changes in gross system costs for each SOS were calculated as compared to SOS $2 c$, the no-action alternative. These changes are shown in Table 5-5 of Appendix I (Power).

\subsubsection{Rate Impact Analysis Methodology}

Gross system generation and capacity costs are the starting point for the rate impact analysis. These costs are calculated in Appendix I, Power, where they are referred to as total regional costs. For each SOS, these are the costs of replacing losses in hydropower generation, assuming demand stays constant. Accounting for differences in implementation timing of each SOS gives equivalent annual power system impacts. The effects of demand reductions due to increases in rates and implementation costs were not considered in Appendix I (Power) but will be addressed in this appendix.

\subsection{Changes in the Pacific Northwest Electric Utility Industry since DEIS}

The rate impact analysis in this FEIS is substantially different from the methodology used for the DEIS. This is primarily due to recent changes in the Pacific Northwest utility industry. Several events have contributed to a significantly different wholesale electric market than was present even just a few years ago.

Competition has increased considerably in the electricity industry in general and in the Pacific Northwest in particular. This increase in competition is due to a number of factors, including: deregulation as outlined in the Energy Policy Act of 1992 (EPAct); prolonged low natural gas prices combined with an increase in supply; increases in combustion turbine efficiency combined with reductions in their capital costs; and additional competition in the market from power marketers and brokers.

Two provisions of the EPAct will have profound effects on BPA. One allows for the formation of "exempt wholesale generators," also referred to as independent power producers (IPPs), that are exempt from certain restrictions in the Public Utility Regulatory Policies Act of 1978 (PURPA). IPPs are now able to build generating plants and sell the power to any wholesale customer rather than only to utilities, as was the case under PURPA. The other provision of the EPAct allows greater access to transmission grids by competing wholesale electricity sellers, including these IPPs. This access is known as "wholesale wheeling." Both of these changes provide utilities with more alternatives for purchasing wholesale power at competitive prices.

In addition, the Federal Energy Regulatory Commission has recently proposed rules that will order utilities to unbundle their transmission and generation and open their grids for comparable service to all users.

The EPAct provisions and the proposed FERC rules are based on FERC's previous experience with deregulating the natural gas industry. Removal of regulation initially increased the price of natural gas and provided an economic incentive for increasing gas supply. In response to this price signal the supply of gas increased significantly. This over capacity of gas in turn led to a dramatic reduction in natural gas prices. Thus the acquisition of new gas resources is now a function of the competitive gas market with the market price acting as a signal to determine the need for new gas supply. A gas futures market developed which allows gas users to hedge against uncertain future gas prices. The wholesale electricity market is now evolving in a similar fashion.

During the 1990's, the wholesale market for electricity has broadened to become much more of a West Coast rather than a Pacific Northwest regional market. Completion of the third AC intertie increased the capability of the interconnected system. The supply of natural gas in California increased significantly as a result of major expansions of pipeline capacity encouraged by deregulation from Canadian, Rocky Mountain, and Gulf Coast production areas. At the same time, the demand for electricity in California declined. Prices of natural gas 
reached remarkably low levels during 1994 and 1995, with the November 1994 spot price of natural gas down by 65 percent compared to the price in October 1993. BPA estimates that natural gas prices to electric utilities in California will decline in 1995. In addition, the efficiency of combustion turbines has increased (in part as a result of deregulation in the airline industry that required more efficient turbine engines), such that the fully allocated cost of output from a new CT can be as low as 24 mills per kilowatt-hour in the first year of operation, depending on fuel arrangements. Even more efficient combined cycle combustion turbines will be available in the next few years. In addition, at current gas prices the variable cost for some older less efficient gas fired plants whose fixed costs have been fully amortized can be lower than 20 mills per kilowatt-hour.

Marketers and brokers are new participants in the electricity market, making the market picture more competitive. These companies are willing to take risks in order to gain market share. In addition, some have access to capital and to financial instruments that allow them to buy and sell power on the open market as if it were a commodity. Neither marketers nor brokers own the generation equipment that produces the electricity, so they have very low fixed costs. Brokers merely match up buyers and sellers, for a fee, and never own the electricity themselves. With the advent of wholesale wheeling, these types of businesses have increased dramatically.

Hence competition has increased significantly in the electricity industry in the Pacific Northwest.

\subsection{Consequences for BPA}

The above factors have a number of consequences for BPA. BPA is facing increasing competition which threatens its once-stable customer base. Longterm customer load placement on BPA is no longer assured. New market participants can now easily generate or purchase low-cost electricity and get it to a variety of markets. Other suppliers can effectively compete for the business that BPA has always expected to serve.
BPA is now a price-taker in a competitive wholesale market. BPA rates are no longer necessarily lower than alternative sources of power. If BPA's costs result in rates higher than the market, BPA will need to reduce costs or find other sources of revenues. BPA cannot raise rates and expect to keep all of its current customers.

In addition, BPA is changing some of its contract provisions to allow previously captive wholesale customers to buy power elsewhere.

\subsection{Rate Impact Analysis Methodology in DEIS}

The rate impact analysis in the DEIS assumed that all increases in costs due to changes in hydropower operations in each SOS would be paid by BPA and lead to increases in BPA rates. It also assumed that these rate increases would cause end-use consumers (the consumers who purchase electricity from BPA customers) to use less electricity due to the economic price elasticity of demand, leading to the need to acquire fewer replacement resources.

The reality is that BPA has determined it cannot raise its rates past the competitive market rate, or it will lose load to competition. Hence it cannot necessarily expect to raise rates to cover the cost of changes in operation of the hydropower system.

For example, current cost increases due to implementation of the National Marine Fisheries Service's 1995 Biological Opinion are being absorbed by BPA in at least three ways: 1) significant agency-wide cost cutting; 2) credits from the federal government under the Regional Power Act section 4(h)(10)(C) for the river system's non-power users' share of these cost increases; and, 3) reduced probability of repaying the US Treasury the yearly payment required for amortization of the cost of the dams and BPA's transmission system.

It is currently assumed that if the above cost increases were included in BPA rates, BPA would lose customers to other regional utilities, IPP's, brokers, etc. End-use demand for electricity would likely not change. 


\subsection{Implication for Rate Impact Analysis Methodology in FEIS}

Consequently, the rate impact analysis methodology presented in the DEIS is irrelevant given the situation in which BPA currently finds itself. However, analysts felt that it was important to include some type of rate impact analysis to give the reader a basis for comparison across SOSs in terms that were understandable.

Therefore, a number of simplifying assumptions were made in order to do the rate impact analysis for this FEIS. First of all it was assumed that all equivalent annual power system impacts plus equivalent annual implementation costs (referred to as total equivalent annual gross costs in this appendix) would be initially recovered through rates by spreading the increased costs among all Pacific Northwest regional rate payers in proportion to the revenues they generate. The total equivalent annual gross cost increases were divided among utility ratepayers and DSI ratepayers in proportion to their calendar year 1994 revenues. It was assumed that end-use consumers would react to these rate increases by reducing demand, causing a reduction in costs due to the need for fewer replacement resources. This would result in an estimate of equivalent annual net replacement costs and an eventual final rate impact. This impact would be an average change in regional retail rates, assuming all net replacement costs were covered by changes in regional retail rates.

This will give an adequate representation of how regional retail rates might change if all the power impact costs were recovered through rates. It will give the reader a useful method for comparing SOSs using rate impacts. However, due to all the conditions mentioned above, it is unlikely that rates will increase due to these changes. So the reader must understand the limited value and use of this analysis.

\subsubsection{Recreation}

An important aspect of the SOR analysis is the evaluation of the outdoor recreation associated with the operation of the Columbia River system. The economic values associated with recreation can be separated into direct and indirect economic values. The direct values represent the recreator's willingness to pay for the recreation activity which includes two components: (1) the costs to participate (e.g., the entrance fee); and, (2) the dollar amount the recreator is willing to pay above the out of pocket costs (entitled the consumer surplus). The indirect impacts are the effects on local economies, in terms of income and jobs, associated with the expenditures that recreators make to participate in recreation activities, including expenditures for lodging, food, auto, boat, fishing and hunting supplies, etc.. This section presents the methodologies used to estimate the direct economic impacts for each System Operation Strategy (SOS) in terms of expected recreation activities and the economic value of those activities. Procedures for estimating indirect economic impacts are explained in Sections 3.5 and 3.6 of this appendix.

\subsubsection{Individual Willingness-To-Pay for Recreation}

A measure of the direct economic value of goods and services, including recreation activity, is the willingness - to-pay (WTP) of the users. For goods that are sold in a market the WTP is the amount actually paid to obtain the good plus an additional amount an individual would have been willing to pay for the chosen quantity of the good. This latter monetary amount is generally referred to as the consumer surplus and represents the value of the quantity of the good purchased by the consumer, over and above the amount actually paid. Increases in consumer surplus are considered as welfare gains to the consumer because this extra value is obtained without charge. Total consumer welfare to society is measured by summing the consumer surplus across all participants. In the case of valuing recreation, the amount charged for the activity is generally very small or non-existent. This presents a problem to the economist in trying to estimate the demand curve for recreation activities and the related consumer surplus. Since there is no well established market for which recreation goods are exchanged, the economist must utilize non-market approaches to develop demand curves for the estimation of consumer surplus. 
The two most widely used methods to derive demand curves for recreation activity are the travel cost method (TCM) and the contingent valuation method (CVM). The TCM uses indirect means to determine the demand curve. The TCM relies on variations in travel cost (of recreators) and their visitation rates to trace out the demand curve. The basic premise of the approach is that the number of trips to a recreation site will decrease as the direct out-of-pocket and time costs of travel increase, other things remaining equal (Walsh, 1986). Examples of out-of-pockets costs are vehicle operation costs, opportunity costs of time, and lodging costs which all vary with the distance traveled. By observing participation rates from different locations (distances) from a recreation site, the associated travel costs are used to impute the amount individuals are willing to pay for the use of the site. A demand curve for a site is derived from this information to show the number of trips at various travel costs (out-of-pocket costs.) The area under the estimated demand curve, but above actual costs, is the measure of the net WTP and is defined as the consumer surplus.

The CVM is a direct approach to determine the demand for and value of recreation. The object of the CVM approach is to use surveys to determine the individual's net WTP to recreate. In this approach, a sample of the affected population is asked to report their maximum willingness-to-pay, contingent on hypothetical changes in recreation opportunities or resources (Walsh, 1986). CVM can be implemented using several different questioning approaches. The bidding game approach uses an iterative questioning technique which involves repeatedly asking the person if he/she would pay successively higher and higher amounts of money. Once the person reaches the maximum amount he/she would pay, this final value is recorded (Donnelly, Loomis, Sorg, and Nelson, 1985). Another approach is open-ended questions where the respondent is asked to state the amount he/she would pay for the described good. The close-ended approach uses questions that require the respondent to answer a single willingness - to-pay question with a "yes" or "no". For example, "Would you pay $\$ 20$ for the described recreation experience?" Each of these approaches have their advantages and disadvantages which influences a study's sample size, sample design (in-person, phone, or mail-out questionnaires), and data manipulation requirements.

A variation on the CVM is the contingent behavior approach. This approach is similar to CVM because the individual is asked to report changes in behavior based on hypothetical changes in recreation opportunities or resources. The individual is asked to report behavioral changes, such as changes in recreation trips or activities, rather than the willingnessto-pay values asked for in CVM. The contingent behavior approach can complement other approaches such as TCM to reduce uncertainty in projections of recreator's reactions to changes in recreation opportunities or resources.

\subsubsection{Recreation Use and Value Estimation Procedures}

The DEIS used a facilities-based recreation model to estimate recreation demand with the different SOSs, in terms of recreation days. This recreation impact assessment model related pool elevations and stream flows to the level of recreation activity. To assign values to the recreation day estimates, the DEIS relied on a literature search of economic evaluation studies. The averages of numerous recreation values developed in other studies were applied to the recreation day estimates, by activity, to determine the economic impacts of each SOS. Several issues were raised in the economic analysis of recreation impacts in the DEIS. The RWG and EAG recognized that the recreation use and value models used for the DEIS had numerous limitations, foremost of which were (1) heavy reliance on professional judgment of expected reaction of recreators to pool level fluctuations and varied flows, (2) application of economic values derived in other studies to the conditions being examined in the SOR, and (3) inadequate accounting for substitution of lost recreation opportunity at one site to another recreation site.

The procedures used in this FEIS to estimate recreational use and values are based on the results of a Pacific Northwest-wide survey of recreators to develop models that define trips to Federal reser- 
voirs and the associated consumer surplus. A detailed description of the recreation survey approach and the development of regional recreation models is included in Technical Appendix J1 to Appendix J (Recreation), entitled, "Columbia River System Operation Review Recreation Impacts: Demand Model and Simulation Results" (RCG/Hagler Bailly). Following is a description of the basic elements of the survey and modeling process as presented in the RCG/Hagler Bailly report. Use and valuation results for each of the SOSs are presented in Chapter 4 of this appendix.

The objectives of the recreation survey and subsequent modeling were to develop and apply the capability to predict (1) the number of trips individuals in the PNW will take to selected Federal projects and other areas in the Columbia River Basin under existing hydrologic conditions and those characterized in the SOSs and (2) the economic value of these trips, as measured by consumer surplus. Accomplishment of these objectives would then allow us to calculate changes in those values across the different SOSs.

The recreation survey and demand studies were undertaken to meet the following criteria:

- Ability to model the behavior of recreators and nonrecreators;

- Ability to adjust for nonresponse of recreators and nonrecreators;

- Ability to take into account the fact that more avid recreators may live in the least densely populated counties, many of them close to the project;

- Ability to forecast changes in welfare and trip-taking in response to changes in monthly site characteristics affected by reservoir operation;

- Inclusion of multiple recreation types;

- Inclusion of multiple recreation sites with substitution/complementary relationships between them;

- Inclusion of numerous zero trip possibilities;
- Ability to predict changes in welfare and trip-taking in response to hydrologic conditions that are systematically beyond the range of observation; and

- Ability to model impacts on all SOR Federal reservoirs.

The development and application of a PNW recreation survey and associated demand models were able to address the above criteria with varying degrees of success. The survey design and process, and development and application of the recreation demand and value models are described in the following paragraphs.

\section{The Recreation Survey}

The recreation survey instrument was developed in an iterative process that involved a panel of experts and pretesting by a focus group. Participants in the pretest were asked to complete both the survey instrument and an accompanying assessment questionnaire. The assessment questionnaire elicited opinions regarding the clarity and complexity of the survey's questions and instructions. The opinions of the focus group participants were used to guide development of the final questionnaire.

The final survey instrument was a 12 page mail-out questionnaire, in the form of a small booklet. In addition to the survey questions, the questionnaire included a cover page and two pages showing maps. Four versions of the survey were prepared, one for each of the four geographic subregions. The subregions were based on project visitation results obtained from a survey done for the DEIS. Each version of the survey included three or four Federal projects or river reaches which were determined to be likely substitutes. Time and funding constraints of the study required a reduction in the number of recreation sites that could be studied. Since the focus of the SOR is the operation of the Federal Columbia River system, nine areas directly affected by Federal projects were included in the four different survey versions: seven reservoirs (Dworshak, Hungry Horse, Pend Oreille, Libby, Grand Coulee, Lower Granite, and John Day) and two river locations (Kootenai and Clearwater Rivers). All 14 Fed- 
eral reservoirs included in the SOR were not included because of the extreme data requirements. For modeling purposes the RWG, EAG, and the contractor judged that Lower Granite results could be utilized for Ice Harbor, Lower Monumental, and Little Goose because of the project similarities. Impacts from alternative SOSs were judged to be minimal for Chief Joseph, McNary, The Dalles, and Bonneville and were not modeled. The Clearwater River below Dworshak and the Kootenai River below Libby were selected for modeling because they were judged to have relatively high use and to be subjected to the most direct impact from the alternative SOSs.

The sampling strategy combined random general population surveys with surveys of recreators at Federal projects. The recreation model was designed to predict how changes in the operation of the Federal projects would effect recreation behavior in the general population. Consequently, the model had to be estimated from a random sample of the general population in the Pacific Northwest. However, the sample also had to obtain enough trip information from the respondents to estimate the model parameters. This latter requirement was met by sampling individuals who visited Federal projects and those who live close to the projects. The sampling was stratified as follows: (1) 3,000 random sample directory-listed individuals (including 150 from southern British Columbia and southwestern Alberta, Canada); (2) 3064 individuals from counties adjacent to the Federal projects; (3) 500 individuals who were surveyed in the previous stage of study (Phase 1A) of which 388 were water-based recreators; and, (4) 577 individuals who returned post cards that were distributed at the Federal projects in August and September of 1993 (2,000 postcards were distributed with 577 useable responses). The initial mailing and two follow-up mailings took place in October and November 1993. The entire sample of 7,030 was used in the survey response modeling process, as described later. The non-responses were used to help define the total demand, by being the basis for defining the probability that any individual will recreate. Response rates are presented in Table 3-8. After "data cleaning" there were 2,795 useable survey responses.

The 2,795 useable survey responses were separated into two groups: (1) 1,620 "recreators" who reported taking at least one trip in the survey region in the past 12 months, and (2) 1,175 "nonrecreators" who reported taking no trips in the past 12 months. Summary information for the recreator's responses on travel costs per trip and the number of annual trips is shown in Table 3-9. See Technical Appendix (J1) to Appendix J (Recreation) for a more detailed discussion of survey responses.

\section{Table 3-8. Recreation Survey Response Rate Summary by Population Strata}

\begin{tabular}{|l|r|r|r|r|r|}
\hline & \multicolumn{5}{|c|}{ POPULATION } \\
\cline { 2 - 6 } & PNW & $\begin{array}{c}\text { Adjacent } \\
\text { County }\end{array}$ & $\begin{array}{c}\text { Post } \\
\text { Card }\end{array}$ & $\begin{array}{c}\text { Phase } \\
\text { 1A }\end{array}$ & Canada \\
\hline Sample Size & 2,850 & 3,064 & 577 & 389 & 150 \\
\hline Return-to-Sender & 334 & 604 & 12 & 21 & 44 \\
\hline Return-to-Sender Rate & $12 \%$ & $20 \%$ & $2 \%$ & $5 \%$ & $29 \%$ \\
\hline Other Ineligible & 38 & 47 & 0 & 0 & 2 \\
\hline Potential Respondents & 2,478 & 2,413 & 565 & 368 & 104 \\
\hline Completed Questionnaires & 1,054 & 1,218 & 410 & 172 & 31 \\
\hline Raw Response Rate & $37 \%$ & $40 \%$ & $71 \%$ & $44 \%$ & $21 \%$ \\
\hline Completion Rate & $43 \%$ & $50 \%$ & $73 \%$ & $47 \%$ & $30 \%$ \\
\hline
\end{tabular}


Table 3-9. Selected Recreation Survey Response Data by Survey Version

\begin{tabular}{|c|c|c|}
\hline $\begin{array}{l}\text { Survey Version } \\
\text { and Area }\end{array}$ & $\begin{array}{c}\text { Mean } \\
\text { Travel } \\
\text { Costs/Trip } \\
\text { (\$) }\end{array}$ & $\begin{array}{c}\text { Annual } \\
\text { Trips }\end{array}$ \\
\hline \multicolumn{3}{|l|}{ Version 1: } \\
\hline Hungry Horse & 118 & 2.9 \\
\hline Pend Oreille & 147 & 5.9 \\
\hline Libby & 142 & 7.5 \\
\hline Kootenai River & 131 & 9.2 \\
\hline \multicolumn{3}{|l|}{ Version 2: } \\
\hline Dworshak & 120 & 7.9 \\
\hline Clearwater River & 111 & 6.9 \\
\hline Lower Granite & 93 & 9.3 \\
\hline Pend Oreille & 157 & 6.2 \\
\hline \multicolumn{3}{|l|}{ Version 3: } \\
\hline Grand Coulee & 198 & 4.2 \\
\hline John Day & 117 & 6.3 \\
\hline Lower Granite & 182 & 4.1 \\
\hline \multicolumn{3}{|l|}{ Version 4: } \\
\hline Grand Coulee & 126 & 6.3 \\
\hline Dworshak & 190 & 4.0 \\
\hline Lower Granite & 154 & 7.0 \\
\hline Pend Oreille & 174 & 13.3 \\
\hline
\end{tabular}

\section{Survey Response Models}

The modeling of expected recreation use (demand) and economic value (consumer surplus) was a multiple-step process. The starting point of the analysis was the survey of recreators. Since this survey was a mail-out survey it was the survey recipient's choice whether to respond or not. This self-selection nature of the mail-out survey could introduce bias in the results. To correct for this bias,
Survey Response Models were developed. These models estimated the propensity of an individual in a sample to respond to the survey, as a function of numerous explanatory variables. The explanatory variables included socioeconomic characteristics, distances to regional waters, and population strata. The parameter estimates from the Survey Response Models were used to calculate a variable entitled the inverse Mill's ratio (IMR) which was incorporated into the demand models. The IMRs corrected for potential bias that differences in the propensity to respond with useable recreation data might have on the recreation demand model parameters. With this approach all 7,030 mail-out surveys were utilized to estimate the general populations' recreation demand at the Federal projects.

\section{Recreation Demand Models}

A two stage recreation demand model for each of the nine survey areas (seven reservoirs and two river reaches) was estimated. To do this nine distinct estimation samples from the data were developed. The first stage of the model answers the question of whether an individual recreates at a specific project. If he/she does, then the next step is to estimate the determining factors. This first stage of modeling, called monthly trip demand, defines the number of summer trips an individual will take to a project during a specified time frame--in this case the summer months. The number of trips is a function of (1) price from the individual's home to the specific recreation project and other recreation destinations (travel costs), (2) water levels at the project, (3) water levels at alternative projects, (4) socio-economic characteristics, and (5) a time variable. Nearly 50 independent variables were tested to determine significance in estimating the dependent variable of the number of trips from an individual to a project. Development of the model was based on the trips defined in the survey responses. The questionnaires included contingent behavior questions in which expected trips to areas were related to water levels. These contingent behavior responses were treated as actual trips, and consequently expanded the data source significantly. The econometric process of model development was extremely complicated and 
the interested reader is referred to the Appendix J-1 for a more complete explanation.

The monthly trip demand models are models of recreation area demand, which varies for the four summer months, across areas and also differs across the types of recreation activities in which individuals engage. The model equations were aggregated so that all individuals are assumed to have behaved identically in response to explanatory variables if they visited a particular project and engaged in the same activity. The result is that for each recreation area, a demand equation was estimated using observed trips and characteristics of those who visited the area, correcting for possible bias caused by excluding those who could have, but did not visit the area.

\section{Simulation Models}

To evaluate the impacts of each alternative SOS, a PC-based computer model was developed which estimates the number of trips and total summer consumer surplus for each of the nine recreation areas based on changes in water level conditions.

The simulation model contains nine distinct submodels which operate independently during a simulation. To estimate the expected demand of a single individual, the model requires three types of information: personal characteristics, water levels, and the model parameters from the Recreation Demand Models. The model uses standard procedures for the Travel Cost Method to construct a demand curve for each individual by varying the travel cost variable. The resulting demand curve is used to compute the consumer surplus for the individual, by project, and by the summer month time period, consisting of four summer months.

Given a set of water levels the simulation sub-model for a recreation area calculates values for $\mathrm{ex}$ pected monthly demand for each of the four summer months over 50 water years and expected monthly consumer surplus for every individual in the submodel's sample. Averages over the sample are saved. Then the water levels are set equal to the next set of monthly values for the next water year, and new expected demand and consumer surplus values are computed. At the completion of the analysis of all 50 water years, the model has saved 200 monthly average values for each individual. These interim results become inputs for a calibration process that uses actual 1993 visitation data to convert average expected monthly trips and consumer surplus per person to aggregate visitation and consumer surplus measures.

The model outputs provide estimates of average annual recreation days by area, by activity, for the 50-year time period, and the low and high water years of 1941 and 1976, respectively. The models also provide the summer consumer surplus for each recreation area for the average of the 50-year time period, and the 1941 and 1976 water years. To provide this information for all the areas several adjustments were made. Only nine recreation areas were modeled, and Lower Granite was the only project modeled on the lower Snake River. The simulation model allows estimates to be created for Ice Harbor, Lower Monumental and Little Goose, based on the demand model results for Lower Granite. This was judged to be a suitable approach for most of the SOSs for three reasons: First, Lower Granite receives more than 64 percent of the total recreation at the four lower Snake River projects. Second, the operating scenarios are very similar for all four projects. And, third, project characteristics of the four projects are very similar.

The survey obtained the number of trips to recreation areas, but the RWG wanted the impacts associated with each SOS to be based on the number of recreation days. Therefore, it was assumed for this study that the number of trips and recreation days were the same. This is somewhat of an underestimation because some trips result in more than one recreation day, especially for camping trips. This approach, however, does not bias the consumer surplus estimates because the number of trips is the major variable for the travel cost computations.

There also was a need to estimate annual recreation days from the models which included only the four summer months. This was done by simply adding a fixed non-summer visitation amount to the summer month estimates. Actual non-summer month visitation for each project for the November 1992 through October 1993 was used to correspond with 
the recreation survey period. Since the non-summer months are fixed between alternative SOSs, any comparison of the SOSs will net out the non-summer visitation. The simulation results are also available by recreation activity. The demand models were not broken down into individual recreation activity models, but did include some dummy variables to account for different recreation demand for boaters and fishers. However, the activity breakdown in the model results was fixed based on survey results. Thus, total visitation results from the simulation models were multiplied by a fixed percentage for each activity to provide the activity-by-activity estimates.

\subsection{WATER QUALITY}

The economic value of water quality changes are measured indirectly through analysis of water uses, such as fish production and recreation.

\subsection{REGIONAL ECONOMIC EVALUATION, THE CONCEPTS}

Regional economic activity is measured using inputoutput analysis which is a method to estimate the size of economic impacts to regions and communities. Many of the operating strategies evaluated would affect local economies. Strategies that increase anadromous fish runs near certain communities may result in more tourists and fishermen spending money in that region. Conversely, strategies that decrease opportunities to recreate, say through lowering pool elevations, may result in less recreators spending money in that region. Regional economic analysis was done for the System Operation Review using the input-output model IMPLAN. All input-output $(\mathrm{I}-\mathrm{O})$ models begin with the construction of a set of accounts which describe the transactions between industries, their purchases of primary inputs, and their sales to final demand. The following paragraphs explain the transaction, direct requirements, and total requirements tables and how they are used to estimate regional economic impacts in a simplified example.

A complete set of documentation for the thirteen regional, state, and subregional models developed for the SOR has been made available to the SOR Economic Analysis Group. The fully adjusted models are available on 3.5" diskettes, stored using the DOS 5.0 Backup utility. Documentation is available for all price, employment, RPC, and production function adjustments made to the inputoutput models.

A more detailed discussion of the model construction is included in an earlier report, System Operation Review: Framework for Indirect Impacts Analysis, prepared by Northwest Economic Associates.

Exhibit $\mathbf{E}$ provides further description and results of the regional analysis.

\subsubsection{Validating the Basic Data}

The basic data for the IMPLAN system was developed by the University of Minnesota for the USDA Forest Service. The most recent data available at the time of model construction was for the base year 1985. In developing models for the Columbia River System Operation Review (SOR), it was necessary to review this data and evaluate changes in economic activity and adjustments in relative prices that may have occurred since 1985. After researching data availability, it was decided that 1989 was the latest year for which consistent data were available for all model regions.

\subsubsection{Adjusting the Trade Relationships and Production Functions}

After evaluating and adjusting the basic data, the initial social accounts were developed. An important step in the development of the social accounts is the evaluation of the regional purchase coefficients (RPC's). A regional purchase coefficient is the fraction of locally produced goods and services that is used to meet local demand. These values are initially set the first time the social accounts are constructed using a combination of predictive equations and observed values from multi-regional input-output models. Reports displaying the supply/demand pool ratio and the initial RPC for each commodity were prepared for each sub-regional, state, and regional model. This information was put in spreadsheets and consistency across models was checked.

After the RPC's were set, the social accounts were developed again, and production function reports for selected industries were obtained. These reports were 
checked to ensure that regional economic structures were reasonably represented by the model production functions.

\subsubsection{Construction of the Models}

After changes to the price relationships, employment levels, trade relationships, and production functions have been made, the social accounts are constructed. While the social accounts themselves are very useful as an aid to understanding economic structure, they have even more power in understanding economic structure and analyzing economic change when transformed into an I-O model. Two matrices are involved, the "make" matrix and the "use" matrix for each industry. The make matrix lists the quantity of each commodity produced by each industry, the use matrix lists the quantity of each commodity it uses to produce its output. Transformation of the social accounts into the input-output accounts begins with converting the make and use matrices into technical coefficient matrices. The normalized regional use matrix is called the regional absorption matrix. It shows the proportion of each industry's total outlay spent on locally produced commodities. The normalized regional make matrix is called the regional market shares matrix. It shows a given industry's proportion of a region's total commodity production.

The regional direct requirements matrix is derived by multiplying the regional market shares matrix by the regional absorption matrix. The result is an industry by industry direct requirements matrix that establishes interindustry purchases per dollar of industry output by tracing the use of a commodity by an industry to the industries that produce the commodity. The data has at this point been transformed from a commodity and industry basis to an industry basis. In the IMPLAN system terminology, this step is called developing the input-output accounts, or squaring the matrix.

The next step is to transform the direct requirements matrix into a direct plus indirect requirements matrix. Matrix algebra methods are used to develop a table of these direct plus indirect requirements. Any standard text on $\mathrm{I}-\mathrm{O}$ methods provides for the details of this operation.
At the completion of this step, the social accounts have been transformed into an input-output model. The resultant matrix is referred to as the direct and indirect requirements matrix or the inverse matrix. Column sums of this matrix are the so called output multipliers. Additional multipliers are constructed by incorporating the direct relationships between output, employment, income, and value added.

\subsubsection{Transaction Tables}

An input-output model can be used to approximate the local economy by expressing economic relationships among economic sectors. Any developed economy, whether national, regional, or local, is characterized by a high degree of interdependence among industries of the economy. Each economic industry not only produces goods or services, but is also a consumer itself, purchasing other goods and services for use in the production process. Economic relationships are measured by dollar values of purchases or sales among economic sectors. The key to input-output analysis is the construction of the input-output or transactions table, which shows the flow of commodities from each of a number of producing industries to all consuming industries and final demand. A transactions table portrays the dollar flows of goods and services among industries in an economy for a given accounting period. From transaction tables, information about total sales, sectorial input requirements, possible input substitutions, etc., can be estimated. From these flows between economic industries, two other structural tables can be developed:

(1) a table of direct requirements and (2) a table of total requirements.

In the transaction table, Table 3-10 sales and purchase transactions within the economy are set forth in a matrix of rows and columns. Each row shows the output sold by each industry shown along the lefthand side of the table to each industry shown across the top of the table. Each column shows the purchases made by each industry shown along the top of the table from the industries along the left-hand side. Because this is a square table, one row corresponds to each column. The entry in each cell represents a purchase for the column industry and a sale for the row industry. 
Table 3-10. Hypothetical Transaction Table

\begin{tabular}{|c|c|c|c|c|c|}
\hline \multirow{2}{*}{$\begin{array}{l}\text { Producing } \\
\text { Industries }\end{array}$} & \multicolumn{3}{|c|}{ Purchasing Industries } & \multirow{2}{*}{$\begin{array}{c}\text { Final } \\
\text { Demand }\end{array}$} & \multirow{2}{*}{$\begin{array}{l}\text { Total } \\
\text { Output }\end{array}$} \\
\hline & Agriculture & Manufacturing & Services & & \\
\hline Agriculture & 10 & 6 & 2 & 18 & 36 \\
\hline Manufacturing & 4 & 4 & 3 & 26 & 37 \\
\hline Services & 6 & 2 & 1 & 35 & 44 \\
\hline Primary Inputs & 16 & 25 & 38 & 0 & 79 \\
\hline Total Outlay & 36 & 37 & 44 & 79 & 196 \\
\hline
\end{tabular}

Thus, the entries in the first column show agriculture purchasing $\$ 10$ worth of output from itself, $\$ 4$ worth of output from manufacturing, $\$ 6$ from services, and $\$ 16$ from primary inputs (e.g. labor), summing to a total outlay of $\$ 36$. Reading along the row, agriculture sells $\$ 10$ worth of output to itself, $\$ 6$ to manufacturing, $\$ 2$ to services, and $\$ 18$ to final demand. Summing the sales results in a total output value of $\$ 36$.

\subsubsection{Direct Requirements Table}

Table $3-11$ is a direct requirements table for the preceding transaction table. The entries in this table are to be interpreted as the minimal requirements from each of the producing industries at the left of the table in order for each industry at the top to produce one dollar's worth of output.

These direct requirements are determined by dividing the column entries for agriculture, manufacturing, and services in the transaction table by the outlay of the respective column. In this example, the manufacturing industry requires 16.2 cents worth of input from agriculture (\$6/\$37), 10.8 cents from manufacturing industries, and 5.4 cents from services in order to produce one dollar of output. In other words, the 16.2 cents would be interpreted as the "dollar's worth of inputs from agriculture per dollar's worth of output from manufacturing." The remaining inputs to the manufacturing industry come from the primary inputs part of the model.

\subsubsection{Total Requirements Table}

One of the most important applications of the input-output model is to calculate the equilibrium output levels in each industry of the economy. Output is in equilibrium if it is just equal to the quantity demanded for all purposes, such as inputs for production, consumption, investment, and exports. Once the transactions table is balanced and aggregate final demand equals aggregate primary inputs, an equilibrium exists.

Now suppose that someone, probably in a final demand institution, would like to buy more. This starts a chain reaction of increasing production everywhere. Using the direct requirements table, it is possible to calculate by hand the reaction as it ripples through all industries in the economy.

For example, suppose a foreign country would like to purchase $\$ 1$ more from the agriculture industry. Using the direct requirements table one can trace the results. In order to sell an additional dollar's worth of output to final demand (in this case, exports), the agriculture industry must purchase 27.8 cents of output from itself, 11.1 cents of output from the manufacturing industry, and 16.7 cents of output from the services industry. This is the first round. Now for agriculture to sell 27.8 cents to itself, it must again purchase 7.7 cents more output (\$.278 times .278) cents to itself and 3.1 cents (\$.278 times $\$ .111$ ) from manufacturing and 4.6 cents ( $\$ .278$ times $\$ .167$ ) from services. The second round 
Table 3-11. Hypothetical Direct Requirements Table

\begin{tabular}{|l|c|c|c|}
\hline \multirow{2}{*}{$\begin{array}{c}\text { Producing } \\
\text { Industries }\end{array}$} & \multicolumn{3}{|c|}{ Purchasing Industries } \\
\cline { 2 - 4 } & Agriculture & Manufacturing & Services \\
\hline Agriculture & .278 & .162 & .045 \\
\hline Manufacturing & .111 & .108 & .068 \\
\hline Services & .167 & .054 & .023 \\
\hline Primary Inputs & .444 & .676 & .864 \\
\hline
\end{tabular}

is not finished, because for manufacturing to sell 11.1 cents to agriculture, it must buy 1.8 cents (\$.111 times $\$ .054$ ) from services. Services must also purchase 0.8 cents (16.7 cents times .045 ) from agriculture, 1.1 cents $(16.7$ cents times .068$)$ from manufacturing, and 0.4 cents ( 16.7 cents times .023 ) from itself to sell 16.7 cents to agriculture. In just the first two rounds, agriculture has produced $\$ 1$ for export, 27.8 cents plus 7.7 cents for itself, 1.8 cents for manufacturing, and 0.8 cents for services, totaling $\$ 1.38$. Now if one were to follow this procedure ad infinitum, the total amount each industry would be required to produce could be calculated.

Another mathematical procedure called "inverting the matrix" can also be used to estimate the continuous effect of any change in one of the sectors in the model. This can be done using the information on final demands and total outputs using the transactions table combined with the information contained in the direct requirements table and some matrix algebra. From this information, the following system of equations can be developed.

$$
\begin{aligned}
& \mathrm{X}_{1}=.278 \mathrm{X}_{1}+.162 \mathrm{X}_{2}+.045 \mathrm{X}_{3}+\mathrm{Y}_{1} \\
& \mathrm{X}_{2}=.111 \mathrm{X}_{1}+.108 \mathrm{X}_{2}+.068 \mathrm{X}_{3}+\mathrm{Y}_{2} \\
& \mathrm{X}_{3}=.167 \mathrm{X}_{1}+.054 \mathrm{X}_{2}+.023 \mathrm{X}_{3}+\mathrm{Y}_{3}
\end{aligned}
$$

where $X_{1}, X_{2}$, and $X_{3}$ are the total outputs of the three endogenous industries, While $Y_{1}, Y_{2}$, and $Y_{3}$ are the respective processing industries' sales to final demand, and the coefficients are the entries in the direct requirements table. In matrix notation, the system becomes:

$$
\left|\begin{array}{l}
\mathrm{X}_{1} \\
\mathrm{X}_{2} \\
\mathrm{X}_{3}
\end{array}\right|=\left|\begin{array}{lll}
.278 & .162 & .045 \\
.111 & .108 & .068 \\
.167 & .054 & .023
\end{array}\right| \times\left|\begin{array}{l}
\mathrm{X}_{1} \\
\mathrm{X}_{2} \\
\mathrm{X}_{3}
\end{array}\right|+\left|\begin{array}{l}
\mathrm{Y}_{1} \\
\mathrm{Y}_{2} \\
\mathrm{Y}_{3}
\end{array}\right|
$$

Or more simply stated:

$$
\mathrm{X}=\mathrm{AX}+\mathrm{Y}
$$

Where vector $X$ is the vector of total outputs, $A$ is the matrix of direct coefficients, and $Y$ is the vector of final demands. The above may also be written as

$$
\begin{aligned}
& (1-.278) \mathrm{X}_{1}-.162 \mathrm{X}_{2}-.045 \mathrm{X}_{3}=\mathrm{Y}_{1} \\
& -.111 \mathrm{X}_{1}+(1-.108) \mathrm{X}_{2}-.068 \mathrm{X}_{3}=\mathrm{Y}_{2} \\
& -.167 \mathrm{X}_{1}-.054 \mathrm{X}_{2}+(1-.023) \mathrm{X}_{3}=\mathrm{Y}_{3}
\end{aligned}
$$

Which may also be written in matrix notation as:

$$
\left|\begin{array}{lll}
1 & 0 & 0 \\
0 & 1 & 0 \\
0 & 0 & 1
\end{array}\right|-\left|\begin{array}{ccc}
.278 & .162 & .045 \\
.111 & .108 & .068 \\
.167 & .054 & .023
\end{array}\right| \times\left|\begin{array}{c}
\mathrm{X}_{1} \\
\mathrm{X}_{2} \\
\mathrm{X}_{3}
\end{array}\right|=\left|\begin{array}{c}
\mathrm{Y}_{1} \\
\mathrm{Y}_{2} \\
\mathrm{Y}_{3}
\end{array}\right|
$$

and may be reduced to:

Where $I$ is the identity matrix, $(I-A)$ is called the Leontief matrix, and $\mathrm{A}, \mathrm{X}, \mathrm{Y}$ are as previously defined.

The coefficients are now in the proper form to solve the system and find the vector of outputs required to sustain a given vector of final demands. The mechanical process is to find the Leontief inverse or the inverse of the Leontief $(I-A)$ matrix. The Leontief inverse $(I-A)^{-1}$ is defined as the total requirements matrix and is presented in Table 3-12. 
Table 3-12. Hypothetical Total Requirements Table

\begin{tabular}{|l|c|c|c|}
\hline \multirow{2}{*}{$\begin{array}{c}\text { Producing } \\
\text { Industries }\end{array}$} & \multicolumn{3}{|c|}{ Purchasing Industries } \\
\cline { 2 - 4 } & Agriculture & Manufacturing & Services \\
\hline Agriculture & 1.4459 & 0.2678 & 0.0852 \\
\hline Manufacturing & 0.1996 & 1.1628 & 0.0901 \\
\hline Services & 0.2582 & 0.1100 & 1.0431 \\
\hline Total or Output Multiplier & 1.91 & 1.54 & 1.22 \\
\hline
\end{tabular}

To develop a solution, both sides of the above equation must be premultiplied by the Leontief inverse, as follows:

$$
(\mathrm{I}-\mathrm{A}) \mathrm{X}=\mathrm{Y}
$$

which reduces to:

$$
X=(I-A)^{-1} Y
$$

Using the information in the table form and the above matrix, we can develop the following system equations:

$$
\begin{aligned}
& \mathrm{X}_{1}=1.4459 \mathrm{Y}_{1}+0.2678 \mathrm{Y}_{2}+.00852 \mathrm{Y}_{3} \\
& \mathrm{X}_{2}=0.1996 \mathrm{Y}_{1}+1.1628 \mathrm{Y}_{2}+.0901 \mathrm{Y}_{3} \\
& \mathrm{X}_{3}=0.2582 \mathrm{Y}_{1}+0.1100 \mathrm{Y}_{2}+1.0431 \mathrm{Y}_{3}
\end{aligned}
$$

Returning to our example, when a foreign country (or final demand institution outside of the model "region") wants to purchase $\$ 1$ more from the agriculture industry, we would like to determine the total increase in output resulting from this $\$ 1$ increase in final demand.

Using the above system of equations and looking at the $\$ 1$ increase only, agriculture sales to final demand $\left(Y_{1}\right)$ would equal 1 and manufacturing $\left(Y_{2}\right)$ and services $\left(Y_{3}\right)$ sales to final demand would be zero. After multiplying through, agriculture total output $\left(\mathrm{X}_{1}\right)$ equals $\$ 1.4459$ (1 times the coefficient associated with $\left.\mathrm{Y}_{1}\right)$, manufacturing output $\left(\mathrm{X}_{2}\right)$ equals $\$ .1996$, and services output $\left(X_{3}\right)$ equals $\$ .2582$. Summing the three outputs, we find the total increase in output resulting from a $\$ 1$ increase in final demand of the agriculture industry to be $\$ 1.91$. We have found the total output, both direct and indirect, that this hypothetical economy is required to produce in order for the agriculture industry to sell one more dollar of output to a final demand industry. The total output requirement divided by the output sold to the final demand industry is designated as the "output multiplier." The output multiplier is calculated by summing the appropriate column of the Leontief inverse. As presented in the total requirements table by summing each column the output multipliers are 1.91, 1.54 , and 1.22 for the agriculture, manufacturing, and service industries, respectively.

\subsubsection{Multipliers}

As an initial amount of income earned in a community is spent and re-spent to purchase goods and services produced within that community, the total amount of income generated within the community because of the initial expenditure becomes substantially larger than the initial amount. This is referred to as the mulitplier effect. To illustrate how it works, consider the following example. An industry in a community exports goods outside the local area and receives money for those goods. The industry spends part of this money on goods and services in the local community. Expenditures that are for inputs and labor in the local economy are part of the multiplier process. Expenditures that are for imports (goods and services outside the local economy) are not spent in the local community and are called "leakages". For example the industry may receive $\$ 1$ and spend $\$ 0.60$ of this dollar paying for local labor and inputs. The other $\$ 0.40$ is a leakage as it goes to buy imports. Of the $\$ 0.60$ used to pay laborers and inputs, $\$ 0.30$ could 
be re-spent in the community, while the rest leaks out. This process continues

until the amount remaining in the local economy is negligible. In order to determine the multiplier value, the initial dollar is added to the sum of the local re-spending. In the above example, $\$ 1.00$ (initial change) $+\$ 0.60$ (labor and inputs) + $\$ 0.30$ (re-spent in community) $+\ldots$ and so on. For example, a multiplier of $\$ 2.49$ indicates that for each dollar that enters the local economy $\$ 2.49$ worth of local business activity will be generated.

\subsection{REGIONAL ECONOMIC ANALYSIS IN SOR}

The regional economic analysis examines how regional and local economies are affected by the SOR operating strategies described in Chapter 4. The direct economic impacts associated with the SOR alternatives are measured on a national basis. However, the actual incidence of these impacts are distributed across various locations within the Columbia River basin region. Consequently, the secondary (or regional) impacts of these changes would occur in some parts of the region and not in others.

\subsubsection{Study Areas}

In total, thirteen study areas are recognized as locations of potential SOR-related economic impacts. Five of these study areas are defined for the Pacific Northwest and the four states which comprise the region. The remaining eight study areas are referred to as subregions and are made up of multi-county groupings, six of which cross state boundaries. The primary objective in specifying the regions and subregions was to identify areas that could potentially be directly and indirectly affected by changes in system operations. Specification of the subregions was an iterative process that involved Northwest Economic Associates (NEA) and the SOR Economics Work Group. The final set of subregions, presented at the May 1992 Economics Work Group meeting and accepted by the work group, is shown in Table 3-13. Input-output models are built for each of the subregions, or study areas, identified. The IMPLAN regional economic model used is discussed in detail in Exhibit E.

\subsubsection{Linking the Direct and Indirect Economic Impacts}

The first step of the regional analysis is to translate the direct economic impacts into measures of economic change that can be incorporated into the indirect impact analysis. For some of the resource uses the NED benefit and cost values can be included in the regional analysis without any modification. In other cases, only the direct measure of physical change is carried over and alternative values are developed to describe the direct impact. For example, since recreation occurs in a non-market environment, the NED value of recreation benefits is willingness to pay, but the regional analysis is driven by actual expenditures. Therefore, recreation expenditure data are used in the regional analysis rather than NED benefits. Once the appropriate measure of the value of direct economic impacts has been determined, the direct impacts are allocated to the various regions and the IMPLAN models are executed to determine the indirect impacts. The determination of indirect impacts from the direct impacts is discussed in Chapter 4 (Section 4.11) and Exhibit $E$ of this appendix to the SOR FEIS.

\subsection{SOCIAL IMPACT EVALUATION}

The social impact analysis is a representative assessment of potential socio-economic impacts of changes in the operation of the Columbia River system on specific local communities. The analysis is considered to be representative because it was not possible to assess potential impacts to all communities, subregions, states, the region in general, and areas outside the Pacific Northwest. This section describes the social impact analysis process. 
Table 3-13. PNW Subregions for Analysis of Indirect Economic Impacts

\begin{tabular}{|l|l|}
\hline \multicolumn{1}{|c|}{ SubRegion } & \multicolumn{1}{c|}{ Counties Included in the Subregion } \\
\hline 1. Puget Sound & Washington: Whatcom, Skagit, Snohomish, King, Pierce, Thurston \\
\hline 2. West Coast & $\begin{array}{l}\text { Washington: Clallam, Jefferson, Grays Harbor, Pacific, Wahkiakum, Cowlitz } \\
\text { Oregon: Clatsop, Tillamook, Lincoln, Columbia }\end{array}$ \\
\hline 3. Portland & $\begin{array}{l}\text { Oregon: Multnomah, Washington, Clackamas, Yamhill } \\
\text { Washington: Clark }\end{array}$ \\
\hline 4. Mid Columbia & $\begin{array}{l}\text { Oregon: Hood River, Wasco, Sherman, Gilliam, Morrow, Umatilla. } \\
\text { Washington: Skamania, Klickitat, Benton, Franklin, Walla Walla }\end{array}$ \\
\hline 5. Upper Columbia & $\begin{array}{l}\text { Washington: Yakima, Kittitas, Chelan, Okanogan, Douglas, Grant, Lincoln, } \\
\text { Adams }\end{array}$ \\
\hline 6. Lower Snake & $\begin{array}{l}\text { Washington: Columbia, Garfield, Asotin, Whitman } \\
\text { Oregon: Wallowa } \\
\text { Idaho: Latah, Nez Perce, Lewis, Clearwater, Idaho, Custer, Lemhi }\end{array}$ \\
\hline 7. Northeast & $\begin{array}{l}\text { Washington: Pend Orielle, Spokane, Ferry, Stevens } \\
\text { Idaho: Boundary, Bonner, Kootenai, Benewah, Shoshone } \\
\text { Montana: Lincoln, Flathead, Sanders, Lake, Missoula, Mineral }\end{array}$ \\
\hline 8. Southern Idaho & $\begin{array}{l}\text { Oregon: Malheur } \\
\text { Idaho: Adams, Washington, Payette, Gem, Canyon, Ada, Elmore, Owyhee, Boise, } \\
\text { Valley, Camas Blaine, Gooding, Lincoln, Jerome, Minidoka, Twin Falls, } \\
\text { Cassia, Jefferson, Madison, Teton, Clark, Fremont, Butte, Bingham, } \\
\text { Bonneville, Power, Bannock, Caribou, Oneida, Franklin, Bear Lake }\end{array}$ \\
\hline
\end{tabular}

\subsubsection{Focus Communities}

Communities and Indian Tribes within each subregion would be impacted by varying degrees from changes in the operation of the Columbia River System. Since it was not possible to provide an analysis of all of these, focal points for the analysis were identified. The focus communities selected for the assessment are shown in Table 3-14. The focus communities were selected to represent the extreme, or maximum, expected extent of potential impacts on communities within the Pacific Northwest. In addition to the focus communities, however, it is recognized that a number of other geographical areas would also be impacted to varying degrees. Areas identified which would be directly impacted by changes in the operation of the Columbia River System are as follows:

- The Pacific Northwest (OR, ID, WA, and Western Montana)
- Individual states of the Pacific Northwest

- Subregions of the Pacific Northwest, as defined for the SOR regional economic analysis (see Section 3.6)

- Non-PNW Areas: Areas outside the Pacific Northwest which would be impacted include the Pacific Southwest, primarily California; Montana east of the Continental Divide; North Dakota; and, portions of British Columbia, Canada.

\subsubsection{Basis for Social Impacts}

The basis for estimating social impacts was the analysis of indirect economic impacts which would accrue to communities and Tribes within each subregion. Expert judgment was used to allocate subregional indirect economic impacts and to estimate the significance and probable incidence of impacts to specific communities within each of the subregions 
Table 3-14. Focus Communities for Social Impact Analysis, by Subregion

\begin{tabular}{|l|l|}
\hline SOR Subregion & $\begin{array}{l}\text { Focus Communities for } \\
\text { Social Impacts }\end{array}$ \\
\hline 1. Puget Sound & None \\
\hline 2. West Coast & Oregon: Astoria \\
\hline 3. Portland & Oregon: Portland \\
\hline 4. Mid Columbia & Oregon: Umatilla/Morrow \\
\cline { 2 - 2 } & Washington: Tri-cities \\
\hline $\begin{array}{l}\text { 5. Upper } \\
\text { Columbia }\end{array}$ & $\begin{array}{l}\text { Washington: Colville } \\
\text { Reservation, Grand } \\
\text { Coulee/Coulee Dam }\end{array}$ \\
\hline 6. Lower Snake & $\begin{array}{l}\text { Idaho: Orofino, Lewiston, } \\
\text { Nez Perce Reservation }\end{array}$ \\
\cline { 2 - 2 } & Washington: Clarkston \\
\hline 7. Northeast & $\begin{array}{l}\text { Montana: Libby, } \\
\text { Columbia Falls, Flathead } \\
\text { Lake, Flathead Reservation }\end{array}$ \\
\cline { 2 - 2 } & $\begin{array}{l}\text { Idaho: Bonners Ferry, } \\
\text { Kootenai Reservation }\end{array}$ \\
\cline { 2 - 2 } & $\begin{array}{l}\text { Washington: Spokane } \\
\text { Reservation }\end{array}$ \\
\hline 8. Southern Idaho & None \\
\hline
\end{tabular}

modeled in IMPLAN. The analysis includes allocating employment, income, and population changes to focus communities and Tribes. IMPLAN model output was analyzed to estimate significance of impacts. The list of focus communities was reviewed and revised to verify that the identified communities and tribes would experience significant impacts. Communities and tribes without significant impacts were not included.

\subsubsection{Social Impacts Assessment Process}

The social impacts assessment process consisted of the following activities:

- Focus communities were selected. The selection criteria were designed to (1) include communities with potential significant impacts; (2) include representative communities from all of the subregions for which direct and indirect economic impacts were estimated; and, (3) to include some Native American communities.

- Current socio-economic profiles of the focus communities were prepared (see Exhibit F).

- Indirect economic impacts from the regional economic impacts analysis were allocated to the focus communities as the basis for determining the significance of the impacts.

- Allocated indirect economic impacts were compared with the current level of economic activity of each community to obtain an estimate of the significance of the impacts.

- Finally, potential responses of the communities to the impacts were estimated and indicators of significance for each river use and alternative system operating strategy were developed. This assessment consisted of estimating and describing the significance of indirect economic impacts to specific communities and the response of the communities, groups, and individuals to the impacts. The analysis was completed in a workshop by key individuals from the EAG and representatives of a contractor (Northwest Economic Associates). The analysis included estimating the significance of indirect impacts to the communities/tribes, translation of indirect impacts by industry code into specific economic activities/entities in the community, assessment of likely community response to these changes, assessment of impacts to groups and individuals including changes in their way of life and values. Results of the assessment are presented in Chapter 5 and Exhibit $F$ of this appendix to the SOR FEIS. 


\section{CHAPTER 4}

\section{ALTERNATIVES AND THEIR IMPACTS}

\subsection{GENERAL DESCRIPTION OF ALTERNATIVES}

Seven alternative System Operating Strategies (SOS) were considered in the Draft EIS. Each of the 7 SOSs contained several options, bringing the total number of alternatives considered to 21 . This Final EIS also evaluates 7 operating strategies, with a total of 13 alternatives now under consideration when accounting for options. Section 4.1 of this chapter describes the 13 alternatives and provides the rationale for including these alternatives in the Final EIS. Operating elements for each alternative are summarized in Table 4-1. Later sections of this chapter describe the effects of these alternatives on economic and social impacts

The 13 final alternatives represent the results of the third analysis and review phase completed since SOR began. In 1992, the agencies completed an initial effort, known as "Screening" which identified 90 possible alternatives. Simulated operation for each alternative was completed for five water year conditions ranging from dry to wet years, impacts to each river use area were estimated using simplified analysis techniques, and the results were compared to develop 10 "candidate SOSs." The candidate SOSs were the subject of a series of public meetings held throughout the Pacific Northwest in September 1992. After reviewing public comment on the candidate strategies, the SOR agencies further reduced the number of SOSs to seven. These seven SOSs were evaluated in more detail by performing 50-year hydroregulation model simulations and by determining river use impacts. The impact analysis was completed by the SOR workgroups. Each SOS had several options so, in total, 21 alternatives were evaluated and compared. The results were presented in the Draft EIS, published in July, 1994. As was done after Screening, broad public review and comment was sought on the Draft EIS. A series of nine public meetings was held in September and
October 1994, and a formal comment period on the Draft EIS was held open for over $41 / 2$ months. Following this last process, the SOR agencies have again reviewed the list of alternatives and have selected 13 alternatives for consideration and presentation in the Final EIS.

Six options for the alternatives remain unchanged from the specific options considered in the Draft EIS. One option (SOS 4c) is a revision to a previously considered alternative, and the rest represent replacement or new alternatives. The basic categories of SOSs and the numbering convention remains the same as was used in the Draft EIS. However, because some of the alternatives have been dropped, the final SOSs are not numbered consecutively. There is one new SOS category, Settlement Discussion Alternatives, which is labeled SOS 9 (see Section 4.1.6 for discussion).

The 13 alternatives have been evaluated through the use of a computerized model known as HYDROSIM. Developed by BPA, HYDROSIM is a hydroregulation model that simulates the coordinated operation of all projects in the Columbia River system. It is a monthly model with 14 total time periods. April and August are split into two periods each, because major changes can occur in streamflows in the first and second half of each of these months. The model is based on hydrologic data for a 50-year period of record from 1928 through 1978. For a given set of operating rule inputs and other project operating requirements, HYDROSIM will simulate elevations, flows, spill, storage content and power generation for each project or river control point for the 50-year period. For more detailed information, please refer to Appendix A, River Operation Simulation.

The following section describes the final alternatives and reviews the rationale for their inclusion in the Final EIS. 
Table 4-1. Sos Alternative-1

\section{Summary of SOS}

$\begin{array}{|ccc|}\text { SOS } 1 & \text { SOS } 2 & \text { SOS } 4 \\ \text { Pre-ESA Operation } & \text { Current Operations } & \text { Stable Storage Project } \\ \text { Operation }\end{array}$

SOS 1 represents system operations before changes were made as a result of the ESA listing of three Snake River salmon stocks. SOS 1 a represents operations from 1983 through the 1990-91 operating year, influenced by Northwest Power Acl; SOS Ib represents how the system would operate without the Water Budget and related operations to benefit anadromous fish. Short-term operations would be conducted to meet power demands while satisfying nonpower requirements.
SOS 2 reflects operation of the system with interim flow improvement measures in response to the ESA salmon listings. It is consistent with the 1992-93 operations described in the Corps' 1993 Interim Columbia and Snake River Flow Improvement Measures Supplemental EIS. SOS $2 c$ represents the operating decision made as a result of the 1993 Supplemental EIS and is the no action alternalive for the SOS. Relative to SOS 1a, primary changes are additlonal flow augmentation in the Columbla and Snake Rivers and modífied pool levels al lower Snake and John Day reservoirs during juvenile salmon migration. SOS 20 represents operations of the 1994-98 Biological Opinion issued by NMFS, with additional flow aumentation measures compared to SOS $2 c$.
SOS 4 would coordinate operation of storage reservoirs to benefit recreation, resident fish, wildifie, and anadromous fish, while minimizing impacts to power and flood control. Reservoirs would be managed to specific elevations on a monthly basis; they would be kept full longer, while still providing spring flows for fish and space for flood control. The goal is to minimize reservoir fluctuations while moving closer to natural flow conditions. SOS $4 c$ attempts to accommodate anadromous fish needs by shaping mainstem flows to benefit migrations and would modify the flood control operations at Grand Coulee.

\section{Actions by Project}

\section{SOS 1}

\section{$\operatorname{sos} 2$}

\section{4}

\section{LIBBY}

Whom

Normal 1983-1991 storage project operations

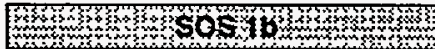

- Minimum project flow $3 \mathrm{kcfs}$

- No refill targets

- Summer draft limit of 5-10 feet

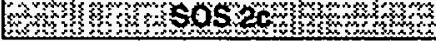

Operate on system proportional draft as in SOS 1a

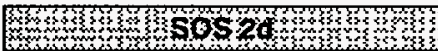

- Provide flow augmentation for salmon and sturgeon when Jan. to July forecast is greater than 6.5 MAF

- Meat sturgeon flows of 15,20 , and 12.5 kofs in May, June, and July, respectively, in at leest 3 out of 10 years

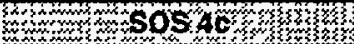

- Meet specific elevation targets as indicated by Integrated Rule Curves (IRCs); IRCs are based on storage content at the end of the previous year, determination of the appropriate year within the crilical period, and runoff forecasts beginning in January

- IRCs seek to keep reservoir full $(2,459$ feet) June-Sept; minimum annual elevation ranges from 2,399 to 2,327 feet, depending on critical year determinatlon

- Meet variable sturgeon flow targets at Bonners Ferry during May 25-August 16 period; flow targets peak as high as $35 \mathrm{kcfs}$ in the wettest years 
Table 4-1. Sos Alternative-1

\begin{tabular}{|c|c|c|c|}
\hline $\begin{array}{l}\text { SOS } 5 \\
\text { Natural River Operation }\end{array}$ & $\begin{array}{c}\text { SOS } 6 \\
\text { Fixed Drawdown }\end{array}$ & $\begin{array}{c}\text { SOS } 9 \\
\text { Settlement Discussion } \\
\text { Alternatives }\end{array}$ & SOS PA \\
\hline $\begin{array}{l}\text { SOS } 5 \text { would ald juvenile } \\
\text { salmon by increasing river } \\
\text { veloclty. The four lower Snake } \\
\text { River projecls would have new } \\
\text { outlets installed, allowing the } \\
\text { reservoirs to be drawn down } \\
\text { to near the orlginal rlver eleva- } \\
\text { tlon. The "natural river" } \\
\text { operatlon would be done for } \\
41 / 2 \text { months in SOS } 5 \text { b and } \\
\text { year-round in SOS } 5 c \text {. John } \\
\text { Day would also be operated at } \\
\text { MOP for } 4 \text { months, and flow } \\
\text { augmentation measures on } \\
\text { the Columbia River portion of } \\
\text { the basin would contlnue as in } \\
\text { sos } 2 c \text {. }\end{array}$ & $\begin{array}{l}\text { SOS } 6 \text { involves drawing down } \\
\text { lower Snake River projects to } \\
\text { fixed elevations below MOP to } \\
\text { aid anadromous fish. SOS } 6 b \\
\text { provides for fixed drawdowns } \\
\text { for all four lower Snake } \\
\text { projects for } 41 / 2 \text { months; SOS } \\
6 \text { draws down Lower Granlte } \\
\text { only for } 41 / 2 \text { months. John } \\
\text { Day would also be operated at } \\
\text { MOP for } 4 \text { months, and flow } \\
\text { augmentation measures on the } \\
\text { Columbia River portion of the } \\
\text { basin would continue as in } \\
\text { SOS } 2 c \text {. }\end{array}$ & $\begin{array}{l}\text { SOS } 9 \text { represents operations } \\
\text { suggested by the USFWS, } \\
\text { NMFS, the state fisheries } \\
\text { agencles, Native American } \\
\text { tribes, and the Federal operat- } \\
\text { ing agencies during the } \\
\text { settlement discussions in re- } \\
\text { sponse to the IDFG v. NMFS } \\
\text { court proceedings. This alter- } \\
\text { natlve has three options, SOSs } \\
9 a, 9 \mathrm{~b}, \text { and } 9 \mathrm{c} \text {, that represent } \\
\text { different scenarios to provide } \\
\text { increased river velocities for } \\
\text { anadromous fish by establish- } \\
\text { ing flow targets during } \\
\text { migration and to carry out } \\
\text { other actions lo benefit ESA- } \\
\text { listed species. The three } \\
\text { optlons are termed the De- } \\
\text { talled Fishery Operating Plan } \\
\text { (9a), Adoptive Management } \\
\text { (9b), and the Balanced Im- } \\
\text { pacts Operation (9c). }\end{array}$ & $\begin{array}{l}\text { SOS PA represents the opera- } \\
\text { tion recommended by NMFS } \\
\text { and the USFWS Biological } \\
\text { Opinions issued March 1, } \\
\text { 1995. This SOS supports re- } \\
\text { covery of ESA-listed species } \\
\text { by storing water during the fall } \\
\text { and winter to meet spring and } \\
\text { summer flow targets, and pro- } \\
\text { tects other resources by } \\
\text { setting summer draft limits to } \\
\text { manage negative effects, by } \\
\text { providing flood protection, and } \\
\text { by providing for reasonable } \\
\text { power generatlon. }\end{array}$ \\
\hline
\end{tabular}

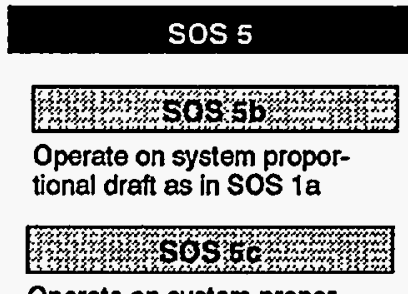

Operate on system proportlonal draft as in SOS 1 a

$\operatorname{sos} 6$

$\operatorname{sos} 9$

\section{W}

Operale on system proportional draft as in SOS $1 a$

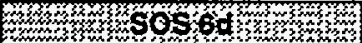

Operate on system proportional diaft as in Sos 12
$1 \mathrm{kcfs}=28 \mathrm{cms}$

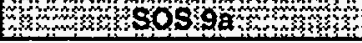

- Operate on minimum flow up to flood control rule curves year-round, except during flow augmentation period

- Provide sturgeon flow releases April-Aug. to achleve up to $35 \mathrm{kcfs}$ at Bonner's Ferry with appropriate ramp up and ramp down rates

\section{Whos 50596 का}

- Operate on minimum flow up to flood control rule curves year-round, except during flow augmentation

- Provide sturgeon flow releases similar to SOS 2d

- Can draft to elevation 2,435 by end of July to meet flow targets

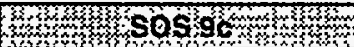

- Operate to the Integrated Rule Curves and provide sturgeon flow releases as in SOS $4 c$
SOS PA

Whan

- Operate on minimum flow up to flood control rule curves beginning in Jan., except during flow augmentation period

- Strive to achieve flood control elevations in Dec. in all years and by April 15 in 75 percent of years

- Provide sturgeon flows of 25 kcts 42 days in Juno and July

- Provide sufficlent flows to achieve 11 kcfs flow at Bonner's Ferry for 21 days after maximum flow period

- Draft to meet flow targets, to a minimum end of Aug. elevation of 2,439 feet, unless deeper drafts needed to meet sturgeon flows 
Table 4-1. SOS Alternative-2

Actions by Project

sos 1

\section{HUNGRY}

HORSE

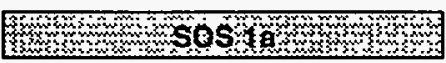

Normal 1983-1991 storage project operations

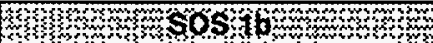

- No maximum flow restriction from mid-Oct. to mid-Nov.

- No draft limit; no refill target

Sos 2

\section{$\operatorname{sos} 4$}

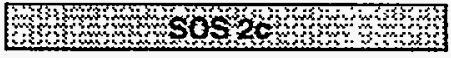

Operate on system proportional draft as in SOS 1a

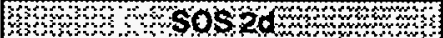

Operate on system proportional draft as in SOS 12

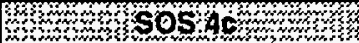

- Meet specific elevation targets as indicated by Integrated Rule Curves (IRCs), similar to operation for Libby

- IRCs seek to keep reservoir full $(3,560$ feet) June-Sept.; minimum annual elevation ranges from 3,520 to 3,450 feet, depending on critical year $\operatorname{sos} 1$

\section{ALBEN}

FALLS

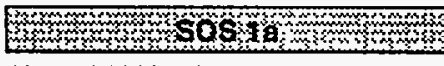

Normal 1983-1991 storage project operations

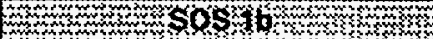

No refill target
Sos 2

\section{Whow 5052}

Operate on system proportional dr as in SOS 1a

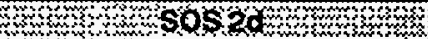

Operate on system proportional drafi as in SOS $1 \mathrm{a}$

\section{$\operatorname{sos} 4$}

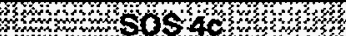

Elevation targets established for each month, generally 2,056 feet Oct.-March, 2,058 to 2,062.5 feet April-May. 2,062.5 feet (full) June, 2,060 feet July-Sept. (but higher if runoff high); Oct.-March drawdown to 2,051 feet every 6th year 
Table 4-1. SOS Alternative-2

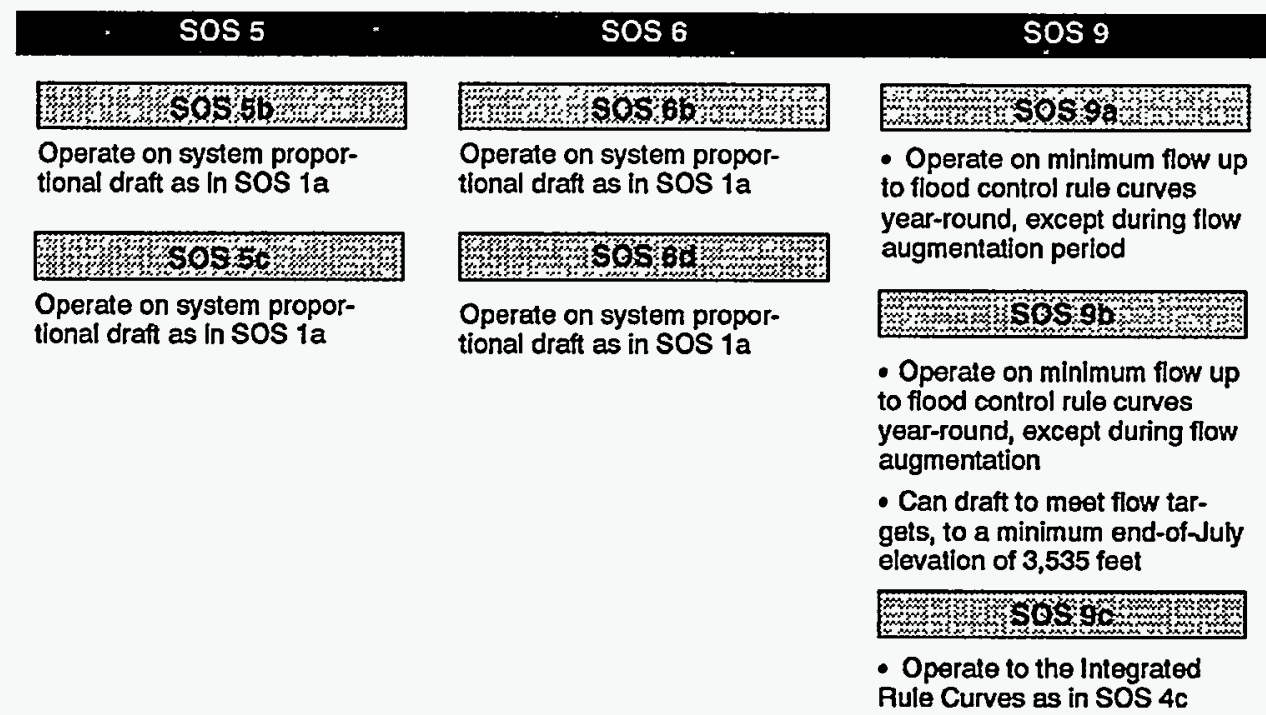

SOS PA

W

- Operate on minimum flow up to flood control rule curves year-round, except during flow augmentation period

- Strive to achieve flood control elevations by April 15 in 75 percent of the years

- Draft to meet flow targets, to a minimum end-of-August elevation of 3,540 feet

\section{$\operatorname{sos} 5$}

\section{溪策}

Operate on system proportional draft as in Sos 1a

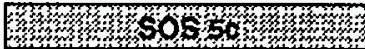

Operate on system proportional draft as in SOS 1a

\section{$\operatorname{sos} 6$}

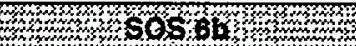

Operate on system proportional draft as in SOS 1a

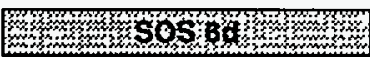

Operate on system proportional draft as in SOS 1a

\section{$\operatorname{SOS} 9$}

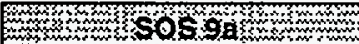

Operate on minimum flow up to flood control rule curves year-round, excepl during flow augmentation period

\section{Mxphos}

- Operate on minimum flow up to flood control rule curves year-round, except during flow augmentation period

- Can draft to meet target flows, to a minimum end-ofJuly elevation of 2,060 feet

\section{Wh $150580 \mathrm{~m}$}

- Elevation targets established for each month generally no lower than 2,056 feet Dec.April, no lower than 2,057 feet end of May, full $(2,062.5$ feet) June-Aug., 2,056 feet Sept.-Nov.

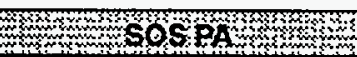

- Operate to flood control elevations by April 15 in 90 percent of the years

- Operate to help meet flow targets, but do not draft below full pool through Aug. 
Table 4-1. SOS Alternative-3

Actions by Project

$\operatorname{sos} 1$

GRAND

COULEE

\section{Whom}

- Operate to meet Waler Budget target flows of $134 \mathrm{kcts}$ at Priest Rapids in May ${ }^{1 /}$

- Meet minimum elevation of 1,240 feet in May

W.

- No refill target of 1,240 feet in May

- Maintain 1,285 feet June-Sept.; minimum 1,220 feet rest of year

- No May-June flow target

Sos 2

Wos

- Storage of water for flow augmentation from January through April

- Supplemental releases (in conjunction with upstream projects) to provide up to 3 MAF additional (above Water Budget) flow augmentation in May and June, based on sliding scale for runoff forecasts - System flood control space shifted from Brownlee, Dworshak

\section{Whom}

- Contribute, in conjunction with upstream storage projects, up to 4 MAF for additional flow augmentation

- Operate in summer to provide flow augmentation water and meet downstream flow targets, but draft no lower than 1,280 feet $\operatorname{sos} 4$

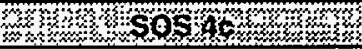

- Operate to end-of-month elevation targets, as follows:
1,288 Sept.-Nov
1,287 Dec.
1,270 Jan.
1,260 Feb.
1,270 Mar.
1,272 Apr. 15
1,275 Apr. 30
1,280 May
1,288 Jun.-Aug.

- Meet flood control rule curves only when Jan.-June runoff forecast exceeds 68 MAF
- Meet May-June flow targets $y$

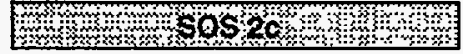

Operate as in SOS 1a

- Maintain minimum flows to meet Vernita Bar Agreement ${ }^{2}$

\section{W.m.}

Operate as in SOS 1a

\section{W}

- No May flow target

- Meet Vernita Bar Agreement

1/ Flow targets are weekly averages with weekend and holiday flows no less than 80 percent of flows over previous 5 days.

2/ $55 \mathrm{kcfs}$ during heavy load hours October 15 to November 30; minimum instantaneous flow 70 kcfs December to April $\mathrm{KAF}=1.234$ million cubic meters

\author{
MAF $=1.234$ billion cubic moters
}


Table 4-1. SOS Alternative-3

$\operatorname{sos} 5$

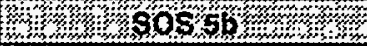

Operate on system proportional draft and provide flow augmentation as in SOS $2 c$

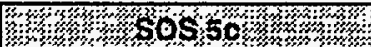

Operate on system proportional draft and provide flow augmentation as in SOS 2C

$\operatorname{sos} 6$ SOS 9 SOS PA

\section{Wonos}

Operate on system proportional draft and provide flow augmentation as in SOS $2 \mathrm{c}$

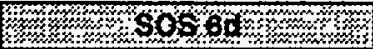

Operale on system proportional draft and provide flow augmentation as in SOS $2 \mathrm{c}$
Whos

- Operate to meet flood control requirements and Vernita Bar agreement

- Provide flow augmentation releases to help meet targets at The Dalles of 220-300 kefs April 16-June 15, 200 kcfs June 16July 31 , and 160 kcts Aug. 1-Aug.31, based on appropriate critical year determination

- In above average runoff years provide $40 \%$ of the additional runoff volume as flow augmentation

\section{符}

- Operate on minimum flow up to flood control rule curves year-sound, except during flow augmentation period

- Can draft to meet flow targets, bounded by SOS $9 \mathrm{a}$ and $9 \mathrm{c}$ targets, to a minimum endof-July elevation of 1,265 feet

\section{y.}

- Operate to meet McNary flow targets of 200 kefs April

16-June 30 and $160 \mathrm{kcfs}$ in July

- Can draft to meet flow targets, to a minimum end-of-July elevation of 1,280 feet

- Contribute up to 4 MAF for additional fiow augmentation, based on sliding scale for runoff forecasts, in conjunction with other upstream projects

- System flood control shifted to this project
Sos 5

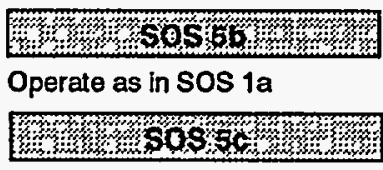

Operate as in SOS 1a

sos 6

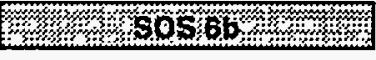

Operate as in SOS 1a

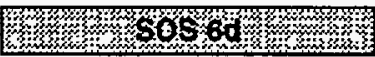

Operate as in SOS 1a

$\operatorname{sos} 9$

SOS PA

Wospan

Operate as in SOS 1a

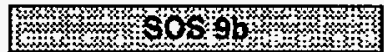

Operate as in SOS 1a

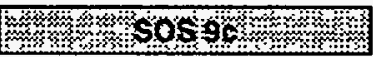

Operate as in SOS 1a
Sospan

- Operate to achieve flood control elevations by April 15 in $85 \%$ of years

- Draft to meet flow targels, down to minimum end-of-Aug. elevation of 1,280 feet

- Provide flow augmentation releases to meet Columbia River flow targets at McNary of 220-260 kcfs April 20-June 30 , based on runoff forecast, and 200 kefs July-Aug.
$1 \mathrm{ft}=0.3048$ meter 
Table 4-1. sos Alternative-4

\section{Actions by Project}

\begin{tabular}{|c|c|c|}
\hline \multirow{3}{*}{$\begin{array}{l}\text { SNAKE } \\
\text { RIVER } \\
\text { ABOVE } \\
\text { BROWNLEE }\end{array}$} & sos 1 & sos 2 \\
\hline & W & 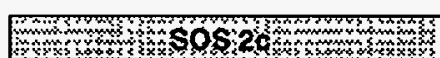 \\
\hline & $\begin{array}{l}\text { Normal 1990_91 operations; no } \\
\text { Water Budget flows }\end{array}$ & $\begin{array}{l}\text { Release up to } 427 \text { KAF (190 KAF } \\
\text { April 16-June } 15 ; 137 \text { KAF Aug.; } \\
100 \text { KAF Sept.) for flow augmenta- } \\
\text { tion }\end{array}$ \\
\hline & 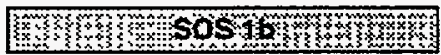 & 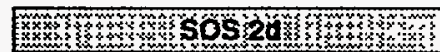 \\
\hline & Same as SOS 1a & $\begin{array}{l}\text { - Release up to } 427 \mathrm{KAF} \text {, as in SOS } \\
2 \mathrm{c}\end{array}$ \\
\hline & & $\begin{array}{l}\text { - Release additional water obtained } \\
\text { by purchase or other means and } \\
\text { shaped per Reclamation releases } \\
\text { and Brownlee draft requirements; } \\
\text { simulation assumed } 927 \text { KAF avail- } \\
\text { able }\end{array}$ \\
\hline
\end{tabular}

\begin{tabular}{|c|c|c|c|}
\hline \multirow{12}{*}{ BROWNLEE } & $\operatorname{sos} 1$ & sos 2 & $\operatorname{sos} 4$ \\
\hline & W & 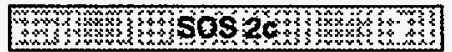 & 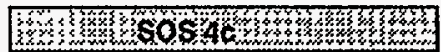 \\
\hline & \multirow{5}{*}{$\begin{array}{l}\text { Draft as needed (up to } 110 \text { KAF in } \\
\text { May) for Water Budget, based on } \\
\text { target flows of } 85 \mathrm{kcfs} \text { at Lower } \\
\text { Granite } \\
\text { - Operate per FERC license } \\
\text { - Provide system flood control stor- } \\
\text { age space }\end{array}$} & $\begin{array}{l}\text { Same as SOS 1a except for addi- } \\
\text { tional flow augmentation as follows: }\end{array}$ & \multirow[t]{10}{*}{$\begin{array}{l}\text { Same as SOS 1a except } \\
\text { slightly different flood control } \\
\text { rule curves }\end{array}$} \\
\hline & & $\begin{array}{l}\text { - Draft up to } 137 \mathrm{KAF} \text { in July, but not } \\
\text { drafting below } 2,067 \text { feet; refill from }\end{array}$ & \\
\hline & & the Snake River above Brownle日 in & \\
\hline & & August & \\
\hline & & - Draft up to $100 \mathrm{KAF}$ in Sept. & \\
\hline & 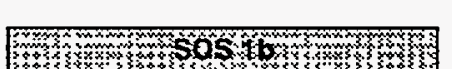 & $\begin{array}{l}\text { - Shift system flood control to Grand } \\
\text { Coulee }\end{array}$ & \\
\hline & $\begin{array}{l}\text { - No maximum flow restriction from } \\
\text { mid-Oct to mid-Nov. }\end{array}$ & $\begin{array}{l}\text { - Provide } 9 \text { kcfs or less in November; } \\
\text { fill project by end of month }\end{array}$ & \\
\hline & - No draft limit; no refill target & $\begin{array}{l}\text { - Maintain November monthly aver- } \\
\text { age flow December through April }\end{array}$ & \\
\hline & & 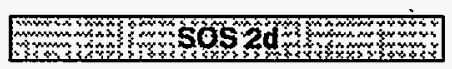 & \\
\hline & & $\begin{array}{l}\text { Same as SOS } 2 c \text {, plus pass addi- } \\
\text { tlonal flow augmentation releases } \\
\text { from upstream projects }\end{array}$ & \\
\hline
\end{tabular}


Table 4-1. Sos Alternative-4

\begin{tabular}{|c|c|c|c|}
\hline SOS 5 & $\operatorname{sos} 6$ & Sos 9 & SOS PA \\
\hline 世 & KX) & 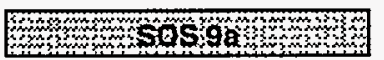 & 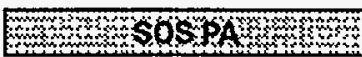 \\
\hline 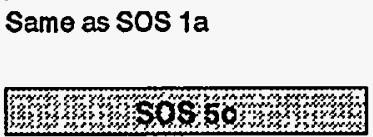 & 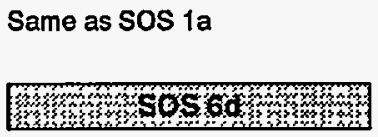 & $\begin{array}{l}\text { Provide up to } 1.927 \text { MAF } \\
\text { through Brownlee for flow aug- } \\
\text { mentation, as determined by } \\
\text { Reclamation }\end{array}$ & $\begin{array}{l}\text { Provide } 427 \text { KAF through } \\
\text { Brownlee for flow augmenta- } \\
\text { tion, as determined by } \\
\text { Reciamalion }\end{array}$ \\
\hline \multirow[t]{4}{*}{ Same as SOS 1a } & Same as SOS 1a & oxpososobon & \\
\hline & & $\begin{array}{l}\text { Provide up to } 927 \text { KAF through } \\
\text { Brownle日 as determined by } \\
\text { Reclamation }\end{array}$ & \\
\hline & & Kow & \\
\hline & & $\begin{array}{l}\text { Provide up to } 927 \mathrm{KAF} \text { through } \\
\text { Brownlee as determined by } \\
\text { Reclamation }\end{array}$ & \\
\hline
\end{tabular}

SOS 5

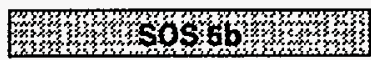

Same as SOS $4 c$

\%

Same as SOS $4 c$
SOS 6

Hxw

Same as SOS 4c

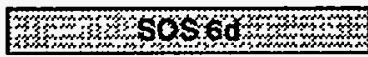

Same as SOS $4 c$

sos 9

SOS PA

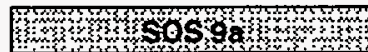

- Draft up to 110 KAF in May, $137 \mathrm{KAF}$ in July, 140 KAF in Aug., $100 \mathrm{KAF}$ in Sept. for flow augmentation

- Shift system flood control to Grand Coulee

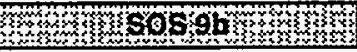

- Draft up to 190 KAF AprilMay. 137 KAF in July, 100

KAF in Sept. for flow augmentation

- Shift system flood control to Grand Coulee

- Provide an additional 110

KAF in May if elevation is above 2,068 feet and $110 \mathrm{KAF}$ in Sept. If elevation is above 2,043.3 feet

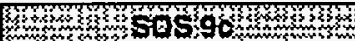

Same as SOS 9b
W whing

Draft to elovalion 2,069 foot in May, 2,067 foet in July, and 2,059 feet in Sept., passing Inflow after May and July drafts 


\section{Table 4-1. SOS Alternative-5}

\section{Actions by Project}

Sos 1

DWORSHAK

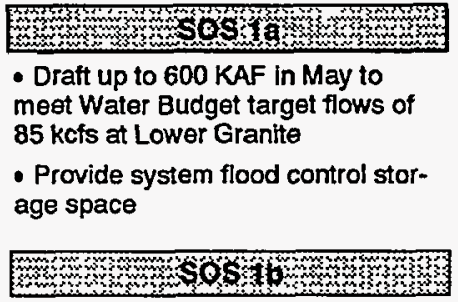

- Meet minimum project flows

(2 kofs, except for 1 kcfs in August); summer draft limits; maximum discharge requirement Oct. to Nov.

(1.3 kcts plus inflow)

- No Water Budget releases

\section{SOS 2}

\section{$\operatorname{SOS} 4$}

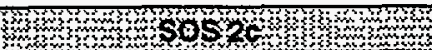

Same as SOS 1a, plus the following supplemental releases:

- 900 KAF or more from April 16 to June 15, depending on runoff fore. cast at Lower Granite

- Up to $470 \mathrm{KAF}$ above $1.2 \mathrm{kcfs}$ minimum release from June 16 to Aug. 31

- Maintain $1.2 \mathrm{kcfs}$ discharge from Oct. through April, unless higher required

- Shift system flood control to Grand Coulee April-July if runoff forecasts at Dworshak are 3.0 MAF or less

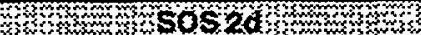

- Operate on 1.2 kcfs minimum dlscharge up to flood control rule curve, except when providing flow augmentation (April 10 to July 31)

- Provide flow augmentation of 1.0 MAF plus $1.2 \mathrm{kcts}$ minimum discharge, or $927 \mathrm{KAF}$ and $1.2 \mathrm{kcfs}$, from April 10-June 20, based on runoff forecasts, to meet Lower Granite flow target of $85 \mathrm{kcfs}$

- Provide $470 \mathrm{KAF}$ from June 21 to July 31 to meet Lower Granite flow larget of 50 kcfs

- Draft to 1,520 feet after volume is expended, if Lower Granite flow target is not met; if volume is not expended, draft below 1,520 feet until volume is expended

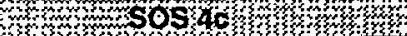

Elevation targets established for each month: 1,599 feet Sept.-Oct.; flood control rule curves

Nov.-April; 1,595 foet May; 1,599

feet June-Aug. 
Table 4-1. SOS Alternative-5

\section{sos 5}

药

- Operate to local flood control rule curve

- No proportional draft for power

- Shift system flood control to lower Snake projects

- Provide Water Budget flow augmentatlon as in SOS 1a

- Draft to refill lower Snake projects if natural inflow is inadequate

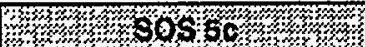

- Operate to flood control during spring

- Refill in June or July and maintaln through August

- Draft for power production during fall

\section{$\operatorname{sos} 6$}

$\operatorname{sos} 9$

SOS PA

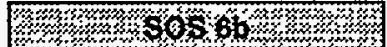

Same as SOS 5b

xhy

Same as'sos $5 b$

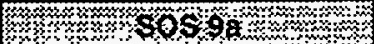

- Remove from proportional draft for power

- Operate to local flood contro rule curves, with system flood control shifted to Grand

Couleo

- Maintain flow at $1.2 \mathrm{kcfs}$ minimum discharge, except for flood control or flow augmentation discharges

- Operate to meet Lower

Granite flow targets (at spillway crest) of $74 \mathrm{kcts}$ April 16-June 30, 45 kcts July, 32 kcts August

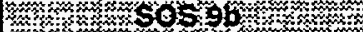

- Similar to SOS 9a, except operate to meet flow targets at Lower Granite ranging from 85 to $140 \mathrm{kcfs}$ April 16-June 30 and 50-55 kcts in July

- Can draft to meet flow targets to a min. end-of-July elevation of 1.490 feet

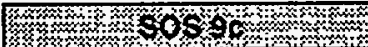

- Similar to SOS 9a, except operate to meet Lower Granite flow target (at spillway crest) of 63 kcfs April-June

- Can draft to meet flow targets to a min. end-of-July elevation of 1,520 feet 
Table 4-1. SOS Alternative-6

Actions by Project

\section{Sos 1}

$\operatorname{sos} 2$

$\operatorname{SOS} 4$

LOWER

SNAKE

XY

- Normal operations at 4 lower Snake River projects (within 3 to 5 teet of full pool, daily and weekly fluctuations)

- Provide maximum peaking capacity of 20 kcfs over daily average flow in May

\section{6xim}

Same as 1a, except:

- No minimum flow limit (11,500 cfs)

during fall and winter

- No fish-related rate of change in flows In May

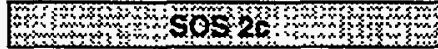

- Operate reservoirs within 1 foot above MOP from April 16 to July 31

- Same as SOS 1a for rest of year

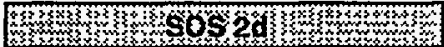

Same as SOS 2c

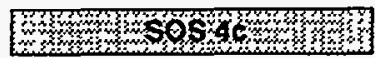

Same as SOS 2c

sos 1

$\operatorname{sos} 2$

$\operatorname{sos} 4$

\section{LOWER}

COLUMBIA Whym

- Normal operations at 4 lower Columbia prolects (generally within 3 to 5 feet of full pool, daily and weekly fluctuations)

- Restricted operation of Bonneville second powerhouse

KKny

Same as 1a, except no restrictions on Bonneville second powerhouse

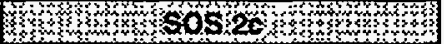

Same as SOS 1a except: lower John Day to minimum irrigation pool

(approx. 262.5 feet) from April 15 to Aug. 31; operate within 1.5 feel of forebay range, unless need to raise to avoid irrigation impacts

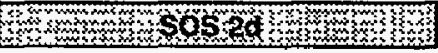

Same as SOS 2c

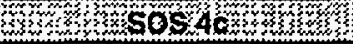

Same as SOS 2c, except operate John Day within 2 feet of elevation 263.5 feet Nov. 1 through June 30 
Table 4-1. SOS Alternative-6

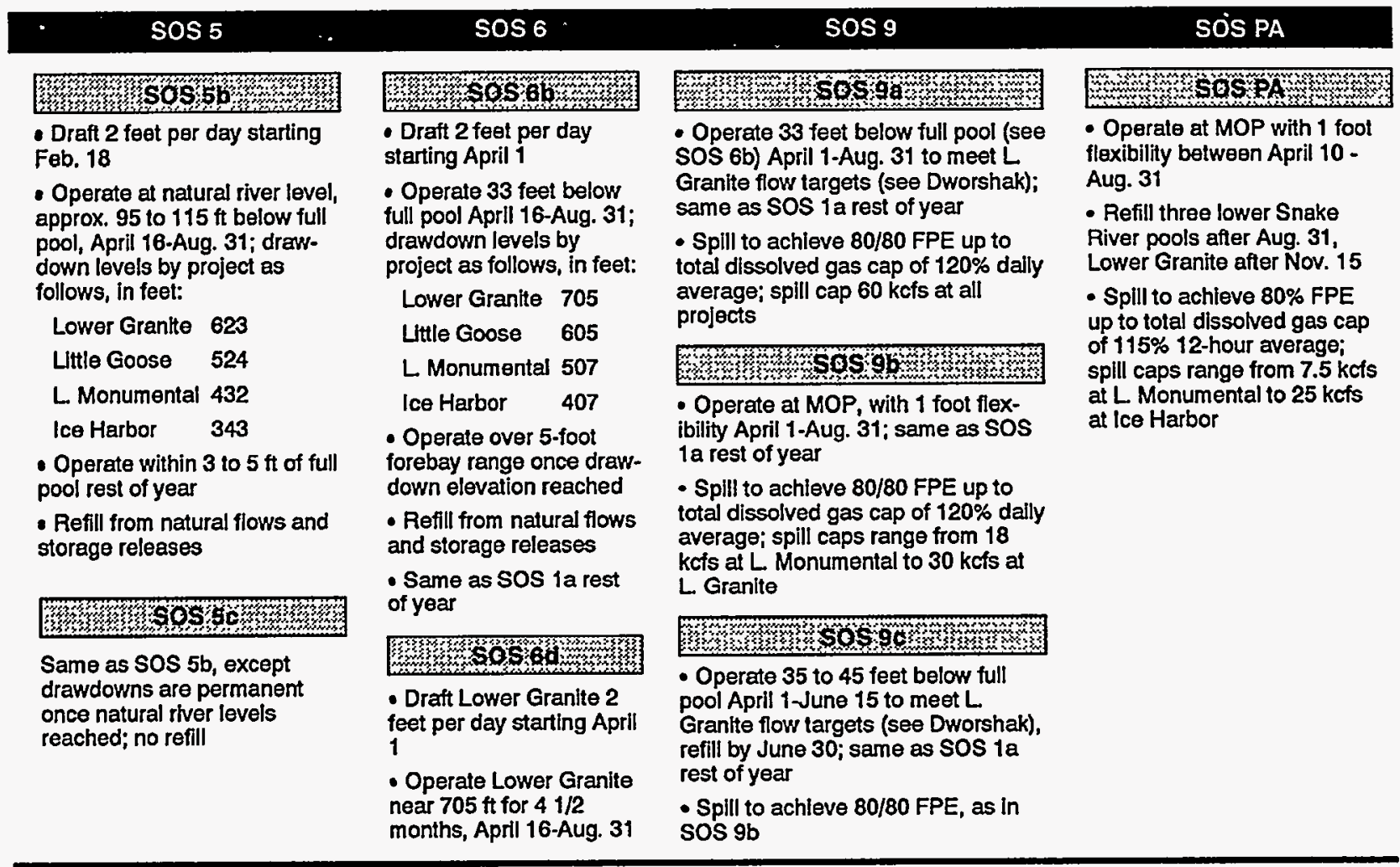

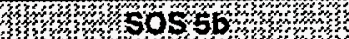

Same as SOS 2, except operate John Day within 1.5 foet above elevation 257 feet (MOP) from May 1 through Aug. 31; $\operatorname{sam} \theta$ as SOS 2 c rest of year

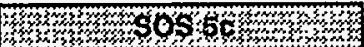

Same as SOS 5b

\section{Whosob}

Same as SOS 5

Wosos

Same as SOS 5

\section{Wx SoS9ax}

- Same as SOS 5, except operate John Day within 1 foot above elevation 257 feet April 15-Aug. 31

- McNary flow targets as described for Grand Coulee

- Spill to achieve 80/80 FPE, up to total dissolved gas cap of $120 \%$ dally average, as derived by agencies

Wxom

- Same as SOS 2, except operate John Day at minimum Irrigation poo or 262.5 feet with 1 foot of flexibility from April 16-Aug. 31

- McNary flow targets as described for Grand Coulee

- Spill to achieve 80/80 FPE, up to total dissolved gas cap of $120 \%$ daily average, as derived by Corps

Xon

Same as SOS 9b, except operate John Day at minimum operating pool

if $=0.3048$ meter

\section{Wx WOSPA}

- Pool operations same as SOS 2c, except operate John Day at 257 feet (MOP) yearround, with 3 feet of flexiblity March-Oct. and 5 feot of flexibility Nov.-Feb.

- Spill to achieve $80 \%$ FPE up to total dissolved gas cap of $115 \% 12$-hour average; spill caps range from $9 \mathrm{kcfs}$ at John Day to $90 \mathrm{kcfs}$ at The Dalles 


\subsubsection{SOS 1-Pre-ESA Operation}

This alternative represents one end of the range of the SOR strategies in terms of their similarity to historical system operations. This strategy reflects Columbia River system operations before changes were made as a result of the ESA listing of three Snake River salmon stocks. This SOS has two options:

- SOS 1a (Pre-Salmon Summit Operation) represents operations as they existed from 1983 through the 1990-91 operating year, including Northwest Power Act provisions to restore and protect fish populations in the basin. Specific volumes for the Water Budget would be provided from Dworshak and Brownlee reservoirs to attempt to meet a target flow of $85 \mathrm{kcfs}(2,380 \mathrm{cms})$ at Lower Granite Dam in May. Sufficient flows would be provided on the Columbia River to meet a target flow of $134 \mathrm{kcfs}(3,752 \mathrm{cms})$ at Priest Rapids Dam in May. Lower Snake River projects would operate within 3 to 5 feet $(0.9$ to $1.5 \mathrm{~m}$ ) of full pool. Other projects would operate as they did in 1990-91, with no additional water provided from the Snake River above Brownlee Dam.

- SOS 1b (Optimum Load-Following Operation) represents operations as they existed prior to changes resulting from the Northwest Power Act. It is designed to demonstrate how much power could be produced if most flow-related operations to benefit anadromous fish were eliminated including: the Water Budget; fish spill requirements; restrictions on operation of Bonneville's second powerhouse; and refill targets for Libby, Hungry Horse, Grand Coulee, Dworshak, and Albeni Falls. It assumes that transportation would be used to the maximum to aid juvenile fish migration.

\subsubsection{Sos 2-Current Operations}

This alternative reflects operation of the Columbia River system with interim flow improvement measures made in response to ESA listings of Snake
River salmon. It is very similar to the way the system operated in 1992 and reflects the results of ESA Section 7 consultation with NMFS then. The strategy is consistent with the 1992-93 operations described in the Corps' 1993 Interim Columbia and Snake Rivers Flow Improvement Measures Supplemental EIS (SEIS). SOS 2 also most closely represents the recommendations issued by the NMFS Snake River Salmon Recovery Team in May 1994. Compared to SOS 1 , the primary changes are additional flow augmentation in the Columbia and Snake Rivers and modified pool levels at lower Snake and John Day reservoirs during juvenile salmon migration. This strategy has two options:

- SOS 2c (Final SEIS Operation- No Action Alternative) matches exactly the decision made as a resuit of the 1993 SEIS. Flow augmentation water of up to $3.0 \mathrm{MAF}$ $\left(3.7\right.$ billion $\mathrm{m}^{3}$ ) on the Columbia River (in addition to the existing Water Budget) would be stored during the winter and released in the spring in low-runoff years. Dworshak would provide at least an additional $300 \mathrm{KAF}$ ( 370 million $\mathrm{m}^{3}$ ) in the spring and $470 \mathrm{KAF}$ $\left(580\right.$ million $\mathrm{m}^{3}$ ) in the summer for flow augmentation. System flood control shifts from Dworshak and Brownlee to Grand Coulee would occur through April as needed. It also provides up to $427 \mathrm{KAF}$ (527 million $\mathrm{m}^{3}$ ) of additional water from the Snake River above Brownlee Dam.

- SOS 2d (1994-98 Biological Opinion) matches the hydro operations contained in the 1994-98 Biological Opinion issued by NMFS in mid-1994. This alternative provides water for the existing Water Budget as well as additional water, up to $4 \mathrm{MAF}$, for flow augmentation to benefit the anadromous fish migration. The additional water of up to 4 MAF would be stored in Grand Coulee, Libby and Arrow, and provided on a sliding scale tied to runoff forecasts. Flow targets are established at Lower Granite and McNary.

In cases such as the SOR, where the proposed action is a new management plan, the No Action Alterna- 
tive means continuing with the present course of action until that action is changed (46 FR 13027). Among all of the strategies and options, SOS $2 \mathrm{c}$ best meets this definition for the No Action Alternative.

\subsubsection{SOS 4-Stable Storage Project Operation}

This alternative is intended to operate the storage reservoirs to benefit recreation, resident fish, wildlife, and anadromous fish while minimizing impacts of such operation to power and flood control. Reservoirs would be kept full longer, but still provide spring flows for fish and space for flood control. The goal is to minimize reservoir fluctuations while moving closer to natural flow conditions. For the Final EIS, this alternative has one option:

- SOS 4c (Stable Storage Operation with Modified Grand Coulee Flood Control) applies year-round Integrated Rule Curves (IRCs) developed by the State of Montana for Libby and Hungry Horse. Other reservoirs would be managed to specific elevations on a monthly basis; they would be kept full longer, while still providing spring flows for fish and space for flood control. The goal is to minimize reservoir fluctuations while moving closer to natural flow conditions. Grand Coulee would meet elevation targets year-round to provide acceptable water retention times; however, upper rule curves would apply at Grand Coulee if the January to July runoff forecast at the project is greater than $68 \mathrm{MAF}$ ( 84 billion $\mathrm{m}^{3}$ ).

\subsubsection{Sos 5-Natural River Operation}

This alternative is designed to aid juvenile salmon migration by drawing down reservoirs (to increase the velocity of water) at four lower Snake River projects. SOS 5 reflects operations after the installation of new outlets in the lower Snake River dams, permitting the lowering of reservoirs approximately 100 feet $(30 \mathrm{~m})$ to near original riverbed levels. This operation could not be implemented for a number of years, because it requires major structural modifications to the dams. Elevations would be: Lower Granite -623 feet $(190 \mathrm{~m})$; Little Goose -524 feet
$(160 \mathrm{~m})$; Lower Monumental - 432 feet $(132 \mathrm{~m})$; and Ice Harbor -343 feet $(105 \mathrm{~m})$. Drafting would be at the rate of 2 feet $(0.6 \mathrm{~m})$ per day beginning February 18 . The reservoirs would refill again with natural inflows and storage releases from upriver projects, if needed. John Day would be lowered as much as 11 feet $(3.3 \mathrm{~m})$ to minimum pool, elevation 257 feet $(78.3 \mathrm{~m})$, from May through August. All other projects would operate essentially the same as in SOS 1a, except that up to 3 MAF ( 3.7 billion $\mathrm{m}^{3}$ ) of water (in addition to the Water Budget) would be provided to augment flows on the Columbia River in May and June. System flood control would shift from Brownlee and Dworshak to the lower Snake River projects. Also, Dworshak would operate for local flood control. This alternative has two options:

- SOS 5b (Four and One-half Month Natural River Operation) provides for a lower Snake River drawdown lasting 4.5 months, beginning April 16 and ending August 31. Dworshak would be drafted to refill the lower Snake River projects if natural inflow were inadequate for timely refill.

- SOS 5c (Permanent Natural River Operation) provides for a year-round drawdown, and projects would not be refilled after each migration season.

\subsubsection{Sos 6-Fixed Drawdown}

This alternative is designed to aid juvenile anadromous fish by drawing down one or all four lower Snake River projects to fixed elevations approximately 30 to 35 feet $(9$ to $10 \mathrm{~m}$ ) below minimum operating pool. As with SOS 5, fixed drawdowns depend on prior structural modifications and could not be instituted for a number of years. Draft would be at the rate of 2 feet $(0.6 \mathrm{~m})$ per day beginning April 1. John Day would be lowered to elevation 257 feet $(78.3 \mathrm{~m})$ from May through August. All other projects would operate essentially the same as under SOS 1a, except that up to 3 MAF (3.7 billion $\mathrm{m}^{3}$ ) of water would be provided to augment flows on the Columbia River in May and June. System flood control would shift from Brownlee and Dworshak to the lower Snake projects. Also, Dwor- 
shak would operate for local flood control. This alternative has two options:

- SOS $6 \mathrm{~b}$ (Four and One-half Month Fixed Drawdown) provides for a 4.5-month drawdown at all four lower Snake River projects beginning April 16 and ending August 31. Elevations would be: Lower Granite 705 feet $(215 \mathrm{~m})$; Little Goose - 605 feet $(184 \mathrm{~m})$; Lower Monumental - 507 feet (155 m); and Ice Harbor - 407 feet $(124 \mathrm{~m})$.

- SOS 6d (Four and One-half Month Lower Granite Fixed Drawdown) provides for a 4.5-month drawdown to elevation 705 feet at Lower Granite beginning April 16 and ending August 31.

\subsubsection{Sos 9-Settlement Discussion Alternatives}

This SOS represents operations suggested by USFWS and NMFS (as SOR cooperating agencies), the State fisheries agencies, Native American tribes, and the Federal operating agencies during the settlement discussions in response to a court ruling in the IDFG v. NMFS lawsuit. The objective of SOS 9 is to provide increased velocities for anadromous fish by establishing flow targets during the migration period and by carrying out other actions that benefit ESA-listed species. The specific options were developed by a group of technical staff representing the parties in the lawsuit. The group was known as the Reasonable and Prudent Alternatives Workgroup. They developed three possible operations in addition to the 1994-98 Biological Opinion. This strategy has three options:

- SOS 9a (Detailed Fishery Operating Plan [DFOP]) establishes flow targets at The Dalles based on the previous year's end-ofyear storage content, similar to how PNCA selects operating rule curves. Grand Coulee and other storage projects are used to meet The Dalles flow targets. Specific volumes of releases are made from Dworshak, Brownlee, and upper Snake River to try to meet Lower Granite flow targets. Lower Snake River projects are drawn down to near spillway crest level for $41 / 2$ months. Specific spill percentages are established at run-of-river projects to achieve no higher than 120 percent daily average total dissolved gas. Fish transportation is assumed to be eliminated.

- SOS 9b (Adaptive Management) establishes flow targets at McNary and Lower Granite based on runoff forecasts. Grand Coulee and other storage projects are used to meet the McNary flow targets. Specific volumes of releases are made from Dworshak, Brownlee, and the upper Snake River to try to meet Lower Granite flow targets. Lower Snake River projects are drawn down to minimum operating pool levels and John Day is at minimum irrigation pool level. Specific spill percentages are established at run-of-river projects to achieve no higher than 120 percent daily average for total dissolved gas.

- SOS 9c (Balanced Impacts Operation) draws down the four lower Snake River projects to near spillway crest levels for $21 / 2$ months during the spring salmon migration period. Full drawdown level is achieved on April 1. Refill begins after June 15. This alternative also provides 1994-98 Biological Opinion flow augmentation (as in SOS 2d), IRC operation at Libby and Hungry Horse, a reduced flow target at Lower Granite due to drawdown, limits on winter drafting at Albeni Falls, and spill to achieve no higher than 120 percent daily average for total dissolved gas.

\subsubsection{SOS PA-Preferred Alternative}

This SOS represents the operation recommended by NMFS and USFWS in their respective Biological Opinions issued on March 1, 1995. SOS PA is intended to support recovery of ESA-listed species by storing water during the fall and winter to meet spring and summer flow targets, and to protect other resources by managing detrimental effects through maximum summer draft limits, by providing public safety through flood protection, and by providing for reasonable power generation. This SOS would operate the system during the fall and winter to achieve a high confidence of 
refill to flood control elevations by April 15 of each year, and use this stored water for fish flow augmentation. It establishes spring flow targets at McNary and Lower Granite based on runoff forecasts, and a similar sliding scale flow target at Lower Granite and a fixed flow target at McNary for the summer. It establishes summer draft limits at Hungry Horse, Libby, Grand Coulee, and Dworshak. Libby is also operated to provide flows for Kootenai River white sturgeon. Lower Snake River projects are drawn down to minimum operating pool levels during the spring and summer. John Day is operated at minimum operating pool level year-round. Specific spill percentages are established at run-of-river projects to achieve 80-percent FPE, with no higher than 115-percent 12 -hour daily average for total dissolved gas measured at the forebay of the next downstream project.

\subsubsection{Rationale for Selection of the Final SoSs}

Table 4-2 summarizes the changes to the set alternatives from the Draft EIS to the Final EIS. SOS $1 \mathrm{a}$ and $1 \mathrm{~b}$ are unchanged from the Draft EIS. SOS 1a represents a base case condition and reflects system operation during the period from passage of the Northwest Power Planning and Conservation Act until ESA listings. It provides a baseline alternative that allows for comparison of the more recent alternatives and shows the recent historical operation. SOS $1 \mathrm{~b}$ represents a limit for system operation directed at maximizing benefits from development-oriented uses, such as power generation, flood control, irrigation and navigation and away from natural resources protection. It serves as one end of the range of alternatives and provides a basis for comparison of the impacts to power generation from all other alternatives. Public comment did not recommend elimination of this alternative because it serves as a useful milepost. However, the SOR agencies recognize it is unlikely that decisions would be made to move operations toward this alternative.

In the Draft EIS, SOS 2 represented current operation. Three options were considered. Two of these options have been eliminated for the Final EIS and one new option has been added. SOS $2 c$ continues as the No Action Alternative. Maintaining this option as the No Action Alternative allows for consistent comparisons in the Final EIS to those made in the Draft EIS. However, within the current practice category, new operations have been developed since the original identification of SOS 2c. In 1994, the SOR agencies, in consultation with the NMFS and USFWS, agreed to an operation, which was reflected in the 1994-98 Biological Opinion. This operation (SOS 2d) has been modeled for the Final EIS and represents the most "current" practice. SOS $2 \mathrm{~d}$ also provides a good baseline comparison for the other, more unique alternatives. SOS $2 a$ and $2 b$ from the Draft EIS were eliminated because they are so similar to SOS $2 c$. SOS $2 a$ is identical to SOS $2 c$ except for the lack of an assumed additional $427 \mathrm{KAF}$ of water from the upper Snake River Basin. This additional water did not cause significant changes to the effects between SOS $2 a$ and $2 c$. There is no reason to continue to consider an alternative that has impacts essentially equal to another alternative. SOS $2 b$ is also similar to SOS $2 c$, except it modified operation at Libby for Kootenai River white sturgeon. Such modifications are included in several other alternatives, namely SOS 2d, 9a, 9c, and the Preferred Alternative.

SOS $3 a$ and $3 b$, included in the Draft EIS, have been dropped from consideration in the Final EIS. Both of these alternatives involved anadromous fish flow augmentation by establishing flow targets based on runoff forecast on the Columbia and Snake Rivers. SOS $3 b$ included additional water from the upper Snake River Basin over what was assumed for SOS 3a. This operation is now incorporated in several new alternatives, including SOS $9 a$ and $9 b$. Public comment also did not support continued consideration of the SOS 3 alternatives.

SOS 4 originally included 5 options in the Draft EIS. They were similar in operation and impact. In SOS $4 \mathrm{a}$ and $4 \mathrm{~b}$, the primary feature was the use of Biological Rule Curves for Libby and Hungry Horse 
Table 4-2. Summary of Alternatives in the Draft and Final EIS

Draft EIS Alternatives

SOS 1 Pre-ESA Operation

SOS 1a Pre-Salmon Summit Operation

SOS $1 \mathrm{~b}$ Optimum Load Following Operation

SOS 2 Current Practice

SOS 2a Final Supplemental EIS Operation

SOS $2 b$ Final Supplemental EIS with Sturgeon Operations at Libby

SOS2c Final Supplemental EIS Operation No-Action Alternative

SOS 3 Flow Augmentation

SOS 3a Monthly Flow Targets

SOS 3b Monthly Flow Targets with additional Snake River Water

SOS 4 Stable Storage Project Operation SOS 4a1 Enhanced Storage Level Operation SOS 4a 3 Enhanced Storage Level Operation SOS $4 \mathrm{~b} 1$ Compromise Storage Level Operation SOS 4b3 Compromise Storage Level Operation

SOS 4c Enhanced Operation with modified Grand Coulee Flood Control

SOS 5 Natural River Operation

SOS 5a Two Month Natural River Operation

SOS $5 b$ Four and One Half Month Natural River Operation

SOS 6 Fixed Drawdown

SOS 6a Two Month Fixed Drawdown Operation

SOS $6 \mathrm{~b}$ Four and One Half Month Fixed Drawdown Operation

SOS 6c Two Month Lower Granite Drawdown Operation

Sos 6d Four and One Half Month Lower Granite Drawdown Operation

SOS 7 Federal Resource Agency Operations

SOS 7a Coordination Act Report Operation

SOS $7 \mathrm{~b}$ Incidental Take Statement Flow Targets

SOS 7c NMFS Conservation Recommendations
Final EIS Alternatives

SOS 1 Pre-ESA Operation

SOS 1a Pre-Salmon Summit Operation

SOS $1 \mathrm{~b}$ Optimum Load Following Operation

SOS 2 Current Practice

SOS2c Final Supplemental EIS Operation No-Action Alternative

SOS 2d 1994-98 Biological Opinion Operation

SOS 4 Stable Storage Project Operation

SOS 4c Enhanced Operation with modified Grand Coulee Flood Control

SOS 5 Natural River Operation

SOS 5b Four and One Half Month Natural River Operation

SOS 5c Permanent Natural River Operation

SOS 6 Fixed Drawdown

SOS $6 \mathrm{~b}$ Four and One Half Month Fixed Drawdown Operation

SOS 6d Four and One Half Month Lower Granite Drawdown Operation

SOS 9 Settlement Discussion Alternatives

SOS 9a Detailed Fishery Operating Plan

SOS 9b Adaptive Management

SOS 9c Balance Impacts Operation

SOS Preferred Alternative

Bold indicates a new or revised SOS alternative 
reservoirs. SOS $4 \mathrm{c}$ also included these rule curves but went further by optimizing the operation of the other storage projects, particularly Grand Coulee and Dworshak. For the Final EIS, the SOR agencies have decided to update the alternative by substituting the IRC for the Biological Rule Curves and by eliminating SOS $4 \mathrm{a}$ and $4 \mathrm{~b}$. The IRCs are a more recent, acceptable version of minimum elevations for Libby and Hungry Horse. Significant public comment in support of this alternative with IRCs was received. Similar to SOS 2 above, SOS $4 a$ and $4 b$ were not different enough in operation or impacts to warrant continued consideration.

The Natural River (SOS 5) and the Spillway Crest Drawdown (SOS 6) alternatives in the Draft EIS originally included options for 2 months of drawdown to the appropriate pool level and $41 / 2$ months of drawdown. The practicality of $2-$ month drawdowns was questioned during public review, particularly for the natural river. It did not appear that the time involved in drawing down the reservoirs and later refilling them provided the needed consideration for other uses. Flows are restricted to refill the reservoirs at a time when juvenile fall chinook are migrating downstream and various adult species are returning upstream. The $21 / 2$ month drawdown strategies (SOS 5a, 6a, and 6c) have been dropped from the Final EIS. However, 2 1/2 month spillway crest drawdown at all four lower Snake projects is still an element in SOS 9c, so the impacts associated with this type of operation are assessed in the Final EIS.

A new option was added to SOS 5 , namely SOS $5 \mathrm{c}$. This option includes natural river drawdown of the lower Snake River projects on a permanent, yearround basis. The Corps received comment on this type of alternative during the review of Phase $I$ of the SCS, a reconnaissance assessment of potential physical modifications for the system to enhance fish passage. Many believe the cost for such modification would be less than that required for periodic, temporary drawdowns, which would require specialized facilities to enable the projects to refill and operate at two different pool elevations.

SOS 7 Federal Resource Agencies Operations, which included 3 options in the Draft EIS, has been dropped from the Final EIS and replaced with an alternative now labeled as SOS 9 that also has 3 options. SOS 7a was suggested by the USFWS and represented the State fishery agencies and tribes' recommended operation. Since the issuance of the Draft EIS, this particular operation has been revised and replaced by the DFOP (SOS 9a). The SOR agencies received comment that the DFOP was not evaluated, but should be. Therefore, we have included this alternative exactly as proposed by these agencies; it is SOS 9a. SOS $7 \mathrm{~b}$ and 7c were suggested by NMFS through the 1993 Biological Opinion. This opinion suggested two sets of flow targets as a way of increasing flow augmentation levels for anadromous fish. The flow targets came from the Incidental Take Statement and the Conservation Recommendation sections of that Biological Opinion. The opinion was judged as arbitrary and capricious as a result of legal action, and these operational alternatives have been replaced with other alternatives that were developed through settlement discussions among the parties to this lawsuit. SOS $7 \mathrm{~b}$ and $7 \mathrm{c}$ have been dropped, but SOS $9 \mathrm{~b}$ and $9 \mathrm{c}$ have been added to represent operations stemming from NMFS or other fishery agencies. In particular, SOS $9 \mathrm{~b}$ is like DFOP but has reduced flow levels and forgoes drawdowns. It is a modification to DFOP. SOS 9c incorporates elements of operation supported by the State of Idaho in its "Idaho Plan." It includes a 2 1/2-month spillway crest drawdown on the lower Snake River projects and several other elements that attempt to strike a balance among the needs of anadromous fish, resident fish, wildlife and recreation.

Shortly after the alternatives for the Draft EIS were identified, the Nez Perce Tribe suggested an operation that involved drawdown of Lower Granite, significant additional amounts of upper Snake River water, and full pool operation at Dworshak (i.e., Dworswak remains full year round). It was labeled as SOS 8a. Hydroregulation of that operation was completed and provided to the Nez Perce Tribe. No technical response has been received from the $\mathrm{Nez}$ Perce Tribe regarding the features or results of this alternative. However, the elements of this operation are generally incorporated in one or more of the other alternatives, or impose requirements on the 
system or specific projects that are outside the range considered reasonable. Therefore, this alternative has not been carried forward into the Final EIS.

The Preferred Alternative represents operating requirements contained in the 1995 Biological Opinions issued by NMFS and USFWS on operation of the FCRPS. These opinions resulted from ESA consultation conducted during late 1994 and early 1995, which were a direct consequence of the lawsuit and subsequent judgement in Idaho v. NMFS. The SOR agencies are now implementing this operating strategy and have concluded that it represents an appropriate balance among the multiple uses of the river. This strategy recognizes the importance of anadromous fish and the need to adjust river flows to benefit the migration of all salmon stocks, as well as the needs of resident fish and wildlife species at storage projects.

\subsection{IMPLEMENTATION COSTS}

\subsubsection{Nature of Implementation Costs}

Several of the SOSs require considerable construction to be implemented while other alternatives are primarily changes in the operation of the existing system and will not require modification or construction of projects. This section describes the construction, mitigation, operation and maintenance, and interest costs that will be required to implement the SOSs.

Implementation costs consist of all of the costs which would be incurred to modify the Federal projects to operate in the manner prescribed by the SOS and the cost of mitigating impacts to other public and private facilities and to cultural and resident fish and wildlife resources. In addition, implementation costs include the costs of planning and engineering, construction management, and interest during construction (IDC). IDC represents the opportunity cost of the money used for construction, for the period of time that the project is under construction. IDC is a project cost because if construction funds were not committed to construction of the project modifications, etc., they could be used for other purposes to enhance the national income. Since detailed construction expenditure schedules were not available, IDC was computed by dividing the total first cost (construction plus planning, engineering and construction management) by the number of years of construction and summing the compound interest that would accrue to each year's expenditures until the end of the construction period.

Implementation costs presented are those developed by the Corps of Engineers for the System Configuration Study. The level of detail of costs presented in the SOR, however, is limited to a summary of the costs. The detailed cost estimates, except those for SOS 5c--year-around natural river drawdown-and costs for irrigation and water supply systems are presented in, and were taken from, the reports listed below. Costs for modification of irrigation and other water supply facilities were taken from the SOR FEIS, Appendix F (Irrigation and Municipal and Industrial Water Supply).

- Columbia River Salmon Mitigation Analysis System Configuration Study Phase I, Lower Snake Reservoir Drawdown Technical Report Appendix A, April 1994, US Army Corps of Engineers, Walla Walla District.

- Columbia River Salmon Mitigation Analysis System Configuration Study Phase I, Appendix B, John Day Reservoir Minimum Operating Pool Technical Report, April 1994, US Army Corps of Engineers, Portland District

\subsubsection{Potential Cost Savings to the Existing System Operation}

Implementation of any of the SOSs, other than continuation of the assumed without project condition or base case operation (SOS 2c), would result in changes in costs associated with the existing operation of the system, especially the fish program. Implementation of SOSs which include drawdown of the lower Snake River reservoirs would result in the most significant changes to the existing fish program. Generally, these changes would be reductions in the cost of the fish program, as compared with the existing program. For example, it has been suggested that drawdown of the lower Snake River reservoirs to the level of the natural river would obviate the 
need for the entire current fish program, resulting in a potential annual savings of about $\$ 336$ million. Potential changes to the cost of the existing fish program were not evaluated for the SOR and are not reflected in the implementation costs presented below. Thus, the costs presented below may overstate actual costs, but to an unknown degree.

\subsubsection{Construction Requirements and Implementation Timing}

The SOSs with implementation costs, as described above, are SOSs $5 \mathrm{~b}, 5 \mathrm{c}, 6 \mathrm{~b}, 6 \mathrm{~d}, 9 \mathrm{a}, 9 \mathrm{c}$, and the preferred alternative. A brief description of the construction required to implement these SOSs is shown in Table 4-3. Also shown is the date (year) in which each of the SOSs could be implemented. Implementation dates are somewhat arbitrary in that they are based on a presumption that 1995 is the base-year for implementing SOSs which do not require modification of existing projects or other construction. If this base year slips, then all of the implementation dates would also slip. Despite the uncertainty about the base-year, the implementation dates shown represent the relative amount of time required to complete necessary construction work.

\subsubsection{Construction and Annual Costs by SOS}

Implementation costs are summarized in Tables 4-4 and 4-5 for the lower Snake River projects and the John Day project, respectively. Construction costs are based on 1992 price levels and do not include inflation during construction, except for SOS 5c where costs are at the January 1995 price level. The costs for SOS $5 \mathrm{c}$ were not adjusted to the 1992 price level because the change in the price level is relatively small and the difference in price levels would not affect the relative costs of this SOS compared with the others. Investment costs include total first costs and IDC. Annual costs include the amortization of the investment costs over a 100-year period of time, at the alternative interest rates of 7.75 and 3.0 percent and the estimated increase in annual operation and maintenance costs. Annual costs do not include replacement costs which would be required for irrigation and water supply pump modifications which have expected economic lives of 20 and 30 years, respectively. Thus, estimated annual costs of capital expenditures are somewhat lower than they actually would be. However, since these facilities would require replacement in the base case, the costs are only understated by the amount of the difference between replacement costs in the base case and the costs associated with the alternatives. This difference is relatively insignificant. Annual costs are presented for two different points in time--at the POL (project-on-line) date for the SOS and at a common point in time (1995). The first, referred to as the average annual cost, is the annual costs as computed from the POL date. The second, referred to as the equivalent annual cost, is the annual cost as computed at a common point in time. Equivalent annual costs were computed by present valuing the average annual cost of each SOS back to 1995 .

\section{Table 4-3. Summary Description of Construction Requirements and Implementation (POL-project-on-line) Dates of System Operation Strategies}

\begin{tabular}{|c|c|c|}
\hline $\begin{array}{c}\text { SOS } \\
(\mathrm{SCS} 1 /)\end{array}$ & Description of SOS \& Construction Requirements 2/ & $\begin{array}{l}\text { POL } \\
\text { Date }\end{array}$ \\
\hline $\begin{array}{c}\text { SOS 5b } \\
\text { (Alt 4A) }\end{array}$ & $\begin{array}{l}\text { Natural river operation--Part-year river-level drawdown at Snake projects from April through } \\
\text { August \& John Day at MOP from May through August. New controlled by-pass channel and re- } \\
\text { lated features, including modifications to adult passage facilities, are required at the four lower } \\
\text { Snake River projects and some minor modifications of John Day dam are required. }\end{array}$ & 2010 \\
\hline SOS 5c & $\begin{array}{l}\text { Permanent natural river operation--Year-round river-level drawdown of Snake projects \& } \\
\text { John Day at MOP from May through August. New uncontrolled by-pass channel and related fea- } \\
\text { tures are required at the four lower Snake River projects and some minor modifications of John } \\
\text { Day dam are required. }\end{array}$ & 2000 \\
\hline
\end{tabular}


Table 4-3. Summary Description of Construction Requirements and Implementation (POL-project-on-line) Dates of System Operation Strategies - CONT

\begin{tabular}{|c|c|c|}
\hline $\begin{array}{c}\operatorname{sos} \\
(\operatorname{SCS} 1 /)\end{array}$ & Description of SOS \& Construction Requirements 2/ & $\begin{array}{l}\text { POL } \\
\text { Date }\end{array}$ \\
\hline $\begin{array}{c}\text { SOS 6b } \\
\text { (Alt 13) }\end{array}$ & $\begin{array}{l}\text { Fixed drawdown operation--Spillway-crest drawdown at Snake projects from April through Au- } \\
\text { gust \& John Day at MOP from May through August. Modification of stilling basins and adult and } \\
\text { juvenile fish passage facilities are required at the Snake River dams and minor modifications of } \\
\text { John Day dam are required. }\end{array}$ & 2005 \\
\hline $\begin{array}{c}\text { SOS 6d } \\
\text { (Alt 13A) }\end{array}$ & $\begin{array}{l}\text { Lower Granite drawdown operation--Spillway crest, fixed-pool drawdown from April through } \\
\text { August at Lower Granite \& John Day at MOP from April through August. Modification of the stil- } \\
\text { ling basin and adult and juvenile fish passage facilities at Lower Granite and minor modifications of } \\
\text { John Day dam are required. }\end{array}$ & 2000 \\
\hline $\begin{array}{l}\text { SOS 9a } \\
\text { (Alt 13) }\end{array}$ & $\begin{array}{l}\text { Detailed fishery operating plan - - Spillway crest drawdown during April through August at Snake } \\
\text { projects \& John Day at MOP for a comparable period. Modifications required are the same as } \\
\text { those required for SOS } 6 \mathrm{~b} \text {. }\end{array}$ & 2005 \\
\hline $\begin{array}{l}\text { SOS 9c } \\
\text { (Alt 13) }\end{array}$ & $\begin{array}{l}\text { Balanced impacts operation (Idaho Plan)--Spillway crest, variable-pool drawdown at Snake } \\
\text { projects from April through mid-June and John at MOP from April through August.Modifications } \\
\text { required are the same as those required for SOS } 6 \text { b. }\end{array}$ & 2005 \\
\hline PA & $\begin{array}{l}\text { Preferred alternative--Snake projects operated at MOP from April through August \& John Day } \\
\text { operated at MOPyear-around. Minor modifications of John Day dam are required. }\end{array}$ & 1998 \\
\hline \multicolumn{3}{|c|}{$\begin{array}{l}\text { 1/SCS (System Configuration Study) alternatives are shown in parentheses so that the SOSs can be crossed referenced to the } \\
\text { SCSdocuments. } \\
2 / \text { For discounting purposes, the period of analysis is } 100 \text { years, } 1995 \text { to } 2095 \text { and the discount rates are } 3 \text { percent (BPA rate) } \\
\text { and } 7-3 / 4 \text { percent (Federal rate). }\end{array}$} \\
\hline
\end{tabular}

Table 4-4. Summary of Implementation Costs for Lower Snake River Projects1992 Price Level $(\$ 1,000)$

\begin{tabular}{|c|c|c|c|c|c|c|}
\hline \multirow{2}{*}{$\begin{array}{c}\text { Construction Item/ } \\
\text { Contingency Rate (\%) }\end{array}$} & \multicolumn{6}{|c|}{ System Operation Strategies \& Cost w/Contingencies 1/ 2/ } \\
\hline & $\mathbf{5 b}$ & $\mathbf{5 c}$ & $\mathbf{6 b}$ & 6d & $9 \mathbf{a}$ & $9 c$ \\
\hline Real Estate (40) & 507.5 & 0.0 & 507.5 & 126.9 & 507.5 & 507.5 \\
\hline \multicolumn{7}{|l|}{ Construction Costs } \\
\hline Relocations $(40)$ & $5,596.6$ & 0.0 & 0.0 & 0.0 & 0.0 & 0.0 \\
\hline Stilling Basin Gates (50) & $327,641.4$ & 0.0 & $327,641.4$ & 0.0 & $327,641.4$ & $327,641.4$ \\
\hline $\begin{array}{l}\text { Removal of Dam Non-Overflow } \\
\text { Section (50) }\end{array}$ & 0.0 & $124,005.0$ & 0.0 & 0.0 & 0.0 & 0.0 \\
\hline New River Bypass (40) & $1,760,931.3$ & 0.0 & 0.0 & 0.0 & 0.0 & 0.0 \\
\hline River Bypass Channel (50) & 0.0 & $128,270.0$ & 0.0 & 0.0 & 0.0 & 0.0 \\
\hline Levee (50) & 0.0 & $20,496.0$ & 0.0 & 0.0 & 0.0 & 0.0 \\
\hline Powerhouse Modifications (50) & 0.0 & $122,028.0$ & 0.0 & 0.0 & 0.0 & 0.0 \\
\hline Misc Dam Modifications (40) & $3,035.3$ & 0.0 & $3,035.3$ & 758.8 & $3,035.3$ & $3,035.3$ \\
\hline Fish Facilities $(50)$ & 0.0 & 968.0 & 0.0 & 0.0 & 0.0 & 0.0 \\
\hline Adult Fish Passage (40) & $242,509.5$ & 0.0 & $252,241.4$ & $5,614.2$ & $252,241.4$ & $252,241.4$ \\
\hline Juvenile Fish Passage (40) & 0.0 & 0.0 & $61,368.0$ & $15,346.5$ & $61,368.0$ & $61,368.0$ \\
\hline Bank Stabilization (50) & 0.0 & $1,073.0$ & 0.0 & 0.0 & 0.0 & 0.0 \\
\hline Riprap Slope Protection (40) & $57,751.2$ & 0.0 & $45,077.6$ & $28,872.7$ & $45,077.6$ & $45,077.6$ \\
\hline
\end{tabular}


Table 4-4. Summary of Implementation Costs for Lower Snake River Projects1992 Price Level $(\$ 1,000)$ - CONT

\begin{tabular}{|c|c|c|c|c|c|c|}
\hline \multirow{2}{*}{$\begin{array}{c}\text { Construction Item/ } \\
\text { Contingency Rate (\%) }\end{array}$} & \multicolumn{6}{|c|}{ System Operation Strategies \& Cost w/Contingencies 1/ $2 /$} \\
\hline & $5 b$ & $5 c$ & $6 \mathrm{~b}$ & $6 \mathrm{~d}$ & $9 a$ & $9 c$ \\
\hline Irrigation \& Water Supply $3 /$ & $26,806.2$ & $26,806.2$ & $14,952.3$ & $2,294.6$ & $14,943.8$ & $16,164.6$ \\
\hline Recreation Sites 4/ & 0.0 & 0.0 & 0.0 & 0.0 & 0.0 & 0.0 \\
\hline Total Construction Cost & $2,424,271.5$ & $423,646.2$ & $704,316.0$ & $52,886.8$ & $704,307.5$ & $\mathbf{7 0 5 , 5 2 8 . 3}$ \\
\hline Total Construction \& Real Estate & $2,424,779.0$ & $423,646.2$ & $704,823.5$ & $53,013.7$ & $704,815.0$ & $706,035.8$ \\
\hline Plan, Engr, Design (20) 5/ & $574,432.9$ & $71,933.8$ & $160,781.0$ & $12,771.2$ & $160,778.5$ & $161,144.7$ \\
\hline Const Management (10) & $203,968.2$ & $32,012.0$ & $56,284.9$ & $4,351.2$ & $56,284.9$ & $56,284.9$ \\
\hline Total First Cost & $3,203,180.1$ & $527,592.0$ & $921,889.4$ & $70,136.1$ & $921,878.4$ & $923,465.4$ \\
\hline Investment \& Annual Costs at $7.75 \%$ & 0.0775 & & & & & \\
\hline IDCCosts 6/ & $2,699,684.5$ & $111,786.8$ & $448,046.5$ & $14,860.5$ & $448,041.2$ & $448,812.5$ \\
\hline Total Investment Costs $7 /$ & $5,902,864.6$ & $639,378.8$ & $1,369,935.9$ & $84,996.6$ & $1,369,919.6$ & $1,372,277.9$ \\
\hline Annual Investment Cost 8/ & $457,734.4$ & $49,580.3$ & $106,230.9$ & $6,591.0$ & $106,229.7$ & $106,412.5$ \\
\hline Annual O\&M Costs $9 /$ & $2,137.0$ & $2,214.0$ & $1,115.0$ & 150.0 & $1,115.0$ & $1,141.0$ \\
\hline Average Annual Costs 10/ & $459,871.4$ & $51,794.3$ & $107,345.9$ & $6,741.0$ & $107,344.7$ & $107,553.5$ \\
\hline Equivalent Annual Costs 11/ & $150,098.8$ & $35,661.2$ & $50,887.7$ & $4,641.3$ & $50,887.1$ & $50,986.1$ \\
\hline Investment \& Annual Costs at $3.0 \%$ & 0.0300 & & & & & \\
\hline IDC Costs 6/ & $827,666.7$ & $40,960.6$ & $150,689.0$ & $5,445.1$ & $150,687.2$ & $150,946.6$ \\
\hline Total Investment Costs 7/ & $4,030,846.8$ & $568,552.6$ & $1,072,578.4$ & $75,581.2$ & $1,072,565.6$ & $1,074,412.0$ \\
\hline Annual Investment Cost $8 /$ & $127,562.9$ & $17,992.8$ & $33,943.5$ & $2,391.9$ & $33,943.1$ & $34,001.6$ \\
\hline Annual O\&M Costs 9/ & $2,137.0$ & $2,214.0$ & $1,115.0$ & 150.0 & $1,115.0$ & $1,141.0$ \\
\hline Average Annual Costs 10/ & $129,699.9$ & $20,206.8$ & $35,058.5$ & $2,541.9$ & $35,058.1$ & $35,142.6$ \\
\hline Equivalent Annual Costs 11/ & $83,249.4$ & $17,430.6$ & $26,086.8$ & $2,192.7$ & $26,086.5$ & $26,149.4$ \\
\hline $\begin{array}{l}\text { Notes: } \\
\text { 1/ Costs do not include estimatedinf } \\
\text { 2/ Costs to modify the lower Snake I } \\
\text { 3/ Various contingency rates were us } \\
\text { 4/ Costs of impacts on recreation fac } \\
5 / \text { Includes costs for irrigation and } \\
\text { 6/ Interest during construction, base } \\
\text { 7/ The sum of Total First Cost and I } \\
\text { 8/ Includes amortization of investm } \\
\text { 9/ Annual O\&M costs for irrigation } \\
\text { has not been estimated. } \\
\text { 10/ Annual investment cost amortize } \\
\text { 11/ Average annual costs discounted }\end{array}$ & $\begin{array}{l}\text { during constr } \\
\text { projects in SO } \\
\text { ccludes planni } \\
\text { have not been } \\
\text { ater, estimate } \\
\text { otal first cost a } \\
\text { sts and annual } \\
\text { ater supply ar } \\
100 \text { years-- } \\
\text { POL date to th }\end{array}$ & $\begin{array}{l}\text { ction. } \\
5 \mathrm{c} \text { are at the } \\
\text { g, engineerir } \\
\text { stimated. } \\
\text { at } 30 \text { percen } \\
\text { suming equa } \\
\text { \&M costs. } \\
\text { from Appen } \\
\text { cludes repla } \\
\text { base year, } 1\end{array}$ & $\begin{array}{l}1995 \text { price lev } \\
\text { and design. } \\
\text { of constructio } \\
\text { expenditures } \\
\text { ix F. The chan } \\
\text { ement costs. } \\
95\end{array}$ & $\begin{array}{l}\text { costs. } \\
\text { er year. }\end{array}$ & osts for the & \\
\hline
\end{tabular}


Table 4-5. Summary of Implementation Costs for John Day Project-1992 Price Level $(\$ 1,000)$

\begin{tabular}{|c|c|c|c|c|c|c|c|}
\hline \multirow{2}{*}{$\begin{array}{c}\text { Construction Item } \\
\text { (contingency rate, percent) }\end{array}$} & \multicolumn{7}{|c|}{ System Operation Strategies \& Costs w/Contingencies } \\
\hline & $5 \mathbf{b}$ & $5 c$ & $\mathbf{6 b}$ & 6d & $9 \mathbf{a}$ & $9 c$ & $\mathbf{P A}$ \\
\hline Navigation (35) & 417.0 & 417.0 & 417.0 & 417.0 & 417.0 & 417.0 & 417.0 \\
\hline Adult Fish Passage (35) & 944.0 & 944.0 & 944.0 & 944.0 & 944.0 & 944.0 & 944.0 \\
\hline Fish \& Wildlife Mitigation (35) & $13,500.0$ & $13,500.0$ & $13,500.0$ & $13,500.0$ & $13,500.0$ & $13,500.0$ & $10,100.0$ \\
\hline Recreation Sites (35) & $12,972.0$ & $12,972.0$ & $12,972.0$ & $12,972.0$ & $12,972.0$ & $12,972.0$ & $12,972.0$ \\
\hline Water Supply (35) 2/ & $27,805.4$ & $27,805.4$ & $27,805.4$ & $27,805.4$ & $27,805.4$ & $27,805.4$ & $30,403.1$ \\
\hline Irrigation $2 /$ & $11,030.8$ & $11,030.8$ & $11,030.8$ & $11,030.8$ & $8,300.0$ & $11,030.8$ & $11,030.8$ \\
\hline Other Impacts (35) $3 /$ & 951.0 & 951.0 & 951.0 & 951.0 & 951.0 & 951.0 & 951.0 \\
\hline Total Construction Cost & $67,620.2$ & $67,620.2$ & $67,620.2$ & $67,620.2$ & $64,889.4$ & $67,620.2$ & $66,817.8$ \\
\hline Plan, Engr, Design (30\%) & $20,286.0$ & $20,286.0$ & $20,286.0$ & $20,286.0$ & $19,466.8$ & $20,286.0$ & $20,045.4$ \\
\hline Const Management $(10 \%)$ & $6,762.0$ & $6,762.0$ & $6,762.0$ & $6,762.0$ & $6,488.9$ & $6,762.0$ & $6,681.8$ \\
\hline Total First Cost & $94,668.2$ & $94,668.2$ & $94,668.2$ & $94,668.2$ & $90,845.1$ & $94,668.2$ & $93,545.0$ \\
\hline Investment \& Annual Costs at $7.75 \%$ & 0.0775 & & & & & & \\
\hline IDC Costs 4/ & $11,412.5$ & $11,412.5$ & $11,412.5$ & $11,412.5$ & $10,951.6$ & $11,412.5$ & $11,277.1$ \\
\hline Total Investment Costs 5/ & $106,080.7$ & $106,080.7$ & $106,080.7$ & $106,080.7$ & $101,796.7$ & $106,080.7$ & $104,822.0$ \\
\hline Annual Investment Cost $6 /$ & $8,226.0$ & $8,226.0$ & $8,226.0$ & $8,226.0$ & $7,893.8$ & $8,226.0$ & $8,128.4$ \\
\hline Annual O\&M Costs $7 /$ & $5,141.0$ & $5,179.0$ & $4,230.0$ & $3,321.0$ & $4,179.9$ & $4,281.0$ & $3,375.2$ \\
\hline Average Annual Costs 8/ & $13,367.0$ & $13,405.0$ & $12,456.0$ & $11,547.0$ & $12,073.7$ & $12,507.0$ & $11,503.6$ \\
\hline Equivalent Annual Costs 9/ & $4,362.9$ & $9,229.5$ & $5,904.8$ & $7,950.3$ & $5,723.6$ & $5,929.0$ & $9,195.6$ \\
\hline Investment \& Annual Costs at $3.0 \%$ & 0.0300 & & & & & & \\
\hline IDCCosts 4/ & $4,320.7$ & $4,320.7$ & $4,320.7$ & $4,320.7$ & $4,146.2$ & $4,320.7$ & $4,269.4$ \\
\hline Total Investment Costs 5/ & $98,988.9$ & $98,988.9$ & $98,988.9$ & $98,988.9$ & $94,991.3$ & $98,988.9$ & $97,814.4$ \\
\hline Annual Investment Cost $6 /$ & $3,132.7$ & $3,132.7$ & $3,132.7$ & $3,132.7$ & $3,006.2$ & $3,132.7$ & $3,095.5$ \\
\hline Annual O\&M Costs 7/ & $5,141.0$ & $5,179.0$ & $4,230.0$ & $3,321.0$ & $4,179.9$ & $4,281.0$ & $3,375.2$ \\
\hline Average Annual Costs 4/ & $8,273.7$ & $8,311.7$ & $7,362.7$ & $6,453.7$ & $7,186.1$ & $7,413.7$ & $6,470.7$ \\
\hline Equivalent Annual Costs 9/ & $5,310.6$ & $7,169.7$ & $5,478.5$ & $5,567.0$ & $5,347.1$ & $5,516.5$ & $5,921.6$ \\
\hline $\begin{array}{l}\text { Notes: } \\
\text { 1/ Costs do not include estimated infl } \\
\text { 2/ Capital costs from Appendix F, adj } \\
\text { estimated average of } 30 \text { percent. V } \\
\text { 3/ Includes cultural resources, utilitie } \\
\text { 4/ Interest during construction, based } \\
\text { 5/ The sum of Total First Cost and ID } \\
\text { 6/ Annual investment cost amortized } \\
\text { 7/ Annual costs for irrigation and wat } \\
\text { 8/ Indudy, Phase I. } \\
\text { 9/ Average amortization of investmer } \\
\text { 9/ }\end{array}$ & $\begin{array}{l}14 \text { slide m } \\
\text { otal first co } \\
100 \text { years- } \\
\text { pply are fr }\end{array}$ & $\begin{array}{l}\text { sitoring, } \\
\text { st assumi } \\
\text { - exclude } \\
\text { m Appen } \\
\text { ual O\&M }\end{array}$ & $\begin{array}{l}\text { nd design } \\
\text { Umatilla } \\
\text { qual expen } \\
\text { placemen } \\
\text { E. Annual } \\
\text { s. } \\
\text {, }\end{array}$ & $\begin{array}{l}\text { d construc } \\
\text { er dredgin } \\
\text { tures perye } \\
\text { sts. } \\
\text { sts for othe }\end{array}$ & $\begin{array}{l}\text { ion manag } \\
\text { ar. } \\
\text { sare from }\end{array}$ & tem Conf & ration \\
\hline
\end{tabular}




\subsection{ANADROMOUS FISH}

\subsubsection{Fish Survival Estimates}

\subsubsection{General}

As explained in Section 3.3.1, the estimates of the impact of each SOS on salmon and steelhead were developed by the Anadromous Fish Work Group (AFW) and are detailed in Appendix C (Anadromous Fish). The estimated levels of fish runs over time developed by the AFW serve as the foundation for the analysis of economic impacts.

Appendix $\mathrm{C}$ includes several different modeling approaches and fish survival assumptions. The model results used in the economic analysis were based on the results from the Stochastic Life Cycle Model (SLCM) which provided both the estimated number of returning anadromous fish spawners and the number of fish harvested in the commercial and sport fisheries. The other computer models did not provide the harvest information needed to identify economic impacts.

The biological fish models and this economic analysis assume a fixed ratio over time of the number of fish harvested and the number of fish that escape harvest to spawn. Hence, the rate of change in survival of the various stocks over time is reflected as an identical rate of change in the number of fish harvested.

\subsubsection{Transportation Survival Uncertainty}

It is possible that the transportation of smolts in trucks and barges cause mortality from such things as high levels of stress, diseases transmitted during transportation, and delayed mortality after release from barges or trucks. In order to compare estimates of survival with transportation to in-river migration, two methods for estimating juvenile transportation survival were studied. The first method (transport scenario FB) was based solely on observed barged survival and assumes a constant 98 percent survival. The second method was based on transport to in-river ratios, which could change each year. Two transport to in-river ratios were modeled, and applied to some of the indicator species. The transport scenario F86 has an assumed transport survival of 76 percent, and scenario A86 has a transport survival of 36 percent. For this economic analysis, transport scenario F86 survival assumptions were used. Exhibit $A$ of this appendix, provides results for the other transport survival scenarios.

\subsubsection{Drawdown Survival Uncertainty}

To evaluate the SOSs, outside of historic operating conditions, assumptions had to be made to account for the lack of actual survival data. Because no information is available on how effectively smolts would be guided past dams under drawdown and combinations of drawdown alternatives, two sets of fish guidance efficiency (FGE) assumptions were modeled: (1) optimistic passage values that assume FGE would increase by 25 percent; and, (2) pessimistic passage values that assume FGE would decrease by 50 percent. The optimistic and pessimistic assumptions were developed by the Technical Advisory Group for the Corps' System Configuration Study. These assumptions are used only for the four lower Snake River dams--Lower Granite, Little Goose, Lower Monumental, and Ice Harbor. Both the optimistic and pessimistic FGE are reported in this section. However, in the summary section of this chapter (Section 4.10) and in chapter 5 only the optimistic assumptions are reported.

\subsubsection{Variability of Estimates of Survival}

The variability of the estimates produced by the fish life-cycle models used by the AFW are documented and described in Appendix $\mathrm{C}$. The wide ranges of survival clearly limits any accuracy of defining the true economic impacts associated with anadromous fish. The comparisons made here are based on the median values provided for survival of the indicator stocks. Limiting the analysis to just the median values does not present the full picture, but does provide a reasonable comparison of the alternative SOSs. The figures in Appendix $\mathrm{C}$ show the variability of SLCM results over the range of the 10 percentile estimate to the 90 percentile estimate. Despite the variability in the estimates, in almost every case the relative ranking of the SOSs, in terms of survival 
of the salmon stocks, does not change with either the 10 percentile estimate, the 90 percentile estimate, or the median. So, even though the variability and magnitude of economic impacts changes significantly with the extreme ranges of fish survival estimates, the relative ranking of alternatives can be described by comparing the median values.

\subsubsection{Discounting Estimates of Survival}

The timing of impacts to salmon and steelhead are important from an economic standpoint. To make equal comparisons of the estimated fish survival impacts of each SOS, the survival numbers must be based on a common time frame. Several SOSs can be implemented immediately, while others cannot be implemented for 10 or 15 years. This analysis is presented in two ways. The "undiscounted" values describe the magnitude of the impacts and the expected timing of those impacts with each SOS. The discounted values analysis presented in this section is done to account for the different effects on fish survival and the timing of those effects with each SOS, by presenting results on an average annual equivalent basis.

\subsubsection{Analysis of Number of Fish Harvested}

Economic data are provided for four stocks: fall chinook, spring and summer chinook, steelhead, and sockeye. The results of SLCM were provided for the indicator stocks for each SOS. To compute the economic impacts, each of the four stocks were treated separately and catch estimates were based on SLCM results for the most appropriate indicator stocks. The indicator stocks were selected based on their correlation with dam counts as described in Section 3.3.1.1. In addition, some of the runs are dominated by a specific stock. For example, the fall chinook run was modeled based on the Hanford fall chinook SLCM results. This indicator stock was highly correlated to dam counts at Bonneville and McNary. The upriver bright runs from the Hanford reach comprise the vast majority of the Columbia River fall chinook catch and is the most valuable for both the commercial and sport fisheries.

The steelhead run was modeled by the Dworshak Hatchery indicator stock. Spring and summer chinook catch estimates were based on the Snake River spring chinook. No indicator stocks were analyzed for the sockeye run, but, it is the opinion of the AFW that sockeye survival variables would be most similar to spring chinook. The addition of sockeye to the analysis is not significant in terms of economic impacts, but sockeye are modeled here for informational purposes, based on the SLCM results for Snake River spring chinook.

To present a historical perspective, the catch and value information provided in Section 3.3.1 was based on an annual average for the years 1987 to 1991. The SLCM modeling included estimates of harvests for 1995 conditions which were assumed to be the starting point for the catch amounts for each SOS. The SLCM catch values are somewhat different than the 1987 to 1991 historic averages. The value estimates in this section are based on the 1992 dollar values to be consistent with price levels of other impacts.

The SLCM results contained considerable variability from year to year. The average SLCM results for the period of year 31 to year 40 was assumed to represent the amount of fish harvested annually from year 41 to year 100 of the SOS.

\subsubsection{Catch Estimates Over Time}

Figure 4-1 presents the estimated fish harvest numbers for the three major species for the base condition of SOS 2c, over time. Similar estimates were made for each of the SOSs. The estimated number of fish harvested over time with each SOS is presented in Exhibit $A$ of this appendix. 


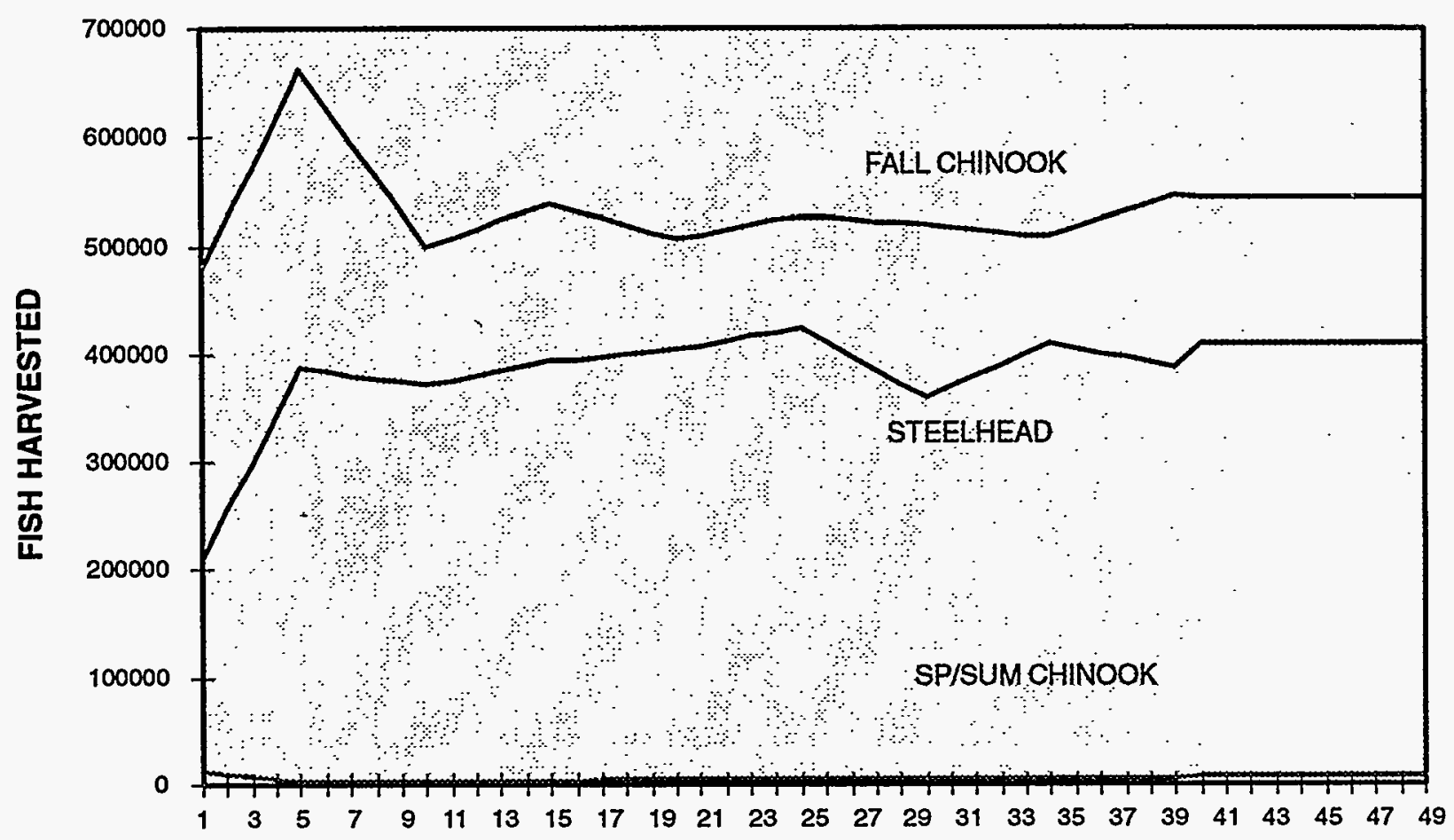

YEARS FROM 1995

Figure 4-1. Annual Fish Harvest with SOS 2c

\subsubsection{Average Annual Equivalent Catch}

To compare alternatives on an identical basis the economic impacts must be analyzed over a common time frame. This is done by converting the estimated values over time with the different alternative SOSs to an equivalent annual basis. Since the economic values of commercial and sport fisheries are determined by the fish catch amounts, in this analysis, the number of fish harvested over time was converted to an average annual catch figure for each SOS.

For alternative SOSs which could not be implemented immediately (1995), it was assumed that SOS $2 c$ would be implemented from 1995 until the SOS could be implemented. For example, SOS 5B will not be implemented until 2010. Figure 4-2 shows harvest over time for fall chinook with SOS $2 \mathrm{C}$ and $5 \mathrm{~B}$, and the harvest amounts are equal until year 2010.

The estimated harvest numbers over time for each SOS were discounted from the POL date of each SOS to 1995 using discount rates of 3.0 percent and 7.75 percent, and the equivalent annual was computed over a 100 year period. Table $4-6$ shows the estimated equivalent annual number of fish harvested for the four major stocks with each SOS for each of the two interest rates. 


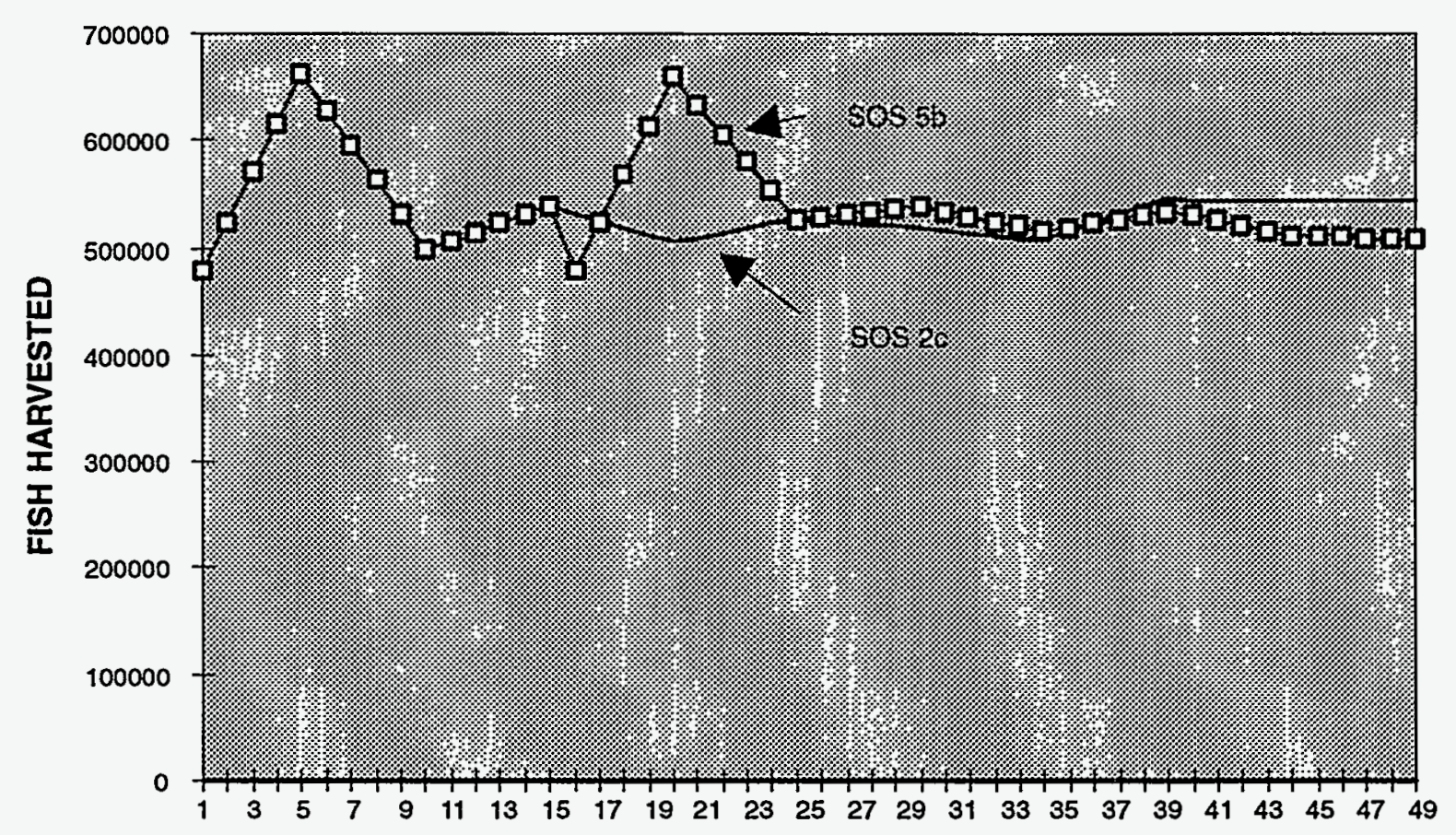

YEARS FROM 1995

Figure 4-2. Fall Chinook with SOS $2 c$ and 5b

\subsubsection{Undiscounted Value of Recreational and Commerical Fisheries}

Tables A-1, A-2, and A-3 in Exhibit $A$ show the total annual harvest for selected years for each of the indicator species and each SOS. The total annual harvest numbers over time were allocated to the various commercial and recreational fisheries using the approach described in Section 3.3.1. For example, Table 4-7 shows how the total annual harvest was allocated to commercial and sport fisheries for SOS $2 c$, SOS $9 b$, and the Preferred Alternative, in year 2010.

The harvest distribution numbers, computed in the manner shown in Table 4-6, were applied to the value per fish amounts shown in Tables $3-2$ to $3-6$ to arrive at the annual economic value for all SOSs at different time frames. The results are illustrated in Tables 4-8 and 4-9 which show economic values for SOS $2 c$ and SOS $9 b$ (Table 4-8) and the Preferred Alternative (Table 4-9) for the year 2010, with the "high" value assumptions for commercial and recreational economic values. A similar approach was used to compute annual values by decade for each of the SOSs. The results of the computations are shown in Table 4-10 which presents the summary of total annual economic values for each SOS by selected years for the "low" and "high" value assumptions. 
Table 4-6. Equivalent Annual Harvest Based on 100 Year Analysis for Interest Rates of 3.0 and 7.75 Percent (Number Of Fish Harvested) 1/

\begin{tabular}{|c|c|c|c|c|c|c|c|c|}
\hline $\operatorname{sos} 21$ & $\begin{array}{l}\text { Fall } \\
\text { Chinook } \\
\text { AAE @ } \\
3.0 \%\end{array}$ & $\begin{array}{l}\text { Fall } \\
\text { Chinook } \\
\text { AAE @ } \\
7.75 \%\end{array}$ & $\begin{array}{l}\text { Spring } \\
\text { Chinook } \\
\text { AAE @ } \\
3.0 \%\end{array}$ & $\begin{array}{l}\text { Spring } \\
\text { Chinook } \\
\text { AAE @ } \\
7.75 \%\end{array}$ & $\begin{array}{c}\text { Steelhd } \\
\text { AAE @ } \\
\text { 3.0\% }\end{array}$ & $\begin{array}{l}\text { Steelhd } \\
\text { AAE @ } \\
7.75 \%\end{array}$ & $\begin{array}{c}\text { Sockeye } \\
\text { AAE@ } \\
\text { 3.0\% }\end{array}$ & $\begin{array}{l}\text { Sockeye } \\
\text { AAE@ } \\
7.75 \%\end{array}$ \\
\hline $1 \mathrm{a}$ & 534,400 & 540,500 & 5,570 & 5,130 & 379,300 & 357,200 & 10,800 & 10,000 \\
\hline $1 b$ & 540,600 & 547,000 & 5,630 & 5,160 & 378,900 & 356,900 & 10,900 & 10,000 \\
\hline $2 c$ & 538,900 & 545,200 & 5,680 & 5,190 & 382,200 & 359,800 & 11,000 & 10,100 \\
\hline $2 d$ & 549,800 & 557,100 & 5,920 & 5,310 & 380,300 & 358,200 & 11,500 & 10,300 \\
\hline $4 c$ & 547,400 & 552,100 & 5,710 & 5,160 & 381,200 & 358,900 & 11,100 & 10,000 \\
\hline $5 b$ & 547,500 & 554,200 & 4,610 & 5,050 & 295,400 & 312,000 & 8,900 & 9,800 \\
\hline $5 c$ & 535,900 & 544,100 & 4,810 & 5,570 & 269,600 & 267,400 & 9,300 & 10,800 \\
\hline $6 b-o p$ & 545,900 & 555,100 & 2,990 & 4,640 & 234,700 & 265,500 & 5,800 & 9,000 \\
\hline $6 b-p$ & 548,700 & 557,000 & 2,320 & 4,230 & 179,000 & 233,500 & 4,500 & 8,200 \\
\hline $6 d-o p$ & 538,300 & 546,800 & 3,340 & 4,930 & 311,000 & 297,000 & 6,500 & 9,600 \\
\hline $6 d-p$ & 543,800 & 553,100 & 2,640 & 4,580 & 276,100 & 271,900 & 5,100 & 8,900 \\
\hline $9 a-o p$ & $413,10 \hat{0}$ & 475,600 & 2,990 & 4,640 & 208,300 & 250,300 & 5,800 & 9,000 \\
\hline $9 a-p$ & 410,800 & 474,600 & 2,350 & 4,260 & 164,700 & 225,000 & 4,600 & 8,300 \\
\hline $9 b$ & 511,100 & 520,400 & 4,500 & 4,580 & 348,200 & 329,800 & 8,700 & 8,900 \\
\hline $9 c-o p$ & 527,900 & 544,600 & 3,160 & 4,700 & 236,200 & 266,400 & 6,100 & 9,100 \\
\hline $9 c-p$ & 528,700 & 545,300 & 2,350 & 4,260 & 184,000 & 236,300 & 4,600 & 8,300 \\
\hline $\begin{array}{l}\text { Preferred } \\
\text { Alt }\end{array}$ & 559,100 & 563,600 & 5,660 & 5,130 & 375,600 & 354,100 & 11,000 & 10,000 \\
\hline \multicolumn{9}{|c|}{$\begin{array}{l}\text { 1/ With transport Scenario F86. } \\
2 \text { / SOSs which end in "-op" represent "optimistic" assumptions of an increase of } 25 \% \text { in FGE with draw- } \\
\text { down. SOSs which end in "-p" represent "pessimistic" assumptions of a decrease of } 50 \% \text { in FGE with } \\
\text { drawdown. }\end{array}$} \\
\hline
\end{tabular}


Table 4-7. Allocation of Annual Catch to Commercial and Sport Fisheries in 2010 for SOS 2c, SOS 9b, and the Preferred Alternative (1,000 Fish Per Year) $1 /$

\begin{tabular}{|c|c|c|c|c|}
\hline sos & FALL CHK & $\begin{array}{c}\text { SP/SUM } \\
\text { CHINOOK }\end{array}$ & STLHEAD & SOCKEYE \\
\hline \multicolumn{5}{|l|}{ SOS 2c } \\
\hline \multicolumn{5}{|l|}{ COMMERCIAL: } \\
\hline AlaskaCommercial & 49.6 & 0.0 & 0.0 & 0.0 \\
\hline CanadaCommercial & 166.0 & 3.1 & 0.0 & 0.0 \\
\hline USOcean Commercial & 39.8 & 0.1 & 0.0 & 0.0 \\
\hline In-RiverCommercial & 217.1 & 0.2 & 221.9 & 6.8 \\
\hline \multicolumn{5}{|l|}{ SPORT: } \\
\hline Alaska Sport & 2.9 & 0.0 & 0.0 & 0.0 \\
\hline CanadaSport & 12.2 & 0.0 & 0.0 & 0.0 \\
\hline US Ocean Sport & 29.4 & 0.0 & 0.0 & 0.0 \\
\hline In-RiverSport & 14.7 & 0.0 & 174.0 & 0.0 \\
\hline TOTAL CATCH: & 531.6 & 3.5 & 395.9 & 6.8 \\
\hline \multicolumn{5}{|l|}{ sos 9b } \\
\hline \multicolumn{5}{|l|}{ COMMERCLAL: } \\
\hline AlaskaCommercial & 46.1 & 0.0 & 0.0 & 0.0 \\
\hline CanadaCommercial & 154.2 & 2.7 & 0.0 & 0.0 \\
\hline USOcean Commercial & 36.9 & 0.1 & 0.0 & 0.0 \\
\hline In-RiverCommercial & 201.7 & 0.2 & 199.0 & 5.8 \\
\hline \multicolumn{5}{|l|}{ SPORT: } \\
\hline Alaska Sport & 2.7 & 0.0 & 0.0 & 0.0 \\
\hline Canada Sport & 11.4 & 0.0 & 0.0 & 0.0 \\
\hline US Ocean Sport & 27.3 & 0.0 & 0.0 & 0.0 \\
\hline In-RiverSport & 13.6 & 0.0 & 156.0 & 0.0 \\
\hline TOTAL CATCH: & 493.9 & 3.0 & 355.0 & 5.8 \\
\hline \multicolumn{5}{|c|}{ PREFERREDALTERNATIVE } \\
\hline \multicolumn{5}{|c|}{ COMMERCIAL: } \\
\hline AlaskaCommercial & 50.0 & 0.0 & 0.0 & 0.0 \\
\hline CanadaCommercial & 167.2 & 3.4 & 0.0 & 0.0 \\
\hline USOcean Commercial & 40.1 & 0.1 & 0.0 & 0.0 \\
\hline In-RiverCommercial & 218.8 & 0.2 & 217.6 & 7.3 \\
\hline \multicolumn{5}{|l|}{ SPORT: } \\
\hline Alaska Sport & 2.9 & 0.0 & 0.0 & 0.0 \\
\hline CanadaSport & 12.3 & 0.0 & 0.0 & 0.0 \\
\hline USOcean Sport & 29.6 & 0.0 & 0.0 & 0.0 \\
\hline In-RiverSport & 14.8 & 0.0 & 170.7 & 0.0 \\
\hline TOTAL CATCH: & 535.7 & 3.8 & 388.3 & 7.3 \\
\hline
\end{tabular}


Table 4-8. Columbia River Salmon and Steelhead "High" Value Estimates for Catch in 2010 SOS 2c and SOS 9b. 1/ 2/

\begin{tabular}{|c|c|c|c|c|c|}
\hline & $\underset{(\$ 100)}{\text { FALL }}$ & $\begin{array}{c}\text { SPRG/SUMM } \\
\text { CHINOOK } \\
\text { (\$100) }\end{array}$ & $\begin{array}{c}\text { STEELHEAD } \\
(\$ 1000)\end{array}$ & $\begin{array}{c}\text { SOCKEYE } \\
(\$ 1000)\end{array}$ & $\begin{array}{l}\text { TOTAL } \\
\text { VALUE } \\
\text { (\$1000) }\end{array}$ \\
\hline \multicolumn{6}{|l|}{ SOS 2c } \\
\hline COMMERCIAL: & . & & & & \\
\hline Alaska Commercial & 1,310 & 0 & 0 & 0 & 1,310 \\
\hline Canada Commercial & 4,360 & 80 & 0 & 0 & 4,440 \\
\hline US Ocean Commercial & 1,050 & 0 & 0 & 0 & 1,050 \\
\hline In-River Commercial & 3,820 & 10 & 2,440 & 60 & 6,330 \\
\hline \multicolumn{6}{|l|}{ SPORT: } \\
\hline Alaska Sport & 140 & 0 & 0 & 0 & 140 \\
\hline Canada Sport & 620 & 0 & 0 & 0 & 620 \\
\hline US Ocean Sport & 1,490 & 0 & 0 & 0 & 1,490 \\
\hline In-River Sport & 1,500 & 0 & 27,630 & 0 & 29,130 \\
\hline Total Commercial & 10,540 & 90 & 2,440 & 60 & 13,130 \\
\hline Total Sport & 3,750 & $\mathbf{0}$ & 27,630 & 0 & 31,380 \\
\hline Total Commercial + Sport & 14,290 & 90 & 30,070 & 60 & 44,510 \\
\hline \multicolumn{6}{|l|}{ SOS 9b } \\
\hline \multicolumn{6}{|l|}{ COMMERCIAL: } \\
\hline Alaska Commercial & 1,210 & 0 & 0 & 0 & 1,210 \\
\hline Canada Commercial & 4,050 & 70 & 0 & 0 & 4,120 \\
\hline US Ocean Commercial & 970 & 0 & 0 & 0 & 970 \\
\hline In-River Commercial & 3,550 & 10 & 2,190 & 50 & 5,800 \\
\hline \multicolumn{6}{|l|}{ SPORT: } \\
\hline Alaska Sport & 130 & 0 & 0 & 0 & 130 \\
\hline Canada Sport & 580 & 0 & 0 & 0 & 580 \\
\hline US Ocean Sport & 1,390 & 0 & 0 & 0 & 1,390 \\
\hline In-River Sport & 1,390 & 0 & 24,770 & 0 & 26,160 \\
\hline Total Commercial & 9,780 & 80 & 2,190 & 50 & 12,100 \\
\hline Total Sport & 3,490 & 0 & 24,770 & 0 & 28,260 \\
\hline Total Commercial + Sport & 13,270 & 80 & 26,960 & 50 & 40,360 \\
\hline
\end{tabular}


Table 4-9. Columbia River Salmon and Steelhead "High" Value Estimates for Catch in 2010 for Preferred Alternative. 1/ 2/

\begin{tabular}{|c|c|c|c|c|c|}
\hline & $\begin{array}{c}\text { FALL } \\
\text { CHINOOK } \\
\mathbf{( \$ 1 0 0 0 )}\end{array}$ & $\begin{array}{c}\text { SPRG/SUMM } \\
\text { CHINOOK } \\
(\$ 1000)\end{array}$ & $\begin{array}{l}\text { STEELHEAD } \\
(\$ 1000)\end{array}$ & $\begin{array}{c}\text { SOCKEYE } \\
(\$ 1000)\end{array}$ & $\begin{array}{l}\text { TOTAL } \\
\text { VALUE } \\
\text { (\$1000) }\end{array}$ \\
\hline \multicolumn{6}{|l|}{ PREFERRED ALT. } \\
\hline \multicolumn{6}{|l|}{ COMMERCIAL: } \\
\hline Alaska Commercial & 1,320 & 0 & 0 & 0 & 1,320 \\
\hline Canada Commercial & 4,400 & 90 & 0 & 0 & 4,490 \\
\hline US Ocean Commercial & 1,050 & 0 & 0 & 0 & 1,050 \\
\hline In-River Commercial & 3,850 & 10 & 2,390 & 60 & 6,310 \\
\hline \multicolumn{6}{|l|}{ SPORT: } \\
\hline Alaska Sport & 150 & 0 & 0 & 0 & 150 \\
\hline Canada Sport & 630 & 0 & 0 & 0 & 630 \\
\hline US Ocean Sport & 1,500 & 0 & $\mathbf{0}$ & 0 & 1,500 \\
\hline In-River Sport & 1,510 & 0 & 27,090 & $\mathbf{0}$ & 28,600 \\
\hline Total Commercial & 10,620 & 100 & 2,390 & 60 & 13,170 \\
\hline Total Sport & 3,790 & 0 & 27,090 & 0 & 30,880 \\
\hline $\begin{array}{l}\text { Total Commercial + } \\
\text { Sport }\end{array}$ & 14,410 & 100 & 29,480 & 60 & 44,050 \\
\hline
\end{tabular}


Table 4-10. Annual Commercial and Sport Values $(\$ 1,000)$ of Salmon and Steelhead Catch for Each SoS for Selected Years 1/

\begin{tabular}{|c|c|c|c|c|c|c|}
\hline $\operatorname{sos} 4 /$ & $\begin{array}{c}\text { "Low" 2/ } \\
\text { Values Totals } \\
1995\end{array}$ & $\begin{array}{c}\text { "Low" 2/ } \\
\text { Values Totals } \\
2010\end{array}$ & $\begin{array}{c}\text { "Low" 2/ } \\
\text { Values Totals } \\
2035\end{array}$ & $\begin{array}{c}\text { "High" 3/ } \\
\text { Values Totals } \\
1995\end{array}$ & $\begin{array}{c}\text { "High" 3/ } \\
\text { Values Totals } \\
2010\end{array}$ & $\begin{array}{c}\text { "High" 3/ } \\
\text { Values Totals } \\
2035\end{array}$ \\
\hline SOS 1a & 20,040 & 29,080 & 32,290 & 29,430 & 40,320 & 45,620 \\
\hline $\operatorname{SOS} 1 b$ & 20,040 & 31,230 & 32,290 & 29,430 & 44,080 & 45,640 \\
\hline $\operatorname{sOS} 2 c$ & 20,040 & 31,520 & 32,550 & 29,420 & $44 ; 510$ & 45,980 \\
\hline $\operatorname{sOS} 2 d$ & 20,040 & 31,370 & 32,580 & 29,420 & 44,330 & 46,150 \\
\hline $\operatorname{SOS} 4 c$ & 20,040 & 31,370 & 32,610 & 29,430 & 44,270 & 46,170 \\
\hline SOS 5b & 20,040 & 24,080 & 24,780 & 29,420 & $34 ; 840$ & 35,910 \\
\hline SOS $5 c$ & 20,040 & 23,940 & 24,760 & 29,430 & 34,590 & 35,760 \\
\hline sos $6 b-o p$ & 20,040 & 19,480 & 20,370 & 29,430 & 28,860 & 30,120 \\
\hline sOS $6 b-p$ & 20,040 & 14,790 & 15,350 & 29,430 & 22,790 & 23,570 \\
\hline sOS 6d-op & 20,040 & 26,880 & 27,850 & 29,430 & 38,340 & 39,820 \\
\hline sos $6 d-p$ & 20,040 & 24,360 & 25,180 & 29,430 & 35,130 & 36,330 \\
\hline SOS 9a-op & 20,040 & 13,980 & 14,920 & 29,420 & 20,290 & 21,690 \\
\hline SOS $9 a-p$ & 20,040 & 10,040 & 10,960 & 29,430 & 15,080 & 16,510 \\
\hline SOS 9b & 20,040 & 28,550 & 29,750 & 29,430 & 40,360 & 42,120 \\
\hline SOS 9c-op & 20,040 & 19,080 & 20,050 & 29,400 & 28,070 & 29,520 \\
\hline SOS 9c-p & 20,040 & 14,560 & 15,340 & 29,400 & 22,170 & 23,370 \\
\hline PA & 20,040 & 31,170 & 32,420 & 29,420 & 44,050 & 45,970 \\
\hline
\end{tabular}

1/ With transport scenario F86.

$2 /$ "Low" values based on net-to-gross of $50 \%$, sport value of $\$ 50.50$ per day.

$3 /$ "High" values based on full ex-vessel value (net-to-gross $100 \%$ ), sport value of $\$ 63.50$ per day.

4/ SOSs which end in "-op" represent "optimistic" assumptions of an increase of $25 \%$ in FGE with drawdown. SOSs which end in "-p" represent "pessimistic" assumptions of a decrease of 50\% in FGE with drawdown. 


\subsubsection{Average Annual Value of Recreation and Commercial Fishery}

For each SOS the average annual catch was allocated to the various commercial and recreational fisheries using the approach described in Section 3.3.1. Table 4-11 shows the allocation of equivalent annual catch (with catch discounted at a 3\% discount rate) for SOSs $2 c$ and $5 b$. Using the harvest allocation shown in Table 4-11, the value per fish amounts shown in Tables 3-2 to 3-6 were applied to arrive at the average annual value for commercial and recreational fishery. Tables $4-12$ and $4-13$ provide the equivalent annual value of the commercial and recreational catch for each SOS, for "low" and "high" value assumptions, and discounted at 3 percent (Table 4-12) and 7-3/4 percent (Table 4-13).

\section{Table 4-11. Summary of Equivalent Annual Catch (@ 3.0 percent) Number of Fish} Harvested (1,000 Fish Per Year) 1/

\begin{tabular}{|c|c|c|c|c|}
\hline $\operatorname{sos} 2 c$ & Fall Chinook & $\begin{array}{c}\text { Spring/Summer } \\
\text { Chinook }\end{array}$ & Steelhead & Sockeye \\
\hline \multicolumn{5}{|l|}{ COMMERCIAL: } \\
\hline \multirow{4}{*}{$\begin{array}{l}\text { Alaska Commercial } \\
\text { Canada Commercial } \\
\text { US Ocean Commercial } \\
\text { In-River Commercial }\end{array}$} & 50.3 & 0.0 & 0.0 & 0.0 \\
\hline & 168.2 & 5.1 & 0.0 & 0.0 \\
\hline & 40.3 & 0.1 & 0.0 & 0.0 \\
\hline & 220.1 & 0.3 & 214.2 & 11.0 \\
\hline \multicolumn{5}{|l|}{ SPORT: } \\
\hline Alaska Sport & 2.9 & 0.0 & 0.0 & 0.0 \\
\hline Canada Sport & 12.4 & 0.0 & 0.0 & 0.0 \\
\hline US Ocean Sport & 29.8 & 0.0 & 0.0 & 0.0 \\
\hline In-River Sport & 14.9 & 0.0 & 168.0 & 0.0 \\
\hline TOTAL CATCH & 538.9 & 5.7 & 382.2 & 11.0 \\
\hline SOS $5 b$ & Fall Chinook & $\begin{array}{c}\text { Spring/Summer } \\
\text { Chinook }\end{array}$ & Steelhead & Sockeye \\
\hline \multicolumn{5}{|l|}{ COMMERCIAL: } \\
\hline Alaska Commercial & 51.1 & 0.0 & 0.0 & 0.0 \\
\hline Canada Commercial & 170.9 & 4.1 & 0.0 & 0.0 \\
\hline US Ocean Commercial & 40.9 & 0.1 & 0.0 & 0.0 \\
\hline In-River Commercial & 223.6 & 0.3 & 165.6 & 8.9 \\
\hline \multicolumn{5}{|l|}{ SPORT: } \\
\hline Alaska Sport & 2.9 & 0.0 & 0.0 & 0.0 \\
\hline Canada Sport & 12.6 & 0.0 & 0.0 & 0.0 \\
\hline US Ocean Sport & 30.2 & 0.0 & 0.0 & 0.0 \\
\hline In-River Sport & 15.1 & 0.0 & 129.8 & 0.0 \\
\hline TOTAL CATCH & 547.5 & 4.6 & 295.4 & 8.9 \\
\hline
\end{tabular}


Table 4-12. Summary of the Equivalent Annual Value of the Commercial and Sport Catch of Salmon and Steelhead for Each SOS-Annual Values Discounted at 3.0 Percent $(\$ 1,000) 1 /$

\begin{tabular}{|c|c|c|c|c|c|c|}
\hline $\operatorname{sos} 41$ & $\begin{array}{c}\text { "Low" 2/ } \\
\text { Values } \\
\text { Commercial }\end{array}$ & $\begin{array}{l}\text { "Low" 2/ } \\
\text { Values } \\
\text { Sport }\end{array}$ & $\begin{array}{c}\text { "Low" 2/ } \\
\text { Value Totals }\end{array}$ & $\begin{array}{l}\text { "High" 3/ } \\
\text { Values } \\
\text { Commercial }\end{array}$ & $\begin{array}{c}\text { "High" 3/ } \\
\text { Values Sport }\end{array}$ & $\begin{array}{c}\text { "High" 3/ } \\
\text { Values Totals }\end{array}$ \\
\hline SOS 1a & 6,600 & 24,060 & 30,660 & 13,170 & 30,250 & 43,420 \\
\hline SOS 1b & 6,650 & 24,070 & 30,720 & 13,300 & 30,270 & 43,570 \\
\hline SOS $2 c$ & 6,650 & 24,240 & 30,890 & 13,270 & 30,480 & 43,750 \\
\hline $\operatorname{sos} 2 \mathrm{~d}$ & 6,760 & 24,190 & 30,950 & 13,490 & 30,420 & 43,910 \\
\hline SOS 4c & 6,740 & 24,230 & 30,970 & 13,430 & 30,480 & 43,910 \\
\hline $\operatorname{sos} 5 b$ & 6,440 & 19,470 & 25,910 & 12,890 & 24,490 & 37,380 \\
\hline SOS $5 c$ & 6,260 & 17,980 & 24,240 & 12,490 & 22,600 & 35,090 \\
\hline SOS 6b-op & 6,200 & 16,100 & 22,300 & 12,390 & 20,240 & 32,630 \\
\hline $\operatorname{sos} 6 b-p$ & 6,030 & 13,010 & 19,040 & 12,070 & 16,370 & 28,440 \\
\hline SOS 6d-op & 6,370 & 20,290 & 26,660 & 12,740 & 25,510 & 38,250 \\
\hline SOS $6 \mathrm{~d}-\mathrm{p}$ & 6,280 & 18,380 & 24,660 & 12,590 & 23,130 & 35,720 \\
\hline sos 9a-op & 4,810 & 13,880 & 18,690 & 9,590 & 17,450 & 27,040 \\
\hline SOS $9 a-p$ & 4,630 & 11,450 & 16,080 & 9,270 & 14,390 & 23,660 \\
\hline SOS $9 \mathrm{~b}$ & 6,240 & 22,200 & 28,440 & 12,490 & 27,910 & 40,400 \\
\hline SOS 9c-op & 6,050 & 16,080 & 22,130 & 12,050 & 20,210 & 32,260 \\
\hline $\operatorname{sos} 9 c-p$ & 5,860 & 13,180 & 19,040 & 11,720 & 16,570 & 28,290 \\
\hline Preferred Alt & 6,840 & 23,990 & 30,830 & 13,640 & 30,160 & 43,800 \\
\hline \multicolumn{7}{|c|}{$\begin{array}{l}\text { 1/ With transport scenario F86. } \\
\text { 2/ "Low" values based on net-to-gross of 50\%, sport value of } \$ 50.50 \text { per day } \\
\text { 3/ "High" values based on full ex-vessel value (net-to-gross } 100 \% \text { ), sport value of } \$ 63.50 / \text { day. } \\
\text { 4/ SOSs which end in "-op" represent "optimistic" assumptions of an increase of } 25 \% \text { in FGE with draw- } \\
\text { down. SOSs which end in "-p" represent "pessimistic" assumptions of a decrease of } 50 \% \text { in FGE with } \\
\text { drawdown. }\end{array}$} \\
\hline
\end{tabular}


Table 4-13. Summary of the Equivalent Annual Value of the Commercial and Sport Catch of Salmon and Steelhead for Each SOS-Annual Values Discounted at 7.75 Percent $(\$ 1,000) 1 /$

\begin{tabular}{|c|c|c|c|c|c|c|}
\hline $\operatorname{sos} 4 /$ & $\begin{array}{c}\text { "LOW" } 2 / \\
\text { VALUES } \\
\text { COMMERCIAL } \\
(\$ 1,000)\end{array}$ & $\begin{array}{l}\text { "LOW" 2/ } \\
\text { VALUES } \\
\text { Sport } \\
(\$ 1,000)\end{array}$ & $\begin{array}{l}\text { “LOW" 2/ } \\
\text { VALUES } \\
\text { TOTALS } \\
(\$ 1,000)\end{array}$ & $\begin{array}{c}\text { “HIGH" 3/ } \\
\text { VALUES } \\
\text { COMMERCIAL } \\
(\$ 1,000)\end{array}$ & $\begin{array}{c}\text { “HIGH" 3/ } \\
\text { VALUES } \\
\text { Sport } \\
(\$ 1,000)\end{array}$ & $\begin{array}{l}\text { "HIGH” } 3 / \\
\text { VALUES } \\
\text { TOTALS } \\
(\$ 1,000)\end{array}$ \\
\hline SOS 1a & 6,560 & 22,860 & 29,420 & 13,150 & 28,750 & 41,900 \\
\hline SOS $1 b$ & 6,640 & 22,890 & 29,530 & 13,270 & 28,760 & 42,030 \\
\hline SOS 2c & 6,630 & 23,040 & 29,670 & 13,260 & 28,970 & 42,230 \\
\hline $\operatorname{sos} 2 d$ & 6,730 & 23,010 & 29,740 & 13,480 & 28,920 & 42,400 \\
\hline $\operatorname{SOS} 4 c$ & 6,690 & 23,020 & 29,710 & 13,390 & 28,950 & 42,340 \\
\hline $\operatorname{sos} 5 b$ & 6,570 & 20,430 & 27,000 & 13,120 & 25,680 & 38,800 \\
\hline $\operatorname{sos} 5 c$ & 6,350 & 17,900 & 24,250 & 12,680 & 22,520 & 35,200 \\
\hline SOS 6b-op & 6,430 & 17,860 & 24,290 & 12,850 & 22,460 & 35,310 \\
\hline SOS $6 b-p$ & 6,330 & 16,090 & 22,420 & 12,670 & 20,220 & 32,890 \\
\hline SOS 6d-op & 6,450 & 19,560 & 26,010 & 12,890 & 24,580 & 37,470 \\
\hline $\operatorname{sos} 6 \mathrm{~d}-\mathrm{p}$ & 6,420 & 18,190 & 24,610 & 12,860 & 22,880 & 35,740 \\
\hline SOS 9a-op & 5,580 & 16,560 & 22,140 & 11,180 & 20,830 & 32,010 \\
\hline $\operatorname{sos} 9 a-p$ & 5,500 & 15,160 & 20,660 & 10,990 & 19,050 & 30,040 \\
\hline SOS 9B & 6,280 & 21,220 & 27,500 & 12,550 & 26,690 & 39,240 \\
\hline SOS 9c-op & 6,340 & 17,850 & 24,190 & 12,640 & 22,450 & 35,090 \\
\hline SOS $9 c-p$ & 6,240 & 16,180 & 22,420 & 12,460 & 20,350 & 32,810 \\
\hline Preferred Alt & 6,780 & 22,820 & 29,600 & $13 ; 580$ & 28,690 & 42,270 \\
\hline \multicolumn{7}{|c|}{$\begin{array}{l}\text { 1/ With transport scenario F86. } \\
2 / \text { "Low" values based on net-to-gross of 50\%, sport value of } \$ 50.50 \text { per day } \\
\text { 3/"High" values based on full ex-vessel value (net-to-gross } 100 \% \text { ), sport value of } \$ 63.50 / \text { day. } \\
\text { 4/SOSs which end in "-op" represent "optimistic" assumptions of an increase of } 25 \% \text { in FGE with drawdown. SOSs which } \\
\text { end in "-p" represent "pessimistic" assumptions of a decrease of } 50 \% \text { in FGE with drawdown. }\end{array}$} \\
\hline
\end{tabular}




\subsection{RESIDENT FISH AND WILDLIFE}

The analysis of potential impacts of the SOSs on resident fish and wildlife can be found in Appendices $\mathrm{K}$ and $\mathrm{N}$, respectively. From an economic perspective, the monetary value of the resident fish and wildlife would be captured in the recreation analysis. Fishing and hunting success and the quality of wildlife viewing opportunities influence visitor days at any recreation facility. The change in visitor days resulting from changes in the resident fish and wildlife populations would be translated into monetary values the same way that sport fishing of anadromous fish was done in Section 4.2 and Exhibit D of this appendix.

The estimation of visitor days indirectly accounts for changes in fish and wildlife with each SOS. However, the RWG did not have the data required to explicitly model correlations in fish and wildlife habitat to recreation activity or value. But the RWG observed from review of the trends demonstrated for fish habitat (and therefore fishing success), which are described in Appendix $\mathrm{K}$, that very similar trends in recreation access occurr for each SOS. Recreation access was the determining factor in the recreation use estimating model. Hence, the economic values of fish and wildlife impacts were indirectly accounted for in the recreation analysis.

\subsection{FLOOD CONTROL}

The analysis of flood damages divides the region into the following sub-areas: upper Columbia River, Clearwater River, and lower Columbia River. In addition, levees protect the Tri-Cities area, principally from the backwater of the reservoir created by the McNary Dam. This area is located on the Columbia River just upstream from its confluence with the Snake River. Impacts of the various SOSs on flood control are measured in terms of average annual damages which are based on July 1992 prices and 1995 (base year) conditions. Future growth in damages was not considered significant for this study and was therefore not included in the analysis. A summary of the analysis of expected average annual flood damages for each of the damage centers within each of the sub-areas included in the study are presented in this chapter. Detailed information correlating expected average annual damages by damage category, by damage center, and SOS can be found in Exhibit B of this appendix

An important consideration in the analysis is that none of the SOSs evaluated for either the Draft EIS or the Final EIS included changes to the flood control operating rule curves of the storage projects in the Columbia/Snake system. The flood control operating rule curves, which incorporate consideration of the amount of water that is forecast to runoff during each water-year included in the historic record, specify the upper limit of the pool elevation of each flood control storage project. Since these curves were not changed for any of the SOSs, every SOS provided for the same amount of total storage available to control floods in the Columbia River Basin above Bonneville Dam. Without changes to the flood control rule curves, the EAG expected that only minor changes in peak discharges and stages would occur among the SOSs and that changes in expected flood damages would be relatively insignificant. As shown in the following summary of expected damages, this expectation was generally correct.

In addition, readers are cautioned that the Corps has initiated a comprehensive review of the operation of the Columbia/Snake system for flood control. Thus, the information presented here and in Exhibit $B$ may change as a result of that review. The initial phase of the review will be completed and preliminary results will be available in about November 1996. A summary description of the review is included in Section B4.2 of Exhibit B of this appendix.

\subsubsection{Upper Columbia River}

In the Upper Columbia subarea, SOS $4 c$ (stable storage operation) will increase flood damages over the base case (SOS 2c) in the damage reach below Libby Dam as a result of reduced flood control storage space. SOSs 9a, 9b, and 9c (Settlement Discussion Alternatives) also tend to increase flood damages in the Upper Columbia subarea to varying degrees. In addition, the preferred alternative (PA), results in an increase in flood damages because the 
1995 Biological Opinions upon which this alternative is based tends to hold pools in the storage reservoirs at higher elevations. Alternatives $1 \mathrm{a}, 1 \mathrm{~b}, 2 \mathrm{~d}, 5 \mathrm{~b}, 5 \mathrm{c}$, $6 \mathrm{~b}$, and $6 \mathrm{~d}$ have no affect on flood damages in the Upper Columbia subarea.

A summary of expected average annual damages associated with each SOS for the six damage centers located in this subarea is shown in Table 4-14. Since damages are expected to be the same over the entire period of analysis, it was not necessary to present-value damages for any of the SOSs. Therefore, average annual damages and equivalent annual damages are the same for both rates of interest used in the study- -7.75 percent and 3.0 percent.

\subsubsection{Clearwater River}

This subarea is composed of two damage reaches: Dworshak Dam to Lewiston Levees, and Lewiston Levees to Snake River. In addition to the flood control storage at Dworshak Dam, the major dam- age centers of Lewiston, Idaho and Clarkston, Washington are protected by levees. As none of the SOSs would result in a discharge which exceeds the safe-water height of the levees at Lewiston, all flood damages associated with the various SOSs within this subarea are located in the upriver Dworshak Dam to Lewiston levees reach. Since development in the Dworshak to Lewiston reach is relatively minor and the extent of overbank flooding would be relatively minor, expected damages in the reach are minimal for all of the alternatives. In fact, the analysis of discharge and expected damages for the SOSs included in the FEIS showed that expected damages for each of the alternatives would be exactly equal to those for the base case (SOS 2c). Expected damages for each of the SOSs for the two interest rates of 7.75 percent and 3.0 percent are shown in Tables 4-15 and 4-16, respectively. Expected damages are the same for each SOS because they each used exactly the same flood control rule curves for operation of the Dworshak project.

Table 4-14. Summary of Flood Damages, Upper Columbia River Subarea $(\$ 1,000)$

\begin{tabular}{|c|c|c|c|c|c|c|c|}
\hline SOS & $\begin{array}{c}\text { Libby } \\
\text { Dam/ } \\
\text { Kootenay } \\
\text { Falls }\end{array}$ & $\begin{array}{c}\text { Columbia } \\
\text { Falls/ } \\
\text { Flathead } \\
\text { Lake }\end{array}$ & $\begin{array}{c}\text { Flathead } \\
\text { Lake }\end{array}$ & $\begin{array}{c}\text { Kerr Dam/ } \\
\text { Thompson }\end{array}$ & $\begin{array}{c}\text { Pend } \\
\text { Oreille } \\
\text { Lake }\end{array}$ & $\begin{array}{c}\text { Albeni Falls } \\
\text { Dam/ } \\
\text { Cusick }\end{array}$ & $\begin{array}{c}\text { Total } \\
\text { Damages }\end{array}$ \\
\hline SOS 1a & $\$ 17.5$ & $\$ 1032.5$ & $\$ 194.9$ & $\$ 299.6$ & $\$ 674.0$ & $\$ 1056.2$ & $\$ 3,274.7$ \\
\hline SOS 1b & 17.5 & 1032.5 & 194.9 & 299.6 & 674.0 & 1056.2 & $3,274.7$ \\
\hline SOS 2c & 17.5 & 1032.5 & 194.9 & 299.6 & 674.0 & 1056.2 & $3,274.7$ \\
\hline SOS 2d & 17.5 & 1032.5 & 194.9 & 299.6 & 674.0 & 1056.2 & $3,274.7$ \\
\hline SOS 4c & 461.6 & 1032.5 & 194.9 & 299.6 & 674.0 & 1056.2 & $3,718.8$ \\
\hline SOS 5b & 17.5 & 1032.5 & 194.9 & 299.6 & 674.0 & 1056.2 & $3,274.7$ \\
\hline SOS 5c & 17.5 & 1032.5 & 194.9 & 299.6 & 674.0 & 1056.2 & $3,274.7$ \\
\hline SOS 6b & 17.5 & 1032.5 & 194.9 & 299.6 & 674.0 & 1056.2 & $3,274.7$ \\
\hline SOS 6d & 17.5 & 1032.5 & 194.9 & 299.6 & 674.0 & 1056.2 & $3,274.7$ \\
\hline SOS 9a & 38.8 & 1268.7 & 194.9 & 299.6 & 674.0 & 1056.2 & $3,532.2$ \\
\hline SOS 9b & 44.9 & 1032.5 & 194.9 & 299.6 & 674.0 & 1056.2 & $3,302.1$ \\
\hline SOS 9c & 476.3 & 1032.5 & 194.9 & 299.6 & 674.0 & 1056.2 & $3,733.5$ \\
\hline PA & 49.3 & 1032.5 & 301.3 & 384.2 & 674.0 & 1056.2 & $3,497.5$ \\
\hline
\end{tabular}


Table 4-15. Analysis of Equivalent Annual Flood Damages Dworshak to Lewiston Levees (7.75 Percent Interest)

\begin{tabular}{|l|c|c|c|c|c|c|c|c|c|}
\hline SOS & $\begin{array}{c}\text { Year } \\
\text { on- } \\
\text { Line }\end{array}$ & $\begin{array}{c}\text { Initial } \\
\text { Expected } \\
\text { Annual } \\
\text { Damage }\end{array}$ & $\begin{array}{c}\text { Duration } \\
\text { of Initial } \\
\text { Damage } \\
\text { (No. Years) }\end{array}$ & $\begin{array}{c}\text { Ultimate } \\
\text { Expected } \\
\text { Annual } \\
\text { Damage }\end{array}$ & $\begin{array}{c}\text { Duration } \\
\text { of } \\
\text { Ultimate } \\
\text { Damage } \\
\text { (No. Years) }\end{array}$ & $\begin{array}{c}\text { Present } \\
\text { Value } \\
\text { Initial } \\
\text { Damage }\end{array}$ & $\begin{array}{c}\text { Present } \\
\text { Value } \\
\text { Ultimate } \\
\text { Damage }\end{array}$ & $\begin{array}{c}\text { Total } \\
\text { Present } \\
\text { Value }\end{array}$ & $\begin{array}{c}\text { Equivalent } \\
\text { Annual } \\
\text { Damage } \\
\mathbf{7 . 7 5 \%}\end{array}$ \\
\hline SOS 1a & 1995 & $\$ 10,275$ & 0 & $\$ 10,275$ & 100 & $\$ 0$ & $\$ 132,505$ & $\$ 132,505$ & $\$ 10,275$ \\
\hline SOS 1b & 1995 & $\$ 10,275$ & 0 & $\$ 10,275$ & 100 & $\$ 0$ & $\$ 132,505$ & $\$ 132,505$ & $\$ 10,275$ \\
\hline SOS 2b & 1995 & $\$ 10,275$ & 0 & $\$ 10,275$ & 100 & $\$ 0$ & $\$ 132,505$ & $\$ 132,505$ & $\$ 10,275$ \\
\hline SOS 2c & 1995 & $\$ 10,275$ & 0 & $\$ 10,275$ & 100 & $\$ 0$ & $\$ 132,505$ & $\$ 132,505$ & $\$ 10,275$ \\
\hline SOS 2d & 1995 & $\$ 10,275$ & 0 & $\$ 10,275$ & 100 & $\$ 0$ & $\$ 132,505$ & $\$ 132,505$ & $\$ 10,275$ \\
\hline SOS 4c & 1995 & $\$ 10,275$ & 0 & $\$ 10,275$ & 100 & $\$ 0$ & $\$ 132,505$ & $\$ 132,505$ & $\$ 10,275$ \\
\hline SOS 5b & 2010 & $\$ 10,275$ & 15 & $\$ 10,275$ & 85 & $\$ 89,308$ & $\$ 43,197$ & $\$ 132,505$ & $\$ 10,275$ \\
\hline SOS 5c & 2000 & $\$ 10,275$ & 5 & $\$ 10,275$ & 95 & $\$ 41,297$ & $\$ 91,208$ & $\$ 132,505$ & $\$ 10,275$ \\
\hline SOS 6b & 2005 & $\$ 10,275$ & 10 & $\$ 10,275$ & 90 & $\$ 69,731$ & $\$ 62,774$ & $\$ 132,505$ & $\$ 10,275$ \\
\hline SOS 6d & 2000 & $\$ 10,275$ & 5 & $\$ 10,275$ & 95 & $\$ 41,297$ & $\$ 91,208$ & $\$ 132,505$ & $\$ 10,275$ \\
\hline SOS 9a & 2005 & $\$ 10,275$ & 10 & $\$ 10,275$ & 90 & $\$ 41,297$ & $\$ 91,208$ & $\$ 132,505$ & $\$ 10,275$ \\
\hline SOS 9b & 1995 & $\$ 10,275$ & 0 & $\$ 10,275$ & 100 & $\$ 0$ & $\$ 132,505$ & $\$ 132,505$ & $\$ 10,275$ \\
\hline SOS 9c & 2005 & $\$ 10,275$ & 10 & $\$ 10,275$ & 90 & $\$ 69,731$ & $\$ 62,774$ & $\$ 132,505$ & $\$ 10,275$ \\
\hline PA & 1998 & $\$ 10,275$ & 3 & $\$ 10,275$ & 97 & $\$ 26,600$ & $\$ 105,905$ & $\$ 132,505$ & $\$ 10,275$ \\
\hline
\end{tabular}


Table 4-16. Analysis of Equivalent Annual Flood Damages, Dworshak to Lewiston Levees (3.0 Percent Interest)

\begin{tabular}{|l|c|c|c|c|c|r|r|r|r|}
\hline SOS & $\begin{array}{c}\text { Year } \\
\text { on- } \\
\text { Line }\end{array}$ & $\begin{array}{c}\text { Initial } \\
\text { Expected } \\
\text { Annual } \\
\text { Damage }\end{array}$ & $\begin{array}{c}\text { Duration } \\
\text { of Initial } \\
\text { Damage } \\
\text { (No. } \\
\text { Years) }\end{array}$ & $\begin{array}{c}\text { Ultimate } \\
\text { Expected } \\
\text { Annual } \\
\text { Damage }\end{array}$ & $\begin{array}{c}\text { Duration } \\
\text { of } \\
\text { Ultimate } \\
\text { Damage } \\
\text { (No. } \\
\text { Years) }\end{array}$ & $\begin{array}{c}\text { Present } \\
\text { Value } \\
\text { Initial } \\
\text { Damage }\end{array}$ & $\begin{array}{c}\text { Present } \\
\text { Value } \\
\text { Ultimate } \\
\text { Damage }\end{array}$ & $\begin{array}{c}\text { Total } \\
\text { Present } \\
\text { Value }\end{array}$ & $\begin{array}{c}\text { Equivalent } \\
\text { Annual } \\
\text { Damage } \\
\mathbf{3 . 0 \%}\end{array}$ \\
\hline SOS 1a & 1995 & $\$ 10,275$ & 0 & $\$ 10,275$ & 100 & $\$ 0$ & $\$ 324,679$ & $\$ 324,679$ & $\$ 10,275$ \\
\hline SOS 1b & 1995 & $\$ 10,275$ & 0 & $\$ 10,275$ & 100 & $\$ 0$ & $\$ 324,679$ & $\$ 324,679$ & $\$ 10,275$ \\
\hline SOS 2b & 1995 & $\$ 10,275$ & 0 & $\$ 10,275$ & 100 & $\$ 0$ & $\$ 324,679$ & $\$ 324,679$ & $\$ 10,275$ \\
\hline SOS 2c & 1995 & $\$ 10,275$ & 0 & $\$ 10,275$ & 100 & $\$ 0$ & $\$ 324,679$ & $\$ 324,679$ & $\$ 10,275$ \\
\hline SOS 2d & 1995 & $\$ 10,275$ & 0 & $\$ 10,275$ & 100 & $\$ 0$ & $\$ 324,679$ & $\$ 324,679$ & $\$ 10,275$ \\
\hline SOS 4c & 1995 & $\$ 10,275$ & 0 & $\$ 10,275$ & 100 & $\$ 0$ & $\$ 324,679$ & $\$ 324,679$ & $\$ 10,275$ \\
\hline SOS 5b & 2010 & $\$ 10,275$ & 15 & $\$ 10,275$ & 85 & $\$ 122,662$ & $\$ 202,017$ & $\$ 324,679$ & $\$ 10,275$ \\
\hline SOS 5c & 2000 & $\$ 10,275$ & 5 & $\$ 10,275$ & 95 & $\$ 47,057$ & $\$ 277,622$ & $\$ 324,679$ & $\$ 10,275$ \\
\hline SOS 6b & 2005 & $\$ 10,275$ & 10 & $\$ 10,275$ & 90 & $\$ 87,648$ & $\$ 237,031$ & $\$ 324,679$ & $\$ 10,275$ \\
\hline SOS 6d & 2000 & $\$ 10,275$ & 5 & $\$ 10,275$ & 95 & $\$ 47,057$ & $\$ 277,622$ & $\$ 324,679$ & $\$ 10,275$ \\
\hline SOS 9a & 2005 & $\$ 10,275$ & 10 & $\$ 10,275$ & 90 & $\$ 87,648$ & $\$ 237,031$ & $\$ 324,679$ & $\$ 10,275$ \\
\hline SOS 9b & 1995 & $\$ 10,275$ & 0 & $\$ 10,275$ & 100 & $\$ 0$ & $\$ 324,679$ & $\$ 324,679$ & $\$ 10,275$ \\
\hline SOS 9c & 2005 & $\$ 10,275$ & 10 & $\$ 10,275$ & 90 & $\$ 87,648$ & $\$ 237,031$ & $\$ 324,679$ & $\$ 10,275$ \\
\hline PA & 1998 & $\$ 10,275$ & 3 & $\$ 10,275$ & 97 & $\$ 29,064$ & $\$ 295,615$ & $\$ 324,679$ & $\$ 10,275$ \\
\hline
\end{tabular}

\subsubsection{Tri-Cities}

The Tri-Cities area is located on the Columbia River just upstream from its confluence with the Snake River. The area includes the cities of Kennewick, Pasco, and Richland. All three cities are protected from flooding by the Columbia River by levees. The levees were constructed in the early 1950's as part of the McNary Dam project to protect the three cities from the backwaters of the dam.

The area now has a very high level of flood protection as is indicated by a study by the Corps of Engineers (Reconnaissance Report, Tri-Cities Levees, Washington, 9 August 1991) which concluded that the levees could be lowered from 5 to 6 feet (depending on the levee) without reducing the level of flood protection. Since only minor changes in the maximum level of flow and stage are expected with the SOSs included in the FEIS, a specific analysis of changes in stage at Tri-Cities and expected damages was not conducted.

\subsubsection{Lower Columbia River}

In the lower Columbia River subarea, only major damage centers, all of which are protected by levees as well the upstream storage reservoirs in the US and Canada, were evaluated for potential flood damages. Currently available information indicate 
that under the base case (SOS 2c), flood damages in this subarea range from an estimated $\$ 9$ million at a peak discharge at The Dalles of $450,000 \mathrm{cfs}$ to an estimated $\$ 1.4$ billion at a peak discharge at The Dalles of $850,000 \mathrm{cfs}$. These estimates of damages, however, are based on relatively old data and recent experience with flows in the range of $450,000 \mathrm{cfs}$ indicates that estimate of damages may overstate actual damages. With the base case operation of the system, a peak discharge at The Dalles of 450,000 is expected to occur about once in every two to five years. A peak discharge of $850,000 \mathrm{cfs}$ is expected to occur about once in every 200 to 500 years. Although SOSs 1, 9 and the preferred alternative would increase river stages throughout the subarea, the increase would be less than one foot at each location. This would not impact the levee-protected areas evaluated in the study as they would have from $\mathbf{3 . 5}$ to 11.4 feet of free-board above the highest discharges considered--an event which could be expected to occur only about once in about 500 years. Areas not protected by major levee systems would continue to experience flooding and floodrelated damages under high discharge conditions, both under the base case and with each of the alternative operating plans. A damage assessment of those areas was not conducted during this study.

Table 4-17 provides a comparison between levee crest elevations and river stage elevation, based upon the highest discharge event related to each SOS. None of the six damage centers included in the study would experience overtopping of levees under any of the proposed SOS scenarios. Consequently, no flood damages are expected to result, because in all cases, river stages are well below the existing crest elevations of the levees.

\subsubsection{Summary of Flood Damages}

Expected average annual flood damages for each subarea of the river by SOS are summarized in Tables 4-18 and 4-19 for discount rates of 7.75 percent and 3.0 percent, respectively. The values shown are equivalent annual damages which represent average conditions which would occur over the 100-year period of analysis beginning in 1995.

\subsection{IRRIGATION AND MUNICIPAL AND INDUSTRIAL WATER SUPPLY}

\subsubsection{Overview}

This chapter identifies the monetary impacts on irrigation and M\&I water users who pump from reservoir pools on the Columbia and Lower Snake rivers and would be directly impacted by SOR alternative SOSs. Specifically, SOSs which include reservoir drawdown would affect the pumping operations of these water users. Drawdown lowers the water surface which increases the pumping lift and, in most cases, requires relocation and modification of the pumping facilities. The methodology and measurement concepts used to quantify the impacts are presented in Section 3.3.4 of Chapter 3. Monetary impacts for each SOS are presented in this section. A detailed discussion of the analysis of the impacts of the alternative SOSs on irrigation and M\&I water users is presented in Appendix F (Irrigation, Municipal and Industrial Water Supply).

The results of the analysis of impacts on reservoir pumpers who might be impacted by the alternative SOSs are presented in two parts: (1) irrigation pumping associated with commercial agriculture termed "commercial irrigation"; and (2) M\&I users, which includes water users who pump water from the reservoirs for municipal and industrial purposes (M\&I), fish hatcheries, recreation areas, wildlife habitat, and other uses.

Impacts on commercial irrigators have been identified for water users who pump from Grand Coulee, Ice Harbor and John Day pools. There is no irrigation water use at the other lower Snake River reservoirs. Impacts on M\&I water users have been identified for Lower Granite, Little Goose, Lower Monumental, Ice Harbor and John Day reservoir pools.

Because the SOSs have different implementation dates it was necessary to discount all values to first year of the period of analysis--1995. Economic information presented in this section shows values at the time in which each SOS could be implemented, as well as annual equivalent values. Annual 
Table 4-17. Comparison of Levee Crest Elevations to River Stages* $-500-$ Year Discharge Event at The Dalles, OR (in Feet NGVD)

\begin{tabular}{|c|c|c|c|c|c|c|c|c|c|c|c|c|c|c|c|c|}
\hline District & $\begin{array}{l}\text { River } \\
\text { Mile }\end{array}$ & $\begin{array}{c}\text { Levee } \\
\text { Crest } \\
\text { Elevation }\end{array}$ & $\begin{array}{c}\text { (Base) } \\
\text { SOS } \\
2-C\end{array}$ & $\begin{array}{c}\text { Net } \\
\text { Free- } \\
\text { Board }\end{array}$ & $\begin{array}{l}\text { SOS } \\
1-A\end{array}$ & $\begin{array}{c}\text { Net } \\
\text { Free- } \\
\text { Board }\end{array}$ & $\begin{array}{l}\text { SOS } \\
4-C\end{array}$ & $\begin{array}{c}\text { Net } \\
\text { Free- } \\
\text { Board }\end{array}$ & $\begin{array}{l}\text { SOS } \\
\text { 5-B }\end{array}$ & $\begin{array}{c}\text { Net } \\
\text { Free- } \\
\text { Board }\end{array}$ & $\begin{array}{l}\text { SOS } \\
6-B\end{array}$ & $\begin{array}{c}\text { Net } \\
\text { Free- } \\
\text { Board }\end{array}$ & $\begin{array}{l}\text { SOS } \\
9-C\end{array}$ & $\begin{array}{l}\text { Net } \\
\text { Free- } \\
\text { Board }\end{array}$ & PA & $\begin{array}{c}\text { Net } \\
\text { Free- } \\
\text { Board }\end{array}$ \\
\hline Washougal & 125.4 & 43 & 36.7 & 6.3 & 37.3 & 5.7 & 36.3 & 6.7 & 36.7 & 6.3 & 36.6 & 6.4 & 37.4 & 5.6 & 37.4 & 5.6 \\
\hline Sandy & 120.2 & 45 & 35.2 & 9.8 & 35.9 & 9.1 & 34.8 & 10.2 & 35.9 & 9.8 & 35.1 & 9.9 & 36.0 & 9 & 36.0 & 9.0 \\
\hline Multnomah & 113.7 & 44 & 33.2 & 10.8 & 33.9 & 10.1 & 32.6 & 11.4 & 33.2 & 10.8 & 33.0 & 11 & 34.0 & 10 & 34.0 & 10.0 \\
\hline Peninsula 2 & 107 & 35.8 & 31.1 & 4.7 & 31.8 & 4 & 30.6 & 5.2 & 31.1 & 4.7 & 31.0 & 4.8 & 32.0 & 3.8 & 32.0 & 3.8 \\
\hline Peninsula 1 & 106.1 & 35.3 & 30.9 & 4.4 & 31.6 & 3.7 & 30.4 & 4.9 & 30.9 & 4.4 & 30.7 & 4.6 & 31.8 & 3.5 & 31.8 & 3.5 \\
\hline Longview & 64.4 & 28.9 & 18.3 & 10.6 & 18.9 & 10 & 17.9 & 11 & 18.3 & 10.6 & 18.2 & 10.7 & 19.0 & 9.9 & 19.0 & 9.9 \\
\hline
\end{tabular}


Table 4-18. Total Equivalent Annual Flood Damages, Columbia Basin (Discount Rate of 7.75 Percent- $\$ 1,000$ )

\begin{tabular}{|l|r|r|r|r|}
\hline \multicolumn{1}{|c|}{ SOS } & $\begin{array}{c}\text { Upper } \\
\text { Columbia }\end{array}$ & $\begin{array}{c}\text { Clearwater } \\
\text { River }\end{array}$ & $\begin{array}{c}\text { Lower } \\
\text { Columbia }\end{array}$ & $\begin{array}{c}\text { Total } \\
\text { Damages }\end{array}$ \\
\hline SOS 1a & $\$ 3,274.7$ & $\$ 10.3$ & $\$ 0$ & $\$ 3285.0$ \\
\hline SOS 1b & $\$ 3,274.7$ & $\$ 10.3$ & 0 & $\$ 3285.0$ \\
\hline SOS 2c & $\$ 3,274.7$ & $\$ 10.3$ & 0 & $\$ 3285.0$ \\
\hline SOS 2d & $\$ 3,274.7$ & $\$ 10.3$ & 0 & $\$ 3285.0$ \\
\hline SOS 4c & $\$ 3,718.8$ & $\$ 10.3$ & 0 & $\$ 3729.1$ \\
\hline SOS 5b & $\$ 3,274.7$ & $\$ 10.3$ & 0 & $\$ 3285.0$ \\
\hline SOS 5c & $\$ 3,274.7$ & $\$ 10.3$ & 0 & $\$ 3285.0$ \\
\hline SOS 6b & $\$ 3,274.7$ & $\$ 10.3$ & 0 & $\$ 3285.0$ \\
\hline SOS 6d & $\$ 3,274.7$ & $\$ 10.3$ & 0 & $\$ 3285.0$ \\
\hline SOS 9a & $\$ 3,532.0$ & $\$ 10.3$ & 0 & $\$ 3,542.3$ \\
\hline SOS 9b & $\$ 3,302.1$ & $\$ 10.3$ & 0 & $\$ 3.312 .4$ \\
\hline SOS 9c & $\$ 3,733.5$ & $\$ 10.3$ & 0 & $\$ 3,743.8$ \\
\hline PA & $\$ 3,497.5$ & $\$ 10.3$ & & $\$ 3,507.8$ \\
\hline
\end{tabular}

Table 4-19. Total Equivalent Annual Flood Damages, Columbia Basin (Discount Rate of 3.0 Percent- $\$ 1,000)$

\begin{tabular}{|l|r|r|r|r|}
\hline \multicolumn{1}{|c|}{ SOS } & $\begin{array}{c}\text { Upper } \\
\text { Columbia }\end{array}$ & $\begin{array}{c}\text { Clearwater } \\
\text { River }\end{array}$ & $\begin{array}{c}\text { Lower } \\
\text { Columbia }\end{array}$ & $\begin{array}{c}\text { Total } \\
\text { Damages }\end{array}$ \\
\hline SOS 1a & $\$ 3,274.7$ & $\$ 10.3$ & 0 & $\$ 3285.0$ \\
\hline SOS 1b & $\$ 3,274.7$ & $\$ 10.3$ & 0 & $\$ 3285.0$ \\
\hline SOS 2c & $\$ 3,274.7$ & $\$ 10.3$ & 0 & $\$ 3285.0$ \\
\hline SOS 2d & $\$ 3,274.7$ & $\$ 10.3$ & 0 & $\$ 3285.0$ \\
\hline SOS 4c & $\$ 3,718.8$ & $\$ 10.3$ & 0 & $\$ 3729.1$ \\
\hline SOS 5b & $\$ 3,274.7$ & $\$ 10.3$ & 0 & $\$ 3285.0$ \\
\hline SOS 5c & $\$ 3,274.7$ & $\$ 10.3$ & 0 & $\$ 3285.0$ \\
\hline SOS 6b & $\$ 3,274.7$ & $\$ 10.3$ & 0 & $\$ 3285.0$ \\
\hline SOS 6d & $\$ 3,274.7$ & $\$ 10.3$ & $\$ 3285.0$ \\
\hline SOS 9a & $\$ 3,532.0$ & $\$ 10.3$ & 0 & $\$ 3,542.3$ \\
\hline SOS 9b & $\$ 3,302.1$ & $\$ 10.3$ & 0 & $\$ 3.312 .4$ \\
\hline SOS 9c & $\$ 3,733.5$ & $\$ 10.3$ & 0 & $\$ 3,743.8$ \\
\hline PA & $\$ 3,497.5$ & $\$ 10.3$ & & $\$ 3,507.8$ \\
\hline
\end{tabular}


equivalent values were computed by present valuing average annual values back to 1995 . Average annual and equivalent annual values are shown at both of the interest rates used in the SOR, 3 percent and 7.75 percent.

\subsubsection{Impacts of Reservoir Drawdown on Commercial Irrigation}

Economic impacts of the SOSs on reservoir water users classified as commercial irrigators was analyzed for two categories of users: (1) irrigators receiving water from Grand Coulee; and (2) irrigators pumping water from the John Day and Ice Harbor. These impacts are discussed in the following paragraphs.

\subsubsection{Grand Coulee}

Water is pumped from Lake Roosevelt to Banks Lake by Reclamation for use by irrigators who belong to the three irrigation districts served by the Columbia Basin Federal Reclamation Project (Columbia Basin Project). Reclamation delivers water to the districts in accordance with Federal law and contracts with the irrigation districts. The districts pay pumping costs based on criteria established in the contract. The current repayment rate (1993), subject to review at 5 -year intervals, is 0.95 mills per kilowatt-hour $(\$ .00095 / \mathrm{kwh})$.

Irrigation pumping requirements for the Columbia Basin Project at Grand Coulee were analyzed for each of the 13 SOSs, which includes the Base Case (SOS 1a) and the No Action Alternative (SOS 2c). Chapter 3 (Section 3.3.4) describes the variables and measurement standards used to model the pumping requirement.

The annual irrigation pumping requirement at Coulee and the repayment cost to pump the water is approximately $959,300 \mathrm{MWhrs}$ and $\$ 911,300$ respectively under the No Action Alternative (SOS 2c). Annual pumping requirements in MWhrs and the cost of that power at the current power rate for each of the 13 final SOSs at 3.0 and 7.75 percent interest are shown in Table 4-20. Average annual and equivalent annual costs are the same for both interest rates because the analysis assumes that changes in the operation of Grand Coulee Dam for all of the SOSs could be implemented at the same point in time--1995. This assumption is based on the fact that no physical modifications of the existing pumping plant would be required.

The analysis shows that the alternative SOSs have only relatively minor effects on irrigation pumping costs at Grand Coulee. These impacts are illustrated in Figure 4-3. The greatest impact would occur under SOS 9a which has a total annual pumping cost of $\$ 946,200$.

\subsubsection{Ice Harbor and John Day}

The analysis of commercial irrigation identified 13 irrigators irrigating a combined total of 36,389 acres (14,726.16 hectares) from the Ice Harbor pool and 25 irrigators irrigating a combined total of 139,500 acres $(56,497.50$ hectares) from the John Day Pool. Under reservoir drawdown, costs of pumping for agricultural purposes the Ice Harbor reservoir are increased under SOS's $5 b, 5 c, 6 b, 9 a$ and 9c. With drawdown at John Day reservoir, commercial irrigation pumping costs are increased under SOS's $5 \mathrm{~b}, 5 \mathrm{c}, 6 \mathrm{~b}, 6 \mathrm{~d}, 9 \mathrm{a}, 9 \mathrm{c}$, and the preferred alternative.

Implementation of SOSs which include drawdown of the Ice Harbor and John Day reservoir pools would increase capital and operating costs of pumping plant systems located on or adjacent to the reservoir pools. As discussed in Chapter 3, Section 3.3.4, increased costs include the capital cost incurred to modify the pumping plants, increased annual operation and maintenance costs, and the increased power cost due to greater lift requirements (total dynamic head). Table 4-21 shows modification costs and increased operating costs for commercial irrigation for each of the SOSs at Ice Harbor and John Day reservoirs. Total average annual, equivalent annual cost is shown in tables 4-22 (7.75 percent interest rate) and 4-23 (3.0 percent interest rate). These costs are somewhat higher than those reported in the DEIS primarily because of revisions to the number of irrigated acres and the number of pump stations requiring modification. 
Table 4-20. Annual Irrigation Pumping Requirement and Cost from Grand Coulee to Banks Lake (Federal Columbia Basin Project)

\begin{tabular}{|c|c|c|c|c|c|}
\hline SOS & $\begin{array}{c}\text { Annual Megawatt } \\
\text { Hours of } \\
\text { Pumping }\end{array}$ & $\begin{array}{c}\text { Value of Energy at } \\
\text { Repayment Rate } \\
\text { @ \$.95/mwh }\end{array}$ & $\begin{array}{c}\text { Implementation } \\
\text { Date }\end{array}$ & \multicolumn{2}{|c|}{$\begin{array}{c}\text { Equivalent Annual } \\
\text { Value (\$) }\end{array}$} \\
\cline { 5 - 6 } & 968,701 & $\$ 920,300$ & 1995 & $\$ 920,300$ & $\$ 920,300$ \\
\hline SOS 1a & 968,667 & 920,200 & 1995 & 920,200 & 920,200 \\
\hline SOS 1b & 959,254 & 911,300 & 1995 & 911,300 & 911,300 \\
\hline SOS 2c & 955,776 & 908,000 & 1995 & 908,000 & 908,000 \\
\hline SOS 2d & 939,874 & 892,900 & 1995 & 892,900 & 892,900 \\
\hline SOS 4c & 959,279 & 911,300 & 2010 & 911,300 & 911,300 \\
\hline SOS 5b & 959,279 & 911,300 & 2000 & 911,300 & 911,300 \\
\hline SOS 5c & 959,279 & 911,300 & 2005 & 911,300 & 911,300 \\
\hline SOS 6b & 959,279 & 911,300 & 2000 & 911,300 & 911,300 \\
\hline SOS 6d & 995,961 & 946,200 & 2005 & 946,200 & 946,200 \\
\hline SOS 9a & 964,975 & 916,700 & 1995 & 916,700 & 916,700 \\
\hline SOS 9b & 965,600 & 917,300 & 2005 & 917,300 & 917,300 \\
\hline SOS 9c & 956,300 & 908,500 & 1998 & 908,500 & 908,500 \\
\hline PA & & & & \\
\hline
\end{tabular}

Impacts: Pumping from FDR to Banks Lake

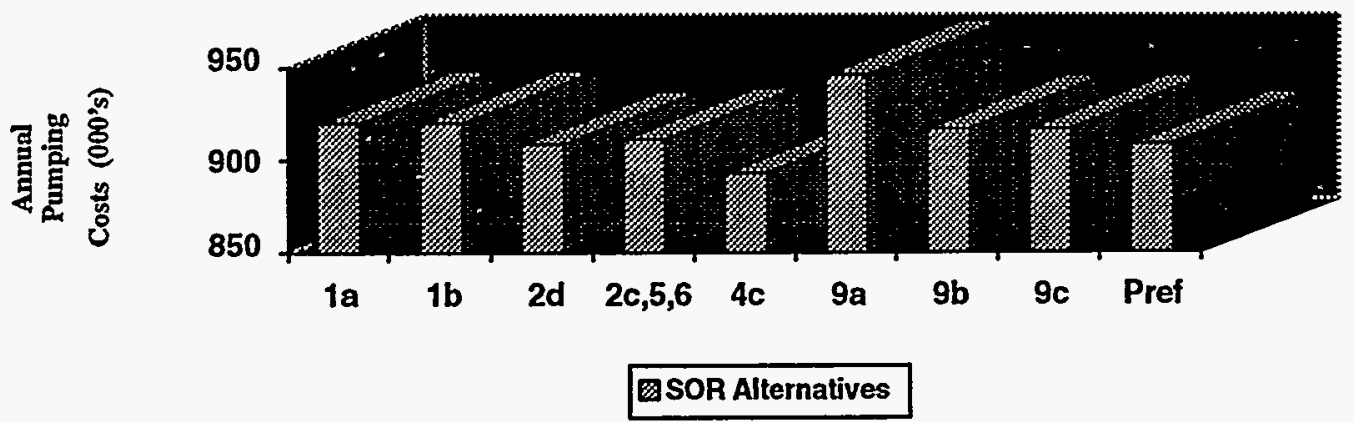

Figure 4-3. Grand Coulee Irrigation 
Table 4-21. Summary of Modification and Annual Costs for Irrigation Pump Stations on the John Day and Ice Harbor Pools 1/

\begin{tabular}{|l|c|c|c|c|c|c|c|}
\hline \multirow{2}{*}{ Alternative } & $\begin{array}{c}\text { Implementation } \\
\text { Date }\end{array}$ & \multicolumn{2}{|c|}{ John Day Costs } & \multicolumn{2}{c|}{ Ice Harbor Costs } & \multicolumn{2}{c|}{ Total Costs } \\
\cline { 2 - 8 } & Capital (\$) & O\&M (\$) 2/ & Capital (\$) & O\&M (\$) & Capital (\$) & O\&M (\$) \\
\hline SOS 1a & 1995 & 0 & 0 & 0 & 0 & 0 & 0 \\
\hline SOS 1b & 1995 & 0 & 0 & 0 & 0 & 0 & 0 \\
\hline SOS 2c & 1995 & 0 & 0 & 0 & 0 & 0 & 0 \\
\hline SOS 2d & 1995 & 0 & 0 & 0 & 0 & 0 & 0 \\
\hline SOS 4c & 1995 & 0 & 0 & 0 & 0 & 0 & 0 \\
\hline SOS 5b & 2010 & $14,340,000$ & 664,000 & $28,300,000$ & $1,800,000$ & $42,640,000$ & $2,464,000$ \\
\hline SOS 5c & 2000 & $14,340,000$ & 664,000 & $28,300,000$ & $1,838,000$ & $42,640,000$ & $2,502,000$ \\
\hline SOS 6b & 2005 & $14,340,000$ & 664,000 & $15,000,000$ & 889,000 & $29,340,000$ & $1,553,000$ \\
\hline SOS 6d & 2000 & $14,340,000$ & 664,000 & 0 & 0 & $14,340,000$ & 664,000 \\
\hline SOS 9a & 2005 & $10,790,000$ & 578,000 & $15,000,000$ & 890,000 & $25,790,000$ & $1,468,000$ \\
\hline SOS 9b & 1995 & \multicolumn{7}{|c|}{0} & 0 & 0 & 0 & 0 & 0 \\
\hline SOS 9c & 2005 & $14,340,000$ & 708,000 & $16,020,000$ & 890,000 & $30,360,000$ & $1,598,000$ \\
\hline
\end{tabular}

Table 4-22. Summary of Total Increased Costs for Commercial Irrigation @ $73 / 4 \%$, Compared to SOS 2c

\begin{tabular}{|c|c|c|c|c|c|}
\hline Alternative & Year on Line & $\begin{array}{c}\text { Total } \\
\text { Modification } \\
\text { Cost } \mathbf{( \$ 1 , 0 0 0 )}\end{array}$ & $\begin{array}{c}\text { Annual O\&M } \\
\text { and Power Cost } \\
\mathbf{( \$ 1 , 0 0 0 )} \mathbf{1} /\end{array}$ & $\begin{array}{c}\text { Average Annual } \\
\text { Cost } \mathbf{( \$ 1 , 0 0 0 )} 2 /\end{array}$ & $\begin{array}{c}\text { Equivalent } \\
\text { Annual } \\
\text { Cost (\$1,000) 3/ }\end{array}$ \\
\hline SOS 1a & 1995 & $\mathbf{0}$ & 9.0 & 9.0 & 9.0 \\
\hline SOS 1b & 1995 & 0 & 8.9 & 8.9 & 8.9 \\
\hline SOS 2c & 1995 & 0 & 0 & 0 & 0 \\
\hline SOS 2d & 1995 & 0 & $(3.3)$ & $(3.3)$ & $(3.3)$ \\
\hline SOS 4c & 1995 & 0 & $(18.4)$ & $(18.4)$ & $(18.4)$ \\
\hline SOS 5b & 2010 & 42,640 & 2,464 & $6,726.5$ & $2,094.5$ \\
\hline SOS 5c & 2000 & 42,640 & 2,502 & $6,764.5$ & $4,445.9$ \\
\hline SOS 6b & 2005 & 29,340 & 1,553 & $4,486.0$ & $2,026.1$ \\
\hline SOS 6d & 2000 & 14,340 & 664 & $2,097.5$ & $1,373.0$ \\
\hline SOS 9a & 2005 & 25,790 & $1,502.9$ & $4,081.0$ & $1,864.6$ \\
\hline
\end{tabular}


Table 4-22. Summary of Total Increased Costs for Commercial Irrigation @ $73 / 4 \%$, Compared to SOS 2c - CONT

\begin{tabular}{|l|c|c|c|c|c|}
\hline Alternative & Year on Line & $\begin{array}{c}\text { Total } \\
\text { Modification } \\
\text { Cost } \mathbf{( \$ 1 , 0 0 0 )}\end{array}$ & $\begin{array}{c}\text { Annual O\&M } \\
\text { and Power Cost } \\
\mathbf{( \$ 1 , 0 0 0 )} \mathbf{1 /}\end{array}$ & $\begin{array}{c}\text { Average Annual } \\
\text { Cost (\$1,000) 2/ }\end{array}$ & $\begin{array}{c}\text { Equivalent } \\
\text { Annual } \\
\text { Cost (\$1,000) 3/ }\end{array}$ \\
\hline SOS 9b & 1995 & 0 & 5.4 & 5.4 & 5.4 \\
\hline SOS 9c & 2005 & 30,360 & 1,604 & $4,638.9$ & $2,098.3$ \\
\hline PA & 1998 & 14,340 & 748.2 & $2,181.7$ & $1,660.9$ \\
\hline $\begin{array}{l}\text { 1/ Includes costs for Grand Coulee. } \\
\text { 2/ Annual modifications costs were computed using an interest rate of 7.75 percent and a replacement life of } \\
\text { 20 years. Values are not discounted to account for differences in implementation timing. } \\
\text { 3/ Future expenditures have been discounted to put all costs at a common point in time--1995, using an } \\
\text { interest rate of 7.75 percent and a replacement life of 20 years (30 years in some cases). }\end{array}$ \\
\hline
\end{tabular}

Table 4-23. Summary of Total Increased Costs for Commercial Irrigation @ 3\%, Compared to SOS 2c

\begin{tabular}{|c|c|c|c|c|c|}
\hline Alternative & Year on Line & $\begin{array}{c}\text { Total } \\
\text { Modification Cost } \\
(\mathbf{\$ 1 , 0 0 0 )}\end{array}$ & $\begin{array}{l}\text { Annual O\&M } \\
\text { and Power Cost } \\
(\$ 1,000) 1 /\end{array}$ & $\begin{array}{c}\text { Average } \\
\text { Annual Cost } \\
(\$ 1,000) 2 /\end{array}$ & $\begin{array}{c}\text { Equivalent } \\
\text { Annual Cost } \\
(\$ 1,000) 3 /\end{array}$ \\
\hline SOS 1a & 1995 & 0 & 9.0 & 9.0 & 9.0 \\
\hline SOS $1 b$ & 1995 & 0 & 8.9 & 8.9 & 8.9 \\
\hline $\operatorname{sos} 2 c$ & 1995 & 0 & 0 & 0 & 0 \\
\hline $\operatorname{sos} 2 d$ & 1995 & 0 & (3.3) & (3.3) & (3.3) \\
\hline $\operatorname{sOS} 4 c$ & 1995 & 0 & (18.4) & (18.4) & $(18.4)$ \\
\hline SOS $5 b$ & 2010 & 42,640 & 2,464 & $5,330.1$ & $3,319.2$ \\
\hline SOS 5c & 2000 & 42,640 & 2,502 & $5,368.1$ & $4,539.7$ \\
\hline SOS $6 b$ & 2005 & 29,340 & 1,553 & $3,525.1$ & $2,558.5$ \\
\hline SOS 6d & 2000 & 14,340 & 664 & $1,627.9$ & $1,375.0$ \\
\hline SOS 9a & 2005 & 25,790 & $1,502.9$ & $3,236.4$ & $2,358.9$ \\
\hline SOS $9 b$ & 1995 & 0 & 5.4 & 5.4 & 5.4 \\
\hline $\operatorname{sos} 9 \mathrm{c}$ & 2005 & 30,360 & 1,604 & $3,644.7$ & $2,646.8$ \\
\hline PA & 1998 & 14,340 & 748.2 & $1,712.1$ & $1,537.2$ \\
\hline \multicolumn{6}{|c|}{$\begin{array}{l}\text { 1/ Includes costs for Grand Coulee. } \\
\text { 2/ Annual modifications costs were computed using an interest rate of } 3.0 \text { percent and a replacement life of } \\
20 \text { years. Values are not discounted to account for differences in implementation timing. } \\
\text { 3/ Future expenditures have been discounted to put all costs at a common point in time--1995, using an } \\
\text { interest rate of } 3.0 \text { percent and a replacement life of } 20 \text { years ( } 30 \text { years in some cases). }\end{array}$} \\
\hline
\end{tabular}




\subsubsection{Impacts on M\&l Water Users - Pumpers}

The impact on M\&I users directly affected by reservoir drawdown was analyzed in terms of the cost to modify pumping plants and the associated increased operating and power costs. Incurring these costs would allow these water users to continue pumping from the reservoir pools under drawdown conditions as identified in the SOSs.

Significant impacts on M\&I water users were identified at five reservoir pools: Lower Granite, Little Goose, Lower Monumental, Ice Harbor, John Day. Minor impacts on M\&I water users and a small tract irrigation were identified at Grand Coulee but were not evaluated. Also minor impacts are expected to occur at recreation sites where irrigation systems use water from the Columbia and Snake Rivers, but these impacts were not evaluated.
Impacts on M\&I pumpers were identified for SOR alternatives SOS $5 \mathrm{~b}$, SOS $5 \mathrm{c}$, SOS $6 \mathrm{~b}$, SOS $6 \mathrm{~d}$, SOS $9 \mathrm{a}, \operatorname{SOS} 9 \mathrm{c}$, and the preferred alternative. The most significant costs are modifying the water supply systems for the Irrigon and Umatilla Hatcheries on the John Day pool. The most recent estimate puts first costs for these modifications at almost $\$ 30$ million.

Table 4-24 shows a summary of pump station modification costs and Table 4-25 shows increased annual operation, maintenance and power costs at the five reservoirs, as compared to SOS 2c. Data are shown for each of the 13 SOR alternatives. Columns with a zero entry indicate that pump modification and increased operating costs were not required under that alternative. M\&I water pumping costs for these SOSs would remain the same at the same level as is currently being experienced.

Table 4-24. Summary of Pump Station Modification Costs for M\&I Pumpers "

\begin{tabular}{|c|c|c|c|c|c|c|}
\hline Alternatives & $\begin{array}{l}\text { John Day } \\
(\$ 1,000)\end{array}$ & $\begin{array}{l}\text { Ice Harbor } \\
(\$ 1,000)\end{array}$ & $\begin{array}{c}\text { Lower } \\
\text { Granite } \\
\mathbf{( \$ 1 , 0 0 0 )}\end{array}$ & $\begin{array}{c}\text { Little Goose } \\
\quad(\$ 1,000)\end{array}$ & $\begin{array}{c}\text { Lower } \\
\text { Monumental } \\
(\$ 1,000)\end{array}$ & $\begin{array}{c}\text { Total } \\
\text { Costs } \\
(\$ 1,000)\end{array}$ \\
\hline SOS 1a & 0 & 0 & 0 & 0 & 0 & 0 \\
\hline $\operatorname{SOS} 1 \mathrm{~b}$ & 0 & 0 & 0 & 0 & 0 & 0 \\
\hline SOS 2c & 0 & 0 & 0 & 0 & 0 & 0 \\
\hline $\operatorname{SOS} 2 d$ & 0 & 0 & 0 & 0 & 0 & 0 \\
\hline SOS $4 c$ & 0 & 0 & 0 & 0 & 0 & 0 \\
\hline SOS $5 b$ & 36,147 & 1,468 & 3,523 & 705 & 852 & 42,695 \\
\hline SOS 5c & 36,147 & 1,468 & 3,523 & 705 & 852 & 42,695 \\
\hline SOS $6 b$ & 36,147 & 768 & 2,983 & 286 & 401 & 40,585 \\
\hline SOS 6d & 36,147 & 0 & 2,983 & 0 & 0 & 39,898 \\
\hline SOS 9a & 36,147 & 768 & 2,983 & 286 & 390 & 40,574 \\
\hline SOS 9b & 0 & 0 & 0 & 0 & 0 & 0 \\
\hline SOS 9c & 36,147 & 819 & 3,258 & 385 & 532 & 41,141 \\
\hline Pref & 39,524 & 0 & 0 & 0 & 0 & 39,524 \\
\hline
\end{tabular}


Table 4-25. Increased Annual Operation Maintenance and Power Cost, M\&I Pumpers, Compared to SOS 2c $1 /$

\begin{tabular}{|c|c|c|c|c|c|c|}
\hline Alternatives & $\begin{array}{c}\text { John Day } \\
\text { (\$) }\end{array}$ & $\begin{array}{c}\text { Ice Harbor } \\
(\$)\end{array}$ & $\begin{array}{c}\text { Lower } \\
\text { Granite } \\
(\$)\end{array}$ & $\begin{array}{l}\text { Little Goose } \\
\text { (\$) }\end{array}$ & $\begin{array}{c}\text { Lower } \\
\text { Monumental } \\
(\$)\end{array}$ & $\begin{array}{c}\text { Total } \\
\text { Costs } \\
(\$)\end{array}$ \\
\hline SOS 1a & 0 & 0 & 0 & 0 & 0 & 0 \\
\hline SOS $1 b$ & 0 & 0 & 0 & 0 & 0 & 0 \\
\hline SOS 2c & 0 & 0 & 0 & 0 & 0 & 0 \\
\hline $\operatorname{sOS} 2 d$ & 0 & 0 & 0 & 0 & 0 & 0 \\
\hline SOS $4 c$ & 0 & 0 & 0 & 0 & 0 & 0 \\
\hline SOS $5 b$ & $2,552,000$ & 77,000 & 177,000 & 39,000 & 44,000 & $2,889,000$ \\
\hline SOS 5c & $2,552,000$ & 78,000 & 178,000 & 76,000 & 44,000 & $2,928,000$ \\
\hline SOS $6 b$ & $2,552,000$ & 40,000 & 150,000 & 15,000 & 21,000 & $2,778,000$ \\
\hline SOS 6d & $2,552,000$ & 0 & 150,000 & 0 & 0 & $2,702,000$ \\
\hline SOS 9a & $2,552,000$ & 40,000 & 150,000 & 15,000 & 20,000 & $2,777,000$ \\
\hline SOS $9 b$ & 0 & 0 & 0 & 0 & 0 & 0 \\
\hline SOS 9c & $2,552,000$ & 41,000 & 163,000 & 20,000 & 27,000 & $2,803,000$ \\
\hline Pref. Alt. & $2,552,000$ & 0 & 0 & 0 & 0 & $2,552,000$ \\
\hline
\end{tabular}

Tables 4-26 and 4-27 are summaries of total modification costs; average annual modification and $O \& M$ and pumping costs and equivalent annual costs at interest rates of 7.75 percent and 3.0 percent, respectively. The expected implementation date for each alternative is also shown.

Increased equivalent annual costs for modifications and O\&M range from about $\$ 2,111,100$ for SOS $5 b$ to $\$ 4,670,300$ for the preferred alternative, at an interest rate of 7.75 percent. At an interest rate of 3.0 percent, equivalent annual costs range from approximately $\$ 3,256,900$ for SOS $5 b$ to $\$ 4,520,100$ for SOS $5 c$. 
Table 4-26. Summary of Total Increased Pumping Costs for M\&I @ $73 / 4 \%$, Compared to Sos $2 \mathrm{c} 1 /$

\begin{tabular}{|c|c|c|c|c|c|}
\hline Alternative & Year on Line & $\begin{array}{c}\text { Total } \\
\text { Modification Cost } \\
(\$ 1,000)\end{array}$ & $\begin{array}{c}\text { Annual O\&M and } \\
\text { Power Cost } \\
(\$ 1,000)\end{array}$ & $\begin{array}{c}\text { Average } \\
\text { Annual Cost } \\
(\$ 1,000) 2 J\end{array}$ & $\begin{array}{c}\text { Equivalent } \\
\text { Annual Cost } \\
(\$ 1,000) 3 /\end{array}$ \\
\hline SOS 1a & 1995 & 0 & 0 & 0 & 0 \\
\hline $\operatorname{SOS} 1 \mathrm{~b}$ & 1995 & 0 & 0 & 0 & 0 \\
\hline SOS 2c & 1995 & 0 & 0 & 0 & 0 \\
\hline SOS 2d & 1995 & 0 & 0 & 0 & 0 \\
\hline $\operatorname{SOS} 4 c$ & 1995 & 0 & 0 & 0 & 0 \\
\hline SOS $5 b$ & 2010 & 42,695 & 2,889 & $6,750.9$ & $2,111.1$ \\
\hline SOS $5 c$ & 2000 & 42,695 & 2,928 & $6,789.9$ & $4,483.8$ \\
\hline SOS $6 b$ & 2005 & 40,585 & 2,778 & $6,429.0$ & $2,921.6$ \\
\hline SOS 6d & 2000 & 39,898 & 2,702 & $6,284.3$ & $4,100.5$ \\
\hline SOS 9a & 2005 & 40,574 & 2,777 & $6,426.9$ & $2,920.6$ \\
\hline SOS $9 b$ & 1995 & 0 & 0 & 0 & 0 \\
\hline SOS 9c & 2005 & 41,141 & 2,803 & $6,509.6$ & $2,957.8$ \\
\hline $\mathrm{PA}$ & 1998 & 39,524 & 2,552 & $6,096.9$ & $4,670.3$ \\
\hline \multicolumn{6}{|c|}{$\begin{array}{l}\text { 1/ Impacts on Grand Coulee Dam (Lake Roosevelt) are considered to be insignificant and are not included } \\
\text { 2/ Annual modifications costs were computed using an interest rate of } 7.75 \text { percent and a replacement life } \\
\text { that varies by the type of improvement ( } 20 \text { yrs - pumps, } 30 \text { yrs -hatcheries, } 50 \text { yrs-dredging). Values are } \\
\text { not present worthed to account for differences in implementation timing. } \\
\text { 3/ Future expenditures have been present -worthed to put all costs at a common point in time--1995, and } \\
\text { annual costs were computed using an interest rate of } 7.75 \text { percent and various replacement lives ( } 20 \text { yrs- } \\
\text { pumps, } 30 \text { yrs - hatcheries, } 50 \text { yrs - dredging). }\end{array}$} \\
\hline
\end{tabular}


Table 4-27. Summary of Total Increased Pumping Costs for M\&l @ 3\%, Compared to $\operatorname{sos} 2 c 11$

\begin{tabular}{|l|c|c|c|c|c|}
\hline Alternative & Year on Line & $\begin{array}{c}\text { Total } \\
\text { Modification Cost } \\
\mathbf{( \$ 1 , 0 0 0 )}\end{array}$ & $\begin{array}{c}\text { Annual O\&M } \\
\text { and Power Cost } \\
(\mathbf{\$ 1 , 0 0 0 )}\end{array}$ & $\begin{array}{c}\text { Average } \\
\text { Annual Cost } \\
\mathbf{( \$ 1 , 0 0 0 )} \mathbf{2} /\end{array}$ & $\begin{array}{c}\text { Equivalent } \\
\text { Annual Cost } \\
\mathbf{( \$ 1 , 0 0 0 )} \mathbf{3} /\end{array}$ \\
\hline SOS 1a & 1995 & 0 & 0 & 0 & 0 \\
\hline SOS 1b & 1995 & 0 & 0 & 0 & 0 \\
\hline SOS 2c & 1995 & 0 & 0 & 0 & 0 \\
\hline SOS 2d & 1995 & 0 & 0 & 0 & 0 \\
\hline SOS 4c & 1995 & 0 & 0 & $5,259.7$ & $3,256.9$ \\
\hline SOS 5b & 2010 & 42,695 & 2,889 & $5,259.7$ & $4,520.1$ \\
\hline SOS 5c & 2000 & 42,695 & 2,928 & $5,298.7$ & $3,617.3$ \\
\hline SOS 6b & 2005 & 40,585 & 2,778 & $5,006.9$ & $4,126.2$ \\
\hline SOS 6d & 2000 & 39,898 & 2,702 & $4,884.7$ & $3,616.0$ \\
\hline SOS 9a & 2005 & 40,574 & 2,777 & $5,005.1$ & 0 \\
\hline SOS 9b & 1995 & 0 & 0 & 0 & $3,662.5$ \\
\hline SOS 9c & 2005 & 41,141 & 2,803 & $5,069.2$ & $4,273.4$ \\
\hline PA & 1998 & 39,524 & 2,552 & $4,709.5$ & 0 \\
\hline
\end{tabular}

1/ Impacts on Grand Coulee Dam (Lake Roosevelt) are considered to be insignificant and are not included.

2/ Annual modifications costs were computed using an interest rate of 3.0 percent and a replacement life that varies by the type of improvement ( 20 yrs-pumps, 30 yrs-hatcheries, 50 yrs-dredging). Values are not present worthed to account for differences in implementation timing.

3/ Future expenditures have been present-worthed to put all costs at a common point in time--1995, and annual costs were computed using an interest rate of 3.0 percent and various replacement lives (20 yrspumps, 30 yrs-hatcheries, 50 yrs-dredging).

\subsection{ANALYSIS OF NAVIGATION IMPACTS}

\subsubsection{Introduction}

Changes in the operation of the Columbia/Snake system could potentially impact deep draft navigation on lower Columbia River, navigation on Columbia/Snake shallow draft waterway and the use of the Dworshak Reservoir to transport logs. Impacts to navigation on the shallow draft waterway are evaluated in Section 4.7.2; impacts to deep draft navigation are evaluated in Section 4.7.3; and, impacts to transport of logs on the Dworshak Reservoir are evaluated in Section 4.7.4.

Any change in river condition that affects tow speed, size, maximum vessel draft, or transit through the system locks will impact costs related to waterborne transportation on the Columbia-Snake River System (CSRS), and thus, overall costs of transporting commodities and other products to and from the region. Increased transportation costs will have different effects on agricultural commodity and other shipments depending on the costs and capacity of transportation and storage alternatives relative to the magnitude and duration of river impairment. Under the base condition, the transportation cost savings between CSRS water transportation and alternative modes such as rail, are translated into the capitalized values of agricultural investments in the economic region served by the waterway. The impact on producers of any operating strategy that affects navigation will be a function of producer 
location, capacity and storage alternatives, and transportation costs.

For the FEIS 13 full-scale system operating strategies have been evaluated. The various strategies are described at the beginning of this chapter. Strategies which involve the drawdown of reservoirs vary depending upon the duration of drawdown. SOSs that require drawdown below minimum operating pool (MOP) elevation prevent use of the locks and thus disrupt commercial navigation and patterns of commodity transport. These strategies include SOSs 5,6 , and 9. Implementation of the remaining SOSs, 1 through $4,9 \mathrm{~b}$, and the preferred alternative, would generally not interrupt waterborne transportation and for the most part, would be similar to the base condition. The more extreme salmon mitigation proposals would effectively make the Snake River a free-flowing waterway by lowering the pools to the level of the natural river, while others would lower the pools to about the level of the existing spillways. Such actions would close the Snake River to navigation either permanently or temporarily for periods of from 3 to 7 months each year.

The base condition, against which all other operating strategies are compared, is SOS 2c. Under this strategy, all of the locks and dams in the system are operated between MOP and full pool such that there are no impediments to navigation. Under this condition, the expected average pool elevations are assumed to be 2-feet below normal full pool at all of the locks and dams.

\subsubsection{Shallow Draft Navigation}

Impacts to shallow draft commercial navigation on the Columbia-Snake River System (CSRS) were analyzed by use of a system transportation model which was developed to simulate transportation responses under varying operating scenarios and to measure the costs of commodity transportation under each scenario. The model simulates the economic impacts of impairments to navigation and captures the changes in the costs of storage, handling, or transport that present users of the Columbia-Snake River system would incur. Impacts upon transportation costs relative to the base condition occur as a result of reservoir drawdown, which prevents use of the locks and curtails commercial navigation on segments of the Columbia-Snake system. Operating strategies that would disrupt navigation are noted below.

Accessibility of the four Snake River locks under each drawdown scenario is shown below.

\begin{tabular}{|c|l|c|c|}
\hline SOS & \multicolumn{1}{|c|}{ Description } & $\begin{array}{c}\text { Locks } \\
\text { Accessible } \\
\text { (Months) }\end{array}$ & $\begin{array}{c}\text { Locks } \\
\text { Not Acces- } \\
\text { sible } \\
\text { (Months) }\end{array}$ \\
\hline 5b & $\begin{array}{l}\text { Natural River, Feb. - } \\
\text { Aug, 4 Snake River } \\
\text { projects }\end{array}$ & 5 & 7 \\
\hline 5c & $\begin{array}{l}\text { Natural River, Jan } \\
\text { Dec, 4 Snake River } \\
\text { projects }\end{array}$ & 0 & 12 \\
\hline 6b & $\begin{array}{l}\text { Draw down of 33 ft } \\
\text {--Apr - Aug, 4 } \\
\text { Snake River projects }\end{array}$ & 7 & 5 \\
\hline 6d & $\begin{array}{l}\text { Draw down of 33 ft } \\
\text {--Apr - Aug, } \\
\text { Lower Granite only }\end{array}$ & 7 & 5 \\
\hline 9a & $\begin{array}{l}\text { Draw down to spillway } \\
\text { crest -- Apr-Aug, 4 } \\
\text { Snake River projects }\end{array}$ & 7 & 5 \\
\hline 9c & $\begin{array}{l}\text { Draw down to spillway } \\
\text { crest--Mar - May, 4 } \\
\text { Snake River projects }\end{array}$ & 9 & 3 \\
\hline
\end{tabular}

For the base condition and the alternative operating plans, the transportation model simulates the following conditions: (1) an un-optimized base case which reflects historical commodity flows under existing conditions; (2) an unconstrained drawdown, where system-wide transportation costs are computed assuming handling or storage capacity is not a limiting factor; and (3) a constrained drawdown, wherein handling and/or storage capacity are limiting factors.

The unconstrained drawdown event captures the total costs of responses to drawdown (cessation of barge transport) assuming that none of the responses (alternative mode or node) are limited by capacity (transport, handling or storage) through the 
duration of the drawdown period. This applies to non-grain commodities wherein the volume of products shipped on the waterway is such that handling and storage would not act as constraints during a river drawdown. The constrained drawdown is an extension of the unconstrained drawdown in which the model takes into account the capacity limitations of existing transportation, storage and handling facilities for grain. The constrained drawdown scenarios simulate handling and throughput at various country and river elevators and produce changes in system-wide transportation costs, given the existing storage capacity within the region. The constrained drawdown scenario thus reflects options that would likely be exercised given limitations of transport, handling or storage capacity.

As grain or other commodity transport is impacted by drawdown, the model considers rerouting commodities and use of alternative transportation modes such as trucks to access river elevators located on the McNary pool and rail to ship grain directly to export elevators on the lower Columbia or Puget Sound. In some cases, the model shifts back to the pre-drawdown transportation mode, but in others permanent shifts may occur in the mode of transportation, thereby amplifying the impact of draw- down on river ports and other distribution points. The decision to revert to the pre-drawdown mode or make the modal shift permanent is base on the minimum cost combination for commodity handling and transport given the duration and magnitude of waterway impairment.

The operating strategy that involves drawdown of the four Snake River projects, SOS $6 \mathrm{~b}$, would be implemented in 2005, whereas drawdown of Lower Granite only (SOS 6d) would occur in 2000. Strategies that simulate natural river conditions, SOS $5 \mathrm{~b}$ and SOS $5 \mathrm{c}$, would be implemented by 2010 and 2000 , respectively. SOS 9a and SOS 9c would be implemented in 2005, and the Preferred Alternative by 1998. All other SOSs would be implemented in 1995. Direct navigation impacts associated with each SOS, in the form of increased system transportation costs, are displayed in Table 4-28. For those SOSs scheduled for implementation after 1995, costs have been adjusted to reflect 1995 conditions and along with the other strategies, are presented as average annual amounts for the period of analysis, 1995-2095. These average annual amounts, computed at 3 percent and 7.75 percent and expressed in 1992 dollars, are displayed in Table 4-29.

Table 4-28. Gross Annual Costs of Commodity Shipments on the Columbia-Snake River System (1992 dollars)

\begin{tabular}{|c|c|c|c|c|c|c|}
\hline SOS & Grain & Petroleum & $\begin{array}{c}\text { Logs and } \\
\text { Woodchips }\end{array}$ & $\begin{array}{c}\text { Wood } \\
\text { Products }\end{array}$ & All Other & \multicolumn{1}{|c|}{ Total } \\
\hline SOS 1a & $\$ 355,682,962$ & $\$ 9,847,860$ & $\$ 42,483,744$ & $\$ 1,648,992$ & $\$ 4,763,196$ & $\$ 414,426,754$ \\
\hline SOS 1b & $355,682,962$ & $9,847,860$ & $42,483,744$ & $1,648,992$ & $4,763,196$ & $414,426,754$ \\
\hline SOS 2c & $355,682,962$ & $9,847,860$ & $42,483,744$ & $1,648,992$ & $4,763,196$ & $414,426,754$ \\
\hline SOS 2d & $355,682,962$ & $9,847,860$ & $42,483,744$ & $1,648,992$ & $4,763,196$ & $414,426,754$ \\
\hline SOS 4c & $355,682,962$ & $9,847,860$ & $42,483,744$ & $1,648,992$ & $4,763,196$ & $414,426,754$ \\
\hline SOS 5b & $376,179,948$ & $10,046,100$ & $43,229,531$ & $1,882,778$ & $5,011,073$ & $436,349,430$ \\
\hline SOS 5c & $397,145,542$ & $10,187,700$ & $43,762,236$ & $2,049,768$ & $5,188,128$ & $458,333,374$ \\
\hline SOS 6b & $371,550,352$ & $9,989,460$ & $43,016,449$ & $1,815,982$ & $4,940,251$ & $431,312,494$ \\
\hline SOS 6d & $357,184,095$ & $9,989,460$ & $43,016,449$ & $1,815,982$ & $4,940,251$ & $416,946,237$ \\
\hline SOS 9a & $371,550,352$ & $9,989,460$ & $43,016,449$ & $1,815,982$ & $4,940,251$ & $431,312,494$ \\
\hline SOS 9b & $355,682,962$ & $9,847,860$ & $42,483,744$ & $1,648,992$ & $4,763,196$ & $414,426,754$ \\
\hline SOS 9c & $365,169,671$ & $9,932,820$ & $42,803,367$ & $1,749,186$ & $4,869,429$ & $424,524,473$ \\
\hline PA & $355,682,962$ & $9,847,860$ & $42,483,744$ & $1,648,992$ & $4,763,196$ & $414,426,754$ \\
\hline
\end{tabular}


Table 4-29. Average Annual and Equivalent Annual Transportation Costs Associated with System Operating Strategies

\begin{tabular}{|c|c|c|c|c|c|c|}
\hline \multirow{2}{*}{ sos } & \multirow{2}{*}{$\begin{array}{l}\text { POL } \\
\text { Date }\end{array}$} & \multirow{2}{*}{$\begin{array}{c}\text { Annual } \\
\text { Transportation } \\
\text { Cost } \\
(\$ 1992)\end{array}$} & \multicolumn{2}{|c|}{$\begin{array}{c}\text { Accumulate Present Value } \\
\text { 1995-2095 }\end{array}$} & \multicolumn{2}{|c|}{ Equivalent Annual Cost } \\
\hline & & & $3 \%$ & $7.75 \%$ & $3 \%$ & $7.75 \%$ \\
\hline $\operatorname{sos} 1 \mathrm{a}$ & 1995 & $\$ 414,426,754$ & $\$ 13,095,431,629$ & $\$ 5,026,565,522$ & $\$ 414,426,754$ & $\$ 414,426,754$ \\
\hline SOS $1 b$ & 1995 & $414,426,754$ & $13,095,431,629$ & $5,026,565,522$ & $414,426,754$ & $414,426,754$ \\
\hline $\operatorname{SOS} 2 \mathrm{c}$ & 1995 & $414,426,754$ & $13,095,431,629$ & $5,026,565,522$ & $414,426,754$ & $414,426,754$ \\
\hline $\operatorname{SOS} 2 \mathrm{~d}$ & 1995 & $414,426,754$ & $13,095,431,629$ & $5,026,565,522$ & $414,426,754$ & $414,426,754$ \\
\hline SOS 4c & 1995 & $414,426,754$ & $13,095,431,629$ & $5,026,565,522$ & $414,426,754$ & $414,426,754$ \\
\hline SOS $5 b$ & 2010 & $436,349,430$ & $13,526,452,172$ & $5,434,518,490$ & $428,058,105$ & $421,392,564$ \\
\hline SOS $5 c$ & 2000 & $458,333,374$ & $14,281,751,781$ & $5,733,813,235$ & $451,960,317$ & $444,599,878$ \\
\hline $\operatorname{sos} 6 b$ & 2005 & $431,312,494$ & $13,484,832,669$ & $5,447,150,023$ & $426,741,015$ & $422,372,013$ \\
\hline $\operatorname{sos} 6 \mathrm{~d}$ & 2000 & $416,946,237$ & $13,163,504,667$ & $5,366,455,130$ & $416,572,269$ & $416,114,931$ \\
\hline $\operatorname{sos} 9 a$ & 2005 & $431,312,494$ & $13,484,832,669$ & $5,447,150,023$ & $426,741,015$ & $422,372,013$ \\
\hline SOS 9b & 1995 & $414,426,754$ & $13,095,431,629$ & $5,026,565,522$ & $414,426,754$ & $414,426,754$ \\
\hline $\operatorname{sos} 9 \mathrm{c}$ & 2005 & $424,524,473$ & $13,328,243,892$ & $5,405,682,600$ & $421,785,606$ & $419,156,629$ \\
\hline PA & 1998 & $414,426,754$ & $13,095,431,629$ & $5,026,565,522$ & $414,426,754$ & $414,426,754$ \\
\hline
\end{tabular}




\subsubsection{Deep Draft Navigation}

\subsubsection{Analysis for the FEIS}

For the FEIS, a number of new SOSs were identified and evaluated for most river uses. Also, some of the SOSs which were carried over to the FEIS from the DEIS were revised. These SOSs were also evaluated for most river uses. The new and revised SOSs were reviewed to determine if they would have any effect on water depths in the deep-draft navigation channel and if they could have the potential to adversely impact deep-draft navigation. This review concluded that the flows on the Columbia River at Bonneville Dam for the SOSs included in the FEIS would be very similar to the flows associated with the SOSs which were evaluated for the DEIS. Therefore, it was concluded the results of the model studies which were conducted for the DEIS would be applicable for the FEIS, even though the SOSs are somewhat different. In other words, despite of slight differences between FEIS and DEIS SOSs, their potential for impacting deep-draft navigation is the same. Accordingly, the conclusions for the FEIS is that none of the SOSs considered for the SOR would have any impact on deep-draft navigation. On this basis, the results of the analysis conducted for the DEIS of combined flow and tidal impacts on the stage of the river for deep-draft navigation are presented in the following section.

\subsubsection{Analysis for the DEIS}

During the screening phase of System Operation Review (SOR) alternative measures, consideration was given to the potential impacts on deep-draft commercial navigation on the lower Columbia River that might result from the drawdown and subsequent refill of Snake River Dams. Diminished inflow from Snake River into the Columbia during the seasonal low point of the Snake and Columbia River natural hydrographs would serve to reduce normal river stages along the Lower Columbia River. This in turn could impact commercial shipping within the 40-foot navigation channel. With normally maintained channel depths, deep draft vessels calling at Lower Columbia River ports regularly utilize an average of 2-6 feet of additional stage provided by tidal effects of the Pacific Ocean.

An analysis was made to determine the extent to which river stages within the authorized navigation channel would be reduced during the refill of Snake River reservoirs to normal operating elevations following drawdown. Discharge and tidal data were utilized to identify the potential impacts on waterborne commerce for each of the strategies that involve drawdown.

Using modeling procedures described in Chapter 3, a set of tables and curves were prepared to identify stage elevations at certain locations along the 40-foot channel. Daily discharges from Bonneville Dam, hourly tidal data, and steady state flows for major tributaries for eight operating strategies were incorporated into the model. These strategies included the base condition (1993 operating strategy defined in the 1993 Supplemental Environmental Impact Statement for the Operation of the Hydropower system), pre-Salmon Summit operation, and six scenarios that involve drawdown for varying periods of time, and also the return of Snake River pools to a natural hydrograph condition.

Using the above data, direct comparisons were made of the percent of time the river stage is within a specific stage interval during the months of August, September, and October at each location for each strategy. Tables $4-30$ and $4-31$ indicate the percentage of time that river stages under each operating mode are within a given range of stage intervals during the 3-month refill period. Tables 4-32, 4-33, and 4-34 display the variation between these stage intervals and those which would be experienced under the base condition. 
Table 4-30. Kalama Percent of Time Stage is within the Stage Interval for Specific Operating Strategy

\begin{tabular}{|c|c|c|c|c|c|c|c|c|c|}
\hline \multicolumn{10}{|c|}{ KALAMA } \\
\hline \multicolumn{10}{|c|}{ August } \\
\hline \multirow{2}{*}{$\begin{array}{c}\text { Operating } \\
\text { Strategy }\end{array}$} & \multicolumn{9}{|c|}{ Stage Interval (ft.) } \\
\hline & -2 & -1 & $\mathbf{0}$ & 1 & 2 & 3 & 4 & 5 & 6 \\
\hline $1 \mathrm{a}$ & 0.0 & 0.0 & 2.6 & 24.1 & 32.6 & 23.9 & 14.5 & 1.6 & 0.6 \\
\hline $2 c$ & 0.0 & 0.0 & 2.7 & 24.1 & 32.6 & 23.9 & 14.5 & 1.6 & 0.6 \\
\hline $5 \mathrm{a}$ & 0.0 & 0.0 & 3.0 & 24.3 & 32.4 & 23.8 & 14.2 & 1.6 & 0.6 \\
\hline $5 b$ & 0.0 & 0.0 & 3.1 & 24.4 & 32.4 & 23.7 & 14.1 & 1.5 & 0.6 \\
\hline $6 a$ & 0.0 & 0.0 & 3.0 & 24.3 & 32.5 & 23.8 & 14.3 & 1.6 & 0.6 \\
\hline $6 \mathrm{~b}$ & 0.0 & 0.0 & 3.2 & 24.5 & 32.4 & 23.8 & 14.1 & 1.5 & 0.6 \\
\hline \multicolumn{10}{|c|}{ September } \\
\hline \multirow{2}{*}{$\begin{array}{c}\text { Operating } \\
\text { Strategy }\end{array}$} & \multicolumn{9}{|c|}{ Stage Interval (ft.) } \\
\hline & -2 & -1 & 0 & 1 & 2 & 3 & 4 & 5 & 6 \\
\hline 1a & 0.0 & 0.0 & 1.1 & 16.8 & 33.3 & 26.4 & 18.5 & 3.9 & 0.0 \\
\hline $2 c$ & 0.0 & 0.0 & 1.2 & 17.1 & 33.5 & 26.2 & 18.3 & 3.8 & 0.0 \\
\hline $5 a$ & 0.0 & 0.0 & 1.7 & 18.2 & 33.0 & 26.2 & 17.6 & 3.5 & 0.0 \\
\hline $5 b$ & 0.0 & 0.0 & 2.3 & 20.1 & 33.1 & 25.4 & 16.4 & 2.9 & 0.0 \\
\hline $6 a$ & 0.0 & 0.0 & 1.6 & 18.0 & 33.0 & 26.2 & 17.7 & 3.5 & 0.0 \\
\hline $6 \mathrm{~b}$ & 0.0 & 0.0 & 2.1 & 19.6 & 33.1 & 25.5 & 16.7 & 3.1 & 0.0 \\
\hline \multicolumn{10}{|c|}{ October } \\
\hline \multirow{2}{*}{$\begin{array}{c}\text { Operating } \\
\text { Strategy }\end{array}$} & \multicolumn{9}{|c|}{ Stage Interval (ft.) } \\
\hline & -2 & -1 & $\mathbf{0}$ & 1 & 2 & 3 & 4 & 5 & 6 \\
\hline $1 \mathrm{a}$ & 0.0 & 0.0 & 0.9 & 13.0 & 31.2 & 28.8 & 20.3 & 5.7 & 0.0 \\
\hline $2 c$ & 0.0 & 0.0 & 0.9 & 13.1 & 31.3 & 28.8 & 20.4 & 5.7 & 0.0 \\
\hline $5 \mathrm{a}$ & 0.0 & 0.0 & 1.1 & 13.5 & 31.3 & 28.7 & 20.0 & 5.6 & 0.0 \\
\hline $5 b$ & 0.0 & 0.0 & 1.1 & 13.5 & 31.3 & 28.7 & 20.0 & 5.5 & 0.0 \\
\hline $6 a$ & 0.0 & 0.0 & 1.0 & 13.4 & 31.2 & 28.7 & 20.0 & 5.6 & 0.0 \\
\hline $6 b$ & 0.0 & 0.0 & 1.0 & 13.4 & 31.2 & 28.7 & 20.1 & 5.6 & 0.0 \\
\hline
\end{tabular}


Table 4-31. Wauna Percent of Time Stage is within the Stage Interval for Specific Operating Strategy

\begin{tabular}{|c|c|c|c|c|c|c|c|c|c|c|c|}
\hline \multicolumn{12}{|c|}{ WAUNA } \\
\hline \multicolumn{12}{|c|}{ August } \\
\hline \multirow{2}{*}{$\begin{array}{c}\text { Operating } \\
\text { Strategy }\end{array}$} & \multicolumn{11}{|c|}{ Stage Interval (ft.) } \\
\hline & -2 & -1 & 0 & 1 & 2 & 3 & 4 & 5 & 6 & 7 & 8 \\
\hline $1 \mathrm{a}$ & 0.1 & 7.6 & 7.6 & 14.8 & 16.9 & 15.1 & 12.4 & 12.4 & 9.8 & 3.0 & 0.0 \\
\hline $2 c$ & 0.1 & 7.6 & 7.6 & 14.8 & 16.9 & 15.1 & 12.4 & 12.4 & 9.8 & 3.0 & 0.0 \\
\hline $5 a$ & 0.2 & 7.6 & 7.7 & 14.9 & 16.8 & 15.1 & 12.4 & 12.4 & 9.8 & 3.0 & 0.0 \\
\hline $5 b$ & 0.2 & 7.6 & 7.7 & 14.9 & 16.8 & 15.1 & 12.3 & 12.4 & 9.8 & 3.0 & 0.0 \\
\hline $6 a$ & 0.2 & 7.6 & 7.7 & 14.9 & 16.8 & 15.1 & 12.4 & 12.4 & 9.8 & 3.0 & 0.0 \\
\hline $6 b$ & 0.2 & 7.6 & 7.7 & 15.0 & 16.9 & 15.1 & 12.4 & 12.4 & 9.8 & 3.0 & 0.0 \\
\hline \multicolumn{12}{|c|}{ September } \\
\hline \multirow{2}{*}{$\begin{array}{c}\text { Operating } \\
\text { Strategy }\end{array}$} & \multicolumn{11}{|c|}{ Stage Interval (ft.) } \\
\hline & -2 & -1 & 0 & 1 & 2 & 3 & 4 & 5 & 6 & 7 & 8 \\
\hline 1a & 0.2 & 7.7 & 7.7 & 14.8 & 17.0 & 15.1 & 12.4 & 12.4 & 9.8 & 3.0 & 0.0 \\
\hline $2 c$ & 0.2 & 7.7 & 7.7 & 14.8 & 17.0 & 15.1 & 12.4 & 12.4 & 9.8 & 3.0 & 0.0 \\
\hline $5 a$ & 0.3 & 7.7 & 7.8 & 15.1 & 16.9 & 15.0 & 12.3 & 12.4 & 9.7 & 2.9 & 0.0 \\
\hline $5 b$ & 0.3 & 7.8 & 7.9 & 15.2 & 16.9 & 14.8 & 12.3 & 12.4 & 9.7 & 2.7 & 0.0 \\
\hline $6 a$ & 0.2 & 7.7 & 7.8 & 15.0 & 16.9 & 15.0 & 12.3 & 12.4 & 9.7 & 2.9 & 0.0 \\
\hline $6 b$ & 0.3 & 7.8 & 7.9 & 15.2 & 16.9 & 14.8 & 12.3 & 12.4 & 9.7 & 2.8 & 0.0 \\
\hline \multicolumn{12}{|c|}{ October } \\
\hline \multirow{2}{*}{$\begin{array}{l}\text { Operating } \\
\text { Strategy }\end{array}$} & \multicolumn{11}{|c|}{ Stage Interval (ft.) } \\
\hline & -2 & -1 & 0 & 1 & 2 & 3 & 4 & 5 & 6 & 7 & 8 \\
\hline $1 \mathrm{a}$ & 0.0 & 4.4 & 7.2 & 12.7 & 16.2 & 14.6 & 15.2 & 13.2 & 11.9 & 4.1 & 0.5 \\
\hline $2 c$ & 0.0 & 4.4 & 7.2 & 12.8 & 16.3 & 14.6 & 15.3 & 13.2 & 11.9 & 4.1 & 0.5 \\
\hline $5 a$ & 0.0 & 4.5 & 7.3 & 12.7 & 16.3 & 14.6 & 15.1 & 13.3 & 11.8 & 4.1 & 0.5 \\
\hline $5 b$ & 0.0 & 4.5 & 7.3 & 12.7 & 16.3 & 14.6 & 15.1 & 13.3 & 11.8 & 4.1 & 0.5 \\
\hline $6 a$ & 0.0 & 4.4 & 7.3 & 12.7 & 16.3 & 14.6 & 15.1 & 13.3 & 11.8 & 4.1 & 0.5 \\
\hline $6 b$ & 0.0 & 4.4 & 7.3 & 12.7 & 16.3 & 14.6 & 15.1 & 13.3 & 11.8 & 4.1 & 0.5 \\
\hline
\end{tabular}


Table 4-32. Vancouver Percent of Time Comparison of Specific Operating Strategy with SOS 2c

\begin{tabular}{|c|c|c|c|c|c|c|c|c|c|c|c|}
\hline \multicolumn{12}{|c|}{ VANCOUVER } \\
\hline \multicolumn{12}{|c|}{ August } \\
\hline \multirow{2}{*}{$\begin{array}{l}\text { Operating } \\
\text { Strategy }\end{array}$} & \multicolumn{11}{|c|}{ Stage Interval (ft.) } \\
\hline & -2 & -1 & 0 & 1 & 2 & 3 & 4 & 5 & 6 & 7 & 8 \\
\hline $1 \mathrm{a}$ & 0.0 & 0.0 & 0.0 & 0.0 & 0.0 & 0.0 & 0.0 & 0.0 & 0.0 & 0.0 & 0.0 \\
\hline \multicolumn{12}{|l|}{$2 c$} \\
\hline $5 a$ & 0.0 & 0.1 & 1.0 & -0.4 & -0.3 & -0.5 & 0.0 & 0.0 & 0.0 & 0.0 & 0.0 \\
\hline $5 b$ & 0.0 & 0.1 & 1.4 & -0.5 & -0.4 & -0.6 & 0.0 & 0.0 & 0.0 & 0.0 & 0.0 \\
\hline $6 a$ & 0.0 & 0.1 & 1.0 & -0.3 & -0.3 & -0.4 & 0.0 & 0.0 & 0.0 & 0.0 & 0.0 \\
\hline $6 b$ & 0.0 & 0.1 & 1.5 & -0.4 & -0.4 & -0.6 & 0.0 & 0.0 & 0.0 & 0.0 & 0.0 \\
\hline \multicolumn{12}{|c|}{ September } \\
\hline \multirow{2}{*}{$\begin{array}{l}\text { Operating } \\
\text { Strategy }\end{array}$} & \multicolumn{11}{|c|}{ Stage Interval (ft.) } \\
\hline & -2 & -1 & o & 1 & 2 & 3 & 4 & 5 & 6 & 7 & 8 \\
\hline $1 \mathrm{a}$ & 0.0 & 0.0 & -0.3 & -0.6 & 0.3 & 0.3 & 0.2 & 0.0 & 0.0 & 0.0 & 0.0 \\
\hline \multicolumn{12}{|l|}{$2 c$} \\
\hline $5 a$ & 0.0 & 0.0 & 2.2 & 0.1 & -0.6 & -1.2 & -0.4 & 0.0 & 0.0 & 0.0 & 0.0 \\
\hline $5 b$ & 0.0 & 0.0 & 4.5 & 2.4 & -2.4 & -3.1 & -1.4 & 0.0 & 0.0 & 0.0 & 0.0 \\
\hline $6 a$ & 0.0 & 0.0 & 1.9 & -0.1 & -0.5 & -1.1 & -0.3 & 0.0 & 0.0 & 0.0 & 0.0 \\
\hline $6 \mathrm{~b}$ & 0.0 & 0.0 & 3.9 & 2.0 & -2.0 & -2.6 & -1.2 & 0.0 & 0.0 & 0.0 & 0.0 \\
\hline \multicolumn{12}{|c|}{ October } \\
\hline \multirow{2}{*}{$\begin{array}{c}\text { Operating } \\
\text { Strategy }\end{array}$} & \multicolumn{11}{|c|}{ Stage Interval (ft.) } \\
\hline & -2 & -1 & $\mathbf{0}$ & 1 & 2 & 3 & 4 & 5 & 6 & 7 & 8 \\
\hline $1 \mathrm{a}$ & 0.0 & 0.0 & 0.0 & -0.1 & 0.0 & 0.0 & 0.0 & 0.0 & 0.0 & 0.0 & 0.0 \\
\hline $2 c$ & & & & & & & & & & & \\
\hline $5 a$ & 0.0 & 0.0 & 0.7 & 0.0 & -0.2 & -0.4 & -0.3 & 0.0 & 0.0 & 0.0 & 0.0 \\
\hline $5 b$ & 0.0 & 0.0 & 0.8 & 0.1 & -0.2 & -0.4 & -0.3 & 0.0 & 0.0 & 0.0 & 0.0 \\
\hline $6 a$ & 0.0 & 0.0 & 0.7 & -0.2 & -0.2 & -0.4 & -0.2 & 0.0 & 0.0 & 0.0 & 0.0 \\
\hline $6 b$ & 0.0 & 0.0 & 0.6 & -0.2 & -0.1 & -0.3 & -0.2 & 0.0 & 0.0 & 0.0 & 0.0 \\
\hline
\end{tabular}


Table 4-33. Kalama Percent of Time Comparison of Specific Operating Strategy with SOS 2c

\begin{tabular}{|c|c|c|c|c|c|c|c|c|c|c|c|}
\hline \multicolumn{12}{|c|}{ KALAMA } \\
\hline \multicolumn{12}{|c|}{ August } \\
\hline \multirow{2}{*}{$\begin{array}{l}\text { Operating } \\
\text { Strategy }\end{array}$} & \multicolumn{11}{|c|}{ Stage Interval (ft.) } \\
\hline & -2 & -1 & 0 & 1 & 2 & 3 & 4 & 5 & 6 & 7 & 8 \\
\hline $1 \mathrm{a}$ & 0.0 & 0.0 & 0.0 & 0.0 & 0.0 & 0.0 & 0.0 & 0.0 & 0.0 & 0.0 & 0.0 \\
\hline \multicolumn{12}{|l|}{$2 c$} \\
\hline $5 \mathrm{a}$ & 0.0 & 0.0 & 0.4 & 0.2 & -0.2 & -0.2 & -0.3 & 0.0 & 0.0 & 0.0 & 0.0 \\
\hline $5 b$ & 0.0 & 0.0 & 0.5 & 0.3 & -0.3 & -0.2 & -0.4 & 0.0 & 0.0 & 0.0 & 0.0 \\
\hline $6 a$ & 0.0 & 0.0 & 0.4 & 0.2 & -0.2 & -0.2 & -0.2 & 0.0 & 0.0 & 0.0 & 0.0 \\
\hline $6 \mathrm{~b}$ & 0.0 & 0.0 & 0.5 & 0.4 & -0.2 & -0.2 & -0.4 & 0.0 & 0.0 & 0.0 & 0.0 \\
\hline \multicolumn{12}{|c|}{ September } \\
\hline \multirow{2}{*}{$\begin{array}{c}\text { Operating } \\
\text { Strategy }\end{array}$} & \multicolumn{11}{|c|}{ Stage Interval (ft.) } \\
\hline & -2 & -1 & o & 1 & 2 & 3 & 4 & 5 & 6 & 7 & 8 \\
\hline $1 \mathrm{a}$ & 0.0 & 0.0 & -0.1 & -0.3 & -0.1 & 0.2 & 0.2 & 0.1 & 0.0 & 0.0 & 0.0 \\
\hline \multicolumn{12}{|l|}{$2 c$} \\
\hline $5 a$ & 0.0 & 0.0 & 0.5 & 1.1 & -0.5 & 0.0 & -0.7 & -0.3 & 0.0 & 0.0 & 0.0 \\
\hline $5 b$ & 0.0 & 0.0 & 1.0 & 2.9 & -0.4 & -0.9 & -1.9 & -0.8 & 0.0 & 0.0 & 0.0 \\
\hline $6 a$ & 0.0 & 0.0 & 0.4 & 0.9 & -0.5 & 0.0 & -0.6 & -0.2 & 0.0 & 0.0 & 0.0 \\
\hline $6 b$ & 0.0 & 0.0 & 0.9 & 2.5 & -0.3 & -0.7 & -1.6 & -0.7 & 0.0 & 0.0 & 0.0 \\
\hline \multicolumn{12}{|c|}{ October } \\
\hline \multirow{2}{*}{$\begin{array}{c}\text { Operating } \\
\text { Strategy }\end{array}$} & \multicolumn{11}{|c|}{ Stage Interval (ft.) } \\
\hline & -2 & -1 & $\mathbf{0}$ & 1 & 2 & 3 & 4 & 5 & 6 & 7 & 8 \\
\hline 1a & 0.0 & 0.0 & 0.0 & -0.1 & -0.1 & 0.0 & 0.0 & 0.0 & 0.0 & 0.0 & 0.0 \\
\hline $2 c$ & & & & & & & & & & & \\
\hline $5 \mathrm{a}$ & 0.0 & 0.0 & 0.2 & 0.4 & 0.0 & -0.2 & -0.3 & -0.2 & 0.0 & 0.0 & 0.0 \\
\hline $5 b$ & 0.0 & 0.0 & 0.2 & 0.4 & 0.0 & -0.2 & -0.4 & -0.2 & 0.0 & 0.0 & 0.0 \\
\hline $6 a$ & 0.0 & 0.0 & 0.2 & 0.3 & -0.1 & -0.2 & -0.3 & -0.1 & 0.0 & 0.0 & 0.0 \\
\hline $6 \mathrm{~b}$ & 0.0 & 0.0 & 0.2 & 0.3 & -0.1 & -0.1 & -0.3 & -0.1 & 0.0 & 0.0 & 0.0 \\
\hline
\end{tabular}


Table 4-34. Wauna Percent of Time Comparison of Specific Operating Strategy with SOS $2 c$

\begin{tabular}{|c|c|c|c|c|c|c|c|c|c|c|c|}
\hline \multicolumn{12}{|c|}{ WAUNA } \\
\hline \multicolumn{12}{|c|}{ August } \\
\hline \multirow{2}{*}{$\begin{array}{l}\text { Operating } \\
\text { Strategy }\end{array}$} & \multicolumn{11}{|c|}{ Stage Interval (ft.) } \\
\hline & -2 & -1 & 0 & 1 & 2 & 3 & 4 & 5 & 6 & 7 & 8 \\
\hline $1 a$ & 0.0 & 0.0 & 0.0 & 0.0 & 0.0 & 0.0 & 0.0 & 0.0 & 0.0 & 0.0 & 0.0 \\
\hline \multicolumn{12}{|l|}{$2 c$} \\
\hline $5 a$ & 0.0 & 0.0 & 0.0 & 0.1 & -0.1 & 0.0 & 0.0 & 0.0 & 0.0 & 0.0 & 0.0 \\
\hline $5 b$ & 0.0 & 0.0 & 0.0 & 0.1 & -0.1 & -0.1 & 0.0 & 0.0 & 0.0 & 0.0 & 0.0 \\
\hline $6 a$ & 0.0 & 0.0 & 0.0 & 0.1 & -0.1 & 0.0 & 0.0 & 0.0 & 0.0 & 0.0 & 0.0 \\
\hline $6 \mathrm{~b}$ & 0.0 & 0.0 & 0.1 & 0.2 & -0.1 & 0.0 & 0.0 & 0.0 & 0.0 & 0.0 & 0.0 \\
\hline \multicolumn{12}{|c|}{ September } \\
\hline \multirow{2}{*}{$\begin{array}{l}\text { Operating } \\
\text { Strategy }\end{array}$} & \multicolumn{11}{|c|}{ Stage Interval (ft.) } \\
\hline & -2 & -1 & 0 & 1 & 2 & 3 & 4 & 5 & 6 & 7 & 8 \\
\hline $1 \mathrm{a}$ & 0.0 & 0.0 & 0.0 & 0.0 & 0.0 & 0.0 & 0.0 & 0.0 & 0.0 & 0.0 & 0.0 \\
\hline \multicolumn{12}{|l|}{$2 c$} \\
\hline $5 a$ & 0.1 & 0.0 & 0.1 & 0.2 & -0.2 & -0.1 & 0.0 & 0.0 & 0.0 & -0.1 & 0.0 \\
\hline $5 b$ & 0.2 & 0.1 & 0.2 & 0.4 & -0.2 & -0.3 & -0.1 & 0.0 & -0.1 & -0.2 & 0.0 \\
\hline $6 a$ & 0.1 & 0.0 & 0.0 & 0.2 & -0.2 & -0.1 & -0.1 & 0.0 & 0.0 & -0.1 & 0.0 \\
\hline $6 \mathrm{~b}$ & 0.1 & 0.1 & 0.2 & 0.3 & -0.1 & -0.2 & 0.0 & 0.0 & -0.1 & -0.2 & 0.0 \\
\hline \multicolumn{12}{|c|}{ October } \\
\hline \multirow{2}{*}{$\begin{array}{l}\text { Operating } \\
\text { Strategy }\end{array}$} & \multicolumn{11}{|c|}{ Stage Interval (ft.) } \\
\hline & -2 & -1 & 0 & 1 & 2 & 3 & 4 & 5 & 6 & 7 & 8 \\
\hline $1 \mathrm{a}$ & 0.0 & 0.0 & 0.0 & 0.0 & 0.0 & 0.0 & 0.0 & 0.0 & 0.0 & 0.0 & 0.0 \\
\hline $2 c$ & & & & & & & & & & & \\
\hline $5 \mathrm{a}$ & 0.0 & 0.0 & 0.1 & -0.1 & 0.1 & 0.0 & -0.2 & 0.0 & -0.1 & 0.0 & 0.0 \\
\hline $5 b$ & 0.0 & 0.0 & 0.1 & 0.0 & 0.1 & 0.0 & -0.2 & 0.0 & -0.1 & 0.0 & 0.0 \\
\hline $6 a$ & 0.0 & 0.0 & 0.0 & -0.1 & 0.0 & 0.0 & -0.2 & 0.0 & -0.1 & 0.0 & 0.0 \\
\hline $6 \mathrm{~b}$ & 0.0 & 0.0 & 0.0 & -0.1 & 0.1 & 0.0 & -0.2 & 0.0 & -0.1 & 0.0 & 0.0 \\
\hline
\end{tabular}


The impacts of refill operations on river stage at key locations (Vancouver, Kalama and Wauna) during the critical months of August, September and October were found to be relatively small. Differences in stage intervals between the drawdown/refill scenarios and the base condition are such that the physical impact upon deep-draft vessel operations would be negligible. Waterborne commerce on the deep-draft navigation channel would not be significantly affected by any of the drawdown plans.

\subsubsection{Reservoir Navigation}

\subsubsection{Summary of Analysis}

During screening, a model was developed to assess the impacts on log rafting operations at Dworshak Reservoir which could occur from one or more of the operating strategies being considered. Log rafting operations on Dworshak Reservoir would be impaired or would cease where the elevation of the pool is lower than that of the log dump sites. The value measure for the Dworshak screening model is the added transportation costs of trucking logs to more distant dump sites or all the way to Lewiston, Idaho when the pool elevation falls below the lowest dump site. The methodology used in the analysis is described in Section 3.3.5.2 of Chapter 3 of this appendix. Table 4-35 displays the mean annual values derived for each respective SOS, arrayed in numerical order. The mean values range from $\$ 28,060$ to $\$ 400,913$. These costs were generated by the model used to analyze log transport from the Dworshak watershed. Table 4-36 displays the alternative SOSs in ascending order by mean value. In the last column of the table, the mean value for each SOS is compared to the mean value of the base condition, SOS $2 \mathrm{c}$. Values in parenthesis indicate potential reduction in log transport costs compared to the base condition. The negative values indicate that most of the alternatives analyzed in the screening process would result in improved conditions for log rafting operation in terms of lower transportation costs. Specifically, $\log$ rafting activities benefit from system operations which limit draft of the Dworshak reservoir between May and October.

The enhanced storage SOSs are most beneficial for rafted log transport because the pool is kept full and stable throughout the summer. (timber harvest season) The next least costly alternatives are the drawdown strategies, as water is held in Dworshak until it is needed to assist in the refill of the Snake River Dams. Pre-salmon summit operations and the compromised storage plans are mid-range in their impacts. With the exception of the flow augmentation strategies which require drafting the reservoir early in the conservation season, each of the operating plans would result in net savings compared to the base case, which relies heavily on drafting of Dworshak to augment spring and early summer flows in the Snake River.

Because not all plans can be implemented in the same year, the values for each SOS were adjusted to reflect the average annual equivalent value of each for the period of analysis 1995-2095. These equivalent annual amounts are displayed in Table 4-37, and reflect 1992 price levels, 1995 conditions, and discount rates of 3 percent and 7.75 percent respectively.

\subsubsection{Conclusions}

In the scenarios examined under the SOR, those SOSs requiring drafting of Dworshak for flow augmentation early in the summer have the greatest negative impact on log rafting, since transport by truck is made necessary earlier in the year. Those SOSs that hold the pool stable or delay drafting until late in the summer or early fall yield positive impacts on rafting activities by allowing logs to be moved to Lewiston in the least expensive manner. 
Table 4-35. Average Annual Cost of Transportation of Logs by Truck, Dworshak Project Area Costs (\$)

\begin{tabular}{|c|l|r|r|r|r|c|}
\hline SOS & \multicolumn{1}{|c|}{ Description } & Minimum & 10 Percent & 90 Percent & Maximum & Mean \\
\hline 1a & Pre-Salmon Summit & $\$ 92,118$ & $\$ 99,071$ & $\$ 134,283$ & $\$ 168,264$ & $\$ 116,064$ \\
\hline 1b & Load Following Operations & $\$ 83,537$ & $\$ 939,291$ & $\$ 126,286$ & $\$ 161,192$ & $\$ 108,541$ \\
\hline 2c & $\begin{array}{l}\text { SEIS w/ Upper Snake Water } \\
\text { (427kaf) }\end{array}$ & $\$ 185,072$ & $\$ 20,331$ & $\$ 256,039$ & $\$ 320,563$ & $\$ 228,188$ \\
\hline 2d & 94-98 Biological Opinion & $\$ 255,217$ & $\$ 285,463$ & $\$ 357,533$ & $\$ 411,156$ & $\$ 321,252$ \\
\hline 4c & $\begin{array}{l}\text { Stable Storage w/Mod of Grand } \\
\text { Coulee Flood Control }\end{array}$ & $\$ 0$ & $\$ 0$ & $\$ 0$ & $\$ 0$ & \\
\hline 5b & Natural River, 4.5 Mo. & $\$ 118,621$ & $\$ 132,158$ & $\$ 161,452$ & $\$ 186,975$ & $\$ 146,144$ \\
\hline 5c & Permanent Natural River & $\$ 21,377$ & $\$ 23,491$ & $\$ 34,414$ & $\$ 47,245$ & $\$ 28,060$ \\
\hline 6b & DD 4 Snake Projects, 4.5 Mo. & $\$ 48,758$ & $\$ 53,997$ & $\$ 74,548$ & $\$ 106,860$ & $\$ 63,461$ \\
\hline 6d & DD Lower Granite, 4.5 Mo. & $\$ 47,587$ & $\$ 53,573$ & $\$ 73,204$ & $\$ 92,584$ & $\$ 63,103$ \\
\hline 9a & Detailed Fishery Operation Plan & $\$ 129,937$ & $\$ 149,302$ & $\$ 194,649$ & $\$ 231,004$ & $\$ 171,326$ \\
\hline 9b & Adaptive Management & $\$ 317,002$ & $\$ 361,913$ & $\$ 446,219$ & $\$ 494,576$ & $\$ 400,913$ \\
\hline 9c & Balanced Impacts & $\$ 172,890$ & $\$ 195,396$ & $\$ 248,738$ & $\$ 298,267$ & $\$ 220,790$ \\
\hline PA & Preferred Alternative & $\$ 289,914$ & $\$ 323,051$ & $\$ 398,252$ & $\$ 459,878$ & $\$ 359,721$ \\
\hline
\end{tabular}


Table 4-36. Average Annual Cost of Transportation of Logs by Truck, Dworshak Project Area (\$): Ascending Order by Mean Value

\begin{tabular}{|c|l|r|r|r|r|r|r|}
\hline SOS & \multicolumn{1}{|c|}{ Description } & Min & 10 Percent & Mean & 90 Percent & MAX & \multicolumn{1}{c|}{$\begin{array}{c}\text { 2c Diff } \\
\text { Mean }\end{array}$} \\
\hline 4c & $\begin{array}{l}\text { Stable Storage w/mod of } \\
\text { Grand Coulee Flood } \\
\text { Control }\end{array}$ & $\$ 0$ & $\$ 0$ & $\$ 0$ & $\$ 0$ & $(\$ 228,188)$ \\
\hline 5c & Permanent Natural River & $\$ 21,377$ & $\$ 23,491$ & $\$ 28,060$ & $\$ 34,414$ & $\$ 47,245$ & $(\$ 200,128)$ \\
\hline 6d & $\begin{array}{l}\text { DD Lower Granite, } 4.5 \\
\text { Mo. }\end{array}$ & $\$ 47,587$ & $\$ 53,573$ & $\$ 63,103$ & $\$ 73,204$ & $\$ 92,584$ & $(\$ 165,085)$ \\
\hline 6b & $\begin{array}{l}\text { DD 4 Snake Projects, } \\
\text { 4.51 Mo. }\end{array}$ & $\$ 48,758$ & $\$ 53,997$ & $\$ 63,461$ & $\$ 74,548$ & $\$ 106,860$ & $(\$ 164,727)$ \\
\hline 1b & $\begin{array}{l}\text { Load Following } \\
\text { Operations }\end{array}$ & $\$ 83,537$ & $\$ 939,291$ & $\$ 108,541$ & $\$ 126,286$ & $\$ 161,192$ & $(\$ 119,647)$ \\
\hline 1a & $\begin{array}{l}\text { Pre-Salmon Summit } \\
\text { Operations }\end{array}$ & $\$ 92,118$ & $\$ 99,071$ & $\$ 116,064$ & $\$ 134,283$ & $\$ 168,264$ & $(\$ 112,124)$ \\
\hline 5b & Natural River, 4.5 Mo. & $\$ 118,621$ & $\$ 132,158$ & $\$ 146,144$ & $\$ 161,452$ & $\$ 186,975$ & $(\$ 82,044)$ \\
\hline 9a & $\begin{array}{l}\text { Detailed Fishery } \\
\text { Operation Plan }\end{array}$ & $\$ 129,937$ & $\$ 149,302$ & $\$ 171,326$ & $\$ 194,649$ & $\$ 231,004$ & $(\$ 56,862)$ \\
\hline 9c & Balanced Impacts & $\$ 172,890$ & $\$ 195,396$ & $\$ 220,790$ & $\$ 248,738$ & $\$ 298,267$ & $(\$ 7,398)$ \\
\hline 2c & $\begin{array}{l}\text { SEIS w/ Upper Snake } \\
\text { Water (427kaf) }\end{array}$ & $\$ 185,072$ & $\$ 20,331$ & $\$ 228,188$ & $\$ 256,039$ & $\$ 320,563$ & $\$ 0$ \\
\hline 2d & $94-98$ Biological Opinion & $\$ 255,217$ & $\$ 285,463$ & $\$ 321,252$ & $\$ 357,533$ & $\$ 411,156$ & $\$ 93,064$ \\
\hline PA & Preferred Alternative & $\$ 289,914$ & $\$ 323,051$ & $\$ 359,721$ & $\$ 398,252$ & $\$ 459,878$ & $\$ 131,533$ \\
\hline 9b & Adaptive Management & $\$ 317,002$ & $\$ 361,913$ & $\$ 400,913$ & $\$ 446,219$ & $\$ 494,576$ & $\$ 172,725$ \\
\hline
\end{tabular}


Table 4-37. Average Annual and Equivalent Annual Cost of Transportation of Logs by Truck, Dworshak Project Area (\$), as Compared to SOS 2c: Ascending Order by Average Annual Values

\begin{tabular}{|c|c|c|c|c|c|}
\hline \multirow[t]{2}{*}{ Sos } & \multirow[t]{2}{*}{ Description } & \multirow{2}{*}{$\begin{array}{l}\text { Average Annual } \\
\text { Costs } 1992 \text { Price } \\
\text { Levels }\end{array}$} & \multirow[t]{2}{*}{$\begin{array}{c}\text { Year of } \\
\text { Implementation }\end{array}$} & \multicolumn{2}{|c|}{$\begin{array}{l}\text { Equivalent Annual Costs } \\
1995 \text { Conditions } \\
1992 \text { Price Levels }\end{array}$} \\
\hline & & & & $3 \%$ & $7.75 \%$ \\
\hline $4 c$ & $\begin{array}{l}\text { Stable Storage w/mod of Grand } \\
\text { Coulee Flood Control }\end{array}$ & $(\$ 228,188)$ & 1995 & $(\$ 228,188)$ & $(\$ 228,188)$ \\
\hline $5 \mathrm{c}$ & Permanent Natural River & $(\$ 200,128)$ & 2000 & $(\$ 171,129)$ & $(\$ 137,748)$ \\
\hline $6 \mathrm{~d}$ & DD Lower Granite, $4.5 \mathrm{Mo}$. & $(\$ 165,085)$ & 2000 & $(\$ 141,164)$ & $(\$ 113,628)$ \\
\hline $6 b$ & DD 4 Snake Projects, 4.5 Mo. & $(\$ 164,727)$ & 2005 & $(\$ 120,267)$ & $(\$ 78,028)$ \\
\hline $1 \mathrm{~b}$ & Load Following Operations & $(\$ 119,647)$ & 1995 & $(\$ 119,647)$ & $(\$ 119,647)$ \\
\hline 1a & Pre-Salmon Summit & $(\$ 112,124)$ & 1995 & $(\$ 112,124)$ & $(\$ 112,124)$ \\
\hline $5 b$ & Natural River, $4.5 \mathrm{Mo}$. & $(\$ 82,044)$ & 2010 & $(\$ 51,048)$ & $(\$ 26,714)$ \\
\hline $9 a$ & Detailed Fishery Operation Plan & $(\$ 56,862)$ & 2005 & $(\$ 41,515)$ & $(\$ 26,934)$ \\
\hline $9 c$ & Balanced Impacts & $(\$ 7,398)$ & 2005 & $(\$ 5,401)$ & $(\$ 3,504)$ \\
\hline $2 c$ & $\begin{array}{l}\text { SEIS w/ Upper Snake Water } \\
\text { (427kaf) }\end{array}$ & $\$ 0$ & 1995 & $\$ 0$ & $\$ 0$ \\
\hline $2 d$ & 94-98 Biological Opinion & $\$ 93,064$ & 1995 & $\$ 93,064$ & $\$ 93,064$ \\
\hline PA & Preferred Alternative & $\$ 131,533$ & 1998 & $\$ 119,748$ & $\$ 105,069$ \\
\hline $9 \mathrm{~b}$ & Adaptive Management & $\$ 172,725$ & 1995 & $\$ 172,725$ & $\$ 172,725$ \\
\hline
\end{tabular}

\subsection{POWER}

\subsubsection{Gross System Replacement Costs}

Total gross system generation and capacity replacement costs developed for each SOS are summarized in Table 4-38. These costs are identical to Table 4-15, Total Regional Costs, shown in Chapter 4 of Appendix I (Power), with the exception that they are expressed in this appendix in 1993 dollars. They include the total system energy cost, combined with changes in sustained and instantaneous capacity costs, for replacing hydropower losses. These gross replacement costs are calculated for the operating year September 1995-August 1996 (OY 1996) through the operating year September 2003-August 2004 (OY 2004). 
Table 4-38. Total Gross System Replacement Costs (Millions 1993 Dollars) 1/

\begin{tabular}{|l|c|c|c|c|c|c|c|c|c|}
\hline \multirow{2}{*}{ Alternative } & \multicolumn{8}{|c|}{ System Costs by Operating Year } \\
\cline { 2 - 11 } & 1996 & 1997 & 1998 & 1999 & 2000 & 2001 & 2002 & 2003 & 2004 \\
\hline SOS 1a & 923 & 978 & 1033 & 1087 & 1142 & 1197 & 1251 & 1306 & 1361 \\
\hline SOS 1b & 909 & 960 & 1011 & 1062 & 1113 & 1164 & 1216 & 1267 & 1318 \\
\hline SOS 2c & 956 & 1012 & 1069 & 1125 & 1181 & 1237 & 1294 & 1350 & 1406 \\
\hline SOS 2d & 984 & 1040 & 1096 & 1152 & 1208 & 1264 & 1320 & 1376 & 1433 \\
\hline SOS 4c & 1030 & 1090 & 1150 & 1210 & 1269 & 1329 & 1389 & 1449 & 1509 \\
\hline SOS 5b & 1052 & 1116 & 1181 & 1246 & 1310 & 1375 & 1440 & 1504 & 1569 \\
\hline SOS 5c & 1085 & 1154 & 1223 & 1292 & 1361 & 1430 & 1499 & 1568 & 1637 \\
\hline SOS 6b & 996 & 1054 & 1113 & 1171 & 1230 & 1288 & 1347 & 1405 & 1464 \\
\hline SOS 6d & 976 & 1033 & 1089 & 1146 & 1203 & 1259 & 1316 & 1373 & 1429 \\
\hline SOS 9a & 1237 & 1304 & 1370 & 1436 & 1502 & 1568 & 1634 & 1700 & 1766 \\
\hline SOS 9b & 1161 & 1223 & 1285 & 1347 & 1409 & 1471 & 1533 & 1595 & 1657 \\
\hline SOS 9c & 1113 & 1176 & 1240 & 1303 & 1367 & 1430 & 1494 & 1557 & 1621 \\
\hline $\begin{array}{l}\text { Preferred } \\
\text { Alternative }\end{array}$ & 1083 & 1143 & 1203 & 1263 & 1323 & 1384 & 1444 & 1504 & 1564 \\
\hline $\begin{array}{l}1 / \text { Costs are not discounted to account for differences in implementation timing of the SOSs and do not } \\
\text { include implementation costs }\end{array}$ & & & & & & & \\
\hline
\end{tabular}

\subsubsection{Equivalent Annual Changes in Gross System Replacement Costs}

Table 4-39 shows the equivalent annual change in gross system replacement cost for each SOS.

Table 4-39 is identical to Table 5-7, Chapter 5, Appendix I, Power. This table accounts for the implementation timing of each SOS, as described in Appendix I and elsewhere in this appendix. In order to account for implementation timing, a number of assumptions were necessary. For each SOS, it was assumed that the gross system replacement costs for OY 1995 would be identical to OY 1996, costs through OY 2004 would be as shown in Table 4-38, and costs from OY 2004 through OY 2094 would be constant at the level in OY 2004.
For SOSs with implementation dates later than OY 1995 , the costs associated with SOS $2 \mathrm{c}$ were assumed from OY 1995 to the implementation date. For example, SOS $6 \mathrm{~b}$ has an implementation date of OY 2005. To determine the equivalent annual change in gross replacement costs for SOS $6 \mathrm{~b}$, the gross replacement costs for SOS $2 \mathrm{c}$ were assumed from $O Y$ 1995 through OY 2004, and the gross replacement costs for SOS $6 \mathrm{~b}$ were assumed from OY 2005 through OY 2094.

Table 4-39 shows the equivalent annual gross replacement cost for each SOS as compared to SOS 2c, at two discount rates, 3 percent and 7.75 percent. Positive numbers are increases in costs; negative numbers are decreases in costs. 
Table 4-39. Equivalent Annual Gross Replacement Cost Deltas from SOS 2c (Millions of 1993 Dollars) $1 /$

\begin{tabular}{|l|c|c|}
\hline & \multicolumn{2}{|c|}{ Discount Rate } \\
\hline \multicolumn{1}{|c|}{ Alternative } & 3 percent & 7.75 percent \\
\hline SOS 1a & -43 & -41 \\
\hline SOS 1b & -82 & -75 \\
\hline SOS 2c & 0 & 0 \\
\hline SOS 2d & 27 & 27 \\
\hline SOS 4c & 98 & 93 \\
\hline SOS 5b & 101 & 53 \\
\hline SOS 5c & 194 & 153 \\
\hline SOS 6b & 20 & 27 \\
\hline SOS 6d & 263 & 16 \\
\hline SOS 9a & 244 & 236 \\
\hline SOS 9b & 157 & 102 \\
\hline SOS 9c & 142 & 122 \\
\hline $\begin{array}{l}\text { Preferred Alter- } \\
\text { native }\end{array}$ & & 171 \\
\hline $\begin{array}{l}\text { 1/ Costs are discounted to account for differ- } \\
\text { ences in implementation timing of the SOSs but } \\
\text { do not include implementation costs. }\end{array}$ \\
\hline
\end{tabular}

\subsubsection{Equivalent Annual Implementation Costs}

In addition to the information on gross system costs shown above, the rate impact analysis required information on the implementation costs of each of the SOSs. Implementation costs are described in Section 4.2. It was assumed that some portion of implementation costs would be covered by other use areas, and that only a percentage would be allocated to power and recovered through regional rates. It was assumed that 91.1 percent of Lower Snake implementation costs would be allocated to power and that 77.5 percent of John Day implementation costs would be allocated to power. The equivalent annual implementation cost allocated to power for each SOS is shown in Table 4-40.

Table 4-40. Equivalent Annual Implementation Cost Deltas from SOS 2c (Millions 1993 Dollars)

\begin{tabular}{|l|c|c|}
\hline & \multicolumn{2}{|c|}{ Discount Rate } \\
\hline Alternative & 3 percent & 7.75 percent \\
\hline SOS 1a & 0 & 0 \\
\hline SOS 1b & 0 & 0 \\
\hline SOS 2c & 0 & 0 \\
\hline SOS 2d & 0 & 0 \\
\hline SOS 4c & 0 & 0 \\
\hline SOS 5b & 80 & 140 \\
\hline SOS 5c & 21 & 40 \\
\hline SOS 6b & 28 & 51 \\
\hline SOS 6d & 6 & 10 \\
\hline SOS 9a & 28 & 51 \\
\hline SOS 9b & 0 & 0 \\
\hline SOS 9c & 28 & 51 \\
\hline Preferred & 5 & 7 \\
\hline Ilternative & & \\
\hline
\end{tabular}

\subsubsection{Initial Rate Impacts}

The changes in total costs assumed to be recovered in regional rates are shown in Table 4-41. This is merely the sum of the changes in equivalent annual gross replacement costs and changes in equivalent annual implementation costs. Although costs are shown for 3 percent and 7.75 percent, initial rate impacts were estimated only for the 3 percent discount rate case. 
Table 4-41. Total Equivalent Annual Gross Costs Delta from SOS $2 \mathrm{c}$ (Millions 1993 Dollars) $1 /$

\begin{tabular}{|l|c|c|}
\hline & \multicolumn{2}{|c|}{ Discount Rate } \\
\hline Alternative & 3 percent & 7.75 percent \\
\hline SOS 1a & -43 & -41 \\
\hline SOS 1b & -82 & -75 \\
\hline SOS 2c & 0 & 0 \\
\hline SOS 2d & 27 & 27 \\
\hline SOS 4c & 98 & 93 \\
\hline SOS 5b & 181 & 193 \\
\hline SOS 5c & 216 & 193 \\
\hline SOS 6b & 70 & 78 \\
\hline SOS 6d & 26 & 26 \\
\hline SOS 9a & 291 & 221 \\
\hline SOS 9b & 244 & 236 \\
\hline SOS 9c & 185 & 153 \\
\hline $\begin{array}{l}\text { Preferred } \\
\text { Alternative }\end{array}$ & 146 & 129 \\
\hline $\begin{array}{l}\text { 1/ Costs are discounted to account for differences } \\
\text { in implementation timing of the SOSs and include } \\
\text { implementation costs }\end{array}$ \\
\hline \multicolumn{2}{|c|}{} \\
\hline
\end{tabular}

These costs were translated into percentage changes in gross average regional retail rates as shown in Table 4-42. Rate changes are shown for the utility and DSI sectors. The rate changes are identical, since gross replacement costs were allocated between these two sectors based on revenues, so rates increased proportionately.

\subsubsection{Price Elasticities}

An elasticity of -0.26 for the utility sector was used to determine changes in demand as a result of the above rate changes. This elasticity was based on a long-term econometric model, and was an average
Table 4-42. Gross Average Regional Retail Rate Impact, Percent Change from SOS 2c (Discount Rate of 3 Percent)

\begin{tabular}{|l|c|c|}
\hline \multicolumn{1}{|c|}{ Alternative } & Utility Sector & DSI Sector \\
\hline SOS 1a & -0.6 & -0.6 \\
\hline SOS 1b & -1.2 & -1.2 \\
\hline SOS 2c & 0.0 & 0.0 \\
\hline SOS 2d & 0.4 & 0.4 \\
\hline SOS 4c & 1.5 & 1.5 \\
\hline SOS 5b & 2.7 & 2.7 \\
\hline SOS 5c & 3.2 & 3.2 \\
\hline SOS 6b & 1.1 & 1.1 \\
\hline SOS 6d & 0.4 & 0.4 \\
\hline SOS 9a & 4.4 & 4.4 \\
\hline SOS 9b & 3.7 & 3.7 \\
\hline SOS 9c & 2.8 & 2.8 \\
\hline $\begin{array}{l}\text { Preferred } \\
\text { Alternative }\end{array}$ & 2.2 & 2.2 \\
\hline
\end{tabular}

of private and public sector elasticities. DSI load changes were examined on a plant-by-plant basis.

\subsubsection{Effects on Demand}

Table 4-43 shows the change in demand for electricity for the utility and DSI sectors as a result of the rate changes shown in Table 4-42. Demand changes in Table 4-43 are as compared to SOS $2 c$. For the utility sector, the demand impacts are the product of the retail rate change times the respective elasticity times the base demand for the sector.

There are no long-term impacts on the operations of the aluminum smelter DSIs under any of the rate change scenarios in the SOR. The new rates remain low enough across all scenarios such that no production cutbacks will occur. (This does not necessarily mean DSIs will continue to buy power from BPA--only that production will not be reduced. See section 4.8.10.) 
Table 4-43. Change in Regional Electricity Demand, from SOS 2c (Average MWs, Discount Rate of 3 Percent)

\begin{tabular}{|l|c|c|}
\hline Alternative & Utility Sector & DSI Sector \\
\hline SOS 1a & 27 & 0 \\
\hline SOS $1 b$ & 51 & 0 \\
\hline SOS $2 \mathrm{c}$ & 0 & 0 \\
\hline SOS $2 \mathrm{~d}$ & -17 & 0 \\
\hline SOS 4c & -61 & 0 \\
\hline SOS 5b & -113 & 0 \\
\hline SOS 5c & -135 & 0 \\
\hline SOS 6b & -44 & 0 \\
\hline SOS 6d & -16 & 0 \\
\hline SOS 9a & -182 & 0 \\
\hline SOS 9b & -152 & 0 \\
\hline SOS 9c & -116 & 0 \\
\hline $\begin{array}{l}\text { Preferred } \\
\text { Alternative }\end{array}$ & -91 & 0 \\
\hline
\end{tabular}

\subsubsection{Net System Replacement Costs}

Given the changes in power demand shown in Table 4-43, net system replacement costs were estimated using the assumptions and techniques used to develop gross system replacement costs in Appendix I. Although net energy replacement costs were estimated, net capacity costs were assumed unchanged from gross capacity costs. The resulting total net system replacement costs after accounting for these changes in demand are shown in Table 4-44.

\subsubsection{Equivalent Annual Changes in Net System Replacement Costs}

Table 4-45 shows the equivalent annual change in net system replacement cost for each SOS $^{1}$. This table accounts for the implementation timing of each SOS, as described in Appendix I and elsewhere in this appendix. Implementation costs for modifying projects to accommodate drawdown are unchanged. Hence adding implementation costs to Table 4-45 gives the total equivalent annual net costs shown in Table 4-46.

Table 4-44. Total Net System Replacement Costs (Millions 1993 Dollars) 1/

\begin{tabular}{|l|r|r|r|r|r|r|r|r|r|}
\hline Alternative & \multicolumn{10}{|c|}{ Cost by Operating Year } \\
\hline & 1996 & $\mathbf{1 9 9 7}$ & $\mathbf{1 9 9 8}$ & $\mathbf{1 9 9 9}$ & $\mathbf{2 0 0 0}$ & $\mathbf{2 0 0 1}$ & $\mathbf{2 0 0 2}$ & $\mathbf{2 0 0 3}$ & $\mathbf{2 0 0 4}$ \\
\hline SOS 1a & 927 & 982 & 1037 & 1092 & 1147 & 1202 & 1257 & 1312 & 1367 \\
\hline SOS 1b & 916 & 967 & 1019 & 1070 & 1122 & 1174 & 1225 & 1277 & 1328 \\
\hline SOS 2c & 956 & 1012 & 1069 & 1125 & 1181 & 1237 & 1294 & 1350 & 1406 \\
\hline SOS 2d & 981 & 1037 & 1093 & 1149 & 1205 & 1261 & 1317 & 1373 & 1429 \\
\hline SOS 4c & 1022 & 1081 & 1140 & 1199 & 1258 & 1317 & 1376 & 1436 & 1495 \\
\hline SOS 5b & 1035 & 1098 & 1162 & 1225 & 1289 & 1352 & 1415 & 1479 & 1542 \\
\hline SOS 5c & 1065 & 1132 & 1200 & 1268 & 1335 & 1403 & 1470 & 1538 & 1605 \\
\hline
\end{tabular}

1 Although rate impacts were not explicitly calculated for the 7.75 percent discount rate, it was assumed that demand changes would be very close, and hence net replacement costs were calculated assuming the same demand changes for the 7.75 percent discount rate case as were assumed for the 3 percent discount rate case. 
Table 4-44. Total Net System Replacement Costs (Millions 1993 Dollars) 1/ - CONT

\begin{tabular}{|l|r|r|r|r|r|r|r|r|r|}
\hline SOS 6b & 990 & 1048 & 1106 & 1164 & 1222 & 1280 & 1338 & 1396 & 1454 \\
\hline SOS 6d & 974 & 1030 & 1087 & 1143 & 1200 & 1256 & 1313 & 1369 & 1426 \\
\hline SOS 9a & 1205 & 1271 & 1336 & 1402 & 1467 & 1533 & 1598 & 1664 & 1729 \\
\hline SOS 9b & 1136 & 1197 & 1258 & 1320 & 1381 & 1442 & 1503 & 1564 & 1626 \\
\hline SOS 9c & 1095 & 1157 & 1220 & 1282 & 1345 & 1408 & 1470 & 1533 & 1595 \\
\hline $\begin{array}{l}\text { Preferred } \\
\text { Alternative }\end{array}$ & 1069 & 1129 & 1189 & 1248 & 1308 & 1367 & 1427 & 1487 & 1546 \\
\hline $\begin{array}{l}\text { 1/ Costs are not discounted to account for differences in implementation timing of the SOSs and do not } \\
\text { include implementation costs. }\end{array}$ \\
\hline
\end{tabular}

Table 4-45. Equivalent Annual Net Replacement Cost Deltas from SOS 2c (Millions 1993 Dollars)

\begin{tabular}{|l|r|r|}
\hline Alternative & \multicolumn{2}{|c|}{ Discount Rate } \\
\hline & 3 percent & 7.75 percent \\
\hline SOS 1a & -38 & -36 \\
\hline SOS 1b & -72 & -66 \\
\hline SOS 2c & 0 & 0 \\
\hline SOS 2d & 24 & 24 \\
\hline SOS 4c & 85 & 81 \\
\hline SOS 5b & 85 & 44 \\
\hline SOS 5c & 167 & 132 \\
\hline SOS 6b & 35 & 23 \\
\hline SOS 6d & 17 & 14 \\
\hline SOS 9a & 236 & 153 \\
\hline SOS 9b & 213 & 207 \\
\hline SOS 9c & 138 & 90 \\
\hline $\begin{array}{l}\text { Preferred } \\
\text { Alternative }\end{array}$ & 126 & 108 \\
\hline & & \\
\hline $\begin{array}{l}\text { 1/ Costs are discounted to account for differ- } \\
\text { ences in implementation timing of the SOSs but } \\
\text { do not include implementation costs. }\end{array}$ \\
\hline
\end{tabular}

In the case of alternatives where Upper Snake water was added, no costs were included for acquisition of this water. Therefore, net costs are slightly understated in these alternatives.

\subsubsection{Final Rate Impacts}

Given the total equivalent annual net costs shown in Table 4-46, a final rate impact was estimated for each SOS. Normally, the process of rate changes causing demand changes and leading again to further rate changes would iterate until an equilibrium point was reached. However, given that the demand changes shown here are smäll, only one iteration was performed. The final rates are shown in Table 4-47. Although the first iteration changes in demand were explicitly calculated only for the cost changes estimated in the 3 percent discount rate case, the final iteration recognizes the cost differences between the discount rate cases which result from the changes in demand shown in Table 4-43. Hence rate impacts both for 3 percent and 7.75 percent are shown.

Since these rate impacts include implementation timing, they should be viewed as the increase in rates that would be needed today in order to have sufficient revenue to pay all increased costs for each SOS into the future. The fact that revenues would be recovered today to pay for future implementation costs is what causes the rate impacts to differ across discount rates. If money earns more (a higher discount rate), rate impacts can be lower in some 
Table 4-46. Total Equivalent Annual Net Cost Deltas from SOS 2c (Millions 1993 Dollars)

\begin{tabular}{|l|r|r|}
\hline \multicolumn{1}{|c|}{ Alternative } & \multicolumn{2}{|c|}{ Discount Rate } \\
\hline & 3 percent & 7.75 percent \\
\hline SOS 1a & -38 & -36 \\
\hline SOS 1b & -72 & -66 \\
\hline SOS 2c & 0 & 0 \\
\hline SOS 2d & 24 & 24 \\
\hline SOS 4c & 85 & 81 \\
\hline SOS 5b & 165 & 185 \\
\hline SOS 5c & 189 & 172 \\
\hline SOS 6b & 63 & 74 \\
\hline SOS 6d & 23 & 24 \\
\hline SOS 9a & 264 & 204 \\
\hline SOS 9b & 213 & 207 \\
\hline SOS 9c & 166 & 141 \\
\hline $\begin{array}{l}\text { Preferred } \\
\text { Alternative }\end{array}$ & 130 & 116 \\
\hline $\begin{array}{l}\text { 1/ Costs are discounted to account for differ- } \\
\text { ences in implementation timing of the SOSs and } \\
\text { include implementation costs. }\end{array}$ \\
\hline
\end{tabular}

alternatives and still pay for the necessary cost increases.

\subsubsection{Aluminum Industry Impacts}

A key consideration in the demand impacts listed above is the effect on the aluminum industry in the region. This analysis assumes for the base case that over the longer term, 100 percent of the aluminum industry would be operational. This assumption is consistent with BPA's 1996 Rate Case assumption, which recognizes a strong outlook for the aluminum industry.

The most extreme SOSs cause aluminum rates to increase by 4 percent. This assumes that the DSIs pay through rates for their share of any cost in- creases associated with each SOS. It is not expected that such a small rate increase would cause any of the smelters to become uneconomic.

As discussed above, however, it is unlikely that rate increases due to changes in hydro operations will actually be passed through to rates, especially DSI rates. The DSIs have a wide choice of suppliers for power--several have already chosen to buy part of their electricity supply from other than BPA.

Whether or not a mechanism is put in place to recover costs of changes in hydro operation from the DSIs remains to be seen. However, it is safe to assume that the DSIs will have an economical supply of power within the Pacific Northwest for many years to come, and that even rate changes on the order shown in this appendix are unlikely to effect their long-term economic outlook.

Table 4-47. Net Average Regional Retail Rate Impact, Percent Change from SOS $2 c$

\begin{tabular}{|c|c|c|c|c|}
\hline \multirow[t]{2}{*}{ Alternative } & \multicolumn{2}{|c|}{3 Percent } & \multicolumn{2}{|c|}{ 7.75 Percent } \\
\hline & $\begin{array}{l}\text { Utility } \\
\text { Sector }\end{array}$ & $\begin{array}{c}\text { DSI } \\
\text { Sector }\end{array}$ & $\begin{array}{l}\text { Utility } \\
\text { Sector }\end{array}$ & $\begin{array}{c}\text { DSI } \\
\text { Sector }\end{array}$ \\
\hline SOS 1a & -0.6 & -0.6 & -0.5 & -0.5 \\
\hline $\operatorname{sos} 1 b$ & -1.1 & -1.1 & -1.0 & -1.0 \\
\hline $\operatorname{SOS} 2 c$ & 0.0 & 0.0 & 0.0 & 0.0 \\
\hline $\operatorname{SOS} 2 \mathrm{~d}$ & 0.4 & 0.4 & 0.4 & 0.4 \\
\hline SOS $4 c$ & 1.3 & 1.3 & 1.2 & 1.2 \\
\hline SOS $5 b$ & 2.5 & 2.5 & 2.8 & 2.8 \\
\hline SOS $5 c$ & 2.8 & 2.8 & 2.6 & 2.6 \\
\hline sos $6 b$ & 0.9 & 0.9 & 1.1 & 1.1 \\
\hline sos 6d & 0.3 & 0.3 & 0.4 & 0.4 \\
\hline $\operatorname{sos} 9 a$ & 4.0 & 4.0 & 3.1 & 3.1 \\
\hline SOS $9 b$ & 3.2 & 3.2 & 3.1 & 3.1 \\
\hline SOS 9c & 2.5 & 2.5 & 2.1 & 2.1 \\
\hline $\begin{array}{l}\text { Preferred } \\
\text { Alternative }\end{array}$ & 2.0 & 2.0 & 1.7 & 1.7 \\
\hline
\end{tabular}




\subsection{RECREATION}

\subsubsection{Summary of Impacts}

The economic impacts to recreation for the FEIS were determined by using a recreational demand model that incorporates results from a 1993 mail-out survey in the Pacific Northwest and parts of Canada. The modeling process, as described in Section 3.6 of Appendix J, and Exhibit E of Appendix J, contains several state-of-the-art procedures. The survey design was well tested in advance and included computer-enhanced photos of projects at various water levels. Respondents were asked to define their behavior contingent on different water levels. This allowed demand and value estimates to be made for water levels associated with the SOSs which may not have been experienced by the respondents.

Three modeling phases were incorporated into the evaluation process. First, a selectivity model (Survey Response Model) was developed to estimate the propensity of an individual in the sample to respond to the survey, as a function of numerous explanatory variables. The explanatory variables included socioeconomic characteristics, distances to regional waters, and population strata. Second, the Demand Model estimated the number of trips to a recreation project based on, (1) the price from the individual's home to the specific recreation project and other recreation destinations (travel costs), (2) water levels at the project, (3) water levels at alternative projects, (4) socio-economic characteristics, and (5) a time variable. By using standard Travel Cost Method procedures, individual demand curves were estimated and the consumer surplus of each SOS was estimated. Third, the Simulation Model used water levels of the projects as input to the demand models to estimate total annual visitation in recreation days and total summer season consumer surplus. The Simulation Model results are provided as the average over the 50 water years. Also, the results for a low water year (1941) and a high water year (1976) are provided. The results presented in this appendix are only for the 50-year average.

The recreation survey only covered the summer months, so the resulting computation of consumer surplus is only for the value of recreation over the four summer months (May, June, July and August). This understates the total annual consumer surplus. This is not a large underestimation because the vast majority of recreation visits occur during the summer months. Consideration was given to applying consumer surplus per visitor day values as computed in the simulation models to a fixed level of non-summer month visits. This approach was judged to inappropriate for several reasons: (1) it is likely that the consumer surplus for non-summer recreation is considerably different than summer, and there was no supportable way to make this adjustment; (2) a fixed consumer surplus for non-summer months would net out in any comparisons between SOSs; and, (3) most of the reservoirs under each SOS have minimal differences in nonsummer water levels and the impacts on non-summer recreation was not expected to be influenced significantly by the differences in water level.

Recreation visitation and consumer surplus estimate for each SOS are calibrated to 1993 conditions (e.g. level of recreation demand), and represent an average over the 50 water years considered in the analysis. No adjustments over time for changes in population, demand, and socioeconomic characteristics were made. Hence, the estimates are point-in-time estimates of the first year of each SOS, even though many of the SOSs have different implementation dates.

\subsubsection{Average Annual Recreation Values}

Table 4-48 shows the estimated annual recreation days by $S O S$ and by the projects and river reaches modeled for the SOR. Since no projections of changes in recreation use over time were made, this table provides the average annual recreation use over the life of each SOS. As explained in Section 3.3.7, two river reaches were modeled because they were judged to be the most impacted reaches; the Kootenai River below Libby, and the Clearwater River below Dworshak. Some of the SOR Federal projects were not modeled because recreation impacts were judged to be minimal; Chief Joseph, McNary, The Dalles, and Bonneville. Figure 4-4 graphically portrays the annual recreation visits for each SOS compared to the 
Table 4-48. Recreation Use Summary in Annual Recreation Days Based on 50-Year Period of Record Average

\begin{tabular}{|c|c|c|c|c|c|c|c|c|c|c|c|c|c|}
\hline SOS & $\begin{array}{l}\text { Hungry } \\
\text { Horse }\end{array}$ & $\begin{array}{l}\text { Pend } \\
\text { Oreille }\end{array}$ & $\begin{array}{c}\text { Lake } \\
\text { Koocan- } \\
\text { usa }\end{array}$ & $\begin{array}{c}\text { Kootenai } \\
\text { River }\end{array}$ & Dworshak & $\begin{array}{l}\text { Clearwatr } \\
\text { River }\end{array}$ & $\begin{array}{l}\text { Lower } \\
\text { Granite }\end{array}$ & $\begin{array}{l}\text { Little } \\
\text { Goose }\end{array}$ & $\begin{array}{l}\text { Lower } \\
\text { Monu- } \\
\text { mental }\end{array}$ & $\begin{array}{c}\text { Ice } \\
\text { Harbor }\end{array}$ & $\begin{array}{c}\text { Lake } \\
\text { Roosevelt }\end{array}$ & John Day & Total \\
\hline 1a & 128,303 & $1,215,923$ & 604,590 & 34,316 & 182,676 & 109,147 & $1,653,879$ & 244,797 & 140,009 & 525,658 & $1,630,971$ & $2,860,009$ & $9,330,278$ \\
\hline $1 b$ & 125,670 & $1,216,917$ & 603,795 & 34,912 & 185,625 & 105,285 & $1,687,100$ & 244,861 & 140,052 & 525,916 & $1,637,181$ & $2,860,009$ & $9,367,323$ \\
\hline $2 c$ & 129,257 & $1,222,511$ & 607,247 & 35,636 & 201,413 & 128,224 & $1,662,699$ & 240,402 & 137,598 & 514,730 & $1,670,069$ & $2,555,389$ & $9,105,175$ \\
\hline $2 d$ & 128,574 & $1,222,511$ & 605,012 & 35,062 & 159,655 & 198,900 & $1,662,699$ & 240,402 & 137,598 & 514,730 & $1,662,812$ & $2,555,389$ & $9,123,344$ \\
\hline $4 c$ & 152,601 & $1,183,126$ & 619,879 & 34,006 & 207,566 & 147,346 & $1,649,772$ & 239,610 & 136,673 & 507,022 & $1,661,461$ & $2,760,038$ & $9,299,100$ \\
\hline $5 b$ & 126,532 & $1,217,773$ & 602,870 & 34,989 & 213,711 & 126,711 & 859,290 & 92,671 & 57,577 & 164,147 & $1,665,931$ & $2,120,958$ & $7,283,160$ \\
\hline $5 c$ & 126,533 & $1,217,773$ & 602,871 & 34,989 & 226,932 & 141,589 & 652,290 & 71,143 & 44,052 & 127,270 & $1,665,931$ & $2,120,958$ & $7,032,331$ \\
\hline $6 \mathrm{~b}$ & 126,533 & $1,217,773$ & 602,871 & 34,989 & 198,854 & 133,905 & $1,250,024$ & 164,402 & 96,492 & 335,312 & $1,665,931$ & $2,120,958$ & $7,948,044$ \\
\hline $6 d$ & 126,533 & $1,217,773$ & 602,871 & 34,989 & 198,854 & 133,905 & $1,250,024$ & 240,402 & 137,598 & 514,730 & $1,665,931$ & $2,120,958$ & $8,244,568$ \\
\hline $9 \mathrm{a}$ & 91,036 & $1,001,121$ & 546,186 & 14,270 & 180,361 & 136,247 & $1,175,338$ & 151,909 & 89,356 & 301,583 & $1,257,182$ & $2,103,849$ & $7,048,438$ \\
\hline $9 \mathrm{~b}$ & 135,367 & $1,148,023$ & 596,840 & 28,942 & 133,202 & 135,271 & $1,618,319$ & 233,075 & 133,421 & 494,838 & $1,482,095$ & $2,555,389$ & $8,694,782$ \\
\hline $9 c$ & 152,580 & $1,187,905$ & 618,419 & 33,881 & 183,092 & 143,327 & $1,485,478$ & 203,317 & 119,271 & 449,605 & $1,570,658$ & $2,068,283$ & $8,215,816$ \\
\hline PA & 133,530 & $1,243,190$ & 601,640 & 24,960 & 149,645 & 151,296 & $1,673,460$ & 242,655 & 138,766 & 519,212 & $1,612,827$ & $1,502,081$ & $7,993,262$ \\
\hline
\end{tabular}

RECREATION USE - DIFFERENCES FROM SOS 2C

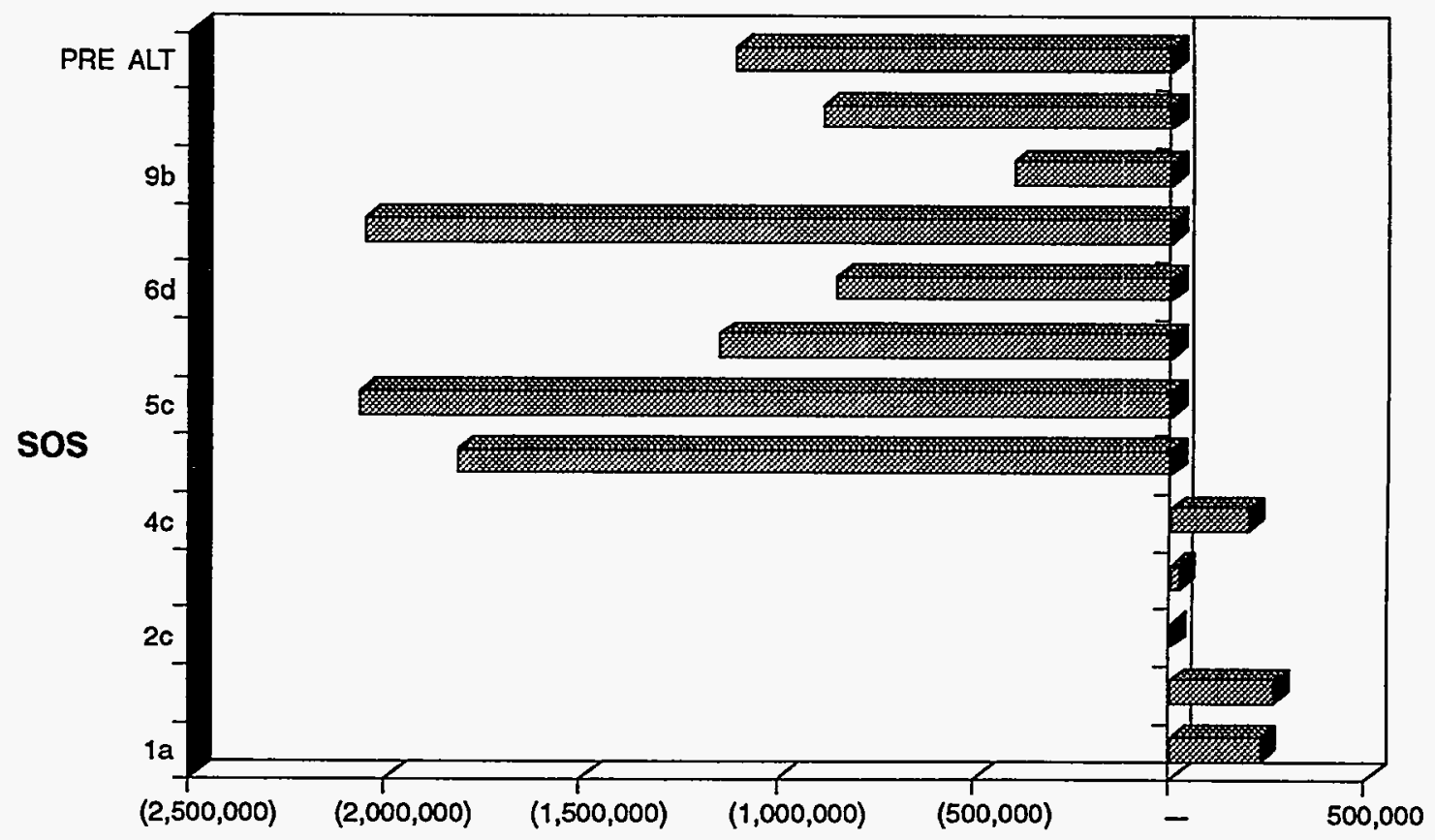

RECREATION DAYS

Figure 4-4. Differences in Annual Recreation Days from SOS 2c 
base case, SOS 2c. Exhibit D provides the breakdown of recreation use by recreation activity based on the percentage use by activity as provided from the recreation survey results for the summer of 1993.

Table 4-49 provides the summer consumer surplus for the modeled reservoirs and river reaches. As noted above, the annual consumer surplus is represented by the consumer surplus over the summer recreation season of four months. This, consequently, underestimates the total annual consumer surplus. Figure 4-5 graphically displays summer consumer surplus for the base case, SOS 2 .

\subsubsection{Average Annual and Equivalent Annual Recreation Values}

The use and value estimates discussed above are point-in-time estimates for the initial year of full operation of each SOS. To compare between alternatives, all impacts must be evaluated on at a common time frame. Table $4-50$ presents the adjustments made to the average annual consumer surplus values for the initial conditions to provide an annual equivalent estimate at two separate discount rates of 3.0 percent and 7.75 percent, respectively. As noted above, the average annual consumer surplus in Table 4-49 is represented by the consumer surplus over the summer recreation season of four months. This, consequently, underestimates the total annual consumer surplus.

The equivalent annual amounts shown in Table 4-50 are based on a 100 year period of analysis beginning in year 1995. Many of the SOSs could be implemented in 1995, so the equivalent annual amounts are the same as the initial condition estimates. For

Table 4-49. Average Annual Summer Consumer Surplus for Modeled Reservoirs and River Reaches (Undiscounted) - 50-year Period of Record

\begin{tabular}{|c|c|c|c|c|c|c|c|c|c|c|c|c|c|}
\hline sos & $\begin{array}{l}\text { Hungry } \\
\text { Horse }\end{array}$ & $\begin{array}{l}\text { Pend } \\
\text { Oreille }\end{array}$ & $\begin{array}{c}\text { Lake } \\
\text { Koocanusa }\end{array}$ & $\begin{array}{c}\text { Kootenai } \\
\text { River }\end{array}$ & Drorshak & $\begin{array}{c}\text { Clearwr } \\
\text { River }\end{array}$ & $\begin{array}{c}\text { Cower } \\
\text { Granite }\end{array}$ & $\begin{array}{l}\text { Little } \\
\text { Goose }\end{array}$ & $\begin{array}{c}\text { Lower } \\
\text { Monumntl }\end{array}$ & $\begin{array}{c}\text { Ice } \\
\text { Harbor }\end{array}$ & $\begin{array}{c}\text { Lake } \\
\text { Rooserelt }\end{array}$ & John Day & Total \\
\hline $1 a$ & $7,156,000$ & $35,179,000$ & $4,028,000$ & 504,000 & $11,364,000$ & 64,000 & $54,161,000$ & $10,378,000$ & $5,626,000$ & $24,693,000$ & $117,564,000$ & $48,763,000$ & $\beta 19,480,000$ \\
\hline $1 b$ & $6,970,000$ & $35,215,000 \mid$ & $4,018,000$ & 513,000 & $11,731,000$ & 56,000 & $56,490,000 \mid$ & $10,383,000$ & $5,628,000$ & $24,709,000$ & $118,254,000$ & $48,763,000$ & $322,730,000$ \\
\hline $2 c$ & $7,213,000$ & $35,420,000$ & $4,063,000$ & 526,000 & $13,520,000$ & 99,000 & $54,679,000$ & $10,051,000$ & $5,446,000$ & $23,882,000$ & $121,730,000$ & $38,160,000$ & $314,789,000$ \\
\hline $2 d$ & $7,171,000$ & $35,420,000 \mid$ & $4,034,000$ & 517,000 & $9,350,000$ & 375,000 & $54,679,000$ & $10,051,000$ & $5,446,000$ & $23,882,000$ & $120,689,000$ & $38,160,000$ & $309,774,000$ \\
\hline $4 c$ & $8,892,000$ & $33,969,000$ & $4,227,000$ & 500,000 & $13,979,000$ & 237,000 & $53,876,000$ & $10,004,000$ & $5,389,000$ & $23,399,000$ & $119,233,000$ & $45,255,000$ & $318,960,000$ \\
\hline $5 b$ & $7,030,000$ & $35,246,000 \mid$ & $4,006,000$ & 515,000 & $14,896,000$ & 1119,000 & $2,068,000$ & 378,000 & 206,000 & 913,000 & $121,250,000$ & $21,638,000$ & $208,265,000$ \\
\hline $5 c$ & $7,030,000$ & $35,246,000$ & $4,006,000$ & 515,000 & $16,317,000$ & 210,000 & $2,068,000$ & 378,000 & 206,000 & 913,000 & $121,250,000$ & $21,638,000$ & $209,777,000$ \\
\hline $6 b$ & $7,030,000$ & $35,246,000 \mid$ & $4,006,000$ & 515,000 & $13,065,000$ & 129,000 & $25,971,000$ & $4,766,000$ & $2,587,000$ & $11,389,000$ & $121,250,000$ & $21,638,000$ & $247,592,000$ \\
\hline $6 d$ & $7,030,000$ & $35,246,000$ & $4,006,000$ & 515,000 & $13,065,000$ & 129,000 & $25,971,000$ & $10,051,000$ & $5,446,000$ & $23,882,000$ & $121,250,000$ & $21,638,000$ & $268,229,000$ \\
\hline $9 a$ & $4,611,000$ & $27,322,000$ & $3,271,000$ & 192,000 & $11,450,000$ & 195,000 & $21,535,000$ & $4,024,000$ & $2,163,000$ & $9,385,000$ & $76,708,000$ & $21,241,000$ & $182,097,000$ \\
\hline $9 b$ & $7,695,000$ & $32,697,000$ & $3,928,000$ & 417,000 & $7,218,000$ & 188,000 & $51,820,000$ & $9,579,000$ & $5,177,000$ & $22,602,000$ & $99,890,000$ & $38,160,000$ & $279,371,000$ \\
\hline $9 c$ & $8,890,000$ & $34,156,000$ & $4,207,000$ & 498,000 & $11,453,000$ & 254,000 & $42,578,000$ & $7,509,000$ & $4,194,000$ & $19,461,000$ & $109,931,000$ & $19,709,000$ & $262,840,000$ \\
\hline PA & $7,581,000$ & $36,189,000$ & $3,990,000$ & 359,000 & $7,595,000$ & 280,000 & $55,328,000$ & $10,188,000$ & $5,517,000$ & $24,154,000$ & $114,858,000$ & $19,709,000$ & $285,748,000$ \\
\hline
\end{tabular}


SOS 2C SUMMER CONSUMER SURPLUS

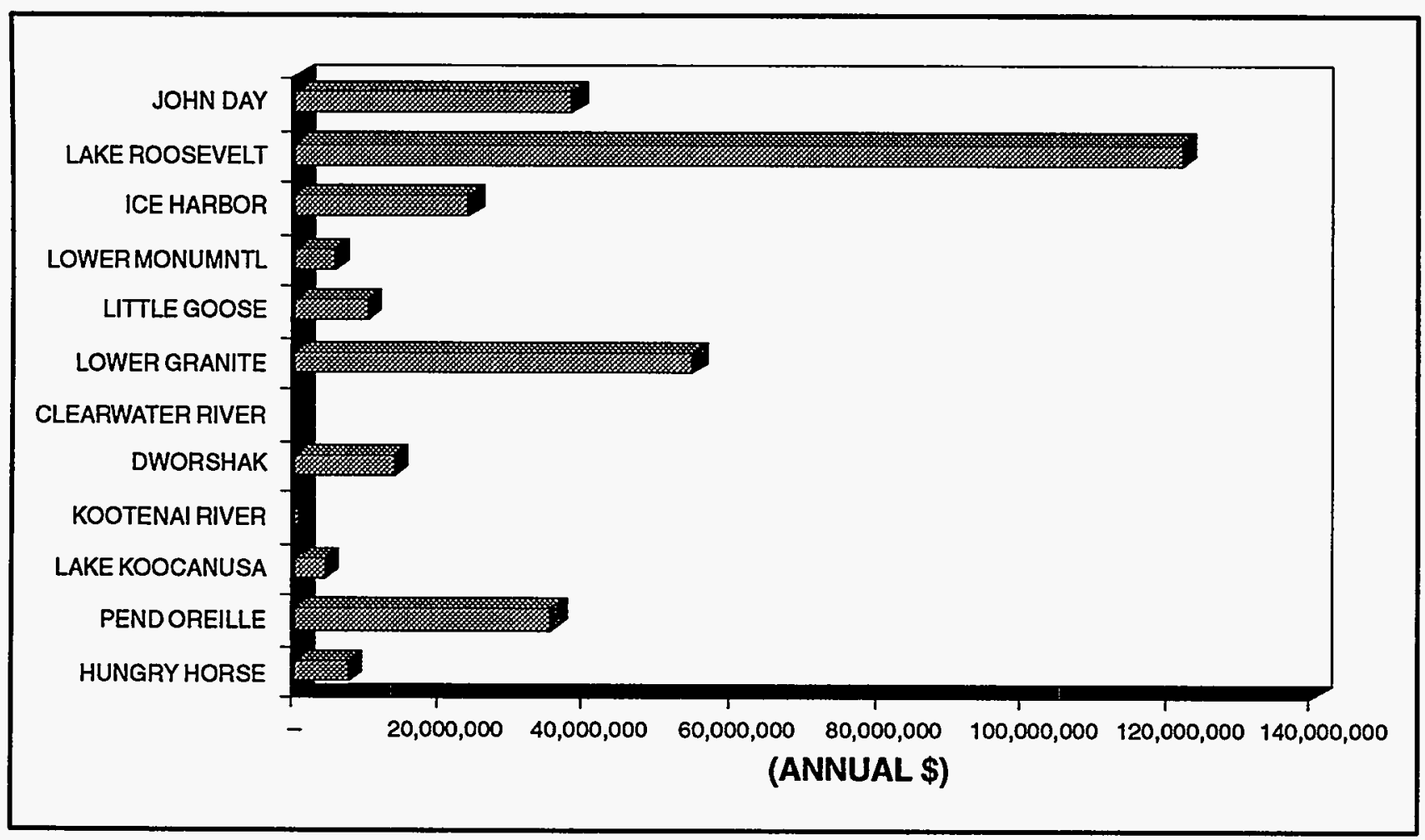

Figure 4-5. Summer Consumer Surplus for SOS $2 c$

Table 4-50. Equivalent Annual Consumer Surplus (\$), Summer Season

\begin{tabular}{|c|c|c|c|c|}
\hline \multirow{2}{*}{ SOS } & \multirow{2}{*}{$\begin{array}{c}\text { Total (Initial } \\
\text { Conditions) }\end{array}$} & \multirow{2}{*}{ Implementation Date } & \multicolumn{2}{|c|}{ Equivalent Annual Value } \\
\cline { 3 - 5 } & $319,480,000$ & 1995 & $319,480,000$ & at 7.75 \% \\
\hline SOS 1a & $322,730,000$ & 1995 & $32,73,480,000$ \\
\hline SOS 1b & $314,789,000$ & 1995 & $314,789,000$ & $314,789,000$ \\
\hline SOS 2c & $309,774,000$ & 1995 & $309,774,000$ & $309,774,000$ \\
\hline SOS 2d & $318,960,000$ & 1995 & $318,960,000$ & $318,960,000$ \\
\hline SOS 4c & $208,265,000$ & 2010 & $248,509,000$ & $280,061,000$ \\
\hline SOS 5b & $209,777,000$ & 2000 & $224,997,000$ & $242,505,000$ \\
\hline SOS 5c & $247,592,000$ & 2005 & $265,732,000$ & $282,954,000$ \\
\hline SOS 6b & $268,229,000$ & 2000 & $274,977,000$ & $282,740,000$ \\
\hline SOS 6d & $182,097,000$ & 1995 & $217,918,000$ & $251,926,000$ \\
\hline SOS 9a & $279,371,000$ & 1995 & $279,371,000$ & $279,371,000$ \\
\hline SOS 9b & $262,840,000$ & 2005 & $276,864,000$ & $290,178,000$ \\
\hline SOS 9c & $285,748,000$ & 1998 & $288,348,000$ & $291,578,000$ \\
\hline Pref Alt & & & & \\
\hline
\end{tabular}


the SOSs which will be implemented after 1995, the recreation associated with the base case condition of SOS $2 c$ was assumed to occur until the project on-line date. For example, the SOS 5c project on line date is year 2000 , so it was assumed the consumer surplus values for SOS $2 c(\$ 314,789,000)$ will occur from 1995 to 2000 . The values for $5 \mathrm{c}$ $(\$ 209,777,000)$ were assumed to occur for the period of 2000 to 2095. Hence, the equivalent annual amount of $\$ 224,997,000$ (at a discount rate of 3.0 percent) is somewhat higher than the initial amount for SOS $5 \mathrm{c}$.

These equivalent annual estimates do not include adjustments for the growth in water-related recreation use and value that may occur in the future with continued population growth. It must be recognized that per-capita recreation participation does change over time with changes in population and income. This "growth" over time was not included here to be consistent with procedures used for the other uses of water from the SOR sites, like hydropower and flood control.

\subsection{SUMMARY OF SYSTEM ANNUAL COSTS-CHANGES FROM SOS $2 \mathrm{C}$}

In the previous sections of this chapter, results of the analysis of costs and benefits of each of the SOSs were presented by system function or impact category. The purpose of this section is to present a summary of these costs and benefits and show the total system cost of each SOS. This summary is shown in Tables 4-51 and 4-52 for interest rates of 7.75 percent and 3.0 percent, respectively. Values shown are annual amounts and are the changes from SOS $2 c$, the base case system operating strategy for the SOR. Changes from SOS $2 c$ are shown, rather than total values, for two reasons: First, this allows readers to focus on the changes in costs and system benefits which would occur by changing the operation of the system from the base case operation. And second, because costs for the base case (SOS 2c) were not computed for all river uses (i.e. irrigation and M\&I water). Values included in the tables are not discounted to account for differences in implementation timing. Instead, costs and benefits are shown for the years $1995,2000,2005$, 2010, and 2020 and beyond. These years generally span the total period of time that would be required to implement each of the alternatives and for changes in anadromous fish production, which would theortically ressult from the SOSs, to stabilize. Equivalent annual costs which account for the differences in the implementation timing of the SOSs are presented in Chapter 5 as the basis for the economic comparisons of the alternatives.

In order to understand how total increased system costs for each alternative SOS were derived, the reader must understand which impact categories represent benefits, which are costs, and how they are combined mathematically to arrive at total system costs. A brief explanation is provided as follows:

Implementation Costs: Implementation costs are the annual cost of implementing each of the SOSs. The costs include engineering, construction, fish and wildlife and other mitigation--where available--and interest during construction. Annual costs include interest and amortization of investment costs, computed over a 100-year expected project life, beginning at the time of implementation, and annual operation and maintenance costs. These costs are additions to system costs. Data for tables 4-51 and 4-52 were compiled from Table 4-4 (Lower Snake River projects) and Table 4-5 (John Day project). The values shown are average annual costs, adjusted to take out the cost of irrigation and M\&I water supply. These are shown in their own categories.

\section{Commercial and Recreation Anadromous Fish}

Benefits: Commercial and recreation anadromous fish benefits represent the total commercial harvest and recreational harvest value of salmon and steelhead under each of the SOSs. Benefits change over time because of the change in production of anadromous fish (the number of returning adults) in response to a particular SOS. As such, they are an output of the system and are deductions from system costs. Data for Tables 4-51 and 4-52 were compiled from Table 4-10 ("High" Values Totals). Since estimates for each of the selected years are not available in Table 4-10, estimates for the years 2000 
and 2005 were calculated using the average annual rate of growth between 1995 and 2010. The value in Table 4-10 for the 2035 is shown for 2020 and beyond.

Flood Damages: Flood damages represent the expected cost of flood damages that would occur with each of the SOSs and are additions to system costs. For SOSs which would be implemented after 1995 , the values presented are "ultimate" damages. Data were compiled from Table 4-18 for Table 4-51 and Table 4-19 for Table 4-52.

Irrigation Costs: Increased irrigation costs result from changes in pool elevations at the reservoirs from which irrigators pump water. These costs are an increase in farm operating costs over and above those costs incurred with the base case system operation, SOS 2c. Data in Table 4-51 were taken from Table 4-22 and data in Table 4-52 were taken from Table 4-23. Since these costs are also included in the implementation costs described above, they have been deducted from "total implementation costs" to avoid double-counting.

M\&I Water Costs: M\&I water costs represent the expected costs of pumping water from reservoirs on the Columbia/Snake River System which would be incurred with each of the SOSs and are additions to system costs. Data for Table 4-51 were compiled from Table 4-26 and data for Table 4-52 were complied from Table 4-27 (Average Annual Cost). Since these costs are also included in the implementation costs described above, they have been deducted from "total implementation costs" to avoid double-counting.

Transportation Costs: Increased transportation costs result from closure during part or all of each year of the shallow-draft navigation channel on the lower Snake River between the head of the McNary pool on the Snake River below Ice Harbor dam and Lewiston, Idaho. The transportation costs shown in Tables 4-51 and 4-52 are the increased costs under each of the SOSs associated with transportation of commodities which could be impacted by changes in the operation of the Columbia/Snake river shallowdraft waterway. The costs include rail, truck, and barge shipment costs and handling and storage costs. These costs are additions to system costs. Data for Tables 4-51 and 4-52 were compiled from

Table 4-29.

\section{Dworshak Log Transportation Costs: Log trans-} portation costs are the costs of trucking logs harvested in the vicinity of the Dworshak pool. Under normal reservoir operating conditions, the logs are hauled by truck to the reservoir, dumped into the reservoir and then rafted to a take-out point near the dam. During times when the pool is drawn down to an elevation below which the log dumps on the reservoir can be used, the logs are trucked directly to the mills. Cost data for Tables 4-51 and 4-52 were compiled from Table 4-37. These costs are the net difference from SOS $2 c$ (the base case) and are additions to system costs.

Power Costs: Annual system generation costs represent the variable (operating) and fixed (capital) costs associated with generating power in the Pacific Northwest to meet power demand. Total operating costs of the Pacific Northwest hydro-thermal system are included, but capital costs are limited to the cost of acquiring new combustion turbine power plants needed to replace any hydropower system load-carrying capability that would be lost with implementation of a particular SOS. The portion of the cost of implementing the SOSs which would be allocated to the power system is not included. These costs are additions to system costs. The cost data shown in Tables 4-51 and 4-52 were compiled from Table 4-44.

Recreation Benefits: Recreation benefits are the value of recreation activity with each of the SOSs. As such, they are an output of the system and are deductions from system costs. Data for both Tables 4-51 and 4-52 were complied from Table 4-49. 
Table 4-51. Summary of Costs and Benefits of Alternative SOSs as Compared with SOS 2c- Average Annual Values by Year of Impact (7.75 percent discount rate)

\begin{tabular}{|c|c|c|c|c|c|}
\hline SOS and Impact & 1995 & 2000 & 2005 & 2010 & $\begin{array}{l}2020 \& \\
\text { Beyond }\end{array}$ \\
\hline \multicolumn{6}{|c|}{ SOS $1 \mathrm{a}--\mathrm{POL}=1995$} \\
\hline $\begin{array}{l}\text { (1a) Implementation Cost-- } \\
\text { Lower Snake 1/ }\end{array}$ & 0 & 0 & 0 & 0 & 0 \\
\hline $\begin{array}{l}\text { (1b) Implementation Cost-- } \\
\text { John Day 1/ }\end{array}$ & 0 & 0 & 0 & 0 & 0 \\
\hline (1) Total Implementation Cost $2 /$ & 0 & 0 & 0 & 0 & 0 \\
\hline (2) Anadromous Fish: Benefit $3 /$ & 10,000 & $(1,306,000)$ & $(2,976,000)$ & $(4,190,000)$ & $(360,000)$ \\
\hline (3) Flood Damages: Cost & 0 & 0 & 0 & 0 & 0 \\
\hline (4) Irrigation: Cost & 9,000 & 9,000 & 9,000 & 9,000 & 9,000 \\
\hline (5) M\&I Water Supply: Cost & 0 & 0 & 0 & 0 & 0 \\
\hline (6) Shallow Draft Navigation Cost & 0 & 0 & 0 & 0 & 0 \\
\hline (7) Dworshak Log Transportation: Cost & $(112,124)$ & $(112,124)$ & $(112,124)$ & $(112,124)$ & $(112,124)$ \\
\hline (8) Power: Cost & $(29,000,000)$ & $(35,000,000)$ & $(39,000,000)$ & $(39,000,000)$ & $(39,000,000)$ \\
\hline (9) Recreation: Benefit & $4,691,000$ & $4,691,000$ & $4,691,000$ & $4,691,000$ & $4,691,000$ \\
\hline SOS 1a Totals 4/ & $(33,804,124)$ & $(38,488,124)$ & $(40,818,124)$ & $(39,604,124)$ & $(43,434,124)$ \\
\hline \multicolumn{6}{|c|}{ SOS $1 \mathrm{~b}--\mathrm{POL}=1995$} \\
\hline $\begin{array}{l}\text { (1a) Implementation Cost-- } \\
\text { Lower Snake 1/ }\end{array}$ & 0 & 0 & 0 & 0 & 0 \\
\hline $\begin{array}{l}\text { (1b) Implementation Cost-- } \\
\text { John Day 1/ }\end{array}$ & 0 & 0 & 0 & 0 & 0 \\
\hline (1) Total Implementation Cost 2/ & 0 & 0 & 0 & 0 & 0 \\
\hline (2) Anadromous Fish: Benefit 3/ & 10,000 & $(351,000)$ & $(820,000)$ & $(430,000)$ & $(340,000)$ \\
\hline (3) Flood Damages: Cost & 0 & 0 & 0 & 0 & 0 \\
\hline (4) Irrigation: Cost & 8,900 & 8,900 & 8,900 & 8,900 & 8,900 \\
\hline (5) M\&I Water Supply: Cost & 0 & 0 & 0 & 0 & 0 \\
\hline (6) Shallow Draft Navigation Cost & 0 & 0 & 0 & 0 & \\
\hline (7) Dworshak Log Transportation: Cost & $(119,647)$ & $(119,647)$ & $(119,647)$ & $(119,647)$ & $(119,647)$ \\
\hline (8) Power: Cost & $(40,000,000)$ & $(59,000,000)$ & $(78,000,000)$ & $(78,000,000)$ & $(78,000,000)$ \\
\hline (9) Recreation: Benefit & $7,941,000$ & $7,941,000$ & $7,941,000$ & $7,941,000$ & $7,941,000$ \\
\hline SOS 1b Totals $4 /$ & $(48,061,747)$ & $(66,700,747)$ & $(85,231,747)$ & $(85,621,747)$ & $(85,711,747)$ \\
\hline
\end{tabular}


Table 4-51. Summary of Costs and Benefits of Alternative SOSs as Compared with SOS 2c- Average Annual Values by Year of Impact (7.75 percent discount rate) - CONT

\begin{tabular}{|c|c|c|c|c|c|}
\hline SOS and Impact & 1995 & 2000 & 2005 & 2010 & $\begin{array}{l}2020 \& \\
\text { Beyond }\end{array}$ \\
\hline \multicolumn{6}{|c|}{ SOS $2 c--P O L=1995$} \\
\hline $\begin{array}{l}\text { (1a) Implementation Cost-- } \\
\text { Lower Snake 1/ }\end{array}$ & 0 & 0 & 0 & 0 & 0 \\
\hline $\begin{array}{l}\text { (1b) Implementation Cost-- } \\
\text { John Day 1/ }\end{array}$ & 0 & 0 & 0 & 0 & 0 \\
\hline (1) Total Implementation Cost $2 /$ & 0 & 0 & 0 & 0 & 0 \\
\hline (2) Anadromous Fish: Benefit 3/ & 0 & 0 & 0 & 0 & 0 \\
\hline (3) Flood Damages: Cost & 0 & 0 & 0 & 0 & 0 \\
\hline (4) Irrigation: Cost & 0 & 0 & 0 & 0 & 0 \\
\hline (5) M\&I Water Supply: Cost & 0 & 0 & 0 & 0 & 0 \\
\hline (6) Shallow Draft Navigation Cost & 0 & 0 & 0 & 0 & \\
\hline (7) Dworshak Log Transportation: Cost & 0 & 0 & 0 & 0 & 0 \\
\hline (8) Power: Cost & 0 & 0 & 0 & 0 & 0 \\
\hline (9) Recreation: Benefit & 0 & 0 & 0 & 0 & 0 \\
\hline SOS 2c Totals $4 /$ & $\mathbf{0}$ & $\mathbf{0}$ & $\mathbf{0}$ & $\mathbf{0}$ & $\mathbf{0}$ \\
\hline \multicolumn{6}{|c|}{ SOS $2 d--P O L=1995$} \\
\hline $\begin{array}{l}\text { (1a) Implementation Cost-- } \\
\text { Lower Snake 1/ }\end{array}$ & 0 & 0 & 0 & 0 & 0 \\
\hline $\begin{array}{l}\text { (1b) Implementation Cost-- } \\
\text { John Day 1/ }\end{array}$ & 0 & 0 & 0 & 0 & 0 \\
\hline (1) Total Implementation Cost 2/ & 0 & 0 & 0 & 0 & 0 \\
\hline (2) Anadromous Fish: Benefit 3/ & 0 & $(296,000)$ & $(683,000)$ & $(180,000)$ & 170,000 \\
\hline (3) Flood Damages: Cost & 0 & 0 & 0 & 0 & 0 \\
\hline (4) Irrigation: Cost & $(3,300)$ & $(3,300)$ & $(3,300)$ & $(3,300)$ & $(3,300)$ \\
\hline (5) M\&I Water Supply: Cost & 0 & 0 & 0 & 0 & 0 \\
\hline (6) Shallow Draft Navigation Cost & 0 & 0 & 0 & 0 & \\
\hline (7) Dworshak Log Transportation: Cost & 93,064 & 93,064 & 93,064 & 93,064 & 93,064 \\
\hline (8) Power: Cost & $25,000,000$ & $24,000,000$ & $23,000,000$ & $23,000,000$ & $23,000,000$ \\
\hline (9) Recreation: Benefit & $(5,015,000)$ & $(5,015,000)$ & $(5,015,000)$ & $(5,015,000)$ & $(5,015,000)$ \\
\hline SOS 2d Totals 4/ & $30,104,764$ & $29,400,764$ & $28,787,764$ & $28,284,764$ & $27,934,764$ \\
\hline
\end{tabular}


Table 4-51. Summary of Costs and Benefits of Alternative SOSs as Compared with SOS 2c- Average Annual Values by Year of Impact (7.75 percent discount rate) - CONT

\begin{tabular}{|c|c|c|c|c|c|}
\hline SOS and Impact & 1995 & 2000 & 2005 & 2010 & $\begin{array}{l}2020 \& \\
\text { Beyond }\end{array}$ \\
\hline \multicolumn{6}{|c|}{ SOS $4 c--$ POL = 1995} \\
\hline $\begin{array}{l}\text { (1a) Implementation Cost-- } \\
\text { Lower Snake 1/ }\end{array}$ & 0 & 0 & 0 & 0 & 0 \\
\hline $\begin{array}{l}\text { (1b) Implementation Cost-- } \\
\text { John Day } 1 /\end{array}$ & 0 & 0 & 0 & 0 & 0 \\
\hline (1) Total Implementation Cost $2 /$ & 0 & 0 & 0 & 0 & 0 \\
\hline (2) Anadromous Fish: Benefit 3/ & 10,000 & $(301,000)$ & $(707,000)$ & $(240,000)$ & 190,000 \\
\hline (3) Flood Damages: Cost & 444,100 & 444,100 & 444,100 & 444,100 & 444,100 \\
\hline (4) Irrigation: Cost & $(18,400)$ & $(18,400)$ & $(18,400)$ & $(18,400)$ & $(18,400)$ \\
\hline (5) M\&I Water Supply: Cost & 0 & 0 & 0 & 0 & 0 \\
\hline (6) Shallow Draft Navigation Cost & 0 & 0 & 0 & 0 & \\
\hline (7) Dworshak Log Transportation: Cost & $(228,188)$ & $(228,188)$ & $(228,188)$ & $(228,188)$ & $(228,188)$ \\
\hline (8) Power: Cost & $66,000,000$ & $77,000,000$ & $89,000,000$ & $89,000,000$ & $89,000,000$ \\
\hline (9) Recreation: Benefit & $4,171,000$ & $4,171,000$ & $4,171,000$ & $4,171,000$ & $4,171,000$ \\
\hline SOS $4 c$ Totals $4 /$ & $62,016,512$ & $73,327,512$ & $85,733,512$ & $85,266,512$ & $84,836,512$ \\
\hline \multicolumn{6}{|c|}{ SOS $5 b--P O L=2010$} \\
\hline $\begin{array}{l}\text { (1a) Implementation Cost-- } \\
\text { Lower Snake 1/ }\end{array}$ & 0 & 0 & 0 & $459,871,400$ & $459,871,400$ \\
\hline $\begin{array}{l}\text { (1b) Implementation Cost-- } \\
\text { John Day } 1 /\end{array}$ & 0 & 0 & 0 & $13,367,000$ & $13,367,000$ \\
\hline (1) Total Implementation Cost $2 /$ & 0 & 0 & 0 & $459,761,000$ & $459,761,000$ \\
\hline (2) Anadromous Fish: Benefit 3/ & 0 & 0 & 0 & $(9,670,000)$ & $(10,070,000)$ \\
\hline (3) Flood Damages: Cost & 0 & 0 & 0 & 0 & 0 \\
\hline (4) Irrigation: Cost & 0 & 0 & 0 & $6,726,500$ & $6,726,500$ \\
\hline (5) M\&I Water Supply: Cost & 0 & 0 & 0 & $6,750,900$ & $6,750,900$ \\
\hline (6) Shallow Draft Navigation Cost & 0 & 0 & 0 & $21,922,676$ & $21,922,676$ \\
\hline (7) Dworshak Log Transportation: Cost & 0 & 0 & 0 & $(82,004)$ & $(82,004)$ \\
\hline (8) Power: Cost & 0 & 0 & 0 & $136,000,000$ & $136,000,000$ \\
\hline (9) Recreation: Benefit & 0 & 0 & 0 & $(106,524,000)$ & $(106,524,000)$ \\
\hline SOS 5b Totals 4 & 0 & $\mathbf{0}$ & 0 & $747,273,072$ & $747,673,072$ \\
\hline
\end{tabular}


Table 4-51. Summary of Costs and Benefits of Alternative SOSs as Compared with SOS 2c- Average Annual Values by Year of Impact (7.75 percent discount rate) - CONT

\begin{tabular}{|c|c|c|c|c|c|}
\hline SOS and Impact & 1995 & 2000 & 2005 & 2010 & $\begin{array}{l}2020 \& \\
\text { Beyond }\end{array}$ \\
\hline \multicolumn{6}{|c|}{ SOS $5 c--P O L=2000$} \\
\hline $\begin{array}{l}\text { (1a) Implementation Cost-- } \\
\text { Lower Snake 1/ }\end{array}$ & 0 & $51,794,300$ & $51,794,300$ & $51,794,300$ & $51,794,300$ \\
\hline $\begin{array}{l}\text { (1b) Implementation Cost-- } \\
\text { John Day 1/ }\end{array}$ & 0 & $13,405, \mathrm{G} 00$ & $13,405,000$ & $13,405,000$ & $13,405,000$ \\
\hline (1) Total Implementation Cost $2 /$ & 0 & $51,644,900$ & $51,644,900$ & $51,644,900$ & $51,644,900$ \\
\hline (2) Anadromous Fish: Benefit 3/ & 0 & $(2,954,000)$ & $(6,547,000)$ & $(9,920,000)$ & $(10,220,000)$ \\
\hline (3) Flood Damages: Cost & 0 & 0 & 0 & 0 & 0 \\
\hline (4) Irrigation: Cost & 0 & $6,764,500$ & $6,764,500$ & $6,764,500$ & $6,764,500$ \\
\hline (5) M\&I Water Supply: Cost & 0 & $6,789,900$ & $6,789,900$ & $6,789,900$ & $6,789,900$ \\
\hline (6) Shallow Draft Navigation Cost & 0 & $43,906,620$ & $43,906,620$ & $43,906,620$ & $43,906,620$ \\
\hline (7) Dworshak Log Transportation: Cost & 0 & $(200,128)$ & $(200,128)$ & $(200,128)$ & $(200,128)$ \\
\hline (8) Power: Cost & 0 & $154,000,000$ & $199,000,000$ & $199,000,000$ & $199,000,000$ \\
\hline (9) Recreation: Benefit & 0 & $(105,012,000)$ & $(105,012,000)$ & $(105,012,000)$ & $(105,012,000)$ \\
\hline SOS 5c Totals $4 /$ & 0 & $370,871,792$ & $419,464,792$ & $422,837,792$ & $423,137,792$ \\
\hline \multicolumn{6}{|c|}{ SOS 6b-op- $-\mathrm{POL}=2005$} \\
\hline $\begin{array}{l}\text { (1a) Implementation Cost-- } \\
\text { Lower Snake 1/ }\end{array}$ & 0 & 0 & $107,345,900$ & $107,345,900$ & $107,345,900$ \\
\hline $\begin{array}{l}\text { (1b) Implementation Cost-- } \\
\text { John Day 1/ }\end{array}$ & 0 & 0 & $12,456,000$ & $12,456,000$ & $12,456,000$ \\
\hline (1) Total Implementation Cost $2 /$ & 0 & 0 & $108,886,900$ & $108,886,900$ & $108,886,900$ \\
\hline (2) Anadromous Fish: Benefit 3/ & 0 & 0 & $(10,297,000)$ & $(15,650,000)$ & $(15,860,000)$ \\
\hline (3) Flood Damages: Cost & 0 & 0 & 0 & 0 & 0 \\
\hline (4) Irrigation: Cost & 0 & 0 & $4,486,000$ & $4,486,000$ & $4,486,000$ \\
\hline (5) M\&I Water Supply: Cost & 0 & 0 & $6,429,000$ & $6,429,000$ & $6,429,000$ \\
\hline (6) Shallow Draft Navigation Cost & 0 & 0 & $16,885,740$ & $16,885,740$ & $16,885,740$ \\
\hline (7) Dworshak Log Transportation: Cost & 0 & 0 & $(164,727)$ & $(164,727)$ & $(164,727)$ \\
\hline (8) Power: Cost & 0 & 0 & $48,000,000$ & $48,000,000$ & $48,000,000$ \\
\hline (9) Recreation: Benefit & 0 & 0 & $(67,197,000)$ & $(67,197,000)$ & $(67,197,000)$ \\
\hline SOS 6b-op Totals $4 /$ & $\mathbf{0}$ & $\mathbf{0}$ & $262,016,913$ & $267,369,913$ & $267,579,913$ \\
\hline
\end{tabular}


Table 4-51. Summary of Costs and Benefits of Alternative SOSs as Compared with SOS 2c- Average Annual Values by Year of Impact (7.75 percent discount rate) - CONT

\begin{tabular}{|c|c|c|c|c|c|}
\hline SOS and Impact & 1995 & 2000 & 2005 & 2010 & $\begin{array}{l}2020 \& \\
\text { Beyond }\end{array}$ \\
\hline \multicolumn{6}{|c|}{ SOS 6d-op- -POL $=2000$} \\
\hline $\begin{array}{l}\text { (1a) Implementation Cost-- } \\
\text { Lower Snake 1/ }\end{array}$ & 0 & $6,741,000$ & $6,741,000$ & $6,741,000$ & $6,741,000$ \\
\hline $\begin{array}{l}\text { (1b) Implementation Cost }-- \\
\text { John Day 1/ }\end{array}$ & 0 & $11,547,000$ & $11,547,000$ & $11,547,000$ & $11,547,000$ \\
\hline (1) Total Implementation Cost 2/ & 0 & $9,906,200$ & $9,906,200$ & $9,906,200$ & $9,906,200$ \\
\hline (2) Anadromous Fish: Benefit 3/ & 0 & $(1,879,000)$ & $(4,238,000)$ & $(6,170,000)$ & $(6,160,000)$ \\
\hline (3) Flood Damages: Cost & 0 & 0 & 0 & 0 & 0 \\
\hline (4) Irrigation: Cost & 0 & $2,097,500$ & $2,097,500$ & $2,097,500$ & $2,097,500$ \\
\hline (5) M\&I Water Supply: Cost & 0 & $6,284,300$ & $6,284,300$ & $.6,284,300$ & $6,284,300$ \\
\hline (6) Shallow Draft Navigation Cost & 0 & $2,519,483$ & $2,519,483$ & $.2,519,483$ & $2,519,483$ \\
\hline (7) Dworshak Log Transportation: Cost & 0 & $(165,085)$ & $(165,085)$ & $(165,085)$ & $(165,085)$ \\
\hline (8) Power: Cost & 0 & $19,000,000$ & $20,000,000$ & $20,000,000$ & $20,000,000$ \\
\hline (9) Recreation: Benefit & 0 & $(46,560,000)$ & $(46,560,000)$ & $(46,560,000)$ & $(46,560,000)$ \\
\hline SOS 6d-op Totals 4 / & $\mathbf{0}$ & $88,081,398$ & $91,440,398$ & $93,372,398$ & $93,362,398$ \\
\hline \multicolumn{6}{|c|}{ SOS 9a-op- - POL $=2005$} \\
\hline $\begin{array}{l}\text { (1a) Implementation Cost-- } \\
\text { Lower Snake 1/ }\end{array}$ & 0 & 0 & $107,344,700$ & $107,344,700$ & $107,344,700$ \\
\hline $\begin{array}{l}\text { (1b) Implementation Cost-- } \\
\text { John Day } 1 /\end{array}$ & 0 & 0 & $12,073,700$ & $12,073,700$ & $12,073,700$ \\
\hline (1) Total Implementation Cost 2/ & 0 & 0 & $108,910,500$ & $108,910,500$ & $108,910,500$ \\
\hline (2) Anadromous Fish: Benefit 3/ & 0 & 0 & $(16,389,000)$ & $(24,220,000)$ & $(24,290,000)$ \\
\hline (3) Flood Damages: Cost & 0 & 0 & 257,300 & 257,300 & 257,300 \\
\hline (4) Irrigation: Cost & 0 & 0 & $4,081,000$ & $4,081,000$ & $4,081,000$ \\
\hline (5) M\&I Water Supply: Cost & 0 & 0 & $6,426,900$ & $6,426,900$ & $6,426,900$ \\
\hline (6) Shallow Draft Navigation Cost & 0 & 0 & $16,885,740$ & $16,885,740$ & $16,885,740$ \\
\hline (7) Dworshak Log Transportation: Cost & 0 & 0 & $(56,862)$ & $(56,862)$ & $(56,862)$ \\
\hline (8) Power: Cost & 0 & 0 & $286,000,000$ & $323,000,000$ & $323,000,000$ \\
\hline (9) Recreation: Benefit & 0 & 0 & $(132,692,000)$ & $(132,692,000)$ & $(132,692,000)$ \\
\hline SOS 9a-op Totals $4 /$ & 0 & $\mathbf{0}$ & $571,585,578$ & $616,416,578$ & $616,486,578$ \\
\hline
\end{tabular}


Table 4-51. Summary of Costs and Benefits of Alternative SOSs as Compared with SOS 2c- Average Annual Values by Year of Impact (7.75 percent discount rate) - CONT

\begin{tabular}{|c|c|c|c|c|c|}
\hline SOS and Impact & 1995 & 2000 & 2005 & 2010 & $\begin{array}{l}2020 \& \\
\text { Beyond }\end{array}$ \\
\hline \multicolumn{6}{|c|}{ SOS 9b-op- -POL $=1995$} \\
\hline $\begin{array}{l}\text { (1a) Implementation Cost-- } \\
\text { Lower Snake 1/ }\end{array}$ & 0 & 0 & 0 & 0 & 0 \\
\hline $\begin{array}{l}\text { (1b) Implementation Cost-- } \\
\text { John Day 1/ }\end{array}$ & 0 & 0 & 0 & 0 & 0 \\
\hline (1) Total Implementation Cost $2 /$ & 0 & 0 & 0 & 0 & 0 \\
\hline (2) Anadromous Fish: Benefit 3/ & 10,000 & $(1,322,000)$ & $(3,012,000)$ & $(4,150,000)$ & $(3,860,000)$ \\
\hline (3) Flood Damages: Cost & 27,400 & 27,400 & 27,400 & 27,400 & 27,400 \\
\hline (4) Irrigation: Cost & 5,400 & 5,400 & 5,400 & 5,400 & 5,400 \\
\hline (5) M\&I Water Supply: Cost & 0 & 0 & 0 & 0 & 0 \\
\hline (6) Shallow Draft Navigation Cost & 0 & 0 & 0 & 0 & $\mathbf{0}$ \\
\hline (7) Dworshak Log Transportation: Cost & 172,725 & 172,725 & 172,725 & 172,725 & 172,725 \\
\hline (8) Power: Cost & $180,000,000$ & $200,000,000$ & $220,000,000$ & $220,000,000$ & $220,000,000$ \\
\hline (9) Recreation: Benefit & $(35,418,000)$ & $(35,418,000)$ & $(35,418,000)$ & $(35,418,000)$ & $(35,418,000)$ \\
\hline SOS 9b-op Totals $4 /$ & $215,613,525$ & $236,945,525$ & $258,635,525$ & $259,773,525$ & $259,483,525$ \\
\hline \multicolumn{6}{|c|}{ SOS 9c-op- -POL $=2005$} \\
\hline $\begin{array}{l}\text { (1a) Implementation Cost-- } \\
\text { Lower Snake 1/ }\end{array}$ & 0 & 0 & $107,553,500$ & $107,553,500$ & $107,553,500$ \\
\hline $\begin{array}{l}\text { (1b) Implementation Cost-- } \\
\text { John Day } 1 /\end{array}$ & 0 & 0 & $12,507,000$ & $12,507,000$ & $12,507,000$ \\
\hline (1) Total Implementation Cost 2/ & 0 & 0 & $108,912,000$ & $108,912,000$ & $108,912,000$ \\
\hline (2) Anadromous Fish: Benefit 3/ & 0 & 0 & $(10,845,000)$ & $(16,440,000)$ & $(16,460,000)$ \\
\hline (3) Flood Damages: Cost & 0 & 0 & 458,800 & 458,800 & 458,800 \\
\hline (4) Irrigation: Cost & 0 & 0 & $4,638,900$ & $4,638,900$ & $4,638,900$ \\
\hline (5) M\&I Water Supply: Cost & 0 & 0 & $6,509,600$ & $6,509,600$ & $6,509,600$ \\
\hline (6) Shallow Draft Navigation Cost & 0 & $\mathbf{0}$ & $10,097,719$ & $10,097,719$ & $10,097,719$ \\
\hline (7) Dworshak Log Transportation: Cost & 0 & 0 & $(7,398)$ & $(7,398)$ & $(7,398)$ \\
\hline (8) Power: Cost & 0 & 0 & $189,000,000$ & $189,000,000$ & $189,000,000$ \\
\hline (9) Recreation: Benefit & 0 & 0 & $(51,949,000)$ & $(51,949,000)$ & $(51,949,000)$ \\
\hline SOS 9c-op Totals $4 /$ & $\mathbf{0}$ & 0 & $382,403,621$ & $387,998,621$ & $388,018,621$ \\
\hline
\end{tabular}


Table 4-51. Summary of Costs and Benefits of Alternative SOSs as Compared with SOS 2c- Average Annual Values by Year of Impact (7.75 percent discount rate) - CONT

\begin{tabular}{|c|c|c|c|c|c|}
\hline SOS and Impact & 1995 & 2000 & 2005 & 2010 & $\begin{array}{l}2020 \& \\
\text { Beyond }\end{array}$ \\
\hline \multicolumn{6}{|c|}{ SOS Preferred Alt- -POL $=1998$} \\
\hline $\begin{array}{l}\text { (1a) Implementation Cost-- } \\
\text { Lower Snake 1/ }\end{array}$ & 0 & 0 & 0 & 0 & 0 \\
\hline $\begin{array}{l}\text { (1b) Implementation Cost-- } \\
\text { John Day 1/ }\end{array}$ & 0 & $11,503,600$ & $11,503,600$ & $11,503,600$ & $11,503,600$ \\
\hline (1) Total Implementation Cost 2/ & $\mathbf{0}$ & $3,225,000$ & $3,225,000$ & $3,225,000$ & $3,225,000$ \\
\hline (2) Anadromous Fish: Benefit 3/ & 0 & $(362,000)$ & $(833,000)$ & $(460,000)$ & $(10,000)$ \\
\hline (3) Flood Damages: Cost & 0 & 222,800 & 222,800 & 222,800 & 222,800 \\
\hline (4) Irrigation: Cost & 0 & $2,181,700$ & $2,181,700$ & $2,181,700$ & $2,181,700$ \\
\hline (5) M\&I Water Supply: Cost & 0 & $6,096,900$ & $6,096,900$ & $6,096,900$ & $6,096,900$ \\
\hline (6) Shallow Draft Navigation Cost & 0 & $\mathbf{0}$ & $\mathbf{0}$ & 0 & 0 \\
\hline (7) Dworshak Log Transportation: Cost & 0 & 131,533 & 131,533 & 131,533 & 131,533 \\
\hline (8) Power: Cost & $\mathbf{0}$ & $127,000,000$ & $140,000,000$ & $140,000,000$ & $140,000,000$ \\
\hline (9) Recreation: Benefit & 0 & $(29,041,000)$ & $(29,041,000)$ & $(29,041,000)$ & $(29,041,000)$ \\
\hline SOS Preferred Alt Totals 4 / & 0 & $168,260,933$ & $181,731,933$ & $181,358,933$ & $180,908,933$ \\
\hline \multicolumn{6}{|c|}{$\begin{array}{l}\text { Notes: } \\
1 / \text { Includes irrigation and M\&I water costs. } \\
\text { 2/ Includes costs for Lower Snake (row 1a) and John Day (row 1b) less irrigation (row 4) and M\&I (row 5). } \\
\text { 3/ Uses "high" values and "optimistic" survival assumptions } \\
\text { 4/ Computed by adding cost rows and subtracting benefit rows: Totals = } \\
\quad+(1)-(2)+(3)+(4)+(5)+(6)+(7)+(8)-(9) \text {. }\end{array}$} \\
\hline
\end{tabular}


Table 4-52. Summary of Costs and Benefits of Alternative SOSs as Compared with SOS 2c- Average Annual Values by Year of Impact (3.0 percent discount rate)

\begin{tabular}{|c|c|c|c|c|c|}
\hline SOS and Impact & 1995 & 2000 & 2005 & 2010 & $\begin{array}{l}2020 \& \\
\text { Beyond }\end{array}$ \\
\hline \multicolumn{6}{|c|}{ SOS 1a--POL = 1995} \\
\hline $\begin{array}{l}\text { (1a) Implementation Cost-- } \\
\text { Lower Snake 1/ }\end{array}$ & 0 & 0 & 0 & 0 & $\mathbf{0}$ \\
\hline $\begin{array}{l}\text { (1b) Implementation Cost-- } \\
\text { John Day 1/ }\end{array}$ & 0 & 0 & 0 & 0 & 0 \\
\hline (1) Total Implementation Cost 2/ & 0 & 0 & 0 & 0 & $\mathbf{0}$ \\
\hline (2) Anadromous Fish: Benefit 3/ & 10,000 & $(1,306,000)$ & $(2,976,000)$ & $(4,190,000)$ & $(360,000)$ \\
\hline (3) Flood Damages: Cost & 0 & 0 & 0 & 0 & 0 \\
\hline (4) Irrigation: Cost & 9,000 & 9,000 & 9,000 & 9,000 & 9,000 \\
\hline (5) M\&I Water Supply: Cost & $\mathbf{0}$ & 0 & 0 & $\mathbf{0}$ & 0 \\
\hline (6) Transportation Cost & $\mathbf{0}$ & 0 & 0 & $\mathbf{0}$ & 0 \\
\hline (7) Dworshak Log Transportation: Cost & $(112,124)$ & $(112,124)$ & $(112,124)$ & $(112,124)$ & $(112,124)$ \\
\hline (8) Power: Cost & $(29,000,000)$ & $(35,000,000)$ & $(39,000,000)$ & $(39,000,000)$ & $(39,000,000)$ \\
\hline (9) Recreation: Benefit & $4,691,000$ & $4,691,000$ & $4,691,000$ & $4,691,000$ & $4,691,000$ \\
\hline SOS 1a Totals $4 /$ & $(33,804,124)$ & $(38,488,124)$ & $(40,818,124)$ & $(39,604,124)$ & $(43,434,124)$ \\
\hline \multicolumn{6}{|c|}{ SOS $1 b--P O L=1995$} \\
\hline $\begin{array}{l}\text { (1a) Implementation Cost-- } \\
\text { Lower Snake 1/ }\end{array}$ & 0 & 0 & 0 & 0 & 0 \\
\hline $\begin{array}{l}\text { (1b) Implementation Cost-- } \\
\text { John Day } 1 /\end{array}$ & 0 & 0 & $\mathbf{0}$ & 0 & 0 \\
\hline (1) Total Implementation Cost $2 /$ & 0 & 0 & 0 & 0 & 0 \\
\hline (2) Anadromous Fish: Benefit 3/ & 10,000 & $(351,000)$ & $(820,000)$ & $(430,000)$ & $(340,00)$ \\
\hline (3) Flood Damages: Cost & 0 & 0 & 0 & 0 & 0 \\
\hline (4) Irrigation: Cost & 8,900 & 8,900 & 8,900 & 8,900 & 8,900 \\
\hline (5) M\&I Water Supply: Cost & 0 & 0 & 0 & $\mathbf{0}$ & 0 \\
\hline (6) Shallow Draft Navigation Cost & $\mathbf{0}$ & 0 & 0 & $\mathbf{0}$ & $\mathbf{0}$ \\
\hline (7) Dworshak Log Transportation: Cost & $(119,647)$ & $(119,647)$ & $(119,647)$ & $(119,647)$ & $(119,647)$ \\
\hline (8) Power: Cost & $(40,000,000)$ & $(59,000,000)$ & $(78,000,000)$ & $(78,000,000)$ & $(78,000,000)$ \\
\hline (9) Recreation: Benefit & $7,941,000$ & $7,941,000$ & $7,941,000$ & $7,941,000$ & $7,941,000$ \\
\hline SOS $1 \mathrm{~b}$ Totals $4 /$ & $(48,061,747)$ & $(66,700,747)$ & $(85,231,747)$ & $(85,621,747)$ & $(85,711,747)$ \\
\hline
\end{tabular}


Table 4-52. Summary of Costs and Benefits of Alternative SOSs as Compared with SOS 2c- Average Annual Values by Year of Impact (3.0 percent discount rate) - CONT

\begin{tabular}{|c|c|c|c|c|c|}
\hline SOS and Impact & 1995 & 2000 & 2005 & 2010 & $\begin{array}{l}2020 \& \\
\text { Beyond }\end{array}$ \\
\hline \multicolumn{6}{|c|}{ SOS $2 c--P O L=1995$} \\
\hline $\begin{array}{l}\text { (1a) Implementation Cost-- } \\
\text { Lower Snake 1/ }\end{array}$ & 0 & 0 & 0 & 0 & 0 \\
\hline $\begin{array}{l}\text { (1b) Implementation Cost-- } \\
\text { John Day 1/ }\end{array}$ & 0 & 0 & 0 & 0 & 0 \\
\hline (1) Total Implementation Cost 2/ & 0 & 0 & 0 & 0 & 0 \\
\hline (2) Anadromous Fish: Benefit 3/ & 0 & 0 & 0 & $\mathbf{0}$ & 0 \\
\hline (3) Flood Damages: Cost & 0 & 0 & 0 & 0 & 0 \\
\hline (4) Irrigation: Cost & 0 & 0 & 0 & 0 & 0 \\
\hline (5) M\&I Water Supply: Cost & 0 & 0 & $\mathbf{0}$ & 0 & 0 \\
\hline (6) Shallow Draft Navigation Cost & 0 & 0 & 0 & 0 & 0 \\
\hline (7) Dworshak Log Transportation: Cost & 0 & 0 & 0 & 0 & 0 \\
\hline (8) Power: Cost & 0 & 0 & 0 & 0 & 0 \\
\hline (9) Recreation: Benefit & 0 & 0 & 0 & 0 & 0 \\
\hline SOS 2c Totals 4 / & $\mathbf{0}$ & $\mathbf{0}$ & 0 & $\mathbf{0}$ & $\mathbf{0}$ \\
\hline \multicolumn{6}{|c|}{ SOS 2d--POL = 1995} \\
\hline $\begin{array}{l}\text { (1a) Implementation Cost-- } \\
\text { Lower Snake 1/ }\end{array}$ & 0 & 0 & 0 & 0 & 0 \\
\hline $\begin{array}{l}\text { (1b) Implementation Cost-- } \\
\text { John Day 1/ }\end{array}$ & 0 & 0 & 0 & 0 & 0 \\
\hline (1) Total Implementation Cost 2/ & 0 & 0 & 0 & 0 & 0 \\
\hline (2) Anadromous Fish: Benefit 3/ & 0 & $(296,000)$ & $(683,000)$ & $(180,000)$ & 170,000 \\
\hline (3) Flood Damages: Cost & 0 & 0 & 0 & 0 & 0 \\
\hline (4) Irrigation: Cost & $(3,300)$ & $(3,300)$ & $(3,300)$ & $(3,300)$ & $(3,300)$ \\
\hline (5) M\&I Water Supply: Cost & 0 & 0 & 0 & 0 & 0 \\
\hline (6) Shallow Draft Navigation Cost & 0 & 0 & $\mathbf{0}$ & 0 & 0 \\
\hline (7) Dworshak Log Transportation: Cost & 93,064 & 93,064 & 93,064 & 93,064 & 93,064 \\
\hline (8) Power: Cost & $25,000,000$ & $24,000,000$ & $23,000,000$ & $23,000,000$ & $23,000,000$ \\
\hline (9) Recreation: Benefit & $(5,015,000)$ & $(5,015,000)$ & $(5,015,000)$ & $(5,015,000)$ & $(5,015,000)$ \\
\hline SOS 2d Totals $4 /$ & $30,104,764$ & $29,400,764$ & $28,787,764$ & $28,284,764$ & $27,934,764$ \\
\hline
\end{tabular}


Table 4-52. Summary of Costs and Benefits of Alternative SOSs as Compared with SOS 2c- Average Annual Values by Year of Impact (3.0 percent discount rate) - CONT

\begin{tabular}{|c|c|c|c|c|c|}
\hline SOS and Impact & 1995 & 2000 & 2005 & 2010 & $\begin{array}{l}2020 \& \\
\text { Beyond }\end{array}$ \\
\hline \multicolumn{6}{|c|}{ SOS $4 c--P O L=1995$} \\
\hline $\begin{array}{l}\text { (1a) Implementation Cost-- } \\
\text { Lower Snake 1/ }\end{array}$ & 0 & 0 & 0 & 0 & 0 \\
\hline $\begin{array}{l}\text { (1b) Implementation Cost-- } \\
\text { John Day 1/ }\end{array}$ & 0 & 0 & 0 & 0 & 0 \\
\hline (1) Total Implementation Cost 2/ & 0 & 0 & 0 & 0 & 0 \\
\hline (2) Anadromous Fish: Benefit 3/ & 10,000 & $(301,000)$ & $(707,000)$ & $(240,000)$ & 190,000 \\
\hline (3) Flood Damages: Cost & 444,100 & 444,100 & 444,100 & 444,100 & 444,100 \\
\hline (4) Irrigation: Cost & $(18,400)$ & $(18,400)$ & $(18,400)$ & $(18,400)$ & $(18,400)$ \\
\hline (5) M\&I Water Supply: Cost & 0 & 0 & 0 & 0 & 0 \\
\hline (6) Shallow Draft Navigation Cost & 0 & 0 & 0 & 0 & 0 \\
\hline (7) Dworshak Log Transportation: Cost & $(228,188)$ & $(228,188)$ & $(228,188)$ & $(228,188)$ & $(228,188)$ \\
\hline (8) Power: Cost & $66,000,000$ & $77,000,000$ & $89,000,000$ & $89,000,000$ & $89,000,000$ \\
\hline (9) Recreation: Benefit & $4,171,000$ & $4,171,000$ & $4,171,000$ & $4,171,000$ & $4,171,000$ \\
\hline SOS 4c Totals $4 /$ & $62,016,512$ & $73,327,512$ & $85,733,512$ & $85,266,512$ & $84,836,512$ \\
\hline \multicolumn{6}{|c|}{ SOS $5 b--P O L=2010$} \\
\hline $\begin{array}{l}\text { (1a) Implementation Cost-- } \\
\text { Lower Snake 1/ }\end{array}$ & 0 & 0 & 0 & $129,699,900$ & $129,699,900$ \\
\hline $\begin{array}{l}\text { (1b) Implementation Cost-- } \\
\text { John Day 1/ }\end{array}$ & & & & $8,273,700$ & $8,273,700$ \\
\hline (1) Total Implementation Cost 2/ & 0 & 0 & 0 & $127,383,800$ & $127,383,800$ \\
\hline (2) Anadromous Fish: Benefit 3/ & 0 & 0 & 0 & $(9,670,000)$ & $(10,070,000)$ \\
\hline (3) Flood Damages: Cost & 0 & 0 & 0 & 0 & 0 \\
\hline (4) Irrigation: Cost & 0 & 0 & 0 & $5,330,100$ & $5,330,100$ \\
\hline (5) M\&I Water Supply: Cost & 0 & 0 & 0 & $5,259,700$ & $5,259,700$ \\
\hline (6) Shallow Draft Navigation Cost & 0 & 0 & 0 & $21,922,676$ & $21,922,676$ \\
\hline (7) Dworshak Log Transportation: Cost & 0 & 0 & 0 & $(82,004)$ & $(82,004)$ \\
\hline (8) Power: Cost & 0 & 0 & 0 & $136,000,000$ & $136,000,000$ \\
\hline (9) Recreation: Benefit & 0 & 0 & 0 & $(106,524,000$ & $(106,524,000)$ \\
\hline SOS 5b Totals 4 / & $\mathbf{0}$ & $\mathbf{0}$ & 0 & $412,008,272$ & $412,408,272$ \\
\hline
\end{tabular}


Table 4-52. Summary of Costs and Benefits of Alternative SOSs as Compared with SOS 2c-Average Annual Values by Year of Impact (3.0 percent discount rate) - CONT

\begin{tabular}{|c|c|c|c|c|c|}
\hline SOS and Impact & 1995 & 2000 & 2005 & 2010 & $\begin{array}{l}2020 \& \\
\text { Beyond }\end{array}$ \\
\hline \multicolumn{6}{|c|}{ SOS $5 c--P O L=2000$} \\
\hline $\begin{array}{l}\text { (1a) Implementation Cost-- } \\
\text { Lower Snake 1/ }\end{array}$ & 0 & $20,206,800$ & $20,206,800$ & $20,206,800$ & $20,206,800$ \\
\hline $\begin{array}{l}\text { (1b) Implementation Cost-- } \\
\text { John Day 1/ }\end{array}$ & 0 & $8,311,700$ & $8,311,700$ & $8,311,700$ & $8,311,700$ \\
\hline (1) Total Implementation Cost $2 /$ & 0 & $17,851,700$ & $17,851,700$ & $17,851,700$ & $17,851,700$ \\
\hline (2) Anadromous Fish: Benefit 3/ & 0 & $(2,954,000)$ & $(6,547,000)$ & $(9,920,000)$ & $(10,220,000)$ \\
\hline (3) Flood Damages: Cost & 0 & 0 & 0 & 0 & 0 \\
\hline (4) Irrigation: Cost & 0 & $5,368,100$ & $5,368,100$ & $5,368,100$ & $5,368,100$ \\
\hline (5) M\&I Water Supply: Cost & 0 & $5,298,700$ & $5,298,700$ & $5,298,700$ & $5,298,700$ \\
\hline (6) Shallow Draft Navigation Cost & 0 & $43,906,620$ & $43,906,620$ & $43,906,620$ & $43,906,620$ \\
\hline (7) Dworshak Log Transportation: Cost & 0 & $(200,128)$ & $(200,128)$ & $(200,128)$ & $(200,128)$ \\
\hline (8) Power: Cost & 0 & $154,000,000$ & $199,000,000$ & $199,000,000$ & $199,000,000$ \\
\hline (9) Recreation: Benefit & 0 & $(105,012,000)$ & $(105,012,000)$ & $(105,012,000)$ & $(105,012,000)$ \\
\hline SOS 5c Totals $4 /$ & o & $334,190,992$ & $382,783,992$ & $386,156,992$ & $386,456,992$ \\
\hline \multicolumn{6}{|c|}{ SOS 6b-op--POL $=2005$} \\
\hline $\begin{array}{l}\text { (1a) Implementation Cost-- } \\
\text { Lower Snake 1/ }\end{array}$ & $\mathbf{0}$ & 0 & $35,058,500$ & $35,058,500$ & $35,058,500$ \\
\hline $\begin{array}{l}\text { (1b) Implementation Cost-- } \\
\text { John Day 1/ }\end{array}$ & 0 & 0 & $7,362,700$ & $7,362,700$ & $7,362,700$ \\
\hline (1) Total Implementation Cost $2 /$ & 0 & 0 & $33,889,200$ & $33,889,200$ & $33,889,200$ \\
\hline (2) Anadromous Fish: Benefit 3/ & 0 & 0 & $(10,297,000)$ & $(15,650,000)$ & $(15,860,000)$ \\
\hline (3) Flood Damages: Cost & 0 & 0 & 0 & 0 & 0 \\
\hline (4) Irrigation: Cost & 0 & 0 & $3,525,100$ & $3,525,100$ & $3,525,100$ \\
\hline (5) M\&I Water Supply: Cost & 0 & 0 & $5,006,900$ & $5,006,900$ & $5,006,900$ \\
\hline (6) Shallow Draft Navigation Cost & 0 & 0 & $16,885,740$ & $16,885,740$ & $16,885,740$ \\
\hline (7) Dworshak Log Transportation: Cost & $\mathbf{0}$ & 0 & $(164,727)$ & $(164,727)$ & $(164,727)$ \\
\hline (8) Power: Cost & 0 & 0 & $48,000,000$ & $48,000,000$ & $48,000,000$ \\
\hline (9) Recreation: Benefit & 0 & 0 & $(67,197,000)$ & $(67,197,000)$ & $(67,197,000)$ \\
\hline SOS 6b-op Totals $4 /$ & 0 & 0 & $184,636,213$ & $189,989,213$ & $190,199,213$ \\
\hline
\end{tabular}


Table 4-52. Summary of Costs and Benefits of Alternative SOSs as Compared with SOS 2c- Average Annual Values by Year of Impact (3.0 percent discount rate) - CONT

\begin{tabular}{|c|c|c|c|c|c|}
\hline SOS and Impact & 1995 & 2000 & 2005 & 2010 & $\begin{array}{l}2020 \& \\
\text { Beyond }\end{array}$ \\
\hline \multicolumn{6}{|c|}{ SOS 6d-op--POL $=2000$} \\
\hline $\begin{array}{l}\text { (1a) Implementation Cost-- } \\
\text { Lower Snake 1/ }\end{array}$ & 0 & $2,541,900$ & $2,541,900$ & $2,541,900$ & $2,541,900$ \\
\hline $\begin{array}{l}\text { (1b) Implementation Cost-- } \\
\text { John Day 1/ }\end{array}$ & 0 & $6,453,700$ & $6,453,700$ & $6,453,700$ & $6,453,700$ \\
\hline (1) Total Implementation Cost 2/ & 0 & $2,483,000$ & $2,483,000$ & $2,483,000$ & $2,483,000$ \\
\hline (2) Anadromous Fish: Benefit 3/ & 0 & $(1,879,000)$ & $(4,238,000)$ & $(6,170,000)$ & $(6,160,000)$ \\
\hline (3) Flood Damages: Cost & 0 & 0 & 0 & 0 & 0 \\
\hline (4) Irrigation: Cost & $\mathbf{0}$ & $1,627,900$ & $1,627,900$ & $1,627,900$ & $1,627,900$ \\
\hline (5) M\&I Water Supply: Cost & 0 & $4,884,700$ & $4,884,700$ & $4,884,700$ & $4,884,700$ \\
\hline (6) Shallow Draft Navigation Cost & 0 & $2,519,483$ & $2,519,483$ & $2,519,483$ & $2,519,483$ \\
\hline (7) Dworshak Log Transportation: Cost & 0 & $(165,085)$ & $(165,085)$ & $(165,085)$ & $(165,085)$ \\
\hline (8) Power: Cost & 0 & $19,000,000$ & $20,000,000$ & $20,000,000$ & $20,000,000$ \\
\hline (9) Recreation: Benefit & 0 & $(46,560,000)$ & $(46,560,000)$ & $(46,560,000)$ & $(46,560,000)$ \\
\hline SOS 6d-op Totals 4/ & 0 & $78,788,998$ & $82,147,998$ & $84,079,998$ & $84,069,998$ \\
\hline \multicolumn{6}{|c|}{ SOS 9a-op--POL $=2005$} \\
\hline $\begin{array}{l}\text { (1a) Implementation Cost-- } \\
\text { Lower Snake 1/ }\end{array}$ & 0 & 0 & $35,058,100$ & $35,058,100$ & $35,058,100$ \\
\hline $\begin{array}{l}\text { (1b) Implementation Cost-- } \\
\text { John Day 1/ }\end{array}$ & 0 & 0 & $7,186,100$ & $7,186,100$ & $7,186,100$ \\
\hline (1) Total Implementation Cost 2/ & 0 & 0 & $34,002,700$ & $34,002,700$ & $34,002,700$ \\
\hline (2) Anadromous Fish: Benefit 3/ & 0 & 0 & $(16,389,000)$ & $(24,220,000)$ & $(24,290,000)$ \\
\hline (3) Flood Damages: Cost & 0 & 0 & 257,300 & 257,300 & 257,300 \\
\hline (4) Irrigation: Cost & 0 & 0 & $3,236,400$ & $3,236,400$ & $3,236,400$ \\
\hline (5) M\&I Water Supply: Cost & 0 & 0 & $5,005,100$ & $5,005,100$ & $5,005,100$ \\
\hline (6) Shallow Draft Navigation Cost & 0 & 0 & $16,885,740$ & $16,885,740$ & $16,885,740$ \\
\hline (7) Dworshak Log Transportation: Cost & 0 & 0 & $(56,862)$ & $(56,862)$ & $(56,862)$ \\
\hline (8) Power: Cost & 0 & 0 & $286,000,000$ & $323,000,000$ & $323,000,000$ \\
\hline (9) Recreation: Benefit & 0 & 0 & $(132,692,000)$ & $(132,692,000)$ & $(132,692,000)$ \\
\hline SOS 9a-op Totals $4 /$ & 0 & $\mathbf{0}$ & $494,411,378$ & $539,242,378$ & $539,312,378$ \\
\hline
\end{tabular}


Table 4-52. Summary of Costs and Benefits of Alternative SOSs as Compared with SOS 2c- Average Annual Values by Year of Impact (3.0 percent discount rate) - CONT

\begin{tabular}{|c|c|c|c|c|c|}
\hline SOS and Impact & 1995 & 2000 & 2005 & 2010 & $\begin{array}{l}2020 \& \\
\text { Beyond }\end{array}$ \\
\hline \multicolumn{6}{|c|}{ SOS 9b--POL = 1995} \\
\hline $\begin{array}{l}\text { (1a) Implementation Cost-- } \\
\text { Lower Snake 1/ }\end{array}$ & 0 & 0 & 0 & 0 & 0 \\
\hline $\begin{array}{l}\text { (1b) Implementation Cost-- } \\
\text { John Day 1/ }\end{array}$ & 0 & 0 & 0 & 0 & 0 \\
\hline (1) Total Implementation Cost 2/ & 0 & 0 & 0 & 0 & 0 \\
\hline (2) Anadromous Fish: Benefit 3/ & 10,000 & $(1,322,000)$ & $(3,012,000)$ & $(4,150,000)$ & $(3,860,000)$ \\
\hline (3) Flood Damages: Cost & 27,400 & 27,400 & 27,400 & 27,400 & 27,400 \\
\hline (4) Irrigation: Cost & 5,400 & 5,400 & 5,400 & 5,400 & 5,400 \\
\hline (5) M\&I Water Supply: Cost & 0 & 0 & 0 & 0 & 0 \\
\hline (6) Shallow Draft Navigation Cost & 0 & 0 & 0 & 0 & $\mathbf{0}$ \\
\hline (7) Dworshak Log Transportation: Cost & 172,725 & 172,725 & 172,725 & 172,725 & 172,725 \\
\hline (8) Power: Cost & $180,000,000$ & $200,000,000$ & $220,000,000$ & $220,000,000$ & $220,000,000$ \\
\hline (9) Recreation: Benefit & $(35,418,000)$ & $(35,418,000)$ & $(35,418,000)$ & $(35,418,000)$ & $(35,418,000)$ \\
\hline SOS 9b Totals $4 /$ & $215,613,525$ & $236,945,525$ & $258,635,525$ & $.259,773,525$ & $259,483,525$ \\
\hline \multicolumn{6}{|c|}{ SOS 9c-op--POL $=2005$} \\
\hline $\begin{array}{l}\text { (1a) Implemẹntation Cost-- } \\
\text { Lower Snake 1/ }\end{array}$ & 0 & 0 & $35,142,600$ & $35,142,600$ & $35,142,600$ \\
\hline $\begin{array}{l}\text { (1b) Implementation Cost-- } \\
\text { John Day 1/ }\end{array}$ & 0 & 0 & $7,413,700$ & $7,413,700$ & $7,413,700$ \\
\hline (1) Total Implementation Cost $2 /$ & 0 & 0 & $33,842,400$ & $33,842,400$ & $33,842,400$ \\
\hline (2) Anadromous Fish: Benefit 3/ & 0 & 0 & $(10,845,000)$ & $(16,440,000)$ & $(16,460,000)$ \\
\hline (3) Flood Damages: Cost & 0 & 0 & 458,800 & 458,800 & 458,800 \\
\hline (4) Irrigation: Cost & 0 & 0 & $3,644,700$ & $3,644,700$ & $3,644,700$ \\
\hline (5) M\&I Water Supply: Cost & 0 & 0 & $5,069,200$ & $5,069,200$ & $5,069,200$ \\
\hline (6) Shallow Draft Navigation Cost & 0 & 0 & $10,097,719$ & $10,097,719$ & $10,097,719$ \\
\hline (7) Dworshak Log Transportation: Cost & 0 & 0 & $(7,398)$ & $(7,398)$ & $(7,398)$ \\
\hline (8) Power: Cost & 0 & 0 & $189,000,000$ & $189,000,000$ & $189,000,000$ \\
\hline (9) Recreation: Benefit & 0 & 0 & $(51,949,000)$ & $(51,949,000)$ & $(51,949,000)$ \\
\hline SOS 9c-op Totals 4/ & $\mathbf{0}$ & $\mathbf{0}$ & $304,899,421$ & $310,494,421$ & $310,514,421$ \\
\hline
\end{tabular}


Table 4-52. Summary of Costs and Benefits of Alternative SOSs as Compared with SOS 2c- Average Annual Values by Year of Impact (3.0 percent discount rate) - CONT

\begin{tabular}{|c|c|c|c|c|c|}
\hline SOS and Impact & 1995 & 2000 & 2005 & 2010 & $\begin{array}{l}2020 \text { \& } \\
\text { Beyond }\end{array}$ \\
\hline \multicolumn{6}{|c|}{ SOS Preferred Alt- - POL $=1998$} \\
\hline $\begin{array}{l}\text { (1a) Implementation Cost-- } \\
\text { Lower Snake 1/ }\end{array}$ & 0 & 0 & 0 & 0 & 0 \\
\hline $\begin{array}{l}\text { (1b) Implementation Cost-- } \\
\text { John Day 1/ }\end{array}$ & 0 & $6,470,700$ & $6,470,700$ & $6,470,700$ & $6,470,700$ \\
\hline (1) Total Implementation Cost 2/ & 0 & 49,100 & 49,100 & 49,100 & 49,100 \\
\hline (2) Anadromous Fish: Benefit $3 /$ & 0 & $(362,000)$ & $(833,000)$ & $(460,000)$ & $(10,000)$ \\
\hline (3) Flood Damages: Cost & 0 & 222,800 & 222,800 & 222,800 & 222,800 \\
\hline (4) Irrigation: Cost & 0 & $1,712,100$ & $1,712,100$ & $1,712,100$ & $1,712,100$ \\
\hline (5) M\&I Water Supply: Cost & 0 & $4,709,500$ & $4,709,500$ & $4,709,500$ & $4,709,500$ \\
\hline (6) Shallow Draft Navigation Cost & 0 & 0 & 0 & 0 & 0 \\
\hline (7) Dworshak Log Transportation: Cost & 0 & 131,533 & 131,533 & 131,533 & 131,533 \\
\hline (8) Power: Cost & 0 & $127,000,000$ & $140,000,000$ & $140,000,000$ & $140,000,000$ \\
\hline (9) Recreation: Benefit & 0 & $(29,041,000)$ & $(29,041,000)$ & $(29,041,000)$ & $(29,041,000)$ \\
\hline SOS Preferred Alt Totals 4/ & $\mathbf{0}$ & $163,228,033$ & $176,699,033$ & $176,326,033$ & $175,876,033$ \\
\hline \multicolumn{6}{|c|}{$\begin{array}{l}\text { Notes: } \\
\text { 1/ Includes irrigation and M\&I water costs. } \\
\text { 2/ Includes costs for Lower Snake (row 1a) and John Day (row 1b) less irrigation (row 4) and M\&I (row 5). } \\
\text { 3/ Uses "high" values and "optimistic" survival assumptions. } \\
\text { 4/ Computed by adding cost rows and subtracting benefit rows: Totals = } \\
\quad+(1)-(2)+(3)+(4)+(5)+(6)+(7)+(8)-(9) \text {. }\end{array}$} \\
\hline
\end{tabular}

\subsection{REGIONAL ECONOMIC ANALYSIS}

\subsubsection{General}

Under the framework of the SOR, regional economic impacts will be generated by changes to river operations strategies that positively or negatively affect the production and utilization of local goods and services. The impacts are brought about by resource-related changes to existing economic activity. Therefore, for each SOR alternative the measure of direct economic impact is incorporated into the regional analysis as a change from alternative SOS $2 c$, which was considered to be the strategy most representative of current system operations.
The benefits and costs to each of the affected resource activities of changing river operations, including the costs to implement the operations strategy, are computed and summed for each alternative. The net impacts for each alternative are compared to the net benefits of SOS $2 c$, the base case, to determine whether society would be made better off or worse off as a result of implementing a new operations strategy.

This section presents a summary of the procedures required to analyze each of the direct impacts, which were been described in the previous sections of this chapter, to obtain estimates of the related indirect economic impacts. The results of the analysis and 
the comparison of the regional, state-wide, and subregional economic impacts of each SOS to the base case scenario are presented in Chapter 5. A brief description of the measures of direct economic impacts of the five river uses for which indirect economic impacts were estimated is presented in Table 4-53.

The results of the analysis of regional or indirect economic impacts of the alternative SOSs are presented in Chapter 5 of this appendix.

\subsubsection{Anadromous Fisheries}

The analysis of direct economic impacts in the Pacific Northwest anadromous fisheries includes four components: 1)the commercial ocean and in-river fisheries, 2)the commercial Indian fishery, 3)the ocean and lower Columbia sport fisheries, and 4)the mid-Columbia and Snake River Basin sport fisheries. Harvest data shown in Table 4-6 were used as the basis for the analysis.

The direct economic impact of alternative system operations on commercial fishermen is the change in net income. The change in income is a function of changes in the number of fish harvested, the expenditures to catch these fish, and the price received for the fish. The indirect impacts stem from the changes in expenditures for the fishing operation and the change in net income retained by the commercial operators.

The direct impact of alternative system operations on recreational fishermen is the change in angler days, the change in consumer surplus, and changes in expenditures made by anglers. The indirect impacts stem from the changes in expenditures.

\subsubsection{Expenditure Patterns for Commercial Fisheries}

Expenditures for commercial fishing have been compiled from various surveys conducted by Dr. Hans Radtke. Gillnet budgets are considered most appropriate for in-river commercial fisheries. Information on the average catch for commercial gillnetters was used to convert the annual expenditures to a per pound and per fish basis(see Exhibit E for expenditures per fish).

Expenditure patterns for ocean fisheries also were developed by Radtke. Again the annual expenditures are converted to per pound and per fish expenditures using the average annual catch per troller(see Exhibit $\mathrm{E}$ for expenditures per fish).

\section{Table 4-53. Economic Measures Used to Value Direct Impacts for the Analysis of Indirect Impacts}

\begin{tabular}{|l|l|}
\hline \multicolumn{1}{|c|}{ Resource Activity } & \multicolumn{1}{c|}{ Measure of Direct Economic Impact } \\
\hline Anadromous Fish & $\begin{array}{l}\text { - Fish harvested in commercial fisheries, the change in operat- } \\
\text { ing expenditures, and the change in revenue as determined } \\
\text { using exvessel prices for fish } \\
\text { - Fish harvested in recreational fisheries, the number of fisher- } \\
\text { man days and estimated actual expenditures per day }\end{array}$ \\
\hline Irrigation & $\begin{array}{l}\text { Increased costs for irrigation pump modifications, annual } \\
\text { O\&M costs, and increased energy costs }\end{array}$ \\
\hline Navigation (transportation) & $\begin{array}{l}\text { Increased transportation costs associated with mode shifts and } \\
\text { increased storage and handling costs }\end{array}$ \\
\hline Power & \begin{tabular}{l} 
Net system generation costs \\
\hline Recreation
\end{tabular} \\
\hline $\begin{array}{l}\text { The number of recreation days and estimated actual expendi- } \\
\text { tures per day }\end{array}$ \\
\hline
\end{tabular}




\subsubsection{Allocation of Harvest to Subregions}

The regional economic impacts related to commercial harvest under the SOR alternatives were evaluated only for in the US ocean and in-river fisheries, including:

- the US ocean troll fishery;

- the non-Indian gillnet commercial fishery in the Columbia River below Bonneville Dam (River Zones 1-5); and,

- the Native American commercial fishery in the Columbia River from Bonneville Dam to McNary Dam (River Zone 6).

Harvest activity in each of the subregions was allocated based on the distribution of actual harvest between 1987 and 1991. Information from the Oregon Department of Fish and Wildlife and the Pacific Fishery Management Council was used to develop the state and subregion allocations. The allocation of commercial harvest to the subregions is shown in Table 4-54.

Ceremonial and subsistence use in the Native American Zone 6 fishery was estimated using current information on harvest for these purposes. These uses were allocated as follows: 1)5\% of fall chinook harvest up to 6,000 fish; 2) $5 \%$ of spring chinook harvest up to 4,000 fish; and 3)5\% of sockeye and steelhead harvest. All remaining harvest in the Native American fishery was assumed to be used for commercial purposes.

\subsubsection{Expenditure Patterns for Fish Processors}

Changes in commercial fish harvest directly affect activity levels in the related fish processing industries. The estimated change in economic activity in fish processing is measured as the increase or decrease in operating expenditures related to the change in volume of fish harvested along with the associate change in ownership returns.

Table 4-54. Allocation of Commercial Harvest to Subregions, in Percent

\begin{tabular}{|c|c|c|c|c|}
\hline & Fall Chinook & $\begin{array}{l}\text { Spring/Summer } \\
\text { Chinook }\end{array}$ & Steedhead & Sockeye \\
\hline \multicolumn{5}{|c|}{ Ocean Commercial Harvest } \\
\hline \multicolumn{5}{|l|}{ By State } \\
\hline Washington & 20 & 20 & & \\
\hline Oregon & 80 & 80 & & \\
\hline \multicolumn{5}{|l|}{ By Subregion } \\
\hline West Coast & 100 & 100 & & \\
\hline \multicolumn{5}{|c|}{ In-River Commercial Harvest } \\
\hline \multicolumn{5}{|l|}{ By River Zone } \\
\hline Zones $1-5$ & 40 & 25 & 0 & 30 \\
\hline Zone 6 & 60 & 75 & 100 & 70 \\
\hline \multicolumn{5}{|l|}{ By State } \\
\hline Washington & 40 & 40 & 60 & 60 \\
\hline Oregon & 60 & 60 & 40 & 40 \\
\hline \multicolumn{5}{|l|}{ By Subregion } \\
\hline West Coast & 28 & 17.5 & $\mathbf{0}$ & 27 \\
\hline Portland & 12 & 7.5 & 0 & 3 \\
\hline Mid-Columbia & 60 & 75 & 100 & 70 \\
\hline
\end{tabular}


Annual operating cost data for the fish processing were developed by Radtke. Expenditures per pound of fish harvested are shown in Exhibit $\mathrm{E}$. The expenditures are presented in 1992 dollars. It is important to note that operating costs related to fish purchases are excluded from the expenditure pattern when the regional impact are generated with the input-output models. This is because the impact of the fish purchases are accounted for in the commercial fishing analysis. The fish processing impacts reflect only the incremental value added by the processing activity.

\subsubsection{Allocation of Processing to Subregions}

For the regional analysis, it is assumed that all changes in commercial ocean harvest and commercial in-river harvest in zones $1-5$ would result in an equivalent change in fish processed by local processors. Processing impacts in zone 6 were not estimated due to lack of sufficient information on the processing activity in this region.

\subsubsection{Expenditure Patterns for Recreational Fisheries}

Expenditure patterns for recreational fisheries were developed using information provided in the Oregon Angler Suney and Economic Study. This study has expenditures per angler day differentiated for the various Oregon Fish and Wildlife management areas of the state. Expenditures are also differentiated by species and water type (river, lake, ocean, estuary). The budget for the Columbia River management area, in-river salmon fishermen was used as the representative budget for all in-river impacts. One modification was made to that budget. Because of the small sample size, no guide or charter fees were identified in the Oregon Angler Survey budget. Based on discussions with the authors of this study, a decision was made to include this category of expenditures. The state-wide average charter and guide fee for river fishing was added to the budget. The final nonresident expenditures for Columbia River recreational salmon fishing are shown in Exhibit E.
For recreational ocean fisheries, the budget for ocean salmon fishing in the Northwest management area was used as the representative expenditure pattern. The angler day expenditure patterns, expressed in 1992 dollars, were converted to a per fish basis using data on average catch per angler day from the Pacific Management Council, the Oregon Department of Fish and Wildlife and the Washington Department of Fisheries. Per fish expenditures incorporated into the regional analysis are presented in Exhibit $\mathrm{E}$ of this appendix.

\subsubsection{Allocation of Harvest to Subregions}

As with the commercial fisheries, regional economic impacts related to the SOR alternatives were estimated only for sport harvest in the US ocean and in-river fisheries. Locations for the anadromous sport fisheries include the ocean areas off the Oregon and Washington coasts, the mouth of the Columbia River below Buoy 10, and the mainstem and tributaries of the Columbia River. Expected sport harvest under the SOR alternatives were allocated to states and subregions on the basis of actual harvest in these areas between 1987 and 1991. Information from the Oregon Department of Fish and Wildlife and the Pacific Fishery Management Council was used to develop the state and subregion allocations. The allocation of the recreational harvest to the subregions is shown in Table 4-55.

\subsubsection{Combined Anadromous Fisheries Impacts}

Regional economic impacts were estimated separately for each of the anadromous fisheries for which separate expenditure activities could be defined. Seven distinct expenditure patterns were developed to estimate the effects of changes in anadromous fish harvests. An additional two expenditure patterns were developed to evaluate impacts related to fish processing. Economic impacts were estimated for all subregions where harvest changes are expected to occur.

\section{Commercial Fisheries}

- ocean fall chinook harvest

- ocean spring chinook harvest 
Table 4-55. Allocation of Sport Harvest to Subregions, in Percent

\begin{tabular}{|c|c|c|c|c|}
\hline & Fall Chinook & $\begin{array}{c}\text { Spring/Summer } \\
\text { Chinook }\end{array}$ & Steedhead & Sockeye \\
\hline \multicolumn{5}{|c|}{ Ocean Sport Harvest } \\
\hline \multicolumn{5}{|l|}{ By State } \\
\hline Washington & 40 & 40 & & \\
\hline Oregon & 60 & 60 & & \\
\hline \multicolumn{5}{|l|}{ By Subregion } \\
\hline West Coast & 100 & 100 & & \\
\hline \multicolumn{5}{|c|}{ In-River Sport Harvest } \\
\hline \multicolumn{5}{|l|}{ By River Zone } \\
\hline $\begin{array}{l}\text { Below Bonneville } \\
\text { and Buoy } 10\end{array}$ & 50 & 100 & 10 & \\
\hline $\begin{array}{l}\text { Mid/Upper } \\
\text { Columbia }\end{array}$ & 50 & 0 & 30 & \\
\hline $\begin{array}{l}\text { Idaho (Clearwater, } \\
\text { Snake, Salmon) }\end{array}$ & 0 & 0 & 60 & \\
\hline \multicolumn{5}{|l|}{ By State } \\
\hline Washington & 40 & 40 & 24 & \\
\hline Oregon & 60 & 60 & 16 & \\
\hline Idaho & 0 & 0 & 60 & \\
\hline \multicolumn{5}{|l|}{ By Subregion } \\
\hline West Coast & 25 & 50 & 5 & \\
\hline Portland & 25 & 50 & 5 & \\
\hline Mid-Columbia & 25 & 0 & 15 & \\
\hline Upper Columbia & 25 & 0 & 15 & \\
\hline Lower Snake & 0 & 0 & 60 & \\
\hline
\end{tabular}

- in-river fall chinook harvest

- in-river spring chinook harvest

- in-river sockeye harvest

Sport Fisheries

- ocean sport harvest (all species)

- in-river sport harvest (all species)
All of the commercial and sport fishing expenditure patterns identified in the previous sections have been expressed in terms of the number of fish harvested, the direct measure of physical change incorporated into the regional analysis (see Exhibit E).

Regional economic impacts are estimated separately for harvest changes in each of the affected fisheries present within a subregion. The impacts generated for each fishery are then summed together to deter- 
mine the total anadromous fish impacts for each subregion.

\subsubsection{Irrigation and $M /$ Water Supply}

The direct economic impacts of the SOR alternatives were estimated for those individuals and activities that pump water directly from reservoir pools on the Columbia/Snake River system. Impacts were estimated separately for pumping relàted to commercial agriculture irrigation and for pumping related to water supply, including municipal, industrial, recreations, and wildlife uses. Six reservoirs currently utilized for irrigation and water supply pumping would be affected by the SOR alternatives. The reservoirs include Grand Coulee (irrigation pumping), John Day and Ice Harbor (irrigation and $\mathrm{M} / \mathrm{I}$ water supply pumping), and Lower Granite, Little Goose, and Lower Monumental (M/I water supply pumping).

Following the format of the direct economic analysis prepared by the SOR Irrigation Work Group, the regional economic impacts related to reservoir pumping were estimated separately for irrigation pumping from the Grand Coulee pool, irrigation pumping from the John Day and Ice Harbor pools, and $\mathrm{M} / \mathrm{I}$ pumping from the John Day, Ice Harbor, Lower Monumental, Little Goose, and Lower Granite pools.

\subsubsection{Grand Coulee Irrigation Pumping}

For purposes of the regional impact analysis it is assumed that the decline in net farm income will have a two-fold effect on the farming operation: 1)with less business income available, farm investments will be delayed or withheld; and 2)with lower returns to land, management, and capital, less money is available to the farm household. These alternatives are considered to be equally likely. One-half of the change in net farm income is assumed to generate regional impacts through the effects on household income and the consequent reduction in the market basket of household expenditures. The remaining portion of the change in farm income is assumed to generate regional impacts by reducing purchases of farm machinery. Purchases of farm machinery are generally the primary type of investment made by the crops-producing farm sector.

\subsubsection{Allocation of Grand Coulee Costs to Subregions}

The increased pumping costs from Roosevelt Lake were taken directly from Table 4-20 of this appendix. The increased costs were distributed to the Mid Columbia and Upper Columbia subregions on the basis of the proportion of Columbia Basin Project irrigated crop acreage located in each area. Twenty-six percent of the cost change was allocated to the Mid-Columbia subregion with the remaining 74 percent of the change distributed to Upper Columbia. All of the area served by the Roosevelt Lake is located within Washington State.

\subsubsection{Ice Harbor/John Day Agricultural Irrigation}

The regional economic impacts associated with the costs of the pump modifications will depend in large part on whether these costs are paid for by the public sector or whether these costs are paid for by the pump owners. If the costs are paid by regional electricity ratepayers, as the public sector, then the modification costs are likely to be translated into higher electricity rates and a subsequent decline in regional household incomes. If the costs are paid by the taxpayer, as the public sector, then any associated secondary impacts are not likely to be measurable because of the much broader base over which the costs are distributed.

For modification costs paid for by the pump owners, the regional impacts will depend on whether the pumps are under public or private ownership. Pump modifications paid for by private owners will have a direct impact on the net income available to the operation for which the pumps are required. In the case of irrigated agriculture, producers will be required to withhold or delay investment in other farm activities in order to meet the modification expenses. The higher cost of pumping facilities is also likely to reduce returns to the farm household. 
In addition to pump station modification costs, most irrigators will experience higher horse-power requirements and higher energy costs due to increased pumping lifts under a drawdown scenario. Irrigators will also experience an increase in annual operations and maintenance costs as a result of the modifications. All of these costs combine to determine total pumping costs and the annual impact on net farm income.

Similar to the analysis for Grand Coulee irrigation pumping, the regional impacts associated with changes in pumping costs for irrigators along the John Day and Ice Harbor pools are estimated assuming two-fold effect on the farming operation. One-half of the change in net farm income is assumed to generate impacts through the effects on household income and the consequent reduction in the market basket of household expenditures. The remaining portion of the change in farm income is assumed to reduce purchases of farm machinery.

\subsubsection{Allocation of Ice Harbor/John Day Costs to Subregions}

The increased costs for irrigation pumping from the John Day and Ice Harbor pools were taken directly from Tables 4-23 of this appendix. Both pools lie completely within the Mid Columbia subregion. Impacts were distributed across Oregon and Washington based on the number and size of pumps located on each side of the Columbia River. Twenty-six percent of the income change was allocated to Oregon and the remaining 74 percent of the change was distributed to Washington irrigators.

\subsubsection{John Day/Lower Snake M/l Irrigation}

As in the case of irrigation pumping, drawdown of these pools under several of the SOR alternatives would be significant enough to require modification of the existing pumping stations. The regional economic impacts associated with the costs of the modifications will depend on whether the pumps are publicly or privately owned. To evaluate the impacts linked to pumps owned by local, state, or federal governments it is first necessary to know whether the modification costs will be funded through diversion of existing expenditures or whether new funds will be required, and the likely source for these funds. From this it can be determined whether existing regional activities will be displaced in order to fund the pump modifications. Although data was available on pump ownership, insufficient information was available to determine the manner in which the increased pumping costs for the government-owned pumps would be paid. Therefore, it was assumed that the costs would be passed along to regional households, causing a reduction in the market basket of personal consumption expenditures. This assumption is likely to provide a measure of 'greatest potential impact' to the regional economy.

For private owners of the recreation and $\mathrm{M} / \mathrm{I}$ pumping stations, the regional effects of increased pumping costs will depend on whether the increased business costs can be passed along to the final consumer through higher product or service prices. If the modification costs cannot be passed along to the final consumer, the annualized costs would result in a decline in net business income and returns to ownership. Impacts would be measured through changes in the appropriate investment sectors and in household consumption.

\subsubsection{Allocation to Subregions}

The increased costs measured for $\mathrm{M} / \mathrm{I}$ pumping from the John Day and four lower Snake pools were taken directly from Table 4-27 of this appendix. The John Day, Ice Harbor, and Lower Monumental pools are located in the mid Columbia subregion; the Lower Granite and Little Goose pools are located in the Lower Snake subregion. Therefore, additional information was required from the SOR Economic Analysis Group to allocate the M/I pumping costs to the appropriate subregions. Using pool-specific data on pump modifications, 86 percent of the $M / I$ costs were allocated to the Mid Columbia subregion with the remaining 14 percent allotted to the Lower Snake subregion. Impacts were distributed across Oregon and Washington based on the number and size of pumps located on each side of the Columbia River. Forty-four per- 
cent of the income change was allocated to Oregon and the remaining 56 percent of the change was distributed to pumpers located in Washington.

\subsubsection{Navigation}

Alternative river operations strategies would affect cargo transportation on the Columbia-Snake river system by limiting and/or restricting barge navigation along specific river reaches during periods of drawdown. The barge restrictions would, in turn, lead to an increase in the costs of transporting goods from their point of origin to their final destination. Increasing transportation costs result from two general adjustments that may occur as a result of restrictions to barge navigation:

- The restrictions may cause shifts from barge movements to other transportation modes or modal combinations (e.g. shifts from truckbarge to truck rail); or

- The drawdown restrictions may result in commodities being transported to alternative river locations before being placed on barge; (e.g. shifts from river ports in the Lewiston area to river ports in the Tri-Cities area).

In addition to increased costs related to modal shifts, it is likely that additional costs will be incurred as a result of increased storage and handling costs related to transferring and holding commodities before delivery along the alternative transportation node. Expected costs were estimated for three categories of water-borne transportation: deepdraft navigation, shallow draft navigation, and log transportation on Dworshak reservoir.

\subsubsection{Deep Draft Navigation}

The Navigation Work Group conducted a study of combined effects of river discharge and tides on the stage of the lower Columbia River. The results of the analysis indicated that the impacts of the refill operations for drawdown alternatives (SOS 5 and 6) on river stages at critical locations along the Lower Columbia River would be relatively small. The Navigation Work Group concluded that the SOR alternatives would have no impact on deep draft navigation. Consequently, no direct or regional economic impacts were measured for this navigation component.

\subsubsection{Dworshak Reservoir Log Transportation}

The Navigation Work Group developed a simulation model to estimate the increased log transportation costs associated with each of the SOR alternatives. These costs were used by the Economic Analysis Group as the measure of direct economic impact.

The measure of the net change in transportation costs is linked to the regional economic analysis by assuming that an equivalent (and opposite)change in the net income earned by the businesses utilizing the $\log$ rafting operations occurs. For purposes of the regional impact analysis it is further assumed that the change in net business income will result in a change in household income through the effect on returns to ownership. Regional impacts would be generated through the effects on household income and the change in household expenditures.

The transportation costs presented in Table 4-37 of this appendix were incorporated into the regional analysis.

\subsubsection{Allocation of Dworshak Log Transportation Costs to Subregions}

Dworshak Reservoir is wholly contained within the Lower Snake subregion. Consequently, the economic impacts related to reservoir transportation are estimated only for this subregion. Regional impacts are also estimated for the state of Idaho.

\subsubsection{Shallow Draft Navigation}

The effects of the SOR alternatives on shallow draft navigation in the Columbia-Snake River system have been measured as the change in the costs associated with transporting commodities from their point of origin to their final destinations. A transportation model was developed by the Navigation Work Group which examined the least cost transportation routes for commodities shipped along the Columbia River system. The analysis included the primary commodities utilizing the water transporta- 
tion network: grain, petroleum, logs and wood chips, and wood products. The model simulates transportation responses to alternative river conditions, computing transportation, storage, handling, and capacity costs under the various scenarios.

The transportation costs presented in Table 4-29 of this appendix were incorporated into the regional analysis.

\subsubsection{Allocation of Shallow Draft Navigation Transportation Costs to Subregions}

Regional economic impacts for shallow draft navigation were distributed to Idaho, Montana Oregon, and Washington, according to the volume of grain and non-grain movements originating within each state. Allocations were based on information from the transportation cost model developed by Transportation Research and Analysis Center (TRAC) for the EAG and were made separately for each of the major commodity groups shipped on the river system. The regional impacts were also allocated to subregions according to the volume of movements originating from counties included in each specific subregion. As with allocations to the states, the TRAC model was used to make the subregional allocations. The percent allocation of shallow-draft navigation related economic impacts to the states and subregions of the SOR study area is shown in Table 4-56.

Table 4-56. Allocation of Shallow Draft Navigation Economic Impacts to the States and Subregions in Percent

\begin{tabular}{|c|c|c|c|c|c|}
\hline \multirow{2}{*}{ State/Subregion } & \multicolumn{5}{|c|}{ Allocation of Economic Impacts in Percent } \\
\hline & Grain & Petroleum & $\begin{array}{l}\text { Log and Wood } \\
\text { Chips }\end{array}$ & $\begin{array}{c}\text { Wood } \\
\text { Products }\end{array}$ & $\begin{array}{c}\text { Other } \\
\text { Commodities }\end{array}$ \\
\hline \multicolumn{6}{|l|}{ States } \\
\hline Idaho & 33 & 0 & 25 & 0 & 40 \\
\hline Montana & 30 & 0 & 0 & 0 & 0 \\
\hline Oregon & 8 & 63 & 50 & 0 & 50 \\
\hline Washington & 29 & 37 & 25 & 100 & 10 \\
\hline Total Allocation & 100 & 100 & 100 & 100 & 100 \\
\hline \multicolumn{6}{|l|}{ Subregions } \\
\hline Lower Snake & 14 & 0 & 25 & 0 & 50 \\
\hline Mid-Columbia & 6 & 50 & 25 & 0 & 50 \\
\hline Northeast & 6 & 0 & 25 & 100 & 0 \\
\hline Portland & $>1$ & 50 & 0 & 0 & 0 \\
\hline Southern Idaho & 30 & 0 & 25 & 0 & 0 \\
\hline Upper Columbia & 15 & 0 & 0 & 0 & 0 \\
\hline Total Allocation & $711 /$ & 100 & 100 & 100 & 100 \\
\hline \multicolumn{6}{|c|}{$\begin{array}{l}\text { Notes: } \\
1 / \text { The remaining } 29 \text { percent of grain transportation costs originate in counties not included in the SOR sub- } \\
\text { region areas. }\end{array}$} \\
\hline
\end{tabular}




\subsubsection{Power}

The direct impacts of the SOR alternatives on the regional power system have been developed by the Bonneville Power Administration. Impacts are measured as the net system replacement cost for electricity, a concept which takes into account the change in resource mix required to meet anticipated regional loads and includes the response in consumer demand to higher energy costs. BPA utilized internal systems analysis and decision models to evaluate the SOR direct power impacts.

Generally, the models evaluate the effects of the hydro operations strategies on power supply, incremental energy costs, and consumer demand. The ability of the regional power system to produce both capacity and energy is affected by the SOR operations alternatives, requiring an adjustment in the least-cost resource mix necessary to meet forecast regional electricity demands. Changes to the resource mix cause average wholesale power rates to increase. As power rates adjust upward regional consumers use less electricity. This leads to continued rounds of adjustments to resource mix, electricity price, and consumer demand until a supply-demand balance is achieved.

The net system resource costs necessary to meet the adjusted forecast of electricity demand is the measure of direct economic impact under the SOR alternatives. The resulting adjustment in retail power rates will lead to a change in electricity costs for all consumers served by the regional system. Regional economic impacts associated with the direct power analysis will be determined by ratepayer adjustment to the change in power costs.

\subsubsection{Ratepayer Response to Power Costs}

Response to the power rate changes associated with the SOR alternatives will differ for the region's major power consumers, including the residential, commercial, industrial, and irrigation customers of BPA's preference utilities, the agency's direct service customers, and private utility residential and irrigation consumers of private utilities. The manner and form of response by these consumers will determine the means by which the regional economies will be affected by changes in power costs.

The net power cost changes incorporated into the regional analysis were based on the equivalent annual net power costs presented in Table 4-44 of this appendix. Additional information was provided by BPA which allocated the change in net system costs to the primary consumer groups served by the agency. These allocated costs became the linkage between the direct and regional impacts for the power analysis.

\subsubsection{Allocating the Power Costs to Subregions}

Regional economic impacts are estimated for the Pacific Northwest and for the states of Washington, Oregon, Idaho, and Montana. The expected power bill changes were allocated to states on the basis of annual load shares for each of the major consumer groups. The allocations are based on 1990 BPA firm sales. Impacts associated with the increased power purchases could not be allocated to the states due to lack of information on the potential locations of the new generating sites.

\subsubsection{Recreation}

Recreation activity at sixteen federal project sites along the Columbia/Snake River system would be affected by the alternative operations strategies under review in the SOR. At least one and sometimes several of the projects would encounter changes in visitor activity under the various alternatives. Activities that may be affected include boating, windsurfing, sport fishing, swimming, hunting, wildlife viewing, camping, and picnicking. The direct economic impacts for recreation are measured as the changes in the consumer surplus associated with the expected increases or decreases in recreation visitor use at the project sites.

The regional economic impacts related to recreation derive from changes in trip-related expenditures made by visitors on-site and en-route to their recreation destinations. It is recognized in the regional analysis that economic impacts will be generated only by changes in the number of non-resident 
recreation visitors. It is assumed that resident participants would substitute the foregone activity at the affected site for another type of recreation opportunity elsewhere in the region. The recreation survey currently underway by the SOR Recreation Work Group will help to determine the degree to which these 'in-region' recreation substitutions are likely to be made by resident participants.

Expenditure patterns developed for the Army Corps of Engineers by Michigan State University and the Waterways Experiment Station were used to quantify the regional economic impacts related to recreation. This research project developed spending profiles for twelve types of visitors including resident day-users (boaters and non-boaters), non-resident day-users (boaters and non-boaters), resident campers (boaters and non-boaters), non-resident campers (boaters and non-boaters), resident other overnight lodgings (boaters and non-boaters), and non-resident other overnight lodgings (boaters and non-boaters).

The database developed from a survey of the project managers at the 14 Federal projects identifies only the primary purpose of the visit. However, many visitors participate in multiple activities during a given trip, e.g. people fish and boat, or boat and picnic. Given the lack of refinement in the visitor characteristics data, the expenditure patterns in the Waterways Experiment Station study were aggregated into six general groups:

- resident and nonresident day-use;

- resident and non-resident campers; and

- resident and non-resident other overnight lodgings.

Budgets for boaters and non-boaters were averaged to create expenditure patterns for the six aggregated groups. The expenditure patterns were converted from a per visit basis to a per visitor day basis. The final non-resident recreation visitor expenditure patterns used for the regional analysis are shown in Exhibit E of this appendix.

\subsubsection{Allocation of Recreation Impacts to Subregions}

The regional economic impacts related to recreation are estimated for the Pacific Northwest and for the states and subregions identified in Table 4-57. The expected changes in visitor days were allocated to states and subregions on the basis of project location. For projects bordering two states, changes in visitor days were divided equally.

Estimates of total annual visitor days were taken from Table 4-48 of this appendix. The estimated annual recreation visitor days were allocated to the major water-related recreation activities based on responses of recreators to a survey which was conducted in 1993 for the SOR. The resulting allocation, which is shown in Tables D-4 through D-15 of Exhibit D of this appendix, was incorporated into the regional analysis. Estimates were provided for each of the SOR alternatives. These data were combined with the recreation visitor characteristics and estimated expenditure patterns to evaluate expected regional economic impacts. Results of the regional recreation analysis are presented later in this document.

\subsubsection{Regional Economic Impacts Related to Project Implementation}

Several of the SOR alternatives will require physical project modifications and mitigation activities in order to achieve the objectives of the operations strategy. The proposed adaptations include modification of irrigation pumping stations, development of new power stations, improvements to boat ramps and moorages, and dam modifications to improve fish passage. The construction activity associated with these mitigation actions and project modifications will provide short-term positive economic benefits to the region through increased employment and earnings opportunities. The expected benefits are short-term in that they are expected to last only throughout the duration of the construction activity. 
Table 4-57. Location of Federal Projects within SOR Subregions

\begin{tabular}{|l|l|l|}
\hline \multirow{2}{*}{ Federal Project } & \multicolumn{2}{c|}{ Project Location } \\
\cline { 2 - 3 } & SOR Subregion & State \\
\hline Bonneville & Mid-Columbia & Washington/Oregon \\
\hline The Dalles & Mid-Columbia & Washington/Oregon \\
\hline John Day & Mid-Columbia & Washington/Oregon \\
\hline McNary & Mid-Columbia & Washington/Oregon \\
\hline Chief Joseph & Upper Columbia & Washington \\
\hline Grand Coulee & Upper Columbia & Washington \\
\hline Libby/Below Libby Dam & Northeast & Montana \\
\hline Albeni Falls & Northeast & Idaho \\
\hline Hungry Horse & Northeast & Montana \\
\hline Ice Harbor & Mid-Columbia & Washington \\
\hline Lower Monumental & Mid-Columbia & Washington \\
\hline Little Goose & Lower Snake & Washington \\
\hline Lower Granite & Lower Snake & Washington/Idaho \\
\hline Dworshak/Below Dworshak & Lower Snake & Idaho \\
\hline
\end{tabular}

The regional economic impacts associated with project implementation were evaluated for a selected set of construction activities. The SOR Economic Analysis Group provided estimates of the expected construction costs for the dam modifications required to meet operations objectives for SOR alternatives SOS $5 a$ and $5 b$, SOS $6 a$ and $6 \mathrm{~b}$, and SOS $6 \mathrm{c}$ and $6 \mathrm{~d}$. The construction estimates for SOS's $5 \mathrm{a} / 5 \mathrm{~b}$ and $6 \mathrm{a} / 6 \mathrm{~b}$ include modifications at the four Lower Snake Reservoirs: Ice Harbor, Lower Monumental, Little Goose, and Lower Granite. The construction estimate for SOS's 6c/6d include dam modifications at Lower Granite only. The cost estimates are expressed in 1992 dollars and represent total construction costs, including planning and design, construction management, and interest during construction.
Expenditures for the construction activities will generate positive short-term indirect impacts in the regional economy. These effects are differentiated from the secondary linkages to the direct SOR economic impacts in that they can be expected to last only through the duration of the construction activity, perhaps a few months to a few years. The indirect effects associated with the SOR alternatives will continue throughout the length of the direct impact, in many cases reflecting permanent changes in regional economic activity.

The implementation costs shown in Tables $4-4$ and 4-5 of this appendix were incorporated into the regional analysis. 


\subsubsection{Allocation to Subregions}

Construction expenditures were allocated to the SOR subregions on the basis of location of the project site. The Economic Analysis Group provided detailed information on expected implementation costs at each of the Lower Snake reservoir sites. Expenditures at Ice Harbor and Lower Monumental reservoirs were allocated to the Mid Columbia subregion while expenditures at Little Goose and Lower Granite were allocated to the Lower Snake subregion. Construction expenditures were allocated to states also on the basis of project location. Costs for Ice Harbor and Lower Monumental were apportioned to Washington while the costs for Lower Granite and Little
Goose were divided equally to Washington and Idaho.

\subsection{SOCIAL IMPACTS ASSESSMENT}

As with potential regional economic impacts, potential social impacts are presented as changes from current conditions. Because SOS $2 \mathrm{c}$ has been designated the most representative of current system operations, the social impacts analysis identifies changes from the economic impacts incurred with SOS 2c. The assessment of social impacts on selected focus communities, representing the various subregions where direct impacts would occur, is summarized in Chapter 5 of this appendix. A more detailed description of the focus communities and the assessment is presented in Exhibit $\mathrm{F}$ of this appendix. 


\section{CHAPTER 5}

\section{COMPARISON OF ALTERNATIVES}

\subsection{GENERAL}

The analysis of economic impacts associated with the SOSs considered potential changes to the following uses of the system: commercial and recreational harvest of anadromous fish, flood control, irrigation, M\&I water supply, shallow-draft navigation, transportation of logs on Dworshak reservoir, power generation, and recreation. In addition, costs of implementing each of the SOSs were considered. The purpose of this chapter is to compare the alternatives to the base case to show how the economic benefits and costs of each of the SOSs differ from the base case (SOS 2c). Within this context, three separate comparisons of the alternatives are presented: direct economic impacts; cost effectiveness; and, indirect economic impacts. In addition potential social impacts to selected focus communities are presented.

Economic impacts related to anadromous fish were developed using alternative assumptions about economic values and survival rates. The comparisons shown in this chapter are made using estimates of impacts developed using "high" economic values and "optimistic" survival assumptions. High anadromous fish values are used because economic values available do not account for existence and cultural values and, therefore, understate the total value of anadromous fish. Optimistic survival assumptions are used to show the highest benefit possible and because of the high degree of uncertainty about survival rates. This bias is considered acceptable in this study because a major consideration in designing the SOSs was to enhance production of stocks of anadromous fish. Even with this bias, however, the comparisons show that none of the SOSs are very effective in achieving the goal of enhancing the economic value of anadromous fish, relative to the base case. Furthermore, the comparisons show that many of the SOSs result in decreases in economic value of anadromous fish and that those which do show increases, do so at a relatively high cost.

\subsection{SIGNIFICANCE AND APPLICABILITY OF ESTIMATES OF ECONOMIC IMPACTS IN DECISION MAKING}

There is a concern that categories of economic impacts (changes from the base case) of the SOSs should not be combined to show total impacts because economic effects in each category may not have been measured on a consistent basis. An additional concern is that some values, especially existence, cultural, and social values associated with threatened or endangered anadromous fish stocks and regional economic impacts are not accounted for in the estimates of impacts. With regards to the concern that impacts were not evaluated on a consistent basis, the EAG acknowledges that, in some cases, simplified analytical procedures and simplifying assumptions were used. In spite of this, in every case analyses were made following accepted methods and procedures. On this basis, the estimates are comparable in a relative sense: i.e., the estimates represent an "apples-to-apples" comparison and not an "apples-to-oranges" comparison. However, this does not mean that the estimates are absolutely correct. The estimates have a level of accuracy appropriate to a reconnaissance-level study, and are intended to be used only for the purpose of making comparisons among the alternatives.

With regards to the concern that existence and social and cultural values of threatened and endangered species were not included, members of the EAG acknowledge that these values have not been accounted for in the analysis. Decision makers must bare this in mind. This being the case, selection of a "preferred" SOS strictly on the basis of the estimates of direct economic impacts would be inappropriate. At the same time, however, decision 
makers must recognize that selection of an alternative that is not the "best" alternative based on the analysis of direct economic impacts requires an assumption that the value of the increase in the resource obtained (increased production of anadromous fish, for example) through selection of another alternative is at least equal to the difference in economic impacts between the selected alternative and the "best" economic alternative. Other important factors which decision makers must take into consideration are the impacts of the alternatives on regional economies and their associated social impacts to local communities. Regional impacts to the states and sub-regions in the Pacific Northwest are presented in Section 5.5 of this chapter and in Exhibit $\mathrm{E}$ of this appendix. An assessment of potential social impacts to selected communities is presented in Section 5.6 of this chapter and in Exhibit F. of this appendix.

\subsection{COMPARISONS OF DIRECT ECONOMIC IMPACTS OF SOSs}

This comparison the SOSs presents costs and benefits for each SOS, relative to the base case, for each cost/benefit category and total system costs. The comparisons are made using the equivalent annual values developed in Chapter 4. Using these data, rankings are shown for each cost/benefit category and the totals; the significance of the differences among the SOSs are displayed for each type of ranking; and, the difference in total system costs for each SOS, compared to the base case, are displayed graphically. A separate set of these comparisons are presented for each of the two interest rates used in the analysis --7.75 percent, the Federal interest rate used by the Corps and Reclamation, and 3.0 percent, the estimated inflation-free interest rate used by BPA.

The economic impacts shown in this section are presented either as benefits or costs, depending on how each category was evaluated. Benefits represent the estimate of the value (change in value) of the system outputs of each SOS. Benefit categories are anadromous fish and recreation. Cost categories represent costs associated with the SOSs for the categories of flood damages, irrigation, M\&I water, shallow-draft navigation, Dworshak log transportation, and power generation. Positive economic impacts occur when benefits increase or costs decrease. When comparisons are made to the base case of SOS 2c, all impact categories are expressed as differences from the base case.

\subsubsection{Comparison of Direct Economic Impacts at 7.75 Percent Interest Rate.}

Comparisons of the direct economic impacts of the SOSs, assuming a interest rate of 7.75 percent, are shown in Tables 5-1 through 5-3 and in Figure 5-1. Differences in economic values from the base case are shown in Table 5-1, for each cost/benefit category and total system costs. In Table 5-2, the SOSs are ranked from best to worst based on total system costs. Table 5-3 presents rankings of the SOSs for each cost/benefit category and shows the significance of the differences among the SOSs within each category, through the use of blocking and shading. Within each cost/benefit category, shaded SOSs are those which would result in no change from the base case and those which are blocked together are those which are not be significantly different from the base case. The test for significance which was used in each cost/benefit category is a difference in economic impacts of $\$ 1$ million, plus or minus.

Review of the rankings in Table 5-3 reveals the following generalizations about the relative economic impacts of SOSs:

- SOS 1a and SOS $1 \mathrm{~b}$ both provide significant increases in power and recreation benefits. They have no significant effects on any of the other cost/benefit categories. Therefore, based on analyses conducted for the SOR, these SOSs are economically superior to any of the others, including the preferred alternative.

- With the exception that SOS $2 d$ provides less power benefits and recreation benefits, there is no significant economic difference between it and the base case (SOS 2c). 
Table 5-1. Economic Cost/Benefit Differences from the Base Case - SOS 2c (Equivalent Annual Values, 7.75 Percent Interest Rate)

\begin{tabular}{|c|c|c|c|c|c|c|c|c|c|c|c|}
\hline sos & $\begin{array}{c}1 \\
\begin{array}{c}\text { Implementation } \\
\text { Costs } \\
\text { Lower Snake }\end{array} \\
\text { (\$) }\end{array}$ & $\begin{array}{c}2 \\
\begin{array}{c}\text { Implementation } \\
\text { Costs } \\
\text { John Day } \\
\text { (\$) }\end{array}\end{array}$ & $\begin{array}{c}3 \\
\text { Anadromous } \\
\text { Fish Benefits } \\
\text { (\$) }\end{array}$ & $\begin{array}{l}4 \\
\text { Flood Dam- } \\
\text { age Costs } \\
\text { (\$) }\end{array}$ & $\begin{array}{c}5 \\
\begin{array}{c}\text { Commercial } \\
\text { Irrigation } \\
\text { Costs }\end{array} \\
\text { (\$) }\end{array}$ & $\begin{array}{c}6 \\
\begin{array}{c}\text { M \& I } \\
\text { Pumping } \\
\text { Costs }\end{array} \\
\text { (\$) }\end{array}$ & $\begin{array}{c}7 \\
\text { Shallow Dran } \\
\text { Transportation } \\
\text { Costs } \\
\text { (\$) }\end{array}$ & $\begin{array}{c}8 \\
\text { Dworshak } \\
\text { Log } \\
\text { Trucking } \\
\text { Costs } \\
\text { (\$) }\end{array}$ & $\begin{array}{c}9 \\
\text { Power } \\
\text { System } \\
\text { Gencration } \\
\text { Costs } \\
\text { (\$) }\end{array}$ & $\begin{array}{c}10 \\
\text { Recreation } \\
\text { Consumer } \\
\text { Surplus } \\
\text { Benefits } \\
\text { (\$) }\end{array}$ & $\begin{array}{c}11 \\
\text { Total System } \\
\text { Costs 1/ } \\
\text { (\$) }\end{array}$ \\
\hline $\operatorname{sos} 1 \mathrm{a}$ & - & - & $(330,000)$ & - & 9,000 & - & - & $(112,100)$ & $(36,000,000)$ & $4,691,000$ & $(40,464,100)$ \\
\hline $\operatorname{sos} 1 \mathrm{~b}$ & - & - & $(200,000)$ & - & 8,900 & - & - & $(119,700)$ & $(66,000,000)$ & $7,941,000$ & $(73,851,800)$ \\
\hline $\operatorname{sos} 2 c$ & - & - & - & - & - & - & - & - & - & - & - \\
\hline $\operatorname{sos} 2 d$ & - & - & 170,000 & - & $(3,300)$ & - & - & 93,100 & $24,000,000$ & $(5,015,000)$ & $28,934,800$ \\
\hline $\operatorname{sos} 4 c$ & - & - & 110,000 & 444,100 & $(18,400)$ & - & - & $(228,200)$ & $81,000,000$ & $4,171,000$ & $76,916,500$ \\
\hline sos 5b & $150,098,800$ & $4,362,900$ & $(3,430,000)$ & - & $2,094,500$ & $2,111,100$ & $6,965,800$ & $(26,700)$ & $44,000,000$ & $(34,728,000)$ & $247,764,400$ \\
\hline SOS 5c & $35,661,200$ & $9,229,500$ & $(7,030,000)$ & - & $4,445,900$ & $4,483,800$ & $30,173,100$ & $(137,700)$ & $132,000,000$ & $(72,284,000)$ & $295,169,800$ \\
\hline $\operatorname{sos} 6 b$ & $50,887,700$ & $5,904,800$ & $(6,920,000)$ & - & $2,026,100$ & $2,921,600$ & $7,945,300$ & $(78,000)$ & $23,000,000$ & $(31,835,000)$ & $131,362,500$ \\
\hline sos 6d & $4,641,300$ & $7,950,300$ & $(4,760,000)$ & - & $1,373,000$ & $4,100,500$ & $1,688,200$ & $(113,600)$ & $14,000,000$ & $(32,049,000)$ & $70,448,700$ \\
\hline SOS 9a & $50,887,100$ & $5,723,600$ & $(10,220,000)$ & 257,300 & $1,864,600$ & $2,920,600$ & $7,945,300$ & $(26,900)$ & $153,000,000$ & $(62,863,000)$ & $295,654,600$ \\
\hline $\operatorname{sos} 9 \mathrm{~b}$ & - & - & $(2,990,000)$ & 27,400 & 5,400 & - & - & 172,700 & $207,000,000$ & $(35,418,000)$ & $245,613,500$ \\
\hline $\operatorname{sos} 9 c$ & $50,986,100$ & $5,929,000$ & $(7,140,000)$ & 458,800 & $2,098,300$ & $2,957,800$ & $4,729,900$ & $(3,500)$ & $90,000,000$ & $(24,611,000)$ & $188,907,400$ \\
\hline SOS PA & - & $9,195,600$ & 40,000 & 222,800 & $1,660,900$ & $4,670,300$ & - & 105,100 & $108,000,000$ & $(23,211,000)$ & $147,025,700$ \\
\hline Source: & Table 4-4 & Table 4-5 & Table 4-13 & Table 4-18 & Table 4-22 & Table 4-26 & Table 4-29 & Table 4-37 & Table 4-45 & Table 4-50 & \\
\hline
\end{tabular}


Table 5-2. Alternatives Ranked From Best to Worst Bases on Differences in Total System Costs: Economic System Cost Differences From the Base Case - SOS 2c (Equivalent Annual Values, 7.75 Percent Interest Rate)

론

\begin{tabular}{|c|c|c|c|c|c|c|c|c|c|c|c|}
\hline sos & $\begin{array}{c}1 \\
\begin{array}{c}\text { Implementation } \\
\text { Costs } \\
\text { Lower Snake }\end{array} \\
\text { (\$) }\end{array}$ & $\begin{array}{c}2 \\
\begin{array}{c}\text { Implementation } \\
\text { Costs } \\
\text { John Day }\end{array} \\
\text { (\$) }\end{array}$ & $\begin{array}{c}3 \\
\text { Anadromous } \\
\text { Fish Benefits } \\
\text { (\$) }\end{array}$ & $\begin{array}{c}4 \\
\text { Flood } \\
\text { Damage } \\
\text { Costs } \\
\text { (\$) }\end{array}$ & $\begin{array}{c}5 \\
\begin{array}{c}\text { Commercial } \\
\text { Irrigation } \\
\text { Costs }\end{array} \\
(\$)\end{array}$ & $\begin{array}{c}6 \\
\begin{array}{c}\text { M \& I } \\
\text { Pumping } \\
\text { Costs }\end{array} \\
\text { (\$) }\end{array}$ & $\begin{array}{c}7 \\
\text { Shallow Draft } \\
\begin{array}{c}\text { Transportation } \\
\text { Costs }\end{array} \\
\text { (\$) }\end{array}$ & $\begin{array}{c}8 \\
\text { Dworshak } \\
\text { Log } \\
\text { Trucking } \\
\text { Costs } \\
\text { (\$) }\end{array}$ & $\begin{array}{c}9 \\
\text { Power } \\
\text { System } \\
\text { Generation } \\
\text { Costs } \\
\text { (\$) }\end{array}$ & $\begin{array}{c}10 \\
\text { Recreation } \\
\text { Consumer } \\
\text { Surplus } \\
\text { Bencfits } \\
\text { (\$) }\end{array}$ & $\begin{array}{c}11 \\
\text { Total } \\
\text { System } \\
\text { Costs 1/ } \\
\text { (\$) }\end{array}$ \\
\hline SOS $1 b$ & - & - & $(200,000)$ & - & 8,900 & - & - & $(119,700)$ & $(66,000,000)$ & $7,941,000$ & $(73,851,800)$ \\
\hline SOS 1a & - & - & $(330,000)$ & - & 9,000 & - & - & $(112,100)$ & $(36,000,000)$ & $4,691,000$ & $(40,464,100)$ \\
\hline $\operatorname{sos} 2 c$ & - & - & - & - & - & - & - & - & - & - & - \\
\hline $\operatorname{sos} 2 d$ & - & - & 170,000 & - & $(3,300)$ & - & - & 93,100 & $24,000,000$ & $(5,015,000)$ & $28,934,800$ \\
\hline $\operatorname{sos} 6 d$ & $4,641,300$ & $7,950,300$ & $(4,760,000)$ & - & $1,373,000$ & $4,100,500$ & $1,688,200$ & $(113,600)$ & $14,000,000$ & $(32,049,000)$ & $70,448,700$ \\
\hline $\operatorname{sOS} 4 c$ & - & - & 110,000 & 444,100 & $(18,400)$ & - & - & $(228,200)$ & $81,000,000$ & $4,171,000$ & $76,916,500$ \\
\hline $\operatorname{sos} 6 \mathrm{~b}$ & $50,887,700$ & $5,904,800$ & $(6,920,000)$ & - & $2,026,100$ & $2,921,600$ & $7,945,300$ & $(78,000)$ & $23,000,000$ & $(31,835,000)$ & $131,362,500$ \\
\hline SOS PA & - & $9,195,600$ & 40,000 & 222,800 & $1,660,900$ & $4,670,300$ & - & 105,100 & $108,000,000$ & $(23,211,000)$ & $147,025,700$ \\
\hline $\operatorname{sos} 9 \mathrm{c}$ & $50,986,100$ & $5,929,000$ & $(7,140,000)$ & 458,800 & $2,098,300$ & $2,957,800$ & $4,729,900$ & $(3,500)$ & $90,000,000$ & $(24,611,000)$ & $188,907,400$ \\
\hline $\operatorname{sos} 9 \mathrm{~b}$ & - & - & $(2,990,000)$ & 27,400 & 5,400 & - & - & 172,700 & $207,000,000$ & $(35,418,000)$ & $245,613,500$ \\
\hline SOS 5b & $150,098,800$ & $4,362,900$ & $(3,430,000)$ & - & $2,094,500$ & $2,111,100$ & $6,965,800$ & $(26,700)$ & $44,000,000$ & $(34,728,000)$ & $247,764,400$ \\
\hline $\operatorname{sos} 5 c$ & $35,661,200$ & $9,229,500$ & $(7,030,000)$ & - & $4,445,900$ & $4,483,800$ & $30,173,100$ & $(137,700)$ & $132,000,000$ & $(72,284,000)$ & $295,169,800$ \\
\hline sos 9a & $50,887,100$ & $5,723,600$ & $(10,220,000)$ & 257,300 & $1,864,600$ & $2,920,600$ & $7,945,300$ & $(26,900)$ & $153,000,000$ & $(62,863,000)$ & $295,654,600$ \\
\hline Source: & Table 4-4 & Table 4-5 & Table 4-13 & Table 4-18 & Table 4-22 & Table 4-26 & Table 4-29 & Table 4-37 & Table 4-45 & Table 4-50 & \\
\hline
\end{tabular}


Table 5-3. Ranking of Alternatives - Best to Worst - By Cost/Benefit Category Using Differences From the Base Case - SOS 2c (Equivalent Annual Values, 7.75 Percent Interest Rate)

\begin{tabular}{|c|c|c|c|c|c|c|c|c|c|}
\hline $\begin{array}{c}1 \\
\text { Implementation } \\
\text { Costs Lower } \\
\text { Snake }\end{array}$ & $\begin{array}{c}2 \\
\text { Implementation } \\
\text { Costs John Day }\end{array}$ & $\begin{array}{c}\text { 3 } \\
\text { Anadromous } \\
\text { Fish Benefits }\end{array}$ & $\begin{array}{c}4 \\
\text { Flood Damage } \\
\text { Costs }\end{array}$ & $\begin{array}{c}5 \\
\text { Commercial } \\
\begin{array}{c}\text { Irrigation } \\
\text { Costs }\end{array}\end{array}$ & $\begin{array}{c}6 \\
\text { M \& I } \\
\text { Pumping } \\
\text { Costs }\end{array}$ & $\begin{array}{c}7 \\
\text { Shallow Draft } \\
\text { Transportation } \\
\text { Costs }\end{array}$ & $\begin{array}{c}8 \\
\text { Dworshak } \\
\text { Log Trucking } \\
\text { Costs }\end{array}$ & $\begin{array}{c}9 \\
\text { Power System } \\
\text { Generation } \\
\text { Costs }\end{array}$ & $\begin{array}{c}10 \\
\text { Recreation } \\
\text { Consumer } \\
\text { Surplus } \\
\text { Benefits }\end{array}$ \\
\hline 350511 & $1 \% 1051$ s & $\operatorname{sos} 2 \mathrm{~d}$ & $1 \% \operatorname{sos} 14$ & $\operatorname{sos} 4 c$ & $1 \% 105 / 12$ & 50516. & $\operatorname{sos} 4 c$ & $\operatorname{SOS} \mathrm{tb}$ & sos $1 b$ \\
\hline wos. & 18.6516 & $\operatorname{SOS} 4 c$ & $\operatorname{sos} 16$ & $\operatorname{sos} 2 d$ & $6.505 / 16$ & $50 s_{1}$ & SOS 5e & $\operatorname{sos} 1 \mathrm{a}$ & $\operatorname{sos} 1 \mathrm{a}$ \\
\hline $190 s_{2}=1$ & $1-1052$ & SOS PA & $\operatorname{sos} 20$ & $1450 \%$ & $505.2 \%$ & $505 \%$ & $\operatorname{sos} 1 b$ & 10820 & $\operatorname{sos} 4 c$ \\
\hline \%os $20 \%$ & 450,2 & $18,5 s^{2}{ }^{2}$ & sos $\%$ & $\operatorname{sos} 9 b$ & sos 2. & sos: $\%$ & $\operatorname{sos} 6 \mathrm{~d}$ & $\operatorname{sos} 6 \mathrm{~d}$ & 5052 \\
\hline $1 \mathrm{Ses} 4 \mathrm{c}$ & $1 \mathrm{sbs}=1$ & $\operatorname{sOS} 1 b$ & $150 s_{5}$ & $\operatorname{sos} 1 b$ & 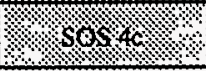 & 50540 & $\operatorname{SOS} 1 \mathrm{a}$ & $\operatorname{sos} 6 b$ & $\operatorname{SOS} 2 \mathrm{~d}$ \\
\hline sos 96 & SOS $9 b$ & $\operatorname{sos} 1 a$ & \% sas sit & SOS 1a & $\%$ sosos & $1.950 \mathrm{sx}$ & $\operatorname{sos} 6 b$ & $\operatorname{sos} 2 \mathrm{~d}$ & SOS PA \\
\hline sos pA & $\operatorname{sos} 5 \mathrm{~b}$ & $\operatorname{sos} 9 \mathrm{~b}$ & \%sos 0 & $\operatorname{sos} 6 \mathrm{~d}$ & SOS 5b & $150590-1$ & $\operatorname{sos} 9 a$ & SOS $5 b$ & sos 9c \\
\hline sos $6 \mathrm{~d}$ & $\operatorname{sos} 9 a$ & sos $5 b$ & F.sos 64 & SOS PA & $\operatorname{sos} 9 \mathrm{a}$ & $\operatorname{sos} 6 d$ & sos $5 b$ & $\operatorname{sOS} 4 c$ & $\operatorname{sos} 6$ \\
\hline SOS $5 \mathrm{c}$ & $\operatorname{sos} 6 \mathrm{~b}$ & $\operatorname{sos} 6 d$ & $\operatorname{sos} 9 b$ & sos 9a & $\operatorname{sos} 6 b$ & $\operatorname{sos} 9 \mathrm{c}$ & sos $9 c$ & SOS $9 c$ & sos 6d \\
\hline $\operatorname{sos} 9 \mathrm{a}$ & $\operatorname{sos} 9 \mathrm{c}$ & $\operatorname{sos} 6 b$ & SOS PA & $\operatorname{sos} 6 b$ & sos $9 c$ & sos $5 b$ & 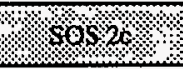 & SOS PA & sos $5 b$ \\
\hline $\operatorname{sos} 6 b$ & sos $6 d$ & SOS $5 \mathrm{c}$ & $\operatorname{sos} 9 a$ & sos $5 b$ & $\operatorname{sos} 6 d$ & $\operatorname{sos} 6 b$ & $\operatorname{sos} 2 d$ & SOS 5c & $\operatorname{sos} 9 \mathrm{~b}$ \\
\hline SOS $9 \mathrm{c}$ & SOS PA & $\operatorname{sos} 9 c$ & SOS $4 c$ & $\operatorname{sos} 9 c$ & sos $5 c$ & $\operatorname{sos} 9 a$ & SOS PA & sos 9a & sos 9a \\
\hline sos $5 b$ & $\operatorname{sos} 5 c$ & $\operatorname{sos} 9 a$ & $\operatorname{sos} 9 \mathrm{c}$ & sos $5 c$ & SOS PA & SOS $5 c$ & $\operatorname{sos} 9 b$ & $\operatorname{sos} 9 \mathrm{~b}$ & $\operatorname{sos} 5 \mathrm{c}$ \\
\hline
\end{tabular}

1. SOSs ranked from low cost to high for each cost/benefit category.

2. Shaded areas represent the base case (SOS $2 \mathrm{c}$ ) or no change from base case.

3 Alternatives above the shaded area have positive economic impacts, compared with the base case.

4. Alternatives below the shaded areas have negative economic impacts, compared with the base case.

5. Blocked areas group alternatives which have economic impacts within $\$ 1$ million, plus or minus. These alternatives are not considered to be significantly different. 


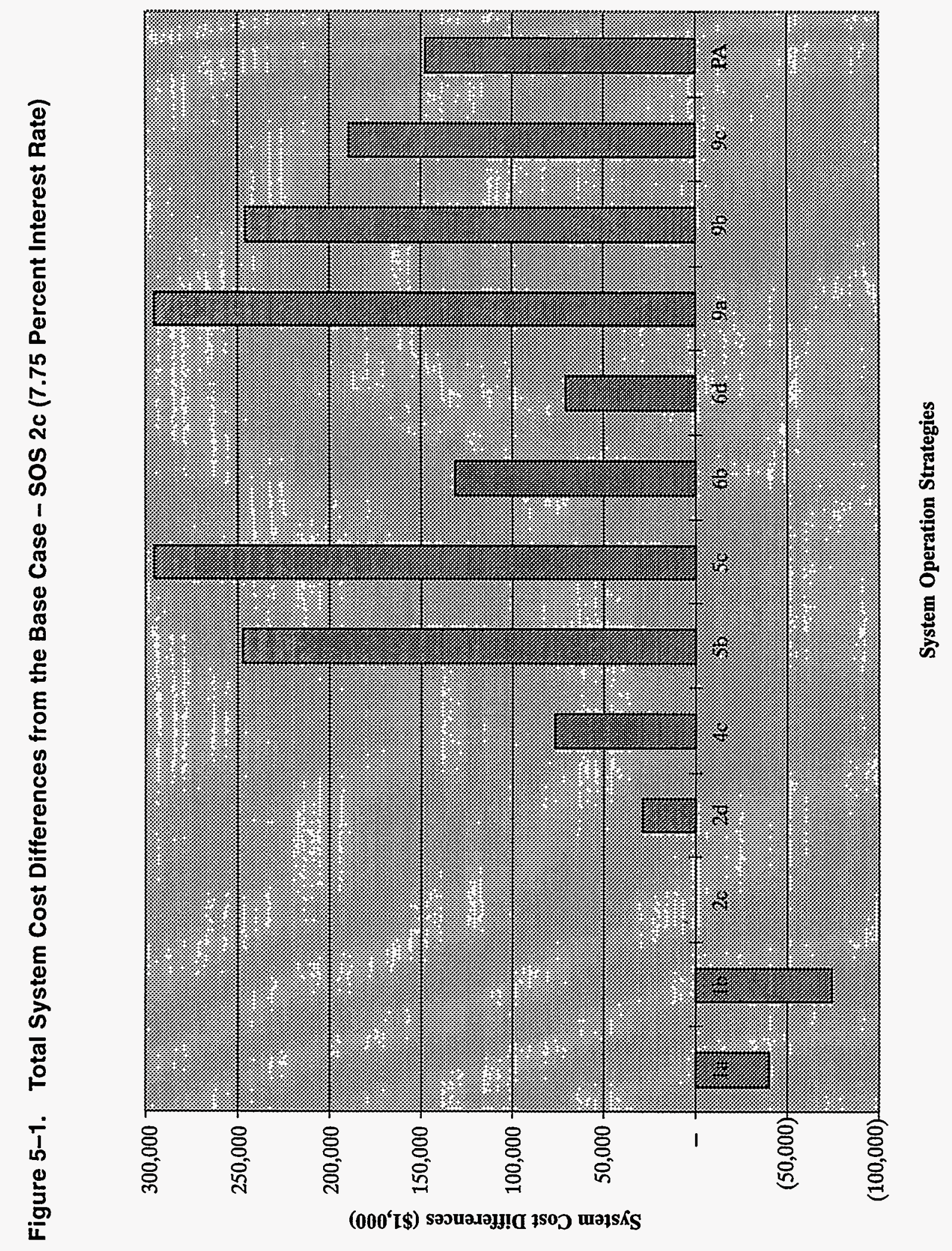


- SOS $4 c$ has significantly higher system power costs and higher recreation benefits than the base case (SOS 2c). Otherwise, the economic cost/benefits of this SOS are not significantly different than those for the base case.

- Economic cost/benefits of drawdown alternatives (SOS $5 b$ and $5 c$ and SOS $6 \mathrm{~b}$ and $6 \mathrm{~d}$, and SOS 9a and 9c) are all worse than, or no better than, the base case (SOS 2c) in every benefit and cost category. They are all significantly worse than the base case in economic value of anadromous fish. This is mainly due to the fact that drawdown primarily benefits only Snake River stocks which are a minor component of the total economic value of Columbia/Snake River runs. In addition, drawdown alternatives have very high implementation costs.

- Economic cost/benefits of SOS $9 \mathrm{~b}$, referred to as the Adaptive Management SOS, are not significantly different from the base case (SOS 2c), except for anadromous fish, power and recreation. In each of these categories, it is significantly worse than the base case. This SOS has the distinction of having highest (worst) system power costs.

- Economic cost/benefits of the preferred alternative (SOS PA) are not significantly different from the base case (SOS 2c), except for John Day implementation costs, irrigation and $M \& I$ water costs, system power costs, and recreation benefits. In each of these categories it is significantly worse than the base case.

As shown by the total system costs in Table 5-2, SOS $1 \mathrm{~b}$ is the alternative with the highest (best) economic value. Within the context of the Water Resource Council's "Principles and Standards for Planning Water and Related Land Resources," this alternative is the NED (national economic development) SOS.

\subsubsection{Comparison of Direct Economic Impacts at 3.0 Percent Interest Rate}

Comparisons of the direct economic impacts of the SOSs, assuming a interest rate of 3.0 percent, are shown in Tables 5-4 through 5-6 and in Figure 5-2. Differences in economic values from the base case are shown in Table 5-4, for each cost/benefit category and total system costs. In Table 5-5, the SOSs are ranked from best to worst based on total system costs. Table 5-6 presents rankings of the SOSs for each cost/benefit category and shows the significance of the differences among the SOSs within each category, through the use of blocking and shading. Within each cost/benefit category, shaded SOSs are those which would result in no change from the base case and those which are blocked together are those which are not be significantly different from the base case. The test for significance which was used is a difference in economic impacts of $\$ 1$ million, plus or minus.

Review of the rankings in Table 5-6 and comparison of these rankings with rankings in Table 5-3 reveals that the rankings are essentially the same for both interest rates. Thus, the generalizations presented above for economic values computed using the 7.75 percent interest rate apply to this case, as well. At the lower interest rate SOS $1 \mathrm{~b}$ has the lowest total system costs and continues to be the NED (national economic development) alternative.

\subsection{COST-EFFECTIVENESS COMPARISONS}

Cost effectiveness of the alternative actions can be demonstrated on the basis of a comparison of their per/unit costs of achieving a desired output. While this comparison is useful in determining which action yields the highest output for the cost and, therefore, has the lowest per unit costs, additional information is needed to determine if any of the actions should be undertaken. That information is some standard which establish the acceptable upper limit of costs. The comparisons presented here are not made against such a limit, because that limit has not been set. Thus, the information displayed in this comparison is useful for ranking the SOSs on the basis of their cost-effectiveness, but it does not 
Table 5-4. Economic Cost/Benefit Differences from the Base Case - Sos 2c (Equivalent Annual Values, 3.0 Percent Interest Rate)

\begin{tabular}{|c|c|c|c|c|c|c|c|c|c|c|c|}
\hline sos & 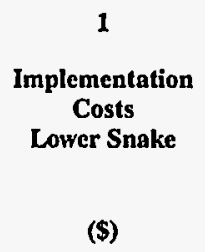 & 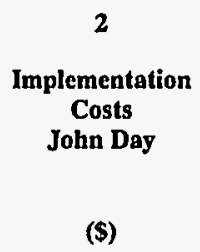 & $\begin{array}{c}\text { 3 } \\
\text { Anadromous } \\
\text { Fish Benefits } \\
\\
\text { (\$) }\end{array}$ & $\begin{array}{c}4 \\
\text { Flood } \\
\text { Damage } \\
\text { Costs } \\
\text { (\$) }\end{array}$ & $\begin{array}{c}5 \\
\begin{array}{c}\text { Commercial } \\
\text { Irrigation } \\
\text { Costs }\end{array} \\
\text { (\$) }\end{array}$ & $\begin{array}{c}6 \\
\text { M \& I } \\
\text { Pumping } \\
\text { Costs } \\
\text { (\$) }\end{array}$ & $\begin{array}{c}7 \\
\text { Shallow Draft } \\
\text { Transportation } \\
\text { Costs } \\
\text { (\$) }\end{array}$ & $\begin{array}{c}8 \\
\text { Dworshak } \\
\text { Log } \\
\text { Trucking } \\
\text { Costs } \\
\text { (\$) }\end{array}$ & $\begin{array}{c}9 \\
\text { Power } \\
\text { System } \\
\text { Generation } \\
\text { Costs } \\
\text { (\$) }\end{array}$ & $\begin{array}{c}10 \\
\text { Recreation } \\
\text { Consumer } \\
\text { Surplus } \\
\text { Benefits } \\
\text { (\$) }\end{array}$ & $\begin{array}{c}11 \\
\text { Total } \\
\text { System } \\
\text { Costs 1/ } \\
\text { (\$) }\end{array}$ \\
\hline sos 1a & - & - & $(330,000)$ & - & 9,000 & - & - & $(112,100)$ & $(38,000,000)$ & $4,691,000$ & $(42,464,100)$ \\
\hline SOS $1 \mathrm{~b}$ & - & - & $(180,000)$ & - & 8,900 & - & - & $(119,600)$ & $(72,000,000)$ & $7,941,000$ & $(79,871,700)$ \\
\hline $\operatorname{sos} 2 c$ & - & - & - & - & - & - & - & - & - & - & - \\
\hline $\operatorname{SOS} 2 d$ & - & - & 160,000 & - & $(3,300)$ & - & - & 93,100 & $24,000,000$ & $(5,015,000)$ & $28,944,800$ \\
\hline SOS $4 c$ & - & - & 160,000 & 444,100 & $(18,400)$ & - & - & $(228,200)$ & $85,000,000$ & $4,171,000$ & $80,866,500$ \\
\hline $\operatorname{sos} 5 b$ & $83,249,400$ & $5,310,600$ & $(6,370,000)$ & - & $3,319,200$ & $3,256,900$ & $13,631,400$ & $(51,000)$ & $85,000,000$ & $(66,280,000)$ & $266,366,500$ \\
\hline sos $5 c$ & $17,430,600$ & $7,169,700$ & $(8,660,000)$ & - & $4,539,700$ & $4,520,100$ & $37,533,600$ & $(171,100)$ & $167,000,000$ & $(89,792,000)$ & $336,474,600$ \\
\hline sos $6 b$ & $26,086,800$ & $5,478,500$ & $(11,120,000)$ & - & $2,558,500$ & $3,617,300$ & $12,314,300$ & $(120,300)$ & $35,000,000$ & $(49,057,000)$ & $145,112,100$ \\
\hline $\operatorname{sos} 6 d$ & $2,192,700$ & $5,567,000$ & $(5,500,000)$ & - & $1,375,000$ & $4,126,200$ & $2,145,500$ & $(141,200)$ & $17,000,000$ & $(39,812,000)$ & $77,577,200$ \\
\hline $\operatorname{sos} 9 a$ & $26,086,500$ & $5,347,100$ & $(16,710,000)$ & 257,300 & $2,358,900$ & $3,616,000$ & $12,314,300$ & $(41,500)$ & $236,000,000$ & $(96,871,000)$ & $399,519,600$ \\
\hline sos $9 b$ & - & - & $(3,350,000)$ & 27,400 & 5,400 & - & - & 172,700 & $213,000,000$ & $(35,418,000)$ & $251,973,500$ \\
\hline $\operatorname{sos} 9 c$ & $26,149,400$ & $5,516,500$ & $(11,490,000)$ & 458,800 & $2,646,800$ & $3,662,500$ & $7,358,900$ & $(5,400)$ & $138,000,000$ & $(37,925,000)$ & $233,202,500$ \\
\hline SOS PA & - & $5,921,600$ & 50,000 & 222,800 & $1,537,200$ & $4,273,400$ & - & 119,700 & $126,000,000$ & $(26,441,000)$ & $164,465,700$ \\
\hline Source: & Table 4-4 & Table 4-5 & Table 4-12 & Table 4-19 & Table 4-23 & Table 4-27 & Table 4-29 & Table 4-37 & Table 4-45 & Table 4-50 & \\
\hline
\end{tabular}


Table 5-5. Alternatives Ranked From Best to Worst Based on Differences in Total System Costs: Economic System Cost Differences from the Base Case - SOS 2c (Equivalent Annual Values, 3.0 Percent Interest Rate)

\begin{tabular}{|c|c|c|c|c|c|c|c|c|c|c|c|}
\hline sos & $\begin{array}{c}1 \\
\text { Implementation } \\
\text { Costs Lower } \\
\text { Snake } \\
\text { (\$) }\end{array}$ & $\begin{array}{c}2 \\
\text { Implementation } \\
\text { Costs John Day } \\
\text { (\$) }\end{array}$ & $\begin{array}{c}3 \\
\text { Anadromous } \\
\text { Fish Benefits } \\
\\
\text { (\$) }\end{array}$ & $\begin{array}{c}4 \\
\begin{array}{c}\text { Flood } \\
\text { Damage } \\
\text { Costs }\end{array} \\
(\$)\end{array}$ & $\begin{array}{l}5 \\
\text { Commercial } \\
\text { Irrigation } \\
\text { Costs } \\
\text { (\$) }\end{array}$ & $\begin{array}{c}6 \\
\text { M \&1 } \\
\text { Pumping } \\
\text { Costs } \\
\text { (\$) }\end{array}$ & $\begin{array}{c}7 \\
\text { Shallow Draf } \\
\text { Transportation } \\
\text { Costs } \\
\text { (\$) }\end{array}$ & $\begin{array}{c}8 \\
\text { Dworshak } \\
\text { Log } \\
\text { Trucking } \\
\text { Costs } \\
\text { (\$) }\end{array}$ & $\begin{array}{c}9 \\
\text { Power } \\
\text { System } \\
\text { Generation } \\
\text { Costs } \\
\text { (\$) }\end{array}$ & $\begin{array}{c}10 \\
\text { Recreation } \\
\text { Consumer } \\
\text { Surplus } \\
\text { Benefits } \\
\text { (\$) }\end{array}$ & $\begin{array}{c}11 \\
\text { Total } \\
\text { System } \\
\text { Costs } 1 / \\
\text { (\$) }\end{array}$ \\
\hline $\operatorname{sos} 1 b$ & - & - & $(180,000)$ & - & 8,900 & - & - & $(119,600)$ & $(72,000,000)$ & $7,941,000$ & $(79,871,700)$ \\
\hline $\operatorname{sos} 1 \mathrm{a}$ & - & - & $(330,000)$ & - & 9,000 & - & - & $(112,100)$ & $(38,000,000)$ & $4,691,000$ & $(42,464,100)$ \\
\hline $\operatorname{sos} 2 c$ & - & - & - & - & - & - & - & - & - & - & - \\
\hline $\operatorname{sos} 2 d$ & - & - & 160,000 & - & $(3,300)$ & - & - & 93,100 & $24,000,000$ & $(5,015,000)$ & $28,944,800$ \\
\hline $\operatorname{sos} 6 \mathrm{~d}$ & $2,192,700$ & $5,567,000$ & $(5,500,000)$ & - & $1,375,000$ & $4,126,200$ & $2,145,500$ & $(141,200)$ & $17,000,000$ & $(39,812,000)$ & $77,577,200$ \\
\hline $\operatorname{sOS} 4 c$ & - & - & 160,000 & 444,100 & $(18,400)$ & - & - & $(228,200)$ & $85,000,000$ & $4,171,000$ & $80,866,500$ \\
\hline $\operatorname{sos} 6 \mathrm{~b}$ & $26,086,800$ & $5,478,500$ & $(11,120, \infty 00)$ & - & $2,558,500$ & $3,617,300$ & $12,314,300$ & $(120,300)$ & $35,000,000$ & $(49,057,000)$ & $145,112,100$ \\
\hline SOS PA & - & $5,921,600$ & 50,000 & 222,800 & $1,537,200$ & $4,273,400$ & - & 119,700 & $126,000,000$ & $(26,441,000)$ & $164,465,700$ \\
\hline $\operatorname{sos} 9 \mathrm{c}$ & $26,149,400$ & $5,516,500$ & $(11,490,000)$ & 458,800 & $2,646,800$ & $3,662,500$ & $7,358,900$ & $(5,400)$ & $138,000,000$ & $(37,925,000)$ & $233,202,500$ \\
\hline $\operatorname{sos} 9 \mathrm{~b}$ & - & - & $(3,350,000)$ & 27,400 & 5,400 & - & - & 172,700 & $213,000,000$ & $(35,418,000)$ & $251,973,500$ \\
\hline sos $5 b$ & $83,249,400$ & $5,310,600$ & $(6,370,000)$ & - & $3,319,200$ & $3,256,900$ & $13,631,400$ & $(51,000)$ & $85,000,000$ & $(66,280,000)$ & $266,366,500$ \\
\hline SOS $5 c$ & $17,430,600$ & $7,169,700$ & $(8,660,000)$ & - & $4,539,700$ & $4,520,100$ & $37,533,600$ & $(171,100)$ & $167,000,000$ & $(89,792,000)$ & $336,474,600$ \\
\hline $\operatorname{sos} 9 \mathrm{a}$ & $26,086,500$ & $5,347,100$ & $(16,710,000)$ & 257,300 & $2,358,900$ & $3,616,000$ & $12,314,300$ & $(41,500)$ & $236,000,000$ & $(96,871,000)$ & $399,519,600$ \\
\hline Source: & Table 4-4 & Table 4-5 & Table 4-12 & Table 4-19 & Table 4-23 & Table 4-27 & Table 4-29 & Table 4-37 & Table 4-45 & & \\
\hline $\begin{array}{l}\text { Notes: } \\
1 / \text { Com }\end{array}$ & ed: & 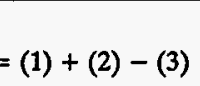 & & & & & & & & & \\
\hline
\end{tabular}


Table 5-6. Ranking of Alternatives - Best to Worst - By Cost/Benefit Category using Differences from the Base Case - SOS 2c (Equivalent Annual Values, 3.0 Percent Interest Rate)

诰

\begin{tabular}{|c|c|c|c|c|c|c|c|c|c|}
\hline $\begin{array}{c}1 \\
\text { Implementation } \\
\text { Costs Lower } \\
\text { Snake }\end{array}$ & $\begin{array}{c}2 \\
\text { Impiementation } \\
\text { Costs } \\
\text { John Day }\end{array}$ & $\begin{array}{c}\text { 3 } \\
\text { Anadromous } \\
\text { Fish Benefits }\end{array}$ & $\begin{array}{c}4 \\
\text { Flood } \\
\text { Damage } \\
\text { Costs }\end{array}$ & $\begin{array}{c}5 \\
\text { Commercial } \\
\text { Irrigation } \\
\text { Costs }\end{array}$ & $\begin{array}{c}6 \\
\text { M \& I } \\
\text { Pumping } \\
\text { Costs }\end{array}$ & $\begin{array}{c}7 \\
\text { Shallow Draft } \\
\text { Transportation } \\
\text { Costs }\end{array}$ & $\begin{array}{c}8 \\
\text { Dworshak } \\
\text { Log Trucking } \\
\text { Costs }\end{array}$ & $\begin{array}{c}9 \\
\text { Power System } \\
\text { Generation } \\
\text { Costs }\end{array}$ & $\begin{array}{l}10 \\
\text { Recreation } \\
\text { Consumer } \\
\text { Surplus } \\
\text { Benefits }\end{array}$ \\
\hline sosin & $4, \operatorname{sos}^{\prime} 6=$ & $\operatorname{sos} 2 d$ & $1 \% .85 \% 1 \%$ & $\operatorname{SOS} 4 c$ & $50516 \%$ & \%sos $1 \%$ & $\operatorname{SOS} 4 c$ & SOS $1 b$ & $\operatorname{sos} 1 b$ \\
\hline $1.505 \%$ & $\% .50 \%$ & $\operatorname{SOS} 4 c$ & \%०SS & $\operatorname{sos} 2 d$ & $\%$ oss & $\%$ sos $10 \%$ & SOS 5c & SOS 1a & sos 1a \\
\hline $6.9051 \%$ & \% & SOS PA & sos 6 & $50 S_{2} 0$ & KKos & 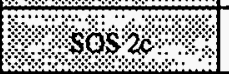 & $\operatorname{sos} 6 d$ & $2.08 \%$ & $\operatorname{sos} 4 c$ \\
\hline $4 . \operatorname{sos}_{2} \mathrm{~d}$. & $1 \% \cos 20 \%$ & \% & $505 \%$ & $\operatorname{sos} 9 b$ & KSos 2 & $160520 \%$ & $\operatorname{sos} 6 b$ & $\operatorname{sos} 6 \mathrm{~d}$ & $1858 \%$ \\
\hline \% & sos & $\operatorname{sos} 1 \mathrm{~b}$ & 6os & $\operatorname{sos} 1 b$ & $1 \%$ sos 1 . & . & SOS $1 \mathrm{~b}$ & $\operatorname{sos} 2 \mathrm{~d}$ & $\operatorname{sos} 2 d$ \\
\hline $2 / \operatorname{sos} 12 \%$ & sos. & $\operatorname{sos} 1 a$ & 50,60 & $\operatorname{sos} 1 \mathrm{a}$ & $\%$ sos $0 \%$. & $1 . \operatorname{sps} 0 \%$ & $\operatorname{sos} 1 \mathrm{a}$ & $\operatorname{sos} 6 b$ & SOS PA \\
\hline s.s. & sos $5 b$ & sos 9b & s.os 6 \% & $\operatorname{sos} 6 \mathrm{~d}$ & sos $5 b$ & 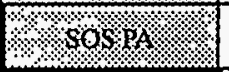 & $\operatorname{sos} 5 b$ & $\operatorname{sos} 4 c$ & $\operatorname{sos} 9 b$ \\
\hline $\operatorname{sos} 6 d$ & sos 9a & $\operatorname{sos} 6 \mathrm{~d}$ & 1.50550 & SOS PA & sos 9a & $\operatorname{sos} 6 d$ & $\operatorname{sos} 9 a$ & $\operatorname{sos} 5 b$ & sos $9 c$ \\
\hline $\operatorname{sOS} 5 \mathrm{c}$ & $\operatorname{sos} 6 b$ & $\operatorname{sos} 5 b$ & $\operatorname{sos} 9 b$ & $\operatorname{sos} 9 a$ & $\operatorname{sos} 6 b$ & $\operatorname{sos} 9 \mathrm{c}$ & $\operatorname{sos} 9 \mathrm{c}$ & SOS PA & $\operatorname{sos} 6 d$ \\
\hline $\operatorname{sos} 9 \mathrm{a}$ & $\operatorname{sos} 9 \mathrm{c}$ & SOS $5 \mathrm{c}$ & SOS PA & $\operatorname{sos} 6 b$ & $\operatorname{sos} 9 \mathrm{c}$ & $\operatorname{sos} 6 b$ & $4 \operatorname{sos} 2 \%$ & $\operatorname{sos} 9 \mathrm{c}$ & $\operatorname{sos} 6 b$ \\
\hline $\operatorname{sos} 6 \mathrm{~b}$ & $\operatorname{sos} 6 d$ & $\operatorname{sos} 6 b$ & $\operatorname{sos} 9 a$ & SOS $9 \mathrm{c}$ & $\operatorname{sos} 6 \mathrm{~d}$ & sos $9 a$ & $\operatorname{sos} 2 \mathrm{~d}$ & sos $5 c$ & SOS $5 b$ \\
\hline $\operatorname{sos} 9 \mathrm{c}$ & SOS PA & $\operatorname{sos} 9 c$ & SOS $4 c$ & SOS 5b & SOS PA & $\operatorname{sos} 5 b$ & SOS PA & sos $9 b$ & $\operatorname{sos} 5 c$ \\
\hline $\operatorname{sos} 5 b$ & sos $5 c$ & sos 9a & $\operatorname{sos} 9 \mathrm{c}$ & $\operatorname{sos} 5 \mathrm{c}$ & SOS $5 \mathrm{c}$ & sos $5 c$ & SOS $9 b$ & $\operatorname{sos} 9 a$ & $\operatorname{sos} 9 a$ \\
\hline \multicolumn{10}{|c|}{$\begin{array}{l}\text { Notes: } \\
\text { 1. SOSs ranked from low cost to bigh for each cost/benefit category. } \\
\text { 2. Shaded areas represent the base case (SOS } 2 \mathrm{c} \text { ) or no change from base case. } \\
\text { 3. Alternatives above the shaded area have positive economic impacts, compared with the base case. } \\
\text { 4. Alternatives below the shaded areas have negative economic impacts, compared with the base case. } \\
\text { 5. Blocked areas group alternatives which have economic impacts within } \$ 1 \text { million, plus or minus. These alternatives are not considered to be significantly different. }\end{array}$} \\
\hline
\end{tabular}




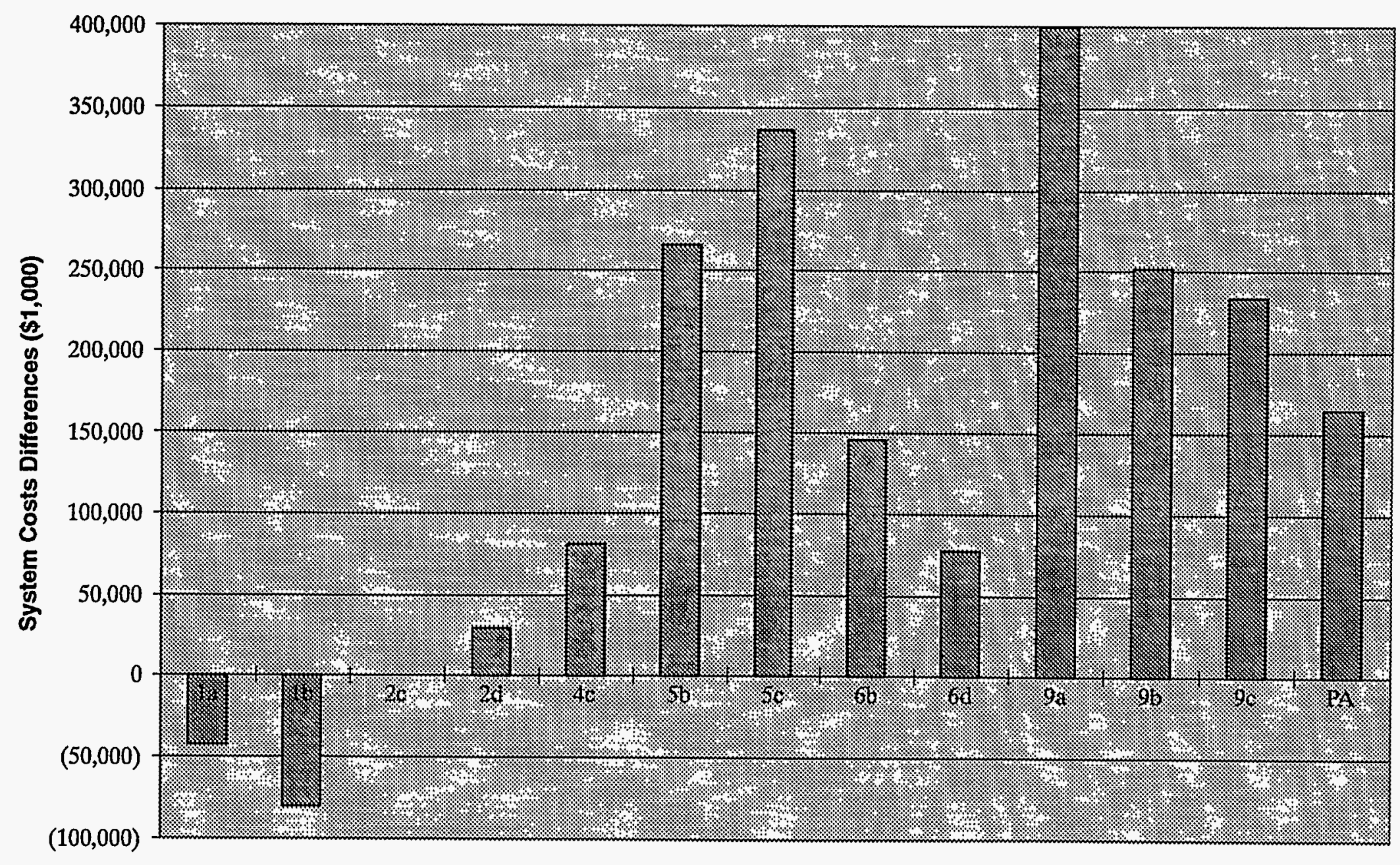

System Operation Strategies 
provide the basis for a decision to implement or not implement any of the strategies. Nevertheless, the comparison does establish the logical order, rank or preference of the alternatives.

In the case of the SOR, the desired output that is considered in the comparisons of the cost-effectiveness of the SOSs for survival of anadromous fish. The approach used in this comparison is to examine the change in harvest of anadromous fish (from Table 4-6), with changes in harvest being a surrogate for changes in the overall numbers of all stocks and an indicator of their survivability. Thus, the comparison combines all stocks of salmon and steelhead in the Columbia and Snake Rivers above Bonneville Dam. Nevertheless, it is recognized that a more important factor to many interests is the natural production of endangered species. Therefore, the cost-effectiveness ranking shown here should not be the only factor for consideration in selecting an alternative for implementation.

The cost basis for the cost effectiveness comparisons is the equivalent annual costs. Comparisons are shown for both interest rates $-\mathbf{- 7 . 7 5}$ percent and $\mathbf{3 . 0}$ percent. These comparisons are shown in Figures $5-3$ and 5-4, respectively. The figures clearly show that SOSs $2 \mathrm{~d}, 4 \mathrm{c}$, and the preferred alternative are the only ones which would result in an increase in production/harvest of anadromous fish. These, therefore, are the only ones which should be considered for implementation on the basis of cost-effectiveness. This is the case because it would be irrational to make expenditures on alternatives which decrease fish production, if increasing fish production is the only consideration in making the investment decision. Of the three SOSs which fall in the rational range of cost-effectiveness, the most cost-effective alternative is SOS $2 \mathrm{~d}$, which has much lower costs than the other two SOSs and produces nearly as many fish as the preferred alternative. Comparison of Figures 5-3 and 5-4 shows that the results are essentially the same for both interest rates.

\subsection{REGIONAL ECONOMIC IMPACTS}

\subsubsection{General}

Thirteen system operations alternatives were evaluated for the SOR FEIS direct economic impacts analysis. Regional economic impacts were estimated for each of these SOSs. The regional impacts were developed from the estimates of direct economic impacts which are presented in Chapter 4. The direct economic values used in the analysis are average annual values--computed at the three percent rate of interest--for the year 2020 and beyond. The SOSs evaluated in the regional analysis are presented in Table 5-7.

SOR alternative 2c, Final SEIS Operation-No Action Alternative, was identified as the no action alternative for the operations analysis. It was considered to be most representative of current system operations.

Adjustments in river operations will affect the demand for local goods and services, causing the output levels in many related industries to change. Input requirements will be affected as will the distribution of regional output to local and export markets. Labor requirements will change, increasing or decreasing the availability of regional jobs.

Personal income will rise or fall depending on the job impacts. The regional trade balance will shift as the availability of local commodities is affected by changes in production levels.

The most common indicators of changes in regional economic activity however, are adjustments in regional employment and earnings. These are the measures from the input-output models which best describe the change in the economic well-being for the local population. Employment is measured as the total number of jobs and includes both full-time and part-time workers. Earnings, or income, is measured as wage and salary income paid to employees plus income earned by business owners and sole-proprietorships. 


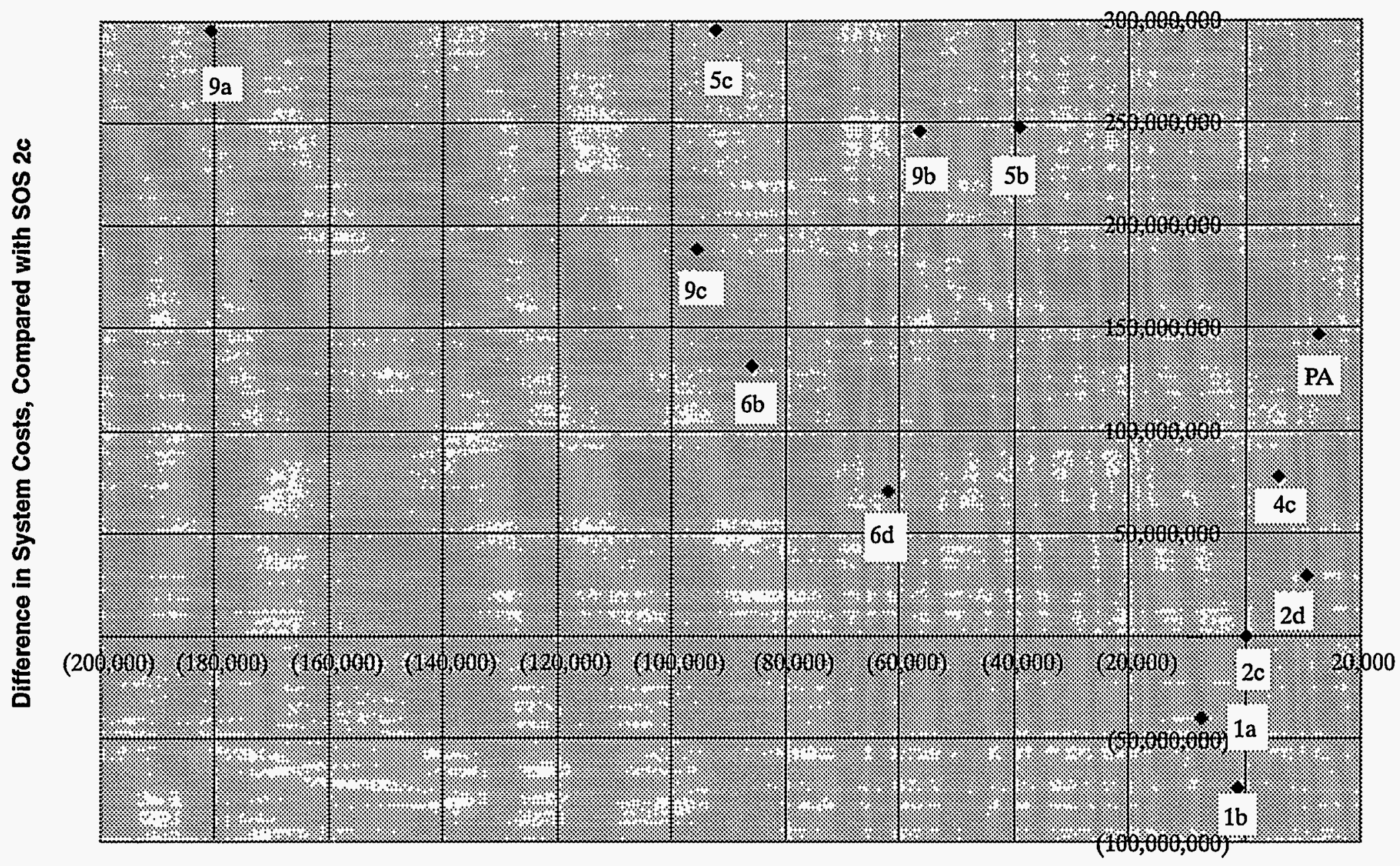

Difference in Fish Harvested, Compared with SOS $2 c$ 


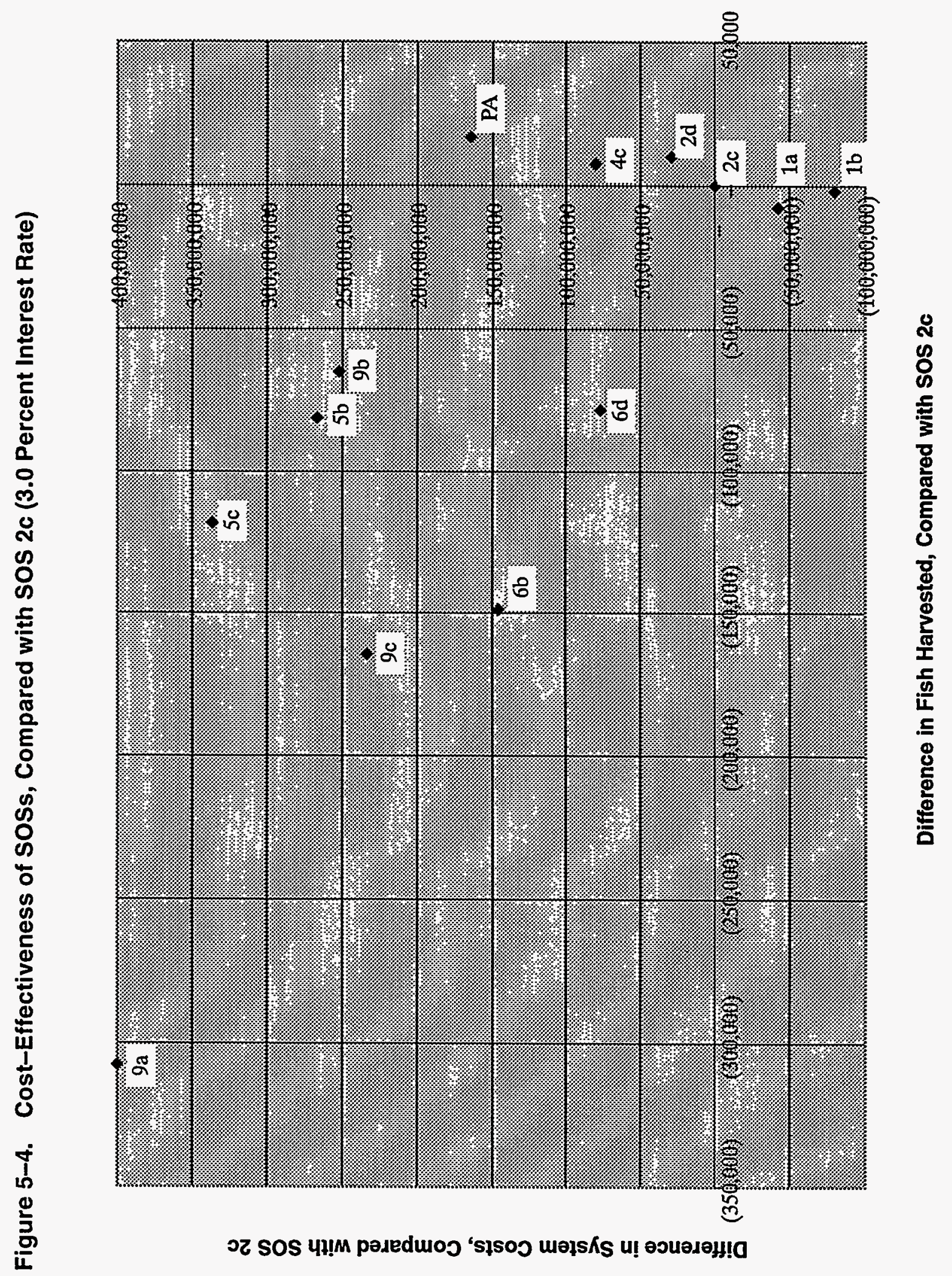


Table 5-7. SOR Alternatives Evaluated in the Regional Analysis

\begin{tabular}{|l|l|}
\hline \multicolumn{1}{|c|}{ Alternative } & \multicolumn{1}{|c|}{ Description } \\
\hline SOS $1 \mathrm{a}$ & Pre-Salmon Summit Operation \\
\hline SOS $1 \mathrm{~b}$ & Optimum Load Following Operation \\
\hline \multicolumn{1}{|c|}{ SOS 2c } & \multicolumn{1}{|c|}{ Final SEIS Operation--No Action Alternative } \\
\hline SOS $2 \mathrm{~d}$ & 1994-98 Biological Opinion Operation \\
\hline SOS 4c & Enhanced Operation with Modified Grand Coulee Flood Control \\
\hline SOS 5b & Four and One-Half Month Natural River Operation \\
\hline SOS $6 \mathrm{~b}$ & Four and One-Half Month Fixed Drawdown Operation \\
\hline SOS 6d & Four and One-Half Month Lower Granite Drawdown Operation \\
\hline SOS 9a & Detailed Fishery Operating Plan \\
\hline SOS 9b & Adaptive Management \\
\hline SOS 9c & Balanced Impacts Operation \\
\hline
\end{tabular}

As was explained in Chapter 3, regional impacts of the alternatives were estimated using IMPLAN regional, state and sub-regional models. The following caution applies to the results: Results from the State and subregion analyses are not additive to the Pacific Northwest. Also, in one case, the allocation of the expected direct economic impacts to states and subregions could not be fully made. A component of the expected impacts related to power will be an increase in the generation of non-hydro based electricity resources. The operation of these facilities will generate economic impacts within the region. However, insufficient information was available to determine where within the Pacific Northwest these sites might be located. Therefore, the regional impacts associated with these facilities are measured only for the larger PNW region.

The following subsections of Section 5.5 of this chapter present a summary of indirect impacts for the region, the states and the sub-regions for the five resources affected by the SOR alternatives: anadromous fish, irrigation, navigation, power, and recreation. Impacts related to project implementation and pump modification are discussed separate- ly. A more detailed summary of expected regional impacts for the five resource areas is presented in Exhibit E.

\subsubsection{Economic Impacts in the Pacific Northwest Region}

Regional economic impacts related to all of the expected changes in resource activity which would occur with implementation of the SOSs were evaluated for the Pacific Northwest Region. These impacts provide an indication of the net effect of the adjustments in river operations on regional employment and income.

\subsubsection{Pacific Northwest Regional Employment Impacts}

The total employment impacts for the Pacific Northwest which are likely to result from the alternative river operations are presented in Table 5-8. Expected changes in regional employment range from a net increase of over 2,000 jobs annually under SOS $1 \mathrm{~b}$ to a loss of 9,450 jobs annually under SOS 9 a. Only two of the twelve alternatives evaluated resulted in a net increase in regional employment. 
Table 5-8. Summary of Pacific Northwest Regional Employment Impacts (Total Number of Jobs per Year)

\begin{tabular}{|c|c|c|c|c|c|c|c|}
\hline & All Resources & AFish & Irrigation & Navigation & Power & Recreation & $\begin{array}{c}\text { Power } \\
\text { Purchases }\end{array}$ \\
\hline SOS 1a & 1,036 & $(5)$ & 0 & 2 & 1,505 & 60 & $(526)$ \\
SOS 1b & 2,021 & $(6)$ & 0 & 2 & 3,016 & 63 & $(1,055)$ \\
\hline SOS 2d & $(578)$ & 0 & 0 & $(2)$ & $(886)$ & 0 & 310 \\
\hline SOS 4c & $(2,191)$ & 1 & 0 & 5 & $(3,443)$ & 42 & 1,204 \\
\hline SOS 5b & $(4,095)$ & $(114)$ & $(434)$ & 158 & $(5,265)$ & $(281)$ & 1,841 \\
SOS 5c & $(7,486)$ & $(246)$ & $(437)$ & 94 & $(9,271)$ & $(318)$ & 2,693 \\
\hline SOS 6b & $(2,264)$ & $(388)$ & $(347)$ & $(132)$ & $(1,854)$ & $(191)$ & 648 \\
SOS 6d & $(1,083)$ & $(144)$ & $(261)$ & $(26)$ & $(769)$ & $(153)$ & 269 \\
\hline SOS 9a & $(9,451)$ & $(557)$ & $(335)$ & $(133)$ & $(12,509)$ & $(290)$ & 4,373 \\
SOS 9b & $(5,662)$ & $(82)$ & 0 & $(4)$ & $(8,519)$ & $(36)$ & 2,978 \\
SOS 9c & $(5,678)$ & $(394)$ & $(356)$ & $(17)$ & $(7,317)$ & $(152)$ & 2,558 \\
\hline SOS PA & $(4,029)$ & $(6)$ & $(259)$ & $(2)$ & $(5,419)$ & $(237)$ & 1,895 \\
\hline
\end{tabular}

\subsubsection{Pacific Northwest Regional Income Impacts}

The effects of the SOR alternatives on Pacific Northwest regional income are presented in Table 5-9. They include the direct economic changes along with the indirect and induced changes that resuit from the interdependencies which exist throughout the regional economy. Expected changes in regional income range from a net increase of over $\$ 56$ million annually under SOS $1 \mathrm{~b}$ to a loss of over $\$ 260$ million annually under SOS 9a. The distribution of changes in regional income across alternatives is consistent with the distribution of the employment impacts.

\subsubsection{Economic Impacts in the States}

The expected state-level economic impacts related to the direct changes in river operations were evaluated for each of the SOR alternatives. These impacts provide an indication of the broad distribution of the regional economic impacts across the four Pacific Northwest States. The state by state distribution of expected regional economic impacts was made using information and analysis provided by the direct economic work groups. Additional information was furnished by the regional impact models.

\subsubsection{State Level Employment Impacts}

State-level employment impacts expected to result from the SOR alternatives are presented in Table 5-10. Under each of the SOR alternatives Washington accounts for over sixty percent of the regional job impacts, ranging from a net increase of nearly 1,500 jobs with SOS $1 \mathrm{~b}$ to a loss of nearly 6,600 jobs for SOS 9a. Employment impacts in Oregon range from a net increase of nearly 800 jobs under alternative SOS $1 \mathrm{~b}$ to a loss of over 3,300 jobs under alternative SOS 9a. Net job impacts in Idaho range from forty to seventy-five percent of Oregon levels for alternatives $1 \mathrm{a}$ and $6 \mathrm{~b}$ respectively. Net job impacts in Montana range from one to twenty-six percent of Oregon levels for alternatives $5 b$ and $6 b$ respectively. Once again, the net effect of the SOR alternatives on Pacific Northwest state-level employment is dominated by the impact of the operations strategies on the regional power system (see Exhibit E). 
Table 5-9. Summary of Pacific Northwest Regional Income Impacts (Million Dollars per Year)

\begin{tabular}{|l|c|c|c|c|c|c|c|}
\hline & All Resources & AFish & Irrigation & Navigation & Power & Recreation & $\begin{array}{c}\text { Power } \\
\text { Purchases }\end{array}$ \\
\hline SOS 1a & $\$ 25.6$ & $(\$ 0.2)$ & $\$ 0.0$ & $\$ 0.1$ & $\$ 45.8$ & $(\$ 1.6)$ & $(\$ 18.5)$ \\
SOS 1b & $\$ 56.4$ & $(\$ 0.2)$ & $\$ 0.0$ & $\$ 0.1$ & $\$ 91.8$ & $\$ 1.7$ & $(\$ 37.0)$ \\
\hline SOS 2d & $(\$ 16.2)$ & $\$ 0.0$ & $\$ 0.0$ & $(\$ 0.1)$ & $(\$ 27.0)$ & $\$ 0.0$ & $\$ 10.9$ \\
\hline SOS 4c & $(\$ 61.2)$ & $\$ 0.0$ & $\$ 0.0$ & $\$ 0.2$ & $(\$ 104.8)$ & $\$ 1.1$ & $\$ 42.2$ \\
\hline SOS 5b & $(\$ 106.8)$ & $(\$ 3.4)$ & $(\$ 13.4)$ & $\$ 13.6$ & $(\$ 160.2)$ & $(\$ 8.0)$ & $\$ 64.5$ \\
SOS 5c & $(\$ 199.4)$ & $(\$ 7.4)$ & $(\$ 13.5)$ & $\$ 19.3$ & $(\$ 283.2)$ & $(\$ 9.1)$ & $\$ 94.4$ \\
\hline SOS 6b & $(\$ 59.1)$ & $(\$ 11.6)$ & $(\$ 10.7)$ & $\$ 2.2$ & $(\$ 56.4)$ & $(\$ 5.4)$ & $\$ 22.7$ \\
SOS 6d & $(\$ 31.5)$ & $(\$ 4.3)$ & $(\$ 8.0)$ & $(\$ 0.8)$ & $(\$ 23.4)$ & $(\$ 4.3)$ & $\$ 9.4$ \\
\hline SOS 9a & $(\$ 260.2)$ & $(\$ 16.6)$ & $(\$ 10.3)$ & $\$ 2.2$ & $(\$ 380.6)$ & $(\$ 8.2)$ & $\$ 153.3$ \\
SOS 9b & $(\$ 158.4)$ & $(\$ 2.5)$ & $\$ 0.0$ & $(\$ 0.1)$ & $(\$ 259.2)$ & $(\$ 1.0)$ & $\$ 104.4$ \\
SOS 9c & $(\$ 160.5)$ & $(\$ 11.8)$ & $(\$ 11.0)$ & $(\$ 0.6)$ & $(\$ 222.6)$ & $(\$ 4.2)$ & $\$ 89.7$ \\
\hline SOS PA & $(\$ 113.1)$ & $(\$ 0.2)$ & $(\$ 8.0)$ & $(\$ 0.1)$ & $(\$ 164.9)$ & $(\$ 6.4)$ & $\$ 66.4$ \\
\hline
\end{tabular}

Table 5-10. Summary of State Employment Impacts-Washington, Oregon, Idaho and Montana (Total Number of Jobs per Year)

\begin{tabular}{|l|c|c|c|c|}
\hline & Washington & Oregon & Idaho & Montana \\
\hline SOS 1a & 753 & 408 & 160 & 69 \\
SOS 1b & 1,479 & 779 & 334 & 146 \\
\hline SOS 2d & $(422)$ & $(214)$ & $(96)$ & $(42)$ \\
\hline SOS 4c & $(1,614)$ & $(815)$ & $(395)$ & $(152)$ \\
\hline SOS 5b & $(3,133)$ & $(1,464)$ & $(736)$ & $(16)$ \\
SOS 5c & $(4,397)$ & $(2,083)$ & $(1,135)$ & $(140)$ \\
\hline SOS 6b & $(1,364)$ & $(677)$ & $(497)$ & $(175)$ \\
SOS 6d & $(641)$ & $(394)$ & $(176)$ & $(39)$ \\
\hline SOS 9a & $(6,598)$ & $(3,352)$ & $(1,845)$ & $(807)$ \\
SOS 9b & $(4,127)$ & $(2,107)$ & $(1,062)$ & $(439)$ \\
SOS 9c & $(3,901)$ & $(2,053)$ & $(1,077)$ & $(349)$ \\
\hline SOS PA & $(2,486)$ & $(1,594)$ & $(629)$ & $(281)$ \\
\hline
\end{tabular}


It is important to note that the state analysis excludes the estimation of impacts related to the purchase of non-hydro based power. Insufficient information was available to allocate the direct changes to the states. Therefore, the net economic impacts within one or more of the states are likely to be somewhat less than those presented in this analysis.

\subsubsection{State Level Income Impacts}

Results of the analysis of state level income impacts are presented in Tables 5-11. They include the direct, indirect, and induced income changes that result from the interdependencies which exist throughout the regional economy.

\subsubsection{Economic Impacts in the SOR Subregions}

Economic impacts were evaluated for each of the SOR subregions where direct changes in river operations are expected to result in adjustments in resource use. These impacts provide a more detailed indication of the expected distribution of the region- al economic impacts than those estimated for the individual states. Results of the impact analysis are presented below for expected changes in total regional employment, allocated by subregion.

Allocations to the subregions were made using information and analysis provided by the direct economic work groups, along with information from the regional impact models. It is important to note that the subregion analysis excludes the estimation of impacts related to the purchase of non-hydro based power. Insufficient information was available to allocate the direct changes to the SOR subregions. Therefore, the net economic impacts in one or more of the subregions are likely to be somewhat less than those presented in this analysis.

\subsubsection{Subregion-Level Employment Impacts}

Expected changes in subregion employment resulting from the SOR alternatives are presented in Table 5-12. Employment impacts are presented for the net job effects aggregated across the five resources (anadromous fish, irrigation, navigation, power, and

Table 5-11. Summary of State Income Impacts-Washington, Oregon, Idaho and Montana (Million Dollars per Year)

\begin{tabular}{|l|c|c|c|c|}
\hline & Washington & Oregon & Idaho & Montana \\
\hline SOS 1a & $\$ 23.6$ & $\$ 12.5$ & $\$ 4.2$ & $\$ 1.7$ \\
SOS 1b & $\$ 46.4$ & $\$ 24.0$ & $\$ 8.7$ & $\$ 3.5$ \\
\hline SOS 2d & $(\$ 13.3)$ & $(\$ 6.6)$ & $(\$ 2.6)$ & $(\$ 1.0)$ \\
\hline SOS 4c & $(\$ 50.8)$ & $(\$ 25.3)$ & $(\$ 10.3)$ & $(\$ 3.7)$ \\
\hline SOS 5b & $(\$ 95.4)$ & $(\$ 45.0)$ & $(\$ 14.1)$ & $\$ 2.0$ \\
SOS 5c & $(\$ 131.7)$ & $(\$ 63.9)$ & $(\$ 19.5)$ & $(\$ 1.0)$ \\
\hline SOS 6b & $(\$ 40.6)$ & $(\$ 20.6)$ & $(\$ 9.2)$ & $(\$ 3.1)$ \\
SOS 6d & $(\$ 20.1)$ & $(\$ 12.1)$ & $(\$ 4.6)$ & $(\$ 0.9)$ \\
\hline SOS 9a & $(\$ 204.9)$ & $(\$ 103.1)$ & $(\$ 42.6)$ & $(\$ 18.3)$ \\
SOS 9b & $(\$ 129.7)$ & $(\$ 65.1)$ & $(\$ 27.8)$ & $(\$ 10.6)$ \\
SOS 9c & $(\$ 122.5)$ & $(\$ 63.1)$ & $(\$ 28.1)$ & $(\$ 8.5)$ \\
\hline SOS PA & $(\$ 89.1)$ & $(\$ 48.8)$ & $(\$ 16.5)$ & $(\$ 6.8)$ \\
\hline
\end{tabular}


Table 5-12. Summary of Subregional Employment Impacts (Total Number of Jobs per Year)

\begin{tabular}{|l|c|c|c|c|c|c|c|c|}
\hline & $\begin{array}{c}\text { Puget } \\
\text { Sound }\end{array}$ & $\begin{array}{c}\text { West } \\
\text { Coast }\end{array}$ & Portland & $\begin{array}{c}\text { Mid } \\
\text { Columbia }\end{array}$ & $\begin{array}{c}\text { Upper } \\
\text { Columbia }\end{array}$ & $\begin{array}{c}\text { Lower } \\
\text { Snake }\end{array}$ & Northeast & $\begin{array}{c}\text { Southern } \\
\text { Idaho }\end{array}$ \\
\hline SOS 1a & 262 & 116 & 173 & 234 & 57 & 60 & 181 & 101 \\
SOS 1b & 527 & 234 & 351 & 318 & 129 & 147 & 368 & 204 \\
\hline SOS 2d & $(153)$ & $(66)$ & $(100)$ & $(48)$ & $(42)$ & $(39)$ & $(105)$ & $(58)$ \\
\hline SOS 4c & $(601)$ & $(266)$ & $(401)$ & $(95)$ & $(162)$ & $(162)$ & $(417)$ & $(233)$ \\
\hline SOS 5b & $(921)$ & $(412)$ & $(623)$ & $(476)$ & $(145)$ & $(2,409)$ & $(54)$ & $(76)$ \\
SOS 5c & $(1,349)$ & $(610)$ & $(916)$ & $(214)$ & $(234)$ & $(3,839)$ & 137 & 35 \\
\hline SOS 6b & $(323)$ & $(156)$ & $(235)$ & $(320)$ & $(23)$ & $(1,645)$ & 256 & 78 \\
SOS 6d & $(133)$ & $(63)$ & $(91)$ & $(493)$ & $(49)$ & $(313)$ & $(104)$ & $(54)$ \\
\hline SOS 9a & $(2,191)$ & $(1,023)$ & $(1,494)$ & $(957)$ & $(680)$ & $(2,260)$ & $(1,124)$ & $(649)$ \\
SOS 9b & $(1,491)$ & $(670)$ & $(999)$ & $(493)$ & $(473)$ & $(500)$ & $(1,059)$ & $(582)$ \\
SOS 9c & $(1,280)$ & $(587)$ & $(869)$ & $(1,030)$ & $(415)$ & $(685)$ & $(902)$ & $(502)$ \\
\hline SOS PA & $(948)$ & $(419)$ & $(632)$ & $(1,036)$ & $(274)$ & $(275)$ & $(666)$ & $(369)$ \\
\hline
\end{tabular}

recreation). Job impacts across all subregions range from a net increase of nearly 530 jobs in Puget Sound with alternative SOS $1 \mathrm{~b}$, to a loss of over 3,800 jobs for Lower Snake with alternative SOS 5c, the permanent natural river operation alternative. SOS $1 \mathrm{a}$ and $1 \mathrm{~b}$ generate net increases in jobs across all subregions. All other SOS alternatives result in net losses. Exceptions are SOS $5 \mathrm{c}$ and SOS $6 \mathrm{~b}$ which generate net job increases in the Northeast and Southern Idaho subregions.

Job impacts within the Lower Snake subregion are generated primarily by changes in anadromous fish, navigation, power, and recreation resource use. The most significant impacts occur in SOS $5 \mathrm{c}$ and $9 \mathrm{a}$, with job losses of 3,800 and 2,300 respectively.

Job impacts within the Mid Columbia subregion are generated primarily by changes in irrigation, navigation, power, and recreation resource use. SOS 9c and SOS PA result in losses of over 1,000 jobs.

Job impacts within the Northeast, Upper Columbia, and Southern Idaho subregions are generated by changes in navigation and power resource use. Excluding power, resource use in all subregions other then Mid Columbia and Lower Snake generate insignificant impacts, generally accounting for employment changes of less than 20 jobs. Exceptions are Upper Columbia and Northeast where expected changes in recreation use under alternative SOS 9a result in losses of 145 and 62 jobs, respectively.

\subsubsection{Subregion-Level Income Impacts}

Results of the analysis of subregion-level income impacts are presented in Tables 5-13. They include the direct, indirect, and induced income changes that result from the interdependencies which exist throughout the regional economy.

\subsubsection{Economic Impacts of Project Implementation and Pump Modification}

Many of the SOR alternatives will require physical project modifications and mitigation activities in order to achieve the objectives of the operations 
Table 5-13. Summary of Subregional Income Impacts (Million Dollars per Year)

\begin{tabular}{|l|c|c|c|c|c|c|c|c|}
\hline & $\begin{array}{c}\text { Puget } \\
\text { Sound }\end{array}$ & $\begin{array}{c}\text { West } \\
\text { Coast }\end{array}$ & Portland & $\begin{array}{c}\text { Mid } \\
\text { Columbia }\end{array}$ & $\begin{array}{c}\text { Upper } \\
\text { Columbia }\end{array}$ & $\begin{array}{c}\text { Lower } \\
\text { Snake }\end{array}$ & Northeast & $\begin{array}{c}\text { Southern } \\
\text { Idaho }\end{array}$ \\
\hline SOS 1a & $\$ 9.7$ & $\$ 2.9$ & $\$ 6.1$ & $\$ 3.4$ & $\$ 1.5$ & $\$ 1.2$ & $\$ 5.1$ & $\$ 2.9$ \\
SOS 1b & $\$ 19.3$ & $\$ 5.9$ & $\$ 12.2$ & $\$ 4.7$ & $\$ 3.6$ & $\$ 2.9$ & $\$ 10.4$ & $\$ 5.9$ \\
\hline SOS 2d & $(\$ 5.7)$ & $(\$ 1.7)$ & $(\$ 3.5)$ & $(\$ 0.7)$ & $(\$ 1.2)$ & $(\$ 0.7)$ & $(\$ 3.0)$ & $(\$ 1.7)$ \\
\hline SOS 4c & $(\$ 22.1)$ & $(\$ 6.8)$ & $(\$ 14.0)$ & $(\$ 1.4)$ & $(\$ 4.5)$ & $(\$ 3.1)$ & $(\$ 11.8)$ & $(\$ 6.7)$ \\
\hline SOS 5b & $(\$ 33.8)$ & $(\$ 10.5)$ & $(\$ 21.8)$ & $(\$ 3.5)$ & $(\$ 2.9)$ & $(\$ 47.2)$ & $\$ 2.7$ & $(\$ 2.7)$ \\
SOS 5c & $(\$ 49.5)$ & $(\$ 15.5)$ & $(\$ 31.9)$ & $\$ 4.7$ & $(\$ 4.6)$ & $(\$ 78.6)$ & $\$ 11.2$ & $\$ 0.4$ \\
\hline SOS 6b & $(\$ 11.9)$ & $(\$ 4.0)$ & $(\$ 8.3)$ & $(\$ 2.2)$ & $\$ 0.2$ & $(\$ 31.9)$ & $\$ 10.6$ & $\$ 1.7$ \\
SOS 6d & $(\$ 4.9)$ & $(\$ 1.6)$ & $(\$ 3.2)$ & $(\$ 7.4)$ & $(\$ 1.4)$ & $(\$ 6.9)$ & $(\$ 3.0)$ & $(\$ 1.6)$ \\
\hline SOS 9a & $(\$ 80.3)$ & $(\$ 26.0)$ & $(\$ 52.1)$ & $(\$ 11.5)$ & $(\$ 18.1)$ & $(\$ 44.1)$ & $(\$ 28.4)$ & $(\$ 19.1)$ \\
SOS 9b & $(\$ 54.7)$ & $(\$ 17.0)$ & $(\$ 34.8)$ & $(\$ 7.2)$ & $\$ 6.7$ & $(\$ 10.0)$ & $(\$ 29.9)$ & $(\$ 16.7)$ \\
SOS 9c & $(\$ 47.0)$ & $(\$ 14.9)$ & $(\$ 30.3)$ & $(\$ 15.3)$ & $(\$ 11.6)$ & $(\$ 14.4)$ & $(\$ 25.4)$ & $(\$ 14.4)$ \\
\hline SOS PA & $(\$ 34.8)$ & $(\$ 10.6)$ & $(\$ 22.0)$ & $(\$ 15.2)$ & $(\$ 7.6)$ & $(\$ 5.4)$ & $(\$ 18.8)$ & $(\$ 10.6)$ \\
\hline
\end{tabular}

strategy. The proposed adaptations include modification of irrigation pumping stations, development of new power stations, improvements to boat ramps and moorages, and dam modifications to improve fish passage. The construction activities associated with these mitigation actions and project modifications will provide short-term positive economic benefits to the region through increased employment and earnings opportunities. The expected benefits are short-term in that they are expected to last only throughout the duration of the construction activity. The employment and income impacts for this construction are not included in the above tables of income and employment effects, because of the expected short term duration of these impacts.

\subsubsection{Employment Impacts of Project Implementation}

Estimated total employment impacts related to project implementation are presented in Table 5-14. Project implementation will occur over several years and could take as long as 15 years with SOS $5 \mathrm{~b}$. The employment figures represent the expected number of jobs per year throughout the duration of the construction period. Project construction SOS $5 \mathrm{~b}$ is expected to generate nearly 7,600 jobs annually over the 15 year time construction period. Employment impacts for the Preferred Alternative are expected to be about 470 jobs while impacts under the remaining alternatives will vary between 3,300 and 3,800 jobs. The employment impacts associated with SOS $5 \mathrm{~b}$ reflect the significantly higher construction expenditures associated with this alternative.

\subsubsection{Employment Impacts of Pump Modification}

Estimated total employment impacts related to pump modification are presented in Table 5-15. Impacts related to pump modifications are expected to last one year. The employment impacts associated with SOS $5 \mathrm{~b}$ and SOS 5c, nearly 2,900 jobs, reflect the significantly higher pump modification expenditures associated with these alternatives. 
Table 5-14. Employment Impacts Related to Project Construction (Total Number of Jobs per Construction Year)

\begin{tabular}{|l|c|c|c|c|c|c|c|}
\hline & $\begin{array}{c}\text { Construction } \\
\text { Period }\end{array}$ & $\begin{array}{c}\text { Pacific } \\
\text { Northwest }\end{array}$ & Washington & Oregon & Idaho & $\begin{array}{c}\text { Mid } \\
\text { Columbia }\end{array}$ & $\begin{array}{c}\text { Lower } \\
\text { Snake }\end{array}$ \\
\hline SOS 1a & N/A & 0 & 0 & 0 & 0 & 0 & 0 \\
SOS 1b & N/A & 0 & 0 & 0 & 0 & 0 & 0 \\
\hline SOS 2d & N/A & 0 & 0 & 0 & 0 & 0 & 0 \\
\hline SOS 4c & N/A & 0 & 0 & 0 & 0 & 0 & 0 \\
\hline SOS 5b & 15 years & 7,592 & 4,674 & 41 & 1,754 & 2,931 & 4,052 \\
SOS 5c & 5 years & 3,807 & 2,419 & 127 & 693 & 1,839 & 1,602 \\
\hline SOS 6b & 10 years & 3,353 & 1,876 & 63 & 915 & 1,015 & 2,116 \\
SOS 6d & 5 years & 787 & 335 & 127 & 201 & 264 & 467 \\
\hline SOS 9a & 10 years & 3,364 & 1,881 & 68 & 915 & 1,025 & 2,116 \\
SOS 9b & N/A & 0 & 0 & 0 & 0 & 0 & 0 \\
SOS 9c & 10 years & 3,353 & 1,876 & 63 & 915 & 1,015 & 2,116 \\
\hline SOS PA & 3 years & 468 & 199 & 190 & 0 & 395 & 0 \\
\hline
\end{tabular}

Table 5-15. Employment Impacts Related to Pump Modification (Total Number of Jobs per Construction Year)

\begin{tabular}{|l|c|c|c|c|c|c|}
\hline & $\begin{array}{c}\text { Pacific } \\
\text { Northwest }\end{array}$ & Washington & Oregon & Idaho & Mid Columbia & Lower Snake \\
\hline SOS 1a & 0 & 0 & 0 & 0 & 0 & 0 \\
SOS 1b & 0 & 0 & 0 & 0 & 0 & 0 \\
\hline SOS 2d & 0 & 0 & 0 & 0 & 0 & 0 \\
\hline SOS 4c & 0 & 0 & 0 & 0 & 0 & 0 \\
\hline SOS 5b & 2,887 & 1,710 & 705 & 59 & 2,320 & 137 \\
SOS 5c & 2,887 & 1,710 & 705 & 59 & 2,320 & 137 \\
\hline SOS 6b & 2,366 & 1,269 & 705 & 46 & 1,907 & 106 \\
SOS 6d & 1,809 & 788 & 705 & 42 & 1,444 & 96 \\
\hline SOS 9a & 2,245 & 1,216 & 656 & 46 & 1,805 & 106 \\
SOS 9b & 0 & 0 & 0 & 0 & 0 & 0 \\
SOS 9c & 2,419 & 1,310 & 705 & 51 & 1,941 & 118 \\
\hline SOS PA & 1,822 & 794 & 753 & 0 & 1,541 & 0 \\
\hline
\end{tabular}




\subsection{SOCIAL IMPACTS}

This section describes the expected socioeconomic impacts of the SOR alternatives. Changes in subregion employment and income estimated using the

IMPLAN models are described according to specific resource effects. The overall impacts to the subregions and focus communities are then addressed. A more detailed examination of the socioeconomic impacts of the SOR alternatives on the seventeen focus communities is presented in Exhibit $F$.

\subsubsection{Anadromous Fish}

There are 26 anadromous fish stocks which originate and spawn in the Columbia River Basin. Three of the most economically important runs were used as indicator species to assess the effects of the strategies on anadromous fish. Impacts on the catch of fall and spring chinook salmon and steelhead were evaluated. Fall chinook is the major commercial run.

SOS $4 \mathrm{c}$ is the only alternative that has an increase in employment associated with anadromous fish. SOS $4 \mathrm{c}$ would add one job in the Pacific Northwest Region.

SOS 9a has the most adverse effect on employment. SOS 9a would result in a loss of nearly 560 jobs in the Pacific Northwest Region. The Lower Snake subregion would experience the largest subregional loss, over 250 jobs with SOS 9a.

\subsubsection{Irrigation and Municipal and Industrial Water}

The alternatives that directly impact irrigation and municipal and industrial (M\&I) water supplies are the SOSs 5, 6, 9a, 9c, and PA. These alternatives would affect irrigators and M\&I suppliers that use water from John Day and the four Lower Snake pools. Because of the draw downs associated at these reservoirs, pump modifications would be required at John Day, Ice Harbor, Lower Granite, Little Goose, and Lower Monumental Reservoirs in order to continue to provide present irrigation and M\&I water supplies. In addition, irrigation water pumped from FDR Reservoir to Banks Lake is affected by many of the alternatives, with SOS 9a showing the greatest impact.

\subsubsection{Irrigation}

During the irrigation season, SOSs $5 b, 5 c, 6 b, 9 a$, and $9 \mathrm{c}$ would lower water levels at John Day and Ice Harbor. As a result, irrigators would pay higher annual operating costs due to the increased costs associated with pumping from a lower reservoir elevation. Annual net farm income of irrigators could drop by as much as $\$ 5.3$ million under SOSs $5 b$ and 5c; by as much as $\$ 3.5$ million under SOSs $6 b$, $9 \mathrm{a}$, and $9 \mathrm{c}$; and by as much as $\$ 1.6$ million under SOSs 6d and PA.

Grand Coulee/Banks Lake Pumping. The largest impact on irrigation water pumped from FDR Reservoir to Banks Lake occurs under alternative SOS 9a with a 4 percent increase in pumping costs. SOS alternatives $2 \mathrm{~d}, 4 \mathrm{c}$, and PA show a decrease in pumping cost, the remainder of the alternatives result in an increase in pumping costs.

\subsubsection{M\&I}

SOSs $5 b, 5 c, 6 b, 9 a$, and $9 c$ would lower water levels at John Day, Ice Harbor, Lower Granite, Little Goose, and Lower Monumental. SOS $6 \mathrm{~d}$ would lower pool levels at John Day and Lower Granite only. SOS PA would lower water levels at John Day only. Average annual water M\&I water supply costs would increase due to the increased costs associated with pumping from a lower reservoir elevation. The increase in average annual M\&I water costs range from $\$ 5.2$ million with SOS PA, to $\$ 5.8$ million with SOS $5 c$.

Regional employment losses associated with the increased costs of irrigation and M\&I water supply pumping would be most significant in the Mid-Columbia subregion. Under SOS alternatives $5 \mathrm{~b}$ and $5 \mathrm{c}$ it estimated that approximately 360 jobs would be lost. Alternatives $6 \mathrm{~b}, 9 \mathrm{a}$, and $9 \mathrm{c}$ would result in 280 to 290 job losses while SOSs $6 \mathrm{~d}$ and PA would result in a loss of approximately 220 jobs. Employment losses in the Lower Snake subregion would range from 10 to 20 jobs under all of the alternatives.

There would be short term (one year) job increases associated with the irrigation and M\&I water supply 
pump modification work for SOSs $5,6,9 \mathrm{a}, 9 \mathrm{c}$, and PA. Either version of SOS 5 would generate 1,100 direct jobs in the Mid Columbia subregion (400 in Umatilla and Morrow counties, 700 in the Tri-Cities), and 60 direct jobs in the Lower Snake subregion, primarily in the Lewiston/Clarkston area.

There would be an overall increase of 2,300 direct and indirect jobs in the Mid Columbia subregion ( 2 percent of total subregion employment), 140 direct and indirect jobs in the Lower Snake subregion (less than one-half percent of total subregion employment). The remaining alternatives would generate 750 to 950 direct jobs in the Mid Columbia subregion with total job impacts ranging from 1,400 to 1,900. The total employment impacts in the Lower Snake subregions under the remaining alternatives would be approximately 100 jobs.

\subsubsection{Navigation}

\subsubsection{Reservoir Navigation}

Two ferries providing important across-river transportation links operate on FDR Lake. The Gifford-Inchelium Ferry, operated by the Colville Confederated Tribes provides service between the communities of Gifford and Inchelium. The Keller Ferry, operated by the Washington State Department of Transportation as a part of the state highway system, provides service between the communities of Wilbur and Keller on State Route 21. None of the SOR alternatives will affect the operation of either ferry.

Log rafting activities have historically been present on Dworshak Reservoir. Logs are skidded into the Dworshak pool and then rafted across the reservoir to areas where they are loaded onto trucks. Approximately 20 million board feet of timber are rafted each year. At certain minimum pool elevations, the timber has to roll too far to the pool and can be damaged, so log rafting has to be replaced by trucking. SOSs $2 \mathrm{~d}, 9 \mathrm{~b}$, and PA would cut short the operating season for Dworshak log transport, increasing costs by about $\$ 90,000$ to $\$ 170,000$ annually. All other SOS alternatives would lengthen the operating season for Dworshak log transport, reducing annual trucking costs. Changes in employment in the
Pacific Northwest Region range from a loss of four jobs with alternative $9 \mathrm{~b}$ to an increase of six jobs with alternative $4 \mathrm{c}$.

\subsubsection{Shallow Draft Navigation}

Drawdown alternatives would close ports on the lower Snake River to barge traffic for varying periods of time every year. Because of slow drawdown and refill during low water years, this could close Lewiston/Clarkston to barge traffic for as long as eight months. Ten million tons, 20 percent of the region's annual grain production, ordinarily moves through this area. Implementation of any of these alternatives would result in a portion of this grain, primarily from Montana and Idaho, being moved by truck. Another portion would be trucked to the Tri-cities and barged from there.

SOSs $5 b$ and $5 c$, which draw the Snake River down to near natural (pre-dam) levels, would have a significant negative impact on employment in the Lower Snake and Lewiston/Clarkston areas because of port closures; employment in the Tri-Cities and Morrow/Umatilla County areas would increase because of reductions in transportation costs for growers in the area. Income in the Lower Snake subregion decreases while income in the Mid Columbia and Northeast Subregion would increase. The Northeast Subregion experiences an increase in employment due to an increase in rail traffic and lower transportation costs for farmers.

SOS $5 \mathrm{c}$ has the largest impact on employment region-wide. SOS 5c would result in the loss of nearly 2,800 jobs in the Lower Snake subregion, but an increase of about 1,000 jobs in both the Mid Columbia and Northeast subregions. SOS $5 b$ results in the loss of 1,500 jobs in Lower Snake subregion, but increases of $570,1,000$, and 1,100 jobs in the Southern Idaho, Mid Columbia, and Northeast subregions, respectively.

Changes in transportation costs for SOS $6 \mathrm{~b}$ and SOS $9 \mathrm{a}$ are the same, resulting in equivalent impacts. Losses of 1,100 jobs in the Lower Snake subregion are counterbalanced by increases of 200 jobs in Southern Idaho, 420 jobs in Mid Columbia, and 480 jobs in the Northeast. Transportation costs for SOS 
$6 \mathrm{~d}$ and SOS 9c were not allocated to states or subregions due to time and resource constraints.

\subsubsection{Power}

Under all of the SOR alternatives except SOS 1 , average retail power rates paid by residential, industrial, irrigation, and commercial customers are expected to increase. Power rate increases are expected to range from a low of 0.3 percent under SOS $6 \mathrm{~d}$ to a high of 4 percent under SOS $9 \mathrm{a}$. These rate increases are less than some past increases (unrelated to SOR) and would not be expected to significantly affect economic activity. Regional job losses associated with the increased power costs would be somewhat mitigated by the job increases that would be associated with regional power generation activities necessary to replace lost hydropower resources. It is expected that net employment losses would range from approximately 500 jobs under SOS $6 d$ to 8,100 jobs under SOS $9 \mathrm{a}$, less than one quarter percent of total regional jobs.

\subsubsection{Recreation}

Changes in SOR river operations would most adversely impact recreational employment with implementation of SOSs $5 b, 5 c$, and $9 a$. Nearly all of these losses would be experienced in the Mid Columbia and Lower Snake subregions. In the Mid Columbia subregion, the most significant employment losses would occur under the Preferred Alternative, with approximately 510 jobs lost. Slightly less than $\mathbf{4 0 0}$ jobs are lost in the subregion under alternatives $5 \mathrm{~b}$ and $5 \mathrm{c}$. In the Lower Snake subregion, the most significant employment losses would occur under SOS 5C, with approximately 540 jobs lost. Approximately 450 jobs are lost under alternative $5 \mathrm{~b}$. The most significant job losses in the Upper Columbia subregion occur under SOS 9a with a loss of 145 jobs.

\subsubsection{Construction}

Significant social impacts could occur in local communities from implementation of the alternatives that require modification of the four Lower Snake River dams and the John Day dam, SOSs $5 b, 5 c, 6 b$, $6 \mathrm{~d}, 9 \mathrm{a}, 9 \mathrm{c}$, and PA. A substantial influx of non-local workers and their families would have significant impacts on and in some cases could adversely affect the infrastructure (housing, schools, etc.) of local communities.

It is anticipated that construction activities over a 15 year time period for SOS $5 \mathrm{~b}$ would annually generate 2,900 jobs in the Mid Columbia subregion and over 4,000 jobs in the Lower Snake subregion. SOS $5 \mathrm{c}$ would annually generate over 1,800 jobs in Mid Columbia and over 1,600 jobs in the Lower Snake over a 5 year time period.

SOS $6 \mathrm{~b}$, SOS $9 \mathrm{a}$, and SOS $9 \mathrm{c}$ would annually generate 1,000 jobs in Mid Columbia and 2,100 jobs in the Lower Snake over a 10 year time construction period. SOS $6 \mathrm{~d}$, with a construction period of 5 years, would generate the fewest number of annual jobs, 260 and 470 in Mid Columbia and the Lower Snake respectively. Under SOS PA there are no modifications to the Lower Snake dams, only to John Day dam. Employment impacts to Mid Columbia subregion over the 3 year construction period, would be 400 jobs annually.

\subsubsection{Impacts to Subregions and Focus Communities}

At the present time, uncertainty is the most significant social impact occurring throughout the Pacific Northwest. Because the current operation of the Columbia River is subject to change and the future operation is not known, individuals and economic entities are experiencing stress because they are unable to make decisions for their short or long term futures. It was pointed out during public meetings held in May 1994 on the System Configuration Study/Lower Snake River Biological Drawdown Test Draft Environmental Impact Statement at Lewiston, Idaho, economic investments are being withheld which is affecting economic growth which in turn creates stress for individuals, families, and business interests. The stress of uncertainty will continue until decisions for the future operation of the Columbia River are made.

Overall changes in employment and income would be relatively minor from regional and sub-regional perspectives. Alternatives $5 b, 5 c, 9 a, 9 b, 9 c$, and the 
Preferred Alternative result in the greatest change in regional jobs and income. SOS 9a would have the largest impact on employment in the Pacific Northwest Region with job losses of 9,450 and a decrease in regional personal income of $\$ 260$ million (less than on-quarter percent of total regional employment and income).

The largest relative changes in subregional employment and income would occur in the Lower Snake and Mid Columbia subregions. The largest net change in employment and income in the Lower Snake subregion would occur with SOS 5c, a loss of 3,800 jobs and a decrease in regional personal income of $\$ 79$ million (approximately five percent of regional income and employment.) Most of these losses in the Lower Snake subregion occur as a result of the increased transportation costs caused by the closure of barge navigation at the lower Snake River ports. The largest net change in employment and income in the Mid Columbia subregion would occur with the Preferred Alternative, a loss of 1,040 and a decrease in income of $\$ 28$ million jobs (just less than a one percent loss in total subregion employment and income). The losses are attributable to increased irrigation costs, increased power costs, and declines in recreation activity.

Employment and income in the Mid Columbia subregion focus communities of the Tri-Cities in Washington and the Umatilla/Morrow Counties area in Oregon would generally be positively affected by increases in grain transportation costs and negatively affected by increased pumping costs for irrigation and M\&I water supplies, increased power costs, lower levels of anadromous fish harvest, and reduced levels of reservoir recreation activity. The communities are likely to experience relatively short-term positive increases in regional employment and income during the construction periods for project modifications and pump modifications of irrigation and M\&I water supplies. The construction activities associated with pump and project modifications would likely cause the greatest social impact to the Mid Columbia focus communities. While providing an increase in employment, there would potentially be transitional impacts on local infrastructure and services resulting from the short-term influx of construction workers and their families.

The focus communities of Lewiston, Orofino, and the Nez Perce Reservation, Idaho and Clarkston, Washington, in the Lower Snake subregion would experience negative employment and income changes associated with declining levels of anadromous fish harvest, increased grain transportation costs, increased power costs, declining levels of reservoir recreation activity. Decreases in navigation employment and income associated with the drawdown alternatives would occur in Lewiston/ Clarkston. Orofino and the $\mathrm{Nez}$ Perce Reservation would be primarily affected by loss of employment associated with declines in recreation activity and anadromous fish harvests. All of the communities would be affected by increasing power costs. Lewiston and Clarkston would likely experience shortterm increases in employment and income from the construction activities associated with pump and project modifications. Dam modification construction in this subregion would cause the greatest social impact in the Lewiston/Clarkston area. While providing an increase in construction-related employment, there would potentially be transitional impacts on local infrastructure and services resulting from the short-term influx of construction workers and their families.

The Upper Columbia subregion would be most affected by net changes in employment and income associated with SOS 9a, a loss of nearly 700 jobs and a decrease of $\$ 18$ million in regional income (approximately one-half percent of regional employment and income). These changes would be associated primarily with reductions in anadromous fish harvests, increased power costs, and lower levels of reservoir recreation activity. The region would experience positive changes to employment and income due to declining costs for grain transportation. The focus communities of Grand Coulee/Coulee Dam, the Colville and Spokane Reservations, Washington, would be primarily affected by reduced levels of recreation activity at Lake Roosevelt.

The focus communities of Astoria and Portland in the West Coast and Portland subregions, respective- 
ly, would be primarily affected by increasing regional power costs, although the impacts are not expected to be significant. Additional employment and income effects associated with declining anadromous fish harvests would also occur. In both subregions the expected impacts would be greatest with SOS 9a. Employment and income losses in the Portland subregion under this scenario would include 1,500 jobs and $\$ 52$ million (One-quarter percent of regional employment and income). In the West Coast subregion employment losses under SOS 9a would reach nearly 1,023 jobs with associated income losses of $\$ 26$ million (approximately three quarters of percent of regional employment and income. In May 1994, the Pacific Coast area was declared an Economic Disaster Area because of the decline in the fishery. Employment and income impacts to the focus community of Astoria, Oregon, would be negative which would add to the decline.

The Northeast subregion would be most affected by the net changes in employment and income associated with SOS 9a, an annual loss of 1,125 jobs and an decline in income of $\$ 28$ million. (one half percent of total subregion employment and income).
Positive job and income effects would be associated with decreased costs for grain transportation while negative impacts would result from increased regional power costs. Minor declines would also be associated with some decrease in reservoir recreation. The focus communities of Libby, Flathead Lake, and the Flathead Reservation in Montana and Bonners Ferry and the Kootenai Reservation in Idaho would be primarily affected by increased regional power costs. The Montana communities would also be minimally impacted by changing levels of recreation activities at Hungry Horse Reservoir.

Overall, the expected changes in subregion employment and income associated with the SOR alternatives are generally less than one percent of current levels. The greatest changes in regional activity are associated with the drawdown alternatives, including SOSs $5 \mathrm{~b}, 5 \mathrm{c}, 6 \mathrm{~b}, 6 \mathrm{~d}$, and $9 \mathrm{a}$. The most significant impacts are generally related to increased regional power costs and increases (or decreases) in transportation costs for grain. It is likely that the dispersion of regional impacts will be most adverse in the Lower Snake subregion. 


\section{CHAPTER 6}

\section{LIST OF PREPARERS}

Table 6-1. List of Preparers, U.S. Army Corps of Engineers

\begin{tabular}{|c|c|c|c|}
\hline Name & $\begin{array}{c}\text { Education/Years of } \\
\text { Experience }\end{array}$ & $\begin{array}{l}\text { Experience and } \\
\text { Expertise }\end{array}$ & $\begin{array}{l}\text { Role In } \\
\text { Preparation }\end{array}$ \\
\hline $\begin{array}{l}\text { Patricia Cardinal } \\
\text { Economist }\end{array}$ & $\begin{array}{l}\text { B.A. Economics } \\
4 \text { years }\end{array}$ & $\begin{array}{l}\text { Economic analysis of water } \\
\text { resources development } \\
\text { projects }\end{array}$ & Flood control \\
\hline $\begin{array}{l}\text { Sheryl Carrubba, P.E. } \\
\text { Civil Engineer }\end{array}$ & $\begin{array}{l}\text { B.S. Engineering } \\
11 \text { years }\end{array}$ & $\begin{array}{l}\text { Environmental Coordination } \\
\text { and Project Mgmt. of } \\
\text { maintenance dredging on } \\
\text { Federal navigation projects }\end{array}$ & Navigation \\
\hline $\begin{array}{l}\text { Jim Fredericks } \\
\text { Economist }\end{array}$ & $\begin{array}{l}\text { B.S. Economics } \\
6 \text { years }\end{array}$ & $\begin{array}{l}\text { Economic analysis of water } \\
\text { resources development } \\
\text { projects }\end{array}$ & $\begin{array}{l}\text { Irrigation, navigation, and } \\
\text { indirect and social impacts }\end{array}$ \\
\hline $\begin{array}{l}\text { Paul Fredericks } \\
\text { Economist } \\
\text { (retired) }\end{array}$ & $\begin{array}{l}\text { M.A. Economics } \\
30 \text { years }\end{array}$ & $\begin{array}{l}\text { Economic analysis of water } \\
\text { resources development } \\
\text { projects }\end{array}$ & Navigation and flood control \\
\hline $\begin{array}{l}\text { Joe Hise } \\
\text { Economist }\end{array}$ & $\begin{array}{l}\text { M.A. Economics } \\
22 \text { years }\end{array}$ & $\begin{array}{l}\text { Economic analysis of water } \\
\text { resources development } \\
\text { projects }\end{array}$ & $\begin{array}{l}\text { Navigation, flood control, and } \\
\text { social impacts }\end{array}$ \\
\hline $\begin{array}{l}\text { Keith Hofseth } \\
\text { Economist }\end{array}$ & $\begin{array}{l}\text { B.S. Finance and Economics } \\
10 \text { years }\end{array}$ & $\begin{array}{l}\text { Economic analysis of water } \\
\text { resources development } \\
\text { projects }\end{array}$ & $\begin{array}{l}\text { Technical Review and draft } \\
\text { report preparation }\end{array}$ \\
\hline $\begin{array}{l}\text { Brent Mahan } \\
\text { Economist }\end{array}$ & $\begin{array}{l}\text { B.B.A Economics } \\
11 \text { years }\end{array}$ & $\begin{array}{l}\text { Economic analysis of water } \\
\text { resources development } \\
\text { projects }\end{array}$ & $\begin{array}{l}\text { Coordinator and editor, draft } \\
\text { appendix }\end{array}$ \\
\hline $\begin{array}{l}\text { James Smith } \\
\text { Economist }\end{array}$ & $\begin{array}{l}\text { M.A. Economics } \\
24 \text { Years }\end{array}$ & $\begin{array}{l}\text { Economic analysis of water } \\
\text { resources development } \\
\text { projects }\end{array}$ & $\begin{array}{l}\text { Flood control and technical } \\
\text { review }\end{array}$ \\
\hline $\begin{array}{l}\text { Gina Trafton } \\
\text { Economist }\end{array}$ & $\begin{array}{l}\text { B.A. Economics } \\
\text { B.A. Political Science } \\
7 \text { years }\end{array}$ & $\begin{array}{l}\text { Economic analysis of water } \\
\text { resources development } \\
\text { projects }\end{array}$ & $\begin{array}{l}\text { Flood Control, social impacts, } \\
\text { and technical review }\end{array}$ \\
\hline $\begin{array}{l}\text { Tom White } \\
\text { Water Resource Planner }\end{array}$ & $\begin{array}{l}\text { B.A. Economics and } \\
\text { Ag. Economics, } \\
\text { M.A. Ag. Economics } \\
23 \text { years }\end{array}$ & $\begin{array}{l}\text { Economic analysis of water } \\
\text { resources development } \\
\text { projects }\end{array}$ & $\begin{array}{l}\text { EAG Coordinator, technical } \\
\text { review, food control, } \\
\text { hydropower, irrigation, } \\
\text { navigation, and indirect and } \\
\text { social impacts } \\
\text { Editor final report }\end{array}$ \\
\hline $\begin{array}{l}\text { Edwin Woodruff } \\
\text { Economist }\end{array}$ & $\begin{array}{l}\text { B.A. Economics } \\
\text { B.A. Mathematics } \\
20 \text { years }\end{array}$ & $\begin{array}{l}\text { Economic analysis of water } \\
\text { resources development } \\
\text { projects }\end{array}$ & $\begin{array}{l}\text { Anadromous fish, recreation, } \\
\text { social impacts, and technical } \\
\text { review }\end{array}$ \\
\hline
\end{tabular}


Table 6-2. List of Preparers, Bonneville Power Administration

\begin{tabular}{|l|l|l|l|}
\hline \multicolumn{1}{|c|}{ Name } & \multicolumn{1}{|c|}{$\begin{array}{c}\text { Education/Years of } \\
\text { Experience }\end{array}$} & \multicolumn{1}{|c|}{$\begin{array}{c}\text { Experience and } \\
\text { Expertise }\end{array}$} & \multicolumn{1}{c|}{$\begin{array}{c}\text { Role In } \\
\text { Preparation }\end{array}$} \\
\hline $\begin{array}{l}\text { John McConnaughey } \\
\text { Economist }\end{array}$ & $\begin{array}{l}\text { M.A. and PhD Economics } \\
18 \text { years }\end{array}$ & Power rates & Power rate impacts \\
\hline $\begin{array}{l}\text { Audrey Perino } \\
\text { Economist }\end{array}$ & $\begin{array}{l}\text { B.A. and M.A. Economics } \\
18 \text { years }\end{array}$ & $\begin{array}{l}\text { Economic analysis of power } \\
\text { system operations }\end{array}$ & Power system impacts \\
\hline $\begin{array}{l}\text { Pete West } \\
\text { Economist }\end{array}$ & $\begin{array}{l}\text { B.S. Economics } \\
\text { M.S. Agr. and Resource } \\
\text { Economics } \\
10 \text { years }\end{array}$ & $\begin{array}{l}\text { Economic analysis of Regional } \\
\begin{array}{l}\text { Economics, Forecasting of } \\
\text { Regions's economy, Analysis of } \\
\text { impacts of power rate changes }\end{array}\end{array}$ & $\begin{array}{l}\text { Power demand forecasts and } \\
\text { indirect impacts }\end{array}$ \\
\hline
\end{tabular}

Table 6-3. List of Preparers, U.S. Bureau of Reclamation

\begin{tabular}{|c|c|c|c|}
\hline Name & $\begin{array}{c}\text { Education/Years of } \\
\text { Experience }\end{array}$ & $\begin{array}{l}\text { Experience and } \\
\text { Expertise }\end{array}$ & $\begin{array}{c}\text { Role in } \\
\text { Preparation }\end{array}$ \\
\hline $\begin{array}{l}\text { Susan Black } \\
\text { Social Science Analyst }\end{array}$ & $\begin{array}{l}\text { B.A. Economics } \\
11 \text { years } \\
\end{array}$ & $\begin{array}{l}\text { Social and Economic Analysis } \\
\text { of Water Resources Projects }\end{array}$ & Social Impacts \\
\hline $\begin{array}{l}\text { Allen Reiners } \\
\text { Economist }\end{array}$ & $\begin{array}{l}\text { B.S. Agr. Economics } \\
\text { M.S. Agr. Economics } \\
26 \text { years }\end{array}$ & $\begin{array}{l}\text { Economic Justification - } \\
\text { Water Resources } \\
\text { Financial Analysis } \\
\text { Repayment and Contracts }\end{array}$ & $\begin{array}{l}\text { Coordinator, Irrigation and } \\
\text { M\&I Work Group; Member } \\
\text { EAG }\end{array}$ \\
\hline $\begin{array}{l}\text { Harold Ward } \\
\text { Economist } \\
\text { (retired) }\end{array}$ & $\begin{array}{l}\text { B.S. Agr. Economics } \\
\text { M.S. Agr. Economics } \\
35 \text { years (retired) }\end{array}$ & $\begin{array}{l}\text { Economic Justification - } \\
\text { Water Resources } \\
\text { Financial Analysis } \\
\end{array}$ & $\begin{array}{l}\text { Coordinator, Irigation and } \\
\text { M\&I Work Group; Member } \\
\text { EAG }\end{array}$ \\
\hline $\begin{array}{l}\text { David Smith } \\
\text { Economist } \\
\text { (retired) }\end{array}$ & $\begin{array}{l}\text { B.S. Agr. Economics } \\
33 \text { years }\end{array}$ & $\begin{array}{l}\text { Economic Feasibility Analysis } \\
\text { Financial Analysis }\end{array}$ & $\begin{array}{l}\text { Technical review of draft } \\
\text { report }\end{array}$ \\
\hline
\end{tabular}

Table 6-4. List of Preparers, Northwest Economic Associates

\begin{tabular}{|l|l|l|l|}
\hline \multicolumn{1}{|c|}{ Name } & \multicolumn{1}{|c|}{$\begin{array}{c}\text { EducationYears of } \\
\text { Experience }\end{array}$} & \multicolumn{1}{c|}{$\begin{array}{c}\text { Experience and } \\
\text { Expertise }\end{array}$} & \multicolumn{1}{c|}{$\begin{array}{c}\text { Role In } \\
\text { Preparation }\end{array}$} \\
\hline $\begin{array}{l}\text { James Youde } \\
\text { Economist }\end{array}$ & $\begin{array}{l}\text { PhD Agr. Economics } \\
30 \text { years }\end{array}$ & $\begin{array}{l}\text { Economic analysis of natural } \\
\text { resource development } \\
\text { Regional economics }\end{array}$ & $\begin{array}{l}\text { Regional economic and social } \\
\text { impacts analysis }\end{array}$ \\
\hline $\begin{array}{l}\text { Linda Wear } \\
\text { Economist }\end{array}$ & $\begin{array}{l}\text { PhD Agr. Economics } \\
10 \text { years }\end{array}$ & $\begin{array}{l}\text { Economic analysis of natural } \\
\text { resource development } \\
\text { Regional economics }\end{array}$ & $\begin{array}{l}\text { Regional economic and social } \\
\text { impacts analysis }\end{array}$ \\
\hline $\begin{array}{l}\text { Kevin Swan } \\
\text { Economist }\end{array}$ & $\begin{array}{l}\text { B.S. Economics } \\
5 \text { years }\end{array}$ & Regional economics & $\begin{array}{l}\text { Regional economic and social } \\
\text { impacts analysis }\end{array}$ \\
\hline $\begin{array}{l}\text { Alan Fox } \\
\text { Economist }\end{array}$ & $\begin{array}{l}\text { PhD Agr. Economics } \\
30 \text { years }\end{array}$ & $\begin{array}{l}\text { Economic analysis of natural } \\
\text { resource development } \\
\text { Regional Economics }\end{array}$ & $\begin{array}{l}\text { Regional economic and social } \\
\text { impacts analysis }\end{array}$ \\
\hline $\begin{array}{l}\text { Greg Mallette } \\
\text { Economist }\end{array}$ & Information not available & $\begin{array}{l}\text { Economic and environmental } \\
\text { analysis of water resource } \\
\text { projects }\end{array}$ & Potential impacts in Canada \\
\hline
\end{tabular}


Table 6-5. List of Preparers, Transportation Research Analysis Center

\begin{tabular}{|l|l|l|l|}
\hline \multicolumn{1}{|c|}{ Name } & $\begin{array}{l}\text { Education/Years of } \\
\text { Experience }\end{array}$ & \multicolumn{1}{c|}{$\begin{array}{c}\text { Experience and } \\
\text { Expertise }\end{array}$} & \multicolumn{1}{c|}{$\begin{array}{c}\text { Role in } \\
\text { Preparation }\end{array}$} \\
\hline $\begin{array}{l}\text { Kevin Hom } \\
\text { Transportation \& Water Re- } \\
\text { source Planner }\end{array}$ & $\begin{array}{l}\text { Ph.D. Business } \\
\text { Administration } \\
20 \text { years }\end{array}$ & $\begin{array}{l}\text { Transportation planning and } \\
\text { water resources analysis }\end{array}$ & SOR Transportation Model \\
\hline $\begin{array}{l}\text { Steven Taylor } \\
\text { Data Base Manager }\end{array}$ & $\begin{array}{l}\text { MBA General } \\
\text { Business } \\
15 \text { years }\end{array}$ & Data base management & SOR Transportation Model \\
\hline $\begin{array}{l}\text { Bob Laping } \\
\text { Computer Programmer }\end{array}$ & $\begin{array}{l}\text { MBA } \\
20 \text { years }\end{array}$ & Data base management & SOR Transportation Model \\
\hline
\end{tabular}

Table 6-6. List of Members of the Economic Analysis Group

\begin{tabular}{|c|c|c|}
\hline Name & Affiliation & Interest/Expertise \\
\hline Cart Almquist & US Bureau of Mines & Power \\
\hline Witt Anderson & Corps of Engineers & General \\
\hline Jim Barton & Corps of Engineers & River Operations \\
\hline John Bennett & US Bureau of Mines & Power, Indirect Impacts \\
\hline Susan Black & Bureau of Reclamation & See Table 6-3 \\
\hline Lorri Bodi & American Rivers & Irrigation \\
\hline Peter Brooks & Corps of Engineers & Flood Control \\
\hline Andy Brunelle & Idaho & Navigation \\
\hline Patricia Cardinal & Corps of Engineers & See Table 6-1 \\
\hline Geoff Carr & Public Power Council & Power \\
\hline Sheryl Carnubba & Corps of Engineers & See Table 6-1 \\
\hline Bob Daniel & Corps of Engineers & General \\
\hline Sebastian Degens & Port of Portland & Navigation \\
\hline John Dooley & Bureau of Reclamation & General \\
\hline Ann Eike & Port of Portland & Navigation \\
\hline Jim Fredericks & Corps of Engineers & See Table 6-1 \\
\hline Paul Fredericks & Corps of Engineers & See Table 6-1 \\
\hline Ellen Hall & Foster-Wheller & General \\
\hline Joe Hise & Corps of Engineers & See Table 6-1 \\
\hline Keith Hofseth & Corps of Engineers & See Table 6-1 \\
\hline Martin Hudson & Corps of Engineers & General \\
\hline Ray Jaren & Corps of Engineers & General \\
\hline Steve Kale & OR Dept. of Transportation & Navigation \\
\hline
\end{tabular}


Table 6-6. List of Members of the Economic Analysis Group - CONT

\begin{tabular}{|c|c|c|}
\hline Name & Affiliation & Interest/Expertise \\
\hline Ronald Kerr & ID Dept. of Transportation & Navigation \\
\hline Debbie Kitchin & Power Council & General \\
\hline Jeff Laufle & Corps of Engineers & Resident Fish \\
\hline Chris Lawson & Foster-Wheeler & General \\
\hline Robin MacKay & Bonneville Power & Anadromous Fish \\
\hline Brent Mahan & Corps of Engineers & See Table 6-1 \\
\hline John Marinosky & ERS, USDA & Irrigation \\
\hline John McConnaugaey & Bonneville Power & See Table 6-2 \\
\hline Frank McDonald & Corps of Engineers & Irrigation \\
\hline Michael Moore & ERS, USDA & Irrigation \\
\hline Pat Obradovich & Corps of Engineers & General \\
\hline Daryyll Olsen & Northwest Project & General \\
\hline Rick Paschall & PNUCC & Power \\
\hline Audrey Perino & Bonneville Power & See Table 6-2 \\
\hline Bruce Prossak & BC Hydro & Impacts in Canada \\
\hline Matt Rea & Corps of Engineers & Recreation \\
\hline Allen Reiners & Bureau of Reclamation & See Table 6-3 \\
\hline Mark Reller & Power Council, MT & Navigation \\
\hline Len Shabman & Department of Amy & General \\
\hline James Smith & Corps of Engineers & See Table 6-1 \\
\hline Dave Smith & Bureau of Reclamation & See Table 6-3 \\
\hline Bolyvong Tanovan & Corps of Engineers & Water Quality \\
\hline Phil Thor & Bonneville Power & General \\
\hline Gina Trafton & Corps of Engineers & See Table 6-1 \\
\hline Don Treasure & Bureau of Reclamation & Wildlife \\
\hline John Tyger & Corps of Engineers & NEPA Requirements \\
\hline Glen Vanselow & PNW Waterways & Navigation \\
\hline Harold Ward & Bureau of Reclamation & See Table 6-3 \\
\hline Linda Wear & NEA & See Table 6-4 \\
\hline Pete West & Bonneville Power & See Table 6-2 \\
\hline Tom White & Corps of Engineers & See Table 6-1 \\
\hline Bill Willingham & Corps of Engineers & Cultural Resources \\
\hline Ed Woodruff & Corps of Engineers & See Table 6-1 \\
\hline
\end{tabular}




\section{CHAPTER 7}

\section{GLOSSARY}

AFW: Anadromous Fish Workgroup

aMW: average megawatt hour

ASA: Assistant Secretary of the Army

Bonneville: Bonneville Power Administration

BOR: Bureau of Reclamation

BPA: Bonneville Power Administration

CBP: County Business Patterns

CEQ: Council on Environmental Quality

CFS: cubic feet per second

Consumer Surplus: Economic value received above the price actually paid

Corps: U.S Army Corps of Engineers

CPI: consumer price index

CRD: Columbia river datum

CRFMP: Columbia River Fisheries Management Plan

CRISP: Columbia River Salmon Passage Model

CRITFC: Columbia River Inter-Tribal Fish Commission

CSRS: Columbia-Snake River system

CT: combustion turbine

CVM: contingent value method

CWT: coded wire tag(s)
DEIS: draft environmental statement

Demand Curve: Quantities of a good or service that will be consumed at different prices

DSI: direct services industry

DWOPER: The National Weather Service Operational Dynamic Wave Model

EAD: Expected annual damages

EAG: Economic analysis work group

EIS: Environmental impact statement

ELCM: Empirical Life Cycle Model

ES: Endangered species

ESA -Endangered Species Act

Existence Value: The value individuals place on the mere existence of something

FDR: Franklin Delenor Roosevelt

FEIS: Final Environmental Impact Statement

FEMA: Federal Emergency Management Administration

FS: U.S. Forest Service

HYDROSIM: Computer model used to simulate the operation on the Columbia-Snake River system

IMPLAN: Input-Output model used to estimate effects of changes in direct benefits and costs on regional economies

IOU: Investor-owned utility 
IP: Industrial Firm Power

IWR: Institute for Water Resources, U.S. Army Corps of Engineers

KAF: Thousand acre-feet

KCFS: Thousand cubic-feet per second

M\&I: Municipal and Industrial

MAF: Million acre-feet

MMBF: million board feet

MSL: mean sea level

MWHRS: megawatt-hours

NEA: Northwest Economics Associates

NED: National Economic Development

NEPA: National Environmental Protection Act

NGVD: National Geodesic Vertical Datum

NMFS: National Marine Fisheries Service

NPPC: Northwest Power Planning Council

NPS: National Park Service

NR: New Resource Firm Power

ODFW: Oregon Department of Fish and Wildlife

OM\&P: Operation, Maintenance and Power

Opportunity Cost: The value of the opportunity foregone when a choice is made between two or more options

OSN: Oregon Steam Navigation Company

OSU: Oregon State University

PAM: Passage Analysis Model
PANAMAX: The largest vessel capable of going through the Panama Canal

PF: Priority Firms

PNCA: Pacific Northwest Coordination Agreement

PNW: Pacific Northwest

POL: Project- or power-on-line

Producer Surplus: The difference between total revenue and the opportunity cost of producing a good or service

PSC: Pacific Salmon Commission

PUD: Public Utility District

Reclamation: U.S. Bureau of Reclamation

RED: Regional economic development

RM: River mile

RPA: Resource Planning Act

RPC: regional purchase coefficients

RWG: Recreational Work Group

RWI: Resource Writers Incorporated

SCS: System Configuration Study

SEIS: Supplemental environmental impact statement

SLCM: Stochastic Life-Cycle Model

SOR: System Operation Review

SOS: System Operation Strategy

SP: Surplus Firm Power

SPF: Standard Project Flood

SPM: Salmon Passage Model 
SPM: Supply Pricing Model

SSARR: System flood regulation model

Supply Curve: Quantities of a good or service that firms will produce at different prices

TC: Total Cost

TIM: Travel Cost Method

TR: Total Revenue

TRIBS: Tributaries

USACE: United States Army Corps of Engineers

USBR: U.S. Bureau of Reclamation
USFS: United States Forest Service

Utility: Satisfaction associated with the use or consumption of something

Willingness to Pay: The expressed amount an individual would pay for something for which there is no market

Willingness to Accept: The expressed amount an individual would accept for something $\mathrm{s} / \mathrm{he}$ possesses, but for which there is no market

WTP: Willingness to pay

WWII: World War II 


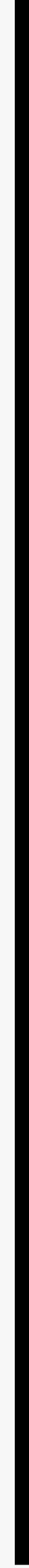




\section{CHAPTER 8}

\section{TECHNICAL REFERENCES}

A.G. Crook Company, April 1993. Modified

Streamflows, 1990 Level of Irrigation, 1928-1989, Columbia River and Coastal Basins.

Bergstrom, J. C., Cordell, H.K., and Klinko,D., 1990. "Recreational Benefits of Reservoir Water-Level Management." Western Regional Research Project. 133, Second Interim Report.

Berrens, Robert, 1992. "Using Contingent Valuation to Estimate Recreational Impacts from Proposed Columbia River System Operational Changes: Some Experimental Design and Modeling Considerations." Draft Discussion Paper. 5 April.

Boyle, K.J., Welsh, M.P., Bishop, R.C., and Baumgartner, R.M., 1988. "Analyzing the Effects of Glen Canyon Dam Releases on Colorado River Recreation Using Scenarios of Unexperienced Flow Conditions." Western Regional Research Project. 133, Second Interim Report.

Boyle, Kevin J. and Bergstrom, J.C., 1992. "Benefit Transfer Studies: Myth, Pragmatism, and Idealism." Water Resources Research, Vol. 28, No. 3, March 1992.

Cameron, T.A. and James, M.D., 1986. Draft, "The Determinants of Value for a Recreation Fishing Day: Estimates from a Contingent Valuation Survey." 21 October.

Columbia Basin Fish and Wildlife Authority, 1991.

Crutchfield, J.A. and Schelle, K., 1979. “An Economic Analysis of Washington Ocean Recreational Salmon Fishing with Particular Emphasis on the Role Played by the Charter Industry." For Pacific Fishery Management Council.

Daubert, J.T. and Young, R.A., 1981. "Recreational Demands for Maintaining Instream Flows: A Con- tingent Valuation Approach." American Journal of Agricultural Economics. 63 (4)

Desvousges, W.H., Naughton, M.C., and Parsons, G.R., 1992. "Benefit Transfer: Conceptual Problems in Estimating Water Quality Benefits Using Existing Studies." Water Resources Research, Vol. 28, No. 3, March 1992.

Donnelly, D.M., Loomis, J.B., Sorg, C.F., and Nelson, L.J., 1985. "Net Economic Value of Recreational Steelhead Fishing in Idaho." USDA Forest Service Resource Bulletin RM-9, April 1985.

Duffield, J., Loomis, J., and Brooks, R, August, 1987. "The Net Economic Value of Fishing In Montana." Montana Department of Fish, Wildlife \& Parks.

Economic Analysis Group, System Operation Review, 1993. Economic Analysis Requirements and Procedures. (Unpublished). Faucett, Jack, 1989. Mill Creek Project, Walla Walla. Bethesda, Maryland.

Federal Emergency Management Agency, November 1979. Flood Insurance Study, Clearwater County.

Federal Emergency Management Agency, February 1983a. Flood Insurance Study, Nez Perce County.

Federal Emergency Management Agency, 1983b. Floodway boundary Map - Clearwater County. Federal Emergency Management Agency, 1983c. Floodway Boundary Map - Clearwater County.

Hanemann, W.M., 1986. "Economic Valuation of Changes in the Catch of Sacramento River Chinook Salmon." Department of Agricultural and Resource Economics, University of California at Berkeley. Prepared for EA Engineering, Science, and Technology, Inc. 
Huppert, Daniel D., Fluharty, David L., and Kenny, Elizabeth S., June 4, 1992. "Economic Effects of Management Measures within the Range of Potential Critical Habitat for Snake River Endangered and Threatened Salmon Species." School of Marine Affairs, University of Washington, Seattle, Washington.

Hydrosphere, Resource Consultants, July 1991. "Evaluation of Economic Impacts of Alternatives for Designation of Winter-Run Chinook Salmon Critical Habitat in the Sacramento River."

Lavender, David, 1956, 1958. Land of Giants, The Drive to the Pacific Northwest, 1750-1950. Garden City, New York.

Loomis, John B., 1992. "The Evolution of a More Rigorous Approach to Benefit Transfer: Benefit Function Transfer." Water Resources Research, Vol. 28, No. 3, March 1992.

Mason, Ron, Editor, 1991. The Great Waterway. Marine Publishing, Inc., Seattle, Washington.

Morishima, G.S., February 1993. "Distribution of Columbia River, Washington Coastal, \& Puget Sound Chinook Salmon Stocks." Presented to PUD\#1 Clark County, Washington.

Meyers Resources, 1988. "A Bioeconomic Model for Evaluation of Flow Changes Affecting Chinook Salmon, Agriculture and Power - Economic SubModel." Developed for BioSystems Analysis, Inc.

Narayanan, R., Parvaneh, A., Bishop, A.B., and Larson, D., 1985. "A Methodology for Estimating Instream Flow Values for Recreation." Utah Water Research Laboratory. UWRL/P-85/01, - May.

Northwest Economic Associates, June 1995. The Local Impacts of Recent Changes in the Operations of Dworshak Dam and Reservoir, Measuring Economic Impacts for Clearwater County. Vancouver, Washington.

Olsen, Darryll and Richards, Jack, February, 1992. "Economic Costs of Fisheries Management Actions for the Columbia River." Northwest Irrigation Utilities. Portland, OR.
Olsen, D., Richards, J., and Scott, R.D., 1990. "A Study of Existence and Sport Values for Doubling the Size of the Columbia River Basin Salmon and Steelhead Runs." Columbia River and Tributaries Study. CRT 73, January.

Oregon Department of Fish and Wildlife (ODFW), Washington Department of Fisheries, 1991. "Status Report: Columbia River Fish Runs and Fisheries, 1960 to 1990." Portland, OR.

Oregon Department of Fish and Wildlife, 1991. "Status Report: Columbia River Fish Runs and Fisheries, 1960 - 1991."

Pacific Northwest Power Planning Council, __date. Appendix D of the 1987 Columbia River Basin Fish and Wildlife Plan.

Radke, Hans, November 1992. "Economic Contribution of Salmon to Oregon's Coastal Communities." Prepared for Governor's Coastal Salmonid Initiative Conference.

Rettig, R.B. and McCarl, B.A., 1984. "Potential and Actual Benefits from Commercial Fishing Activities." Presented at July 1984 Workshop for Making Economic Information More Useful for Salmon and Steelhead Production Decisions. NOAA Technical Memorandum, NMFS F/NWR-8.

Samual Ben-Zvi \& Associates, 1990. "Evaluation of Nonpower Impacts from Reservoir Drawdown at Hungry Horse Reservoir." For USBR, February.

Schwantes, Carlos A., 1989. Pacific Northwest, An Interpretive History. University of Nebraska Press, Linclon and London.

Sorg, C.F. and Loomis, J.B., 1984. "Empirical Estimates of Amenity Forest Values: A Comparative Review." Rocky Mountain Forest and Range Experiment, Station. GTR RM-107.

U.S. Army Corps of Engineers, Institute for Water Resources, December 1984. Business Depth-Damage Analysis Procedures. Ft. Belvoir, Virginia.

U.S. Army Corps of Engineers, Institute for Water Resources, November 1988, Inland Waterway Review. Ft. Belvoir, Virginia. 
U.S. Army Corps of Engineers, Institute for Water Resources, October 1991, Draft National Economic Development Procedures Manual - Overview Manual for Conducting National Economic Development Analysis. IWR Report 91-R-11.

U.S. Army Corps of Engineers, Walla Walla District, May 1968. Floodplain Information - Orofino and Riverside, Idaho, Clearwater River. Walla Walla, Washington.

U.S. Army Corps of Engineers, Portland District, Revised, November 1971. "Flood Profiles, Columbia River and Tributaries Washington and Oregon below Bonneville Dam."

U.S. Army Corps of Engineers, Walla Walla District, October 1972. 1972 Flood Year Operation Foresight - After Action Report and Post Flood Report. Walla Walla, Washington.

U.S. Army Corps of Engineers, Walla Walla District, December 1974. 1974 Post Flood Report. Walla Walla, Washington.

U.S. Army Corps of Engineers, Walla Walla District, 1986. Water Control Manual for Dworshak Dam and Reservoir, North Fork Clearwater River, Idaho. Walla Walla, Washington.

U.S. Army Corps of Engineers, Walla Walla District, 9 August 1991. Reconnaissance Report, Tri-Cities Levees, Washington. Walla Walla, Washington.
U.S. Army Corps of Engineers, Walla Walla District, 1991. Investigation of Pumping Facilities, Lower Snake River, Walla Walla, Washington.

U.S. Army Corps of Engineers, Walla Walla District, December 1992. Lower Granite Sedimentation Study Draft Preliminary Evaluation and Progress Report. Walla Walla, Washington.

U.S. Department of Energy, Bonneville Power Administration, 1992. Draft Environmental Impact Statement, Resource Programs, Volume 1: Environmental Analysis. Portland, Oregon.

Walsh, R.G., 1986. "Recreation Economic Decisions: Comparing Benefits and Costs." Colorado State University. Venture Pub. Inc., State College, Pennsylvania.

Walsh, R.G., Johnson, D.M., and McKean, J.R., 1992. "Benefit Transfer of Outdoor Recreation Demand Studies, 1968-1988." Water Resources Research. Vol. 28, No. 3, March.

Wandscheider, P.R., Demirelli, L.K., and Heckelei,T., 1993. "The Recreational Value of Washington Steelhead." PNW Economic Conference. 29 April, Kennewick, WA.

Water Resources Council, March 10, 1983. Economic and Environmental Principles and Guidelines for Water and Related Land Resources Implementation Studies. 


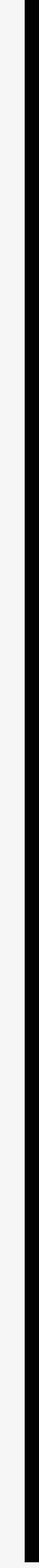




\section{EXHIBIT A}

\section{ANADROMOUS FISH}

\section{A.1 GENERAL}

The analysis of economic impacts associated with changes in anadromous fish (salmon and steelhead) production under each of the SOSs was based on estimates of production developed by the Anadromous Fish Work Group (see Appendix C, Anadromous Fish). The Anadromous Fish appendix contains the Stochastic Life Cycle Model (SLCM) results that are used in the economic analysis and in this technical exhibit. Since the economic analysis depends on estimates of harvest of adults and the SLCM model was the only evaluation tool which provided this information, only the SLCM results are evaluated.

Estimates of sport and commercial harvest rates used in the analysis are presented in this technical exhibit. The data presented include changes in harvest over time and average annual equivalent amounts. Harvest over time covers the 100-year period of analysis used in the SOR and is shown for the years 1995 (the initial on-line date for some SOR alternatives), 2005, 2015, 2035, and 2095. Estimates of average annual equivalents were obtained by present-valuing the estimates of future changes in harvest. These harvest numbers were the basic input to the economic analysis.

\section{A.2 SALMON AND STEELHEAD HARVEST OVER TIME}

Based on the results of the SLCM fish model, projections of the number of fish harvested over time with each SOS were made. The economic analysis used key indicator stocks to represent the entire Columbia River run. The analysis concentrated on four species of salmon and steelhead: fall chinook, spring/summer chinook, sockeye and steelhead. Estimated harvest over time of fall chinook, spring-summer chinook, and steelhead with each SOS is shown in Tables $A-1, A-2$, and $A-3$, respectively. The rate of change shown for the spring chinook was used to define the harvest of sockeye over time: i.e., the rate of change in the harvest of sockeye is assumed to be the same as the rate of change for spring chinook. It was necessary to use an assumed rate of change for sockeye because sockeye were not evaluated in the fish model studies.

\section{A.3 AVERAGE ANNUAL.EQUIVALENTS WITH DIFFERENT TRANSPORT CONDITIONS}

The SLCM results assumed different levels of transportation of juveniles in barges and trucks with different survival assumptions. In order to compare estimates of survival with transport to in-river migration, two methods for estimating juvenile transportation survival were studied. The first method (transport scenario FB) was based solely on observed barged survival and assumes a constant 98 percent survival. The second method was based on transport to in-river ratios, which could change each year. Two transport to in-river ratios were modeled, and applied to some of the indicator species. The transport scenario F86 has an assumed survival of 76 percent, and scenario A86 has a transport survival of 36 percent.

The basic estimates of fish harvested over time were discounted at the interest rates of 3.0 percent and 7.75 percent. The analysis was done for the period of 1995 to 2095, and the annual equivalent was computed using a 100 year period of analysis.

Section 4.3 of this Appendix used the F86 transport survival assumptions for all SOSs, and Table 4-6 shows the average annual equivalent harvest with F86. Table $\mathrm{A}-4$ shows the results of the average annual harvest computations by species and the two interest rates, for the A86 transport scenario. Scenario A86 is applied only to the Snake River stocks. The Snake River spring chinook is the indicator stock for all SOR related spring and summer chinook, and sockeye in the economic analysis, and hence these fish harvest numbers are impacted 
with the A86 scenario. Table $\mathrm{A}-5$ provides the results with transport scenario FB.

The economic values with the different transport scenarios are shown is Tables $A-6$ to $A-9$, using the different interest rates of 3.0 and 7.75 percent. These tables can be compared to Tables 4-12 and 4-13, which show the economic values with scenario F86 at 3.0 and 7.75 percent, respectively.

Table A-1. Estimated Harvest Over Time of Fall Chinook (Numbers of Fish Harvested per Year) $1 /$

\begin{tabular}{|c|c|c|c|c|c|c|c|}
\hline \multicolumn{8}{|c|}{ FALL CHINOOK } \\
\hline $\begin{array}{c}\text { SOS } \\
3 /\end{array}$ & $\begin{array}{c}\text { IN-SERVICE } \\
\text { DATE }\end{array}$ & $\begin{array}{c}1995 \\
\text { HARVEST }\end{array}$ & $\begin{array}{c}2005 \\
\text { HARVEST }\end{array}$ & $\begin{array}{c}2015 \\
\text { HARVEST }\end{array}$ & $\begin{array}{c}2025 \\
\text { HARVEST }\end{array}$ & $\begin{array}{c}2035 \\
\text { HARVEST }\end{array}$ & $\begin{array}{c}2095 \\
\text { HARVEST } \\
2 /\end{array}$ \\
\hline SOS 1a & 1995 & 478,315 & 511,212 & 502,150 & 510,047 & 538,706 & 538,706 \\
\hline $\operatorname{SOS} 1 \mathrm{~b}$ & 1995 & 478,254 & 519,493 & 509,323 & 518,035 & 541,657 & 541,657 \\
\hline $\operatorname{SOS} 2 c$ & 1995 & 477,854 & 507,204 & 509,569 & 516,921 & 542,437 & 542,437 \\
\hline $\operatorname{sos} 2 d$ & 1995 & 477,868 & 526,060 & 518,799 & 521,756 & 552,816 & 552,816 \\
\hline SOS $4 c$ & 1995 & 478,158 & 526,894 & 521,008 & 527,739 & 552,735 & 552,735 \\
\hline SOS $5 b$ & 2010 & 477,854 & 507,204 & 632,804 & 533,301 & 530,071 & 545,166 \\
\hline SOS $5 c$ & 2000 & 477,854 & 607,257 & 519,186 & 517,228 & 508,712 & 535,759 \\
\hline SOS $6 b-o p$ & 2005 & 477,854 & 478,297 & 505,003 & 512,616 & 516,833 & 546,715 \\
\hline SOS $6 b-p$ & 2005 & 477,854 & 478,282 & 523,454 & 513,490 & 511,371 & 545,658 \\
\hline SOS 6d-op & 2000 & 477,854 & 618,597 & 513,756 & 516,746 & 503,328 & 540,339 \\
\hline SOS $6 \mathrm{~d}-\mathrm{p}$ & 2000 & 477,854 & 638,570 & 522,282 & 524,314 & 510,060 & 540,547 \\
\hline SOS 9a-op & 2005 & 477,854 & 478,006 & 326,977 & 316,376 & 344,641 & 347,660 \\
\hline SOS $9 a-p$ & 2005 & 477,854 & 478,245 & 333,081 & 310,941 & 342,046 & 343,943 \\
\hline SOS 9b & 1995 & 478,368 & 491,075 & 480,357 & 478,277 & 513,618 & 513,618 \\
\hline SOS 9c-op & 2005 & 477,854 & 477,728 & 493,136 & 485,092 & 481,818 & 518,158 \\
\hline SOS 9c-p & 2005 & 477,854 & 477,737 & 491,231 & 483,845 & 491,582 & 515,701 \\
\hline $\begin{array}{l}\text { Preferred } \\
\text { Alt }\end{array}$ & 1995 & 477,987 & 537,628 & 533,550 & 542,706 & 561,986 & 561,986 \\
\hline \multicolumn{8}{|c|}{$\begin{array}{l}\text { 1/ Transport Scenario F86 - } 76 \% \text { survival. } \\
\text { 2/ Assumes Average For Years } 31-40 \text { Are Held Constant. } \\
\text { 3/ SOSs which end in "-op" represent "optimistic" assumptions of an increase of } 25 \% \text { in FGE with } \\
\text { drawdown. SOSs which end in "-p" represent "pessimistic" assumptions of a decrease of } 50 \% \text { in FGE with } \\
\text { drawdown. }\end{array}$} \\
\hline
\end{tabular}


Table A-2. Estimated Harvest Over Time of Spring-Summer Chinook (Numbers of Fish Harvested Per Year) 1/

\begin{tabular}{|l|c|r|r|r|r|r|r|}
\hline \multicolumn{1}{|c|}{ SOS } & $\begin{array}{c}\text { IN-SERVICE } \\
\text { DATE }\end{array}$ & $\begin{array}{c}\text { 1995 } \\
\text { HARVEST }\end{array}$ & $\begin{array}{c}\text { 2005 } \\
\text { HARVEST }\end{array}$ & $\begin{array}{c}\text { 2015 } \\
\text { HARVEST }\end{array}$ & $\begin{array}{c}\text { 2025 } \\
\text { HARVEST }\end{array}$ & $\begin{array}{c}\text { 2035 } \\
\text { HARVEST }\end{array}$ & $\begin{array}{c}\text { 2095 } \\
\text { HARVST } \\
\text { 2/ }\end{array}$ \\
\hline SOS 1a & 1995 & 12,195 & 2,902 & 4,299 & 4,617 & 8,207 & 8,207 \\
\hline SOS 1b & 1995 & 12,145 & 2,738 & 4,513 & 4,774 & 8,172 & 8,172 \\
\hline SOS 2c & 1995 & 12,151 & 2,918 & 4,468 & 4,762 & 8,500 & 8,500 \\
\hline SOS 2d & 1995 & 12,160 & 2,916 & 5,136 & 4,661 & 8,915 & 8,915 \\
\hline SOS 4c & 1995 & 12,137 & 3,007 & 4,472 & 4,725 & 8,526 & 8,526 \\
\hline SOS 5b & 2010 & 12,151 & 2,918 & 2,720 & 3,073 & 3,020 & 3,567 \\
\hline SOS 5c & 2000 & 12,151 & 2,634 & 2,943 & 3,121 & 3,070 & 5,643 \\
\hline SOS 6b-op & 2005 & 12,151 & 12,151 & 1,504 & 1,166 & 680 & 1,154 \\
\hline SOS 6b-p & 2005 & 12,151 & 12,131 & 376 & 50 & 8 & 9 \\
\hline SOS 6d-op & 2000 & 12,151 & 2,252 & 1,658 & 1,303 & 1,036 & 2,126 \\
\hline SOS 6d-p & 2000 & 12,151 & 1,862 & 936 & 496 & 308 & 737 \\
\hline SOS 9a-op & 2005 & 12,151 & 12,157 & 1,532 & 1,124 & 624 & 1,146 \\
\hline SOS 9a-p & 2005 & 12,151 & 12,166 & 494 & 104 & 20 & 20 \\
\hline SOS 9b & 1995 & 12,186 & 2,505 & 3,492 & 3,168 & 6,052 & 6,052 \\
\hline SOS 9c-op & 2005 & 12,151 & 12,125 & 1,537 & 1,417 & 844 & 1,589 \\
\hline SOS 9c-p & 2005 & 12,151 & 12,090 & 505 & 99 & 17 & 23 \\
\hline Preferred & 1995 & 12,197 & 2,877 & 4,427 & 4,900 & 8,343 & 8,343 \\
Alt & & & & & & & \\
\hline I/ & & & & & & & \\
\hline
\end{tabular}

1/ Transport scenario F86 - 76\% survival.

2/ Assumes average for years 31-40 are held constant.

3 / SOSs which end in "-op" represent "optimistic" assumptions of an increase of $25 \%$ in FGE with drawdown. SOSs which end in "-p" represent "pessimistic" assumptions of a decrease of $50 \%$ in FGE with drawdown. 
Table A-3. Estimated Harvest Over Time of Steelhead (Numbers of Fish Harvested Per Year) $1 /$

\begin{tabular}{|c|c|c|c|c|c|c|c|}
\hline \multicolumn{8}{|c|}{ STEELHEAD } \\
\hline SOS & $\begin{array}{c}\text { IN-SERVICE } \\
\text { DATE }\end{array}$ & $\begin{array}{c}1995 \\
\text { HARVEST }\end{array}$ & $\begin{array}{c}2005 \\
\text { HARVEST }\end{array}$ & $\begin{array}{c}2015 \\
\text { HARVEST }\end{array}$ & $\begin{array}{c}2025 \\
\text { HARVEST }\end{array}$ & $\begin{array}{c}2035 \\
\text { HARVEST }\end{array}$ & $\begin{array}{c}2095 \\
\text { HARVEST } \\
2 / \\
\end{array}$ \\
\hline SOS 1a & 1995 & 210,809 & 372,089 & 404,588 & 366,080 & 405,064 & 405,064 \\
\hline SOS $1 b$ & 1995 & 210,773 & 372,497 & 404,149 & 366,915 & 404,268 & 404,268 \\
\hline $\operatorname{SOS} 2 c$ & 1995 & 210,738 & 375,831 & 408,036 & 369,674 & 408,357 & 408,357 \\
\hline SOS 2d & 1995 & 210,776 & 373,586 & 405,954 & 367,220 & 406,390 & 406,390 \\
\hline SOS $4 c$ & 1995 & 210,845 & 374,588 & 406,565 & 369,530 & 406,979 & 406,979 \\
\hline SOS $5 b$ & 2010 & 210,738 & 375,831 & 259,305 & 268,144 & 278,711 & 275,983 \\
\hline $\operatorname{SOS} 5 \mathrm{c}$ & 2000 & 210,738 & 261,081 & 269,887 & 280,013 & 275,051 & 277,963 \\
\hline SOS $6 b-o p$ & 2005 & 210,738 & 210,768 & 188,947 & 204,904 & 180,868 & 202,372 \\
\hline SOS $6 b-p$ & 2005 & 210,738 & 210,642 & 111,147 & 119,322 & 104,919 & 117,218 \\
\hline SOS 6d-op & 2000 & 210,738 & 311,756 & 321,952 & 335,334 & 328,286 & 331,608 \\
\hline SOS $6 \mathrm{~d}-\mathrm{p}$ & 2000 & 210,738 & 268,277 & 277,216 & 289,534 & 283,656 & 286,373 \\
\hline SOS 9a-op & 2005 & 210,738 & 210,806 & 152,625 & 164,691 & 144,639 & 161,968 \\
\hline SOS $9 a-p$ & 2005 & 210,738 & 210,681 & 90,345 & 99,804 & 84,882 & 95,855 \\
\hline SOS 9b & 1995 & 210,841 & 342,223 & 372,250 & 335,270 & 369,219 & 369,219 \\
\hline SOS 9c-op & 2005 & 210,738 & 210,825 & 191,790 & 207,672 & 182,139 & 204,302 \\
\hline SOS $9 c-p$ & 2005 & 210,738 & 210,688 & 117,529 & 126,099 & 112,310 & 125,050 \\
\hline $\begin{array}{l}\text { Preferred } \\
\text { Alt }\end{array}$ & 1995 & 210,747 & 368,689 & 400,073 & 362,108 & 401,131 & 401,131 \\
\hline \multicolumn{8}{|c|}{$\begin{array}{l}\text { 1/ Transport scenario F86 - } 76 \% \text { survival. } \\
\text { 2/ Assumes average for years } 31-40 \text { are held constant. } \\
\text { 3/ SOSs which end in "-op" represent "optimistic" assumptions of an increase of } 25 \% \text { in FGE with } \\
\text { drawdown. SOSs which end in "-p" represent "pessimistic" assumptions of a decrease of } 50 \% \text { in FGE with } \\
\text { drawdown. }\end{array}$} \\
\hline
\end{tabular}


Table A-4. Average Annual Harvest - Transport Sensitivity (Scenario A86 for SpringSummer Chinook and Sockeye - 36\% Survival and Scenario F86 for Fall Chinook and Steelhead $-76 \%$ Survival)

\begin{tabular}{|c|c|c|c|c|c|c|c|c|}
\hline \multirow[b]{2}{*}{ sos1/ } & \multicolumn{2}{|c|}{ HANFORD FALLS } & \multicolumn{2}{|c|}{$\begin{array}{l}\text { SPRING/SUMMER } \\
\text { CHINOOK }\end{array}$} & \multicolumn{2}{|c|}{ STEELHEAD } & \multicolumn{2}{|c|}{ SOCKEYE } \\
\hline & $\begin{array}{c}\text { AAE@ } \\
\text { 3\% } \\
\text { (Harvest \#) }\end{array}$ & $\begin{array}{c}\text { AAE@ } \\
\text { 7.75\% } \\
\text { (Harvest \#) }\end{array}$ & $\begin{array}{c}\text { AAE@ } \\
\text { 3\% } \\
\text { (Harvest \#) }\end{array}$ & $\begin{array}{c}\text { AAE@ } \\
\text { 7.75\% } \\
\text { (Harvest \#) }\end{array}$ & $\begin{array}{c}\text { AAE@ } \\
\text { 3\% } \\
\text { (Harvest \#) }\end{array}$ & $\begin{array}{c}\text { AAE@ } \\
7.75 \% \\
\text { (Harvest \#) }\end{array}$ & $\begin{array}{c}\text { AAE@ } \\
\text { 3\% } \\
\text { (Harvest \#) }\end{array}$ & $\begin{array}{c}\text { AAE@ } \\
\text { 7.75\% } \\
\text { (Harvest \#) }\end{array}$ \\
\hline $\operatorname{sos} 1 \mathrm{a}$ & 534,400 & 540,500 & 3,920 & 4,350 & 379,300 & 357,200 & 7,600 & 8,400 \\
\hline $\operatorname{sos} 1 b$ & 540,600 & 547,000 & 3,830 & 4,350 & 378,900 & 356,900 & 7,400 & 8,400 \\
\hline $\operatorname{sos} 2 c$ & 538,900 & 545,200 & 4,030 & 4,470 & 382,200 & 359,800 & 7,800 & 8,700 \\
\hline $\operatorname{sos} 2 d$ & 549,800 & 557,100 & 3,940 & 4,380 & 380,300 & 358,200 & 7,600 & 8,500 \\
\hline $\operatorname{sos} 4 c$ & 547,400 & 552,100 & 3,970 & 4,380 & 381,200 & 358,900 & 7,700 & 8,500 \\
\hline sos $5 b$ & 547,500 & 554,200 & 13,570 & 7,370 & 295,400 & 312,000 & 26,300 & 14,300 \\
\hline SOS 5c & 535,900 & 544,100 & 16,940 & 10,500 & 269,600 & 267,400 & 32,900 & 20,400 \\
\hline $\begin{array}{l}\text { SOS } \\
6 b-o p\end{array}$ & 545,900 & 555,100 & 7,160 & 6,000 & 234,700 & 265,500 & 13,900 & 11,600 \\
\hline SOS $6 b-p$ & 548,700 & 557,000 & 2,470 & 4,290 & 179,000 & 233,500 & 4,800 & 8,300 \\
\hline $\begin{array}{l}\text { SOS } \\
6 d-\text { op }\end{array}$ & 538,300 & 546,800 & 3,680 & 5,100 & 311,000 & 297,000 & 7,100 & 9,900 \\
\hline $\operatorname{sos} 6 d-p$ & 543,800 & 553,100 & 2,760 & 4,610 & 276,100 & 271,900 & 5,400 & 8,900 \\
\hline $\begin{array}{l}\text { SOS } \\
9 a-o p\end{array}$ & 413,100 & 475,600 & 12,670 & 7,830 & 208,300 & 250,300 & 24,600 & 15,200 \\
\hline $\operatorname{sos} 9 a-p$ & 410,800 & 474,600 & 3,160 & 4,640 & 164,700 & 225,000 & 6,100 & 9,000 \\
\hline SOS $9 b$ & 511,100 & 520,400 & 3,800 & 4,320 & 348,200 & 329,800 & 7,400 & 8,400 \\
\hline $\begin{array}{l}\text { sos } \\
9 c-o p\end{array}$ & 527,900 & 544,600 & 8,210 & 6,320 & 236,200 & 266,400 & 15,900 & 12,300 \\
\hline $\operatorname{sos} 9 c-p$ & 528,700 & 545,300 & 2,610 & 4,380 & 184,000 & 236,300 & 5,100 & 8,500 \\
\hline $\begin{array}{l}\text { Preferred } \\
\text { Ait }\end{array}$ & 559,100 & 563,600 & 3,890 & 4,290 & 375,600 & 354,100 & 7,500 & 8,300 \\
\hline
\end{tabular}


Table A-5. Average Annual Harvest - Transport Sensitivity (Scenario FB - 98\% Survival For All Species)

\begin{tabular}{|c|c|c|c|c|c|c|c|c|}
\hline \multirow[b]{2}{*}{ sos $1 /$} & \multicolumn{2}{|c|}{ HANFORD FALLS } & \multicolumn{2}{|c|}{$\begin{array}{c}\text { SPRING/SUMMER } \\
\text { CHINOOK } \\
\end{array}$} & \multicolumn{2}{|c|}{ STEELHEAD } & \multicolumn{2}{|c|}{ SOCKEYE } \\
\hline & $\begin{array}{c}\text { AAE@ } \\
\text { 3\% } \\
\text { (Harvest \#) }\end{array}$ & $\begin{array}{c}\text { AAE@ } \\
7.75 \% \\
\text { (Harvest \#) }\end{array}$ & $\begin{array}{c}\text { AAE@ } \\
\text { 3\% } \\
\text { (Harvest \#) }\end{array}$ & $\begin{array}{c}\text { AAE@ } \\
7.75 \% \\
\text { (Harvest \#) }\end{array}$ & $\begin{array}{c}\text { AAE@ } \\
\text { 3\% } \\
\text { (Harvest \#) }\end{array}$ & $\begin{array}{c}\text { AAE@ } \\
7.75 \% \\
\text { (Harvest \#) }\end{array}$ & $\begin{array}{c}\text { AAE@ } \\
\text { 3\% } \\
\text { (Harvest \#) }\end{array}$ & $\begin{array}{c}\text { AAE@ } \\
7.75 \% \\
\text { (Harvest \#) }\end{array}$ \\
\hline SOS 1a & 534,400 & 540,500 & 6,260 & 5,370 & 402,200 & 374,000 & 12,100 & 10,400 \\
\hline $\operatorname{SOS} 1 b$ & 540,600 & 547,000 & 6,210 & 5,390 & 401,400 & 373,400 & 12,000 & 10,500 \\
\hline $\operatorname{SOS} 2 c$ & 538,900 & 545,200 & 6,350 & 5,480 & 405,000 & 376,300 & 12,300 & 10,600 \\
\hline $\operatorname{SOS} 2 d$ & 549,800 & 557,100 & 6,580 & 5,660 & 403,400 & 375,000 & 12,800 & 11,000 \\
\hline $\operatorname{sos} 4 c$ & 547,400 & 552,100 & 6,440 & 5,540 & 403,800 & 375,400 & 12,500 & 10,700 \\
\hline SOS $5 b$ & 547,500 & 554,200 & 3,630 & 4,790 & 305,400 & 321,200 & 7,000 & 9,300 \\
\hline SOS $5 c$ & 535,900 & 544,100 & 3,540 & 5,020 & 276,800 & 271,700 & 6,900 & 9,700 \\
\hline $\begin{array}{l}\text { SOS } \\
6 b-o p\end{array}$ & 545,900 & 555,100 & 2,700 & 4,500 & 242,000 & 271,300 & 5,200 & 8,700 \\
\hline $\operatorname{sOS} 6 \mathrm{~b}-\mathrm{p}$ & 548,700 & 557,000 & 2,290 & 4,210 & 183,800 & 237,900 & 4,400 & 8,200 \\
\hline $\begin{array}{l}\text { SOS } \\
6 d-o p\end{array}$ & 538,300 & 546,800 & 3,250 & 4,870 & 326,900 & 306,400 & 6,300 & 9,400 \\
\hline $\operatorname{sos} 6 d-p$ & 548,700 & 553,100 & 2,610 & 4,550 & 290,100 & 280,200 & 5,100 & 8,800 \\
\hline $\begin{array}{l}\text { SOS } \\
9 a-o p\end{array}$ & 538,300 & 475,600 & 2,520 & 4,380 & 209,800 & 253,300 & 4,900 & 8,500 \\
\hline $\operatorname{sos} 9 a-p$ & 543,800 & 474,600 & 2,290 & 4,210 & 166,400 & 228,100 & 4,400 & 8,200 \\
\hline SOS 9b & 413,100 & 520,400 & 4,700 & 4,670 & 368,800 & 344,900 & 9,100 & 9,100 \\
\hline $\begin{array}{l}\text { Sos } \\
9 c-o p\end{array}$ & 410,800 & 544,600 & 2,760 & 4,500 & 242,900 & 271,900 & 5,400 & 8,700 \\
\hline $\operatorname{sos} 9 c-p$ & 511,100 & 545,300 & 2,320 & 4,230 & 188,900 & 240,900 & 4,500 & 8,200 \\
\hline $\begin{array}{l}\text { Preferred } \\
\text { Alt }\end{array}$ & 527,900 & 563,600 & 6,210 & 5,420 & 383,500 & 355,600 & 12,000 & 10,500 \\
\hline
\end{tabular}

1 / SOSs which end in "-op" represent "optimistic" assumptions of an increase of $25 \%$ in FGE with drawdown. SOSs which end in "-p" represent "pessimistic" assumptions of a decrease of $50 \%$ in FGE with drawdown. 
Table A-6. Summary of Average Annual Values With Transportation (Scenario A86 - 36\% Survival), Annual Values Discounted At 3.0\% (\$1,000)

\begin{tabular}{|c|c|c|c|c|c|c|c|}
\hline SOS 3/ & $\begin{array}{l}\text { "LOW" 1/ } \\
\text { Values } \\
\text { Commercial }\end{array}$ & $\begin{array}{c}\text { "LOW" 1/ } \\
\text { Values } \\
\text { Sport } \\
\end{array}$ & $\begin{array}{c}\text { "LOW" 1/ } \\
\text { Values } \\
\text { Total } \\
\end{array}$ & 19. & $\begin{array}{c}\text { "HIGH" 2/ } \\
\text { Values } \\
\text { Commercial }\end{array}$ & $\begin{array}{c}\text { "HIGH" 2/ } \\
\text { Values } \\
\text { Sport } \\
\end{array}$ & $\begin{array}{c}\text { "HIGH" 2/ } \\
\text { Values } \\
\text { Total } \\
\end{array}$ \\
\hline SOS 1a & 6,560 & 24,060 & 30,620 & & 13,090 & 30,250 & 43,340 \\
\hline SOS $1 b$ & 6,600 & 24,070 & 30,670 & & 13,220 & 30,270 & 43,490 \\
\hline SOS 2c & 6,610 & 24,240 & 30,850 & & 13,200 & 30,480 & 43,680 \\
\hline $\operatorname{sos} 2 \mathrm{~d}$ & 6,720 & 24,190 & 30,910 & & 13,390 & 30,420 & 43,810 \\
\hline SOS $4 c$ & 6,700 & 24,230 & 30,930 & & 13,360 & 30,480 & 43,840 \\
\hline SOS $5 b$ & 6,630 & 19,480 & 26,110 & & 13,280 & 24,510 & 37,790 \\
\hline SOS $5 c$ & 6,530 & 18,000 & 24,530 & & 13,030 & 22,620 & 35,650 \\
\hline SOS 6b-op & 6,280 & 16,100 & 22,380 & & 12,580 & 20,250 & 32,830 \\
\hline SOS $6 b-p$ & 6,030 & 13,010 & 19,040 & & 12,080 & 16,370 & 28,450 \\
\hline SOS 6d-op & 6,370 & 20,290 & 26,660 & & 12,750 & 25,510 & 38,260 \\
\hline $\operatorname{sos} 6 \mathrm{~d}-\mathrm{p}$ & 6,280 & 18,380 & 24,660 & & 12,600 & 23,130 & 35,730 \\
\hline SOS 9a-op & 5,010 & 13,890 & 18,900 & & 10,030 & 17,470 & 27,500 \\
\hline SOS $9 a-p$ & 4,660 & 11,450 & 16,110 & & 9,290 & 14,390 & 23,680 \\
\hline SOS $9 b$ & 6,220 & 22,200 & 28,420 & & 12,450 & 27,910 & 40,360 \\
\hline SOS 9c-op & 6,150 & 16,090 & 22,240 & & 12,290 & 20,220 & 32,510 \\
\hline SOS $9 c-p$ & 5,860 & 13,180 & 19,040 & & 11,720 & 16,570 & 28,290 \\
\hline SOS PA & 6,800 & 23,990 & 30,790 & & 13,560 & 30,160 & 43,720 \\
\hline \multicolumn{8}{|c|}{$\begin{array}{l}\text { 1/ "Low" values based on net-to-gross of } 50 \% \text {, sport value of } \$ 50.50 \text { per day. } \\
2 / \text { "High" values based on full ex-vessel value (net-to-gross } 100 \% \text {, sport value of } \$ 63.50 \text { a day. } \\
3 \text { / SOSs which end in "-op" represent "optimistic" assumptions of an increase of } 25 \% \text { in FGE with } \\
\text { drawdown. SOSs which end in "-p" represent "pessimistic" assumptions of a decrease of } 50 \% \text { in FGE with } \\
\text { drawdown. }\end{array}$} \\
\hline
\end{tabular}


Table A-7. Summary of Average Annual Values With Transportation (Scenario FB - 98\% Survival), Annual Values Discounted At $3.0 \%(\$ 1,000)$

\begin{tabular}{|l|c|c|c|c|c|c|}
\hline SOS 3/ & $\begin{array}{c}\text { "LOW" 1/ } \\
\text { Values } \\
\text { Commercial }\end{array}$ & $\begin{array}{c}\text { "LOW" 1/ } \\
\text { Values } \\
\text { Sport }\end{array}$ & $\begin{array}{c}\text { "LOW" 1/ } \\
\text { Values } \\
\text { Total }\end{array}$ \\
\hline SOS 1a & 6,670 & 25,330 & 32,000 \\
\hline SOS 1b & 6,720 & 25,320 & 32,040 \\
\hline SOS 2c & 6,720 & 25,500 & 32,220 & $\begin{array}{c}\text { "HIGH" 2/ } \\
\text { Values }\end{array}$ & $\begin{array}{c}\text { "HIGH" 2/ } \\
\text { Values } \\
\text { Sport }\end{array}$ & $\begin{array}{c}\text { "HIGH" 2/ } \\
\text { Values } \\
\text { Total }\end{array}$ \\
\hline SOS 2d & 6,840 & 25,480 & 32,320 & 13,340 & 31,850 & 45,190 \\
\hline SOS 4c & 6,810 & 25,490 & 32,300 & 13,460 & 31,850 & 45,310 \\
\hline SOS 5b & 6,450 & 20,030 & 26,480 & 32,080 & 45,520 \\
\hline SOS 5c & 6,250 & 18,380 & 24,630 & 13,660 & 32,040 & 45,700 \\
\hline SOS 6b-op & 6,210 & 16,510 & 22,720 & 12,900 & 25,190 & 38,090 \\
\hline SOS 6b-p & 6,050 & 13,280 & 19,330 & 12,480 & 23,100 & 35,580 \\
\hline SOS 6d-op & 6,420 & 21,170 & 27,590 & 12,410 & 20,750 & 33,160 \\
\hline SOS 6d-p & 6,370 & 19,180 & 25,550 & 12,100 & 16,710 & 28,810 \\
\hline SOS 9a-op & 6,030 & 14,670 & 20,700 & 12,830 & 26,620 & 39,450 \\
\hline SOS 9a-p & 5,940 & 12,290 & 18,230 & 12,770 & 24,120 & 36,890 \\
\hline SOS 9b & 5,350 & 22,790 & 28,140 & 12,070 & 18,450 & 30,520 \\
\hline SOS 9c-op & 4,870 & 15,790 & 20,660 & 11,910 & 15,470 & 27,380 \\
\hline SOS 9c-p & 5,700 & 13,360 & 19,060 & 10,660 & 28,650 & 39,310 \\
\hline SOS PA & 6,550 & 25,250 & 30,800 & 9,760 & 19,850 & 29,610 \\
\hline $1 / 29$ & 11,400 & 16,790 & 28,190 \\
\hline
\end{tabular}

$1 /$ "Low" values based on net-to-gross of $50 \%$, sport value of $\$ 50.50$ per day.

$2 /$ "High" values based on full ex-vessel value (net-to-gross $100 \%$ ), sport value of $\$ 63.50$ a day.

3 / SOSs which end in "-op" represent "optimistic" assumptions of an increase of 25\% in FGE with drawdown. SOSs which end in " $-\mathrm{p}$ " represent "pessimistic" assumptions of a decrease of $50 \%$ in FGE with drawdown. 
Table A-8. Summary of Average Annual Values With Transportation (Scenario A86 - 76\% Survival), Annual Values Discounted At $7.75 \%(\$ 1,000)$

\begin{tabular}{|c|c|c|c|c|c|c|c|}
\hline sos & $\begin{array}{l}\text { "LOW" 1/ } \\
\text { Values } \\
\text { Commercial }\end{array}$ & $\begin{array}{l}\text { "LOW" 1/ } \\
\text { Values } \\
\text { Sport } \\
\end{array}$ & $\begin{array}{c}\text { "LOW" 1/ } \\
\text { Values } \\
\text { Total } \\
\end{array}$ & 8 & $\begin{array}{l}\text { "HIGH" } 2 / \\
\text { Values } \\
\text { Commercial }\end{array}$ & $\begin{array}{l}\text { "HIGH" 2/ } \\
\text { Values } \\
\text { Sport }\end{array}$ & $\begin{array}{c}\text { "HIGH" 2/ } \\
\text { Values } \\
\text { Total }\end{array}$ \\
\hline SOS 1a & 6,550 & 22,860 & 29,410 & & 13,110 & 28,750 & 41,860 \\
\hline SOS $1 b$ & 6,630 & 22,890 & 29,520 & & 13,230 & 28,760 & 41,990 \\
\hline $\operatorname{SOS} 2 c$ & 6,620 & 23,040 & 29,660 & $\%$ & 13,230 & 28,970 & 42,200 \\
\hline $\operatorname{sos} 2 d$ & 6,720 & 23,010 & 29,730 & & 13,440 & 28,920 & 42,360 \\
\hline SOS $4 c$ & 6,680 & 23,020 & 29,700 & & 13,350 & 28,950 & 42,300 \\
\hline sos $5 b$ & 6,620 & 20,430 & 27,050 & & 13,220 & 25,690 & 38,910 \\
\hline SOS 5c & 6,450 & 17,910 & 24,360 & & 12,910 & 22,530 & 35,440 \\
\hline SOS $6 b-o p$ & 6,460 & 17,860 & 24,320 & & 12,900 & 22,470 & 35,370 \\
\hline SOS $6 b-p$ & 6,340 & 16,090 & 22,430 & & 12,670 & 20,220 & 32,890 \\
\hline SOS 6d-op & 6,450 & 19,560 & 26,010 & & 12,890 & 24,580 & 37,470 \\
\hline $\operatorname{sOS} 6 \mathrm{~d}-\mathrm{p}$ & 6,420 & 18,190 & 24,610 & 8 & 12,860 & 22,880 & 35,740 \\
\hline SOS $9 a-o p$ & 5,640 & 16,570 & 22,210 & & 11,320 & 20,840 & 32,160 \\
\hline SOS $9 a-p$ & 5,500 & 15,160 & 20,660 & & 11,010 & 19,050 & 30,060 \\
\hline SOS 9b & 6,280 & 21,220 & 27,500 & & 12,530 & 26,690 & 39,220 \\
\hline SOS 9c-op & 6,360 & 17,850 & 24,210 & & 12,700 & 22,460 & 35,160 \\
\hline SOS $9 c-p$ & 6,240 & 16,180 & 22,420 & & 12,460 & 20,350 & 32,810 \\
\hline SOS PA & 6,770 & 22,820 & 29,590 & & 13,540 & 28,690 & 42,230 \\
\hline \multicolumn{8}{|c|}{$\begin{array}{l}\text { 1/ "Low" values based on net-to-gross of } 50 \% \text {, sport value of } \$ 50.50 \text { per day. } \\
2 / \text { "High" values based on full ex-vessel value (net-to-gross } 100 \% \text { ), sport value of } \$ 63.50 \text { a day. } \\
3 \text { / SOSs which end in "-op" represent "optimistic" assumptions of an increase of } 25 \% \text { in FGE with } \\
\text { drawdown. SOSs which end in "-p" represent "pessimistic" assumptions of a decrease of } 50 \% \text { in FGE with } \\
\text { drawdown. }\end{array}$} \\
\hline
\end{tabular}


Table A-9. Summary of Average Annual Values With Transportation (Scenario FB - 98\% Survival), Annual Values Discounted At 7.75\% (\$1,000)

\begin{tabular}{|c|c|c|c|c|c|c|}
\hline sos & $\begin{array}{l}\text { "LOW" 1/ } \\
\text { Values } \\
\text { Commercial }\end{array}$ & $\begin{array}{c}\text { "LOW" 1/ } \\
\text { Values } \\
\text { Sport } \\
\end{array}$ & $\begin{array}{c}\text { "LOW" 1/ } \\
\text { Values } \\
\text { Total } \\
\end{array}$ & $\begin{array}{c}\text { "HIGH" } 2 / \\
\text { Values } \\
\text { Commercial }\end{array}$ & $\begin{array}{c}\text { "HIGH" } 2 / \\
\text { Values } \\
\text { Sport } \\
\end{array}$ & $\begin{array}{c}\text { "HIGH" 2/ } \\
\text { Values } \\
\text { Total } \\
\end{array}$ \\
\hline SOS 1a & 6,610 & 23,790 & 30,400 & 13,270 & 29,930 & 43,200 \\
\hline SOS $1 b$ & 6,690 & 23,800 & 30,490 & 13,380 & 29,920 & 43,300 \\
\hline $\operatorname{SOS} 2 c$ & 6,690 & 23,950 & 30,640 & 13,370 & 30,120 & 43,490 \\
\hline $\operatorname{SOS} 2 \mathrm{~d}$ & 6,810 & 23,940 & 30,750 & 13,590 & 30,100 & 43,690 \\
\hline SOS $4 c$ & 6,760 & 23,930 & 30,690 & 13,500 & 30,100 & 43,600 \\
\hline $\operatorname{sOS} 5 b$ & 6,600 & 20,940 & 27,540 & 13,170 & 26,320 & 39,490 \\
\hline SOS 5c & 6,350 & 18,140 & 24,490 & 12,690 & 22,820 & 35,510 \\
\hline SOS 6b-op & 6,450 & 18,190 & 24,640 & 12,870 & 22,860 & 35,730 \\
\hline SOS $6 b-p$ & 6,340 & 16,330 & 22,670 & 12,700 & 20,530 & 33,230 \\
\hline SOS 6d-op & 6,470 & 20,080 & 26,550 & 12,940 & 25,240 & 38,180 \\
\hline SOS $6 \mathrm{~d}-\mathrm{p}$ & 6,440 & 18,650 & 25,090 & 12,900 & 23,460 & 36,360 \\
\hline SOS $9 a-o p$ & 5,590 & 16,730 & 22,320 & 11,180 & 21,030 & 32,210 \\
\hline SOS $9 a-p$ & 5,500 & 15,330 & 20,830 & 11,010 & 19,270 & 30,280 \\
\hline SOS $9 b$ & 6,320 & 22,060 & 28,380 & 12,650 & 27,750 & 40,400 \\
\hline SOS 9c-op & 6,350 & 18,160 & 24,510 & 12,670 & 22,830 & 35,500 \\
\hline $\operatorname{sos} 9 c-p$ & 6,240 & 16,440 & 22,680 & 12,490 & 20,670 & 33,160 \\
\hline SOS PA & 6,790 & 22,900 & 29,690 & 13,600 & 28,790 & 42,390 \\
\hline \multicolumn{7}{|c|}{$\begin{array}{l}\text { 1/ "Low" values based on net-to-gross of } 50 \% \text {, sport value of } \$ 50.50 \text { per day. } \\
2 / \text { "High" values based on full ex-vessel value (net-to-gross } 100 \% \text {, sport value of } \$ 63.50 \text { a day. } \\
3 \text { / SOSs which end in "-op" represent "optimistic" assumptions of an increase of } 25 \% \text { in FGE with } \\
\text { drawdown. SOSs which end in "-p" represent "pessimistic" assumptions of a decrease of } 50 \% \text { in FGE with } \\
\text { drawdown. }\end{array}$} \\
\hline
\end{tabular}




\section{EXHIBIT B}

\section{FLOOD CONTROL}

Damage centers within the geographic scope of the SOR are shown in Figure B-1. The analysis of flood damages divides the region into the following subareas: upper Columbia River, Clearwater River, and lower Columbia River. In addition, levees protect the Tri-Cities area, principally from the backwater of the reservoir created by the McNary Dam. This area is located on the Columbia River just upstream from its confluence with the Snake River. The characteristics, flood history, existing flood protection, and the results of the analysis of potential flood damages are presented in this exhibit for each of the subareas.

An important consideration in the analysis is that none of the SOSs evaluated for either the Draft EIS or the Final EIS included changes to the flood control operating rule curves of the storage projects. The flood control operating rule curves, which incorporate consideration of the amount of water that is forecast to runoff during each water-year included in the historic record, specify the upper limit of the pool elevation of each flood control storage project. Since these curves were not changed for any of the SOSs, every SOS provided for the same amount of total storage available to control floods in the Columbia River Basin above Bonneville Dam. Without changes to the flood control rule curves, the EAG expected that only minor changes in peak discharges and stages would occur among the SOSs and that changes in potential flood damages would be relatively insignificant. As shown, in the following sections, this expectation is generally true.

\section{SECTION B1.0 - UPPER COLUMBIA RIVER SUBAREA}

As can be seen in Figure B-1, the upper Columbia River flood control study area is geographically diverse. For this reason, the characteristics, flood history, and analysis of damages for each damage center is discussed separately.

\section{B1.1 LIBBY DAM TO KOOTENAY LAKE}

The area of potential flood damage along the Kootenai River downstream of Libby Dam occurs in the reach known as Kootenai Flats, extending from Bonners Ferry, Idaho, to Kootenay Lake in Canada. In addition to Libby Dam, flood protection is provided in the United States portion of the floodplain by approximately 95 miles $(153 \mathrm{~km})$ of levees that protect about 35,000 acres (14,000 hectares) of agricultural lands used to grow wheat, barley, oats, and hops. Levees also protect about 17,000 acres (6,800 hectares) in Canada, between the international boundary and Kootenay Lake. Cropping patterns are similar to those in the United States. About 190 acres ( 76 hectares) within the town of Bonners Ferry are also in the Kootenai River floodplain. This area consists of 106 homes, 66 commercial establishments and 12 public facilities.

\section{B1.1.1 Flood History}

Historically, before the area was partially protected by man-made levees, yearly high water would flood portions of the floodplain and more infrequent events would flood the entire valley, in excess of 60,000 acres $(24,000$ hectares). Floods in the Kootenai Basin generally occurred during the snow-melt season often augmented by intense rainfall. Floods are of long duration and are notable for great volume rather than extreme stage crest. Because of the backwater effect of Kootenay Lake, maximum discharge of the river at Bonners Ferry usually occurs prior to the maximum river elevation. As Kootenay Lake rises, the gradient of the river becomes less, the velocity decreases and a higher stage for a given discharge occurs. The 1894 flood, the highest known in the Columbia River Basin as a whole, was exceeded in stage by the 1948 flood in the Kootenay Valley, although not in discharge. 
Estimates of flood damage caused by the 1948 flood totaled $\$ 5,792,000$ (1948 prices and conditions). Prior to the completion of Libby Dam (operational for flood control in 1972), the town of Bonners Ferry experienced a 50-year event in 1894, a 40-year event in 1916, a 25-year event in 1948, and a 10-year even in 1956. During the course of interviews with merchants in Bonners Ferry, many revealed that they had been forced to move inventory and supplies four to six times between 1948 and 1972.

\section{B1.1.2 Stage-Damage Analysis}

Data on damageable property, including residential structures and contents, commercial/industrial, public, agriculture and emergency aid, were obtained from a detailed 1987 study, updated for price level and an assumed rate of growth, using field observations, interviews, maps, aerial photographs, and property tax assessment data. Damage, by stage, for all categories of damage is summarized on Table $B-1$. The zero dollar damage point for this reach is 1766.5 feet (assumed to be design levee height).

\section{B1.1.3 Average Annual Damages}

Stage - frequency relationships developed for the Bonners Ferry gage for each SOS were used to derive average annual damages for this damage reach. Details of this derivation can be found in Appendix E (Flood Control). Average annual damages were derived using Corps of Engineers Hydrologic Engineering Center computer program "Expected Annual Flood Damage Computation." This program integrates exceedence frequency with associated damages to determine annual damages for a given frequency interval. Even though some of the SOSs have different implementation dates (see Section 4.2 of this appendix), because none of the SOSs require modification of projects in the upper Columbia River Subarea, the analysis of average annual damages is based on the presumption that system operation changes affecting upper Columbia River projects can be made in 1995 (the base year for the analysis of impacts) for all SOSs. With implementation of upper Columbia River elements of each SOS possible in 1995, potential flood dam- ages in this reach are expected to be the same over the entire period of analysis. Therefore, it was not necessary to present-value damages for any of the SOSs, and average annual damages are the same for both rates of interest used in the study -3.0 percent and 7.75 percent. Table $B-2$ presents a summary of expected average annual damages by damage category for each SOS.

\section{B1.2 COLUMBIA FALLS TO FLATHEAD LAKE}

The primary area of potential flood damages along the upper Flathead River downstream of Hungry Horse Dam occurs in the reach between Columbia Falls, Montana and Flathead Lake. Residential and commercial damages are concentrated in an area adjacent to the city of Kalispell, Montana, and agricultural damages are predominately upstream and downstream of this area. The slope of the Flathead River from its source to Columbia Falls is very steep. In the damage reach between Columbia Falls and Flathead Lake, the slope varies from 5 to 7 feet per mile $(1.5-2.1 \mathrm{~m} / \mathrm{km})$. The river flows through meandering channels in a floodplain varying from 1 to about 3 miles $(1.6-4.8 \mathrm{~km})$ wide. Duration of floods are relatively short because of regulation of the South Fork of the Flathead River by Hungry Horse Dam. During the extremely rare flood of June 1964, the river had a maximum rate of rise of about 1 foot $(.30 \mathrm{~m})$ per hour at the Columbia Falls gage and remained out of banks between two and three days. Velocities of water during major floods range up to six feet $(1.83 \mathrm{~m})$ per second in the channel. Overbank velocities vary widely, depending on location, but are generally less than three feet (.91 m) per second.

Flood damage prevention measures within this damage reach include several miles of levees along both banks of the river, channel improvements and realignments, bank protection and erosion control devices. The South Fork of the Flathead River, a major tributary of the river upstream of Columbia Falls, is regulated by Hungry Horse Dam, a Federal multi-purpose project completed in 1951. The regulation of the South Fork during large floods reduces the extent and duration of flooding in the lower valley. 


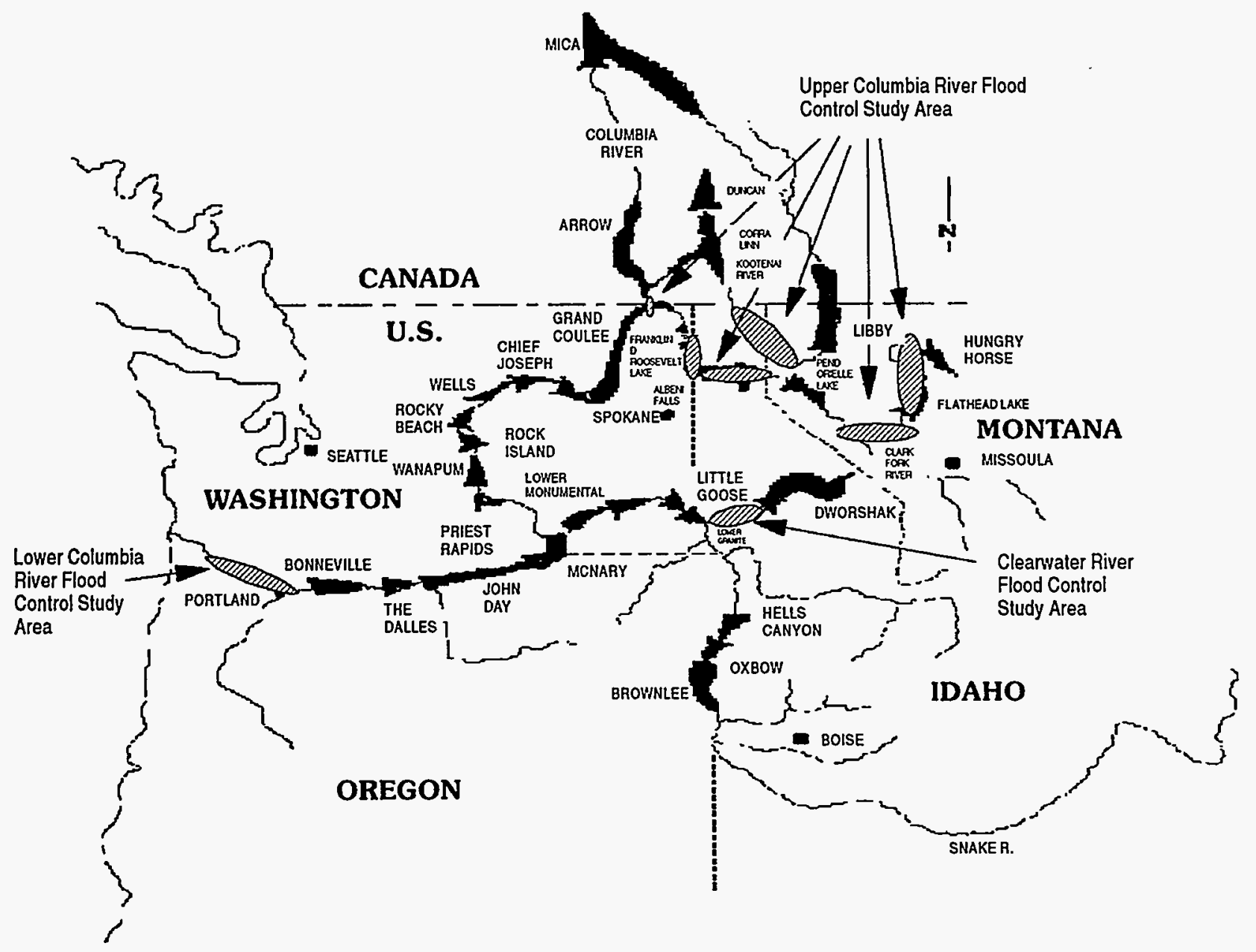

Figure B-1. Analysis of Flood Damages 
Table B-1. Stage vs Flood Damage Libby Dam to Kootney Lake (July 1992 Prices \& 1995 Conditions) $(\$ 1,000)$

\begin{tabular}{|c|c|c|c|c|c|c|c|}
\hline Stage* & Residential & $\begin{array}{c}\text { Commercial/ } \\
\text { Industrial }\end{array}$ & Public & $\begin{array}{c}\text { Agri- } \\
\text { cultural }\end{array}$ & $\begin{array}{c}\text { Emergency } \\
\text { Aid }\end{array}$ & Other & $\begin{array}{c}\text { Total } \\
\text { Damages }\end{array}$ \\
\hline 1766.5 & 0 & 0 & 0 & 0 & 0 & 0 & 0 \\
\hline 1768.0 & 13 & 176 & 88 & 202 & 107 & 44 & 630 \\
\hline 1770.0 & 27 & 382 & 192 & 436 & 232 & 95 & 1,364 \\
\hline 1772.0 & 46 & 647 & 322 & 739 & 393 & 162 & 2,309 \\
\hline 1776.0 & 164 & 2,291 & 1,146 & 2,620 & 1,392 & 573 & 8,186 \\
\hline 1777.0 & 235 & 3,291 & 1,646 & 3,761 & 1,998 & 823 & 11,754 \\
\hline 1778.0 & 399 & 5,583 & 2,792 & 6,380 & 3,390 & 1,396 & 19,940 \\
\hline 1780.0 & 936 & 13,107 & 6,553 & 14,978 & 7,957 & 3,276 & 46,807 \\
\hline 1781.0 & 1,008 & 14,105 & 7,052 & 16,120 & 8,564 & 3,526 & 50,375 \\
\hline 1782.0 & 1,049 & 14,693 & 7,346 & 16,792 & 8,921 & 3,673 & 52,474 \\
\hline
\end{tabular}

* Elevation in MSL Datum

\section{B1.2.1 Flood History}

The Flathead River floods the lower portions of this damage reach about once in every four years.

Higher elevations of the floodplain are flooded less frequently. Normally flooding is caused by runoff from snowmelt. Floods from snowmelt are the basis for the Standard Project Flood. Normally, Standard Project Floods are extremely rare occurrences and on most rivers are usually larger than floods that have occurred. The largest recent flood was larger than the standard project flood (SPF) and occurred in June of 1964. The June 1964 flood was approximately 70 percent greater in magnitude than the calculated SPF on the Flathead River. The June 1964 flood, however, was caused by rainfall rather than snowmelt and is an extremely rare event. Nevertheless, a recurrence of this flood event in 1995 (July 1992 prices) would result in $\$ 27.8$ million in damages. Major floods in 1932, 1933, and 1948 also caused extensive damage. Damages from past floods have been revalued based on July 1992 prices and 1995 levels of development and are tabulated in Table B-3. Actual discharges of floods and damages caused by floods prior to October 1951 would now be reduced somewhat by available storage at Hungry Horse Reservoir. 
Table B-2. Average Annual Damages Libby Dam to Kootnay Lake (July 1992 Prices \& 1995 Conditions) $(\$ 1,000)$

\begin{tabular}{|l|r|r|r|r|r|r|r|}
\hline SOS & Residential & $\begin{array}{c}\text { Commercial/ } \\
\text { Industrial }\end{array}$ & Public & $\begin{array}{c}\text { Agri- } \\
\text { cultural }\end{array}$ & $\begin{array}{c}\text { Emergency } \\
\text { Aid }\end{array}$ & Other & $\begin{array}{c}\text { Total } \\
\text { Damages }\end{array}$ \\
\hline SOS 1a & $\$ 0.35$ & $\$ 4.90$ & $\$ 2.45$ & $\$ 5.60$ & $\$ 2.98$ & $\$ 1.22$ & $\$ 17.50$ \\
\hline SOS 1b & .35 & 4.90 & 2.45 & 5.60 & 2.98 & 1.22 & 17.50 \\
\hline SOS 2c & .35 & 4.90 & 2.45 & 5.60 & 2.98 & 1.22 & 17.50 \\
\hline SOS 2d & .35 & 4.90 & 2.45 & 5.60 & 2.98 & 1.22 & 17.50 \\
\hline SOS 4c & 9.24 & 129.22 & 64.61 & 147.71 & 78.49 & 32.30 & 461.57 \\
\hline SOS 5b & .35 & 4.90 & 2.45 & 5.60 & 2.98 & 1.22 & 17.50 \\
\hline SOS 5c & .35 & 4.90 & 2.45 & 5.60 & 2.98 & 1.22 & 17.50 \\
\hline SOS 6b & .35 & 4.90 & 2.45 & 5.60 & 2.98 & 1.22 & 17.50 \\
\hline SOS 6d & .35 & 4.90 & 2.45 & 5.60 & 2.98 & 1.22 & 17.50 \\
\hline SOS 9a & .79 & 10.86 & 5.44 & 12.43 & 6.60 & 2.71 & 38.83 \\
\hline SOS 9b & .91 & 12.57 & 6.29 & 14.38 & 7.64 & 3.14 & 44.93 \\
\hline SOS 9c & 9.35 & 133.36 & 66.68 & 152.44 & 81.00 & 33.33 & 476.34 \\
\hline PA & 1.00 & 13.78 & 6.90 & 15.77 & 8.37 & 3.44 & 49.26 \\
\hline
\end{tabular}

Table B-3. Historical Flows \& Flood Damage Columbia Falls to Flathead Lake (July 1992 Prices \& 1995 Conditions)

\begin{tabular}{|c|c|c|}
\hline Date of Flood & $\begin{array}{c}\text { Discharge* } \\
\text { (c.f.s.) }\end{array}$ & Damages \\
\hline May 1932 & 89,800 & $\$ 8,837,000$ \\
\hline June 1933 & 91,200 & $\$ 9,167,000$ \\
\hline May 1947 & 83,700 & $\$ 12,665,000$ \\
\hline May 1948 & 102,000 & $\$ 27,800,000$ \\
\hline June 1964 & 176,000 & $\$ 7,000$ \\
\hline $\begin{array}{l}\text { * Discharge at Columbia Falls U.S.G.S. Floods since October 1951 reduced by storage at Hungry Horse } \\
\text { Reservoir. }\end{array}$
\end{tabular}




\section{B1.2.2 Discharge - Damage Analysis}

Data on damageable property including residential, commercial, agriculture, and other (emergency aid and public) were obtained from a detailed 1980 study, updated for price level and an assumed rate of growth, using field observations, interviews, maps, aerial photographs, and property tax assessment data. Damage, by discharge, for all categories of damage is summarized on Table $\mathrm{B}-4$. The zero dollar damage point for this reach (assumed to be design levee height in areas with levees) is 52,000 c.f.s. $(1,472 \mathrm{~m} 3 / \mathrm{s})$.

\section{B1.2.3 Average Annual Damages}

The point of zero damage (assumed to be design level height in areas with levees) for this reach was determined from historical flood records and available information on stream bank-full capacity. Average annual damages were derived from discharge-damage data calculated for three hypothetical floods and the 1964 flood event. Discharge-frequency relationships developed for the Columbia Falls gage for each SOS were used in this analysis. Details of this derivation can be found in the Ap- pendix E (Flood Control). Average annual damages were derived using Corps of Engineers Hydrologic Engineering Center computer program "Expected Annual Flood Damage Computation." This program integrates exceedence frequency with associated damages to determine annual damages for a given frequency interval. Even though some of the SOSs have different implementation dates (see Section 4.2 of this appendix), because none of the SOSs require modification of projects in the upper Columbia River Subarea, the analysis of average annual damages is based on the presumption that system operation changes affecting upper Columbia River projects can be made in 1995 (the base year for the analysis of impacts) for all SOSs. With implementation of upper Columbia River elements of each SOS possible in 1995, potential flood damages in this reach are expected to be the same over the entire period of analysis. Therefore, it was not necessary to present-value damages for any of the SOSs and average annual damages are the same for both rates of interest used in the study -3.0 percent and 7.75 percent. Table B-5 presents a summary of expected average annual damages by damage category for each SOS.

Table B-4. Discharge vs Flood Damage Columbia Falls to Flathead Lake (July 1992 Prices \& 1995 Conditions) $(\$ 1,000)$

\begin{tabular}{|c|c|c|c|c|c|}
\hline Discharge & Residential & Commercial & $\begin{array}{c}\text { Agri- } \\
\text { cultural }\end{array}$ & Other & $\begin{array}{c}\text { Total } \\
\text { Damages }\end{array}$ \\
\hline $52,000 \mathrm{cfs}$ & $\$ 0$ & $\$ 0$ & $\$ 0$ & $\$ 0$ & $\$ 0$ \\
\hline 79,000 & 2,500 & 800 & 1,500 & 600 & 5,400 \\
\hline 100,000 & 6,500 & 2,400 & 4,000 & 1,500 & 14,400 \\
\hline 130,000 & 9,700 & 3,500 & 5,900 & 2,200 & 21,300 \\
\hline 176,000 & 12,600 & 4,700 & 7,700 & 2,800 & 27,800 \\
\hline
\end{tabular}


Table B-5. Average Annual Damages Columbia Falls to Flathead Lake (July 1992 Prices \& 1995 Conditions) $(\$ 1,000)$

\begin{tabular}{|l|l|l|l|l|l|}
\hline SOS & \multicolumn{1}{|c|}{ Residential } & $\begin{array}{c}\text { Commercial } \\
\text { Industrial }\end{array}$ & \multicolumn{1}{|c|}{ Agricultural } & \multicolumn{1}{|c|}{ Other } & \multicolumn{1}{c|}{$\begin{array}{c}\text { Total } \\
\text { Damages }\end{array}$} \\
\hline SOS 1a & $\$ 464.60$ & $\$ 154.90$ & $\$ 309.80$ & $\$ 103.20$ & $\$ 1032.50$ \\
\hline SOS 1b & 464.60 & 154.90 & 309.80 & 103.20 & 1032.50 \\
\hline SOS 2c & 464.60 & 154.90 & 309.80 & 103.20 & 1032.50 \\
\hline SOS 2d & 464.60 & 154.90 & 309.80 & 103.20 & 1032.50 \\
\hline SOS 4c & 464.60 & 154.90 & 309.80 & 103.20 & 1032.50 \\
\hline SOS 5b & 464.60 & 154.90 & 309.80 & 103.20 & 1032.50 \\
\hline SOS 5c & 464.60 & 154.90 & 309.80 & 103.20 & 1032.50 \\
\hline SOS 6b & 464.60 & 154.90 & 309.80 & 103.20 & 1032.50 \\
\hline SOS 6d & 464.60 & 154.90 & 309.80 & 103.20 & 1032.50 \\
\hline SOS 9a & 580.90 & 199.50 & 352.20 & 136.10 & 1268.70 \\
\hline SOS 9b & 464.60 & 154.90 & 309.80 & 103.20 & 1032.50 \\
\hline SOS 9c & 464.60 & 154.90 & 309.80 & 103.20 & 1032.50 \\
\hline PA & 464.60 & 154.90 & 309.80 & 103.20 & 1032.50 \\
\hline
\end{tabular}

\section{B1.3 FLATHEAD LAKE}

Flathead Lake is controlled by Kerr Dam which is located near Polson, Montana. Kerr Dam is owned by Montana Power Company and operated for power, flood control, and recreation. While Kerr Dam regulates the level of Flathead Lake and thus prevents flooding to lake front property, the dam is primarily operated to prevent flooding upstream of the lake which is caused by backwater effects of high lake levels and high Flathead River flows. Specifically, flooding in the Kalispell area begins if the lake level reaches elevation 2893 feet coincident with the river flow being above 52,000 c.f.s. $(1,472 \mathrm{~m} 3 / \mathrm{s})$. The zero damage lake stage for lake front flooding is also 2893 feet. The springtime refill of Flathead Lake is jointly managed for flood control by the Corps of Engineers and Montana Power Company. The agreed upon target flood control rule curve for
Flathead Lake, if no flood potential exists in the river basin above the lake, is as follows:

\begin{tabular}{cc} 
Date & Lake Stage $(\mathbf{f t})$ \\
\cline { 2 - 2 } 15 April & 2883.0 \\
30 May & 2890.0 \\
15 June & 2893.0
\end{tabular}

\section{B1.3.1 Flood History}

No information has been found regarding historic flooding of Flathead Lake, but it is believed that lake front flooding has not been a significant problem since construction of Kerr Dam in 1938.

\section{B1.3.2 Stage-Damage Analysis}

Data on damageable property including residential, commercial, agriculture, and public were obtained by updating earlier studies through windshield field 
surveys conducted in 1993 and analysis of aerial photographs. Erosion losses of waterfront land and dock damage represent the majority of damages.

Erosion damage is included in the Residential and Public categories, and dock damage is included in the Residential category. The lake front floodplain has changed significantly over the years from a primarily rural agricultural area to a developing residential area of primary or recreational second homes. Damage, by lake stage, for all categories of damage is summarized on Table $B-6$. The zero dollar damage point for this reach is 2893 feet.

\section{B1.3.3 Average Annual Damages}

Average annual damages were derived for stagedamage data calculated for four hypothetical floods. Stage-frequency relationships, developed for the Polson gage, were used in this analysis. Details of these derivations can be found in Appendix E (Flood Control). Average annual damages were derived using Corps of Engineers Hydrologic Engineering Center computer program "Expected Annual Flood Damage Computation." This program integrates exceedence frequency with associated damage to determine annual damages for a given frequency interval. Even though some of the SOSs have different implementation dates (see Section 4.2 of this appendix), because none of the SOSs require modification of projects in the upper Columbia River Subarea, the analysis of average annual dam- ages is based on the presumption that system operation changes affecting upper Columbia River projects can be made in 1995 (the base year for the analysis of impacts) for all SOSs. With implementation of upper Columbia River elements of each SOS possible in 1995, potential flood damages in this reach are expected to be the same over the entire period of analysis. Therefore, it was not necessary to present-value damages for any of the SOSs and average annual damages are the same for both rates of interest used in the study -3.0 percent and 7.75 percent. Table B-7 presents a summary of expected average annual damages by damage category for each SOS.

\section{B1.4 KERR DAM TO THOMPSON FALLS}

The primary areas of potential flooding in this damage reach include the lower Flathead River from Kerr Dam to the confluence with the Clark Fork River, and along the Clark Fork to Thompson Falls, Montana. Partial flood protection is provided by Hungry Horse Dam and locally constructed levees at several locations. This reach, which extends over 100 miles $(161 \mathrm{~km})$, is primarily rural, with agricultural activities predominating. The one urban area in this reach with potential significant flood damages is the town of Plains, Montana, with a 1990 population of 992. In addition to residential development, the Sanders County Fairground is located in the floodplain in this community.

Table B-6. Stage vs Flood Damage - Flathead Lake (July 1992 Prices \& 1995 Conditions) $(\$ 1,000)$

\begin{tabular}{|c|c|c|c|c|c|}
\hline Stage* & Residential & Commercial & $\begin{array}{c}\text { Agri- } \\
\text { culture }\end{array}$ & Public & $\begin{array}{c}\text { Total } \\
\text { Damages }\end{array}$ \\
\hline 2893 & $\$ 0$ & $\$ 0$ & $\$ 0$ & $\$ 0$ & $\$ 0$ \\
\hline 2895 & 2,000 & 80 & 40 & 520 & 2,640 \\
\hline 2897 & 3,970 & 200 & 100 & 1,040 & 5,310 \\
\hline 2899 & 5,990 & 400 & 200 & 1,580 & 8,170 \\
\hline 2900 & 7,300 & 500 & 250 & 2,100 & 10,150 \\
\hline
\end{tabular}

* Elevation in MSL Datum 
Table B-7. Average Annual Damages Flathead Lake (July 1992 Prices \& 1995 Conditions) $(\$ 1,000)$

\begin{tabular}{|l|l|l|l|l|l|}
\hline SOS & Residential & $\begin{array}{c}\text { Commercial/ } \\
\text { Industrial }\end{array}$ & \multicolumn{1}{|c|}{ Agricultural } & \multicolumn{1}{c|}{ Public } & \multicolumn{1}{c|}{$\begin{array}{c}\text { Total } \\
\text { Damages }\end{array}$} \\
\hline SOS 1a & $\$ 146.20$ & $\$ 5.80$ & $\$ 3.90$ & $\$ 39.00$ & $\$ 194.90$ \\
\hline SOS 1b & 146.20 & 5.80 & 3.90 & 39.00 & 194.90 \\
\hline SOS 2c & 146.20 & 5.80 & 3.90 & 39.00 & 194.90 \\
\hline SOS 2d & 146.20 & 5.80 & 3.90 & 39.00 & 194.90 \\
\hline SOS 4c & 146.20 & 5.80 & 3.90 & 39.00 & 194.90 \\
\hline SOS 5b & 146.20 & 5.80 & 3.90 & 39.00 & 194.90 \\
\hline SOS 5c & 146.20 & 5.80 & 3.90 & 39.00 & 194.90 \\
\hline SOS 6b & 146.20 & 5.80 & 3.90 & 39.00 & 194.90 \\
\hline SOS 6d & 146.20 & 5.80 & 3.90 & 39.00 & 194.90 \\
\hline SOS 9a & 146.20 & 5.80 & 3.90 & 39.00 & 194.90 \\
\hline SOS 9b & 146.20 & 5.80 & 3.90 & 39.00 & 194.90 \\
\hline SOS 9c & 146.20 & 5.80 & 3.90 & 39.00 & 194.90 \\
\hline PA & 227.90 & 9.40 & 4.70 & 59.30 & 301.30 \\
\hline
\end{tabular}

\section{B1.4.1 Flood History}

No information has been found regarding historic flooding in this damage reach, but the Corps of Engineers has repaired flood damaged levees several times over the years in this area.

\section{B1.4.2 Discharge - Damage Analysis}

Data on damageable property including agriculture, residential and public were obtained by updating earlier studies by windshield field surveys conducted in 1992 and analysis of aerial photographs. Damageable property in the floodplain has changed little (except cropping patterns) in the last 25 years. Damage, by discharge, for all categories of damage is summarized on Table B-8. The zero dollar damage point for this reach (assumed to be design levee height in the area with a levee) is 28,000 c.f.s. (793 m3/s).

\section{B1.4.3 Average Annual Damages}

Average annual damages were derived for discharge-damage data calculated for five hypothetical floods. Discharge-frequency relationships, developed for the Polson gage, were used in this analysis. Details of these derivations can be found in the Appendix E (Flood Control). Average annual damages were derived using Corps of Engineers Hydrologic Engineering Center Computer Program "Expected Annual Flood Damage Computation. This program integrates exceedance frequency with associated damage to determine annual damages for a given frequency interval. Even though some of the SOSs have different implementation dates (see Section 4.2 of this appendix), because none of the SOSs require modification of projects in the upper Columbia River Subarea, the analysis of average annual damages is based on the presumption that system operation changes affecting upper Columbia River projects can be made in 1995 (the base year for the analysis of impacts) for all SOSs. With 
implementation of upper Columbia River elements of each SOS possible in 1995, potential flood damages in this reach are expected to be the same over the entire period of analysis. Therefore, it was not necessary to present-value damages for any of the SOSs and average annual damages are the same for both rates of interest used in the study- -3.0 percent and 7.75 percent. Table $B-9$ presents a summary of expected average annual damages by damage category for each SOS.
This program integrates exceedance frequency with associated damage to determine annual damages for a given frequency interval. Table B-9 presents a summary of expected average annual damages for each SOS. Since damages are expected to be the same over the entire period of analysis, it was not necessary to present-value damages for any of the SOSs. Therefore, average annual damages are the same for both rates of interest used in the study --3.0 percent and 8.25 percent.

Table B-8. Discharge vs Flood Damage Kerr Dam to Thompson Falls (July 1992 Prices \& 1995 Conditions-\$)

\begin{tabular}{|c|c|c|c|c|}
\hline Discharge & Agriculture & Residential & $\begin{array}{c}\text { Total } \\
\text { Public }\end{array}$ & Damages \\
\hline 28,000 & 0 & 0 & 0 & 0 \\
\hline 40,000 & $\$ 173,000$ & $\$ 92,000$ & $\$ 92,000$ & $\$ 357,000$ \\
\hline 60,000 & 330,000 & 176,000 & 175,000 & 681,000 \\
\hline 80,000 & 498,000 & 266,000 & 264,000 & $1,028,000$ \\
\hline 100,000 & 672,000 & 358,000 & 356,000 & $1,386,000$ \\
\hline 110,000 & 758,000 & 404,000 & 404,000 & $1,566,000$ \\
\hline
\end{tabular}

Table B-9. Average Annual Damages Kerr Dam to Thompson Falls (July 1992 Prices \& 1995 Conditions) $(\$ 1,000)$

\begin{tabular}{|c|c|c|c|c|}
\hline SOS & Residential & Agricultural & Public & $\begin{array}{c}\text { Total } \\
\text { Damages }\end{array}$ \\
\hline SOS 1a & $\$ 77.36$ & $\$ 145.18$ & $\$ 77.07$ & $\$ 299.61$ \\
\hline SOS 1b & 77.36 & 145.18 & 77.07 & 299.61 \\
\hline SOS 2c & 77.36 & 145.18 & 77.07 & 299.61 \\
\hline SOS 2d & 77.36 & 145.18 & 77.07 & 299.61 \\
\hline SOS 4c & 77.36 & 145.18 & 77.07 & 299.61 \\
\hline SOS 5b & 77.36 & 145.18 & 77.07 & 299.61 \\
\hline SOS 5c & 77.36 & 145.18 & 77.07 & 299.61 \\
\hline SOS 6b & 77.36 & 145.18 & 77.07 & 299.61 \\
\hline
\end{tabular}


Table B-9. Average Annual Damages Kerr Dam to Thompson Falls (July 1992 Prices \& 1995 Conditions) $(\$ 1,000)-$ CONT

\begin{tabular}{|l|c|c|c|c|}
\hline \multicolumn{1}{|c|}{ SOS } & Residential & Agricultural & Public & $\begin{array}{c}\text { Total } \\
\text { Damages }\end{array}$ \\
\hline SOS 6d & 77.36 & 145.18 & 77.07 & 299.61 \\
\hline SOS 9a & 77.36 & 145.18 & 77.07 & 299.61 \\
\hline SOS 9b & 77.36 & 145.18 & 77.07 & 299.61 \\
\hline SOS 9c & 77.36 & 145.18 & 77.07 & 299.61 \\
\hline PA & 99.18 & 186.16 & 98.83 & 384.17 \\
\hline
\end{tabular}

\section{B1.5 PEND OREILLE LAKE}

Pend Oreille Lake is controlled by Albeni Falls Dam which was constructed by the Corps of Engineers starting in 1951. It was authorized for the regulation of Pend Oreille Lake and for the associated purposes of flood control, navigation, conservation, recreation and power generation as part of the comprehensive plan of improvement for the Columbia River system. The flood control benefits of the project are realized from lowering of maximum stages on Pend Oreille Lake and controlling downstream discharges. The project was operational for flood control in 1952. The reservoir is formed by artificial control of Pend Oreille Lake between elevations 2062.5 and 2051.0 feet. The area of the lake at elevation 2062.5 is 94,600 acres $(37,840$ hectares) with 226 miles $(364 \mathrm{~km})$ of shoreline. The maximum flood control rule curve for Pend Oreille Lake as measured at Hope, Idaho, as well as minimum lake elevations allowed due to operating the project for other purposes are shown in Table $\mathrm{B}-10$.

\section{B1.5.1 Flood History}

The lowlands along Lake Pend Oreille and portions of the cities of Sandpoint and Priest River have been flooded in 1894, 1913, 1927, 1928, 1933, 1948, 1956, 1969, and 1974. The major cause of this flooding is snow-melt. The highest flooding occurred in 1894 , with damages estimated at $\$ 6.8$ million (1967 prices and development). Damage from previous flooding has included residential and commercial develop- ment in urban areas and grain crops, pasture land and roads in rural areas around the lake. Table B-11 presents maximum lake stages for selected historical floods.

\section{B1.5.2 Stage-Damage Analysis}

Data on damageable property including residential, commercial, agriculture, and public were obtained by updating earlier studies through windshield field surveys conducted in 1992 and analysis of aerial photographs. The lake front floodplain has changed significantly over the years from a primarily rural agricultural area to a developed area of commercial activity and primary or recreational second homes. Damage, by lake stage, for all categories of damage is summarized on Table $\mathrm{B}-12$. The zero dollar damage point for this reach is 2062.5 feet.

\section{B1.5.3 Average Annual Damages}

Average annual damages were derived for stagedamage data calculated for four hypothetical floods. Stage-frequency relationships, developed for the Hope gage, were used in this analysis. Details of these derivations can be found in Appendix E (Flood Control). Average annual damages were derived using Corps of Engineers Hydrologic Engineering Center Computer Program "Expected Annual Flood Damage Computation. This program integrates exceedance frequency with associated damage to determine annual damages for a given frequency interval. Even though some of the SOSs have different implementation dates (see Section 4.2 
of this appendix), because none of the SOSs require modification of projects in the upper Columbia River Subarea, the analysis of average annual damages is based on the presumption that system operation changes affecting upper Columbia River projects can be made in 1995 (the base year for the analysis of impacts) for all SOSs. With implementation of upper Columbia River elements of each SOS possible in 1995, potential flood damages in this reach are expected to be the same over the entire period of analysis. Therefore, it was not necessary to present-value damages for any of the SOSs and average annual damages are the same for both rates of interest used in the study- -3.0 percent and 7.75 percent. Table $B-13$ presents a summary of expected average annual damages by damage category for each SOS.

Table B-10. Maximum and Minimum Elevation for Pend Oreille Lake, as Measured at Hope Idaho

\begin{tabular}{|l|c|c|}
\hline \multirow{2}{*}{ Date } & \multicolumn{2}{|c|}{ Lake Stage } \\
\cline { 2 - 3 } & Maximum for Flood Control & Minimum \\
\hline July 31 & $2,062.5$ & $2,062.0$ \\
\hline August 31 & $2,062.5$ & $2,062.0$ \\
\hline September 30 & $2,062.5$ & $2,060.0$ \\
\hline October 31 & $2,060.0$ & $2,054.0$ \\
\hline December 31 & $2,056.0$ & $2,051.0$ \\
\hline January 31 & $2,060.0$ & $2,051.0$ \\
\hline February 28 & $2,060.0$ & $2,051.0$ \\
\hline March 31 & $2,056.0$ & $2,051.0$ \\
\hline April 30 & $2,056.0$ & $2,054.0$ \\
\hline
\end{tabular}

Table B-11. Maximum Stages of Lake Pend Oreille for Historic Floods (at Hope, Idaho)

\begin{tabular}{|c|c|}
\hline Date & Lake Stage \\
\hline 1894 Flood & $2075.9^{*}$ \\
\hline 1913 Flood & 2068.6 \\
\hline 1927 Flood & 2068.0 \\
\hline 1928 Flood & 2068.5 \\
\hline 1933 Flood & 2068.6 \\
\hline 1948 Flood & $2071.6^{*}$ \\
\hline 1974 Flood & not available \\
\hline \multicolumn{2}{|c|}{$\begin{array}{l}{ }^{*} \text { With present upstream storage regulation } \\
\text { the maximum elevation of Lake Pend Oreille } \\
\text { for the } 1894 \text { and } 1948 \text { floods would be } 2069.3 \\
\text { and } 2067.7 \text {, respectively. }\end{array}$} \\
\hline
\end{tabular}


Table B-12. Stage vs Flood Damage Pend Oreille Lake (July 1992 Prices \& 1995 Conditions) $(\$ 100,000)$

\begin{tabular}{|l|c|c|c|c|c|}
\hline Stage & Residential & Commercial & Agriculture & Public & $\begin{array}{c}\text { Total } \\
\text { Damages }\end{array}$ \\
\hline 2062.5 & 0 & 0 & 0 & 0 & 0 \\
\hline 2065.0 & 10 & 7 & 2 & 6 & 25 \\
\hline 2067.0 & 26 & 17 & 6 & 15 & 64 \\
\hline 2069.0 & 58 & 35 & 14 & 34 & 141 \\
\hline 2071.0 & 113 & 69 & 26 & 67 & 275 \\
\hline
\end{tabular}

Table B-13. Average Annual Damages Pend Oreille Lake (July 1992 Prices \& 1995 Conditions) $(\$ 1,000)$

\begin{tabular}{|l|c|c|c|c|c|}
\hline \multicolumn{1}{|c|}{ SOS } & Residential & $\begin{array}{c}\text { Commercial/ } \\
\text { Industrial }\end{array}$ & Agricultural & Public & $\begin{array}{c}\text { Total } \\
\text { Damages }\end{array}$ \\
\hline SOS 1a & 269.60 & 168.50 & 67.40 & 168.50 & 674.00 \\
\hline SOS 1b & 269.60 & 168.50 & 67.40 & 168.50 & 674.00 \\
\hline SOS 2c & 269.60 & 168.50 & 67.40 & 168.50 & 674.00 \\
\hline SOS 2d & 269.60 & 168.50 & 67.40 & 168.50 & 674.00 \\
\hline SOS 4c & 269.60 & 168.50 & 67.40 & 168.50 & 674.00 \\
\hline SOS 5b & 269.60 & 168.50 & 67.40 & 168.50 & 674.00 \\
\hline SOS 5c & 269.60 & 168.50 & 67.40 & 168.50 & 674.00 \\
\hline SOS 6b & 269.60 & 168.50 & 67.40 & 168.50 & 674.00 \\
\hline SOS 6d & 269.60 & 168.50 & 67.40 & 168.50 & 674.00 \\
\hline SOS 9a & 269.60 & 168.50 & 67.40 & 168.50 & 674.00 \\
\hline SOS 9b & 269.60 & 168.50 & 67.40 & 168.50 & 674.00 \\
\hline SOS 9c & 269.60 & 168.50 & 67.40 & 168.50 & 674.00 \\
\hline PA & 269.60 & 168.50 & 67.40 & 168.50 & 674.00 \\
\hline
\end{tabular}




\section{B1.6 ALBENI FALLS DAM TO CUSICK}

The area subject to flooding along the Pend Oreille River downstream of Albeni Falls Dam is located in the reach known as Calispell Flats, in the vicinity of Cusick, Washington. In addition to the community of Cusick (1990 population 223), areas subject to flooding under natural conditions include about 15,000 acres $(6,000$ hectares) of agricultural land on the left (west) bank of the river and about 2,000 acres (800 hectares) of Kalispel Indian Reservation land located opposite of Cusick, on the east bank of the river. Prior to the completion of Albeni Falls Dam and other upstream storage, low levels of flood protection were provided to Cusick and agricultural lands on the left bank by locally constructed levees, which are no longer maintained.

\section{B1.6.1 Flood History}

Historically, before the area was partially protected by man-made levees, portions of the Calispell Flats area were inundated by yearly high water. The flood of record occurred in 1894 and had an estimated peak discharge of 195,000 cubic feet per second $(5,520 \mathrm{~m} 3 / \mathrm{s})$ at the Albeni Falls Dam site. Other major floods occurred in 1913, 1927, 1928, 1933, and 1948. Damage from previous flooding has been primarily agricultural and residential, but has also included some commercial and public property. Table $\mathrm{B}-14$ presents peak discharges for selected historical floods.

\section{Table B-14. Peak Discharges for Historic Floods (at Albeni Falls Damsite)}

\begin{tabular}{|c|c|}
\hline Date & Lake Stage \\
\hline 1894 Flood & 195,000 \\
\hline 1913 Flood & 139,000 \\
\hline 1927 Flood & 133,000 \\
\hline 1928 Flood & 137,000 \\
\hline 1933 Flood & 137,000 \\
\hline 1948 Flood & 171,300 \\
\hline
\end{tabular}

\section{B1.6.2 Discharge-Damage Analysis}

Data on damageable property including agriculture, residential, public, and commercial were obtained by updating earlier studies via windshield field surveys conducted in 1992 and analysis of aerial photographs. Damageable property in the floodplain has changed little (except cropping patterns) in the last 25 years. Damage, by discharge, for all categories of damage is summarized on Table B-15. The zero dollar damage point for this reach is 85,000 c.f.s. $(2,406 \mathrm{~m} 3 / \mathrm{s})$ which causes nuisance flooding in areas without levees. Substantial damages begin to occur at flows of about $120,000 \mathrm{cfs}$ which approximates the design levee height in the area protected by levees.

\section{B1.6.3 Average Annual Damages}

Average annual damages were derived for discharge-damage data calculated for five hypothetical floods. Discharge-frequency relationships, developed for the Newport gage, were used in this analysis. Details of these derivations can be found in Appendix E (Flood Control). Average annual damages were derived using Corps of Engineers Hydrologic Engineering Center computer program "Expected Annual Flood Damage Computation." This program integrates exceedance frequency with associated damage to determine annual damages for a given frequency interval. Even though some of the SOSs have different implementation dates (see Section 4.2 of this appendix), because none of the SOSs require modification of projects in the upper Columbia River Subarea, the analysis of average annual damages is based on the presumption that system operation changes affecting upper Columbia River projects can be made in 1995 (the base year for the analysis of impacts) for all SOSs. With implementation of upper Columbia River elements of each SOS possible in 1995, potential flood damages in this reach are expected to be the same over the entire period of analysis. Therefore, it was not necessary to present-value damages for any of the SOSs and average annual damages are the same for both rates of interest used in the study- -3.0 percent and 7.75 percent. Table B-16 presents a summary of expected average annual damages by damage category for each SOS. 
B1.7 SUMMARY OF FLOOD DAMAGES.

Flood damages for the Upper Columbia River subarea are summarized in Table B-17 by reach and SOS.

Table B-15. Discharge vs Flood Damage Albeni Falls to Cusick (July 1992 Prices \& 1995 Conditions) $(\$ 1,000)$

\begin{tabular}{|c|c|c|c|c|c|}
\hline Alt & Residential & $\begin{array}{c}\text { Commercial/ } \\
\text { Industrial }\end{array}$ & $\begin{array}{c}\text { Agri- } \\
\text { cultural }\end{array}$ & Public & $\begin{array}{c}\text { Total } \\
\text { Damages }\end{array}$ \\
\hline 85,000 & 0 & 0 & 0 & 0 & 0 \\
\hline 120,000 & 300 & 100 & 900 & 200 & 1,500 \\
\hline 140,000 & 900 & 200 & 2,700 & 400 & 4,200 \\
\hline 160,000 & 2,900 & 700 & 9,200 & 1,500 & 14,300 \\
\hline 180,000 & 4,200 & 1,100 & 13,100 & 2,100 & 20,500 \\
\hline 200,000 & 5,600 & 1,400 & 17,700 & 2,800 & 27,500 \\
\hline
\end{tabular}

Table B-16. Average Annual Damages Albeni Falls to Cusick (July 1992 Prices \& 1995 Conditions) $(\$ 1,000)$

\begin{tabular}{|l|c|c|c|c|c|}
\hline \multicolumn{1}{|c|}{ SOS } & Residential & $\begin{array}{c}\text { Commercial/ } \\
\text { Industrial }\end{array}$ & Agricultural & Public & $\begin{array}{c}\text { Total } \\
\text { Damages }\end{array}$ \\
\hline SOS 1a & $\$ 216.17$ & $\$ 57.65$ & $\$ 665.77$ & $\$ 116.61$ & $\$ 1056.20$ \\
\hline SOS 1b & 216.17 & 57.65 & 665.77 & 116.61 & 1056.20 \\
\hline SOS 2c & 216.17 & 57.65 & 665.77 & 116.61 & 1056.20 \\
\hline SOS 2d & 216.17 & 57.65 & 665.77 & 116.61 & 1056.20 \\
\hline SOS 4c & 216.17 & 57.65 & 665.77 & 116.61 & 1056.20 \\
\hline SOS 5b & 216.17 & 57.65 & 665.77 & 116.61 & 1056.20 \\
\hline SOS 5c & 216.17 & 57.65 & 665.77 & 116.61 & 1056.20 \\
\hline SOS 6b & 216.17 & 57.65 & 665.77 & 116.61 & 1056.20 \\
\hline SOS 6d & 216.17 & 57.65 & 665.77 & 116.61 & 1056.20 \\
\hline SOS 9a & 216.17 & 57.65 & 865.77 & 116.61 & 1056.20 \\
\hline SOS 9b & 216.17 & 57.65 & 665.77 & 116.61 & 1056.20 \\
\hline SOS 9c & 216.17 & 57.65 & 665.77 & 116.61 & 1056.20 \\
\hline PA & 216.17 & 57.65 & 665.77 & 116.61 & 1056.20 \\
\hline
\end{tabular}


Table B-17. Summary of Flood Damages, Upper Columbia River Subarea $(\$ 1,000)$

\begin{tabular}{|c|c|c|c|c|c|c|c|}
\hline SOS & $\begin{array}{c}\text { Libby } \\
\text { Dam/ } \\
\text { Kootenay } \\
\text { Falls }\end{array}$ & $\begin{array}{c}\text { Columbia } \\
\text { Falls/ } \\
\text { Llathead } \\
\text { Lake }\end{array}$ & $\begin{array}{c}\text { Flathead } \\
\text { Lake }\end{array}$ & $\begin{array}{c}\text { Kerr } \\
\text { Dam/ } \\
\text { Thompson }\end{array}$ & $\begin{array}{c}\text { Pend } \\
\text { Oreille } \\
\text { Lake }\end{array}$ & $\begin{array}{c}\text { Albenai } \\
\text { Dam/ } \\
\text { Cusick }\end{array}$ & $\begin{array}{c}\text { Total } \\
\text { Damages }\end{array}$ \\
\hline SOS 1a & $\$ 17.50$ & $\$ 1032.50$ & $\$ 194.90$ & $\$ 299.60$ & $\$ 674.00$ & $\$ 1056.20$ & $\$ 3,274.70$ \\
\hline SOS 1b & 17.50 & 1032.50 & 194.90 & 299.60 & 674.00 & 1056.20 & $3,274.70$ \\
\hline SOS 2c & 17.50 & 1032.50 & 194.90 & 299.60 & 674.00 & 1056.20 & $3,274.70$ \\
\hline SOS 2d & 17.50 & 1032.50 & 194.90 & 299.60 & 674.00 & 1056.20 & $3,274.70$ \\
\hline SOS 4c & 461.60 & 1032.50 & 194.90 & 299.60 & 674.00 & 1056.20 & $3,718.80$ \\
\hline SOS 5b & 17.50 & 1032.50 & 194.90 & 299.60 & 674.00 & 1056.20 & $3,274.70$ \\
\hline SOS 5c & 17.50 & 1032.50 & 194.90 & 299.60 & 674.00 & 1056.20 & $3,274.70$ \\
\hline SOS 6b & 17.50 & 1032.50 & 194.90 & 299.60 & 674.00 & 1056.20 & $3,274.70$ \\
\hline SOS 6d & 17.50 & 1032.50 & 194.90 & 299.60 & 674.00 & 1056.20 & $3,274.70$ \\
\hline SOS 9a & 38.80 & 1268.70 & 194.90 & 299.60 & 674.00 & 1056.20 & $3,532.20$ \\
\hline SOS 9b & 44.90 & 1032.50 & 194.90 & 299.60 & 674.00 & 1056.20 & $3,302.10$ \\
\hline SOS 9c & 476.30 & 1032.50 & 194.90 & 299.60 & 674.00 & 1056.20 & $3,733.50$ \\
\hline PA & 49.30 & 1032.50 & 301.30 & 384.20 & 674.00 & 1056.20 & $3,497.50$ \\
\hline
\end{tabular}




\section{SECTION B2.0 - CLEARWATER RIVER SUBAREA}

\section{B2.1 INTRODUCTION}

The area of potential flood damage along the Clearwater River between Dworshak Dam and Lower Granite Reservoir has been divided into two damage centers or reaches. These areas are shown in Figure B-1 and are described below.

Flood control is one function of the present operation of the projects that make up the Columbia River System. In many cases, information on damage potential and flood control benefits have not been collected since the individual projects were formulated. In order to accurately assess tradeoffs between system outputs, it is necessary to have a current estimate of damage potential in areas protected. Changes in remaining average annual damages can then be weighed against other system outputs in considering changes to system operations.

Dworshak Dam and Reservoir on the North Fork, Clearwater River, is an element of the Columbia River System and provides flood damage reduction between the dam and Lower Granite Reservoir as well as on the lower Columbia River. The reach from Dworshak Dam to Lower Granite Reservoir is the subject of the discussion that follows. The lower Columbia River will be discussed separately as several system projects contribute to flood damage reduction there.

\section{B2.2 DAMAGE CENTERS}

The area of potential flood damage along the Clearwater River between Dworshak Dam and Lower Granite Reservoir has been divided into two reaches, as follows (the reaches are shown on Figure $B-1)$ :

Reach 1: The reach of the Clearwater River from Dworshak Dam to the upstream end of the Lewiston levees, near Potlatch, has no flood protection other than Dworshak. It is a long, relatively narrow valley whose floodplain includes roads and a railroad that parallel the river and occasional small areas of primarily residential development.

Reach 2: This reach begins at the upstream end of the Lewiston levees, near Potlatch, and ends at the confluence of the Snake and Clearwater Rivers. The city of Lewiston, at the confluence of the Clearwater and Snake Rivers, is protected by levees up to about river mile five on the Clearwater. These levees were built as part of the Lower Granite project in order to allow slackwater navigation to Lewiston. The levees provide Standard Project Flood protection with the existing regulation at Dworshak. The area protected by the levees is highly developed industrial, commercial and residential property.

\section{B2.2.1 Characteristics of the Floodplain}

Land forms in the area are comprised of high mountain ridges, steep slopes, narrow canyons and valleys, and a few sloping plateaus. Sites suitable for building are usually limited to the narrow valley bottoms which comprise the floodplain. Elevations in the area range from about 980 feet ( 300 meters) along the Clearwater River at Riverside to about 720 feet (219 meters) at Lewiston.

The lower Clearwater River between Orofino and Lewiston has an average width of about 600 feet (183 meters), a minimum width of about 300 feet (91 meters), and a maximum width of about 1,100 feet (335 meters). The average slope of the lower Clearwater River is approximately six to seven feet (1.8 to 2.1 meters) per mile. The average annual precipitation at Orofino and Lewiston is 27.60 and 12.78 inches (701.0 to 324.6 millimeters), respectively. At higher elevations, snow accumulates on the ground generally from September through the early spring and melts off in the late spring and early summer. The floodplain is approximately 40 miles (64.4 kilometers) in length and varies from approximately 0.06 miles ( 0.1 kilometer) wide downstream from 
Riverside to approximately 0.88 miles ( 1.4 kilometer) wide at the city of Lewiston.

The lower Clearwater River is generally well served by railroads, highways, and secondary roads from Lewiston upstream to Orofino. Five roadway bridges and two railroad bridges cross the lower Clearwater. U.S. Highway 12, which crosses Lolo Pass into Montana, parallels the river.

\section{B2.2.2 Flood History}

Large floods on the Clearwater River derive from three general causes: (1) spring snowmelt either with or without spring rainstorms, (2) severe winter rainstorms accompanied by snowmelt with high run-off induced by frozen ground, or (3) ice jams. The larger floods experienced in the floodplain in the period of record have been of the first of these types.

High velocity flows characteristic of floods on the Clearwater River result in water depths ranging from up to three feet in Reach 1 and up to 18 feet in Reach 2. These fast moving flows transport a large quantity of floating debris (trees, logs, parts, of houses, etc.). Flood protection varies from no levee protection in Reach 1 to Standard Project Flood protection in Reach 2--Standard Project Flood is defined as the flood that may be expected from the most severe combination of meteorological land hydrological conditions that are considered reasonably characteristic of the geographical area in which the drainage basin is located, excluding extremely rare conditions.

Floods on the Clearwater River at Spalding with unregulated maximum mean daily discharges in excess of approximately $100,000 \mathrm{cfs}(2,830$ cubic meters per second) have occurred on 19 occasions since October 1910 (see Table B-18). During the October 1910 through September 1913 and October 1925 through September 1985 periods (56 years), 17 events were spring snowmelt floods and two events were winter rainstorm and snowmelt floods. There was a damaging ice jam flood in 1963. During this period, the maximum peak instantaneous unregulated discharge was $177,000 \mathrm{cfs}$ ( 5,010 cubic meters per second) on 29 May 1948.

Unit 1 of power plant at Dworshak Dam was placed in service in March 1973. Since that time, regulated discharges above $100,000 \mathrm{cfs}$ (2,830 cubic meters per second) have occurred only twice. Table $B-18$ is a listing of maximum mean daily unregulated discharges of $99,000 \mathrm{cfs}(2,800$ cubic meters per second) or greater which have occurred (or would have occurred without Dworshak Dam) since 1927.

Available postflood information is not sufficiently detailed to allow identification of damages in the specific reach between Lewiston and Orofino.

\section{B2.3 PROPERTY INVENTORY}

In order to properly assess flood damages, an inventory of property within the floodplain was taken. A dollar value was assessed to each type of damage in order to obtain as accurate as possible total damage figure for the entire reach.

\section{B2.3.1 Analytical Procedures}

Different methods were used to determine property inventory for Reaches 1 and 2 because of the differences between the two reaches. Reach 1 is essentially undeveloped. The approximate 240 damageable structures are located in the extreme upstream portion of the reach. These structures are basically single family residences. Reach 2 , however, is essentially totally developed. In addition to over 900 damageable structures, Reach 2 also accrues significantly more damage to roads, railroads, utilities, emergency expenses (than Reach 1) as well as navigation and hydropower loss. The following paragraphs detail the procedures followed in determining property inventory. 
Table B-18. Clearwater River Winter Rainstorms and Winter and Spring Snowmelt Floods Summary of Unregulated Discharge and Runoff at Spalding

\begin{tabular}{|c|c|c|}
\hline $\begin{array}{l}\text { Sequential } \\
\text { Order }\end{array}$ & $\begin{array}{l}\text { Date of } \\
\text { Flood }\end{array}$ & $\begin{array}{c}\text { Maximum Mean } \\
\text { Daily Discharge } \\
\text { (CFS) }\end{array}$ \\
\hline 1 & June 9, 1927 & 106,000 \\
\hline 2 & May 26, 1928 & 104,000 \\
\hline 3 & May 14,1932 & 114,000 \\
\hline 4 & June 10,1933 & 128,000 \\
\hline 5 & Dec 23, 1933 & 157,000 \\
\hline 6 & May 15,1936 & 101,000 \\
\hline 7 & Apr 19, 1938 & 123,000 \\
\hline 8 & May 9, 1947 & 108,000 \\
\hline 9 & May 29, 1948 & 166,000 \\
\hline 10 & May 16, 1949 & 117,000 \\
\hline 11 & May 21, 1956 & 112,000 \\
\hline 12 & May 20, 1957 & 123,000 \\
\hline 13 & June 9,1964 & 117,000 \\
\hline 14 & Dec 23, 1964 & 99,000 \\
\hline 15 & April 21, 1965 & 109,000 \\
\hline 16 & May 13,1971 & 100,000 \\
\hline 17 & June 2, 1972 & 123,700 \\
\hline 18 & June 16,1974 & 132,000 \\
\hline 19 & May 11, 1976 & 104,600 \\
\hline \multicolumn{3}{|c|}{$\begin{array}{l}\text { *1 Maximum peak discharge of } 177,000 \text { cfs occurred only once during the period of record--May } 29,1948 . \\
\text { The period of record extends over water years } 1911-1913 \text { and } 1926-1985 \text {. This was the instantaneous peak } \\
\text { during a } 15-\text { minute period, the average daily discharge for this event was } 166,000 \mathrm{cfs} \text {. } \\
\text { Source: Water Control Manual for Dworshak Dam \& Reservoir, North Fork Clearwater River, Idaho. } \\
\text { USACE, CENPW, November } 1986 \text { pp. 4-20/4-21. }\end{array}$} \\
\hline
\end{tabular}




\section{B2.3.1.1 Reach 1 - Dworshak Dam to Lewiston Levees}

The floodplain from Dworshak Dam to the upstream end of the Lewiston levees was defined for two floods using floodway boundary maps issued by FEMA (Federal Emergency Management Agency $1983 \mathrm{~b}$ and 1983c). Water surface elevations (profiles) were obtained from Corps of Engineers, (Walla Walla District, Corps of Engineers 1968), and FEMA (Federal Emergency Management Agency, 1983a and 1979). The point at which damages begin was assumed to be 115,000 cfs based on historical flood damages, discussion with Corps of Engineers, Walla Walla District, Hydrology Branch, and reference material (Walla Walla District, Corps of Engineers, 1986).

Ground elevations and floodplain cross sections, used to establish water depths, were derived from Department of the Interior, Geological Survey, quadrangle maps and the floodplain information cited above. A field inventory of structures in the floodplain was made in April 1992. Data gathered included structure type, square footage, distance from first floor to ground, age, and condition.

Data on other types of damageable property including roads, bridges, utilities, and agricultural land was obtained from field observations, maps, aerial photographs and interviews (that included city, county, railroad, and utility officials).

\section{B2.3.1.2 Reach 2 - Lewiston Levees to the Snake River}

The only flood event for which damage was estimated for Reach 2 was a levee overtopping event. Levees, which were built as part of the Lower Granite project, provide protection from flows up to and including $150,000 \mathrm{cfs}$. This discharge is the Standard Project Flood with the current regulation by Dworshak Dam and Reservoir. Floodplain and water surface elevations were obtained from Corps of Engineers, Walla Walla District, Hydrology Branch.

Structure values within the floodplain were obtained from the Nez Perce County Assessor. Data on other types of damageable property including roads, bridges, and utilities was obtained from field observations, maps, aerial photographs and interviews (that included city, county, railroad and utility officials).

\section{B2.3.2 Description of the Floodplain}

The area of potential flood damage along the Clearwater River between Dworshak Dam and Lower Granite Reservoir is a relatively narrow, long (approximately 40 miles in length) floodplain. Structure development is centered on either end of the floodplain with agriculture and undeveloped land in between. A system of roads, railroads and bridges run throughout the study area.

\section{B2.3.2.1 Reach 1}

The floodplain in Reach 1 extends approximately from river mile five to river mile 40 . The area ranges in width from 0.06 miles wide just downstream of Riverside to 0.77 miles at the Potlatch industrial site. Discharges, for which damages were estimated, in this reach range from 122,000 and $142,000 \mathrm{cfs}$ at the Spalding gauge, (Walla Walla District, Corps of Engineers, 1968, plate 12, and Federal Emergency Management Agency, 1983a, page 9).

The winter Standard Project Flood at Spalding has a natural peak of $280,000 \mathrm{cfs}$ and can be regulated to $150,000 \mathrm{cfs}$ by Dworshak. The bankfull and flood stage discharges at Spalding are both $115,000 \mathrm{cfs}$. (Walla Walla District, Corps of Engineers, 1986, pages 4 - 27.)

\section{B2.3.2.2 Reach 2}

The floodplain in Reach 2 extends from the upstream end of the Lewiston levees at the Potlatch Forest Industries site to the confluence of the Snake and Clearwater Rivers. The area ranges in width from 0.77 miles at the Potlatch site to 0.88 miles wide at downtown Lewiston. Levees provide protection from flows up to and including $150,000 \mathrm{cfs}$ which is Standard Project Flood with the current regulation by Dworshak Dam and Reservoir. Flood damage discharge for this reach was assumed to be $151,000 \mathrm{cfs}$, which would be a levee overtopping flood. 


\section{B2.3.3 Quantitative Reach Information}

Land and improvements in Reaches 1 and 2 sustain significantly different damages because of the variation in level and type of development and disparity in depth of flooding.

\section{B2.3.3.1 Reach 1}

Flood damage in Reach 1 consists of erosion of highways, railroads, levees, and bridge abutments, with some flooding of low-lying rural residential and agricultural properties. The type and number of structures and other property included in this reach are listed in Table B-19. These structures are affected by flows of $140,000 \mathrm{cfs}$ (in the upstream portion of the reach) and $142,000 \mathrm{cfs}$ (in the downstream portion of the reach).

\section{B2.3.3.2 Reach 2}

Flood damage in the Reach 2 would be catastrophic. Damage to this highly developed area would include loss of residential, commercial, industrial, and public structures and contents, as well as damage to roads, railroads, utilities, navigation and hydropower. Also, in spite of the warning time, there is a moderate probability that the high water velocity combined with the water depth (eight feet and 13 feet) could lead to loss of life. The structures are affected by the levee overtopping flood. The type and number of structures and other property included in this reach are listed in Table B-20.

\section{B2.4 PROPERTY VALUATION AND DAMAGE}

To obtain an accurate assessment of property valuation and damage, each damage category was studied independently. The value and damage of each category was determined by the best method available (assessor's data, depreciated replacement value, or values assigned by category experts).

Table B-19. Inventory of Damageable Property, Reach 1 *

\begin{tabular}{|l|c|}
\hline Category & Number \\
\hline Residential & 234 structures \\
\hline Commercial & 120 structures \\
\hline Subject to Emergency Expense & 1.7 miles \\
\hline Gravel Roads & 2.3 miles \\
\hline Paved Roads & 1.5 miles \\
\hline Railroad & 44 acres \\
\hline Agricultural Land & 5 acres \\
\hline Scrap Yards & 146 nests \\
\hline Sports Access & boat ramps \\
\hline Goose Nests & * \\
\hline * Two different source books were used due to geographic regions within the reach. \\
\hline
\end{tabular}


Table B-20. Inventory of Damageable Property, Reach 2

\begin{tabular}{|c|c|}
\hline Category & Number \\
\hline Residential & 205 structures \\
\hline Commercial & 518 structures \\
\hline Industrial & 20 structures \\
\hline Substructures & 17 structures \\
\hline Public & 148 structures \\
\hline Gravel Roads & 11 miles \\
\hline Paved Roads & 28 miles \\
\hline Parking Lots & 156 acres \\
\hline Railroad & 7 miles of track \\
\hline Power & 3 substations \\
\hline Traffic Signals & 16 signals \\
\hline Telephone, Electric \& Cable TV & 31 miles \\
\hline Subject to Emergency Expense & 205 structures \\
\hline Waterworks & 55 miles \\
\hline Natural Gas & 26 miles \\
\hline Junk Yards & 3 acres \\
\hline Sports Access & 2 boat ramps \\
\hline
\end{tabular}

\section{B2.4.1 Reach 1}

The damages in this reach, are the result of fast moving, high volume water up to depths of three feet. The major categories of damageable property include residential, commercial and industrial structures and contents, railroads, roads, emergency expenses, agriculture, scrap yards, boat ramps, and goose nests. Flood damage estimates at various discharges are shown in Table B-21. 


\section{Table B-21. SOR Flood Control - Discharge/Damage Summary Clearwater River - Reach 1 Mouth of North Fork, Clearwater River to the Upstream End of Lewiston Levees, October 1992 Price Level}

\begin{tabular}{|l|r|r|r|r|r|r|}
\hline Discharge & $\begin{array}{c}\text { Total } \\
\text { Structures }\end{array}$ & $\begin{array}{c}\text { Total } \\
\text { Contents }\end{array}$ & \multicolumn{1}{c|}{ Rail road } & \multicolumn{1}{c|}{ Road } & \multicolumn{1}{c|}{$\begin{array}{c}\text { Total } \\
\text { Other }\end{array}$} & $\begin{array}{c}\text { Total } \\
\text { Damages }\end{array}$ \\
\hline $115,000 \mathrm{CFS}$ & $\$ 0$ & $\$ 0$ & $\$ 0$ & $\$ 0$ & $\$ 0$ & $\$ 0$ \\
\hline $120,000 \mathrm{CFS}$ & $\$ 84,000$ & $\$ 30,000$ & $\$ 177,500$ & $\$ 430,000$ & $\$ 35,000$ & $\$ 756,500$ \\
\hline $122,000 \mathrm{CFS}$ & $\$ 117,243$ & $\$ 43,254$ & $\$ 250,000$ & $\$ 507,829$ & $\$ 42,969$ & $\$ 961,295$ \\
\hline $125,000 \mathrm{CFS}$ & $\$ 145,000$ & $\$ 72,500$ & $\$ 342,500$ & $\$ 677,500$ & $\$ 62,500$ & $\$ 1,300,000$ \\
\hline $130,000 \mathrm{CFS}$ & $\$ 231,539$ & $\$ 190,878$ & $\$ 593,260$ & $\$ 826,532$ & $\$ 99,891$ & $\$ 1,942,100$ \\
\hline $140,000 \mathrm{CFS}$ & $\$ 451,497$ & $\$ 253,062$ & $\$ 642,010$ & $\$ 954,433$ & $\$ 131,169$ & $\$ 2,432,171$ \\
\hline $142,000 \mathrm{CFS}$ & $\$ 466,352$ & $\$ 257,880$ & $\$ 645,260$ & $\$ 972,400$ & $\$ 135,929$ & $\$ 2,477,821$ \\
\hline
\end{tabular}

Assumptions used in the calculation of damages in Reach 1 are as follows:

Structures: Structure values were estimated using the replacement cost less depreciation method. The estimates were based on square footage, age, and condition. The structure data was obtained during the April 1992 field survey.

Contents: Value of contents were assumed to be 40 percent of structure value. Damage to structures and content was estimated by combining water depths and depth damage functions for various structure types to estimate damages to structures and contents. Data for structures was entered into a computer program created by Walla Walla District, Corps of Engineers, that calculates depreciated structure value. The program also calculates damage in 0.10 foot increments based on depth damage relationships for structures and contents for 27 building types (structures and substructures).

Emergency Expense: The number of structures that would have water depth over the first floor multiplied by the number of days that inhabitants would have to relocate to a motel multiplied by $\$ 70$ per day.

Agriculture: The 44 acres of agricultural land was assumed to hay crop land. Damage was calculated to be $\$ 210$ per acre.
Bridges: Bridge decks within the reach were compared with water surface profiles. It was determined that the closest bridge deck (at Cherry Lane) is 1.0 feet above the 500 Year Flood (i.e. Standard Project Flood). Therefore, we assumed no direct damage to bridges. Damages to bridge approaches were included in road damages.

Utilities: There is a minimal amount of utilities in the floodplain. Damages are included in estimates for structures and roads.

Railroad: Based on an interview with the Camas Prairie Railroad Roadmaster, a value of $\$ 190$ per linear foot was assigned to inundated track.

Roads: Damage to roads was calculated on costs per mile of inundation. Values of $\$ 52.40$ and $\$ 36.05$ per linear foot were assigned to paved and gravel roads respectively. These values were based on actual flood damages in a similar floodplain situation in which high velocity water intermittently washed out roads. No dollar value was assigned for traffic interruption or detours.

Scrap Yards: A value of $\$ 2,000$ per acre, based on depths of one to two feet, was assigned for cleanup.

Sports Access: A value of $\$ 3,000$ per boat ramp was assigned. Total destruction was assumed based on interviews with Walla Walla District, Corps of Engineers, Operations Branch, Resource Management. 
Goose Nests: Based on interviews with Idaho Fish and Game and Walla Walla District, Corps of Engineers, Environmental Branch, a value of $\$ 27,000$ was assigned for loss of goslings and nests.

\section{B2.4.2 Reach 2}

Damages in Reach 2 are the result of a levee overtopping event. High velocity water overtops, and consequently undermines the levee, resulting in a levee breach. The subsequent flooding results in water depths of up to 18 feet of fast moving water and debris. The major categories of damageable property include residential, commercial, industrial and public structures and contents, roads, railroads, utilities, emergency expenses, and losses to navigation and power. The value of damageable property and damages at the $151,000 \mathrm{cfs}$ flood event are shown in Table B-22. (The format is different for Tables $\mathrm{B}-21$ and $\mathrm{B}-22$ because flood damages were analyzed for a range of flows in Reach 1 . However, only the levee overtopping event was addressed in Reach 2.)

Assumptions used in the calculation of the damages in Reach 2 are as follows:

Structures: Structure values were obtained from Nez Perce County Assessor. Floodplain structure data in Reach 2 was combined with water depths and depth damage functions to estimate damages.

However, given that flooding in Reach 2 would be characterized by deep, fast moving water, Building Collapse Curves and Depth-Percent Damage curves were used (Institute for Water Resources, 1984). Rather than compute damage to structures in Reach 2 on an individual basis as in Reach 1, damage was computed in groups because of the large number of like structures flooded to a similar depth and degree. Structures in Reach 2 were grouped by category (residential, commercial, industrial, and public) in areas corresponding to Assessor's records (Short Codes), and of similar flood depths. Table B-23 shows depth and percent damage for Reach 2 by structure type and location.

Inventory: Inventory value and damage was not included in calculations because inventory valuation data was not available from the Nez Perce County Assessor and another reliable method of estimating inventory value was not available. Therefore, damage figures are not inclusive of inventory damage. However, with warning of impending levee overtopping, efforts will be made to relocate inventory and this is not believed to be a significant omission of damage.

Residential Contents: Residential content value was assigned 40 percent of structure value.

Industrial Contents: Industrial content value was obtained from Nez Perce County Assessor.

Commercial Contents: Content value of commercial structures was derived by subtracting industrial personal property from total personal property value in the commercial and industrial areas (both of which were provided by Nez Perce County Assessor). To be consistent with our procedure of accounting for structure and content values by the Assessor Short Code zones, the total commercial content value was allocated among the Assessor Short Code zones based on a ratio of total commercial structures to total structures in the floodplain.

Public Contents: Content value of public buildings was obtained by taking the percentage of commercial content value to commercial structure value and applying this factor to public structures. Note that Port of Lewiston structures compose 70 percent of public structures.

Emergency Expense: Levee repair and cleanup of debris was added to the relocation cost of inhabitants of structures with water over the first floor. Cleanup and repair was calculated at $\$ 1,100$ per foot of the 4,000 foot levee system. (This figure was derived for reports that were used as a backup for the Lower Granite Sedimentation Study, (Walla Walla District, Corps of Engineers, 1992.)

Traffic Signals: Based on an interview with City of Lewiston Transportation Engineer, it was estimated to cost $\$ 100,000$ to replace a four-leg traffic signal intersection and $\$ 25,000$ for minor repair. For the levee overtopping flood, it was assumed that one out of five traffic signals was destroyed and the other four would require repair. 
Table B-22. SOR Flood Control - Damage Summary Clearwater River - Reach 2 Confluence of Snake River to Downstream of Lewiston Levee with Occurrence of a Levee Overtopping Flood $\quad(151,000 \mathrm{cfs})-$ October 1992 Price Level

\begin{tabular}{|c|c|c|c|c|c|c|}
\hline $\begin{array}{c}\text { Property } \\
\text { Type }\end{array}$ & $\begin{array}{l}\text { Number of } \\
\text { Structures }\end{array}$ & $\begin{array}{l}\text { Value of } \\
\text { Structures }\end{array}$ & $\begin{array}{l}\text { Structure } \\
\text { Damage }\end{array}$ & $\begin{array}{l}\text { Value of } \\
\text { Contents }\end{array}$ & $\begin{array}{l}\text { Contents } \\
\text { Damage }\end{array}$ & $\begin{array}{c}\text { Total } \\
\text { Damage }\end{array}$ \\
\hline Residential & 205 & $\$ 4,795,000$ & $\$ 4,765,000$ & $\$ 1,918,000$ & $\$ 1,724,000$ & $\$ 6,489,000$ \\
\hline Commercial & 518 & $\$ 48,067,000$ & $\$ 48,001,000$ & $\$ 72,700,000$ & $\$ 65,034,000$ & $\$ 113,035,000$ \\
\hline Industrial & 20 & $\$ 77,413,000$ & $\$ 33,984,000$ & $\$ 41,795,000$ & $\$ 21,565,000$ & $\$ 55,549,000$ \\
\hline Substructures & 17 & $\$ 12,000$ & $\$ 12,000$ & $\$ 5,000$ & $\$ 4,000$ & $\$ 16,000$ \\
\hline Public & 148 & $\$ 20,982,000$ & $\$ 20,982,000$ & $\$ 31,683,000$ & $\$ 28,515,000$ & $\$ 49,497,000$ \\
\hline Roads, Railroads \& Utilities $*_{1}$ & na & na & na & na & na & $\$ 50,714,000$ \\
\hline Emergency Expenses \& Misc ${ }^{*} 2$ & na & na & na & na & na & $\$ 4,862,000$ \\
\hline Navigation & na & na & na & na & na & $\$ 7,074,000$ \\
\hline Power & & & & & & $\$ 10,795,000$ \\
\hline Total & & $\$ 151,269,000$ & $\$ 107,744,000$ & $\$ 148,101,000$ & $\$ 116,842,000$ & $\$ 298,031,000$ \\
\hline \multicolumn{7}{|c|}{$\begin{array}{l}\text { *1 Power includes Washington Water Power and Potlatch Forest Industries substations. } \\
\text { Miles of PFI lines unknown. Damage to these lines included with industrial content. } \\
\text { *2 Includes } 205 \text { evacuated residences }+4000 \mathrm{ft} \text { of levee repair. } \\
\text { na = Not Applicable. }\end{array}$} \\
\hline
\end{tabular}


Table B-23. SOR Flood Control, Lewiston, Idaho-Percent Damage to Structures and Contents (by Assessor Short Code Location)

\begin{tabular}{|c|c|c|c|c|}
\hline Area & $\begin{array}{l}\text { Flood } \\
\text { Depth } \\
\text { (Feet) }\end{array}$ & $\begin{array}{l}\text { Structure } \\
\text { Type }\end{array}$ & $\begin{array}{l}\text { Structure } \\
\text { Damage } \\
(\%)\end{array}$ & $\begin{array}{l}\text { Content } \\
\text { Damage } \\
(\%)\end{array}$ \\
\hline \multirow{3}{*}{$\begin{array}{l}\text { North Lewiston, East of Highway } 95-12 \\
\text { Assessor's Short Code: } 11 \mathrm{~A}, 7 \mathrm{~A}, \mathrm{NW} 1 / 4 \text { OF 10B, } 6 \mathrm{~B}\end{array}$} & \multirow[t]{3}{*}{8} & Residential/Substructures & 100.0 & 90.0 \\
\hline & & Commercial/Public & 100.0 & 90.0 \\
\hline & & Industrial & 100.0 & 90.0 \\
\hline \multirow{3}{*}{$\begin{array}{l}\text { N Lewiston, W of Hwy } 95-12 \\
\text { Assessor's short code: } 8 \mathrm{~B}, 8 \mathrm{~A}, 7 \mathrm{~B}, 9 \mathrm{~A}\end{array}$} & \multirow[t]{3}{*}{13} & Residential/Substructures & 100.0 & 90.0 \\
\hline & & Commercial/Public & 100.0 & 90.0 \\
\hline & & Industrial & 100.0 & 90.0 \\
\hline \multirow{3}{*}{$\begin{array}{l}\text { Potlatch Forest Industries (pfi) } \\
\text { Assessor's Short Code: } 5 \mathrm{~B}, 6 \mathrm{~A}, 79 \mathrm{~A}, 78 \mathrm{~B}, 10 \mathrm{~B}\end{array}$} & \multirow[t]{3}{*}{7} & Residential & 41.9 & 86.2 \\
\hline & & Commercial/Public & 23.0 & 46.2 \\
\hline & & Industrial/Substructures & 43.0 & 46.2 \\
\hline \multirow{3}{*}{$\begin{array}{l}\text { Memorial Bridge Strip, S Side of River } \\
\text { Assessor's Short Code: } 11 b, 12 a\end{array}$} & \multirow[t]{3}{*}{4} & Residential/Substructures & 32.1 & 71.1 \\
\hline & & Commercial/Public & 13.0 & 35.5 \\
\hline & & Industrial & 20.0 & 35.5 \\
\hline \multirow{3}{*}{$\begin{array}{l}\text { Downtown, D \& Main Streets } \\
\text { Assessor's Short Code: 2B } \\
\text { Location L1 }\end{array}$} & \multirow[t]{3}{*}{8} & Residential/Substructures & 100.0 & 90.0 \\
\hline & & Commercial/Public & 100.0 & 90.0 \\
\hline & & Industrial & 100.0 & 90.0 \\
\hline \multirow{3}{*}{$\begin{array}{l}\text { Downtown B \& C Streets and 1st }-7 \text { th Streets } \\
\text { Assessor's Short Code: } 2 \mathrm{~b}, 9 \mathrm{a} \\
\text { Location } 12\end{array}$} & \multirow[t]{3}{*}{18 and 13} & Residential/Substructures & 100.0 & 90.0 \\
\hline & & Commercial/Public & 100.0 & 90.0 \\
\hline & & Industrial & 100.0 & 90.0 \\
\hline \multirow{3}{*}{$\begin{array}{l}\text { Courthouse Area, 7th - 19th } \\
\text { Assessor's Short Code: 9B, 10A }\end{array}$} & \multirow[t]{3}{*}{8} & Residential/Substructures & 100.0 & 90.0 \\
\hline & & Commercial/Public & 100.0 & 90.0 \\
\hline & & Industrial & 100.0 & 90.0 \\
\hline
\end{tabular}


Parking Lot Cleanup: Cleanup was assumed to be $\$ 1,114$ per acre based on sediment removal rates (Faucett, 1989).

Bridges: Bridge deck elevations of railroad and highway bridges were compared with water surface profiles. We assumed no direct damage to bridges since the bridge decks are above the Standard Project Flood. Damages to bridge approaches were included in road damages.

Utilities: Because sewer and gas lines run on both sides of a street, damage to utilities was assumed to be two times the street length for sewers and gas lines. However, water lines were assumed to be two times the street length plus 25 feet to each structure. The high velocity water was assumed to flow mainly down the streets and fan outward. Since sewer and gas lines are normally buried deeper than water lines, no damage was assumed for the 25 feet of the lines that lead to the individual structures (Faucett, 1989).

Sewers: The length of sewer lines was assumed to be two times the street length in the reach. Ten percent of the sewers were assumed to require cleaning at $\$ 10,560$ per mile. Five percent of the lines were assumed to require replacement at $\$ 211,200$ per mile (Faucett, 1989).

Water Lines: The length of water lines was assumed to be two times the street length in the reach plus 25 feet of line to each structure. Seventy five percent of the line was assumed to rupture because the lines are normally buried more shallow than sewer and gas lines, at a damage of $\$ 237,600$ per mile. The remaining 25 percent of line was assumed to require cleaning and disinfecting at $\$ 5,280$ per mile. Emergency water service was estimated at $\$ 100,000$ per event (Faucett, 1989).

Natural Gas: The length of gas lines was assumed to be two times the street length in the reach. It was assumed that 20 percent of the lines required replacement at $\$ 237,600$ per mile. A one time $\$ 20,000$ per event cost was assessed to shut down, purge and start up the system (Faucett, 1989).

Electric, Telephone, Cable TV: Calculations were estimated for above ground and underground cables.
Above ground telephone line locations in the reach were obtained from U S West Engineer Department. Pole replacement and line restringing were assumed to be required on 20 percent of the length. Line repair was assumed to be required on the remaining 80 percent of line. Underground lines were estimated to be the street length minus aerial length. It was assumed that the total underground length would require cleaning, repairing, and the replacement of above ground fittings at $\$ 11,160$ per mile (Faucett, 1989).

Railroad: Based on an interview with the Camas Prairie Railroad Roadmaster, a value of $\$ 190$ per linear foot was assigned to inundated track.

Roads: It was assumed that 75 percent of the roads in Reach 2 would suffer "major damage" (i.e. the roads would have to be rebuilt or replaced). Damage to roads was calculated on mile of inundation. Values of $\$ 250,000$ per mile for North Lewiston and $\$ 500,000$ per mile for Lewiston were assigned for major damage. It was assumed that the remaining 25 percent of roads required only cleanup at $\$ 5,400$ per mile (Faucett, 1989). Higher damage values were used for Reach 2 (than for Reach 1) because the levee overtopping event in Reach 2 would cause more devastating damage.

Sports Access: A value of $\$ 3,000$ per boat ramp was assigned. Total destruction was assumed based on interviews with Walla Walla District, Corps of Engineers, Operations Branch, Resource Management.

Scrap Yards: A value of $\$ 5,000$ per acre was assigned for cleanup based on depths of eight feet of high velocity water.

Power: Two Washington Water Power Substations (Clearwater and Holbrook) and the Potlatch Forest Industries Substation are subject to damage. Interviews with company representatives yielded the consensus that the plants would require replacement.

Navigation Loss: Lower Granite Reservoir would initially be lowered in anticipation of the catastrophic flood event. The pool would continue to be held at a low elevation during an extended period following the flood event to allow levee reconstruction. The pool drawdown would result in insufficient 
clearance over the navigation lock sill resulting in the suspension of barge traffic in the interim. Navigation losses are computed as the increase in transportation cost for shipping commodities which would normally move by barge for the period when slack water navigation would be unavailable on Lower Granite Reservoir. This period is estimated to be from May 1 through December and represents the time when the flood event would occur and the subsequent repair period until the pool can be raised high enough for tug and barge navigation.

The cost differential between barge transportation and the alternate modes, truck or rail, was derived from detailed studies of transportation cost differences done for the Bonneville Lock Study and a subsequent study by Transportation Research and Analysis Center for SOR. These differences are expressed in costs per ton per mile. It was assumed that the added cost would be incurred over the distance from Lewiston area ports to Central Ferry, the nearest downstream port facility, which is a distance of about 56 miles by truck or rail. Tonnage estimated for the May through December period was the 5 year average, 1986 to 1990 . This approach is not exactly analogous to the SOR navigation analysis, which is not available yet, but will consider the transportation system-wide, least cost adjustment to an interruption in slackwater navigation. That is, the least cost response could be something other than trucking to the next downstream port. However, this oversimplification is believed reasonable for the navigation loss which is a relatively small part of the damage associated with an extremely rare event.

The application of the above described procedure resulted in a damage estimate of $\$ 7,074,000$. Table B-24 shows increased transportation cost by commodity group.

Table B-24. Transportation Cost by Commodity Group-October 1992 Price Level

\begin{tabular}{|c|c|c|c|}
\hline \multirow{2}{*}{ Commodity } & \multirow{2}{*}{$\begin{array}{c}\text { Tonnage } \\
\text { Through } \\
\text { Lower } \\
\text { Granite }\end{array}$} & \multicolumn{2}{|c|}{ Cost to Truck to Central Ferry, WA 56 Miles } \\
\hline & & Ton/Mile & Total \\
\hline Petroleum Products & 77,685 & $\$ 0.096$ & $\$ 417,635$ \\
\hline Wood Products & 24,776 & $\$ 0.052$ & $\$ 72,148$ \\
\hline Logs & 119,781 & $\$ 0.115$ & $\$ 771,390$ \\
\hline Wood Chips & 204,850 & $\$ 0.100$ & $\$ 1,147,160$ \\
\hline Paper & 74,085 & $\$ 0.093$ & $\$ 385,835$ \\
\hline Total Wood Products & 423,492 & & $\$ 2,376,532$ \\
\hline Grain & 918,652 & $\$ 0.080$ & $\$ 4,115,561$ \\
\hline Total Miscellaneous & 43,683 & $\$ 0.067$ & $\$ 163,899$ \\
\hline Total Commodities & $1,463,512$ & & $\$ 7,073,626$ \\
\hline
\end{tabular}


Hydropower Loss: Power generation at Lower Granite Lock and Dam was computed with and without overtopping and levee failure. The assumed period of analysis is from May to January. Flow conditions are assumed to be above normal, because failure would most likely occur during a year of historic high flows. Two options for the value of power were considered: (1) displacement of thermal resources of the Pacific Southwest (PSW); and (2) displacement of a new coal-fired plant in the Pacific Northwest (PNW). In both cases, because of the uncertainty of when a failure might actually occur, fuel cost escalation was not included. The value of thermal resource displacement in the PSW comes from other studies (Galloway Dam), and the displacement value of a new coal plant in the PNW is the value for the fiscal year (FY) 1989 budget, at the 1 October 1987 cost level.

The analysis was based on the assumption that, under both normal and post-levee failure conditions, the project would be operated run-of-river, with the number of units on-line being determined by the flow in the river. Results of the analysis are displayed in Table B-25.
Because the year in the future in which a levee overtopping flood would occur is unpredictable, the status of surplus hydropower and sales to the Pacific Southwest is also unpredictable. Therefore, the higher value, make up of lost generation at Lower Granite from a Pacific Northwest coal-fired plant is estimated to be the hydropower loss: $\$ 10,795,000$. This analysis is consistent with studies of Lower Granite Sedimentation. Although the scenario of loss of generation at Lower Granite due to levee overtopping at Lewiston and subsequent reservoir drawdown has not been run through SOR hydroregulation and power models, there is no reason to think analysis of loss would be different.

\section{B2.5 DISCHARGE - DAMAGE ANALYSIS}

\section{B2.5.1 Reach 1}

Total combined damage for Reach 1 and Reach 2, by discharge for all categories of damage, is summarized in Table B-26. In Reach 1, flood damages begin to occur when river flows exceed $115,000 \mathrm{cfs}$.

Table B-25. Generation (Kilowatt Hours)—October 1992 Price Level

\begin{tabular}{|l|c|c|c|}
\hline & $\begin{array}{c}\text { Without } \\
\text { Levee Failure }\end{array}$ & $\begin{array}{c}\text { With } \\
\text { Levee Failure }\end{array}$ & Net Loss \\
\hline Total & $2,266,120,000$ & $1,647,830,000$ & $618,290,000$ \\
\hline & & & \\
\hline Exported *1 & $2,039,510,000$ & $1,483,050,000$ & $556,460,000$ \\
\hline & & & \\
\hline Value & & & $\$ 8,665,000$ \\
\hline PSW Displacement & $\$ 27,378,000$ & $\$ 18,713,000$ & $\$ 10,795,000$ \\
\hline \multicolumn{1}{|c|}{ PNW Displacement } & $\$ 39,566,000$ & $\$ 28,771,000$ & \\
\hline *1 Total generation reduced by 10 percent for transmission losses. &
\end{tabular}




\section{B2.5.2 Reach 2}

Because the city of Lewiston is protected by levees (for floods up to and including the Standard Project Flood) which were built as part of the Lower Granite project, the only flood event for which damage was estimated for Reach 2 was a levee overtopping event. The levees provide protection from flows up to and including $150,000 \mathrm{cfs}$ which is a Standard Project Flood with the current regulation by Dworshak Dam and Reservoir. Flood damages in Reach 2 occur when river flows exceed 150,000 cfs. Essentially all of the floodplain is inundated in a levee overtopping event and flood depths result in a high proportion of damage to property value. Therefore, damages would be expected to increase slowly for flows greater than $151,000 \mathrm{cfs}$. Guidance for flood damage reduction studies call for evaluation of the Standard Project Flood. It is possible that SOR alternatives could increase the probability of flooding at Lewiston. Damage for all damage categories is summarized in Table B-22. Table B-26 shows the damage summary, by category, for Reaches 1 and 2 combined.

\section{B2.6 DISCHARGE - FREQUENCY ANALYSIS}

Discharge frequency curves were developed by the Flood Control Work Group. The derivation of the discharge frequency curves is explained in Appendix E (Flood Control).

The amount of damages which would occur in the Clearwater Subarea at varying levels of discharge on the Clearwater River at Spalding, Idaho is shown in Figure B-2. The damage amounts shown in the figure are composite damages for all categories of damage in both reaches of the subarea.

\section{Table B-26. SOR Flood Control - Damage Summary Clearwater River - Total of Reaches 1 and 2-October 1992 Price Level}

\begin{tabular}{|c|c|}
\hline $\begin{array}{c}\text { Discharge } \\
\text { (cfs) }\end{array}$ & $\begin{array}{l}\text { Total of All } \\
\text { Damages }\end{array}$ \\
\hline 115,000 & $\$ 0$ \\
\hline 120,000 & $\$ 756,500$ \\
\hline 122,000 & $\$ 961,000$ \\
\hline 125,000 & $\$ 1,300,000$ \\
\hline 130,000 & $\$ 1,942,000$ \\
\hline 140,000 & $\$ 2,432,000$ \\
\hline 142,000 & $\$ 2,478,000$ \\
\hline 150,000 & $\$ 2,601,500$ \\
\hline 151,000 & $\$ 300,645,500$ \\
\hline \multicolumn{2}{|c|}{$\begin{array}{l}\text { Damages include residential, commercial, industrial and public structures and contents, railroad, road, } \\
\text { utilities, ag, navigation and power loss, emergency expenses, scrap yards, bridges, environmental and } \\
\text { misc. }\end{array}$} \\
\hline
\end{tabular}




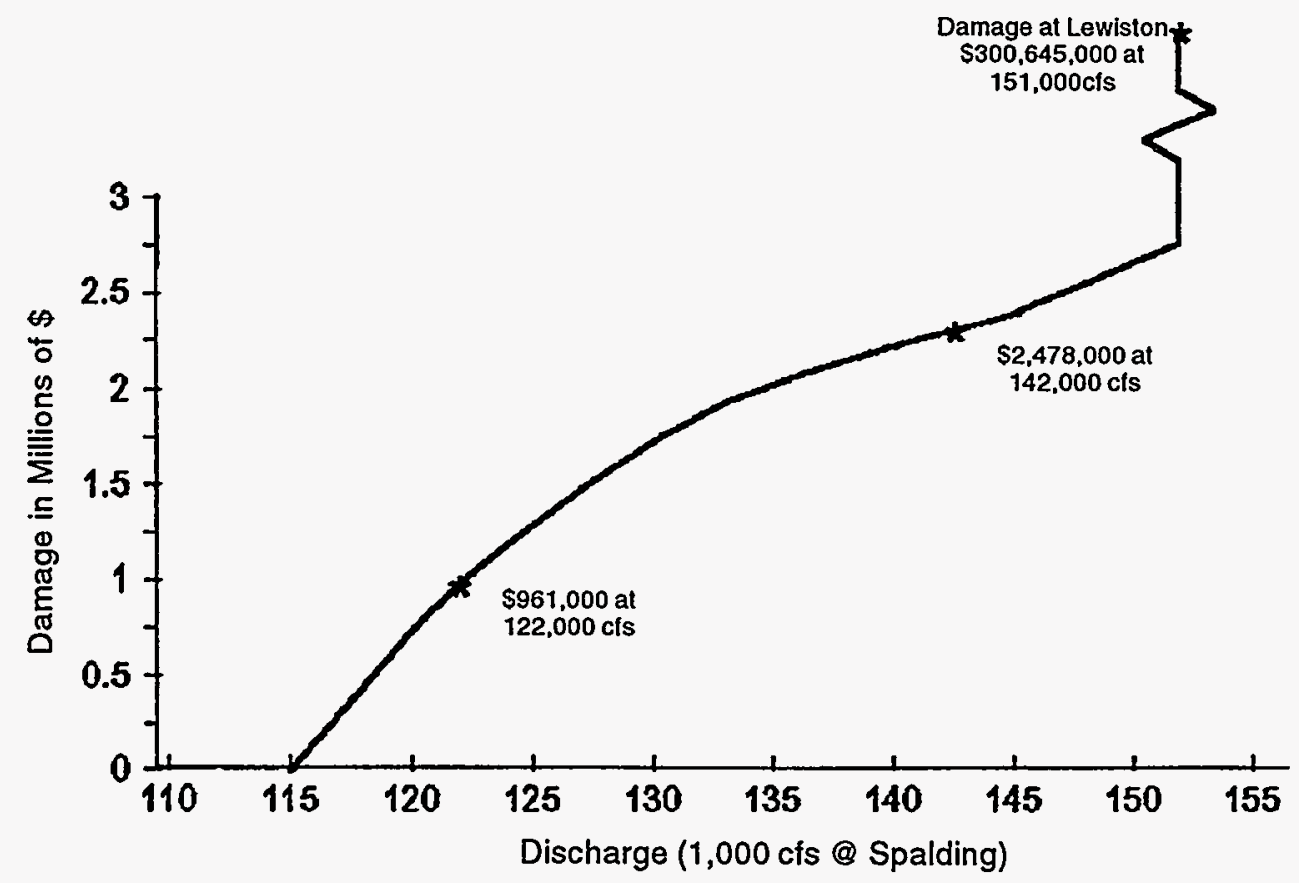

Figure B-2. Discharge Damage Curve Dworshak to Clearwater

\section{B2.7 EXPECTED ANNUAL DAMAGE}

Expected annual flood damage is the average flood damage expected over the long run. To compare alternative plans or to compare damage with costs, an equivalent annual value is computed. In the calculation of equivalent annual damage, each year's expected annual values are discounted back to time zero (1995) to obtain the present value of damages over the period of analysis (100 years). The present value amount is then amortized to determine the equivalent expected annual damage. This equivalent value represents a uniform distribution (the same each year) of annual values. The discounting and amortizing takes into account the time value of money associated with damage values.

Results of the analysis of potential flood damages in the Lewiston area for each SOS are shown in Table B-27 and Table B-28. Equivalent annual damage was calculated using rates of interest of 7.75 percent and 3.0 percent. The former is required for analysis by the Corps and the Bureau of Reclamation, and the later is used in analyses by BPA.

\section{B2.8 FUTURE DEVELOPMENT}

Future economic conditions will affect future damage potential. Population changes are a good overall indicator of economic change and have a direct bearing on most damage categories, for example; residential, commercial, and public property. Bonneville Power Administration has made projections of population by county in conjunction with power demand forecasts. The projected rate of growth in the population of Nez Perce County, which covers almost all of the damage center, is 0.15 percent per year through 2010. Extending this rate through 2015, the time horizon for SOR, produces a total projected population growth of 3.45 percent over the 20 -year period (1995 to 2015). Growth of this magnitude is inconsequential and, for the sake of simplicity has not been applied to estimated potential damage. 
Table B-27. Analysis of Equivalent Annual Flood Damages Dworshak to Lewiston Levees (7.75 Percent Interest)

\begin{tabular}{|c|c|c|c|c|c|c|c|c|c|}
\hline \multirow[b]{2}{*}{ sos } & \multirow[b]{2}{*}{$\begin{array}{l}\text { Year } \\
\text { on } \\
\text { Line }\end{array}$} & \multirow[b]{2}{*}{$\begin{array}{c}\text { Initial } \\
\text { Expected } \\
\text { Annual } \\
\text { Damage }\end{array}$} & \multirow[b]{2}{*}{$\begin{array}{c}\text { Duration } \\
\text { Of Initial } \\
\text { Damage } \\
\text { (no. years) }\end{array}$} & \multirow[b]{2}{*}{$\begin{array}{c}\text { Ultimate } \\
\text { Expected } \\
\text { Annual } \\
\text { Damage }\end{array}$} & \multirow{2}{*}{$\begin{array}{c}\text { Duration } \\
\text { Of } \\
\text { Ultimate } \\
\text { Damage } \\
\text { (no. years) }\end{array}$} & \multicolumn{4}{|c|}{ Interest Rate $=7.75$ Percent } \\
\hline & & & & & & $\begin{array}{l}\text { Present } \\
\text { Value } \\
\text { Initial } \\
\text { Damage }\end{array}$ & $\begin{array}{l}\text { Present } \\
\text { Value } \\
\text { Ultimate } \\
\text { Damage }\end{array}$ & $\begin{array}{c}\text { Total } \\
\text { Present } \\
\text { Value }\end{array}$ & $\begin{array}{c}\text { Equivalent } \\
\text { Annual } \\
\text { Damage }\end{array}$ \\
\hline SOS 1a & 1995 & $\$ 10,275$ & 0 & $\$ 10,275$ & 100 & $\$ 0$ & $\$ 132,505$ & $\$ 132,505$ & $\$ 10,275$ \\
\hline SOS $1 b$ & 1995 & $\$ 10,275$ & 0 & $\$ 10,275$ & 100 & $\$ 0$ & $\$ 132,505$ & $\$ 132,505$ & $\$ 10,275$ \\
\hline $\operatorname{SOS} 2 c$ & 1995 & $\$ 10,275$ & 0 & $\$ 10,275$ & 100 & $\$ 0$ & $\$ 132,505$ & $\$ 132,505$ & $\$ 10,275$ \\
\hline SOS 2d & 1995 & $\$ 10,275$ & 0 & $\$ 10,275$ & 100 & $\$ 0$ & $\$ 132,505$ & $\$ 132,505$ & $\$ 10,275$ \\
\hline SOS 4c & 1995 & $\$ 10,275$ & 0 & $\$ 10,275$ & 100 & $\$ 0$ & $\$ 132,505$ & $\$ 132,505$ & $\$ 10,275$ \\
\hline SOS 5b & 2010 & $\$ 10,275$ & 15 & $\$ 10,275$ & 85 & $\$ 89,308$ & $\$ 43,197$ & $\$ 132,505$ & $\$ 10,275$ \\
\hline SOS 5c & 2000 & $\$ 10,275$ & 5 & $\$ 10,275$ & 95 & $\$ 41,297$ & $\$ 91,208$ & $\$ 132,505$ & $\$ 10,275$ \\
\hline SOS 6b & 2005 & $\$ 10,275$ & 10 & $\$ 10,275$ & 90 & $\$ 69,731$ & $\$ 62,774$ & $\$ 132,505$ & $\$ 10,275$ \\
\hline SOS 6d & 2000 & $\$ 10,275$ & 5 & $\$ 10,275$ & 95 & $\$ 41,297$ & $\$ 91,208$ & $\$ 132,505$ & $\$ 10,275$ \\
\hline SOS 9a & 2005 & $\$ 10,275$ & 10 & $\$ 10,275$ & 90 & $\$ 69,731$ & $\$ 62,774$ & $\$ 132,505$ & $\$ 10,275$ \\
\hline SOS 9b & 1995 & $\$ 10,275$ & 0 & $\$ 10,275$ & 100 & $\$ 0$ & $\$ 132,505$ & $\$ 132,505$ & $\$ 10,275$ \\
\hline SOS 9c & 2005 & $\$ 10,275$ & 10 & $\$ 10,275$ & 90 & $\$ 69,731$ & $\$ 62,774$ & $\$ 132,505$ & $\$ 10,275$ \\
\hline $\mathrm{PA}$ & 1998 & $\$ 10,275$ & 3 & $\$ 10,275$ & 97 & $\$ 26,600$ & $\$ 105,905$ & $\$ 132,505$ & $\$ 10,275$ \\
\hline
\end{tabular}

Table B-28. Analysis of Equivalent Annual Flood Damages, Dworshak to Lewiston Levees (3.0 Percent Interest)

\begin{tabular}{|c|c|c|c|c|c|c|c|c|c|}
\hline \multirow[b]{2}{*}{ sos } & \multirow[b]{2}{*}{$\begin{array}{l}\text { Year } \\
\text { on } \\
\text { Line }\end{array}$} & \multirow[b]{2}{*}{$\begin{array}{c}\text { Initial } \\
\text { Expected } \\
\text { Annual } \\
\text { Damage }\end{array}$} & \multirow[b]{2}{*}{$\begin{array}{l}\text { Duration } \\
\text { Of Initial } \\
\text { Damage } \\
\text { (no. years) }\end{array}$} & \multirow[b]{2}{*}{$\begin{array}{c}\text { Ultimate } \\
\text { Expected } \\
\text { Annual } \\
\text { Damage }\end{array}$} & \multirow{2}{*}{$\begin{array}{l}\text { Duration } \\
\text { Of } \\
\text { Ultimate } \\
\text { Damage } \\
\text { (no. years) }\end{array}$} & \multicolumn{4}{|c|}{ Interest Rate $=3.0$ Percent } \\
\hline & & & & & & $\begin{array}{r}\text { Present } \\
\text { Value } \\
\text { Initial } \\
\text { Damage }\end{array}$ & $\begin{array}{c}\text { Present } \\
\text { Value } \\
\text { Ultimate } \\
\text { Damage }\end{array}$ & $\begin{array}{c}\text { Total } \\
\text { Present } \\
\text { Value }\end{array}$ & $\begin{array}{l}\text { Equivalent } \\
\text { Annual } \\
\text { Damage }\end{array}$ \\
\hline SOS 1a & 1995 & $\$ 10,275$ & 0 & $\$ 10,275$ & 100 & $\$ 0$ & $\$ 324,679$ & $\$ 324,679$ & $\$ 10,275$ \\
\hline SOS 1b & 1995 & $\$ 10,275$ & 0 & $\$ 10,275$ & 100 & $\$ 0$ & $\$ 324,679$ & $\$ 324,679$ & $\$ 10,275$ \\
\hline SOS $2 c$ & 1995 & $\$ 10,275$ & 0 & $\$ 10,275$ & 100 & \$o & $\$ 324,679$ & $\$ 324,679$ & $\$ 10,275$ \\
\hline $\operatorname{SOS} 2 d$ & 1995 & $\$ 10,275$ & 0 & $\$ 10,275$ & 100 & So & $\$ 324,679$ & $\$ 324,679$ & $\$ 10,275$ \\
\hline $\operatorname{SOS} 4 c$ & 1995 & $\$ 10,275$ & 0 & $\$ 10,275$ & 100 & $\$ 0$ & $\$ 324,679$ & $\$ 324,679$ & $\$ 10,275$ \\
\hline SOS 5b & 2010 & $\$ 10,275$ & 15 & $\$ 10,275$ & 85 & $\$ 122,662$ & $\$ 202,017$ & $\$ 324,679$ & $\$ 10,275$ \\
\hline SOS 5c & 2000 & $\$ 10,275$ & 5 & $\$ 10,275$ & 95 & $\$ 47,057$ & $\$ 277,622$ & $\$ 324,679$ & $\$ 10,275$ \\
\hline SOS 6b & 2005 & $\$ 10,275$ & 10 & $\$ 10,275$ & 90 & $\$ 87,648$ & $\$ 237,031$ & $\$ 324,679$ & $\$ 10,275$ \\
\hline $\operatorname{sos} 6 \mathrm{~d}$ & 2000 & $\$ 10,275$ & 5 & $\$ 10,275$ & 95 & $\$ 47,057$ & $\$ 277,622$ & $\$ 324,679$ & $\$ 10,275$ \\
\hline $\operatorname{SOS} 9 a$ & 2005 & $\$ 10,275$ & 10 & $\$ 10,275$ & 90 & $\$ 87,648$ & $\$ 237,031$ & $\$ 324,679$ & $\$ 10,275$ \\
\hline SOS 9b & 1995 & $\$ 10,275$ & 0 & $\$ 10,275$ & 100 & $\$ 0$ & $\$ 324,679$ & $\$ 324,679$ & $\$ 10,275$ \\
\hline SOS 9c & 2005 & $\$ 10,275$ & 10 & $\$ 10,275$ & 90 & $\$ 87,648$ & $\$ 237,031$ & $\$ 324,679$ & $\$ 10,275$ \\
\hline $\mathrm{PA}$ & 1998 & $\$ 10,275$ & 3 & $\$ 10,275$ & 97 & $\$ 29,064$ & $\$ 295,615$ & $\$ 324,679$ & $\$ 10,275$ \\
\hline
\end{tabular}




\section{B2.9 EFFECTIVE LEVEE HEIGHT}

Corps of Engineers policy guidance requires evaluation of the reliability of existing levees that do not meet Corps of Engineers design criteria. Since the Lewiston levees were built and are maintained by the Corps, this policy guidance does not apply. The design capacity of the Lewiston levees along the Clearwater River is 150,000 cfs. These levees were built with five feet of freeboard because of the uncertainties associated with sedimentation, wind driven wave conditions during floods, and the possibility of flood-borne debris causing obstructions at bridges, as well as the catastrophic damage that would occur with levee overtopping.

The subject of levee adequacy is discussed in detail (US Army Corps of Engineers, 1992, Appendix C). That report also points out that sediment accumulation has reduced the originally designed five feet of freeboard at a Standard Project Flood to three feet and that the level of flood protection has been stable since 1986 because of interim dredging and less than average run-off. While a future program of dredging or other measures to maintain flood control are unknown at this time, it is not likely that the Corps of Engineers will allow the level of levee protection to seriously degrade. Therefore, the best estimate of levee capacity at this time is the design flow of $150,000 \mathrm{cfs}$.

\section{B2.10 RISK AND UNCERTAINTY}

Risk and uncertainty affects many of the elements that go into the estimation of flood damages. The variability of these affects is magnified in a study like this where there is no history of the flood events being analyzed and the reconnaissance scope does not allow in-depth analysis. The following is a list of factors subject to risk and uncertainty. The list is not all inclusive; many elements are built on subelements which are not listed. It is beyond the scope of this study to define the bounds and probability distributions for the items effected by risk and uncertainty.

- Flooded area

- Flood depths

- Topography

- Flood flow velocity

- Flood frequency (probability of occurrence)

- Structure value estimates (as a proxy for replacement cost less depreciation

- Number of structures

- Physical characteristics of structures

- First floor elevations

- Structure depth-damage functions

- Contents Value

- Contents depth-damage functions

- Units and unit damages for non-structure property

- Levee restoration time and cost

- Transportation system response to loss of navigation

- Power system response to loss of hydropower generation

\section{B2.11 IMPACT OF INCREASED FREQUENCY OF HIGH FLOWS ON LEVEES}

Lewiston levees are designed and built for exposure to frequent flows over their full height. Therefore, increased frequency of higher flows within the design capacity will not require levee upgrading. (See preceding section on Effective Levee Height for more discussion.) Levee raise costs have been estimated at approximately $\$ 24,000,000$ for a three foot raise and $\$ 51,000,000$ for a seven foot raise (1992 price level). 


\section{SECTION B3.0 - LOWER COLUMBIA RIVER SUBAREA}

\section{B3.1 DESCRIPTION OF THE SUBAREA}

\section{B3.1.1 General}

The lower Columbia River flood control subarea extends from Bonneville Lock and Dam at river mile (RM) $145(\mathrm{~km} \mathrm{233.3)} \mathrm{downstream} \mathrm{to} \mathrm{the} \mathrm{mouth} \mathrm{of}$ the Columbia River. The portion of the subarea included in this study, however, extends only to RM $40,(\mathrm{~km} \mathrm{64.4)}$ and comprises approximately twothirds of the Lower Columbia River below the Bonneville project.

Improvements located in potential damage areas include public and private property, utilities, transportation systems and agricultural crops and facilities. Five counties are adjacent to the Columbia River within the study area: Skamania, Clark, and Cowlitz Counties on the Washington shore, and Multnomah and Columbia Counties on the Oregon shore. There are no dams on the river within this reach. There are major tributaries to the river within the reach. The rivers and the location of confluence with the Columbia River are listed in Table B-29. Listings are in order from upstream to downstream.

The entire lower Columbia River is estuarial, with the tidal influence of the Pacific Ocean ranging from about 0.5 foot $(.15 \mathrm{~m})$ at the tailwater of Bonneville Dam to approximately 6 feet $(1.8 \mathrm{~m})$ at RM $40(\mathrm{~km}$ 64.4) and about 8 feet $(2.4 \mathrm{~m})$ at the river's mouth. The lower Columbia River floodplain, in contrast to much of the Columbia Basin, has a limited variety of natural resources. Nearly the entire area is alluvium deposited by the stream, and the only readily exploitable resources are sand and gravel. The floodplains are generally very productive, the soil consisting of river deposited silts and sands. Much of the floodplain has long been cleared for agricultural or urban uses, and only portions of the non-diked areas retain much semblance to their original aspect.

\section{B3.1.2 Bonneville Dam to Washougal}

The upper 17 miles $(27.4 \mathrm{~km})$ of river from Bonneville Dam downstream to Washougal, Washington (RM 120), (km 193) intersect the Cascade Range in the western end of the Columbia River Gorge. The river throughout this section is about 1 mile $(1.6 \mathrm{~km})$ wide, and is split by a number of large islands. The land on both shores is steep and forested, and provides minimal floodplain. Development in this area is limited to a few small communities, homes, and farms. The cities of Camas and Washougal are located at RM $120(\mathrm{~km} \mathrm{193)}$ along the Washington shore.

Table B-29. Major Tributaries to the Columbia River Downstream from Bonneville Dam

\begin{tabular}{|l|l|l|}
\hline \multicolumn{1}{|c|}{ Tributary } & \multicolumn{1}{|c|}{ State } & River Mile \\
\hline Sandy River & Oregon & 120.5 \\
\hline Washougal River & Washington & 118.1 \\
\hline Willamette River & Oregon & 101.5 \\
\hline Lewis River & Washington & 87.0 \\
\hline Kalama River & Washington & 73.1 \\
\hline Cowlitz River & Washington & 68.0 \\
\hline Clatskanie River & Oregon & 49.7 \\
\hline
\end{tabular}




\section{B3.1.3 Washougal to the Willamette River}

From Washougal to the mouth of the Willamette River (RM 101.5) (km 163.3) in Oregon, the character of the shore area changes abruptly. The forested mountains bordering the river recede to low hills and floodplain while the number and size of islands and slough channels increase. Predominantly agricultural land use in the upstream portion gives way to increased industrial development as the river approaches the Portland, Oregon/Vancouver, Washington, metropolitan area, which is situated near the confluence of the Columbia and Willamette Rivers. The eastern portion of this area marks the beginning of areas protected by levees.

The Portland/Vancouver metropolitan area is the largest population concentration in the Columbia River Basin, and second largest in the Pacific Northwest region. Portland and Vancouver, both adjacent to the Columbia River between RM 101 (km 162.5)

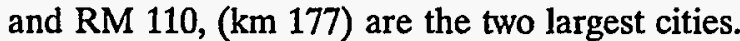
The Portland Metropolitan Statistical Area (PMSA) on the south side of the river consists of Multnomah, Clackamas, Washington and Yamhill Counties, with a combined population exceeding one million, or approximately 42 percent of the population of the State of Oregon. In addition, the cities of Milwaukee (RM 18), (km 29) Lake Oswego (RM 21), (km 33.8) West Linn (RM 26), ( $\mathrm{km} \mathrm{41.8)} \mathrm{and} \mathrm{Oregon}$ City (RM 26) (km 41.8) are located along the lower Willamette River. Vancouver (RM 106.5), (km 171.4) in Clark County, is directly across the river. This city, with a population of more than 40,000 , has a significant industrial area and a deep-draft port. Vancouver is the upstream limit of major ocean-going navigation on the Columbia River.

The Portland-Vancouver area is served by excellent road, rail, and air transportation networks, as well as deep draft ports for ocean-going vessels on the lower Willamette and Columbia Rivers. Land in Portland and Vancouver is heavily urbanized, with extensive port facilities and heavy and light manufacturing activity. The floodplain is narrower along the Washington shore than on the Oregon shore. The majority of land in the 100-year floodplain is leveed to protect intensive commercial and industrial development, including the Portland International Airport. Other major tributaries in this area are Sandy River, Oregon (RM 120.5), (193.9 km.) and Washougal River, Washington (RM 118.1). (km 190)

\section{B3.1.4 Willamette River to River Mile $\mathbf{4 0}$}

From Portland downstream, the Columbia River flows in a northerly direction between the Cascade and Coast Range mountains from RM $101(\mathrm{~km}$ $162.5)$ to RM $60(\mathrm{~km} \mathrm{96.5)}$ where the river turns west and flows through the Coast Range. Hillside areas bordering the lowlands increase in elevation and extent of tree cover as the river traverses the Coast Range on its downstream course. The river averages about 1 mile $(1.6 \mathrm{~km})$ in width in this section. Major tributaries entering the Columbia River here include the Cowlitz, Kalama, and Lewis Rivers of Washington.

Land use is rural-agricultural, changing again to heavy industrial/manufacturing as the river reaches Longview, Washington. Most development is located within the floodplain, and the small amount of agriculture is situated behind levees. Cities and towns along the lower Columbia River are Woodland (RM 85), (km 136.8) Longview-Kelso (RM 68), $(\mathrm{km} \mathrm{109.4)}$ and Cathlamet (RM 40) (km 64.4) in Washington; and St Helens (RM 87), (km 140) Rainier (RM 68), (km 109.4) Clatskanie (RM 52), ( $\mathrm{km} \mathrm{83.7)} \mathrm{and} \mathrm{Westport} \mathrm{(RM} \mathrm{40)} \mathrm{(km} \mathrm{64.4)} \mathrm{in}$ Oregon. The cities of Woodland in Cowlitz County, Washington, and St. Helens in Columbia County, Oregon, have populations exceeding 2,500, while Kalama, Washington, has a population of just over 1,000. The cities of Longview and Kelso have a combined population of about 40,000 and contain significant industrial development protected by levees along the Columbia and lower Cowlitz Rivers. Longview has a deep draft port for ocean-going vessels and both industrial and port activities are closely related to timber and wood products. Cowlitz and Columbia Counties have historically been dependent upon forestry and wood products industries as a major source of income. 


\section{B3.1.5 River Mile 40 to the Mouth}

The Columbia River in its lowermost 40 miles (64.4 $\mathrm{km}$ ) flows westward to the Pacific Ocean through a flat-bottomed valley bounded on the north by a steep rocky headland and on the south by a broad, low peninsula. Three counties are adjacent to the river within this reach; Pacific and Wahkiakum Counties on the Washington (north) shore, and Clatsop County on the Oregon (south) shore. There are few cities along the river in this reach, with Astoria, Oregon (population 10,000), and Warrenton, Oregon (population 2,500), the only two of any size. These lower 40 river miles are excluded from the study area as they contain no major damage centers. Flood levels are governed largely by tidal activity, with flood potential increasing when runoff in Columbia River is high. The practical effect is that below RM 40, (km 64.4) upstream storage is not effective for flood control and flood relief must be achieved by levees or nonstructural means.

The lower Columbia River area is served by a welldeveloped regional transportation system consisting of highways, railroads, and navigation channels.

\section{B3.2 FLOOD PROBLEMS AND CHARACTERISTICS}

This section describes those factors that influence flooding and the potential for flooding in the study reach (Bonneville Dam to Westport, Oregon). These factors apply to the entire floodplain as well as major damage centers that could be affected by operational changes within the system. The region is influenced by a marine climate, characterized by wet, mild winters and dry, moderately warm summers. The drainage area below Bonneville Dam is about 19,000 square miles, $(49,188(\mathrm{~km})$ and comprises approximately 7 percent of the 259,000 square mile $(670,520 \mathrm{~km})$ Columbia River drainage. As noted previously, the area's topography is typical of estuarial floodplains found on large rivers in western Washington and Oregon. Floodplain scar features that originated during flood activity are prominent, and many slough channels remain in drainage districts as evidence of the river's former extent during flooding. Factors that influence flooding along
Columbia River differ fundamentally above and below RM 40 (km 64.4) (Westport, Oregon). Although the entire reach from the mouth to Bonneville Dam is estuarial, flooding upstream of Westport (RM 40/km 64.4) is primarily a function of runoff, while below RM 40 , tidal influence is of increasingly greater significance.

Flooding in the study area results from runoff of spring snowmelt, sometimes augmented by spring rains, or from intense winter rainstorms augmented by snowmelt. The upper Columbia and Snake River Basins are the predominant source of runoff during spring flood events, while the Willamette River and other tributaries of the lower Columbia River produce the most significant winter runoff.

Flooding from spring snowmelt has historically been the most severe, but extensive upstream storage reservoirs have reduced peak flood stages. Flood events also result from intense rainfall occurring during the winter months, causing heavy runoff from the Willamette River and other lower Columbia River tributaries. Both winter rainfall and spring snowmelt flood events cause high river stages and pose a threat to major damage centers. The duration of spring flooding is characteristically much longer than for winter floods because of the greater volume of runoff, and thus spring floods are potentially the most severe. Because spring floods originate in the drier eastern part of the Columbia River Basin rather than in western Oregon and Washington, spring river stages on the lower Columbia River can only be regulated by the system of reservoirs in the Columbia River Basin upstream of Bonneville Dam. Hence, spring flood damages are classified as system-dependent. Winter flood levels on the lower Willamette River are regulated almost entirely by Willamette River Basin reservoirs and are thus considered project-dependent.

Flood damages throughout the subarea result from breaching or overtopping of levees and by overbank flows within unprotected areas. Flood risk areas include agricultural lands, portions of cities and towns, and transportation facilities consisting of railroads, highways, air terminals, and navigation facilities. Bank erosion is a chronic problem for all leveed areas within the subarea. Erosion is caused 
by currents at high river stages and by wave action from wind, deep-draft navigation traffic, and passage of other marine traffic. Prolonged high water saturates and weakens levee embankment materials. In addition to high river stages, duration of high water is a major contributing factor to flood damages in the study area. From Bonneville Dam to Washougal the riverbanks tend to be rocky or otherwise erosion resistant.

Drainage problems also exist throughout the subarea. Considerable seepage under Columbia River levees occurs during high water events. Rainfall combines with this seepage and accumulates in low areas. Seepage can lead to internal erosion of levee embankment material (piping). Pumping and tideboxes are used in numerous areas to facilitate drainage of storm water and seepage.

The Standard Project Flood for this reach is 900,000 cfs $(25,485 \mathrm{~m} / \mathrm{second})$ measured at The Dalles.

Bank full, or zero damage stage, corresponds to a regulated discharge of $450,000 \mathrm{cfs}(12,740 \mathrm{~m} / \mathrm{second})$ at The Dalles, or a flood stage at the Vancouver gage of 16.5 feet. $(5.03 \mathrm{~m})$ When discharges exceed $450,000 \mathrm{cfs}$ at The Dalles, flood damages are experienced at some downstream locations in the study reach. Unleveed areas within the study reach contain improvements which could be susceptible to damage from large infrequent flood events. No extensive stage-damage analyses were made of these areas, however, a field check was performed to verify elevations and to identify the types of improvements potentially subject to damage. Columbia River discharges exceeding 700,000 cfs $(19,817$ $\mathrm{m} 3 / \mathrm{second})$ at The Dalles would inundate the unleveed Rivergate area in North Portland which contains some development above the regulated 100-year flood level. This is also the case for other unleveed areas in both Oregon and Washington that contain commercial, industrial, and residential improvements located above the 100-year flood elevation.

For purposes of evaluating the impact of alternative operating strategies, consideration was given only to those major levee systems which protect large urban centers on the Lower Columbia. This approach was also applied for the levee systems at Tri-Cities, Washington, and at Lewiston, Idaho.

The largest flood of record on the Columbia River occurred in June 1894, which created a flood level elevation measuring 36.2 feet $(11.03 \mathrm{~m})$ at Vancouver. The second largest flood of record occurred in June 1948, with floodwaters reaching elevation 32.8 feet $(10.0 \mathrm{~m})$ at the same gage. The 1948 flood remained within a foot of its crest for 2 weeks, with 26 major flood days recorded. Other record flood events occurred in June 1956 and December 1964, with flood elevations of 29.4 feet $(8.96 \mathrm{~m})$ and 29.5 feet, $(9.0 \mathrm{~m})$ respectively, measured at Vancouver. The largest flood since completion of construction of storage projects above Bonneville Dam occurred in 1974. This flood had an estimated unregulated peak stage of 30.6 feet $(9.33 \mathrm{~m})$ and a regulated peak stage of 21.1 feet $(6.43 \mathrm{~m})$, measured at Vancouver. Elevations and estimated frequencies at the Vancouver gage are shown in Table B-30.

Table B-30. Frequency of Occurrence and Elevation of Regulated Flood Events as Measured at Vancouver, Washington (RM 106.5)

\begin{tabular}{|c|c|c|}
\hline Recurrence Interval & Exceedance Frequency & Elevation (MSL)*(ft) \\
\hline 2-year & .5 & 16.5 \\
\hline 10-year & .1 & 21.5 \\
\hline 50-year & .02 & 24.9 \\
\hline 100-year & .01 & 26.5 \\
\hline SPF & N/A & 30.7 \\
\hline *MSL = Mean Sea Level \\
$\begin{array}{l}\text { Source: Flood Profiles, Columbia River and Tributaries, Washington and Oregon Below Bonneville Dam, } \\
\text { Revised, US Army Corps of Engineers, November, 1971. }\end{array}$ \\
\hline
\end{tabular}




\section{B3.3 EXISTING FLOOD PROTECTION AND DAMAGES}

\section{B3.3.1 Description of Flood Protection Systems}

Based on documentation of a treaty between Canada and the United States (Treaty Between Canada and the United States of America Relating to Cooperative Development of the Water Resources of the Columbia River Basin), the flood control objective for the lower Columbia River at The Dalles is the reduction of the 1894 flood to $800,000 \mathrm{cfs}(22,654$ meters/second), through construction and operation of storage projects in the United States and Canada. Additional flood protection was to be provided to damage centers below Bonneville Dam through construction of levees designed to contain the regulated flow at The Dalles. In accordance with the system flood control objectives, numerous Corpsconstructed levees and revetments provide flood protection to damage centers throughout the subarea. The study area (Bonneville Dam to Westport) contains 29 drainage districts. An additional 24 districts are located between Westport and the river's mouth. Between Bonneville Dam (RM $145 / \mathrm{km} \mathrm{233.3)}$ and Westport, Oregon (RM 40/km 64.4) there are almost 130 thousand acres $(53,610$ ha) within the 500-year floodplain, with about 83 thousand acres $(33,590 \mathrm{ha})$ protected to varying degrees by levees. Much of the land protected is used for agriculture, but protection is also afforded to municipal commercial and industrial developments in the Portland, Vancouver, Washougal, Longview, and Kelso areas. For the major levees, annual inspections are performed before each spring freshet. In addition, Portland District carries out an ongoing maintenance program.

As noted above, flood control on the lower Columbia River is attained by the system of levees downstream of Bonneville Dam together with operation of storage projects within the Columbia-Snake River system. John Day Dam, which forms Lake Umatilla, is the initial upstream project that contains flood control storage. Other storage reservoirs are located in the upper reaches of the basin. Total system storage above Bonneville Dam, including John Day, amounts to 39.737 million acre-feet
(49.01 billion $\mathrm{m}$ ). Slightly more than half ( 52 percent) of this storage is located in Canada. The system flood protection plan consists of flow regulation by Federally-owned upstream multiple-purpose lakes/reservoirs in conjunction with levee protection at individual flood risk areas downstream. Storage projects in the upper Columbia Basin are most effective in controlling spring flooding, while storage projects in the lower Snake and Willamette Basin are major factors in controlling winter flooding. The Willamette River floods are regulated by 11 storage projects with combined flood control storage of 1.702 million acre-feet (2.1 billion $\mathrm{m}$ ).

Levee Districts between Bonneville Dam (RM 145/km 233.3)and Westport (RM 40/km 64.4) are listed in Table B-31 by name, location, number of acres protected, and land use. Land use categories include agriculture (ag), brush land (mb), cultivated poplars (cp), rural residential/farm sites, (rrf), wildlife refuge (wr), municipal improvements such as residential, golf courses, and airports (mu), and commercial/industrial (ci). Many of the smaller agricultural districts shown have levee protection rated considerably below the 100 -year regulated flood level. Mainline levees that protect the major damage centers evaluated in this study are identified by footnote.

\section{B3.3.2 Existing Flood Damages}

Major levee systems, together with upstream storage in the United States and Canada, provide significant protection for major urban areas along the Lower Columbia River. These major levee systems comprise only six of the 53 drainage districts which exist between Bonneville Dam and the mouth of the Columbia River. The remaining 47 drainage districts generally protect agricultural areas with levees built to lower elevations than the major levee systems. Based on data currently available, expected flood damages to these areas range from about $\$ 9$ million with a peak discharge at The Dalles of $450,000 \mathrm{cfs}(12,744 \mathrm{~m} / \mathrm{s})$ to about $\$ 1.4$ billion with a peak discharge of $850,000 \mathrm{cfs}(24,072 \mathrm{~m} / \mathrm{s})$. Expected total damages for the subarea for selected levels of discharge at The Dalles, under existing conditions and base case (SOS $2 c$ operation of the system) are summarized in Table $\mathrm{B}-32$. 
Table B-31. Flood Protection Levee Districts on the Lower Columbia River Between Bonneville Dam and River Mile $\mathbf{4 0}$

\begin{tabular}{|c|c|c|c|}
\hline Levee District & River Mile & $\begin{array}{c}\text { Acres } \\
\text { Protected }\end{array}$ & Land Use ${ }^{2 /}$ \\
\hline Washougal $^{1}$ & 125.4 & 1,800 & mu, ag \\
\hline Sandy D.D., OR ${ }^{1}$ & 120.2 & 1,556 & $\mathrm{mu}, \mathrm{ag}$ \\
\hline Multnomah Co. D.D. No.1, OR ${ }^{1}$ & 113.7 & 8,417 & $\mathrm{mu}, \mathrm{ag}, \mathrm{ci}$ \\
\hline Peninsula D.D. No. $2, \mathrm{OR}^{1}$ & 107.0 & 1,475 & $\mathrm{mu}, \mathrm{ci}$ \\
\hline Peninsula D.D. No. $1, \mathrm{OR}^{1}$ & 106.1 & 901 & $\mathrm{mu}, \mathrm{ci}$ \\
\hline Sauvie Island, OR & 98.6 & 1,233 & $\mathrm{ag}, \mathrm{rrf}, \mathrm{ci}$ \\
\hline Clark Co. No. 14, WA & 98.2 & 3,730 & ag, $\operatorname{rrf}$ \\
\hline Columbia Co. No. 1 , OR & 94.6 & 1,680 & wr, ag, rrf \\
\hline Scappoose D.D., OR & 93.5 & 1,530 & ag, rrf, ci \\
\hline Cowlitz Consl. No. 2, Woodland, WA & 83.6 & 7,750 & $\mathrm{mu}, \mathrm{ag}, \mathrm{rrf}$ \\
\hline Deer Island, OR & 79.0 & 3,920 & ag, $\mathrm{rff}$ \\
\hline Cowlitz Co. No. 3, Kelso, WA & 68.3 & 1,360 & $\mathrm{mu}$ \\
\hline Rainier, OR & 64.5 & 1,287 & rrf, ag \\
\hline Cowlitz Consl. No. 1 , Longview, WA ${ }^{1}$ & 64.4 & 9,885 & $\mathrm{mu}, \mathrm{ci}$ \\
\hline Cowlitz Co. No. 15, WA & 58.6 & 847 & ag, $\mathrm{rrf}$ \\
\hline John, OR & 56.0 & 147 & $\mathrm{ag}, \mathrm{rrf}$ \\
\hline Beaver, OR & 52.6 & 5,595 & $\mathrm{cp}, \mathrm{ag}, \mathrm{rrf}$ \\
\hline Clatskanie, OR & 50.0 & 325 & $\mathrm{cp}, \mathrm{ag}, \mathrm{rrf}$ \\
\hline Magruder, OR & 49.0 & 592 & $\mathrm{cp}, \mathrm{ag}, \mathrm{rrf}$ \\
\hline Midland, OR & 48.8 & 1,330 & $\mathrm{cp}, \mathrm{ag}, \mathrm{rrf}$ \\
\hline Webb, OR & 47.1 & 733 & $\mathrm{cp}, \mathrm{ag}, \mathrm{rrf}$ \\
\hline Marshland, OR & 47.0 & 1,145 & $\mathrm{cp}, \mathrm{ag}, \mathrm{rrf}$ \\
\hline Woodson, OR & 46.0 & 355 & $\mathrm{cp}, \mathrm{ag}, \mathrm{rrf}$ \\
\hline Westland, OR & 45.2 & 1,091 & $\mathrm{cp}, \mathrm{ag}, \mathrm{rrf}$ \\
\hline Clatsop No. 15, OR & 44.1 & 233 & $\mathrm{cp}, \mathrm{ag}$ \\
\hline Wahkiakum Co. No. 1, WA & 41.7 & 3,865 & $\mathrm{ag}, \mathrm{rrf}$ \\
\hline \multicolumn{4}{|c|}{$\begin{array}{l}\text { 1/ These districts are those which were evaluated for potential flood damages. } \\
\text { 2/ Land use abbreviations are: agriculture (ag), brush land (mb), cultivated poplars (cp), rura } \\
\text { residential/farm sites, (rrf), wildlife refuge (wr), municipal improvements such as residential, golf courses } \\
\text { and airports (mu), and commercial/industrial (ci). }\end{array}$} \\
\hline
\end{tabular}


Table B-32. Flood Protection Levee Districts on the Lower Columbia River

\begin{tabular}{|c|c|c|c|}
\hline $\begin{array}{c}\text { Discharge at } \\
\text { The Dalles (cfs) }\end{array}$ & $\begin{array}{c}\text { Frequency of } \\
\text { Occurrence }\end{array}$ & $\begin{array}{c}\text { Selected } \\
\text { Discharges (cfs) }\end{array}$ & $\begin{array}{c}\text { Damages } \\
(\$)\end{array}$ \\
\hline 412,000 & .5 & 450,000 & 9,000 \\
519,000 & .2 & 625,000 & 69,000 \\
\hline 587,000 & .1 & & 172,000 \\
650,000 & .05 & 700,000 & 293,000 \\
\hline 651,000 & .05 & 800,000 & $1,434,000$ \\
\hline 732,000 & .01 & & \\
\hline 792,000 & .005 & 850,000 & \\
\hline 852,000 & .005 & & \\
\hline 852,000 & \multicolumn{2}{|c|}{} &
\end{tabular}

\section{B3.4 ANALYSIS OF FLOOD DAMAGES}

\section{B3.4.1 Introduction}

Within the reach of Columbia River between Bonneville Dam and the river's mouth entrance are numerous land areas subject to potential flooding. Between river miles 100 and $125,(\mathrm{~km} 161$ and 201) and 64 and 66, (km 103 and 106) land and extensive improvements are protected by major levees. Protected areas are comprised of diking and/or drainage districts wherein damages associated with flooding would constitute major economic losses. These specific locations have been analyzed to determine the extent to which the risk of flooding would be affected under each of the alternative SOR system operating strategies. (SOSs)

In addition to the system of levees downstream of Bonneville Dam, flood control on the Lower Columbia River is attained by operation of storage projects within the Columbia-Snake River system. John Day Dam, which forms Lake Umatilla, is the initial upstream project that contains flood control storage. Other storage reservoirs are located in the upper reaches of the basin. Operation of system storage projects provides flood protection by controlling excess river discharges during the spring-summer freshet period. System operating strategies designed to meet flow targets could produce greater discharges at downstream damage centers than would be experienced under the base condition (SOS 2C). Operational strategies that require drawdown of Snake River projects, including those which would return the lower Snake River to natural river conditions, and stable pool alternatives would a have negligible impact on the system flood control objective. A listing and description of the respective operating strategies is presented in the preface to this appendix.

\section{B3.4.2 Stage/Frequency Analysis}

For each operating strategy, frequency-discharge data were developed using the SSARR (Streamflow Synthesis and Reservoir Regulation) model. The model incorporates 50 water years of record, 1928 to 1978, and provides computed discharges at The Dalles, Oregon over a range of frequencies. Frequencies range from .99 (annual probability of occurrence) to .002 (500-year regulated discharge as observed at The Dalles). The range of discharge frequencies includes a standard project flood event (SPF) as regulated by existing storage, which is $900,000 \mathrm{cfs}\left(25,485 \mathrm{~m}^{3} / \mathrm{s}\right)$ at The Dalles. Discharge/ frequency data developed using the model are displayed in Table B-33. 
Table B-33. Columbia River Discharge Frequency Data at The Dalles Alternative Plans (Cubic-ft/Second)

\begin{tabular}{|c|c|c|c|c|c|c|c|c|c|c|c|c|c|}
\hline $\begin{array}{c}\text { Error! } \\
\text { Bookmark } \\
\text { not defined. } \\
\text { Probability }\end{array}$ & SOS 1a & SOS 1b & SOS 2c & SOS 2d & SOS 4c & SOS 5b & SOS 5c & sos $6 b$ & SOS 6d & SOS 9a & SOS 9b & SOS 9c & $\mathbf{P A}$ \\
\hline 0.002 & 931,800 & 888,600 & 897,900 & 897,900 & 874,000 & 897,900 & 897,900 & 887,400 & 878,700 & 844,900 & 935,500 & 939,500 & 942,000 \\
\hline 0.005 & 852,200 & 824,900 & 831,200 & 831,200 & 819,200 & 831,200 & 831,200 & 819,400 & 818,300 & 781,100 & 858,200 & 849,600 & 869,400 \\
\hline 0.01 & 792,200 & 774,800 & 779,400 & 779,400 & 774,700 & 779,400 & 779,400 & 766,700 & 770,700 & 732,500 & 799,300 & 783,000 & 813,200 \\
\hline 0.02 & 732,000 & 722,500 & 726,000 & 726,000 & 726,900 & 726,000 & 726,000 & 712,500 & 721,000 & 683,200 & 739,500 & 717,100 & 755,400 \\
\hline 0.05 & 650,900 & 649,000 & 651,800 & 651,800 & 657,000 & 651,800 & 651,800 & 637,600 & 650,600 & 616,200 & 658,200 & 630,300 & 675,500 \\
\hline 0.1 & 587,200 & 588,400 & 591,600 & 591,600 & 597,300 & 591,600 & 591,600 & 576,800 & 592,400 & 562,800 & 593,400 & 563,600 & 610,800 \\
\hline 0.2 & 519,100 & 520,700 & 525,200 & 525,200 & 528,500 & 525,200 & 525,200 & 510,100 & 727,100 & 505,000 & 523,500 & 493,800 & 539,700 \\
\hline 0.5 & 412,200 & 407,900 & 416,100 & 416,100 & 408,700 & 416,100 & 416,100 & 401,100 & 417,300 & 412,200 & 411,800 & 387,500 & 423,800 \\
\hline 0.8 & 329,400 & 315,000 & 327,500 & 327,500 & 306,600 & 327,500 & 327,500 & 313,300 & 326,000 & 338,400 & 324,000 & 308,100 & 330,500 \\
\hline 0.9 & 293,700 & 273,700 & 288,300 & 288,300 & 260,500 & 288,300 & 288,300 & 274,600 & 284,900 & 305,900 & 285,800 & 274,800 & 289,400 \\
\hline 0.95 & 267,500 & 242,900 & 259,001 & 259,001 & 226,100 & 259,001 & 259,001 & 245,900 & 254,200 & 281,800 & 257,700 & 250,600 & 259,000 \\
\hline 0.99 & 225,200 & 192,800 & 211,200 & 211,200 & 170,600 & 211,200 & 211,200 & 199,200 & 203,800 & 242,200 & 212,200 & 212,200 & 209,600 \\
\hline
\end{tabular}

Note: Stage data on the following pages is based on rating curve data with flows ranging from $450,000 \mathrm{cfs}$ to $1,200,000 \mathrm{cfs}$ at The Dalles. Only stage data corresponding to flows in this range are considered reliable. 
Discharge events of varying frequencies were then converted to corresponding river stages at selected locations of major damage centers. This was accomplished by use of rating curves. In some instances, stage elevations were determined by interpolation. The specific river miles correspond to the location of major levees. These are displayed in Table B-34. The range of river stages, up to a 500-year dis- charge event, was compared to levee crest elevations at each levee location. This was done for the base condition (SOS 2c) and each of the system operating strategies under consideration.

Table B-35 compares the respective river stages associated with a 500-year event for the base condition, to equivalent stages of each alternative operating scenario at each levee location.

Table B-34. Columbia River Stage-Discharge Relationships by Location (ft-NGVD)

\begin{tabular}{|c|c|c|c|c|c|c|c|}
\hline $\begin{array}{c}\text { Error! } \\
\text { Bookmark } \\
\text { not defined. } \\
\text { Flow (cfs) }\end{array}$ & $\begin{array}{c}\text { RM 64.4 } \\
\text { Cowlitz, } \\
\text { Lons. No. 1 } \\
\text { WA }\end{array}$ & $\begin{array}{c}\text { RM 106.1 } \\
\text { Peninsula } \\
\text { Diking Dist. } \\
\text { No. 1, OR }\end{array}$ & $\begin{array}{c}\text { RM 106.5 } \\
\text { Vancouver, } \\
\text { WA }\end{array}$ & $\begin{array}{c}\text { RM 107 } \\
\text { Peninsula } \\
\text { Diking Dist. } \\
\text { No. 2, OR }\end{array}$ & $\begin{array}{c}\text { RM 113.7 } \\
\text { Multnomah } \\
\text { D.D. No. 1, } \\
\text { OR }\end{array}$ & $\begin{array}{c}\text { RM 120.2 } \\
\text { Sandy } \\
\text { Diking } \\
\text { Dist., OR }\end{array}$ & $\begin{array}{c}\text { RM 125.5 } \\
\text { Washougal, } \\
\text { WA }\end{array}$ \\
\hline 450,000 & 12.3 & 19.7 & 19.8 & 19.9 & 21.8 & 23.9 & 26.0 \\
\hline 500,000 & 12.8 & 21.3 & 21.4 & 21.6 & 23.6 & 25.6 & 27.4 \\
\hline 550,000 & 13.4 & 22.8 & 22.9 & 23.1 & 25.2 & 27.1 & 28.8 \\
\hline 600,000 & 14.0 & 24.2 & 24.3 & 24.4 & 26.5 & 28.5 & 30.1 \\
\hline 650,000 & 14.7 & 25.4 & 25.5 & 25.6 & 27.7 & 29.7 & 31.2 \\
\hline 700,000 & 15.4 & 26.5 & 26.6 & 26.8 & 28.7 & 30.7 & 32.3 \\
\hline 750,000 & 16.1 & 27.6 & 27.8 & 27.9 & 29.9 & 31.8 & 33.3 \\
\hline 800,000 & 16.8 & 28.7 & 28.9 & 29.0 & 31.0 & 32.9 & 34.4 \\
\hline 850,000 & 17.5 & 29.8 & 29.9 & 30.1 & 32.1 & 34.2 & 35.8 \\
\hline 900,000 & 18.3 & 30.9 & 31.1 & 31.2 & 33.2 & 35.3 & 36.8 \\
\hline 950,000 & 19.2 & 32.0 & 32.1 & 32.2 & 34.2 & 36.2 & 37.5 \\
\hline $1,000,000$ & 19.9 & 32.9 & 33.0 & 33.1 & 35.1 & 37.1 & 38.3 \\
\hline $1,050,000$ & 20.6 & 33.9 & 34.0 & 34.1 & 36.2 & 38.1 & 39.3 \\
\hline $1,100,000$ & 21.2 & 34.8 & 34.9 & 35.0 & 37.2 & 39.2 & 40.3 \\
\hline $1,150,000$ & 21.8 & 35.7 & 35.8 & 35.9 & 38.2 & 40.2 & 41.3 \\
\hline $1,200,000$ & 22.5 & 36.5 & 36.7 & 36.8 & 39.2 & 41.1 & 42.3 \\
\hline $\begin{array}{l}\text { Source: Columbia River Profiles, Combined Probability Floods, US Army Engineer District, Portland, Revised, } \\
\text { March 1988. }\end{array}$ & & & & & & & \\
\hline
\end{tabular}


Table B-35. Comparative River Stages, Base Condition vs. Alternative Plans $\mathbf{5}^{\star} \mathbf{5 0}-$ Year Discharge Event at The Dalles, OR - River Stage in feet, msl

\begin{tabular}{|c|c|c|c|c|c|c|c|c|c|c|c|c|c|c|}
\hline District & $\begin{array}{l}\text { River } \\
\text { Mile }\end{array}$ & $\begin{array}{l}\text { Base } \\
\text { Condi } \\
\text { tion } \\
2-C\end{array}$ & $1-A$ & $\begin{array}{c}\text { Variance } \\
\text { from } \\
2-C\end{array}$ & $3-B$ & $\begin{array}{l}\text { Variance } \\
\text { from } \\
2-C\end{array}$ & $4-A 3$ & $\begin{array}{l}\text { Variance } \\
\text { from } \\
2-C\end{array}$ & $5-B$ & $\begin{array}{l}\text { Variance } \\
\text { from } \\
2-\mathrm{C}\end{array}$ & $\begin{array}{c}6-\mathrm{AF} \\
52\end{array}$ & $\begin{array}{l}\text { Variance } \\
\text { from } \\
2-C\end{array}$ & $7-C$ & $\begin{array}{l}\text { Variance } \\
\text { from } \\
2-C\end{array}$ \\
\hline Washougal & 125.4 & 36.7 & 37.3 & 0.6 & 36.3 & -0.4 & 36.7 & 0 & 36.6 & -0.1 & 37.4 & 0.7 & 37.4 & 0.7 \\
\hline Sandy & 120.2 & 35.2 & 35.9 & 0.7 & 34.8 & -0.4 & 35.2 & 0 & 35.1 & -0.1 & 36.0 & 0.8 & 36.0 & 0.8 \\
\hline Multnomah & 113.7 & 33.2 & 33.9 & 0.7 & 32.6 & -0.6 & 33.2 & $\mathbf{0}$ & 33.0 & -0.2 & 34.0 & 0.8 & 34.0 & 0.8 \\
\hline Peninsula 2 & 107.0 & 31.1 & 31.8 & 0.7 & 30.6 & -0.5 & 31.1 & 0 & 31.0 & -0.1 & 32.0 & 0.9 & 32.0 & 0.9 \\
\hline Peninsula 1 & 106.1 & 30.9 & 31.6 & 0.7 & 30.4 & -0.5 & 30.9 & 0 & 30.7 & -0.2 & 31.8 & 0.9 & 31.8 & 0.9 \\
\hline Longview & 64.4 & 18.3 & 18.9 & 0.6 & 17.9 & -0.4 & 18.3 & 0 & 18.2 & -0.1 & 19.0 & 0.7 & 19.0 & 0.7 \\
\hline
\end{tabular}

\section{B3.4.3 Potential Damages}

The analysis of potential flooding focuses on individual areas with levees (districts) that contain extensive improvements. Five of the six areas considered are located in the Portland-Vancouver metropolitan area upstream of the mouth of Willamette River. The remaining damage-prone area is a diking district with levees at Longview, Washington, river mile 64 (Km 103). The topography within the protected areas is relatively flat, with only minor variations in ground elevation. The majority of damageable property is generally contained within the district boundaries.

Because of zoning and land use requirements which limit new floodplain development to lands having $100-y r$ or greater existing protection, and because of physical limitations of the diking/drainage districts with respect to new developments, no growth in value of improvements has been projected with respect to flood control. For existing improvements, increases in the current dollar cost of replacement over time will be offset by the depreciation of those assets, reflecting the declining physical life of improvements over time. In the case of new improvements added over time, these would be limited largely by geographical limitations of the respective districts, most of which are presently well developed. In consideration of these factors, no net growth in value is projected over the life of the project.

\section{B3.4.4 Consideration of Safe Levee Height}

Levees on the lower Columbia River were inspected and safe levee heights were established in 1978. The results of the inspection are included in the report, "Drainage District Condition Survey on Safe Water Surface Levels," Corps of Engineers, Portland District, May 1978. The report is significantly dated but constitutes the most recent published comprehensive survey of levees made by Portland District. The reports lists levee capacity in terms of safe levee height and top of levee. Safe levee height was subjectively determined based upon structural factors, levee height, and maintenance performance. This standard represents a level above which the levee could fail if no emergency remedial measures were undertaken during the course of a flood to combat any levee deficiencies. At safe levee height, there is a $\mathbf{1 0 0}$ percent level of confidence that there is no risk to the structural integrity of the levee.

Water levels that exceed the safe height elevation, however, do not necessarily cause levee breaching or 
failure. On the Columbia River, damage to levees typically begins with seepage under the levees. As the event progresses, saturation begins to occur. Below safe height elevation, seepage and saturation do not constitute significant problems. Potential levee failure with stages which would result from the SOSs included in the SOR was evaluated. Through this evaluation the Portland District determined that there were no flood conditions (from SOR alternatives) which would cause levee failure. In addition, in several cases of mainline levees on the Lower Columbia, there is 10 or more feet of elevation between safe heights cited in the 1978 survey and actual top of levee. At river stages associated with a 500-year flood event, levees included in this study have a remaining freeboard ranging from 6 to 13 feet $(1.83 \mathrm{~m}$ to $3.96 \mathrm{~m})$. As a result, levee overtopping would not occur. Additionally, only SOS 7 would produce a stage difference greater than one foot at a 500-year flood event, as compared with the present operation of the system. Levees may be subject to damage from erosion and require subsequent repair, however, there is no likelihood of failure. For this reason, the potential magnitude of damages resulting from levee failure was not estimated for this study.

Some of the SOSs, however, could significantly affect discharge in the lower portion of the river (below RM 64/km 103). Significant flood damages would be experienced throughout this reach in the event of a 500-year flood event. The majority of damage, however, would be to areas without levees and improvements not otherwise protected.

\section{B3.4.5 Summary and Conclusions}

Land and improvements in the lower Columbia River area are protected by levees and by storage projects located in the middle and upper reaches of the basin with the capability to regulate excess runoff. In addition, Lake Umatilla (John Day Dam) on the main stem of the Columbia River contains 500,000 acre - feet ( 617 million $\mathrm{m}$ ) of storage to control excess runoff.
No flood damages to mainline levee protected areas, beyond those that would be anticipated to take place under the base or no-action condition, are expected to result from any of the SOSs evaluated in the SOR. The study evaluated potential flood damages to six of 53 drainage districts, each of which protects major urban areas. SOSs with flow enhancement measures have important, but less significant flood control consequences. These operating strategies increase the frequency of releases and could impact protective works at certain locations in terms of increased levee saturation and erosion. This could potentially affect the cost of levee maintenance. Increased maintenance costs, however, are excepted to be relatively minor and were not evaluated for this study. Since the overall flood control objective would not change, adverse impacts with respect to flood potential at downstream damage centers would be minimal.

The only event for which flood damages were considered (in all cases) was a levee overtopping event. Table B-36 provides a comparison of levee crest elevations to river stage elevation, for the highest discharge event associated with each SOS. None of the six damage centers evaluated in this study would experience levee failure under any of the alternative SOSs.

As shown in Table B-35, SOS 1, SOS 9, and the preferred alternative would increase the flood stage of a 500-year discharge event at each levee location relative to the base condition (SOS 2c). The increase in each case, however would be less than one foot. SOS 4 and SOS 6, which involve stable storage and variable pool drawdown, produce slightly lower stages over a range of flood events than would be experienced under the base condition (SOS $2 c$ ). And, SOS 5, the natural river alternative, produces the same flows and stages as does the base condition. Stages are well below the existing crest elevations of the respective levees for all of the final SOSs. Net freeboard related to each SOS is displayed in Table B-36. 
Table B-36. Comparison of Levee Crest Elevations to River Stages * -500-Year Discharge Event at The Dalles, OR (In Feet NGVD)

\begin{tabular}{|c|c|c|c|c|c|c|c|c|c|c|c|c|c|c|c|c|}
\hline District & $\begin{array}{l}\text { River } \\
\text { Mile }\end{array}$ & $\begin{array}{c}\text { Levee } \\
\text { Crest } \\
\text { Elevation }\end{array}$ & $\begin{array}{c}\text { (Base) } \\
\text { SOS } \\
2 \mathrm{c}\end{array}$ & $\begin{array}{l}\text { Net } \\
\text { Free- } \\
\text { Board }\end{array}$ & $1-A$ & $\begin{array}{l}\text { Net } \\
\text { Free- } \\
\text { Board }\end{array}$ & $3-B$ & $\begin{array}{l}\text { Net } \\
\text { Free- } \\
\text { Board }\end{array}$ & $4-A \hat{3}$ & $\begin{array}{c}\text { Net } \\
\text { Free- } \\
\text { Board }\end{array}$ & 5-B & $\begin{array}{l}\text { Net } \\
\text { Free- } \\
\text { Board }\end{array}$ & $\begin{array}{c}\text { SOS } \\
6-a \\
\text { (F52) }\end{array}$ & $\begin{array}{l}\text { Net } \\
\text { Free- } \\
\text { Board }\end{array}$ & $\begin{array}{l}\text { SOS } \\
7-c\end{array}$ & $\begin{array}{l}\text { Net } \\
\text { Free- } \\
\text { Board }\end{array}$ \\
\hline Washougal & 125.4 & 43 & 36.7 & 6.3 & 37.3 & 5.7 & 37.3 & 5.7 & 36.6 & 6.4 & 36.5 & 6.5 & 36.6 & 6.4 & 37.7 & 5.3 \\
\hline Sandy & 120.2 & 45 & 35.2 & 9.8 & 35.9 & 9.1 & 36 & 9 & 35.1 & 9.9 & 35 & 10 & 35.2 & 9.8 & 36.4 & 8.6 \\
\hline Multnomah & 113.7 & 44 & 33.2 & 10.8 & 33.9 & 10.1 & 34 & 10 & 33 & 11 & 32.8 & 11.2 & 33.1 & 10.9 & 34.5 & 9.5 \\
\hline Peninsula 2 & 107 & 35.8 & 31.1 & 4.7 & 31.8 & 4 & 31.9 & 3.9 & 31 & 4.8 & 30.8 & 5 & 31 & 4.8 & 32.5 & 3.3 \\
\hline Peninsula 1 & 106.1 & 35.3 & 30.9 & 4.4 & 31.6 & 3.7 & 31.7 & 3.6 & 30.8 & 4.5 & 30.5 & 4.8 & 30.8 & 4.5 & 32.2 & 3.1 \\
\hline Longview & 64.4 & 28.9 & 18.3 & 10.6 & 18.9 & 10 & 18.9 & 10 & 18.2 & 10.7 & 18 & 10.9 & 18.2 & 10.7 & 19.4 & 9.5 \\
\hline
\end{tabular}

* For each of the alternative plans, 1-7, those options having the highest stage associated with a 500-year event are shown above.

Source: "Flood Profiles, Columbia River and Tributaries Washington and Oregon below Bonneville Dam." U.S. Army Corps of Engineers,

Portland District, Revised, November 1971. 


\section{SECTION B4.0 - SUMMARY OF FLOOD DAMAGE ANALYSES}

\section{B4.1 SUMMARY OF RESULTS}

Tables B-37 and B-38 summarize the expected average annual flood damages for each subarea of the river by system operating strategy, for discount rates of 7.75 percent and 3.0 percent, respectively. The values shown are equivalent annual damages which represent average conditions which would occur over the 100-year period of analysis beginning in 1995. The equivalent annual damage combines initial and ultimate damages into a single average annual amount. Initial damages represent damages that would be expected to occur at the being of the period of analysis - 1995. Ultimate damages represent the damages that would occur with implementation of each SOS. For those SOSs which do not require physical modifications of the system and, therefore, could be implemented in 1995, initial and ultimate damages are the same. The analysis did not consider future development of the floodplains.

In the Upper Columbia subarea, SOS $4 c$ (stable storage operation) will increase flood damages over the base case (SOS $2 c$ ) in the damage reach below Libby Dam as a result of reduced flood control storage space. SOSs $9 \mathrm{a}, 9 \mathrm{~b}$, and $9 \mathrm{c}$ (resource agency strategies) also tend to increase flood damages in the Upper Columbia subarea to varying degrees. In addition, the preferred alternative (PA), results in an increase in flood damages because the 1995 Biological Opinions upon which this alternative is based tends to hold pools in the storage reservoirs at higher elevations. Alternatives 1a, 1b, 2d, 5b, 5c, 6b, and $6 \mathrm{~d}$ have no affect on flood damages in the Upper Columbia subarea.

In the Clearwater River subarea, the major damage centers of Lewiston, Idaho and Clarkston, Washington are protected by levees. $\mathrm{Re}$-analysis of the alternative SOSs included in the FEIS by the Flood Control Work Group showed that they would all have the same flood discharge/frequency characteristics as the base case, SOS 2c. Therefore, none of the alternatives would result in peak discharges which would exceed the safe height of these levees and expected potential damages would be identical to those for SOS $2 c$

In the lower Columbia River subarea, only major damage centers, all of which are protected by levees as well the upstream storage reservoirs in the US and Canada, were evaluated for potential flood damages. Under the base case (SOS 2c), flood damages in this subarea range from an estimated $\$ 9$ million at a peak discharge at The Dalles of 450,000 cfs to an estimated $\$ 1.4$ billion at a peak discharge at The Dalles of $850,000 \mathrm{cfs}$. With the base case operation of the system, a peak discharge at The Dalles of 450,000 is expected to occur about once in every two to five years. A peak discharge of $850,000 \mathrm{cfs}$ is expected to occur about once in every 200 to 500 years. Although SOSs 1, 9 and the preferred alternative would increase river stages throughout the subarea, the increase would be less than one foot at each location. This would not impact the levee-protected areas evaluated in the study. The levees would have from 3.7 to 11.4 feet of free-board above the highest discharges considered--an event which could be expected to occur only about once in about 500 years. Areas not protected by major levee systems would continue to experience flooding and flood-related damages under high discharge conditions, both under the base case and with each of the alternative operating plans. A damage assessment of those areas was not conducted during this study.

\section{B4.2 REVIEW OF SYSTEM FLOOD CONTROL}

As stated above, the SOSs included in the SOR did not consider changes in flood control storage. For this reason, the amount of additional water which could be provided by the system to augment flow during the juvenile fish migration for any given SOS was relatively limited. In recognition of the relationship between storage space reserved for flood control and the amount of water held in storage which might be used for flow augmentation purposes, the National Marine Fisheries Service has requested that the Corps conduct a review of flood control storage requirements (NMFS, 1995). In response to that request, the Corps has initiated a review of 
system flood control. A preliminary analysis will be completed by November 1996 . The study will include the following major elements:

- Analysis of system storage requirements to regulate the flow at The Dalles to alternative levels, ranging form $450,000 \mathrm{cfs}$ (current flow objective) to $800,000 \mathrm{cfs}$.

- Analysis of stage/discharge and stage/damage data for all damage centers in the basin which could be affected.
- Analysis of the safe-water height of levees and the probability of their failure for water heights above the safe-water height.

- Assessment of economic and environmental impacts of alternative levels of system flood control.

- Identification of structural and non-structural alternatives to system storage to maintain current levels of flood protection.

- Coordination of the analysis with Federal, state, and public interests and with Canada.

Table B-37. Total Average Annual Equivalent Damages Columbia Basin at a Discount Rate of 7.75 Percent

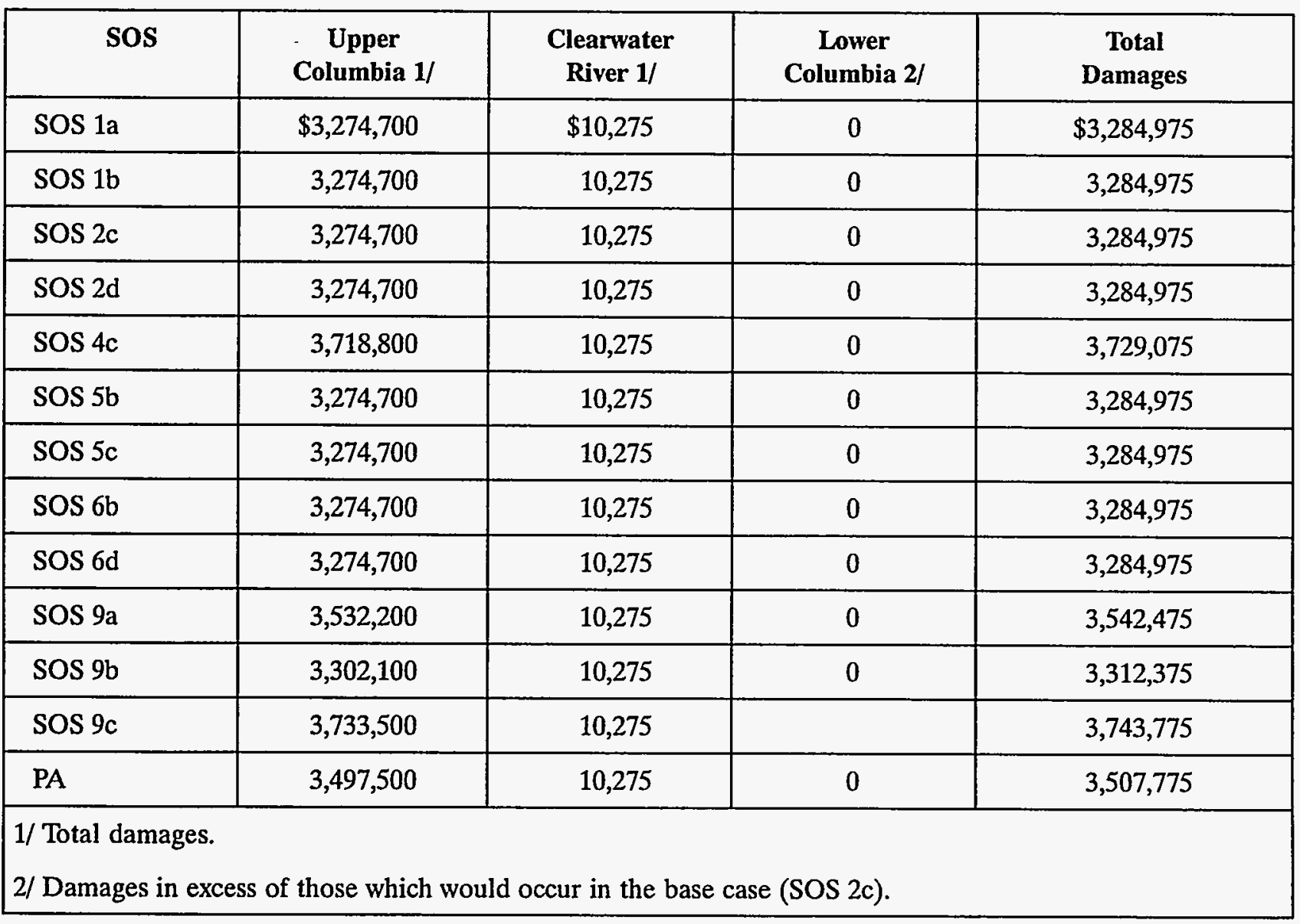


Table B-38. Total Average Annual Equivalent Damages Columbia Basin 3.0\%

\begin{tabular}{|c|c|c|c|c|}
\hline Sos & $\begin{array}{c}\text { Upper } \\
\text { Columbia 1/ }\end{array}$ & $\begin{array}{l}\text { Clearwater } \\
\text { River 1/ }\end{array}$ & $\begin{array}{c}\text { Lower } \\
\text { Columbia } 2 /\end{array}$ & $\begin{array}{c}\text { Total } \\
\text { Damages }\end{array}$ \\
\hline SOS 1a & $\$ 3,274,700$ & $\$ 10,275$ & 0 & $\$ 3,284,975$ \\
\hline SOS $1 b$ & $3,274,700$ & 10,275 & 0 & $3,284,975$ \\
\hline $\operatorname{SOS} 2 c$ & $3,274,700$ & 10,275 & 0 & $3,284,975$ \\
\hline SOS $2 d$ & $3,274,700$ & 10,275 & 0 & $3,284,975$ \\
\hline SOS 4c & $3,718,800$ & 10,275 & 0 & $3,729,075$ \\
\hline SOS $5 b$ & $3,274,700$ & 10,275 & 0 & $3,284,975$ \\
\hline SOS 5c & $3,274,700$ & 10,275 & 0 & $3,284,975$ \\
\hline SOS $6 \mathrm{~b}$ & $3,274,700$ & 10,275 & 0 & $3,284,975$ \\
\hline SOS 6d & $3,274,700$ & 10,275 & 0 & $3,284,975$ \\
\hline SOS 9a & $3,532,200$ & 10,275 & 0 & $3,542,475$ \\
\hline SOS 9b & $3,302,100$ & 10,275 & 0 & $3,312,375$ \\
\hline SOS 9c & $3,733,500$ & 10,275 & & $3,743,775$ \\
\hline PA & $3,497,500$ & 10,275 & 0 & $3,507,775$ \\
\hline \multicolumn{5}{|c|}{$\begin{array}{l}\text { 1/ Total damages. } \\
\text { 2/ Damages in excess of those which would occur in the base case (SOS } 2 c \text { ). }\end{array}$} \\
\hline
\end{tabular}




\section{EXHIBIT C}

\section{SHALLOW-DRAFT NAVIGATION}

\section{C.1 GENERAL}

This exhibit provides a general description of the methodology used to identify the transportation system impacts of SOSs which include drawdown of lower Snake River reservoirs and seasonal or yeararound closure of a portion or all of this reach of the Columbia-Snake shallow-draft waterway. The analysis was performed using a computer simulation model which was developed to measure the direct economic impacts of drawdown of one or more of the lower Snake River reservoirs. A detailed description of the model is provided in the report entitled, "System Operation Review Transportation Model", December 1993, US Army Corps of Engineers - Portland District, prepared by Transportation Research \& Analysis Center, Ponte Verda Beach, Florida. The model is designed to estimate transportation system responses to a variety of system operating regimes, some of which involve drawdown of the Snake River pools for varying periods of time. The model also estimates the added transportation costs that existing users of the Columbia-Snake River System (CSRS)would incur as a result of impairment of navigation. Adjustments made to the original model are described in later sections of this exhibit.

The geographic area addressed in the model is the Pacific Northwest region of the United States that is served by the shallow-draft channels of the Columbia and Snake Rivers between Portland, Oregon (river mile 105) and Lewiston, Idaho (river mile 465 ), the deep water ports on the Columbia and Willamette Rivers below Bonneville dam which transship export items, and the deep-draft ports at Puget Sound, which represent alternative deep water destination ports. Included in Pacific Northwest region, for the transportation impacts analysis, are the states of Oregon, Washington, Idaho, Montana, and North Dakota.

The level of commerce on the waterway is defined by the volume of commodities which moved on the river system during the five-year period from 1986 through 1990. For purposes of modeling, major commodities shipped on the Columbia-Snake navigation system were grouped into the following five groups: (1) grain, (2) petroleum products, (3) wood chips and logs, (4) wood products, and (5) all other (including containerized products). Regionally, grain accounts for the majority of tonnage moved by water. This is reflected in the model, which contains 900 flow links (movement from one point to the next) for grain and 120 flow links for other commodities. Summary results of the analysis are presented in Chapter 4

\section{C.2 DESCRIPTION OF THE SOR TRANSPORTATION MODEL}

The model is a Lotus 123 spreadsheet model and consists of two simulation models and a set of input files. The primary model addresses the impacts of seasonal drawdown of the four Snake River reservoirs--Ice Harbor, Lower Monumental, Little Goose and Lower Granite. A modified version of the primary model was constructed to measure the transportation impacts of a single-pool drawdown (Lower Granite). Both versions of the model are otherwise the same. They are menu driven such that the user can specify changes in a number of variables, including seasonality factors, modal transport rates and costs, storage and handling costs, and other parameters.

The models trace commodity movements on a monthly basis from origin to destination, including movement of grain from growing areas within Ore- 
gon, Washington, Idaho, Western Montana and portions of North Dakota to export elevators on the Lower Columbia. Wheat and other grains grown throughout the Columbia River Basin that are destined for export markets are typically moved from farms to country elevators, to river elevators, and then to downstream export elevators where they are loaded on oceangoing vessels. Grain shipped to export elevators by rail is normally delivered by truck to country elevators where it is loaded on rail cars.

In order to simulate commodity flows within the region, the following conventions and assumptions were employed.

- Upbound barge shipments originating at lower river ports were traced to their county of destination.

- Origins of downriver barge shipments were identified as the county wherein transport is initiated. In the case of grain, origins are farms or country elevators, and destinations are deep-draft export elevators.

- Downbound rail and truck movements of grain likewise originate at farms or country elevators and move from there to deepdraft elevators for transshipment or domestic use.

- Data for water transport were obtained from Waterborne Commerce Statistics and the lock performance monitoring system. (LPMS).

- Where commodity movements such as grain vary by season, the model contains seasonality factors based upon historical monthly volume shipped from river elevators.

- Seasonal volumes shipped from river elevators were then correlated with the volume of products arriving by water at export elevators.

- The transportation costs of the commodity movements included in the model, including handling and storage, are compiled within the model. For grain, transport costs are an aggregation of costs associated with movement from farm to country elevator, to river elevator, to deep-draft export elevator.

- The detailed analysis of rail and truck shipments is limited to downbound or export shipments of grain.

- For upstream movements, costs reflect transport by water from point of origin to the off-load destination on the waterway.

- The model calculates the lowest cost for at least two alternative routes for each origindestination pair affected by a closure of the Snake River to navigation, and for the closure of the Lower Granite pool only.

Flow diagrams which illustrate user defined options and the computation sequence of the model are shown in Figures $\mathrm{C}-1$ through $\mathrm{C}-4$.

\section{C.3 ANALYSIS OF ALTERNATIVE SYSTEM OPERATION STRATEGIES}

\section{C.3.1 BASE CASE}

In the base case, all of the locks and dams in the system are operated between MOP (minimum operating pool) and full pool such that there are no significant impediments to navigation. Commodity flows represented in the models are at the county level and are generally the average of movements for the two-year period, 1990 and 1991, including the volume of shipments and the cost and availability of alternative modes of transportation. The Table $\mathrm{C}-1$ displays the volume of grain shipped by barge on the shallow-draft waterway for the years 1986 through 1990. 


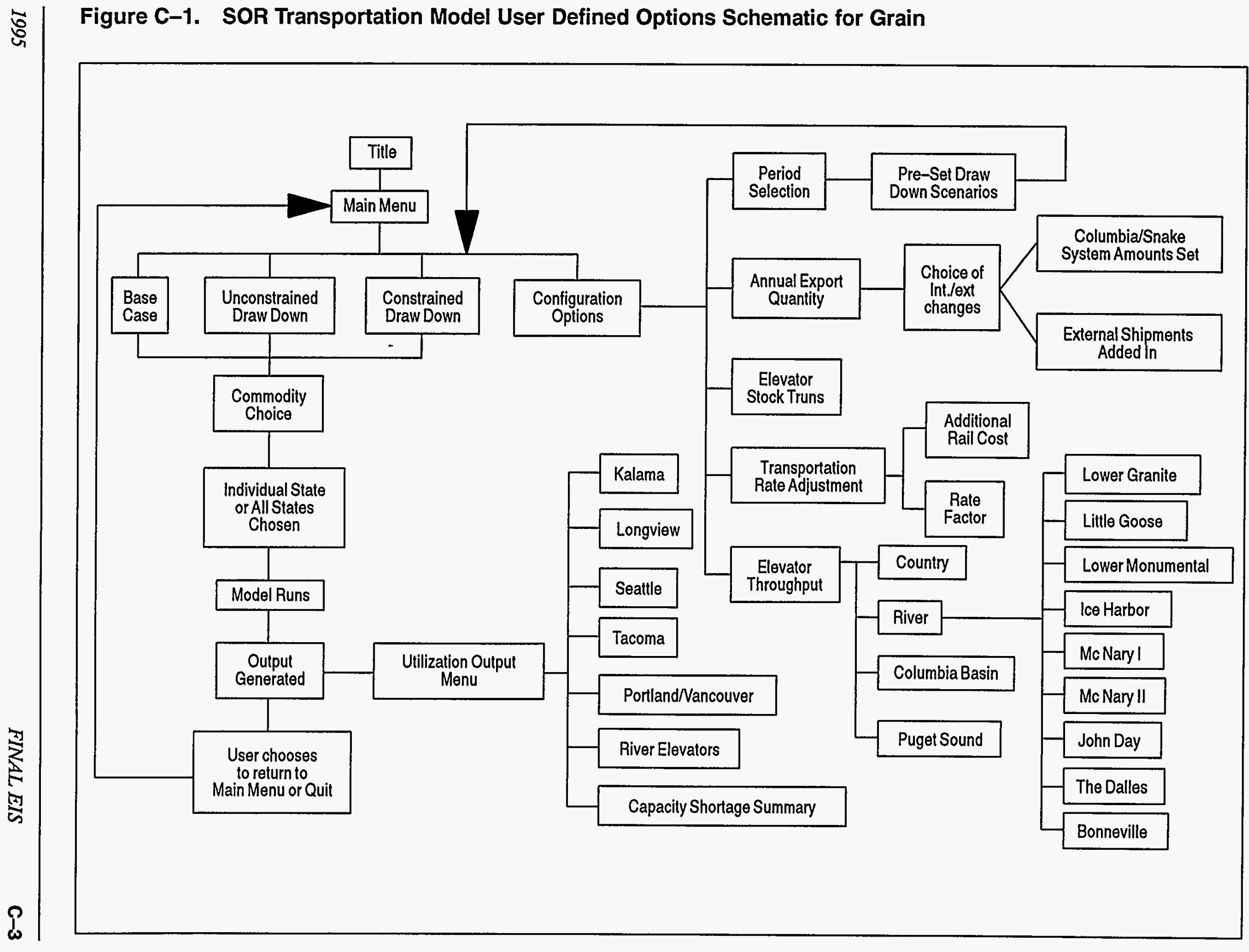


$\{$ Figure C-2. SOR Transportation Model User Defined Options Schematic for Non-Grain Commodities

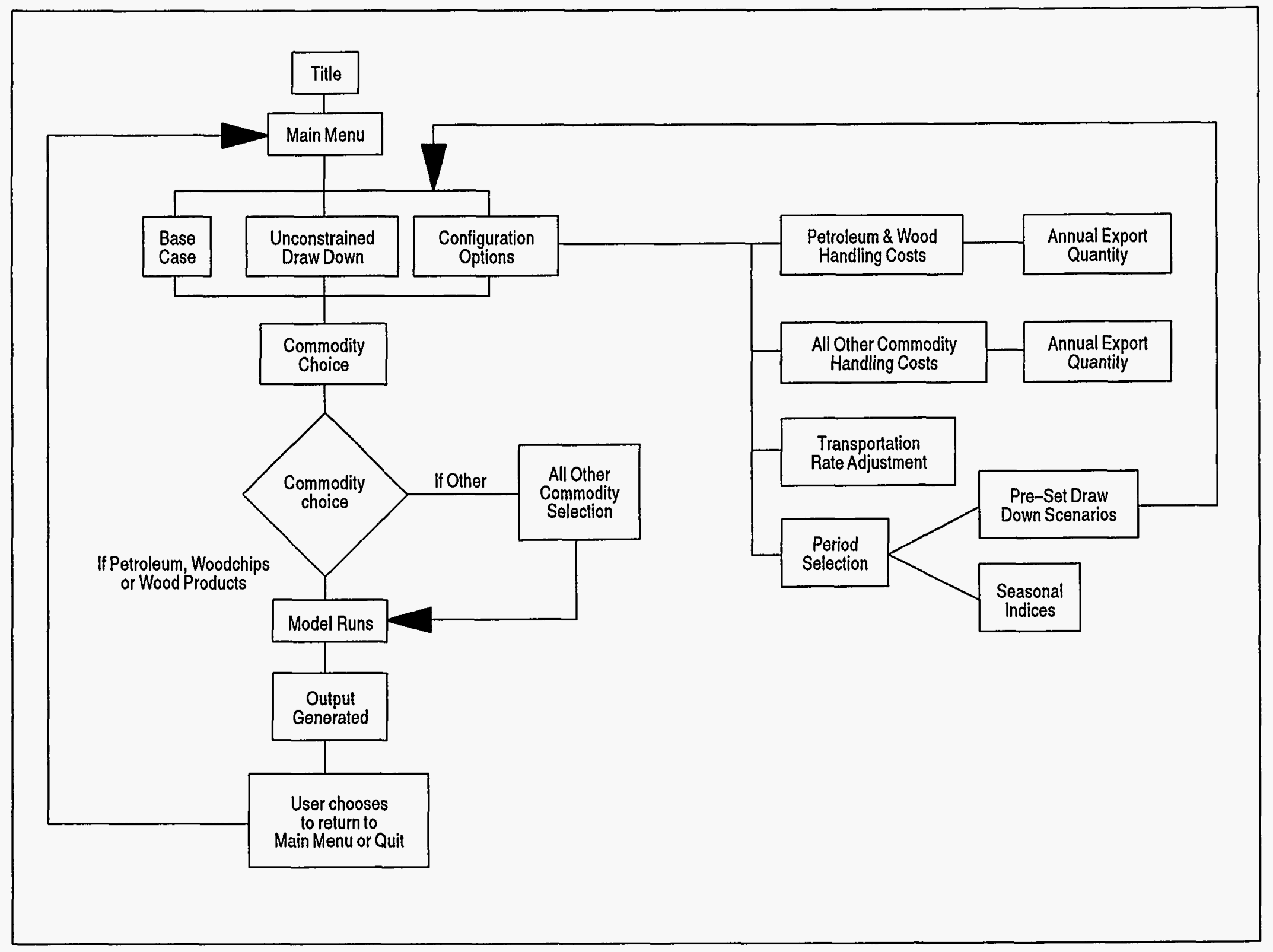




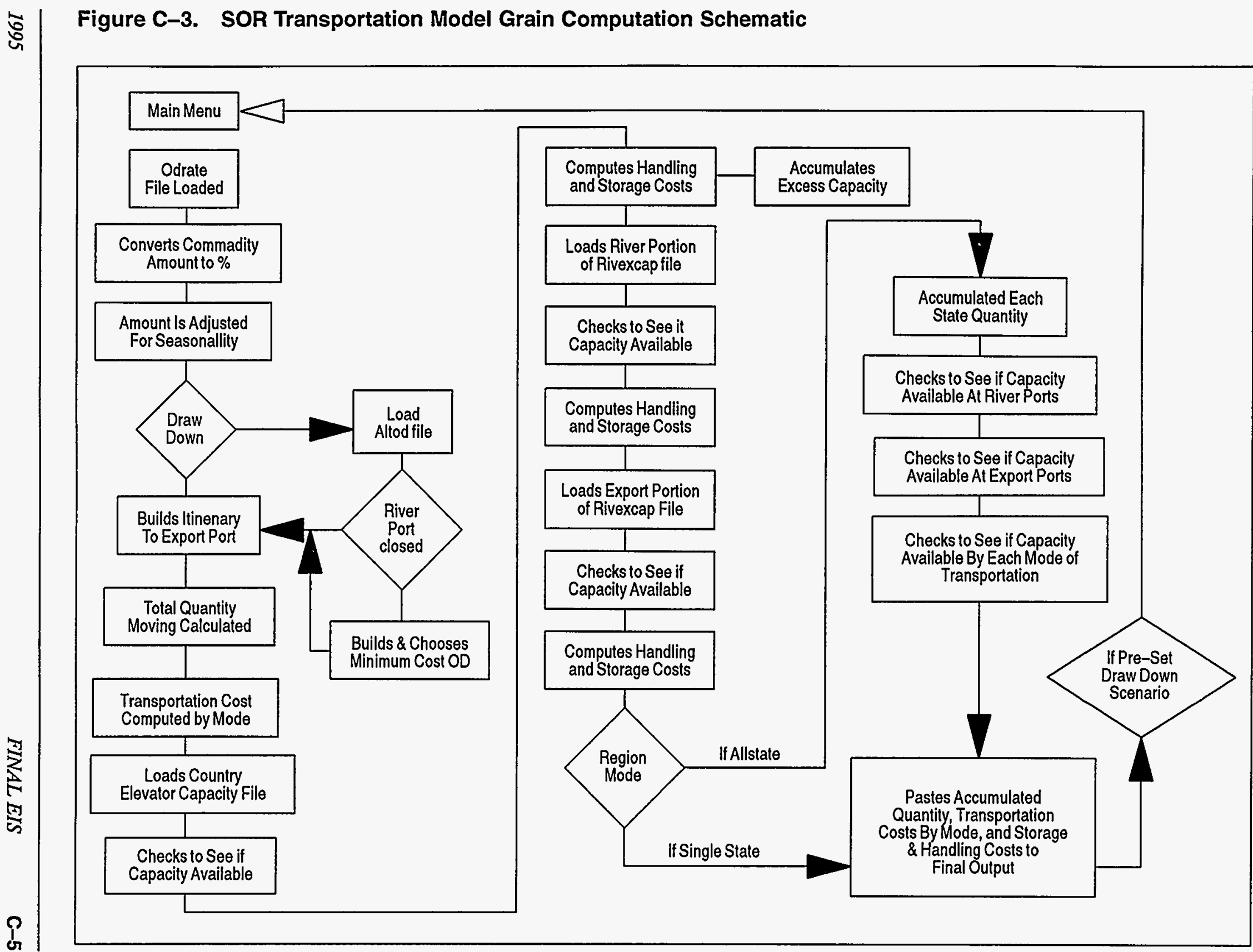


Figure C-4. SOR Transportation Model Non-Grain Computation Schematic

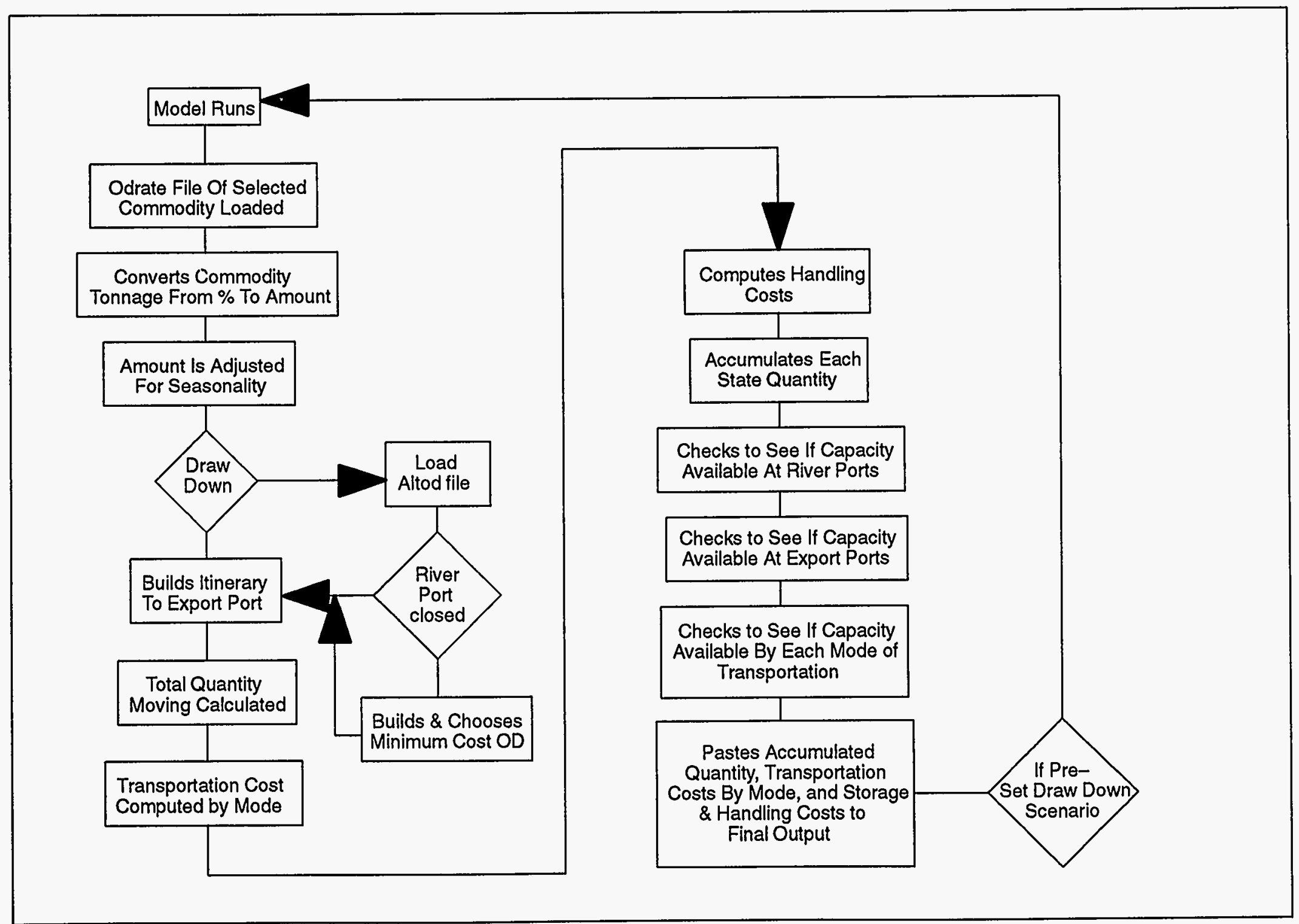


Displayed in Table C-2 are the number of country elevators or regions by state which are included in the model. Data on the number of country elevators in Montana and North Dakota were not compiled because state agencies which collect these data consider grain shipment data at that level of detail to be proprietary. These states compile the data only to a regional level of detail. Since county level data were not available, information on the number of country elevators was not relevant to the analysis, and grain shipments from these two states were modeled on a regional basis.

Table C-1. Volume of Grain Shipped by Barge on the Shallow-Draft Waterway, 1986 through 1990

\begin{tabular}{|l|l|}
\hline \multicolumn{1}{|c|}{ Year } & Tons \\
\hline 1986 & $3,797,351$ \\
\hline 1987 & $4,785,649$ \\
\hline 1988 & $6,608,996^{1 /}$ \\
\hline 1989 & $4,723,810$ \\
\hline 1990 & $4,938,106$ \\
\hline Average & $4.970,782$ \\
\hline $\begin{array}{l}1 / \text { Reflects drought conditions on the Missouri River system which resulted } \\
\text { in closure of the waterway and diversion of shipments to the } \\
\text { Columbia-Snake waterway. }\end{array}$ \\
\hline
\end{tabular}

Table C-2. Number of Country Elevators by State

\begin{tabular}{|l|c|c|}
\hline \multicolumn{1}{|c|}{ State } & No. Country Elevators & No. Regions \\
\hline Washington & 297 & \\
\hline Oregon & 76 & \\
\hline Idaho & 111 & 5 \\
\hline Montana $1 /$ & N.A. & 9 \\
\hline North Dakota $1 /$ & N.A. & \\
\hline $\begin{array}{l}\text { 1/ The number of country elevators was not available, and not relevant because grain shipment data were only } \\
\text { obtainable on a regional basis. }\end{array}$ \\
\hline
\end{tabular}


Table C-3. River Ports and Elevators Located on the Shallow-Draft Waterway, by Pool and River Mile

\begin{tabular}{|c|c|c|c|}
\hline \multirow{4}{*}{$\begin{array}{c}\text { Pool } \\
\text { Lower Granite }\end{array}$} & Port & River Mile & Major Commodities \\
\hline & Lewiston & 2 (Clearwater $\mathrm{R}$ ) & Grain, pulses, logs, containers \\
\hline & Clarkston & $138($ Snake R) & Grain, containers, logs \\
\hline & Wilma & 135 (Snake R) & Grain, wood concrete, petroleum \\
\hline :4, & স্য়- & (3. & איক \\
\hline \multirow[t]{4}{*}{ Little Goose } & Almota & 104 (Snake R) & Grain \\
\hline & Central Ferry & 83 (Snake R) & Grain fertilizer \\
\hline & Garfield & 83 (Snake R) & Grain \\
\hline & 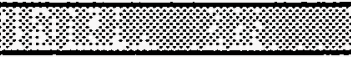 & ২. & \% \\
\hline \multirow{2}{*}{ Lower Monumental } & Lyons Ferry & 61 (Snake R) & Grain \\
\hline & ) & (1., & 8.1 .8$. \\
\hline \multirow[t]{3}{*}{ Ice Harbor } & Windust & 38 (Snake R) & Grain \\
\hline & Sheffler & 29 (Snake R) & Grain \\
\hline & \%४. & & 17 \\
\hline \multirow[t]{6}{*}{ McNary } & Burbank & 2 (Snake R) & Grain \\
\hline & Pasco & 328 (Col. R) & $\begin{array}{l}\text { Petroleum, chemicals, fertilizer, plate } \\
\text { glass }\end{array}$ \\
\hline & Kennewick & 328 (Col. R) & Grain, fertilizer \\
\hline & Wallula & 314 (Col. R) & Grain \\
\hline & Port Kelley & 312 (Col. R) & Grain \\
\hline & Umatilla & 293 (Col. R) & $\begin{array}{l}\text { Containers, logs, woodchips, general } \\
\text { cargo }\end{array}$ \\
\hline $4.48 \%$ & & & 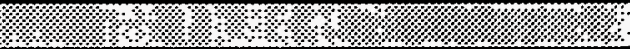 \\
\hline \multirow[t]{4}{*}{ John Day } & $\begin{array}{l}\text { Hogue Warner, Port } \\
\text { of Morrow }\end{array}$ & 278 (Col. R & Grain \\
\hline & Morrow & 275 (Col. R) & Grain, containers, logs, wood chips \\
\hline & Roosevelt & 240 (Col. R) & Grain \\
\hline & Arlington & 240 (Col. R) & Grain \\
\hline \multirow{2}{*}{$\begin{array}{l}\text { The Dalles } \\
\text { The }\end{array}$} & (1., & & $11 \%, 4$ \\
\hline & Biggs & $208(\mathrm{Col} \mathrm{R})$ & Grain \\
\hline 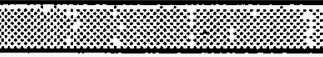 & (19. & স্য়- & 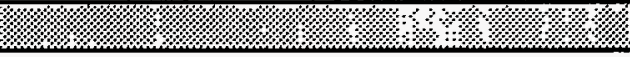 \\
\hline \multirow[t]{2}{*}{ Bonneville } & The Dalles & $190(\mathrm{Col} \mathrm{R})$ & Wood chips, grain \\
\hline & Klickitat & $170(\mathrm{Col} \mathrm{R})$ & Lumber, grain, aggregate \\
\hline
\end{tabular}

\section{C.3.2 DRAWDOWN SIMULATION}

The models simulate two types of drawdown: (1) "unconstrained", and; (2) "constrained". The unconstrained drawdown captures the total costs of responses to drawdown (removal of barge transportation) assuming that alternative transportation modes and nodes are not limited by the capacity of transportation, handling, or storage facilities. The unconstrained drawdown was developed to allow the model to reflect options that would likely be exercised given the transportation, handling and storage alternatives that are most applicable for non-grain commodities. The unconstrained drawdown is not considered to be representative of real world supply conditions with many alternatives that typify grain 
distribution. This scenario, however, does capture the transportation responses to drawdown for those commodities that do not have any capacity constraints. Therefore, the unconstrained drawdown scenario is applicable to all commodities except grain

The constrained drawdown is an extension of the unconstrained drawdown simulation. It incorporates alternative transportation and handling nodes and allows the least total cost of the alternatives to be selected subject to the availability of capacity as calculated by the model. The constrained drawdown thus allows the model to incorporate capacity limitations of existing transportation and handling facilities for grain. The lowest total cost alternative is selected through an array of "if" statements in the programming logic of the model.

\section{C.3.3 MODELING CRITERIA AND ASSUMPTIONS}

\section{C.3.3.1 General}

Major criteria which govern the modeling process are discussed in the following paragraphs. The model is demand driven and executed, assuming that throughput to export terminals will be maintained on a monthly basis. This means that the logic in the model assumes that the present volume of grain moved to export terminals via the waterway would continue at a rate consistent with recent historical shipments from upriver sources. Although temporal shifts of grain supplies among upriver and downriver sources were not examined in detail, since the export market for grain is sensitive to changes in protein levels, it is unlikely that temporal shifts in the supply of grain could be used to meet export demand. The simulation does not adjust any of the current flows to "optimize" the existing system, nor does it incorporate inventory responses or measure short-run related storage responses to impending drawdown. This generally precludes storing grain at upriver terminals or at country elevators during river closure for shipment to export terminals at a later date, or pre-positioning supplies in anticipation of river closure.

\section{C.3.3.2 Capacity Assumptions}

Except for capacity (throughput) constraints, the model ignores time, therefore, shipments are instantaneous. Storage capacity at elevators is used only to calculate turnover of grain relative to inventory costs, although the user can specify turnover factors for the elevators to simulate possible responses to drawdown by holding grain for longer or shorter periods of time than is customary in the base case. The model can also calculate overtime cost based on user specified parameters.

No specific assumptions were made with respect to the size of on-farm inventory capacity or stockpiles. The model runs assuming that existing beginning, intermediate and ending storage capacities and grain stockpiles are adequate to maintain throughput (flow of grain to export terminals). Storage is not assumed to affect the throughput capacity of river and deep water grain elevators. Capacity is synonymous with throughput and is calculated at each node consisting of country elevator, river elevator, and export elevator for both the navigation and rail modes under drawdown conditions (seasonally adjusted monthly demand over the duration of the drawdown). For each handling node, capacity is developed from the lesser of unloading or loading rates over a time frame (hours per day and days per month) defined by the model user.

\section{C.3.3.3 Monthly Volume of Shipments}

For grain movements, monthly volumes leaving upstream river elevators were used to establish seasonal patterns of Columbia-Snake River grain shipments. For non-grain commodities, the monthly (seasonal) indices are assumed to be 1 (equal monthly shipments throughout the year), and monthly transportation costs are calculated for the applicable duration of each drawdown scenario. During the remainder of the year when the locks would be accessible, monthly costs associated with normal shipping conditions remain unchanged from the base case. 


\section{C.3.3.4 Storage, Handling and Transportation Rates}

Actual published or quoted rates or costs for storage and handling at the elevators were initially used in the models, or in their absence, rates were estimated based on statistical relationships. Based on comments from representatives of the grain transportation industry, handling and storage costs were subsequently adjusted to more closely approximate longrun marginal costs. For country elevators, the handling rates used are a weighted average rate obtained from interviews (based upon the number of elevators per state). For rates applicable to river elevators, an average of all river elevator rates obtained from interviews was used. Costs at export elevators are essentially the same, based on industry interviews. For transport modes, long-run marginal costs have been applied in lieu of published or quoted tariff rates. This was done to avoid discrepancies between published tariff rates and charges applied in actual practice. Additional discussion of these adjustments is presented below.

For Washington, Idaho, and Oregon, truck costs per mile assume a 25 ton load, at 33.3 bushels/ton. For Oregon, Washington, and Idaho, truck rates of $\$ 1.25 /$ ton-mile were utilized for round-trip hauls, based upon one-way mileage. For states of Montana and North Dakota, backhauls were assumed to occur, therefore their effective rates are lower. For Montana, a backhaul rate of $\$ 0.52 /$ ton-mile assuming a 23-ton load was applied based upon information from the State of Montana. For North Dakota, $\$ 0.42 /$ ton-mile assuming a 25 ton load was used based on information gathered through interviews of industry officials. With respect to rail transport, based on directly assignable variable costs, LRMC are about 70 percent of current wheat tariffs in the Columbia Snake hinterland, except unit (26 car) train rates.

\section{C.3.3.5 Modal Shifts with Drawdown}

Since potential changes in the operation of the system are assumed to be long term, permanent (year round) changes in modes of transport would occur in some instances. Decisions on which county movements would shift to rail were made based on the availability of rail facilities, distance to unaffected river elevators, and the modes presently used for movements from each county. Under drawdown conditions, grain movements from Montana and North Dakota would shift to the rail mode and would remain on rail throughout the year. These movements of grain could be routed from Montana/ North Dakota to Portland or Puget Sound via unit train as an alternative to moving to the closest river port not affected by river draw down.

For all counties in Idaho, truck movements that go to river elevators in the base case were assumed to shift to rail under drawdown conditions with the exception of Twin Falls, Canyon, Owyhee, Ada, and Gem Counties. These counties are located near the I-84 corridor and deliver many shipments in the base case to the McNary pool, which is unaffected by drawdown alternatives. Therefore, these counties would send shipments by rail or truck, whichever is most cost effective. Truck shipments that originate in certain Washington counties and go to river elevators in the base case were assumed to shift to rail under drawdown conditions because of their proximity to unit rail facilities. Those counties affected include Whitman, Spokane, Lincoln, and Asotin.

The approximate percentage of shipments that would shift from barge to rail under drawdown conditions, with the movements described above shifting to rail for the states of Montana, North Dakota, Idaho, and Washington--no movements from Oregon are assumed to shift to rail--is shown in Table C-4. For example, 90 percent of the movements that come to Wilma in the base case originate in counties or states that would likely shift to rail under drawdown.

\section{C.4 CHANGES IN TRANSPORTATION COSTS}

A comparison was made between the base condition and permanent closure of the Snake River to barge traffic (year round drawdown--SOS 5c). Table $\mathrm{C}-5$ displays this comparison for storage, handling, and transport - by mode and state. 
Table C-4. Percent Shift of Grain Movements from Barge to Rail by River Port with Lower Snake River Drawdown

\begin{tabular}{|l|l|l|l|}
\hline \multicolumn{1}{|c|}{ River Port } & Shift to Rail & \multicolumn{1}{c|}{ River Port } & Shift to Rail \\
\hline Wilma & $90 \%$ & Lyons Ferry & $0 \%$ \\
\hline Lewiston & $100 \%$ & Central Ferry & $86 \%$ \\
\hline Garfield & $36 \%$ & Almota & $100 \%$ \\
\hline
\end{tabular}

Table C-5. Grain Transportation Costs for Storage, Handling, and Transportation Mode, by State: Base Case vs. Drawdown with SOS $5 \mathrm{c}$

\begin{tabular}{|c|c|c|c|c|c|c|}
\hline & \multicolumn{2}{|c|}{ IDAHO } & \multicolumn{2}{|c|}{ WASHINGTON } & \multicolumn{2}{|c|}{ OREGON } \\
\hline Costs & $\begin{array}{c}\text { Base } \\
\text { Condition }\end{array}$ & $\begin{array}{l}\text { Annual } \\
\text { Closure }\end{array}$ & $\begin{array}{c}\text { Base } \\
\text { Condition }\end{array}$ & $\begin{array}{l}\text { Annual } \\
\text { Closure }\end{array}$ & $\begin{array}{c}\text { Base } \\
\text { Condition }\end{array}$ & $\begin{array}{l}\text { Annual } \\
\text { Closure }\end{array}$ \\
\hline Storage & $\$ 18,037,451$ & $\$ 21,263,312$ & $\$ 21,615,300$ & $\$ 25,702,969$ & $\$ 6,619,493$ & $\$ 6,619,493$ \\
\hline Handling & $21,411,445$ & $22,479,994$ & $28,160,970$ & $28,479,295$ & $8,368,249$ & $8,368,249$ \\
\hline Rail & $28,790,698$ & $50,358,765$ & $8,328,096$ & $28,061,582$ & $1,765,558$ & $1,765,558$ \\
\hline Truck & $22,553,310$ & $15,649,700$ & $12,730,806$ & $23,859,598$ & $4,654,372$ & $4,747,058$ \\
\hline Barge & $6,965,363$ & 898,939 & $13,743,084$ & $6,631,613$ & $3,151,872$ & $3,124,615$ \\
\hline Total & $\$ 97,758,267$ & $\$ 110,650,710$ & $\$ 84,578,256$ & $\$ 112,735,057$ & $\$ 24,559,544$ & $\$ 24,624,973$ \\
\hline Difference & & $\$ 12,892,443$ & & $\$ 28,156,801$ & & $\$ 65,429$ \\
\hline 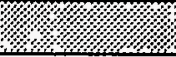 & $1819.1 .1 \%$ & & \%ै. & & & 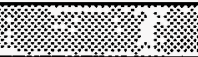 \\
\hline & NORTH & DAKOTA & MON & CANA & & \\
\hline Costs & $\begin{array}{c}\text { Base } \\
\text { Condition }\end{array}$ & $\begin{array}{l}\text { Annual } \\
\text { Closure }\end{array}$ & $\begin{array}{c}\text { Base } \\
\text { Condition }\end{array}$ & $\begin{array}{l}\text { Annual } \\
\text { Closure }\end{array}$ & & \\
\hline Storage & $\$ 8,136,070$ & $\$ 8,027,421$ & $\$ 14,715,601$ & $\$ 14,530,698$ & & \\
\hline Handling & $8,734,909$ & $8,529,135$ & $15,847,138$ & $15,496,943$ & & \\
\hline Rail & $41,831,399$ & $44,421,612$ & $52,622,254$ & $56,043,922$ & & \\
\hline Truck & $1,843,767$ & 0 & $3,958,616$ & $1,913,619$ & & \\
\hline Barge & 342,613 & 0 & 754,527 & 171,452 & & \\
\hline Total & $\$ 60,888,758$ & $\$ 60,978,168$ & $\$ 87,898,136$ & $\$ 88,156,634$ & & \\
\hline & & & & & & \\
\hline Difference & & $\$ 89,410$ & & $\$ 258,498$ & & \\
\hline & & & & & & \\
\hline
\end{tabular}




\section{C.5 MODAL SHIFTS}

\section{C.5.1 BASE CASE}

Grain movements by truck from grain producing areas above Bonneville Dam to the export elevators on the Columbia/Willamette Rivers are less than five percent of the movements arriving at the elevators. The truck deliveries are characterized by relatively short haul distances from the states of Oregon and Washington. Since the costs become prohibitive of trucking grain over long distances, trucking grain was not considered a viable alternative during the drawdown of the Snake River.

Ninety-five percent of the grain movements from Montana and North Dakota to Columbia River export elevators come by rail. By contrast, the states of Washington and Idaho ship a significant share of their grain via the Snake River by barge. Oregon also ships significant quantities by barge but most of these movements originate on the Columbia River and would not be affected by drawdown.

\section{C.5.2 DRAWDOWN}

Under a seven-month closure of the navigation channel on the Snake River, barge traffic from Idaho and Washington would be severely curtailed. Barge tonnage from Idaho would drop from 43.6 million bushels to 24.9 million bushels, while barge tonnage from Washington would drop from 93.8 million bushels to 73.8 million bushels. Barge movements that formerly utilized the Snake River would be shipped by rail to terminal ports or trucked to river ports on the McNary pool. Barge traffic originating on the McNary pool would increase from 41 million bushels to 52 million bushels. Shipments of grain from North Dakota and Montana that formerly moved by barge from Snake River ports would shift permanently to rail. Total barge movements of grain which now originate in North Dakota and Montana would drop from 6.9 million bushels to 1.3 million bushels. Truck movements from Montana to river elevators on the McNary pool would continue.
Oregon movements would be largely unaffected. Total rail shipments would increase by 42 million bushels with 37 million bushels originating in the states of Washington and Idaho.

Figures $\mathrm{C}-5$ and $\mathrm{C}-6$ show the amount of grain (in bushels)) currently shipped from each state by mode, and how equivalent quantities would move given closure of the Snake River shallow-draft waterway from February through August of each year, as would be the case with SOS $5 \mathrm{~b}$.

\section{C.6 IMPACT OF WATERWAY CLOSURE ON TRANSPORTATION REVENUES}

Implementation of any of the SOSs which involve drawdown and closure of one or all of the Snake River pools would disrupt the transportation patterns and practices that presently characterize the region. Both temporary and permanent shifts would result in changes in revenues among the various transport modes as well as related handling and storage (elevator) operations.

Given the assumption that the seasonal volume of commodities transported would continue to be maintained over time, changes in existing infrastructure would occur and continue until equilibrium was restored within the region. Should an SOS involving river closure be permanently implemented, existing levels of revenue to the barge and trucking industries would decline, at least in the short term, while rail revenues would increase. For each strategy that involves river closure, lesser amounts of grain would be barged, leaving a revenue shortfall to the barge industry. Also for the region, total revenues associated with trucking would likewise be reduced. However, there would be revenue gains for railroads.

Revenues associated with storage and handling would shift among locations and facilities, with gains and losses resulting as links and nodes were expanded, created, and abandoned. For those commodities other than grain, similar impacts upon revenue would occur, but to a relatively lesser degree. 


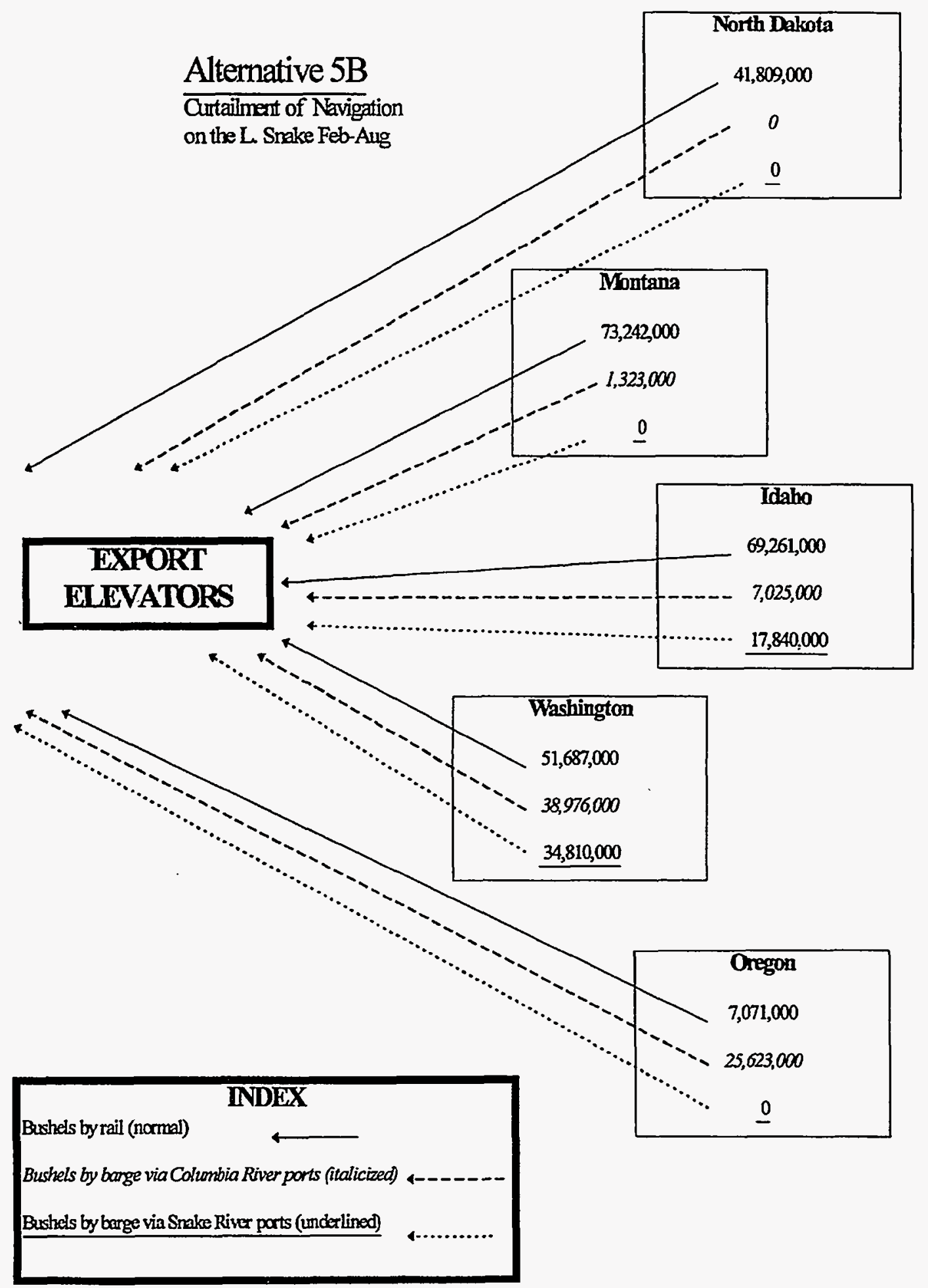

Figure C-5. Grain (in bushels) Currently Shipped for Each State by Mode under SOS 5b 


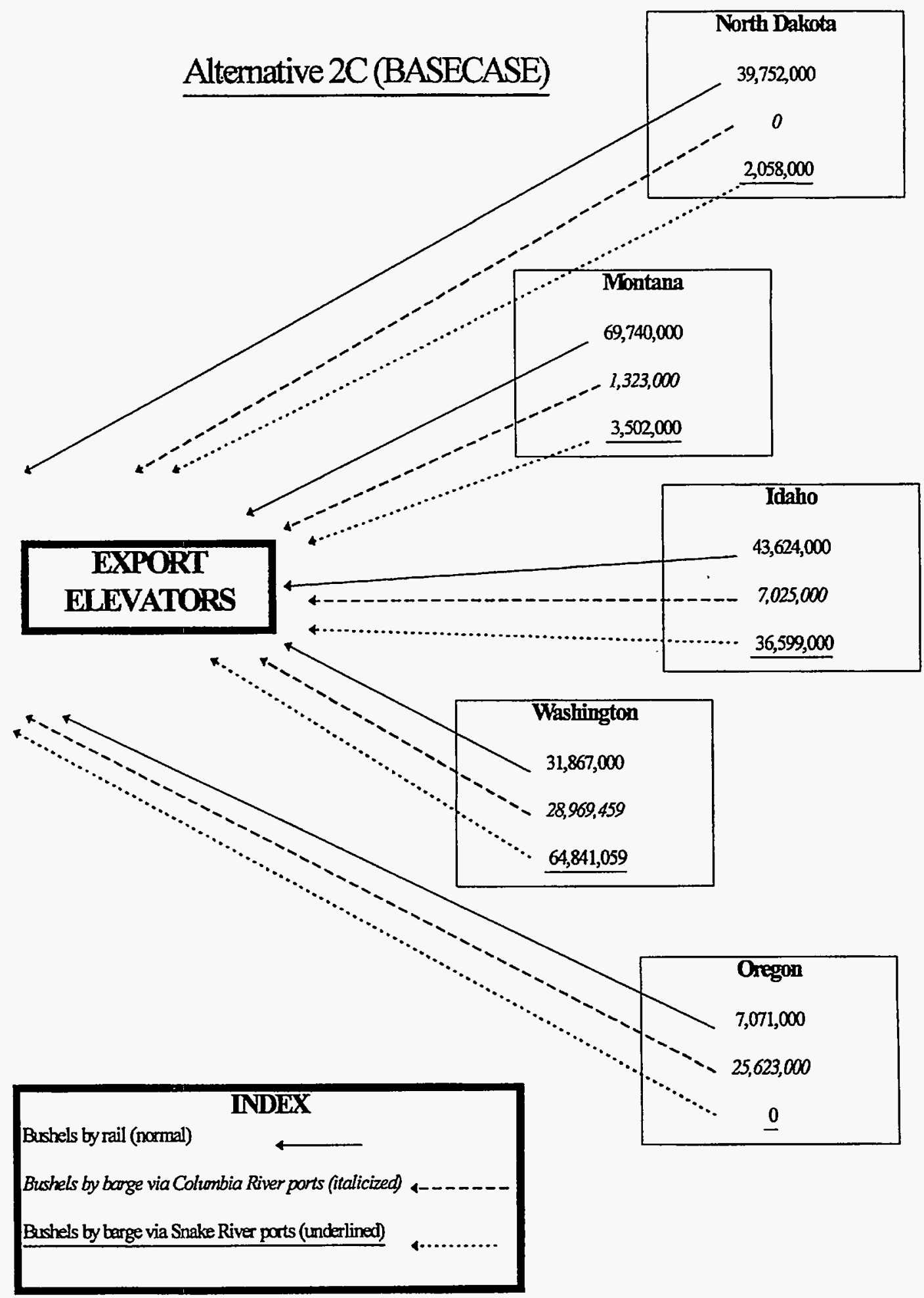

Figure C-6. Grain (in bushels) Currently Shipped for Each State by Mode under SOS 5b 


\section{C.7 TRANSPORTATION RATE IMPACTS}

For this FEIS, no extensive analysis was made of specific rate impacts for the various modes. A simplified analysis, however, was performed to estimate possible rate impacts to barge and river port traffic. This analysis does not take into account the increases in tonnage by other modes and through other non-river ports. The analysis also does not take into account the price elasticity of the barge rates and storage and handling rates of river ports.

The tonnage and cost calculated by the transportation model in the no impact scenario (alternative SOS 2c) was extracted from the model and compared to costs and tonnage moving in alternative SOS 5b (Lower Snake closed to navigation February - August). For barge movements, the revenue for barge operators was assumed to be the estimated barge rate multiplied by the bushels using that mode in the no impact scenario (alternative SOS 2c). Using the estimated barge tonnage with alternative SOS $5 b$, the rate increase necessary to keep revenue constant was calculated. This analysis showed that, on average, rates would need to be increased 35 percent to keep barge revenues constant. As shifts occur among modes, maintenance of existing levels of revenue may not be possible for barge operations.

For river ports, the revenues for the elevators was assumed to be the estimated storage and handling rates multiplied by the bushels using that river port facility in the no impact scenario (SOS 2c). Using the estimated tonnage moving through the river port facilities during drawdown, the rate increase necessary to keep revenue constant was calculated. This analysis showed that, on average, rates would need to be increased 35 percent to keep port revenues constant. Some river ports would be adversely effected while other river ports on pools not drawn down are expected to see increases in service and revenue. For those river ports on drawn-down pools, rate increases would range from 50 percent to 169 percent. It is likely that operators that are able to raise rates to maintain revenues would do so.

\section{C.8 IMPACT OF INCREASED TRUCK TRAFFIC ON HIGHWAY MAINTENANCE}

An analysis was made to assess the impacts of drawdown on highway maintenance costs, assuming that a greater or lesser volume of grain would be transported by truck under these conditions. For the states of Oregon and Washington, there would be an increase in ton-miles of truck transport under both single and four-pool drawdown conditions. For both of the these conditions, however, ton-miles via truck transport would decline to a much larger degree for Idaho, Montana, and North Dakota grain shipments, as volume would shift from truck-barge to rail. For the region as a whole, the use of truck transport would be reduced, resulting in lower highway maintenance requirements and costs.

Table $\mathrm{C}-6$ below provides tabular data by state which reflect impacts of drawdown on truck transport of grain and the estimated effect upon highway maintenance costs resulting from seasonal closure of the Snake River to navigation.

\section{C.9 RAILROAD IMPACTS}

\section{C.9.1 AVAILABILITY OF RAIL CARS}

The analysis of rail car capacity by TRAC indicated that there is a surplus of about 1,000 cars per month. This would translate into capacity to haul up to 7 million bushels per month (2.2 car trips * 98 tons/ car*1,000 cars). As shown in Table C-7, the largest increase in rail haul as a result of drawdown is 6.5 million bushels (during the month of August). Thus, it appears that a sufficient supply of rail cars exists to accommodate a closure of the Lower Snake River waterway, with a modal shift of grain to rail. 


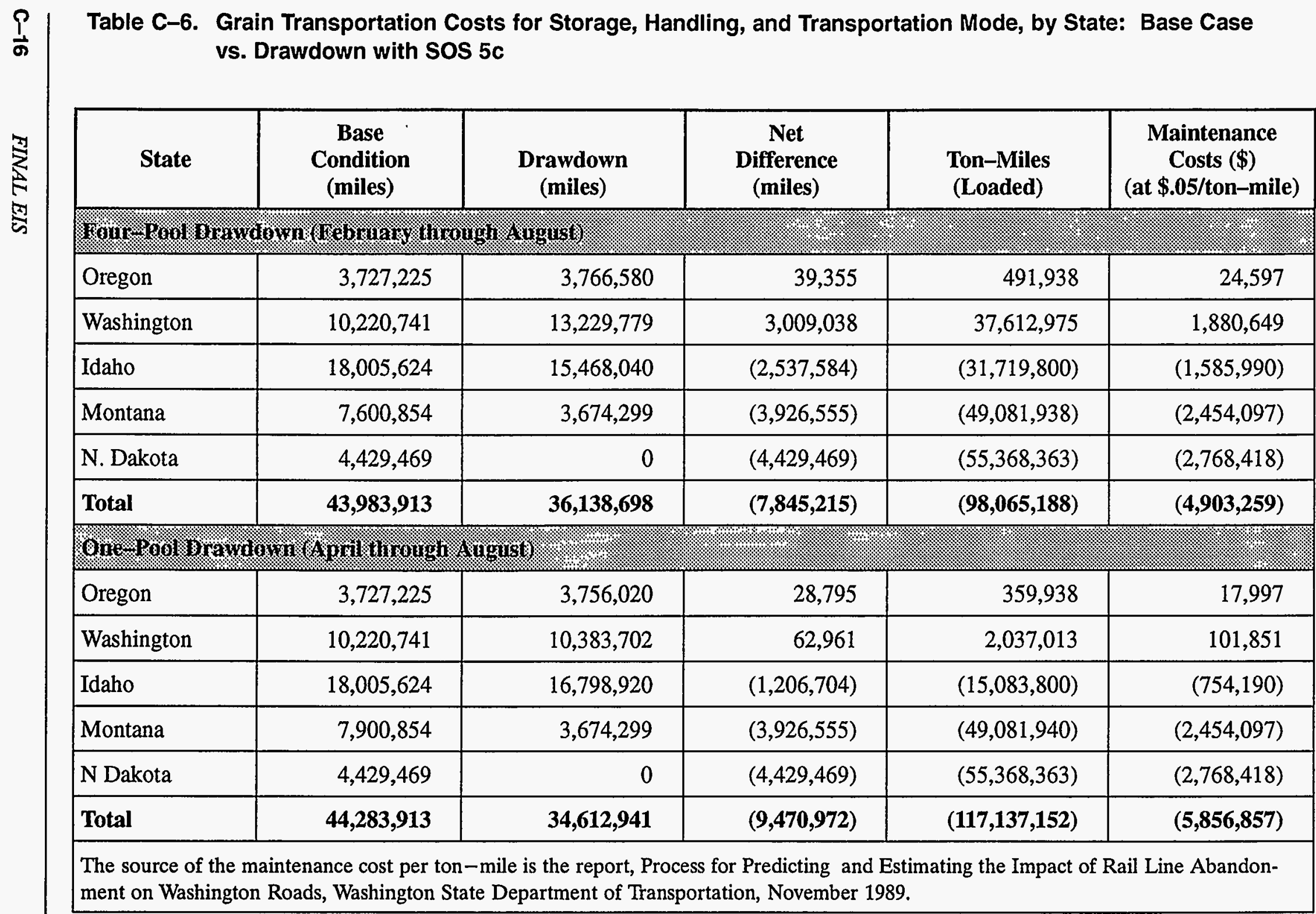




\section{C.9.2 RAIL FACILITY, GRAIN HANDLING CAPACITY}

\section{C.9.2.1 Country and River Elevators}

Through a telephone survey of existing country elevators with unit train loading facilities, it was determined that unit rail loading are available in sufficient numbers within in each state and region such that rail is a viable alternative transportation mode for grain, except that a facility at Lewiston would be needed. Through discussions with representatives of the Port of Lewiston, it was determined that grain storage facilities at Lewiston could be modified to accommodate loading of unit trains (26-car capacity facility) at a cost of approximately $\$ 1$ million. A completely new unit train loading facility would cost about $\$ 4.5$ million.

\section{C.9.2.2 Export Elevators}

Approximately 133,489 rail cars unloaded grain at the export elevators in 1990, based upon reports from
Burlington Northern and Union Pacific. Based on statistics from the Port Series, unloading capacity is 85 cars per hour, or 176,800 cars per year (assuming a 40 hour week for 52 weeks). With a seven month drawdown, approximately 12,000 cars would require unloading. It appears that export elevators could unload approximately 43,000 rail cars before reaching capacity. Given the above information, it appears there would be adequate unloading capability at the export elevators.

\section{C.9.3 LIMITATIONS TO THE ASSESSMENT OF RAIL CAPACITY}

The preliminary assessment of rail capacity which was conducted for the SOR does not address the issue of how much track is available to store waiting rail cars, line capacity, or the differing varieties of grain that may come predominately by one mode.

Table C-7. Difference in Bushels Shipped by Rail for a Drawdown During the Month of August

\begin{tabular}{|l|r|r|r|r|r|r|}
\hline & Wash. & \multicolumn{1}{c|}{ Oregon } & \multicolumn{1}{c|}{ Idaho } & \multicolumn{1}{c|}{ N. Dakota } & \multicolumn{1}{c|}{ Montana } & \multicolumn{1}{c|}{ Total } \\
\hline Base Case & $\mathbf{3 , 2 0 3 , 9 7 7}$ & 706,602 & $5,175,483$ & $3,972,232$ & $6,978,684$ & $20,036,978$ \\
\hline Drawdown & $6,590,684$ & 706,602 & $7,751,803$ & $4,140,398$ & $7,264,727$ & $26,454,214$ \\
\hline Difference & $3,386,707$ & 0 & $2,576,320$ & 168,166 & 286,043 & $6,417,236$ \\
\hline
\end{tabular}




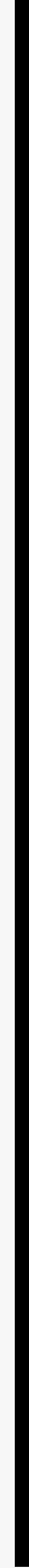




\section{EXHIBIT D}

\section{RECREATION}

\section{D.1 OVERVIEW}

This exhibit provides the detailed estimates of recreation use with each of the System Operation Strategies (SOSs) at each of the recreation sites investigated in the SOR.

\section{D.2 RECREATION USE WITH DIFFERENT WATER CONDITIONS}

Appendix J, Recreation, describes how the estimation of use with each SOS was done. Estimations were made for three different water conditions to fully describe the range of possible impacts. Estimates of use in terms of recreation days by selected activities were made for a low water year (using 1941 water year), a high water year (using 1976), and expected value of the 50 years of historic water conditions. This Appendix provides information primarily on the expected value, or average, water conditions. Table $\mathrm{D}-1$ summarizes the estimated use for each SOS based on the expected value water condition. For comparison purposes, table D-2 provides the estimated use with each SOS assuming low water conditions and table $D-3$ provides the use estimates with high water conditions.

\section{D.3 RECREATION USE BY RECREATION ACTIVITY AND PROJECT}

The estimated annual recreation use was distributed over the major water-related recreation activities based on results of the survey of Northwest recreators. Recreators' responses to the mail-out questionnaires defined the types of activities they participated in 1993 at each Federal project. The distribution of total recreation visits to the activities of boating, fishing, camping, picnicking (and other day-use) was done on a fixed proportional basis for each project based on the 1993 responses. Tables $\mathrm{D}-4$ through $\mathrm{D}-15$ provide the distribution by recreation activity for each of the recreation sites in the SOR. These use estimates are for the expected value condition over the 50 water years. 
Table D-1. Summary of Recreation Use by Project/Reach (Annual Recreation Days - 50-Year Averages)

\begin{tabular}{|c|c|c|c|c|c|c|c|c|c|c|c|c|c|}
\hline sos & $\begin{array}{l}\text { Hungry } \\
\text { Horse }\end{array}$ & $\begin{array}{l}\text { Pend } \\
\text { Oreille }\end{array}$ & $\begin{array}{c}\text { Lake } \\
\text { Koocanusa }\end{array}$ & $\begin{array}{l}\text { Kootenai } \\
\text { River }\end{array}$ & Dworshak & $\begin{array}{l}\text { Cleanwater } \\
\text { River }\end{array}$ & $\begin{array}{l}\text { Lower } \\
\text { Granite }\end{array}$ & $\begin{array}{l}\text { Little } \\
\text { Goose }\end{array}$ & $\begin{array}{c}\text { Lower } \\
\text { Monumental }\end{array}$ & $\begin{array}{c}\text { Ice } \\
\text { Harbor }\end{array}$ & $\begin{array}{c}\text { Lake } \\
\text { Roosevelt }\end{array}$ & John Day & Total \\
\hline SOS $1 \mathrm{a}$ & 128,303 & $1,215,923$ & 604,590 & 34,316 & 182,676 & 109,147 & $1,653,879$ & 244,797 & 140,009 & 525,658 & $1,630,971$ & $2,860,009$ & $9,330,278$ \\
\hline $\operatorname{sos} 1 \mathrm{~b}$ & 125,670 & $1,216,917$ & 603,795 & 34,912 & 185,625 & 105,285 & $1,687,100$ & 244,861 & 140,052 & 525,916 & $1,637,181$ & $2,860,009$ & $9,367,323$ \\
\hline $\operatorname{sos} 2 c$ & 129,257 & $1,222,511$ & 607,247 & 35,636 & 201,413 & 128,224 & $1,662,699$ & 240,402 & 137,598 & 514,730 & $1,670,069$ & $2,555,389$ & $9,105,175$ \\
\hline $\operatorname{sos} 2 \mathrm{~d}$ & 128,574 & $1,222,511$ & 605,012 & 35,062 & 159,655 & 198,900 & $1,662,699$ & 240,402 & 137,598 & 514,730 & $1,662,812$ & $2,555,389$ & $9,123,344$ \\
\hline $\operatorname{sos} 4 c$ & 152,601 & $1,183,126$ & 619,879 & 34,006 & 207,566 & 147,346 & $1,649,772$ & 239,610 & 136,673 & 507,022 & $1,661,461$ & $2,760,038$ & $9,299,100$ \\
\hline sos $5 b$ & 126,532 & $1,217,773$ & 602,870 & 34,989 & 213,711 & 126,711 & 859,290 & 92,671 & 57,577 & 164,147 & $1,665,931$ & $2,120,958$ & $7,283,160$ \\
\hline $\operatorname{sos} 5 c$ & 126,533 & $1,217,773$ & 602,871 & 34,989 & 226,932 & 141,589 & 652,290 & 71,143 & 44,052 & 127,270 & $1,665,931$ & $2,120,958$ & $7,032,331$ \\
\hline $\operatorname{sos} 6 b$ & 126,533 & $1,217,773$ & 602,871 & 34,989 & 198,854 & 133,905 & $1,250,024$ & 164,402 & 96,492 & 335,312 & $1,665,931$ & $2,120,958$ & $7,948,044$ \\
\hline$\overline{\operatorname{sos} 6 d}$ & 126,533 & $1,217,773$ & 602,871 & 34,989 & 198,854 & 133,905 & $1,250,024$ & 240,402 & 137,598 & 514,730 & $1,665,931$ & $2,120,958$ & $8,244,568$ \\
\hline $\operatorname{sos} 9 a$ & 91,036 & $1,001,121$ & 546,186 & 14,270 & 180,361 & 136,247 & $1,175,338$ & 151,909 & 89,356 & 301,583 & $1,257,182$ & $2,103,849$ & $7,048,438$ \\
\hline SOS $9 b$ & 135,367 & $1,148,023$ & 596,840 & 28,942 & 133,202 & 135,271 & $1,618,319$ & 233,075 & 133,421 & 494,838 & $1,482,095$ & $2,555,389$ & $8,694,782$ \\
\hline $\operatorname{sos} 9 c$ & 152,580 & $1,187,905$ & 618,419 & 33,881 & 183,092 & 143,327 & $1,485,478$ & 203,317 & 119,271 & 449,605 & $1,570,658$ & $2,068,283$ & $8,215,816$ \\
\hline $\mathrm{PA}$ & 133,530 & $1,243,190$ & 601,640 & 24,960 & 149,645 & 151,296 & $1,673,460$ & 242,655 & 138,766 & 519,212 & $1,612,827$ & $1,502,081$ & $7,993,262$ \\
\hline \multicolumn{14}{|c|}{ … } \\
\hline sos & $\begin{array}{c}\text { Hungry } \\
\text { Horse }\end{array}$ & $\begin{array}{c}\text { Pend } \\
\text { Oreille }\end{array}$ & $\begin{array}{c}\text { Lake } \\
\text { Koocanusa }\end{array}$ & $\begin{array}{c}\text { Kootenai } \\
\text { River }\end{array}$ & Dworshak & $\begin{array}{c}\text { Clearwater } \\
\text { River }\end{array}$ & $\begin{array}{c}\text { Lower } \\
\text { Granite }\end{array}$ & $\begin{array}{l}\text { Little } \\
\text { Goose }\end{array}$ & $\begin{array}{c}\text { Lower } \\
\text { Monumental }\end{array}$ & $\begin{array}{c}\text { Ice } \\
\text { Harbor }\end{array}$ & $\begin{array}{c}\text { Lake } \\
\text { Roosevelt }\end{array}$ & John Day & Total \\
\hline SOS 1a & $(954)$ & $(6,588)$ & $(2,657)$ & $(1,320)$ & $(18,737)$ & $(19,077)$ & $(8,820)$ & 4,395 & 2,411 & 10,928 & $(39,098)$ & 304,620 & 225,103 \\
\hline $\operatorname{sos} 1 \mathrm{~b}$ & $(3,587)$ & $(5,594)$ & $(3,452)$ & (724) & $(15,788)$ & $(22,939)$ & 24,401 & 4,459 & 2,454 & 11,186 & $(32,888)$ & 304,620 & 262,148 \\
\hline $\operatorname{sos} 2 c$ & - & - & - & - & - & - & - & - & - & - & - & - & - \\
\hline $\operatorname{sos} 2 d$ & (683) & - & $(2,235)$ & $(574)$ & $(41,758)$ & 70,676 & - & - & - & - & $(7,257)$ & - & 18,169 \\
\hline $\operatorname{SOS} 4 c$ & 23,344 & $(39,385)$ & 12,632 & $(1,630)$ & 6,153 & 19,122 & $(12,927)$ & $(792)$ & (925) & $(7,708)$ & $(8,608)$ & 204,649 & 193,925 \\
\hline SOS $5 b$ & $(2,725)$ & $(4,738)$ & $(4,377)$ & (647) & 12,298 & $(1,513)$ & $(803,409)$ & $(147,731)$ & $(80,021)$ & $(350,583)$ & $(4,138)$ & $(434,431)$ & $(1,822,015)$ \\
\hline SOS $5 c$ & $(2,724)$ & $(4,738)$ & $(4,376)$ & $(647)$ & 25,519 & 13,365 & $(1,010,409)$ & $(169,259)$ & $(93,546)$ & $(387,460)$ & $(4,138)$ & $(434,431)$ & $(2,072,844)$ \\
\hline SOS $6 b$ & $(2,724)$ & $(4,738)$ & $(4,376)$ & (647) & $(2,559)$ & 5,681 & $(412,675)$ & $(76,000)$ & $(41,106)$ & $(179,418)$ & $(4,138)$ & $(434,431)$ & $(1,157,131)$ \\
\hline SOS 6d & $(2,724)$ & $(4,738)$ & $(4,376)$ & (647) & $(2,559)$ & 5,681 & $(412,675)$ & - & - & - & $(4,138)$ & $(434,431)$ & $(860,607)$ \\
\hline $\operatorname{SOS} 9 a$ & $(38,221)$ & $(221,390)$ & $(61,061)$ & $(21,366)$ & $(21,052)$ & 8,023 & $(487,361)$ & $(88,493)$ & $(48,242)$ & $(213,147)$ & $(412,887)$ & $(451,540)$ & $(2,056,737)$ \\
\hline $\operatorname{sos} 9 b$ & 6,110 & $(74,488)$ & $(10,407)$ & $(6,694)$ & $(68,211)$ & 7,047 & $(44,380)$ & $(7,327)$ & $(4,177)$ & $(19,892)$ & $(187,974)$ & - & $(410,393)$ \\
\hline SOS $9 c$ & 23,323 & $(34,606)$ & 11,172 & $(1,755)$ & $(18,321)$ & 15,103 & $(177,221)$ & $(37,085)$ & $(18,327)$ & $(65,125)$ & $(99,411)$ & $(487,106)$ & $(889,359)$ \\
\hline $\mathrm{PA}$ & 4,273 & 20,679 & $(5,607)$ & $(10,676)$ & $(51,768)$ & 23,072 & 10,761 & 2,253 & 1,168 & 4,482 & $(57,242)$ & $(1,053,308)$ & $(1,111,913)$ \\
\hline
\end{tabular}


Table D-2. Summary of Recreation Use by Project/Reach (Annual Recreation Days - Low Water Year, 1941)

\begin{tabular}{|c|c|c|c|c|c|c|c|c|c|c|c|c|c|}
\hline SOS & $\begin{array}{c}\text { Hungry } \\
\text { Horse }\end{array}$ & $\begin{array}{l}\text { Pend } \\
\text { Oreille }\end{array}$ & $\begin{array}{c}\text { Lake } \\
\text { Koocanusa }\end{array}$ & $\begin{array}{l}\text { Kootenai } \\
\text { River }\end{array}$ & Dworshak & $\begin{array}{c}\text { Clearwater } \\
\text { River }\end{array}$ & $\begin{array}{c}\text { Lower } \\
\text { Granite }\end{array}$ & $\begin{array}{l}\text { Little } \\
\text { Goose }\end{array}$ & $\begin{array}{c}\text { Lower } \\
\text { Monumental }\end{array}$ & $\begin{array}{c}\text { Ice } \\
\text { Harbor }\end{array}$ & $\begin{array}{c}\text { Lake } \\
\text { Roosevelt }\end{array}$ & John Day & Total \\
\hline SOS 1a & 80,903 & $1,195,462$ & 603,968 & 36,500 & 181,604 & 124,969 & $1,503,126$ & 241,693 & 138,442 & 519,755 & $1,683,439$ & $2,860,009$ & $9,169,870$ \\
\hline SOS $1 \mathrm{~b}$ & 59,080 & $1,195,462$ & 593,359 & 41,996 & 145,697 & 159,583 & $1,671,616$ & 241,693 & 138,442 & 519,755 & $1,719,220$ & $2,860,009$ & $9,345,912$ \\
\hline $\operatorname{SOS} 2 c$ & 94,240 & $1,195,462$ & 608,735 & 45,402 & 223,487 & 129,289 & $1,643,500$ & 236,440 & 135,603 & 507,249 & $1,788,762$ & $2,555,389$ & $9,163,558$ \\
\hline SOS $2 d$ & 92,848 & $1,195,462$ & 602,979 & 46,639 & 137,712 & 112,769 & $1,643,500$ & 236,440 & 135,603 & 507,249 & $1,604,149$ & $2,555,389$ & $8,870,739$ \\
\hline SOS 4c & 146,042 & $1,024,343$ & 603,565 & 54,794 & 190,814 & 103,898 & $1,548,965$ & 220,368 & 126,441 & 462,740 & $1,575,542$ & $2,760,038$ & $8,817,549$ \\
\hline SOS 5b & 80,903 & $1,195,462$ & 603,968 & 36,500 & 168,373 & 111,363 & 858,143 & 92,436 & 57,458 & 163,687 & $1,788,762$ & $2,120,958$ & $7,278,013$ \\
\hline SOS $5 \mathrm{c}$ & 80,903 & $1,195,462$ & 603,968 & 36,500 & 232,514 & 103,539 & 651,144 & 70,908 & 43,933 & 126,811 & $1,788,762$ & $2,120,958$ & $7,055,401$ \\
\hline SOS $6 \mathrm{~b}$ & 80,903 & $1,195,462$ & 603,968 & 36,500 & 184,648 & 178,242 & $1,240,964$ & 162,553 & 95,550 & 331,691 & $1,788,762$ & $2,120,958$ & $8,020,201$ \\
\hline SOS 6d & 80,903 & $1,195,462$ & 603,968 & 36,500 & 184,648 & 178,242 & $1,240,964$ & 236,440 & 135,603 & 507,249 & $1,788,762$ & $2,120,958$ & $8,309,698$ \\
\hline $\operatorname{sos} 9 a$ & 36,712 & 847,301 & 476,616 & 7,541 & 110,637 & 119,213 & $1,122,451$ & 142,677 & 84,238 & 279,073 & $1,127,004$ & $2,103,849$ & $6,457,312$ \\
\hline SOS 9b & 126,517 & $1,013,870$ & 587,880 & 40,965 & 110,543 & 91,491 & $1,530,151$ & 216,005 & 124,500 & 458,960 & $1,329,307$ & $2,555,389$ & $8,185,579$ \\
\hline SOS 9c & 146,042 & $1,155,626$ & 618,443 & 54,794 & 166,616 & 100,026 & $1,471,296$ & 200,496 & 117,810 & 443,601 & $1,507,837$ & $2,068,283$ & $8,050,869$ \\
\hline $\mathrm{PA}$ & 122,384 & $1,214,704$ & 591,582 & 25,318 & 154,163 & 86,189 & $1,653,949$ & 238,668 & 136,747 & 511,493 & $1,554,798$ & $1,502,081$ & $7,792,077$ \\
\hline
\end{tabular}

Table D-3. Summary of Recreation Use by Project/Reach (Annual Recreation Days - High Water Year, 1976)

\begin{tabular}{|c|c|c|c|c|c|c|c|c|c|c|c|c|c|}
\hline SOS & $\begin{array}{c}\text { Hungry } \\
\text { Horse }\end{array}$ & $\begin{array}{c}\text { Pend } \\
\text { Oreille } \\
\end{array}$ & $\begin{array}{c}\text { Lake } \\
\text { Koocanusa }\end{array}$ & $\begin{array}{c}\text { Kootenai } \\
\text { River }\end{array}$ & Dworshak & $\begin{array}{c}\text { Clearwater } \\
\text { River }\end{array}$ & $\begin{array}{c}\text { Lower } \\
\text { Granite }\end{array}$ & $\begin{array}{l}\text { Little } \\
\text { Goose }\end{array}$ & $\begin{array}{c}\text { Lower } \\
\text { Monumental }\end{array}$ & $\begin{array}{c}\text { Ice } \\
\text { Harbor }\end{array}$ & $\begin{array}{c}\text { Lake } \\
\text { Roosevelt }\end{array}$ & John Day & Total \\
\hline SOS 1a & 143,913 & $1,253,451$ & 607,318 & 35,064 & 191,260 & 102,636 & $1,714,670$ & 250,820 & 142,904 & 535,416 & $1,682,318$ & $2,860,009$ & $9,519,777$ \\
\hline SOS 1b & 144,101 & $1,253,451$ & 607,818 & 35,431 & 192,138 & 102,299 & $1,714,670$ & 250,820 & 142,904 & 535,416 & $1,683,807$ & $2,860,009$ & $9,522,865$ \\
\hline SOS $2 c$ & 148,416 & $1,253,451$ & 615,899 & 33,343 & 213,106 & 135,859 & $1,685,198$ & 245,280 & 139,925 & 522,412 & $1,685,820$ & $2,555,389$ & $9,234,098$ \\
\hline SOS 2d & 145,809 & $1,253,451$ & 611,078 & 26,921 & 226,572 & 134,892 & $1,685,198$ & 245,280 & 139,925 & 522,412 & $1,702,592$ & $2,555,389$ & $9,249,520$ \\
\hline SOS $4 c$ & 154,917 & $1,221,005$ & 629,248 & 30,394 & 222,212 & 118,452 & $1,671,309$ & 243,233 & 138,772 & 517,331 & $1,644,998$ & $2,760,038$ & $9,351,908$ \\
\hline SOS 5b & 143,913 & $1,253,451$ & 607,318 & 35,064 & 238,205 & 106,457 & 861,114 & 93,072 & 57,766 & 164,753 & $1,685,820$ & $2,120,958$ & $7,367,891$ \\
\hline SOS 5c & 143,913 & $1,253,451$ & 607,318 & 35,064 & 229,017 & 118,100 & 654,115 & 71,543 & 44,241 & 127,877 & $1,685,820$ & $2,120,958$ & $7,091,417$ \\
\hline SOS 6b & 143,913 & $1,253,451$ & 607,318 & 35,064 & 220,558 & 111,428 & $1,264,949$ & 167,649 & 98,036 & 340,383 & $1,685,820$ & $2,120,958$ & $8,049,526$ \\
\hline SOS 6d & 143,913 & $1,253,451$ & 607,318 & 35,064 & 220,558 & 111,428 & $1,264,949$ & 245,280 & 139,925 & 522,412 & $1,685,820$ & $2,120,958$ & $8,351,075$ \\
\hline SOS 9a & 135,458 & $1,266,429$ & 594,648 & 19,128 & 206,088 & 100,830 & $1,269,465$ & 168,534 & 98,510 & 342,223 & $1,705,435$ & $2,103,849$ & $8,010,595$ \\
\hline SOS 9b & 141,869 & $1,244,277$ & 610,476 & 31,495 & 155,485 & 299,870 & $1,677,201$ & 243,924 & 139,172 & 518,384 & $1,649,332$ & $2,555,389$ & $9,266,874$ \\
\hline SOS 9c & 154,917 & $1,222,186$ & 629,016 & 30,394 & 226,756 & 105,741 & $1,498,768$ & 206,416 & 120,655 & 453,333 & $1,645,073$ & $2,068,283$ & $8,361,538$ \\
\hline PA & 148,279 & $1,265,964$ & 617,068 & 32,820 & 184,230 & 198,435 & $1,690,393$ & 246,418 & 140,524 & 524,681 & $1,705,435$ & $1,502,081$ & $8,256,327$ \\
\hline
\end{tabular}


Table D-4. Summary of Average Annual Recreation Days by Activity for Hungry Horse

\begin{tabular}{|c|c|c|c|c|c|}
\hline & Boating & Fishing & Camping & Picnicking & Swimming \\
\hline sos & $\begin{array}{c}50 \text { - Year } \\
\text { Average }\end{array}$ & $\begin{array}{c}50 \text { - Year } \\
\text { Average }\end{array}$ & $\begin{array}{c}50 \text { - Year } \\
\text { Average }\end{array}$ & $\begin{array}{c}50 \text { - Year } \\
\text { Average }\end{array}$ & $\begin{array}{c}50 \text { - Year } \\
\text { Average }\end{array}$ \\
\hline SOS 1a & 9,533 & 9,725 & 100,384 & 7,044 & 1,617 \\
\hline SOS $1 \mathrm{~b}$ & 9,337 & 9,526 & 98,324 & 6,899 & 1,583 \\
\hline SOS 2c & 9,604 & 9,798 & 101,130 & 7,096 & 1,629 \\
\hline SOS $2 d$ & 9,553 & 9,746 & 100,596 & 7,059 & 1,620 \\
\hline SOS $4 c$ & 11,338 & 11,567 & 119,395 & 8,378 & 1,923 \\
\hline SOS $5 b$ & 9,401 & 9,591 & 98,999 & 6,947 & 1,594 \\
\hline SOS 5c & 9,401 & 9,591 & 98,999 & 6,947 & 1,594 \\
\hline SOS $6 \mathrm{~b}$ & 9,401 & 9,591 & 98,999 & 6,947 & 1,594 \\
\hline SOS 6d & 9,401 & 9,591 & 98,999 & 6,947 & 1,594 \\
\hline SOS $9 a$ & 6,764 & 6,901 & 71,227 & 4,998 & 1,147 \\
\hline SOS $9 b$ & 10,058 & 10,261 & 105,911 & 7,432 & 1,706 \\
\hline SOS 9c & 11,337 & 11,566 & 119,379 & 8,377 & 1,923 \\
\hline Preferred Alternative & 9,921 & 10,122 & 104,474 & 7,331 & 1,682 \\
\hline
\end{tabular}

Table D-5. Summary of Average Annual Recreation Days by Activity for Lake Pend Oreille

\begin{tabular}{|c|c|c|c|c|c|}
\hline & Boating & Fishing & Camping & Picnicking & Swimming \\
\hline sos & $\begin{array}{c}50 \text { - Year } \\
\text { Average }\end{array}$ & $\begin{array}{c}50-\text { Year } \\
\text { Average }\end{array}$ & $\begin{array}{c}50 \text { - Year } \\
\text { Average }\end{array}$ & $\begin{array}{c}50 \text { - Year } \\
\text { Average }\end{array}$ & $\begin{array}{c}50-\text { Year } \\
\text { Average }\end{array}$ \\
\hline SOS 1a & 103,232 & 91,073 & 363,561 & 478,101 & 179,835 \\
\hline SOS $1 b$ & 103,316 & 91,147 & 363,858 & 478,492 & 179,982 \\
\hline $\operatorname{SOS} 2 c$ & 103,791 & 91,566 & 365,531 & 480,691 & 180,809 \\
\hline $\operatorname{sOS} 2 d$ & 103,791 & 91,566 & 365,531 & 480,691 & 180,809 \\
\hline $\operatorname{sOS} 4 c$ & 100,447 & 88,616 & 353,755 & 465,205 & 174,984 \\
\hline SOS $5 b$ & 103,389 & 91,211 & 364,114 & 478,828 & 180,109 \\
\hline SOS $5 c$ & 103,389 & 91,211 & 364,114 & 478,828 & 180,109 \\
\hline SOS $6 \mathrm{~b}$ & 103,389 & 91,211 & 364,114 & 478,828 & 180,109 \\
\hline SOS 6d & 103,389 & 91,211 & 364,114 & 478,828 & 180,109 \\
\hline $\operatorname{SOS} 9 \mathrm{a}$ & 84,995 & 74,984 & 299,335 & 393,641 & 148,066 \\
\hline SOS $9 b$ & 97,467 & 85,987 & 343,259 & 451,403 & 169,793 \\
\hline SOS $9 c$ & 100,853 & 88,974 & 355,183 & 467,084 & 175,691 \\
\hline Preferred Alternative & 105,547 & 93,115 & 371,714 & 488,822 & 183,868 \\
\hline
\end{tabular}


Table D-6. Summary of Average Annual Recreation Days by Activity for Lake Koocanusa

\begin{tabular}{|c|c|c|c|c|c|}
\hline & Boating & Fishing & Camping & Picnicking & Swimming \\
\hline sos & $\begin{array}{c}50 \text { - Year } \\
\text { Average }\end{array}$ & $\begin{array}{c}50 \text { - Year } \\
\text { Average }\end{array}$ & $\begin{array}{c}50 \text { - Year } \\
\text { Average }\end{array}$ & $\begin{array}{c}50 \text { - Year } \\
\text { Average }\end{array}$ & $\begin{array}{c}50 \text { - Year } \\
\text { Average }\end{array}$ \\
\hline SOS 1a & 80,592 & 239,780 & 196,613 & 75,090 & 12,515 \\
\hline $\operatorname{SOS} 1 b$ & 80,486 & 239,465 & 196,354 & 74,991 & 12,499 \\
\hline SOS 2c & 80,946 & 240,834 & 197,477 & 75,420 & 12,570 \\
\hline $\operatorname{sos} 2 d$ & 80,648 & 239,948 & 196,750 & 75,142 & 12,524 \\
\hline $\operatorname{SOS} 4 c$ & 82,630 & 245,844 & 201,584 & 76,989 & 12,831 \\
\hline SOS $5 b$ & 80,363 & 239,098 & 196,053 & 74,876 & 12,479 \\
\hline SOS $5 c$ & 80,363 & 239,099 & 196,054 & 74,877 & 12,479 \\
\hline SOS $6 \mathrm{~b}$ & 80,363 & 239,099 & 196,054 & 74,877 & 12,479 \\
\hline SOS 6d & 80,363 & 239,099 & 196,054 & 74,877 & 12,479 \\
\hline SOS 9a & 72,807 & 216,617 & 177,620 & 67,836 & 11,306 \\
\hline SOS $9 b$ & 79,559 & 236,707 & 194,092 & 74,128 & 12,355 \\
\hline SOS 9c & 82,435 & 245,265 & 201,110 & 76,808 & 12,801 \\
\hline Preferred Alternative & 80,199 & 238,610 & 195,653 & 74,724 & 12,454 \\
\hline
\end{tabular}

Table D-7. Summary of Average Annual Recreation Days by Activity for Kootenai River

\begin{tabular}{|c|c|c|c|c|c|}
\hline & Boating & Fishing & Camping & Picnicking & Swimming \\
\hline sos & $\begin{array}{c}50 \text { - Year } \\
\text { Average }\end{array}$ & $\begin{array}{c}50 \text { - Year } \\
\text { Average }\end{array}$ & $\begin{array}{c}50-\text { Year } \\
\text { Average }\end{array}$ & $\begin{array}{c}50-\text { Year } \\
\text { Average }\end{array}$ & $\begin{array}{c}50-\text { Year } \\
\text { Average }\end{array}$ \\
\hline SOS 1a & - & 34,316 & - & - & - \\
\hline SOS $1 b$ & - & 34,912 & - & - & - \\
\hline $\operatorname{sos} 2 c$ & - & 35,636 & - & - & - \\
\hline $\operatorname{SOS} 2 d$ & - & 35,062 & - & - & - \\
\hline$\overline{\operatorname{sos} 4 c}$ & - & 34,006 & - & - & - \\
\hline SOS $5 b$ & - & 34,989 & - & - & - \\
\hline SOS 5c & - & 34,998 & - & - & - \\
\hline SOS $6 \mathrm{~b}$ & - & 34,998 & - & - & - \\
\hline SOS 6d & - & 34,998 & - & - & - \\
\hline SOS 9a & - & 14,270 & - & - & - \\
\hline SOS $9 b$ & - & 28,942 & - & - & - \\
\hline SOS 9c & - & 33,881 & - & - & - \\
\hline Preferred Alternative & - & 24,960 & - & - & - \\
\hline
\end{tabular}


Table D-8. Summary of Average Annual Recreation Days by Activity for Dworshak Lake

\begin{tabular}{|c|c|c|c|c|c|}
\hline & Boating & Fishing & Camping & Picnicking & Swimming \\
\hline sos & $\begin{array}{c}50 \text { - Year } \\
\text { Average }\end{array}$ & $\begin{array}{c}50 \text { - Year } \\
\text { Average }\end{array}$ & $\begin{array}{c}50 \text { - Year } \\
\text { Average }\end{array}$ & $\begin{array}{c}50 \text { - Year } \\
\text { Average }\end{array}$ & $\begin{array}{c}50 \text { - Year } \\
\text { Average }\end{array}$ \\
\hline SOS 1a & 39,001 & 34,909 & 37,083 & 65,033 & 6,649 \\
\hline $\operatorname{SOS} 1 \mathrm{~b}$ & 39,631 & 35,473 & 37,682 & 66,083 & 6,757 \\
\hline $\operatorname{SOS} 2 c$ & 43,002 & 38,490 & 40,887 & 71,703 & 7,331 \\
\hline SOS 2d & 34,086 & 30,510 & 32,410 & 56,837 & 5,811 \\
\hline SOS $4 c$ & 44,315 & 39,666 & 42,136 & 73,893 & 7,555 \\
\hline SOS $5 b$ & 45,627 & 40,840 & 43,383 & 76,081 & 7,779 \\
\hline $\operatorname{SOS} 5 \mathrm{c}$ & 48,450 & 43,367 & 46,067 & 80,788 & 8,260 \\
\hline SOS $6 \mathrm{~b}$ & 42,455 & 38,001 & 40,367 & 70,792 & 7,238 \\
\hline SOS 6d & 42,455 & 38,001 & 40,367 & 70,792 & 7,238 \\
\hline SOS 9a & 38,507 & 34,467 & 36,613 & 64,208 & 6,565 \\
\hline SOS $9 b$ & 28,439 & 25,455 & 27,040 & 47,420 & 4,849 \\
\hline SOS 9c & 39,090 & 34,989 & 37,168 & 65,181 & 6,665 \\
\hline Preferred Alternative & 31,949 & 28,597 & 30,378 & 53,274 & 5,447 \\
\hline
\end{tabular}

Table D-9. Summary of Average Annual Recreation Days by Activity for Clearwater River

\begin{tabular}{|c|c|c|c|c|c|}
\hline & Boating & Fishing & Camping & Picnicking & Swimming \\
\hline sos & $\begin{array}{c}\text { 50 - Year } \\
\text { Average }\end{array}$ & $\begin{array}{c}50 \text { - Year } \\
\text { Average }\end{array}$ & $\begin{array}{c}50 \text { - Year } \\
\text { Average }\end{array}$ & $\begin{array}{c}50 \text { - Year } \\
\text { Average }\end{array}$ & $\begin{array}{c}50 \text { - Year } \\
\text { Average }\end{array}$ \\
\hline SOS $1 a$ & - & 109,147 & - & - & - \\
\hline SOS $1 b$ & - & 105,285 & - & - & - \\
\hline SOS 2c & - & 128,224 & - & - & - \\
\hline $\operatorname{SOS} 2 d$ & - & 198,900 & - & - & - \\
\hline SOS $4 c$ & - & 147,346 & - & - & - \\
\hline SOS $5 b$ & - & 126,711 & - & - & - \\
\hline SOS 5c & - & 141,589 & - & - & - \\
\hline SOS $6 b$ & - & 133,905 & - & - & - \\
\hline SOS 6d & - & 133,905 & - & - & - \\
\hline SOS 9a & - & 136,247 & - & - & - \\
\hline SOS 9b & - & 135,271 & - & - & - \\
\hline SOS 9c & - & 143,327 & - & - & - \\
\hline Preferred Alternative & - & 151,296 & - & - & - \\
\hline
\end{tabular}


Table D-10. Summary of Average Annual Recreation Days by Activity for Lower Granite

\begin{tabular}{|c|c|c|c|c|c|}
\hline & Boating & Fishing & Camping & Picnicking & Swimming \\
\hline sos & $\begin{array}{c}50 \text { - Year } \\
\text { Average }\end{array}$ & $\begin{array}{c}50 \text { - Year } \\
\text { Average }\end{array}$ & $\begin{array}{c}50 \text { - Year } \\
\text { Average }\end{array}$ & $\begin{array}{l}50 \text { - Year } \\
\text { Average }\end{array}$ & $\begin{array}{c}50 \text { - Year } \\
\text { Average }\end{array}$ \\
\hline SOS 1a & 327,303 & 188,873 & 77,402 & 804,612 & 255,690 \\
\hline SOS $1 b$ & 333,877 & 192,667 & 78,956 & 820,774 & 260,826 \\
\hline SOS $2 c$ & 329,048 & 189,880 & 77,814 & 808,903 & 257,053 \\
\hline $\operatorname{SOS} 2 \mathrm{~d}$ & 329,048 & 189,880 & 77,814 & 808,903 & 257,053 \\
\hline SOS $4 c$ & 326,490 & 188,404 & 77,209 & 802,614 & 255,055 \\
\hline SOS 5b & 170,053 & 98,131 & 40,215 & 418,044 & 132,846 \\
\hline SOS 5c & 129,088 & 74,492 & 30,527 & 317,339 & 100,844 \\
\hline SOS $6 \mathrm{~b}$ & 247,380 & 142,753 & 58,501 & 608,137 & 193,254 \\
\hline SOS 6d & 247,380 & 142,753 & 58,501 & 608,137 & 193,254 \\
\hline SOS 9a & 232,599 & 134,224 & 55,006 & 571,802 & 181,707 \\
\hline SOS $9 b$ & 320,265 & 184,812 & 75,737 & 787,312 & 250,192 \\
\hline SOS 9c & 293,976 & 169,642 & 69,520 & 722,685 & 229,655 \\
\hline Preferred Alternative & 331,178 & 191,109 & 78,318 & 814,138 & 258,717 \\
\hline
\end{tabular}

Table D-11. Summary of Average Annual Recreation Days by Activity for Little Goose

\begin{tabular}{|c|c|c|c|c|c|}
\hline & Boating & Fishing & Camping & Picnicking & Swimming \\
\hline sos & $\begin{array}{c}50 \text { - Year } \\
\text { Average }\end{array}$ & $\begin{array}{c}50 \text { - Year } \\
\text { Average }\end{array}$ & $\begin{array}{c}50 \text { - Year } \\
\text { Average }\end{array}$ & $\begin{array}{c}50-\text { Year } \\
\text { Average }\end{array}$ & $\begin{array}{c}50 \text { - Year } \\
\text { Average }\end{array}$ \\
\hline SOS 1a & 43,231 & 27,319 & 23,256 & 108,102 & 42,913 \\
\hline SOS $1 b$ & 43,242 & 27,327 & 23,262 & 108,131 & 42,924 \\
\hline SOS 2c & 42,455 & 26,829 & 22,838 & 106,162 & 42,142 \\
\hline $\operatorname{sos} 2 d$ & 42,455 & 26,829 & 22,838 & 106,162 & 42,142 \\
\hline SOS $4 c$ & 42,315 & 26,741 & 22,763 & 105,812 & 42,004 \\
\hline SOS $5 b$ & 16,366 & 10,342 & 8,804 & 40,923 & 16,245 \\
\hline SOS 5c & 12,564 & 7,940 & 6,759 & 31,417 & 12,471 \\
\hline SOS $6 \mathrm{~b}$ & 29,033 & 18,347 & 15,618 & 72,600 & 28,820 \\
\hline SOS 6d & 42,455 & 26,829 & 22,838 & 106,162 & 42,142 \\
\hline SOS 9a & 26,827 & 16,953 & 14,431 & 67,083 & 26,630 \\
\hline SOS $9 b$ & 41,161 & 26,011 & 22,142 & 102,926 & 40,858 \\
\hline SOS 9c & 35,906 & 22,690 & 19,315 & 89,785 & 35,641 \\
\hline Preferred Alternative & 42,853 & 27,080 & 23,052 & 107,157 & 42,538 \\
\hline
\end{tabular}


Table D-12. Summary of Average Annual Recreation Days by Activity for Lower Monumental

\begin{tabular}{|c|c|c|c|c|c|}
\hline & Boating & Fishing & Camping & Picnicking & Swimming \\
\hline sos & $\begin{array}{c}50 \text { - Year } \\
\text { Average }\end{array}$ & $\begin{array}{c}50 \text { - Year } \\
\text { Average }\end{array}$ & $\begin{array}{c}50 \text { - Year } \\
\text { Average }\end{array}$ & $\begin{array}{c}50 \text { - Year } \\
\text { Average }\end{array}$ & $\begin{array}{c}50-\text { Year } \\
\text { Average }\end{array}$ \\
\hline SOS $1 \mathrm{a}$ & 23,998 & 32,692 & 32,664 & 37,438 & 13,217 \\
\hline SOS $1 b$ & 24,005 & 32,702 & 32,674 & 37,450 & 13,221 \\
\hline SOS 2c & 23,584 & 32,129 & 32,102 & 36,794 & 12,989 \\
\hline SOS 2d & 23,584 & 32,129 & 32,102 & 36,794 & 12,989 \\
\hline $\operatorname{sos} 4 c$ & 23,426 & 31,913 & 31,886 & 36,546 & 12,902 \\
\hline SOS $5 b$ & 9,869 & 13,444 & 13,433 & 15,396 & 5,435 \\
\hline SOS 5c & 7,551 & 10,286 & 10,277 & 11,780 & 4,159 \\
\hline SOS $6 b$ & 16,539 & 22,531 & 22,512 & 25,802 & 9,109 \\
\hline SOS 6d & 23,584 & 32,129 & 32,102 & 36,794 & 12,989 \\
\hline SOS $9 a$ & 15,316 & 20,865 & 20,847 & 23,894 & 8,435 \\
\hline SOS $9 b$ & 22,868 & 31,154 & 31,127 & 35,677 & 12,595 \\
\hline SOS $9 c$ & 20,443 & 27,850 & 27,826 & 31,893 & 11,259 \\
\hline Preferred Alternative & 23,784 & 32,402 & 32,374 & 37,106 & 13,099 \\
\hline
\end{tabular}

Table D-13. Summary of Average Annual Recreation Days by Activity for Ice Harbor

\begin{tabular}{|c|c|c|c|c|c|}
\hline & Boating & Fishing & Camping & Picnicking & Swimming \\
\hline sos & $\begin{array}{c}50 \text { - Year } \\
\text { Average }\end{array}$ & $\begin{array}{c}50 \text { - Year } \\
\text { Average }\end{array}$ & $\begin{array}{c}50 \text { - Year } \\
\text { Average }\end{array}$ & $\begin{array}{c}50 \text { - Year } \\
\text { Average }\end{array}$ & $\begin{array}{c}50 \text { - Year } \\
\text { Average }\end{array}$ \\
\hline SOS 1a & 67,547 & 89,940 & 35,640 & 259,202 & 73,382 \\
\hline $\operatorname{SOS} 1 b$ & 67,580 & 89,984 & 35,657 & 259,329 & 73,418 \\
\hline $\operatorname{SOS} 2 c$ & 66,143 & 88,070 & 34,899 & 253,813 & 71,856 \\
\hline $\operatorname{SOS} 2 d$ & 66,143 & 88,070 & 34,899 & 253,813 & 71,856 \\
\hline $\operatorname{sos} 4 c$ & 65,152 & 86,751 & 34,376 & 250,013 & 70,780 \\
\hline SOS $5 b$ & 21,093 & 28,085 & 11,129 & 80,941 & 22,915 \\
\hline SOS $5 c$ & 16,354 & 21,776 & 8,629 & 62,757 & 17,767 \\
\hline SOS $6 b$ & 43,088 & 57,372 & 22,734 & 165,342 & 46,810 \\
\hline SOS $6 \mathrm{~d}$ & 66,143 & 88,070 & 34,899 & 253,813 & 71,856 \\
\hline SOS 9a & 38,753 & 51,601 & 20,447 & 148,710 & 42,101 \\
\hline $\operatorname{SOS} 9 \mathrm{~b}$ & 63,587 & 84,667 & 33,550 & 244,004 & 69,079 \\
\hline SOS 9c & 57,774 & 76,927 & 30,483 & 221,700 & 62,765 \\
\hline Preferred Alternative & 66,719 & 88,837 & 35,203 & 256,024 & 72,482 \\
\hline
\end{tabular}


Table D-14. Summary of Average Annual Recreation Days by Activity for Lake Roosevelt

\begin{tabular}{|c|c|c|c|c|c|}
\hline & Boating & Fishing & Camping & Picnicking & Swimming \\
\hline sos & $\begin{array}{c}50 \text { - Year } \\
\text { Average }\end{array}$ & $\begin{array}{c}50 \text { - Year } \\
\text { Average }\end{array}$ & $\begin{array}{c}50 \text { - Year } \\
\text { Average }\end{array}$ & $\begin{array}{c}50 \text { - Year } \\
\text { Average }\end{array}$ & $\begin{array}{c}50 \text { - Year } \\
\text { Average }\end{array}$ \\
\hline SOS 1a & 426,010 & 301,403 & 354,410 & 393,716 & 155,595 \\
\hline SOS $1 b$ & 427,632 & 302,551 & 355,759 & 395,215 & 156,187 \\
\hline $\operatorname{SOS} 2 c$ & 436,222 & 308,629 & 362,906 & 403,155 & 159,325 \\
\hline $\operatorname{SOS} 2 d$ & 434,326 & 307,288 & 361,329 & 401,403 & 158,632 \\
\hline SOS $4 c$ & 433,974 & 307,038 & 361,035 & 401,077 & 158,503 \\
\hline SOS $5 b$ & 435,141 & 307,864 & 362,007 & 402,156 & 158,930 \\
\hline SOS 5c & 435,141 & 307,864 & 362,007 & 402,156 & 158,930 \\
\hline SOS $6 b$ & 435,141 & 307,864 & 362,007 & 402,156 & 158,930 \\
\hline SOS 6d & 435,141 & 307,864 & 362,007 & 402,156 & 158,930 \\
\hline SOS 9a & 328,376 & 232,327 & 273,186 & 303,484 & 119,935 \\
\hline SOS 9b & 387,123 & 273,891 & 322,059 & 357,778 & 141,392 \\
\hline SOS 9c & 410,256 & 290,258 & 341,304 & 379,157 & 149,841 \\
\hline Preferred Alternative & 421,271 & 298,050 & 350,467 & 389,337 & 153,864 \\
\hline
\end{tabular}

Table D-15. Summary of Average Annual Recreation Days by Activity for John Day

\begin{tabular}{|c|c|c|c|c|c|}
\hline & Boating & Fishing & Camping & Picnicking & Swimming \\
\hline sos & $\begin{array}{c}50 \text { - Year } \\
\text { Average }\end{array}$ & $\begin{array}{c}50 \text { - Year } \\
\text { Average }\end{array}$ & $\begin{array}{c}50 \text { - Year } \\
\text { Average }\end{array}$ & $\begin{array}{c}50 \text { - Year } \\
\text { Average }\end{array}$ & $\begin{array}{c}50 \text { - Year } \\
\text { Average }\end{array}$ \\
\hline SOS 1a & 756,472 & 649,222 & 573,432 & 570,858 & 310,025 \\
\hline SOS $1 b$ & 756,472 & 649,222 & 573,432 & 570,858 & 310,025 \\
\hline $\operatorname{sOS} 2 c$ & 675,900 & 580,073 & 512,355 & 510,056 & 277,004 \\
\hline $\operatorname{sos} 2 d$ & 675,900 & 580,073 & 512,355 & 510,056 & 277,004 \\
\hline SOS 4c & 730,030 & 626,529 & 553,388 & 550,904 & 299,188 \\
\hline SOS $5 b$ & 560,993 & 481,458 & 425,252 & 423,343 & 229,912 \\
\hline SOS $5 c$ & 560,993 & 481,458 & 425,252 & 423,343 & 229,912 \\
\hline SOS 6b & 560,993 & 481,458 & 425,252 & 423,343 & 229,912 \\
\hline SOS 6d & 560,993 & 481,458 & 425,252 & 423,343 & 229,912 \\
\hline SOS 9a & 556,468 & 477,574 & 421,822 & 419,928 & 228,057 \\
\hline SOS $9 b$ & 675,900 & 580,073 & 512,355 & 510,056 & 277,004 \\
\hline SOS $9 c$ & 547,061 & 469,500 & 414,691 & 412,829 & 224,202 \\
\hline Preferred Alternative & 397,300 & 340,972 & 301,167 & 299,815 & 162,826 \\
\hline
\end{tabular}




\section{EXHIBIT E}

\section{The Framework for Analysis}

\section{E.1 INTRODUCTION}

The direct economic effects of the system operation strategies (SOSs) included in the SOR were estimated and provide the basis for the analysis of the indirect economic impacts evaluated in this study. Direct economic effects are measured in terms of changes in the value of commodities and activities directly affected by the river operations strategies. These primary, or direct, economic impacts are determined using the National Economic Development procedures outlined in the Water Resources Council's Principles and Guidelines. Direct economic impacts have been evaluated for the following river-based commodities and activities:

- Anadromous fish

- Flood control

- Irrigation and municipal water supply

- Navigation

- Hydropower generation

- Recreation

The purpose of this study is to measure the secondary, or indirect, economic impacts of the alternative operations strategies evaluated under the SOR. The indirect analysis measures the regional economic impacts generated by the output or income changes in five of the six river-based commodities and activities identified above. ${ }^{1}$ Regional input-output models are used to estimate the indirect impacts. Models have been previously developed for the Pacific Northwest and for twelve state and multicounty subregions throughout the study area. ${ }^{2}$ Measures of direct economic changes for the five river uses are disaggregated by study region so that the localized changes to jobs and income can be measured. The regional economic impacts associated with project implementation expenditures are also examined.

\section{E.2 STUDY REGIONS}

The direct economic impacts of the SOR alternatives have been measured for activities occurring throughout the Pacific Northwest (Washington, Oregon, Idaho, and Montana). However, the actual incidence of the direct impacts will be distributed across various locations throughout the region. Consequently, the secondary regional impacts associated with the direct changes will occur in some parts of the Pacific Northwest, while not in others. To better reflect the distribution of intra-regional impacts, eight multi-county subregions were identified. The boundaries of the regions were determined in part by the expected incidence of the direct economic impacts. The eight subregions are defined below.

Puget Sound: $\quad$ Five (5) counties in northwestern Washington.

1 Regional economic impacts were not evaluated for the direct costs associated with flood control damages. The SOR Economic Analysis Group (EAG) has elected to evaluate only the direct impacts to flood control.

2 The reader is referred to two earlier studies prepared by Northwest Economic Associates: Regional Economic Analysis for the System Operation Review: An Analysis of Indirect Economic Impacts for Inclusion in the Draft EIS, June 1995, and System Operation Review: Framework for Indirect Impacts Analysis, February 1993. 
West Coast

Ten (10) counties extending from the central Washington coast southward to the central Oregon coast.

Portland:

Five (5) counties in Oregon and Washington surrounding the Portland metropolitan area.

Mid Columbia: Eleven (11) counties in Oregon and Washington located along the mainstem of the Columbia River above Portland.

Upper Columbia: Eight (8) counties in north central Washington, including counties along the upper reaches of the Columbia River.

Lower Snake:

Twelve (12) counties in southeastern Washington, central Idaho, and northeastern Oregon located along the Clearwater, Salmon, and Lower Snake Rivers.

Northeast:

Fifteen (15) counties in northeastern Washington, northern Idaho, and western Montana.

Southern Idaho: Thirty-three (33) counties, including all of southern Idaho, along the upper Snake River, and a portion of southeastern Oregon.

Counties included in the eight subregions are identified in Table E-1. Separate input-output models were developed for each of the subregions. The basic data was developed by the University of Minnesota for the USDA Forest Service.
The regional effects of the direct economic impacts were further evaluated to determine the state-level changes likely to occur under the various SOR operations alternatives. To measure these impacts, individual input-output models were developed for Oregon, Washington, Idaho, and Montana.

\section{E.3 DEVELOPING THE INPUT-OUTPUT MODELS}

All input-output $(\mathrm{I}-\mathrm{O})$ models begin with the construction of a set of accounts which describe the transactions between industries, their purchases of primary inputs, and their sales to final demand sectors. With the rising costs of collecting this data, economists began to explore ways of estimating these relationships in less expensive ways. This is called a non-survey approach and is the approach used in the IMPLAN system.

The non-survey approach has as its basis the premise that some of the necessary input-output accounts data can initially be approximated by national or regional average relationships. For example, the national or regional household consumption patterns are an adequate first approximation of the household consumption patterns to be estimated for the regional accounts. Likewise, relationships between total output per worker, between total output and other factor payments, for government purchases, capital formation, etc., are assumed to be adequate starting points.

Finding data sources useful in directly constructing the final demand and factor payments information is not insurmountable. The estimation for a first approximation of interindustry transactions requires an indirect approach. It begins with estimating total output by industry. In the $\mathrm{I}-\mathrm{O}$ framework of accounts, total output and total outlay are equal. By multiplying each industry's total output by the column coefficients in the direct requirements matrix, an estimate of interindustry transactions is obtained. 
Table E-1. Multi-County Subregions Identified for the Regional Economic Impact Analysis

\begin{tabular}{|c|c|c|}
\hline Subregion & & Counties Included in the Subregion \\
\hline Puget Sound & Washington: & King, Pierce, Skagit, Snohomish, Thurston, Whatcom \\
\hline West Coast & $\begin{array}{l}\text { Washington: } \\
\text { Oregon: }\end{array}$ & $\begin{array}{l}\text { Clallam, Jefferson, Grays Harbor, Pacific, Wahkiakum, Cowlitz } \\
\text { Clatsop, Columbia, Lincoln, Tillamook }\end{array}$ \\
\hline Portland & $\begin{array}{l}\text { Oregon: } \\
\text { Washington: }\end{array}$ & $\begin{array}{l}\text { Clackamas, Multnomah, Washington, Yamhill } \\
\text { Clark }\end{array}$ \\
\hline Mid Columbia & Oregon: & Gilliam, Hood River, Morrow, Sherman, Umatilla, Wasco \\
\hline & Washington: & Benton, Franklin, Klickitat, Skamania, Walla Walla \\
\hline Upper Columbia & Washington: & $\begin{array}{l}\text { Adams, Chelan, Douglas, Grant, Kittitas, Lincoln, Okanogan, } \\
\text { Yakima }\end{array}$ \\
\hline Lower Snake & $\begin{array}{l}\text { Washington: } \\
\text { Oregon: } \\
\text { Idaho: }\end{array}$ & $\begin{array}{l}\text { Asotin, Columbia, Garfield, Whitman } \\
\text { Wallowa } \\
\text { Clearwater, Custer, Idaho, Latah, Lemhi, Lewis, Nez Perce }\end{array}$ \\
\hline Northeast & $\begin{array}{l}\text { Washington: } \\
\text { Idaho: } \\
\text { Montana: }\end{array}$ & $\begin{array}{l}\text { Ferry, Pend Oreille, Spokane, Stevens } \\
\text { Benewah, Bonner, Boundary, Kootenai, Shoshone } \\
\text { Flathead, Lake, Lincoln, Mineral, Missoula, Sanders }\end{array}$ \\
\hline Southern Idaho & $\begin{array}{l}\text { Oregon: } \\
\text { Idaho: }\end{array}$ & $\begin{array}{l}\text { Malheur } \\
\text { Ada, Adams, Bannock, Bear Lake, Bingham, Blaine, Boise, Bonne- } \\
\text { ville, Butte, Camas, Canyon, Caribou, Cassia, Clark, Elmore, } \\
\text { Franklin, Fremont, Gem, Gooding, Jefferson, Jerome, Lincoln, } \\
\text { Madison, Minidoka, Oneida, Owyhee, Payette, Power, Teton, Twin } \\
\text { Falls, Valley, Washington }\end{array}$ \\
\hline
\end{tabular}

\section{E.3.1 Validating The Basic Data}

The basic data for the IMPLAN system was developed by the University of Minnesota for the USDA Forest Service [Minnesota IMPLAN Group]. The most recent data available at the time of model construction was for the base year $1985 .{ }^{3}$ In developing models for the Columbia River System Operation Review (SOR), it was necessary to review this data and evaluate changes in economic activity that may have occurred since 1985. In addition to changes in economic activity, adjustments in relative prices have occurred. To accomplish this review, data are needed for both changes in relative prices for commodities and changes in employment and payroll for economic sectors.

The availability of validation data was reviewed as part of the input-out modeling effort. It was determined that 1989 was the latest year for which consistent data were available for all of the model regions. After reviewing employment and payroll data sources, it was decided that state employment data (ES-202 data) provided the best source for the states of Oregon and Washington, and County Business Patterns (CBP) data was the best source of information for the states of Idaho and Montana.

3 Construction of the thirteen SOR regional input-output models began in the first half of 1992. 
The CBP data was also determined to be the most consistent source of information for the individual counties included in the eight subregions. A primary consideration in selecting the appropriate data sources was the availability of information at the four-digit Standard Industrial Classification (SIC) level of detail.

\section{E.3.2 Adjusting the Trade Relationships}

After evaluating and adjusting the basic data, the initial social accounts were developed. An important step in the development of the social accounts is the evaluation of the regional purchase coefficients (RPCs). A regional purchase coefficient is the fraction of locally produced goods and services that is used to meet local demand. These values are initially set the first time the social accounts are constructed. The initial RPCs are set using a combination of predictive equations and observed values from multi-regional input-output models. By definition, RPCs cannot exceed one and cannot be negative. A further upper limit is that they cannot exceed the supply/demand pool ratio if the ratio is one or less (if the supply/demand pool ratio exceeds one, it is reset to one).

Reports displaying the supply/demand pool ratio and the initial RPC for each commodity were prepared for each sub-regional, state, and regional model. This information was entered in spreadsheets, and consistency across models was checked. Evaluating the appropriateness of the RPC for a commodity involves consideration of a number of factors.

The setting of RPCs is directly related to interregional trading patterns. The size of the economy and number of economic linkages within the economy is one important factor. Another factor is the nature of the commodity itself. Commodities are defined as bundles of goods. In some cases, e.g., for IMPLAN commodity 1 (dairy farm products), the bundle of goods is small - primarily raw milk, with some livestock sales. For other commodities, e.g., commodity 315 (screw machine products and bolts), the bundle of goods is large. When the bundle of goods is large, it is more important to know specifically which good(s) are being produced locally, and how much is likely to be used to meet local demand. State directories of manufacturers, knowledge of local conditions, and other data sources were used in this evaluation. Setting RPCs high means that less will be imported (and less exported), and setting them low means that more will be imported (and more exported). The IMPLAN import/export editor shows the effect on imports and exports interactively as RPC values are entered. This allows some fine tuning of RPCs with respect to local trading patterns.

After the RPCs were set, the social accounts were developed again, and production function reports for selected industries were obtained. These reports were checked to ensure that regional economic structures were reasonably represented by the model production functions.

\section{E.3.3 Construction of the 1-O Models}

After changes to the price relationships, employment levels, trade relationships, and production functions have been made, the social accounts are constructed. While the social accounts themselves are very useful as an aid to understanding economic structure, they have even more power in understanding economic structure and analyzing economic change when transformed into an $\mathrm{I}-\mathrm{O}$ model. Two matrices are involved, the "make" matrix and the "use" matrix for each industry. The make matrix lists the quantity of each commodity produced by each industry; the use matrix lists the quantity of each commodity it uses to produce its output. Transformation of the social accounts into the input-output accounts begins with converting the make and use matrices into technical coefficient matrices. The normalized regional use matrix is called the regional absorption matrix. It shows the proportion of each industry's total outlay spent on locally-produced commodities. The normalized regional make matrix is called the regional market shares matrix. It shows a given industry's proportion of a region's total commodity production.

The regional direct requirements matrix is derived by multiplying the regional market shares matrix by the regional absorption matrix. The result is an industry-by-industry direct requirements matrix 
that establishes interindustry purchases per dollar of industry output by tracing the use of a commodity by an industry to the industries that produce the commodity. The data has at this point been transformed from a commodity and industry basis to an industry basis. In the IMPLAN system terminology, this step is called developing the input-output accounts, or squaring the matrix.

The next step is to transform the direct requirements matrix into a direct plus indirect requirements matrix. Matrix algebra methods are used to develop a table of these direct plus indirect requirements. Any standard text on $\mathrm{I}-\mathrm{O}$ methods provides the details of this operation.

At the completion of this step, the social accounts have been transformed into an input-output model. The resultant matrix is referred to as the direct and indirect requirements matrix or the inverse matrix. Column sums of this matrix are the so-called output multipliers. Additional multipliers are constructed by incorporating the direct relationships between output, employment, income, and value added.

\section{E.3.4 Documentation for the Models}

A complete set of documentation for the thirteen regional, state, and subregional models developed for the SOR has been made available to the SOR Economic Analysis Group. The fully adjusted models are available on 3.5" diskettes, stored using the DOS 5.0 Backup utility. Documentation is available for all price, employment, RPC, and production function adjustments made to the inputoutput models.

A more detailed discussion of the model construction is included in an earlier report, System Operation Review: Framework for Indirect Impacts Analysis, prepared by Northwest Economic Associates. ${ }^{4}$

\section{E.4 LINKING THE DIRECT ECONOMIC IMPACTS TO THE REGIONAL ANALYSIS}

\section{E.4.1 Measures of Direct Economic Impacts}

The direct economic impacts associated with the SOR operation strategies are measured as the costs or benefits that accrue to the recreation, irrigation, navigation, hydropower generation, anadromous fish, and flood control activities affected by implementation of the alternatives. National Economic Development (NED) guidelines and principles are used to measure the direct economic costs and benefits associated with the SOR alternatives. The basis for the NED procedures is to determine whether the benefits associated with alternative river operations exceed the costs associated with the revised operations. However, the measurement of direct impacts is complicated by the fact that expected changes to some of the river-based activities are measured in terms of non-marketed biological or physical outputs rather than economic values (e.g., anadromous fish, recreation). In these cases, the value of changes in physical output are approximated using willingness - to-pay measures which quantify the amount of money an individual would be willing to pay for the expected changes in physical output.

The benefits and costs to each of the affected resource activities, including the project costs to implement the operations strategy, are computed and summed for each alternative. Results are compared to the base case to determine whether society is made better off or worse off as a result of the operations strategy. The measurement of net gain or net loss is from a national perspective and does not take into account any differences in subregional gains and losses that may result.

Table E-2 presents a brief description of the direct measures of economic change in the five resource areas for which indirect economic impacts are measured. A description is also provided for project implementation. Except for sport harvest of anadromous fish and recreation, the direct economic measurements provide the starting point for the analysis

4 Northwest Economic Associates, System Operation Review: Framework for Indirect Impacts Analysis, Final Report, prepared for the U.S. Army Corps of Engineers, Portland District, February 1993. 
Table E-2. Economic Measures Used to Value the Direct Impacts of the SOR Alternatives

\begin{tabular}{|l|l|}
\hline \multicolumn{1}{|c|}{ Resource Activity } & \multicolumn{1}{c|}{ Measure of Direct Economic Impact } \\
\hline Anadromous Fish & $\begin{array}{l}\text { Fish harvested in commercial fisheries valued using ex-vessel fish prices; } \\
\text { and } \\
\text { Fish harvested in recreational fisheries valued using willingness-to-pay } \\
\text { values for sport fishing. }\end{array}$ \\
\hline Irrigation & $\begin{array}{l}\text { Increased costs for irrigation pump modifications, annual operation and } \\
\text { maintenance costs, and increased energy costs. }\end{array}$ \\
\hline Navigation & $\begin{array}{l}\text { Increased transportation costs associated with mode shifts and increased } \\
\text { storage and handling costs. }\end{array}$ \\
\hline Power & Net system generation costs. \\
\hline Recreation & $\begin{array}{l}\text { Changes in the willingness - to-pay values for alternative levels of reser- } \\
\text { voir recreation activities. }\end{array}$ \\
\hline Construction & $\begin{array}{l}\text { Construction costs associated with project implementation requirements, } \\
\text { including dam and irrigation pump modifications. }\end{array}$ \\
\hline
\end{tabular}

of the indirect impacts. In the case of fishing and recreation, the changes in number of fish harvested and recreation visitor days were used as inputs to the indirect analysis.

The benefits and costs of the alternative SOR river operations are compared over a 100-year time frame. Because the operation strategies have different implementation dates, the costs and benefits over time are discounted using a federal project discount rate of $7.75 \%$ and a real rate of return of 3\%. Constant prices are assumed using a 1992 base year. The direct economic impacts are presented in terms of actual average annual values at the time of the implementation of the alternative, and as average annual equivalent values which take into account the time distribution of the impacts. It was determined by the SOR Economic Analysis Group that the measurement of indirect economic impacts should be based on the average annual values computed for the year 2020 and beyond for the direct economic impacts.

\section{E.4.1.1 Linking the Direct and Indirect Economic Impacts}

The first step of the regional analysis is to translate the direct economic impacts into measures of eco- nomic change that can be incorporated into the indirect impact analysis. For some of the resource uses, the direct values can be included in the regional analysis without any modification. In other cases, only the direct measure of physical change is carried over, and alternative values are developed to describe the direct impact.

The linkages between the measures of direct and indirect economic impact for the five resources evaluated in the regional analysis, as well as for project implementation, are described in the following sections.

\section{E.4.2 Anadromous Fish}

The direct economic effects of the SOR alternatives on the anadromous fish resource are valued according to the recreational and commercial uses of the fish. Expected changes in fish harvest were measured for Columbia River fall chinook salmon, spring/summer chinook salmon, steelhead, and sockeye salmon fish stocks. Harvest occurs in ocean and in-river commercial fisheries and in ocean and in-river sport fisheries located in Canada, Alaska, and the U.S. West Coast regions. The distribution of these stocks, by location of fishery, is presented in Table E-3. 
Table E-3. Distribution of Anadromous Stocks by Harvest Fisheries

\begin{tabular}{|c|c|c|c|c|}
\hline Location & $\begin{array}{c}\text { Fall } \\
\text { Chinook }\end{array}$ & $\begin{array}{l}\text { Spr/Sum } \\
\text { Chinook }\end{array}$ & Steelhead & Sockeye \\
\hline \multicolumn{5}{|c|}{ Commercial Harvest } \\
\hline Alaska & + & $*$ & $\mathrm{a} /$ & a/ \\
\hline Canada & $*$ & $*$ & a/ & a/ \\
\hline U.S. Ocean & 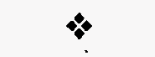 & $*$ & a/ & a/ \\
\hline U.S. In-River & $\star$ & $*$ & $*$ & $*$ \\
\hline \multicolumn{5}{|l|}{ Sport Harvest } \\
\hline Alaska & $*$ & a/ & $a /$ & a/ \\
\hline Canada & $*$ & a/ & a/ & a/ \\
\hline U.S. Ocean & $\star$ & $\star$ & a/ & a/ \\
\hline U.S. In-River & $*$ & $*$ & $*$ & a/ \\
\hline
\end{tabular}

a/ Blank cells indicate that no harvest of the species occurs in the indicated fisheries.

Simulation models were used by the Anadromous Fish Work Group to estimate fish harvest over the 100-year time frame of the SOR analysis. Direct economic impacts were measured by the Economic Analysis Group using an average annual equivalent estimate of the number of fish harvested over the 100-year time frame. The direct impacts were also estimated using average annual harvest estimates for the years 1995, 2005, 2010, and 2020 and beyond. The harvest figures for 2020 and beyond were carried over to the regional analysis.

\section{E.4.2.1 The Commercial Harvest Fisheries}

The regional economic impacts related to commercial harvest under the SOR alternatives were evaluated only for the U.S. ocean and in-river fisheries, including:

- U.S. ocean troll fishery;

- Non-Indian gillnet commercial fishery in the Columbia River below Bonneville Dam (River Zones 1-5); and

- Native American commercial fishery in the Columbia River from Bonneville Dam to McNary Dam (River Zone 6).

\section{Allocation of Harvest to Subregions}

Harvest activity in each of the subregions was allocated based on the distribution of actual harvest between 1987 and 1991. Allocation percentages for each of the subregions with commercial harvest activity are presented in Table E-4. Information from the Oregon Department of Fish and Wildlife and the Pacific Fishery Management Council was used to develop the state and subregion allocations [Pacific Fishery Management Council; Washington Department of Fisheries].

Ceremonial and subsistence use in the Native American Zone 6 fishery was estimated by the Anadromous Fish Work Group using current information on harvest for these purposes. These uses were allocated as follows: 1) five percent of fall chinook harvest up to 6,000 fish; 2) five percent of spring chinook harvest up to 4,000 fish; and 3) five percent of sockeye and steelhead harvest. All remaining harvest in the Native American fishery was assumed to be used for commercial purposes.

The number of fish expected to be harvested in the ocean commercial fishery under each of the final SOR alternatives is presented in Table E-5. Harvest figures are shown for the Pacific Northwest, 
Table E-4. Allocation of Commercial Harvest to Subregions

\begin{tabular}{|c|c|c|c|c|}
\hline & Fall Chinook & Spr/Sum Chinook & Steelhead & Sockeye \\
\hline \multicolumn{5}{|c|}{ Ocean Commercial Harvest } \\
\hline \multicolumn{5}{|c|}{ By State } \\
\hline Washington & $20 \%$ & $20 \%$ & a/ & a/ \\
\hline Oregon & $80 \%$ & $80 \%$ & a/ & a/ \\
\hline \multicolumn{5}{|l|}{ By Subregion } \\
\hline West Coast & $100 \%$ & $100 \%$ & a/ & $\mathrm{a} /$ \\
\hline \multicolumn{5}{|c|}{ In-River Commercial Harvest } \\
\hline \multicolumn{5}{|c|}{\begin{tabular}{l|l} 
By River Zone &
\end{tabular}} \\
\hline Zones $1-5$ & $40 \%$ & $25 \%$ & $0 \%$ & $30 \%$ \\
\hline Zone 6 & $60 \%$ & $75 \%$ & $100 \%$ & $70 \%$ \\
\hline \multicolumn{5}{|l|}{ By State } \\
\hline Washington & $40 \%$ & $40 \%$ & $60 \%$ & $60 \%$ \\
\hline Oregon & $60 \%$ & $60 \%$ & $40 \%$ & $40 \%$ \\
\hline \multicolumn{5}{|l|}{ By Subregion } \\
\hline West Coast & $28 \%$ & $17.5 \%$ & $0 \%$ & $27 \%$ \\
\hline Portland & $12 \%$ & $7.5 \%$ & $0 \%$ & $3 \%$ \\
\hline Mid Columbia & $60 \%$ & $75 \%$ & $100 \%$ & $70 \%$ \\
\hline
\end{tabular}

a/ Blank cells indicate that no harvest of the species occurs in the state and/or subregion.

Table E-5. Estimated Number of Fish Harvested in the Ocean Commercial Fishery, 2020 and Beyond

\begin{tabular}{|c|c|c|c|c|c|c|}
\hline \multirow[b]{2}{*}{ Alternative } & \multicolumn{2}{|c|}{$\begin{array}{c}\text { PNW Region/ } \\
\text { West Coast (equivalent) }\end{array}$} & \multicolumn{2}{|c|}{ Oregon } & \multicolumn{2}{|c|}{ Washington } \\
\hline & $\begin{array}{c}\text { Fall } \\
\text { Chinook }\end{array}$ & $\begin{array}{l}\text { Spr/Sum } \\
\text { Chinook }\end{array}$ & $\begin{array}{c}\text { Fall } \\
\text { Chinook }\end{array}$ & $\begin{array}{l}\text { Spr/Sum } \\
\text { Chinook }\end{array}$ & $\begin{array}{c}\text { Fall } \\
\text { Chinook }\end{array}$ & $\begin{array}{l}\text { Spr/Sum } \\
\text { Chinook }\end{array}$ \\
\hline SOS 2c & 40,600 & 200 & 32,480 & 160 & 8,120 & 40 \\
\hline \multicolumn{7}{|c|}{ Change from Base Case (SOS 2c) } \\
\hline SOS 1a & $(300)$ & 0 & $(240)$ & 0 & $(60)$ & 0 \\
\hline $\operatorname{SOS} 1 \mathrm{~b}$ & $(100)$ & 0 & $(80)$ & 0 & $(20)$ & 0 \\
\hline SOS $2 d$ & 700 & 0 & 560 & 0 & 140 & 0 \\
\hline $\operatorname{sos} 4 c$ & 700 & 0 & 560 & 0 & 140 & 0 \\
\hline SOS 5b & 200 & 0 & 160 & 0 & 40 & 0 \\
\hline $\operatorname{sos} 5 \mathrm{c}$ & $(500)$ & $(100)$ & $(400)$ & $(80)$ & $(100)$ & $(20)$ \\
\hline $\operatorname{sos} 6 \mathrm{~b}-\mathrm{o}$ & 300 & $(200)$ & 240 & $(160)$ & 60 & $(40)$ \\
\hline $\operatorname{SOS} 6 \mathrm{~d}-0$ & (200) & (100) & (160) & $(80)$ & $(40)$ & (20) \\
\hline $\operatorname{SOS} 9 a-0$ & $(14,600)$ & (200) & $(11,680)$ & $(160)$ & $(2,920)$ & (40) \\
\hline $\operatorname{sos} 9 b-0$ & $(2,200)$ & $(100)$ & $(1,760)$ & $(80)$ & $(440)$ & (20) \\
\hline $\operatorname{sos} 9 c-0$ & $(1,800)$ & (200) & $(1,440)$ & (160) & $(360)$ & (40) \\
\hline SOS PA & 1,400 & 0 & 1,120 & 0 & 280 & 0 \\
\hline
\end{tabular}


Table E-3. Distribution of Anadromous Stocks by Harvest Fisheries

\begin{tabular}{|c|c|c|c|c|}
\hline Location & $\begin{array}{c}\text { Fall } \\
\text { Chinook }\end{array}$ & $\begin{array}{l}\text { Spr/Sum } \\
\text { Chinook }\end{array}$ & Steelhead & Sockeye \\
\hline \multicolumn{5}{|c|}{ Commercial Harvest } \\
\hline Alaska & $\star$ & $\star$ & $\mathrm{a} /$ & a/ \\
\hline Canada & $\star$ & $\star$ & a/ & a/ \\
\hline U.S. Ocean & $\star$ & $\nLeftarrow$ & a/ & $a /$ \\
\hline U.S. In-River & $*$ & $\star$ & $*$ & $\star$ \\
\hline \multicolumn{5}{|l|}{ Sport Harvest } \\
\hline Alaska & $*$ & a/ & $\mathrm{a} /$ & $\mathrm{a} /$ \\
\hline Canada & 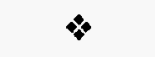 & a/ & a/ & $\mathrm{a} /$ \\
\hline U.S. Ocean & $\nLeftarrow$ & $*$ & a/ & a/ \\
\hline U.S. In-River & $\nLeftarrow$ & $\nLeftarrow$ & $\nLeftarrow$ & a/ \\
\hline
\end{tabular}

a/ Blank cells indicate that no harvest of the species occurs in the indicated fisheries.

Simulation models were used by the Anadromous Fish Work Group to estimate fish harvest over the 100-year time frame of the SOR analysis. Direct economic impacts were measured by the Economic Analysis Group using an average annual equivalent estimate of the number of fish harvested over the 100-year time frame. The direct impacts were also estimated using average annual harvest estimates for the years 1995, 2005, 2010, and 2020 and beyond. The harvest figures for 2020 and beyond were carried over to the regional analysis.

\section{E.4.2.1 The Commercial Harvest Fisheries}

The regional economic impacts related to commercial harvest under the SOR alternatives were evaluated only for the U.S. ocean and in-river fisheries, including:

- U.S. ocean troll fishery;

- Non-Indian gillnet commercial fishery in the Columbia River below Bonneville Dam (River Zones 1-5); and

- Native American commercial fishery in the Columbia River from Bonneville Dam to McNary Dam (River Zone 6).

\section{Allocation of Harvest to Subregions}

Harvest activity in each of the subregions was allocated based on the distribution of actual harvest between 1987 and 1991. Allocation percentages for each of the subregions with commercial harvest activity are presented in Table $\mathrm{E}-4$. Information from the Oregon Department of Fish and Wildlife and the Pacific Fishery Management Council was used to develop the state and subregion allocations [Pacific Fishery Management Council; Washington Department of Fisheries].

Ceremonial and subsistence use in the Native American Zone 6 fishery was estimated by the Anadromous Fish Work Group using current information on harvest for these purposes. These uses were allocated as follows: 1) five percent of fall chinook harvest up to 6,000 fish; 2) five percent of spring chinook harvest up to 4,000 fish; and 3) five percent of sockeye and steelhead harvest. All remaining harvest in the Native American fishery was assumed to be used for commercial purposes.

The number of fish expected to be harvested in the ocean commercial fishery under each of the final SOR alternatives is presented in Table E-5. Harvest figures are shown for the Pacific Northwest, 
Table E-4. Allocation of Commercial Harvest to Subregions

\begin{tabular}{|c|c|c|c|c|}
\hline & Fall Chinook & Spr/Sum Chinook & Steelhead & Sockeye \\
\hline \multicolumn{5}{|c|}{ Ocean Commercial Harvest } \\
\hline \multicolumn{5}{|c|}{ By State } \\
\hline Washington & $20 \%$ & $20 \%$ & a/ & a/ \\
\hline Oregon & $80 \%$ & $80 \%$ & a/ & a/ \\
\hline \multicolumn{5}{|l|}{ By Subregion } \\
\hline West Coast & $100 \%$ & $100 \%$ & a/ & a/ \\
\hline \multicolumn{5}{|c|}{ In-River Commercial Harvest } \\
\hline \multicolumn{5}{|c|}{\begin{tabular}{|l|l} 
By River Zone &
\end{tabular}} \\
\hline Zones $1-5$ & $40 \%$ & $25 \%$ & $0 \%$ & $30 \%$ \\
\hline Zone 6 & $60 \%$ & $75 \%$ & $100 \%$ & $70 \%$ \\
\hline \multicolumn{5}{|l|}{ By State } \\
\hline Washington & $40 \%$ & $40 \%$ & $60 \%$ & $60 \%$ \\
\hline Oregon & $60 \%$ & $60 \%$ & $40 \%$ & $40 \%$ \\
\hline \multicolumn{5}{|l|}{ By Subregion } \\
\hline West Coast & $28 \%$ & $17.5 \%$ & $0 \%$ & $27 \%$ \\
\hline Portland & $12 \%$ & $7.5 \%$ & $0 \%$ & $3 \%$ \\
\hline Mid Columbia & $60 \%$ & $75 \%$ & $100 \%$ & $70 \%$ \\
\hline
\end{tabular}

a/ Blank cells indicate that no harvest of the species occurs in the state and/or subregion.

Table E-5. Estimated Number of Fish Harvested in the Ocean Commercial Fishery, 2020 and Beyond

\begin{tabular}{|c|c|c|c|c|c|c|}
\hline \multirow[b]{2}{*}{ Alternative } & \multicolumn{2}{|c|}{$\begin{array}{c}\text { PNW Region/ } \\
\text { West Coast (equivalent) }\end{array}$} & \multicolumn{2}{|c|}{ Oregon } & \multicolumn{2}{|c|}{ Washington } \\
\hline & $\begin{array}{c}\text { Fall } \\
\text { Chinook }\end{array}$ & $\begin{array}{l}\text { Spr/Sum } \\
\text { Chinook }\end{array}$ & $\begin{array}{c}\text { Fall } \\
\text { Chinook }\end{array}$ & $\begin{array}{l}\text { Spr/Sum } \\
\text { Chinook }\end{array}$ & $\begin{array}{c}\text { Fall } \\
\text { Chinook }\end{array}$ & $\begin{array}{l}\text { Spr/Sum } \\
\text { Chinook }\end{array}$ \\
\hline SOS 2c & 40,600 & 200 & 32,480 & 160 & 8,120 & 40 \\
\hline \multicolumn{7}{|c|}{ Change from Base Case (SOS 2c) } \\
\hline SOS 1a & $(300)$ & 0 & $(240)$ & 0 & $(60)$ & 0 \\
\hline SOS 1b & $(100)$ & 0 & $(80)$ & 0 & (20) & 0 \\
\hline $\operatorname{sos} 2 d$ & 700 & 0 & 560 & 0 & 140 & 0 \\
\hline SOS $4 c$ & 700 & 0 & 560 & 0 & 140 & 0 \\
\hline SOS 5b & 200 & 0 & 160 & 0 & 40 & 0 \\
\hline SOS 5c & $(500)$ & $(100)$ & $(400)$ & $(80)$ & $(100)$ & $(20)$ \\
\hline SOS $6 b-0$ & 300 & $(200)$ & 240 & (160) & 60 & $(40)$ \\
\hline SOS 6d-o & (200) & (100) & (160) & $(80)$ & $(40)$ & (20) \\
\hline SOS 9a-o & $(14,600)$ & (200) & $(11,680)$ & (160) & $(2,920)$ & (40) \\
\hline SOS $9 b-0$ & $(2,200)$ & (100) & $(1,760)$ & $(80)$ & $(440)$ & (20) \\
\hline $\operatorname{sos} 9 c-0$ & $(1,800)$ & (200) & $(1,440)$ & $(160)$ & $(360)$ & (40) \\
\hline SOS PA & 1,400 & 0 & 1,120 & 0 & 280 & 0 \\
\hline
\end{tabular}


Table E-6. Estimated Number of Fish Harvested in the In-River Commercial Fishery, 2020 and Beyond

\begin{tabular}{|c|c|c|c|c|}
\hline Region & $\begin{array}{c}\text { Fall } \\
\text { Chinook }\end{array}$ & $\begin{array}{l}\text { Spr/Sum } \\
\text { Chinook }\end{array}$ & Steelhead & Sockeye \\
\hline \multicolumn{5}{|l|}{ Pacific Northwest } \\
\hline SOS 2c & 221,600 & 500 & 228,900 & 16,500 \\
\hline \multicolumn{5}{|c|}{ Change from Base Case (SOS 2c) } \\
\hline SOS 1a & $(1,600)$ & 0 & $(1,805)$ & (579) \\
\hline SOS 1b & $(400)$ & 0 & $(2,185)$ & (579) \\
\hline $\operatorname{SOS} 2 \mathrm{~d}$ & 4,200 & 0 & $(1,045)$ & 772 \\
\hline $\operatorname{SOS} 4 c$ & 4,200 & 0 & (760) & 0 \\
\hline SOS 5b & 1,100 & (40) & $(70,490)$ & $(4,342)$ \\
\hline SOS 5c & $(2,800)$ & (80) & $(69,445)$ & $(5,404)$ \\
\hline SOS $6 b-0$ & 1,700 & $(160)$ & $(109,725)$ & $(13,799)$ \\
\hline SOS 6d-o & $(900)$ & $(160)$ & $(40,945)$ & $(11,966)$ \\
\hline SOS $9 a-0$ & $(77,860)$ & $(160)$ & $(131,195)$ & $(13,799)$ \\
\hline SOS $9 b-0$ & $(11,800)$ & (80) & $(20,900)$ & $(4,632)$ \\
\hline $\operatorname{sos} 9 c-0$ & $(10,000)$ & $(160)$ & $(108,680)$ & $(12,931)$ \\
\hline SOS PA & 7,900 & 0 & $(3,895)$ & (290) \\
\hline \multicolumn{5}{|l|}{ West Coast } \\
\hline $\operatorname{SOS} 2 c$ & 62,048 & 88 & $\mathbf{0}$ & 4,455 \\
\hline \multicolumn{5}{|c|}{ Change from Base Case (SOS 2c) } \\
\hline SOS 1a & (448) & 0 & 0 & (162) \\
\hline $\operatorname{SOS} 1 \mathrm{~b}$ & (112) & 0 & 0 & (162) \\
\hline $\operatorname{sos} 2 \mathrm{~d}$ & 1,176 & 0 & 0 & 216 \\
\hline $\operatorname{sOS} 4 c$ & 1,176 & 0 & 0 & 0 \\
\hline SOS 5b & 308 & (18) & 0 & $(1,215)$ \\
\hline SOS $5 c$ & (784) & (35) & 0 & $(1,512)$ \\
\hline SOS $6 \mathrm{~b}-\mathbf{a}$ & 476 & (70) & 0 & $(3,861)$ \\
\hline SOS 6d-o & (252) & (70) & 0 & $(3,348)$ \\
\hline SOS $9 a-0$ & $(22,288)$ & (70) & 0 & $(3,861)$ \\
\hline SOS $9 b-0$ & $(3,304)$ & (35) & 0 & $(1,296)$ \\
\hline $\operatorname{sos} 9 c-0$ & $(2,800)$ & (70) & 0 & $(3,618)$ \\
\hline SOS PA & 2,212 & 0 & 0 & (81) \\
\hline
\end{tabular}


Table E-6. Estimated Number of Fish Harvested in the In-River Commercial Fishery, 2020 and Beyond - CONT

\begin{tabular}{|c|c|c|c|c|}
\hline Region & $\begin{array}{c}\text { Fall } \\
\text { Chinook }\end{array}$ & $\begin{array}{l}\text { Spr/Sum } \\
\text { Chinook }\end{array}$ & Steelhead & Sockeye \\
\hline \multicolumn{5}{|l|}{ Portland } \\
\hline $\operatorname{sos} 2 c$ & 26,592 & 38 & 0 & 495 \\
\hline \multicolumn{5}{|c|}{ Change from Base Case (SOS 2c) } \\
\hline SOS 1a & $(192)$ & 0 & 0 & $(18)$ \\
\hline SOS $1 b$ & $(48)$ & 0 & 0 & (18) \\
\hline SOS $2 \mathrm{~d}$ & 504 & 0 & 0 & 24 \\
\hline $\operatorname{sos} 4 c$ & 504 & 0 & 0 & 0 \\
\hline SOS $\mathbf{5 b}$ & 132 & $(8)$ & 0 & (135) \\
\hline $\operatorname{SOS} 5 c$ & (336) & (15) & 0 & $(168)$ \\
\hline SOS $6 b-0$ & 204 & $(30)$ & 0 & $(429)$ \\
\hline SOS 6d-0 & $(108)$ & $(30)$ & 0 & $(372)$ \\
\hline SOS $9 a-0$ & $(9,552)$ & (30) & 0 & $(429)$ \\
\hline $\operatorname{sos} 9 b-0$ & $(1,416)$ & $(15)$ & 0 & $(144)$ \\
\hline SOS $9 c-0$ & $(1,200)$ & $(30)$ & 0 & $(402)$ \\
\hline SOS PA & 948 & 0 & 0 & $(9)$ \\
\hline \multicolumn{5}{|l|}{ Mid Columbia } \\
\hline $\operatorname{SOS} 2 c$ & 132,960 & 375 & 228,900 & 11,550 \\
\hline \multicolumn{5}{|c|}{ Change from Base Case (SOS 2c) } \\
\hline SOS 1a & $(960)$ & 0 & $(1,805)$ & $(399)$ \\
\hline SOS $1 \mathbf{b}$ & $(240)$ & 0 & $(2,185)$ & $(399)$ \\
\hline SOS 2d & 2,520 & 0 & $(1,045)$ & 532 \\
\hline $\operatorname{sos} 4 c$ & 2,520 & 0 & $(760)$ & 0 \\
\hline SOS 5b & 660 & $(15)$ & $(70,490)$ & $(2,992)$ \\
\hline SOS 5c & $(1,680)$ & (30) & $(69,445)$ & $(3,724)$ \\
\hline SOS $6 \mathrm{~b}-0$ & 1,020 & $(60)$ & $(109,725)$ & $(9,510)$ \\
\hline SOS 6d-o & $(540)$ & $(60)$ & $(40,945)$ & $(8,246)$ \\
\hline SOS $9 a-0$ & $(46,020)$ & $(60)$ & $(131,195)$ & $(9,510)$ \\
\hline SOS $9 b-0$ & $(7,080)$ & (30) & $(20,900)$ & $(3,192)$ \\
\hline $\operatorname{sos} 9 c-0$ & $(6,000)$ & $(60)$ & $(108,680)$ & $(8,911)$ \\
\hline SOS PA & 4,740 & 0 & $(3,895)$ & $(200)$ \\
\hline
\end{tabular}


Table E-6. Estimated Number of Fish Harvested in the In-River Commercial Fishery, 2020 and Beyond - CONT

\begin{tabular}{|c|c|c|c|c|}
\hline Region & $\begin{array}{c}\text { Fall } \\
\text { Chinook }\end{array}$ & $\begin{array}{c}\text { Spr/Sum } \\
\text { Chinook }\end{array}$ & Steelhead & Sockeye \\
\hline \multicolumn{5}{|l|}{ Washington } \\
\hline SOS 2c & 88,640 & 200 & 137,340 & 9,900 \\
\hline \multicolumn{5}{|c|}{ Change from Base Case (SOS 2c) } \\
\hline SOS 1a & $(640)$ & $\mathbf{0}$ & $(1,083)$ & (347) \\
\hline Sos $1 \mathbf{b}$ & $(160)$ & 0 & $(1,311)$ & (347) \\
\hline SOS 2d & 1,680 & $\mathbf{0}$ & (627) & 463 \\
\hline SOS 4c & 1,680 & $\mathbf{0}$ & $(456)$ & 0 \\
\hline SOS 5b & 440 & $(16)$ & $(42,294)$ & $(2,605)$ \\
\hline SOS 5c & $(1,120)$ & $(32)$ & $(41,667)$ & $(3,242)$ \\
\hline SOS $6 b-0$ & 680 & (64) & $(65,835)$ & $(8,280)$ \\
\hline SOS 6d-o & $(360)$ & (64) & $(24,567)$ & $(7,180)$ \\
\hline $\operatorname{sos} 9 a-0$ & $(31,144)$ & (64) & $(78,717)$ & $(8,280)$ \\
\hline $\operatorname{sos} 9 \mathrm{~b}-0$ & $(4,720)$ & (32) & $(12,540)$ & $(2,779)$ \\
\hline $\operatorname{sos} 9 \mathrm{c}-0$ & $(4,000)$ & (64) & $(65,208)$ & $(7,759)$ \\
\hline SOS PA & 3,160 & 0 & $(2,337)$ & (174) \\
\hline \multicolumn{5}{|l|}{ Oregon } \\
\hline SOS $2 c$ & 132,960 & 300 & 91,560 & 6,600 \\
\hline \multicolumn{5}{|c|}{ Change from Base Case (SOS 2c) } \\
\hline SOS 1a & $(960)$ & 0 & $(722)$ & (232) \\
\hline SOS 1b & $(240)$ & 0 & (874) & (232) \\
\hline $\operatorname{SOS} 2 d$ & 2,520 & 0 & (418) & 309 \\
\hline $\operatorname{SOS} 4 c$ & 2,520 & 0 & $(304)$ & 0 \\
\hline SOS 5b & 660 & (24) & $(28,196)$ & $(1,737)$ \\
\hline SOS 5c & $(1,680)$ & (48) & $(27,778)$ & $(2,162)$ \\
\hline SOS 6b-o & 1,020 & (96) & $(43,890)$ & $(5,520)$ \\
\hline $\operatorname{sos} 6 \mathrm{~d}-0$ & $(540)$ & (96) & $(16,378)$ & $(4,786)$ \\
\hline $\operatorname{sos} 9 a-0$ & $(46,716)$ & (96) & $(52,478)$ & $(5,520)$ \\
\hline $\operatorname{sos} 9 b-0$ & $(7,080)$ & (48) & $(8,360)$ & $(1,853)$ \\
\hline $\operatorname{sos} 9 c-0$ & $(6,000)$ & (96) & $(43,472)$ & $(5,172)$ \\
\hline SOS PA & 4,740 & 0 & $(1,558)$ & (116) \\
\hline
\end{tabular}


Washington, Oregon, and the West Coast subregion. Expected harvest numbers for the in-river commercial fishery are presented in Table E-6; figures are shown for the Pacific Northwest, Washington, Oregon, and the West Coast, Portland, and Mid Columbia subregions.

\section{Measures of Economic Change}

The direct economic impact of alternative system operations on commercial fishermen is measured as the change in net income earnings. The change in income is a function of changes in the number of fish harvested, the expenditures to catch these fish, and the price received for the fish. The indirect impacts stem from the changes in expenditures for the fishing operation and the change in net income retained by the commercial operators.

Indirect impacts in the commercial fisheries (ocean, in-river, and Indian) are generated by the increase or decrease in the value of the fishing activity required to harvest additional or fewer fish. The change in activity is measured by the adjustment in operating expenditures and revenues within the commercial industry. 5 Expenditure patterns for commercial fishing have been compiled from various surveys conducted by Dr. Hans Radtke [Radtke]. Gillnet budgets are considered most appropriate for the in-river non-Indian and Native American commercial fisheries. The typical annual expenditures, on a per fish basis, for commercial gillnetters are shown in Table E-7. Expenditures are expressed in 1992 dollars. Information on average annual expenditures per pound and average pounds per fish were used to develop the commercial harvest costs [Oregon Department of Fish and Wildlife, Pacific Fishery Management Council].

Expenditure patterns for the commercial ocean fisheries were also developed by Radtke. The salmon troller budgets shown in Table $\mathrm{E}-8$ were used for measuring changes in expenditures of commercial ocean fishermen. Again, the annual expenditures are converted to a per-fish expenditure using the average annual catch per troller and the average pounds per fish harvested.

Table E-7. Operating Expenditures for the In-River Commercial Fisheries

\begin{tabular}{|l|r|r|r|r|}
\hline Operating Expenditures & $\begin{array}{c}\text { Fall } \\
\text { Chinook }\end{array}$ & $\begin{array}{c}\text { Spr/Sum } \\
\text { Chinook }\end{array}$ & Steelhead & Sockeye \\
\hline Variable Expenses & $\$ /$ fish & $\$$ fish & $\$ /$ fish & $\$$ fish \\
Vessel/Engine Repair & $\$ .97$ & $\$ .97$ & $\$ .45$ & $\$ .18$ \\
Gear Repair/Replacement & $\$ .73$ & $\$ .73$ & $\$ .34$ & $\$ .14$ \\
Fuel and Lubricants & $\$ .42$ & $\$ .42$ & $\$ .20$ & $\$ .08$ \\
Food and Supplies & $\$ .23$ & $\$ .23$ & $\$ .11$ & $\$ .04$ \\
Ice and Bait & $\$ .52$ & $\$ .52$ & $\$ .24$ & $\$ .10$ \\
Dues and Fees & $\$ .08$ & $\$ .08$ & $\$ .04$ & $\$ .02$ \\
Transportation & $\$ .38$ & $\$ .38$ & $\$ .18$ & $\$ .07$ \\
Miscellaneous & $\$ .11$ & $\$ .11$ & $\$ .05$ & $\$ .02$ \\
Crew Shares & $\$ 6.86$ & $\$ 6.86$ & $\$ 3.20$ & $\$ 1.26$ \\
Total Variable Costs & $\$ 10.30$ & $\$ 10.30$ & $\$ 4.80$ & $\$ 1.89$ \\
Fixed Expenses & $\$ 6.30$ & $\$ 6.30$ & $\$ 2.94$ & $\$ 1.16$ \\
Operator Returns & $\$ 4.22$ & $\$ 56.37$ & $\$ .84$ & $\$ 2.88$ \\
\hline Total Costs & $\$ \mathbf{2 0 . 8 2}$ & $\$ 72.97$ & $\$ 8.58$ & $\$ 5.93$ \\
\hline
\end{tabular}

5 The SOR Economic Analysis Group concluded that fixed costs for the commercial operators would be unaffected by harvest changes estimated for the alternative river operation strategies. 
Regional Impacts on Fish Processing

Changes in commercial fish harvest directly affect activity levels in the related fish processing industries. The estimated change in economic activity in fish processing is measured as the increase or decrease in operating expenditures related to the change in volume of fish harvested, along with the associated changes in ownership returns.

Annual operating cost data for the fish processing were developed by Radtke. Expenditures per thousands of pounds of fish harvested are shown in Table E-9. The expenditures are presented in 1992 dollars. It is important to note that operating costs related to the purchase of fish from commercial fishermen (raw material cost) are excluded from the expenditure pattern when the regional impacts are generated with the input-output models. This is because the impact of the raw material purchases are accounted for in the commercial fishing analysis.
The fish processing impacts reflect only the incremental value added by the processing activity.

For the regional analysis, it is assumed that all changes in commercial ocean harvest and commercial in-river harvest in zones $1-5$ would result in an equivalent change in fish processed by local processors. Processing impacts in zone 6 were not estimated due to lack of sufficient information on the processing activity in this region.

\section{E.4.2.2 The Sport Harvest Fisheries}

As with the commercial fisheries, regional economic impacts related to the SOR alternatives were estimated only for sport harvest in the U.S. ocean and in-river fisheries. Locations for the anadromous sport fisheries include the ocean areas off the Oregon and Washington coasts, the mouth of the Columbia River inside Buoy 10, and the mainstem and tributaries of the Columbia River.

\section{Table E-8. Operating Expenditures for the Ocean Commercial Fisheries}

\begin{tabular}{|l|c|c|}
\hline \multicolumn{1}{|c|}{ Operating Expenditures } & Fall Chinook & Spr/Sum Chinook \\
\hline Variable Expenses & $\$ /$ fish & $\$ /$ fish \\
Vessel/Engine Repair & $\$ .20$ & $\$ .20$ \\
Gear Repair/Replacement & $\$ .20$ & $\$ .20$ \\
Fuel and Lubricants & $\$ .74$ & $\$ .74$ \\
Food and Supplies & $\$ .39$ & $\$ .39$ \\
Ice and Bait & $\$ .13$ & $\$ .13$ \\
Dues and Fees & $\$ .10$ & $\$ .10$ \\
Transportation & $\$ .38$ & $\$ .38$ \\
Miscellaneous & $\$ .42$ & $\$ .42$ \\
Crew Shares & $\$ 6.24$ & $\$ 6.24$ \\
Total Variable Costs & $\$ 8.79$ & $\$ 8.79$ \\
Fixed Expenses & $\$ 3.41$ & $\$ 3.41$ \\
Operator Returns & $\$ 15.15$ & $\$ 15.15$ \\
\hline Total Costs & $\$ 27.35$ & $\$ 27.35$ \\
\hline
\end{tabular}


Table E-9. Operating Expenditures for Fish Processing

\begin{tabular}{|l|c|}
\hline Operating Expenditures & \$ per 1,000 lb. \\
\hline Raw Material Cost & $\$ 500$ \\
Processing Labor & $\$ 100$ \\
Direct Materials Costs & $\$ 27$ \\
Manufacturing Overhead & $\$ 12$ \\
Miscellaneous & $\$ 4$ \\
Operator Return & $\$ 128$ \\
\hline Total Costs & $\$ 771$ \\
\hline
\end{tabular}

\section{Allocation of Harvests to Subregions}

Expected sport harvests under the SOR alternatives were allocated to states and subregions on the basis of actual harvest in these areas between 1987 and 1991 [Washington Department of Fisheries]. The regional distribution of the anadromous sport harvest is presented in Table $\mathrm{E}-10$. Information from the Washington Department of Fisheries, the Oregon Department of Fish and Wildlife, and the Pacific Fishery Management Council was used to develop the state and subregion allocations.

The number of fish expected to be harvested in the ocean sport fishery under each of the final SOR alternatives is presented in Table E-11. Harvest figures are shown for the Pacific Northwest, Washington, Oregon, and the West Coast subregion.
Expected harvest numbers for the in-river sport fishery are presented in Table E-12; figures are shown for the Pacific Northwest, Washington, Oregon, Idaho, and the West Coast, Portland, Mid Columbia, Upper Columbia, and Lower Snake subregions.

\section{Measures of Economic Change}

The direct impacts of system operations on recreational fishing are measured by the changes in consumer surplus values associated with increases and decreases in the number of angler days taken under the alternative fish harvest scenarios. The indirect economic impacts stem from changes in the recreational expenditures associated with the changes in sport angler days.

Regional economic impacts associated with the additional sport harvest are generated as a result of the recreation expenditures made by anglers participating in the sport fisheries. The total increase in sport fishing expenditures is estimated using the expected increase in angler days and the expenditures per angler day. Expenditure patterns for the ocean and in-river sport fisheries were developed using information provided in the Oregon Angler Survey and Economic Study [The Research Group]. The study differentiated expenditures per angler day for a variety of fish species and for various Oregon Department of Fish and Wildlife management areas around the state, including the Pacific Ocean and Columbia River mainstem and tributary areas. The angler day expenditure patterns were converted to a per fish basis using data on average catch per angler day from the Pacific Fisheries Management Council, the Oregon Department of Fish and Wildlife, and the Washington Department of Fisheries. Per fish expenditures incorporated into the regional analysis are presented in Table $\mathrm{E}-13$. Values are expressed in 1992 dollars. 
Table E-10. Allocation of Sport Harvest to Subregions

\begin{tabular}{|c|c|c|c|c|}
\hline & $\begin{array}{c}\text { Fall } \\
\text { Chinook }\end{array}$ & $\begin{array}{l}\text { Spr/Sum } \\
\text { Chinook }\end{array}$ & Steelhead & Sockeye \\
\hline \multicolumn{5}{|l|}{ Ocean Sport Harvest } \\
\hline \multicolumn{5}{|l|}{ By State } \\
\hline Washington & $40 \%$ & $40 \%$ & a/ & $\mathrm{a} /$ \\
\hline Oregon & $60 \%$ & $60 \%$ & a/ & a/ \\
\hline \multicolumn{5}{|l|}{ By Subregion } \\
\hline West Coast & $100 \%$ & $100 \%$ & a/ & a/ \\
\hline \multicolumn{5}{|l|}{ In-River Sport Harvest } \\
\hline \multicolumn{5}{|l|}{ By River Zone } \\
\hline $\begin{array}{l}\text { Below Bonneville and } \\
\text { Buoy } 10\end{array}$ & $50 \%$ & $100 \%$ & $10 \%$ & a/ \\
\hline Mid/Upper Columbia & $50 \%$ & $\mathrm{a} /$ & $30 \%$ & a/ \\
\hline $\begin{array}{l}\text { Idaho (Clearwater, } \\
\text { Snake, Salmon) }\end{array}$ & a/ & $\mathrm{a} /$ & $60 \%$ & a/ \\
\hline \multicolumn{5}{|l|}{ By State } \\
\hline Washington & $40 \%$ & $40 \%$ & $24 \%$ & a/ \\
\hline Oregon & $60 \%$ & $60 \%$ & $16 \%$ & a/ \\
\hline Idaho & $\mathrm{a} /$ & a/ & $60 \%$ & a/ \\
\hline \multicolumn{5}{|l|}{ By Subregion } \\
\hline West Coast & $25 \%$ & $50 \%$ & $5 \%$ & a/ \\
\hline Portland & $25 \%$ & $50 \%$ & $5 \%$ & a/ \\
\hline Mid Columbia & $25 \%$ & a/ & $15 \%$ & a/ \\
\hline Upper Columbia & $25 \%$ & a/ & $15 \%$ & a/ \\
\hline Lower Snake & a/ & a/ & $60 \%$ & a/ \\
\hline
\end{tabular}

a/ Blank cells indicate that no harvest of the species occurs in the state and/or subregion. 
Table E-11. Estimated Number of Fish Harvested in the Ocean Sport Fishery, 2020 and Beyond

\begin{tabular}{|c|c|c|c|c|c|c|}
\hline \multirow[b]{2}{*}{ Alternative } & \multicolumn{2}{|c|}{$\begin{array}{c}\text { PNW Region/ } \\
\text { West Coast (equivalent) }\end{array}$} & \multicolumn{2}{|c|}{ Oregon } & \multicolumn{2}{|c|}{ Washington } \\
\hline & $\begin{array}{c}\text { Fall } \\
\text { Chinook }\end{array}$ & $\begin{array}{l}\text { Spr/Sum } \\
\text { Chinook }\end{array}$ & $\begin{array}{c}\text { Fall } \\
\text { Chinook }\end{array}$ & $\begin{array}{l}\text { Spr/Sum } \\
\text { Chinook }\end{array}$ & $\begin{array}{c}\text { Fall } \\
\text { Chinook }\end{array}$ & $\begin{array}{l}\text { Spr/Sum } \\
\text { Chinook }\end{array}$ \\
\hline $\operatorname{SOS} 2 \mathrm{c}$ & 30,000 & 100 & 18,000 & 60 & 12,000 & 40 \\
\hline \multicolumn{7}{|c|}{ Change from Base Case (SOS 2c) } \\
\hline SOS 1a & $(200)$ & 0 & (120) & 0 & (80) & 0 \\
\hline SOS 1b & $(100)$ & 0 & (60) & 0 & (40) & 0 \\
\hline SOS 2d & 500 & 0 & 300 & 0 & 200 & 0 \\
\hline $\operatorname{sos} 4 c$ & 500 & 0 & 300 & 0 & 200 & 0 \\
\hline SOS 5b & 100 & 0 & 60 & 0 & 40 & 0 \\
\hline SOS 5c & $(400)$ & $(100)$ & (240) & $(60)$ & $(160)$ & $(40)$ \\
\hline $\operatorname{sos} 6 \mathbf{b}-0$ & 200 & $(100)$ & 120 & $(60)$ & 80 & (40) \\
\hline SOS 6d-o & $(200)$ & $(100)$ & (120) & (60) & (80) & (40) \\
\hline SOS 9a-o & $(10,800)$ & $(100)$ & $(6,480)$ & (60) & $(4,320)$ & (40) \\
\hline SOS $9 b-0$ & $(1,600)$ & $(100)$ & (960) & $(60)$ & (640) & (40) \\
\hline SOS $9 c-0$ & $(1,400)$ & $(100)$ & (840) & $(60)$ & (560) & (40) \\
\hline SOS PA & 1,000 & 0 & 600 & 0 & 400 & 0 \\
\hline
\end{tabular}


Table E-12. Estimated Number of Fish Harvested in the In-River Sport Fishery, 2020 and Beyond

\begin{tabular}{|c|c|c|c|}
\hline Region & $\begin{array}{c}\text { Fall } \\
\text { Chinook }\end{array}$ & $\begin{array}{l}\text { Spr/Sum } \\
\text { Chinook }\end{array}$ & Steelhead \\
\hline \multicolumn{4}{|l|}{ Pacific Northwest Region } \\
\hline $\operatorname{SOS} 2 c$ & 15,000 & 100 & 179,500 \\
\hline \multicolumn{4}{|c|}{ Change from Base Case (SOS 2c) } \\
\hline SOS 1a & $(100)$ & 0 & $(1,500)$ \\
\hline SOS 1b & 0 & $\mathbf{0}$ & $(1,800)$ \\
\hline SOS 2d & 300 & 0 & (900) \\
\hline $\operatorname{sos} 4 c$ & 300 & 0 & $(600)$ \\
\hline SOS 5b & 100 & 0 & $(24,800)$ \\
\hline SOS 5c & $(200)$ & $(100)$ & $(57,300)$ \\
\hline SOS $6 \mathfrak{b}-0$ & 100 & $(100)$ & $(90,500)$ \\
\hline SOS 6d-0 & $(100)$ & $(100)$ & $(33,700)$ \\
\hline SOS 9a-o & $(5,400)$ & (100) & $(108,300)$ \\
\hline SOS $9 b-0$ & $(800)$ & $(100)$ & $(17,200)$ \\
\hline SOS $9 c-0$ & $(700)$ & $(100)$ & $(89,700)$ \\
\hline SOS PA & 500 & 0 & $(3,200)$ \\
\hline \multicolumn{4}{|l|}{ West Coast Subregion } \\
\hline SOS 2c & 3,750 & 50 & 8,975 \\
\hline \multicolumn{4}{|c|}{ Change from Base Case (SOS 2c) } \\
\hline SOS 1a & $(25)$ & 0 & (75) \\
\hline SOS $1 b$ & 0 & 0 & (90) \\
\hline SOS 2d & 75 & 0 & (45) \\
\hline $\operatorname{sos} 4 c$ & 75 & 0 & (30) \\
\hline SOS 5b & 25 & 0 & $(1,240)$ \\
\hline SOS 5c & $(50)$ & (50) & $(2,865)$ \\
\hline SOS $6 b-0$ & 25 & (50) & $(4,525)$ \\
\hline SOS Gd-o & $(25)$ & (50) & $(1,685)$ \\
\hline SOS 9a-o & $(1,350)$ & (50) & $(5,415)$ \\
\hline SOS $9 b-0$ & (200) & (50) & $(860)$ \\
\hline SOS 9c-o & (175) & (50) & $(4,485)$ \\
\hline SOS PA & 125 & 0 & (160) \\
\hline
\end{tabular}


Table E-12. Estimated Number of Fish Harvested in the In-River Sport Fishery, 2020 and Beyond - CONT

\begin{tabular}{|c|c|c|c|}
\hline Region & $\begin{array}{c}\text { Fall } \\
\text { Chinook }\end{array}$ & $\begin{array}{l}\text { Spr/Sum } \\
\text { Chinook }\end{array}$ & Steelhead \\
\hline \multicolumn{4}{|l|}{ Portland Subregion } \\
\hline $\operatorname{SOS} 2 \mathrm{c}$ & 3,750 & 50 & 8,975 \\
\hline \multicolumn{4}{|c|}{ Change from Base Case (SOS 2c) } \\
\hline SOS 1a & $(25)$ & 0 & (75) \\
\hline SOS 1b & 0 & 0 & (90) \\
\hline $\operatorname{SOS} 2 \mathrm{~d}$ & 75 & 0 & (45) \\
\hline $\operatorname{sos} 4 c$ & 75 & 0 & $(30)$ \\
\hline SOS 5b & 25 & 0 & $(1,240)$ \\
\hline SOS 5c & $(50)$ & $(50)$ & $(2,865)$ \\
\hline $\operatorname{SOS} 6 \mathrm{~b}-0$ & 25 & $(50)$ & $(4,525)$ \\
\hline SOS 6d-o & $(25)$ & $(50)$ & $(1,685)$ \\
\hline $\operatorname{sos} 9 a-0$ & $(1,350)$ & $(50)$ & $(5,415)$ \\
\hline SOS $9 b-0$ & $(200)$ & $(50)$ & $(860)$ \\
\hline SOS 9c-o & $(175)$ & $(50)$ & $(4,485)$ \\
\hline SOS PA & 125 & 0 & $(160)$ \\
\hline \multicolumn{4}{|c|}{ Mid Columbia Subregion } \\
\hline SOS 2c & 3,750 & 0 & 26,925 \\
\hline \multicolumn{4}{|c|}{ Change from Base Case (SOS 2c) } \\
\hline SOS 1a & $(25)$ & 0 & $(225)$ \\
\hline SOS 1b & 0 & 0 & $(270)$ \\
\hline $\operatorname{SOS} 2 \mathrm{~d}$ & 75 & 0 & $(135)$ \\
\hline $\operatorname{sos} 4 c$ & 75 & 0 & $(90)$ \\
\hline SOS 5b & 25 & 0 & $(3,720)$ \\
\hline SOS 5c & $(50)$ & 0 & $(8,595)$ \\
\hline $\operatorname{SOS} 6 \mathrm{~b}-0$ & 25 & 0 & $(13,575)$ \\
\hline SOS 6d-o & (25) & 0 & $(5,055)$ \\
\hline $\operatorname{sos} 9 a-0$ & $(1,350)$ & 0 & $(16,245)$ \\
\hline $\operatorname{sos} 9 \mathrm{~b}-\mathbf{0}$ & $(200)$ & 0 & $(2,580)$ \\
\hline $\operatorname{sos} 9 c-0$ & $(175)$ & 0 & $(13,455)$ \\
\hline SOS PA & 125 & 0 & $(480)$ \\
\hline
\end{tabular}


Table E-12. Estimated Number of Fish Harvested in the In-River Sport Fishery, 2020 and Beyond - CONT

\begin{tabular}{|c|c|c|c|}
\hline Region & $\begin{array}{c}\text { Fall } \\
\text { Chinook }\end{array}$ & $\begin{array}{l}\text { Spr/Sum } \\
\text { Chinook }\end{array}$ & Steelhead \\
\hline \multicolumn{4}{|c|}{ Upper Columbia Subregion } \\
\hline $\operatorname{SOS} 2 c$ & 3,750 & 0 & 26,925 \\
\hline \multicolumn{4}{|c|}{ Change from Base Case (SOS 2c) } \\
\hline SOS 1a & $(25)$ & 0 & (225) \\
\hline SOS 1b & 0 & 0 & $(270)$ \\
\hline SOS 2d & 75 & 0 & $(135)$ \\
\hline $\operatorname{sOS} 4 c$ & 75 & 0 & (90) \\
\hline SOS 5b & 25 & 0 & $(3,720)$ \\
\hline SOS 5c & (50) & 0 & $(8,595)$ \\
\hline SOS $6 b-0$ & 25 & 0 & $(13,575)$ \\
\hline SOS Gd-o & (25) & 0 & $(5,055)$ \\
\hline SOS 9a-o & $(1,350)$ & 0 & $(16,245)$ \\
\hline $\operatorname{sos} 9 \mathrm{~b}-0$ & $(200)$ & 0 & $(2,580)$ \\
\hline SOS 9c-o & (175) & 0 & $(13,455)$ \\
\hline SOS PA & 125 & 0 & $(480)$ \\
\hline \multicolumn{4}{|l|}{ Lower Snake Subregion } \\
\hline SOS 2c & 0 & 0 & 107,700 \\
\hline \multicolumn{4}{|c|}{ Change from Base Case (SOS 2c) } \\
\hline SOS 1a & 0 & 0 & (900) \\
\hline SOS 1b & 0 & 0 & $(1,080)$ \\
\hline SOS 2d & 0 & 0 & $(540)$ \\
\hline $\operatorname{sos} 4 c$ & 0 & 0 & $(360)$ \\
\hline SOS 5b & 0 & $\mathbf{0}$ & $(14,880)$ \\
\hline SOS 5c & 0 & 0 & $(34,380)$ \\
\hline SOS $6 b-0$ & 0 & 0 & $(54,300)$ \\
\hline SOS 6d-o & 0 & 0 & $(20,220)$ \\
\hline SOS 9a-0 & 0 & 0 & $(64,980)$ \\
\hline $\operatorname{sos} 9 b-0$ & 0 & 0 & $(10,320)$ \\
\hline $\operatorname{sos} 9 c-0$ & 0 & 0 & $(53,820)$ \\
\hline SOS PA & 0 & 0 & $(1,920)$ \\
\hline
\end{tabular}


Table E-12. Estimated Number of Fish Harvested in the In-River Sport Fishery, 2020 and Beyond - CONT

\begin{tabular}{|c|c|c|c|}
\hline Region & $\begin{array}{c}\text { Fall } \\
\text { Chinook }\end{array}$ & $\begin{array}{l}\text { Spr/Sum } \\
\text { Chinook }\end{array}$ & Steelhead \\
\hline \multicolumn{4}{|l|}{ Washington State } \\
\hline $\operatorname{sos} 2 c$ & 6,000 & 40 & 43,080 \\
\hline \multicolumn{4}{|c|}{ Change from Base Case (SOS 2c) } \\
\hline SOS 1a & (40) & 0 & $(360)$ \\
\hline $\operatorname{sos} 1 \mathrm{~b}$ & 0 & 0 & (432) \\
\hline $\operatorname{sos} 2 d$ & 120 & 0 & (216) \\
\hline $\operatorname{SOS} 4 c$ & 120 & 0 & (144) \\
\hline sos $5 b$ & 40 & 0 & $(5,952)$ \\
\hline $\operatorname{sos} 5 c$ & (80) & (40) & $(13,752)$ \\
\hline SOS $6 \mathrm{~b}-0$ & 40 & (40) & $(21,720)$ \\
\hline SOS 6d-o & (40) & (40) & $(8,088)$ \\
\hline $\operatorname{sos} 9 a-0$ & $(2,160)$ & (40) & $(25,992)$ \\
\hline $\operatorname{sos} 9 \mathrm{~b}-0$ & $(320)$ & (40) & $(4,128)$ \\
\hline $\operatorname{sos} 9 c-0$ & (280) & (40) & $(21,528)$ \\
\hline SOS PA & 200 & 0 & (768) \\
\hline \multicolumn{4}{|l|}{ Oregon State } \\
\hline $\operatorname{sos} 2 c$ & 9,000 & 60 & 28,720 \\
\hline \multicolumn{4}{|c|}{ Change from Base Case (SOS 2c) } \\
\hline SOS 1a & (60) & 0 & $(240)$ \\
\hline sos 1b & 0 & 0 & (288) \\
\hline $\operatorname{sos} 2 d$ & 180 & 0 & (144) \\
\hline $\operatorname{sos} 4 c$ & 180 & 0 & (96) \\
\hline SOS 5b & 60 & $\mathbf{0}$ & $(3,968)$ \\
\hline SOS 5c & (120) & $(60)$ & $(9,168)$ \\
\hline $\operatorname{sos} 6 \mathrm{~b}-0$ & 60 & (60) & $(14,480)$ \\
\hline SOS 6d-o & (60) & (60) & $(5,392)$ \\
\hline $\operatorname{sos} 9 a-0$ & $(3,240)$ & (60) & $(17,328)$ \\
\hline $\operatorname{sos} 9 b-0$ & $(480)$ & (60) & $(2,752)$ \\
\hline $\operatorname{SOS} 9 c-0$ & (420) & (60) & $(14,352)$ \\
\hline SOS PA & 300 & 0 & $(512)$ \\
\hline
\end{tabular}


Table E-12. Estimated Number of Fish Harvested in the In-River Sport Fishery, 2020 and Beyond - CONT

\begin{tabular}{|c|c|c|c|}
\hline Region & $\begin{array}{c}\text { Fall } \\
\text { Chinook }\end{array}$ & $\begin{array}{c}\text { Spr/Sum } \\
\text { Chinook }\end{array}$ & Steelhead \\
\hline \multicolumn{4}{|l|}{ Idaho State } \\
\hline $\operatorname{SOS} 2 c$ & 0 & 0 & 107,700 \\
\hline \multicolumn{4}{|c|}{ Change from Base Case (SOS 2c) } \\
\hline $\operatorname{sos} 1 \mathrm{a}$ & 0 & 0 & $(900)$ \\
\hline SOS 1b & 0 & 0 & $(1,080)$ \\
\hline SOS 2d & 0 & 0 & $(540)$ \\
\hline $\operatorname{sos} 4 c$ & 0 & 0 & $(360)$ \\
\hline SOS 5b & 0 & 0 & $(14,880)$ \\
\hline SOS 5c & 0 & 0 & $(34,380)$ \\
\hline SOS $6 b-0$ & 0 & 0 & $(54,300)$ \\
\hline SOS 6d-0 & 0 & $\mathbf{0}$ & $(20,220)$ \\
\hline SOS 9a-0 & 0 & 0 & $(64,980)$ \\
\hline $\operatorname{sos} 9 \mathrm{~b}-0$ & 0 & 0 & $(10,320)$ \\
\hline $\operatorname{sos} 9 c-0$ & 0 & 0 & $(53,820)$ \\
\hline SOS PA & 0 & 0 & $(1,920)$ \\
\hline
\end{tabular}

Table E-13. Recreation Expenditures for Sport Fishing

\begin{tabular}{|l|c|c|c|c|}
\hline & \multicolumn{2}{|c|}{ Ocean Sport Fishing } & \multicolumn{2}{c|}{ In-River Sport Fishing } \\
\hline \multicolumn{1}{|c|}{ Expenditures } & (\$/Angler Day) & $\mathbf{( \$ / F i s h )}$ & (\$/Angler Day) & (\$/Fish) \\
\hline Transportation & $\$ 1.67$ & $\$ 1.32$ & $\$ 2.08$ & $\$ 4.93$ \\
Lodging & $\$ 7.89$ & $\$ 6.23$ & $\$ 1.38$ & $\$ 3.28$ \\
Food/Drink at Stores & $\$ 5.49$ & $\$ 4.33$ & $\$ 11.53$ & $\$ 27.35$ \\
Restaurants & $\$ 8.81$ & $\$ 6.95$ & $\$ 0.83$ & $\$ 1.97$ \\
Guide/Charter Fees & $\$ 9.96$ & $\$ 7.86$ & $\$ 2.42$ & $\$ 5.75$ \\
Boat Gas & $\$ 3.33$ & $\$ 2.63$ & $\$ 4.64$ & $\$ 11.00$ \\
Rental Equipment & $\$ 5.53$ & $\$ 4.37$ & $\$ 0.00$ & $\$ 0.00$ \\
Supplies and misc. & $\$ 2.95$ & $\$ 2.33$ & $\$ 12.95$ & $\$ 30.73$ \\
Other Expenses & $\$ 2.32$ & $\$ 1.83$ & $\$ 3.23$ & $\$ 7.66$ \\
Total Expenditures & $\$ 47.95$ & $\$ 37.85$ & $\$ 39.06$ & $\$ 92.67$ \\
\hline
\end{tabular}




\section{Combined Anadromous Fisheries Impacts}

Regional economic impacts are estimated separately for each of the anadromous fisheries for which separate expenditure activities could be defined. Seven distinct expenditure patterns were developed to estimate the effects of changes in anadromous fish harvests. Two additional expenditure patterns were developed to evaluate impacts related to fish processing. Economic impacts were estimated for all subregions where harvest changes are expected to occur. ${ }^{6}$

\section{Commercial Fisheries}

- ocean fall chinook harvest

- ocean spring chinook harvest

- in-river fall chinook harvest

- in-river spring chinook harvest

- in-river sockeye harvest

\section{Sport Fisheries}

- ocean sport harvest (all species)

- in-river sport harvest (all species)

All of the commercial and sport fishing expenditure patterns identified in the previous sections have been expressed in terms of the number of fish harvested, the direct measure of physical change incorporated into the regional analysis. Data on expected U.S. ocean and in-river commercial and sport harvests for each of the SOR alternatives were obtained from Exhibit Table A-5, an attachment to Appendix $O$ of the SOR Final Environmental Impact Statement. As stated earlier, the harvest data are expressed in terms of average annual harvest numbers for 2020 and beyond. The harvest data from Exhibit Table A-5 were further disaggregated by fishery and subregion, using the allocations described in previous sections.
Regional economic impacts are estimated separately for harvest changes in each of the affected fisheries present within a subregion. The impacts generated for each fishery are then summed together to determine the total anadromous fish impacts for each subregion. Results of the regional economic analysis related to anadromous fish harvest changes are presented in a later section, Results of the Regional Economic Impact Analysis.

\section{E.4.3 Irrigation and $M /$ Water Supply}

The direct economic impacts of the SOR alternatives were estimated for those individuals and activities that pump water directly from reservoir pools on the Columbia/Snake River system. Impacts were estimated separately for pumping related to commercial agriculture irrigation and pumping related to water supply, including municipal, industrial, recreation, and wildlife uses. Six reservoirs currently utilized for irrigation and water supply pumping would be affected by the SOR alternatives. The affected reservoirs include Grand Coulee (irrigation pumping), John Day and Ice Harbor (irrigation and $\mathrm{M} / \mathrm{I}$ water supply pumping), and Lower Granite, Little Goose, and Lower Monumental (M/I water supply pumping).

Following the format of the direct economic analysis prepared by the SOR Irrigation Work Group, the regional economic impacts related to reservoir pumping are estimated separately for irrigation pumping from the Grand Coulee pool; irrigation pumping from the John Day and Ice Harbor pools; and $\mathrm{M} / \mathrm{I}$ pumping from the John Day, Ice Harbor, Lower Monumental, Little Goose, and Lower Granite pools.

\section{E.4.3.1 Grand Coulee Irrigation Pumping}

Several of the SOR alternatives affect the level of Franklin D. Roosevelt Lake at Grand Coulee Dam. Water is pumped out of Roosevelt Lake and delivered to irrigators receiving water from the federal Columbia Basin Project. As the level of the lake is

$6 \quad$ These regions were previously identified in Table E-3. 
lowered or raised under the SOR alternatives, energy requirements to pump the water out of the lake into the irrigation project will increase or decrease. The change in energy requirements will, in turn, increase or decrease the pumping costs that must be paid by growers.

The direct economic impacts related to irrigation are measured as the change in net (farm) producer income resulting from the increase or decrease in pumping costs. The measure of net income change is linked directly to the estimate of regional economic impacts related to Grand Coulee irrigation pumping.

For purposes of the regional impact analysis it is assumed that the decline in net farm income will have a two-fold effect on the farming operation: 1) with less business income available, farm investments will be delayed or withheld; and 2) with lower returns to land, management, and capital, less money is available to the farm household. These income effects are assumed to be equally likely. One-half of the change in net farm income is assumed to generate regional impacts through the effects on household income and the consequent reduction in the market basket of household expenditures. ${ }^{7}$ The remaining portion of the change in farm income is assumed to generate regional impacts by reducing purchases of farm machinery. Purchases of farm machinery are generally the primary type of investment made by the crop-producing farm sector.

\section{Allocation to Subregions}

The net farm income impacts measured for pumping from Roosevelt Lake were taken directly from Table 4-20 of Appendix $O$ of the FEIS. Income changes were distributed to the Mid Columbia and Upper Columbia subregions on the basis of the proportion of Columbia Basin Project irrigated crop acreage located in each area. Twenty-six percent of the income change was allocated to the Mid Columbia subregion, with the remaining 74 percent of the change distributed to Upper Columbia. ${ }^{8}$ All of the area served by Roosevelt Lake is located within Washington State. The net income changes associated with changes in irrigation pumping at Grand Coulee are presented in Table E-14.

\section{E.4.3.2 Ice Harbor/John Day Agricultural Irrigation}

Irrigation pumping directly from the John Day and Ice Harbor reservoir pools occurs on both the Oregon and Washington sides of the Columbia River. Under several of the SOR alternatives the drawdown of these pools would be significant enough to require modification of the existing pumping stations in order to maintain pumping throughout the irrigation season. Significant capital costs are associated with the pump modifications necessary to maintain pumping at the lower pool elevations. The regional economic impacts associated with the costs of the pump modifications will depend in large part on whether these costs are paid for by the public sector or by the pump owners. If the costs are paid by regional electricity ratepayers, as the public sector, then the modification costs are likely to be translated into higher electricity rates and a subsequent decline in regional household incomes. If the costs are paid by the taxpayer, as the public sector, then any associated secondary impacts are not likely to be measurable because of the much broader base over which the costs are distributed.

For modification costs paid for by the pump owners, the regional impacts will depend on whether the pumps are under public or private ownership. Pump modifications paid for by private owners will have a direct impact on the net income available to the operation for which the pumps are required. In the case of irrigated agriculture, producers will be required to withhold or delay investment in other farm activities in order to meet the modification expenses. The lower net income is also likely to reduce returns to the farm household.

7 The reduction in household expenditures is incorporated into the input-output modeling framework as a proportional reduction in the vector of personal consumption expenditures. The consumption vectors are included as part of the base data provided by the IMPLAN modeling system.

8 Based on acreage distribution information received from the SOR Irrigation Work Group. 
Table E-14. Average Annual Pumping Costs for Grand Coulee Irrigation Pumping

\begin{tabular}{|l|r|r|r|r|}
\hline \multicolumn{1}{|c|}{ Alternative } & $\begin{array}{c}\text { Pacific } \\
\text { Northwest }\end{array}$ & Washington & Mid Columbia & $\begin{array}{c}\text { Upper } \\
\text { Columbia }\end{array}$ \\
\hline SOS 2c & $\$ 911,300$ & $\$ 911,300$ & $\$ 236,900$ & $\$ 674,400$ \\
\hline Change from Base Case (SOS 2c) & \multicolumn{3}{|c|}{} \\
\hline SOS 1a & $\$ 9,000$ & $\$ 9,000$ & $\$ 2,300$ & $\$ 6,700$ \\
SOS 1b & $\$ 8,900$ & $\$ 8,900$ & $\$ 2,300$ & $\$ 6,600$ \\
SOS 2d & $(\$ 3,300)$ & $(\$ 3,300)$ & $(\$ 900)$ & $(\$ 2,400)$ \\
SOS 4c & $(\$ 18,400)$ & $(\$ 18,400)$ & $(\$ 4,800)$ & $(\$ 13,600)$ \\
SOS 5b & $\$ 0$ & $\$ 0$ & $\$ 0$ & $\$ 0$ \\
SOS 5c & $\$ 0$ & $\$ 0$ & $\$ 0$ & $\$ 0$ \\
SOS 6b & $\$ 0$ & $\$ 0$ & $\$ 0$ & $\$ 0$ \\
SOS 6d & $\$ 0$ & $\$ 0$ & $\$ 0$ & $\$ 0$ \\
SOS 9a & $\$ 34,900$ & $\$ 34,900$ & $\$ 9,100$ & $\$ 25,800$ \\
SOS 9b & $\$ 5,400$ & $\$ 5,400$ & $\$ 1,400$ & $\$ 4,000$ \\
SOS 9c & $\$ 6,000$ & $\$ 6,000$ & $\$ 1,600$ & $\$ 4,400$ \\
SOS PA & $(\$ 2,800)$ & $(\$ 2,800)$ & $(\$ 700)$ & $(\$ 2,100)$ \\
\hline
\end{tabular}

In addition to pump station modification costs, most irrigators will experience higher horse-power requirements and higher energy costs due to increased pumping lifts under a drawdown scenario. Irrigators will also experience an increase in annual operations and maintenance costs as a result of the modifications. All of these costs combine to determine the annual impacts on net farm income.

Similar to the analysis for Grand Coulee irrigation pumping, the regional impacts associated with net farm income adjustments for irrigators along the John Day and Ice Harbor pools are estimated assuming a two-fold effect on the farming operation. One-half of the change in net farm income is assumed to generate impacts through the effects on household income and the consequent reduction in the market basket of household expenditures. The remaining portion of the change in farm income is assumed to reduce purchases of farm machinery.

\section{Allocation to Subregions}

The net farm income impacts measured for irrigation pumping from the John Day and Ice Harbor pools were taken directly from Tables 4-21 and 4-23 of Appendix O of the FEIS. Both pools lie completely within the Mid Columbia subregion. Impacts were distributed across Oregon and Washington based on the number and size of pumps located on each side of the Columbia River. ${ }^{9}$ Twenty-six percent of the income change was allocated to Oregon and the remaining 74 percent of the change was distributed to Washington irrigators. The net income changes associated with changes in irrigation pumping at John Day and Ice Harbor pools are presented in Table E-15.

\footnotetext{
9 Based on pump modification cost data received from the SOR Economic Analysis Group.
} 
Table E-15. Average Annual Modification Pumping Costs for Ice Harborl John Day Irrigation Pumping Stations

\begin{tabular}{|c|r|r|r|r|}
\hline Alternative & $\begin{array}{c}\text { Pacific } \\
\text { Northwest }\end{array}$ & Washington & Oregon & Mid Columbia \\
\hline SOS 2c & $\$ 0$ & $\$ 0$ & $\$ 0$ & $\$ 0$ \\
\hline \multicolumn{2}{|c|}{ Change from Base Case (SOS 2c) } & \multicolumn{2}{|c|}{$\mid$} \\
\hline SOS 1a & $\$ 0$ & $\$ 0$ & $\$ 0$ & $\$ 0$ \\
SOS 1b & $\$ 0$ & $\$ 0$ & $\$ 0$ & $\$ 0$ \\
SOS 2d & $\$ 0$ & $\$ 0$ & $\$ 0$ & $\$ 0$ \\
SOS 4c & $\$ 0$ & $\$ 0$ & $\$ 0$ & $\$ 0$ \\
SOS 5b & $\$ 5,330,100$ & $\$ 4,418,500$ & $\$ 911,600$ & $\$ 5,330,100$ \\
SOS 5c & $\$ 5,368,100$ & $\$ 4,456,500$ & $\$ 911,600$ & $\$ 5,368,100$ \\
SOS 6b & $\$ 3,525,100$ & $\$ 2,613,500$ & $\$ 911,600$ & $\$ 3,525,100$ \\
SOS 6d & $\$ 1,627,900$ & $\$ 716,300$ & $\$ 911,600$ & $\$ 1,627,900$ \\
SOS 9a & $\$ 3,201,500$ & $\$ 2,471,700$ & $\$ 729,800$ & $\$ 3,201,500$ \\
SOS 9b & $\$ 0$ & $\$ 0$ & $\$ 0$ & $\$ 0$ \\
SOS 9c & $\$ 3,638,700$ & $\$ 2,702,400$ & $\$ 936,200$ & $\$ 3,638,700$ \\
SOS PA & $\$ 1,671,900$ & $\$ 735,600$ & $\$ 936,200$ & $\$ 1,671,900$ \\
\hline
\end{tabular}

\section{E.4.3.3 John Day and Lower Snake Municipal and Industrial Water Use}

Pumping for nonagricultural water supply occurs on five of the six reservoir pools affected by the SOR alternatives: John Day, Ice Harbor, Lower Granite, Little Goose, and Lower Monumental. The pumpers include $M / I$ water users, state and federal recreation and wildlife areas, and city and county parks. As in the case of irrigation pumping, drawdown of these pools under several of the SOR alternatives would be significant enough to require modification of the existing pumping stations. The regional economic impacts associated with the costs of the modifications will depend on whether the pumps are publicly or privately owned. To evaluate the impacts linked to pumps owned by local, state, or federal governments it is first necessary to know whether the modification costs will be funded through diversion of existing expenditures or whether new funds will be required, and the likely source of these funds.

From this it can be determined whether existing regional activities will be displaced in order to fund the pump modifications. Although data was available on pump ownership, insufficient information was available to determine the manner in which the increased pumping costs for the government-owned pumps would be paid. Therefore, it was assumed that the costs would be passed along to regional households, causing a reduction in the market basket of personal consumption expenditures. This assumption is likely to provide a measure of 'greatest potential impact' to the regional economy.

For private owners of the recreation and $M / I$ pumping stations, the regional effects of increased pumping costs will depend on whether the increased business costs can be passed along to the final consumer through higher product or service prices. If the modification costs cannot be passed along to the final consumer, the annualized costs would result in a decline in net business income and returns to ownership. Impacts would be measured through changes in the appropriate investment sectors and in household consumption. 


\section{Allocation to Subregions}

The increased costs measured for $\mathrm{M} / \mathrm{I}$ pumping from the John Day and four lower Snake pools were taken directly from Tables 4-24 and 4-25 of Appendix $O$ of the FEIS. The John Day, Ice Harbor, and Lower Monumental pools are located in the Mid Columbia subregion; the Lower Granite and Little Goose pools are located in the Lower Snake subregion. Using pool-specific data on pump modifications, 86 percent of the $M / I$ costs were allocated to the Mid Columbia subregion, with the remaining 14 percent allotted to the Lower Snake subregion. Impacts were distributed across Oregon and Washington based on the number and size of pumps located on each side of the Columbia River [Anderson-Perry \& Associates; IR2 Consulting]. Oregon was allocated 44 percent of the income change and the remaining 56 percent was distributed to pumpers located in Washington. The net income changes associated with changes in $\mathrm{M} / \mathrm{I}$ pumping at the John Day and four Lower Snake pools are presented in Table E-16.

Table E-16. Average Annual Modification Costs for John Day and Lower Snake M/I Pumping Stations

\begin{tabular}{|c|c|c|c|}
\hline Alternative & $\begin{array}{c}\text { Pacific } \\
\text { Northwest }\end{array}$ & $\begin{array}{c}\text { Mid } \\
\text { Columbia }\end{array}$ & $\begin{array}{l}\text { Lower } \\
\text { Snake }\end{array}$ \\
\hline SOS 2c & $\$ 0$ & $\$ 0$ & $\$ 0$ \\
\hline \multicolumn{4}{|c|}{ Change from Base Case (SOS 2c) } \\
\hline SOS 1a & $\$ 0$ & $\$ 0$ & $\$ 0$ \\
\hline $\operatorname{SOS} 1 \mathbf{b}$ & $\$ 0$ & $\$ 0$ & $\$ 0$ \\
\hline $\operatorname{sos} 2 d$ & $\$ 0$ & $\$ 0$ & $\$ 0$ \\
\hline SOS $4 c$ & $\$ 0$ & $\$ 0$ & $\$ 0$ \\
\hline SOS 5b & $\$ 5,758,800$ & $\$ 5,258,600$ & $\$ 500,200$ \\
\hline $\operatorname{SOS~5c}$ & $\$ 5,797,800$ & $\$ 5,259,600$ & $\$ 538,200$ \\
\hline $\operatorname{SOS} 6 \mathrm{~b}$ & $\$ 5,505,900$ & $\$ 5,121,200$ & $\$ 384,700$ \\
\hline SOS 6d & $\$ 5,332,200$ & $\$ 4,981,600$ & $\$ 350,500$ \\
\hline SOS 9a & $\$ 5,504,200$ & $\$ 5,119,500$ & $\$ 384,700$ \\
\hline SOS 9b & $\$ 0$ & $\$ 0$ & $\$ 0$ \\
\hline SOS 9c & $\$ 5,568,300$ & $\$ 5,140,500$ & $\$ 427,900$ \\
\hline \multirow[t]{2}{*}{ SOS PA } & $\$ 5,208,600$ & $\$ 5,208,600$ & $\$ 0$ \\
\hline & Washington & $\overline{\text { Oregon }}$ & Idaho \\
\hline $\operatorname{SOS} 2 c$ & $\$ 0$ & $\$ 0$ & $\$ 0$ \\
\hline \multicolumn{4}{|c|}{ Change from Base Case (SOS 2c) } \\
\hline SOS 1a & $\$ 0$ & $\$ 0$ & $\$ 0$ \\
\hline SOS $1 b$ & $\$ 0$ & $\$ 0$ & $\$ 0$ \\
\hline SOS 2d & $\$ 0$ & $\$ 0$ & $\$ 0$ \\
\hline $\operatorname{sos} 4 c$ & $\$ 0$ & $\$ 0$ & $\$ 0$ \\
\hline SOS 5b & $\$ 2,956,800$ & $\$ 2,739,900$ & $\$ 62,100$ \\
\hline SOS 5c & $\$ 2,995,600$ & $\$ 2,739,900$ & $\$ 62,200$ \\
\hline SOS $6 \mathrm{~b}$ & $\$ 2,713,500$ & $\$ 2,739,900$ & $\$ 52,600$ \\
\hline SOS 6d & $\$ 2,539,700$ & $\$ 2,739,900$ & $\$ 52,600$ \\
\hline $\operatorname{sos} 9 a$ & $\$ 2,711,700$ & $\$ 2,739,900$ & $\$ 52,600$ \\
\hline SOS 9b & $\$ 0$ & $\$ 0$ & $\$ 0$ \\
\hline $\operatorname{sos} 9 c$ & $\$ 2,771,100$ & $\$ 2,739,900$ & $\$ 57,300$ \\
\hline SOS PA & $\$ 2,343,900$ & $\$ 2,864,700$ & $\$ 0$ \\
\hline
\end{tabular}




\section{E.4.3.4 Combined Irrigation Impacts}

The regional economic impacts related to irrigation are estimated separately for Grand Coulee agricultural pumping, John Day/Ice Harbor agricultural pumping, and $\mathrm{M} / \mathrm{I}$ pumping at John Day and the four lower Snake pools. Economic impacts were estimated for all subregions where changes in pumping costs are expected to occur. A summary of the subregion distribution of increased pumping costs is presented in Table E-17.

Regional economic impacts are estimated separately for each of the affected groups of irrigation and water supply pumpers within a subregion. The individual impacts are then summed to determine the total irrigation impacts for each subregion. Results of the regional economic analysis related to irrigation pumping cost changes are presented in a later section, Results of the Regional Economic Impact Analysis.

\section{E.4.4 Navigation}

Alternative river operations strategies would affect cargo transportation on the Columbia-Snake river system by limiting and/or restricting barge navigation along specific river reaches during periods of drawdown. The barge restrictions would, in turn, lead to increases in the costs of transporting goods from their point of origin to their final destination. Increasing transportation costs result from two general adjustments that may occur as a result of restrictions to barge navigation:

- The restrictions may cause shifts from barge movements to other transportation modes or modal combinations (e.g., shifts from truckbarge to truck-rail); or

- The drawdown restrictions may result in commodities being transported to alternative river locations before being placed on barges; (e.g., shifts from river ports in the Lewiston area to river ports in the Tri-Cities area).

In addition to increased costs related to modal shifts, it is likely that additional costs will be incurred as a result of increased storage and handling related to transferring and holding commodities before delivery along the alternative transportation nodes.

The direct economic impacts related to navigation on the Columbia-Snake system were measured as the change in total system-related transportation costs resulting from each SOR alternative compared to costs related to the existing system transportation

\section{Table E-17. Allocation of Increased Pumping Costs to Subregions a/}

\begin{tabular}{|l|c|c|c|}
\hline & \multicolumn{2}{|c|}{ Irrigation Pumping } & \multirow{2}{*}{ M/I Water Supply } \\
\cline { 2 - 3 } & Grand Coulee & $\begin{array}{c}\text { John Day/ } \\
\text { Ice Harbor }\end{array}$ & \\
\hline By State & $100 \%$ & $74 \%$ & $56 \%$ \\
Washington & $\mathrm{a} /$ & $26 \%$ & $44 \%$ \\
Oregon & & $100 \%$ & \\
By Subregion & $26 \%$ & a/ & $86 \%$ \\
Mid Columbia & $74 \%$ & a/ & a/ \\
Upper Columbia & a/ & $14 \%$ \\
Lower Snake & &
\end{tabular}

a/ Blank cells indicate that the specified pumping costs are not applicable to the state and/or subregion. 
network. Expected costs were estimated for three categories of water-borne transportation: deep draft navigation, log transportation on Dworshak reservoir, and shallow draft navigation.

\section{E.4.4.1 Deep Draft Navigation}

An analysis was done by the Navigation Work Group to determine whether ocean-going vessels utilizing the forty-foot navigation channel between Vancouver, Washington, and the mouth of the Columbia River would incur delays or other problems during refill of the Snake River reservoirs that would be lowered during drawdown. The refill requirements would reduce Snake River inflows into the Columbia below present levels. The lower inflows would alter river stages along the Lower Columbia River, potentially affecting deep draft navigation for in-bound and out-bound ocean vessels.

The results of the analysis indicated that the impacts of the refill operations on river stages at critical locations along the Lower Columbia River would be relatively small. It was concluded by the Navigation Work Group that the SOR alternatives would have no impact on deep draft navigation. Consequently, no direct or regional economic impacts were measured for this navigation component.

\section{E.4.4.2 Dworshak Reservoir Navigation}

Dworshak Reservoir is the location of log rafting operations which transport raw logs from various log dump sites around the reservoir to their final destination in Lewiston. These operations would be affected by those SOR alternatives which lower the reservoir sufficiently to prevent access to one or more of the dump sites. In these cases, alternate dump sites must be utilized or the logs must be transported by truck to Lewiston. In either of these cases, increased trucking costs would be incurred.

The Navigation Work Group developed a simulation model to estimate the increased log transportation costs associated with each of the SOR alternatives. These costs were used by the Economic Analysis Group as the measure of direct economic impacts.
The measure of the net change in transportation costs is linked to the regional economic analysis by assuming that an equivalent (and opposite) change occurs in the net income earned by the businesses utilizing the log rafting operations. For purposes of the regional impact analysis it is further assumed that the change in net business income will result in a change in household income through the effect on returns to ownership. Regional impacts would be generated through the effects on household income and the change in household expenditures.

The transportation costs presented in Table 4-37 of Appendix $O$ of the FEIS are incorporated into the regional analysis.

\section{Allocation to Subregions}

Dworshak Reservoir is wholly contained within the Lower Snake subregion. Consequently, the economic impacts related to reservoir transportation are estimated only for this subregion. Regional impacts are also estimated for the state of Idaho. The transportation cost increases associated with reservoir navigation for each of the final SOR alternatives are presented in Table E-18.

\section{Shallow Draft Navigation}

The direct economic effects of the SOR alternatives on shallow draft navigation in the Columbia-Snake River system have been measured as the changes in costs associated with transporting commodities from their point of origin to their final destinations. A transportation model was developed by the Transportation Research and Analysis Center (TRAC) for the SOR Econiomic Analysis Group. The model examined the least-cost transportation routes for commodities shipped along the Columbia River system. The analysis included the primary commodities utilizing the water transportation network: grain, petroleum, logs and wood chips, and wood products. Grain accounts for over $85 \%$ of the commodity movements along the Columbia/Snake River system. The model simulates transportation responses to alternative river conditions, and computes transportation, storage, handling, and capacity costs under the various scenarios. 
Table E-18. Average Annual Truck Transportation Costs for Dworshak Reservoir Navigation al

\begin{tabular}{|c|c|}
\hline Alternative & Average Annual Values \\
\hline SOS 2c & $\$ 228,188$ \\
\hline \multicolumn{2}{|c|}{ Change from Base Case (SOS 2c) } \\
\hline SOS 1a & $(\$ 112,124)$ \\
\hline SOS $1 \mathrm{~b}$ & $(\$ 119,647)$ \\
\hline SOS 2d & $\$ 93,064$ \\
\hline SOS $4 c$ & $(\$ 228,188)$ \\
\hline SOS 5b & $(\$ 51,048)$ \\
\hline SOS 5c & $(\$ 171,129)$ \\
\hline SOS $6 b$ & $(\$ 120,267)$ \\
\hline SOS 6d & $(\$ 141,164)$ \\
\hline $\operatorname{sos} 9 a$ & $(\$ 41,515)$ \\
\hline SOS 9b & $\$ 172,725$ \\
\hline SOS 9c & $(\$ 5,401)$ \\
\hline SOS PA & $\$ 119,748$ \\
\hline
\end{tabular}

a/ The reservoir transportation costs are as shown for the Pacific Northwest, Idaho, and Lower Snake regions.

The most significant impediment to shallow draft navigation is expected to result from drawdown of the Lower Snake reservoirs. The transportation model has been designed to estimate the costs associated with these drawdowns. Responses to drawdown include rerouting commodities to alternate transportation nodes, including rail direct to export destinations or trucking to river ports downstream of the drawdown locations. Transportation costs are estimated separately for the grain and non-grain commodities.

\section{Grain Transportation}

The increased transportation costs measured for grain reflect the increased costs paid by crop producers to ship their commodities from the farm to export elevators located along the lower Columbia River. As farmers pay more to ship their commodities down river, the net income earned from crop production is reduced. Similar to the direct economic impacts generated through increased irrigation pumping costs, it is assumed that the decline in net farm income will have a two-fold effect on the farming operation. One-half of the change in net farm income is assumed to generate regional impacts through the effects on household income and the consequent reduction in the market basket of household expenditures. ${ }^{10}$ The remaining portion of the change in farm income is assumed to generate regional impacts by reducing purchases of farm machinery.

The increases in grain transportation costs were allocated to states and subregions according to the volume of movements originating from specific country elevators located throughout the Pacific Northwest. Grain shipments from elevators located within the same subregion were aggregated together. Transportation costs were allocated to the subregion according to the proportion of total movements originating from the area. Similarly, transportation costs were allocated to states based on the proportion of total movements originating within the state.

State and subregion allocations of the increased grain transportation costs which would be paid by farmers were prepared by the SOR Economic Analysis Group. These expected changes in costs to growers are presented in Table E-19.11

10 The reduction in household expenditures is incorporated into the input-output modeling framework as a proportional reduction in the vector of personal consumption expenditures. The consumption vectors are included as part of the base data provided by the IMPLAN modeling system.

11 The Pacific Northwest transportation costs presented in Table 19 differ from values presented in Table 4-28 from Appendix $O$ of the FEIS. Values in Appendix $O$ include rain shipments originating from North Dakota whereas the values in Table 19 do not. 


\section{Changes in Grain Transportation Modes}

The increased costs for grain transportation paid by farmers occur as a result of the changes in shipping modes that are required when portions of the river system are closed to barge traffic. The resulting change in the mix of regional transportation activities will also generate local economic impacts as shipping revenues are shifted from truck/barge activities to truck/rail alternatives. Changes in system operations which close specific river segments will shift the location of intermediate shipping nodes; this will also generate regional economic impacts by lengthening necessary trucking segments and shortening barge routes. The change in regional grain shipping movements will also lead to a shift in the related storage and handling activities. This redistribution of shipping revenues generates region- al economic impacts in addition to those that occur as a result of lower net incomes available to regional grain producers.

The expected changes in transportation revenues for Columbia/Snake River grain movements are presented in Table E-20. This information was prepared by members of the Economic Analysis Group using information from the transportation model developed by the Transportation Research and Analysis Center.

It should be noted that increases in shipping costs paid by Pacific Northwest grain producers will be equal to the changes in transportation revenues received by Pacific Northwest shippers, handlers, and storage facilities. ${ }^{12}$ However, the distribution of the cost and revenue impacts throughout the region will vary considerably.

Table E-19. Transportation Costs Paid by Farmers Shipping Grain on the ColumbiaSnake River System (measured in \$1,000)

\begin{tabular}{|lcrrrr|}
\hline & $\begin{array}{c}\text { Pacific } \\
\text { Northwest }\end{array}$ & Washington & Oregon & Idaho & Montana \\
\hline SOS 2c & $\$ 294,794$ & $\$ 84,578$ & $\$ 24,560$ & $\$ 97,758$ & $\$ 87,898$ \\
\hline Change from Base Case (SOS 2c) & & & & \\
\hline SOS 1a & $\$ 0$ & $\$ 0$ & $\$ 0$ & $\$ 0$ & $\$ 0$ \\
SOS 1b & $\$ 0$ & $\$ 0$ & $\$ 0$ & $\$ 0$ & $\$ 0$ \\
SOS 2d & $\$ 0$ & $\$ 0$ & $\$ 0$ & $\$ 0$ & $\$ 0$ \\
SOS 4c & $\$ 0$ & $\$ 0$ & $\$ 0$ & $\$ 0$ & $\$ 0$ \\
SOS 5b & $\$ 20,408$ & $\$ 13,510$ & $\$ 35$ & $\$ 6,605$ & $\$ 258$ \\
SOS 5c & $\$ 41,372$ & $\$ 28,157$ & $\$ 65$ & $\$ 12,892$ & $\$ 258$ \\
SOS 6b & $\$ 15,178$ & $\$ 9,987$ & $\$ 25$ & $\$ 4,907$ & $\$ 258$ \\
SOS 6d a/ & N/A & N/A & N/A & N/A & N/A \\
SOS 9a & $\$ 15,178$ & $\$ 9,987$ & $\$ 25$ & $\$ 4,907$ & $\$ 258$ \\
SOS 9b & $\$ 0$ & $\$ 0$ & $\$ 0$ & $\$ 0$ & $\$ 0$ \\
SOS 9c a/ & N/A & N/A & N/A & N/A & N/A \\
SOS PA & $\$ 0$ & $\$ 0$ & $\$ 0$ & $\$ 0$ & $\$ 0$ \\
\hline
\end{tabular}

12 The SOR Transportation Model developed by TRAC defines the Pacific Northwest transportation shipping region to include commodities originating in North Dakota as well as in Washington, Oregon, Idaho, and Montana. Therefore, increased costs will be exactly offset by increased revenues only for this larger five-state region. The Pacific Northwest region costs and revenues presented in Tables 19 and 20 are not equal because the associated values for shipments from North Dakota are not included. 
Table E-19. Transportation Costs Paid by Farmers Shipping Grain on the ColumbiaSnake River System (measured in \$1,000) - CONT

\begin{tabular}{|c|c|c|c|c|c|c|}
\hline & Portland & $\begin{array}{c}\text { Mid } \\
\text { Columbia }\end{array}$ & $\begin{array}{l}\text { Upper } \\
\text { Columbia }\end{array}$ & $\begin{array}{l}\text { Lower } \\
\text { Snake }\end{array}$ & Northeast & $\begin{array}{l}\text { Southern } \\
\text { Idaho }\end{array}$ \\
\hline SOS 2c & $\$ 982$ & $\$ 17,299$ & $\$ 43,981$ & $\$ 40,447$ & $\$ 17,609$ & $\$ 87,043$ \\
\hline \multicolumn{7}{|c|}{ Change from Base Case (SOS 2c) } \\
\hline SOS 1a & $\$ 0$ & $\$ 0$ & $\$ 0$ & $\$ 0$ & $\$ 0$ & $\$ 0$ \\
\hline SOS 1b & $\$ 0$ & $\$ 0$ & $\$ 0$ & $\$ 0$ & $\$ 0$ & $\$ 0$ \\
\hline SOS 2d & $\$ 0$ & $\$ 0$ & $\$ 0$ & $\$ 0$ & $\$ 0$ & $\$ 0$ \\
\hline $\operatorname{sOS} 4 c$ & $\$ 0$ & $\$ 0$ & $\$ 0$ & $\$ 0$ & $\$ 0$ & $\$ 0$ \\
\hline SOS 5b & $\$ 132$ & $(\$ 4,975)$ & $\$ 7,547$ & $\$ 31,623$ & $(\$ 4,662)$ & $(\$ 9,999)$ \\
\hline SOS 5c & $\$ 249$ & $(\$ 9,408)$ & $\$ 14,838$ & $\$ 62,952$ & $(\$ 8,488)$ & $(\$ 19,169)$ \\
\hline $\operatorname{sos} 6 b$ & $\$ 106$ & $(\$ 4,035)$ & $\$ 5,824$ & $\$ 24,270$ & $(\$ 3,825)$ & $(\$ 7,978)$ \\
\hline SOS 6d a/ & N/A & N/A & N/A & N/A & N/A & N/A \\
\hline sos 9a & $\$ 106$ & $(\$ 4,035)$ & $\$ 5,824$ & $\$ 24,270$ & $(\$ 3,825)$ & $(\$ 7,978)$ \\
\hline SOS 9b & $\$ 0$ & $\$ 0$ & $\$ 0$ & $\$ 0$ & $\$ 0$ & $\$ 0$ \\
\hline $\operatorname{SOS} 9 \mathrm{c}$ a/ & N/A & N/A & N/A & N/A & N/A & N/A \\
\hline SOS PA & $\$ 0$ & $\$ 0$ & $\$ 0$ & $\$ 0$ & $\$ 0$ & $\$ 0$ \\
\hline
\end{tabular}

a/ Due to time and resource constraints, transportation costs for SOS $6 \mathrm{~d}$ and SOS $9 \mathrm{c}$ were not allocated to states or subregions.

Table E-20. Transportation Revenues from Grain Shipments, Allocated by Mode and Activity $(\$ 1,000)$

\begin{tabular}{|c|c|c|c|c|c|}
\hline Alternative & $\begin{array}{c}\text { Pacific } \\
\text { Northwest }\end{array}$ & Washington & Oregon & Idaho & Montana \\
\hline \multicolumn{6}{|l|}{ SOS 2c } \\
\hline Barge & $\$ 24,957$ & $\$ 17,158$ & $\$ 3,018$ & $\$ 4,781$ & $\$ 0$ \\
\hline Truck & $\$ 43,897$ & $\$ 12,731$ & $\$ 4,654$ & $\$ 22,553$ & $\$ 3,959$ \\
\hline Rail & $\$ 91,507$ & $\$ 8,328$ & $\$ 1,766$ & $\$ 28,791$ & $\$ 52,622$ \\
\hline Storage & $\$ 54,663$ & $\$ 22,614$ & $\$ 6,719$ & $\$ 17,303$ & $\$ 8,027$ \\
\hline Handling & $\$ 75,834$ & $\$ 31,018$ & $\$ 12,962$ & $\$ 17,394$ & $\$ 14,461$ \\
\hline \multicolumn{6}{|c|}{ Change from Base Case (SOS 2c) } \\
\hline \multicolumn{6}{|c|}{\begin{tabular}{l|l} 
SOS 1a & \\
\end{tabular}} \\
\hline Barge & $\$ 0$ & $\$ 0$ & $\$ 0$ & $\$ 0$ & $\$ 0$ \\
\hline Truck & $\$ 0$ & $\$ 0$ & $\$ 0$ & $\$ 0$ & $\$ 0$ \\
\hline Rail & $\$ 0$ & $\$ 0$ & $\$ 0$ & $\$ 0$ & $\$ 0$ \\
\hline Storage & $\$ 0$ & $\$ 0$ & $\$ 0$ & $\$ 0$ & $\$ 0$ \\
\hline Handling & $\$ 0$ & $\$ 0$ & $\$ 0$ & $\$ 0$ & $\$ 0$ \\
\hline
\end{tabular}


Table E-20. Transportation Revenues from Grain Shipments, Allocated by Mode and Activity $(\$ 1,000)$ - CONT

\begin{tabular}{|c|c|c|c|c|c|}
\hline Alternative & $\begin{array}{c}\text { Pacific } \\
\text { Northwest }\end{array}$ & Washington & Oregon & Idaho & Montana \\
\hline \multicolumn{6}{|l|}{ SOS 1b } \\
\hline Barge & $\$ 0$ & $\$ 0$ & $\$ 0$ & $\$ 0$ & $\$ 0$ \\
\hline Truck & $\$ 0$ & $\$ 0$ & $\$ 0$ & $\$ 0$ & $\$ 0$ \\
\hline Rail & $\$ 0$ & $\$ 0$ & $\$ 0$ & $\$ 0$ & $\$ 0$ \\
\hline Storage & $\$ 0$ & $\$ 0$ & $\$ 0$ & $\$ 0$ & $\$ 0$ \\
\hline Handling & $\$ 0$ & $\$ 0$ & $\$ 0$ & $\$ 0$ & $\$ 0$ \\
\hline \multicolumn{6}{|l|}{ SOS 2d } \\
\hline Barge & $\$ 0$ & $\$ 0$ & $\$ 0$ & $\$ 0$ & $\$ 0$ \\
\hline Truck & $\$ 0$ & $\$ 0$ & $\$ 0$ & $\$ 0$ & $\$ 0$ \\
\hline Rail & $\$ 0$ & $\$ 0$ & $\$ 0$ & $\$ 0$ & $\$ 0$ \\
\hline Storage & $\$ 0$ & $\$ 0$ & $\$ 0$ & $\$ 0$ & $\$ 0$ \\
\hline Handling & $\$ 0$ & $\$ 0$ & $\$ 0$ & $\$ 0$ & $\$ 0$ \\
\hline \multicolumn{6}{|l|}{ SOS $4 c$} \\
\hline Barge & $\$ 0$ & $\$ 0$ & $\$ 0$ & $\$ 0$ & $\$ 0$ \\
\hline Truck & $\$ 0$ & $\$ 0$ & $\$ 0$ & $\$ 0$ & $\$ 0$ \\
\hline Rail & $\$ 0$ & $\$ 0$ & $\$ 0$ & $\$ 0$ & $\$ 0$ \\
\hline Storage & $\$ 0$ & $\$ 0$ & $\$ 0$ & $\$ 0$ & $\$ 0$ \\
\hline Handling & $\$ 0$ & $\$ 0$ & $\$ 0$ & $\$ 0$ & $\$ 0$ \\
\hline \multicolumn{6}{|l|}{ SOS 5b } \\
\hline Barge & $(\$ 7,525)$ & $(\$ 4,622)$ & $(\$ 282)$ & $(\$ 2,621)$ & $\$ 0$ \\
\hline Truck & $(\$ 194)$ & $\$ 5,376$ & $\$ 50$ & $(\$ 3,574)$ & $(\$ 2,045)$ \\
\hline Rail & $\$ 23,880$ & $\$ 9,377$ & $(\$ 0)$ & $\$ 11,081$ & $\$ 3,422$ \\
\hline Storage & $\$ 9,747$ & $\$ 1,240$ & $\$ 272$ & $\$ 1,800$ & $\$ 6,434$ \\
\hline Handling & $(\$ 645)$ & $(\$ 1,318)$ & $\$ 1,054$ & $\$ 822$ & $(\$ 1,205)$ \\
\hline \multicolumn{6}{|l|}{ SOS 5c } \\
\hline Barge & $(\$ 14,130)$ & $(\$ 9,027)$ & $(\$ 322)$ & $(\$ 4,781)$ & $\$ 0$ \\
\hline Truck & $\$ 2,273$ & $\$ 11,129$ & $\$ 93$ & $(\$ 6,903)$ & $(\$ 2,045)$ \\
\hline Rail & $\$ 44,723$ & $\$ 19,734$ & $(\$ 0)$ & $\$ 21,568$ & $\$ 3,422$ \\
\hline Storage & $\$ 13,453$ & $\$ 2,818$ & $\$ 612$ & $\$ 3,589$ & $\$ 6,434$ \\
\hline Handling & $\$ 161$ & $(\$ 2,090)$ & $\$ 1,698$ & $\$ 1,757$ & $(\$ 1,205)$ \\
\hline \multicolumn{6}{|l|}{ SOS 6b } \\
\hline Barge & $(\$ 5,897)$ & $(\$ 3,565)$ & $(\$ 118)$ & $(\$ 2,214)$ & $\$ 0$ \\
\hline Truck & $(\$ 660)$ & $\$ 3,965$ & $\$ 36$ & $(\$ 2,616)$ & $(\$ 2,045)$ \\
\hline Rail & $\$ 18,636$ & $\$ 7,060$ & $(\$ 0)$ & $\$ 8,155$ & $\$ 3,422$ \\
\hline Storage & $\$ 2,320$ & $\$ 901$ & $\$ 121$ & $\$ 1,298$ & $\$ 0$ \\
\hline Handling & $(\$ 752)$ & $(\$ 983)$ & $\$ 822$ & $\$ 613$ & $(\$ 1,205)$ \\
\hline
\end{tabular}


Table E-20. Transportation Revenues from Grain Shipments, Allocated by Mode and Activity $(\$ 1,000)$ - CONT

\begin{tabular}{|c|c|c|c|c|c|}
\hline Alternative & $\begin{array}{c}\text { Pacific } \\
\text { Northwest }\end{array}$ & Washington & Oregon & Idaho & Montana \\
\hline \multicolumn{6}{|l|}{ SOS 6d a/ } \\
\hline Barge & N/A & N/A & N/A & N/A & N/A \\
\hline Truck & N/A & N/A & N/A & N/A & N/A \\
\hline Rail & N/A & N/A & N/A & N/A & N/A \\
\hline Storage & N/A & N/A & N/A & N/A & N/A \\
\hline Handling & N/A & N/A & N/A & N/A & N/A \\
\hline \multicolumn{6}{|l|}{$\operatorname{sos} 9 a$} \\
\hline Barge & $(\$ 5,897)$ & $(\$ 3,565)$ & $(\$ 118)$ & $(\$ 2,214)$ & $\$ 0$ \\
\hline Truck & $(\$ 660)$ & $\$ 3,965$ & $\$ 36$ & $(\$ 2,616)$ & $(\$ 2,045)$ \\
\hline Rail & $\$ 18,636$ & $\$ 7,060$ & $(\$ 0)$ & $\$ 8,155$ & $\$ 3,422$ \\
\hline Storage & $\$ 2,320$ & $\$ 901$ & $\$ 121$ & $\$ 1,298$ & $\$ 0$ \\
\hline Handling & $(\$ 752)$ & $(\$ 983)$ & $\$ 822$ & $\$ 613$ & $(\$ 1,205)$ \\
\hline \multicolumn{6}{|l|}{ SOS 9b } \\
\hline Barge & $\$ 0$ & $\$ 0$ & $\$ 0$ & $\$ 0$ & $\$ 0$ \\
\hline Truck & $\$ 0$ & $\$ 0$ & $\$ 0$ & $\$ 0$ & $\$ 0$ \\
\hline Rail & $\$ 0$ & $\$ 0$ & $\$ 0$ & $\$ 0$ & $\$ 0$ \\
\hline Storage & $\$ 0$ & $\$ 0$ & $\$ 0$ & $\$ 0$ & $\$ 0$ \\
\hline Handling & $\$ 0$ & $\$ 0$ & $\$ 0$ & $\$ 0$ & $\$ 0$ \\
\hline \multicolumn{6}{|l|}{$\operatorname{sos} 9 \mathrm{c} a /$} \\
\hline Barge & N/A & N/A & N/A & N/A & N/A \\
\hline Truck & N/A & N/A & N/A & N/A & N/A \\
\hline Rail & N/A & N/A & N/A & N/A & N/A \\
\hline Storage & N/A & N/A & N/A & N/A & N/A \\
\hline Handling & N/A & $N / A$ & N/A & N/A & N/A \\
\hline \multicolumn{6}{|l|}{ SOS PA } \\
\hline Barge & $\$ 0$ & $\$ 0$ & $\$ 0$ & $\$ 0$ & $\$ 0$ \\
\hline Truck & $\$ 0$ & $\$ 0$ & $\$ 0$ & $\$ 0$ & $\$ 0$ \\
\hline Rail & $\$ 0$ & $\$ 0$ & $\$ 0$ & $\$ 0$ & $\$ 0$ \\
\hline Storage & $\$ 0$ & $\$ 0$ & $\$ 0$ & $\$ 0$ & $\$ 0$ \\
\hline Handling & $\$ 0$ & $\$ 0$ & $\$ 0$ & $\$ 0$ & $\$ 0$ \\
\hline
\end{tabular}


Table E-20. Transportation Revenues from Grain Shipments, Allocated by Mode and Activity $(\$ 1,000)-$ CONT

\begin{tabular}{|c|c|c|c|c|c|c|}
\hline Alternative & Portland & $\begin{array}{c}\text { Mid } \\
\text { Columbia }\end{array}$ & $\begin{array}{l}\text { Upper } \\
\text { Columbia }\end{array}$ & $\begin{array}{l}\text { Lower } \\
\text { Snake }\end{array}$ & Northeast & $\begin{array}{l}\text { Southern } \\
\text { Idaho }\end{array}$ \\
\hline \multicolumn{7}{|l|}{ SOS $2 c$} \\
\hline Barge & $\$ 0$ & $\$ 14,169$ & $\$ 0$ & $\$ 10,782$ & $\$ 0$ & $\$ 0$ \\
\hline Truck & $\$ 186$ & $\$ 2,949$ & $\$ 6,620$ & $\$ 7,379$ & $\$ 2,500$ & $\$ 19,758$ \\
\hline Rail & $\$ 0$ & $\$ 1,758$ & $\$ 4,747$ & $\$ 1,863$ & $\$ 2,063$ & $\$ 27,869$ \\
\hline Storage & $\$ 243$ & $\$ 7,226$ & $\$ 3,484$ & $\$ 10,664$ & $\$ 1,622$ & $\$ 11,268$ \\
\hline Handling & $\$ 7,912$ & $\$ 15,417$ & $\$ 5,804$ & $\$ 16,990$ & $\$ 1,976$ & $\$ 10,329$ \\
\hline \multicolumn{7}{|c|}{ Change from Base Case (SOS 2c) } \\
\hline \multicolumn{7}{|c|}{\begin{tabular}{l|l|l} 
SOS 1a & & \\
\end{tabular}} \\
\hline Barge & $\$ 0$ & $\$ 0$ & $\$ 0$ & $\$ 0$ & $\$ 0$ & $\$ 0$ \\
\hline Truck & $\$ 0$ & $\$ 0$ & $\$ 0$ & $\$ 0$ & $\$ 0$ & $\$ 0$ \\
\hline Rail & $\$ 0$ & $\$ 0$ & $\$ 0$ & $\$ 0$ & $\$ 0$ & $\$ 0$ \\
\hline Storage & $\$ 0$ & $\$ 0$ & $\$ 0$ & $\$ 0$ & $\$ 0$ & $\$ 0$ \\
\hline Handling & $\$ 0$ & $\$ 0$ & $\$ 0$ & $\$ 0$ & $\$ 0$ & $\$ 0$ \\
\hline \multicolumn{7}{|l|}{ SOS 1b } \\
\hline Barge & $\$ 0$ & $\$ 0$ & $\$ 0$ & $\$ 0$ & $\$ 0$ & $\$ 0$ \\
\hline Truck & $\$ 0$ & $\$ 0$ & $\$ 0$ & $\$ 0$ & $\$ 0$ & $\$ 0$ \\
\hline Rail & $\$ 0$ & $\$ 0$ & $\$ 0$ & $\$ 0$ & $\$ 0$ & $\$ 0$ \\
\hline Storage & $\$ 0$ & $\$ 0$ & $\$ 0$ & $\$ 0$ & $\$ 0$ & $\$ 0$ \\
\hline Handling & $\$ 0$ & $\$ 0$ & $\$ 0$ & $\$ 0$ & $\$ 0$ & $\$ 0$ \\
\hline \multicolumn{7}{|l|}{ SOS 2d } \\
\hline Barge & $\$ 0$ & $\$ 0$ & $\$ 0$ & $\$ 0$ & $\$ 0$ & $\$ 0$ \\
\hline Truck & $\$ 0$ & $\$ 0$ & $\$ 0$ & $\$ 0$ & $\$ 0$ & $\$ 0$ \\
\hline Rail & $\$ 0$ & $\$ 0$ & $\$ 0$ & $\$ 0$ & $\$ 0$ & $\$ 0$ \\
\hline Storage & $\$ 0$ & $\$ 0$ & $\$ 0$ & $\$ 0$ & $\$ 0$ & $\$ 0$ \\
\hline Handling & $\$ 0$ & $\$ 0$ & $\$ 0$ & $\$ 0$ & $\$ 0$ & $\$ 0$ \\
\hline \multicolumn{7}{|l|}{ SOS $4 c$} \\
\hline Barge & $\$ 0$ & $\$ 0$ & $\$ 0$ & $\$ 0$ & $\$ 0$ & $\$ 0$ \\
\hline Truck & $\$ 0$ & $\$ 0$ & $\$ 0$ & $\$ 0$ & $\$ 0$ & $\$ 0$ \\
\hline Rail & $\$ 0$ & $\$ 0$ & $\$ 0$ & $\$ 0$ & $\$ 0$ & $\$ 0$ \\
\hline Storage & $\$ 0$ & $\$ 0$ & $\$ 0$ & $\$ 0$ & $\$ 0$ & $\$ 0$ \\
\hline Handling & $\$ 0$ & $\$ 0$ & $\$ 0$ & $\$ 0$ & $\$ 0$ & $\$ 0$ \\
\hline
\end{tabular}


Table E-20. Transportation Revenues from Grain Shipments, Allocated by Mode and Activity $(\$ 1,000)$ - CONT

\begin{tabular}{|c|c|c|c|c|c|c|}
\hline Alternative & Portland & $\begin{array}{c}\text { Mid } \\
\text { Columbia }\end{array}$ & $\begin{array}{l}\text { Upper } \\
\text { Columbia }\end{array}$ & $\begin{array}{l}\text { Lower } \\
\text { Snake }\end{array}$ & Northeast & $\begin{array}{l}\text { Southern } \\
\text { Idaho }\end{array}$ \\
\hline \multicolumn{7}{|l|}{ SOS 5b } \\
\hline Barge & $\$ 0$ & $(\$ 1,835)$ & $\$ 0$ & $(\$ 5,564)$ & $\$ 0$ & $\$ 0$ \\
\hline Truck & $\$ 28$ & $(\$ 732)$ & $\$ 2,822$ & $\$ 5,695$ & $(\$ 788)$ & $(\$ 5,225)$ \\
\hline Rail & $\$ 0$ & $\$ 4,684$ & $\$ 2,218$ & $\$ 5,770$ & $\$ 7,391$ & $\$ 894$ \\
\hline Storage & $\$ 4$ & $\$ 6,614$ & $\$ 4,182$ & $\$ 405$ & $\$ 2,984$ & $\$ 873$ \\
\hline Handling & $\$ 3$ & $\$ 3,402$ & $\$ 988$ & $(\$ 7,047)$ & $\$ 2,164$ & $\$ 800$ \\
\hline \multicolumn{7}{|l|}{ SOS 5c } \\
\hline Barge & $\$ 0$ & $(\$ 3,342)$ & $\$ 0$ & $(\$ 10,782)$ & $\$ 0$ & $\$ 0$ \\
\hline Truck & $\$ 51$ & $(\$ 1,279)$ & $\$ 5,633$ & $\$ 11,167$ & $(\$ 1,395)$ & $(\$ 9,855)$ \\
\hline Rail & $\$ 0$ & $\$ 14,704$ & $\$ 4,794$ & $\$ 11,403$ & $\$ 12,361$ & $\$ 2,427$ \\
\hline Storage & $\$ 7$ & $\$ 9,187$ & $\$ 5,642$ & $(\$ 2,948)$ & $\$ 5,599$ & $\$ 1,703$ \\
\hline Handling & $\$ 6$ & $\$ 3,622$ & $\$ 2,065$ & $(\$ 10,075)$ & $\$ 4,470$ & $\$ 1,561$ \\
\hline \multicolumn{7}{|l|}{ sos 6b } \\
\hline Barge & $\$ 0$ & $(\$ 1,362)$ & $\$ 0$ & $(\$ 4,375)$ & $\$ 0$ & $\$ 0$ \\
\hline Truck & $\$ 23$ & $(\$ 628)$ & $\$ 2,148$ & $\$ 4,444$ & $(\$ 648)$ & $(\$ 4,018)$ \\
\hline Rail & $\$ 0$ & $\$ 3,579$ & $\$ 1,630$ & $\$ 4,399$ & $\$ 5,650$ & $\$ 358$ \\
\hline Storage & $(\$ 141)$ & $\$ 5,928$ & $\$ 3,846$ & $\$ 1,137$ & $\$ 2,583$ & $\$ 573$ \\
\hline Handling & $(\$ 130)$ & $\$ 1,265$ & $\$ 718$ & $(\$ 4,035)$ & $\$ 1,810$ & $\$ 525$ \\
\hline \multicolumn{7}{|l|}{ SOS 6d a/ } \\
\hline Barge & N/A & N/A & N/A & N/A & N/A & N/A \\
\hline Truck & N/A & N/A & N/A & N/A & N/A & N/A \\
\hline Rail & N/A & N/A & N/A & N/A & N/A & N/A \\
\hline Storage & N/A & N/A & N/A & N/A & N/A & N/A \\
\hline Handling & N/A & N/A & N/A & N/A & N/A & N/A \\
\hline \multicolumn{7}{|l|}{ SOS 9a } \\
\hline Barge & $\$ 0$ & $(\$ 1,362)$ & $\$ 0$ & $(\$ 4,375)$ & $\$ 0$ & $\$ 0$ \\
\hline Truck & $\$ 23$ & $(\$ 628)$ & $\$ 2,148$ & $\$ 4,444$ & $(\$ 648)$ & $(\$ 4,018)$ \\
\hline Rail & $\$ 0$ & $\$ 3,579$ & $\$ 1,630$ & $\$ 4,399$ & $\$ 5,650$ & $\$ 358$ \\
\hline Storage & $(\$ 141)$ & $\$ 5,928$ & $\$ 3,846$ & $\$ 1,137$ & $\$ 2,583$ & $\$ 573$ \\
\hline Handling & $(\$ 130)$ & $\$ 1,265$ & $\$ 718$ & $(\$ 4,035)$ & $\$ 1,810$ & $\$ 525$ \\
\hline
\end{tabular}

a/ Due to time and resource constraints, transportation costs for SOS 6d and SOS $9 \mathrm{c}$ were not allocated to states and subregions. 
Table E-20. Transportation Revenues from Grain Shipments, Allocated by Mode and Activity $(\$ 1,000)$ - CONT

\begin{tabular}{|c|c|c|c|c|c|c|}
\hline Alternative & Portland & $\begin{array}{c}\text { Mid } \\
\text { Columbia }\end{array}$ & $\begin{array}{l}\text { Upper } \\
\text { Columbia }\end{array}$ & $\begin{array}{l}\text { Lower } \\
\text { Snake }\end{array}$ & Northeast & $\begin{array}{c}\text { Southern } \\
\text { Idaho }\end{array}$ \\
\hline \multicolumn{7}{|l|}{ SOS 9b } \\
\hline Barge & $\$ 0$ & $\$ 0$ & $\$ 0$ & $\$ 0$ & $\$ 0$ & $\$ 0$ \\
\hline Truck & $\$ 0$ & $\$ 0$ & $\$ 0$ & $\$ 0$ & $\$ 0$ & $\$ 0$ \\
\hline Rail & $\$ 0$ & $\$ 0$ & $\$ 0$ & $\$ 0$ & $\$ 0$ & $\$ 0$ \\
\hline Storage & $\$ 0$ & $\$ 0$ & $\$ 0$ & $\$ 0$ & $\$ 0$ & $\$ 0$ \\
\hline Handling & $\$ 0$ & $\$ 0$ & $\$ 0$ & $\$ 0$ & $\$ 0$ & $\$ 0$ \\
\hline \multicolumn{7}{|l|}{ SOS $9 \mathrm{ca}$} \\
\hline Barge & N/A & N/A & N/A & N/A & N/A & N/A \\
\hline Truck & N/A & N/A & N/A & N/A & N/A & N/A \\
\hline Rail & N/A & N/A & N/A & N/A & N/A & N/A \\
\hline Storage & N/A & N/A & N/A & N/A & N/A & N/A \\
\hline Handling & N/A & N/A & N/A & N/A & N/A & N/A \\
\hline \multicolumn{7}{|l|}{ SOS PA } \\
\hline Barge & $\$ 0$ & $\$ 0$ & $\$ 0$ & $\$ 0$ & $\$ 0$ & $\$ 0$ \\
\hline Truck & $\$ 0$ & $\$ 0$ & $\$ 0$ & $\$ 0$ & $\$ 0$ & $\$ 0$ \\
\hline Rail & $\$ 0$ & $\$ 0$ & $\$ 0$ & $\$ 0$ & $\$ 0$ & $\$ 0$ \\
\hline Storage & $\$ 0$ & $\$ 0$ & $\$ 0$ & $\$ 0$ & $\$ 0$ & $\$ 0$ \\
\hline Handling & $\$ 0$ & $\$ 0$ & $\$ 0$ & $\$ 0$ & $\$ 0$ & $\$ 0$ \\
\hline
\end{tabular}

a/ Due to time and resource constraints, transportation costs for SOS 6d and SOS 9c were not allocated to states and subregions.

\section{E.4.4.3 Non-Grain Commodity Movements}

Transportation costs for the non-grain commodities shipped along the Columbia/Snake River system are also expected to increase under the SOR alternatives that include drawdown of the Lower Snake reservoirs. As in the case of grain movements, it is anticipated that the producers of the commodities will pay the increased costs of shipping. These increased transportation costs result in lower net returns to the commodity manufacturers. The lower returns to net income are assumed to result in reduced consumption and investment activities, thereby generating regional economic impacts.

The origins of the non-grain commodity movements are shown by state and subregion in Table E-21. The expected increases in transportation costs paid by non-grain commodity producers under each of the SOR alternatives are presented in Table $\mathrm{E}-22$. 
Table E-21. Allocation of Non-Grain Commodity Origins to Subregions

\begin{tabular}{|l|c|c|c|c|}
\hline \multicolumn{1}{|c|}{ Region } & Petroleum & $\begin{array}{c}\text { Logs and } \\
\text { Wood Chips }\end{array}$ & Wood Products & $\begin{array}{c}\text { Other } \\
\text { Commodities }\end{array}$ \\
\hline By State & $37 \%$ & $25 \%$ & a/ & $10 \%$ \\
Washington & $63 \%$ & $50 \%$ & a/ & $50 \%$ \\
Oregon & a/ & $25 \%$ & $100 \%$ & $40 \%$ \\
Idaho & $50 \%$ & & & \\
By Subregion & $50 \%$ & a/ & a/ & a/ \\
Portland & a/ & $25 \%$ & a/ & $50 \%$ \\
Mid Columbia & a/ & $25 \%$ & a/ & $50 \%$ \\
Lower Snake & a/ & $25 \%$ & $100 \%$ & a/ \\
Northeast & & a/ & a/ \\
Southern Idaho & & &
\end{tabular}

a/ Blank cells indicate that the commodity does not originate in the state and/or subregion.

Table E-22. Transportation Revenues from Non-Grain Commodity Shipments $(\$ 1,000)$

\begin{tabular}{|c|c|c|c|c|}
\hline Alternative & $\begin{array}{c}\text { Pacific } \\
\text { Northwest }\end{array}$ & Washington & Oregon & Idaho \\
\hline \multicolumn{5}{|l|}{ SOS 2c } \\
\hline Petroleum & $\$ 9,848$ & $\$ 3,693$ & $\$ 6,155$ & $\$ 0$ \\
\hline Logs/Wood Chips & $\$ 42,484$ & $\$ 10,621$ & $\$ 21,242$ & $\$ 10,621$ \\
\hline Wood Products & $\$ 1,649$ & $\$ 0$ & $\$ 0$ & $\$ 1,649$ \\
\hline All Others & $\$ 4,763$ & $\$ 476$ & $\$ 2,382$ & $\$ 1,905$ \\
\hline TOTAL & $\$ 58,744$ & $\$ 14,790$ & $\$ 29,778$ & $\$ 14,175$ \\
\hline \multicolumn{5}{|c|}{ Change from Base Case (SOS 2c) } \\
\hline \multicolumn{5}{|c|}{\begin{tabular}{l|l} 
SOS 1a & \\
\end{tabular}} \\
\hline Petroleum & $\$ 0$ & $\$ 0$ & $\$ 0$ & $\$ 0$ \\
\hline Logs/Wood Chips & $\$ 0$ & $\$ 0$ & $\$ 0$ & $\$ 0$ \\
\hline Wood Products & $\$ 0$ & $\$ 0$ & $\$ 0$ & $\$ 0$ \\
\hline All Others & $\$ 0$ & $\$ 0$ & $\$ 0$ & $\$ 0$ \\
\hline TOTAL & $\$ 0$ & $\$ 0$ & $\$ 0$ & $\$ 0$ \\
\hline \multicolumn{5}{|l|}{ SOS 1b } \\
\hline Petroleum & $\$ 0$ & $\$ 0$ & $\$ 0$ & $\$ 0$ \\
\hline Logs/Wood Chips & $\$ 0$ & $\$ 0$ & $\$ 0$ & $\$ 0$ \\
\hline Wood Products & $\$ 0$ & $\$ 0$ & $\$ 0$ & $\$ 0$ \\
\hline All Others & $\$ 0$ & $\$ 0$ & $\$ 0$ & $\$ 0$ \\
\hline TOTAL & $\$ 0$ & $\$ 0$ & $\$ 0$ & $\$ 0$ \\
\hline
\end{tabular}


Table E-22. Transportation Revenues from Non-Grain Commodity Shipments $(\$ 1,000)$ - CONT

\begin{tabular}{|c|c|c|c|c|}
\hline Alternative & $\begin{array}{c}\text { Pacific } \\
\text { Northwest }\end{array}$ & Washington & Oregon & Idaho \\
\hline \multicolumn{5}{|l|}{ SOS 2d } \\
\hline Petroleum & $\$ 0$ & $\$ 0$ & $\$ 0$ & $\$ 0$ \\
\hline Logs/Wood Chips & $\$ 0$ & $\$ 0$ & $\$ 0$ & $\$ 0$ \\
\hline Wood Products & $\$ 0$ & $\$ 0$ & $\$ 0$ & $\$ 0$ \\
\hline All Others & $\$ 0$ & $\$ 0$ & $\$ 0$ & $\$ 0$ \\
\hline TOTAL & $\$ 0$ & $\$ 0$ & $\$ 0$ & $\$ 0$ \\
\hline \multicolumn{5}{|l|}{ SOS 4c } \\
\hline Petroleum & $\$ 0$ & $\$ 0$ & $\$ 0$ & $\$ 0$ \\
\hline Logs/Wood Chips & $\$ 0$ & $\$ 0$ & $\$ 0$ & $\$ 0$ \\
\hline Wood Products & $\$ 0$ & $\$ 0$ & $\$ 0$ & $\$ 0$ \\
\hline All Others & $\$ 0$ & $\$ 0$ & $\$ 0$ & $\$ 0$ \\
\hline TOTAL & $\$ 0$ & $\$ 0$ & $\$ 0$ & $\$ 0$ \\
\hline \multicolumn{5}{|l|}{ SOS 5b } \\
\hline Petroleum & $\$ 141$ & $\$ 53$ & $\$ 88$ & $\$ 0$ \\
\hline Logs/Wood Chips & $\$ 532$ & $\$ 133$ & $\$ 266$ & $\$ 133$ \\
\hline Wood Products & $\$ 167$ & $\$ 0$ & $\$ 0$ & $\$ 167$ \\
\hline All Others & $\$ 177$ & $\$ 18$ & $\$ 88$ & $\$ 71$ \\
\hline TOTAL & $\$ 1,018$ & $\$ 204$ & $\$ 444$ & $\$ 371$ \\
\hline \multicolumn{5}{|l|}{ SOS 5c } \\
\hline Petroleum & $\$ 340$ & $\$ 127$ & $\$ 212$ & $\$ 0$ \\
\hline Logs/Wood Chips & $\$ 1,278$ & $\$ 320$ & $\$ 639$ & $\$ 320$ \\
\hline Wood Products & $\$ 401$ & $\$ 0$ & $\$ 0$ & $\$ 401$ \\
\hline All Others & $\$ 425$ & $\$ 43$ & $\$ 212$ & $\$ 170$ \\
\hline TOTAL & $\$ 2,444$ & $\$ 490$ & $\$ 1,064$ & $\$ 891$ \\
\hline \multicolumn{5}{|l|}{ SOS 6b } \\
\hline Petroleum & $\$ 141$ & $\$ 53$ & $\$ 88$ & $\$ 0$ \\
\hline Logs/Wood Chips & $\$ 532$ & $\$ 133$ & $\$ 266$ & $\$ 133$ \\
\hline Wood Products & $\$ 167$ & $\$ 0$ & $\$ 0$ & $\$ 167$ \\
\hline All Others & $\$ 177$ & $\$ 18$ & $\$ 88$ & $\$ 71$ \\
\hline TOTAL & $\$ 1,018$ & $\$ 204$ & $\$ 444$ & $\$ 371$ \\
\hline \multicolumn{5}{|l|}{ SOS 6d } \\
\hline Petroleum & $\$ 141$ & $\$ 53$ & $\$ 88$ & $\$ 0$ \\
\hline Logs/Wood Chips & $\$ 532$ & $\$ 133$ & $\$ 266$ & $\$ 133$ \\
\hline Wood Products & $\$ 167$ & $\$ 0$ & $\$ 0$ & $\$ 167$ \\
\hline All Others & $\$ 177$ & $\$ 18$ & $\$ 88$ & $\$ 71$ \\
\hline TOTAL & $\$ 1,018$ & $\$ 204$ & $\$ 444$ & $\$ 371$ \\
\hline
\end{tabular}


Table E-22. Transportation Revenues from Non-Grain Commodity Shipments $(\$ 1,000)$ - CONT

\begin{tabular}{|c|c|c|c|c|}
\hline Alternative & $\begin{array}{c}\text { Pacific } \\
\text { Northwest }\end{array}$ & Washington & Oregon & Idaho \\
\hline \multicolumn{5}{|l|}{ SOS 9a } \\
\hline Petroleum & $\$ 141$ & $\$ 53$ & $\$ 88$ & $\$ 0$ \\
\hline Logs/Wood Chips & $\$ 532$ & $\$ 133$ & $\$ 266$ & $\$ 133$ \\
\hline Wood Products & $\$ 167$ & $\$ 0$ & $\$ 0$ & $\$ 167$ \\
\hline All Others & $\$ 177$ & $\$ 18$ & $\$ 88$ & $\$ 71$ \\
\hline TOTAL & $\$ 1,018$ & $\$ 204$ & $\$ 444$ & $\$ 371$ \\
\hline \multicolumn{5}{|l|}{ SOS 9b } \\
\hline Petroleum & $\$ 0$ & $\$ 0$ & $\$ 0$ & $\$ 0$ \\
\hline Logs/Wood Chips & $\$ 0$ & $\$ 0$ & $\$ 0$ & $\$ 0$ \\
\hline Wood Products & $\$ 0$. & $\$ 0$ & $\$ 0$ & $\$ 0$ \\
\hline All Others & $\$ 0$ & $\$ 0$ & $\$ 0$ & $\$ 0$ \\
\hline TOTAL & $\$ 0$ & $\$ 0$ & $\$ 0$ & \$0 \\
\hline \multicolumn{5}{|l|}{ SOS 9c } \\
\hline Petroleum & $\$ 85$ & $\$ 32$ & $\$ 53$ & $\$ 0$ \\
\hline Logs/Wood Chips & $\$ 319$ & $\$ 80$ & $\$ 160$ & $\$ 80$ \\
\hline Wood Products & $\$ 100$ & $\$ 0$ & $\$ 0$ & $\$ 100$ \\
\hline All Others & $\$ 106$ & $\$ 11$ & $\$ 53$ & $\$ 43$ \\
\hline TOTAL & $\$ 611$ & $\$ 123$ & $\$ 266$ & $\$ 223$ \\
\hline \multicolumn{5}{|l|}{ SOS PA } \\
\hline Petroleum & $\$ 0$ & $\$ 0$ & $\$ 0$ & $\$ 0$ \\
\hline Logs/Wood Chips & $\$ 0$ & $\$ 0$ & $\$ 0$ & $\$ 0$ \\
\hline Wood Products & $\$ 0$ & $\$ 0$ & $\$ 0$ & $\$ 0$ \\
\hline All Others & $\$ 0$ & $\$ 0$ & $\$ 0$ & $\$ 0$ \\
\hline TOTAL & $\$ 0$ & $\$ 0$ & $\$ 0$ & $\$ 0$ \\
\hline
\end{tabular}

Table E-22. Transportation Revenues from Non-Grain Commodity Shipments $(\$ 1,000)$ - CONT

\begin{tabular}{|l|c|c|c|c|c|}
\hline \multicolumn{1}{|c|}{ Alternative } & Portland & $\begin{array}{c}\text { Mid } \\
\text { Columbia }\end{array}$ & $\begin{array}{c}\text { Lower } \\
\text { Snake }\end{array}$ & Northeast & $\begin{array}{c}\text { Southern } \\
\text { Idaho }\end{array}$ \\
\hline SOS 2c & & & & & \\
Petroleum & $\$ 4,924$ & $\$ 4,924$ & $\$ 0$ & $\$ 0$ & $\$ 0$ \\
Logs/Wood Chips & $\$ 0$ & $\$ 10,621$ & $\$ 10,621$ & $\$ 10,621$ & $\$ 10,621$ \\
Wood Products & $\$ 0$ & $\$ 0$ & $\$ 0$ & $\$ 1,649$ & $\$ 0$ \\
All Others & $\$ 0$ & $\$ 2,382$ & $\$ 2,382$ & $\$ 0$ & $\$ 0$ \\
TOTAL & $\$ 4,924$ & $\$ 17,926$ & $\$ 13,003$ & $\$ \mathbf{\$ 1 2 , 2 7 0}$ & $\$ \mathbf{1 0 , 6 2 1}$
\end{tabular}


Table E-22. Transportation Revenues from Non-Grain Commodity Shipments $(\$ 1,000)$ - CONT

\begin{tabular}{|c|c|c|c|c|c|}
\hline Alternative & Portland & $\begin{array}{c}\text { Mid } \\
\text { Columbia }\end{array}$ & $\begin{array}{l}\text { Lower } \\
\text { Snake }\end{array}$ & Northeast & $\begin{array}{c}\text { Southern } \\
\text { Idaho }\end{array}$ \\
\hline \multicolumn{6}{|c|}{ Change from Base Case (SOS 2c) } \\
\hline \multicolumn{6}{|c|}{\begin{tabular}{l|l} 
SOS 1a & \\
\end{tabular}} \\
\hline Petroleum & $\$ 0$ & $\$ 0$ & $\$ 0$ & $\$ 0$ & $\$ 0$ \\
\hline Logs/Wood Chips & $\$ 0$ & $\$ 0$ & $\$ 0$ & $\$ 0$ & $\$ 0$ \\
\hline Wood Products & $\$ 0$ & $\$ 0$ & $\$ 0$ & $\$ 0$ & $\$ 0$ \\
\hline All Others & $\$ 0$ & $\$ 0$ & $\$ 0$ & $\$ 0$ & $\$ 0$ \\
\hline TOTAL & $\$ 0$ & \$0 & $\$ 0$ & $\$ 0$ & $\$ 0$ \\
\hline \multicolumn{6}{|l|}{ SOS 1b } \\
\hline Petroleum & $\$ 0$ & $\$ 0$ & $\$ 0$ & $\$ 0$ & $\$ 0$ \\
\hline Logs/Wood Chips & $\$ 0$ & $\$ 0$ & $\$ 0$ & $\$ 0$ & $\$ 0$ \\
\hline Wood Products & $\$ 0$ & $\$ 0$ & $\$ 0$ & $\$ 0$ & $\$ 0$ \\
\hline All Others & $\$ 0$ & $\$ 0$ & $\$ 0$ & $\$ 0$ & $\$ 0$ \\
\hline TOTAL & $\$ 0$ & $\$ 0$ & $\$ 0$ & $\$ 0$ & $\$ 0$ \\
\hline \multicolumn{6}{|l|}{ SOS 2d } \\
\hline Petroleum & $\$ 0$ & $\$ 0$ & $\$ 0$ & $\$ 0$ & $\$ 0$ \\
\hline Logs/Wood Chips & $\$ 0$ & $\$ 0$ & $\$ 0$ & $\$ 0$ & $\$ 0$ \\
\hline Wood Products & $\$ 0$ & $\$ 0$ & $\$ 0$ & $\$ 0$ & $\$ 0$ \\
\hline All Others & $\$ 0$ & $\$ 0$ & $\$ 0$ & $\$ 0$ & $\$ 0$ \\
\hline TOTAL & $\$ 0$ & $\$ 0$ & $\$ 0$ & $\$ 0$ & $\$ 0$ \\
\hline \multicolumn{6}{|l|}{ SOS 4c } \\
\hline Petroleum & $\$ 0$ & $\$ 0$ & $\$ 0$ & $\$ 0$ & $\$ 0$ \\
\hline Logs/Wood Chips & $\$ 0$ & $\$ 0$ & $\$ 0$ & $\$ 0$ & $\$ 0$ \\
\hline Wood Products & $\$ 0$ & $\$ 0$ & $\$ 0$ & $\$ 0$ & $\$ 0$ \\
\hline All Others & $\$ 0$ & $\$ 0$ & $\$ 0$ & $\$ 0$ & $\$ 0$ \\
\hline TOTAL & $\$ 0$ & $\$ 0$ & $\$ 0$ & $\$ 0$ & $\$ 0$ \\
\hline \multicolumn{6}{|l|}{ SOS 5b } \\
\hline Petroleum & $\$ 71$ & $\$ 71$ & $\$ 0$ & $\$ 0$ & $\$ 0$ \\
\hline Logs/Wood Chips & $\$ 0$ & $\$ 133$ & $\$ 133$ & $\$ 133$ & $\$ 133$ \\
\hline Wood Products & $\$ 0$ & $\$ 0$ & $\$ 0$ & $\$ 167$ & $\$ 0$ \\
\hline All Others & $\$ 0$ & $\$ 88$ & $\$ 88$ & $\$ 0$ & $\$ 0$ \\
\hline TOTAL & $\$ 71$ & $\$ 293$ & $\$ 221$ & $\$ 300$ & $\$ 133$ \\
\hline \multicolumn{6}{|l|}{ SOS 5c } \\
\hline Petroleum & $\$ 170$ & $\$ 170$ & $\$ 0$ & $\$ 0$ & $\$ 0$ \\
\hline Logs/Wood Chips & $\$ 0$ & $\$ 320$ & $\$ 320$ & $\$ 320$ & $\$ 320$ \\
\hline Wood Products & $\$ 0$ & $\$ 0$ & $\$ 0$ & $\$ 401$ & $\$ 0$ \\
\hline All Others & $\$ 0$ & $\$ 212$ & $\$ 212$ & $\$ 0$ & $\$ 0$ \\
\hline TOTAL & $\$ 170$ & $\$ 702$ & $\$ 532$ & $\$ 720$ & $\$ 320$ \\
\hline
\end{tabular}


Table E-22. Transportation Revenues from Non-Grain Commodity Shipments $(\$ 1,000)$ - CONT

\begin{tabular}{|c|c|c|c|c|c|}
\hline Alternative & Portland & $\begin{array}{c}\text { Mid } \\
\text { Columbia }\end{array}$ & $\begin{array}{l}\text { Lower } \\
\text { Snake }\end{array}$ & Northeast & $\begin{array}{l}\text { Southern } \\
\text { Idaho }\end{array}$ \\
\hline \multicolumn{6}{|l|}{ SOS 6b } \\
\hline Petroleum & $\$ 71$ & $\$ 71$ & $\$ 0$ & $\$ 0$ & $\$ 0$ \\
\hline Logs/Wood Chips & $\$ 0$ & $\$ 133$ & $\$ 133$ & $\$ 133$ & $\$ 133$ \\
\hline Wood Products & $\$ 0$ & $\$ 0$ & $\$ 0$ & $\$ 167$ & $\$ 0$ \\
\hline All Others & $\$ 0$ & $\$ 88$ & $\$ 88$ & $\$ 0$ & $\$ 0$ \\
\hline TOTAL & $\$ 71$ & $\$ 293$ & $\$ 221$ & $\$ 300$ & $\$ 133$ \\
\hline \multicolumn{6}{|l|}{ SOS 6d } \\
\hline Petroleum & $\$ 71$ & $\$ 71$ & $\$ 0$ & $\$ 0$ & $\$ 0$ \\
\hline Logs/Wood Chips & $\$ 0$ & $\$ 133$ & $\$ 133$ & $\$ 133$ & $\$ 133$ \\
\hline Wood Products & $\$ 0$ & $\$ 0$ & $\$ 0$ & $\$ 167$ & $\$ 0$ \\
\hline All Others & $\$ 0$ & $\$ 88$ & $\$ 88$ & $\$ 0$ & $\$ 0$ \\
\hline TOTAL & $\$ 71$ & $\$ 293$ & $\$ 221$ & $\$ 300$ & $\$ 133$ \\
\hline \multicolumn{6}{|l|}{ SOS 9a } \\
\hline Petroleum & $\$ 71$ & $\$ 71$ & $\$ 0$ & $\$ 0$ & $\$ 0$ \\
\hline Logs/Wood Chips & $\$ 0$ & $\$ 133$ & $\$ 133$ & $\$ 133$ & $\$ 133$ \\
\hline Wood Products & $\$ 0$ & $\$ 0$ & $\$ 0$ & $\$ 167$ & $\$ 0$ \\
\hline All Others & $\$ 0$ & $\$ 88$ & $\$ 88$ & $\$ 0$ & $\$ 0$ \\
\hline TOTAL & $\$ 71$ & $\$ 293$ & $\$ 221$ & $\$ 300$ & $\$ 133$ \\
\hline \multicolumn{6}{|l|}{ SOS 9b } \\
\hline Petroleum & $\$ 0$ & $\$ 0$ & $\$ 0$ & $\$ 0$ & $\$ 0$ \\
\hline Logs/Wood Chips & $\$ 0$ & $\$ 0$ & $\$ 0$ & $\$ 0$ & $\$ 0$ \\
\hline Wood Products & $\$ 0$ & $\$ 0$ & $\$ 0$ & $\$ 0$ & $\$ 0$ \\
\hline All Others & $\$ 0$ & $\$ 0$ & $\$ 0$ & $\$ 0$ & $\$ 0$ \\
\hline TOTAL & $\$ 0$ & $\$ 0$ & $\$ 0$ & $\$ 0$ & $\$ 0$ \\
\hline \multicolumn{6}{|l|}{ SOS 9c } \\
\hline Petroleum & $\$ 42$ & $\$ 42$ & $\$ 0$ & $\$ 0$ & $\$ 0$ \\
\hline Logs/Wood Chips & $\$ 0$ & $\$ 80$ & $\$ 80$ & $\$ 80$ & $\$ 80$ \\
\hline Wood Products & $\$ 0$ & $\$ 0$ & $\$ 0$ & $\$ 100$ & $\$ 0$ \\
\hline All Others & $\$ 0$ & $\$ 53$ & $\$ 53$ & $\$ 0$ & $\$ 0$ \\
\hline TOTAL & $\$ 42$ & $\$ 176$ & $\$ 133$ & $\$ 180$ & $\$ 80$ \\
\hline \multicolumn{6}{|l|}{ SOS PA } \\
\hline Petroleum & $\$ 0$ & $\$ 0$ & $\$ 0$ & $\$ 0$ & $\$ 0$ \\
\hline Logs/Wood Chips & $\$ 0$ & $\$ 0$ & $\$ 0$ & $\$ 0$ & $\$ 0$ \\
\hline Wood Products & $\$ 0$ & $\$ 0$ & $\$ 0$ & $\$ 0$ & $\$ 0$ \\
\hline All Others & $\$ 0$ & $\$ 0$ & $\$ 0$ & $\$ 0$ & $\$ 0$ \\
\hline TOTAL & $\$ 0$ & $\$ 0$ & $\$ 0$ & $\$ 0$ & $\$ 0$ \\
\hline
\end{tabular}




\section{Changes in Non-Grain Transportation Modes}

As in the case of grain movements, the increased transportation costs for the non-grain commodities result from modal shifts and from changes in the location of intermediate shipping nodes. This change in regional transportation activity associated with the shipment of non-grain commodities along the Columbia-Snake River system will also result in a shift in the related regional income and employment generated by these activities. ${ }^{13}$ However, due to limited time and resource constraints, the Economic Analysis Group was unable to allocate the shift in non-grain transportation revenues that would occur to specific state and subregional transportation activities.

\section{E.4.5 Power}

The direct impacts of the SOR alternatives on the regional power system were developed by the SOR Power Work Group. Impacts are measured as the net system replacement cost for electricity, a concept which takes into account the changes in resource mix required to meet anticipated regional loads, including the response in consumer demand to higher energy costs. BPA utilized internal systems analysis and decision models to evaluate the SOR direct power impacts.

Generally, the models evaluate the effects of the hydro operations strategies on power supply, incremental energy costs, and consumer demand. The ability of the regional power system to produce both capacity and energy is affected by the SOR operations alternatives, requiring an adjustment in the least-cost resource mix necessary to meet forecasted regional electricity demands. Changes to the resource mix cause average wholesale power rates to increase. As power rates adjust upward, regional consumers use less electricity. This leads to continued rounds of adjustments to resource mix, electric- ity price, and consumer demand until a supply-demand balance is achieved. ${ }^{14}$

The net system resource costs necessary to meet the adjusted forecast of electricity demand is the measure of direct economic impacts under the SOR alternatives. The resulting adjustments in wholesale power rates will lead to changes in electricity costs for all consumers served through the federal system. Regional economic impacts associated with the direct power analysis will be determined by ratepayer adjustments to the changes in power costs.

In the indirect economic analysis it is assumed that an increase in the regional power bill results in a direct decline in household income available to purchase other goods and services. This is reflected in the regional analysis as a final demand change in a set of personal consumption vectors that incorporates a wide range of household purchases of goods and services.

\section{E.4.5.1 Allocating the Power Cost Impacts to Subregions}

Regional economic power impacts are estimated for the Pacific Northwest as a whole, the states of Washington, Oregon, Idaho, and Montana, and the eight SOR subregions. The expected power bill changes were allocated to states and subregions on the basis of 1990 annual load shares for utility and direct service industry sales. Distribution of the power impacts by state are presented in Table E-23. The allocations are based upon the 1990 regional sales data for all Pacific Northwest public and private electric utilities. ${ }^{15}$ Results of the regional economic analysis related to power are presented in a later section, Results of the Regional Economic Impact Analysis.

Expected changes in regional power costs were also allocated to the eight SOR subregions. Power costs were allocated based on the proportion of 1990 regional power sales made to customers located in

13 The shift in regional transportation activity would be similar to that discussed previously for gain movements.

14 Appendix O of the SOR Final Environmental Impact Statement provides a more extensive discussion of the methodology and calculations for the direct economic impacts.

15 Information received from Bonneville Power Administration, March, 1994, and September, 1995. 
the subregions. The distribution of power impacts by subregion are presented in Table E-24.

\section{E.4.5.2 Increased Power Purchases}

The increased power bills expected to be paid by regional consumers under several of the SOR alternatives result from increases in non-hydro power purchases that become necessary under the revised river operations. It is expected that these increased purchases will also generate economic impacts throughout the region.
BPA estimates that under the power purchase scenarios relying on combustion turbines, $60 \%$ of the required purchases will be made outside the Pacific Northwest region. The remaining $40 \%$ of purchases will generate economic impacts within the region. These impacts are taken into account in the regional power analysis. Impacts associated with the increased power purchases could not be allocated to the states or subregions due to lack of information on the potential locations of new generating sites.

Table E-23. Net System Power Replacement Costs Allocated to States, 2020 and Beyond $(\$ 1,000)$

\begin{tabular}{|l|c|c|c|c|c|}
\hline Alternative & $\begin{array}{c}\text { Pacific } \\
\text { Northwest }\end{array}$ & Washington & Oregon & Idaho & Montana \\
\hline SOS 2c & $\$ 1,406,000$ & $\$ 781,736$ & $\$ 403,522$ & $\$ 163,096$ & $\$ 57,646$ \\
\hline Change from Base Case (SOS 2c) & \multicolumn{5}{|l|}{} \\
\hline SOS 1a & $(\$ 39,000)$ & $(\$ 21,684)$ & $(\$ 11,193)$ & $(\$ 4,524)$ & $(\$ 1,599)$ \\
SOS 1b & $(\$ 78,000)$ & $(\$ 43,368)$ & $(\$ 22,386)$ & $(\$ 9,048)$ & $(\$ 3,198)$ \\
SOS 2d & $\$ 23,000$ & $\$ 12,788$ & $\$ 6,601$ & $\$ 2,668$ & $\$ 943$ \\
SOS 4c & $\$ 89,000$ & $\$ 49,484$ & $\$ 25,543$ & $\$ 10,324$ & $\$ 3,649$ \\
SOS 5b & $\$ 136,000$ & $\$ 75,616$ & $\$ 39,032$ & $\$ 15,776$ & $\$ 5,576$ \\
SOS 5c & $\$ 199,000$ & $\$ 110,644$ & $\$ 57,113$ & $\$ 23,084$ & $\$ 8,159$ \\
SOS 6b & $\$ 48,000$ & $\$ 26,688$ & $\$ 13,776$ & $\$ 5,568$ & $\$ 1,968$ \\
SOS 6d & $\$ 20,000$ & $\$ 11,120$ & $\$ 5,740$ & $\$ 2,320$ & $\$ 820$ \\
SOS 9a & $\$ 323,000$ & $\$ 179,588$ & $\$ 92,701$ & $\$ 37,468$ & $\$ 13,243$ \\
SOS 9b & $\$ 220,000$ & $\$ 122,320$ & $\$ 63,140$ & $\$ 25,520$ & $\$ 9,020$ \\
SOS 9c & $\$ 189,000$ & $\$ 105,084$ & $\$ 54,243$ & $\$ 21,924$ & $\$ 7,749$ \\
SOS PA & $\$ 140,000$ & $\$ 77,840$ & $\$ 40,180$ & $\$ 16,240$ & $\$ 5,740$ \\
\hline
\end{tabular}


Table E-24. Net System Power Replacement Costs Allocated to Subregions, 2020 and Beyond $(\$ 1,000)$

\begin{tabular}{|c|c|c|c|c|}
\hline Alternative & $\begin{array}{l}\text { Lower } \\
\text { Snake }\end{array}$ & $\begin{array}{c}\text { Mid } \\
\text { Columbia }\end{array}$ & Northeast & Portland \\
\hline $\operatorname{SOS} 2 \mathrm{c}$ & $\$ 51,849$ & $\$ 93,444$ & $\$ 160,296$ & $\$ 216,618$ \\
\hline \multicolumn{5}{|c|}{ Change from Base Case (SOS 2c) } \\
\hline SOS 1a & $(\$ 1,438)$ & $(\$ 2,592)$ & $(\$ 4,446)$ & $(\$ 6,009)$ \\
\hline SOS $1 b$ & $(\$ 2,876)$ & $(\$ 5,184)$ & $(\$ 8,893)$ & $(\$ 12,017)$ \\
\hline SOS 2d & $\$ 848$ & $\$ 1,529$ & $\$ 2,622$ & $\$ 3,544$ \\
\hline $\operatorname{SOS} 4 c$ & $\$ 3,282$ & $\$ 5,915$ & $\$ 10,147$ & $\$ 13,712$ \\
\hline SOS $5 b$ & $\$ 5,015$ & $\$ 9,039$ & $\$ 15,505$ & $\$ 20,953$ \\
\hline $\operatorname{sos} 5 \mathrm{c}$ & $\$ 7,339$ & $\$ 13,226$ & $\$ 22,688$ & $\$ 30,659$ \\
\hline SOS $6 \mathbf{b}$ & $\$ 1,770$ & $\$ 3,190$ & $\$ 5,472$ & $\$ 7,395$ \\
\hline SOS 6d & $\$ 738$ & $\$ 1,329$ & $\$ 2,280$ & $\$ 3,081$ \\
\hline SOS 9a & $\$ 11,911$ & $\$ 21,467$ & $\$ 36,825$ & $\$ 49,764$ \\
\hline SOS 9b & $\$ 8,113$ & $\$ 14,621$ & $\$ 25,082$ & $\$ 33,895$ \\
\hline $\operatorname{sos} 9 \mathrm{c}$ & $\$ 6,970$ & $\$ 12,561$ & $\$ 21,548$ & $\$ 29,119$ \\
\hline SOS PA & $\$ 5,163$ & $\$ 9,305$ & $\$ 15,961$ & $\$ 21,569$ \\
\hline Alternative & $\begin{array}{l}\text { Puget } \\
\text { Sound }\end{array}$ & $\begin{array}{c}\text { Southern } \\
\text { Idaho }\end{array}$ & $\begin{array}{c}\text { Upper } \\
\text { Columbia }\end{array}$ & $\begin{array}{l}\text { West } \\
\text { Coast }\end{array}$ \\
\hline SOS 2c & $\$ 397,186$ & $\$ 110,047$ & $\$ 84,374$ & $\$ 127,626$ \\
\hline \multicolumn{5}{|c|}{ Change from Base Case (SOS 2c) } \\
\hline SOS 1a & $(\$ 11,017)$ & $(\$ 3,053)$ & $(\$ 2,340)$ & $(\$ 3,540)$ \\
\hline $\operatorname{SOS} 1 \mathbf{b}$ & $(\$ 22,035)$ & $(\$ 6,105)$ & $(\$ 4,681)$ & $(\$ 7,080)$ \\
\hline $\operatorname{sos} 2 \mathrm{~d}$ & $\$ 6,497$ & $\$ 1,800$ & $\$ 1,380$ & $\$ 2,088$ \\
\hline $\operatorname{sOS} 4 c$ & $\$ 25,142$ & $\$ 6,966$ & $\$ 5,341$ & $\$ 8,079$ \\
\hline SOS 5b & $\$ 38,419$ & $\$ 10,645$ & $\$ 8,161$ & $\$ 12,345$ \\
\hline SOS 5c & $\$ 56,216$ & $\$ 15,576$ & $\$ 11,942$ & $\$ 18,064$ \\
\hline SOS $\mathbf{6 b}$ & $\$ 13,560$ & $\$ 3,757$ & $\$ 2,880$ & $\$ 4,357$ \\
\hline SOS 6d & $\$ 5,650$ & $\$ 1,565$ & $\$ 1,200$ & $\$ 1,815$ \\
\hline SOS 9a & $\$ 91,246$ & $\$ 25,281$ & $\$ 19,383$ & $\$ 29,320$ \\
\hline SOS 9b & $\$ 62,149$ & $\$ 17,219$ & $\$ 13,202$ & $\$ 19,970$ \\
\hline Sos 9c & $\$ 53,391$ & $\$ 14,793$ & $\$ 11,342$ & $\$ 17,156$ \\
\hline SOS PA & $\$ 39,549$ & $\$ 10,958$ & $\$ 8,401$ & $\$ 12,708$ \\
\hline
\end{tabular}




\section{E.4.6 Recreation}

Recreation activity at sixteen federal project sites along the Columbia/Snake River system would be affected by the alternative operations strategies being evaluated in the SOR. ${ }^{16}$ Locations of the federal project sites within the SOR subregions are presented in Table E-25. At least one and sometimes several of the projects would encounter changes in visitor activities under the various alternatives. Activities that may be affected include boating, windsurfing, sport fishing, swimming, hunting, wildlife viewing, camping, and picnicking. Estimates of recreation visits at each of the project sites under the SOR alternatives were prepared by the Recreation Work Group using a survey-based model developed by RCG/Hagler-Baily [RCG].

The direct economic impacts for recreation are measured as the changes in consumer surplus associated with the expected increases or decreases in recreation visitor use at the project sites. The regional economic impacts related to recreation derive from changes in trip-related expenditures made by visitors on-site and en-route to their recreation destinations. It is assumed in the regional analysis that economic impacts will be generated only by changes in the number of non-resident recreation visitors. ${ }^{17}$ It is also assumed that resident participants would substitute the foregone activity at the affected reservoir site for another type of recreation opportunity elsewhere in the region. ${ }^{18}$

\section{E.4.6.1 Characteristics of the Federal Project Recreation Visitors}

Recreation managers for each of the federal projects were contacted to provide information on key characteristics of recreation visitors to the project sites. A brief questionnaire was designed by Northwest Economic Associates and administered by the Recreation Work Group to collect visitor use data for the sixteen federal sites under study. The objective of the questionnaire was to collect information on the residence origin of visitors to the federal sites, average length of stay (day-use or overnight), lodging choices made by overnight visitors, and primary recreation activity during the trip. The written questionnaire was conveyed to the appropriate project managers by the Recreation Work Group. The managers were instructed to answer the questions with a "best guess" in situations where they lacked sufficient recorded data.

16 It has been determined by the SOR Recreation Work Group that impacts at four of the sixteen projects - Chief Joseph, McNary, the Dalles, and Bonneville - are likely to be minimal.

17 Non-resident visitor refers to recreation participants who do not reside within the particular SOR state or subregion for which impacts are being estimated.

18 A survey of recreation visitors to the federal projects was prepared by RCG for the Recreation Work Group. The survey was conducted to gather visitor data that was later incorporated into a recreation demand model. Among other things, the survey gathered information to determine the degree to which recreation visitors are likely to substitute visits at one site with visits at alternative sites, given varying reservoir water levels. RCG cautioned the Recreation Work Group that while the information collected was appropriate for inclusion in the recreation models, the data were not appropriate for providing descriptive information on the proportion of visitors substituting visits to alternative recreation sites. The survey data has limited descriptive value because the survey sampling procedure included both a random sample of Pacific Northwest residents and an oversample of residents in counties adjacent to the reservoir sites The oversample was prepared to ensure that recreation visitors to the project sites were adequately represented in the sample data set. Therefore, because "resident: visitors are over-represented in the sample data, RCG advised the Recreation Work Group to use alternative information sources to gather descriptive information on visitor characteristics. After consultation with the recreation managers of the federal projects, the Recreation Work Group determined that resident visitors to the project sites would substitute in-region recreation opportunities for alternative in-region opportunities. 
Table E-25. Location of the Federal Projects Within SOR Subregions

\begin{tabular}{|l|l|l|}
\hline \multirow{2}{*}{ Federal Project } & \multicolumn{2}{|c|}{ Project Location } \\
\cline { 2 - 3 } & \multicolumn{1}{|c|}{ SOR Subregion } & \multicolumn{1}{c|}{ State } \\
\hline Bonneville & Mid Columbia & Washington/Oregon \\
The Dalles & Mid Columbia & Washington/Oregon \\
John Day & Mid Columbia & Washington/Oregon \\
McNary & Mid Columbia & Washington/Oregon \\
Chief Joseph & Upper Columbia & Washington \\
Grand Coulee & Upper Columbia & Washington \\
Libby/Below Libby & Northeast & Montana \\
Albeni Falls & Northeast & Idaho \\
Hungry Horse & Northeast & Montana \\
Ice Harbor & Mid Columbia & Washington \\
Lower Monumental & Mid Columbia & Washington \\
Little Goose & Lower Snake & Washington \\
Lower Granite & Lower Snake & Washington/Idaho \\
Dworshak/Below Dworshak & Lower Snake & Idaho \\
\hline
\end{tabular}

Results from the survey of federal project managers are presented in Tables E-26 and E-27. The residence origin of visitors to the project sites and the length of stay of the recreation visit are shown in Table E-26. Non-resident refers to all recreation participants who do not reside within the same SOR subregion as the specific project site. Length of stay distinguishes day use versus overnight activity.

Expenditures by overnight visitors are typically much greater than those made by day-use participants. Choice of lodging by overnight visitors is presented in Table E-27. The information was used to further distinguish expenditure patterns by visitors to the SOR recreation sites.

\section{E.4.6.2 Recreation Visitor Expenditures}

The visitor expenditure patterns used in the regional analysis were developed using existing studies of recreation-related spending. Although a variety of studies are available for specific recreation activities, insufficient information was available to incorporate this level of detail into the analysis. For example, several survey-based studies have developed typical expenditure patterns for windsurfers. However, the survey data provided by the SOR recreation project managers does not provide sufficient detail to determine the residence origin of windsurfers versus the residence origin of campers. Similarly, there is insufficient information to distinguish the day-use vs. overnight use pattern of boaters from that of windsurfers. Therefore, more generalized expenditure patterns were incorporated into the regional analysis.

Expenditure patterns developed for the Army Corps of Engineers by Michigan State University and the Waterways Experiment Station were used to quantify the regional economic impacts related to recreation [Michigan State University]. This research project developed spending profiles for twelve types of visitors, including resident day-users (boaters and non-boaters), non-resident day-users (boaters and non-boaters), resident campers (boaters and non-boaters), non-resident campers (boaters and non-boaters), resident other overnight lodgings (boaters and non-boaters), and non-resident other overnight lodgings (boaters and non-boaters). 
Table E-26. Residence Origin and Length of Stay for Recreation Visitors at the SOR Federal Project Sites

\begin{tabular}{|l|c|c|c|c|}
\hline \multirow{2}{*}{\multicolumn{1}{|c|}{ Federal Project }} & \multicolumn{2}{c|}{ Visitor Origin } & \multicolumn{2}{c|}{ Length of Stay } \\
\cline { 2 - 5 } & Resident & Non-Resident & Day Use & Overnight \\
\hline Bonneville & $1 \%$ & $99 \%$ & $70 \%$ & $30 \%$ \\
The Dalles & $10 \%$ & $90 \%$ & $40 \%$ & $60 \%$ \\
John Day & $20 \%$ & $80 \%$ & $40 \%$ & $60 \%$ \\
McNary & $20 \%$ & $80 \%$ & $83 \%$ & $17 \%$ \\
Chief Joseph & $42 \%$ & $58 \%$ & $90 \%$ & $10 \%$ \\
Grand Coulee & $15 \%$ & $85 \%$ & $70 \%$ & $30 \%$ \\
Libby/Below Libby & $80 \%$ & $20 \%$ & $12 \%$ & $88 \%$ \\
Albeni Falls & $76 \%$ & $24 \%$ & $88 \%$ & $12 \%$ \\
Hungry Horse & $50 \%$ & $50 \%$ & $45 \%$ & $55 \%$ \\
Ice Harbor & $9 \%$ & $91 \%$ & $72 \%$ & $28 \%$ \\
Lower Monumental & $0 \%$ & $100 \%$ & $68 \%$ & $32 \%$ \\
Little Goose & $3 \%$ & $97 \%$ & $65 \%$ & $35 \%$ \\
Lower Granite & $9 \%$ & $91 \%$ & $86 \%$ & $14 \%$ \\
Dworshak/Below Dworshak & $44 \%$ & $56 \%$ & $92 \%$ & $8 \%$ \\
\hline
\end{tabular}

Table E-27. Choice of Lodging by Overnight Visitors to the SOR Federal Project Sites

\begin{tabular}{|l|c|c|c|}
\hline \multirow{2}{*}{\multicolumn{1}{|c|}{ Federal Project }} & \multicolumn{3}{|c|}{ Choice of Overnight Lodging } \\
\cline { 2 - 3 } Bonneville & Camping & Motels/Hotels & Family/Friends \\
The Dalles & $40 \%$ & $45 \%$ & $15 \%$ \\
John Day & $55 \%$ & $25 \%$ & $20 \%$ \\
McNary & $65 \%$ & $20 \%$ & $15 \%$ \\
Chief Joseph & $94 \%$ & $5 \%$ & $1 \%$ \\
Grand Coulee & $91 \%$ & $4 \%$ & $5 \%$ \\
Libby/Below Libby & $75 \%$ & $10 \%$ & $15 \%$ \\
Albeni Falls & $85 \%$ & $10 \%$ & $5 \%$ \\
Hungry Horse & $100 \%$ & $0 \%$ & $0 \%$ \\
Ice Harbor & $90 \%$ & $5 \%$ & $5 \%$ \\
Lower Monumental & $96 \%$ & $1 \%$ & $3 \%$ \\
Little Goose & $100 \%$ & $0 \%$ & $0 \%$ \\
Lower Granite & $100 \%$ & $0 \%$ & $0 \%$ \\
Dworshak/Below Dworshak & $90 \%$ & $8 \%$ & $2 \%$ \\
\hline
\end{tabular}


Information from the project manager survey identifies only the primary purpose of the visit. However, many visitors participate in multiple activities during a given trip, e.g., people fish and boat, or boat and picnic. Given the lack of refinement in the visitor characteristics data, the expenditure patterns in the Waterways Experiment Station study were aggregated into six general groups:

- resident and non-resident day-use;

- resident and non-resident campers; and

- resident and non-resident other overnight lodgings.

Budgets for boaters and non-boaters were averaged to create expenditure patterns for the six aggregated groups. The expenditure patterns were converted from a per visit basis to a per visitor day basis. The final non-resident recreation visitor expenditure patterns used for the regional analysis are shown in Table E-28.

\section{E.4.7 Allocation of Recreation Impacts to Subregions}

The regional economic impacts related to recreation are estimated for the Pacific Northwest and for the states and subregions identified in Table E-25. The expected changes in visitor days were allocated to states and subregions on the basis of project location. For projects bordering two states, changes in visitor days were divided equally between the states. Recreation visitor days for each of the final SOR alternatives are presented by state and subregion in Table E-29.

Estimates of total annual visitor days by primary activity for each project site were prepared by the Recreation Work Group using the recreation model developed for the SOR by RCG. Visitor day estimates were taken directly from Table 4-48 of Appendix $O$ of the FEIS. These data were combined with the recreation visitor characteristics and estimated expenditure patterns to evaluate expected regional economic impacts. Results of the regional recreation analysis are presented in a later section of this document, Results of the Regional Economic Impact Analysis.

Table E-28. Recreation Expenditures of Non-Resident Visitors to the Federal Projects

\begin{tabular}{|l|c|c|c|}
\hline Recreation Expenditures & Day-Use & Campers & Other Overnight \\
\hline Lodging & $\$ 0.00$ & $\$ 3.24$ & $\$ 14.19$ \\
Food & $\$ 5.03$ & $\$ 6.10$ & $\$ 8.32$ \\
Transportation & $\$ 2.05$ & $\$ 3.62$ & $\$ 3.54$ \\
Boat & $\$ 1.64$ & $\$ 2.64$ & $\$ 4.09$ \\
Fishing & $\$ 0.25$ & $\$ 0.39$ & $\$ 0.82$ \\
Hunting & $\$ 0.00$ & $\$ 0.00$ & $\$ 0.46$ \\
Recreation & $\$ 0.19$ & $\$ 0.64$ & $\$ 1.60$ \\
Other & $\$ 1.03$ & $\$ 2.08$ & $\$ 2.36$ \\
\hline Total Expenditures & $\$ 10.19$ & $\$ 18.71$ & $\$ 35.38$ \\
\hline
\end{tabular}


Table E-29. Annual Recreation Days and Length of Stay at the SOR Federal Project Sites, Allocated to States and Subregions

\begin{tabular}{|c|c|c|c|c|c|}
\hline \multirow[b]{2}{*}{ Alternative } & \multirow{2}{*}{$\begin{array}{c}\text { Total } \\
\text { Visitors }\end{array}$} & \multicolumn{2}{|c|}{ Resident } & \multicolumn{2}{|c|}{ Non-Resident } \\
\hline & & Day Use & Overnight & Day Use & Overnight \\
\hline \multicolumn{6}{|c|}{ Pacific Northwest } \\
\hline $\operatorname{SOS} 2 c$ & $9,105,175$ & $5,523,418$ & $2,180,629$ & 232,527 & $1,168,600$ \\
\hline \multicolumn{6}{|c|}{ Change from Base Case (SOS 2c) } \\
\hline SOS 1a & 225,103 & 59,009 & 126,902 & $(1,243)$ & 40,436 \\
\hline $\operatorname{SOS} 1 \mathrm{~b}$ & 262,148 & 88,589 & 127,116 & 1,177 & 45,267 \\
\hline $\operatorname{sos} 2 d$ & 18,169 & 20,880 & $(4,007)$ & 0 & 1,296 \\
\hline Sos $4 c$ & 193,925 & 63,089 & 107,041 & $(4,646)$ & 28,441 \\
\hline SOS 5b & $(1,822,015)$ & $(1,209,848)$ & $(280,097)$ & $(56,689)$ & $(275,381)$ \\
\hline SOS $5 c$ & $(2,072,844)$ & $(1,397,268)$ & $(290,382)$ & $(71,179)$ & $(314,015)$ \\
\hline $\operatorname{SOS} 6 \mathbf{b}$ & $(1,157,131)$ & $(711,891)$ & $(241,680)$ & $(29,337)$ & $(174,223)$ \\
\hline SOS 6d & $(860,607)$ & $(505,358)$ & $(201,214)$ & $(29,337)$ & $(124,698)$ \\
\hline $\operatorname{sos} 9 \mathrm{a}$ & $(2,056,737)$ & $(1,311,311)$ & $(424,593)$ & $(55,147)$ & $(265,685)$ \\
\hline $\operatorname{SOS} 9 \mathrm{~b}$ & $(410,393)$ & $(302,614)$ & $(58,511)$ & $(10,183)$ & $(39,085)$ \\
\hline SOS 9c & $(889,359)$ & $(506,393)$ & $(242,948)$ & $(15,693)$ & $(124,325)$ \\
\hline SOS PA & $(1,111,913)$ & $(457,604)$ & $(496,055)$ & 2,718 & $(160,972)$ \\
\hline \multicolumn{6}{|l|}{ Washington } \\
\hline $\operatorname{SOS} 2 \mathrm{c}$ & $5,858,392$ & $3,353,504$ & 622,904 & 519,057 & $1,362,927$ \\
\hline \multicolumn{6}{|c|}{ Change from Base Case (SOS 2c) } \\
\hline SOS 1a & 164,468 & 59,234 & 70,092 & $(3,963)$ & 39,105 \\
\hline SOS 1b & 204,264 & 83,124 & 70,107 & 5,322 & 45,712 \\
\hline SOS 2d & $(7,257)$ & $(4,790)$ & 0 & $(290)$ & $(2,177)$ \\
\hline $\operatorname{sos} 4 c$ & 99,811 & 32,332 & 46,216 & $(3,860)$ & 25,123 \\
\hline SOS 5b & $(1,663,483)$ & $(989,035)$ & $(125,028)$ & $(218,693)$ & $(330,727)$ \\
\hline SOS 5c & $(1,942,413)$ & $(1,160,493)$ & $(128,579)$ & $(274,997)$ & $(378,345)$ \\
\hline SOS $6 \mathrm{~b}$ & $(990,938)$ & $(562,958)$ & $(112,275)$ & $(112,413)$ & $(203,292)$ \\
\hline SOS 6d & $(694,414)$ & $(356,425)$ & $(98,826)$ & $(112,413)$ & $(126,751)$ \\
\hline sos 9a & $(1,538,664)$ & $(918,278)$ & $(118,523)$ & $(149,078)$ & $(352,785)$ \\
\hline SOS 9b & $(263,750)$ & $(172,083)$ & $(1,384)$ & $(19,590)$ & $(70,692)$ \\
\hline SOS 9c & $(708,430)$ & $(377,779)$ & $(116,622)$ & $(52,181)$ & $(161,848)$ \\
\hline SOS PA & $(711,642)$ & $(295,192)$ & $(239,239)$ & 637 & $(177,848)$ \\
\hline
\end{tabular}


Table E-29. Annual Recreation Days and Length of Stay at the SOR Federal Project Sites, Allocated to States and Subregions - CONT

\begin{tabular}{|c|c|c|c|c|c|}
\hline \multicolumn{6}{|l|}{ Oregon } \\
\hline $\operatorname{SOS} 2 c$ & 922,495 & 368,998 & 155,902 & 0 & 397,596 \\
\hline \multicolumn{6}{|c|}{ Change from Base Case (SOS 2c) } \\
\hline $\operatorname{sos} 1 a$ & 109,968 & 43,987 & 18,585 & 0 & 47,396 \\
\hline $\operatorname{sos} 1 b$ & 109,968 & 43,987 & 18,585 & 0 & 47,396 \\
\hline $\operatorname{sos} 2 d$ & 0 & 0 & 0 & 0 & 0 \\
\hline SOS $4 c$ & 73,878 & 29,551 & 12,485 & 0 & 31,842 \\
\hline SOS 5b & $(156,830)$ & $(62,732)$ & $(26,504)$ & 0 & $(67,594)$ \\
\hline $\operatorname{SOS} 5 \mathrm{c}$ & $(156,830)$ & $(62,732)$ & $(26,504)$ & 0 & $(67,594)$ \\
\hline $\operatorname{sos} 6 b$ & $(156,830)$ & $(62,732)$ & $(26,504)$ & 0 & $(67,594)$ \\
\hline $\operatorname{sos} 6 d$ & $(156,830)$ & $(62,732)$ & $(26,504)$ & 0 & $(67,594)$ \\
\hline $\operatorname{sos} 9 a$ & $(163,006)$ & $(65,202)$ & $(27,548)$ & 0 & $(70,256)$ \\
\hline SOS 9b & 0 & 0 & 0 & 0 & 0 \\
\hline $\operatorname{sos} 9 c$ & $(175,845)$ & $(70,338)$ & $(29,718)$ & 0 & $(75,789)$ \\
\hline SOS PA & $(380,244)$ & $(152,098)$ & $(64,261)$ & 0 & $(163,885)$ \\
\hline \multicolumn{6}{|l|}{ Idaho } \\
\hline $\operatorname{sos} 2 c$ & $1,552,148$ & 448,485 & 0 & 930,591 & 173,072 \\
\hline \multicolumn{6}{|c|}{ Change from Base Case (SOS 2c) } \\
\hline SOS 1a & $(44,402)$ & $(16,832)$ & 0 & $(23,754)$ & $(3,816)$ \\
\hline $\operatorname{sos} 1 \mathrm{~b}$ & $(44,321)$ & $(16,940)$ & 0 & $(23,612)$ & $(3,769)$ \\
\hline $\operatorname{SOS} 2 \mathrm{~d}$ & 28,918 & 11,567 & 0 & 15,037 & 2,313 \\
\hline $\operatorname{sos} 4 c^{\circ}$ & $(14,110)$ & $(91)$ & 0 & $(11,315)$ & $(2,704)$ \\
\hline SOS 5b & 6,047 & 3,087 & 0 & 2,666 & 294 \\
\hline sos 5c & 34,146 & 14,326 & 0 & 17,277 & 2,542 \\
\hline $\operatorname{sos} 6 b$ & $(1,616)$ & 22 & 0 & $(1,319)$ & (319) \\
\hline $\operatorname{sos} 6 \mathrm{~d}$ & $(1,616)$ & 22 & 0 & $(1,319)$ & (319) \\
\hline SOS 9a & $(234,419)$ & $(62,552)$ & 0 & $(144,258)$ & $(27,609)$ \\
\hline $\operatorname{sos} 9 \mathrm{~b}$ & $(135,652)$ & $(43,758)$ & 0 & $(78,062)$ & $(13,832)$ \\
\hline $\operatorname{sos} 9 c$ & $(37,824)$ & $(10,250)$ & 0 & $(23,164)$ & $(4,410)$ \\
\hline SOS PA & $(8,017)$ & $(6,123)$ & 0 & $(2,080)$ & 186 \\
\hline
\end{tabular}


Table E-29. Annual Recreation Days and Length of Stay at the SOR Federal Project Sites, Allocated to States and Subregions - CONT

\begin{tabular}{|c|c|c|c|c|c|}
\hline \multirow[b]{2}{*}{ Alternative } & \multirow{2}{*}{$\begin{array}{c}\text { Total } \\
\text { Visitors }\end{array}$} & \multicolumn{2}{|c|}{ Resident } & \multicolumn{2}{|c|}{ Non-Resident } \\
\hline & & Day Use & Overnight & Day Use & Overnight \\
\hline \multicolumn{6}{|l|}{ Montana } \\
\hline $\operatorname{sOS} 2 c$ & 772,140 & 98,732 & 94,504 & 36,580 & 542,325 \\
\hline \multicolumn{6}{|c|}{ Change from Base Case (SOS 2c) } \\
\hline SOS 1a & $(4,931)$ & (637) & $(585)$ & (270) & $(3,440)$ \\
\hline $\operatorname{sos} 1 \mathrm{~b}$ & $(7,763)$ & $(1,100)$ & (614) & $(1,015)$ & $(5,034)$ \\
\hline SOS 2d & $(3,492)$ & (451) & (413) & (193) & $(2,435)$ \\
\hline $\operatorname{sOS} 4 c$ & 34,346 & 5,219 & 1,617 & 6,606 & 20,904 \\
\hline $\operatorname{sos} 5 b$ & $(7,749)$ & $(1,058)$ & (739) & (771) & $(5,181)$ \\
\hline SOS 5c & $(7,747)$ & $(1,058)$ & (738) & (771) & $(5,180)$ \\
\hline $\operatorname{sos} 6 \mathbf{b}$ & $(7,747)$ & $(1,058)$ & (738) & (771) & $(5,180)$ \\
\hline sos 6d & $(7,747)$ & $(1,058)$ & $(738)$ & (771) & $(5,180)$ \\
\hline $\operatorname{sos} 9 a$ & $(120,648)$ & $(16,274)$ & $(12,117)$ & $(10,817)$ & $(81,441)$ \\
\hline $\operatorname{SOS} 9 \mathrm{~b}$ & $(10,991)$ & $(1,032)$ & $(2,514)$ & 1,729 & $(9,175)$ \\
\hline $\operatorname{SOS} 9 \mathrm{c}$ & 32,740 & 5,025 & 1,384 & 6,600 & 19,730 \\
\hline SOS PA & $(12,010)$ & $(1,240)$ & $(2,394)$ & 1,209 & $(9,585)$ \\
\hline \multicolumn{6}{|c|}{ Mid Columbia } \\
\hline SOS 2c & $3,207,717$ & 557,404 & 0 & 928,924 & $1,721,389$ \\
\hline \multicolumn{6}{|c|}{ Change from Base Case (SOS 2c) } \\
\hline SOS 1a & 317,959 & 61,908 & 0 & 69,448 & 186,603 \\
\hline $\operatorname{SOS} \mathbf{1 b}$ & 318,260 & 61,931 & 0 & 69,640 & 186,689 \\
\hline $\operatorname{sos} 2 \mathrm{~d}$ & 0 & 0 & 0 & 0 & 0 \\
\hline $\operatorname{sOS} 4 c$ & 196,016 & 40,236 & 0 & 35,445 & 120,335 \\
\hline $\operatorname{sos} 5 b$ & $(865,035)$ & $(118,439)$ & 0 & $(362,168)$ & $(384,429)$ \\
\hline SOS 5c & $(915,437)$ & $(121,758)$ & 0 & $(394,597)$ & $(399,082)$ \\
\hline SOS $6 b$ & $(654,955)$ & $(103,034)$ & 0 & $(227,872)$ & $(324,050)$ \\
\hline $\operatorname{sos} 6 d$ & $(434,431)$ & $(86,886)$ & 0 & $(86,886)$ & $(260,659)$ \\
\hline SOS 9a & $(712,929)$ & $(109,491)$ & 0 & $(257,395)$ & $(346,043)$ \\
\hline SOS 9b & $(24,069)$ & $(1,790)$ & 0 & $(15,372)$ & $(6,906)$ \\
\hline $\operatorname{sos} 9 c$ & $(570,558)$ & $(103,282)$ & 0 & $(150,912)$ & $(316,363)$ \\
\hline SOS PA & $(1,047,658)$ & $(210,258)$ & 0 & $(207,044)$ & $(630,356)$ \\
\hline
\end{tabular}


Table E-29. Annual Recreation Days and Length of Stay at the SOR Federal Project Sites, Allocated to States and Subregions - CONT

\begin{tabular}{|c|c|c|c|c|c|}
\hline \multirow[b]{2}{*}{ Alternative } & \multirow{2}{*}{$\begin{array}{c}\text { Total } \\
\text { Visitors }\end{array}$} & \multicolumn{2}{|c|}{ Resident } & \multicolumn{2}{|c|}{ Non-Resident } \\
\hline & & Day Use & Overnight & Day Use & Overnight \\
\hline \multicolumn{6}{|c|}{ Upper Columbia } \\
\hline $\operatorname{SOS} 2 \mathrm{c}$ & $1,670,069$ & 250,510 & 0 & 918,538 & 501,021 \\
\hline \multicolumn{6}{|c|}{ Change from Base Case (SOS 2c) } \\
\hline SOS 1a & $(39,098)$ & $(5,865)$ & 0 & $(21,504)$ & $(11,729)$ \\
\hline SOS 1b & $(32,888)$ & $(4,933)$ & 0 & $(18,088)$ & $(9,866)$ \\
\hline SOS 2d & $(7,257)$ & $(1,089)$ & 0 & $(3,991)$ & $(2,177)$ \\
\hline $\operatorname{sos} 4 c$ & $(8,608)$ & $(1,291)$ & 0 & $(4,734)$ & $(2,582)$ \\
\hline SOS 5b & $(4,138)$ & (621) & 0 & $(2,276)$ & $(1,241)$ \\
\hline SOS 5c & $(4,138)$ & $(621)$ & 0 & $(2,276)$ & $(1,241)$ \\
\hline $\operatorname{SOS} 6 \mathrm{~b}$ & $(4,138)$ & $(621)$ & 0 & $(2,276)$ & $(1,241)$ \\
\hline SOS 6d & $(4,138)$ & $(621)$ & 0 & $(2,276)$ & $(1,241)$ \\
\hline SOS 9a & $(412,887)$ & $(61,933)$ & 0 & $(227,088)$ & $(123,866)$ \\
\hline SOS 9b & $(187,974)$ & $(28,196)$ & 0 & $(103,386)$ & $(56,392)$ \\
\hline SOS 9c & $(99,411)$ & $(14,912)$ & 0 & $(54,676)$ & $(29,823)$ \\
\hline SOS PA & $(57,242)$ & $(8,586)$ & 0 & $(31,483)$ & $(17,173)$ \\
\hline
\end{tabular}

Lower Snake

\begin{tabular}{|c|c|c|c|c|c|}
\hline SOS 2c & $2,232,738$ & 301,895 & 0 & $1,587,553$ & 343,290 \\
\hline \multicolumn{6}{|c|}{ Change from Base Case (SOS 2c) } \\
\hline SOS 1a & $(42,239)$ & $(17,300)$ & 0 & $(22,217)$ & $(2,722)$ \\
\hline $\operatorname{SOS} 1 \mathrm{~b}$ & $(9,867)$ & $(14,710)$ & 0 & 2,964 & 1,879 \\
\hline SOS 2d & 28,918 & 12,724 & 0 & 13,881 & 2,313 \\
\hline SOS $4 c$ & 11,556 & 9,934 & 0 & 1,687 & (65) \\
\hline SOS 5b & $(940,355)$ & $(71,993)$ & 0 & $(705,041)$ & $(163,320)$ \\
\hline $\operatorname{sos} 5 c$ & $(1,140,784)$ & $(78,906)$ & 0 & $(864,291)$ & $(197,587)$ \\
\hline $\operatorname{sos} 6 \mathbf{b}$ & $(485,553)$ & $(38,047)$ & 0 & $(363,381)$ & $(84,125)$ \\
\hline SOS 6d & $(409,553)$ & $(35,767)$ & 0 & $(316,261)$ & $(57,525)$ \\
\hline sos 9a & $(588,883)$ & $(52,250)$ & 0 & $(436,388)$ & $(100,245)$ \\
\hline SOS 9b & $(112,871)$ & $(31,126)$ & 0 & $(68,074)$ & $(13,671)$ \\
\hline $\operatorname{sos} 9 \mathrm{c}$ & $(217,524)$ & $(18,478)$ & 0 & $(160,998)$ & $(38,048)$ \\
\hline SOS PA & $(15,682)$ & $(11,590)$ & 0 & $(4,091)$ & (1) \\
\hline
\end{tabular}


Table E-29. Annual Recreation Days and Length of Stay at the SOR Federal Project Sites, Allocated to States and Subregions - CONT

\begin{tabular}{|c|c|c|c|c|c|}
\hline \multirow[b]{2}{*}{ Alternative } & \multirow{2}{*}{$\begin{array}{c}\text { Total } \\
\text { Visitors }\end{array}$} & \multicolumn{2}{|c|}{ Resident } & \multicolumn{2}{|c|}{ Non-Resident } \\
\hline & & Day Use & Overnight & Day Use & Overnight \\
\hline \multicolumn{6}{|l|}{ Northeast } \\
\hline $\operatorname{SOS} 2 c$ & $1,994,651$ & $1,061,975$ & 443,623 & 149,146 & 339,906 \\
\hline \multicolumn{6}{|c|}{ Change from Base Case (SOS 2c) } \\
\hline SOS 1a & $(11,519)$ & $(5,900)$ & $(2,752)$ & (804) & $(2,063)$ \\
\hline SOS 1b & $(13,357)$ & $(6,356)$ & $(3,019)$ & (682) & $(3,300)$ \\
\hline SOS 2d & $(3,492)$ & $(644)$ & $(1,944)$ & 0 & (903) \\
\hline SOS 4c & $(5,039)$ & $(18,029)$ & 8,649 & $(4,805)$ & 9,146 \\
\hline SOS 5b & $(12,487)$ & $(5,421)$ & $(3,553)$ & (578) & $(2,936)$ \\
\hline SOS 5c & $(12,485)$ & $(5,420)$ & $(3,552)$ & (578) & $(2,935)$ \\
\hline SOS $6 b$ & $(12,485)$ & $(5,420)$ & $(3,552)$ & (578) & $(2,935)$ \\
\hline SOS 6d & $(12,485)$ & $(5,420)$ & $(3,552)$ & (578) & $(2,935)$ \\
\hline sos 9a & $(342,038)$ & $(194,904)$ & $(57,961)$ & $(27,010)$ & $(62,163)$ \\
\hline SOS 9b & $(85,479)$ & $(55,765)$ & $(11,323)$ & $(9,088)$ & $(9,304)$ \\
\hline SOS 9c & $(1,866)$ & $(14,606)$ & 7,570 & $(4,222)$ & 9,392 \\
\hline SOS PA & 8,669 & 15,644 & $(10,859)$ & 2,523 & 1,361 \\
\hline
\end{tabular}

\section{E.4.8 Project Implementation}

Many of the SOR alternatives will require physical project modifications and mitigation activities in order to achieve the objectives of the operations strategy. The proposed adaptations include modification of irrigation pumping stations, development of new power stations, improvements to boat ramps and moorages, and dam modifications to improve fish passage. The construction activities associated with these mitigation actions and project modifications will provide short-term positive economic benefits to the region through increased employment and earnings opportunities. The expected benefits are short-term in that they are expected to last only throughout the duration of the construction activity.

The regional economic impacts associated with project implementation were evaluated for those alternatives requiring construction activities. The estimates for expected construction costs for the dam modifications and irrigation pump modifications required to meet the operations objectives for the SOR alternatives are taken from Tables 4-4, 4-5, 4-21, and 4-24 of Appendix O of the SOR FEIS. ${ }^{19}$ The construction estimates for project implementation include modifications at the four Lower Snake Reservoirs - Ice Harbor, Lower Monumental, Little Goose, and Lower Granite as well as at John Day Reservoir.

19 Additional detail on construction cost estimates was found in U.S. Army Corps of Engineers, Columbia River Salmon Mitigation Analysis, System Configuration Study, Lower Snake River Drawdown Technical Report, April 1994. 
Estimated construction costs and the expected length of the construction period for expected dam modifications are presented in Table E-30. Expected construction costs for irrigation pump modifications are presented in Table E-31. The construction period for these changes is expected to be one year. The cost estimates are expressed in 1992 dollars and represent total construction costs, including direct materials and labor costs, planning and design, and construction management. Real estate costs are not included.

Table E-30. Construction Costs for Project Implementation, $(\$ 1,000)$ (Does Not Include Irrigation Pump Modifications)

\begin{tabular}{|c|c|c|c|c|}
\hline Alternative & $\begin{array}{l}\text { Construction } \\
\text { Period }\end{array}$ & Pacific Northwest & Mid Columbia & Lower Snake \\
\hline SOS 2c & N/A & 0 & 0 & $\overline{0}$ \\
\hline \multicolumn{5}{|c|}{ Change from Base Case (SOS 2c) } \\
\hline SOS 1a & N/A & 0 & 0 & 0 \\
\hline SOS 1b & N/A & 0 & 0 & 0 \\
\hline $\operatorname{sos} 2 d$ & N/A & 0 & 0 & 0 \\
\hline $\operatorname{sos} 4 c$ & N/A & 0 & 0 & 0 \\
\hline SOS 5b & 15 years & $\$ 214,134$ & $\$ 97,964$ & $\$ 116,169$ \\
\hline SOS 5c & 5 years & $\$ 107,385$ & $\$ 61,455$ & $\$ 45,930$ \\
\hline SOS $6 \mathbf{b}$ & 10 years & $\$ 94,615$ & $\$ 33,949$ & $\$ 60,666$ \\
\hline SOS 6d & 5 years & $\$ 22,241$ & $\$ 8,836$ & $\$ 13,405$ \\
\hline $\operatorname{sos} 9 a$ & 10 years & $\$ 94,937$ & $\$ 34,270$ & $\$ 60,666$ \\
\hline SOS 9b & N/A & 0 & 0 & 0 \\
\hline $\operatorname{sos} 9 c$ & 10 years & $\$ 94,615$ & $\$ 33,949$ & $\$ 60,666$ \\
\hline \multirow[t]{2}{*}{ SOS PA } & 3 years & $\$ 13,227$ & $\$ 13,227$ & $\$ 0$ \\
\hline & & Washington & Idaho & Oregon \\
\hline SOS 2c & N/A & 0 & 0 & 0 \\
\hline \multicolumn{5}{|c|}{ Change from Base Case (SOS 2c) } \\
\hline SOS 1a & N/A & 0 & 0 & $\overline{0}$ \\
\hline SOS 1b. & N/A & 0 & 0 & 0 \\
\hline $\operatorname{SOS} 2 d$ & N/A & 0 & 0 & 0 \\
\hline $\operatorname{sos} 4 c$ & N/A & 0 & 0 & 0 \\
\hline SOS 5b & 15 years & $\$ 154,576$ & $\$ 58,085$ & $\$ 1,473$ \\
\hline SOS 5c & 5 years & $\$ 80,002$ & $\$ 22,965$ & $\$ 4,418$ \\
\hline $\operatorname{sos} 6 \mathbf{b}$ & 10 years & $\$ 62,073$ & $\$ 30,333$ & $\$ 2,209$ \\
\hline SOS 6d & 5 years & $\$ 11,121$ & $\$ 6,703$ & $\$ 4,418$ \\
\hline SOS 9a & 10 years & $\$ 62,234$ & $\$ 30,333$ & $\$ 2,370$ \\
\hline $\operatorname{sos} 9 \mathrm{~b}$ & N/A & 0 & 0 & 0 \\
\hline $\operatorname{sos} 9 c$ & 10 years & $\$ 62,073$ & $\$ 30,333$ & $\$ 2,209$ \\
\hline SOS PA & 3 years & $\$ 6,614$ & $\$ 0$ & $\$ 6,614$ \\
\hline
\end{tabular}




\section{E.4.8.1 Allocations to Subregions}

Construction expenditures were allocated to the SOR subregions on the basis of location of the project site. The Economic Analysis Group provided detailed information on expected implementation costs at each of the Lower Snake reservoir sites. Expenditures at Ice Harbor and Lower Monumental reservoirs were allocated to the Mid Columbia subregion, while expenditures at Little Goose and Lower Granite were allocated to the Lower Snake subregion. Construction expenditures were allocated to states on the basis of project location. Costs for Ice Harbor and Lower Monumental were apportioned to Washington, while the costs for Lower Granite and Little Goose were divided equally between Washington and Idaho.

Table E-31. Construction Costs for Irrigation Pump Modifications

\begin{tabular}{|c|c|c|c|}
\hline Alternative & Pacific Northwest & Mid Columbia & Lower Snake \\
\hline SOS 2c & 0 & 0 & $\overline{0}$ \\
\hline \multicolumn{4}{|c|}{ Change from Base Case (SOS 2c) } \\
\hline SOS 1a & 0 & 0 & 0 \\
\hline SOS $1 \mathbf{b}$ & 0 & 0 & 0 \\
\hline SOS 2d & 0 & 0 & 0 \\
\hline SOS $4 c$ & 0 & 0 & 0 \\
\hline SOS 5b & $\$ 85,335$ & $\$ 81,107$ & $\$ 4,228$ \\
\hline SOS 5c & $\$ 85,335$ & $\$ 81,107$ & $\$ 4,228$ \\
\hline SOS $6 \mathbf{b}$ & $\$ 69,925$ & $\$ 66,656$ & $\$ 3,269$ \\
\hline SOS 6d & $\$ 53,470$ & $\$ 50,487$ & $\$ 2,983$ \\
\hline SOS 9a & $\$ 66,364$ & $\$ 63,095$ & $\$ 3,269$ \\
\hline SOS 9b & 0 & 0 & 0 \\
\hline SOS 9c & $\$ 71,501$ & $\$ 67,858$ & $\$ 3,643$ \\
\hline \multirow[t]{2}{*}{ SOS PA } & $\$ 53,864$ & $\$ 53,864$ & $\$ 0$ \\
\hline & Washington & Oregon & Idaho \\
\hline SOS 2c & 0 & 0 & 0 \\
\hline \multicolumn{4}{|c|}{ Change from Base Case (SOS 2c) } \\
\hline SOS 1a & 0 & 0 & 0 \\
\hline SOS $1 \mathrm{~b}$ & 0 & 0 & 0 \\
\hline SOS 2d & 0 & 0 & 0 \\
\hline SOS 4c & 0 & 0 & 0 \\
\hline SOS $5 b$ & $\$ 57,978$ & $\$ 2,114$ & $\$ 25,244$ \\
\hline SOS 5c & $\$ 57,978$ & $\$ 2,114$ & $\$ 25,244$ \\
\hline SOS $6 b$ & $\$ 43,047$ & $\$ 1,635$ & $\$ 25,244$ \\
\hline SOS 6d & $\$ 26,735$ & $\$ 1,492$ & $\$ 25,244$ \\
\hline SOS 9a & $\$ 41,261$ & $\$ 1,635$ & $\$ 23,469$ \\
\hline SOS 9b & 0 & 0 & 0 \\
\hline SOS 9c & $\$ 44,436$ & $\$ 1,822$ & $\$ 25,244$ \\
\hline SOS PA & $\$ 26,932$ & $\$ 0$ & $\$ 26,932$ \\
\hline
\end{tabular}




\section{E.5 RESULTS OF THE REGIONAL ECONOMIC IMPACT ANALYSIS}

\section{E.5.1 SOR Alternatives Evaluated in the Regional Analysis}

Thirteen system operations alternatives were evaluated for the final SOR direct economic impacts analysis. Regional economic impacts were also estimated for each of these alternatives. A brief description of the alternatives evaluated in the regional analysis are presented in Table E-32.

SOR alternative 2c, Final SEIS Operation - No Action Altemative, was identified as the "no action" alternative for the operations analysis. It was considered to be most representative of current system operations.

Under the framework of the SOR, regional economic impacts will be generated by changes to river operations strategies that positively or negatively affect the production and utilization of local goods and services. The impacts are brought about by resource-related changes to existing economic activity. Therefore, for each SOR alternative, the measure of direct economic impact is incorporated into the regional analysis as a change from alternative $2 c$, defined as the base scenario.

\section{E.5.1.1 Evaluating the Alternatives}

The direct economic impacts measured for anadromous fish, irrigation, navigation, power, and recreation were translated into expected changes in the production and utilization of regional goods and services using the methodologies described in previous sections. These expected changes become the final demand measures incorporated into the modeling process. In order to measure the indirect economic impacts associated with the alternative scenarios, the final demand changes must be incorporated into IMPLAN as impact scenarios. To accomplish this the final demand measures are restructured into the activity and event transactions that comprise the IMPLAN scenario files. ${ }^{20}$ In IMPLAN terminology, an activity describes the source of the final demand change, e.g., an increase in industry production or a decrease in the availability of some regional activity or service. The event describes the specific components of the final demand change; e.g., the activity may be a shift in transportation mode, while the events are measured as an increase in rail movements and a decrease in barge movements. An impact scenario can be a combination of many events and activities.

\section{Table E-32. SOR Alternatives Evaluated in the Regional Analysis}

\begin{tabular}{|l|l|}
\hline Alternative & \multicolumn{1}{c|}{ Description } \\
\hline SOS 1a & Pre-Salmon Summit Operation \\
SOS 1b & Optimum Load Following Operation \\
SOS 2c & Final SEIS Operation No Action Alternative \\
SOS 2d & 1994-98 Biological Opinion Operation \\
SOS 4c & Enhanced Operation with Modified Grand Coulee Flood Control \\
SOS 5b & Four and One Half Month Natural River Operation \\
SOS 5c & Permanent Natural River Operation \\
SOS 6b & Four and One Half Month Fixed Drawdown \\
SOS 6d & Four and One Half Month Lower Granite Drawdown Operation \\
SOS 9a & Detailed Fishery Operating Plan \\
SOS 9b & Adaptive Management \\
SOS 9c & Balanced Impacts Operation \\
SOS PA & Preferred Alternative \\
\hline
\end{tabular}

20 The reader is referred to the IMPLAN software manual for a discussion of the mechanics of developing and running impact scenarios within the software. 
To better clarify the relationship between industry final demand changes and the activity and event transactions incorporated into the regional models, a brief description is provided for a typical irrigation scenario. The direct economic impacts for irrigation have been measured as decreases in net farm income resulting from the increased capital and operations costs associated with increased pumping depths. The regional effects of the loss in farm income are modeled as reductions in farm machinery purchases and reductions in household consumption. Consequently, activities are defined within IMPLAN for farm machinery investment and personal consumption. The events include a reduction in final demand for IMPLAN industry sector 332 (farm machinery) and a reduction in the full range of transactions included within the IMPLAN personal consumption vectors. Allocation of the personal consumption expenditures to individual event transactions is included in the IMPLAN software.

Personal consumption expenditures are identified as a component of final demand change in all of the resource scenarios except recreation. The IMPLAN databases developed for the indirect impact analysis permit the allocation of these expenditures across three consumer income categories: low, middle, and high income. The pattern of consumption expenditures varies across the three income groups. Allocation of final demand changes to these income groupings is based on the regional shares of personal consumption expenditures accounted for by each income level. ${ }^{21}$

All of the scenario files describing the activity and event transactions for the final demand changes incorporated into the regional models have been made available to the Corps of Engineers. The thirteen regional, state, and multi-county models and the associated data files which were developed under this study have also been made available.
These models are fully operational and have been used to measure the full range of regional economic impacts related to the SOR alternatives. The regional models were constructed using the most recent IMPLAN software and data sets available at the time of the study. ${ }^{22}$ The reader is referred to the regional models and the specific scenario files for an exact presentation of the scenario/activity/event structures used for the impact analysis.

\section{E.5.2 Summary of Output from the Regional Economic Analysis}

The regional input-output models provide extensive information on the impacts of final demand changes on the local economy. Adjustments in river operations will affect the demand for local goods and services, causing the output levels in many related industries to change. Input requirements will be affected, as will the distribution of regional output to local and export markets. Labor requirements will change, increasing or decreasing the availability of regional jobs. Personal income will rise or fall depending on the job impacts. The regional trade balances will shift as the availability of local commodities and services is affected by changes in production levels.

The most common indicators of changes in regional economic activity are adjustments in regional employment and earnings. These are the measures from the input-output models which best describe the changes in the economic well-being of the local population. Employment is measured as the total number of jobs and includes both full-time and part-time workers. Earnings, or income, is measured as wage and salary income paid to employees, plus income earned by business owners and sole-proprietorships. ${ }^{23}$

The following sections present the results of the regional economic analysis for the selected SOR alternatives. The overall jobs and earnings impacts are presented first for the larger Pacific Northwest region. Results are then presented for the four

21 Income group percentages for SOR regions are developed from the IMPLAN data sets.

22 The models were constructed using IMPLAN v. 92-06; the modified data sets reflect base year 1989.

23 The terms income and earnings are used interchangeably throughout the following discussion. They are meant to refer to the same economic measure: wages and salaries, and income earned by business owners and sole proprietorships (they do not include any form of transfer payment). 
regional states (Washington, Oregon, Idaho, and Montana), and for the eight SOR subregions. ${ }^{24}$

Results from the state and subregion analyses are not additive to the Pacific Northwest. In some cases, the allocation of the expected direct economic impacts to states and subregions could not be fully made. For example, a component of the expected impacts related to power will be an increase in the generation of non-hydro-based electricity resources. The operation of these facilities will generate economic impacts within the region. However, insufficient information was available to determine where within the Pacific Northwest these sites might be located. Therefore, the regional impacts associated with these facilities are measured only for the larger Pacific Northwest region. The allocation of the specific resource impacts to states and subregions was developed fully in earlier sections of this report. The reader is referred to the previous chapter for a description of the resource allocations.

\section{E.5.2.1 Economic Impacts in the Pacific Northwest Region}

The regional economic impacts related to all of the expected SOR changes in resource activity were evaluated for the Pacific Northwest region. These impacts provide an indication of the net effect of the adjustments in river operations on regional employment and income. Results are presented below for expected changes in total regional employment and total regional income. This includes the direct economic changes, along with the indirect and induced changes that result from the interdependencies which exist throughout the regional economy.

A summary of expected regional impacts is presented for each of the five resource areas affected by the SOR alternatives: anadromous fish, irrigation, navigation, power and power purchases, and recreation. The combined effects for all resources are also presented.

\section{E.5.2.1.1 Regional Employment}

The total employment impacts for the Pacific Northwest which are likely to result from the alternative river operations are presented in Table E-33. Expected changes in regional employment range from a net increase of over 2,000 jobs annually under SOS $1 \mathrm{~b}$, to a loss of over 9,400 jobs annually under SOS 9a. Only two of the twelve evaluated alternatives resulted in a net increase in regional employment.

The net effect of the SOR alternatives on Pacific Northwest employment is dominated by the impact of the operations strategies on the regional power system. Changes in regional power costs are assumed to affect employment through adjustments in expenditures by regional households, changes in industrial output by the region's electricity-intensive industries, and changes in the generation activity of non-hydro based power resources. The power-related impacts account for fifty to seventy percent of the total regional employment impacts under various SOR alternatives. Regional employment impacts related to navigation under the natural river alternatives (SOS $5 \mathrm{~b}$ and SOS 5c) are positive; job losses associated with increased transportation costs are offset by job increases that occur as a result of the change in transportation modes for grain shipments.

\section{E.5.2.2 Regional Income}

The effects of the SOR alternatives on Pacific Northwest regional income are presented in Table E-34. Expected changes in regional income range from a net increase of over $\$ 50$ million annually under SOS $1 b$, to a loss of over $\$ 260$ million annually under SOS 9a. The distribution of changes in regional income across alternatives is consistent with the distribution of the employment impacts that were presented above.

Consistent with the regional employment analysis, income changes are dominated by the impact of the operations strategies on the regional power system.

24 A detailed description of the direct and total economic impacts, by resource, for each of the SOR states and subregions is presented in Appendices A, B, and C. 
Table E-33. Summary of Pacific Northwest Regional Employment Impacts

Total Number of Jobs per Year

\begin{tabular}{|l|c|c|c|c|c|c|c|}
\hline & $\begin{array}{c}\text { All } \\
\text { Resources }\end{array}$ & $\begin{array}{c}\text { Anadromous } \\
\text { Fish }\end{array}$ & Irrigation & Navigation & Power & $\begin{array}{c}\text { Power } \\
\text { Purchases }\end{array}$ & Recreation \\
\hline SOS 1a & 1,036 & $(5)$ & 0 & 2 & 1,505 & $(526)$ & 60 \\
SOS 1b & 2,021 & $(6)$ & 0 & 2 & 3,016 & $(1,055)$ & 63 \\
SOS 2d & $(578)$ & 0 & 0 & $(2)$ & $(886)$ & 310 & 0 \\
SOS 4c & $(2,191)$ & 1 & 0 & 5 & $(3,443)$ & 1,204 & 42 \\
SOS 5b & $(4,095)$ & $(114)$ & $(434)$ & 158 & $(5,265)$ & 1,841 & $(281)$ \\
SOS 5c & $(7,486)$ & $(246)$ & $(437)$ & 94 & $(9,271)$ & 2,693 & $(318)$ \\
SOS 6b & $(2,264)$ & $(388)$ & $(347)$ & $(132)$ & $(1,854)$ & 648 & $(191)$ \\
SOS 6d & $(1,083)$ & $(144)$ & $(261)$ & $(26)$ & $(769)$ & 269 & $(153)$ \\
SOS 9a & $(9,451)$ & $(557)$ & $(335)$ & $(133)$ & $(12,509)$ & 4,373 & $(290)$ \\
SOS 9b & $(5,662)$ & $(82)$ & 0 & $(4)$ & $(8,519)$ & 2,978 & $(36)$ \\
SOS 9c & $(5,678)$ & $(394)$ & $(356)$ & $(17)$ & $(7,317)$ & 2,558 & $(152)$ \\
SOS PA & $(4,029)$ & $(6)$ & $(259)$ & $(2)$ & $(5,419)$ & 1,895 & $(237)$ \\
\hline
\end{tabular}

Table E-34. Summary of Pacific Northwest Regional Income Impacts

Million Dollars per Year

\begin{tabular}{|l|c|c|c|c|c|c|c|}
\hline & $\begin{array}{c}\text { All } \\
\text { Resources }\end{array}$ & $\begin{array}{c}\text { Anadromous } \\
\text { Fish }\end{array}$ & Irrigation & Navigation & Power & $\begin{array}{c}\text { Power } \\
\text { Purchases }\end{array}$ & Recreation \\
\hline SOS 1a & $\$ 25.6$ & $(\$ 0.2)$ & $\$ 0.0$ & $\$ 0.1$ & $\$ 45.8$ & $(\$ 18.5)$ & $(\$ 1.6)$ \\
SOS 1b & $\$ 56.4$ & $(\$ 0.2)$ & $\$ 0.0$ & $\$ 0.1$ & $\$ 91.8$ & $(\$ 37.0)$ & $\$ 1.7$ \\
SOS 2d & $(\$ 16.2)$ & $\$ 0.0$ & $\$ 0.0$ & $(\$ 0.1)$ & $(\$ 27.0)$ & $\$ 10.9$ & $\$ 0.0$ \\
SOS 4c & $(\$ 61.2)$ & $\$ 0.0$ & $\$ 0.0$ & $(\$ 0.2)$ & $(\$ 104.8)$ & $\$ 42.2$ & $\$ 1.1$ \\
SOS 5b & $(\$ 106.8)$ & $(3.4)$ & $(\$ 13.4)$ & $\$ 13.6$ & $(\$ 160.2)$ & $\$ 64.5$ & $(\$ 8.0)$ \\
SOS 5c & $(\$ 199.4)$ & $(\$ 7.4)$ & $(\$ 13.5)$ & $\$ 19.3$ & $(\$ 283.2)$ & $\$ 94.4$ & $(\$ 9.1)$ \\
SOS 6b & $(\$ 59.1)$ & $(\$ 11.6)$ & $(\$ 10.7)$ & $\$ 2.2$ & $(\$ 56.4)$ & $\$ 22.7$ & $(\$ 5.4)$ \\
SOS 6d & $(\$ 31.5)$ & $(\$ 4.3)$ & $(\$ 8.0)$ & $(\$ 0.8)$ & $(\$ 23.4)$ & $\$ 9.4$ & $(\$ 4.3)$ \\
SOS 9a & $(\$ 260.2)$ & $(\$ 16.6)$ & $(\$ 10.3)$ & $\$ 2.2$ & $(\$ 380.6)$ & $\$ 153.3$ & $(\$ 8.2)$ \\
SOS 9b & $(\$ 158.4)$ & $(\$ 2.5)$ & $\$ 0.0$ & $\$ 0.1$ & $(\$ 259.2)$ & $\$ 104.4$ & $(\$ 1.0)$ \\
SOS 9c & $(\$ 160.5)$ & $(\$ 11.8)$ & $(\$ 11.0)$ & $(\$ 0.6)$ & $(\$ 222.6)$ & $\$ 66.4$ & $(\$ 4.2)$ \\
SOS PA & $(\$ 113.1)$ & $(\$ 0.2)$ & $(\$ 8.0)$ & $\$ 0.1$ & $(\$ 164.9)$ & $\$ 66.4$ & $(\$ 6.4)$ \\
\hline
\end{tabular}




\section{E.5.2.3 Economic Impacts in Washington, Oregon, Idaho, and Montana}

The expected state-level economic impacts related to the direct changes in river operations were evaluated for each of the SOR alternatives. These impacts provide an indication of the broad distribution of the regional economic impacts across the four Pacific Northwest states. Results are presented below for expected changes in total regional employment, allocated by state and by resource category. The estimated employment figures represent total job impacts, including the expected changes to direct jobs as well as jobs in interrelated industries. The state distribution of expected changes to regional income are presented in Appendix B.

Economic impacts have been generated for each of the direct resource changes expected to have economic impacts within one or more of the states. The allocation of the resource changes to individual states were presented in earlier sections of this report. The expected distribution of impacts, by resource, is presented in Table $\mathrm{E}-35$.
The state-by-state distribution of expected regional economic impacts was made using information and analysis provided by the direct economic work groups. Additional information was furnished by the regional impact models.

\section{E.5.2.3.1 State Employment Impacts}

State-level employment impacts expected to result from the SOR alternatives are presented in Table E-36. Individual employment changes related to five resources (anadromous fish, irrigation, navigation, power, and recreation) are presented, as are the net changes aggregated over all of the resources, excluding impacts related to power purchases. ${ }^{25}$ Under each of the SOR alternatives, Washington state accounts for over one-half of the regional job impacts, ranging from a net increase of nearly 1,500 jobs with alternative $1 \mathrm{~b}$ to a loss of 6,600 jobs for alternative SOS 9a. Employment impacts in Oregon ranged from a net increase of nearly 800 jobs under alternative SOS $1 \mathrm{~b}$ to a loss of over 3,300 jobs under alternative SOS 9a. Net job impacts in Idaho and Montana are one-half and one-fifth the levels measured for Oregon, respectively.

\section{Table E-35. Distribution of Expected Resource Changes by State}

\begin{tabular}{|c|c|c|c|c|}
\hline Resource & Washington & Oregon & Idaho & Montana \\
\hline Anadromous Fish & $*$ & $*$ & 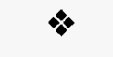 & \\
\hline Irrigation & 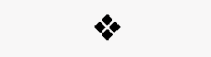 & $*$ & 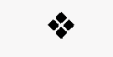 & \\
\hline Navigation & 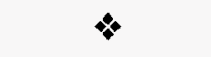 & $*$ & $\%$ & 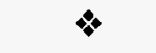 \\
\hline Power & 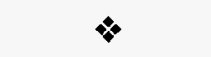 & $*$ & 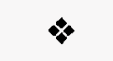 & $*$ \\
\hline Recreation & $*$ & 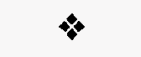 & $\star$ & $\nLeftarrow$ \\
\hline Construction & $*$ & 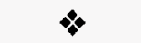 & $*$ & \\
\hline
\end{tabular}

* Symbol denotes location of economic impacts related to the resource change.

25 Economic impacts related to power purchases were estimated only for the larger Pacific Northwest region. The potential distribution of the purchasing across states and subregions is not known. 
Table E-36. Summary of State Employment Impacts

Total Number of Jobs per Year

\begin{tabular}{|c|c|c|c|c|}
\hline & Washington & Oregon & Idaho & Montana \\
\hline \multicolumn{5}{|c|}{ Net Job Impacts for All Resources (does not include power purchases) } \\
\hline SOS 1a & 753 & 408 & 160 & 69 \\
\hline SOS $1 b$ & 1,479 & 779 & 334 & 146 \\
\hline $\operatorname{sos} 2 d$ & $(422)$ & $(214)$ & (96) & $(42)$ \\
\hline $\operatorname{sos} 4 c$ & $(1,614)$ & $(815)$ & (395) & $(152)$ \\
\hline SOS $5 b$ & $(3,133)$ & $(1,464)$ & $(736)$ &.$(16)$ \\
\hline $\operatorname{SOS} 5 c$ & $(4,397)$ & $(2,083)$ & $(1,135)$ & $(140)$ \\
\hline SOS $6 b$ & $(1,364)$ & $(677)$ & $(497)$ & $(175)$ \\
\hline SOS 6d & $(641)$ & $(394)$ & $(176)$ & (39) \\
\hline $\operatorname{sos} 9 \mathrm{a}$ & $(6,598)$ & $(3,352)$ & $(1,845)$ & $(807)$ \\
\hline SOS 9b & $(4,127)$ & $(2,107)$ & $(1,062)$ & (439) \\
\hline SOS 9c & $(3,901)$ & $(2,053)$ & $(1,077)$ & $(349)$ \\
\hline SOS PA & $(2,846)$ & $(1,594)$ & $(629)$ & $(281)$ \\
\hline \multicolumn{3}{|c|}{ Job Impacts Related to Anadromous Fish } & \multicolumn{2}{|c|}{ (- indicates no in-state direct impacts) } \\
\hline SOS 1a & (1) & (1) & (3) & - \\
\hline $\operatorname{SOS} 1 b$ & (1) & (1) & (3) & - \\
\hline $\operatorname{SOS} 2 \mathrm{~d}$ & $(0)$ & 1 & (2) & - \\
\hline $\operatorname{sos} 4 c$ & 0 & 1 & $(1)$ & - \\
\hline $\operatorname{sos} 5 b$ & $(27)$ & (19) & $(60)$ & - \\
\hline $\operatorname{sOS} 5 \mathrm{c}$ & $(54)$ & $(40)$ & (140) & - \\
\hline $\operatorname{sos} 6 b$ & (84) & (63) & (221) & - \\
\hline $\operatorname{SOS} 6 d$ & (31) & (23) & $(81)$ & - \\
\hline $\operatorname{sos} 9 a$ & (129) & (123) & (265) & - \\
\hline $\operatorname{sos} 9 b$ & $(18)$ & $(16)$ & $(41)$ & - \\
\hline $\operatorname{sos} 9 c$ & (87) & (68) & (219) & 一 \\
\hline SOS PA & (1) & 1 & $(7)$ & - \\
\hline \multicolumn{3}{|c|}{ Job Impacts Related to Irrigation } & \multicolumn{2}{|c|}{ ( - indicates no in - state direct impacts) } \\
\hline SOS 1a & 0 & 0 & 0 & - \\
\hline $\operatorname{sos} 1 b$ & 0 & 0 & 0 & - \\
\hline $\operatorname{sos} 2 d$ & 0 & 0 & 0 & - \\
\hline $\operatorname{sOS} 4 c$ & 0 & 0 & 0 & - \\
\hline SOS $5 b$ & (251) & (115) & (1) & - \\
\hline SOS 5c & (254) & (115) & (1) & - \\
\hline $\operatorname{sos} 6 b$ & (176) & (115) & (1) & - \\
\hline $\operatorname{sos} 6 d$ & (101) & (115) & (1) & - \\
\hline $\operatorname{sos} 9 a$ & $(172)$ & (109) & (1) & - \\
\hline $\operatorname{sos} 9 b$ & 0 & 0 & 0 & - \\
\hline SOS 9c & (181) & (115) & (1) & - \\
\hline SOS PA & (96) & (119) & 0 & - \\
\hline
\end{tabular}


Table E-36. Summary of State Employment Impacts - CONT

Total Number of Jobs per Year

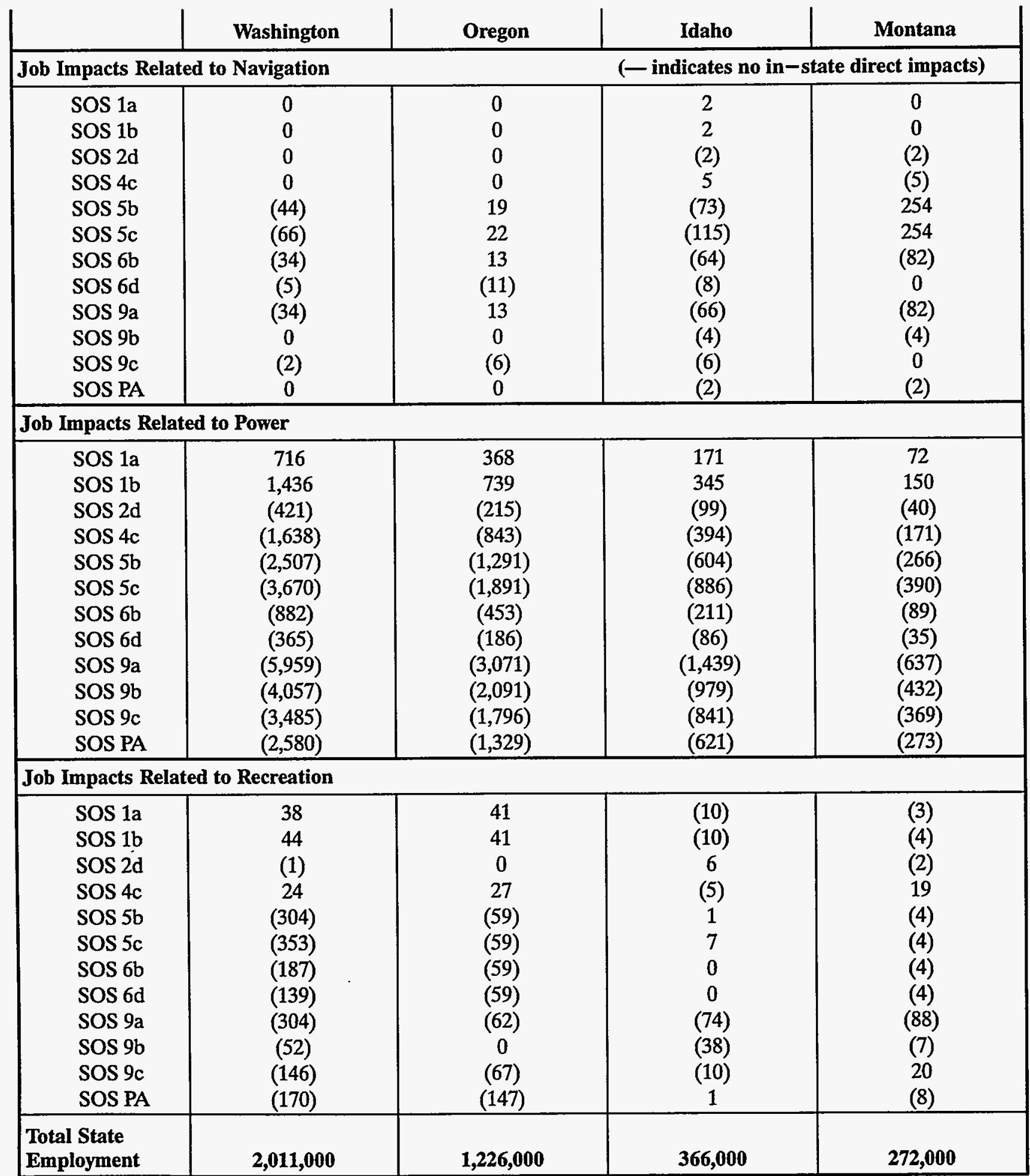


Once again, the net effects of the SOR alternatives on Pacific Northwest state-level employment are dominated by the impacts of the operations strategies on the regional power system. It should be noted that the power estimates do not include state jobs that may be associated with new power purchases; insufficient information was available regarding where these jobs might occur. The net effect of these job impacts would be added to the impact of the power-related job losses.

\section{E.5.2.4 Economic Impacts in the SOR Subregions}

Economic impacts were evaluated for each of the SOR subregions where direct changes in river operations are expected to result in adjustments to resource use. These impacts provide a more detailed indication of the expected distribution of the regional economic impacts than those estimated for the individual states. Results of the impact analysis are presented below for expected changes in total regional employment, allocated by subregion and resource. Expected changes to subregion income are presented in Appendix C.

Regional impacts have been generated only for those subregions where direct resource changes are expected to occur. ${ }^{26}$ The distribution of expected subregion impacts, by resource, is presented in Table E-37. Allocations to the subregions were made using information and analysis provided by the Economic Analysis Group and the resource work groups, along with information from the regional impact models.

\section{E.5.2.4.1 Employment Impacts}

Expected changes in subregion employment resulting from the SOR alternatives are presented in Table E-38. Employment impacts are presented for anadromous fish, irrigation, navigation, power, and recreation, as well as the net effects aggregated across these five resources. Job impacts in subregions range from a net increase of over 500 jobs in Puget Sound with alternative SOS $1 \mathrm{~b}$, the optimum load following operation alternative, to a loss of over 3,800 jobs for Lower Snake under alternative SOS 5c, the permanent natural river operation alternative.

\section{Table E-37. Distribution of Expected Resource Changes by SOR Subregion}

\begin{tabular}{|c|c|c|c|c|c|c|}
\hline Subregion & $\begin{array}{l}\text { Anadromous } \\
\text { Fish }\end{array}$ & Irrigation & Navigation & Power & Recreation & Construction \\
\hline Puget Sound & & & & 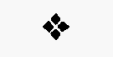 & & \\
\hline West Coast & 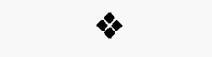 & & & $\$$ & & \\
\hline Portland & 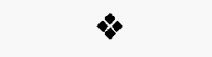 & & $\psi$ & $\&$ & & \\
\hline Mid Columbia & $\star$ & 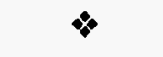 & 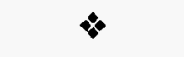 & 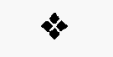 & 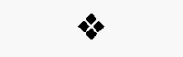 & $\downarrow$ \\
\hline Upper Columbia & 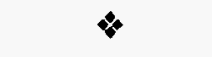 & $*$ & $*$ & $*$ & 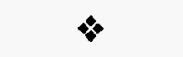 & \\
\hline Lower Snake & 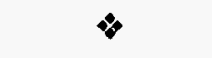 & $\nLeftarrow$ & 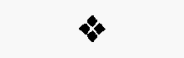 & $*$ & $*$ & $\star$ \\
\hline Northeast & & & 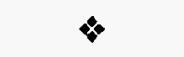 & $*$ & $\star$ & \\
\hline Southern Idaho & & & $\diamond$ & $\star$ & & \\
\hline
\end{tabular}

* Symbol denotes location of economic impacts related to the resource change.

26 Economic impacts related to power purchases were estimated only for the larger Pacific Northwest region. The potential distribution of the purchases across states and subregions is not known. 
Table E-38. Summary of Employment Impacts in the SOR Subregions

Total Number of Jobs per Year

\begin{tabular}{|c|c|c|c|c|c|c|c|c|}
\hline & Puget Sound & West Coast & Portland & $\begin{array}{c}\text { Mid } \\
\text { Columbia }\end{array}$ & $\begin{array}{l}\text { Upper } \\
\text { Columbia }\end{array}$ & $\begin{array}{l}\text { Lower } \\
\text { Snake }\end{array}$ & Northeast & $\begin{array}{l}\text { Southern } \\
\text { Idaho }\end{array}$ \\
\hline \multicolumn{9}{|c|}{$\begin{array}{l}\text { Net Job Impacts for all Resources } \\
\text { (does not include power purchases or project implementation impacts) }\end{array}$} \\
\hline SOS 1a & 262 & 116 & 173 & 234 & 57 & 60 & 181 & 101 \\
\hline $\operatorname{sos} 1 b$ & 527 & 234 & 351 & 318 & 129 & 147 & 368 & 204 \\
\hline $\operatorname{sos} 2 d$ & (153) & $(66)$ & $(100)$ & (48) & $(42)$ & (39) & $(105)$ & $(58)$ \\
\hline $\operatorname{sos} 4 c$ & (601) & (266) & (401) & (95) & (162) & $(162)$ & $(417)$ & (233) \\
\hline $\operatorname{sos} 5 b$ & $(921)$ & (412) & (623) & (476) & (145) & $(2,409)$ & $(54)$ & $(76)$ \\
\hline SOS $5 c$ & $(1,349)$ & (610) & (916) & (214) & (234) & $(3,839)$ & 137 & 35 \\
\hline sos $6 b$ & $(323)$ & (156) & (235) & $(320)$ & $(23)$ & $(1,645)$ & 256 & 78 \\
\hline SOS 6d & (133) & (63) & (91) & (493) & (49) & $(313)$ & $(104)$ & $(54)$ \\
\hline sos $9 a$ & $(2,191)$ & $(1,023)$ & $(1,494)$ & (957) & $(680)$ & $(2,260)$ & $(1,124)$ & (649) \\
\hline $\operatorname{sos} 9 b$ & $(1,491)$ & $(670)$ & $(999)$ & $(493)$ & (473) & $(500)$ & $(1,059)$ & $(582)$ \\
\hline SOS 9c & $(1,280)$ & (587) & (869) & $(1,030)$ & (415) & $(685)$ & $(902)$ & (502) \\
\hline SOS PA & $(948)$ & (419) & (632) & $(1,036)$ & (274) & $(275)$ & $(666)$ & $(369)$ \\
\hline \multicolumn{6}{|c|}{ Job Impacts Related to Anadromous Fish } & \multicolumn{3}{|c|}{ (- indicates no in-region direct impacts) } \\
\hline SOS 1a & - & 0 & 0 & (1) & 0 & (3) & - & - \\
\hline $\operatorname{sos} 1 b$ & - & 0 & 0 & (1) & $(1)$ & (3) & - & - \\
\hline $\operatorname{sos} 2 d$ & - & 1 & 0 & 0 & $(0)$ & (2) & - & - \\
\hline $\operatorname{sos} 4 c$ & - & 1 & 0 & 0 & $(0)$ & $(1)$ & - & - \\
\hline sos $5 b$ & - & (3) & (3) & $(21)$ & $(10)$ & (134) & - & - \\
\hline $\operatorname{sos} 5 \mathrm{c}$ & - & (9) & (7) & (37) & $(25)$ & (134) & - & - \\
\hline sos $6 \mathrm{~b}$ & - & (13) & (12) & (58) & (39) & (211) & - & - \\
\hline sos $6 \mathrm{~d}$ & - & (5) & (4) & (21) & (14) & (78) & - & - \\
\hline sos 9a & - & (47) & (21) & (88) & (50) & (254) & - & - \\
\hline $\operatorname{sos} 9 \mathrm{~b}$ & - & (6) & (3) & (12) & (7) & $(40)$ & - & - \\
\hline $\operatorname{sos} 9 \mathrm{c}$ & - & (17) & (13) & (59) & (39) & $(210)$ & - & - \\
\hline SOS PA & - & 2 & 0 & 0 & $(1)$ & $(7)$ & - & - \\
\hline
\end{tabular}




\begin{tabular}{|c|c|c|c|c|c|c|c|c|}
\hline \multicolumn{9}{|c|}{ Total Number of Jobs per Year } \\
\hline & Puget Sound & West Coast & Portland & $\begin{array}{c}\text { Mid } \\
\text { Columbia }\end{array}$ & $\begin{array}{l}\text { Upper } \\
\text { Columbia }\end{array}$ & $\begin{array}{l}\text { Lower } \\
\text { Snake }\end{array}$ & Northeast & $\begin{array}{c}\text { Southern } \\
\text { Idaho }\end{array}$ \\
\hline \multicolumn{6}{|c|}{ Job Impacts Related to Irrigation } & \multicolumn{3}{|c|}{ ( - indicates no in-region direct impacts) } \\
\hline SOS 1a & - & - & - & 0 & 0 & - & - & - \\
\hline SOS $1 b$ & - & - & - & 0 & 0 & - & - & - \\
\hline SOS 2d & - & - & - & 0 & 0 & - & - & 一 \\
\hline $\operatorname{sos} 4 c$ & - & - & - & 0 & 0 & - & - & - \\
\hline SOS $5 b$ & - & - & - & $(359)$ & 0 & - & - & - \\
\hline SOS $5 c$ & - & - & - & $(361)$ & 0 & - & - & - \\
\hline $\operatorname{sos} 6 b$ & - & - & - & (289) & 0 & - & - & - \\
\hline sos 6d & - & - & - & (216) & 0 & - & - & - \\
\hline SOS 9a & - & - & - & (277) & 1 & - & - & - \\
\hline SOS $9 b$ & - & - & - & 0 & 0 & - & - & - \\
\hline SOS 9c & - & - & - & (294) & 0 & - & - & - \\
\hline SOS PA & - & - & - & $(225)$ & 0 & - & - & - \\
\hline \multicolumn{6}{|c|}{ Job Impacts Related to Navigation } & \multicolumn{3}{|c|}{ (一 indicates no in-region direct impacts) } \\
\hline SOS 1a & - & - & 0 & 0 & 0 & 0 & 0 & 0 \\
\hline SOS $1 b$ & - & - & 0 & 0 & 0 & 0 & $\mathbf{0}$ & 0 \\
\hline $\operatorname{sos} 2 d$ & - & - & 0 & 0 & 0 & 0 & 0 & 0 \\
\hline $\operatorname{sos} 4 c$ & - & - & 0 & 0 & 0 & 0 & 0 & 0 \\
\hline $\operatorname{sos} 5 b$ & - & - & $(7)$ & 566 & 113 & $(1,562)$ & 596 & 282 \\
\hline SOS $5 c$ & - & - & $(8)$ & 1,002 & 153 & $(2,775)$ & 1,088 & 561 \\
\hline SOS $6 b$ & - & - & $(10)$ & 422 & 103 & $(1,109)$ & 483 & 203 \\
\hline $\operatorname{sos} 6 \mathrm{~d}$ & - & - & $(1)$ & $(5)$ & 0 & (5) & (11) & (4) \\
\hline SOS 9a & - & - & $(10)$ & 422 & 103 & $(1,111)$ & 483 & 207 \\
\hline $\operatorname{sos} 9 b$ & - & - & 0 & 0 & 0 & (4) & 0 & 0 \\
\hline $\operatorname{sos} 9 c$ & - & - & (1) & (3) & 0 & (5) & (6) & (2) \\
\hline SOS PA & - & - & 0 & 0 & 0 & (3) & 0 & 0 \\
\hline
\end{tabular}


Table E-38. Summary of Employment Impacts in the SOR Subregions - CONT

Total Number of Jobs per Year

\begin{tabular}{|c|c|c|c|c|c|c|c|c|}
\hline & Puget Sound & West Coast & Portland & $\begin{array}{c}\text { Mid } \\
\text { Columbia }\end{array}$ & $\begin{array}{l}\text { Upper } \\
\text { Columbia }\end{array}$ & $\begin{array}{l}\text { Lower } \\
\text { Snake }\end{array}$ & Northeast & $\begin{array}{l}\text { Southern } \\
\text { Idaho }\end{array}$ \\
\hline \multicolumn{6}{|c|}{ Job Impacts Related to Power } & \multicolumn{3}{|c|}{ (- indicates no in-region direct impacts) } \\
\hline SOS 1a & 262 & 116 & 173 & 83 & 70 & 71 & 182 & 101 \\
\hline $\operatorname{sos} 1 b$ & 527 & 234 & 351 & 167 & 140 & 146 & 370 & 204 \\
\hline $\operatorname{sos} 2 d$ & (153) & $(67)$ & $(100)$ & $(48)$ & $(40)$ & $(41)$ & $(105)$ & $(58)$ \\
\hline SOS $4 c$ & $(601)$ & (267) & $(401)$ & (190) & $(160)$ & $(167)$ & $(422)$ & (233) \\
\hline $\operatorname{sos} 5 b$ & $(921)$ & (409) & (613) & $(292)$ & (247) & (257) & $(648)$ & (358) \\
\hline $\operatorname{sos} 5 \mathrm{c}$ & $(1,349)$ & $(601)$ & (901) & $(429)$ & (361) & $(376)$ & (949) & $(526)$ \\
\hline $\operatorname{sos} 6 b$ & $(323)$ & (143) & (213) & $(102)$ & $(86)$ & $(88)$ & (225) & (125) \\
\hline $\operatorname{sos} 6 \mathrm{~d}$ & (133) & $(58)$ & $(86)$ & $(41)$ & (34) & (35) & $(91)$ & $(50)$ \\
\hline $\operatorname{sos} 9 \mathrm{a}$ & $(2,191)$ & (976) & $(1,463)$ & (697) & (588) & (613) & $(1,545)$ & $(856)$ \\
\hline $\operatorname{sos} 9 b$ & $(1,491)$ & (664) & $(996)$ & (474) & $(400)$ & (417) & $(1,050)$ & $(582)$ \\
\hline $\operatorname{SOS} 9 \mathrm{c}$ & $(1,280)$ & $(570)$ & (855) & (407) & (343) & (358) & $(901)$ & $(500)$ \\
\hline SOS PA & (948) & $(421)$ & $(632)$ & $(301)$ & (254) & (264) & $(667)$ & $(369)$ \\
\hline \multicolumn{6}{|c|}{ Job Impacts Related to Recreation } & \multicolumn{3}{|c|}{ (-indicates no in-region direct impacts) } \\
\hline SOS 1a & - & - & - & 152 & (12) & $(11)$ & $(1)$ & - \\
\hline $\operatorname{sos} 1 b$ & - & - & - & 152 & $(10)$ & 2 & (2) & - \\
\hline $\operatorname{sos} 2 d$ & - & - & - & 0 & $(2)$ & 6 & 0 & - \\
\hline $\operatorname{sos} 4 c$ & - & - & - & 95 & (2) & 0 & 5 & - \\
\hline $\operatorname{sos} 5 b$ & - & - & 一 & $(370)$ & (1) & $(440)$ & (2) & - \\
\hline $\operatorname{sos} 5 \mathrm{c}$ & - & - & - & (389) & (1) & (537) & (2) & - \\
\hline $\operatorname{sos} 6 b$ & - & - & - & (293) & (1) & (225) & (2) & - \\
\hline $\operatorname{sos} 6 d$ & - & - & - & (210) & $(1)$ & (184) & $(2)$ & - \\
\hline SOS 9a & - & - & - & (316) & (145) & (270) & $(62)$ & - \\
\hline $\operatorname{sos} 9 b$ & - & - & - & $(7)$ & $(65)$ & $(39)$ & (9) & - \\
\hline $\operatorname{sos} 9 \mathrm{c}$ & - & - & - & (267) & (33) & (99) & 5 & - \\
\hline SOS PA & - & - & - & $(510)$ & (19) & $(1)$ & 1 & - \\
\hline $\begin{array}{l}\text { Total Regional } \\
\text { Employment }\end{array}$ & $1,475,000$ & 140,000 & 691,000 & 123,000 & 151,000 & 63,000 & 262,000 & 302,000 \\
\hline
\end{tabular}


Job impacts within the Lower Snake subregion are generated primarily by changes in navigation and recreation resource use. Increased transportation costs and the loss of barge activity result in significant job losses in this region. Job impacts within the Mid Columbia subregion are generated primarily by changes in irrigation, navigation, power, and recreation resource use. They range from a net increase of 300 jobs under alternative SOS $1 b$, to a net loss of over 1,000 jobs under the preferred alternative.

Job impacts within the Northeast, Upper Columbia, and Southern Idaho subregions are generated by changes in power and navigation resource use. In the West Coast, Portland, and Puget Sound subregions, power impacts are the primary source of job changes; all other resource use generates insignificant impacts, generally accounting for employment changes of less than 20 jobs. Exceptions are Upper Columbia and Northeast, where expected changes in recreation use under alternative SOS 9a result in losses of 145 and 62 jobs, respectively.

\section{E.5.2.5 Regional Economic Impacts Related to Project Implementation}

Employment impacts are estimated separately for construction activities related to project implementation and pump modifications. Impacts generated by construction activities for project implementation are expected to last 3 to 15 years depending on the duration of the construction period. Impacts related to pump modifications are expected to last one year. Regional employment generated through project implementation is presented in Table E-39 while employment generated through pump modifications is presented in Table $\mathrm{E}-40$.

The employment impacts associated with SOSs $5 \mathrm{~b}$ and $5 \mathrm{c}$ reflect the significantly higher construction expenditures associated with these alternatives.

Table E-39. Employment Impacts Related to Project Implementation Construction

Total Number of Jobs per Construction Year

\begin{tabular}{|c|c|c|c|c|c|c|c|}
\hline Alternative & $\begin{array}{c}\text { Construction } \\
\text { Period }\end{array}$ & $\begin{array}{c}\text { Pacific } \\
\text { Northwest }\end{array}$ & Washington & Oregon & Idaho & $\begin{array}{c}\text { Mid } \\
\text { Columbia }\end{array}$ & $\begin{array}{c}\text { Lower } \\
\text { Snake }\end{array}$ \\
\hline SOS 1a & N/A & 0 & 0 & 0 & 0 & 0 & 0 \\
SOS 1b & N/A & 0 & 0 & 0 & 0 & 0 & 0 \\
SOS 2d & N/A & 0 & 0 & 0 & 0 & 0 & 0 \\
SOS 4c & N/A & 0 & 0 & 0 & 0 & 0 & 0 \\
SOS 5b & 15 years & 7,592 & 4,674 & 41 & 1,754 & 2,931 & 4,052 \\
SOS 5c & 5 years & 3,807 & 2,419 & 127 & 693 & 1,839 & 1,602 \\
SOS 6b & 10 years & 3,353 & 1,876 & 63 & 915 & 1,015 & 2,116 \\
SOS 6d & 5 years & 787 & 335 & 127 & 201 & 264 & 467 \\
SOS 9a & 10 years & 3,364 & 1,881 & 68 & 915 & 1,025 & 2,116 \\
SOS 9b & N/A & 0 & 0 & 0 & 0 & 0 & 0 \\
SOS 9c & 10 years & 3,353 & 1,876 & 63 & 915 & 1,015 & 2,116 \\
SOS PA & 3 years & 468 & 199 & 190 & 0 & 395 & 0 \\
\hline
\end{tabular}


Table E-40. Employment Impacts Related to Construction for Pump Modifications

Total Number of Jobs per One-Year Construction Period

\begin{tabular}{|l|c|c|c|c|c|c|}
\hline Alternative & $\begin{array}{c}\text { Pacific } \\
\text { Northwest }\end{array}$ & Washington & Oregon & Idaho & $\begin{array}{c}\text { Mid } \\
\text { Columbia }\end{array}$ & $\begin{array}{c}\text { Lower } \\
\text { Snake }\end{array}$ \\
\hline SOS 1a & 0 & 0 & 0 & 0 & 0 & 0 \\
SOS 1b & 0 & 0 & 0 & 0 & 0 & 0 \\
SOS 2d & 0 & 0 & 0 & 0 & 0 & 0 \\
SOS 4c & 0 & 0 & 0 & 0 & 0 & 0 \\
SOS 5b & 2,887 & 1,710 & 705 & 59 & 2,320 & 137 \\
SOS 5c & 2,887 & 1,710 & 705 & 59 & 2,320 & 137 \\
SOS 6b & 2,366 & 1,269 & 705 & 46 & 1,907 & 106 \\
SOS 6d & 1,809 & 788 & 705 & 42 & 1,444 & 96 \\
SOS 9a & 2,245 & 1,216 & 656 & 46 & 1,805 & 106 \\
SOS 9b & 0 & 0 & 0 & 0 & 0 & 0 \\
SOS 9c & 2,419 & 1,310 & 705 & 51 & 1,941 & 118 \\
SOS PA & 1,822 & 794 & 753 & 0 & 1,541 & 0 \\
\hline
\end{tabular}

\section{E.6 COMPARISON OF ALTERNATIVES}

The SOR alternatives evaluated in the regional impact analysis were ranked on the basis of net employment impacts in the Pacific Northwest region. The rankings, presented in Table $\mathrm{E}-41$, are based on the net employment impacts for all resources and are ordered from best to worst. Alternatives SOS 1a and SOS $1 \mathrm{~b}$ result in net economic benefits to the region, while the remaining alternatives lead to job losses ranging from nearly 600 jobs under SOS $2 \mathrm{~d}$ to nearly 9,500 jobs under SOS 9a. Although the rankings are based on net jobs for all resources, they follow the same pattern as the job impacts related to power. This once again highlights the predominance of the power impacts in the regional analysis.

The SOR alternatives were also compared on the basis of the net change in economic activity related to each of the resource uses. The alternatives are presented in Table E-42 in a best to worst ranking for each of the resource categories. Two alterna- tives, SOS 1a and SOS $1 \mathrm{~b}$, result in positive net economic benefits or nearly zero change when evaluated across all resource uses, except for power purchases. Two alternatives result in positive economic benefits related to anadromous fish: SOS $2 \mathrm{~d}$ and SOS 4c. Irrigation-related impacts show no change from the base case for SOR alternatives SOS 1a, SOS 1b, SOS $2 \mathrm{~d}, \operatorname{SOS} 4 \mathrm{c}$, and SOS $9 \mathrm{~b}$, and negative changes for all other alternatives. Positive economic benefits related to recreation result from four alternatives: SOS $1 \mathrm{a}, \operatorname{SOS} 1 \mathrm{~b}, \operatorname{SOS} 2 \mathrm{~d}$, and SOS 4c. Power-related impacts are positive under two alternatives, SOS $1 \mathrm{a}$ and SOS $1 \mathrm{~b}$. Navigation has positive impacts under the natural river operation strategies SOS $5 \mathrm{~b}$ and SOS $5 \mathrm{c}$, with no change under SOS 1a, SOS 1b, SOS 2d, SOS $4 c$, SOS $9 \mathrm{~b}$, and SOS PA. Impacts associated with power purchases are positive for all alternatives except SOS 1a and SOS $1 \mathrm{~b}$. In all other cases, the SOR alternatives result in negative impacts to the regional economies evaluated in this analysis. 
Table E-41. Ranking of SOR Alternatives by Regional Employment Impacts for All Resources in the Pacific Northwest Region

\begin{tabular}{|c|c|c|c|c|c|c|c|}
\hline & $\begin{array}{c}\text { All } \\
\text { Resources }\end{array}$ & $\begin{array}{c}\text { Anadromous } \\
\text { Fish }\end{array}$ & Irrigation & Navigation & Power & $\begin{array}{c}\text { Power } \\
\text { Purchases }\end{array}$ & Recreation \\
\hline SOS 1b & 2,016 & $(6)$ & 0 & 0 & 3,016 & $(1,055)$ & 63 \\
SOS 1a & 1,031 & $(5)$ & 0 & 0 & 1,505 & $(526)$ & 60 \\
SOS 2d & $(578)$ & 0 & 0 & 0 & $(886)$ & 310 & 0 \\
SOS 6d & $(1,089)$ & $(144)$ & $(261)$ & $(29)$ & $(769)$ & 269 & $(153)$ \\
SOS 4c & $(2,201)$ & 1 & 0 & 0 & $(3,443)$ & 1,204 & 42 \\
SOS 6b & $(2,269)$ & $(388)$ & $(347)$ & $(134)$ & $(1,854)$ & 648 & $(191)$ \\
SOS PA & $(4,029)$ & $(6)$ & $(259)$ & 0 & $(5,419)$ & 1,895 & $(237)$ \\
SOS 5b & $(4,097)$ & $(114)$ & $(434)$ & 157 & $(5,265)$ & 1,841 & $(281)$ \\
SOS 9b & $(5,662)$ & $(82)$ & 0 & 0 & $(8,519)$ & 2,978 & $(36)$ \\
SOS 9c & $(5,678)$ & $(394)$ & $(356)$ & $(17)$ & $(7,317)$ & 2,558 & $(152)$ \\
SOS 5c & $(7,493)$ & $(246)$ & $(437)$ & 90 & $(9,271)$ & 2,693 & $(318)$ \\
SOS 9a & $(9,452)$ & $(557)$ & $(335)$ & $(134)$ & $(12,509)$ & 4,373 & $(290)$ \\
\hline
\end{tabular}

Table E-42. Ranking of SOR Alternatives by Net Regional Employment Impacts for Each Resource Category

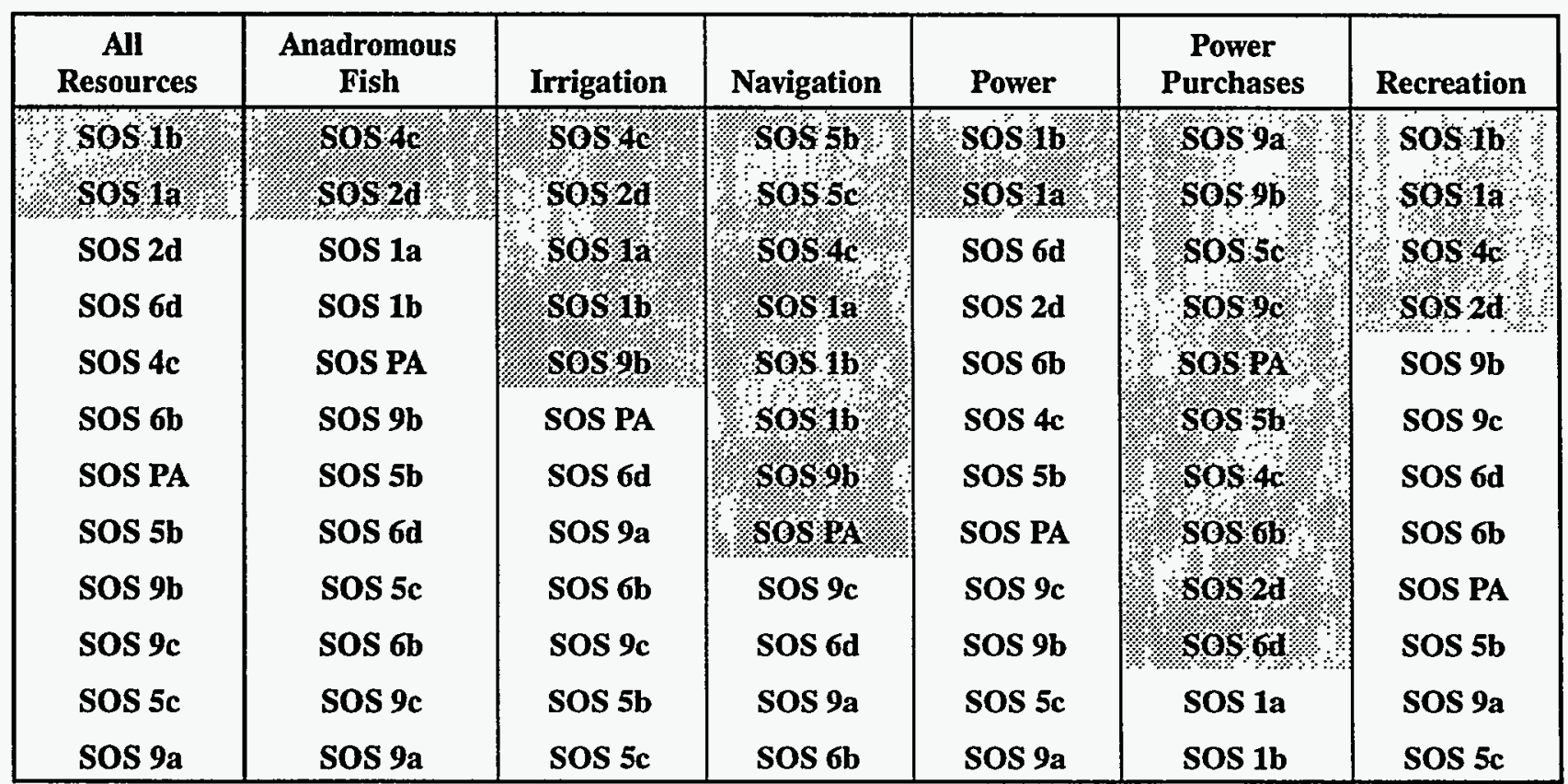

Note: Shading indicates positive economic benefits or no change from SOS $2 c$, the base case scenario. 


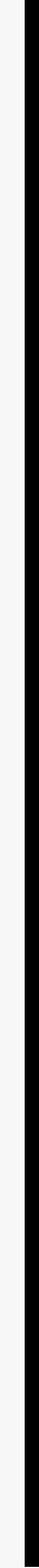




\section{APPENDIX 1}

\section{ECONOMIC IMPACTS IN THE PACIFIC NORTHWEST REGION}


Table E1-1. Pacific Northwest Region, Summary of Regional Economic Impacts 1/

\begin{tabular}{|l|c|c|c|c|}
\hline \multicolumn{5}{|c|}{ Total Regional Impacts 2/ } \\
\hline Alternative & Direct & Total & Direct & Total \\
\hline SOS 1a & 479 & 1,036 & $\$ 11.5$ & $\$ 25.6$ \\
\hline SOS 1b & 935 & 2,021 & $\$ 22.4$ & $\$ 56.4$ \\
\hline SOS 2d & $(269)$ & $(578)$ & $(\$ 6.5)$ & $(\$ 16.2)$ \\
\hline SOS 4c & $(1,013)$ & $(2,191)$ & $(\$ 24.4)$ & $(\$ 61.2)$ \\
\hline SOS 5b & $(1,887)$ & $(4,095)$ & $(\$ 37.1)$ & $(\$ 106.8)$ \\
\hline SOS 5c & $(3,405)$ & $(7,486)$ & $(\$ 70.0)$ & $(\$ 199.4)$ \\
\hline SOS 6b & $(1,028)$ & $(2,264)$ & $(\$ 19.8)$ & $(\$ 59.1)$ \\
\hline SOS 6d & $(500)$ & $(1,083)$ & $(\$ 12.8)$ & $(\$ 31.5)$ \\
\hline SOS 9a & $(4,345)$ & $(9,451)$ & $(\$ 99.8)$ & $(\$ 260.2)$ \\
\hline SOS 9b & $(2,619)$ & $(5,662)$ & $(\$ 63.2)$ & $(\$ 160.5)$ \\
\hline SOS 9c & $(2,617)$ & $(5,678)$ & $(\$ 64.2)$ & $(\$ 113.1)$ \\
\hline SOS PA & $(1,858)$ & $(4,029)$ & $(\$ 45.0)$ & \\
\hline 1/ Does not include $S O S 2 c$ because values shown are changes from SOS 2c. & \\
\hline 2/ Does not include impacts related to project implementation. & \multicolumn{5}{|c}{} \\
\hline
\end{tabular}

\begin{tabular}{|c|c|c|c|c|}
\hline \multicolumn{5}{|c|}{ Anadromous Impacts } \\
\hline \multirow{2}{*}{ Alternative } & \multicolumn{2}{|c|}{ Regional Employment } & \multicolumn{2}{|c|}{ Regional Income $(\$ 1,000,000)$} \\
\hline & Direct & Total & Direct & Total \\
\hline SOS 1a & (3) & (5) & $(\$ 0.1)$ & $(\$ 0.2)$ \\
\hline SOS $1 b$ & (3) & (6) & $(\$ 0.1)$ & $(\$ 0.2)$ \\
\hline SOS 2d & 0 & $(0)$ & $\$ 0.0$ & $\$ 0.0$ \\
\hline SOS $4 c$ & 1 & 1 & $\$ 0.0$ & $\$ 0.0$ \\
\hline SOS 5b & $(52)$ & (114) & $(\$ 1.4)$ & $(\$ 3.4)$ \\
\hline SOS 5c & (112) & (246) & $(\$ 3.0)$ & $(\$ 7.4)$ \\
\hline SOS $6 b$ & (174) & (388) & $(\$ 4.7)$ & $(\$ 11.6)$ \\
\hline SOS $6 \mathrm{~d}$ & $(66)$ & (144) & $(\$ 1.8)$ & $(\$ 4.3)$ \\
\hline SOS 9a & $(250)$ & (557) & $(\$ 6.8)$ & $(\$ 16.6)$ \\
\hline SOS 9b & (39) & $(82)$ & $(\$ 1.1)$ & $(\$ 2.5)$ \\
\hline $\operatorname{SOS} 9 \mathrm{c}$ & (178) & (394) & $(\$ 4.8)$ & $(\$ 11.8)$ \\
\hline SOS PA & (2) & $(6)$ & $(\$ 0.1)$ & $(\$ 0.2)$ \\
\hline
\end{tabular}

Regional Employment and Income Base

\begin{tabular}{|l|l}
\hline Total Employment (jobs): & $3,880,000$ \\
\hline
\end{tabular}

\begin{tabular}{|l|l|l} 
Total Income (\$million): & $\$ 124,851$ \\
\hline
\end{tabular} 
Table E1-1. Pacific Northwest Region, Summary of Regional Economic Impacts - CONT

\begin{tabular}{|l|c|c|c|c|}
\hline \multirow{2}{*}{ Alternative } & \multicolumn{4}{|c|}{ Irrigation Impacts } \\
\cline { 2 - 5 } & Direct & Total & Direct & Total \\
\hline SOS 1a & $(0)$ & $(0)$ & $(\$ 0.0)$ & $(\$ 0.0)$ \\
\hline SOS 1b & $(0)$ & $(0)$ & $(\$ 0.0)$ & $(\$ 0.0)$ \\
\hline SOS 2d & $(0)$ & $(0)$ & $(\$ 0.0)$ & $(\$ 0.0)$ \\
\hline SOS 4c & $(0)$ & $(0)$ & $(\$ 0.0)$ & $(\$ 0.0)$ \\
\hline SOS 5b & $(195)$ & $(434)$ & $(\$ 5.6)$ & $(\$ 13.4)$ \\
\hline SOS 5c & $(196)$ & $(437)$ & $(\$ 5.7)$ & $(\$ 13.5)$ \\
\hline SOS 6b & $(157)$ & $(347)$ & $(\$ 4.5)$ & $(\$ 10.7)$ \\
\hline SOS 6d & $(118)$ & $(261)$ & $(\$ 3.4)$ & $(\$ 8.0)$ \\
\hline SOS 9a & $(151)$ & $(335)$ & $(\$ 4.4)$ & $(\$ 10.3)$ \\
\hline SOS 9b & $(0)$ & $(0)$ & $(\$ 0.0)$ & $(\$ 0.0)$ \\
\hline SOS 9c & $(160)$ & $(356)$ & $(\$ 4.6)$ & $(\$ 11.0)$ \\
\hline SOS PA & $(117)$ & $(259)$ & $(\$ 3.4)$ & $(\$ 8.0)$ \\
\hline
\end{tabular}

\begin{tabular}{|c|c|c|c|c|}
\hline \multicolumn{5}{|c|}{ Navigation Impacts } \\
\hline \multirow{2}{*}{ Alternative } & \multicolumn{2}{|c|}{ Regional Employment } & \multicolumn{2}{|c|}{ Regional Income $(\$ 1,000,000)$} \\
\hline & Direct & Total & Direct & Total \\
\hline SOS 1a & 1 & 2 & $\$ 0.0$ & $\$ 0.1$ \\
\hline SOS $1 \mathrm{~b}$ & 1 & 2 & $\$ 0.1$ & $\$ 0.1$ \\
\hline SOS 2d & (1) & (2) & $(\$ 0.0)$ & $(\$ 0.1)$ \\
\hline SOS $4 c$ & 3 & 5 & $\$ 0.1$ & $\$ 0.2$ \\
\hline SOS $5 b$ & 68 & 158 & $\$ 11.0$ & $\$ 13.6$ \\
\hline SOS 5c & 43 & 94 & $\$ 18.0$ & $\$ 19.3$ \\
\hline SOS $6 \mathrm{~b}$ & (54) & $(132)$ & $\$ 4.9$ & $\$ 2.2$ \\
\hline SOS 6d & (14) & (26) & $(\$ 0.4)$ & $(\$ 0.8)$ \\
\hline $\operatorname{sos} 9 a$ & (55) & (133) & $\$ 4.8$ & $\$ 2.2$ \\
\hline SOS 9b & $(2)$ & (4) & $(\$ 0.1)$ & $(\$ 0.1)$ \\
\hline SOS 9c & (9) & (17) & $(\$ 0.3)$ & $(\$ 0.6)$ \\
\hline SOS PA & (1) & (2) & $(\$ 0.1)$ & $(\$ 0.1)$ \\
\hline
\end{tabular}

\begin{tabular}{|l|r|}
\hline \multicolumn{2}{|c|}{ Regional Employment and Income Base } \\
\hline Total Employment (jobs): & $3,880,000$ \\
\hline Total Income (\$million): & $\$ 124,851$ \\
\hline
\end{tabular}


Table E1-1. Pacific Northwest Region, Summary of Regional Economic Impacts - CONT

\begin{tabular}{|c|c|c|c|c|}
\hline \multicolumn{5}{|c|}{ Power Impacts } \\
\hline \multirow{2}{*}{ Alternative } & \multicolumn{2}{|c|}{ Regional Employment } & \multicolumn{2}{|c|}{ Regional Income $(\$ 1,000,000)$} \\
\hline & Direct & Total & Direct & Total \\
\hline SOS 1a & 654 & 1,505 & $\$ 18.4$ & $\$ 45.8$ \\
\hline $\operatorname{sos} 1 b$ & 1,309 & 3,016 & $\$ 36.8$ & $\$ 91.8$ \\
\hline $\operatorname{sos} 2 d$ & $(386)$ & $(886)$ & $(\$ 10.9)$ & $(\$ 27.0)$ \\
\hline $\operatorname{SOS} 4 c$ & $(1,494)$ & $(3,443)$ & $(\$ 42.0)$ & $(\$ 104.8)$ \\
\hline SOS $5 b$ & $(2,283)$ & $(5,265)$ & $(\$ 64.2)$ & $(\$ 160.2)$ \\
\hline SOS 5c & $(4,023)$ & $(9,271)$ & $(\$ 114.2)$ & $(\$ 283.2)$ \\
\hline SOS $6 b$ & $(805)$ & $(1,854)$ & $(\$ 22.7)$ & $(\$ 56.4)$ \\
\hline SOS $6 \mathrm{~d}$ & $(335)$ & $(769)$ & $(\$ 9.4)$ & $(\$ 23.4)$ \\
\hline $\operatorname{sos} 9 a$ & $(5,423)$ & $(12,509)$ & $(\$ 152.5)$ & $(\$ 380.6)$ \\
\hline $\operatorname{SOS} 9 \mathrm{~b}$ & $(3,694)$ & $(8,519)$ & $(\$ 103.9)$ & $(\$ 259.2)$ \\
\hline SOS 9c & $(3,173)$ & $(7,317)$ & $(\$ 89.2)$ & $(\$ 222.6)$ \\
\hline SOS PA & $(2,350)$ & $(5,419)$ & $(\$ 66.1)$ & $(\$ 164.9)$ \\
\hline
\end{tabular}

\begin{tabular}{|l|c|c|c|c|}
\hline \multirow{2}{*}{ Alternative } & Regional Employment & Regional Income $\mathbf{( \$ 1 , 0 0 0 , 0 0 0 )}$ \\
\cline { 2 - 5 } & Direct & Total & Direct & Total \\
\hline SOS 1a & 28 & 60 & $\$ 0.6$ & $(\$ 1.6)$ \\
\hline SOS 1b & 30 & 63 & $\$ 0.6$ & $\$ 1.7$ \\
\hline SOS 2d & 0 & 0 & $\$ 0.0$ & $\$ 0.0$ \\
\hline SOS 4c & 20 & 42 & $\$ 0.4$ & $\$ 1.1$ \\
\hline SOS 5b & $(125)$ & $(281)$ & $(\$ 2.9)$ & $(\$ 8.0)$ \\
\hline SOS 5c & $(141)$ & $(318)$ & $(\$ 3.3)$ & $(\$ 9.1)$ \\
\hline SOS 6b & $(86)$ & $(191)$ & $(\$ 2.0)$ & $(\$ 5.4)$ \\
\hline SOS 6d & $(70)$ & $(153)$ & $(\$ 1.6)$ & $(\$ 4.3)$ \\
\hline SOS 9a & $(130)$ & $(290)$ & $(\$ 3.0)$ & $(\$ 8.2)$ \\
\hline SOS 9b & $(17)$ & $(36)$ & $(\$ 0.4)$ & $(\$ 1.0)$ \\
\hline SOS 9c & $(70)$ & $(152)$ & $(\$ 1.5)$ & $(\$ 4.2)$ \\
\hline SOS PA & $(108)$ & $(237)$ & $(\$ 2.3)$ & $(\$ 6.4)$ \\
\hline
\end{tabular}

Regional Employment and Income Base

\begin{tabular}{l|r} 
Total Employment (jobs): & $3,880,000$
\end{tabular}

Total Income (\$million): $\quad \$ 124,851$ 
Table E1-1. Pacific Northwest Region, Summary of Regional Economic Impacts - CONT

\begin{tabular}{|c|c|c|c|c|}
\hline \multicolumn{5}{|c|}{ Construction Impacts } \\
\hline \multirow{2}{*}{ Alternative } & \multicolumn{2}{|c|}{ Regional Employment } & \multicolumn{2}{|c|}{ Regional Income $(\$ 1,000,000)$} \\
\hline & Direct & Total & Direct & Total \\
\hline SOS 1a & 0 & 0 & $\$ 0.0$ & $\$ 0.0$ \\
\hline SOS $1 b$ & 0 & 0 & $\$ 0.0$ & $\$ 0.0$ \\
\hline $\operatorname{sos} 2 d$ & 0 & 0 & $\$ 0.0$ & $\$ 0.0$ \\
\hline SOS $4 c$ & 0 & 0 & $\$ 0.0$ & $\$ 0.0$ \\
\hline SOS $5 b$ & 3,719 & 10,479 & $\$ 137.9$ & $\$ 369.6$ \\
\hline SOS 5c & 2,413 & 6,694 & $\$ 89.6$ & $\$ 235.8$ \\
\hline SOS $6 b$ & 2,058 & 5,719 & $\$ 76.4$ & $\$ 201.5$ \\
\hline SOS 6d & 960 & 2,596 & $\$ 35.7$ & $\$ 91.3$ \\
\hline SOS 9a & 2,016 & 5,610 & $\$ 74.8$ & $\$ 197.6$ \\
\hline SOS 9b & 0 & 0 & $\$ 0.0$ & $\$ 0.0$ \\
\hline SOS 9c & 2,078 & 5,772 & $\$ 77.2$ & $\$ 203.3$ \\
\hline SOS PA & 855 & 2,290 & $\$ 31.8$ & $\$ 80.4$ \\
\hline
\end{tabular}

\begin{tabular}{|c|c|c|c|c|}
\hline \multicolumn{5}{|c|}{ Power Purchases Impacts } \\
\hline \multirow{2}{*}{ Alternative } & \multicolumn{2}{|c|}{ Regional Employment } & \multicolumn{2}{|c|}{ Regional Income $(\$ 1,000,000)$} \\
\hline & Direct & Total & Direct & Total \\
\hline SOS 1a & $(201)$ & $(526)$ & $(\$ 7.5)$ & $(\$ 18.5)$ \\
\hline SOS 1b & $(402)$ & $(1,055)$ & $(\$ 15.0)$ & $(\$ 37.0)$ \\
\hline SOS $2 d$ & 118 & 310 & $\$ 4.4$ & $\$ 10.9$ \\
\hline SOS 4c & 458 & 1,204 & $\$ 17.1$ & $\$ 42.2$ \\
\hline SOS 5b & 700 & 1,841 & $\$ 26.1$ & $\$ 64.5$ \\
\hline SOS 5c & 1,024 & 2,693 & $\$ 38.2$ & $\$ 94.4$ \\
\hline SOS $6 b$ & 247 & 648 & $\$ 9.2$ & $\$ 22.7$ \\
\hline SOS 6d & 103 & 269 & $\$ 3.8$ & $\$ 9.4$ \\
\hline sos 9a & 1,663 & 4,373 & $\$ 62.0$ & $\$ 153.3$ \\
\hline SOS 9b & 1,133 & 2,978 & $\$ 42.2$ & $\$ 104.4$ \\
\hline SOS 9c & 973 & 2,558 & $\$ 36.3$ & $\$ 89.7$ \\
\hline SOS PA & 721 & 1,895 & $\$ 26.9$ & $\$ 66.4$ \\
\hline
\end{tabular}

\begin{tabular}{|l|c|}
\hline \multicolumn{2}{|c|}{ Regional Employment and Income Base } \\
\hline Total Employment (jobs): & $3,880,000$ \\
\hline Total Income (\$million): & $\$ 124,851$ \\
\hline
\end{tabular}


APPENDIX 2

\section{ECONOMIC IMPACTS IN WASHINGTON, OREGON, IDAHO, AND MONTANA}


Table E2-1. State of Washington, Summary of Regional Economic Impacts

\begin{tabular}{|l|c|c|c|c|}
\hline \multicolumn{4}{|c|}{ Total Regional Impacts 1/ } \\
\hline \multirow{2}{*}{ Alternative 2/ } & Regional Employment & \multicolumn{2}{c|}{ Regional Income (\$1,000,000) } \\
\cline { 2 - 5 } & Direct & Total & Direct & Total \\
\hline SOS 1a & 377 & 753 & $\$ 10.6$ & $\$ 23.6$ \\
\hline SOS 1b & 740 & 1,479 & $\$ 20.9$ & $(\$ 46.4$ \\
\hline SOS 2d & $(212)$ & $(422)$ & $(\$ 6.0)$ & $(\$ 13.3)$ \\
\hline SOS 4c & $(805)$ & $(1,614)$ & $(\$ 40.8)$ & $(\$ 95.4)$ \\
\hline SOS 5b & $(1,565)$ & $(3,133)$ & $(\$ 54.7)$ & $(\$ 131.7)$ \\
\hline SOS 5c & $(2,191)$ & $(4,397)$ & $(\$ 16.8)$ & $(\$ 40.6)$ \\
\hline SOS 6b & $(686)$ & $(1,364)$ & $(\$ 9.1)$ & $(\$ 20.1)$ \\
\hline SOS 6d & $(329)$ & $(641)$ & $(\$ 90.7)$ & $(\$ 204.9)$ \\
\hline SOS 9a & $(3,297)$ & $(6,598)$ & $(\$ 58.4)$ & $(\$ 129.7)$ \\
\hline SOS 9b & $(2,061)$ & $(4,127)$ & $(\$ 55.3)$ & $(\$ 122.5)$ \\
\hline SOS 9c & $(1,956)$ & $(3,901)$ & $(\$ 40.1)$ & $(\$ 89.1)$ \\
\hline SOS PA & $(1,427)$ & $(2,846)$ & & \\
\hline 1/ Does not include impacts to project implementation. & \multicolumn{2}{|c|}{} \\
\hline 2/ Excludes SOS 2c because the values shown are differences from SOS 2c. & \\
\hline
\end{tabular}

\begin{tabular}{|c|c|c|c|c|}
\hline \multicolumn{5}{|c|}{ Anadromous Fish Impacts } \\
\hline \multirow{2}{*}{ Alternative } & \multicolumn{2}{|c|}{ Regional Employment } & \multicolumn{2}{|c|}{ Regional Income $(\$ 1,000,000)$} \\
\hline & Direct & Total & Direct & Total \\
\hline SOS 1a & $(1)$ & $(1)$ & $(\$ 0.0)$ & $(\$ 0.0)$ \\
\hline SOS $1 b$ & $(1)$ & (1) & $(\$ 0.0)$ & $(\$ 0.0)$ \\
\hline $\operatorname{sOS} 2 \mathrm{~d}$ & 0 & $(0)$ & $\$ 0.0$ & $\$ 0.0$ \\
\hline $\operatorname{sos} 4 \mathrm{c}$ & 0 & 0 & $\$ 0.0$ & $\$ 0.0$ \\
\hline SOS $5 b$ & $(15)$ & (27) & $(\$ 0.4)$ & $(\$ 0.9)$ \\
\hline SOS 5c & $(29)$ & (54) & $(\$ 0.8)$ & $(\$ 1.7)$ \\
\hline $\operatorname{SOS} 6 \mathrm{~b}$ & $(45)$ & $(84)$ & $(\$ 1.3)$ & $(\$ 2.7)$ \\
\hline sos 6d & $(17)$ & $(31)$ & $(\$ 0.5)$ & $(\$ 1.0)$ \\
\hline $\operatorname{sos} 9 a$ & $(69)$ & $(129)$ & $(\$ 1.9)$ & $(\$ 4.0)$ \\
\hline SOS $9 b$ & $(11)$ & $(18)$ & $(\$ 0.3)$ & $(\$ 0.6)$ \\
\hline SOS $9 c$ & (46) & $(87)$ & $(\$ 1.3)$ & $(\$ 2.7)$ \\
\hline SOS PA & $(0)$ & $(1)$ & $(\$ 0.0)$ & $(\$ 0.0)$ \\
\hline
\end{tabular}

\begin{tabular}{|l|c|}
\hline \multicolumn{2}{|c|}{ Regional Employment and Income Base } \\
\hline Total Employment (jobs): & $2,011,000$ \\
\hline Total Income (\$million): & $\$ 68,958$ \\
\hline
\end{tabular}


Table E2-1. State of Washington, Summary of Regional Economic Impacts - CONT

\begin{tabular}{|c|c|c|c|c|}
\hline \multirow{2}{*}{ Alternative } & \multicolumn{3}{|c|}{ Irrigation Impacts } & \multicolumn{2}{c|}{ Regional Income (\$1,000,000) } \\
\cline { 2 - 5 } & Direct & Total & Direct & Total \\
\hline SOS 1a & $(0)$ & $(0)$ & $(\$ 0.0)$ & $(\$ 0.0)$ \\
\hline SOS 1b & $(0)$ & $(0)$ & $(\$ 0.0)$ & $(\$ 0.0)$ \\
\hline SOS 2d & $(0)$ & $(0)$ & $(\$ 0.0)$ & $(\$ 0.0)$ \\
\hline SOS 4c & $(0)$ & $(0)$ & $(\$ 0.0)$ & $(\$ 0.0)$ \\
\hline SOS 5b & $(131)$ & $(251)$ & $(\$ 3.8)$ & $(\$ 8.0)$ \\
\hline SOS 5c & $(132)$ & $(254)$ & $(\$ 3.8)$ & $(\$ 8.1)$ \\
\hline SOS 6b & $(93)$ & $(176)$ & $(\$ 2.7)$ & $(\$ 5.6)$ \\
\hline SOS 6d & $(54)$ & $(101)$ & $(\$ 1.6)$ & $(\$ 3.2)$ \\
\hline SOS 9a & $(90)$ & $(172)$ & $(\$ 2.6)$ & $(\$ 5.5)$ \\
\hline SOS 9b & $(0)$ & $(0)$ & $(\$ 0.0)$ & $(\$ 0.0)$ \\
\hline SOS 9c & $(95)$ & $(181)$ & $(\$ 2.8)$ & $(\$ 5.8)$ \\
\hline SOS PA & $(51)$ & $(96)$ & $(\$ 1.5)$ & $(\$ 3.1)$ \\
\hline
\end{tabular}

\begin{tabular}{|c|c|c|c|c|}
\hline \multicolumn{5}{|c|}{ Navigation Impacts } \\
\hline \multirow{2}{*}{ Alternative } & \multicolumn{2}{|c|}{ Regional Employment } & \multicolumn{2}{c|}{ Regional Income (\$1,000,000) } \\
\cline { 2 - 5 } & Direct & Total & Direct & Total \\
\hline SOS 1a & 0 & 0 & $\$ 0.0$ & $\$ 0.0$ \\
\hline SOS 1b & 0 & 0 & $\$ 0.0$ & $\$ 0.0$ \\
\hline SOS 2d & 0 & 0 & $\$ 0.0$ & $\$ 0.0$ \\
\hline SOS 4c & 0 & 0 & $\$ 0.0$ & $\$ 0.0$ \\
\hline SOS 5b & $(16)$ & $(44)$ & $\$ 2.8$ & $\$ 1.4$ \\
\hline SOS 5c & $(23)$ & $(66)$ & $\$ 6.4$ & $\$ 4.1$ \\
\hline SOS 6b & $(13)$ & $(34)$ & $\$ 2.1$ & $\$ 1.0$ \\
\hline SOS 6d & $(3)$ & $(5)$ & $(\$ 0.1)$ & $(\$ 0.2)$ \\
\hline SOS 9a & $(13)$ & $(34)$ & $\$ 2.1$ & $\$ 1.0$ \\
\hline SOS 9b & 0 & 0 & $\$ 0.0$ & $\$ 0.0$ \\
\hline SOS 9c & $(2)$ & $(2)$ & $(\$ 0.1)$ & $(\$ 0.1)$ \\
\hline SOS PA & 0 & 0 & $\$ 0.0$ & $\$ 0.0$ \\
\hline
\end{tabular}

Regional Employment and Income Base

\begin{tabular}{|l|c|}
\hline Total Employment (jobs): & $2,011,000$ \\
\hline Total Income (\$million): & $\$ 68,958$ \\
\hline
\end{tabular}


Table E2-1. State of Washington, Summary of Regional Economic Impacts - CONT

\begin{tabular}{|c|c|c|c|c|}
\hline \multicolumn{5}{|c|}{ Power Impacts } \\
\hline \multirow{2}{*}{ Alternative } & \multicolumn{2}{|c|}{ Regional Employment } & \multicolumn{2}{|c|}{ Regional Income $(\$ 1,000,000)$} \\
\hline & Direct & Total & Direct & Total \\
\hline SOS 1a & 358 & 716 & $\$ 10.2$ & $\$ 22.5$ \\
\hline SOS $1 b$ & 717 & 1,436 & $\$ 20.4$ & $\$ 45.2$ \\
\hline $\operatorname{sos} 2 d$ & $(211)$ & $(421)$ & $(\$ 6.0)$ & $(\$ 13.2)$ \\
\hline SOS $4 c$ & $(818)$ & $(1,638)$ & $(\$ 23.2)$ & $(\$ 51.5)$ \\
\hline SOS $5 b$ & $(1,251)$ & $(2,507)$ & $(\$ 35.5)$ & $(\$ 78.8)$ \\
\hline SOS $5 c$ & $(1,830)$ & $(3,670)$ & $(\$ 52.0)$ & $(\$ 115.4)$ \\
\hline SOS $6 b$ & $(441)$ & $(882)$ & $(\$ 12.5)$ & $(\$ 27.8)$ \\
\hline SOS 6d & (184) & $(365)$ & $(\$ 5.2)$ & $(\$ 11.5)$ \\
\hline sos 9a & $(2,971)$ & $(5,959)$ & $(\$ 84.4)$ & $(\$ 187.3)$ \\
\hline sos $9 b$ & $(2,023)$ & $(4,057)$ & $(\$ 57.5)$ & $(\$ 127.5)$ \\
\hline SOS 9c & $(1,738)$ & $(3,485)$ & $(\$ 49.4)$ & $(\$ 109.6)$ \\
\hline SOS PA & $(1,287)$ & $(2,580)$ & $(\$ 36.6)$ & $(\$ 81.1)$ \\
\hline
\end{tabular}

\begin{tabular}{|c|c|c|c|c|}
\hline \multicolumn{5}{|c|}{ Recreation Impacts } \\
\hline \multirow{2}{*}{ Alternative } & \multicolumn{2}{|c|}{ Regional Employment } & \multicolumn{2}{c|}{ Regional Income (\$1,000,000) } \\
\cline { 2 - 5 } & Direct & Total & Direct & Total \\
\hline SOS 1a & 20 & 38 & $\$ 0.5$ & $\$ 1.1$ \\
\hline SOS 1b & 24 & 44 & $\$ 0.6$ & $\$ 1.3$ \\
\hline SOS 2d & $(1)$ & $(1)$ & $(\$ 0.0)$ & $(\$ 0.0)$ \\
\hline SOS 4c & 13 & 24 & $\$ 0.3$ & $\$ 0.7$ \\
\hline SOS 5b & $(153)$ & $(304)$ & $(\$ 3.9)$ & $(\$ 9.1)$ \\
\hline SOS 5c & $(177)$ & $(353)$ & $(\$ 4.5)$ & $(\$ 10.6)$ \\
\hline SOS 6b & $(95)$ & $(187)$ & $(\$ 2.4)$ & $(\$ 5.6)$ \\
\hline SOS 6d & $(71)$ & $(139)$ & $(\$ 1.8)$ & $(\$ 4.1)$ \\
\hline SOS 9a & $(153)$ & $(304)$ & $(\$ 3.9)$ & $(\$ 9.0)$ \\
\hline SOS 9b & $(27)$ & $(52)$ & $(\$ 0.7)$ & $(\$ 1.6)$ \\
\hline SOS 9c & $(75)$ & $(146)$ & $(\$ 1.8)$ & $(\$ 4.3)$ \\
\hline SOS PA & $(88)$ & $(170)$ & $(\$ 2.1)$ & $(\$ 4.9)$ \\
\hline
\end{tabular}

Regional Employment and Income Base

\begin{tabular}{|l|c|}
\hline Total Employment (jobs): & $2,011,000$ \\
\hline Total Income (\$million): & $\$ 68,958$ \\
\hline
\end{tabular}


Table E2-1. State of Washington, Summary of Regional Economic Impacts - CONT

\begin{tabular}{|c|c|c|c|c|}
\hline \multicolumn{5}{|c|}{ Construction Impacts } \\
\hline \multirow{2}{*}{ Alternative } & \multicolumn{2}{|c|}{ Regional Employment } & \multicolumn{2}{|c|}{ Regional Income $(\$ 1,000,000)$} \\
\hline & Direct & Total & Direct & Total \\
\hline SOS 1a & 0 & 0 & $\$ 0.0$ & $\$ 0.0$ \\
\hline $\operatorname{sos} 1 b$ & 0 & 0 & $\$ 0.0$ & $\$ 0.0$ \\
\hline SOS 2d & 0 & 0 & $\$ 0.0$ & $\$ 0.0$ \\
\hline $\operatorname{sOS} 4 c$ & 0 & 0 & $\$ 0.0$ & $\$ 0.0$ \\
\hline SOS $5 b$ & 2,661 & 6,384 & $\$ 97.8$ & $\$ 233.3$ \\
\hline SOS 5c & 1,745 & 4,129 & $\$ 64.0$ & $\$ 150.5$ \\
\hline SOS 6b & 1,329 & 3,146 & $\$ 48.8$ & $\$ 114.7$ \\
\hline SOS 6d & 488 & 1,123 & $\$ 17.9$ & $\$ 40.7$ \\
\hline SOS 9a & 1,307 & 3,098 & $\$ 48.0$ & $\$ 112.9$ \\
\hline SOS 9b & 0 & 0 & $\$ 0.0$ & $\$ 0.0$ \\
\hline SOS 9c & 1,347 & 3,187 & $\$ 49.4$ & $\$ 116.1$ \\
\hline SOS PA & 435 & 993 & $\$ 15.9$ & $\$ 35.9$ \\
\hline
\end{tabular}

Regional Employment and Income Base

\begin{tabular}{|l|c|}
\hline Total Employment (jobs): & $2,011,000$ \\
\hline Total Income (\$million): & $\$ 68,958$ \\
\hline
\end{tabular}


Table E2-2. State of Oregon, Summary of Regional Economic Impacts

\begin{tabular}{|c|c|c|c|c|}
\hline \multicolumn{5}{|c|}{ Total Regional Impacts $1 /$} \\
\hline \multirow[t]{2}{*}{ Alternative 2/ } & \multicolumn{2}{|c|}{ Regional Employment } & \multicolumn{2}{|c|}{ Regional Income $(\$ 1,000,000)$} \\
\hline & Direct & Total & Direct & Total \\
\hline SOS 1a & 204 & 408 & $\$ 5.8$ & $\$ 12.5$ \\
\hline SOS $1 b$ & 388 & 779 & $\$ 11.1$ & $\$ 24.0$ \\
\hline SOS $2 d$ & $(107)$ & $(214)$ & $(\$ 3.1)$ & $(\$ 6.6)$ \\
\hline SOS $4 c$ & $(402)$ & $(815)$ & $(\$ 11.7)$ & $(\$ 25.3)$ \\
\hline SOS $5 b$ & $(733)$ & $(1,464)$ & $(\$ 20.8)$ & $(\$ 45.0)$ \\
\hline SOS $5 c$ & $(1,042)$ & $(2,083)$ & $(\$ 29.6)$ & $(\$ 63.9)$ \\
\hline SOS $6 b$ & $(344)$ & $(677)$ & $(\$ 9.6)$ & $(\$ 20.6)$ \\
\hline $\operatorname{sOS} 6 \mathrm{~d}$ & $(205)$ & $(394)$ & $(\$ 5.7)$ & $(\$ 12.1)$ \\
\hline $\operatorname{sOS} 9 \mathrm{a}$ & $(1,671)$ & $(3,352)$ & $(\$ 47.7)$ & $(\$ 103.1)$ \\
\hline SOS $9 b$ & $(1,045)$ & $(2,107)$ & $(\$ 30.1)$ & $(\$ 65.1)$ \\
\hline $\operatorname{SOS} 9 \mathrm{c}$ & $(1,026)$ & $(2,053)$ & $(\$ 29.3)$ & $(\$ 63.1)$ \\
\hline SOS PA & (797) & $(1,594)$ & $(\$ 22.5)$ & $(\$ 48.8)$ \\
\hline
\end{tabular}

\begin{tabular}{|c|c|c|c|c|}
\hline \multicolumn{5}{|c|}{ Anadromous Fish Impacts } \\
\hline \multirow{2}{*}{ Alternative } & \multicolumn{5}{|c|}{ Regional Employment } & \multicolumn{2}{c|}{ Regional Income (\$1,000,000) } \\
\cline { 2 - 5 } & Direct & Total & Direct & Total \\
\hline SOS 1a & $(1)$ & $(1)$ & $(\$ 0.0)$ & $(\$ 0.0)$ \\
\hline SOS 1b & $(1)$ & $(1)$ & $(\$ 0.0)$ & $(\$ 0.0)$ \\
\hline SOS 2d & 1 & 1 & $\$ 0.0$ & $\$ 0.0$ \\
\hline SOS 4c & 1 & 1 & $\$ 0.0$ & $\$ 0.0$ \\
\hline SOS 5b & $(11)$ & $(19)$ & $(\$ 0.3)$ & $(\$ 0.6)$ \\
\hline SOS 5c & $(22)$ & $(40)$ & $(\$ 0.6)$ & $(\$ 1.2)$ \\
\hline SOS 6b & $(34)$ & $(63)$ & $(\$ 0.8)$ & $(\$ 1.8)$ \\
\hline SOS 6d & $(13)$ & $(23)$ & $(\$ 0.3)$ & $(\$ 0.7)$ \\
\hline SOS 9a & $(67)$ & $(123)$ & $(\$ 1.7)$ & $(\$ 3.6)$ \\
\hline SOS 9b & $(10)$ & $(16)$ & $(\$ 0.3)$ & $(\$ 0.5)$ \\
\hline SOS 9c & $(37)$ & $(68)$ & $(\$ 0.9)$ & $(\$ 2.0)$ \\
\hline SOS PA & 1 & 1 & $\$ 0.0$ & $\$ 0.1$ \\
\hline
\end{tabular}

\begin{tabular}{|l|c|}
\hline \multicolumn{2}{|c|}{ Regional Employment and Income Base } \\
\hline Total Employment (jobs): & $1,226,000$ \\
\hline Total Income (\$million): & $\$ 35,747$ \\
\hline
\end{tabular}


Table E2-2. State of Oregon, Summary of Regional Economic Impacts - CONT

\begin{tabular}{|l|c|c|c|c|}
\hline \multirow{2}{*}{ Alternative } & \multicolumn{3}{|c|}{ Irrigation Impacts } & \multicolumn{2}{c|}{ Regional Income $\mathbf{( \$ 1 , 0 0 0 , 0 0 0 )}$} \\
\cline { 2 - 5 } & Direct & Total & Direct & Total \\
\hline SOS 1a & 0 & 0 & $\$ 0.0$ & $\$ 0.0$ \\
\hline SOS 1b & 0 & 0 & $\$ 0.0$ & $\$ 0.0$ \\
\hline SOS 2d & 0 & 0 & $\$ 0.0$ & $\$ 0.0$ \\
\hline SOS 4c & 0 & 0 & $\$ 0.0$ & $\$ 0.0$ \\
\hline SOS 5b & $(60)$ & $(115)$ & $(\$ 1.8)$ & $(\$ 3.6)$ \\
\hline SOS 5c & $(60)$ & $(115)$ & $(\$ 1.8)$ & $(\$ 3.6)$ \\
\hline SOS 6b & $(60)$ & $(115)$ & $(\$ 1.8)$ & $(\$ 3.6)$ \\
\hline SOS 6d & $(60)$ & $(115)$ & $(\$ 1.8)$ & $(\$ 3.6)$ \\
\hline SOS 9a & $(57)$ & $(109)$ & $(\$ 1.7)$ & $(\$ 3.4)$ \\
\hline SOS 9b & 0 & 0 & $\$ 0.0$ & $\$ 0.0$ \\
\hline SOS 9c & $(61)$ & $(115)$ & $(\$ 1.8)$ & $(\$ 3.6)$ \\
\hline SOS PA & $(63)$ & $(119)$ & $(\$ 1.9)$ & $(\$ 3.8)$ \\
\hline
\end{tabular}

\begin{tabular}{|c|c|c|c|c|}
\hline & \multicolumn{4}{|c|}{ Navigation Impacts } \\
\hline \multirow{2}{*}{ Alternative } & Regional Employment & \multicolumn{2}{c|}{ Regional Income (\$1,000,000) } \\
\cline { 2 - 5 } & Direct & Total & Direct & Total \\
\hline SOS 1a & 0 & 0 & $\$ 0.0$ & $\$ 0.0$ \\
\hline SOS 1b & 0 & 0 & $\$ 0.0$ & $\$ 0.0$ \\
\hline SOS 2d & 0 & 0 & $\$ 0.0$ & $\$ 0.0$ \\
\hline SOS 4c & 0 & 0 & $\$ 0.0$ & $\$ 0.0$ \\
\hline SOS 5b & 9 & 19 & $\$ 0.4$ & $\$ 0.7$ \\
\hline SOS 5c & 8 & 22 & $\$ 0.5$ & $\$ 1.0$ \\
\hline SOS 6b & 6 & 13 & $\$ 0.3$ & $\$ 0.5$ \\
\hline SOS 6d & $(7)$ & $(11)$ & $(\$ 0.2)$ & $(\$ 0.4)$ \\
\hline SOS 9a & 6 & 13 & $\$ 0.3$ & $\$ 0.5$ \\
\hline SOS 9b & 0 & 0 & $\$ 0.0$ & $\$ 0.0$ \\
\hline SOS 9c & $(4)$ & $(6)$ & $(\$ 0.1)$ & $(\$ 0.2)$ \\
\hline SOS PA & 0 & 0 & $\$ 0.0$ & $\$ 0.0$ \\
\hline
\end{tabular}

\begin{tabular}{|l|c|}
\hline \multicolumn{2}{|c|}{ Regional Employment and Income Base } \\
\hline Total Employment (jobs): & $1,226,000$ \\
\hline Total Income (\$million): & $\$ 35,747$ \\
\hline
\end{tabular}


Table E2-2. State of Oregon, Summary of Regional Economic Impacts - CONT

\begin{tabular}{|c|c|c|c|c|}
\hline \multicolumn{5}{|c|}{ Power Impacts } \\
\hline \multirow{2}{*}{ Alternative } & \multicolumn{2}{|c|}{ Regional Employment } & \multicolumn{2}{|c|}{ Regional Income $(\$ 1,000,000)$} \\
\hline & Direct & Total & Direct & Total \\
\hline SOS 1a & 183 & 368 & $\$ 5.3$ & $\$ 11.4$ \\
\hline $\operatorname{SOS} 1 b$ & 367 & 739 & $\$ 10.6$ & $\$ 22.9$ \\
\hline SOS $2 d$ & $(108)$ & $(215)$ & $(\$ 3.1)$ & $(\$ 6.7)$ \\
\hline SOS 4c & $(418)$ & $(843)$ & $(\$ 12.1)$ & $(\$ 26.1)$ \\
\hline SOS $5 \mathrm{~b}$ & $(640)$ & $(1,291)$ & $(\$ 18.5)$ & $(\$ 39.9)$ \\
\hline SOS 5c & (936) & $(1,891)$ & $(\$ 27.0)$ & $(\$ 58.4)$ \\
\hline SOS $6 \mathrm{~b}$ & $(225)$ & $(453)$ & $(\$ 6.5)$ & $(\$ 14.0)$ \\
\hline SOS 6d & (94) & $(186)$ & $(\$ 2.7)$ & $(\$ 5.8)$ \\
\hline $\operatorname{sos} 9 a$ & $(1,520)$ & $(3,071)$ & $(\$ 43.9)$ & $(\$ 94.9)$ \\
\hline $\operatorname{SOS} 9 \mathrm{~b}$ & $(1,035)$ & $(2,091)$ & $(\$ 29.9)$ & $(\$ 64.6)$ \\
\hline SOS $9 c$ & $(889)$ & $(1,796)$ & $(\$ 25.7)$ & $(\$ 55.5)$ \\
\hline SOS PA & $(659)$ & $(1,329)$ & $(\$ 19.0)$ & $(\$ 41.1)$ \\
\hline
\end{tabular}

\begin{tabular}{|c|c|c|c|c|}
\hline \multicolumn{5}{|c|}{ Recreation Impacts } \\
\hline \multirow{2}{*}{ Alternative } & \multicolumn{2}{|c|}{ Regional Employment } & \multicolumn{2}{c|}{ Regional Income (\$1,000,000) } \\
\cline { 2 - 5 } & Direct & Total & Direct & Total \\
\hline SOS 1a & 22 & 41 & $\$ 0.5$ & $\$ 1.1$ \\
\hline SOS 1b & 22 & 41 & $\$ 0.5$ & $\$ 1.1$ \\
\hline SOS 2d & 0 & 0 & $\$ 0.0$ & $\$ 0.0$ \\
\hline SOS 4c & 15 & 27 & $\$ 0.3$ & $\$ 0.7$ \\
\hline SOS 5b & $(31)$ & $(59)$ & $(\$ 0.7)$ & $(\$ 1.6)$ \\
\hline SOS 5c & $(31)$ & $(59)$ & $(\$ 0.7)$ & $(\$ 1.6)$ \\
\hline SOS 6b & $(31)$ & $(59)$ & $(\$ 0.7)$ & $(\$ 1.6)$ \\
\hline SOS 6d & $(31)$ & $(59)$ & $(\$ 0.7)$ & $(\$ 1.6)$ \\
\hline SOS 9a & $(33)$ & $(62)$ & $(\$ 0.7)$ & $(\$ 1.7)$ \\
\hline SOS 9b & 0 & 0 & $\$ 0.0$ & $\$ 0.0$ \\
\hline SOS 9c & $(35)$ & $(67)$ & $(\$ 0.8)$ & $(\$ 1.8)$ \\
\hline SOS PA & $(76)$ & $(147)$ & $(\$ 1.7)$ & $(\$ 4.0)$ \\
\hline
\end{tabular}

\begin{tabular}{|l|c|}
\hline \multicolumn{2}{|c|}{ Regional Employment and Income Base } \\
\hline Total Employment (jobs): & $1,226,000$ \\
\hline Total Income (\$million): & $\$ 35,747$ \\
\hline
\end{tabular}


Table E2-2. State of Oregon, Summary of Regional Economic Impacts - CONT

\begin{tabular}{|c|c|c|c|c|}
\hline \multicolumn{4}{|c|}{ Construction Impacts } \\
\hline \multirow{2}{*}{ Alternative } & Regional Employment & \multicolumn{2}{c|}{ Regional Income (\$1,000,000) } \\
\cline { 2 - 5 } & Direct & Total & Direct & Total \\
\hline SOS 1a & 0 & 0 & $\$ 0.0$ & $\$ 0.0$ \\
\hline SOS 1b & 0 & 0 & $\$ 0.0$ & $\$ 0.0$ \\
\hline SOS 2d & 0 & 0 & $\$ 0.0$ & $\$ 0.0$ \\
\hline SOS 4c & 0 & 0 & $\$ 0.0$ & $\$ 0.0$ \\
\hline SOS 5b & 341 & 746 & $\$ 12.8$ & $\$ 26.8$ \\
\hline SOS 5c & 377 & 832 & $\$ 14.1$ & $\$ 29.8$ \\
\hline SOS 6b & 350 & 768 & $\$ 13.1$ & $\$ 27.5$ \\
\hline SOS 6d & 377 & 832 & $\$ 14.1$ & $\$ 29.8$ \\
\hline SOS 9a & 329 & 723 & $\$ 12.3$ & $\$ 25.9$ \\
\hline SOS 9b & 0 & 0 & $\$ 0.0$ & $\$ 0.0$ \\
\hline SOS 9c & 350 & 768 & $\$ 13.1$ & $\$ 27.5$ \\
\hline SOS PA & 426 & 944 & $\$ 15.9$ & $\$ 33.8$ \\
\hline
\end{tabular}

Regional Employment and Income Base

\begin{tabular}{|l|c|}
\hline Total Employment (jobs): & $1,226,000$ \\
\hline Total Income (\$million): & $\$ 35,747$ \\
\hline
\end{tabular}


Table E2-3. State of Idaho, Summary of Regional Economic Impacts

\begin{tabular}{|c|c|c|c|c|}
\hline \multicolumn{5}{|c|}{ Total Regional Impacts $1 /$} \\
\hline \multirow{2}{*}{ Alternative $2 /$} & \multicolumn{2}{|c|}{ Regional Employment } & \multicolumn{2}{|c|}{ Regional Income $(\$ 1,000,000)$} \\
\hline & Direct & Total & Direct & Total \\
\hline SOS 1a & 81 & 160 & $\$ 2.0$ & $\$ 4.2$ \\
\hline SOS $1 b$ & 166 & 334 & $\$ 4.2$ & $\$ 8.7$ \\
\hline $\operatorname{SOS} 2 \mathrm{~d}$ & $(50)$ & $(96)$ & $(\$ 1.3)$ & $(\$ 2.6)$ \\
\hline $\operatorname{SOS} 4 c$ & (198) & $(395)$ & $(\$ 4.9)$ & $(\$ 10.3)$ \\
\hline SOS $5 b$ & $(380)$ & $(736)$ & $(\$ 5.0)$ & $(\$ 14.1)$ \\
\hline SOS 5c & $(591)$ & $(1,135)$ & $(\$ 5.8)$ & $(\$ 19.5)$ \\
\hline SOS $6 b$ & $(259)$ & $(497)$ & $(\$ 3.1)$ & $(\$ 9.2)$ \\
\hline SOS 6d & (91) & (176) & $(\$ 2.3)$ & $(\$ 4.6)$ \\
\hline $\operatorname{sos} 9 a$ & (925) & $(1,845)$ & $(\$ 19.8)$ & $(\$ 42.6)$ \\
\hline SOS 9b & $(528)$ & $(1,062)$ & $(\$ 13.3)$ & $(\$ 27.8)$ \\
\hline SOS 9c & (538) & $(1,077)$ & $(\$ 13.5)$ & $(\$ 28.1)$ \\
\hline SOS PA & (314) & $(629)$ & $(\$ 7.9)$ & $(\$ 16.5)$ \\
\hline
\end{tabular}

\begin{tabular}{|c|c|c|c|c|}
\hline \multicolumn{5}{|c|}{ Anadromous Fish Impacts } \\
\hline \multirow{2}{*}{ Alternative } & \multicolumn{2}{|c|}{ Regional Employment } & \multicolumn{2}{c|}{ Regional Income $\mathbf{( \$ 1 , 0 0 0 , 0 0 0 )}$} \\
\cline { 2 - 5 } & Direct & Total & Direct & Total \\
\hline SOS 1a & $(2)$ & $(3)$ & $(\$ 0.0)$ & $(\$ 0.1)$ \\
\hline SOS 1b & $(2)$ & $(3)$ & $(\$ 0.1)$ & $(\$ 0.1)$ \\
\hline SOS 2d & $(1)$ & $(2)$ & $(\$ 0.0)$ & $(\$ 0.0)$ \\
\hline SOS 4c & $(1)$ & $(1)$ & $(\$ 0.0)$ & $(\$ 0.0)$ \\
\hline SOS 5b & $(30)$ & $(60)$ & $(\$ 0.7)$ & $(\$ 1.5)$ \\
\hline SOS 5c & $(70)$ & $(140)$ & $(\$ 1.7)$ & $(\$ 3.6)$ \\
\hline SOS 6b & $(111)$ & $(221)$ & $(\$ 2.7)$ & $(\$ 5.7)$ \\
\hline SOS 6d & $(41)$ & $(81)$ & $(\$ 1.0)$ & $(\$ 2.1)$ \\
\hline SOS 9a & $(132)$ & $(265)$ & $(\$ 3.2)$ & $(\$ 6.8)$ \\
\hline SOS 9b & $(21)$ & $(41)$ & $(\$ 0.5)$ & $(\$ 1.1)$ \\
\hline SOS 9c & $(110)$ & $(219)$ & $(\$ 2.7)$ & $(\$ 5.7)$ \\
\hline SOS PA & $(4)$ & $(7)$ & $(\$ 0.1)$ & $(\$ 0.2)$ \\
\hline
\end{tabular}

\begin{tabular}{|l|r|}
\hline \multicolumn{2}{|c|}{ Regional Employment and Income Base } \\
\hline Total Employment (jobs): & 336,000 \\
\hline Total Income (\$million): & $\$ 11,583$ \\
\hline
\end{tabular}


Table E2-3. State of Idaho, Summary of Regional Economic Impacts - CONT

\begin{tabular}{|c|c|c|c|c|}
\hline \multirow{2}{*}{ AIternative } & Regional Employment & \multicolumn{2}{c|}{ Regional Income (\$1,000,000) } \\
\cline { 2 - 5 } & Direct & Total & Direct & Total \\
\hline SOS 1a & 0 & 0 & $\$ 0.0$ & $\$ 0.0$ \\
\hline SOS 1b & 0 & 0 & $\$ 0.0$ & $\$ 0.0$ \\
\hline SOS 2d & 0 & 0 & $\$ 0.0$ & $\$ 0.0$ \\
\hline SOS 4c & 0 & 0 & $\$ 0.0$ & $\$ 0.0$ \\
\hline SOS 5b & $(1)$ & $(1)$ & $(\$ 0.0)$ & $(\$ 0.0)$ \\
\hline SOS 5c & $(1)$ & $(1)$ & $(\$ 0.0)$ & $(\$ 0.0)$ \\
\hline SOS 6b & $(0)$ & $(1)$ & $(\$ 0.0)$ & $(\$ 0.0)$ \\
\hline SOS 6d & $(0)$ & $(1)$ & $(\$ 0.0)$ & $(\$ 0.0)$ \\
\hline SOS 9a & $(0)$ & $(1)$ & $(\$ 0.0)$ & $(\$ 0.0)$ \\
\hline SOS 9b & 0 & 0 & $\$ 0.0$ & $\$ 0.0$ \\
\hline SOS 9c & $(0)$ & $(1)$ & $(\$ 0.0)$ & $(\$ 0.0)$ \\
\hline SOS PA & 0 & 0 & $\$ 0.0$ & $\$ 0.0$ \\
\hline
\end{tabular}

\begin{tabular}{|c|c|c|c|c|}
\hline \multicolumn{5}{|c|}{ Navigation Impacts } \\
\hline \multirow{2}{*}{ Alternative } & \multicolumn{2}{|c|}{ Regional Employment } & \multicolumn{2}{|c|}{ Regional Income $(\$ 1,000,000)$} \\
\hline & Direct & Total & Direct & Total \\
\hline SOS 1a & 1 & 2 & $\$ 0.0$ & $\$ 0.1$ \\
\hline SOS 1b & 2 & 2 & $\$ 0.1$ & $\$ 0.1$ \\
\hline SOS 2d & $(1)$ & (2) & $(\$ 0.0)$ & $(\$ 0.1)$ \\
\hline SOS 4c & 3 & 5 & $\$ 0.1$ & $\$ 0.2$ \\
\hline SOS 5b & $(51)$ & $(73)$ & $\$ 3.3$ & $\$ 3.3$ \\
\hline SOS 5c & $(84)$ & $(115)$ & $\$ 6.9$ & $\$ 7.1$ \\
\hline SOS $6 b$ & $(42)$ & $(64)$ & $\$ 2.4$ & $\$ 2.1$ \\
\hline SOS 6d & $(5)$ & $(8)$ & $(\$ 0.1)$ & $(\$ 0.2)$ \\
\hline SOS 9a & $(43)$ & $(66)$ & $\$ 2.3$ & $\$ 2.1$ \\
\hline SOS 9b & $(2)$ & (4) & $(\$ 0.1)$ & $(\$ 0.1)$ \\
\hline SOS 9c & (4) & $(6)$ & $(\$ 0.1)$ & $(\$ 0.2)$ \\
\hline SOS PA & (2) & (2) & $(\$ 0.1)$ & $(\$ 0.1)$ \\
\hline
\end{tabular}

\begin{tabular}{|l|r|}
\hline \multicolumn{2}{|c|}{ Regional Employment and Income Base } \\
\hline Total Employment (jobs): & 336,000 \\
\hline Total Income (\$million): & $\$ 11,583$ \\
\hline
\end{tabular}


Table E2-3. State of Idaho, Summary of Regional Economic Impacts - CONT

\begin{tabular}{|c|c|c|c|c|}
\hline \multirow{2}{*}{ Alternative } & \multicolumn{3}{|c|}{ Regional Employment } & \multicolumn{2}{c|}{ Regional Income (\$1,000,000) } \\
\cline { 2 - 5 } & Direct & Total & Direct & Total \\
\hline SOS 1a & 86 & 171 & $\$ 2.2$ & $\$ 4.5$ \\
\hline SOS 1b & 172 & 345 & $\$ 4.3$ & $\$ 9.0$ \\
\hline SOS 2d & $(51)$ & $(99)$ & $(\$ 1.3)$ & $(\$ 2.6)$ \\
\hline SOS 4c & $(197)$ & $(394)$ & $(\$ 4.9)$ & $(\$ 10.3)$ \\
\hline SOS 5b & $(300)$ & $(604)$ & $(\$ 7.5)$ & $(\$ 15.8)$ \\
\hline SOS 5c & $(440)$ & $(886)$ & $(\$ 11.1)$ & $(\$ 23.1)$ \\
\hline SOS 6b & $(106)$ & $(211)$ & $(\$ 1.1)$ & $(\$ 2.3)$ \\
\hline SOS 6d & $(44)$ & $(86)$ & $(\$ 17.9)$ & $(\$ 37.6)$ \\
\hline SOS 9a & $(714)$ & $(1,439)$ & $(\$ 12.2)$ & $(\$ 25.6)$ \\
\hline SOS 9b & $(486)$ & $(979)$ & $(\$ 10.5)$ & $(\$ 22.0)$ \\
\hline SOS 9c & $(418)$ & $(841)$ & $(\$ 7.8)$ & $(\$ 16.2)$ \\
\hline SOS PA & $(309)$ & $(621)$ & & \\
\hline
\end{tabular}

\begin{tabular}{|c|c|c|c|c|}
\hline \multicolumn{5}{|c|}{ Recreation Impacts } \\
\hline \multirow{2}{*}{ Alternative } & \multicolumn{2}{|c|}{ Regional Employment } & \multicolumn{2}{|c|}{ Regional Income $(\$ 1,000,000)$} \\
\hline & Direct & Total & Direct & Total \\
\hline $\operatorname{SOS} 1 \mathrm{a}$ & (5) & (10) & $(\$ 0.1)$ & $(\$ 0.3)$ \\
\hline SOS $1 b$ & (5) & (10) & $(\$ 0.1)$ & $(\$ 0.3)$ \\
\hline SOS 2d & 3 & 6 & $\$ 0.1$ & $\$ 0.2$ \\
\hline $\operatorname{sos} 4 c$ & (3) & (5) & $(\$ 0.1)$ & $(\$ 0.1)$ \\
\hline SOS $5 b$ & 1 & 1 & $\$ 0.0$ & $\$ 0.0$ \\
\hline SOS 5c & 4 & 7 & $\$ 0.1$ & $\$ 0.2$ \\
\hline SOS $6 \mathrm{~b}$ & 0 & 0 & $(\$ 0.0)$ & $(\$ 0.0)$ \\
\hline $\operatorname{sos} 6 \mathrm{~d}$ & 0 & 0 & $(\$ 0.0)$ & $(\$ 0.0)$ \\
\hline SOS 9a & (35) & (74) & $(\$ 0.9)$ & $(\$ 0.2)$ \\
\hline SOS 9b & (19) & (38) & $(\$ 0.5)$ & $(\$ 1.0)$ \\
\hline SOS 9c & (6) & (10) & $(\$ 0.1)$ & $(\$ 0.3)$ \\
\hline SOS PA & 0 & 1 & $\$ 0.0$ & $\$ 0.0$ \\
\hline
\end{tabular}

\begin{tabular}{|l|c|}
\hline \multicolumn{2}{|c|}{ Regional Employment and Income Base } \\
\hline Total Employment (jobs): & 336,000 \\
\hline Total Income (\$million): & $\$ 11,583$ \\
\hline
\end{tabular}


Table E2-3. State of Idaho, Summary of Regional Economic Impacts - CONT

\begin{tabular}{|c|c|c|c|c|}
\hline \multirow{2}{*}{ Alternative } & \multicolumn{3}{|c|}{ Regional Employment } & \multicolumn{2}{c|}{ Regional Income (\$1,000,000) } \\
\cline { 2 - 5 } & Direct & Total & Direct & Total \\
\hline SOS 1a & $(5)$ & $(10)$ & $(\$ 0.1)$ & $(\$ 0.3)$ \\
\hline SOS 1b & $(5)$ & $(10)$ & $(\$ 0.1)$ & $(\$ 0.3)$ \\
\hline SOS 2d & 3 & 6 & $\$ 0.1$ & $\$ 0.2$ \\
\hline SOS 4c & $(3)$ & $(5)$ & $(\$ 0.1)$ & $(\$ 0.1)$ \\
\hline SOS 5b & 1 & 1 & $\$ 0.0$ & $\$ 0.0$ \\
\hline SOS 5c & 4 & 7 & $\$ 0.1$ & $\$ 0.2$ \\
\hline SOS 6b & 0 & 0 & $(\$ 0.0)$ & $(\$ 0.0)$ \\
\hline SOS 6d & 0 & 0 & $(\$ 0.0)$ & $(\$ 0.0)$ \\
\hline SOS 9a & $(35)$ & $(74)$ & $(\$ 0.9)$ & $(\$ 0.2)$ \\
\hline SOS 9b & $(19)$ & $(38)$ & $(\$ 0.5)$ & $(\$ 1.0)$ \\
\hline SOS 9c & $(6)$ & $(10)$ & $(\$ 0.1)$ & $(\$ 0.3)$ \\
\hline SOS PA & 0 & 1 & $\$ 0.0$ & $\$ 0.0$ \\
\hline
\end{tabular}

Regional Employment and Income Base

\begin{tabular}{|l|r}
\hline Total Employment (jobs): & 336,000
\end{tabular}

\begin{tabular}{l|l} 
Total Income (\$million): & $\$ 11,583$
\end{tabular} 
Table E2-4. State of Montana, Summary of Regional Economic Impacts

\begin{tabular}{|c|c|c|c|c|}
\hline \multirow{2}{*}{ Alternative } & Regional Employment & \multicolumn{2}{c|}{ Regional Income (\$1,000,000) } \\
\cline { 2 - 5 } & Direct & Total & Direct & Total \\
\hline SOS 1a & 31 & 69 & $\$ 0.7$ & $\$ 1.7$ \\
\hline SOS 1b & 64 & 146 & $\$ 1.5$ & $\$ 3.5$ \\
\hline SOS 2d & $(20)$ & $(42)$ & $(\$ 0.5)$ & $(\$ 1.0)$ \\
\hline SOS 4c & $(66)$ & $(152)$ & $(\$ 1.6)$ & $(\$ 3.7)$ \\
\hline SOS 5b & $(20)$ & $(16)$ & $\$ 1.7$ & $\$ 2.0$ \\
\hline SOS 5c & $(73)$ & $(140)$ & $\$ 0.5$ & $(\$ 1.0)$ \\
\hline SOS 6b & $(79)$ & $(175)$ & $(\$ 0.9)$ & $(\$ 3.1)$ \\
\hline SOS 6d & $(19)$ & $(39)$ & $(\$ 0.4)$ & $(\$ 0.9)$ \\
\hline SOS 9a & $(349)$ & $(807)$ & $(\$ 7.0)$ & $(\$ 18.3)$ \\
\hline SOS 9b & $(190)$ & $(439)$ & $(\$ 4.4)$ & $(\$ 10.6)$ \\
\hline SOS 9c & $(150)$ & $(349)$ & $(\$ 3.5)$ & $(\$ 8.5)$ \\
\hline SOS PA & $(122)$ & $(281)$ & $(\$ 2.8)$ & $(\$ 6.8)$ \\
\hline
\end{tabular}

\begin{tabular}{|c|c|c|c|c|}
\hline & \multicolumn{3}{|c|}{ Navigation Impacts } & \multicolumn{2}{c|}{ Regional Income (\$1,000,000) } \\
\hline \multirow{2}{*}{ Alternative } & Regional Employment & Total & Direct & Total \\
\cline { 2 - 5 } & Direct & 0 & $\$ 0.0$ & $\$ 0.0$ \\
\hline SOS 1a & 0 & 0 & $\$ 0.0$ & $\$ 0.0$ \\
\hline SOS 1b & 0 & 0 & $\$ 0.0$ & $\$ 0.0$ \\
\hline SOS 2d & 0 & 0 & $\$ 0.0$ & $\$ 0.0$ \\
\hline SOS 4c & 0 & 254 & $\$ 4.4$ & $\$ 8.5$ \\
\hline SOS 5b & 97 & 254 & $\$ 4.4$ & $\$ 8.5$ \\
\hline SOS 5c & 97 & $(82)$ & $\$ 0.1$ & $\$ 0.9)$ \\
\hline SOS 6b & $(37)$ & 0 & $\$ 0.0$ & $\$ 0.0$ \\
\hline SOS 6d & 0 & $(82)$ & $\$ 0.1$ & $\$ 0.9)$ \\
\hline SOS 9a & $(37)$ & 0 & $\$ 0.0$ & $\$ 0.0$ \\
\hline SOS 9b & 0 & 0 & $\$ 0.0$ & $\$ 0.0$ \\
\hline SOS 9c & 0 & 0 & $\$ 0.0$ & $\$ 0.0$ \\
\hline SOS PA & 0 & & & \\
\hline
\end{tabular}

\begin{tabular}{|l|c|}
\hline \multicolumn{2}{|c|}{ Regional Employment and Income Base } \\
\hline Total Employment (jobs): & 272,000 \\
\hline Total Income (\$million): & $\$ 8,563$ \\
\hline
\end{tabular}


Table E2-4. State of Montana, Summary of Regional Economic Impacts - CONT

\begin{tabular}{|c|c|c|c|c|}
\hline \multicolumn{5}{|c|}{ Power Impacts } \\
\hline \multirow{2}{*}{ Alternative } & \multicolumn{2}{|c|}{ Regional Employment } & \multicolumn{2}{|c|}{ Regional Income $(\$ 1,000,000$} \\
\hline & Direct & Total & Direct & Total \\
\hline SOS 1a & 33 & 72 & $\$ 0.8$ & $\$ 1.8$ \\
\hline $\operatorname{sos} 1 b$ & 66 & 150 & $\$ 1.5$ & $\$ 3.6$ \\
\hline SOS 2d & (19) & $(40)$ & $(\$ 0.4)$ & $(\$ 1.0)$ \\
\hline $\operatorname{sOS} 4 c$ & $(75)$ & $(171)$ & $(\$ 1.7)$ & $(\$ 4.1)$ \\
\hline SOS 5b & $(115)$ & $(266)$ & $(\$ 2.7)$ & $(\$ 6.4)$ \\
\hline SOS 5c & $(168)$ & $(390)$ & $(\$ 3.9)$ & $(\$ 9.4)$ \\
\hline sos $6 \mathrm{~b}$ & $(40)$ & $(89)$ & $(\$ 0.9)$ & $(\$ 2.2)$ \\
\hline SOS 6d & $(17)$ & $(35)$ & $(\$ 0.4)$ & $(\$ 0.9)$ \\
\hline sos 9a & (273) & $(637)$ & $(\$ 6.3)$ & $(\$ 15.4)$ \\
\hline $\operatorname{sos} 9 b$ & $(186)$ & $(432)$ & $(\$ 4.3)$ & $(\$ 10.4)$ \\
\hline SOS $9 c$ & $(160)$ & $(369)$ & $(\$ 3.7)$ & $(\$ 8.9)$ \\
\hline SOS PA & $(118)$ & $(273)$ & $(\$ 2.7)$ & $(\$ 6.6)$ \\
\hline
\end{tabular}

\begin{tabular}{|c|c|c|c|c|}
\hline \multicolumn{5}{|c|}{ Recreation Impacts } \\
\hline \multirow{2}{*}{ Alternative } & \multicolumn{2}{|c|}{ Regional Employment } & \multicolumn{2}{|c|}{ Regional Income $(\$ 1,000,000)$} \\
\hline & Direct & Total & Direct & Total \\
\hline SOS 1a & (2) & (3) & $(\$ 0.0)$ & $(\$ 0.1)$ \\
\hline SOS $1 b$ & (2) & (4) & $(\$ 0.0)$ & $(\$ 0.1)$ \\
\hline SOS 2d & (1) & (2) & $(\$ 0.0)$ & $(\$ 0.0)$ \\
\hline SOS $4 c$ & 9 & 19 & $\$ 0.2$ & $\$ 0.4$ \\
\hline SOS 5b & (2) & (4) & $(\$ 0.0)$ & $(\$ 0.1)$ \\
\hline SOS 5c & $(2)$ & (4) & $(\$ 0.0)$ & $(\$ 0.1)$ \\
\hline SOS $6 b$ & $(2)$ & (4) & $(\$ 0.0)$ & $(\$ 0.1)$ \\
\hline SOS 6d & (2) & (4) & $(\$ 0.0)$ & $(\$ 0.1)$ \\
\hline sos 9a & (39) & $(88)$ & $(\$ 0.8)$ & $(\$ 2.0)$ \\
\hline SOS 9b & $(4)$ & $(7)$ & $(\$ 0.1)$ & $(\$ 0.2)$ \\
\hline SOS 9c & 10 & 20 & $\$ 0.2$ & $\$ 0.5$ \\
\hline SOS PA & (4) & (8) & $(\$ 0.1)$ & $(\$ 0.2)$ \\
\hline
\end{tabular}

\begin{tabular}{|l|c|}
\hline \multicolumn{2}{|c|}{ Regional Employment and Income Base } \\
\hline Total Employment (jobs): & 272,000 \\
\hline Total Income (\$million): & $\$ 8,563$ \\
\hline
\end{tabular}





\section{APPENDIX 3}

\section{ECONOMIC IMPACTS IN THE \\ SOR SUBREGIONS}


Table E3-1. Puget Sound Subregion, Summary of Regional Economic Impacts

\begin{tabular}{|c|c|c|c|c|}
\hline \multicolumn{5}{|c|}{ Total Regional Impacts } \\
\hline \multirow{2}{*}{ Alternative 1/ } & \multicolumn{2}{|c|}{ Regional Employment } & \multicolumn{2}{|c|}{ Regional Income $(\$ 1,000,000)$} \\
\hline & Direct & Total & Direct & Total \\
\hline SOS 1a & 152 & 262 & $\$ 5.2$ & $\$ 9.7$ \\
\hline $\operatorname{SOS} 1 \mathrm{~b}$ & 305 & 527 & $\$ 10.4$ & $\$ 19.3$ \\
\hline SOS 2d & $(89)$ & $(153)$ & $(\$ 3.1)$ & $(\$ 5.7)$ \\
\hline SOS 4c & $(348)$ & $(601)$ & $(\$ 11.8)$ & $(\$ 22.1)$ \\
\hline $\operatorname{sos} 5 b$ & $(532)$ & $(921)$ & $(\$ 18.1)$ & $(\$ 33.8)$ \\
\hline SOS $5 c$ & $(779)$ & $(1,349)$ & $(\$ 26.5)$ & $(\$ 49.5)$ \\
\hline SOS $6 b$ & $(187)$ & $(323)$ & $(\$ 6.4)$ & $(\$ 11.9)$ \\
\hline SOS 6d & $(78)$ & $(133)$ & $(\$ 2.7)$ & $(\$ 4.9)$ \\
\hline SOS 9a & $(1,264)$ & $(2,191)$ & $(\$ 43.0)$ & $(\$ 80.3)$ \\
\hline SOS $9 b$ & $(861)$ & $(1,491)$ & $(\$ 29.3)$ & $(\$ 54.7)$ \\
\hline SOS 9c & $(740)$ & $(1,280)$ & $(\$ 25.2)$ & $(\$ 47.0)$ \\
\hline SOS PA & $(548)$ & (948) & $(\$ 18.6)$ & $(\$ 34.8)$ \\
\hline
\end{tabular}

\begin{tabular}{|c|c|c|c|c|}
\hline \multicolumn{5}{|c|}{ Power Impacts } \\
\hline \multirow{2}{*}{ Alternative } & \multicolumn{2}{|c|}{ Regional Employment } & \multicolumn{2}{|c|}{ Regional Income $(\$ 1,000,000)$} \\
\hline & Direct & Total & Direct & Total \\
\hline SOS 1a & 152 & 262 & $\$ 5.2$ & $\$ 9.7$ \\
\hline $\operatorname{sos} 1 \mathrm{~b}$ & 305 & 527 & $\$ 10.4$ & $\$ 19.3$ \\
\hline $\operatorname{sos} 2 \mathrm{~d}$ & (89) & (153) & $(\$ 3.1)$ & $(\$ 5.7)$ \\
\hline $\operatorname{sos} 4 c$ & (348) & (601) & $(\$ 11.8)$ & $(\$ 22.1)$ \\
\hline SOS $5 b$ & (532) & (921) & $(\$ 18.1)$ & $(\$ 33.8)$ \\
\hline SOS $5 c$ & (779) & $(1,349)$ & $(\$ 26.5)$ & $(\$ 49.5)$ \\
\hline SOS $6 b$ & $(187)$ & (323) & $(\$ 6.4)$ & $(\$ 11.9)$ \\
\hline SOS 6d & (78) & (133) & (\$2.7) & $(\$ 4.9)$ \\
\hline sos 9a & $(1,264)$ & $(2,191)$ & $(\$ 43.0)$ & $(\$ 80.3)$ \\
\hline $\operatorname{sos} 9 b$ & $(861)$ & $(1,491)$ & $(\$ 29.3)$ & $(\$ 54.7)$ \\
\hline $\operatorname{sos} 9 c$ & (740) & $(1,280)$ & $(\$ 25.2)$ & $(\$ 47.0)$ \\
\hline SOS PA & (548) & $(948)$ & $(\$ 18.6)$ & $(\$ 34.8)$ \\
\hline
\end{tabular}

\begin{tabular}{|l|c|}
\hline \multicolumn{2}{|c|}{ Regional Employment and Income Base } \\
\hline Total Employment (jobs): & $1,475,000$ \\
\hline Total Income (\$million): & $\$ 55,702$ \\
\hline
\end{tabular}


Table E3-2. West Coast Subregion, Summary of Regional Economic Impacts

\begin{tabular}{|c|c|c|c|c|}
\hline \multicolumn{5}{|c|}{ Total Regional Impacts } \\
\hline \multirow{2}{*}{ Alternative } & \multicolumn{2}{|c|}{ Regional Employment } & \multicolumn{2}{|c|}{ Regional Income $(\$ 1,000,000)$} \\
\hline & Direct & Total & Direct & Total \\
\hline SOS 1a & 68 & 116 & $\$ 1.7$ & $\$ 2.9$ \\
\hline $\operatorname{SOS} 1 \mathrm{~b}$ & 135 & 234 & $\$ 3.4$ & $\$ 5.9$ \\
\hline $\operatorname{sos} 2 d$ & (39) & $(66)$ & $(\$ 1.0)$ & $(\$ 1.7)$ \\
\hline $\operatorname{sOS} 4 c$ & (153) & $(266)$ & $(\$ 3.8)$ & $(\$ 6.8)$ \\
\hline SOS $5 b$ & (238) & (412) & $(\$ 6.0)$ & $(\$ 10.5)$ \\
\hline SOS 5c & $(352)$ & $(610)$ & $(\$ 8.8)$ & $(\$ 15.5)$ \\
\hline sos $6 b$ & $(91)$ & $(156)$ & $(\$ 2.3)$ & $(\$ 4.0)$ \\
\hline SOS 6d & (37) & (63) & $(\$ 1.0)$ & $(\$ 1.6)$ \\
\hline $\operatorname{sos} 9 a$ & $(590)$ & $(1,023)$ & $(\$ 14.8)$ & $(\$ 26.0)$ \\
\hline SOS $9 b$ & (386) & $(670)$ & $(\$ 9.7)$ & $(\$ 17.0)$ \\
\hline SOS 9c & (338) & $(587)$ & $(\$ 8.5)$ & $(\$ 14.9)$ \\
\hline SOS PA & (242) & (419) & $(\$ 6.0)$ & $(\$ 10.6)$ \\
\hline
\end{tabular}

\begin{tabular}{|c|c|c|c|c|}
\hline \multicolumn{5}{|c|}{ Anadromous Fish Impacts } \\
\hline \multirow{2}{*}{ Alternative } & \multicolumn{2}{|c|}{ Regional Employment } & \multicolumn{2}{|c|}{ Regional Income $(\$ 1,000,000)$} \\
\hline & Direct & Total & Direct & Total \\
\hline SOS 1a & $(0)$ & $(0)$ & $(\$ 0.0)$ & $(\$ 0.0)$ \\
\hline SOS 1b & $(0)$ & $(0)$ & $(\$ 0.0)$ & $(\$ 0.0)$ \\
\hline SOS 2d & 1 & 1 & $\$ 0.0$ & $\$ 0.0$ \\
\hline $\operatorname{sos} 4 c$ & 1 & 1 & $\$ 0.0$ & $\$ 0.0$ \\
\hline SOS $5 b$ & $(2)$ & (3) & $(\$ 0.1)$ & $(\$ 0.1)$ \\
\hline $\operatorname{sOS} 5 \mathrm{c}$ & $(6)$ & (9) & $(\$ 0.2)$ & $(\$ 0.3)$ \\
\hline SOS 6b & $(8)$ & (13) & $(\$ 0.2)$ & $(\$ 0.4)$ \\
\hline SOS 6d & (3) & $(5)$ & $(\$ 0.1)$ & $(\$ 0.1)$ \\
\hline SOS 9a & $(29)$ & $(47)$ & $(\$ 0.8)$ & $(\$ 1.2)$ \\
\hline SOS $9 b$ & (4) & $(6)$ & $(\$ 0.1)$ & $(\$ 0.2)$ \\
\hline SOS 9c & $(10)$ & $(17)$ & $(\$ 0.3)$ & $(\$ 0.5)$ \\
\hline SOS PA & 1 & 2 & $\$ 0.0$ & $\$ 0.1$ \\
\hline
\end{tabular}

\begin{tabular}{|l|c|}
\hline \multicolumn{2}{|c|}{ Regional Employment and Income Base } \\
\hline Total Employment (jobs): & 140,000 \\
\hline Total Income (\$million): & $\$ 4,224$ \\
\hline
\end{tabular}


Table E3-3. West Coast Subregion, Summary of Regional Economic Impacts - CONT

\begin{tabular}{|l|r|r|r|r|}
\hline \multirow{2}{*}{ Alternative } & \multicolumn{2}{|c|}{ Regional Employment } & \multicolumn{2}{c|}{ Regional Income $(\$ 1,000,000)$} \\
\cline { 2 - 5 } & Direct & \multicolumn{1}{|c|}{ Total } & \multicolumn{1}{c|}{ Direct } & Total \\
\hline SOS 1a & 68 & 116 & $\$ 1.7$ & $\$ 3.0$ \\
\hline SOS 1b & 135 & 234 & $\$ 3.4$ & $(\$ 1.0)$ \\
\hline SOS 2d & $(40)$ & $(67)$ & $(\$ 3.9)$ & $(\$ 1.7)$ \\
\hline SOS 4c & $(154)$ & $(267)$ & $(\$ 5.9)$ & $(\$ 6.8)$ \\
\hline SOS 5b & $(236)$ & $(409)$ & $(\$ 8.6)$ & $(\$ 15.2)$ \\
\hline SOS 5c & $(346)$ & $(601)$ & $(\$ 2.1)$ & $(\$ 3.6)$ \\
\hline SOS 6b & $(83)$ & $(143)$ & $(\$ 0.9)$ & $(\$ 1.5)$ \\
\hline SOS 6d & $(34)$ & $(58)$ & $(\$ 14.0)$ & $(\$ 24.8)$ \\
\hline SOS 9a & $(561)$ & $(976)$ & $(\$ 9.6)$ & $(\$ 16.9)$ \\
\hline SOS 9b & $(382)$ & $(664)$ & $(\$ 8.2)$ & $(\$ 14.5)$ \\
\hline SOS 9c & $(328)$ & $(570)$ & $(\$ 6.1)$ & $(\$ 10.7)$ \\
\hline SOS PA & $(243)$ & $(421)$ & & \\
\hline
\end{tabular}

\begin{tabular}{|l|c|}
\hline \multicolumn{2}{|c|}{ Regional Employment and Income Base } \\
\hline Total Employment (jobs): & 140,000 \\
\hline Total Income (\$million): & $\$ 4,224$ \\
\hline
\end{tabular}


Table E3-3. Portland Subregion, Summary of Regional Economic Impacts

\begin{tabular}{|c|c|c|c|c|}
\hline \multicolumn{5}{|c|}{ Total Regional Impacts } \\
\hline \multirow{2}{*}{ Alternative $\mathbf{1}$} & \multicolumn{2}{|c|}{ Regional Employment } & \multicolumn{2}{|c|}{ Regional Income $(\$ 1,000,000)$} \\
\hline & Direct & Total & Direct & Total \\
\hline SOS 1a & 87 & 173 & $\$ 2.8$ & $\$ 6.1$ \\
\hline SOS $1 b$ & 174 & 351 & $\$ 5.7$ & $\$ 12.2$ \\
\hline $\operatorname{sos} 2 \mathrm{~d}$ & (51) & $(100)$ & $(\$ 1.7)$ & $(\$ 3.5)$ \\
\hline $\operatorname{sos} 4 c$ & $(199)$ & $(401)$ & $(\$ 6.5)$ & $(\$ 14.0)$ \\
\hline $\operatorname{sos} 5 b$ & $(310)$ & (623) & $(\$ 10.1)$ & $(\$ 21.8)$ \\
\hline SOS 5c & (453) & (916) & $(\$ 14.8)$ & $(\$ 31.9)$ \\
\hline SOS $6 b$ & $(120)$ & (235) & $(\$ 4.0)$ & $(\$ 8.3)$ \\
\hline SOS 6d & (47) & $(91)$ & $(\$ 1.6)$ & $(\$ 3.2)$ \\
\hline $\operatorname{sos} 9 a$ & $(740)$ & $(1,494)$ & $(\$ 24.2)$ & $(\$ 52.1)$ \\
\hline SOS $9 b$ & (494) & (999) & $(\$ 16.1)$ & $(\$ 34.8)$ \\
\hline SOS 9c & (429) & $(869)$ & $(\$ 14.0)$ & $(\$ 30.3)$ \\
\hline SOS PA & (313) & (632) & $(\$ 10.2)$ & $(\$ 22.0)$ \\
\hline
\end{tabular}

\begin{tabular}{|c|c|c|c|c|}
\hline \multicolumn{5}{|c|}{ Anadromous Fish Impacts } \\
\hline \multirow{2}{*}{ Alternative } & \multicolumn{2}{|c|}{ Regional Employment } & \multicolumn{2}{|c|}{ Regional Income $(\$ 1,000,000)$} \\
\hline & Direct & Total & Direct & Total \\
\hline $\operatorname{SOS} 1 a$ & $(0)$ & $(0)$ & $(\$ 0.0)$ & $(\$ 0.0)$ \\
\hline $\operatorname{SOS} 1 b$ & $(0)$ & $(0)$ & $(\$ 0.0)$ & $(\$ 0.0)$ \\
\hline SOS 2d & 0 & 0 & $\$ 0.0$ & $\$ 0.0$ \\
\hline SOS $4 c$ & 0 & 0 & $\$ 0.0$ & $\$ 0.0$ \\
\hline SOS $5 b$ & (2) & (3) & $(\$ 0.1)$ & $(\$ 0.1)$ \\
\hline SOS $5 c$ & (4) & (7) & $(\$ 0.1)$ & $(\$ 0.3)$ \\
\hline SOS $6 b$ & (7) & (12) & $(\$ 0.2)$ & $(\$ 0.4)$ \\
\hline SOS $6 d$ & (3) & (4) & $(\$ 0.1)$ & $(\$ 0.2)$ \\
\hline $\operatorname{sos} 9 a$ & (12) & (21) & $(\$ 0.4)$ & $(\$ 0.8)$ \\
\hline SOS $9 \mathrm{~b}$ & (2) & (3) & $(\$ 0.1)$ & $(\$ 0.1)$ \\
\hline SOS 9c & $(7)$ & (13) & $(\$ 0.2)$ & $(\$ 0.5)$ \\
\hline SOS PA & 0 & 0 & $\$ 0.0$ & $\$ 0.0$ \\
\hline
\end{tabular}

\begin{tabular}{|l|c|}
\hline \multicolumn{2}{|c|}{ Regional Employment and Income Base } \\
\hline Total Employment (jobs): & 691,000 \\
\hline Total Income (\$million): & $\$ 23,930$ \\
\hline
\end{tabular}


Table E3-3. Portland Subregion, Summary of Regional Economic Impacts - CONT

\begin{tabular}{|c|c|c|c|c|}
\hline \multicolumn{5}{|c|}{ Navigation Impacts } \\
\hline \multirow{2}{*}{ Alternative } & \multicolumn{2}{|c|}{ Regional Employment } & \multicolumn{2}{|c|}{ Regional Income $(\$ 1,000,000)$} \\
\hline & Direct & Total & Direct & Total \\
\hline SOS 1a & 0 & 0 & $\$ 0.0$ & $\$ 0.0$ \\
\hline SOS $1 b$ & 0 & 0 & $\$ 0.0$ & $\$ 0.0$ \\
\hline SOS 2d & 0 & 0 & $\$ 0.0$ & $\$ 0.0$ \\
\hline SOS $4 c$ & 0 & 0 & $\$ 0.0$ & $\$ 0.0$ \\
\hline SOS 5b & (4) & (7) & $(\$ 0.2)$ & $(\$ 0.3)$ \\
\hline SOS 5c & (5) & $(8)$ & $(\$ 0.2)$ & $(\$ 0.3)$ \\
\hline SOS $6 b$ & (6) & $(10)$ & $(\$ 0.3)$ & $(\$ 0.4)$ \\
\hline SOS 6d & (1) & $(1)$ & $(\$ 0.0)$ & $(\$ 0.1)$ \\
\hline SOS 9a & (6) & $(10)$ & $(\$ 0.3)$ & $(\$ 0.4)$ \\
\hline $\operatorname{sos} 9 \mathrm{~b}$ & 0 & $\mathbf{0}$ & $\$ 0.0$ & $\$ 0.0$ \\
\hline SOS 9c & 0 & (1) & $(\$ 0.0)$ & $(\$ 0.0)$ \\
\hline SOS PA & 0 & 0 & $\$ 0.0$ & $\$ 0.0$ \\
\hline
\end{tabular}

\begin{tabular}{|c|c|c|c|c|}
\hline \multicolumn{5}{|c|}{ Power Impacts } \\
\hline \multirow{2}{*}{ Alternative } & \multicolumn{2}{|c|}{ Regional Employment } & \multicolumn{2}{|c|}{ Regional Income $(\$ 1,000,000)$} \\
\hline & Direct & Total & Direct & Total \\
\hline SOS 1a & 87 & 173 & $\$ 2.8$ & $\$ 6.1$ \\
\hline $\operatorname{sos} 1 b$ & 174 & 351 & $\$ 5.7$ & $\$ 12.3$ \\
\hline $\operatorname{sos} 2 d$ & (51) & (100) & $(\$ 1.7)$ & $(\$ 3.5)$ \\
\hline $\operatorname{sos} 4 c$ & (199) & (401) & $(\$ 6.5)$ & $(\$ 14.0)$ \\
\hline $\operatorname{sos} 5 b$ & (304) & (613) & $(\$ 9.9)$ & $(\$ 21.4)$ \\
\hline $\operatorname{sos} 5 c$ & (444) & (901) & $(\$ 14.5)$ & $(\$ 31.4)$ \\
\hline $\operatorname{sos} 6 b$ & $(107)$ & (213) & $(\$ 3.5)$ & $(\$ 7.5)$ \\
\hline SOS 6d & $(44)$ & $(86)$ & $(\$ 1.5)$ & $(\$ 3.0)$ \\
\hline $\operatorname{sos} 9 \mathrm{a}$ & (722) & $(1,463)$ & $(\$ 23.5)$ & $(\$ 51.0)$ \\
\hline $\operatorname{SOS} 9 \mathrm{~b}$ & (492) & (996) & $(\$ 16.0)$ & $(\$ 34.7)$ \\
\hline $\operatorname{sos} 9 c$ & (422) & $(855)$ & $(\$ 13.8)$ & $(\$ 29.8)$ \\
\hline SOS PA & (313) & (632) & $(\$ 10.2)$ & $(\$ 22.0)$ \\
\hline
\end{tabular}

Regional Employment and Income Base

\begin{tabular}{|l|l|}
\hline Total Employment (jobs): & 691,000 \\
\hline Total Income (\$million): & $\$ 23,930$ \\
\hline
\end{tabular}


Table E3-4. Mid-Columbia Subregion, Summary of Regional Economic Impacts

\begin{tabular}{|c|c|c|c|c|}
\hline \multicolumn{5}{|c|}{ Total Regional Impacts 1/ } \\
\hline \multirow{2}{*}{ Alternative $2 /$} & \multicolumn{2}{|c|}{ Regional Employment } & \multicolumn{2}{|c|}{ Regional Income $(\$ 1,000,000)$} \\
\hline & Direct & Total & Direct & Total \\
\hline SOS 1a & 133 & 234 & $\$ 3.4$ & $\$ 6.4$ \\
\hline SOS $1 b$ & 181 & 318 & $\$ 4.7$ & $\$ 8.7$ \\
\hline $\operatorname{sos} 2 d$ & $(28)$ & $(48)$ & $(\$ 0.7)$ & $(\$ 1.3)$ \\
\hline $\operatorname{SOS} 4 \mathrm{c}$ & (56) & (95) & $(\$ 1.4)$ & $(\$ 2.5)$ \\
\hline SOS $5 b$ & (276) & $(476)$ & $(\$ 3.5)$ & $(\$ 9.5)$ \\
\hline SOS $5 \mathrm{c}$ & (133) & (214) & $\$ 4.7$ & $\$ 2.3$ \\
\hline sos $6 b$ & (186) & $(320)$ & $(\$ 2.2)$ & $(\$ 6.2)$ \\
\hline sos 6d & (284) & $(493)$ & $(\$ 7.4)$ & $(\$ 13.5)$ \\
\hline $\operatorname{sos} 9 \mathrm{a}$ & $(549)$ & $(957)$ & $(\$ 11.5)$ & $(\$ 23.4)$ \\
\hline $\operatorname{sos} 9 \mathrm{~b}$ & (284) & $(493)$ & $(\$ 7.2)$ & $(\$ 13.4)$ \\
\hline SOS 9c & $(591)$ & $(1,030)$ & $(\$ 15.3)$ & $(\$ 28.1)$ \\
\hline SOS PA & (588) & $(1,036)$ & $(\$ 15.2)$ & $(\$ 28.3)$ \\
\hline
\end{tabular}

\begin{tabular}{|c|c|c|c|c|}
\hline \multicolumn{5}{|c|}{ Anadromous Fish Impacts } \\
\hline \multirow{2}{*}{ Alternative } & \multicolumn{2}{|c|}{ Regional Employment } & \multicolumn{2}{|c|}{ Regional Income $(\$ 1,000,000)$} \\
\hline & Direct & Total & Direct & Total \\
\hline SOS 1a & (1) & (1) & $(\$ 0.0)$ & $(\$ 0.0)$ \\
\hline $\operatorname{sos} 1 b$ & (1) & (1) & $(\$ 0.0)$ & $(\$ 0.0)$ \\
\hline SOS $2 \mathrm{~d}$ & $\mathbf{0}$ & 0 & $\$ 0.0$ & $\$ 0.0$ \\
\hline $\operatorname{SOS} 4 c$ & 0 & 0 & $\$ 0.0$ & $\$ 0.0$ \\
\hline SOS $5 b$ & (13) & (21) & $(\$ 0.3)$ & $(\$ 0.6)$ \\
\hline SOS $5 c$ & $(22)$ & (37) & $(\$ 0.6)$ & $(\$ 1.0)$ \\
\hline SOS $6 b$ & (34) & (58) & $(\$ 0.9)$ & $(\$ 1.6)$ \\
\hline SOS 6d & (13) & (21) & $(\$ 0.3)$ & $(\$ 0.6)$ \\
\hline $\operatorname{sos} 9 a$ & (52) & (88) & $(\$ 1.4)$ & $(\$ 2.5)$ \\
\hline SOS $9 b$ & (8) & (12) & $(\$ 0.2)$ & $(\$ 0.4)$ \\
\hline $\operatorname{sos} 9 c$ & (35) & (59) & $(\$ 1.0)$ & $(\$ 1.7)$ \\
\hline SOS PA & (0) & (0) & $(\$ 0.0)$ & $(\$ 0.0)$ \\
\hline
\end{tabular}

\begin{tabular}{|l|c|}
\hline \multicolumn{2}{|c|}{ Regional Employment and Income Base } \\
\hline Total Employment (jobs): & 123,000 \\
\hline Total Income (\$million): & $\$ 4,131$ \\
\hline
\end{tabular}


Table E3-4. Mid-Columbia Subregion, Summary of Regional Economic Impacts - CONT

\begin{tabular}{|c|c|c|c|c|}
\hline \multicolumn{5}{|c|}{ Irrigation Impacts } \\
\hline \multirow{2}{*}{ Alternative } & \multicolumn{2}{|c|}{ Regional Employment } & \multicolumn{2}{|c|}{ Regional Income $(\$ 1,000,000)$} \\
\hline & Direct & Total & Direct & Total \\
\hline $\operatorname{sos} 1 a$ & $(0)$ & $(0)$ & $(\$ 0.0)$ & $(\$ 0.0)$ \\
\hline SOS $1 \mathrm{~b}$ & $(0)$ & $(0)$ & $(\$ 0.0)$ & $(\$ 0.0)$ \\
\hline SOS 2d & 0 & 0 & $\$ 0.0$ & $\$ 0.0$ \\
\hline $\operatorname{SOS} 4 c$ & $(0)$ & $(0)$ & $(\$ 0.0)$ & $(\$ 0.0)$ \\
\hline SOS 5b & (209) & (359) & $(\$ 5.4)$ & $(\$ 9.8)$ \\
\hline SOS 5c & (210) & (361) & $(\$ 5.4)$ & $(\$ 9.8)$ \\
\hline SOS $6 b$ & (169) & (289) & $(\$ 4.3)$ & $(\$ 7.9)$ \\
\hline SOS 6d & (126) & (216) & $(\$ 3.2)$ & $(\$ 5.9)$ \\
\hline $\operatorname{sOS} 9 a$ & (162) & $(277)$ & $(\$ 4.2)$ & $(\$ 7.5)$ \\
\hline SOS $9 b$ & 0 & 0 & $\$ 0.0$ & $\$ 0.0$ \\
\hline SOS 9c & $(171)$ & (294) & $(\$ 4.4)$ & $(\$ 8.0)$ \\
\hline SOS PA & (131) & $(225)$ & $(\$ 3.4)$ & $(\$ 6.1)$ \\
\hline
\end{tabular}

\begin{tabular}{|c|c|c|c|c|}
\hline \multicolumn{5}{|c|}{ Navigation Impacts } \\
\hline \multirow{2}{*}{ Alternative } & \multicolumn{2}{|c|}{ Regional Employment } & \multicolumn{2}{|c|}{ Regional Income $(\$ 1,000,000)$} \\
\hline & Direct & Total & Direct & Total \\
\hline SOS 1a & 0 & 0 & $\$ 0.0$ & $\$ 0.0$ \\
\hline SOS 1b & 0 & 0 & $\$ 0.0$ & $\$ 0.0$ \\
\hline $\operatorname{sos} 2 \mathrm{~d}$ & 0 & 0 & $\$ 0.0$ & $\$ 0.0$ \\
\hline $\operatorname{SOS} 4 c$ & 0 & 0 & $\$ 0.0$ & $\$ 0.0$ \\
\hline $\operatorname{sos} 5 b$ & 321 & 566 & $\$ 11.9$ & $\$ 19.0$ \\
\hline $\operatorname{SOS} 5 c$ & 560 & 1,002 & $\$ 22.6$ & $\$ 35.6$ \\
\hline SOS $6 b$ & 239 & 422 & $\$ 8.9$ & $\$ 14.2$ \\
\hline sos $6 d$ & (3) & (5) & $(\$ 0.1)$ & $(\$ 0.2)$ \\
\hline $\operatorname{sos} 9 \mathrm{a}$ & 239 & 422 & $\$ 8.9$ & $\$ 14.2$ \\
\hline $\operatorname{sos} 9 \mathrm{~b}$ & 0 & 0 & $\$ 0.0$ & $\$ 0.0$ \\
\hline SOS 9c & (2) & (3) & $(\$ 0.1)$ & $(\$ 0.1)$ \\
\hline SOS PA & 0 & 0 & $\$ 0.0$ & $\$ 0.0$ \\
\hline
\end{tabular}

Regional Employment and Income Base

\begin{tabular}{|l|c|}
\hline Total Employment (jobs): & 123,000 \\
\hline Total Income (\$million): & $\$ 4,131$ \\
\hline
\end{tabular}


Table E3-4. Mid-Columbia Subregion, Summary of Regional Economic Impacts - CONT

\begin{tabular}{|l|r|r|r|r|}
\hline \multirow{2}{*}{ Alternative } & \multicolumn{2}{|c|}{ Regional Employment } & \multicolumn{2}{c|}{ Regional Income (\$1,000,000) } \\
\cline { 2 - 5 } & Direct & \multicolumn{1}{|c|}{ Total } & \multicolumn{1}{c|}{ Direct } & \multicolumn{1}{c|}{ Total } \\
\hline SOS 1a & 48 & 83 & $\$ 1.2$ & $\$ 2.2$ \\
\hline SOS 1b & 96 & 167 & $\$ 2.4$ & $(\$ 1.3)$ \\
\hline SOS 2d & $(28)$ & $(48)$ & $(\$ 0.7)$ & $(\$ 5.1)$ \\
\hline SOS 4c & $(110)$ & $(190)$ & $(\$ 2.8)$ & $(\$ 7.9)$ \\
\hline SOS 5b & $(168)$ & $(292)$ & $(\$ 4.3)$ & $(\$ 11.6)$ \\
\hline SOS 5c & $(245)$ & $(429)$ & $(\$ 6.2)$ & $(\$ 2.7)$ \\
\hline SOS 6b & $(59)$ & $(102)$ & $(\$ 1.5)$ & $(\$ 1.1)$ \\
\hline SOS 6d & $(24)$ & $(41)$ & $(\$ 0.6)$ & $(\$ 18.8)$ \\
\hline SOS 9a & $(398)$ & $(697)$ & $(\$ 10.1)$ & $(\$ 12.8)$ \\
\hline SOS 9b & $(271)$ & $(474)$ & $(\$ 6.9)$ & $(\$ 11.0)$ \\
\hline SOS 9c & $(233)$ & $(407)$ & $(\$ 5.9)$ & $(\$ 8.1)$ \\
\hline SOS PA & $(172)$ & $(\$ 301)$ & $(\$ 4.4)$ & \\
\hline
\end{tabular}

\begin{tabular}{|c|c|c|c|c|}
\hline \multicolumn{5}{|c|}{ Recreation Impacts } \\
\hline \multirow{2}{*}{ Alternative } & \multicolumn{2}{|c|}{ Regional Employment } & \multicolumn{2}{|c|}{ Regional Income $(\$ 1,000,000)$} \\
\hline & Direct & Total & Direct & Total \\
\hline SOS 1a & 86 & 152 & $\$ 2.2$ & $\$ 4.2$ \\
\hline $\operatorname{sos} 1 b$ & 86 & 152 & $\$ 2.2$ & $\$ 4.2$ \\
\hline SOS $2 d$ & 0 & 0 & $\$ 0.0$ & $\$ 0.0$ \\
\hline SOS 4c & 54 & 95 & $\$ 1.4$ & $\$ 2.6$ \\
\hline SOS $5 b$ & (206) & $(370)$ & $(\$ 5.4)$ & $(\$ 10.3)$ \\
\hline SOS 5c & (216) & (389) & $(\$ 5.7)$ & $(\$ 10.8)$ \\
\hline SOS $6 b$ & $(163)$ & (293) & $(\$ 4.3)$ & $(\$ 8.1)$ \\
\hline SOS 6d & $(118)$ & $(210)$ & $(\$ 3.1)$ & $(\$ 5.8)$ \\
\hline $\operatorname{SOS} 9 \mathrm{a}$ & $(176)$ & $(316)$ & $(\$ 4.6)$ & $(\$ 8.8)$ \\
\hline SOS 9b & $(5)$ & $(7)$ & $(\$ 0.1)$ & $(\$ 0.2)$ \\
\hline SOS 9c & $(149)$ & $(267)$ & $(\$ 3.9)$ & $(\$ 7.4)$ \\
\hline SOS PA & (285) & $(510)$ & $(\$ 7.4)$ & $(\$ 14.1)$ \\
\hline
\end{tabular}

Regional Employment and Income Base

\begin{tabular}{|l|c|}
\hline Total Employment (jobs): & 123,000 \\
\hline Total Income (\$million): & $\$ 4,131$ \\
\hline
\end{tabular}


Table E3-4. Mid-Columbia Subregion, Summary of Regional Economic Impacts - CONT

\begin{tabular}{|c|c|c|c|c|}
\hline \multicolumn{5}{|c|}{ Construction Impacts } \\
\hline \multirow{2}{*}{ Alternative } & \multicolumn{2}{|c|}{ Regional Employment } & \multicolumn{2}{|c|}{ Regional Income $(\$ 1,000,000)$} \\
\hline & Direct & Total & Direct & Total \\
\hline SOS 1a & 0 & 0 & $\$ 0.0$ & $\$ 0.0$ \\
\hline SOS $1 b$ & 0 & 0 & $\$ 0.0$ & $\$ 0.0$ \\
\hline $\operatorname{SOS} 2 \mathrm{~d}$ & 0 & $\mathbf{0}$ & $\$ 0.0$ & $\$ 0.0$ \\
\hline $\operatorname{SOS} 4 c$ & 0 & 0 & $\$ 0.0$ & $\$ 0.0$ \\
\hline sos $5 b$ & 2,454 & 5,252 & $\$ 83.3$ & $\$ 168.3$ \\
\hline SOS 5c & 1,961 & 4,159 & $\$ 66.8$ & $\$ 133.4$ \\
\hline $\operatorname{sos} 6 \mathrm{~b}$ & 1,388 & 2,922 & $\$ 47.4$ & $\$ 93.7$ \\
\hline sos 6d & 823 & 1,708 & $\$ 28.2$ & $\$ 54.9$ \\
\hline $\operatorname{sos} 9 a$ & 1,343 & 2,830 & $\$ 45.8$ & $\$ 90.8$ \\
\hline SOS $9 b$ & 0 & 0 & $\$ 0.0$ & $\$ 0.0$ \\
\hline SOS 9c & 1,405 & 2,957 & $\$ 47.9$ & $\$ 94.9$ \\
\hline SOS PA & 930 & 1,936 & $\$ 31.8$ & $\$ 62.2$ \\
\hline
\end{tabular}

Regional Employment and Income Base

\begin{tabular}{l|l} 
Total Employment (jobs): & 123,000
\end{tabular}

\begin{tabular}{|l|l}
\hline Total Income (\$million): & $\$ 4,131$ \\
\hline
\end{tabular} 
Table E3-5. Upper Columbia Subregion, Summary of Regional Economic Impacts

\begin{tabular}{|c|c|c|c|c|}
\hline \multicolumn{5}{|c|}{ Total Regional Impacts } \\
\hline \multirow{2}{*}{ Alternative 1/ } & \multicolumn{2}{|c|}{ Regional Employment } & \multicolumn{2}{|c|}{ Regional Income $(\$ 1,000,000)$} \\
\hline & Direct & Total & Direct & Total \\
\hline SOS 1a & 34 & 57 & $\$ 0.9$ & $\$ 1.5$ \\
\hline $\operatorname{SOS} 1 b$ & 76 & 129 & $\$ 2.0$ & $\$ 3.6$ \\
\hline $\operatorname{sos} 2 d$ & (25) & (42) & $(\$ 0.7)$ & $(\$ 1.2)$ \\
\hline SOS 4c & (98) & (162) & $(\$ 2.6)$ & $(\$ 4.5)$ \\
\hline $\operatorname{sos} 5 b$ & (96) & (145) & $(\$ 1.5)$ & $(\$ 2.9)$ \\
\hline SOS 5c & (154) & (234) & $(\$ 2.2)$ & $(\$ 4.6)$ \\
\hline SOS $6 b$ & (22) & (23) & $\$ 0.3$ & $\$ 0.2$ \\
\hline SOS 6d & (31) & (49) & $(\$ 0.9)$ & $\begin{array}{l}\$ 1.4) \\
\end{array}$ \\
\hline SOS 9a & (411) & $(680)$ & $(\$ 10.3)$ & $(\$ 18.1)$ \\
\hline SOS $9 b$ & (281) & (473) & $(\$ 7.6)$ & $\$ 6.7$ \\
\hline $\operatorname{sos} 9 \mathrm{c}$ & (247) & (415) & $(\$ 6.7)$ & $(\$ 11.6)$ \\
\hline SOS PA & (164) & (274) & $(\$ 4.4)$ & $(\$ 7.6)$ \\
\hline
\end{tabular}

\begin{tabular}{|l|r|r|r|r|}
\hline \multicolumn{5}{|c|}{ Anadromous Fish Impacts } \\
\hline \multirow{2}{*}{ Alternative } & \multicolumn{2}{|c|}{ Regional Employment } & \multicolumn{2}{c|}{ Regional Income $(\$ 1,000,000)$} \\
\cline { 2 - 5 } & Direct & Total & \multicolumn{1}{c|}{ Direct } & \multicolumn{1}{|c|}{ Total } \\
\hline SOS 1a & $(0)$ & $(0)$ & $(\$ 0.0)$ & $(\$ 0.0)$ \\
\hline SOS 1b & $(0)$ & $(1)$ & $(\$ 0.0)$ & $(\$ 0.0)$ \\
\hline SOS 2d & $(0)$ & $(0)$ & $(\$ 0.0)$ & $(\$ 0.0)$ \\
\hline SOS 4c & $(0)$ & $(0)$ & $(\$ 0.0)$ & $(\$ 0.0)$ \\
\hline SOS 5b & $(6)$ & $(10)$ & $(\$ 0.2)$ & $(\$ 0.3)$ \\
\hline SOS 5c & $(15)$ & $(25)$ & $(\$ 0.4)$ & $(\$ 0.7)$ \\
\hline SOS 6b & $(23)$ & $(39)$ & $(\$ 0.7)$ & $(\$ 1.1)$ \\
\hline SOS 6d & $(9)$ & $(14)$ & $(\$ 0.3)$ & $(\$ 0.4)$ \\
\hline SOS 9a & $(30)$ & $(50)$ & $(\$ 0.9)$ & $(\$ 1.5)$ \\
\hline SOS 9b & $(5)$ & $(7)$ & $(\$ 0.1)$ & $(\$ 0.2)$ \\
\hline SOS 9c & $(23)$ & $(39)$ & $(\$ 0.7)$ & $(\$ 1.2)$ \\
\hline SOS PA & $(1)$ & $(1)$ & $(\$ 0.0)$ & $(\$ 0.0)$ \\
\hline
\end{tabular}

\begin{tabular}{|l|c|}
\hline \multicolumn{2}{|c|}{ Regional Employment and Income Base } \\
\hline Total Employment (jobs): & 151,000 \\
\hline Total Income (\$million): & $\$ 4,352$ \\
\hline
\end{tabular}


Table E3-5. Upper Columbia Subregion, Summary of Regional Economic Impacts - CONT

\begin{tabular}{|c|c|c|c|c|}
\hline \multicolumn{5}{|c|}{ Navigation Impacts } \\
\hline \multirow[t]{2}{*}{ Alternative } & \multicolumn{2}{|c|}{ Regional Employment } & \multicolumn{2}{|c|}{ Regional Income $(\mathbf{\$ 1 , 0 0 0 , 0 0 0 )}$} \\
\hline & Direct & Total & Direct & Total \\
\hline SOS 1a & 0 & 0 & $\$ 0.0$ & $\$ 0.0$ \\
\hline $\operatorname{sos} 1 b$ & 0 & 0 & $\$ 0.0$ & $\$ 0.0$ \\
\hline $\operatorname{sos} 2 d$ & 0 & 0 & $\$ 0.0$ & $\$ 0.0$ \\
\hline SOS $4 c$ & 0 & 0 & $\$ 0.0$ & $\$ 0.0$ \\
\hline SOS $5 b$ & 58 & 113 & $\$ 2.7$ & $\$ 4.2$ \\
\hline SOS 5c & 77 & 153 & $\$ 4.0$ & $\$ 6.1$ \\
\hline SOS $6 b$ & 54 & 103 & $\$ 2.4$ & $\$ 3.8$ \\
\hline Sos 6d & 0 & 0 & $\$ 0.0$ & $\$ 0.0$ \\
\hline SOS 9a & 54 & 103 & $\$ 2.4$ & $\$ 3.8$ \\
\hline SOS $9 b$ & 0 & 0 & $\$ 0.0$ & $\$ 0.0$ \\
\hline SOS 9c & 0 & 0 & $\$ 0.0$ & $\$ 0.0$ \\
\hline SOS PA & 0 & 0 & $\$ 0.0$ & $\$ 0.0$ \\
\hline
\end{tabular}

\begin{tabular}{|c|c|c|c|c|}
\hline \multicolumn{5}{|c|}{ Power Impacts } \\
\hline \multirow{2}{*}{ Alternative } & \multicolumn{2}{|c|}{ Regional Employment } & \multicolumn{2}{|c|}{ Regional Income $(\$ 1,000,000)$} \\
\hline & Direct & Total & Direct & Total \\
\hline SOS 1a & 42 & 70 & $\$ 1.1$ & $\$ 1.9$ \\
\hline $\operatorname{sos} 1 b$ & 84 & 140 & $\$ 2.3$ & $\$ 3.9$ \\
\hline $\operatorname{sos} 2 \mathrm{~d}$ & (24) & (40) & $(\$ 0.7)$ & $(\$ 1.1)$ \\
\hline $\operatorname{SOS} 4 c$ & (96) & $(160)$ & $(\$ 2.6)$ & $(\$ 4.4)$ \\
\hline $\operatorname{sos} 5 b$ & (147) & (247) & $(\$ 3.9)$ & $(\$ 6.8)$ \\
\hline SOS $5 c$ & (215) & (361) & $(\$ 5.8)$ & $(\$ 10.0)$ \\
\hline $\operatorname{sos} 6 b$ & $(52)$ & (86) & $(\$ 1.4)$ & $(\$ 2.4)$ \\
\hline SOS 6d & (21) & (34) & $(\$ 0.6)$ & $(\$ 1.0)$ \\
\hline $\operatorname{sos} 9 \mathrm{a}$ & (349) & (588) & $(\$ 9.3)$ & $(\$ 16.2)$ \\
\hline $\operatorname{sos} 9 b$ & (237) & $(400)$ & $(\$ 6.4)$ & $\$ 11.0$ \\
\hline $\operatorname{sos} 9 c$ & (204) & (343) & $(\$ 5.5)$ & $(\$ 9.5)$ \\
\hline SOS PA & (151) & (254) & $(\$ 4.0)$ & $(\$ 7.0)$ \\
\hline
\end{tabular}

\begin{tabular}{|l|c|}
\hline \multicolumn{2}{|c|}{ Regional Employment and Income Base } \\
\hline Total Employment (jobs): & 151,000 \\
\hline Total Income (\$million): & $\$ 4,352$ \\
\hline
\end{tabular}


Table E3-5. Upper Columbia Subregion, Summary of Regional Economic Impacts - CONT

\begin{tabular}{|l|c|r|r|r|}
\hline \multicolumn{5}{|c|}{ Recreation Impacts } \\
\hline \multirow{2}{*}{ Alternative } & \multicolumn{2}{|c|}{ Regional Employment } & \multicolumn{2}{c|}{ Regional Income $(\$ 1,000,000)$} \\
\cline { 2 - 5 } & Direct & Total & \multicolumn{1}{c|}{ Direct } & \multicolumn{1}{c|}{ Total } \\
\hline SOS 1a & $(8)$ & $(12)$ & $(\$ 0.2)$ & $(\$ 0.4)$ \\
\hline SOS 1b & $(7)$ & $(10)$ & $(\$ 0.2)$ & $(\$ 0.3)$ \\
\hline SOS 2d & $(1)$ & $(2)$ & $(\$ 0.0)$ & $(\$ 0.1)$ \\
\hline SOS 4c & $(2)$ & $(2)$ & $(\$ 0.0)$ & $(\$ 0.1)$ \\
\hline SOS 5b & $(1)$ & $(1)$ & $(\$ 0.0)$ & $(\$ 0.0)$ \\
\hline SOS 5c & $(1)$ & $(1)$ & $(\$ 0.0)$ & $(\$ 0.0)$ \\
\hline SOS 6b & $(1)$ & $(1)$ & $(\$ 0.0)$ & $(\$ 0.0)$ \\
\hline SOS 6d & $(1)$ & $(1)$ & $(\$ 0.0)$ & $(\$ 0.0)$ \\
\hline SOS 9a & $(85)$ & $(145)$ & $(\$ 2.4)$ & $(\$ 4.1)$ \\
\hline SOS 9b & $(39)$ & $(65)$ & $(\$ 1.1)$ & $(\$ 4.1)$ \\
\hline SOS 9c & $(20)$ & $(33)$ & $(\$ 0.6)$ & $(\$ 1.0)$ \\
\hline SOS PA & $(12)$ & $(19)$ & $(\$ 0.3)$ & $(\$ 0.5)$ \\
\hline
\end{tabular}

\begin{tabular}{|l|c|}
\hline \multicolumn{2}{|c|}{ Regional Employment and Income Base } \\
\hline Total Employment (jobs): & 151,000 \\
\hline Total Income (\$million): & $\$ 4,352$ \\
\hline
\end{tabular}


Table E3-6. Lower Snake Subregion, Summary of Regional Economic Impacts

\begin{tabular}{|c|c|c|c|c|}
\hline \multicolumn{5}{|c|}{ Total Regional Impacts $1 /$} \\
\hline \multirow{2}{*}{ Alternative $2 /$} & \multicolumn{2}{|c|}{ Regional Employment } & \multicolumn{2}{|c|}{ Regional Income $(\$ 1,000,000)$} \\
\hline & Direct & Total & Direct & Total \\
\hline SOS $1 a$ & 33 & 60 & $\$ 0.6$ & $\$ 1.2$ \\
\hline SOS $1 b$ & 80 & 147 & $\$ 1.4$ & $\$ 2.9$ \\
\hline $\operatorname{sos} 2 d$ & (21) & (39) & $(\$ 0.4)$ & $(\$ 0.7)$ \\
\hline SOS 4c & (87) & $(162)$ & $(\$ 1.5)$ & $(\$ 3.1)$ \\
\hline SOS 5b & $(1,237)$ & $(2,409)$ & $(\$ 22.6)$ & $(\$ 47.2)$ \\
\hline SOS 5c & $(2,021)$ & $(3,839)$ & $(\$ 39.0)$ & $(\$ 78.6)$ \\
\hline $\operatorname{sos} 6 b$ & $(879)$ & $(1,645)$ & $(\$ 15.3)$ & $(\$ 31.9)$ \\
\hline SOS 6d & (159) & $(313)$ & $(\$ 3.5)$ & $(\$ 6.9)$ \\
\hline $\operatorname{sos} 9 a$ & $(1,201)$ & $(2,260)$ & $(\$ 21.1)$ & $(\$ 44.1)$ \\
\hline $\operatorname{sOS} 9 b$ & (264) & $(500)$ & $(\$ 4.8)$ & $(\$ 10.0)$ \\
\hline $\operatorname{sos} 9 c$ & (356) & $(685)$ & $(\$ 7.2)$ & $(\$ 14.4)$ \\
\hline SOS PA & (149) & (275) & $(\$ 2.6)$ & $(\$ 5.4)$ \\
\hline
\end{tabular}

\begin{tabular}{|c|c|c|c|c|}
\hline \multicolumn{5}{|c|}{ Anadromous Fish Impacts } \\
\hline \multirow{2}{*}{ Alternative } & \multicolumn{2}{|c|}{ Regional Employment } & \multicolumn{2}{|c|}{ Regional Income $(\$ 1,000,000)$} \\
\hline & Direct & Total & Direct & Total \\
\hline SOS 1a & $(2)$ & (3) & $(\$ 0.0)$ & $(\$ 0.1)$ \\
\hline SOS $1 b$ & $(2)$ & (3) & $(\$ 0.1)$ & $(\$ 0.1)$ \\
\hline $\operatorname{SOS} 2 \mathrm{~d}$ & (1) & (2) & $(\$ 0.0)$ & $(\$ 0.0)$ \\
\hline $\operatorname{sos} 4 c$ & (1) & (1) & $(\$ 0.0)$ & $(\$ 0.0)$ \\
\hline SOS $5 b$ & $(29)$ & (134) & $(\$ 1.7)$ & $(\$ 3.1)$ \\
\hline SOS 5c & $(68)$ & (134) & $(\$ 1.7)$ & $(\$ 3.1)$ \\
\hline SOS $6 \mathrm{~b}$ & $(107)$ & $(211)$ & $(\$ 2.6)$ & $(\$ 4.9)$ \\
\hline SOS 6d & $(40)$ & $(78)$ & $(\$ 1.0)$ & $(\$ 1.8)$ \\
\hline SOS 9a & $(128)$ & $(254)$ & $(\$ 3.2)$ & $(\$ 5.9)$ \\
\hline SOS $9 b$ & $(20)$ & $(40)$ & $(\$ 0.5)$ & $(\$ 0.9)$ \\
\hline SOS $9 c$ & $(106)$ & $(210)$ & $(\$ 2.6)$ & $(\$ 4.9)$ \\
\hline SOS PA & (4) & $(7)$ & $(\$ 0.1)$ & $(\$ 0.2)$ \\
\hline
\end{tabular}

\begin{tabular}{|l|r|}
\hline \multicolumn{2}{|c|}{ Regional Employment and Income Base } \\
\hline Total Employment (jobs): & 63,000 \\
\hline Total Income (\$million): & $\$ 1,929$ \\
\hline
\end{tabular}


Table E3-6. Lower Snake Subregion, Summary of Regional Economic Impacts - CONT

\begin{tabular}{|c|c|c|c|c|}
\hline \multicolumn{5}{|c|}{ Irrigation Impacts } \\
\hline \multirow{2}{*}{ Alternative } & \multicolumn{2}{|c|}{ Regional Employment } & \multicolumn{2}{|c|}{ Regional Income $(\$ 1,000,000)$} \\
\hline & Direct & Total & Direct & Total \\
\hline SOS 1a & 0 & 0 & $\$ 0.0$ & $\$ 0.0$ \\
\hline SOS $1 b$ & 0 & 0 & $\$ 0.0$ & $\$ 0.0$ \\
\hline SOS 2d & 0 & 0 & $\$ 0.0$ & $\$ 0.0$ \\
\hline $\operatorname{sOS} 4 c$ & 0 & 0 & $\$ 0.0$ & $\$ 0.0$ \\
\hline SOS 5b & (10) & $(16)$ & $(\$ 0.2)$ & $(\$ 0.4)$ \\
\hline SOS 5c & (11) & (18) & $(\$ 0.3)$ & $(\$ 0.4)$ \\
\hline SOS $6 b$ & (7) & (11) & $(\$ 0.2)$ & $(\$ 0.3)$ \\
\hline SOS 6d & (7) & (10) & $(\$ 0.2)$ & $(\$ 0.3)$ \\
\hline SOS 9a & (7) & (11) & $(\$ 0.2)$ & $(\$ 0.3)$ \\
\hline SOS $9 b$ & 0 & 0 & $\$ 0.0$ & $\$ 0.0$ \\
\hline SOS $9 c$ & $(8)$ & (13) & $(\$ 0.2)$ & $(\$ 0.3)$ \\
\hline SOS PA & 0 & 0 & $\$ 0.0$ & $\$ 0.0$ \\
\hline
\end{tabular}

\begin{tabular}{|l|r|r|r|r|}
\hline \multirow{2}{*}{ Alternative } & \multicolumn{5}{|c|}{ Regional Employment } & \multicolumn{2}{c|}{ Regional Income (\$1,000,000) } \\
\cline { 2 - 5 } & Direct & \multicolumn{1}{|c|}{ Total } & \multicolumn{1}{c|}{ Direct } & Total \\
\hline SOS 1a & 2 & 3 & $\$ 0.0$ & $\$ 0.1$ \\
\hline SOS 1b & 2 & 3 & $\$ 0.1$ & $(\$ 0.1)$ \\
\hline SOS 2d & $(1)$ & $(2)$ & $(\$ 0.0)$ & $\$ 0.2$ \\
\hline SOS 4c & 4 & 6 & $\$ 0.1$ & $(\$ 28.9)$ \\
\hline SOS 5b & $(849)$ & $(1,562)$ & $(\$ 13.6)$ & $(\$ 55.8)$ \\
\hline SOS 5c & $(1,484)$ & $(2,775)$ & $(\$ 27.9)$ & $(\$ 20.0)$ \\
\hline SOS 6b & $(608)$ & $(1,109)$ & $(\$ 9.2)$ & $(\$ 0.1)$ \\
\hline SOS 6d & $(4)$ & $(5)$ & $(\$ 0.0)$ & $(\$ 20.0)$ \\
\hline SOS 9a & $(609)$ & $(1,111)$ & $(\$ 9.3)$ & $(\$ 0.1)$ \\
\hline SOS 9b & $(3)$ & $(4)$ & $(\$ 0.1)$ & $(\$ 0.1)$ \\
\hline SOS 9c & $(3)$ & $(5)$ & $(\$ 0.1)$ & $(\$ 0.1)$ \\
\hline SOS PA & $(2)$ & $(3)$ & $(\$ 0.1)$ & \\
\hline
\end{tabular}

Regional Employment and Income Base

\begin{tabular}{|l|c|}
\hline Total Employment (jobs): & 63,000 \\
\hline Total Income (\$million): & $\$ 1,929$ \\
\hline
\end{tabular}


Table E3-6. Lower Snake Subregion, Summary of Regional Economic Impacts - CONT

\begin{tabular}{|c|c|c|c|c|}
\hline \multicolumn{5}{|c|}{ Power Impacts } \\
\hline \multirow{2}{*}{ Alternative } & \multicolumn{2}{|c|}{ Regional Employment } & \multicolumn{2}{|c|}{ Regional Income $(\$ 1,000,000)$} \\
\hline & Direct & Total & Direct & Total \\
\hline SOS 1a & 39 & 71 & $\$ 0.7$ & $\$ 1.4$ \\
\hline SOS $1 b$ & 79 & 146 & $\$ 1.4$ & $\$ 2.8$ \\
\hline SOS 2d & (23) & (41) & $(\$ 0.4)$ & $(\$ 0.8)$ \\
\hline $\operatorname{sOS} 4 c$ & $(90)$ & $(167)$ & $(\$ 1.5)$ & $(\$ 3.2)$ \\
\hline SOS 5b & $(138)$ & $(257)$ & $(\$ 2.4)$ & $(\$ 5.0)$ \\
\hline SOS 5c & (201) & $(376)$ & $(\$ 3.5)$ & $(\$ 7.3)$ \\
\hline SOS 6b & $(48)$ & $(88)$ & $(\$ 0.8)$ & $(\$ 1.7)$ \\
\hline SOS 6d & $(20)$ & (35) & $(\$ 0.3)$ & $(\$ 0.7)$ \\
\hline $\operatorname{sos} 9 a$ & (327) & $(613)$ & $(\$ 5.6)$ & $(\$ 11.9)$ \\
\hline SOS $9 b$ & $(222)$ & (417) & $(\$ 3.8)$ & $(\$ 8.1)$ \\
\hline SOS $9 c$ & $(191)$ & $(358)$ & $(\$ 3.3)$ & $(\$ 6.9)$ \\
\hline SOS PA & $(142)$ & $(264)$ & $(\$ 2.4)$ & $(\$ 5.1)$ \\
\hline
\end{tabular}

\begin{tabular}{|c|c|c|c|c|}
\hline \multicolumn{5}{|c|}{ Recreation Impacts } \\
\hline \multirow{2}{*}{ Alternative } & \multicolumn{2}{|c|}{ Regional Employment } & \multicolumn{2}{|c|}{ Regional Income $(\$ 1,000,000)$} \\
\hline & Direct & Total & Direct & Total \\
\hline SOS 1a & (6) & (11) & $(\$ 0.1)$ & $(\$ 0.2)$ \\
\hline SOS $1 \mathrm{~b}$ & 1 & 2 & $\$ 0.0$ & $\$ 0.1$ \\
\hline $\operatorname{sos} 2 \mathrm{~d}$ & 4 & 6 & $\$ 0.1$ & $\$ 0.1$ \\
\hline SOS 4c & 0 & 0 & $\$ 0.0$ & $\$ 0.0$ \\
\hline SOS $5 b$ & (211) & (440) & $(\$ 4.7)$ & $(\$ 9.8)$ \\
\hline $\operatorname{sos} 5 c$ & (258) & (537) & $(\$ 5.7)$ & $(\$ 11.9)$ \\
\hline SOS $6 \mathrm{~b}$ & $(109)$ & (225) & $(\$ 2.4)$ & $(\$ 5.0)$ \\
\hline SOS 6d & $(89)$ & (184) & $(\$ 2.0)$ & $(\$ 4.1)$ \\
\hline SOS 9a & (130) & (270) & $(\$ 2.9)$ & $(\$ 6.0)$ \\
\hline $\operatorname{sos} 9 b$ & (19) & (39) & $(\$ 0.4)$ & $(\$ 0.9)$ \\
\hline SOS 9c & (48) & (99) & $(\$ 1.1)$ & $(\$ 2.2)$ \\
\hline SOS PA & (1) & (1) & $(\$ 0.0)$ & $(\$ 0.0)$ \\
\hline
\end{tabular}

Regional Employment and Income Base

\begin{tabular}{|l|l|}
\hline Total Employment (jobs): & 63,000 \\
\hline Total Income (\$million): & $\$ 1,929$ \\
\hline
\end{tabular}


Table E3-6. Lower Snake Subregion, Summary of Regional Economic Impacts - CONT

\begin{tabular}{|c|c|c|c|c|}
\hline \multicolumn{5}{|c|}{ Construction Impacts } \\
\hline \multirow{2}{*}{ Alternative } & \multicolumn{2}{|c|}{ Regional Employment } & \multicolumn{2}{|c|}{ Regional Income $(\$ 1,000,000)$} \\
\hline & Direct & Total & Direct & Total \\
\hline SOS 1a & 0 & 0 & $\$ 0.0$ & $\$ 0.0$ \\
\hline SOS 1b & 0 & 0 & $\$ 0.0$ & $\$ 0.0$ \\
\hline $\operatorname{sos} 2 d$ & 0 & 0 & $\$ 0.0$ & $\$ 0.0$ \\
\hline $\operatorname{sOs} 4 c$ & 0 & 0 & $\$ 0.0$ & $\$ 0.0$ \\
\hline $\operatorname{sos} 5 b$ & 1,532 & 4,189 & $\$ 54.6$ & $\$ 112.2$ \\
\hline SOS 5c & 639 & 1,738 & $\$ 22.8$ & $\$ 46.7$ \\
\hline sos $6 b$ & 814 & 2,221 & $\$ 29.0$ & $\$ 59.5$ \\
\hline SOS 6d & 210 & 563 & $\$ 7.5$ & $\$ 15.2$ \\
\hline $\operatorname{sos} 9 a$ & 814 & 2,221 & $\$ 29.0$ & $\$ 59.5$ \\
\hline SOS $9 b$ & 0 & 0 & $\$ 0.0$ & $\$ 0.0$ \\
\hline SOS 9c & 819 & 2,233 & $\$ 29.2$ & $\$ 59.9$ \\
\hline SOS PA & 0 & 0 & $\$ 0.0$ & $\$ 0.0$ \\
\hline
\end{tabular}

Regional Employment and Income Base

\begin{tabular}{l|l}
\hline Total Employment (jobs): & 63,000
\end{tabular}

\begin{tabular}{l|r} 
Total Income (\$million): & $\$ 1,929$ \\
\hline
\end{tabular} 
Table E3-7. Northeast Subregion, Summary of Regional Economic Impacts

\begin{tabular}{|c|c|c|c|c|}
\hline \multicolumn{5}{|c|}{ Total Regional Impacts } \\
\hline \multirow{2}{*}{ Alternative } & \multicolumn{2}{|c|}{ Regional Employment } & \multicolumn{2}{|c|}{ Regional Income $(\$ 1,000,000)$} \\
\hline & Direct & Total & Direct & Total \\
\hline SOS 1a & 83 & 181 & $\$ 2.1$ & $\$ 5.1$ \\
\hline SOS $1 b$ & 167 & 368 & $\$ 4.3$ & $\$ 10.4$ \\
\hline $\operatorname{SOS} 2 d$ & (49) & $(105)$ & $(\$ 1.3)$ & $(\$ 3.0)$ \\
\hline SOS 4c & $(189)$ & $(417)$ & $(\$ 4.9)$ & $(\$ 11.8)$ \\
\hline SOS $5 b$ & $(38)$ & $(54)$ & $\$ 3.0$ & $\$ 2.7$ \\
\hline SOS 5c & 33 & 137 & $\$ 7.8$ & $\$ 11.2$ \\
\hline SOS $6 \mathrm{~b}$ & 103 & 256 & $\$ 5.8$ & $\$ 10.6$ \\
\hline SOS 6d & $(50)$ & $(104)$ & $(\$ 1.3)$ & $(\$ 3.0)$ \\
\hline $\operatorname{sos} 9 a$ & (519) & $(1,124)$ & $(\$ 10.2)$ & $(\$ 28.4)$ \\
\hline SOS $9 b$ & (479) & $(1,059)$ & $(\$ 12.3)$ & $(\$ 29.9)$ \\
\hline SOS 9c & $(408)$ & $(902)$ & $(\$ 10.5)$ & $(\$ 25.4)$ \\
\hline SOS PA & $(302)$ & $(666)$ & $(\$ 7.7)$ & $(\$ 18.8)$ \\
\hline
\end{tabular}

\begin{tabular}{|c|c|c|c|c|}
\hline \multicolumn{5}{|c|}{ Navigation Impacts } \\
\hline \multirow{2}{*}{ Alternative } & \multicolumn{2}{|c|}{ Regional Employment } & \multicolumn{2}{|c|}{ Regional Income $(\$ 1,000,000)$} \\
\hline & Direct & Total & Direct & Total \\
\hline SOS 1a & 0 & 0 & $\$ 0.0$ & $\$ 0.0$ \\
\hline SOS $1 b$ & 0 & 0 & $\$ 0.0$ & $\$ 0.0$ \\
\hline SOS 2d & 0 & 0 & $\$ 0.0$ & $\$ 0.0$ \\
\hline SOS 4c & 0 & 0 & $\$ 0.0$ & $\$ 0.0$ \\
\hline SOS $5 b$ & 256 & 596 & $\$ 10.5$ & $\$ 21.1$ \\
\hline SOS $5 c$ & 463 & 1,088 & $\$ 18.8$ & $\$ 38.1$ \\
\hline $\operatorname{sos} 6 \mathrm{~b}$ & 207 & 483 & $\$ 8.4$ & $\$ 17.0$ \\
\hline SOS 6d & $(6)$ & $(11)$ & $(\$ 0.2)$ & $(\$ 0.3)$ \\
\hline SOS 9a & 207 & 483 & $\$ 8.4$ & $\$ 17.0$ \\
\hline SOS 9b & 0 & 0 & $\$ 0.0$ & $\$ 0.0$ \\
\hline SOS 9c & $(4)$ & $(6)$ & $(\$ 0.1)$ & $(\$ 0.2)$ \\
\hline SOS PA & 0 & 0 & $\$ 0.0$ & $\$ 0.0$ \\
\hline
\end{tabular}

Regional Employment and Income Base

\begin{tabular}{|l|l}
\hline Total Employment (jobs): & 262,000
\end{tabular}

\begin{tabular}{|l|l}
\hline Total Income (\$million): & $\$ 8,339$ \\
\hline
\end{tabular} 
Table E3-7. Northeast Subregion, Summary of Regional Economic Impacts - CONT

\begin{tabular}{|c|c|c|c|c|}
\hline \multicolumn{5}{|c|}{ Power Impacts } \\
\hline \multirow{2}{*}{ Alternative } & \multicolumn{2}{|c|}{ Regional Employment } & \multicolumn{2}{|c|}{ Regional Income $(\$ 1,000,000)$} \\
\hline & Direct & Total & Direct & Total \\
\hline SOS 1a & 84 & 182 & $\$ 2.2$ & $\$ 5.2$ \\
\hline SOS $1 b$ & 168 & 370 & $\$ 4.3$ & $\$ 10.4$ \\
\hline SOS $2 d$ & $(49)$ & (105) & $(\$ 1.3)$ & $(\$ 3.0)$ \\
\hline SOS $4 c$ & (192) & (422) & $(\$ 4.9)$ & $(\$ 11.9)$ \\
\hline SOS $5 b$ & (293) & (648) & $(\$ 7.5)$ & $(\$ 18.3)$ \\
\hline SOS 5c & $(429)$ & (949) & $(\$ 11.0)$ & $(\$ 26.8)$ \\
\hline SOS $6 \mathrm{~b}$ & $(103)$ & $(225)$ & $(\$ 2.7)$ & $(\$ 6.4)$ \\
\hline SOS 6d & $(43)$ & $(91)$ & $(\$ 1.1)$ & $(\$ 2.6)$ \\
\hline SOS 9a & $(697)$ & $(1,545)$ & $(\$ 17.9)$ & $(\$ 43.5)$ \\
\hline sos 9b & (474) & $(1,050)$ & $(\$ 12.2)$ & $(\$ 29.6)$ \\
\hline SOS 9c & $(407)$ & $(901)$ & $(\$ 10.5)$ & $(\$ 25.4)$ \\
\hline SOS PA & (302) & $(667)$ & $(\$ 7.7)$ & $(\$ 18.8)$ \\
\hline
\end{tabular}

\begin{tabular}{|c|c|c|c|c|}
\hline \multicolumn{5}{|c|}{ Recreation Impacts } \\
\hline \multirow{2}{*}{ Alternative } & \multicolumn{2}{|c|}{ Regional Employment } & \multicolumn{2}{|c|}{ Regional Income $(\$ 1,000,000)$} \\
\hline & Direct & Total & Direct & Total \\
\hline SOS 1a & (1) & (1) & $(\$ 0.0)$ & $(\$ 0.0)$ \\
\hline SOS 1b & (1) & (2) & $(\$ 0.0)$ & $(\$ 0.1)$ \\
\hline SOS 2d & 0 & 0 & $(\$ 0.0)$ & $(\$ 0.0)$ \\
\hline SOS $4 c$ & 3 & 5 & $\$ 0.1$ & $\$ 0.1$ \\
\hline SOS $5 b$ & (1) & $(2)$ & $(\$ 0.0)$ & $(\$ 0.1)$ \\
\hline SOS 5c & (1) & (2) & $(\$ 0.0)$ & $(\$ 0.1)$ \\
\hline $\operatorname{sos} 6 b$ & $(1)$ & $(2)$ & $(\$ 0.0)$ & $(\$ 0.1)$ \\
\hline SOS 6d & (1) & $(2)$ & $(\$ 0.0)$ & $(\$ 0.1)$ \\
\hline SOS 9a & $(29)$ & $(62)$ & $(\$ 0.8)$ & $(\$ 1.8)$ \\
\hline SOS 9b & $(5)$ & (9) & $(\$ 0.1)$ & $(\$ 0.3)$ \\
\hline SOS $9 c$ & 3 & 5 & $\$ 0.1$ & $\$ 0.1$ \\
\hline SOS PA & 0 & 1 & $\$ 0.0$ & $\$ 0.0$ \\
\hline
\end{tabular}

Regional Employment and Income Base

\begin{tabular}{l|l} 
Total Employment (jobs): & 262,000 \\
\hline
\end{tabular}

\begin{tabular}{|l|l}
\hline Total Income (\$million): & $\$ 8,339$ \\
\hline
\end{tabular} 
Table E3-8. Southern Idaho Subregion, Summary of Regional Economic Impacts

\begin{tabular}{|c|c|c|c|c|}
\hline \multicolumn{5}{|c|}{ Total Regional Impacts } \\
\hline \multirow{2}{*}{ Alternative $1 /$} & \multicolumn{2}{|c|}{ Regional Employment } & \multicolumn{2}{|c|}{ Regional Income $(\$ 1,000,000)$} \\
\hline & Direct & Total & Direct & Total \\
\hline SOS 1a & 53 & 101 & $\$ 1.5$ & $\$ 2.9$ \\
\hline SOS $1 \mathrm{~b}$ & 105 & 204 & $\$ 2.9$ & $\$ 5.9$ \\
\hline $\operatorname{sos} 2 \mathrm{~d}$ & (31) & $(58)$ & $(\$ 0.9)$ & $(\$ 1.7)$ \\
\hline $\operatorname{sos} 4 c$ & $(120)$ & (233) & $(\$ 3.3)$ & $(\$ 6.7)$ \\
\hline $\operatorname{sos} 5 b$ & $(31)$ & $(76)$ & $(\$ 1.3)$ & $(\$ 2.7)$ \\
\hline $\operatorname{sos} 5 c$ & 31 & 35 & $\$ 0.3$ & $\$ 0.4$ \\
\hline SOS $6 \mathrm{~b}$ & 47 & 78 & $\$ 0.8$ & $\$ 1.7$ \\
\hline sos 6d & (29) & $(54)$ & $(\$ 0.8)$ & $(\$ 1.6)$ \\
\hline SOS 9a & $(324)$ & $(649)$ & $(\$ 9.5)$ & $(\$ 19.1)$ \\
\hline sos $9 b$ & (298) & $(582)$ & $(\$ 8.3)$ & $(\$ 16.7)$ \\
\hline SOS 9c & $(257)$ & $(502)$ & $(\$ 7.1)$ & $(\$ 14.4)$ \\
\hline SOS PA & (190) & (369) & $(\$ 5.3)$ & $(\$ 10.6)$ \\
\hline
\end{tabular}

\begin{tabular}{|c|c|c|c|c|}
\hline \multicolumn{5}{|c|}{ Navigation Impacts } \\
\hline \multirow{2}{*}{ Alternative } & \multicolumn{2}{|c|}{ Regional Employment } & \multicolumn{2}{|c|}{ Regional Income $(\$ 1,000,000)$} \\
\hline & Direct & Total & Direct & Total \\
\hline SOS 1a & 0 & 0 & $\$ 0.0$ & $\$ 0.0$ \\
\hline SOS $1 b$ & 0 & 0 & $\$ 0.0$ & $\$ 0.0$ \\
\hline $\operatorname{SOS} 2 \mathrm{~d}$ & 0 & 0 & $\$ 0.0$ & $\$ 0.0$ \\
\hline SOS 4c & 0 & 0 & $\$ 0.0$ & $\$ 0.0$ \\
\hline SOS 5b & 153 & 282 & $\$ 3.8$ & $\$ 7.6$ \\
\hline SOS 5c & 301 & 561 & $\$ 7.8$ & $\$ 15.5$ \\
\hline SOS $6 \mathrm{~b}$ & 112 & 203 & $\$ 2.6$ & $\$ 5.3$ \\
\hline SOS 6d & $(2)$ & (4) & $(\$ 0.1)$ & $(\$ 0.1)$ \\
\hline SOS 9a & 114 & 207 & $\$ 2.7$ & $\$ 5.4$ \\
\hline SOS $9 b$ & 0 & 0 & $\$ 0.0$ & $\$ 0.0$ \\
\hline SOS $9 c$ & (1) & $(2)$ & $(\$ 0.0)$ & $(\$ 0.1)$ \\
\hline SOS PA & 0 & 0 & $\$ 0.0$ & $\$ 0.0$ \\
\hline
\end{tabular}

Regional Employment and Income Base

\begin{tabular}{|l|c|}
\hline Total Employment (jobs): & 302,000 \\
\hline Total Income (\$million): & $\$ 9,919$ \\
\hline
\end{tabular}


Table E3-8. Southern Idaho Subregion, Summary of Regional Economic Impacts - CONT

\begin{tabular}{|c|c|c|c|c|}
\hline \multicolumn{5}{|c|}{ Power Impacts } \\
\hline \multirow{2}{*}{ Alternative } & \multicolumn{2}{|c|}{ Regional Employment } & \multicolumn{2}{|c|}{ Regional Income $(\$ 1,000,000)$} \\
\hline & Direct & Total & Direct & Total \\
\hline SOS 1a & 53 & 101 & $\$ 1.5$ & $\$ 2.9$ \\
\hline SOS $1 b$ & 105 & 204 & $\$ 2.9$ & $\$ 5.9$ \\
\hline SOS 2d & $(31)$ & $(58)$ & $(\$ 0.9)$ & $(\$ 1.7)$ \\
\hline SOS 4c & $(120)$ & (233) & $(\$ 3.3)$ & $(\$ 6.7)$ \\
\hline SOS 5b & $(184)$ & (358) & $(\$ 5.1)$ & $(\$ 10.3)$ \\
\hline$\overline{\text { SOS 5c }}$ & $(270)$ & $(526)$ & $(\$ 7.5)$ & $(\$ 15.1)$ \\
\hline SOS $6 b$ & $(65)$ & (125) & $(\$ 1.8)$ & $(\$ 3.6)$ \\
\hline SOS 6d & $(27)$ & $(50)$ & $(\$ 0.7)$ & $(\$ 1.4)$ \\
\hline SOS $9 a$ & $(438)$ & $(856)$ & $(\$ 12.1)$ & $(\$ 24.5)$ \\
\hline SOS $9 b$ & (298) & $(582)$ & $(\$ 8.3)$ & $(\$ 16.7)$ \\
\hline SOS 9c & (256) & $(500)$ & $(\$ 7.1)$ & $(\$ 14.3)$ \\
\hline SOS PA & $(190)$ & $(369)$ & $(\$ 5.3)$ & $(\$ 10.6)$ \\
\hline
\end{tabular}

Regional Employment and Income Base

\begin{tabular}{|l|l}
\hline Total Employment (jobs): & 302,000 \\
\hline
\end{tabular}

\begin{tabular}{l|l} 
Total Income (\$million): & $\$ 9,919$
\end{tabular} 


\section{EXHIBIT F}

\section{SOCIAL IMPACTS ANALYSIS}

\section{F.1 FOCUS COMMUNITY PROFILES}

\section{F.1.1 BACKGROUND}

The System Operation Review includes three components of analysis to evaluate the economic impacts of the operations alternatives: 1) a national economic analysis that takes into account the gains and losses in economic efficiency, 2) a regional economic analysis that takes into account the regional gains and losses in income and employment that would result with implementation of the alternatives, and 3) an evaluation of the potential socioeconomic impacts of the alternatives on selected communities and Indian tribes located throughout the Pacific Northwest. All three components of the economic analysis were prepared by the SOR Economic Analysis Group.

Seventeen communities and Indian tribes in the Pacific Northwest were selected for inclusion in the evaluation of the potential socioeconomic impacts associated with the SOR alternatives. These focus communities were selected to represent the range potential direct economic impacts that may occur under the various alternatives. Most of the focus communities are likely to be impacted by only one or two resource adjustments, such as changes in potential flood damages or changes in anadromous fish harvests. Three of the focus communities (Lewiston, Clarkston, and the Tri--Cities), however, are likely to experience a wide array of impacts under some of the SOR implementation scenarios. The locations of the seventeen focus communities and the reasons for their inclusion in the socioeconomic analysis are presented in Table $\mathbf{F}-1$.

A description of the socioeconomic profiles of each of the focus communities is presented in the follow- ing sections. The profiles include information on population and housing, income and employment, and the river-based resource activities occurring in the vicinity of the community. The reasons for which the community is included in the social impacts analysis are also discussed.

\section{F.1.2 FOCUS COMMUNITIES LOCATED IN MONTANA}

\section{F.1.2.1 THE COMMUNITY OF LIBBY}

Libby is located in Lincoln County along the Kootenai River several miles downstream from Libby Dam and its reservoir, Lake Koocanusa. It was chosen as a focus community because of the recreation opportunities found at Lake Koocanusa and along the Kootenai River below Libby Dam.

Natural resources have been the mainstay of Libby's economy since its settlement in the 1860 s. Silver and copper mining and lumbering are the town's leading businesses. Libby's environmental amenities contribute to the town's popularity as a recreational center. The nearby Kootenai National Forest provides extensive lands for public use, and anglers enjoy fishing in the Kootenai River and its tributaries.

\section{Population and Housing}

The population of Libby in 1990 was 2,532 . This urban area's population declined eight percent between 1980 and 1990 . The median age of Libby residents increased from 31 in 1980 to 37 in 1990. The number of occupied houses in Libby in 1990 was 1,047. Homeowners lived in 54 percent of these houses and renters lived in 43 percent. Between 1980 and 1990 renters occupied 77 more houses and homeowners occupied 60 fewer houses. 
Table F-1. Focus Community Location and Selection Reason

\begin{tabular}{|c|c|c|c|}
\hline State/Community & County & Subregion & Selection Reason \\
\hline \multicolumn{4}{|l|}{ Montana } \\
\hline Libby & Lincoln & Northeast & Recreation, Power \\
\hline Flathead Lake & Flathead, Lake & Northeast & Recreation, Flood Control, Power \\
\hline Columbia Falls & Flathead & Northeast & Power, Flood Control \\
\hline Flathead Reservation & $\begin{array}{l}\text { Flathead, Sanders, } \\
\text { Lake, Missoula }\end{array}$ & Northeast & Recreation, Flood Control, Power \\
\hline \multicolumn{4}{|l|}{ Idaho } \\
\hline Bonners Ferry & Boundary & Northeast & Flood Control, Power \\
\hline Kootenai Reservation & Boundary & Northeast & Flood Control, Power \\
\hline Orofino & Clearwater & Lower Snake & Recreation, Power \\
\hline Nez Perce Reservation & Nez Perce, Lewis & Lower Snake & $\begin{array}{l}\text { Anadromous Fish, Recreation, } \\
\text { Power }\end{array}$ \\
\hline Lewiston & Nez Perce & Lower Snake & $\begin{array}{l}\text { Anadromous Fish, Recreation, } \\
\text { Navigation, Construction, Power }\end{array}$ \\
\hline \multicolumn{4}{|l|}{ Washington } \\
\hline Clarkston & Asotin & Lower Snake & $\begin{array}{l}\text { Anadromous Fish, Recreation, } \\
\text { Navigation, Construction, Power }\end{array}$ \\
\hline Colville Reservation & Ferry, Okanogan & Upper Columbia & Recreation, Power \\
\hline Spokane Reservation & Lincoln, Stevens & Northeast & Recreation, Power \\
\hline Grand Coulee/Coulee Dam & Grant, Okanogan & Upper Columbia & Recreation, Power \\
\hline Tri-Cities & Benton, Franklin & Mid Columbia & $\begin{array}{l}\text { Anadromous Fish, Recreation, } \\
\text { Irrigation/M\&I, Navigation, } \\
\text { Construction, Power }\end{array}$ \\
\hline \multicolumn{4}{|l|}{ Oregon } \\
\hline Umatilla/Morrow & Morrow, Umatilla & Mid-Columbia & $\begin{array}{l}\text { Irrigation/M\&I, Navigation, } \\
\text { Recreation, Construction, Power }\end{array}$ \\
\hline Portland & Multnomah & Portland & $\begin{array}{l}\text { Anadromous Fish, Navigation, } \\
\text { Power }\end{array}$ \\
\hline Astoria & Clatsop & West Coast & Anadromous Fish, Power \\
\hline
\end{tabular}




\section{Income and Employment}

Per capita income in Libby was $\$ 9,589$ in 1990 . Between 1980 and 1990 per capita income increased 50 percent. Sixteen percent of all people in the community for whom poverty was determined were below the poverty level. ${ }^{1}$ Employment in Libby in 1990 was 984 , while unemployment was 184 , an unemployment rate of 15.7 percent. The number of people unemployed decreased 23 percent between 1980 and 1990 . Sixty-nine percent of the employment was private industry and 14 percent was government employment. Employment was highest in durable goods manufacturing and retail trade with 226 and 134 employees respectively. However, since 1980 employment in manufacturing has increased while employment in retail trade has decreased. Between 1980 and 1990, employment more than tripled in other professional and related services and business and repair services.

\section{Recreation}

Formed behind Libby Dam, Lake Koocanusa is located on the Kootenai River in the extreme northwest corner of Montana and southeastern corner of British Columbia, Canada. Most of the land adjacent to the U.S. section of the reservoir and along the Kootenai River below Lake Koocanusa is part of the Kootenai National Forest. These lands are generally managed for timber production, wildlife, and recreation. Privately owned parcels of land in the U.S. section are concentrated near the towns of Libby and Troy, located 18 miles downstream. Much of the private land near Libby that overlooks the Kootenai River is residential.

Both Lake Koocanusa and the Kootenai River are bordered by highways and roads that allow potential visitors to the area to view the reservoir and river. Many of these visitors are residents of nearby towns and include private property owners, travelers on local roads, and visitors to recreation facilities.
Recreationists and tourists from outside the immediate area can also view the reservoir from nearby roads and recreational facilities.

Recreational activities at Lake Koocanusa are water oriented. Fishing is perhaps the most popular activity. The Kootenai River below Libby Dam has developed into an excellent rainbow trout fishery. Although fishing is frequently restricted by water level fluctuations caused by hydropower peaking operations at the dam, it is far superior to that which existed in free-flowing river prior to the dam. Fishing guide services are available on the downstream reaches of the river. This is a popular and growing aspect of the local recreation economy.

\section{F.1.2.2 THE COMMUNITY OF FLATHEAD LAKE}

The Flathead Lake community includes the towns of Bigfork, Somers, Lakeside, and Creston. These towns are located in Flathead County, along the north shore of Flathead Lake. The Flathead Lake community was chosen as a focus community because of Flathead Lake's recreation opportunities and flood damage potential, especially along the north shore. These four communities are very small in size and the area surrounding the community is primarily rural farmland. Many of the local residents are employed in the larger community of Kalispell, located ten miles to the north.

\section{Population and Housing}

The population of the Flathead Lake community in 1990 was 5,147 . This rural area's population increased 25 percent between 1980 and 1990 . The median age of Flathead Lake residents increased from 31 in 1980 to 38 in 1990 . The number of occupied houses in the Flathead Lake community in 1990 was 1,893 . Homeowners lived in 80 percent of these houses and renters lived in 20 percent. Between 1980 and 1990 the number of occupied houses

1. Families and unrelated individuals are classified as being above or below poverty level using the poverty index originating at the Social Security Administration in 1964 and revised by Federal Interagency Committees in 1969 and 1980. The poverty index is based solely on money income and does not reflect the fact that many low-income persons receive noncash benefits. The index reflects the different consumption requirements of families based on their size and composition. 
increased by 373 . In 1990,69 percent of the 514 vacant houses were for seasonal, recreational, or occasional use. Between 1980 and 1990 the number of vacant houses increased by 219 .

\section{Income and Employment}

Per capita income in the Flathead Lake community was $\$ 12,427$ in 1990 . Thirteen percent of all people in the community for whom poverty status was determined were below the poverty level. Employment in the Flathead Lake community in 1990 was 2,045 , while unemployment was 230 , an unemployment rate of 10.1 percent. Sixty-six percent of the employment was private industry and 14 percent was government employment. Employment was highest in retail trade with 412 employees. Construction, health services, manufacturing of durable goods were also large employment sectors, employing 210,189 , and 188 employees respectively.

\section{Flood Control}

Flathead Lake is a natural lake, the largest freshwater lake west of the Mississippi River. It's upper ten feet of elevation is controlled by Kerr Dam, located near Polson, Montana. Kerr Dam is owned by the Montana Power Company and is operated for power, flood control, irrigation, and recreation. While Kerr Dam regulates the level of Flathead Lake, and prevents flooding to the lakefront property, the dam is also operated to relieve flooding upstream of the lake which is caused by backwater effects of high lake levels coupled with high Flathead River flows. Specifically, flooding in the Flathead Lake Community occurs when the lake, which has a natural barrier at its outlet, cannot release the high flows of the Flathead River entering the upper reaches of the Lake. Some of the flows of the Flathead River are controlled by Hungry Horse Dam, located on the South Fork. The springtime refill of Flathead Lake is jointly managed for flood control by the Corps of Engineers and the Montana Power Company.

The last major flood event in the vicinity of the Flathead Lake Community occurred in 1964, when over $\$ 27$ million in damages occurred. Lake front flooding has not been a significant problem since construction of Kerr Dam in 1938.

\section{Recreation}

The three forks of the Flathead River flow to their confluence just north Flathead Lake near Kalispell, Montana. Flathead Lake is one of the major recreation resources in the Flathead Basin surrounded by many permanent and seasonal homes, small communities, and public and private campgrounds. The fishery of the upper Flathead River-Flathead Lake system is nationally renowned, attracting thousands of anglers annually. The Flathead Community provides services to much of the recreation activity on the north end of Flathead Lake. Bigfork is home to a large artist community, with numerous art galleries and a summer performing arts theater.

\section{F.1.2.3 THE COMMUNITY OF COLUMBIA FALLS}

Columbia Falls is located in Flathead County, at the confluence of the North and Middle Forks of the Flathead River. It was chosen as a focus community because of the local aluminum plant and the potential flood damage along the Flathead River downstream of Hungry Horse Dam.

The abundance of water and timber in the area support the Columbia Falls Aluminum Co. and various lumber mills, the town's major industries. Glacier National Park's western entrance, Hungry Horse Dam, and the Great Bear and Bob Marshall wilderness areas are also located nearby.

\section{Population and Housing}

The population of Columbia Falls in 1990 was 2,942. This area's population decreased five percent between 1980 and 1990. The median age of Columbia Falls residents increased from 28 in 1980 to 33 in 1990. The number of occupied houses in Columbia Falls in 1990 was 1,139. Between 1980 and 1990 the number of vacant houses increased by 18 .

\section{Income and Employment}

Per capita income in Columbia Falls was $\$ 6,337$ in 1990. Sixteen percent of all people in the community for whom poverty status was determined were 
below the poverty level. Employment in Columbia Falls in 1990 was 1,213, while unemployment was 120 , an unemployment rate of 9.0 percent. Seventy-seven percent of the employment was private industry and 15 percent was government employment. Employment was highest in durable goods manufacturing and retail trade with 308 and 282 employees respectively. However, since 1980, employment in manufacturing has declined while employment in retail trade has increased. Educational services was also a large employment sector, employing 137 employees.

\section{Potential Flood Damages}

The primary area of potential flood damages along the upper Flathead River downstream of Hungry Horse Dam occurs in the reach between Columbia Falls and Flathead Lake. Residential and commercial damages are concentrated in an area adjacent to the city of Kalispell, Montana, and agricultural damages are predominately upstream and downstream of this area.

Flood damage prevention measures within this damage reach include several miles of levees along both banks of the river, channel improvements and realignments, bank protection and erosion control devices. The South Fork of the Flathead River, a major tributary of the river upstream of Columbia Falls, is regulated by Hungry Horse Dam, a Federal multi-purpose project completed in 1951. The regulation of the South Fork by Hungry Horse Dam during large floods reduces the extent and duration of flooding in the lower valley.

\section{F.1.2.4 THE FLATHEAD INDIAN RESERVATION}

The Flathead Reservation is located in parts of Flathead, Lake, Missoula, and Sanders counties. It was chosen as a focus community because of Flathead Lake's recreation opportunities and shoreline flood damage potential.

The Flathead Reservation, established for the Confederated Salish and Kootenai Tribes, covers about one-fourth of the Flathead River basin area. The Pablo and Ninepipe Wildlife Refuges, as well as the National Bison Range, are located on the reserva- tion. The Flathead Agency Irrigation District is operated by the Bureau of Indian Affairs for both Indians and non-Indians on the reservation. The project utilizes water both from Flathead Lake and from tributaries to the Flathead River to irrigate approximately 175,000 acres of reservation lands.

\section{Population and Housing}

The population of the Flathead Reservation in 1990 was 21,259 ., including 5,130 Indians. Eighty-nine percent of the population lived in Lake County, 8 percent lived in Sanders County, 3 percent lived in Missoula County, and 0.1 percent lived in Flathead County. Eighty-five percent of the people on the Flathead Reservation lived in rural areas and fifteen percent lived in urban areas. The median age of Flathead Reservation residents increased from 21 in 1980 to 34 in 1990. The number of occupied houses on the reservation in 1990 was 7,874 . Homeowners lived in 70 percent of these houses and renters lived in 30 percent. Between 1980 and 1990 renters occupied 576 more houses and homeowners occupied 483 more houses. In 1990, 62 percent of the 2,525 vacant houses were for seasonal, recreational, or occasional use. Between 1980 and 1990 the number of vacant houses increased by 579 .

\section{Income and Employment}

Per capita income on the Flathead Reservation was $\$ 9,059$ in 1990 . Twenty-three percent of all people in the community for whom poverty status was determined were below the poverty level. Between 1980 and 1990 per capita income increased 190 percent. Employment on the reservation in $\mathbf{1 9 9 0}$ was 8,141 , while unemployment was 737 , an unemployment rate of 8.3 percent. Fifty-seven percent of the employment was private industry and 24 percent was government employment. Employment was highest in retail trade and agriculture, forestry, and fisheries with 1,350 and 1,140 employees respectively. Other large industry employers include educational services, manufacturing of durable goods, health services, and construction.

\section{Potential Flood Damages}

The primary areas of potential flooding in this damage reach include the lower Flathead River from 
Kerr Dam to the confluence with the Clark Fork River, and along the Clark Fork to Thompson Falls, Montana. Partial flood protection is provided by Hungry Horse and Kerr Dams and locally constructed levees at several locations. This reach, which extends over 100 miles, is primarily rural, with agricultural activities predominating. No information has been found regarding historic flooding in this damage reach, but the Corps of Engineers has repaired flood damaged levees several times over the years in this area.

\section{F.1.3 FOCUS COMMUNITIES LOCATED IN IDAHO}

\section{F.1.3.1 THE COMMUNITY OF BONNERS FERRY}

Bonners Ferry is located in Boundary County, along the Kootenai River. It was chosen as a focus community because of the potential flood damage along the Kootenai River downstream of Libby Dam.

Boundary County is Idaho's northern-most county, bordering Canada to the north, Washington to the west, and Montana to the east. It ranks twentyseventh among the counties by population and twenty-fourth by area. Nearly 61 percent of the county is federally owned. Forest and wood products companies provide the majority of employment. Total civilian employment grew 15.7 percent from 1983 through 1993.

\section{Population and Housing}

The population of Bonners Ferry in 1990 was 2,193. This rural area's population increased 15 percent between 1980 and 1990. The median age of Bonners Ferry residents was 35 in 1990. The number of occupied houses in Bonners Ferry in 1990 was 856. Homeowners lived in 66 percent of these houses, and renters lived in 34 percent. Between 1980 and 1990 renters occupied 78 more houses and homeowners occupied 88 more houses.

\section{Income and Employment}

Per capita income in Bonners Ferry was $\$ 9,954$ in 1990. Sixteen percent of all people in the communi- ty for whom poverty status was determined were below the poverty level. Employment in Bonners Ferry in 1990 was 868 , while unemployment was 58 , an unemployment rate of 6.3 percent. Fifty-nine percent of the employment was private industry, and 27 percent was government employment. Employment was highest in retail trade and durable goods manufacturing with 154 and 138 employees, respectively. Agriculture, forestry, and fisheries, and educational services were also large employment sectors, employing 118 and 111 employees respectively. The major employers in Bonners Ferry are the U.S. Forest Service, Boundary County School District, Louisiana Pacific Corp., W.I. Forest Products, Inc., Elk Mountain Farms, Kootenai River Inn, and Clifty View Nursery.

\section{Potential Flood Damages}

The area of potential flood damage along the Kootenai River downstream of Libby Dam occurs in the reach known as Kootenai Flats, extending from Bonners Ferry, Idaho, to Kootenay Lake in Canada. Flood protection is provided in the U.S. portion of the flood plain by approximately 95 miles of levees that protect about 35,000 acres of agricultural lands used to grow wheat, barley, and oats. About 190 acres within the town of Bonners Ferry are in the Kootenai River flood plain. This area consists of 106 homes, 66 commercial establishments and 12 public facilities. Prior to completion of Libby Dam, Bonners Ferry merchants were forced to move inventory and supplies four to six times between 1948 and 1972. Since completion of Libby Dam no serious flooding has occurred on the Kootenai River flood plain.

\section{F.1.3.2 THE KOOTENAI INDIAN RESERVATION}

The Kootenai Reservation is located in Boundary County, along the Kootenai River. It was chosen as a focus community because of the potential flood damage along the Kootenai River downstream of Libby Dam.

Boundary County is Idaho's northern-most county, bordering Canada to the north, Washington to the west, and Montana to the east. It ranks twentyseventh among the counties by population and 
twenty-fourth by area. Nearly 61 percent of the county is federally owned. Forest and wood products companies provide the majority of employment. Total civilian employment grew 15.7 percent from 1983 through 1993.

\section{Population and Housing}

The population of the Kootenai Reservation in 1990 was 65,61 of whom are Indians. The median age of Kootenai Reservation residents was 25 in 1990. The number of occupied houses on the Kootenai Reservation in $\mathbf{1 9 9 0}$ was 18 . Homeowners lived in $\mathbf{1 6}$ of the houses and renters lived in two houses.

\section{Income and Employment}

Per capita income on the Kootenai Reservation was $\$ 4,972$ in 1990 . Forty percent of all people in the community for whom poverty status was determined were below the poverty level. Employment on the Kootenai Reservation in 1990 was 36, while unemployment was 3, an unemployment rate of 7.7 percent. Seventy-two percent of the employment was government and 28 percent was private industry. Public administration employed 13 persons, retail trade employed 9 persons, and agriculture, forestry, and fisheries employed 5 persons. The Kootenai Tribe owns and operates the Kootenai Tribal Mission and the Kootenai Experimental Sturgeon Hatchery west of Bonners Ferry.

\section{Potential Flood Damages}

The area of potential flood damage along the Kootenai River downstream of Libby Dam occurs in the reach known as Kootenai Flats, extending from Bonners Ferry, Idaho, to Kootenay Lake in Canada. Flood protection is provided in the U.S. portion of the flood plain by approximately 95 miles of levees that protect about 35,000 acres of agricultural lands used to grow wheat, barley, and oats. The twelve acre Kootenai Reservation is located in the Kootenai River flood plain. Prior to completion of Libby Dam, flooding occurred often along the river. Since completion of the dam, no serious flooding has occurred in the Kootenai River flood plain.

\section{F.1.3.3 THE COMMUNITY OF OROFINO}

Orofino is located in Clearwater County on the $\mathrm{Nez}$ Perce Indian Reservation, approximately 45 river miles above Lewiston on the Clearwater River. It was chosen as a focus community because of the anadromous fish runs in the Clearwater River, potential flood damage along the Clearwater River downstream of Dworshak Dam, and recreation along the Clearwater River and on Dworshak Reservoir.

Clearwater County borders the state of Montana in northern Idaho. It is the state's twenty-sixth most populous county and tenth largest in area. Nearly 27 square miles of the county is water, and about 54 percent of the land area is federally owned. Historically, forest and wood products employment has driven the economy. Total civilian employment in the county decreased 11.5 percent from 1983 through 1993.

Clearwater County is home to a variety of recreation activities. Dworshak Reservoir and the Clearwater River provide excellent fishing opportunities, and the forested lands of the Clearwater drainage are home to large populations of deer and elk. Winter brings ample snow for cross country skiing and snowmobiling on miles of trails. Dworshak Reservoir is a popular boating destination and campgrounds abound on the North Fork of the Clearwater as well as on other streams in the area.

\section{Population and Housing}

The population of Orofino in 1990 was 2,868 . This area's population declined 23 percent between 1980 and 1990. The median age of Orofino residents was 39 in 1990. The number of houses in Orofino in 1990 was 1,231. Between 1980 and 1990 the number of available houses declined by 204 .

\section{Income and Employment}

Per capita income in Orofino was $\$ 12,251$ in 1990. Eleven percent of all people in the community for whom poverty status was determined were below the poverty level. Employment in Orofino in 1990 was 1,162 , while unemployment was 156 , an unemployment rate of 11.8 percent. Fifty-one percent of the employment was private industry and 40 percent was government employment. Employment was highest 
in retail trade and durable goods manufacturing with 178 and 150 employees respectively. Public administration and agriculture, forestry, and fisheries were also large employment sectors, employing 133 and 124 employees respectively. The major employers in Orofino are the Clearwater National Forest, Konkolville Lumber Co., the School District, Potlatch Corporation, Dept. of Health and Welfare, and Clearwater Valley Hospital.

\section{Recreation}

Dworshak Reservoir has a number of day use and overnight recreational facilities. The day use facilities are within five miles of Orofino and the overnight facilities are between 11 and 24 miles of Orofino. The major recreational activities include boating, fishing, swimming, sightseeing, camping, and picnicking. Recreation on Dworshak is primarily a summer activity. The Clearwater River and its upper tributaries are nationally known for yearround trout, salmon and steelhead fishing. Highway 12 follows the mainstem Clearwater River its entire length, from the headwaters on the Montana-Idaho border downstream to Lewiston. Land ownership along the river is mixed and includes ownership by the Nez Perce Indian Tribe, the federal government, and private entities. Log transportation activities on the reservoir and river have ceased in recent years, although lumber, $\log$, and wood chip movements still use Highway 12 extensively.

\section{F.1.3.4 THE NEZ PERCE INDIAN RESERVATION}

The Nez Perce Reservation is located in north central Idaho in parts of Clearwater, Idaho, Lewis, and Nez Perce Counties. The tribal government headquarters are in Lapwai, Idaho, 15 miles from Lewiston. The Nez Perce Reservation was chosen as a focus community because of the anadromous fish runs, potential flood damage, and recreation opportunities along the Clearwater River downstream of Dworshak Dam and Reservoir.

The Nez Perce Indian Reservation geographically is dominated by the Camas Prairie, which is deeply dissected by forested canyons that form the tributaries of the Clearwater, Salmon and Snake Rivers, which bound the prairie on the north, south and west respectively. Much of the prairie supports annual crops of wheat, canola and barley; these crops are interspersed with forests of Douglas Fir and Ponderosa Pine. This forms a rich mosaic of habitat which is home to diverse and abundant populations of wildlife.

The economy of the reservation is very closely tied to the economy of north central Idaho which is primarily based on lumber and paper production, agriculture, and/or agricultural products processing. Many of the reservation's Indian population work either for the government or the Tribe on reservation enterprises.

\section{Population and Housing}

The population of the Nez Perce Reservation in 1990 was $16,160,1,863$ of those being Indians. Thirty-three percent of the population lived in Clearwater County, 22 percent lived in Idaho County, 22 percent lived in Lewis County, and 23 percent lived in Nez Perce County. Between 1980 and 1990 the population decreased nine percent. Eighty-two percent of the population on the reservation live in rural areas and eighteen percent live in urban areas. The median age of reservation residents increased from 22 in 1980 to 37 in 1990 . The number of occupied houses on the reservation in 1990 was 6,122 . Homeowners lived in 75 percent of these houses and renters lived in 25 percent. In 1990,107 of the 798 vacant houses were for seasonal, recreational, or occasional use. Between 1980 and 1990 the number of vacant houses decreased by 59.

\section{Income and Employment}

Per capita income on the Nez Perce Reservation was $\$ 10,268$ in 1990 . Between 1980 and 1990 per capita income increased 201 percent. Sixteen percent of all people in the community for whom poverty status was determined were below the poverty level. Employment on the Nez Perce Reservation in 1990 was 5,948 , while unemployment was 849 , an unemployment rate of 12.5 percent. Fifty-five percent of the employment was private industry and 28 percent was government employment. Agriculture, forestry, and fisheries had the highest employment with 1,036 
employees, followed closely by manufacturing of durable goods with 992 employees. Retail trade was also an important employment sector with 783 employees.

\section{Natural Resources}

The Nez Perce Tribe has both a Forest Resource Management Program and a Fish and Wildlife Program that coordinate fish and wildlife habitat management and forestry resource management activities for protection of both quality and quantity of the natural resources of the reservation.

Two fish hatcheries are located on the banks of the Clearwater River just below Dworshak Dam. These two hatcheries are operated by the U.S. Fish and Wildlife Service and provide fish for stocking area reservoirs and streams. The Tribe has been involved in the planning and construction of the fish hatcheries located below Dworshak Dam, and is planning additional fisheries propagation facilities along both the Clearwater River and its tributaries. The Tribe is currently working with Trihey and Associates of Walnut Creek, CA in the planning of new fish facilities on the reservation. No other agencies have been involved in this development. The Nez Perce Tribe has completed a Master Hatchery Plan as part of it's Fish and Wildlife Program. The plan has been approved by both the Bonneville Power Administration and the Northwest Power Planning Council. An EIS is being completed and BPA will likely provide funding for construction of the proposed facilities.

The Nez Perce Tribe's Wildlife Program involves every phase of wildlife management on the reservation and is involved in several co-management projects outside the reservation boundaries. The Wildlife Program staff are participating in the Environmental Assessment process regarding timber harvests, stream alteration permits, and assessments of the impacts of hydroelectric power production at Dworshak Dam.

The Nez Perce Forest Products Enterprise (NPFPE) aggressively merchandises the timber resources of the tribe and is responsible for reforestation and other aspects of forest management. The tribe manages nearly 50,000 acres of forest lands, both on and off the reservation, and operates a livestock grazing and leasing program on these same lands.

\section{Cultural Interpretation}

At several sites along the Clearwater River corridor, interpretation of the Nez Perce history and the historical presence of the tribe along the river is presented by the National Park Service as part of that agency's Nez Perce National Historic Site. [SOR Final EIS, Appendix J Recreation].

\section{F.1.3.5 THE COMMUNITY OF LEWISTON}

Lewiston is located in Nez Perce County, at the confluence of the Clearwater and Snake Rivers. It was chosen as a focus community for the following reasons: anadromous fish runs in the Clearwater and Snake Rivers, flood damage along the Clearwater River downstream of Dworshak Dam, navigation at the Port of Lewiston, recreation along the Clearwater and Snake Rivers, and the potential construction impacts related to SOS project implementation.

Nez Perce County is on the Washington-Idaho border at the confluence of the Snake and Clearwater Rivers. It is the eighth most populous county in the state and the thirty-third largest in area. Only four percent of the county is federal land, the second lowest of all the counties. While wood products form the foundation of the local economy, trade, and transportation are also important due to the influence of the Port of Lewiston, Idaho's only seaport. Total civilian employment grew 38.4 percent from 1983 through 1993.

The Snake and Clearwater Rivers in Nez Perce County provide extensive river recreation opportunities. This area is the major gateway to the Hells Canyon National Recreation Area, location of the deepest gorge in North America, located approximately 40 miles upstream from Lewiston on the Snake River.

\section{Population and Housing}

The population of Lewiston in 1990 was 28,082 . This urban area's population remained unchanged between 1980 and 1990. The median age of Lewiston residents increased from 31 in 1980 to 35 in 
1990. The number of occupied houses in Lewiston in 1990 was 11,515 . Homeowners lived in 65 percent of these houses and renters lived in 35 percent. In 1990,28 of the 539 vacant houses were for seasonal, recreational, or occasional use. Between 1980 and 1990 the number of vacant houses decreased by 168 . The homeowner and rental vacancy rates also declined during this time.

\section{Income and Employment}

Per capita income in Lewiston was $\$ 12,828$ in 1990. Between 1980 and 1990 per capita income increased 81.6 percent. Eleven percent of all people in the community for whom poverty status was determined were below the poverty level. Employment in Lewiston in 1990 was 13,120 , while unemployment was 901, an unemployment rate of 6.4 percent. The number of people unemployed decreased 18 percent between 1980 and 1990. Seventy-seven percent of the employment was private industry and 14 percent was government employment. Employment was highest in retail trade with 2,607 employees.

Manufacturing of durable and non-durable goods were the next two largest industries, employing 1,550 and 1,221 employees respectively. In addition, the health services and educational services industries employed 1,185 and 1,100 employees respectively. Between 1980 and 1990, employment more than tripled in mining and other professional and related services while employment more than doubled in agriculture, forestry, and fisheries. During the same time period, public administration and construction employment decreased 31 and 14 percent respectively. The major community employers in Lewiston are Potlatch Corporation, Omark Industries, St. Joseph Regional Hospital, Agricultural Insurance Administration, and Lewis-Clark State College.

\section{Flood Protection}

The city of Lewiston, at the confluence of the Clearwater and Snake Rivers, is protected by levees up to about river mile five on the Clearwater and a mile or two up the Snake. These levees were built as part of the Lower Granite project, constructed to allow slackwater navigation to Lewiston. The levees provide Standard Project Flood protection with the existing regulation at Dworshak. The area protected by the levees is highly developed industrial, commercial and residential property. The lower Clearwater River is generally well served by railroads, highways, and secondary roads from Lewiston upstream to Orofino. Five roadway bridges and two railroad bridges cross the lower Clearwater.

\section{Navigation}

The Port of Lewiston on the Snake River is a modern facility able to handle containerized (20- and 40-foot containers) shipments, logs, grain, pulses, wood chips, and general cargo. It is the Northwest's most inland port, providing economical bulk-cargo access to the west coast. Logs that once moved on the river are now trucked to the ports at Lewiston, Clarkston, and Wilma for loading onto barges or for chipping for shipment to paper mills located downstream along the Columbia River. Paper products in containers and wood pulp in break-bulk shipments from Potlatch Corporation's mill at Lewiston are moved by barge downriver on a regular basis from the Port of Lewiston. Barge shipments of sawdust and wood chips occur periodically from ports downstream on the Columbia and Snake Rivers to Potlatch Corporation's facilities.

\section{Recreation}

Hells Gate State Park is located four miles south of Lewiston on the Snake River. Hells Canyon National Recreation Area was established in 1976 and straddles a 67 mile long stretch of the Snake River, beginning 40 miles south of Lewiston. The Corps of Engineers manages and leases numerous recreation sites and facilities along the Lower Snake River from the Tri-Cities to the Lewiston-Clarkston area. Recreation activities at these sites are primarily day-use oriented and include boating, fishing, picnicking, and swimming. Jet boat excursions originate at Lewiston and comprise a significant portion of the local recreation industry. Fishing on both the Clearwater and Snake Rivers is also an important recreational activity as is fishing, boating, and other activities on Dworshak Reservoir, upstream from Lewiston. Several boat manufacturing and sales firms are located in the Lewiston-Clarkston area. 


\section{F.1.4 FOCUS COMMUNITIES LOCATED IN WASHINGTON}

\section{F.1.4.1 THE COMMUNITY OF CLARKSTON}

Clarkston is located in Asotin County, at the confluence of the Snake and Clearwater Rivers. It is joined by two bridges across the Snake River with the community of Lewiston, Idaho. It was chosen as a focus community because of the anadromous fish runs, navigation, construction and recreation opportunities along the Snake River. The community was also selected for flood protection concerns.

Asotin County is located in the far southeast corner of Washington and borders Oregon on the south and Idaho on the east. The county's economy is primarily agricultural, based on food and livestock raising and processing, fruit growing, and wheat and barley production. The timber and pulp and paper industry of neighboring Lewiston is also an influence on the local economy.

\section{Population and Housing}

The population of Clarkston in 1990 was 6,753. This urban area's population decreased two percent between 1980 and 1990. The median age of Clarkston residents increased from 33 in 1980 and 35 in 1990. The number of occupied houses in Clarkston in 1990 was 2,854 . Homeowners lived in 53 percent of these houses and renters lived in 47 percent. In 1990,15 of the 189 vacant houses were for seasonal, recreational, or occasional use. Between 1980 and 1990 the number of vacant houses increased by 11 .

\section{Income and Employment}

Per capita income in Clarkston was \$8,896 in 1990. Between 1980 and 1990 per capita income increased 55 percent. Twenty-six percent of all people in the community for whom poverty status was determined were below the poverty level. Employment in Clarkston in 1990 was 2,347, while unemployment was 298 , an unemployment rate of 11.3 percent. Seventy-eight percent of the employment was private industry and 15 percent was government employment. Employment was highest in retail trade with 602 employees. Manufacturing of durable goods and educational services were also large employment sectors with 283 and 250 employees, respectively. However, since 1980, employment in educational services increased while employment in manufacturing decreased.

\section{Navigation and Recreation}

A series of dams on the Snake River has made Clarkston a shipping center. It is at the head of navigation for barge transportation on the Columbia-Snake River system. Both the Port of Clarkston and the Port of Wilma are located on the Snake River, downstream from its confluence with the Clearwater River. The ports ship logs, wood chips, grain, and general cargo to ports on the lower Columbia and Snake Rivers. Petroleum products, fertilizer, and other cargo are shipped upstream to Clarkston and off-loaded for use in the immediate area and for movement inland.

The town's once barren landscape now offers a variety of recreational opportunities, including boating, camping, fishing, golfing, and swimming. Like Lewiston, Clarkston is gateway to the Hells Canyon National Recreation Area, located approximately 40 miles upstream on the Snake River. Jet boat excursions and boat-building are important industries in the Lewiston-Clarkston communities. Fishing and boating along the Snake and Clearwater Rivers is an important activity year-round.

\section{F.1.4.2 THE COMMUNITIES OF GRAND COULEE AND COULEE DAM}

The communities of Grand Coulee and Coulee Dam are located in Grant and Okanogan counties, along Roosevelt Lake and the Columbia River. They were chosen as a focus community because of the irrigation projects and power generation at Grand Coulee Dam, and recreation opportunities on Roosevelt Lake, the reservoir behind Grand Coulee.

Grant County is located in the east central part of the state and is bounded on the west and south by the Columbia River. The Columbia Basin Irrigation Project of the 1950s made a significant impact on the county when the completion of Grand Coulee Dam opened lands for farming and furnished electric power for industry and irrigation. The county is a 
major agricultural producer and food processing center. Okanogan County is located in the north central part of the state east of the Cascades and bounded on the north by Canada. Mining is an important part of the county's economy along with timber products and agriculture.

\section{F.1.4.3 THE COMMUNITY OF GRAND COULEE}

\section{Population and Housing}

The population of Grand Coulee in 1990 was 984 . This rural area's population decreased 17 percent between 1980 and 1990. The median age of Grand Coulee residents increased from 39 in 1980 to 43 in 1990. The number of occupied houses in Grand Coulee in 1990 was 451 . Homeowners lived in 59 percent of these houses and renters lived in 41 percent. Between 1980 and 1990 homeowners occupied 81 fewer houses and renters occupied five fewer houses.

\section{Income and Employment}

Per capita income in Grand Coulee was $\$ 10,146$ in 1990. Between 1980 and 1990 per capita income increased 46 percent. Twenty-two percent of all people in the community for whom poverty status was determined were below the poverty level. Employment in Grand Coulee in 1990 was 356, while unemployment was 40 , an unemployment rate of 10.0 percent. Employment was highest in retail trade and public administration with 70 and 54 employees respectively. Fifty-four percent of the employment was private industry and 40 percent was government employment.

\section{Grand Coulee Dam}

One of the largest concrete structures ever built, Grand Coulee Dam is also one of the world's largest producers of hydroelectric energy. This powerhouse provides electricity for many cities and towns in several states and supplies water to irrigate more than 500,000 acres of cropland. In addition to Grand Coulee, operated by the federal government, Grant County Public Utility District operates hydroelectric facilities at Wanapum and Priest Rapids
Dams, downstream from Grand Coulee on the Columbia River.

\section{F.1.4.4 THE COMMUNITY OF COULEE DAM}

\section{Population and Housing}

The population of Coulee Dam in 1990 was 1,087 . This rural area's population decreased 23 percent between 1980 and 1990. The median age of Coulee Dam residents increased from 32 in 1980 to 40 in 1990. The number of occupied houses in Coulee Dam in 1990 was 468 . Homeowners lived in 69 percent of these houses and renters lived in 31 percent.

\section{Income and Employment}

Per capita income in Coulee Dam was $\$ 15,662$ in 1990. Between 1980 and 1990 per capita income increased 95.6 percent. Nine percent of all people in the community for whom poverty status was determined were below the poverty level. Employment in Coulee Dam in 1990 was 439, while unemployment was 30, an unemployment rate of 6.4 percent. Sixty-two percent of the employment was government employment and 33 percent was private industry employment. Employment was highest in public administration with 93 employees. Retail trade and educational services are also large employment sectors with 80 and 71 employees respectively.

\section{F.1.4.5 THE COLVILLE INDIAN RESERVATION}

The Colville Reservation is located in parts of Ferry County and Okanogan County. The Columbia River and Roosevelt Lake border the reservation on the east and south sides. It was chosen as a focus community because of the recreation opportunities on the Columbia River and Roosevelt Lake, the reservoir behind Grand Coulee Dam.

Ferry County is located in the eastern part of the state and is bounded on the north by Canada. In 1872 the Colville Indian Reservation was established encompassing over one-half of the county. Lumber, mining, and agriculture are the county's major economic activities. Okanogan County is located in the north central part of the state west of the Cascades and bounded on the north by Canada. Mining 
is an important part of the county's economy along with timber products and agriculture.

\section{Population and Housing}

The population of the Colville Reservation in 1990 was 6,957, 3,788 of whom were Indians. In 1990, 1,552 people lived in Ferry County and 5,405 lived in Okanogan County. The median age of Colville Reservation residents was 30 in 1990 . The number of occupied houses on the reservation in 1990 was $2,398,64$ percent occupied by homeowners, and 36 percent occupied by renters. Vacant homes totaled 598 in 1990.

\section{Income and Employment}

Per capita income on the Colville Reservation was $\$ 7,561$ in 1990. Employment on the Colville Reservation in 1990 was 1,470 . Fifty percent of the employment was government and 46 percent was private industry. Employment was highest in public administration with 225 employees. Durable goods manufacturing and agriculture, forestry, and fisheries were also large employment sectors with 157 and 144 employees respectively. An equally important industry was the 104 employees in retail trade.

\section{Recreation}

Those portions of Roosevelt Lake and shoreline within the Colville Indian Reservation are managed by the Colville Confederated Tribes. Fishing, boating, and other forms of recreation are popular activities for local residents as well as tourists.

\section{F.1.4.6 THE SPOKANE INDIAN RESERVATION}

The Spokane Reservation is located in the southern portion of Stevens County, along the Spokane and Columbia Rivers. It was chosen as a focus community because of the recreation opportunities along those rivers.

Stevens County is located in the northeastern part of the state and is bounded on the north by Canada, on the west by the Columbia River, and on the south by the Spokane River. The Spokane Indian Reservation occupies the southern portion of the county.
The county's economy is based on mining, agriculture, food processing, and tourism.

\section{Population and Housing}

The population of the Spokane Reservation in 1990 was $1,502,1,229$ of whom were Indians. This rural area's population lives in Stevens County. The median age of Spokane Reservation residents increased from 22 in 1980 to 26 in 1990 . The number of occupied houses on the reservation in 1990 was 464. Homeowners lived in 64 percent of these houses and renters lived in 36 percent. Between 1980 and 1990 the number of houses increased by 38.

\section{Income and Employment}

Per capita income on the Spokane Reservation was $\$ 6,022$ in 1990 . Thirty-seven percent of all people in the community for whom poverty status was determined were below the poverty level. Employment on the Spokane Reservation in 1990 was 356. while unemployment was 133, an unemployment rate of 27.2 percent. Forty-seven percent of the employment was private industry and 48 percent was government employment. Public administration and educational services were the largest employment sectors with 76 and 47 employees respectively.

\section{Recreation}

Those portions of Roosevelt Lake and shoreline within the Spokane Indian Reservation are managed by the Spokane Tribe of Indians. Fishing, boating, and other forms of recreation are popular activities for local residents as well as tourists.

\section{F.1.4.7 THE COMMUNITIES OF THE TRI-CITIES}

The Tri-Cities include the cities of Richland, Kennewick, and Pasco. Richland and Kennewick are located in Benton County and Pasco is located in Franklin County at the confluence of the Snake and Columbia Rivers. The Tri-Cities was chosen as a focus community because of the anadromous fish runs, irrigation projects, water transportation, and recreation opportunities along the Columbia and Snake Rivers. 
Benton County is located in the southeastern part of the state and is bordered on the south and east by the Columbia River. The irrigation projects of the 1950 s created a rich agricultural economy that contributes to today's diversified economy based on agriculture and food processing, as well as wood products and government installations. Franklin County is situated in the southeast part of the state and is bounded by the Columbia River on the west and the Snake River on the east. Today Franklin County bases its economy on agriculture with wheat, barley, and beans its principal crops.

\section{F.1.4.7.1 THE COMMUNITY OF RICHLAND}

\section{Population and Housing}

The population of Richland in 1990 was 32,315. This area's urban population declined four percent between 1980 and 1990, although the surrounding urban and suburban areas experienced substantial growth. The median age of Richland residents increased from 31 in 1980 and 35 in 1990. The number of occupied houses in Richland in 1990 was 13,162. Homeowners lived in 62 percent of these houses and renters lived in 38 percent. In 1990, 41 of the 710 vacant houses were for seasonal, recreational, or occasional use. Between 1980 and 1990 the number of vacant houses for seasonal, recreational, or occasional use increased 925 percent.

\section{Income and Employment}

Per capita income in Richland was $\$ 17,085$ in 1990 due in part to the professional and technical jobs at the Hanford Nuclear Reservation nearby. Between 1980 and 1990 per capita income increased 74 percent. Eight percent of all people in the community for whom poverty status was determined were below the poverty level. Employment in Richland in 1990 was 16,010 , while unemployment was 853 , an unemployment rate of 5.0 percent. The number of people unemployed increased 15 percent between 1980 and 1990. Seventy-five percent of the employment was private industry and 19 percent was government employment. Employment was highest in other professional and related services with 4,174 employees. This industry's employment increased by
632 percent between 1980 and 1990 . Retail trade had the next largest employment with 2,272 employees. Communications and other public utilities, manufacturing of non-durable goods, and health services were also large employment sectors with $1,734,1,209$, and 1,048 employees respectively. Between 1980 and 1990 construction employment declined 66 percent and employment in entertainment and recreation services increased 113 percent.

\section{Irrigation}

Irrigation from the Grand Coulee Dam helped develop the area's lush vineyards, fields, and orchards. The Columbia Basin Irrigation Project began serving water for irrigation in 1951, and by 1958 over 350,000 acres were irrigated. Irrigation facilities now serve 543,000 acre of land located primarily north of the Tri-Cities area.

\section{Technology Industries}

Richland is a major center of technological industries, among them Boeing Computer Services, Exxon, the Hanford Works of the Department of Energy, Rockwell, United Nuclear Industries, and Westinghouse. Efforts to decommission the nuclear reactors at Hanford and clean up the reservation have increased activity and employment in the Tri-Cities during the past ten years.

\section{F.1.4.7.2 THE COMMUNITY OF KENNEWICK}

\section{Population and Housing}

The population of Kennewick in 1990 was 42,155. This urban area's population increased 23 percent between 1980 and 1990. The median age of Kennewick residents decreased from 31 in 1980 to 30 in 1990. The number of occupied houses in Kennewick in 1990 was 16,074 . Homeowners lived in 53 percent of these houses and renters lived in 47 percent. Between 1980 and 1990 the number of occupied houses increased by 3,189. In 1990, 42 of the 1,135 vacant houses were for seasonal, recreational, or occasional use. Between 1980 and 1990 houses used for seasonal, recreational, or occasional use increased 600 percent. 
Income and Employment

Per capita income in Kennewick was $\$ 12,767$ in 1990. Between 1980 and 1990 per capita income increased 50 percent. Fourteen percent of all people in the community for whom poverty status was determined were below the poverty level. Employment in Kennewick in 1990 was 19,393, while unemployment was 1,462, an unemployment rate of 7.0 percent. The number of people unemployed increased 20 percent between 1980 and 1990 . Seventy-six percent of the employment was private industry and 19 percent was government employment. Employment was highest in retail trade with 4,089 employees. Other professional and related services had the next largest employment with 2,475 employees. Since 1980 this industry's employment increased 476 percent. Other large employment industries include educational services with 1,691 employees, manufacturing of non-durable goods with 1,415 employees, communications and other public utilities with 1,301 employees, and health services with 1,231 employees. Between 1980 and 1990 construction employment declined 70 percent. During the same time period, employment in the entertainment and recreation services and agriculture, forestry, and fisheries industries increased 108 and 97 percent respectively.

\section{Irrigation}

Kennewick was surrounded by a bunchgrass wasteland until the late $1800 \mathrm{~s}$, when the first of a series of irrigation projects began to convert the sagebrush into farmland. With the irrigation water and short winters, the fertile land became a major agricultural area in the state. The development of the Columbia Basin Project and other irrigation projects in the Tri-Cities area have resulted in Benton County becoming a major producer of hops, apples, cherries, grapes, mint, sweet corn, other vegetables, and field crops.

\section{Recreation}

Near the confluence of the Columbia, Snake, and Yakima Rivers, Kennewick is the departure point for various scenic and recreational cruises on the Columbia River. Fishing and boating are major recre- ational activities on all three rivers and the $\mathrm{Tr} i-\mathrm{Ci}$ ties host a national unlimited hydroplane race each summer. Kennewick is home to a professional hockey team and boasts one of the newest hockey arenas in the Northwest.

\section{F.1.4.7.3 THE COMMUNITY OF PASCO}

\section{Population and Housing}

The population of Pasco in 1990 was 20,337 . Between 1980 and 1990 population increased 13 percent. Ninety-eight percent of Pasco residents live in urban areas and two percent live in rural areas. The median age of Pasco residents was 27 in both 1980 and 1990. The number of occupied houses in Pasco in 1990 was 6,842. Homeowners lived in 47 percent of these houses and renters lived in 53 percent. In 1990,16 of the 856 vacant houses were for seasonal, recreational, or occasional use.

\section{Income and Employment}

Per capita income in Pasco was \$8,016 in 1990. Between 1980 and 1990 per capita income increased 20 percent. Thirty-three percent of all people in the community for whom poverty status was determined were below the poverty level. Employment in Pasco in 1990 was 7,726 , while unemployment was 1,008 , an unemployment rate of 11.5 percent. Eighty-two percent of the employment was private industry and 14 percent was government employment. The number of people unemployed increased 18 percent between 1980 and 1990. Employment was highest in retail trade with 1,387 employees. Agriculture, forestry, and fisheries and non-durable good manufacturing were also large employment sectors with 1,286 and 1,188 employees respectively. Since 1980 employment in agriculture, forestry, and fisheries has increased 170 percent. In addition, employment in other professional and related services rapidly increased adding 510 employees while employment in construction rapidly decreased losing 559 employees.

\section{Transportation/Commercial Development}

Its location at the confluence of the Yakima, Snake, and Columbia Rivers has made Pasco a transportation center since its founding in the late $1800 \mathrm{~s}$. With 
its sister cities, Kennewick and Richland, Pasco dominates commercial development at the southern entrance to the Columbia Basin Irrigation Project. The Port of Pasco is located $\mathbf{3 3 0}$ miles up the Columbia River and is both the furthest point of navigation on the Columbia River as well as the gateway to navigation on the Snake River. The port moves grain, petroleum, chemicals, fertilizer, containers, and general cargo through its marine facilities. The port also operates the Tri-Cities airport, served by three commercial airlines.

\section{F.1.5 FOCUS COMMUNITIES LOCATED IN OREGON}

\section{F.1.5.1 THE COMMYUNITIES OF UMATILLA/MORROW}

The community of Umatilla/Morrow includes the smaller communities of Umatilla, Irrigon, and Boardman. Umatilla is located in Umatilla County and Irrigon and Boardman are located in Morrow County. The focus community was chosen because of the irrigation, barge transportation, and recreation opportunities along the Columbia River.

Morrow County was created from Umatilla County in 1885 and is located in north-central Oregon east of the Cascades. Morrow County is a rich agricultural land that can be roughly divided into four occupational zones: large irrigated farms in the north; vast fields of dryland wheat changing to cattle and sheep ranches as you move through the center of the county; and forested land and timber production in the south. With the advent of center pivot irrigation technology, Morrow County became one of Oregon's fastest growing areas in terms of population, personal income, and agricultural and industrial development. The Port of Morrow serves as a gateway to Pacific Northwest and Pacific Rim markets, and this, together with irrigation growth, has also been the key to economic diversification and growth in Umatilla County.

The principal industries in Umatilla and Morrow Counties are: agriculture, food processing, lumber, utilities, livestock, tourism, manufacturing, and recreation.

\section{F.1.5.1.1 THE COMMUNITY OF UMATILLA}

\section{Population and Housing}

The population of Umatilla in 1990 was 3,046 . This urban area's population decreased five percent between 1980 and 1990 . The median age of Umatilla residents increased from 24 in 1980 to 28 in 1990. The number of occupied houses in Umatilla in 1990 was 1,063 . Homeowners lived in 48 percent of these houses and renters lived in 52 percent. Between 1980 and 1990 homeowners occupied 108 fewer houses and renters occupied 136 more houses. In 1990 , ten of the 167 vacant houses were for seasonal, recreational, or occasional use.

\section{Income and Employment}

Per capita income in Umatilla was $\$ 8,481$ in 1990. Between 1980 and 1990 per capita income increased 40.8 percent. Twenty-one percent of all people in the community for whom poverty status was determined were below the poverty level. Employment in Umatilla in 1990 was 1,232 , while unemployment was 173 , an unemployment rate of 12.3 percent. Seventy percent of the employment was in private industry and 21 percent was government employment. The number of people unemployed increased 82 percent between 1980 and 1990 . Employment was highest in retail trade with 266 employees. Educational services and manufacturing of non-durable goods were also large employment sectors with 131 and 128 employees, respectively. Since 1980 employment in educational services has increased while employment in manufacturing of non-durable goods has decreased. Two additional large employment sectors are agriculture, forestry, fisheries; and wholesale trade with 108 and 101 employees, respectively. Between 1980 and 1990 employment in wholesale trade increased by 83 employees. Construction which was the third largest employment sector in 1980, lost 101 employees through 1990.

\section{Port of Umatilla}

The Port of Umatilla handles non-refrigerated and refrigerated containers, wood chips, logs, and general cargo at its single barge dock. Both Cargill, Inc., Morrow County Grain Growers, and Tidewater Barge Lines operate loading facilities at the Port. 
Agriculture

Located above the community of Umatilla is McNary Dam, the final navigable lock on the Columbia River. Within the pool of McNary Dam, along the shore of the Columbia River, are located large numbers of irrigation pumps that deliver water from the river to lands located several miles away in the Irrigon, Hermiston, and Boardman areas.

Center pivot and other types of irrigation are used to produce potatoes, corn, dry peas and alfalfa hay as well as melons, fruit trees, green peas and other vegetables.

\section{F.1.5.1.2 THE COMMUNITY OF IRRIGON}

\section{Population and Housing}

The population of Irrigon in 1990 was 737 . This area's rural population increased five percent between 1980 and 1990. The median age of Irrigon residents increased from 28 in 1980 to 34 in 1990. The number of occupied housed in Irrigon in 1990 was 276. Homeowners lived in 71 percent of these houses and renters lived in 29 percent. Between 1980 and 1990 there were 15 fewer vacant houses and 30 more occupied houses.

\section{Income and Employment}

Per capita income in Irrigon was \$8,632 in 1990. Between 1980 and 1990 per capita income increased 43.5 percent. Seventeen percent of all people in the community for whom poverty status was determined were below the poverty level. Employment in Irrigon in 1990 was 238 , while unemployment was 20 , an unemployment rate of 7.8 percent. Sixty-seven percent of the employment was private industry and 27 percent was government employment. Employment was highest in retail trade with 46 employees. Educational services and non-durable goods manufacturing were also large employment sectors with 31 employees each. In addition, transportation and agriculture, forestry, and fisheries had 26 and 24 employees respectively.

\section{F.1.5.1.3 THE COMMUNITY OF BOARDMAN}

\section{Population and Housing}

The population of Boardman in 1990 was 1,387. This area's rural population increased 10 percent between 1980 and 1990. The median age of Boardman residents increased from 26 in 1980 to 28 in 1990. The number of occupied houses in Boardman in 1990 was 475 . Homeowners lived in 57 percent of these houses and renters lived in 43 percent.

\section{Income and Employment}

Per capita income in Boardman was $\$ 8,842$ in 1990. Twenty-two percent of all people in the community for whom poverty status was determined were below the poverty level. Employment in Boardman in 1990 was 649 , while unemployment was 73 , an unemployment rate of 10.1 percent. Seventy-five percent of the employment was private industry and 20 percent was government employment. The number of people unemployed increased seven percent between 1980 and 1990. Employment was highest in manufacturing of non-durable goods with 163 employees. Agriculture, forestry and fisheries was the next largest industry with 94 employees. In addition, retail trade and educational services each employ 65 persons.

\section{The Port of Morrow}

The Port of Morrow, located at Boardman, has several loading facilities and handles containers, grain, wood chips, and logs. Docks are operated by Longview Fibre Co., Tidewater Terminal Co., Cargill, Inc., and Morrow County Grain Growers. The Port leases facilities to a number of food processing firms, a large gas-fired co-generation electric power plant owned by PGE, and other tenants.

\section{F.1.5.2 THE CITY OF PORTLAND}

Portland, the "City of Roses," is located in Multnomah County and straddles the Willamette River. It was chosen as a focus community because of its deep water harbor, the Port of Portland, located on both the Willamette and Columbia Rivers.

Multnomah County was created from parts of Washington and Clackamas counties by the Territorial 
Legislature five years before the state came into existence. The county is both the smallest in size and largest in population in Oregon. Over 50 percent of its people live in Portland, a busy metropolis dominated by rivers and green spaces. The remaining area includes picturesque rural land, from pastoral farms on Sauvie Island to the rugged Columbia River Gorge and the western slopes of Mt. Hood.

\section{Population and Housing}

The population of Portland in 1990 was 437,319 although the multi-county urban area is closer to 1.5 million. This urban area's population increased 19 percent between 1980 and 1990 . The median age of Portland residents increased from 31 in 1980 to 35 in 1990. The number of occupied houses in Portland in 1990 was 187,268 . Homeowners lived in 53 percent of these houses and renters lived in 47 percent. Between 1980 and 1990 the number of occupied houses increased 18.1 percent.

\section{Income and Employment}

Per capita income in Portland was $\$ 14,478$ in 1990. Between 1980 and 1990 per capita income increased 78.9 percent. Fifteen percent of all people in the community for whom poverty status was determined were below the poverty level. Employment in Portland in 1990 was 219,165 , while unemployment was 14,379 , an unemployment rate of 6.2 percent. Seventy-nine percent of the employment was private industry and 13 percent was government employment. Between 1980 and 1990 employment increased by 26 percent and unemployment increased by 12 percent. Employment was highest in retail trade with 38,420 employees. Since 1980 retail trade employment has increased 155 percent. Manufacturing of durable goods and health services are the next largest employment sectors with 21,508 and 20,476 employees respectively. Several employment industries experienced large increases in employment between 1980 and 1990, but the largest change was in other professional and related services with 768 percent increase.

\section{Port of Portland}

The Port of Portland, located on the Columbia and Willamette Rivers 110 miles from the Pacific Coast, is Oregon's largest and most diversified port, exporting a larger volume of goods than any other West Coast port. It ranks third in total waterborne commerce behind Long Beach and Los Angeles. In addition to six marine terminals and fifty cargo docks, the port is served by three major rail lines and two interstate highway systems. The Port manages the Portland Ship Repair Yard. The 125 acre Portland Ship Repair Yard, owned by the Port, will be operated effective January 1, 1996 by Cascade General, Inc., as sole contractor at the repair yard.

\section{F.1.5.3 THE CITY OF ASTORIA}

Astoria is located in Clatsop County at the mouth of the Columbia River. It was chosen as a focus community because of the anadromous fish runs that support the local economy. Clatsop County's principal industries are fishing, lumber, and tourism.

\section{Population and Housing}

The population of Astoria in 1990 was 10,069. The median age of Astoria residents was 35 . The number of occupied houses in Astoria in 1990 was 4,216. Homeowners lived in 51 percent of these houses and renters lived in 49 percent. Between 1980 and 1990 the number of available houses decreased by 70 .

\section{Income and Employment}

Per capita income in Astoria was $\$ 12,320$ in 1990. Seventeen percent of all people in the community for whom poverty status was determined were below the poverty level. Employment in Astoria in 1990 was 4,812 , while unemployment was 293 , an unemployment rate of 5.7 percent. Seventy-four percent of the employment was private industry and 17 percent was government employment. Employment was highest in retail trade with 881 employees. Manufacturing of non-durable and durable goods were the next two largest industries, employing 470 and 418 employees respectively. In addition, the educational services and public administration sectors employed 374 and 324 employees respectively. 


\section{Commercial Fishing}

Fishing and seafood processing are vital to Astoria's economy. In 1990 there were 66,254 pounds of coho and 28,861 pounds of chinook salmon commercially landed. The estimated fishermen's value of this fish was $\$ 89,898$ of coho and $\$ 70,514$ of chinook salmon. Since 1990, the fishing industry has declined and is adversely affected by limits on both ocean and river harvest of salmon species.

\section{Recreation}

Sport fishing, camping along the Oregon and Washington coasts, golfing, and other recreation activities have added to Astoria's economy for many years. Several state parks are located in close proximity to Astoria and the community is located at one end of the Astoria-Megler Bridge, the only Columbia River crossing in 25 miles.

\section{F.2 ESTIMATING THE SOCIOECONOMIC IMPACTS OF THE SOR ALTERNATIVES ON THE FOCUS COMMUNITIES}

\section{F.2.1 FRAMEWORK FOR EVALUATION}

Thirteen operations alternatives were evaluated for the SOR direct economic impacts analysis. Regional economic impacts were also estimated for each of these operating strategies. The system alternatives evaluated in the regional analysis are presented in Table F-2.

SOR alternative 2c, Final SEIS Operation-No Action Altemative, was identified as the no action scenario for the operations analysis. It was considered to be most representative of current system operations.

Table F-2. SOR Alternatives Evaluated in the Regional Analysis

\begin{tabular}{|c|c|}
\hline Alternative & Description of the Alternative \\
\hline SOS 1a & Pre-Salmon Summit Operation \\
\hline SOS 1b & Optimum Load Following Operation \\
\hline SOS 2c & Final SEIS Operation No Action Alternative \\
\hline SOS 2d & 1994-98 Biological Opinion Operation \\
\hline SOS 4c & Enhanced Operation with Modified grand Coulee Flood Control \\
\hline SOS 5b & Four and One Half Month Natural River Operation \\
\hline SOS 5c & Permanent Natural River Operation \\
\hline SOS 6b & Four and One Half Month Fixed Drawdown \\
\hline SOS 6d & Four and One Half Month Lower Granite Drawdown Operation \\
\hline SOS 9a & Detailed Fishery Operating Plan \\
\hline SOS 9b & Adaptive Management \\
\hline SOS 9c & Balanced Impacts Operation \\
\hline SOS PA & Preferred Alternative \\
\hline
\end{tabular}


Adjustments in river operations will affect the demand for local goods and services, causing the output levels in many related industries to change. Input requirements will be affected as will the distribution of regional output to local and export markets. Labor requirements will change, increasing or decreasing the availability of regional jobs.

Personal income will rise or fall depending on the job impacts. The regional trade balance will shift as the availability of local commodities is affected by changes in production levels.

The most common indicators of change in regional economic activity, however, are adjustments in regional employment and earnings. These are the measures from the input-output models which best describe the change in the economic well-being for the local population. Employment is measured as the total number of jobs and includes both full-time and part-time workers. Earnings, or income, is measured as wage and salary income paid to employees plus income earned by business owners and sole-proprietorships.

Regional economic impacts were estimated for the Pacific Northwest using an input-output model developed with IMPLAN software. Under the framework of the SOR, regional economic impacts would be generated by changes to river operations strategies that positively or negatively affect the production and utilization of local goods and services. The impacts are brought about by resourcerelated changes to existing economic activity. Therefore, for each SOR alternative the measure of direct economic impact is incorporated into the regional and social analysis as a change from SOS $2 c$, defined as the base case scenario.

The direct economic impacts of the SOR alternatives have been measured for activities occurring throughout the Pacific Northwest. However, the actual incidence of the impacts will be distributed across various locations throughout the region with the resulting employment and income impacts occurring in some parts of the Pacific Northwest while not in others. To better reflect the distribution of the intra-regional impacts, four state (Washington, Oregon, Idaho, and Montana) and eight multi- county subregion input-output models were developed.

The basis for evaluating the social impacts associated with the SOR alternatives is the analysis of the nature and potential magnitude of the direct and regional economic impacts that would accrue to the focus communities and Tribes located within each subregion. The socioeconomic impact assessment conducted for each of the focus communities includes a description and estimate of the significance of the potential employment and income likely to occur under the SOR alternatives. The analysis was completed in a workshop setting with selected members of the EAG. Expert judgment was relied upon to allocate the subregion-level direct and indirect economic impacts, and to estimate the significance and probable incidence of the impacts to specific communities within the subregions.

\section{F.2.2 REGIONAL AND SUBREGIONAL ECONOMIC IMPACTS}

The expected regional and subregional employment impacts related to the SOR alternatives are briefly described below. These impacts provide some perspective on the relative magnitude of the expected impacts occurring in the vicinity of the focus communities.

\section{F.2.2.1 PACIFIC NORTHWEST REGIONAL IMPACTS}

The total employment impacts for the Pacific Northwest that are likely to result from the alternative river operation strategies are presented in Table $\mathrm{F}-3$. Expected changes in regional employment range from a net increase of over 2,000 jobs annually under SOS $1 b$ to a loss of 9,450 jobs annually under SOS 9a. Only two of the twelve alternatives evaluated resulted in a net increase in regional employment. Expected changes in regional income range from a net increase of over $\$ 56$ million annually under SOS $1 b$ to a loss of over $\$ 260$ million annually under SOS 9a. The income estimates include the direct economic changes along with the indirect and induced changes that result from the interdependencies which exist throughout the regional economy. The distribution of changes in regional income 
across alternatives is consistent with the distribution of the employment impacts.

\section{F.2.2.2 ECONOMIC IMPACTS IN THE SOR SUBREGIONS}

Economic impacts were evaluated for each of the SOR subregions where direct changes in river operations are expected to result in resource use adjustments. These impacts provide a more detailed indication of the expected distribution of Pacific Northwest impacts throughout the region. Allocations to the subregions were made using information and analysis provided by the direct economic work groups, along with information from the regional impact models. It is important to note that the subregion analysis excludes the estimation of impacts related to the purchase of non-hydro based power. Insufficient information was available to allocate the direct changes to the SOR subregions. Therefore, the net economic impacts in one or more of the subregions are likely to be somewhat less than those presented in this analysis.

As described in Chapter 1, eight Pacific Northwest subregions were identified to further evaluate the economic effects of the SOR alternatives. The boundaries of the subregions were determined, in part, by the expected incidence of the direct economic impacts. A brief description of the subregion impacts is provided below.

Table F-3. Summary of Pacific Northwest Regional Employment Impacts (Total Number of Jobs per Year)

\begin{tabular}{|c|c|c|c|c|c|c|c|}
\hline & $\begin{array}{c}\text { All } \\
\text { Resources }\end{array}$ & $\begin{array}{c}\text { Anadromous } \\
\text { Fish }\end{array}$ & Irrigation & Navigation & Power & Recreation & $\begin{array}{c}\text { Power } \\
\text { Purchases }\end{array}$ \\
\hline SOS 1a & 1,036 & $(5)$ & 0 & 2 & 1,505 & 60 & $(526)$ \\
SOS 1b & 2,021 & $(6)$ & 0 & 2 & 3,016 & 63 & $(1,055)$ \\
\hline SOS 2d & $(578$ & 0 & 0 & $(2)$ & $(886)$ & 0 & 310 \\
\hline SOS 4c & $(2,191)$ & 1 & 0 & 5 & $(3,443)$ & 42 & 1,204 \\
\hline SOS 5b & $(4,095)$ & $(114)$ & $(434)$ & 158 & $(5,265)$ & $(281)$ & 1,841 \\
SOS 5c & $(7,486)$ & $(246)$ & $(437)$ & 94 & $(9,271)$ & $(318)$ & 2,693 \\
\hline SOS 6b & $(2,264)$ & $(388)$ & $(347)$ & $(132)$ & $(1,854)$ & $(191)$ & 648 \\
SOS 6d & $(1,083)$ & $(144)$ & $(261)$ & $(26)$ & $(769)$ & $(153)$ & 269 \\
\hline SOS 9a & $(9,451)$ & $(557)$ & $(335)$ & $(133)$ & $(12,509)$ & $(290)$ & 4,373 \\
SOS 9b & 5,662 & $(82$ & 0 & $(4)$ & $(8,519)$ & $(36)$ & 2,978 \\
SOS 9c & $(5,678)$ & $(394)$ & $(356)$ & $(17)$ & $(7,317)$ & $(152)$ & 2,558 \\
\hline SOS 9A & $(4,029)$ & $(6)$ & $(259)$ & $(2)$ & $(5,419)$ & $(237)$ & 1,895 \\
\hline
\end{tabular}




\section{F.2.2.2.1 SUBREGION-LEVEL EMPLOYMENT IMPACTS}

Expected changes in subregion employment resulting from the SOR alternatives are presented in Table F-4. Employment impacts are presented for the net job effects aggregated across the five resources (anadromous fish, irrigation, navigation, power, and recreation). Job impacts across all subregions range from a net increase of nearly 530 jobs in Puget Sound with alternative SOS $1 \mathrm{~b}$, to a loss of over 3,800 jobs for Lower Snake with alternative SOS $5 \mathrm{c}$, the permanent natural river operation alternative. SOS $1 \mathrm{a}$ and $1 \mathrm{~b}$ generate net increases in jobs across all subregions because of the decreased power costs associated with the alternative. All other SOS alternatives result in net losses. Exceptions are SOS $5 \mathrm{c}$ and SOS $6 \mathrm{~b}$ which generate net job increases in the Northeast and Southern Idaho subregions as a result of decreased commodity transportation costs.
Job impacts within the Lower Snake subregion are generated primarily by changes in anadromous fish, navigation, power, and recreation resource use. The most significant impacts occur in SOS $5 \mathrm{c}$ and $9 \mathrm{a}$, with job losses of 3,800 and 2,300 respectively. Job impacts within the Mid Columbia subregion are generated primarily by changes in irrigation, navigation, power, and recreation resource use. SOS 9c and SOS PA result in losses of over 1,000 jobs.

Employment impacts within the Northeast, Upper Columbia, and Southern Idaho subregions are generated by changes in navigation and power resource use. Excluding power, resource use in all subregions other then Mid Columbia and Lower Snake generate insignificant impacts, generally accounting for employment changes of less than 20 jobs. Exceptions are Upper Columbia and Northeast where expected changes in recreation use under alternative SOS 9a result in losses of 145 and 62 jobs, respectively.

Table F-4. Summary of Subregional Employment Impacts

(Total number of jobs per year)

\begin{tabular}{|c|c|c|c|c|c|c|c|c|}
\hline & $\begin{array}{c}\text { Puget } \\
\text { Sound }\end{array}$ & $\begin{array}{c}\text { West } \\
\text { Coast }\end{array}$ & Portland & $\begin{array}{c}\text { Mid } \\
\text { Columbia }\end{array}$ & $\begin{array}{c}\text { Upper } \\
\text { Columbia }\end{array}$ & $\begin{array}{c}\text { Lower } \\
\text { Snake }\end{array}$ & Northeast & $\begin{array}{c}\text { Southern } \\
\text { Idaho }\end{array}$ \\
\hline SOS 1a & 262 & 116 & 173 & 234 & 57 & 60 & 181 & 101 \\
SOS 1b & 527 & 234 & 351 & 318 & 129 & 147 & 368 & 204 \\
\hline SOS 2d & $(153)$ & $(66)$ & $(100)$ & $(48)$ & $(42)$ & $(39)$ & $(105)$ & $(58)$ \\
\hline SOS 4c & $(601)$ & $(266)$ & $(401)$ & $(95)$ & $(162)$ & $(162)$ & $(417)$ & $(233)$ \\
\hline SOS 5b & $(921)$ & $(412)$ & $(623)$ & $(476)$ & $(145)$ & $(2,409)$ & $(54)$ & $(76)$ \\
SOS 5c & $(1,349)$ & $(610)$ & $(916)$ & $(214)$ & $(234)$ & $(3,839)$ & 137 & 35 \\
\hline SOS 6b & $(323)$ & $(156)$ & $(235)$ & $(320)$ & $(23)$ & $(1,645)$ & 256 & 78 \\
SOS 6d & $(133)$ & $(63)$ & $(91)$ & $(493)$ & $(49)$ & $(313)$ & $(104)$ & $(54)$ \\
\hline SOS 9a & $(2,191)$ & $(1,023)$ & $(1,494)$ & $(957)$ & $(680)$ & $(2,260)$ & $(1,124)$ & $(649)$ \\
SOS 9b & $(1,491)$ & $(670)$ & $(999)$ & $(493)$ & $(473)$ & $(500)$ & $(1,059)$ & $(582)$ \\
SOS 9c & $(1,280)$ & $(587)$ & $(869)$ & $(1,030)$ & $(415)$ & $(685)$ & $(902)$ & $(502)$ \\
\hline SOS PA & $(948)$ & $(419)$ & $(632)$ & $(1,036)$ & $(274)$ & $(275)$ & $(666)$ & $(369)$ \\
\hline
\end{tabular}




\section{F.2.2.2.2 IMPACTS RELATED TO PROJECT IMPLEMENTATION AND PUMP MODIFICATIONS}

Many of the SOR alternatives will require physical project modifications and mitigation activities in order to achieve the objectives of the operations strategy. The proposed adaptations include modification of irrigation pumping stations, development of new power stations, improvements to boat ramps and moorages, and dam modifications to improve fish passage. The construction activities associated with these mitigation actions and project modifications will provide short-term positive economic benefits to the region through increased employment and earnings opportunities. The expected benefits are short-term in that they are expected to last only throughout the duration of the construction activity. The employment and income impacts for this construction are not included in the above tables of income and employment effects, because of the expected short term duration of these impacts.

Project implementation will occur over several years and could take as long as 15 years with SOS $5 \mathrm{~b}$. The employment figures represent the expected number of jobs per year throughout the duration of the construction period. Project construction SOS $5 b$ is expected to generate nearly 7,600 jobs annually over the 15 year time construction period. Employment impacts for the Preferred Alternative are expected to be about 470 jobs while impacts under the remaining alternatives will vary between 3,300 and 3,800 jobs. The employment impacts associated with SOS $5 \mathrm{~b}$ reflect the significantly higher construction expenditures associated with this alternative.

Impacts related to pump modifications are expected to last one year. The employment impacts associated with SOS $5 \mathrm{~b}$ and SOS $5 \mathrm{c}$, nearly 2,900 jobs, reflect the significantly higher pump modification expenditures associated with these alternatives.

\section{F.2.3 ALLOCATION OF EXPECTED ECONOMIC IMPACTS TO THE FOCUS COMMUNITIES}

Potential focus community impacts were evaluated for each of the five resource areas included in the regional analysis:
- Anadromous fish

- Irrigation and municipal water supply

- Navigation

- Hydropower generation

- Recreation

The methods used to evaluate focus community impacts varied for each resource area. In some cases, the subregion changes were assumed to be equally distributed across counties and communities. In other cases, additional information was available to identify resource changes by reservoir pools with inferences regarding potential impacts to adjacent communities.

\section{F.2.3.1 ANADROMOUS FISH}

There are $\mathbf{2 6}$ anadromous fish stocks which originate and spawn in the Columbia River Basin. Three of the most economically important runs were used as indicator species to assess the effects of the SOR strategies on anadromous fish. Impacts on the catch of fall and spring chinook salmon and steelhead were evaluated. Fall chinook is the major commercial run while steelhead is the primary sport run. It is expected that all of the SOR alternatives would have some impact on the ocean and in-river commercial and sport harvests for these stocks. These potential changes in fish harvests would generate impacts to regional employment and income.

SOS $4 \mathrm{c}$ is the only alternative that would increase in employment associated with anadromous fish. SOS $4 c$ would add one job in the Pacific Northwest Region. SOS 9a would have the most adverse effect on employment, with a loss of nearly 560 jobs in the Pacific Northwest Region. The Lower Snake subregion would experience the largest subregional loss, over 250 jobs with SOS 9a.

Socioeconomic impacts in the focus communities related to anadromous fish were evaluated in terms of two factors: i) the combined change in harvest levels for all fisheries present within the focus community subregion, and ii) the percentage change in subregion employment related to expected changes in fish harvests. The socioeconomic impacts related 
to fish were assumed to be distributed across the communities located within a subregion with no significant disproportionate incidence of the expected changes.

\section{F.2.3.2 IRRIGATION AND MUNICIPAL \& INDUSTRIAL WATER}

Six reservoirs currently utilized for irrigation pumping for commercial agriculture and water supply pumping for municipal, industrial, recreation, and wildlife uses would be affected by changes in system operations. The alternatives that directly impact irrigation and municipal \& industrial (M\&I) water supplies are the SOSs $5,6,9 \mathrm{a}, 9 \mathrm{c}$, and PA. These alternatives would affect irrigators and M\&I suppliers that use water from the John Day and the four Lower Snake pools. Because of the drawdowns associated at these reservoirs, pump modifications would be required at John Day, Ice Harbor, Lower Granite, Little Goose, and Lower Monumental Reservoirs in order to continue to provide present irrigation and M\&I water supplies. In addition, irrigation water pumped from FDR Reservoir to Banks Lake is minimally affected by many of the alternatives, with SOS 9a showing the greatest impact.

\section{Irrigation Pumping}

During the irrigation season, SOSs $5 \mathrm{~b}, 5 \mathrm{c}, 6 \mathrm{~b}, 9 \mathrm{a}$, and $9 \mathrm{c}$ would lower water levels at John Day and Ice Harbor. As a result, irrigators would pay higher annual operating costs due to the increased costs associated with pumping from a lower reservoir elevation. Annual net farm income of irrigators could drop by as much as $\$ 5.3$ million under SOSs $5 \mathrm{~b}$ and $5 \mathrm{c}$; by as much as $\$ 3.5$ million under SOSs $6 \mathrm{~b}$, $9 \mathrm{a}$, and $9 \mathrm{c}$; and by as much as $\$ 1.6$ million under SOSs $6 \mathrm{~d}$ and PA. All of these impacts would occur in the Mid-Columbia subregion.

The effects of increased pumping costs on the focus communities were evaluated according to two factors: i) the expected decline in per acre net farm income, and ii) the percentage change in subregion employment related to the increased irrigation pumping costs and resulting decline in net farm income. The expected increase in irrigation pumping costs have been identified separately for pumps located in the John Day pool and pumps located in the Ice Harbor pool. ${ }^{2}$ Employment impacts associated with the increased pumping costs in each pool were determined by allocating subregion job changes by the percentage of pumping costs in each pool.

\section{Municipal \& Industrial Water Supply Pumping}

SOSs $5 b, 5 c, 6 b, 9 a$, and $9 c$ would lower water levels at John Day, Ice Harbor, Lower Granite, Little Goose, and Lower Monumental. SOS $6 \mathrm{~d}$ would lower pool levels at John Day and Lower Granite only. SOS PA would lower water levels at John Day only. Average annual water M\&I water supply costs would increase as a result of the increased costs associated with pumping from the lower reservoir elevations. The increase in average annual M\&I water costs range from $\$ 5.2$ million with SOS PA, to $\$ 5.8$ million with SOS $5 \mathrm{c}$.

Regional employment losses associated with the increased costs of irrigation and M\&I water supply pumping would be most significant in the Mid-Columbia subregion, where the John Day and Ice Harbor pools are located. Under SOS alternatives $5 b$ and $5 c$ it estimated that approximately 360 jobs would be lost. Alternatives $6 \mathrm{~b}, 9 \mathrm{a}$, and $9 \mathrm{c}$ would result in 280 to 290 job losses while SOSs $6 \mathrm{~d}$ and PA would result in a loss of approximately 220 jobs. Employment losses in the Lower Snake subregion (location of the Lower Monumental, Little Goose, and Lower Granite pools) would range from 10 to 20 jobs under all of the alternatives.

The effects of increased water supply pumping costs on the focus communities were evaluated according to two factors: i) the expected increase in pumping costs, and ii) the percentage change in subregion employment related to the increased costs. The expected increase in irrigation pumping costs have been identified separately for pumps located each of

2. These costs are presented in Chapter 4 , Table 4-21. 
the five pools. ${ }^{3}$ Employment impacts associated with the increased pumping costs in each pool were determined similar to those for irrigation pumping.

\section{F.2.3.3 NAVIGATION}

Alternative operations strategies would affect cargo transportation on the Columbia-Snake river system by limiting and/or restricting barge navigation along specific river reaches during periods of reservoir drawdown. The barge restrictions would, in turn, lead to increases in the costs of transporting goods from their point of origin to their final destination. Increasing transportation costs result from two general adjustments that may occur as a result of restrictions to barge navigation: i) barge movements may shift to other transportation modes or modal combinations, or ii) commodities may be transported to alternative river locations before being loaded on barges. Increased storage and handling costs would also be likely to result from the shifts in transportation activity.

The direct economic impacts related to navigation on the Columbia-Snake river system were measured as the net change in transportation costs for grain and non-grain commodities. Expected costs were estimated for shallow draft navigation and for reservoir navigation. 4

\section{Shallow Draft Navigation}

Drawdown alternatives would close ports on the lower Snake River to barge traffic for varying periods of time every year. Because of slow drawdown and refill during low water years, this could close Lewiston/Clarkston to barge traffic for as long as eight months. Ten million tons, 20 percent of the region's annual grain production, ordinarily moves through this area. Implementation of any of these alternatives would result in a portion of this grain, primarily from Montana and Idaho, being moved by truck. Another portion would be trucked to the Tri-cities and barged from there.

SOSs $5 b$ and $5 c$, which draw the Snake River down to near natural (pre-dam) levels, would have a significant negative impact on employment in the Lower Snake and Lewiston/Clarkston areas because of port closures; employment in the Tri-Cities and Morrow/Umatilla County areas would increase because of reductions in transportation costs for growers in the area. Income in the Lower Snake subregion decreases while income in the Mid Columbia and Northeast Subregion would increase. The Northeast Subregion experiences an increase in employment due to an increase in rail traffic and lower transportation costs for farmers.

SOS $5 \mathrm{c}$ has the largest impact on employment region-wide. SOS $5 \mathrm{c}$ would result in the loss of nearly 2,800 jobs in the Lower Snake subregion, but an increase of about 1,000 jobs in both the Mid Columbia and Northeast subregions. SOS $5 b$ results in the loss of 1,500 jobs in Lower Snake subregion, but increases of $570,1,000$, and 1,100 jobs in the Southern Idaho, Mid Columbia, and Northeast subregions, respectively.

Changes in transportation costs for SOS $6 b$ and SOS $9 \mathrm{a}$ are the same, resulting in equivalent impacts. Losses of 1,100 jobs in the Lower Snake subregion are counterbalanced by increases of 200 jobs in Southern Idaho, 420 jobs in Mid Columbia, and 480 jobs in the Northeast. Transportation costs for SOS $6 \mathrm{~d}$ and SOS $9 \mathrm{c}$ were not allocated to states or subregions due to time and resource constraints.

The socioeconomic impacts generated by changes in shallow draft transportation activity were evaluated at the focus community level using two factors: i) the expected increase in transportation costs necessary to ship commodities to their downstream destinations, and ii) the expected percentage change in subregion employment generated by increased transportation costs and consequent loss in regional

3. These costs are presented in Chapter 4, Tables 4-24 and 4-25.

4. It was determined by the Navigation Work Group that the SOR alternatives would have no impact on deep draft navigation. Therefore, no direct or regional economic impacts were measured for this navigation component. 
income. It is likely that the increased transportation costs would be paid by farmers shipping their grain to export elevators located along the lower Columbia River. The incidence of these impacts and the resulting employment impacts are likely to be distributed throughout the subregions.

\section{Reservoir Navigation}

Two ferries providing important across-river transportation links operate on FDR Lake. The Gifford-Inchelium Ferry, operated by the Colville Confederated Tribes provides service between the communities of Gifford and Inchelium. The Keller Ferry, operated by the Washington State Department of Transportation as a part of the state highway system, provides service between the communities of Wilbur and Keller on State Route 21. None of the SOR alternatives will affect the operation of either ferry.

Log rafting activities have historically been present on Dworshak Reservoir. Logs are skidded into the Dworshak pool and then rafted across the reservoir to areas where they are loaded onto trucks. Approximately 20 million board feet of timber are rafted each year. At certain minimum pool elevations, the timber has to roll too far to the pool and can be damaged, so log rafting has to be replaced by trucking. SOSs $2 d, 9 b$, and PA would cut short the operating season for Dworshak log transport, increasing costs by about $\$ 90,000$ to $\$ 170,000$ annually. All other SOS alternatives would lengthen the operating season for Dworshak log transport, reducing annual trucking costs. Changes in employment in the Pacific Northwest Region range from a loss of four jobs with alternative $9 \mathrm{~b}$ to an increase of six jobs with alternative $4 \mathrm{c}$.

The socioeconomic impacts associated with changes in log rafting operations at Dworshak Reservoir will likely occur primarily within the vicinity of Lewiston, Idaho.

\section{F.2.3.4 POWER}

The direct economic impacts of the SOR alternatives on the regional power system are measured as the net system replacement cost for electricity. The measure takes into account the expected changes in the resource mix necessary to meet anticipated regional electrical power loads, including the response of consumer demand to higher energy costs. The regional economic impacts generated by the increased power costs result from the decline in business and household income available for the purchase of other goods and services.

Under all of the SOR alternatives except SOS 1, average retail power rates paid by residential, industrial, irrigation, and commercial customers are expected to increase. Power rate increases are expected to range from a low of 0.3 percent under SOS $6 \mathrm{~d}$ to a high of 4 percent under SOS 9a. These rate increases are less than some past increases (unrelated to SOR) and would not be expected to significantly affect economic activity. Regional job losses associated with the increased power costs would be somewhat mitigated by the job increases that would be associated with regional power generation activities necessary to replace lost hydropower resources. It is expected that net employment losses would range from approximately 500 jobs under SOS $6 \mathrm{~d}$ to 8,100 jobs under SOS $9 \mathrm{a}$, less than one quarter percent of total regional jobs.

The socioeconomic impacts generated by the changes in regional power costs are evaluated for the focus communities in terms of the percentage change in retail power rates and the expected percentage change in subregion employment generated by increased power costs. The incidence of the power-related impacts are expected to be distributed evenly across subregions and focus communities.

\section{F.2.3.5 RECREATION}

Recreation activity at one and sometimes several of the sixteen federal project sites along the Columbia-Snake river system would be affected by the alternative operations strategies evaluated for the SOR. The direct economic impacts for recreation are measured as the changes in consumer surplus associated with the expected increases or decreases in recreation visitor use at the project sites. Regional economic impacts related to recreation derive from changes in the trip-related expenditures made 
by visitors on-site and en-route to their recreation destinations.

Reservoir recreation would be most adversely impacted by changes in river operations with implementation of SOSs $5 b, 5 c$, and $9 a$. Significant declines in recreation visitors would occur with consequent losses in regional employment linked to the recreation activity. Nearly all of these losses would be occur in the Mid Columbia and Lower Snake subregions. In the Mid Columbia subregion, the most significant employment losses would occur under the Preferred Alternative, with approximately 510 jobs lost. Slightly less than 400 jobs would be lost in the subregion under alternatives $5 \mathrm{~b}$ and $5 \mathrm{c}$. In the Lower Snake subregion, the most significant employment losses would occur under SOS $5 \mathrm{C}$, with approximately 540 jobs lost. Approximately 450 jobs would be lost under SOS $5 \mathrm{~b}$. The most significant job losses in the Upper Columbia subregion would occur under SOS 9a with a loss of 145 jobs.

The focus community impacts generated by changes to regional reservoir recreation activity are measured using two factors: i) the expected percentage change in recreation visitor days at project sites adjacent to the focus communities, and ii) the percentage change in subregion employment related to changes in recreation activity. The expected change in recreation visitors have been identified separately for each of the project sites in the Columbia-Snake river basin. 5 Subregion employment impacts were estimated by aggregating the expected changes in visitor activity for all project sites located within the region. To evaluate potential focus community impacts, the employment changes associated with recreation activity at specific projects were determined by allocating subregion job changes by the percentage of subregion visitors to each site.

\section{F.2.3.6 CONSTRUCTION}

Many of the SOR alternatives will require physical project modifications and mitigation activities in order to achieve the objectives of the operations strategy. The proposed adaptations include modification of irrigation pumping stations, development of new power stations, improvements to boat ramps and moorages, and dam modifications to improve fish passage. The construction activities associated with these mitigation actions and project modifications will provide short-term positive economic benefits to the region through increased employment and earnings opportunities. The expected benefits are short-term in that they are expected to last only throughout the duration of the construction activity. The employment and income impacts for this construction are not included in the above tables of income and employment effects, because of the expected short term duration of these impacts.

Project implementation will occur over several years and could take as long as 15 years with SOS $5 \mathrm{~b}$. Project construction for SOS $5 \mathrm{~b}$ is expected to generate nearly 7,600 jobs annually over the 15 year time construction period. Employment impacts for the Preferred Alternative are expected to be about 470 jobs while impacts under the remaining alternatives will vary between 3,300 and 3,800 jobs. The employment impacts associated with SOS 5 b reflect the significantly higher construction expenditures associated with this alternative. It is expected that most of these job changes would occur in the Lower Snake and Mid Columbia subregions.

Impacts related to pump modifications are expected to last one year. The employment impacts associated with SOS $5 b$ and SOS $5 c$, nearly 2,900 jobs, reflect the significantly higher pump modification expenditures associated with these alternatives. Most of these jobs are expected to occur in the Lower Snake and Mid Columbia subregions.

The relatively short-term focus community impacts generated by construction activities related to project implementation and pump modifications are measured by the expected percentage change in subregion employment related to the construction expenditures. The expected construction costs have been identified separately for each of the five project sites (John Day, Ice Harbor, Lower Monumental,

5. Recreation visits by project site are presented in Chapter 4 , Table 4-48. 
Little Goose, and Lower Granite) ${ }^{6}$ Subregion employment impacts were estimated by aggregating construction costs for all project sites located within the region. To evaluate potential focus community impacts, the employment changes associated with construction activity at specific projects were determined by allocating subregion job changes by the percentage of subregion costs at each site.

\section{F.3 SIGNIFICANCE OF SOCIOECONOMIC IMPACTS IN THE FOCUS COMMUNITIES}

\section{F.3.1 EVALUATION OF SIGNIFICANCE}

The significance of the potential socioeconomic impacts associated with the SOR alternatives was evaluated for each of the seventeen focus communities and Indian tribes included in the social analysis. The assessment of significance was conducted through a workshop with selected members of the Economic Analysis Group. The significance of the various socioeconomic factors evaluated for each community was determined in terms of the expected changes from levels measured for the base case alternative, defined as SOS $2 \mathrm{c}$. The relative significance of impacts across communities was not determined.

The significance of the socioeconomic impacts for each community were measured using a rating system that included five values:

$$
\begin{aligned}
++ & \text { Very Positive } \\
+ & \text { Positive } \\
0 & \text { No Impact } \\
- & \text { Negative } \\
-- & \text { Very Negative }
\end{aligned}
$$

The rating system was used to define the direction and relative magnitude of the expected socioeconomic impacts. The rating system is ordinal in that a value of ++ indicates that an alternative would result in a more positive impact than one assigned a value of + . However, there is no cardinal ranking implied; the alternative receiving $a++$ does not necessarily result in a positive impact twice the level of an alternative with a + value. Each socioeconomic factor evaluated for a community received a separate measure of significance.

The socioeconomic factors selected to evaluate the potential impacts of the SOR alternatives in the focus communities are presented in Table $\mathrm{F}-5$. Evaluation factors were identified for potential changes in flood control, anadromous fish runs, irrigation and municipal water supply, navigation, regional power supply, reservoir recreation, and project construction. In general, two sets of factors were identified for each resource: i) a measure of the physical change in resource supply or activity, or a change in the cost of providing and maintaining a resource (e.g. changes in anadromous fish harvests or increased costs for water supply pumping), and ii) the expected change in subregion employment generated by the resource activity. Potential increases in employment were assumed to generate positive impacts in a community while expected declines in employment were assumed to generate negative impacts.

\section{F.3.2 SOCIOECONOMIC EVALUATIONS FOR THE SEVENTEEN FOCUS COMMUNITIES}

Evaluations of potential socioeconomic impacts in each of the focus communities are presented in the following sections. Specific resources examined for each community have been previously identified in Table $F-1$. The evaluations include a brief socioeconomic profile and a discussion of the significance of the relevant factors for each community. ${ }^{7}$ An evaluation table is also presented for each community.

Only those alternatives with potential positive or negative impacts in a community are evaluated for

6. Construction costs for project implementation and pump modifications are presented in Chapter 4, Tables 4-4, 4-5, 4-21, and 4-24.

7. An expanded description of the socioeconomic characteristics of each focus community is presented in Appendix A: Focus Community Profiles. 
each resource. Alternatives which would result in no impact to the community are not included in the evaluations. For example, all of the SOR alternatives will have potential impacts on regional power costs. Therefore, the effect of these impacts on the focus communities are evaluated for all alternatives.
However, only selected SOR alternatives will have potential impacts on irrigation pumping costs. The effect of these impacts on the focus communities are evaluated only for those alternatives with expected changes.

Table F-5. Evaluation Measures to Identify Socioeconomic Impacts in the SOR Focus Communities

\begin{tabular}{|c|c|c|}
\hline Evaluation Item & Impact Measure & $\begin{array}{c}\text { Effects } \\
(++,+,-,--)\end{array}$ \\
\hline FLOOD CONTROL & $\begin{array}{l}\text { AVERAGE ANNUAL FLOOD DAMAGES (AAFD) } \\
\text { Increase in AAFD }<\$ 200,000 \\
\text { Increase in AAFD }>\$ 200,000 \\
\text { Decrease in AAFD }<\$ 200,000 \\
\text { Decrease in AAFD }>\$ 200,000\end{array}$ & $\begin{array}{c}- \\
- \\
+ \\
+ \\
+\end{array}$ \\
\hline ANADROMOUS FISH & $\begin{array}{l}\text { CHANGE IN FISH HARVEST } \\
\text { Decrease in Combined Harvest } \\
\text { Increase in Combined Harvest }\end{array}$ & $\overline{+}$ \\
\hline ANADROMOUS FISH & $\begin{array}{c}\text { CHANGE IN SUBREGION EMPLOYMENT } \\
\text { Decrease in Employ }<1 \% \text { Total Subregion Employ } \\
\text { Decrease in Employ }>1 \% \text { Total Subregion Employ } \\
\text { Increase in Employ }<1 \% \text { Total Subregion Employ } \\
\text { Increase in Employ }>1 \% \text { Total Subregion Employ }\end{array}$ & $\begin{array}{l}- \\
-- \\
+ \\
++\end{array}$ \\
\hline IRRIGATION & $\begin{array}{c}\text { NET FARM INCOME PER ACRE (NFI/AC) } \\
\text { Decrease in NFI/AC }<\$ 20 / A C \\
\text { Decrease in NFI/AC }>\$ 20 / A C\end{array}$ & - \\
\hline & $\begin{array}{l}\text { CHANGE IN SUBREGION EMPLOYMENT } \\
\text { Decrease in Employ }<1 \% \text { Total Subregion Employ } \\
\text { Decrease in Employ }>1 \% \text { Total Subregion Employ } \\
\text { Increase in Employ }<1 \% \text { Total Subregion Employ } \\
\text { Increase in Employ }>1 \% \text { Total Subregion Employ }\end{array}$ & $\begin{array}{c}- \\
-- \\
+ \\
++\end{array}$ \\
\hline M/I WATER SUPPLY & $\begin{array}{c}\text { PUMPING COST } \\
\text { Increase in Pumping Cost }\end{array}$ & - \\
\hline & $\begin{array}{l}\text { CHANGE IN SUBREGION EMPLOYMENT } \\
\text { Decrease in Employ }<1 \% \text { Total Subregion Employ } \\
\text { Decrease in Employ }>1 \% \text { Total Subregion Employ } \\
\text { Increase in Employ }<1 \% \text { Total Subregion Employ } \\
\text { Increase in Employ }>1 \% \text { Total Subregion Employ }\end{array}$ & $\begin{array}{l}- \\
-- \\
+ \\
+\end{array}$ \\
\hline
\end{tabular}


Table F-5. Evaluation Measures to Identify Socioeconomic Impacts in the SOR Focus Communities - CONT

\begin{tabular}{|c|c|c|}
\hline Evaluation Item & Impact Measure & $\begin{array}{c}\text { Effects } \\
(++,+,-,--)\end{array}$ \\
\hline \multirow[t]{2}{*}{$\begin{array}{l}\text { SHALLOW DRAFT } \\
\text { NAVIGATION }\end{array}$} & $\begin{array}{l}\text { TRANSPIRATION COSTS } \\
\text { Increase in Transp Costs }<10 \% \text { Total Transp Costs } \\
\text { Increase in Transp Costs }>10 \% \text { Total Transp Costs } \\
\text { Decrease in Transp Costs }<10 \% \text { Total Transp Costs } \\
\text { Decrease in Transp Costs }>10 \% \text { Total Transp Costs }\end{array}$ & $\begin{array}{c}- \\
-- \\
+ \\
++\end{array}$ \\
\hline & $\begin{array}{l}\text { CHANGE IN SUBREGION EMPLOYMENT } \\
\text { Decrease in Employ }<1 \% \text { Total Subregion Employ } \\
\text { Decrease in Employ }>1 \% \text { Total Subregion Employ } \\
\text { Increase in Employ }<1 \% \text { Total Subregion Employ } \\
\text { Increase in Employ }>1 \% \text { Total Subregion Employ }\end{array}$ & $\begin{array}{c}- \\
-- \\
+ \\
++\end{array}$ \\
\hline \multirow[t]{2}{*}{$\begin{array}{l}\text { RESERVOIR } \\
\text { NAVIGATION }\end{array}$} & $\begin{array}{l}\text { LOG TRUCKING COSTS } \\
\text { Increase in Trucking Costs } \\
\text { Decrease in Trucking Costs }\end{array}$ & $\begin{array}{l}- \\
+\end{array}$ \\
\hline & $\begin{array}{l}\text { CHANGE IN SUBREGION EMPLOYMENT } \\
\text { Decrease in Employ }<1 \% \text { Total Subregion Employ } \\
\text { Decrease in Employ }>1 \% \text { Total Subregion Employ } \\
\text { Increase in Employ }<1 \% \text { Total Subregion Employ } \\
\text { Increase in Employ }>1 \% \text { Total Subregion Employ }\end{array}$ & $\begin{array}{c}- \\
-- \\
+ \\
++\end{array}$ \\
\hline \multirow[t]{2}{*}{ POWER } & $\begin{array}{c}\text { RETAIL RATE CHANGE } \\
\text { Retail Rate Increase } \\
\text { Retail Rate Decrease }\end{array}$ & $\begin{array}{l}- \\
+\end{array}$ \\
\hline & $\begin{array}{c}\text { CHANGE IN SUBREGION EMPLOYMENT } \\
\text { Decrease in Employ }<1 \% \text { Total Subregion Employ } \\
\text { Decrease in Employ }>1 \% \text { Total Subregion Employ } \\
\text { Increase in Employ }<1 \% \text { Total Subregion Employ } \\
\text { Increase in Employ }>1 \% \text { Total Subregion Employ }\end{array}$ & $\begin{array}{c}- \\
-- \\
+ \\
++\end{array}$ \\
\hline RECREATION & $\begin{array}{l}\text { TOTAL VISITOR DAYS (TVD) } \\
\text { Decrease in TVD } \\
\text { Decrease in TVD > 5\% } \\
\text { Increase in TVD } \\
\text { Increase in TVD }>5 \%\end{array}$ & $\begin{array}{c}- \\
-- \\
+ \\
++\end{array}$ \\
\hline
\end{tabular}


Table F-5. Evaluation Measures to Identify Socioeconomic Impacts in the SOR Focus Communities - CONT

\begin{tabular}{|c|c|c|}
\hline Evaluation Item & Impact Measure & $\begin{array}{c}\text { Effects } \\
(++,+,-,--)\end{array}$ \\
\hline RECREATION & $\begin{array}{l}\text { CHANGE IN SUBREGION EMPLOYMENT } \\
\text { Decrease in Employ }<1 \% \text { Total Subregion Employ } \\
\text { Decrease in Employ }>1 \% \text { Total Subregion Employ } \\
\text { Increase in Employ }<1 \% \text { Total Subregion Employ } \\
\text { Increase in Employ }>1 \% \text { Total Subregion Employ }\end{array}$ & $\begin{array}{c}- \\
-- \\
+ \\
++\end{array}$ \\
\hline CONSTRUCTION & $\begin{array}{l}\text { CHANGE IN SUBREGION EMPLOYMENT } \\
\text { Decrease in Employ }<1 \% \text { Total Subregion Employ } \\
\text { Decrease in Employ }>1 \% \text { Total Subregion Employ } \\
\text { Increase in Employ }<1 \% \text { Total Subregion Employ } \\
\text { Increase in Employ }>1 \% \text { Total Subregion Employ }\end{array}$ & $\begin{array}{l}- \\
-- \\
+ \\
++\end{array}$ \\
\hline
\end{tabular}

\section{F.3.2.1 LIBBY, MONTANA}

The community of Libby, Montana would be impacted by the effects of the SOR system alternatives on local recreation activity and the expected region-wide changes in retail electric power rates. Overall, the socioeconomic impacts are expected to be positive under SOS alternatives $1 \mathrm{a}$ and $1 \mathrm{~b}$, and negative under all other SOSs. The effects are expected to be most adverse under SOSs $9 a, 9 b$, and the Preferred Alternative.

Recreation: The SOR alternative system strategies would affect operation of Libby Dam, resulting in varying reservoir levels for Lake Koocanusa. Water flows along the portions of the Kootenai River below Libby Dam would also be affected. Consequently, recreation activities at both Lake Koocanusa and the river areas below Libby Dam are likely to be impacted. Under all but two of the SOS alternatives, recreation activity is expected to decline relative to current visitor levels. Alternatives $4 \mathrm{c}$ and $9 \mathrm{c}$ are expected to increase reservoir recreation activity by two percent. SOS 9a is expected to lead to a ten percent decline in recreation levels, while activity under all the remaining alternatives is expected to decline by one to two percent.

\begin{tabular}{|lccc|}
\hline \multicolumn{4}{c|}{ Libby, Montana: Overview of Socioeconomic Profile (1990) } \\
\hline Population: & 2,532 & Median Age: & 37.1 \\
County & 17,481 & County & 34.7 \\
State & 799,065 & State & 33.8 \\
Employment: & 984 & Unemployment Rate: & $15.8 \%$ \\
County & 6,500 & County & $16.1 \%$ \\
State & 350,723 & State & $7.0 \%$ \\
Per Capita Income: & $\$ 9,589$ & \% Below Poverty Level:1 & $6.4 \%$ \\
County & $\$ 9,813$ & County & $14.1 \%$ \\
State & $\$ 11,213$ & State & $16.1 \%$ \\
\hline Impacted Resources: & Recreation, Power & & \\
\hline
\end{tabular}


Power: Specific retail power rate impacts for the vicinity of Libby have not been measured. Regionwide however, retail rates under SOSs $1 \mathrm{a}$ and $1 \mathrm{~b}$ would be expected to fall by one-half to one percent relative to current rates. Retail rates are ex- pected to increase under all other SOSs; the increases vary from less than one percent to around four percent. Retail rate changes are expected to be similar for residents and businesses in the Libby area.

Table F-6. Evaluation of Social Impacts for Libby, Montana

\begin{tabular}{|c|c|c|c|}
\hline sos & Evaluation Item & Impact Measure & $\begin{array}{c}\text { Effects } \\
(++,+,-,-)\end{array}$ \\
\hline $4 c, 9 c$ & RECREATION & $\begin{array}{l}\text { Increase in Visitor Days: } \\
\text { Lake Koocanusa }\end{array}$ & + \\
\hline $9 \mathrm{a}$ & RECREATION & $\begin{array}{c}\text { Decrease in Visitor Days: } \\
\text { Lake Koocanusa }\end{array}$ & -- \\
\hline All Other & RECREATION & $\begin{array}{l}\text { Decrease in Visitor Days: } \\
\text { Lake Koocanusa }\end{array}$ & - \\
\hline $4 c, 9 a, 9 b, P A$ & RECREATION & $\begin{array}{l}\text { Decrease in Visitor Days: } \\
\text { Kootenai River Below Libby }\end{array}$ & -- \\
\hline All Other & RECREATION & $\begin{array}{l}\text { Decrease in Visitor Days: } \\
\text { Kootenai River Below Libby }\end{array}$ & - \\
\hline $4 c, 9 c$ & RECREATION & Increase in Subregion Employment & + \\
\hline All Other & RECREATION & Decrease in Subregion Employment & - \\
\hline $1 \mathrm{a}, 1 \mathrm{~b}$ & POWER & Retail Rate Increase & + \\
\hline All Other & POWER & Retail Rate Decrease & - \\
\hline $1 \mathrm{a}, 1 \mathrm{~b}$ & POWER & Increase in Subregion Employment & + \\
\hline All Other & POWER & Decrease in Subregion Employment & - \\
\hline
\end{tabular}

\section{F.3.2.2 FLATHEAD LAKE AREA, MONTANA}

The communities surrounding Flathead Lake, Montana would be impacted by the effects of the SOR system alternatives on local recreation activity and the expected region-wide changes in retail electric power rates. The Preferred Alternative would also affect expected average annual flood damages to properties in the vicinity of Flathead Lake. Overall, the socioeconomic impacts are expected to be positive under SOS alternatives 1a, $1 \mathrm{~b}$, and $9 \mathrm{c}$; and negative under all other SOSs.

Flood Control: The communities adjacent to Flathead Lake would face a slight increase in expected average annual flood damages under the Preferred Alternative.
Recreation: The SOR alternative system strategies would affect operation of Hungry Horse dam, resulting in varying reservoir levels for Hungry Horse Reservoir. Recreation activities at the reservoir are likely to be impacted. Alternatives $4 c, 9 b, 9 c$, and the Preferred Alternative are expected to increase reservoir recreation activity. SOSs $4 c$ and $9 c$ are expected to have an increase of eighteen percent in recreation activity. Under the remaining alternatives, recreation activity is expected to decline. SOS $9 a$ is expected to lead to a thirty percent decline in recreation levels while activity declines under all the other alternatives is expected to be one to three percent.

Power: Region-wide, retail rates under SOSs 1a $\overline{\text { and } 1 \mathrm{~b}}$ would be expected to fall by one-half to one 
percent relative to current rates. Retail rates are expected to increase under all other SOSs; the increases vary from less than one percent to around four percent. Retail rate changes are expected to be similar for residents and businesses in the Flathead Lake area.

\begin{tabular}{|c|c|c|c|}
\hline \multicolumn{4}{|c|}{ Flathead Lake Area, Montana: Overview of Socioeconomic Profile (1990) } \\
\hline Population: & 5,147 & Median Age: & 37.6 \\
\hline County & 21,041 & County & 34.7 \\
\hline State & 799,065 & State & 33.8 \\
\hline Employment: & 2,045 & Unemployment Rate: & $10.1 \%$ \\
\hline County & 8,268 & County & $8.9 \%$ \\
\hline State & 350,723 & State & $7.0 \%$ \\
\hline Per Capita Income: & $\$ 12,427$ & \% Below Poverty Level: & $12.6 \%$ \\
\hline County & $\$ 9,274$ & County & $21.4 \%$ \\
\hline State & $\$ 11,213$ & State & $16.1 \%$ \\
\hline Impacted Resources: & \multicolumn{3}{|c|}{ Flood Control, Recreation, Power } \\
\hline
\end{tabular}

Table F-7. Evaluation of Social Impacts for the Flathead Lake Area, Montana

\begin{tabular}{|c|c|c|c|}
\hline sos & Evaluation Item & Impact Measure & $\begin{array}{c}\text { Effects } \\
(++,+,-,--)\end{array}$ \\
\hline PA & FLOOD CONTROL & $\begin{array}{c}\text { Decrease in Average Annual Flood } \\
\text { Damages }\end{array}$ & - \\
\hline PA & RECREATION & $\begin{array}{c}\text { Increase in Visitor Days: Hungry } \\
\text { Horse Reservoir }\end{array}$ & + \\
\hline $4 c, 9 b, 9 c$ & RECREATION & $\begin{array}{c}\text { Increase in Visitor Days: Hungry } \\
\text { Horse Reservoir }\end{array}$ & ++ \\
\hline $9 a$ & RECREATION & $\begin{array}{c}\text { Decrease in Visitor Days: Hungry } \\
\text { Horse Reservoir }\end{array}$ & -- \\
\hline All Other & RECREATION & $\begin{array}{c}\text { Decrease in Visitor Days: Hungry } \\
\text { Horse Reservoir }\end{array}$ & - \\
\hline $4 c, 9 b, 9 c, P A$ & RECREATION & Increase in Subregion Employment & + \\
\hline All Other & RECREATION & Decrease in Subregion Employment & - \\
\hline $1 \mathrm{a}, 1 \mathrm{~b}$ & POWER & Retail Rate Increase & + \\
\hline All Other & POWER & Retail Rate Decrease & - \\
\hline $1 \mathrm{a}, 1 \mathrm{~b}$ & POWER & Increase in Subregion Employment & + \\
\hline All Other & POWER & Decrease in Subregion Employment & - \\
\hline
\end{tabular}




\section{F.3.2.3 COLUMBIA FALLS, MONTANA}

The community Columbia Falls, Montana would be impacted primarily by the effects of the SOR system alternatives on region-wide changes in retail electric power rates. The Preferred Alternative would also affect expected average annual flood damages in the area. Overall , the socioeconomic impacts are expected to be positive under SOS alternatives 1a and $1 \mathrm{~b}$, and negative under all other SOSs.

Flood Control: Expected average annual flood damages for properties in the vicinity of Columbia Falls are expected to decrease under the Preferred Alternative.
Power: Region-wide, retail rates under SOSs 1a and $1 \mathrm{~b}$ would be expected to fall by one-half to one percent relative to current rates. Retail rates are expected to increase under all other SOSs; the increases vary from less than one percent to around four percent. Retail rate changes are expected to be similar for residents and businesses in the Columbia Falls area. It is expected that BPA's rate changes for its DSI customers, including the Columbia Falls Aluminum Company, will be similar in magnitude with increases ranging from less than one percent to around four percent. Rate changes of this order are not expected to cause any of the region's aluminum smelters to become uneconomic.

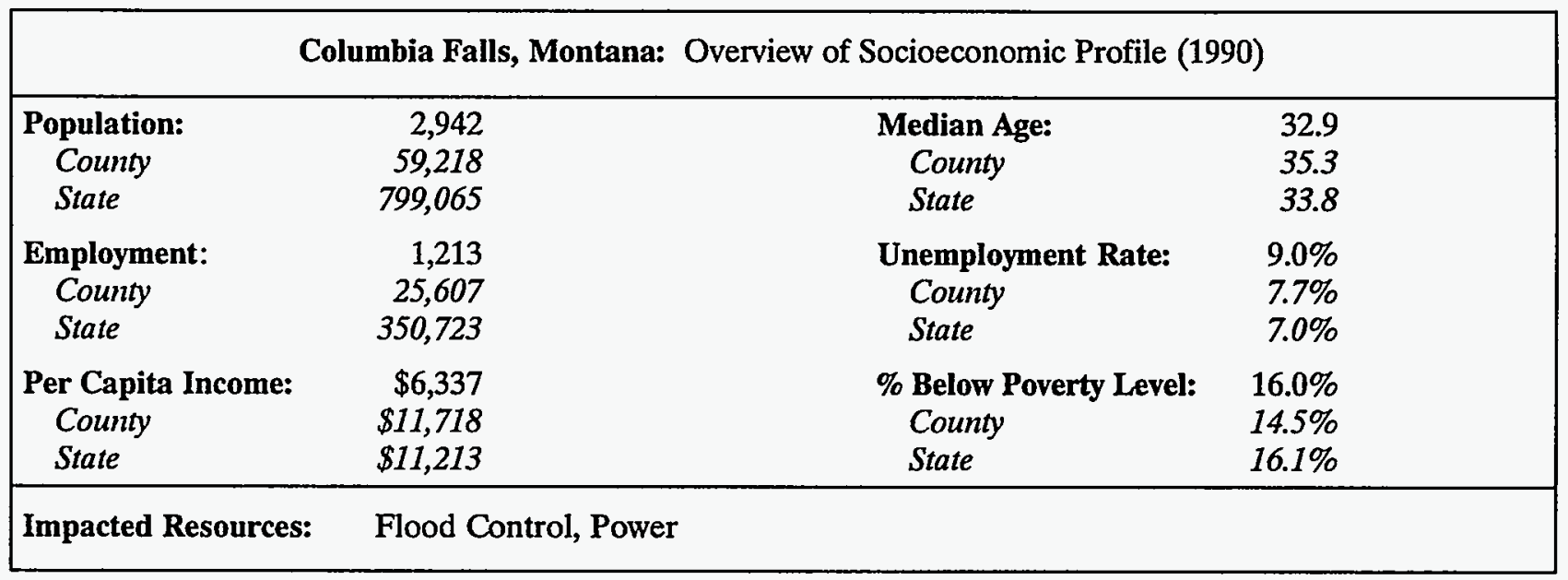

Table F-8. Evaluation of Social Impacts for Columbia Falls, Montana

\begin{tabular}{|c|c|c|c|}
\hline SOS & Evaluation Item & Impact Measure & $\begin{array}{c}\text { Effects } \\
(++,+,-,--)\end{array}$ \\
\hline PA & FLOOD CONTROL & $\begin{array}{c}\text { Decrease in Average Annual } \\
\text { Flood Damages }\end{array}$ & $+t$ \\
\hline $1 \mathrm{a}, 1 \mathrm{~b}$ & POWER & Retail Rate Increase & + \\
\hline All Other & POWER & Retail Rate Decrease & - \\
\hline $1 \mathrm{a}, 1 \mathrm{~b}$ & POWER & $\begin{array}{l}\text { Increase in Subregion } \\
\text { Employment }\end{array}$ & + \\
\hline All Other & POWER & $\begin{array}{c}\text { Decrease in Subregion } \\
\text { Employment }\end{array}$ & - \\
\hline
\end{tabular}




\section{F.3.2.4 FLATHEAD INDIAN RESERVATION}

The Flathead Indian Reservation, located in northwestern Montana, would be impacted by the effects of the SOR system alternatives on local recreation activity and the expected region-wide changes in retail electric power rates. The Preferred Alternative would also affect expected average annual flood damages to properties in the vicinity of Flathead Lake and below Kerr Dam. Overall, the socioeconomic impacts are expected to be positive under SOS alternatives $1 \mathrm{a}, 1 \mathrm{~b}$, and $9 \mathrm{c}$ and negative under all other SOSs.

Flood Control: The Flathead Indian Reservation would face a slight increase in expected average annual flood damages under the Preferred Alternative.

Recreation: The SOR alternative system strategies would affect operation of Hungry Horse dam, result- ing in varying reservoir levels for Hungry Horse Reservoir. Recreation activities at the reservoir are likely to be impacted. Alternatives $4 \mathrm{c}, 9 \mathrm{~b}, 9 \mathrm{c}$, and the Preferred Alternative are expected to increase reservoir recreation activity. SOSs $4 c$ and $9 c$ are expected to have an increase of eighteen percent in recreation activity. Under the remaining alternatives, recreation activity is expected to decline. SOS $9 \mathrm{a}$ is expected to lead to a thirty percent decline in recreation levels while activity declines under all the other alternatives is expected to be one to three percent.

Power: Region-wide, retail rates under SOSs 1a $\overline{\text { and } 1 \mathrm{~b}}$ would be expected to fall by one-half to one percent relative to current rates. Retail rates are expected to increase under all other SOSs; the increases vary from less than one percent to around four percent. Retail rate changes are expected to be similar for residents and businesses on the Flathead Reservation.

Flathead Indian Reservation: Overview of Socioeconomic Profile (1990)

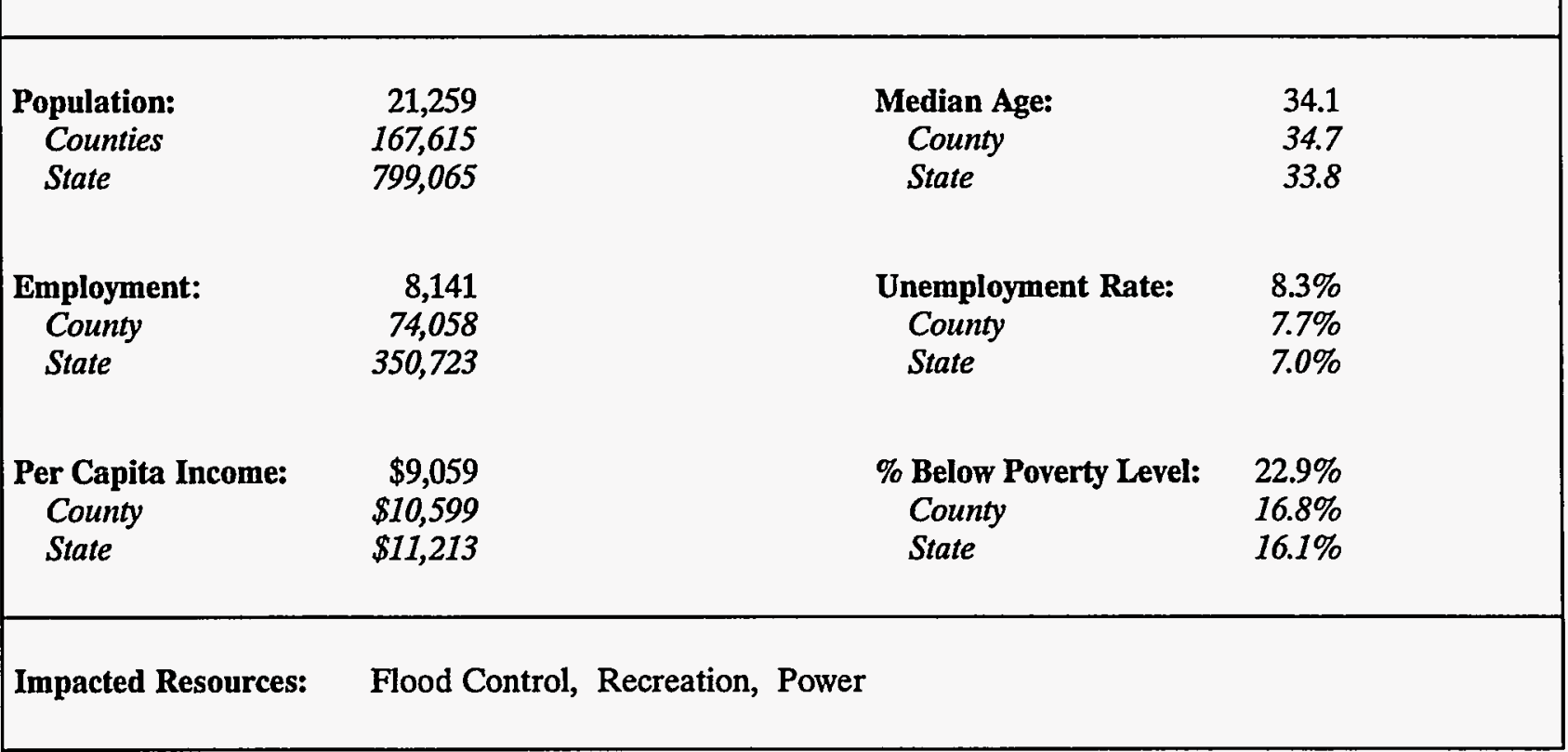


Table F-9. Evaluation of Social Impacts for the Flathead Indian Reservation

\begin{tabular}{|c|c|c|c|}
\hline sos & Evaluation Item & Impact Measure & $\begin{array}{c}\text { Effects } \\
(++,+,-,--)\end{array}$ \\
\hline PA & FLOOD CONTROL & $\begin{array}{c}\text { Decrease in Average Annual } \\
\text { Flood Damages }\end{array}$ & - \\
\hline PA & RECREATION & $\begin{array}{l}\text { Increase in Visitor Days: } \\
\text { Hungry Horse Reservoir }\end{array}$ & + \\
\hline $4 c, 9 b, 9 c$ & RECREATION & $\begin{array}{l}\text { Increase in Visitor Days: } \\
\text { Hungry Horse Reservoir }\end{array}$ & ++ \\
\hline $9 a$ & RECREATION & $\begin{array}{l}\text { Decrease in Visitor Days: } \\
\text { Hungry Horse Reservoir }\end{array}$ & - \\
\hline All Other & RECREATION & $\begin{array}{l}\text { Decrease in Visitor Days: } \\
\text { Hungry Horse Reservoir }\end{array}$ & - \\
\hline $4 c, 9 b, 9 c, P A$ & RECREATION & Increase in Subregion Employment & + \\
\hline All Other & RECREATION & Decrease in Subregion Employment & - \\
\hline $1 \mathrm{a}, 1 \mathrm{~b}$ & POWER & Retail Rate Decrease & + \\
\hline All Other & POWER & Retail Rate Increase & - \\
\hline $1 \mathrm{a}, 1 \mathrm{~b}$ & POWER & Increase in Subregion Employment & + \\
\hline All Other & POWER & Decrease in Subregion Employment & - \\
\hline
\end{tabular}

\section{F.3.2.5 BONNERS FERRY, IDAHO}

The community of Bonners Ferry, Idaho would be impacted primarily by the effects of the SOR system alternatives on region-wide changes in retail electric power rates. Several of the SOR alternatives would also affect expected average annual flood damages in the area. Overall, the socioeconomic impacts are expected to be positive under SOS alternatives $1 \mathrm{a}$ and $1 \mathrm{~b}$, and negative under all other SOSs.

Flood Control: Expected average annual flood damages for properties in the vicinity of Bonners
Ferry are expected to increase under SOR alternatives $4 c, 9 a, 9 b, 9 c$, and the Preferred Alternative. The relative increase in average annual damages would be most significant with alternatives $4 \mathrm{c}$ and PA.

Power: Region-wide, retail rates under SOSs 1a $\overline{\text { and } 1 \mathrm{~b}}$ would be expected to fall by one-half to one percent relative to current rates. Retail rates are expected to increase under all other SOSs; the increases vary from less than one percent to around four percent. Retail rate changes are expected to be similar for residents and businesses in the Bonners Ferry area 
Bonners Ferry, Idaho: Overview of Socioeconomic Profile (1990)

\begin{tabular}{|lrcc|}
\hline Population: & 2,193 & Median Age: & 34.5 \\
County & 8,332 & County & 32.8 \\
State & $1,006,749$ & State & 31.5 \\
Employment: & 868 & Unemployment Rate: & $6.1 \%$ \\
$\quad$ County & 3,045 & County & $8.8 \%$ \\
State & 443,703 & State & $6.3 \%$ \\
Per Capita Income: & $\$ 9,954$ & \% Below Poverty Level: & $16.0 \%$ \\
County & $\$ 9,054$ & County & $14.0 \%$ \\
State & $\$ 11,457$ & State & $13.3 \%$ \\
\hline Impacted Resources: & Flood Control, Power & & \\
\hline
\end{tabular}

Table F-10. Evaluation of Social Impacts for Bonners Ferry, Idaho

\begin{tabular}{|c|c|c|c|}
\hline SOS & Evaluation Item & Impact Measure & $\begin{array}{c}\text { Effects } \\
(++,+,-,-)\end{array}$ \\
\hline $9 \mathrm{a}, 9 \mathrm{~b}, \mathrm{PA}$ & FLOOD CONTROL & $\begin{array}{c}\text { Increase in Average Annual } \\
\text { Flood Damages } \\
\text { Increase in Average Annual } \\
\text { Flood Damages }\end{array}$ & - \\
$4 \mathrm{c}, 9 \mathrm{c}$ & FLOOD CONTROL & Retail Rate Increase & + \\
\hline $1 \mathrm{a}, 1 \mathrm{~b}$ & POWER & Retail Rate Decrease & - \\
All Other & POWER & Increase in Subregion \\
Employment & + \\
\hline 1a, 1b & POWER & $\begin{array}{c}\text { Decrease in Subregion } \\
\text { Employment }\end{array}$ & - \\
\hline
\end{tabular}

\section{F.3.2.6 KOOTENAI INDIAN RESERVATION}

The Kootenai Indian Reservation would be impacted primarily by the effects of the SOR system alternatives on region-wide changes in retail electric power rates. Several of the SOR alternatives would also affect expected average annual flood damages in the area. Overall, the socioeconomic impacts are expected to be positive under SOS alternatives $1 \mathrm{a}$ and $1 \mathrm{~b}$, and negative under all other SOSs.

Flood Control: Expected average annual flood damages for properties in the vicinity of the Koote- nai Reservation are expected to increase under SOR alternatives $4 c, 9 a, 9 b, 9 c$, and the Preferred Alternative. The relative increase in average annual damages would be most significant with alternatives $4 \mathrm{c}$ and PA.

Power: Region-wide, retail rates under SOSs 1a $\overline{\text { and } 1 \mathrm{~b}}$ would be expected to fall by one-half to one percent relative to current rates. Retail rates are expected to increase under all other SOSs; the increases vary from less than one percent to around four percent. Retail rate changes are expected to be similar for the Kootenai Reservation. 


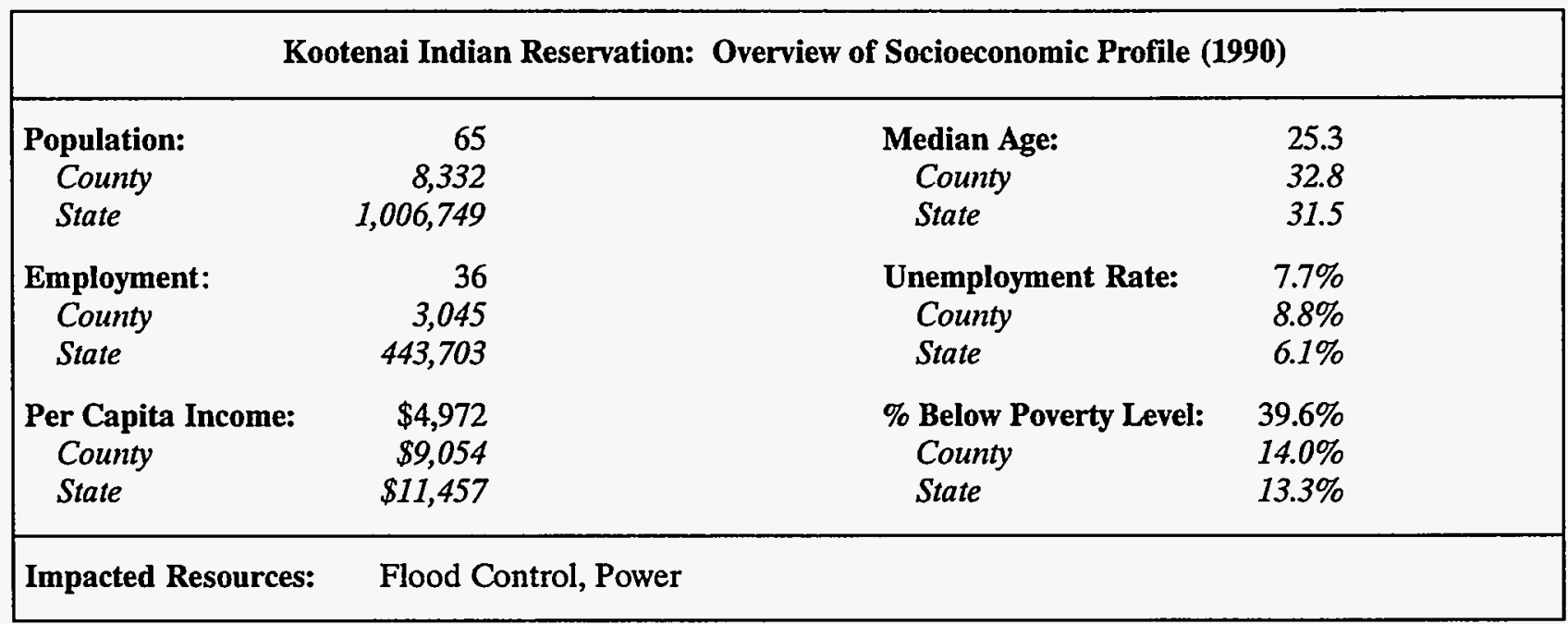

Table F-11. Evaluation of Social Impacts for Kootenai Indian Reservation

\begin{tabular}{|c|c|c|c|}
\hline sos & Evaluation Item & Impact Measure & $\begin{array}{c}\text { Effects } \\
(++,+,-,--)\end{array}$ \\
\hline $9 a, 9 b, P A$ & FLOOD CONTROL & $\begin{array}{c}\text { Increase in Average Annual } \\
\text { Flood Damages }\end{array}$ & - \\
\hline $4 c, 9 c$ & FLOOD CONTROL & $\begin{array}{c}\text { Increase in Average Annual } \\
\text { Flood Damages }\end{array}$ & -- \\
\hline $1 \mathrm{a}, 1 \mathrm{~b}$ & POWER & Retail Rate Increase & + \\
\hline All Other & POWER & Retail Rate Decrease & - \\
\hline $1 \mathrm{a}, 1 \mathrm{~b}$ & POWER & Increase in Subregion Employment & + \\
\hline All Other & POWER & Decrease in Subregion Employment & - \\
\hline
\end{tabular}

\section{F.3.2.7 OROFINO, IDAHO}

The community of Orofino, Idaho would be affected by the impacts of the SOR system alternatives on recreation activity at Dworshak Reservoir and by the expected region-wide changes in retail electric power rates. Overall, the socioeconomic impacts are expected to be positive under SOS alternatives $4 \mathrm{c}$, $5 \mathrm{~b}$, and $5 \mathrm{c}$, and negative under all other SOSs. The effects are expected to be most adverse under SOSs $9 \mathrm{~b}$ and the Preferred Alternative.

Recreation: Alternative operations of the Columbia-Snake River system would include modifications of operations of Dworshak Dam, resulting in adjusted water levels at Dworshak Reservoir. Water flows along the portions of the Clearwater River below the dam would also be affected. It is expected that recreation activities Dworshak Reservoir would be affected by the change in operations. Under all but three of the SOS alternatives, recreation activity is expected to decline relative to current visitor levels. Alternatives $4 c, 5 b$, and $5 c$ are expected to increase reservoir recreation activity by three percent, six percent, and thirteen percent, respectively. The most significant losses in visitor days would occur under SOS 9b, with a 34 percent decline, and under the Preferred Alternative, with a 26 percent 
decline. Activity under all the remaining alternatives is expected to decline by one to ten percent.

Power: Specific retail power rate impacts for the vicinity of Orofino have not been measured. Region-wide however, retail rates under SOSs 1a and $1 \mathrm{~b}$ would be expected to fall by one-half to one percent relative to current rates. Retail rates are expected to increase under all other SOSs; the increases vary from less than one percent to around four percent. Retail rate changes are expected to be similar for residents and businesses in the Orofino area.

\begin{tabular}{|lccc|}
\hline \multicolumn{4}{c}{ Orofino, Idaho: Overview of Socioeconomic Profile (1990) } \\
\hline Population: & 2,868 & Median Age: & 39.0 \\
County & 8,505 & County & 31.5 \\
State & $1,006,749$ & State & $11.8 \%$ \\
Employment: & 1,162 & Unemployment Rate: & $14.0 \%$ \\
County & 3,061 & County & $6.1 \%$ \\
State & 443,703 & State & $11.0 \%$ \\
Per Capita Income: & $\$ 12,251$ & \% Below Poverty Level: & $12.2 \%$ \\
County & $11,234 \$$ & County & $13.3 \%$ \\
State & $11,457 \$$ & State & \\
\hline Impacted Resources: & Recreation, Power & & \\
\hline
\end{tabular}

Table F-12. Evaluation of Social Impacts for Orofino, Idaho

\begin{tabular}{|c|c|c|c|}
\hline SOS & Evaluation Item & Impact Measure & $\begin{array}{c}\text { Effects } \\
(++,+,-,--)\end{array}$ \\
\hline $4 c$ & RECREATION & $\begin{array}{l}\text { Increase in Visitor Days: } \\
\text { Dworshak Reservoir }\end{array}$ & + \\
\hline $5 b, 5 c$ & RECREATION & $\begin{array}{l}\text { Increase in Visitor Days: } \\
\text { Dworshak Reservoir }\end{array}$ & ++ \\
\hline $6 \mathrm{~b}, 6 \mathrm{~d}$ & RECREATION & $\begin{array}{c}\text { Decrease in Visitor Days: } \\
\text { Dworshak Reservoir }\end{array}$ & - \\
\hline All Other & RECREATION & $\begin{array}{l}\text { Decrease in Visitor Days: } \\
\text { Dworshak Reservoir }\end{array}$ & -- \\
\hline $1 b, 2 d, 4 c$ & RECREATION & Increase in Subregion Employment & + \\
\hline All Other & RECREATION & Decrease in Subregion Employment & - \\
\hline $1 \mathrm{a}, 1 \mathrm{~b}$ & POWER & Retail Rate Increase & + \\
\hline All Other & POWER & Retail Rate Decrease & - \\
\hline $1 \mathrm{a}, 1 \mathrm{~b}$ & POWER & Increase in Subregion Employment & + \\
\hline All Other & POWER & Decrease in Subregion Employment & - \\
\hline
\end{tabular}




\section{F.3.2.8 NEZ PERCE INDIAN RESERVATION}

The Nez Perce Indian Reservation would be affected by the impacts of the SOR system alternatives on recreation and sport fishing activity at Dworshak Reservoir and along the Clearwater River below Dworshak Dam. The reservation would also be impacted by the expected region-wide changes in retail electric power rates. Overall, the socioeconomic impacts are expected to be minimal under SOS alternative $4 \mathrm{c}$ and negative under all other SOSs. The effects are expected to be most adverse under SOSs $6 \mathrm{~b}, 9 \mathrm{a}$, and $9 \mathrm{~b}$, where reductions in winter steelhead harvest would range from fifty to sixty percent.

Anadromous Fish: The winter steelhead fishing along the Clearwater River below Dworshak Dam is one of the most important fisheries along the upper stretches of the Columbia-Snake River system. Under all of the proposed SOR alternatives, sport harvest in this fishery is expected to decline. The most significant reductions occur under SOSs $5 c, 6 b$, $9 \mathrm{a}$, and $9 \mathrm{~b}$, where reductions in winter steelhead harvest would reach $30,50,60$, and 50 percent, respectively.
Recreation: Recreation activities Dworshak Reservoir would be affected by the proposed change in river system operations. Under all but three of the SOS alternatives, recreation activity is expected to decline relative to current visitor levels. Alternatives $4 c, 5 b$, and $5 c$ are expected to increase reservoir recreation activity by three percent, six percent, and thirteen percent, respectively. The most significant losses in visitor days would occur under SOS $9 b$, with a 34 percent decline, and under the Preferred Alternative, with a 26 percent decline. Activity under all the remaining alternatives is expected to decline by one to ten percent.

Power: Specific retail power rate impacts for the Nez Perce Indian Reservation have not been measured. Region-wide however, retail rates under SOSs $1 \mathrm{a}$ and $1 \mathrm{~b}$ would be expected to fall by onehalf to one percent relative to current rates. Retail rates are expected to increase under all other SOSs; the increases vary from less than one percent to around four percent. Retail rate changes are expected to be similar for residents and businesses on the Nez Perce Reservation.

\begin{tabular}{|c|c|c|c|}
\hline \multicolumn{4}{|c|}{ Nez Perce Indian Reservation: Overview of Socioeconomic Profile (1990) } \\
\hline $\begin{array}{l}\text { Population: } \\
\text { County } \\
\text { State }\end{array}$ & $\begin{array}{r}16,160 \\
59,558 \\
1,006,749\end{array}$ & $\begin{array}{l}\text { Median Age: } \\
\text { County } \\
\text { State }\end{array}$ & $\begin{array}{l}36.9 \\
36.6 \\
31.5\end{array}$ \\
\hline $\begin{array}{l}\text { Employment: } \\
\text { County } \\
\text { State }\end{array}$ & $\begin{array}{r}5,948 \\
24,943 \\
443,703\end{array}$ & $\begin{array}{l}\text { Unemployment Rate: } \\
\text { County } \\
\text { State }\end{array}$ & $\begin{array}{r}12.5 \% \\
9.7 \% \\
6.1 \%\end{array}$ \\
\hline $\begin{array}{l}\text { Per Capita Income: } \\
\text { County } \\
\text { State }\end{array}$ & $\begin{array}{l}\$ 10,268 \\
\$ 11,004 \\
\$ 11,457\end{array}$ & $\begin{array}{l}\text { \% Below Poverty Level: } \\
\text { County } \\
\text { State }\end{array}$ & $\begin{array}{l}15.7 \% \\
12.7 \% \\
13.3 \%\end{array}$ \\
\hline Impacted Resources: & Anadror & & \\
\hline
\end{tabular}


Table F-13. Evaluation of Social Impacts for the Nez Perce Indian Reservation

\begin{tabular}{|c|c|c|c|}
\hline SOS & Evaluation Item & Impact Measure & $\begin{array}{c}\text { Effects } \\
(++,+,-,--)\end{array}$ \\
\hline $\begin{array}{l}\text { 1a, 1b, 2d, 4c, } \\
9 b, P A\end{array}$ & ANADROMOUS FISH & Decline in Fish Harvest & - \\
\hline All Other & ANADROMOUS FISH & Decline in Fish Harvest & -- \\
\hline All & ANADROMOUS FISH & Decrease in Subregion Employment & - \\
\hline $4 c$ & RECREATION & $\begin{array}{l}\text { Increase in Visitor Days: } \\
\text { Dworshak Reservoir }\end{array}$ & + \\
\hline $5 b, 5 c$ & RECREATION & $\begin{array}{l}\text { Increase in Visitor Days: } \\
\text { Dworshak Reservoir }\end{array}$ & ++ \\
\hline $6 b, 6 d$ & RECREATION & $\begin{array}{l}\text { Decrease in Visitor Days: } \\
\text { Dworshak Reservoir }\end{array}$ & - \\
\hline All Other & RECREATION & $\begin{array}{c}\text { Decrease in Visitor Days: } \\
\text { Dworshak Reservoir }\end{array}$ & -- \\
\hline $1 b, 2 d, 4 c$ & RECREATION & Increase in Subregion Employment & + \\
\hline All Other & RECREATION & Decrease in Subregion Employment & - \\
\hline $1 \mathrm{a}, 1 \mathrm{~b}$ & POWER & Retail Rate Increase & + \\
\hline All Other & POWER & Retail Rate Decrease & - \\
\hline $1 \mathrm{a}, 1 \mathrm{~b}$ & POWER & Increase in Subregion Employment & + \\
\hline All Other & POWER & Decrease in Subregion Employment & - \\
\hline
\end{tabular}

\section{F.3.2.9 LEWISTON, IDAHO}

Many of the SOR alternatives would have varied impacts in the Lewiston area, including the effects of changes in recreation activity, navigation costs, sport fishing, power costs, and construction activity. The community of Lewiston, Idaho would be most adversely affected by the effects of the SOR system alternatives on river navigation, where the costs of shipping grain and other commodities to downstream destinations would be significantly increased. The community would also be affected by the impacts of the alternatives on recreation and sport fishing activity at the Lower Snake projects and along the lower reaches of the Clearwater River. Additional impacts would result from the expected region-wide changes in retail electric power rates. It is expected that the community would realize short-term increases in regional employment under those SOR alternatives requiring construction for pump modifications and project implementation. Overall, the socioeconomic impacts are expected to be minimal under SOS alternatives $1 \mathrm{a}$ and $1 \mathrm{~b}$ and negative under all other SOSs. The effects are expected to have significant adverse impacts under the drawdown alternatives, including SOSs $5 \mathrm{~b}, 5 \mathrm{c}$, $6 \mathrm{~b}, 6 \mathrm{~d}, 9 \mathrm{a}$, and $9 \mathrm{c}$.

Anadromous Fish: The winter steelhead fishing along the lower portion of the Clearwater River is one of the most important fisheries along the upper stretches of the Columbia-Snake River system. Under all of the proposed SOR alternatives, sport harvest in this fishery is expected to decline. The most significant reductions occur under SOSs $5 c, 6 b$, $9 \mathrm{a}$, and $9 \mathrm{~b}$, where reductions in winter steelhead harvest would reach $30,50,60$, and 50 percent, respectively. 
Lewiston, Idaho: Overview of Socioeconomic Profile (1990)

\begin{tabular}{|lrcr|}
\hline Population: & 28,082 & Median Age: & 35.3 \\
County & 33,754 & County & 35.6 \\
State & $1,006,749$ & State & 31.5 \\
& & Unemployment Rate: & $6.4 \%$ \\
Employment: & 13,120 & County & $7.3 \%$ \\
County & 15,295 & State & $6.1 \%$ \\
State & 443,703 & \% Below Poverty Level: & $11.3 \%$ \\
Per Capita Income: & $\$ 12,828$ & County & $12.0 \%$ \\
County & $\$ 12,476$ & State & $13.3 \%$ \\
State & $\$ 11,457$ & \multicolumn{2}{|}{} \\
\hline Impacted Resources: & Anadromous Fish, Navigation, Recreation, Power, Construction \\
\hline
\end{tabular}

Navigation: Log rafting operations would be affected under all of the SOR alternatives. Trucking costs associated with the rafting operations would increase slightly with SOSs $2 \mathrm{~d}, 9 \mathrm{~b}$, and PA and would decrease slightly with the other alternatives. The rafting operations are owned by Potlach Corporation, located in Lewiston. Significant adverse impacts related to shallow draft navigation would occur under the drawdown alternatives. The proposed drawdown alternatives would shut down navigation activities for several months of the year. In the case of SOS 5c, navigation would be shutdown permanently. The drawdown alternatives result in significantly increased costs for shipping grain and other commodities to downstream destinations. Transportation activities in the region shift from barge movements to truck-rail shipments.

Recreation: Recreation activities at the four Lower Snake River projects would be affected by the proposed change in river system operations. Under all but three of the SOS alternatives, recreation activity is expected to decline relative to current visitor levels. Alternatives $1 \mathrm{a}, 1 \mathrm{~b}$, and $\mathrm{PA}$ are expected to result in minor increases reservoir recreation activity, ranging from one to two percent. The most significant losses in visitor days would occur under alternatives $5 \mathrm{~b}, 5 \mathrm{c}, 6 \mathrm{~b}, 6 \mathrm{~d}$, and $9 \mathrm{a}$, with reductions from 25 to 75 percent. Activity at the four reservoirs under all the remaining alternatives is expected to decline by one to fifteen percent.

Power: Specific retail power rate impacts for the Lewiston area have not been measured. Regionwide however, retail rates under SOSs $1 \mathrm{a}$ and $1 \mathrm{~b}$ would be expected to fall by one-half to one percent relative to current rates. Retail rates are expected to increase under all other SOSs; the increases vary from less than one percent to around four percent. Retail rate changes are expected to be similar for residents and businesses in the vicinity of Lewiston.

Construction: Several of the SOR alternatives would require physical project modifications and mitigation activities in order to achieve the objectives of the operating strategies. The construction activities associated with these actions would generate short-term positive economic benefits to the region through increased employment opportunities. The expected benefits are short-term in that they are expected to last only throughout the duration of the construction activity. Employment increases are expected to occur with SOSs $5 b, 5 c, 6 b, 6 d, 9 a$, and 9c. The most significant increases in construction and related employment would occur with SOS $5 b$ where employment in the region surrounding the Lewiston area would increase by 4,000 jobs annually during the fifteen year construction period. 
Table F-14. Evaluation of Social Impacts for Lewiston, Idaho

\begin{tabular}{|c|c|c|c|}
\hline SOS & Evaluation Item & Impact Measure & $\begin{array}{c}\text { Effects } \\
(++,+,-,--)\end{array}$ \\
\hline $\begin{array}{l}\text { 1a, 1b, 2d, 4c, } \\
9 \mathrm{~b}, \mathrm{PA}\end{array}$ & ANADROMOUS FISH & Decline in Fish Harvest & - \\
\hline All Other & ANADROMOUS FISH & Decline in Fish Harvest & -- \\
\hline All & ANADROMOUS FISH & Decrease in Subregion Employment & - \\
\hline 2d, 9b, PA & RESERVOIR NAVIGATION & Increase in Trucking Costs & - \\
\hline All Other & RESERVOIR NAVIGATION & Decline in Trucking Costs & + \\
\hline 2d, 9b, PA & RESERVOIR NAVIGATION & Decrease in Subregion Employment & - \\
\hline All Other & RESERVOIR NAVIGATION & Increase in Subregion Employment & + \\
\hline $5 b, 5 c, 6 b, 9 a, 9 c$ & $\begin{array}{l}\text { SHALLOW DRAFT } \\
\text { NAVIGATION }\end{array}$ & Increase in Transportation Costs & -- \\
\hline $6 d$ & $\begin{array}{l}\text { SHALLOW DRAFT } \\
\text { NAVIGATION }\end{array}$ & Increase in Transportation Costs & - \\
\hline $5 b, 5 c, 6 b, 9 a, 9 c$ & $\begin{array}{l}\text { SHALLOW DRAFT } \\
\text { NAVIGATION }\end{array}$ & Increase in Subregion Employment & -- \\
\hline $6 d$ & $\begin{array}{l}\text { SHALLOW DRAFT } \\
\text { NAVIGATION }\end{array}$ & Increase in Subregion Employment & - \\
\hline $1 \mathrm{a}, 1 \mathrm{~b}$ & POWER & Retail Rate Increase & + \\
\hline All Other & POWER & Retail Rate Decrease & - \\
\hline $1 \mathrm{a}, 1 \mathrm{~b}$ & POWER & Increase in Subregion Employment & + \\
\hline All Other & POWER & Decrease in Subregion Employment & - \\
\hline $1 b$ & RECREATION & $\begin{array}{l}\text { Increase in Visitor Days: } \\
\text { Lower Snake Projects }\end{array}$ & ++ \\
\hline 1a, PA & RECREATION & $\begin{array}{l}\text { Increase in Visitor Days: } \\
\text { Lower Snake Projects }\end{array}$ & + \\
\hline $4 c$ & RECREATION & $\begin{array}{l}\text { Decrease in Visitor Days: } \\
\text { Lower Snake Projects }\end{array}$ & - \\
\hline All Other & RECREATION & $\begin{array}{l}\text { Decrease in Visitor Days: } \\
\text { Lower Snake Projects }\end{array}$ & -- \\
\hline $1 b, 2 d, 4 c$ & RECREATION & Increase in Subregion Employment & + \\
\hline All Other & RECREATION & Decrease in Subregion Employment & - \\
\hline $\begin{array}{c}5 b, 5 c, 6 b, 6 d \\
9 a, 9 c\end{array}$ & $\begin{array}{c}\text { CONSTRUCTION: } \\
\text { PUMP MODIFICATIONS }\end{array}$ & Increase in Subregion Employment & + \\
\hline $5 b, 5 c, 6 b, 9 a, 9 c$ & $\begin{array}{l}\text { CONSTRUCTION: PROJ- } \\
\text { ECT IMPLEMENTATION }\end{array}$ & Increase in Subregion Employment & $+t$ \\
\hline $6 d$ & $\begin{array}{l}\text { CONSTRUCTION: PROJ- } \\
\text { ECT IMPLEMENTATION }\end{array}$ & Increase in Subregion Employment & + \\
\hline
\end{tabular}




\section{F.3.2.10 CLARKSTON, WASHINGTON}

The impacts of the SOR alternatives in the Clarkston area would be similar to those evaluated for Lewiston and would include the effects of changes in recreation activity, navigation costs, sport fishing, power costs, and construction activity. The community would be most adversely affected by the effects of the SOR system alternatives on river navigation, where the costs of shipping grain and other commodities to downstream destinations would be significantly increased. The community would also be affected by the impacts of the alternatives on recreation and sport fishing activity at the Lower Snake projects and along the lower reaches of the Clearwater River. Additional impacts would result from the expected region-wide changes in retail electric power rates. It is expected that the community would realize short-term increases in regional employment under those SOR alternatives requiring construction for pump modifications and project implementation. Overall, the socioeconomic impacts are expected to be minimal under SOS alternatives $1 \mathrm{a}$ and $1 \mathrm{~b}$ and negative under all other SOSs. The effects are expected to have significant adverse impacts under the drawdown alternatives, including SOSs $5 b, 5 c, 6 b, 6 d, 9 a$, and $9 c$.

Anadromous Fish: The winter steelhead fishing along the lower portion of the Clearwater River is one of the most important fisheries along the upper stretches of the Columbia-Snake River system.
Under all of the proposed SOR alternatives, sport harvest in this fishery is expected to decline. The most significant reductions occur under SOSs $5 c, 6 b$, $9 \mathrm{a}$, and $9 \mathrm{~b}$, where reductions in winter steelhead harvest would reach $30,50,60$, and 50 percent, respectively.

Navigation: Significant adverse impacts related to shallow draft navigation would occur under the drawdown alternatives. The proposed drawdown alternatives would shut down navigation activities for several months of the year. In the case of SOS $5 \mathrm{c}$, navigation would be shutdown permanently. The drawdown alternatives result in significantly increased costs for shipping grain and other commodities to downstream destinations. Transportation activities in the region shift from barge movements to truck-rail shipments.

Recreation: Recreation activities at the four Lower Snake River projects would be affected by the proposed change in river system operations. Under all but three of the SOS alternatives, recreation activity is expected to decline relative to current visitor levels. Alternatives $1 \mathrm{a}, 1 \mathrm{~b}$, and PA are expected to result in minor increases reservoir recreation activity, ranging from one to two percent. The most significant losses in visitor days would occur under alternatives $5 b, 5 c, 6 b, 6 d$, and $9 a$, with reductions from 25 to 75 percent. Activity at the four reservoirs under all the remaining alternatives is expected to decline by one to fifteen percent.

\begin{tabular}{|lccr|}
\hline \multicolumn{4}{|c|}{ Clarkston, Washington: Overview of Socioeconomic Profile (1990) } \\
\hline Population: & 6,753 & Median Age: & 34.8 \\
County & 17,605 & County & 34.9 \\
State & $4,866,692$ & State & 33.1 \\
Employment: & 2,347 & Unemployment Rate: & $11.3 \%$ \\
County & 7,111 & County & $8.4 \%$ \\
State & $2,293,961$ & State & $5.7 \%$ \\
Per Capita Income: & $\$ 8,896$ & \% Below Poverty Level: & $26.4 \%$ \\
County & $\$ 11,379$ & County & $19.4 \%$ \\
State & $\$ 14,923$ & State & $10.9 \%$ \\
\hline Impacted Resources: & Anadromous Fish, Navigation, Recreation, Construction \\
\hline
\end{tabular}


Table F-15. Evaluation of Social Impacts for Clarkston, Washington

\begin{tabular}{|c|c|c|c|}
\hline SOS & Evaluation Item & Impact Measure & $\begin{array}{c}\text { Effects } \\
(++,+,-,-)\end{array}$ \\
\hline $\begin{array}{l}\text { 1a, 1b, 2d, } 4 c \\
9 b, P A\end{array}$ & ANADROMOUS FISH & Decline in Fish Harvest & - \\
\hline All Other & ANADROMOUS FISH & Decline in Fish Harvest & -- \\
\hline All & ANADROMOUS FISH & Decrease in Subregion Employment & - \\
\hline $5 b, 5 c, 6 b, 9 a, 9 c$ & $\begin{array}{l}\text { SHALLOW DRAFT } \\
\text { NAVIGATION }\end{array}$ & Increase in Transportation Costs & -- \\
\hline $6 d$ & $\begin{array}{l}\text { SHALLOW DRAFT } \\
\text { NAVIGATION }\end{array}$ & Increase in Transportation Costs & - \\
\hline $5 b, 5 c, 6 b, 9 a, 9 c$ & $\begin{array}{l}\text { SHALLOW DRAFT } \\
\text { NAVIGATION }\end{array}$ & Decrease in Subregion Employment & -- \\
\hline $6 d$ & $\begin{array}{l}\text { SHALLOW DRAFT } \\
\text { NAVIGATION }\end{array}$ & Decrease in Subregion Employment & - \\
\hline $1 b$ & RECREATION & $\begin{array}{l}\text { Increase in Visitor Days: } \\
\text { Lower Snake Projects }\end{array}$ & ++ \\
\hline 1a, PA & RECREATION & $\begin{array}{l}\text { Increase in Visitor Days: } \\
\text { Lower Snake Projects }\end{array}$ & + \\
\hline $4 c$ & RECREATION & $\begin{array}{l}\text { Decrease in Visitor Days: } \\
\text { Lower Snake Projects }\end{array}$ & - \\
\hline All Other & RECREATION & $\begin{array}{l}\text { Decrease in Visitor Days: } \\
\text { Lower Snake Projects }\end{array}$ & -- \\
\hline $1 b, 2 d, 4 c$ & RECREATION & Increase in Subregion Employment & + \\
\hline All Other & RECREATION & Decrease in Subregion Employment & - \\
\hline $1 \mathrm{a}, 1 \mathrm{~b}$ & POWER & Retail Rate Increase & + \\
\hline All Other & POWER & Retail Rate Decrease & - \\
\hline $1 \mathrm{a}, 1 \mathrm{~b}$ & POWER & Increase in Subregion Employment & + \\
\hline All Other & POWER & Decrease in Subregion Employment & - \\
\hline $\begin{array}{c}5 b, 5 c, 6 b, 6 d \\
9 a, 9 c\end{array}$ & $\begin{array}{l}\text { CONSTRUCTION: } \\
\text { PUMP MODIFICATIONS }\end{array}$ & Increase in Subregion Employment & + \\
\hline $5 b, 5 c, 6 b, 9 a, 9 c$ & $\begin{array}{l}\text { CONSTRUCTION: PROJ- } \\
\text { ECT IMPLEMENTATION }\end{array}$ & Increase in Subregion Employment & ++ \\
\hline $6 \mathrm{~d}$ & $\begin{array}{l}\text { CONSTRUCTION: PROJ- } \\
\text { ECT IMPLEMENTATION }\end{array}$ & Increase in Subregion Employment & + \\
\hline
\end{tabular}


Power: Specific retail power rate impacts for the Clarkston area have not been measured. Regionwide however, retail rates under SOSs $1 \mathrm{a}$ and $1 \mathrm{~b}$ would be expected to fall by one-half to one percent relative to current rates. Retail rates are expected to increase under all other SOSs; the increases vary from less than one percent to around four percent. Retail rate changes are expected to be similar for residents and businesses in the vicinity of Clarkston.

Construction: Several of the SOR alternatives would require physical project modifications and mitigation activities in order to achieve the objectives of the operating strategies. The construction activities associated with these actions would generate short-term positive economic benefits to the region through increased employment opportunities. The expected benefits are short-term in that they are expected to last only throughout the duration of the construction activity. Employment increases are expected to occur with SOSs $5 \mathrm{~b}, 5 \mathrm{c}, 6 \mathrm{~b}, 6 \mathrm{~d}, 9 \mathrm{a}$, and 9c. The most significant increases in construction and related employment would occur with SOS $5 b$ where employment in the region surrounding the Clarkston area would increase by 4,000 jobs annually during the fifteen year construction period.

\section{F.3.2.11 GRAND COULEE AND COULEE DAM, WASHINGTON}

The communities of Grand Coulee and Coulee

Dam, Washington would be impacted by the effects of the SOR system alternatives on local recreation activity and the expected region-wide changes in retail electric power rates. Overall, the socioeconomic impacts are expected to be negative under SOS alternatives $9 \mathrm{a}, 9 \mathrm{~b}$, and $9 \mathrm{c}$, and minimal under all other SOSs.

Recreation: The SOR alternative system strategies would affect reservoir levels for Lake Roosevelt through changes in the operation of Grand Coulee Dam. Consequently, reservoir recreation activities at the lake would be impacted. Under all of the SOS alternatives, recreation activity is expected to decline relative to current visitor levels. The most significant declines are expected to occur under SOSs $9 a, 9 b$, and $9 c$, with reductions in visitor days of 25 percent, 11 percent, and 6 percent, respectively.

Power: Specific retail power rate impacts for the vicinity of Grand Coulee and Coulee Dam have not been measured. Region-wide however, retail rates under SOSs $1 \mathrm{a}$ and $1 \mathrm{~b}$ would be expected to fall by one-half to one percent relative to current rates. Retail rates are expected to increase under all other SOSs; the increases vary from less than one percent to around four percent. Retail rate changes are expected to be similar for residents and businesses in the Grand Coulee and Coulee Dam areas.

\begin{tabular}{|c|c|c|c|}
\hline \multicolumn{4}{|c|}{ Grand Coulee \& Coulee Dam, WA: Overview of Socioeconomic Profile (1990) } \\
\hline $\begin{array}{l}\text { Population: } \\
\text { County } \\
\text { State }\end{array}$ & $\begin{array}{r}2,071 \\
88,108 \\
4,866,692\end{array}$ & $\begin{array}{l}\text { Median Age: } \\
\text { County } \\
\text { State }\end{array}$ & $\begin{array}{l}41.3 \\
33.1 \\
33.1\end{array}$ \\
\hline $\begin{array}{l}\text { Employment: } 795 \\
\text { County } \\
\text { State }\end{array}$ & $\begin{array}{r}35,921 \\
2,293,961\end{array}$ & $\begin{array}{l}\text { Unemployment Rate: } \\
\text { County } \\
\text { State }\end{array}$ & $\begin{array}{l}8.1 \% \\
8.7 \% \\
5.7 \%\end{array}$ \\
\hline $\begin{array}{l}\text { Per Capita Income: } \\
\text { County } \\
\text { State }\end{array}$ & $\begin{array}{l}\$ 12,901 \\
\$ 10,364 \\
\$ 14,923\end{array}$ & $\begin{array}{l}\text { \% Below Poverty Level: } \\
\text { County } \\
\text { State }\end{array}$ & $\begin{array}{l}15.5 \% \\
20.4 \% \\
10.9 \%\end{array}$ \\
\hline Impacted Resources: & Recreation, Power & & \\
\hline
\end{tabular}


Table F-16. Evaluation of Social Impacts for Grand Coulee and Coulee Dam, Washington

\begin{tabular}{|c|c|c|c|}
\hline SOS & Evaluation Item & Impact Measure & $\begin{array}{c}\text { Effects } \\
(++,+,-,-)\end{array}$ \\
\hline $9 a, 9 b, 9 c$ & RECREATION & $\begin{array}{c}\text { Decrease in Visitor Days: } \\
\text { Lake Roosevelt }\end{array}$ & -- \\
\hline All Other & RECREATION & $\begin{array}{l}\text { Decrease in Visitor Days: } \\
\text { Lake Roosevelt }\end{array}$ & - \\
\hline All Other & RECREATION & Decrease in Subregion Employment & - \\
\hline $1 \mathrm{a}, 1 \mathrm{~b}$ & POWER & Retail Rate Increase & + \\
\hline All Other & POWER & Retail Rate Decrease & - \\
\hline $1 \mathrm{a}, 1 \mathrm{~b}$ & POWER & Increase in Subregion Employment & + \\
\hline All Other & POWER & Decrease in Subregion Employment & - \\
\hline
\end{tabular}

\section{F.3.2.12 COLVILLE INDIAN RESERVATION}

The Colville Indian Reservation would be impacted by the effects of the SOR system alternatives on local recreation activity and the expected regionwide changes in retail electric power rates. Overall, the socioeconomic impacts are expected to be negative under SOS alternatives $9 \mathrm{a}, 9 \mathrm{~b}$, and $9 \mathrm{c}$, and minimal under all other SOSs.

Recreation: The SOR alternative system strategies would affect reservoir levels for Lake Roosevelt through changes in the operation of Grand Coulee Dam. Consequently, reservoir recreation activities at the lake would be impacted. Under all of the SOS alternatives, recreation activity is expected to decline relative to current visitor levels. The most significant declines are expected to occur under SOSs $9 \mathrm{a}, 9 \mathrm{~b}$, and $9 \mathrm{c}$, with reductions in visitor days of 25 percent, 11 percent, and 6 percent, respectively.

Power: Specific retail power rate impacts for the Colville Indian Reservation have not been measured. Region-wide however, retail rates under SOSs 1a and $1 \mathrm{~b}$ would be expected to fall by one-half to one percent relative to current rates. Retail rates are expected to increase under all other SOSs; the increases vary from less than one percent to around four percent. Retail rate changes are expected to be similar for the Colville Reservation.

\begin{tabular}{|lccc|}
\hline \multicolumn{4}{c}{ Colville Indian Reservation: } \\
\hline Population: & 6,957 & Median Age: & 30.7 \\
County & 11,700 & County & 31.8 \\
State & $4,866,692$ & State & 33.1 \\
Employment: & 2,332 & Unemployment Rate: & $18.5 \%$ \\
County & 4,217 & County & $16.2 \%$ \\
State & $2,293,96,1$ & State & $5.7 \%$ \\
Per Capita Income: & $\$ 8,897$ & \% Below Poverty Level: & $27.5 \%$ \\
County & $\$ 9,519$ & County & $25.0 \%$ \\
State & $\$ 14,923$ & State & $10.9 \%$ \\
\hline Impacted Resources: & Recreation, Power & & \\
\hline
\end{tabular}


Table F-17. Evaluation of Social Impacts for the Colville Indian Reservation

\begin{tabular}{|c|c|c|c|}
\hline SOS & Evaluation Item & Impact Measure & $\begin{array}{c}\text { Effects } \\
(t+,+,-,--)\end{array}$ \\
\hline $9 a, 9 b, 9 c$ & RECREATION & $\begin{array}{c}\text { Decrease in Visitor Days: } \\
\text { Lake Roosevelt }\end{array}$ & -- \\
\hline All Other & RECREATION & $\begin{array}{l}\text { Decrease in Visitor Days: } \\
\text { Lake Roosevelt }\end{array}$ & - \\
\hline All Other & RECREATION & Decrease in Subregion Employment & - \\
\hline $1 \mathrm{a}, 1 \mathrm{~b}$ & POWER & Retail Rate Increase & + \\
\hline All Other & POWER & Retail Rate Decrease & - \\
\hline $1 \mathrm{a}, 1 \mathrm{~b}$ & POWER & Increase in Subregion Employment & + \\
\hline All Other & POWER & Decrease in Subregion Employment & - \\
\hline
\end{tabular}

\section{F.3.2.13 SPOKANE INDIAN RESERVATION}

The Spokane Indian Reservation would be impacted by the effects of the SOR system alternatives on local recreation activity and the expected regionwide changes in retail electric power rates. Overall, the socioeconomic impacts are expected to be negative under SOS alternatives $9 a, 9 b$, and $9 c$, and minimal under all other SOSs.

Recreation: The SOR alternative system strategies would affect reservoir levels for Lake Roosevelt through changes in the operation of Grand Coulee Dam. Consequently, reservoir recreation activities at the lake would be impacted. Under all of the SOS alternatives, recreation activity is expected to decline relative to current visitor levels. The most significant declines are expected to occur under SOSs $9 a, 9 b$, and $9 c$, with reductions in visitor days of 25 percent, 11 percent, and 6 percent, respectively.

Power: Specific retail power rate impacts for the Spokane Indian Reservation have not been measured. Region-wide however, retail rates under SOSs $1 \mathrm{a}$ and $1 \mathrm{~b}$ would be expected to fall by onehalf to one percent relative to current rates. Retail rates are expected to increase under all other SOSs; the increases vary from less than one percent to around four percent. Retail rate changes are expected to be similar for the Spokane Reservation.

\begin{tabular}{|c|c|c|c|}
\hline \multicolumn{4}{|c|}{ Spokane Indian Reservation: Overview of Socioeconomic Profile (1990) } \\
\hline Population: & 1,502 & Median Age: & 26.0 \\
\hline County & 39,812 & County & 36.9 \\
\hline State & $4,866,692$ & State & 33.1 \\
\hline Employment: & 352 & Unemployment Rate: & $27.4 \%$ \\
\hline County & 15,197 & County & $9.2 \%$ \\
\hline State & $2,293,961$ & State & $5.7 \%$ \\
\hline Per Capita Income: & $\$ 6,022$ & \% Below Poverty Level: & $37.1 \%$ \\
\hline County & $\$ 11,281$ & County & $16.1 \%$ \\
\hline State & $\$ 14,923$ & State & $10.9 \%$ \\
\hline \multicolumn{4}{|c|}{ Recreation, Power } \\
\hline
\end{tabular}


Table F-18. Evaluation of Social Impacts for the Spokane Indian Reservation

\begin{tabular}{|c|c|c|c|}
\hline SOS & Evaluation Item & Impact Measure & $\begin{array}{c}\text { Effects } \\
(++,+,-,--)\end{array}$ \\
\hline $9 a, 9 b, 9 c$ & RECREATION & $\begin{array}{l}\text { Decrease in Visitor Days: } \\
\text { Lake Roosevelt }\end{array}$ & -- \\
\hline All Other & RECREATION & $\begin{array}{l}\text { Decrease in Visitor Days: } \\
\text { Lake Roosevelt }\end{array}$ & - \\
\hline All Other & RECREATION & $\begin{array}{c}\text { Decrease in Subregion } \\
\text { Employment }\end{array}$ & - \\
\hline $1 \mathrm{a}, 1 \mathrm{~b}$ & POWER & Retail Rate Increase & + \\
\hline All Other & POWER & Retail Rate Decrease & - \\
\hline $1 \mathrm{a}, 1 \mathrm{~b}$ & POWER & $\begin{array}{c}\text { Increase in Subregion } \\
\text { Employment }\end{array}$ & + \\
\hline All Other & POWER & $\begin{array}{c}\text { Decrease in Subregion } \\
\text { Employment }\end{array}$ & - \\
\hline
\end{tabular}

\section{F.3.2.14 TRI-CITIES, WASHINGTON}

The impacts of the SOR alternatives in the Tri-Cities area would include the effects of changes in recreation activity, navigation costs, sport fishing, irrigation and water supply pumping costs, power costs, and construction activity. The community would be adversely impacted by the effects of the SOR system alternatives on irrigation and water supply pumping costs, regional power costs, and reservoir recreation activity. The Tri-Cities would receive some positive impacts as a result of the expected lower costs for transportation of grain and other commodities. It is expected that the community would also realize short-term increases in regional employment under those SOR alternatives requiring construction for pump modifications and project implementation. Overall, the socioeconomic impacts are expected to be minimal under SOS alternatives $1 \mathrm{a}, 1 \mathrm{~b}, 2 \mathrm{~d}$, and $4 \mathrm{c}$ and negative under all other SOSs. The effects are expected to have significant adverse impacts under alternatives SOS 9c and
PA, primarily related to increased pumping costs and declines in recreation activity.

Anadromous Fish: Sport fishing along the middle section of the Columbia River (Bonneville Dam to the confluence with the Snake River) includes the harvest of both fall chinook and winter steelhead, with steelhead accounting for nearly 90 percent of the harvest. Under all of the proposed SOR alternatives, the overall level of sport harvest along this portion of the river is expected to decline. The most significant reductions occur under SOSs $5 c, 6 b, 9 a$, and $9 c$.

Irrigation and M\&I Water Supply: It is expected that irrigation pumping costs will increase under the SOR alternatives which include drawdown of the Ice Harbor pool, leading to a reduction in net farm income available to regional farmers. Annual irrigation pumping costs are expected to increase significantly with SOSs $5 b, 5 c, 6 b, 9 a$, and $9 c$. These alternatives would also result in increased pumping costs for the municipal and industrial pumps located in the Ice Harbor pool. 
Tri-Cities, Washington: Overview of Socioeconomic Profile (1990)

\begin{tabular}{|c|c|c|c|}
\hline Population: & 94,807 & Median Age: & 31.0 \\
\hline County & 150,033 & County & 31.3 \\
\hline State & $4,866,692$ & State & 33.1 \\
\hline Employment: & 43,129 & Unemployment Rate: & $7.2 \%$ \\
\hline County & 68,126 & County & $6.6 \%$ \\
\hline State & $2,293,961$ & State & $5.7 \%$ \\
\hline Per Capita Income: & $\$ 13,446$ & \% Below Poverty Level: & $15.9 \%$ \\
\hline County & $\$ 13,215$ & County & $14.1 \%$ \\
\hline State & $\$ 14,923$ & State & $10.9 \%$ \\
\hline Impacted Resources: & Anadro & gation, Recreation, Power & Construction \\
\hline
\end{tabular}

Navigation: It is expected that under the drawdown alternatives the transportation costs for shipping grain and other commodities to downstream destinations will decline for producers in the vicinity of the Tri-Cities. Reductions in transportation costs are expected for SOSs $5 b, 5 c, 6 b, 6 d, 9 a$, and $9 c$.

Recreation: Recreation activities at the John Day and Lower Snake River projects would be affected by the proposed change in river system operations. Under all but three of the SOS alternatives, recreation activity is expected to decline relative to current visitor levels. Alternatives 1a, 1b, and PA are expected to result in increases reservoir recreation activity, primarily at the John Day reservoir. The remaining alternatives are expected to lead to declines in reservoir recreation activity. The most significant losses in visitor days at the Lower Snake projects would occur under alternatives $5 b, 5 c, 6 b$, and 9a. Reductions in recreation at John Day would be significant under the Preferred Alternative.

Power: Specific retail power rate impacts for the Tri-Cities area have not been measured. Regionwide however, retail rates under SOSs $1 \mathrm{a}$ and $1 \mathrm{~b}$ would be expected to fall by one-half to one percent relative to current rates. Retail rates are expected to increase under all other SOSs; the increases vary from less than one percent to around four percent. Retail rate changes are expected to be similar for residents and businesses in the vicinity of the Tri-Cities.

Construction: Several of the SOR alternatives would require physical project modifications and mitigation activities in order to achieve the objectives of the operating strategies. The construction activities associated with these actions would generate short-term positive economic benefits to the region through increased employment opportunities. The expected benefits are short-term in that they are expected to last only throughout the duration of the construction activity. Employment increases are expected to occur with SOSs 5b, 5c, 6b, 6d, 9a, and 9c. The most significant increases in construction and related employment would occur with SOS $5 \mathrm{~b}$ where employment in the region surrounding the Tri-Cities area would increase by 2,900 jobs annually during the fifteen year construction period. 
Table F-19. Evaluation of Social Impacts for Tri-Cities, Washington

\begin{tabular}{|c|c|c|c|}
\hline sos & Evaluation Item & Impact Measure & $\begin{array}{c}\text { Effects } \\
(++,+,-,-)\end{array}$ \\
\hline $2 \mathrm{~d}, 4 \mathrm{c}, \mathrm{PA}$ & ANADROMOUS FISH & Increase in Fish Harvest & + \\
\hline $1 a, 1 b, 9 b$ & ANADROMOUS FISH & Decline in Fish Harvest & - \\
\hline All Other & ANADROMOUS FISH & Decline in Fish Harvest & -- \\
\hline $2 \mathrm{~d}, 4 \mathrm{c}$ & ANADROMOUS FISH & Increase in Subregion Employment & + \\
\hline All Other & ANADROMOUS FISH & Decrease in Subregion Employment & - \\
\hline $5 b, 5 c, 6 b, 9 a, 9 c$ & IRRIGATION & $\begin{array}{l}\text { Decrease in Per Acre } \\
\text { Net Farm Income }\end{array}$ & -- \\
\hline $\begin{array}{c}5 \mathrm{~b}, 5 \mathrm{c}, 6 \mathrm{~b}, 6 \mathrm{~d} \\
9 \mathrm{a}, 9 \mathrm{c}, \mathrm{PA}\end{array}$ & IRRIGATION & Decrease in Subregion Employment & - \\
\hline $5 b, 5 c, 6 b, 9 a, 9 c$ & M\&I WATER SUPPLY & Increase in Pumping Costs & - \\
\hline $\begin{array}{c}5 b, 5 c, 6 b, 6 d \\
9 a, 9 c, P A\end{array}$ & M\&I WATER SUPPLY & Decrease in Subregion Employment & - \\
\hline $5 b, 5 c, 6 b, 9 a, 9 c$ & $\begin{array}{l}\text { SHALLOW DRAFT } \\
\text { NAVIGATION }\end{array}$ & Decrease in Transportation Costs & ++ \\
\hline $6 d$ & $\begin{array}{l}\text { SHALLOW DRAFT } \\
\text { NAVIGATION }\end{array}$ & Decrease in Transportation Costs & + \\
\hline $\begin{array}{c}5 b, 5 c, 6 b, 6 d \\
9 a, 9 c\end{array}$ & $\begin{array}{l}\text { SHALLOW DRAFT } \\
\text { NAVIGATION }\end{array}$ & Increase in Subregion Employment & + \\
\hline $1 b$ & RECREATION & $\begin{array}{l}\text { Increase in Visitor Days: John Day/ } \\
\text { Lower Snake Projects }\end{array}$ & ++ \\
\hline 1a, PA & RECREATION & $\begin{array}{l}\text { Increase in Visitor Days: John Day/ } \\
\text { Lower Snake Projects }\end{array}$ & + \\
\hline $4 c$ & RECREATION & $\begin{array}{c}\text { Decrease in Visitor Days: John Day/ } \\
\text { Lower Snake Projects }\end{array}$ & - \\
\hline $\begin{array}{l}5 \mathrm{~b}, 5 \mathrm{c}, 6 \mathrm{~b}, 6 \mathrm{~d} \\
\quad 9 \mathrm{a}, 9 \mathrm{~b}, 9 \mathrm{c}\end{array}$ & RECREATION & $\begin{array}{l}\text { Decrease in Visitor Days: John Day/ } \\
\text { Lower Snake Projects }\end{array}$ & -- \\
\hline $1 \mathrm{a}, 1 \mathrm{~b}, 4 \mathrm{c}$ & RECREATION & Increase in Subregion Employment & + \\
\hline $\begin{array}{l}5 \mathrm{~b}, 5 \mathrm{c}, 6 \mathrm{~b}, 6 \mathrm{~d} \\
9 \mathrm{a}, 9 \mathrm{~b}, 9 \mathrm{c}, \mathrm{PA}\end{array}$ & RECREATION & Decrease in Subregion Employment & - \\
\hline $1 \mathrm{a}, 1 \mathrm{~b}$ & POWER & Retail Rate Increase & + \\
\hline All Other & POWER & Retail Rate Decrease & - \\
\hline $1 \mathrm{a}, 1 \mathrm{~b}$ & POWER & Increase in Subregion Employment & + \\
\hline All Other & POWER & Decrease in Subregion Employment & - \\
\hline
\end{tabular}


Table F-19. Evaluation of Social Impacts for Tri-Cities, Washington - CONT

\begin{tabular}{|c|c|c|c|}
\hline sos & Evaluation Item & Impact Measure & $\begin{array}{c}\text { Effects } \\
(++,+,-,--)\end{array}$ \\
\hline $\begin{array}{c}5 b, 5 c, 6 b, 6 d \\
9 a, 9 c\end{array}$ & $\begin{array}{c}\text { CONSTRUCTION: } \\
\text { PUMP MODIFICATIONS }\end{array}$ & Increase in Subregion Employment & + \\
\hline $5 b, 5 c$ & $\begin{array}{l}\text { CONSTRUCTION: PROJ- } \\
\text { ECT IMPLEMENTATION }\end{array}$ & Increase in Subregion Employment & ++ \\
\hline $\begin{array}{c}6 \mathrm{~b}, 6 \mathrm{~d}, 9 \mathrm{a}, 9 \mathrm{c}, \\
\text { PA }\end{array}$ & $\begin{array}{l}\text { CONSTRUCTION: PROJ- } \\
\text { ECT IMPLEMENTATION }\end{array}$ & Increase in Subregion Employment & + \\
\hline
\end{tabular}

\section{F.3.2.15 UMATILLA/MORROW, OREGON}

The impacts of the SOR alternatives in Oregon's Umatilla and Morrow counties would include the effects of changes in recreation activity, navigation costs, irrigation and water supply pumping costs, power costs, and construction activity. The communities would be adversely impacted by the effects of the SOR system alternatives on irrigation and water supply pumping costs, regional power costs, and reservoir recreation activity. The Umatilla/Morrow area would receive some positive impacts as a result of the expected lower costs for transportation of grain and other commodities. It is expected that the communities would also realize short-term increases in regional employment under those SOR alternatives requiring construction for pump modifications and project implementation. Overall, the socioeconomic impacts are expected to be minimal under SOS alternatives $1 \mathrm{a}, 1 \mathrm{~b}, 2 \mathrm{~d}$, and $4 \mathrm{c}$ and nega- tive under all other SOSs. The effects are expected to have significant adverse impacts under alternatives SOS $9 \mathrm{c}$ and PA, primarily related to increased pumping costs and declines in recreation activity.

Irrigation and M\&I Water Supply: It is expected that irrigation pumping costs will increase under the SOR alternatives which include drawdown of the John Day pool, leading to a reduction in net farm income available to regional farmers. Annual irrigation pumping costs are expected to increase significantly with SOSs 5b, 5c, 6b, 6d, 9a, 9c, and PA. These alternatives would also result in increased pumping costs for the municipal and industrial pumps located in the John Day pool. Annual pumping costs for the City of Boardman are expected to increase by approximately $\$ 170,000$ annually while pumping costs for the City of Umatilla and the Port of Morrow are expected to each increase by $\$ 20,000$ annually.

\begin{tabular}{|c|c|c|c|}
\hline \multicolumn{4}{|c|}{ Umatilla/Morrow, Oregon: Overview of Socioeconomic Profile (1990) } \\
\hline $\begin{array}{l}\text { Population: } \\
\text { County } \\
\text { State }\end{array}$ & $\begin{array}{r}4,433 \\
66,874 \\
2,842,321\end{array}$ & $\begin{array}{l}\text { Median Age: } \\
\text { County } \\
\text { State }\end{array}$ & $\begin{array}{l}27.8 \\
33.2 \\
34.5\end{array}$ \\
\hline $\begin{array}{l}\text { Employment: } \\
\text { County } \\
\text { State }\end{array}$ & $\begin{array}{r}1,866 \\
28,850 \\
1,319,960\end{array}$ & $\begin{array}{l}\text { Unemployment Rate: } \\
\text { County } \\
\text { State }\end{array}$ & $\begin{array}{r}11.6 \% \\
8.5 \% \\
6.2 \%\end{array}$ \\
\hline $\begin{array}{l}\text { Per Capita Income: } \\
\text { County } \\
\text { State }\end{array}$ & $\begin{array}{r}\$ 8,599 \\
\$ 11,092 \\
\$ 13,418\end{array}$ & $\begin{array}{l}\text { \% Below Poverty Level: } \\
\text { County } \\
\text { State }\end{array}$ & $\begin{array}{l}21.6 \% \\
16.4 \% \\
12.4 \%\end{array}$ \\
\hline \multicolumn{4}{|c|}{ Irrigation, Navigation, Recreation, Power, Construction } \\
\hline
\end{tabular}


Navigation: It is expected that under the drawdown alternatives the transportation costs for shipping grain and other commodities to downstream destinations will decline for producers in Umatilla and Morrow Counties. Reductions in transportation costs are expected for SOSs $5 b, 5 c, 6 b, 6 d, 9 a$, and 9c.

Recreation: Recreation activities at the John Day reservoir would be affected by the proposed change in river system operations. Under five of the SOS alternatives, recreation activity is expected to increase or remain constant relative to current visitor levels. Alternatives $1 \mathrm{a}, 1 \mathrm{~b}$, and $4 \mathrm{c}$ are expected to increase reservoir recreation activity with constant levels expected for SOSs $2 \mathrm{~d}$ and $9 \mathrm{~b}$. The remaining alternatives are expected to lead to declines in reservoir recreation activity. The most significant losses in visitor days would occur under the Preferred Alternative, where recreation activity is expected to decline by over 40 percent.

Power: Specific retail power rate impacts for the Umatilla/Morrow area have not been measured. Region-wide however, retail rates under SOSs 1a and $1 \mathrm{~b}$ would be expected to fall by one-half to one percent relative to current rates. Retail rates are expected to increase under all other SOSs; the increases vary from less than one percent to around four percent. Retail rate changes are expected to be similar for residents and businesses in the vicinity of the Umatilla and Morrow counties.

Construction: Several of the SOR alternatives would require physical project modifications and mitigation activities in order to achieve the objectives of the operating strategies. The construction activities associated with these actions would generate short-term positive economic benefits to the region through increased employment opportunities. The expected benefits are short-term in that they are expected to last only throughout the duration of the construction activity. Employment increases are expected to occur with SOSs $5 \mathrm{~b}, 5 \mathrm{c}, 6 \mathrm{~b}, 6 \mathrm{~d}, 9 \mathrm{a}$, and 9c. The most significant increases in construction and related employment would occur with SOS $5 \mathrm{~b}$ where employment in the region including Umatilla and Morrow counties would increase by 2,900 jobs annually during the fifteen year construction period.

Table F-20. Evaluation of Social Impacts for Umatilla/Morrow, Oregon

\begin{tabular}{|c|c|c|c|}
\hline sos & Evaluation Item & Impact Measure & $\begin{array}{c}\text { Effects } \\
(++,+,-,-)\end{array}$ \\
\hline $\begin{array}{c}5 \mathrm{~b}, 5 \mathrm{c}, 6 \mathrm{~b}, 6 \mathrm{~d}, \\
9 \mathrm{a}, 9 \mathrm{c}, \mathrm{PA}\end{array}$ & IRRIGATION & $\begin{array}{c}\text { Decrease in Per Acre } \\
\text { Net Farm Income }\end{array}$ & - \\
\hline $\begin{array}{c}5 \mathrm{~b}, 5 \mathrm{c}, 6 \mathrm{~b}, 6 \mathrm{~d}, \\
9 \mathrm{a}, 9 \mathrm{c}, \mathrm{PA}\end{array}$ & IRRIGATION & Decrease in Subregion Employment & - \\
\hline $\begin{array}{c}5 \mathrm{~b}, 5 \mathrm{c}, 6 \mathrm{~b}, 6 \mathrm{~d}, \\
9 \mathrm{a}, 9 \mathrm{c}, \text { PA }\end{array}$ & M\&I WATER SUPPLY & Increase in Pumping Costs & - \\
$\begin{array}{c}5 \mathrm{~b}, 5 \mathrm{c}, 6 \mathrm{~b}, 6 \mathrm{~d}, \\
9 \mathrm{a}, 9 \mathrm{c}, \mathrm{PA}\end{array}$ & M\&I WATER SUPPLY & Decrease in Subregion Employment & - \\
\hline $\begin{array}{c}5 \mathrm{~b}, 5 \mathrm{c}, 6 \mathrm{~b}, 9 \mathrm{a}, 9 \mathrm{c} \\
6 \mathrm{~d}\end{array}$ & $\begin{array}{c}\text { SHALLOW DRAFT } \\
\text { NAVIGATION }\end{array}$ & Decrease in Transportation Costs & ++ \\
$\begin{array}{c}\text { SHALLOW DRAFT } \\
\text { NAVIGATION }\end{array}$ & Decrease in Transportation Costs & + \\
\hline $\begin{array}{c}5 \mathrm{~b}, 5 \mathrm{c}, 6 \mathrm{~b}, 6 \mathrm{~d}, \\
9 \mathrm{a}, 9 \mathrm{c}\end{array}$ & $\begin{array}{c}\text { SHALLOW DRAFT } \\
\text { NAVIGATION }\end{array}$ & Increase in Subregion Employment & + \\
\hline
\end{tabular}




\section{Table F-20. Evaluation of Social Impacts for Umatilla/Morrow, Oregon - CONT}

\begin{tabular}{|c|c|c|c|}
\hline sos & Evaluation Item & Impact Measure & $\begin{array}{c}\text { Effects } \\
(++,+,-,--)\end{array}$ \\
\hline $1 \mathrm{a}, 1 \mathrm{~b}, 4 \mathrm{c}$ & RECREATION & $\begin{array}{l}\text { Increase in Visitor Days } \\
\text { John Day Project }\end{array}$ & ++ \\
\hline $\begin{array}{c}5 \mathrm{~b}, 5 \mathrm{c}, 6 \mathrm{~b}, 6 \mathrm{~d} \\
9 \mathrm{a}, 9 \mathrm{c}, \mathrm{PA}\end{array}$ & RECREATION & $\begin{array}{c}\text { Increase in Visitor Days } \\
\text { John Day Project }\end{array}$ & -- \\
\hline $1 a, 1 b, 4 c$ & RECREATION & Increase in Subregion Employment & + \\
\hline $\begin{array}{l}5 \mathrm{~b}, 5 \mathrm{c}, 6 \mathrm{~b}, 6 \mathrm{~d} \\
9 \mathrm{a}, 9 \mathrm{~b}, 9 \mathrm{c}, \mathrm{PA}\end{array}$ & RECREATION & Decrease in Subregion Employment & - \\
\hline $1 \mathrm{a}, 1 \mathrm{~b}$ & POWER & Retail Rate Increase & + \\
\hline All Other & POWER & Retail Rate Decrease & - \\
\hline $1 \mathrm{a}, 1 \mathrm{~b}$ & POWER & Increase in Subregion Employment & + \\
\hline All Other & POWER & Decrease in Subregion Employment & - \\
\hline $\begin{array}{c}5 b, 5 c, 6 b, 6 d \\
9 a, 9 c\end{array}$ & $\begin{array}{c}\text { CONSTRUCTION: } \\
\text { PUMP MODIFICATIONS }\end{array}$ & Increase in Subregion Employment & + \\
\hline $5 b, 5 c$ & $\begin{array}{l}\text { CONSTRUCTION: PROJ- } \\
\text { ECT IMPLEMENTATION }\end{array}$ & Increase in Subregion Employment & ++ \\
\hline $\begin{array}{c}6 \mathrm{~b}, 6 \mathrm{~d}, 9 \mathrm{a}, 9 \mathrm{c} \\
\text { PA }\end{array}$ & $\begin{array}{l}\text { CONSTRUCTION: PROJ- } \\
\text { ECT IMPLEMENTATION }\end{array}$ & Increase in Subregion Employment & + \\
\hline
\end{tabular}

\section{F.3.2.16 PORTLAND, OREGON}

The impacts of the SOR alternatives in the Portland, Oregon area would include the effects of changes in navigation costs, commercial and sport fishing harvests, and regional power costs. The community would be somewhat adversely impacted by the effects of the system alternatives on expected higher costs for transportation of grain and other commodities, lower commercial and sport fishing harvests, and increased regional power costs. Overall, the socioeconomic impacts are expected to be minimal under SOS alternatives 1a, 1b, 2d, 4c, and PA and negative under all other SOSs. The effects are expected to have significant adverse impacts under alternatives SOS 9a, primarily related to declines in commercial and sport fishing harvests.

Anadromous Fish: The commercial gillnet fishery in the lower sections of the Columbia River consists primarily of the harvest of fall chinook. Sport fishing along the lower sections of the river (Buoy 10 to Bonneville Dam) includes the harvest of both fall chinook and winter steelhead, with steelhead accounting for approximately two-thirds of the harvest. The combined sport and commercial harvest is expected to increase slightly under SOSs $2 \mathrm{~d}, 4 \mathrm{c}$, and $\mathrm{PA}$, and to decline under the remaining alternatives. The most significant reductions occur under SOS 9a.

Navigation: It is expected that under the drawdown alternatives the transportation costs for shipping grain and other commodities to downstream destinations will increase for shippers in the Portland area. Increases in transportation costs are expected for SOSs $5 b, 5 c, 6 b, 6 d, 9 a$, and $9 c$.

Power: Specific retail power rate impacts for the Portland area have not been measured. Regionwide however, retail rates under SOSs $1 \mathrm{a}$ and $1 \mathrm{~b}$ would be expected to fall by one-half to one percent relative to current rates. Retail rates are 
expected to increase under all other SOSs; the increases vary from less than one percent to around four percent. Retail rate changes are expected to be similar for residents and businesses in the vicinity of Portland.

\begin{tabular}{|c|c|c|c|}
\hline \multicolumn{4}{|c|}{ Portland, Oregon: Overview of Socioeconomic Profile (1990) } \\
\hline Population: & 437,319 & Median Age: & 34.5 \\
\hline County & 583,887 & County & 34.2 \\
\hline State & $2,842,321$ & State & 34.5 \\
\hline Employment: & 218,750 & Unemployment Rate: & $6.2 \%$ \\
\hline County & 292,646 & County & $5.8 \%$ \\
\hline State & $1,319,960$ & State & $6.2 \%$ \\
\hline Per Capita Income: & $\$ 14,478$ & \% Below Poverty Level: & $14.5 \%$ \\
\hline County & $\$ 14,462$ & County & $13.1 \%$ \\
\hline State & $\$ 13,418$ & State & $12.4 \%$ \\
\hline Impacted Resources: & \multicolumn{3}{|c|}{ Anadromous Fish, Navigation, Power } \\
\hline
\end{tabular}

Table F-21. Evaluation of Social Impacts for Portland, Oregon

\begin{tabular}{|c|c|c|c|}
\hline sos & Evaluation Item & Impact Measure & $\begin{array}{c}\text { Effects } \\
(++,+,-,--)\end{array}$ \\
\hline $2 d, 4 c, P A$ & ANADROMOUS FISH & Increase in Fish Harvest & + \\
\hline $9 a$ & ANADROMOUS FISH & Decline in Fish Harvest & -- \\
\hline All Other & ANADROMOUS FISH & Decline in Fish Harvest & - \\
\hline $2 \mathrm{~d}, 4 \mathrm{c}, \mathrm{PA}$ & ANADROMOUS FISH & $\begin{array}{l}\text { Increase in Subregion } \\
\text { Employment }\end{array}$ & + \\
\hline All Other & ANADROMOUS FISH & $\begin{array}{c}\text { Decrease in Subregion } \\
\text { Employment }\end{array}$ & - \\
\hline $\begin{array}{c}5 b, 5 c, 6 b, 6 d \\
9 a, 9 c\end{array}$ & $\begin{array}{l}\text { SHALLOW DRAFT } \\
\text { NAVIGATION }\end{array}$ & Increase in Transportation Costs & - \\
\hline $\begin{array}{c}5 b, 5 c, 6 b, 6 d \\
9 a, 9 c\end{array}$ & $\begin{array}{l}\text { SHALLOW DRAFT } \\
\text { NAVIGATION }\end{array}$ & Decrease in Subregion Employment & - \\
\hline $1 \mathrm{a}, 1 \mathrm{~b}$ & POWER & Retail Rate Increase & + \\
\hline All Other & POWER & Retail Rate Decrease & - \\
\hline $1 \mathrm{a}, 1 \mathrm{~b}$ & POWER & $\begin{array}{l}\text { Increase in Subregion } \\
\text { Employment }\end{array}$ & + \\
\hline All Other & POWER & $\begin{array}{c}\text { Decrease in Subregion } \\
\text { Employment }\end{array}$ & - \\
\hline
\end{tabular}




\section{F.3.2.17 ASTORIA, OREGON}

The impacts of the SOR alternatives in the Astoria, Oregon area would include the effects of changes in commercial and sport fishing harvests and regional power costs. The community would be somewhat adversely impacted by the effects of the system alternatives lower commercial and sport fishing harvests and increased regional power costs. Overall, the socioeconomic impacts are expected to be minimal under SOS alternatives $1 \mathrm{a}, 1 \mathrm{~b}, 2 \mathrm{~d}, 4 \mathrm{c}$, and $\mathrm{PA}$ and negative under all other SOSs. The effects are expected to have significant adverse impacts under alternatives SOS $9 \mathrm{a}$, primarily related to declines in commercial and sport fishing harvests.

Anadromous Fish: The Astoria area will be affected primarily by the effects of the SOR alternatives on ocean harvests in both the commercial and sport fisheries. The area will also be affected by changes in harvest levels for the in-river gillnet and sport fisheries located at the mouth of the Columbia River. The combined harvest for ocean and in-river sport and commercial fisheries is expected to increase slightly under SOSs $2 \mathrm{~d}, 4 \mathrm{c}$, and PA, and to decline under the remaining alternatives. The most significant reductions occur under SOS 9a.

Power: Specific retail power rate impacts for the Astoria area have not been measured. Region-wide however, retail rates under SOSs $1 \mathrm{a}$ and $1 \mathrm{~b}$ would be expected to fall by one-half to one percent relative to current rates. Retail rates are expected to increase under all other SOSs; the increases vary from less than one percent to around four percent. Retail rate changes are expected to be similar for residents and businesses in the vicinity of Astoria.

\begin{tabular}{|lccc|}
\hline \multicolumn{4}{c|}{ Astoria, Oregon: } \\
\hline Population: & 10,069 & Median Age: & 34.7 \\
County & 33,301 & County & 35.9 \\
State & $2,842,321$ & State & 34.5 \\
Employment: & 4,812 & Unemployment Rate: & $6.7 \%$ \\
County & 14,788 & County & $5.4 \%$ \\
State & $1,319,960$ & State & $6.2 \%$ \\
Per Capita Income: & $\$ 12,320$ & \% Below Poverty Level: & $17.0 \%$ \\
County & $\$ 12,568$ & County & $14.4 \%$ \\
State & $\$ 13,418$ & State & $12.4 \%$ \\
\hline Impacted Resources: & Anadromous Fish, Power & & \\
\hline
\end{tabular}

Table F-22. Evaluation of Social Impacts for Astoria, Oregon

\begin{tabular}{|c|c|c|c|}
\hline sos & Evaluation Item & Impact Measure & $\begin{array}{c}\text { Effects } \\
(++,+,-,-)\end{array}$ \\
\hline 2d, $4 \mathrm{c}, \mathrm{PA}$ & ANADROMOUS FISH & Increase in Fish Harvest & + \\
$9 \mathrm{a}$ & ANADROMOUS FISH & Decline in Fish Harvest & - \\
All Other & ANADROMOUS FISH & Decline in Fish Harvest & - \\
\hline 2d, 4c, PA & ANADROMOUS FISH & Increase in Subregion Employment & + \\
All Other & ANADROMOUS FISH & Decrease in Subregion Employment & - \\
\hline 1a, 1b & POWER & Retail Rate Increase & + \\
All Other & POWER & Retail Rate Decrease & - \\
\hline 1a, 1b & POWER & Increase in Subregion Employment & + \\
\hline All Other & POWER & Decrease in Subregion Employment & - \\
\hline
\end{tabular}




\section{F.3.3 SUMMARY OF EXPECTED SOCIOECONOMIC IMPACTS}

At the present time, uncertainty is the most significant social impact occurring throughout the Pacific Northwest. Because the current operation of the Columbia River is subject to change and the future operation is not known, individuals and economic entities are experiencing stress because they are unable to make decisions for their short or long term futures. It was pointed out during public meetings held in May 1994 on the System Configuration Study/Lower Snake River Biological Drawdown Test Draft Environmental Impact Statement at Lewiston, Idaho, economic investments are being withheld which is affecting economic growth which in turn creates stress for individuals, families, and business interests. The stress of uncertainty will continue until decisions for the future operation of the Columbia River are made.

Overall changes in employment and income would be relatively minor from regional and sub-regional perspectives. Alternatives 5b, 5c, 9a, 9b, 9c, and the Preferred Alternative result in the greatest change in regional jobs and income. SOS 9a would have the largest impact on employment in the Pacific Northwest Region with job losses of 9,450 and a decrease in regional personal income of $\$ 260$ million (less than on-quarter percent of total regional employment and income).

The largest relative changes in subregion employment and income would occur in the Lower Snake and Mid Columbia subregions. The largest net change in employment and income in the Lower Snake subregion would occur with SOS 5c, a loss of 3,800 jobs and a decrease in regional personal income of $\$ 79$ million (approximately five percent of regional income and employment.) Most of these losses in the Lower Snake subregion occur as a result of the increased transportation costs caused by the closure of barge navigation at the lower Snake River ports. The largest net change in employment and income in the Mid Columbia subregion would occur with the Preferred Alternative, a loss of 1,040 and a decrease in income of $\$ 28$ million jobs (just less than a one percent loss in total subregion em- ployment and income). The losses are attributable to increased irrigation costs, increased power costs, and declines in recreation activity.

Employment and income in the Mid Columbia subregion focus communities of the Tri-Cities in Washington and the Umatilla/Morrow Counties area in Oregon would generally be positively affected by reductions in grain transportation costs and negatively affected by increased pumping costs for irrigation and M\&I water supplies, increased power costs, lower levels of anadromous fish harvest, and reduced levels of reservoir recreation activity. The communities are likely to experience relatively short-term positive increases in regional employment and income during the construction periods for project modifications and pump modifications of irrigation and M\&I water supplies. The construction activities associated with pump and project modifications would likely cause the greatest social impact to the Mid Columbia focus communities. While providing an increase in employment, there would potentially be transitional impacts on local infrastructure and services resulting from the short-term influx of construction workers and their families.

The focus communities of Lewiston, Orofino, and the Nez Perce Reservation, Idaho and Clarkston, Washington, in the Lower Snake subregion would experience negative employment and income changes associated with declining levels of anadromous fish harvest, increased grain transportation costs, increased power costs, declining levels of reservoir recreation activity. Decreases in navigation employment and income associated with the drawdown alternatives would occur in Lewiston/ Clarkston. Orofino and the Nez Perce Reservation would be primarily affected by loss of employment associated with declines in recreation activity and anadromous fish harvests. All of the communities would be affected by increasing power costs. Lewiston and Clarkston would likely experience shortterm increases in employment and income from the construction activities associated with pump and project modifications. Dam modification construction in this subregion would cause the greatest social impact in the Lewiston/Clarkston area. While providing an increase in construction-related 
employment, there would potentially be transitional impacts on local infrastructure and services resulting from the short-term influx of construction workers and their families.

The Upper Columbia subregion would be most affected by net changes in employment and income associated with SOS 9a, a loss of nearly 700 jobs and a decrease of $\$ 18$ million in regional income (approximately one-half percent of regional employment and income). These changes would be associated primarily with reductions in anadromous fish harvests, increased power costs, and lower levels of reservoir recreation activity. The region would experience positive changes to employment and income due to declining costs for grain transportation. The focus communities of Grand Coulee/Coulee Dam, the Colville and Spokane Reservations, Washington, would be primarily affected by reduced levels of recreation activity at Lake Roosevelt.

The focus communities of Astoria and Portland in the West Coast and Portland subregions, respectively, would be primarily affected by increasing regional power costs, although the impacts are not expected to be significant. Additional employment and income effects associated with declining anadromous fish harvests would also occur. In both subregions the expected impacts would be greatest with SOS 9a. Employment and income losses in the Portland subregion under this scenario would include 1,500 jobs and $\$ 52$ million (One-quarter percent of regional employment and income). In the West Coast subregion employment losses under SOS 9a would reach nearly 1,0025 jobs with associated income losses of $\$ 26$ million (approximately three quarters of percent of regional employment and income. In May 1994, the Pacific Coast area was declared an Economic Disaster Area because of the decline in the fishery. Employment and income impacts to the focus community of Astoria, Oregon, would be negative which would add to the decline.

The Northeast subregion would be most affected by the net changes in employment and income associated with SOS $9 \mathrm{a}$, an annual loss of 1,125 jobs and an decline in income of $\$ 28$ million. (one half percent of total subregion employment and income).
Positive job and income effects would be associated with decreased costs for grain transportation while negative impacts would result from increased regional power costs. Minor declines would also be associated with some decrease in reservoir recreation. The focus communities of Libby, Flathead Lake, and the Flathead Reservation in Montana and Bonners Ferry and the Kootenai Reservation in Idaho would be primarily affected by increased regional power costs. The Montana communities would also be minimally impacted by changing levels of recreation activities at Hungry Horse Reservoir.

Overall, the expected changes in subregion employment and income associated with the SOR alternatives are generally less than one percent of current levels. The greatest changes in regional activity are associated with the drawdown alternatives, including SOSs $5 b, 5 c, 6 b, 6 d$, and 9a. The most significant impacts are generally related to increased regional power costs and increases (or decreases) in transportation costs for grain. It is likely that the dispersion of regional impacts will be most adverse in the Lower Snake subregion.

\section{F.4 REFERENCES}

American Automobile Association, 1995, Idaho, Montana, and Wyoming Tourbook, Heathrow, Florida.

American Automobile Association, 1995, Oregon and Washington Tourbook, Heathrow, Florida.

Columbia-Snake River marketing Group, 1992: The Great Watenway, The Columbia-Snake River System.

Idaho Department of Commerce, 1994, County Profiles of Idaho, Boise.

Idaho Department of Commerce, 1992, Idaho Facts, Boise.

Idaho Secretary of State, 1992, Idaho Blue Book 1991-1992 Edition, Boise.

Nez Perce Forest Resource Management, The Earth and Myself .. Are of One Mind.

Nez Perce Tribe, 1989, Overall Economic Development Plan for 1989-1990. 
Northwest Economic Associates, 1995. The Local Impacts of Recent Changes in the Operations of Dworshak Dam and Reservoir, Vancouver, Washington.

Oregon Secretary of State, 1994, Oregon Blue Book 1993-1994, Salem.

Washington Secretary of State, 1993, Washington State Yearbook, published by Public Sector Information, Eugene, Oregon.

U.S. Army Corps of Engineers, 1995, ColumbiaSnake River System Operation Review, Final EIS, Appendix J: Recreation, Portland, Oregon.

U.S. Department of Commerce, Bureau of the Census, American Indian and Alaska Native Areas: 1990, Washington, D.C.

U.S. Department of Commerce, Bureau of the Census, 1990 Census of Population and Housing, Population and Housing Characteristics for Congressional Districts of the 103rd Congress, Oregon.

U.S. Department of Commerce, Bureau of the Census, 1990 Census of Population and Housing, Population and Housing Characteristics for Congressional Districts of the 103rd Congress, Washington.

U.S. Department of Commerce, Bureau of the Census, 1990 Census of Population, Characteristics of American Indians by Tribe and Language, Washington, D.C.

U.S. Department of Commerce, Bureau of the Census, 1990 Census of Population, General Population Characteristics, American Indian and Alaska Native Areas, Washington, D.C.

U.S. Department of Commerce, Bureau of the Census, 1990 Census of Population, Social and Economic Characteristics, Idaho, Washington, D.C.

U.S. Department of Commerce, Bureau of the Census, 1990 Census of Population, Social and Economic Characteristics, Montana, Washington, D.C.
U.S. Department of Commerce, Bureau of the Census, 1990 Census of Population, Social and Economic Characteristics, Oregon, Washington, D.C.

U.S. Department of Commerce, Bureau of the Census, 1990 Census of Population, Social and Economic Characteristics, Washington, Washington, D.C.

U.S. Department of Commerce, Bureau of the Census, 1990 Census of Population and Housing, Population and Housing Unit Counts, Idaho, Washington, D.C.

U.S. Department of Commerce, Bureau of the Census, 1990 Census of Population and Housing, Population and Housing Unit Counts, Montana, Washington, D.C.

U.S. Department of Commerce, Bureau of the Census, 1990 Census of Population and Housing, Population and Housing Unit Counts, Oregon, Washington, D.C.

U.S. Department of Commerce, Bureau of the Census, 1990 Census of Population and Housing, Population and Housing Unit Counts, Washington, Washington, D.C.

U.S. Department of Commerce, Bureau of the Census, 1992 Census Agriculture, Volume 1, Oregon, Washington, D.C.

U.S. Department of Commerce, Bureau of the Census, 1992 Census Agriculture, Volume 1, Washington, Washington, D.C.

U.S. Department of Commerce, Bureau of the Census, County and City Data Book 1994, Washington, D.C.

U.S. Department of Commerce, Bureau of the Census, Statistical Abstract of the United States, 1994, September 1994.

U.S. Department of the Interior, Bureau of Reclamation, The Story of the Columbia Basin Project, 1978. 


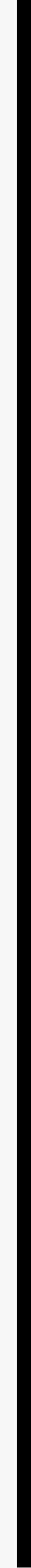




\section{APPENDIX A}

\section{FOCUS COMMUNITY PROFILES}

\section{F.5 Focus Community Profiles}

Focus Communities Located in Montana

- Libby

- Flathead Lake Area

- Columbia Falls

- Flathead Indian Reservation

Focus Communities Located in Idaho

- Bonners Ferry

- Kootenai Indian Reservation

- Orofino

- Nez Perce Indian Reservation

- Lewiston
Focus Communities Located in Washington

- Clarkston

- Grand Coulee/Coulee Dam

- Colville Indian Reservation

- Spokane Indian Reservation

- Tri-Cities

Focus Communities Located in Oregon

- Umatilla/Morrow

- Portland

- Astoria 
Table F-23. Focus Community Profile for Libby, Montana

\begin{tabular}{|c|c|c|c|}
\hline Libby, Montana (1990) & Montana & $\begin{array}{l}\text { Lincoln } \\
\text { County }\end{array}$ & Libby \\
\hline \multicolumn{4}{|l|}{ POPULATION } \\
\hline Total Population & 799,065 & 17,481 & 2,532 \\
\hline White & 741,111 & 17,103 & 2,474 \\
\hline Black & 2,381 & 11 & 3 \\
\hline American Indian, Eskimo, or Aleut & 47,679 & 282 & 41 \\
\hline Asian or Pacific Islander & 4,259 & 54 & 11 \\
\hline Other Race & 3,635 & 31 & 3 \\
\hline Hispanic & 12,174 & 197 & 33 \\
\hline Urban & 419,989 & 2,644 & 2,532 \\
\hline Rural & 379,076 & 14,837 & 0 \\
\hline \multicolumn{4}{|l|}{$\overline{\mathbf{A G E}}$} \\
\hline Median Age & 33.8 & 34.7 & 37.1 \\
\hline Under 18 years & 222,104 & 5,229 & 673 \\
\hline $19-64$ years & 470,464 & 10,110 & 1,355 \\
\hline 65 years and over & 106,497 & 2,142 & 504 \\
\hline \multicolumn{4}{|l|}{ HOUSING } \\
\hline Total Housing Units & 361,155 & 8,002 & 1,141 \\
\hline Occupied housing units & 306,163 & 6,668 & 1,047 \\
\hline Owner occupied & 205,899 & 4,888 & 593 \\
\hline Renter occupied & 100,264 & 1,780 & 454 \\
\hline Vacant housing units & 54,992 & 1,334 & 94 \\
\hline For seasonal, recreational, or occasional use & 20,481 & 581 & 1 \\
\hline \multicolumn{4}{|l|}{ INCOME } \\
\hline Per capita income & $\$ 11,213$ & $\$ 9,813$ & $\$ 9,589$ \\
\hline Total Number of Households & 306,919 & 6,735 & 1,104 \\
\hline With wage and salary income & 227,201 & 4,808 & 668 \\
\hline Mean wage and salary income & $\$ 25,575$ & $\$ 24,152$ & $\$ 22,078$ \\
\hline With nonfarm self-employment income & 49,131 & 1,099 & 153 \\
\hline Mean nonfarm self-employment income & $\$ 15,270$ & $\$ 18,670$ & $\$ 17,028$ \\
\hline With farm self-employment income & 22,050 & 171 & 0 \\
\hline Mean farm self-employment income & $\$ 13,779$ & $\$ 6,446$ & $\$ 0$ \\
\hline With Social Security income & 86,954 & 2,066 & 490 \\
\hline Mean Social Security income & $\$ 7,714$ & $\$ 7,553$ & $\$ 8,171$ \\
\hline With public assistance income & 20,827 & 427 & 69 \\
\hline Mean public assistance income & $\$ 3,620$ & $\$ 3,688$ & $\$ 3,812$ \\
\hline With retirement income & 46,572 & 1,169 & 275 \\
\hline Mean retirement income & $\$ 8,435$ & $\$ 6,685$ & $\$ 7,033$ \\
\hline
\end{tabular}

Source: 1990 Census Data, U.S. Department of Commerce, Bureau of the Census. 
Table F-23. Focus Community Profile for Libby, Montana - CONT

\begin{tabular}{|c|c|c|c|}
\hline Libby, Montana (1990) & Montana & $\begin{array}{l}\text { Linclon } \\
\text { County } \\
\end{array}$ & Libby \\
\hline \multicolumn{4}{|l|}{ POVERTY STATUS IN 1989} \\
\hline All persons for whom poverty status is determined & 776,793 & 17,315 & 2,566 \\
\hline Persons below poverty level & 124,853 & 2,450 & 420 \\
\hline Percent of persons below poverty level: & 16.1 & 14.1 & 16.4 \\
\hline \multicolumn{4}{|l|}{ LABOR FORCE STATUS } \\
\hline Persons 16 years and over & 599,765 & 12,890 & 2,042 \\
\hline Persons in labor force & 381,860 & 7,756 & 1,168 \\
\hline Percent in labor force & 63.7 & 60.2 & 57.2 \\
\hline Civilian labor force & 376,940 & 7,749 & 1,168 \\
\hline Employed & 350,723 & 6,500 & 984 \\
\hline Unemployed & 26,217 & 1,249 & 184 \\
\hline Percent unemployed & 7.0 & 16.1 & 15.8 \\
\hline Armed Forces & 4,920 & 7 & 0 \\
\hline Persons not in labor force & 217,905 & 5,134 & 874 \\
\hline \multicolumn{4}{|l|}{ EMPLOYMENT BY INDUSTRY } \\
\hline Employed persons 16 years and over & 350,723 & 6,500 & 984 \\
\hline Agriculture, forestry, and fisheries & 33,813 & 525 & 50 \\
\hline Mining & 5,537 & 221 & 20 \\
\hline Construction & 20,169 & 333 & 59 \\
\hline Manufacturing, nondurable goods & 9,396 & 100 & 43 \\
\hline Manufacturing, durable goods & 17,145 & 1,543 & 226 \\
\hline Transportation & 16,424 & 144 & 27 \\
\hline Communications and other public utilities & 9,345 & 70 & 16 \\
\hline Wholesale trade & 12,919 & 146 & 23 \\
\hline Retail trade & 68,165 & 1,207 & 134 \\
\hline Finance, insurance and real estate & 17,397 & 148 & 30 \\
\hline Business and repair services & 13,706 & 213 & 50 \\
\hline Personal services & 12,590 & 173 & 46 \\
\hline Entertainment and recreation services & 5,164 & 21 & 13 \\
\hline Health Services & 30,137 & 458 & 62 \\
\hline Educational Services & 35,445 & 561 & 82 \\
\hline Other professional and related services & 23,598 & 629 & 81 \\
\hline Public administration & 19,773 & 308 & 22 \\
\hline \multicolumn{4}{|l|}{ CLASS OF WORKER } \\
\hline Employed persons 16 years and over & 350,723 & 6,500 & 984 \\
\hline Private wage and salary workers & 230,464 & 4,255 & 678 \\
\hline Government workers & 70,280 & 1,365 & 142 \\
\hline Local government workers & 29,367 & 564 & 74 \\
\hline State government workers & 23,795 & 330 & 27 \\
\hline Federal government workers & 17,118 & 471 & 41 \\
\hline Self-employed workers & 46,443 & 856 & 164 \\
\hline Unpaid family workers & 3,536 & 24 & 0 \\
\hline
\end{tabular}


Table F-24. Focus Community Profile for Flathead Lake Area, Montana

\begin{tabular}{|c|c|c|c|}
\hline Creston-Big Fork Division, Montana (1990) & Montana & $\begin{array}{l}\text { Lake } \\
\text { County }\end{array}$ & $\begin{array}{c}\text { Creston-Big } \\
\text { Fork } \\
\text { Division }\end{array}$ \\
\hline $\begin{array}{l}\text { POPULATION } \\
\text { Total Population }\end{array}$ & POPULATION & 21,041 & 5,147 \\
\hline White & 741,111 & 16,411 & 5,059 \\
\hline Black & 2,381 & 15 & 5 \\
\hline American Indian, Eskimo, or Aleut & 47,679 & 4,498 & 47 \\
\hline Asian or Pacific Islander & 4,259 & 32 & 26 \\
\hline Other Race & 3,635 & 85 & 10 \\
\hline Hispanic & 12,174 & 402 & 45 \\
\hline Urban & 419,989 & 3,254 & 0 \\
\hline Rural & 379,076 & 17,787 & 5,121 \\
\hline \multicolumn{4}{|l|}{$\overline{\text { AGE }}$} \\
\hline Median Age & 33.8 & 34.7 & 37.6 \\
\hline Under 18 years & 222,104 & 6,349 & 1,439 \\
\hline $19-64$ years & 470,464 & 11,385 & 2,981 \\
\hline 65 years and over & 106,497 & 3,307 & 727 \\
\hline \multicolumn{4}{|l|}{ HOUSING } \\
\hline Total Housing Units & 361,155 & 10,972 & 2,407 \\
\hline Occupied housing units & 306,163 & 7,814 & 1,893 \\
\hline Owner occupied & 205,899 & 5,485 & 1,512 \\
\hline Renter occupied & 100,264 & 2,329 & 381 \\
\hline Vacant housing units & 54,992 & 3,158 & 514 \\
\hline For seasonal, recreational, or occasional use & 20,481 & 2,302 & 353 \\
\hline \multicolumn{4}{|l|}{ INCOME } \\
\hline Per capita income & $\$ 11,123$ & $\$ 9,274$ & $\$ 12,427$ \\
\hline Total Number of Households & 306,919 & 7,891 & 1,886 \\
\hline With wage and salary income & 227,201 & 5,311 & 1,351 \\
\hline Mean wage and salary income & $\$ 25,575$ & $\$ 20,655$ & $\$ 26,253$ \\
\hline With nonfarm self-employment income & 49,131 & 1,488 & 434 \\
\hline Mean nonfarm self-employment income & $\$ 15,270$ & $\$ 12,085$ & $\$ 17,759$ \\
\hline With farm self-employment income & 22,505 & 826 & 194 \\
\hline Mean farm self-employment income & $\$ 13,779$ & $\$ 9,091$ & $\$ 5,170$ \\
\hline With Social Security income & 86,954 & 2,763 & 548 \\
\hline Mean Social Security income & $\$ 7,714$ & $\$ 7,005$ & $\$ 7,768$ \\
\hline With public assistance income & 20,827 & 811 & 108 \\
\hline Mean public assistance income & $\$ 3,620$ & $\$ 3,326$ & $\$ 4,191$ \\
\hline With retirement income & 46,572 & 1,388 & 295 \\
\hline Mean retirement income & $\$ 8,435$ & $\$ 8,957$ & $\$ 12,101$ \\
\hline
\end{tabular}

Source: 1990 Census Data, U.S. Department of Commerce, Bureau of the Census. 
Table F-24. Focus Community Profile for Flathead Lake Area, Montana - CONT

\begin{tabular}{|c|c|c|c|}
\hline Creston-Big Fork Division, Montana (1990) & Montana & $\begin{array}{c}\text { Lake } \\
\text { County }\end{array}$ & $\begin{array}{l}\text { Creston- } \\
\text { Big Fork } \\
\text { Division }\end{array}$ \\
\hline \multicolumn{4}{|l|}{ POVERTY STATUS IN 1989} \\
\hline All persons for whom poverty status is determined & 776,793 & 20,583 & 5,039 \\
\hline Persons below poverty level & 124,853 & 4,405 & 636 \\
\hline Percent of persons below poverty level: & 16.1 & 21.4 & 12.6 \\
\hline \multicolumn{4}{|l|}{ LABOR FORCE STATUS } \\
\hline Persons 16 years and over & 599,765 & 15,352 & 3,768 \\
\hline Persons in labor force & 381,860 & 9,091 & 2,275 \\
\hline Percent in labor force & 63.7 & 59.2 & 60.4 \\
\hline Civilian labor force & 376,940 & 9,075 & 2,275 \\
\hline Employed & 350,723 & 8,268 & 2,045 \\
\hline Unemployed & 26,217 & 807 & 230 \\
\hline Percent unemployed & 7.0 & 8.9 & 10.1 \\
\hline Armed Forces & 4,920 & 16 & 0 \\
\hline Persons not in labor force & 217,905 & 6,261 & 1,493 \\
\hline \multicolumn{4}{|l|}{ EMPLOYMENT BY INDUSTRY } \\
\hline Employed persons 16 years and over & 350,723 & 8,268 & 2,045 \\
\hline Agriculture, forestry, and fisheries & 33,813 & 1,135 & 145 \\
\hline Mining & 5,537 & 10 & 7 \\
\hline Construction & 20,169 & 753 & 210 \\
\hline Manufacturing, nondurable goods & 9,396 & 176 & 69 \\
\hline Manufacturing, durable goods & 17,145 & 669 & 188 \\
\hline Transportation & 16,424 & 177 & 66 \\
\hline Communications and other public utilities & 9,345 & 256 & 41 \\
\hline Wholesale trade & 12,919 & 182 & 37 \\
\hline Retail trade & 68,165 & 1,390 & 412 \\
\hline Finance, insurance and real estate & 17,397 & 299 & 128 \\
\hline Business and repair services & 13,706 & 285 & 69 \\
\hline Personal services & 12,590 & 242 & 65 \\
\hline Entertainment and recreation services & 5,164 & 104 & 65 \\
\hline Health Services & 30,137 & 631 & 189 \\
\hline Educational Services & 35,445 & 881 & 137 \\
\hline Other professional and related services & 23,598 & 557 & 143 \\
\hline Public administration & 19,773 & 521 & 74 \\
\hline \multicolumn{4}{|l|}{ CLASS OF WORKER } \\
\hline Employed persons 16 years and over & 350,723 & 8,268 & 2,045 \\
\hline Private wage and salary workers & 230,646 & 4,644 & 1,342 \\
\hline Government workers & 70,280 & 1,958 & 296 \\
\hline Local government workers & 29,367 & 1,058 & 166 \\
\hline State government workers & 23,795 & 347 & 47 \\
\hline Federal government workers & 17,118 & 553 & 83 \\
\hline Self-employed workers & 46,443 & 1,545 & 388 \\
\hline Unpaid family workers & 3,536 & 121 & 19 \\
\hline
\end{tabular}


Table F-25. Focus Community Profile for Columbia Falls, Montana

\begin{tabular}{|c|c|c|c|}
\hline $\begin{array}{r}\text { Columbia Falls, Montana (1990) } \\
\end{array}$ & Montana & $\begin{array}{l}\text { Flathead } \\
\text { County }\end{array}$ & $\begin{array}{l}\text { Columbia } \\
\text { Falls }\end{array}$ \\
\hline \multicolumn{4}{|l|}{ POPULATION } \\
\hline Total Population & 799,065 & 59,218 & 2,942 \\
\hline White & 741,111 & 57,987 & 2,857 \\
\hline Black & 2,381 & 56 & 1 \\
\hline American Indian, Eskimo, or Aleut & 47,679 & 880 & 67 \\
\hline Asian or Pacific Islander & 4,259 & 240 & 13 \\
\hline Other Race & 3,635 & 145 & 4 \\
\hline Hispanic & 12,174 & 616 & 48 \\
\hline Urban & 419,989 & 23,492 & \\
\hline Rural & 379,076 & 35,726 & \\
\hline \multicolumn{4}{|l|}{ AGE } \\
\hline Median Age & 33.8 & 35.3 & 32.9 \\
\hline Under 18 years & 222,104 & 16,749 & 909 \\
\hline $19-64$ years & 470,464 & 34,753 & 1,688 \\
\hline 65 years and over & 106,497 & 7,716 & 345 \\
\hline \multicolumn{4}{|l|}{ HOUSING } \\
\hline Total Housing Units & 361,155 & 26,979 & 1,227 \\
\hline Occupied housing units & 306,163 & 22,834 & 1,139 \\
\hline Owner occupied & 205,899 & 16,131 & 725 \\
\hline Renter occupied & 100,264 & 6,703 & 414 \\
\hline Vacant housing units & 54,992 & 4,145 & 88 \\
\hline For seasonal, recreational, or occasional use & 20,481 & 2,517 & 7 \\
\hline \multicolumn{4}{|l|}{ INCOME } \\
\hline Per capita income & $\$ 11,213$ & $\$ 11,718$ & $\$ 6,637$ \\
\hline Total Number of Households & 306,919 & 22,921 & \\
\hline With wage and salary income & 227,201 & 16,829 & \\
\hline Mean wage and salary income & $\$ 25,575$ & $\$ 26,806$ & \\
\hline With nonfarm self-employment income & 49,131 & 4,294 & \\
\hline Mean nonfarm self-employment income & $\$ 15,270$ & $\$ 16,312$ & \\
\hline With farm self-employment income & 22,050 & 844 & \\
\hline Mean farm self-employment income & $\$ 13,779$ & $\$ 4,951$ & \\
\hline With Social Security income & 86,954 & 6,278 & \\
\hline Mean Social Security income & $\$ 7,714$ & $\$ 7,905$ & \\
\hline With public assistance income & 20,827 & 1,254 & \\
\hline Mean public assistance income & $\$ 3,620$ & $\$ 3,895$ & \\
\hline With retirement income & 46,572 & 3,541 & \\
\hline Mean retirement income & $\$ 8,435$ & $\$ 9,547$ & \\
\hline
\end{tabular}

Source: 1990 Census Data, U.S. Department of Commerce, Bureau of the Census. 
Table F-25. Focus Community Profile for Columbia Falls, Montana - CONT

\begin{tabular}{|c|c|c|c|}
\hline Columbia Falls, Montana (1990) & Montana & $\begin{array}{l}\text { Flathead } \\
\text { County }\end{array}$ & $\begin{array}{l}\text { Columbia } \\
\text { Falls }\end{array}$ \\
\hline \multicolumn{4}{|l|}{ POVERTY STATUS IN 1989} \\
\hline All persons for whom poverty status is determined & 776,793 & 58,261 & \\
\hline Persons below poverty level & 124,853 & 8,429 & \\
\hline Percent of persons below poverty level: & 16.1 & 14.5 & 16.0 \\
\hline \multicolumn{4}{|l|}{ LABOR FORCE STATUS } \\
\hline Persons 16 years and over & 599,765 & 44,115 & \\
\hline Persons in labor force & 381,860 & 27,792 & \\
\hline Percent in labor force & 63.7 & 63.0 & \\
\hline Civilian labor force & 376,940 & 27,750 & 1,333 \\
\hline Employed & 350,723 & 25,607 & 1,213 \\
\hline Unemployed & 26,217 & 2,143 & 120 \\
\hline Percent unemployed & 7.0 & 7.7 & 9.0 \\
\hline Armed Forces & 4,920 & 42 & \\
\hline Persons not in labor force & 217,905 & 16,323 & \\
\hline \multicolumn{4}{|l|}{ EMPLOYMENT BY INDUSTRY } \\
\hline Employed persons 16 years and over & 350,723 & 25,607 & 1,213 \\
\hline Agriculture, forestry, and fisheries & 33,813 & 1,159 & \\
\hline Mining & 5,537 & 104 & \\
\hline Construction & 20,169 & 1,621 & \\
\hline Manufacturing, nondurable goods & 9,396 & 626 & \\
\hline Manufacturing, durable goods & 17,145 & 3,422 & 308 \\
\hline Transportation & 16,424 & 1,296 & \\
\hline Communications and other public utilities & 9,345 & 665 & \\
\hline Wholesale trade & 12,919 & 616 & \\
\hline Retail trade & 68,165 & 5,576 & 282 \\
\hline Finance, insurance and real estate & 17,397 & 1,486 & \\
\hline Business and repair services & 13,706 & 1,234 & \\
\hline Personal services & 12,509 & 1,122 & \\
\hline Entertainment and recreation services & 5,164 & 504 & \\
\hline Health Services & 30,137 & 2,018 & \\
\hline Educational Services & 35,445 & 1,935 & 137 \\
\hline Other professional and related services & 23,598 & 1,485 & \\
\hline Public administration & 19,773 & 738 & \\
\hline \multicolumn{4}{|l|}{ CLASS OF WORKER } \\
\hline Employed persons 16 years and over & 350,723 & 25,607 & 1,213 \\
\hline Private wage and salary workers & 230,464 & 18,571 & \\
\hline Government workers & 70,280 & 3,415 & \\
\hline Local government workers & 29,367 & 1,735 & \\
\hline State government workers & 23,795 & 797 & \\
\hline Federal government workers & 17,118 & 883 & \\
\hline $\begin{array}{l}\text { Self-employed workers } \\
\text { Unpaid family workers }\end{array}$ & $\begin{array}{r}46,443 \\
3,536\end{array}$ & $\begin{array}{r}3,407 \\
214\end{array}$ & \\
\hline
\end{tabular}


Table F-26. Focus Community Profile for Flathead Indian Reservation, Montana

\begin{tabular}{|c|c|c|c|}
\hline Flathead Indian Reservation, Montana (1990) & Montana & $\begin{array}{l}\text { Surrounding } \\
\text { Counties }\end{array}$ & $\begin{array}{l}\text { Flathead } \\
\text { Reservation }\end{array}$ \\
\hline $\begin{array}{l}\text { POPULATION } \\
\text { Total Population }\end{array}$ & 799,065 & 167,615 & 21,259 \\
\hline White & 741,111 & 158,093 & 22 \\
\hline Black & 2,381 & 268 & 704 \\
\hline American Indian, Eskimo, or Aleut & 47,679 & 7,667 & 5,130 \\
\hline Asian or Pacific Islander & 4,259 & 1,145 & 45 \\
\hline Other Race & 3,635 & 442 & 76 \\
\hline Hispanic & 12,174 & 2,084 & 408 \\
\hline Urban & 419,989 & 86,498 & 3,254 \\
\hline Rural & 379,076 & 81,117 & 17,807 \\
\hline$\overline{\mathbf{A G E}}$ & & & \\
\hline Median Age & 33.8 & 34.7 & 34.1 \\
\hline Under 18 years & 222,104 & 45,815 & 6,539 \\
\hline $19-64$ years & 470,464 & 101,276 & 11,409 \\
\hline 65 years and over & 106,497 & 20,524 & 3,311 \\
\hline $\begin{array}{l}\text { HOUSING } \\
\text { Total Housing Units }\end{array}$ & 361,155 & 75,752 & 10,399 \\
\hline Occupied housing units & 306,163 & 64,827 & 7,874 \\
\hline Owner occupied & 205,899 & 42,681 & 5,502 \\
\hline Renter occupied & 100,264 & 22,146 & 2,372 \\
\hline Vacant housing units & 54,992 & 10,925 & 2,525 \\
\hline For seasonal, recreational, or occasional use & 20,481 & 6,257 & 1,574 \\
\hline $\begin{array}{l}\text { INCOME } \\
\text { Per capita income }\end{array}$ & $\$ 11,213$ & $\$ 10,599$ & $\$ 9,059$ \\
\hline Total Number of Households & 306,919 & 65,190 & 7,914 \\
\hline $\begin{array}{l}\text { With wage and salary income } \\
\text { Mean wage and salary income }\end{array}$ & $\begin{array}{l}227,201 \\
\$ 25,575\end{array}$ & $\begin{array}{r}48,809 \\
\$ 24,068\end{array}$ & $\begin{array}{r}5,283 \\
\$ 20,242\end{array}$ \\
\hline $\begin{array}{l}\text { With nonfarm self-employment income } \\
\text { Mean nonfarm self-employment income }\end{array}$ & $\begin{array}{r}49,131 \\
\$ 15,270\end{array}$ & $\begin{array}{r}11,548 \\
\$ 13,585\end{array}$ & $\begin{array}{r}1,292 \\
\$ 11,910\end{array}$ \\
\hline $\begin{array}{l}\text { With farm self-employment income } \\
\text { Mean farm self-employment income }\end{array}$ & $\begin{array}{r}22,050 \\
\$ 13,779\end{array}$ & $\begin{array}{r}2,749 \\
\$ 9,857\end{array}$ & $\begin{array}{r}877 \\
\$ 13,929\end{array}$ \\
\hline $\begin{array}{l}\text { With Social Security income } \\
\text { Mean Social Security income }\end{array}$ & $\begin{array}{l}86,954 \\
\$ 7,714\end{array}$ & $\begin{array}{l}17,094 \\
\$ 7,550\end{array}$ & $\begin{array}{r}2,884 \\
\$ 6,796\end{array}$ \\
\hline $\begin{array}{l}\text { With public assistance income } \\
\text { Mean public assistance income }\end{array}$ & $\begin{array}{l}20,827 \\
\$ 3,620\end{array}$ & $\begin{array}{r}4,339 \\
\$ 3,469\end{array}$ & $\begin{array}{r}822 \\
\$ 3,338\end{array}$ \\
\hline With retirement income & 46,572 & 9,806 & 1,276 \\
\hline Mean retirement income & $\$ 8,435$ & $\$ 9,030$ & $\$ 8,458$ \\
\hline
\end{tabular}

Source: 1990 Census Data, U.S. Department of Commerce, Bureau of the Census. 
Table F-26. Focus Community Profile for Flathead Indian Reservation, Montana - CONT

\begin{tabular}{|c|c|c|c|}
\hline Flathead Indian Reservation, Montana (1990) & Montana & $\begin{array}{l}\text { Surrounding } \\
\text { Counties }\end{array}$ & $\begin{array}{c}\text { Flathead } \\
\text { Reservation }\end{array}$ \\
\hline \multicolumn{4}{|l|}{ POVERTY STATUS IN 1989} \\
\hline All persons for whom poverty status is determined & 776,793 & 163,105 & 20,604 \\
\hline Persons below poverty level & 124,853 & 27,378 & 4,710 \\
\hline Percent of persons below poverty level: & 16.1 & 16.8 & 22.9 \\
\hline \multicolumn{4}{|l|}{ LABOR FORCE STATUS } \\
\hline Persons 16 years and over & 599,765 & 126,311 & 15,312 \\
\hline Persons in labor force & 381,860 & 80,355 & $55 \%$ (male) \\
\hline Percent in labor force & 63.7 & 63.7 & $45 \%$ (female) \\
\hline Civilian labor force & 376,940 & 80,218 & 8,878 \\
\hline Employed & 350,723 & 74,058 & 8,141 \\
\hline Unemployed & 26,217 & 6,160 & 737 \\
\hline Percent unemployed & 7.0 & 7.7 & 8.3 \\
\hline Armed Forces & 4,920 & 137 & 16 \\
\hline Persons not in labor force & 217,905 & 45,956 & $\begin{array}{r}29 \% \text { (males) } \\
43 \% \text { (female) }\end{array}$ \\
\hline \multicolumn{4}{|l|}{ EMPLOYMENT BY INDUSTRY } \\
\hline Agriculture, forestry, and fisheries & 33,813 & 4,313 & 1,140 \\
\hline Mining & 5,537 & 253 & 4 \\
\hline Construction & 20,169 & 4,389 & 645 \\
\hline Manufacturing, nondurable goods & 9,396 & 2,279 & 169 \\
\hline Manufacturing, durable goods & 17,145 & 7,342 & 736 \\
\hline Transportation & 16,424 & 3,468 & 199 \\
\hline Communications and other public utilities & 9,345 & 1,589 & 250 \\
\hline Wholesale trade & 12,919 & 2,412 & 194 \\
\hline Retail trade & 68,165 & 15,221 & 1,350 \\
\hline Finance, insurance and real estate & 17,397 & 3,575 & 274 \\
\hline Business and repair services & 13,706 & 3,248 & 264 \\
\hline Personal services & 12,590 & 2,785 & 235 \\
\hline Entertainment and recreation services & 5,164 & 1,168 & 61 \\
\hline Health Services & 30,137 & 6,280 & 696 \\
\hline Educational Services & 35,445 & 8,116 & 842 \\
\hline Other professional and related services & 23,598 & 5,015 & 536 \\
\hline Public administration & 19,773 & 2,596 & 546 \\
\hline \multicolumn{4}{|l|}{ CLASS OF WORKER } \\
\hline Private wage and salary workers & 230,464 & 50,939 & 4,642 \\
\hline Government workers & 70,280 & 13,414 & 1,961 \\
\hline Local government workers & 29,367 & 5,549 & 1,062 \\
\hline State government workers & 23,795 & 4,851 & 299 \\
\hline Federal government workers & 17,118 & 3,014 & 600 \\
\hline Self-employed workers & 46,443 & 9,204 & 1,409 \\
\hline Unpaid family workers & 3,536 & 501 & 129 \\
\hline
\end{tabular}


Table F-27. Focus Community Profile for Bonners Ferry, Idaho

\begin{tabular}{|c|c|c|c|}
\hline Bonners Ferry, Idaho (1990) & Idaho & $\begin{array}{c}\text { Boundary } \\
\text { County }\end{array}$ & $\begin{array}{c}\text { Bonners } \\
\text { Ferry }\end{array}$ \\
\hline \multicolumn{4}{|l|}{ POPULATION } \\
\hline Total Population & $1,006,749$ & 8,332 & 2,193 \\
\hline White & 950,451 & 7,950 & 2,156 \\
\hline Black & 3,370 & 3 & 1 \\
\hline American Indian, Eskimo, or Aleut & 13,780 & 150 & 24 \\
\hline Asian or Pacific Islander & 9,365 & 26 & 4 \\
\hline Other Race & 29,783 & 203 & 8 \\
\hline Hispanic & 52,927 & 310 & 58 \\
\hline Urban & 578,376 & & 6 \\
\hline Rural & 428,373 & & 2,193 \\
\hline \multicolumn{4}{|l|}{$\overline{\mathbf{A G E}}$} \\
\hline Median Age & 31.5 & 32.8 & 34.5 \\
\hline Under 18 years & 308,405 & 2,700 & 645 \\
\hline $19-64$ years & 577,079 & 4,610 & 1,119 \\
\hline 65 years and over & 121,265 & 1,022 & 429 \\
\hline \multicolumn{4}{|l|}{ HOUSING } \\
\hline Total Housing Units & 413,327 & 3,242 & 945 \\
\hline Occupied housing units & 360,723 & 2,857 & 856 \\
\hline Owner occupied & 252,734 & 2,237 & 564 \\
\hline Renter occupied & 107,989 & 620 & 292 \\
\hline Vacant housing units & 52,604 & 385 & 89 \\
\hline For seasonal, recreational, or occasional use & 24,252 & 88 & 5 \\
\hline \multicolumn{4}{|l|}{$\overline{\mathrm{INCOME}}$} \\
\hline Per capita income & $\$ 11,457$ & $\$ 9,054$ & $\$ 9,954$ \\
\hline Total Number of Households & 361,432 & & 866 \\
\hline With wage and salary income & 279,214 & & 590 \\
\hline Mean wage and salary income & $\$ 28,331$ & & $\begin{array}{r}\$ 22,12 \\
4\end{array}$ \\
\hline With nonfarm self-employment income & 56,123 & & 121 \\
\hline Mean nonfarm self-employment income & $\$ 16,015$ & & $\begin{array}{r}\$ 17,01 \\
2\end{array}$ \\
\hline With farm self-employment income & 22,111 & & 26 \\
\hline Mean farm self-employment income & $\$ 15,798$ & & $\$ 5,725$ \\
\hline With Social Security income & 96,073 & & 330 \\
\hline Mean Social Security income & $\$ 7,931$ & & $\$ 6,925$ \\
\hline With public assistance income & 19,215 & & 74 \\
\hline Mean public assistance income & $\$ 3,321$ & & $\$ 2,870$ \\
\hline With retirement income & 53,263 & & 146 \\
\hline Mean retirement income & $\$ 8,515$ & & $\$ 7,760$ \\
\hline
\end{tabular}

Source: 1990 Census Data, U.S. Department of Commerce, Bureau of the Census. 
Table F-27. Focus Community Profile for Bonners Ferry, Idaho - CONT

\begin{tabular}{|c|c|c|c|}
\hline Bonners Ferry, Idaho (1990) & Idaho & $\begin{array}{l}\text { Boundary } \\
\text { County }\end{array}$ & $\begin{array}{c}\text { Bonners } \\
\text { Ferry }\end{array}$ \\
\hline \multicolumn{4}{|l|}{ POVERTY STÁTUS IN 1989} \\
\hline All persons for whom poverty status is determined & 985,553 & 8,036 & 2,135 \\
\hline Persons below poverty level & 130,588 & 1,125 & 341 \\
\hline Percent of persons below poverty level: & 13.3 & 14.0 & 16.0 \\
\hline \multicolumn{4}{|l|}{ LABOR FORCE STATUS } \\
\hline Persons 16 years and over & 729,819 & 5,979 & 1,608 \\
\hline Persons in labor force & 478,286 & 3,436 & 926 \\
\hline Percent in labor force & 65.5 & 57.5 & 57.6 \\
\hline Civilian labor force & 472,773 & 3,436 & 926 \\
\hline Employed & 443,703 & 3,045 & 868 \\
\hline Unemployed & 29,070 & 391 & 58 \\
\hline Percent unemployed & 6.1 & 11.4 & 6.3 \\
\hline Armed Forces & 5,513 & & 0 \\
\hline Persons not in labor force & 251,533 & 2,543 & 682 \\
\hline \multicolumn{4}{|l|}{ EMPLOYMENT BY INDUSTRY } \\
\hline Employed persons 16 years and over & 443,703 & & 868 \\
\hline Agriculture, forestry, and fisheries & 39,790 & & 118 \\
\hline Mining & 3,638 & & 2 \\
\hline Construction & 28,940 & & 37 \\
\hline Manufacturing, nondurable goods & 28,270 & & 20 \\
\hline Manufacturing, durable goods & 37,024 & & 138 \\
\hline Transportation & 17,494 & & 22 \\
\hline Communications and other public utilities & 9,911 & & 10 \\
\hline Wholesale trade & 21,292 & & 12 \\
\hline Retail trade & 76,669 & & 154 \\
\hline Finance, insurance and real estate & 22,387 & & 26 \\
\hline Business and repair services & 17,516 & & 17 \\
\hline Personal services & 13,301 & & 43 \\
\hline Entertainment and recreation services & 5,558 & & 11 \\
\hline Health Services & 29,598 & & 78 \\
\hline Educational Services & 40,768 & & 111 \\
\hline Other professional and related services & 28,682 & & 40 \\
\hline Public administration & 22,865 & & 29 \\
\hline \multicolumn{4}{|l|}{ CLASS OF WORKER } \\
\hline Employed persons 16 years and over & 443,703 & & 868 \\
\hline Private wage and salary workers & 315,190 & & 515 \\
\hline Government workers & 77,080 & & 234 \\
\hline Local government workers & 28,922 & & 155 \\
\hline State government workers & 30,304 & & 21 \\
\hline Federal government workers & 17,854 & & 58 \\
\hline Self-employed workers & 48,890 & & 113 \\
\hline Unpaid family workers & 2,543 & & 6 \\
\hline
\end{tabular}


Table F-28. Focus Community Profile for Kootenai Reservation, Idaho

\begin{tabular}{|c|c|c|c|}
\hline Kootenai Reservation, Idaho (1990) & Idaho & $\begin{array}{l}\text { Boundary } \\
\text { County }\end{array}$ & $\begin{array}{l}\text { Kootenai } \\
\text { Reservation }\end{array}$ \\
\hline $\begin{array}{l}\text { POPULATION } \\
\text { Total Population }\end{array}$ & $1,006,749$ & 8,332 & 653 \\
\hline White & 950,451 & 7,950 & 4 \\
\hline Black & 3,370 & 3 & 0 \\
\hline American Indian, Eskimo, or Aleut & 13,780 & 150 & 61 \\
\hline Asian or Pacific Islander & 9,365 & 26 & 0 \\
\hline Other Race & 29,783 & 203 & 0 \\
\hline Hispanic & 52,927 & 310 & 2 \\
\hline Urban & 578,376 & & 0 \\
\hline Rural & 428,373 & & 65 \\
\hline \multicolumn{4}{|l|}{$\overline{\text { AGE }}$} \\
\hline Median Age & 31.5 & 32.8 & 25.3 \\
\hline Under 18 years & 308,405 & 2,700 & 29 \\
\hline $19-64$ years & 577,079 & 4,610 & 33 \\
\hline 65 years and over & 121,265 & 1,022 & 3 \\
\hline \multicolumn{4}{|l|}{ HOUSING } \\
\hline Total Housing Units & 413,327 & 3,242 & 20 \\
\hline Occupied housing units & 360,723 & 2,857 & 18 \\
\hline Owner occupied & 252,734 & 2,237 & 16 \\
\hline Renter occupied & 107,989 & 620 & 2 \\
\hline Vacant housing units & 52,604 & 385 & 2 \\
\hline For seasonal, recreational, or occasional use & 24,252 & 88 & 1 \\
\hline \multicolumn{3}{|l|}{ INCOME } & $\$ 4,972$ \\
\hline Total Number of Households & 361,432 & & 24 \\
\hline With wage and salary income & 279,214 & & 24 \\
\hline Mean wage and salary income & $\$ 28,331$ & & $\$ 20,391$ \\
\hline $\begin{array}{l}\text { With nonfarm self-employment income } \\
\text { Mean nonfarm self-employment income }\end{array}$ & $\begin{array}{r}56,123 \\
\$ 16,015\end{array}$ & & $\begin{array}{r}2 \\
\$ 120\end{array}$ \\
\hline With farm self-employment income & 22,111 & & $\mathbf{0}$ \\
\hline Mean farm self-employment income & $\$ 15,798$ & & $\$ 0$ \\
\hline $\begin{array}{l}\text { With Social Security income } \\
\text { Mean Social Security income }\end{array}$ & $\begin{array}{l}96,073 \\
\$ 7,931\end{array}$ & & $\begin{array}{r}1 \\
\$ 2,292\end{array}$ \\
\hline With public assistance income & 19,215 & & 2 \\
\hline Mean public assistance income & $\$ 3,321$ & & $\$ 4,416$ \\
\hline With retirement income & 53,263 & & 3 \\
\hline Mean retirement income & $\$ 8,515$ & & $\$ 3,300$ \\
\hline
\end{tabular}

Source: 1990 Census Data, U.S. Department of Commerce, Bureau of the Census. 
Table F-28. Focus Community Profile for Kootenai Reservation, Idaho - CONT

\begin{tabular}{|c|c|c|c|}
\hline Kootenai Reservation, Idaho (1990) & Idaho & $\begin{array}{l}\text { Boundary } \\
\text { County }\end{array}$ & $\begin{array}{l}\text { Kootenai } \\
\text { Reservation }\end{array}$ \\
\hline \multicolumn{4}{|l|}{ POVERTY STATUS IN 1989} \\
\hline All persons for whom poverty status is determined & 985,553 & 8,036 & 101 \\
\hline Persons below poverty level & 130,588 & 1,125 & 40 \\
\hline Percent of persons below poverty level: & 13.3 & 14.0 & 39.6 \\
\hline \multicolumn{4}{|l|}{ LABOR FORCE STATUS } \\
\hline Persons 16 years and over & 729,819 & 5,979 & 54 \\
\hline Persons in labor force & 478,286 & 3,436 & 39 \\
\hline Percent in labor force & 65.5 & 57.5 & 72.2 \\
\hline Civilian labor force & 472,773 & 3,436 & 39 \\
\hline Employed & 443,703 & 3,045 & 36 \\
\hline Unemployed & 29,070 & 391 & 3 \\
\hline Percent unemployed & 6.1 & 11.4 & 7.7 \\
\hline Armed Forces & 5,513 & 0 & 0 \\
\hline Persons not in labor force & 251,533 & 2,543 & 15 \\
\hline \multicolumn{4}{|l|}{ EMPLOYMENT BY INDUSTRY } \\
\hline Employed persons 16 years and over & 443,703 & & 36 \\
\hline Agriculture, forestry, and fisheries & 39,790 & & 5 \\
\hline Mining & 3,638 & & 0 \\
\hline Construction & 28,940 & & 0 \\
\hline Manufacturing, nondurable goods & 28,270 & & 0 \\
\hline Manufacturing, durable goods & 37,024 & & 1 \\
\hline Transportation & 17,494 & & 0 \\
\hline Communications and other public utilities & 9,911 & & 3 \\
\hline Wholesale trade & 21,292 & & $\mathbf{0}$ \\
\hline Retail trade & 76,669 & & 9 \\
\hline Finance, insurance and real estate & 22,387 & & 3 \\
\hline Business and repair services & 17,516 & & 0 \\
\hline Personal services & 13,301 & & 0 \\
\hline Entertainment and recreation services & 5,558 & & 0 \\
\hline Health Services & 29,598 & & 2 \\
\hline Educational Services & 40,768 & & 0 \\
\hline Other professional and related services & 28,682 & & 0 \\
\hline Public administration & 22,865 & & 13 \\
\hline \multicolumn{4}{|l|}{ CLASS OF WORKER } \\
\hline Employed persons 16 years and over & 443,703 & & 36 \\
\hline Private wage and salary workers & 315,190 & & 10 \\
\hline Government workers & 77,080 & & 26 \\
\hline Local government workers & 28,922 & & 11 \\
\hline State government workers & 30,304 & & 0 \\
\hline Federal government workers & 17,854 & & 15 \\
\hline Self-employed workers & 48,890 & & 0 \\
\hline Unpaid family workers & 2,543 & & 0 \\
\hline
\end{tabular}


Table F-29. Focus Community Profile for Orofino, Idaho

\begin{tabular}{|c|c|c|c|}
\hline Orofino, Idaho(1990) & Idaho & $\begin{array}{c}\text { Clearwater } \\
\text { County }\end{array}$ & Orofino \\
\hline \multicolumn{4}{|l|}{ POPULATION } \\
\hline Total Population & $1,006,749$ & 8,505 & 2,868 \\
\hline White & 950,451 & 8,262 & 2,788 \\
\hline Black & 3,370 & 10 & 1 \\
\hline American Indian, Eskimo, or Aleut & 13,780 & 180 & 59 \\
\hline Asian or Pacific Islander & 9,365 & 21 & 9 \\
\hline Other Race & 29,783 & 32 & 11 \\
\hline Hispanic & 52,927 & 112 & 44 \\
\hline Urban & 578,376 & & \\
\hline Rural & 428,373 & & \\
\hline \multicolumn{4}{|l|}{ AGE } \\
\hline Median Age & 31.5 & 37.5 & 38.6 \\
\hline Under 18 years & 308,405 & 2,147 & 717 \\
\hline $19-64$ years & 577,079 & 5,077 & 1,659 \\
\hline 65 years and over & 121,265 & 1,281 & 492 \\
\hline \multicolumn{4}{|l|}{ HOUSING } \\
\hline Total Housing Units & 413,327 & 3,815 & 1,231 \\
\hline Occupied housing units & 360,723 & 3,213 & 1,119 \\
\hline Owner occupied & 252,734 & 2,388 & 751 \\
\hline Renter occupied & 107,989 & 825 & 368 \\
\hline Vacant housing units & 52,604 & 592 & 112 \\
\hline For seasonal, recreational, or occasional use & 24,252 & 206 & 7 \\
\hline \multicolumn{4}{|l|}{ INCOME } \\
\hline Per capita income & $\$ 11,457$ & $\$ 11,234$ & $\$ 12,251$ \\
\hline Total Number of Households & 361,432 & & 1,106 \\
\hline With wage and salary income & 279,214 & & 821 \\
\hline Mean wage and salary income & $\$ 28,331$ & & $\$ 26,691$ \\
\hline With nonfarm self-employment income & 56,123 & & 141 \\
\hline Mean nonfarm self-employment income & $\$ 16,015$ & & $\$ 26,273$ \\
\hline With farm self-employment income & 22,111 & & 15 \\
\hline Mean farm self-employment income & $\$ 15,798$ & & $\$ 11,933$ \\
\hline With Social Security income & 96,073 & & 340 \\
\hline Mean Social Security income & $\$ 7,931$ & & $\$ 7,912$ \\
\hline With public assistance income & 19,215 & & 65 \\
\hline Mean public assistance income & $\$ 3,321$ & & $\$ 3,312$ \\
\hline With retirement income & 53,263 & & 199 \\
\hline Mean retirement income & $\$ 8,515$ & & $\$ 7,277$ \\
\hline
\end{tabular}

Source: 1990 Census Data, U.S. Department of Commerce, Bureau of the Census. 
Table F-29. Focus Community Profile for Orofino, Idaho - CONT

\begin{tabular}{|c|c|c|c|}
\hline Orofino, Idaho (1990) & Idaho & $\begin{array}{l}\text { Clearwater } \\
\text { County }\end{array}$ & Orofino \\
\hline \multicolumn{4}{|l|}{ POVERTY STATUS IN 1989} \\
\hline All persons for whom poverty status is determined & 985,553 & 8,033 & 2,701 \\
\hline Persons below poverty level & 130,588 & 980 & 294 \\
\hline Percent of persons below poverty level: & 13.3 & 12.2 & 10.9 \\
\hline \multicolumn{4}{|l|}{ LABOR FORCE STATUS } \\
\hline Persons 16 years and over & 729,819 & 6,627 & 2,244 \\
\hline $\begin{array}{l}\text { Persons in labor force } \\
\text { Percent in labor force }\end{array}$ & $\begin{array}{r}478,286 \\
65.5\end{array}$ & $\begin{array}{r}3,715 \\
56.1\end{array}$ & $\begin{array}{r}1,320 \\
58.8\end{array}$ \\
\hline Civilian labor force & 472,773 & 3,713 & 1,318 \\
\hline Employed & 443,703 & 3,061 & 1,162 \\
\hline Unemployed & 29,070 & 652 & 156 \\
\hline Percent unemployed & 6.1 & 17.6 & 11.8 \\
\hline Armed Forces & 5,513 & 2 & 2 \\
\hline Persons not in labor force & 251,533 & 2,912 & 924 \\
\hline \multicolumn{4}{|l|}{ EMPLOYMENT BY INDUSTRY } \\
\hline Employed persons 16 years and over & 443,703 & & 1,162 \\
\hline Agriculture, forestry, and fisheries & 39,790 & & 124 \\
\hline Mining & 3,638 & & 2 \\
\hline Construction & 28,940 & & 81 \\
\hline Manufacturing, nondurable goods & 28,270 & & 27 \\
\hline Manufacturing, durable goods & 37,024 & & 150 \\
\hline Transportation & 17,494 & & 12 \\
\hline Communications and other public utilities & 9,911 & & 25 \\
\hline Wholesale trade & 21,292 & & 18 \\
\hline Retail trade & 76,669 & & 178 \\
\hline Finance, insurance and real estate & 22,387 & & 39 \\
\hline Business and repair services & 17,516 & & 43 \\
\hline Personal services & 13,301 & & 47 \\
\hline Entertainment and recreation services & 5,558 & & 13 \\
\hline Health Services & 29,598 & & 137 \\
\hline Educational Services & 40,768 & & 74 \\
\hline Other professional and related services & 28,682 & & 59 \\
\hline Public administration & 22,865 & & 133 \\
\hline \multicolumn{4}{|l|}{ CLASS OF WORKER } \\
\hline Employed persons 16 years and over & 443,703 & & 1,162 \\
\hline Private wage and salary workers & 315,190 & & 587 \\
\hline Government workers & 77,080 & & 463 \\
\hline Local government workers & 28,922 & & 137 \\
\hline State government workers & 30,304 & & 188 \\
\hline Federal government workers & 17,854 & & 138 \\
\hline Self-employed workers & 48,890 & & 110 \\
\hline Unpaid family workers & 2,543 & & 2 \\
\hline
\end{tabular}


Table F-30. Focus Community Profile for Nez Perce Reservation, Idaho

\begin{tabular}{|c|c|c|c|}
\hline Nez Perce Reservation, Idaho (1990) & Idaho & $\begin{array}{l}\text { Surrounding } \\
\text { Counties * }\end{array}$ & $\begin{array}{c}\text { Nez Perce } \\
\text { Reservation }\end{array}$ \\
\hline \multicolumn{4}{|l|}{ POPULATION } \\
\hline Total Population & $1,006,749$ & 59,558 & 16,160 \\
\hline White & 950,451 & 56,643 & 5,283 \\
\hline Black & 3,370 & 65 & 3,516 \\
\hline American Indian, Eskimo, or Aleut & 13,780 & 2,387 & 1,863 \\
\hline Asian or Pacific Islander & 9,365 & 284 & 52 \\
\hline Other Race & 29,783 & 179 & 39 \\
\hline Hispanic & 52,927 & 697 & 206 \\
\hline Urban & 578,376 & 34,176 & 2,868 \\
\hline Rural & 428,373 & 25,382 & 13,291 \\
\hline \multicolumn{4}{|l|}{$\overline{\mathbf{A G E}}$} \\
\hline Median Age & 31.5 & 36.6 & 36.9 \\
\hline Under 18 years & 308,405 & 15,387 & 4,348 \\
\hline $19-64$ years & 577,079 & 34,704 & 9,222 \\
\hline 65 years and over & 121,265 & 9,467 & 2,590 \\
\hline \multicolumn{4}{|l|}{ HOUSING } \\
\hline Total Housing Units & 413,327 & 26,295 & 6,920 \\
\hline Occupied housing units & 360,723 & 23,411 & 6,122 \\
\hline Owner occupied & 252,734 & 16,316 & 4,590 \\
\hline Renter occupied & 107,989 & 7,095 & 1532 \\
\hline Vacant housing units & 52,604 & 2,884 & 798 \\
\hline For seasonal, recreational, or occasional use & 24,252 & 1,000 & 107 \\
\hline \multicolumn{4}{|l|}{ INCOME } \\
\hline Per capita income & $\$ 11,457$ & $\$ 11,004$ & $\$ 10,268$ \\
\hline Total Number of Households & 361,432 & 23,589 & 6,187 \\
\hline With wage and salary income & 279,214 & 17,034 & 4,244 \\
\hline Mean wage and salary income & $\$ 28,331$ & $\$ 23,933$ & $\$ 23,208$ \\
\hline With nonfarm self-employment income & 56,123 & 3,304 & 869 \\
\hline Mean nonfarm self-employment income & $\$ 16,015$ & $\$ 18,137$ & $\$ 17,208$ \\
\hline With farm self-employment income & 22,111 & 1,469 & 604 \\
\hline Mean farm self-employment income & $\$ 15,798$ & $\$ 15,410$ & $\$ 17,135$ \\
\hline With Social Security income & 96,073 & $\begin{array}{r}7,407 \\
\$ 7,843\end{array}$ & $\begin{array}{r}2,134 \\
\$ 7708\end{array}$ \\
\hline With public assistance income & 19,215 & 1,438 & 469 \\
\hline Mean public assistance income & $\$ 3,321$ & $\$ 2,893$ & $\$ 3,044$ \\
\hline With retirement income & 53,263 & 3,829 & 1,106 \\
\hline Mean retirement income & $\$ 8,515$ & $\$ 7,297$ & $\$ 7,057$ \\
\hline
\end{tabular}

* Clearwater, Idaho, Lewis, and Nez Perce Counites.

Source: 1990 Census Data, U.S. Department of Commerce, Bureau of the Census. 
Table F-30. Focus Community Profile for Nez Perce Reservation, Idaho - CONT

\begin{tabular}{|c|c|c|c|}
\hline Nez Perce Reservation, Idaho (1990) & Idaho & $\begin{array}{c}\text { Surrounding } \\
\text { Counties * }\end{array}$ & $\begin{array}{c}\text { Nez Perce } \\
\text { Reservation }\end{array}$ \\
\hline \multicolumn{4}{|l|}{ POVERTY STATUS IN 1989} \\
\hline All persons for whom poverty status is determined & 985,553 & 58,087 & \\
\hline Persons below poverty level & 130,588 & 7,358 & 2,455 \\
\hline Percent of persons below poverty level: & 13.3 & 12.7 & 15.7 \\
\hline \multicolumn{4}{|l|}{ LABOR FORCE STATUS } \\
\hline Persons 16 years and over & 729,819 & 45,869 & 12,389 \\
\hline Persons in labor force & 478,286 & 27,647 & $51.2 \%$ (male) \\
\hline Percent in labor force & 65.5 & 60.3 & $48.8 \%$ (female) \\
\hline Civilian labor force & 472,773 & 27,618 & 6,797 \\
\hline Employed & 443,703 & 24,943 & 5,948 \\
\hline Unemployed & 29,070 & 2,675 & 849 \\
\hline Percent unemployed & 6.1 & 9.7 & 12.5 \\
\hline Armed Forces & 5,513 & 29 & 5 \\
\hline Persons not in labor force & 251,533 & 18,222 & $\begin{array}{r}33.9 \% \text { (male) } \\
48.3 \% \text { (female) }\end{array}$ \\
\hline \multicolumn{4}{|l|}{ EMPLOYMENT BY INDUSSTRY } \\
\hline Employed persons 16 years and over & 443,703 & 24,943 & 5,948 \\
\hline Agriculture, forestry, and fisheries & 39,790 & 2,445 & 1,036 \\
\hline Mining & 3,638 & 110 & 19 \\
\hline Construction & 28,940 & 1,477 & 394 \\
\hline Manufacturing, nondurable goods & 28,270 & 1,505 & 143 \\
\hline Manufacturing, durable goods & 37,024 & 3,545 & 992 \\
\hline Transportation & 17,494 & 940 & 186 \\
\hline Communications and other public utilities & 9,911 & 345 & 70 \\
\hline Wholesale trade & 21,292 & 893 & 171 \\
\hline Retail trade & 76,669 & 4,200 & 783 \\
\hline Finance, insurance and real estate & 22,387 & 1,034 & 166 \\
\hline Business and repair services & 17,516 & 770 & 158 \\
\hline Personal services & 13,301 & 714 & 158 \\
\hline Entertainment and recreation services & 5,558 & 316 & 58 \\
\hline Health Services & 29,598 & 1,896 & 371 \\
\hline Educational Services & 40,768 & 2,129 & 521 \\
\hline Other professional and related services & 28,682 & 1,302 & 235 \\
\hline Public administration & 22,865 & 1,322 & 487 \\
\hline \multicolumn{4}{|l|}{ CLASS OF WORKER } \\
\hline Employed persons 16 years and over & 443,703 & 24,943 & 5,948 \\
\hline Private wage and salary workers & 315,190 & 16,809 & 3,247 \\
\hline Government workers & 77,080 & 4,956 & 1,691 \\
\hline Local government workers & 28,922 & 1,660 & 557 \\
\hline State government workers & 30,304 & 2,033 & 580 \\
\hline Federal government workers & 17,854 & 1,263 & 554 \\
\hline Self-employed workers & 48,890 & 3,027 & 977 \\
\hline Unpaid family workers & 2,543 & 151 & 33 \\
\hline
\end{tabular}

* Clearwater, Idaho, Lewis, and Nez Perce Counties. 
Table F-31. Focus Community Profile for Lewiston, Idaho

\begin{tabular}{|c|c|c|c|}
\hline Lewiston, Idaho (1990) & Idaho & $\begin{array}{l}\text { Nez Perce } \\
\text { County }\end{array}$ & Lewiston \\
\hline \multicolumn{4}{|l|}{$\begin{array}{l}\text { POPULATION } \\
\end{array}$} \\
\hline Total Population & $1,006,749$ & 33,754 & 28,082 \\
\hline White & 950,451 & 31,681 & 27,347 \\
\hline Black & 3,370 & 48 & 38 \\
\hline American Indian, Eskimo, or Aleut & 13,780 & 1,692 & 395 \\
\hline Asian or Pacific Islander & 9,365 & 211 & 190 \\
\hline Other Race & 29,783 & 122 & 112 \\
\hline Hispanic & 52,927 & 419 & 342 \\
\hline Urban & 578,376 & 28,082 & 28,082 \\
\hline Rural & 428,373 & 5,672 & 0 \\
\hline \multicolumn{4}{|l|}{$\overline{\mathbf{A G E}}$} \\
\hline Median Age & 31.5 & 35.6 & 35.3 \\
\hline Under 18 years & 308,405 & 8,405 & 6,911 \\
\hline $19-64$ years & 577,079 & 19,927 & 16,663 \\
\hline 65 years and over & 121,265 & 5,422 & 4,508 \\
\hline \multicolumn{4}{|l|}{ HOUSING } \\
\hline Total Housing Units & 413,327 & 14,463 & 12,054 \\
\hline Occupied housing units & 360,723 & 13,618 & 11,515 \\
\hline Owner occupied & 252,734 & 9,020 & 7,480 \\
\hline Renter occupied & 107,989 & 4,598 & 4,035 \\
\hline Vacant housing units & 52,604 & 845 & 539 \\
\hline For seasonal, recreational, or occasional use & 24,252 & 141 & 28 \\
\hline \multicolumn{4}{|l|}{ INCOME } \\
\hline Per capita income & $\$ 11,457$ & $\$ 12,476$ & $\$ 12,828$ \\
\hline Total Number of Households & 361,432 & 13,710 & 11,599 \\
\hline With wage and salary income & 279,214 & 10,001 & 8,570 \\
\hline Mean wage and salary income & $\$ 28,331$ & $\$ 28,214$ & $\$ 28,705$ \\
\hline With nonfarm self-employment income & 56,123 & 1,764 & 1,477 \\
\hline Mean nonfarm self-employment income & $\$ 16,015$ & $\$ 20,060$ & $\$ 20,071$ \\
\hline With farm self-employment income & 22,111 & 458 & 215 \\
\hline Mean farm self-employment income & $\$ 15,798$ & $\$ 12,589$ & $\$ 7,837$ \\
\hline With Social Security income & 96,073 & 4,190 & 3,507 \\
\hline Mean Social Security income & $\$ 7,931$ & $\$ 8,388$ & $\$ 8,561$ \\
\hline With public assistance income & 19,215 & 740 & 596 \\
\hline Mean public assistance income & $\$ 3,321$ & $\$ 3,100$ & $\$ 3,143$ \\
\hline With retirement income & 53,263 & 2,204 & 1,888 \\
\hline Mean retirement income & $\$ 8,515$ & $\$ 8,255$ & $\$ 8,409$ \\
\hline
\end{tabular}

Source: 1990 Census Data, U.S. Department of Commerce, Bureau of the Census. 
Table F-31. Focus Community Profile for Lewiston, Idaho - CONT

\begin{tabular}{|c|c|c|c|}
\hline Lewiston, Idaho (1990) & Idaho & $\begin{array}{c}\text { Nez Perce } \\
\text { County }\end{array}$ & Lewiston \\
\hline \multicolumn{4}{|l|}{ POVERTY STATUS IN 1989} \\
\hline All persons for whom poverty status is determined & 985,553 & 33,216 & 27,637 \\
\hline Persons below poverty level & 130,588 & 3,997 & 3,131 \\
\hline Percent of persons below poverty level: & 13.3 & 12.0 & 11.3 \\
\hline \multicolumn{4}{|l|}{ LABOR FORCE STATUS } \\
\hline Persons 16 years and over & 729,819 & 26,254 & 21,877 \\
\hline Persons in labor force & 478,286 & 16,525 & 14,042 \\
\hline Percent in labor force & 65.5 & 62.9 & 64.2 \\
\hline Civilian labor force & 472,773 & 16,501 & 14,021 \\
\hline Employed & 443,703 & 15,295 & 13,120 \\
\hline Unemployed & 29,070 & 1,206 & 901 \\
\hline Percent unemployed & 6.1 & 7.3 & 6.4 \\
\hline Armed Forces & 5,513 & 24 & 21 \\
\hline Persons not in labor force & 251,533 & 9,729 & 7,835 \\
\hline \multicolumn{4}{|l|}{ EMPLOYMENT BY INDUSTRY } \\
\hline Employed persons 16 years and over & 443,703 & 15,295 & 13,120 \\
\hline Agriculture, forestry, and fisheries & 39,790 & 813 & 374 \\
\hline Mining & 3,638 & 26 & 25 \\
\hline Construction & 28,940 & 910 & 733 \\
\hline Manufacturing, nondurable goods & 28,270 & 1,358 & 1,221 \\
\hline Manufacturing, durable goods & 37,024 & 1,802 & 1,550 \\
\hline Transportation & 17,494 & 671 & 593 \\
\hline Communications and other public utilities & 9,911 & 231 & 193 \\
\hline Wholesale trade & 21,292 & 605 & 545 \\
\hline Retail trade & 76,669 & 2,850 & 2,607 \\
\hline Finance, insurance and real estate & 22,387 & 743 & 679 \\
\hline Business and repair services & 17,516 & 509 & 457 \\
\hline Personal services & 13,301 & 442 & 395 \\
\hline Entertainment and recreation services & 5,558 & 199 & 177 \\
\hline Health Services & 29,598 & 1,363 & 1,185 \\
\hline Educational Services & 40,768 & 1,240 & 1,100 \\
\hline Other professional and related services & 28,682 & 883 & 822 \\
\hline Public administration & 22,865 & 650 & 464 \\
\hline \multicolumn{4}{|l|}{ CLASS OF WORKER } \\
\hline Employed persons 16 years and over & 443,703 & 15,295 & 13,120 \\
\hline Private wage and salary workers & 315,190 & 11,428 & 10,095 \\
\hline Government workers & 77,080 & 2,273 & 1,840 \\
\hline Local government workers & 28,922 & 802 & 623 \\
\hline State government workers & 30,304 & 1,085 & 982 \\
\hline Federal government workers & 17,854 & 386 & 235 \\
\hline Self-employed workers & 48,890 & 1,510 & 1,137 \\
\hline Unpaid family workers & 2,543 & 84 & 48 \\
\hline
\end{tabular}


Table F-32. Focus Community Profile for Clarkston, Washington

\begin{tabular}{|c|c|c|c|}
\hline Clarkston, Washington (1990) & Washington & $\begin{array}{l}\text { Asotin } \\
\text { County }\end{array}$ & Clarkston \\
\hline \multicolumn{4}{|l|}{ POPULATION } \\
\hline Total Population & $4,866,692$ & 17,605 & 6,753 \\
\hline White & $4,308,937$ & 17,136 & 6,507 \\
\hline Black & 149,801 & 38 & 21 \\
\hline American Indian, Eskimo, or Aleut & 81,483 & 260 & 138 \\
\hline Asian or Pacific Islander & 210,958 & 107 & 51 \\
\hline Other Race & 115,513 & 64 & 36 \\
\hline Hispanic & 214,570 & 278 & 151 \\
\hline Urban & $3,717,124$ & & 6,753 \\
\hline Rural & $1,149,568$ & & 0 \\
\hline \multicolumn{4}{|l|}{$\overline{\mathbf{A G E}}$} \\
\hline Median Age & 33.1 & 34.9 & 34.8 \\
\hline Under 18 years & $1,261,387$ & 4,874 & 1,778 \\
\hline $19-64$ years & $3,030,017$ & 9,811 & 3,554 \\
\hline 65 years and over & 575,288 & 2,920 & 1,421 \\
\hline \multicolumn{4}{|l|}{ HOUSING } \\
\hline Total Housing Units & $2,032,378$ & 7,519 & 3,043 \\
\hline Occupied housing units & $1,872,431$ & 7,003 & 2,854 \\
\hline Owner occupied & $1,171,580$ & 4,594 & 1,512 \\
\hline Renter occupied & 700,851 & 2,409 & 1,342 \\
\hline Vacant housing units & 159,947 & 516 & 189 \\
\hline For seasonal, recreational, or occasional use & 55,832 & 125 & 15 \\
\hline \multicolumn{4}{|l|}{ INCOME } \\
\hline Per capita income & $\$ 14,923$ & $\$ 11,379$ & $\$ 8,896$ \\
\hline Total Number of Households & $1,875,508$ & & 2,866 \\
\hline With wage and salary income & $1,468,311$ & & 1,808 \\
\hline Mean wage and salary income & $\$ 35,853$ & & $\$ 20,399$ \\
\hline With nonfarm self-employment income & 250,076 & & 229 \\
\hline Mean nonfarm self-employment income & $\$ 19,047$ & & $\$ 15,717$ \\
\hline With farm self-employment income & 35,868 & & 25 \\
\hline Mean farm self-employment income & $\$ 11,593$ & & $\$ 5,584$ \\
\hline With Social Security income & 450,010 & & 1,037 \\
\hline Mean Social Security income & $\$ 8,188$ & & $\$ 7,947$ \\
\hline With public assistance income & 126,021 & & 441 \\
\hline Mean public assistance income & $\$ 4,489$ & & $\$ 4,412$ \\
\hline With retirement income & 322,793 & & 430 \\
\hline Mean retirement income & $\$ 9,882$ & & $\$ 7,089$ \\
\hline
\end{tabular}

Source: 1990 Census Data, U.S. Department of Commerce, Bureau of the Census. 
Table F-32. Focus Community Profile for Clarkston, Washington - CONT

\begin{tabular}{|c|c|c|c|}
\hline Clarkston, Washington (1990) & Washington & $\begin{array}{l}\text { Asotin } \\
\text { County }\end{array}$ & Clarkston \\
\hline \multicolumn{4}{|l|}{ POVERTY STATUS IN 1989} \\
\hline All persons for whom poverty status is determined & $4,741,003$ & 17,170 & 6,395 \\
\hline Persons below poverty level & 517,933 & 3,331 & 1,688 \\
\hline Percent of persons below poverty level: & 10.9 & 19.4 & 26.4 \\
\hline \multicolumn{4}{|l|}{ LABOR FORCE STATUS } \\
\hline Persons 16 years and over & $3,730,985$ & 13,253 & 5,119 \\
\hline Persons in labor force & $2,487,073$ & 7,774 & 2,645 \\
\hline Percent in labor force & 66.7 & 58.7 & 51.7 \\
\hline Civilian labor force & $2,433,177$ & 7,761 & 2,645 \\
\hline Employed & $2,293,961$ & 7,111 & 2,347 \\
\hline Unemployed & 139,216 & 650 & 298 \\
\hline Percent unemployed & 5.7 & 8.4 & 11.3 \\
\hline Armed Forces & 53,896 & 13 & 0 \\
\hline Persons not in labor force & $1,243,912$ & 5,479 & 2,474 \\
\hline \multicolumn{4}{|l|}{ EMPLOYMENT BY INDUSTRY } \\
\hline Employed persons 16 years and over & $2,293,961$ & & 2,347 \\
\hline Agriculture, forestry, and fisheries & 85,186 & & 74 \\
\hline Mining & 4,000 & & 6 \\
\hline Construction & 144,458 & & 71 \\
\hline Manufacturing, nondurable goods & 106,401 & & 93 \\
\hline Manufacturing, durable goods & 294,749 & & 283 \\
\hline Transportation & 110,759 & & 62 \\
\hline Communications and other public utilities & 57,430 & & 31 \\
\hline Wholesale trade & 108,172 & & 77 \\
\hline Retail trade & 393,247 & & 602 \\
\hline Finance, insurance and real estate & 145,857 & & 71 \\
\hline Business and repair services & 107,853 & & 135 \\
\hline Personal services & 64,363 & & 103 \\
\hline Entertainment and recreation services & 32,435 & & 21 \\
\hline Health Services & 181,015 & & 197 \\
\hline Educational Services & 181,806 & & 250 \\
\hline Other professional and related services & 163,126 & & 182 \\
\hline Public administration & 113,104 & & 89 \\
\hline \multicolumn{4}{|l|}{ CLASS OF WORKER } \\
\hline Employed persons 16 years and over & $2,293,961$ & & 2,347 \\
\hline Private wage and salary workers & $1,725,934$ & & 1,826 \\
\hline Government workers & 379,622 & & 363 \\
\hline Local government workers & 138,334 & & 176 \\
\hline State government workers & 145,422 & & 169 \\
\hline Federal government workers & 95,866 & & 18 \\
\hline Self-employed workers & 179,204 & & 142 \\
\hline Unpaid family workers & 9,201 & & 16 \\
\hline
\end{tabular}


Table F-33. Focus Community Profile for Grand Coulee and Coulee Dam, Washington

\begin{tabular}{|c|c|c|c|}
\hline Grand Coulee and Coulee Dam, Washington (1990) & Washington & $\begin{array}{c}\text { Grant } \\
\text { County }\end{array}$ & $\begin{array}{c}\text { Okanogan } \\
\text { County }\end{array}$ \\
\hline \multicolumn{4}{|l|}{ POPULATION } \\
\hline Total Population & $4,866,692$ & 54,758 & 33,350 \\
\hline White & $4,308,937$ & 46,976 & 27,615 \\
\hline Black & 149,801 & 599 & 52 \\
\hline American Indian, Eskimo, or Aleut & 81,483 & 568 & 3,597 \\
\hline Asian or Pacific Islander & 210,958 & 641 & 166 \\
\hline Other Race & 115,513 & 5,974 & 1,920 \\
\hline Hispanic & 214,570 & 9,427 & 2,779 \\
\hline Urban & $3,717,124$ & 23,999 & 4,117 \\
\hline Rural & $1,149,568$ & 30,759 & 29,233 \\
\hline \multicolumn{4}{|l|}{$\mathbf{A G E}$} \\
\hline Median Age & 33.1 & 31.9 & 35.0 \\
\hline Under 18 years & $1,261,387$ & 17,182 & 9,587 \\
\hline $19-64$ years & $3,030,017$ & 30,595 & 19,131 \\
\hline 65 years and over & 575,288 & 6,981 & 4,632 \\
\hline \multicolumn{4}{|l|}{ HOUSING } \\
\hline Total Housing Units & $2,032,378$ & 22,809 & 16,629 \\
\hline Occupied housing units & $1,872,431$ & 19,745 & 12,654 \\
\hline Owner occupied & $1,171,580$ & 12,757 & 8,439 \\
\hline Renter occupied & 700,851 & 6,988 & 4,215 \\
\hline Vacant housing units & 159,947 & 3,064 & 3,975 \\
\hline For seasonal, recreational, or occasional use & 55,832 & 1,187 & 1,620 \\
\hline \multicolumn{4}{|l|}{ INCOME } \\
\hline Per capita income & $\$ 14,923$ & $\$ 10,376$ & $\$ 10,346$ \\
\hline Total Number of Households & $1,875,508$ & 19,852 & 12,773 \\
\hline With wage and salary income & $1,468,311$ & 14,372 & 9,160 \\
\hline Mean wage and salary income & $\$ 35,853$ & $\$ 26,272$ & $\$ 24,660$ \\
\hline With nonfarm self-employment income & 250,076 & 2,042 & 1,589 \\
\hline Mean nonfarm self-employment income & $\$ 19,047$ & $\$ 16,637$ & $\$ 20,414$ \\
\hline With farm self-employment income & 35,868 & 1,538 & 919 \\
\hline Mean farm self-employment income & $\$ 11,593$ & $\$ 22,460$ & $\$ 9,348$ \\
\hline With Social Security income & 450,010 & 5,526 & 3,883 \\
\hline Mean Social Security income & $\$ 8,188$ & $\$ 7,832$ & $\$ 7,399$ \\
\hline With public assistance income & 126,021 & 1,814 & 1,444 \\
\hline Mean public assistance income & $\$ 4,489$ & $\$ 4,620$ & $\$ 4,072$ \\
\hline With retirement income & 322,793 & 3,082 & 1,999 \\
\hline Mean retirement income & $\$ 9,882$ & $\$ 8,288$ & $\$ 8,402$ \\
\hline
\end{tabular}

Source: 1990 Census Data, U.S. Department of Commerce, Bureau of the Census. 
Table F-33. Focus Community Profile for Grand Coulee and Coulee Dam, Washington - CONT

\begin{tabular}{|c|c|c|c|}
\hline Grand Coulee and Coulee Dam, Washington (1990) & Washington & $\begin{array}{l}\text { Grant } \\
\text { County }\end{array}$ & $\begin{array}{c}\text { Okanogan } \\
\text { County }\end{array}$ \\
\hline \multicolumn{4}{|l|}{ POVERTY STATUS IN 1989} \\
\hline All persons for whom poverty status is determined & $4,741,003$ & 54,165 & 32,849 \\
\hline Persons below poverty level & 517,933 & 10,631 & 7,077 \\
\hline Percent of persons below poverty level: & 10.9 & 19.6 & 21.5 \\
\hline \multicolumn{4}{|l|}{ LABOR FORCE STATUS } \\
\hline Persons 16 years and over & $3,730,985$ & 39,288 & 24,751 \\
\hline Persons in labor force & $2,487,073$ & 24,207 & 15,185 \\
\hline Percent in labor force & 66.7 & 61.6 & 61.4 \\
\hline Civilian labor force & $2,433,177$ & 24,175 & 15,181 \\
\hline Employed & $2,293,961$ & 22,289 & 13,632 \\
\hline Unemployed & 139,216 & 1,886 & 1,549 \\
\hline Percent unemployed & 5.7 & 7.8 & 10.2 \\
\hline Armed Forces & 53,896 & 32 & 4 \\
\hline Persons not in labor force & $1,243,912$ & 15,081 & 9,566 \\
\hline \multicolumn{4}{|l|}{ EMPLOYMENT BY INDUSTRY } \\
\hline Employed persons 16 years and over & $2,293,961$ & 22,289 & 13,632 \\
\hline Agriculture, forestry, and fisheries & 85,186 & 4,589 & 2,630 \\
\hline Mining & 4,000 & 81 & 56 \\
\hline Construction & 144,458 & 1,110 & 830 \\
\hline Manufacturing, nondurable goods & 106,401 & 2,030 & 173 \\
\hline Manufacturing, durable goods & 294,749 & 825 & 1,323 \\
\hline Transportation & 110,759 & 894 & 546 \\
\hline Communications and other public utilities & 57,430 & 970 & 247 \\
\hline Wholesale trade & 108,172 & 1,243 & 872 \\
\hline Retail trade & 393,247 & 3,346 & 2,161 \\
\hline Finance, insurance and real estate & 145,857 & 664 & 379 \\
\hline Business and repair services & 107,853 & 598 & 382 \\
\hline Personal services & 64,363 & 597 & 408 \\
\hline Entertainment and recreation services & 32,435 & 161 & 148 \\
\hline Health Services & 181,015 & 1,137 & 941 \\
\hline Educational Services & 181,806 & 1,830 & 1,064 \\
\hline Other professional and related services & 163,126 & 1,076 & 542 \\
\hline Public administration & 113,104 & 1,138 & 930 \\
\hline \multicolumn{4}{|l|}{ CLASS OF WORKER } \\
\hline Employed persons 16 years and over & $2,293,961$ & 22,289 & 13,632 \\
\hline Private wage and salary workers & $1,725,934$ & 15,309 & 8,635 \\
\hline Government workers & 379,622 & 4,413 & 3,254 \\
\hline Local government workers & 138,334 & 2,120 & 1,268 \\
\hline State government workers & 145,422 & 1,516 & 974 \\
\hline Federal government workers & 95,866 & 777 & 1,012 \\
\hline Self-employed workers & 179,204 & & 1,617 \\
\hline Unpaid family workers & 9,201 & & 126 \\
\hline
\end{tabular}


Table F-33. Focus Community Profile for Grand Coulee and Coulee Dam, Washington - CONT

\begin{tabular}{|c|c|c|c|}
\hline Grand Coulee and Coulee Dam, Washington (1990) & Washington & $\begin{array}{c}\text { Coulee Dam } \\
\text { Town }\end{array}$ & $\begin{array}{l}\text { Grand } \\
\text { Coulee }\end{array}$ \\
\hline \multicolumn{4}{|l|}{ POPULATION } \\
\hline Total Population & $4,866,692$ & 1,087 & 984 \\
\hline White & $4,308,937$ & 870 & 848 \\
\hline Black & 149,801 & 7 & 34 \\
\hline American Indian, Eskimo, or Aleut & 81,483 & 195 & 90 \\
\hline Asian or Pacific Islander & 210,958 & 11 & 5 \\
\hline Other Race & 115,513 & 4 & 7 \\
\hline Hispanic & 214,570 & 18 & 14 \\
\hline Urban & $3,717,124$ & 0 & 0 \\
\hline Rural & $1,149,568$ & 1,087 & 984 \\
\hline \multicolumn{4}{|l|}{ AGE } \\
\hline Median Age & 33.1 & 39.8 & 42.9 \\
\hline Under 18 years & $1,261,387$ & 277 & 235 \\
\hline $19-64$ years & $3,030,017$ & 594 & 506 \\
\hline 65 years and over & 575,288 & 216 & 243 \\
\hline \multicolumn{4}{|l|}{ HOUSING } \\
\hline Total Housing Units & $2,032,378$ & 528 & 568 \\
\hline Occupied housing units & $1,872,431$ & 468 & 451 \\
\hline Owner occupied & $1,171,580$ & 324 & 266 \\
\hline Renter occupied & 700,851 & 144 & 185 \\
\hline Vacant housing units & 159,947 & 60 & 117 \\
\hline For seasonal, recreational, or occasional use & 55,832 & 1 & 3 \\
\hline \multicolumn{4}{|l|}{ INCOME } \\
\hline Per capita income & $\$ 14,923$ & $\$ 15,662$ & $\$ 10,146$ \\
\hline Total Number of Households & $1,875,508$ & 446 & 447 \\
\hline With wage and salary income & $1,468,311$ & 301 & 248 \\
\hline Mean wage and salary income & $\$ 35,853$ & $\$ 43,278$ & $\$ 25,112$ \\
\hline With nonfarm self-employment income & 250,076 & 32 & 27 \\
\hline Mean nonfarm self-employment income & $\$ 19,047$ & $\$ 13,430$ & $\$ 15,885$ \\
\hline With farm self-employment income & 35,868 & 5 & 0 \\
\hline Mean farm self-employment income & $\$ 11,593$ & $\$ 3,020$ & $\$ 0$ \\
\hline With Social Security income & 450,010 & 139 & 193 \\
\hline Mean Social Security income & $\$ 8,188$ & $\$ 5,634$ & $\$ 6,836$ \\
\hline With public assistance income & 126,021 & 18 & 45 \\
\hline Mean public assistance income & $\$ 4,489$ & $\$ 4,130$ & $\$ 4,777$ \\
\hline With retirement income & 322,793 & 136 & 110 \\
\hline Mean retirement income & $\$ 9,882$ & $\$ 14,852$ & $\$ 8,955$ \\
\hline
\end{tabular}

Source: 1990 Census Data, U.S. Department of Commerce, Bureau of the Census. 
Table F-33. Focus Community Profile for Grand Coulee and Coulee Dam, Washington - CONT

\begin{tabular}{|c|c|c|c|}
\hline Grand Coulee and Coulee Dam, Washington (1990) & Washington & $\begin{array}{c}\text { Coulee Dam } \\
\text { Town }\end{array}$ & $\begin{array}{l}\text { Grand } \\
\text { Coulee }\end{array}$ \\
\hline \multicolumn{4}{|l|}{ POVERTY STATUS IN 1989} \\
\hline All persons for whom poverty status is determined & $4,741,003$ & 1,022 & 957 \\
\hline Persons below poverty level & 517,933 & 95 & 212 \\
\hline Percent of persons below poverty level: & 10.9 & 9.3 & 22.2 \\
\hline \multicolumn{4}{|l|}{ LABOR FORCE STATUS } \\
\hline Persons 16 years and over & $3,730,985$ & 803 & 774 \\
\hline Persons in labor force & $2,487,073$ & 471 & 396 \\
\hline Percent in labor force & 66.7 & 58.7 & 51.2 \\
\hline Civilian labor force & $2,433,177$ & 469 & 396 \\
\hline Employed & $2,293,961$ & 439 & 356 \\
\hline Unemployed & 139,216 & 30 & 40 \\
\hline Percent unemployed. & 5.7 & 6.4 & 10.1 \\
\hline Armed Forces & 53,896 & 2 & 0 \\
\hline Persons not in labor force & $1,243,912$ & 332 & 378 \\
\hline \multicolumn{4}{|l|}{ EMPLOYMENT BY INDUSTRY } \\
\hline Employed persons 16 years and over & $2,293,961$ & 439 & 356 \\
\hline Agriculture, forestry, and fisheries & 85,186 & 20 & 4 \\
\hline Mining & 4,000 & 0 & 0 \\
\hline Construction & 144,458 & 47 & 31 \\
\hline Manufacturing, nondurable goods & 106,401 & 3 & 9 \\
\hline Manufacturing, durable goods & 294,749 & 2 & 10 \\
\hline Transportation & 110,759 & 10 & 10 \\
\hline Communications and other public utilities & 57,430 & 15 & 27 \\
\hline Wholesale trade & 108,172 & 0 & 5 \\
\hline Retail trade & 393,247 & 80 & 70 \\
\hline Finance, insurance and real estate & 145,857 & 16 & 16 \\
\hline Business and repair services & 107,853 & 20 & 29 \\
\hline Personal services & 64,363 & 12 & 25 \\
\hline Entertainment and recreation services & 32,435 & 12 & 0 \\
\hline Health Services & 181,015 & 22 & 28 \\
\hline Educational Services & 181,806 & 71 & 30 \\
\hline Other professional and related services & 163,126 & 16 & 8 \\
\hline Public administration & 113,104 & 93 & 54 \\
\hline \multicolumn{4}{|l|}{ CLASS OF WORKER } \\
\hline Employed persons 16 years and over & $2,293,961$ & 439 & 356 \\
\hline Private wage and salary workers & $1,725,934$ & 143 & 192 \\
\hline Government workers & 379,622 & 272 & 143 \\
\hline Local government workers & 138,334 & 95 & 32 \\
\hline State government workers & 145,422 & 48 & 28 \\
\hline Federal government workers & 95,866 & 129 & 83 \\
\hline Self-employed workers & 179,204 & 24 & \\
\hline Unpaid family workers & 9,201 & 0 & \\
\hline
\end{tabular}


Table F-34. Focus Community Profile for Colville Reservation, Washington

\begin{tabular}{|c|c|c|c|}
\hline Colville Reservation, Washington (1990) & Washington & $\begin{array}{c}\text { Surrounding } \\
\text { Counties * }\end{array}$ & $\begin{array}{c}\text { Colville } \\
\text { Reservation }\end{array}$ \\
\hline \multicolumn{4}{|l|}{ POPULATION } \\
\hline Total Population & $4,866,692$ & 11,700 & 6,957 \\
\hline White & $4,308,937$ & 7,513 & 1,552 \\
\hline Black & 149,801 & 32 & 12 \\
\hline American Indian, Eskimo, or Aleut & 81,483 & 3,938 & 3,788 \\
\hline Asian or Pacific Islander & 210,958 & 43 & 22 \\
\hline Other Race & 115,513 & 174 & 143 \\
\hline Hispanic & 214,570 & 427 & 357 \\
\hline Urban & $3,717,124$ & 851 & 851 \\
\hline Rural & $1,149,568$ & 10,926 & 6,183 \\
\hline \multicolumn{4}{|l|}{$\overline{\text { AGE }}$} \\
\hline Median Age & 33.1 & 31.8 & 30.7 \\
\hline Under 18 years & $1,261,387$ & 3,823 & 2,385 \\
\hline $19-64$ years & $3,030,017$ & 6,662 & 3,855 \\
\hline 65 years and over & 575,288 & 1,215 & 717 \\
\hline \multicolumn{4}{|l|}{ HOUSING } \\
\hline Total Housing Units & $2,032,378$ & 5,360 & 2,996 \\
\hline Occupied housing units & $1,872,431$ & 4,107 & 2,398 \\
\hline Owner occupied & $1,171,580$ & 2,756 & 1,524 \\
\hline Renter occupied & 700,851 & 1,351 & 874 \\
\hline Vacant housing units & 159,947 & 1,253 & 598 \\
\hline For seasonal, recreational, or occasional use & 55,832 & 639 & 294 \\
\hline \multicolumn{4}{|l|}{ INCOME } \\
\hline Per capita income & $\$ 14,923$ & $\$ 9,519$ & $\$ 8,897$ \\
\hline Total Number of Households & $1,875,508$ & 4,130 & 2,421 \\
\hline With wage and salary income & $1,468,311$ & 3,041 & 1,785 \\
\hline Mean wage and salary income & $\$ 35,853$ & $\$ 26,716$ & $\$ 25,854$ \\
\hline With nonfarm self-employment income & 250,076 & 359 & 173 \\
\hline Mean nonfarm self-employment income & $\$ 19,047$ & $\$ 16,980$ & $\$ 14,669$ \\
\hline With farm self-employment income & 35,868 & 265 & 114 \\
\hline Mean farm self-employment income & $\$ 11,593$ & $\$ 14,309$ & $\$ 13,346$ \\
\hline With Social Security income & 450,010 & 1,071 & 631 \\
\hline Mean Social Security income & $\$ 8,188$ & $\$ 7,089$ & $\$ 6,527$ \\
\hline With public assistance income & 126,021 & 519 & 408 \\
\hline Mean public assistance income & $\$ 4,489$ & $\$ 3,806$ & $\$ 4,191$ \\
\hline With retirement income & 322,793 & 662 & 435 \\
\hline Mean retirement income & $\$ 9,882$ & $\$ 8,164$ & $\$ 8,575$ \\
\hline
\end{tabular}

* Lincoln and Stevens Counties.

Source: 1990 Census Data, U.S. Department of Commerce, Bureau of the Census. 
Table F-34. Focus Community Profile for Colville Reservation, Washington - CONT

\begin{tabular}{|c|c|c|c|}
\hline Colville Reservation, Washington (1990) & Washington & $\begin{array}{c}\text { Surrounding } \\
\text { Counties * }\end{array}$ & $\begin{array}{c}\text { Colville } \\
\text { Reservation }\end{array}$ \\
\hline \multicolumn{4}{|l|}{ POVERTY STATUS IN 1989} \\
\hline All persons for whom poverty status is determined & $4,741,003$ & 11,640 & 6,935 \\
\hline Persons below poverty level & 517,933 & 2,915 & 1,909 \\
\hline Percent of persons below poverty level: & 10.9 & 25.0 & 27.5 \\
\hline \multicolumn{4}{|l|}{ LABOR FORCE STATUS } \\
\hline Persons 16 years and over & $3,730,985$ & 8,363 & 4,848 \\
\hline Persons in labor force & $2,487,073$ & 5,036 & $56.7 \%$ (male) \\
\hline Percent in labor force & 66.7 & 60.6 & $43.3 \%$ (female) \\
\hline Civilian labor force & $2,433,177$ & 5,034 & 2,863 \\
\hline Employed & $2,293,961$ & 4,217 & 2,332 \\
\hline Unemployed & 139,216 & 817 & 531 \\
\hline Percent unemployed & 5.7 & 16.2 & 18.5 \\
\hline Armed Forces & 53,896 & 2 & 2 \\
\hline Persons not in labor force & $1,243,912$ & 3,327 & $\begin{array}{r}27.5 \% \text { (male) } \\
41.7 \% \text { (female) }\end{array}$ \\
\hline \multicolumn{4}{|l|}{ EMPLOYMENT BY INDUSTRY } \\
\hline Employed persons 16 years and over & $2,293,961$ & 4,217 & 2,332 \\
\hline Agriculture, forestry, and fisheries & 85,186 & 561 & 363 \\
\hline Mining & 4,000 & 263 & 6 \\
\hline Construction & 144,458 & 335 & 162 \\
\hline Manufacturing, nondurable goods & 106,401 & 42 & 23 \\
\hline Manufacturing, durable goods & 294,749 & 451 & 246 \\
\hline Transportation & 110,759 & 89 & 61 \\
\hline Communications and other public utilities & 57,430 & 93 & 52 \\
\hline Wholesale trade & 108,172 & 80 & 71 \\
\hline Retail trade & 393,247 & 578 & 305 \\
\hline Finance, insurance and real estate & 145,857 & 126 & 51 \\
\hline Business and repair services & 107,853 & 103 & 60 \\
\hline Personal services & 64,363 & 78 & 48 \\
\hline Entertainment and recreation services & 32,435 & 56 & 47 \\
\hline Health Services & 181,015 & 227 & 135 \\
\hline Educational Services & 181,806 & 393 & 220 \\
\hline Other professional and related services & 163,126 & 250 & 130 \\
\hline Public administration & 113,104 & 492 & 352 \\
\hline \multicolumn{4}{|l|}{ CLASS OF WORKER } \\
\hline Employed persons 16 years and over & $2,293,961$ & 4,217 & 2,332 \\
\hline Private wage and salary workers & $1,725,934$ & 2,188 & 1,157 \\
\hline Government workers & 379,622 & 1,602 & 993 \\
\hline Local government workers & 138,334 & 622 & 349 \\
\hline State government workers & 145,422 & 304 & 189 \\
\hline Federal government workers & 95,866 & 676 & 455 \\
\hline Self-employed workers & 179,204 & 419 & 174 \\
\hline Unpaid family workers & 9,201 & 8 & 8 \\
\hline
\end{tabular}

* Okanogan and Ferry Counties. 
Table F-35. Focus Community Profile for Spokane Indian Reservation, Washington

\begin{tabular}{|c|c|c|c|}
\hline Spokane Reservation, Washington (1990) & Washington & $\begin{array}{c}\text { Surrounding } \\
\text { Counties* }\end{array}$ & $\begin{array}{c}\text { Spokane } \\
\text { Reservation }\end{array}$ \\
\hline \multicolumn{4}{|l|}{ POPULATION } \\
\hline Total Population & $4,866,692$ & 39,812 & 1,502 \\
\hline White & $4,308,937$ & 37,404 & 1,502 \\
\hline Black & 149,801 & 80 & 3 \\
\hline American Indian, Eskimo, or Aleut & 81,483 & 1,941 & 1,229 \\
\hline Asian or Pacific Islander & 210,958 & 212 & 3 \\
\hline Other Race & 115,513 & 175 & 6 \\
\hline Hispanic & 214,570 & 566 & 49 \\
\hline Urban & $3,717,124$ & 4,360 & 0 \\
\hline Rural & $1,149,568$ & 35,452 & 1,502 \\
\hline \multicolumn{4}{|l|}{ AGE } \\
\hline Median Age & 33.1 & 36.9 & 26.0 \\
\hline Under 18 years & $1,261,387$ & 12,114 & 579 \\
\hline $19-64$ years & $3,030,017$ & 22,089 & 821 \\
\hline 65 years and over & 575,288 & 5,609 & 102 \\
\hline \multicolumn{4}{|l|}{ HOUSING } \\
\hline Total Housing Units & $2,032,378$ & 19,208 & 565 \\
\hline Occupied housing units & $1,872,431$ & 14,846 & 464 \\
\hline Owner occupied & $1,171,580$ & 11,182 & 295 \\
\hline Renter occupied & 700,851 & 3,664 & 169 \\
\hline Vacant housing units & 159,947 & 4,362 & 101 \\
\hline For seasonal, recreational, or occasional use & 55,832 & 2,347 & 8 \\
\hline \multicolumn{4}{|l|}{ INCOME } \\
\hline Per capita income & $\$ 14,923$ & $\$ 11,281$ & $\$ 6,022$ \\
\hline Total Number of Households & $1,875,508$ & 14,960 & 431 \\
\hline With wage and salary income & $1,468,311$ & 10,665 & 328 \\
\hline Mean wage and salary income & $\$ 35,853$ & $\$ 25,064$ & $\$ 18,982$ \\
\hline With nonfarm self-employment income & 250,076 & 2,147 & 26 \\
\hline Mean nonfarm self-employment income & $\$ 19,047$ & $\$ 15,377$ & $\$ 18,826$ \\
\hline With farm self-employment income & 35,868 & 1,438 & 22 \\
\hline Mean farm self-employment income & $\$ 11,593$ & $\$ 13,079$ & $\$ 3,613$ \\
\hline With Social Security income & 450,010 & 4,708 & 96 \\
\hline Mean Social Security income & $\$ 8,188$ & $\$ 7,848$ & $\$ 7,935$ \\
\hline With public assistance income & 126,021 & 1,290 & 117 \\
\hline Mean public assistance income & $\$ 4,489$ & $\$ 4,933$ & $\$ 4,157$ \\
\hline With retirement income & 322,793 & 2,609 & 55 \\
\hline Mean retirement income & $\$ 9,882$ & $\$ 8,243$ & $\$ 5,909$ \\
\hline
\end{tabular}

* Lincoln and Stevens Counties.

Source: 1990 Census Data, U.S. Department of Commerce, Bureau of the Census. 
Table F-35. Focus Community Profile for Spokane Reservation, Washington - CONT

\begin{tabular}{|c|c|c|c|}
\hline Spokane Reservation, Washington (1990) & Washington & $\begin{array}{l}\text { Surrounding } \\
\text { Counties * }\end{array}$ & $\begin{array}{c}\text { Spokane } \\
\text { Reservation }\end{array}$ \\
\hline \multicolumn{4}{|l|}{ POVERTY STATUS IN 1989} \\
\hline All persons for whom poverty status is determined & $4,741,003$ & 39,269 & 1,435 \\
\hline Persons below poverty level & 517,933 & 6,320 & 533 \\
\hline Percent of persons below poverty level: & 10.9 & 16.1 & 37.1 \\
\hline \multicolumn{4}{|l|}{ LABOR FORCE STATUS } \\
\hline Persons 16 years and over & $3,730,985$ & 28,992 & 943 \\
\hline Persons in labor force & $2,487,073$ & 16,790 & $56.2 \%$ (male) \\
\hline Percent in labor force & 66.7 & 57.9 & $43.7 \%$ (female) \\
\hline Civilian labor force & $2,433,177$ & 16,743 & 485 \\
\hline Employed & $2,293,961$ & 15,197 & 352 \\
\hline Unemployed & 139,216 & 1,546 & 133 \\
\hline Percent unemployed & 5.7 & 9.2 & 27.4 \\
\hline Armed Forces & 53,896 & 47 & 4 \\
\hline Persons not in labor force & $1,243,912$ & 12,202 & $\begin{array}{r}37.2 \% \text { (male) } \\
55.6 \% \text { (female) }\end{array}$ \\
\hline \multicolumn{4}{|l|}{ EMPLOYMENT BY INDUSTRY } \\
\hline Employed persons 16 years and over & $2,293,961$ & 15,197 & 352 \\
\hline Agriculture, forestry, and fisheries & 85,186 & 1,934 & 32 \\
\hline Mining & 4,000 & 103 & 7 \\
\hline Construction & 144,458 & 904 & 33 \\
\hline Manufacturing, nondurable goods & 106,401 & 530 & 0 \\
\hline Manufacturing, durable goods & 294,749 & 2,316 & 32 \\
\hline Transportation & 110,759 & 532 & 8 \\
\hline Communications and other public utilities & 57,430 & 312 & 0 \\
\hline Wholesale trade & 108,172 & 419 & 9 \\
\hline Retail trade & 393,247 & 2,535 & 24 \\
\hline Finance, insurance and real estate & 145,857 & 552 & 3 \\
\hline Business and repair services & 107,853 & 546 & 14 \\
\hline Personal services & 64,363 & 302 & 11 \\
\hline Entertainment and recreation services & 32,435 & 171 & 5 \\
\hline Health Services & 181,015 & 866 & 31 \\
\hline Educational Services & 181,806 & 1,447 & 47 \\
\hline Other professional and related services & 163,126 & 739 & 20 \\
\hline Public administration & 113,104 & 818 & 76 \\
\hline \multicolumn{4}{|l|}{ CLASS OF WORKER } \\
\hline Employed persons 16 years and over & $2,293,961$ & 15,197 & 352 \\
\hline Private wage and salary workers & $1,725,934$ & 9,447 & 164 \\
\hline Government workers & 379,622 & 3,380 & 169 \\
\hline Local government workers & 138,334 & 1,259 & 62 \\
\hline State government workers & 145,422 & 1,369 & 25 \\
\hline Federal government workers & 95,866 & 752 & 82 \\
\hline Self-employed workers & 179,204 & 2,272 & 19 \\
\hline Unpaid family workers & 9,201 & 98 & 0 \\
\hline
\end{tabular}

* Lincoln and Stevens Counties. 
Table F-36. Focus Community Profile for Tri-Cities, Washington

\begin{tabular}{|c|c|c|c|}
\hline Tri-Cities, Washington (1990) & Washington & $\begin{array}{l}\text { Benton } \\
\text { County }\end{array}$ & $\begin{array}{c}\text { Franklin } \\
\text { County }\end{array}$ \\
\hline \multicolumn{4}{|l|}{ POPULATION } \\
\hline Total Population & $4,866,692$ & 112,560 & 37,473 \\
\hline White & $4,308,937$ & 102,832 & 26,917 \\
\hline Black & 149,801 & 1,085 & 1,310 \\
\hline American Indian, Eskimo, or Aleut & 81,483 & 861 & 263 \\
\hline Asian or Pacific Islander & 210,958 & 2,246 & 869 \\
\hline Other Race & 115,513 & 5,536 & 8,114 \\
\hline Hispanic & 214,570 & 8,624 & 11,316 \\
\hline Urban & $3,717,124$ & 98,156 & 27,247 \\
\hline Rural & $1,149,568$ & 14,404 & 10,226 \\
\hline \multicolumn{4}{|l|}{ AGE } \\
\hline Median Age & 33.1 & 32.1 & 28.7 \\
\hline Under 18 years & $1,261,387$ & 33,733 & 12,959 \\
\hline $19-64$ years & $3,030,017$ & 67,464 & 20,784 \\
\hline 65 years and over & 575,288 & 11,363 & 3,730 \\
\hline \multicolumn{4}{|l|}{ HOUSING } \\
\hline Total Housing Units & $2,032,378$ & 44,877 & 13,664 \\
\hline Occupied housing units & $1,872,431$ & 42,227 & 12,196 \\
\hline Owner occupied & $1,171,580$ & 26,663 & 7,277 \\
\hline Renter occupied & 700,851 & 15,564 & 4,919 \\
\hline Vacant housing units & 159,947 & 2,650 & 1,468 \\
\hline For seasonal, recreational, or occasional use & 55,832 & 137 & 73 \\
\hline \multicolumn{4}{|l|}{ INCOME } \\
\hline Per capita income & $\$ 14,923$ & $\$ 14,027$ & $\$ 10,407$ \\
\hline Total Number of Households & $1,875,508$ & 42,384 & 12,248 \\
\hline With wage and salary income & $1,468,311$ & 34,216 & 9,447 \\
\hline Mean wage and salary income & $\$ 35,853$ & $\$ 36,048$ & $\$ 27,958$ \\
\hline With nonfarm self-employment income & 250,076 & 4,428 & 1,197 \\
\hline Mean nonfarm self-employment income & $\$ 19,047$ & $\$ 13,300$ & $\$ 20,120$ \\
\hline With farm self-employment income & 35,868 & 1,193 & 794 \\
\hline Mean farm self-employment income & $\$ 11,593$ & $\$ 8,236$ & $\$ 33,687$ \\
\hline With Social Security income & 450,010 & 9,279 & 3,057 \\
\hline Mean Social Security income & $\$ 8,188$ & $\$ 8,388$ & $\$ 8,223$ \\
\hline With public assistance income & 126,021 & 3,073 & 1,138 \\
\hline Mean public assistance income & $\$ 4,489$ & $\$ 4,425$ & $\$ 3,956$ \\
\hline With retirement income & 322,793 & 7,184 & 1,729 \\
\hline Mean retirement income & $\$ 9,882$ & $\$ 9,212$ & $\$ 7,524$ \\
\hline
\end{tabular}

Source: 1990 Census Data, U.S. Department of Commerce, Bureau of the Census. 
Table F-36. Focus Community Profile for Tri-Cities, Washington - CONT

\begin{tabular}{|c|c|c|c|}
\hline Tri-Cities, Washington (1990) & Washington & $\begin{array}{l}\text { Benton } \\
\text { County } \\
\end{array}$ & $\begin{array}{c}\text { Franklin } \\
\text { County }\end{array}$ \\
\hline \multicolumn{4}{|l|}{ POVERTY STATUS IN 1989} \\
\hline All persons for whom poverty status is determined & $4,741,003$ & 111,634 & 36,926 \\
\hline Persons below poverty level & 517,933 & 12,402 & 8,491 \\
\hline Percent of persons below poverty level: & 10.9 & 11.1 & 23.0 \\
\hline \multicolumn{4}{|l|}{ LABOR FORCE STATUS } \\
\hline Persons 16 years and over & $3,730,985$ & 82,333 & 25,831 \\
\hline Persons in labor force & $2,487,073$ & 55,932 & 17,113 \\
\hline Percent in labor force & 66.7 & 67.9 & 66.2 \\
\hline Civilian labor force & $2,433,177$ & 55,842 & 17,090 \\
\hline Employed & $2,293,961$ & 52,440 & 15,686 \\
\hline Unemployed & 139,216 & 3,402 & 1,404 \\
\hline Percent unemployed & 5.7 & 6.1 & 8.2 \\
\hline Armed Forces & 53,896 & 90 & 23 \\
\hline Persons not in labor force & $1,243,912$ & 26,401 & 8,718 \\
\hline \multicolumn{4}{|l|}{ EMPLOYMENT BY INDUSTRY } \\
\hline Employed persons 16 years and over & $2,293,961$ & 52,440 & 15,686 \\
\hline Agriculture, forestry, and fisheries & 85,186 & 2,724 & 3,349 \\
\hline Mining & 4,000 & 26 & 5 \\
\hline Construction & 144,458 & 2,964 & 699 \\
\hline Manufacturing, nondurable goods & 106,401 & 4,072 & 1,937 \\
\hline Manufacturing, durable goods & 294,749 & 2,092 & 306 \\
\hline Transportation & 110,759 & 1,808 & 713 \\
\hline Communications and other public utilities & 57,430 & 4,235 & 551 \\
\hline Wholesale trade & 108,172 & 1,533 & 644 \\
\hline Retail trade & 393,247 & 8,935 & 2,280 \\
\hline Finance, insurance and real estate & 145,857 & 1,935 & 327 \\
\hline Business and repair services & 107,853 & 2,196 & 592 \\
\hline Personal services & 64,363 & 1,371 & 308 \\
\hline Entertainment and recreation services & 32,435 & 536 & 139 \\
\hline Health Services & 181,015 & 3,086 & 671 \\
\hline Educational Services & 181,806 & 3,957 & 1,260 \\
\hline Other professional and related services & 163,126 & 8,894 & 1,229 \\
\hline Public administration & 113,104 & 2,076 & 676 \\
\hline \multicolumn{4}{|l|}{ CLASS OF WORKER } \\
\hline Employed persons 16 years and over & $2,293,961$ & 52,440 & 15,686 \\
\hline Private wage and salary workers & $1,725,934$ & 39,081 & 11,695 \\
\hline Government workers & 379,622 & 9,817 & 2,548 \\
\hline Local government workers & 138,334 & 3,328 & 1,136 \\
\hline State government workers & 145,422 & 3,011 & 839 \\
\hline Federal government workers & 95,866 & 3,478 & 573 \\
\hline Self-employed workers & 179,204 & 3,353 & 1,356 \\
\hline Unpaid family workers & 9,201 & 189 & 87 \\
\hline
\end{tabular}


Table F-36. Focus Community Profile for Tri-Cities, Washington - CONT

\begin{tabular}{|c|c|c|c|}
\hline Tri-Cities, Washington (1990) & $\begin{array}{l}\text { Kennewick } \\
\text { City }\end{array}$ & $\begin{array}{c}\text { Pasco } \\
\text { City }\end{array}$ & $\begin{array}{l}\text { Richland } \\
\text { City }\end{array}$ \\
\hline \multicolumn{4}{|l|}{ POPULATION } \\
\hline Total Population & 42,155 & 20,337 & 32,315 \\
\hline White & 37,892 & 12,179 & 30,053 \\
\hline Black & 476 & 1,147 & 461 \\
\hline American Indian, Eskimo, or Aleut & 323 & 187 & 220 \\
\hline Asian or Pacific Islander & 837 & 502 & 1,071 \\
\hline Other Race & 2,627 & 6,322 & 510 \\
\hline Hispanic & 3,684 & 8,300 & 983 \\
\hline Urban & 42,155 & 19,935 & 32,354 \\
\hline Rural & 0 & 402 & 0 \\
\hline \multicolumn{4}{|l|}{ AGE } \\
\hline Median Age & 30.0 & 27.2 & 34.7 \\
\hline Under 18 years & 13,004 & 6,947 & 8,585 \\
\hline $19-64$ years & 25,333 & 11,104 & 19,651 \\
\hline 65 years and over & 3,818 & 2,286 & 4,079 \\
\hline \multicolumn{4}{|l|}{ HOUSING } \\
\hline Total Housing Units & 17,209 & 7,698 & 13,872 \\
\hline Occupied housing units & 16,074 & 6,842 & 13,162 \\
\hline Owner occupied & 8,532 & 3,241 & 8,155 \\
\hline Renter occupied & 7,542 & 3,601 & 5,007 \\
\hline Vacant housing units & 1,135 & 568 & 710 \\
\hline For seasonal, recreational, or occasional use & 42 & 16 & 41 \\
\hline \multicolumn{4}{|l|}{ INCOME } \\
\hline Per capita income & $\$ 12,767$ & $\$ 8,016$ & $\$ 17,085$ \\
\hline Total Number of Households & 16,169 & 6,806 & 13,174 \\
\hline With wage and salary income & 13,213 & 4,935 & 10,407 \\
\hline Mean wage and salary income & $\$ 32,282$ & $\$ 23,416$ & $\$ 41,672$ \\
\hline With nonfarm self-employment income & 1,468 & 435 & 1,310 \\
\hline Mean nonfarm self-employment income & $\$ 14,368$ & $\$ 15,450$ & $\$ 13,299$ \\
\hline With farm self-employment income & 176 & 91 & 181 \\
\hline Mean farm self-employment income & $\$ 4,372$ & $\$ 21,859$ & $\$ 2,414$ \\
\hline With Social Security income & 3,206 & 1,851 & 3,117 \\
\hline Mean Social Security income & $\$ 7,918$ & $\$ 7,965$ & $\$ 8,947$ \\
\hline With public assistance income & 1,447 & 875 & 731 \\
\hline Mean public assistance income & $\$ 4,315$ & $\$ 3,998$ & $\$ 4,561$ \\
\hline With retirement income & 2,283 & 939 & 2,692 \\
\hline Mean retirement income & $\$ 8,771$ & $\$ 6,907$ & $\$ 9,462$ \\
\hline
\end{tabular}

Source: 1990 Census Data, U.S. Department of Commerce, Bureau of the Census. 
Table F-36. Focus Community Profile for Tri-Cities, Washington - CONT

\begin{tabular}{|c|c|c|c|}
\hline Tri-Cities, Washington (1990) & $\begin{array}{l}\text { Kennewick } \\
\text { City }\end{array}$ & $\begin{array}{l}\text { Pasco } \\
\text { City }\end{array}$ & $\begin{array}{l}\text { Richland } \\
\text { City }\end{array}$ \\
\hline \multicolumn{4}{|l|}{ POVERTY STATUS IN 1989} \\
\hline All persons for whom poverty status is determined & 41,750 & 19,904 & 32,129 \\
\hline Persons below poverty level & 5,814 & 6,570 & 2,502 \\
\hline Percent of persons below poverty level: & 13.9 & 33.0 & 7.8 \\
\hline \multicolumn{4}{|l|}{ LABOR FORCE STATUS } \\
\hline Persons 16 years and over & 30,296 & 14,010 & 24,794 \\
\hline Persons in labor force & 20,886 & 8,757 & 16,879 \\
\hline Percent in labor force & 68.9 & 62.5 & 68.1 \\
\hline Civilian labor force & 20,855 & 8,735 & 16,863 \\
\hline Employed & 19,363 & 7,726 & 16,010 \\
\hline Unemployed & 1,462 & 1,008 & 853 \\
\hline Percent unemployed & 7.0 & 11.5 & 5.1 \\
\hline Armed Forces & 31 & 23 & 16 \\
\hline Persons not in labor force & 9,410 & 5,253 & 7,915 \\
\hline \multicolumn{4}{|l|}{ EMPLOYMENT BY INDUSTRY } \\
\hline Employed persons 16 years and over & 19,393 & 7,726 & 16,010 \\
\hline Agriculture, forestry, and fisheries & 598 & 1,286 & 164 \\
\hline Mining & 5 & 0 & 0 \\
\hline Construction & 923 & 295 & 748 \\
\hline Manufacturing, nondurable goods & 1,415 & 1,188 & 1,209 \\
\hline Manufacturing, durable goods & 856 & 164 & 618 \\
\hline Transportation & 851 & 404 & 267 \\
\hline Communications and other public utilities & 1,301 & 286 & 1,734 \\
\hline Wholesale trade & 718 & 408 & 261 \\
\hline Retail trade & 4,089 & 1,387 & 2,272 \\
\hline Finance, insurance and real estate & 907 & 167 & 467 \\
\hline Business and repair services & 872 & 312 & 697 \\
\hline Personal services & 532 & 173 & 450 \\
\hline Entertainment and recreation services & 246 & 49 & 168 \\
\hline Health Services & 1,231 & 274 & 1,048 \\
\hline Educational Services & 1,691 & 457 & 944 \\
\hline Other professional and related services & 2,475 & 574 & 4,174 \\
\hline Public administration & 683 & 302 & 788 \\
\hline \multicolumn{4}{|l|}{ CLASS OF WORKER } \\
\hline Employed persons 16 years and over & 19,393 & 7,726 & 160,110 \\
\hline Private wage and salary workers & 14,692 & 6,324 & 12,048 \\
\hline Government workers & 3,668 & 1,054 & 3,049 \\
\hline Local government workers & 1,274 & 471 & 917 \\
\hline State government workers & 1,185 & 359 & 801 \\
\hline Federal government workers & 1,209 & 224 & 1,331 \\
\hline Self-employed workers & 998 & 335 & 866 \\
\hline Unpaid family workers & 35 & 13 & 47 \\
\hline
\end{tabular}


Table F-37. Focus Community Profile for Umatilla, Oregon

\begin{tabular}{|c|c|c|c|}
\hline Umatilla, Oregon (1990) & Oregon & $\begin{array}{l}\text { Umatilla } \\
\text { County }\end{array}$ & $\begin{array}{l}\text { Morrow } \\
\text { County }\end{array}$ \\
\hline \multicolumn{4}{|l|}{ POPULATION } \\
\hline Total Population & $2,842,231$ & 59,249 & 7,625 \\
\hline White & $2,636,787$ & 52,743 & 6,829 \\
\hline Black & 46,178 & 371 & 8 \\
\hline American Indian, Eskimo, or Aleut & 38,496 & 1,850 & 75 \\
\hline Asian or Pacific Islander & 69,269 & 533 & 30 \\
\hline Other Race & 51,591 & 3,752 & 683 \\
\hline Hispanic & 112,707 & 5,307 & 825 \\
\hline Urban & $2,002,999$ & 33,570 & 0 \\
\hline Rural & 839,322 & 25,679 & 7,625 \\
\hline \multicolumn{4}{|l|}{ AGE } \\
\hline Median Age & 34.5 & 33.2 & 33.6 \\
\hline Under 18 years & 724,130 & 16,506 & 2,312 \\
\hline $19-64$ years & $1,726,777$ & 34,532 & 4,418 \\
\hline 65 years and over & 391,324 & 8,211 & 895 \\
\hline \multicolumn{4}{|l|}{ HOUSING } \\
\hline Total Housing Units & $1,193,567$ & 24,333 & 3,412 \\
\hline Occupied housing units & $1,103,313$ & 22,020 & 2,803 \\
\hline Owner occupied & 695,957 & 13,647 & 1,906 \\
\hline Renter occupied & 407,356 & 8,373 & 897 \\
\hline Vacant housing units & 90,254 & 2,313 & 609 \\
\hline For seasonal, recreational, or occasional use & 30,200 & 359 & 172 \\
\hline \multicolumn{4}{|l|}{ INCOME } \\
\hline Per capita income & $\$ 13,418$ & $\$ 11,178$ & $\$ 10,412$ \\
\hline Total Number of Households & $1,105,362$ & 22,047 & 2,796 \\
\hline With wage and salary income & 835,626 & 16,441 & 2,117 \\
\hline Mean wage and salary income & $\$ 31,797$ & $\$ 25,614$ & $\$ 24,293$ \\
\hline With nonfarm self-employment income & 159,941 & 2,590 & 333 \\
\hline Mean nonfarm self-employment income & $\$ 17,775$ & $\$ 17,533$ & $\$ 11,701$ \\
\hline With farm self-employment income & 33,146 & 1,364 & 341 \\
\hline Mean farm self-employment income & $\$ 10,241$ & $\$ 17,244$ & $\$ 23,352$ \\
\hline With Social Security income & 306,040 & 6,331 & 749 \\
\hline Mean Social Security income & $\$ 8,268$ & $\$ 7,936$ & $\$ 7,941$ \\
\hline With public assistance income & 66,998 & 1,507 & 191 \\
\hline Mean public assistance income & $\$ 3,798$ & $\$ 3,549$ & $\$ 3,919$ \\
\hline With retirement income & 185,721 & 3,592 & 422 \\
\hline Mean retirement income & $\$ 8,815$ & $\$ 7,566$ & $\$ 7,676$ \\
\hline
\end{tabular}

Source: 1990 Census Data, U.S. Department of Commerce, Bureau of the Census. 
Table F-37. Focus Community Profile for Umatilla, Oregon - CONT

\begin{tabular}{|c|c|c|c|}
\hline Umatilla, Oregon (1990) & Oregon & $\begin{array}{c}\text { Umatilla } \\
\text { County }\end{array}$ & $\begin{array}{l}\text { Morrow } \\
\text { County }\end{array}$ \\
\hline \multicolumn{4}{|l|}{ POVERTY STATUS IN 1989} \\
\hline All persons for whom poverty status is determined & $2,775,907$ & 57,046 & 7,539 \\
\hline Persons below poverty level & 344,867 & 9,419 & 1,141 \\
\hline Percent of persons below poverty level: & 12.4 & 16.5 & 15.1 \\
\hline \multicolumn{4}{|l|}{ LABOR FORCE STATUS } \\
\hline Persons 16 years and over & $2,191,764$ & 44,531 & 5,544 \\
\hline Persons in labor force & $1,410,695$ & 28,016 & 3,571 \\
\hline Percent in labor force & 64.4 & 62.9 & 64.4 \\
\hline Civilian labor force & $1,407,143$ & 27,984 & 3,558 \\
\hline Employed & $1,319,960$ & 25,612 & 3,238 \\
\hline Unemployed & 87,183 & 2,372 & 320 \\
\hline Percent unemployed & 6.2 & 8.5 & 9.0 \\
\hline Armed Forces & 3,552 & 32 & 13 \\
\hline Persons not in labor force & 781,069 & 16,515 & 1,973 \\
\hline \multicolumn{4}{|l|}{ EMPLOYMENT BY INDUSTRY } \\
\hline Employed persons 16 years and over & $1,319,960$ & 25,612 & 3,238 \\
\hline Agriculture, forestry, and fisheries & 66,730 & 3,362 & 843 \\
\hline Mining & 2,479 & 55 & 2 \\
\hline Construction & 74,206 & 1,096 & 157 \\
\hline Manufacturing, nondurable goods & 61,873 & 2,678 & 364 \\
\hline Manufacturing, durable goods & 171,335 & 1,718 & 229 \\
\hline Transportation & 55,283 & 1,262 & 150 \\
\hline Communications and other public utilities & 31,006 & 523 & 95 \\
\hline Wholesale trade & 61,938 & 859 & 58 \\
\hline Retail trade & 239,010 & 4,437 & 376 \\
\hline Finance, insurance and real estate & 78,671 & 988 & 86 \\
\hline Business and repair services & 60,660 & 660 & 86 \\
\hline Personal services & 40,768 & 773 & 61 \\
\hline Entertainment and recreation services & 17,650 & 251 & 22 \\
\hline Health Services & 103,623 & 2,078 & 139 \\
\hline Educational Services & 112,018 & 1,887 & 287 \\
\hline Other professional and related services & 88,577 & 1,305 & 110 \\
\hline Public administration & 54,133 & 1,680 & 173 \\
\hline \multicolumn{4}{|l|}{ CLASS OF WORKER } \\
\hline Employed persons 16 years and over & $1,319,960$ & 25,612 & 3,238 \\
\hline Private wage and salary workers & 990,564 & 18,259 & 2,045 \\
\hline Government workers & 199,627 & 4,549 & 644 \\
\hline Local government workers & 97,378 & 1,839 & 404 \\
\hline State government workers & 64,595 & 1,664 & 92 \\
\hline Federal government workers & 37,654 & 1,046 & 148 \\
\hline Self-employed workers & 122,886 & 2,575 & 523 \\
\hline Unpaid family workers & 6,883 & 229 & 26 \\
\hline
\end{tabular}


Table F-37. Focus Community Profile for Umatilla, Oregon - CONT

\begin{tabular}{|c|c|c|c|}
\hline Umatilla, Oregon (1990) & $\begin{array}{c}\text { Irrigon } \\
\text { City }\end{array}$ & $\begin{array}{l}\text { Boardman } \\
\text { City }\end{array}$ & $\begin{array}{c}\text { Umatilla } \\
\text { City }\end{array}$ \\
\hline \multicolumn{4}{|l|}{ POPULATION } \\
\hline Total Population & 737 & 1,387 & 3,046 \\
\hline White & 716 & 1,045 & 2,546 \\
\hline Black & 0 & 5 & 6 \\
\hline American Indian, Eskimo, or Aleut & 7 & 22 & 49 \\
\hline Asian or Pacific Islander & 1 & 15 & 26 \\
\hline Other Race & 13 & 300 & 419 \\
\hline Hispanic & 27 & 357 & 521 \\
\hline Urban & 0 & 0 & 3,046 \\
\hline Rural & 737 & 1,387 & 0 \\
\hline \multicolumn{4}{|l|}{ AGE } \\
\hline Median Age & 33.5 & 27.5 & 27.9 \\
\hline Under 18 years & 231 & 475 & 1,078 \\
\hline $19-64$ years & 400 & 832 & 1,746 \\
\hline 65 years and over & 106 & 80 & 222 \\
\hline \multicolumn{4}{|l|}{ HOUSING } \\
\hline Total Housing Units & 302 & 571 & 1,230 \\
\hline Occupied housing units & 276 & 475 & 1,063 \\
\hline Owner occupied & 196 & 270 & 512 \\
\hline Renter occupied & 80 & 205 & 551 \\
\hline Vacant housing units & 26 & 96 & 167 \\
\hline For seasonal, recreational, or occasional use & 1 & 1 & 0 \\
\hline \multicolumn{4}{|l|}{ INCOME } \\
\hline Per capita income & $\$ 8,632$ & $\$ 8,842$ & $\$ 8,481$ \\
\hline Total Number of Households & 259 & 494 & 1,020 \\
\hline With wage and salary income & 167 & 433 & 804 \\
\hline Mean wage and salary income & $\$ 23,650$ & $\$ 23,283$ & $\$ 23,003$ \\
\hline With nonfarm self-employment income & 14 & 45 & 96 \\
\hline Mean nonfarm self-employment income & $\$ 8,575$ & $\$ 9,845$ & $\$ 12,836$ \\
\hline With farm self-employment income & 7 & 22 & 34 \\
\hline Mean farm self-employment income & $\$ 16,622$ & $\$ 9,147$ & $\$ 2,972$ \\
\hline With Social Security income & 89 & 91 & 205 \\
\hline Mean Social Security income & $\$ 9,744$ & $\$ 7,397$ & $\$ 7,981$ \\
\hline With public assistance income & 30 & 49 & 107 \\
\hline Mean public assistance income & $\$ 3,192$ & $\$ 3,583$ & $\$ 3,415$ \\
\hline $\begin{array}{l}\text { With retirement income } \\
\text { Mean retirement income }\end{array}$ & $\begin{array}{r}54 \\
\$ 10,514\end{array}$ & $\begin{array}{r}46 \\
\$ 8,324\end{array}$ & $\begin{array}{r}181 \\
\$ 5,235\end{array}$ \\
\hline
\end{tabular}

Source: 1990 Census Data, U.S. Department of Commerce, Bureau of the Census. 
Table F-37. Focus Community Profile for Umatilla, Oregon - CONT

\begin{tabular}{|c|c|c|c|}
\hline Umatilla, Oregon (1990) & $\begin{array}{c}\text { Irrigon } \\
\text { City }\end{array}$ & $\begin{array}{c}\text { Boardman } \\
\text { City }\end{array}$ & $\begin{array}{c}\text { Umatilla } \\
\text { City }\end{array}$ \\
\hline \multicolumn{4}{|l|}{ POVERTY STATUS IN 1989} \\
\hline All persons for whom poverty status is determined & 690 & 1,415 & 2,848 \\
\hline Persons below poverty level & 114 & 313 & 609 \\
\hline Percent of persons below poverty level: & 16.5 & 22.1 & 21.4 \\
\hline \multicolumn{4}{|l|}{ LABOR FORCE STATUS } \\
\hline Persons 16 years and over & 500 & 980 & 1,973 \\
\hline Persons in labor force & 258 & 722 & 1,405 \\
\hline Percent in labor force & 51.6 & 73.7 & 71.2 \\
\hline Civilian labor force & 256 & 714 & 1,398 \\
\hline Employed & 236 & 641 & 1,225 \\
\hline Unemployed & 20 & 73 & 173 \\
\hline Percent unemployed & 7.8 & 10.2 & 12.4 \\
\hline Armed Forces & 2 & 8 & 7 \\
\hline Persons not in labor force & 242 & 258 & 568 \\
\hline \multicolumn{4}{|l|}{ EMPLOYMENT BY INDUSTRY } \\
\hline Employed persons 16 years and over & 236 & 641 & 1,225 \\
\hline Agriculture, forestry, and fisheries & 24 & 94 & 108 \\
\hline Mining & 0 & 2 & 23 \\
\hline Construction & 6 & 22 & 49 \\
\hline Manufacturing, nondurable goods & 31 & 163 & 128 \\
\hline Manufacturing, durable goods & 17 & 22 & 80 \\
\hline Transportation & 26 & 44 & 20 \\
\hline Communications and other public utilities & 4 & 29 & 24 \\
\hline Wholesale trade & 2 & 15 & 101 \\
\hline Retail trade & 46 & 65 & 266 \\
\hline Finance, insurance and real estate & 6 & 10 & 50 \\
\hline Business and repair services & 6 & 8 & 33 \\
\hline Personal services & 4 & 25 & 28 \\
\hline Entertainment and recreation services & 0 & 8 & 11 \\
\hline Health Services & 9 & 12 & 33 \\
\hline Educational Services & 31 & 65 & 131 \\
\hline Other professional and related services & 9 & 14 & 43 \\
\hline Public administration & 15 & 43 & 97 \\
\hline \multicolumn{4}{|l|}{ CLASS OF WORKER } \\
\hline Employed persons 16 years and over & 236 & 641 & 1,225 \\
\hline Private wage and salary workers & 158 & 478 & 853 \\
\hline Government workers & 63 & 125 & 261 \\
\hline Local government workers & 33 & 90 & 85 \\
\hline State government workers & 12 & 14 & 97 \\
\hline Federal government workers & 18 & 21 & 79 \\
\hline Self-employed workers & 13 & 38 & 105 \\
\hline Unpaid family workers & 2 & 0 & 6 \\
\hline
\end{tabular}


Table F-38. Focus Community Profile for Portland, Oregon

\begin{tabular}{|c|c|c|c|}
\hline Portland, Oregon (1990) & Oregon & $\begin{array}{l}\text { Multnomah } \\
\text { County }\end{array}$ & Portland \\
\hline \multicolumn{4}{|l|}{ POPULATION } \\
\hline Total Population & $2,842,231$ & 583,887 & 437,319 \\
\hline White & $2,636,787$ & 507,890 & 370,135 \\
\hline Black & 46,178 & 35,133 & 33,530 \\
\hline American Indian, Eskimo, or Aleut & 38,496 & 6,734 & 5,399 \\
\hline Asian or Pacific Islander & 69,269 & 27,326 & 23,185 \\
\hline Other Race & 51,591 & 6,804 & 5,070 \\
\hline Hispanic & 112,707 & 18,390 & 13,874 \\
\hline Urban & $2,002,999$ & 572,582 & 437,398 \\
\hline Rural & 839,322 & 11,305 & 0 \\
\hline \multicolumn{4}{|l|}{ AGE } \\
\hline Median Age & 34.5 & 34.2 & 34.5 \\
\hline Under 18 years & 724,130 & 134,920 & 95,762 \\
\hline $19-64$ years & $1,726,777$ & 369,574 & 277,900 \\
\hline 65 years and over & 391,324 & 79,393 & 63,657 \\
\hline \multicolumn{4}{|l|}{ HOUSING } \\
\hline Total Housing Units & $1,193,567$ & 255,751 & 198,368 \\
\hline Occupied housing units & $1,103,313$ & 242,140 & 187,268 \\
\hline Owner occupied & 695,957 & 133,981 & 99,206 \\
\hline Renter occupied & 407,356 & 108,159 & 88,062 \\
\hline Vacant housing units & 90,254 & 13,611 & 11,100 \\
\hline For seasonal, recreational, or occasional use & 30,200 & 533 & 391 \\
\hline \multicolumn{4}{|l|}{ INCOME } \\
\hline Per capita income & $\$ 13,418$ & $\$ 14,462$ & $\$ 14,478$ \\
\hline Total Number of Households & $1,105,362$ & 242,320 & 187,262 \\
\hline With wage and salary income & 835,626 & 186,878 & 141,678 \\
\hline Mean wage and salary income & $\$ 31,797$ & $\$ 32,491$ & $\$ 31,437$ \\
\hline With nonfarm self-employment income & 159,941 & 33,044 & 25,549 \\
\hline Mean nonfarm self-employment income & $\$ 17,775$ & $\$ 18,791$ & $\$ 19,365$ \\
\hline With farm self-employment income & 33,146 & 2,325 & 1,410 \\
\hline Mean farm self-employment income & $\$ 10,241$ & $\$ 7,065$ & $\$ 6,161$ \\
\hline With Social Security income & 306,040 & 62,154 & 49,784 \\
\hline Mean Social Security income & $\$ 8,268$ & $\$ 8,236$ & $\$ 8,205$ \\
\hline With public assistance income & 66,998 & 15,836 & 12,926 \\
\hline Mean public assistance income & $\$ 3,798$ & $\$ 3,880$ & $\$ 3,877$ \\
\hline With retirement income & 185,721 & 37,139 & 28,944 \\
\hline Mean retirement income & $\$ 8,815$ & $\$ 8,311$ & $\$ 8,203$ \\
\hline
\end{tabular}

Source: 1990 Census Data, U.S. Department of Commerce, Bureau of the Census. 
Table F-38. Focus Community Profile for Portland, Oregon - CONT

\begin{tabular}{|c|c|c|c|}
\hline Portland, Oregon (1990) & Oregon & $\begin{array}{l}\text { Multnomah } \\
\text { County }\end{array}$ & Portland \\
\hline \multicolumn{4}{|l|}{ POVERTY STATUS IN 1989} \\
\hline All persons for whom poverty status is determined & $2,775,907$ & 571,049 & 427,011 \\
\hline Persons below poverty level & 344,867 & 74,885 & 82,058 \\
\hline Percent of persons below poverty level: & 12.4 & 13.1 & 14.5 \\
\hline \multicolumn{4}{|l|}{ LABOR FORCE STATUS } \\
\hline Persons 16 years and over & $2,191,764$ & 461,230 & 350,048 \\
\hline Persons in labor force & $1,410,695$ & 311,325 & 233,544 \\
\hline Percent in labor force & 64.4 & 67.5 & 66.7 \\
\hline Civilian labor force & $1,407,143$ & 310,738 & 233,129 \\
\hline Employed & $1,319,960$ & 292,646 & 218,750 \\
\hline Unemployed & 87,183 & 18,092 & 14,379 \\
\hline Percent unemployed & 6.2 & 5.8 & 6.2 \\
\hline Armed Forces & 3,552 & 587 & 415 \\
\hline Persons not in labor force & 781,069 & 149,905 & 116,504 \\
\hline \multicolumn{4}{|l|}{ EMPLOYMENT BY INDUSTRY } \\
\hline Employed persons 16 years and over & $1,319,960$ & 292,646 & 218,750 \\
\hline Agriculture, forestry, and fisheries & 66,730 & 5,220 & 3,112 \\
\hline Mining & 2,479 & 323 & 179 \\
\hline Construction & 74,206 & 15,305 & 11,059 \\
\hline Manufacturing, nondurable goods & 61,873 & 15,190 & 11,544 \\
\hline Manufacturing, durable goods & 171,335 & 29,662 & 21,508 \\
\hline Transportation & 55,283 & 16,042 & 11,112 \\
\hline Communications and other public utilities & 31,006 & 7,625 & 5,817 \\
\hline Wholesale trade & 61,938 & 16,720 & 12,112 \\
\hline Retail trade & 239,010 & 52,546 & 38,420 \\
\hline Finance, insurance and real estate & 78,671 & 21,435 & 15,955 \\
\hline Business and repair services & 60,660 & 17,368 & 13,399 \\
\hline Personal services & 40,768 & 9,385 & 7,052 \\
\hline Entertainment and recreation services & 17,650 & 4,583 & 3,574 \\
\hline Health Services & 103,623 & 26,603 & 20,476 \\
\hline Educational Services & 112,018 & 2,693 & 17,253 \\
\hline Other professional and related services & 88,577 & 23,857 & 19,271 \\
\hline Public administration & 54,133 & 9,089 & 6,907 \\
\hline \multicolumn{4}{|l|}{ CLASS OF WORKER } \\
\hline Employed persons 16 years and over & $1,319,960$ & 292,646 & 218,750 \\
\hline Private wage and salary workers & 990,564 & 232,507 & 172,933 \\
\hline Government workers & 199,627 & 36,646 & 28,236 \\
\hline Local government workers & 97,378 & 18,216 & 13,785 \\
\hline State government workers & 64,595 & 9,803 & 8,080 \\
\hline Federal government workers & 37,654 & 8,627 & 6,371 \\
\hline Self-employed workers & 122,886 & 22,552 & 16,885 \\
\hline Unpaid family workers & 6,883 & 941 & 696 \\
\hline
\end{tabular}


Table F-39. Focus Community Profile for Astoria, Oregon

\begin{tabular}{|c|c|c|c|}
\hline Astoria, Oregon (1990) & Oregon & $\begin{array}{l}\text { Clatsop } \\
\text { County }\end{array}$ & Astoria \\
\hline \multicolumn{4}{|l|}{ POPULATION } \\
\hline Total Population & $2,842,231$ & 33,301 & 10,069 \\
\hline White & $2,636,787$ & 32,118 & 9,617 \\
\hline Black & 46,178 & 114 & 34 \\
\hline American Indian, Eskimo, or Aleut & 38,496 & 373 & 140 \\
\hline Asian or Pacific Islander & 69,269 & 446 & 207 \\
\hline Other Race & 51,591 & 253 & 71 \\
\hline Hispanic & 112,707 & 648 & 255 \\
\hline Urban & $2,002,999$ & & \\
\hline Rural & 839,322 & & \\
\hline \multicolumn{4}{|l|}{$\overline{\text { AGE }}$} \\
\hline Median Age & 34.5 & 35.9 & 34.7 \\
\hline Under 18 years & 724,130 & 8,560 & 2,561 \\
\hline $19-64$ years & $1,726,777$ & 19,337 & 5,838 \\
\hline 65 years and over & 391,324 & 5,404 & 1,670 \\
\hline \multicolumn{4}{|l|}{ HOUSING } \\
\hline Total Housing Units & $1,193,567$ & 17,367 & 4,631 \\
\hline Occupied housing units & $1,103,313$ & 13,374 & 4,216 \\
\hline Owner occupied & 695,957 & 8,459 & 2,146 \\
\hline Renter occupied & 407,356 & 4,915 & 2,070 \\
\hline Vacant housing units & 90,254 & 3,993 & 415 \\
\hline For seasonal, recreational, or occasional use & 30,200 & 2,733 & 45 \\
\hline \multicolumn{4}{|l|}{ INCOME } \\
\hline Per capita income & $\$ 13,418$ & $\$ 12,568$ & $\$ 12,320$ \\
\hline Total Number of Households & $1,105,362$ & & 4,254 \\
\hline With wage and salary income & 835,626 & & 3,095 \\
\hline Mean wage and salary income & $\$ 31,797$ & & $\$ 26,896$ \\
\hline With nonfarm self-employment income & 159,941 & & 569 \\
\hline Mean nonfarm self-employment income & $\$ 17,775$ & & $\$ 15,795$ \\
\hline With farm self-employment income & 33,146 & & 33 \\
\hline Mean farm self-employment income & $\$ 10,241$ & & $\$ 13,611$ \\
\hline With Social Security income & 306,040 & & 1,298 \\
\hline Mean Social Security income & $\$ 8,268$ & & $\$ 7,795$ \\
\hline With public assistance income & 66,998 & & 303 \\
\hline Mean public assistance income & $\$ 3,798$ & & $\$ 3,421$ \\
\hline With retirement income & $\begin{array}{r}185,721 \\
\$ 8815\end{array}$ & & $\begin{array}{r}787 \\
\$ 8247\end{array}$ \\
\hline
\end{tabular}

Source: 1990 Census Data, U.S. Department of Commerce, Bureau of the Census. 
Table F-39. Focus Community Profile for Astoria, Oregon - CONT

\begin{tabular}{|c|c|c|c|}
\hline Astoria, Oregon (1990) & Oregon & $\begin{array}{l}\text { Clatsop } \\
\text { County }\end{array}$ & Astoria \\
\hline \multicolumn{4}{|l|}{ POVERTY STATUS IN 1989} \\
\hline All persons for whom poverty status is determined & $2,775,907$ & 32,826 & 9,831 \\
\hline Persons below poverty level & 344,867 & 4,727 & 1,618 \\
\hline Percent of persons below poverty level: & 12.4 & 14.4 & 16.5 \\
\hline \multicolumn{4}{|l|}{ LABOR FORCE STATUS } \\
\hline Persons 16 years and over & $2,191,764$ & 25,677 & 7,740 \\
\hline Persons in labor force & $1,410,695$ & 15,872 & 4,812 \\
\hline Percent in labor force & 64.4 & 61.8 & 62.2 \\
\hline Civilian labor force & $1,407,143$ & 15,637 & 4,722 \\
\hline Employed & $1,319,960$ & 14,788 & 4,429 \\
\hline Unemployed & 87,183 & 849 & 293 \\
\hline Percent unemployed & 6.2 & 5.4 & 6.2 \\
\hline Armed Forces & 3,552 & 235 & 90 \\
\hline Persons not in labor force & 781,069 & 9,805 & 2,928 \\
\hline \multicolumn{4}{|l|}{ EMPLOYMENT BY INDUSTRY } \\
\hline Employed persons 16 years and over & $1,319,960$ & & 4,429 \\
\hline Agriculture, forestry, and fisheries & 66,730 & & 194 \\
\hline Mining & 2,479 & & 0 \\
\hline Construction & 74,206 & & 201 \\
\hline Manufacturing, nondurable goods & 61,873 & & 470 \\
\hline Manufacturing, durable goods & 171,335 & & 148 \\
\hline Transportation & 55,283 & & 213 \\
\hline Communications and other public utilities & 31,006 & & 63 \\
\hline Wholesale trade & 61,938 & & 189 \\
\hline Retail trade & 239,010 & & 881 \\
\hline Finance, insurance and real estate & 78,671 & & 145 \\
\hline Business and repair services & 60,660 & & 136 \\
\hline Personal services & 40,768 & & 208 \\
\hline Entertainment and recreation services & 17,650 & & 79 \\
\hline Health Services & 103,623 & & 272 \\
\hline Educational Services & 112,018 & & 374 \\
\hline Other professional and related services & 88,577 & & 262 \\
\hline Public administration & 54,133 & & 324 \\
\hline \multicolumn{4}{|l|}{ CLASS OF WORKER } \\
\hline Employed persons 16 years and over & $1,319,960$ & & 4,429 \\
\hline Private wage and salary workers & 990,564 & & 3,278 \\
\hline Government workers & 199,627 & & 774 \\
\hline Local government workers & 97,378 & & 386 \\
\hline State government workers & 64,595 & & 174 \\
\hline Federal government workers & 37,654 & & 214 \\
\hline Self-employed workers & 122,886 & & 361 \\
\hline Unpaid family workers & 6,883 & & 16 \\
\hline
\end{tabular}




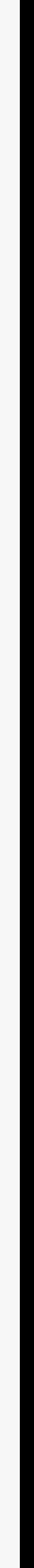

